\title{
Water Resources of
}

Southeastern Florida

By GARALD G. PARKER, G. E. FERGUSON, S. K. LOVE, and others

WITH SPECIAL REFERENCE TO THE GEOLOGY AND GROUND WATER OF THE MIAMI AREA

GEOLOGICAL SURVEY WATER-SUPPLY PAPER 1255

Prepared in cooperation with the Florida Geological Survey, Dade County, cities of Miami and Miami Beach, and other agencies

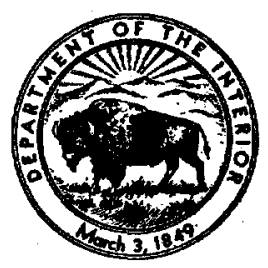

Library

\section{9}

North Florida Subdistrict Offica U.S. Geological Survey. 


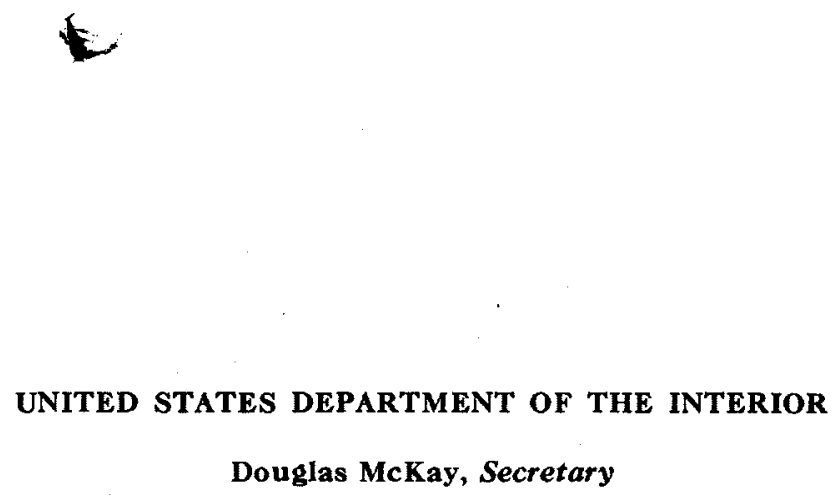

GEOLOGICAL SURVEY

W. E. Wrather, Director 


\section{PREFACE}

The research incident to the preparation of this report was performed by the Water Resources Division of the U.f. Geological Survey under the general supervision of N. C. Grover (retired, 1940), G. L. Parker (died, 1946), and C. G. Paulsen, all of whom successively held the position of chief hydraulic engineer.

The geologic and ground-water investigations were made under the general administrative supervision of the late $\mathbf{O}$. E. Meinzer, geologist in charge, Ground Water Branch (retired, 1946), and A. N. Sayre, present geologist in charge. V. T. Stringfield, ge ologist, exercised general technical supervision of the project, and the general fieldand office work in southern Florida was under the direct supervision of $W$. P. Cross, hydraulic engineer (Oct. 1939-May 1942), R. H. Brown, hydraulic engineer (June 1942June 1943), and Garald G. Parker, district geologist (Jure 1943April 1949). Geologic research and test-well drilling was under the direction of Garald G. Parker beginning in February 1940.

The surface-water investigations were made under the general administrative supervision of R. G. Kasel, chief of the Surface Water Branch (died, 1946), and J. V. B. Wells, present chief. The field and office work in Florida was under the direct supervision of D. S. Wallace (until 1941), G. E. Ferguson (1941-47), and A. O. Patterson (after 1947), all of whom successively held the position of district engineer. C. C. Yonker, hydraulic engineer, developed field methods and supervised the computation of records for stream-gaging stations. D. B. Bogart, hydraulic engineer, supervised the surface-water activities of the Miami suboffice from 1942 to 1949.

Quality of water investigations were made under the general administrative direction of W. D. Collins, chief of the Quality of Water Branch (retired, 1946), and S. K. Love, present chief. Technical supervision of quality of water studies, including chemical analyses of water samples, was exercised by S. K. Love, assisted by H. A. Swenson, chemist.

From field tabulations, R. W. Davenport, chief of the Technical Coordination Branch, and W. B. Langbein, hydraulic engineer, prepared the section on quantitative surface-water studies.

Acknowledgment is made to all who have aided in this investigation. So many individuals and organizations have helped that it is impossible to name and give credit to each in this report. 
Chief credit for starting the investigation is due to Alexander Orr, Jr., former city commissioner and former mayor of Miami. Others who materially aided in the early planning of the project included Malcolm Pirnie, consulting engineer of New York City; Dr. Abel Whoan and G. W. Simons, Jr., Water-Resources Committee of the National Resources Planning Board; A. B. Hale and Dr. A. P. Black, Peninsular Florida Basin Committee; G. W. Simons, Jr., Florida State Planning Board; C. A. Renshaw, city manager of Miami Beach; U. S. Senators Charles O. Andrews and Claude Pepper; U. S. 'Representative Pat Cannon; and other public officials and private citizens. As a result of their effortsparticularly Mr. Orr's-Miami, Miami Beach, Coral Gables and. Dade County, jointly with the U. S. Geological Survey, furnished the financial support for the major part of the investigation.

The city of Miami furnished office, laboratory, drafting room, and storage space for the survey from 1939 through 1946; since 1946, the city of Miami and Dade County have jointly contributed one-half and the U. S. Geological Survey and the Florida Geological Survey have contributed the other half of the cost of rented quarters. Personnel of the Miami city manager's office, of the Department of Public Service, and of the Department of Water and Sewers have been especially helpful; officials of Miami Beach, Coral Gables and Dade County generously contributed of their time and efforts.

Thanks are extended to the municipalities of Fort Myers, Fort Lauderdale, Fort Pierce, Lake Worth, Delray Beach, and Dania for the use of data, equipment, materials and labor in cooperative investigations of the geology and water resources during and since World War II.

Water-resources investigations that began in 1930 in cooperation with the Florida Geological Survey, the Corps of Engineers, and other agencies, made it possible to anticipate some of the. problems and conditions to be encountered, and intensive work started in the Miamiarea as soon as funds became available. Special acknowledgment is due Dr. Herman Gunter, director of the Florida Geological Survey, and his staff (particularly Dr. Robert $O$. Vernon, assistant director), for their very considerable assistance in this investigation.

State agencies, in addition to the Flor ida Geological Survey, who have contributed valuable aid include the trustees of the Florida Internal Improvement Fund, Florida Division of Water Surveys and Research, Florida State Board of Health, Everglades Drainage District, Okeechobee Flood Control District, Lake Worth Drainage District, University of Florida Agricultural Experiment Stations, and the Florida State Road Department. 
The Department of Agriculture, Soil Conservation Service, Everglades Project, and Farm Security Administration; Department of the Army, Corps of Engineers, Jacksonville District; and the U. S. Weather Bureau have been of help, either through cooperative investigations that required financial support, by furnishing data, machinery, and equipment.

Consulting engineers practicing in Florida have been instrumental in starting the southeastern Florida water-resources investigation as well as later cooperative investigations, and they have given their full support to all these investigations. The following consulting engineers and chemists have furnished data, loaned equipment, and assisted with field investigations: Alvin P. Black, head of the Department of Chemistry, University of Florida; C. K. Dodd, city engineer, Sarasota; Prof. N. C. Ebaugh, head of the Department of Mechanical Engineering, University of Florida; H. M. Freeborn, engineer, Philadelphia; Wylie W. Gillespie, Jacksonville; Elson T. Killam, engineer, New York; Harvey F. Pierce, engineer, and Edmund Friedman, Maurice $\mathrm{H}$. Connell \& Associates, Miami; Malcolm Pirnie, engineer, Malcolm Pirnie Engineers, New York; Charle: A. Pohl, engineer, Bogart and Pohl, New York; O. J. Seiplein, chemist, Miami; George W. Simons, Jr., engineer, Jacksonviile; Leslie B. Taylor, engineer, Miami; Joseph Weil, Dean of the airge of Engineering, University of Florida, Gainesville; Claude 4 . Wertz, engineer, Day \& Zimmermann, Inc., Philadelphia; Joe Williamson, Jr., engineer, Russell \& Axon, Daytona Beach; George E. Wingerter, engineer, H. C. Nutting Co., Miami; and Abel Wolman, engineer, Johns Hopkins University, Baltimore.

Appreciation is expressed for the support and cooperation of the Florida Well Drillers Contractors Association, the Southeastern Florida Drillers Association, and the many well-drilling contractors operating in Florida. Those who have actively aided these investigations, either by furnishing file data or other information, or by collecting and saving rock cuttings and water samples from wells, are: Edwin Anderson, Hallandale; J. P. Carroll, West Palm Beach; L. C. Coe, Miami; J. E. Cousins, Layne-Atlantic Co., Orlando; E. W. Dansby, Wauchula; J. C. Dibble, Kissimmee; F. Clyde Freeman, Libby and Freeman Drilling Co., Orlando; A. C. Gray, Gray Well \& Pump Co., Jacksonville; H. Clay Gardenhire, Jr., Gardenhire Bros., Bartow; John B. Hurst; Hurst Drilling and Equipment Co., Miami; Oliver Kelly, Northwest Pump Co., Miami; C. P. Leverett, Miami; Paul, Donald, and Harry Kiser, Kiser Drilling Co., Miami; J. L. Knight, Knight \& King, Vero Beach; R. H. Magruder, Magruder Well Drilling Co., Coconut Grove; Joe P. Maharrey and Joe P. Maharrey, Jr., Fort Myers; Harold and Douglas May, May Brothers Drilling Co., Tampa; R. J. Maxson, Miami; E. P. Maxson, Oakland Park; Robert and Emory Meredith, Libby \& Freeman Drilling Co., Or- 
lando; Richard L. Smith, formerly with Libby \& Freeman, now with Gardenhire Bros., Bartow; A. F. Stevens, Stevens-Southern Co., Jacksonville; W. Guy Tanner, Miami; R. M. Vickers, Miami; L. N. Williams, Fort Myers; and C. R. Wright, Hurst Drilling \& Equicment Co., Miami. Without the active and wholehearted assisrance of these drillers the comprehensive results obtained in these investigations could not have been achieved.

Others who have been especially helpful were H. H. Hyman, engineer, Florida Power \& Light Co., who furnished data on the historical development of the Miami water supply, and other engineers of the same company who supplied information on test wells, including logs, water levels, quality of water results, and reports of pumping tests. R. Y. Patterson, H. A. Bestor, and others of the U.S. Sugar Corporation at Clewiston, furnished data on wells and water levels and contributed information on the historical development of drainage and industries in the Everglades. J. M. McBride, Agricultural Agent of the Seaboard Air Line R. R. Co., gave detailed data on the geology and ground water of the Indian Town area. Stanley B. Wright, National Resources Planning Board, who served as coordinator of the Southeastern Florida Joint Investigation during 1940-41.

Many persons have helped in the geologic studies, and appreciation is expressed to each of them. Particular acknowledgment is made of the work of these geologists of the U. S. Geological Survey: Nevin D. Hoy, whose unfailing assistance from 1929 through the present, 'contributed immeasurably to the progress on the ground-water studies; C. Wythe Cooke, who spent several weeks in the field with Garald G. Parker studying areal geology; and J. B. Reeside, Jr., Julia A. Gardner, J. A. Cushman, Ruth Todd, Remington Kellogg, F. Stearns MacNeil, and Lloyd B. Henbest, who aided by identifying fossils. Other scientists, not connected with either the Florida or the U. S. Geological Survey, have been of great help, including Horace G. Richards of the Philadelphia Academy of Sciences, who directly aided this investigation by his identification of fossils from several test wells; Robert B. Campbell, petroleum geologist, who furnished data on the geology and ground water of the deeper formations; and Richard F. Flint, of Yale University, who aided in the study of Pleistocene geology. 
Geology-Continued

Stratigraphy and water-bearing characteristics of the formations-Continued Quaternary system-Continued

Pleistocene series-Continued

Key Largo limestone.

Anastatia formation.

Miami oolite..

High terrace deposits.

Pamlico sand.

Late Plei stocene and Recent deposits.

Lake Flirt marl.

Organic soils

Laterite of the Redlands district.

Beach sand.

Late Cenozoic history

General statement.

The Pleistocene or "Great Ice Age".

General effect of glacial control of sea level.

Effects of changing sea levels in southern Florida........................................

Nebraskan glacial age..

Aftonian interglacial age.

Kansan glacial age..

Yarmouth intergl acial age...........................................................................

Illinoian glacial age..

Sangamon interglacial age.

Wisconsin glacial age.

Recent epoch

Geomorphology, by Garald G. Parker.

Factors affecting land forms..

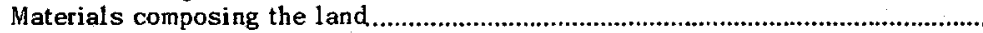

Fluctuating sea level.

Shoreline processes.

Climate and vegetation.

Solution.

Erosion.

Marine terraces.

General statement

Wi comico terrace.

Penholoway terrace,

Kissimnee River basin.

Fisheating Creek valley.

Talbot terrace.

Painlico terrace.

The sandy flatlands.

The Okaloacoochee Slough and Devil's Garden

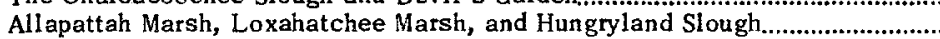

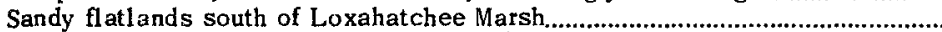

The Big Cypress Swamp.

The Atlantic Coastal Ridge.

Silver Bluff terrace.

The Everglades

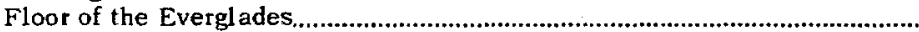

Drainage pattern of the Everglades..................................................................

Lake Okeechobee.

Hillsboro Lakes Marsh.

Coastal marshes and mangrove swamps............................................................

The Florida Keys

Ground water, by Garald G. Parker.

Occurrence.....

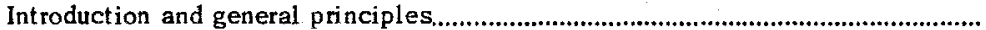

Definition of ground water...

Nonartesian water and the water table.

Artesian water and the piezometric surface.

Methods of investigation. 
Ground water-Continued

Occurrence-Continued

Nonartesian water.

The Biscayne aquifer.

Greater Miami area.

Early supplies

Effects of drainage.

Present supplies,

Atlantic Coastal Ridge south of Greater Miami in Dade County........................

The aquifer and ground water.

Development of wells.

Atlantic Coastal Ridge north of Greater Miami to, and including, Dania in Broward County

The aquifer and ground water.

Development of wells.

Atlantic Coastal Ridge in Broward

The aquifer and ground water

Effects of drainage.

Development of wells.

Atlantic Coastal Ridge in Palm Beach County.

The aquifer and ground water..

Effects of drainage..

Development of wells.

Atlantic Coastal Ridge in Martin County........................................................... 174

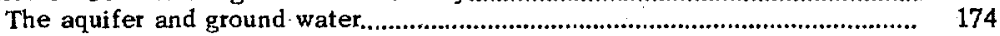

Effects of drainage..................................................................................... 175

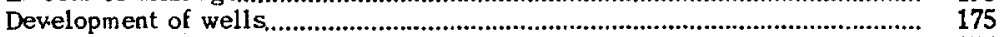

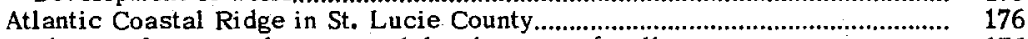

The aquifer, ground water, and development of wells.................................... 176

The Florida Keys.................................................................................................. ; 176

The aquifer, ground water, and development of wells..................................... 176

The Everglades National Park area........................................................................ 178

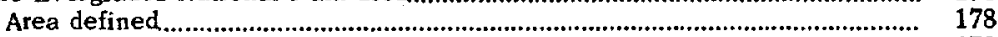

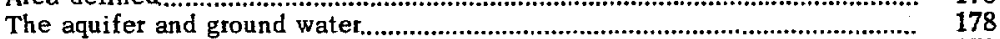

Developrient of wells.................................................................................... 178

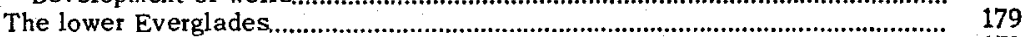

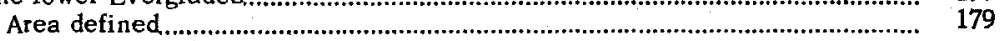

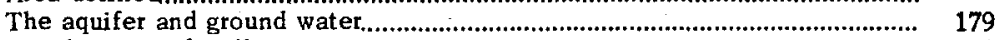

Development of wells................................................................................. 180

The area west of Hialeah.......................................................................... 180

Seepage.......................................................................................................... 183

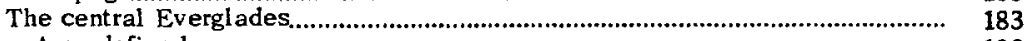

Area defined .......................................................................................... 183

The aquifer and ground water................................................................. 183

Development of wells.......................................................................... 184

Seepage................................................................................................. 184

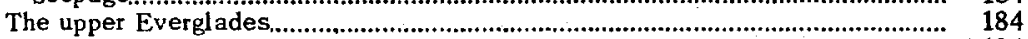

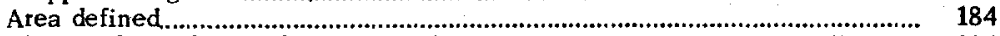

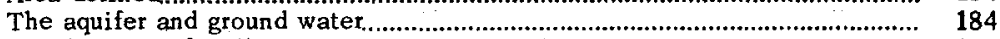

Development of wells............................................................................ 185

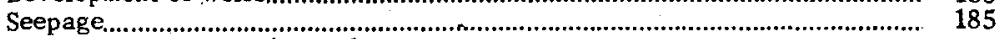

The Big Cypress-Devil's Garden area .............................................................. 186

Area defined ......................................................................................., 186

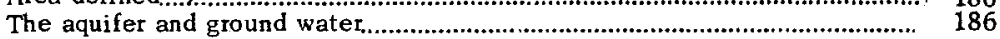

Development of wells........................................................................................ 186

The Kissimmee valley........................................................................................ 186

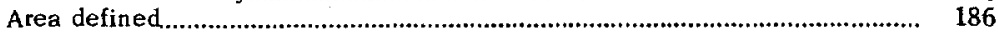

The aquifer and ground water........................................................................ 187

Development of wells............................................................................... 187

The high marine terraces east of Kissimmee valley....................................... 187

Area defined .............................................................................................. 187

The aquifer and ground water............................................................................. 187

Development of wells............................................................................... 188 
Ground water-Continued

Occurrence-Continued

Artesian water.

General statement.

The Floridan aquifer and aquiclude.

Distribution.

Artesian pressure.

Yield to wells.

Utility.

Contamination of nonartesian aquifers by leaky or flowing artesian wells...

Shallow artesian aquifers.

Pleistocene artesian aquifer at Indian Town.................................................

Pliocene and Miocene aquifers at Fort Pierce, St. Lucie County, and in the Kissimmee valley.

Miocene aquifer at Everglades, Collier County..

Quantitative studies in the Miami area, by M. A. Warren and Garald G. Parker........

Introduction..

General statement.

Ground-water inventory.

The Biscayne aquifer.

Response to sudden pressure changes.

Pumpage.

Earthquake shocks and passing trains

Variable hydrologic factors affecting the aquifer.........................................

Salt-water encroachment.

Perennial yield.

The water table.

General statement.

Effect of canals on the water table.

Water-table studies of the Miami area

Water table at low stage, February 3, 1942

Water table at medium stage, July 26, 1941

Water table at high stage, September 30,1940 .

Water-table studies of Dade County..

Water table at low stage, May 19, 1945

Water table at medium stage, March 17, 1941.

Water table at high stage, September 23, 1940

Ground-water recharge.

General statement

Definitions...

Water table and rainfall correlations.

Rainfalt and the water table in muck of the Everglades.

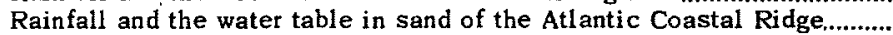

Rainfall and the water table in the oolite of the Atlantic Coastal Ridge.

Ground-water discharge..

General statement,

Evaporation and transpiration.

Evapotranspiration and discharge studies in Dade County.

Ground-water discharge studies in the Atlantic Coastal Ridge south of

Kendall.

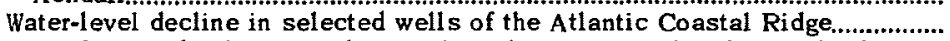

Ground-water discharge studies in the Atlantic Coastal Ridge north of

Kendall.

Estimated ground-water pumpage in Dade County.

Itydrologic properties of water-bearing materials.

Coefficient of permeability.

Coefficient of transmissibility.

Coefficient of storage.

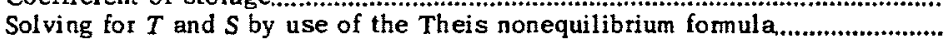

Large-scale pumping tests..

$\mathrm{S} 1$ pumping test.

$\mathrm{G} 551, \mathrm{G} 552$, and $\mathrm{G} 553$ pumping tests.

G 551 pumping test.

G 552 pumping test.

G 553 pumping test. 
Ground water-Continued

Quantitative studies in the Miami, area-Continued

Large-scale pumping tests-Continued

Conclusions regarding $T$ and $S$ from data obtained from large-scale pumping tests.

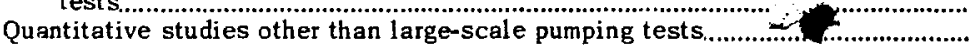

F 85 pumping test.

G 218 pumping test

Studies of cone of depression in Miami well field.

Canal inflow studies

Factors to be considered regarding the proposed well field in the Miami area....

General analysis.

Theoretical drawdowns in an infinite aquifer.

Cone of depression in an area in which the aquifer is uniformly recharged....

Evapotran spi ration salvage...

Infiltration from canals.

Conclusions.

Surface water, by D. B. Bogart and G. E. Ferguson.;

Characteristics of drainage basins and summaries of gaging-station records............

Methods of investigation and explanation of data.

Collection of field data.

Interpretation of data.

Stage records.

Definition of terms.

Index of gaging stations.

Basins tributary to Lake Okeechobee.

General drainage system

Kissimmee River.

Upper Kissimmee basin

Flood frequency...

Reedy Creek.

Lower Kissimmee basin

Flood frequency.

Arbuckle Creek

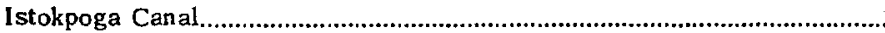

Fisheating Creek.

Minor tributaries..

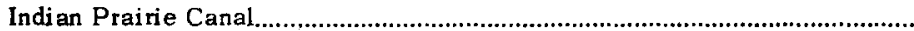

Harney Pond Canal.

Taylor Creek.

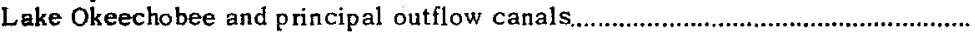

Physical features.

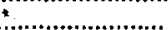

Lake-regulation program.

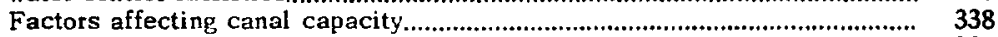

Soil subsi dence...................................................................................... 338

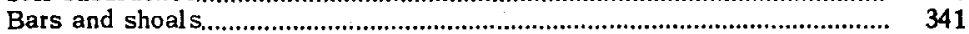

Aquatic weeds........................................................................................... 342

Topographic and geologic factors of water control.............................................. $\quad 344$

The combined natural and artificial control regimen...................................... 347

West Palm Beach Canal............................................................................................ 348

Physical description,......................................................................................... 348

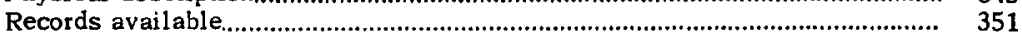

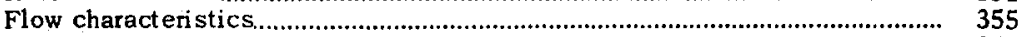

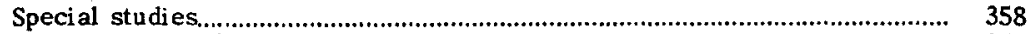

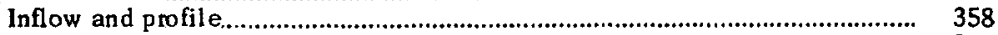

Discharge at range line 41-42

Hillsboro Canal........................................................................................................... 362

Physical description......................................................................................... 362

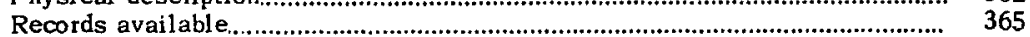


Surface water-Continued

Characteristics of drainage basins and summaties of gaging-station records-Con.

Hillsboro Canal _-Continued

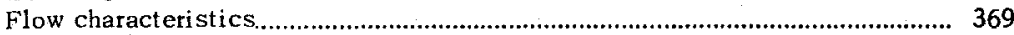

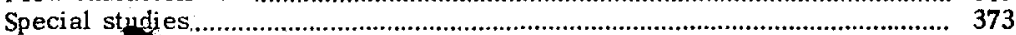

Pumping $\mathrm{f}$ lower reaches............................................................................. 373

Seepage in tidal reach................................................................................... 374

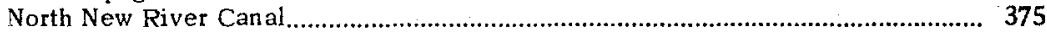

Physical description....................................................................................... 375

Records available.......................................................................................... 378

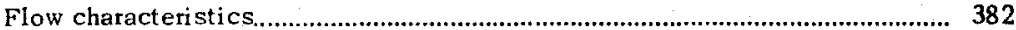

Seepage rates..................................................................................................... 386

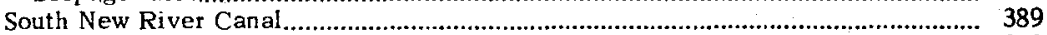

Physical description..................................................................................... 389

Records available............................................................................................... 391

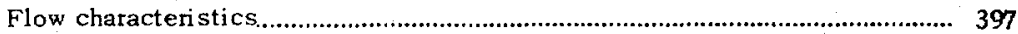

Lower New River basin..................................................................................... 399

Physical description....................................................................................... 399

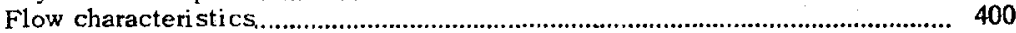

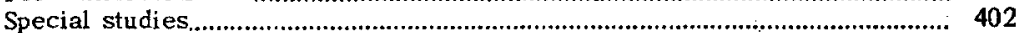

General flow distribution........................................................................... 402

Tide stage and discharge relationships....................................................... 404

Miami Can al _- upper and middle reaches..................................................... 406

Physical description............................................................................................. 406

Records available.......................................................................................... 408

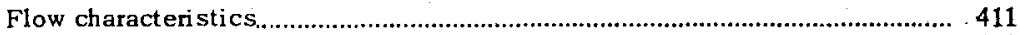

Lower Mi ami Canal............................................................................................ 412

Physical description...................................................................................... 413

Records available.................................................................................... 421

Hydraulic characteristics of headwaters...........................................................4 435

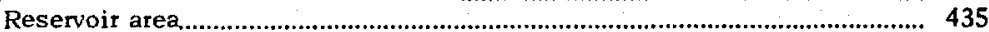

Storage inflow reach............................................................................... 438

Tidal reaches............................................................................................... 439

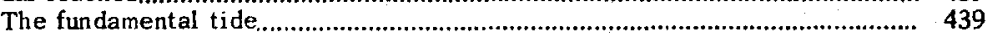

Tide levels.................................................................................................., 441

Tidal characteristics of sea-level canals,..................................................... 444

Tidal fluctuations in Miami Canal............................................................. 448

Flow characteristics of Miami Canal................................................................... 458

Computation of discharge by tide-correction method, by C. C. Yonker.............. 471

Physical characteristics of stream........................................................ 471

Measurements of discharge............................................................................... 472

Development of rating curve....................................................................... 475

Special studies........................................................................................ 476

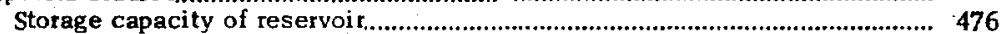

Seepage rates and profiles in tidal reaches......................................... 478

Backwater effect in tidal reaches...................................................................... 481

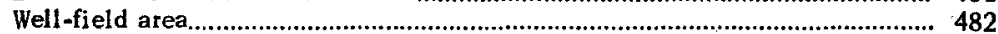

Tidal storage of Miami River.................................................................... 484

Tamiami Canal..................................................................................................... 486

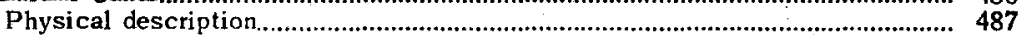

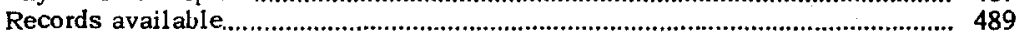

Flow characteristics......................................................................................... 495

Seepage rates and profile in lower reaches......................................................... 501

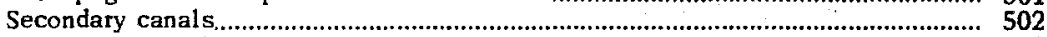

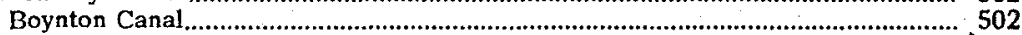

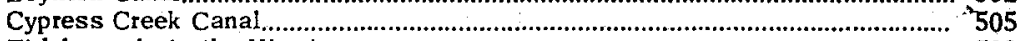

Tidal canals in the Miami area........................................................................... 508

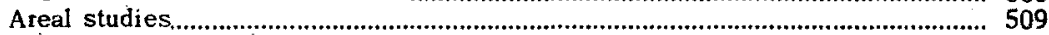

General study of Everglades................................................................................ 510

Area west of Hialeah............................................................................................. 510

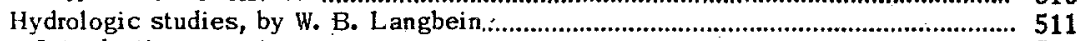

Int roduction......................................................................................................... 511

General hydrology of the area......................................................................... 512

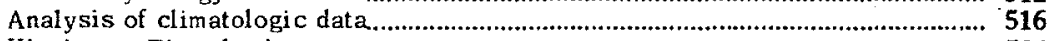

Kissimmee River basin............................................................................... 524 
Surface water-Continued

Hydrologic studies-Continued

Kissimmee River basin-Continued

Explanation of methods.

Separation of direct and base flow. $\quad 524$

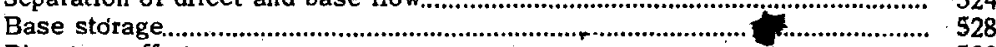

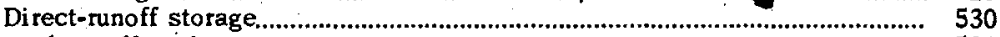

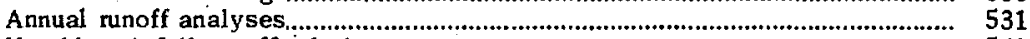

Monthly rainfall-runoff relations....................................................................... $\quad 540$

Water losses and storage................................................................................ 544

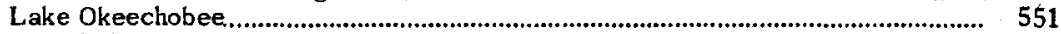

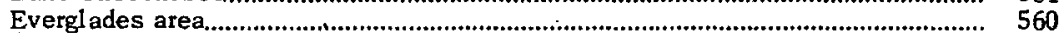

Salt-water encroachment, by Garald G. Parker, R. H. Brown, D. B. Bogart, and

S. K. Love......................................................................................................... 571

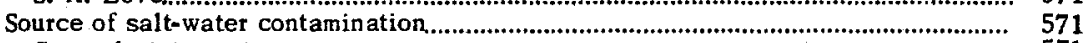

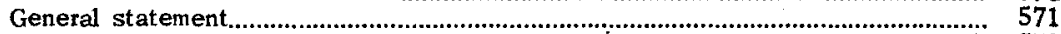

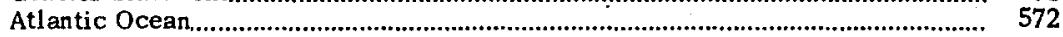

Chemical composition of sea water near Miami...................................................... 572

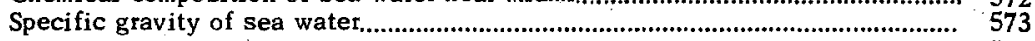

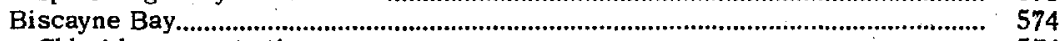

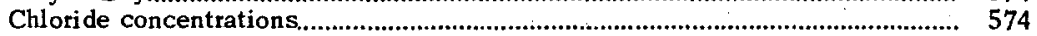

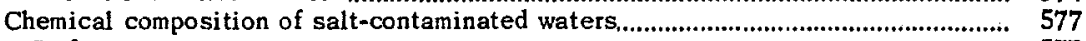

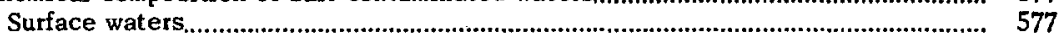

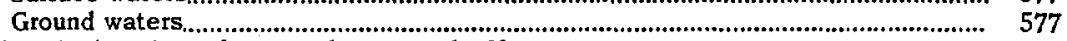

Historical review of encroachment in the Miami area................................................ 580

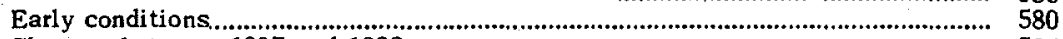

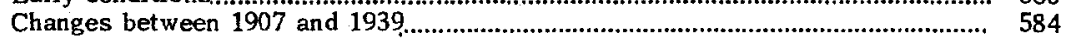

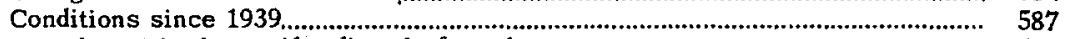

Encroachment in the aquifer directly from the ocean,.................................................. 591

Historical review of literature on coastal ground water........................................... 591

Studies in the Silver Bluff area of Miami.............................................................. 593

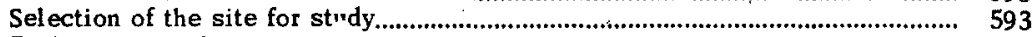

Preliminary work ............................................................................................................. 594

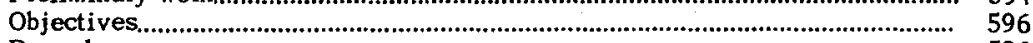

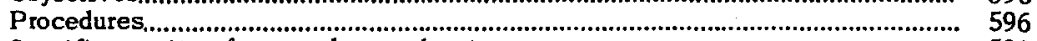

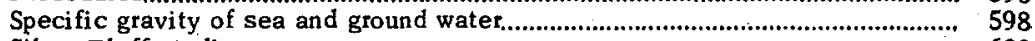

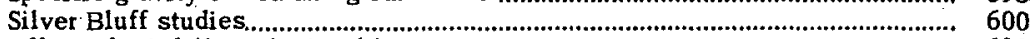

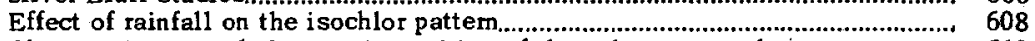

Characteristics and changes in position of the salt-water wedge........................ 610

Tidal-storage changes........................................................................................... 617

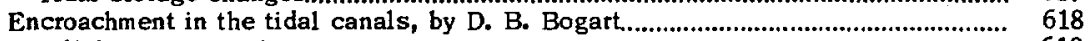

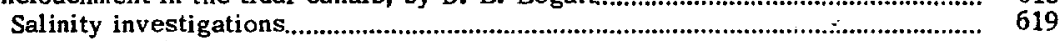

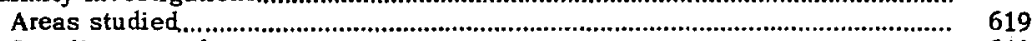

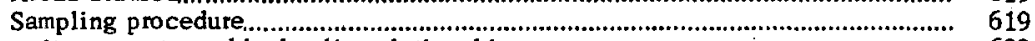

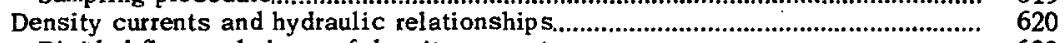

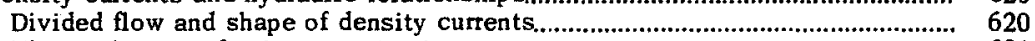

The mechanics of salt contamination................................................................ 621

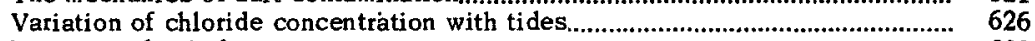

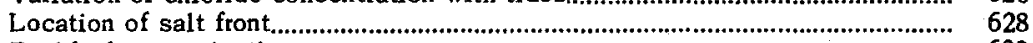

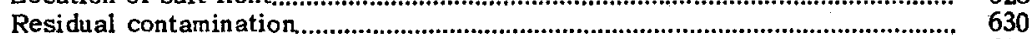

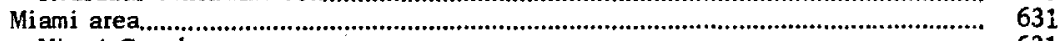

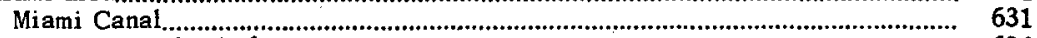

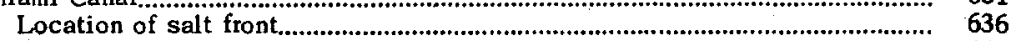

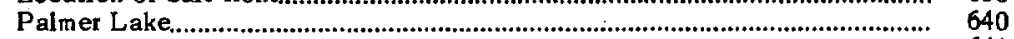

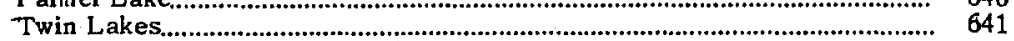

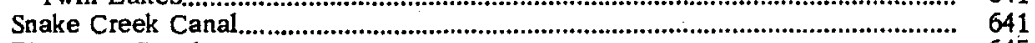

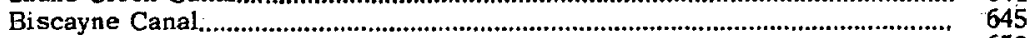

Little River Canal................................................................................................... 652

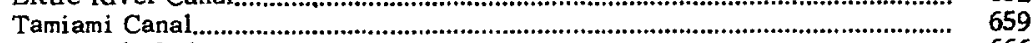

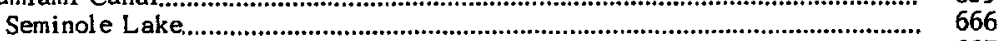

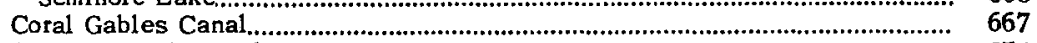

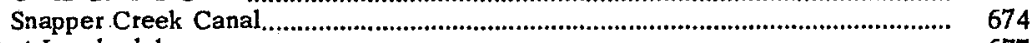

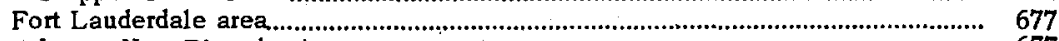

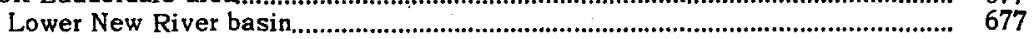

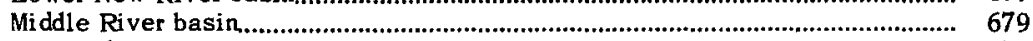

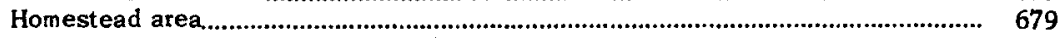


Salt-water encroachment_-Continued

Salt-water contamination of the aquifer from tidal canals, by Garald G. Parker.

Contamination of canals by residual salty ground water.

Salt-water encroachment in the Miami well fields.

Spring Gardens well field.

Miami Spring Hialeah well field.

Salt-water intrusions in the Miami Canal

Contamination of wells.

Coconut Grove well field.

Salt-water encroachment along the Dade County shoreline other than at Silver Bluff.

Electrical-resistivity studies, by H. Cecil Spicer.

Introduction,

Electric conduction.

Field measurem ents.

Interpretation of the resistivity curves.

Measurements at Miami.

Silver Bluff area.

Cutler area,

Measurem ents at Fort Lauderdale..

Evaluation of the method.

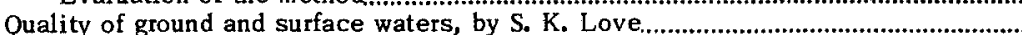

Introduction

Earlier reports on quality of water..

Methods of investigation.

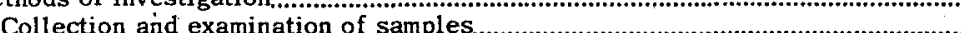

Expression of results.

Constituents and properties of natural waters.

Color.

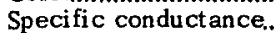

Silica.

Iron......

Calcium.

Magnesium.

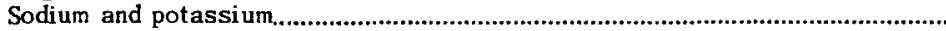

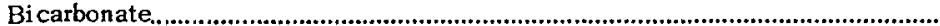

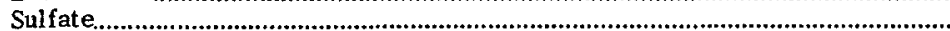

Chloride.

Fluoride,

Nitrate.

Dissolved solids

Hardness.

Hydrogen sulfide.

Hydrogen-ion concentration $(\mathrm{pH})$

Corrosiveness.

Chemical character of surface waters

Kissimmee River.

Other streams contributing to L ake Okeechobee.

Lake Okeechobee and principal outflow canals,

Lake Okeechobee,

St. Lucie Canal

Caloosahatchee Canal

Major Evergl ades drainage canals..

West Palm Beach Canal

Hillsboro Canal.

North New River Canal

South New River Canal

Miami Canal.

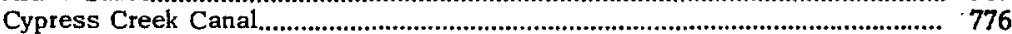

Tamiami Canal................................................................................................... 777

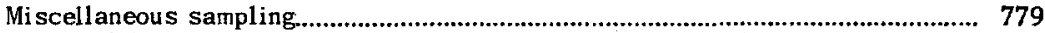

Effect of drought conditions on chemical quality of Everglades canals............... 784

Chemical character of nonartesian ground waters........................................................ 784

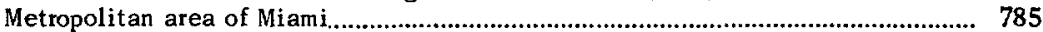

Coastal areas south of Miami.. 
Quality of ground and surface waters-Continued

Chemical character of nonartesian ground waters-Continued

Coastal areas north of Miami.

Broward County

Palm Beach County

Areas surrounding Lake Okeechobee..

Glades County

Hendry County.

Palm Beach County

Martin County.

Okeechobee County

Summary of quality of ground water in Lake Okeechobee area.

The Everglades.

Source of mineralization of ground waters in the Everglades.

Collier County.

Chemical character of artesian waters.

Public water supplies.

\section{ILLUSTRATIONS}

\section{[A11 plates in box]}

Plate 1. Map of southern Florida, showing locations of meteorological and stream-gaging stations.

2. Maps of southern Florida, showing annual rainfall; 1932-46, in percent of normal.

3. Graph, showing climatological data for southeastern Florida.

4. Geologic map of southern Florida.

5. Index map, showing location of geologic ctoss sections $A-A^{\prime}, B-B^{\prime}$, $C-C^{\prime}, D-D^{\prime}, E-E^{\prime}, F-F^{\prime}, G-G^{\prime}, H-G^{\prime}, I-I^{\prime}$, and $J-J^{\prime}$, Dade County.

6. Geologic cross section $A-A^{\prime}$, Dade County.

7. Geologic cross section $B-B^{\prime}$, Dade County.

8. Geologic cross sections $C-C^{\prime}, D-D^{\prime}, E-E^{\prime}, G-G^{\prime}, H-G^{\prime}$, and $I-I^{\prime}$, Dade County.

9. Geologic cross sections $F-F^{\prime}$ and $J-J^{\prime}$, Dade County.

10. Hypsometric map of southern Florida.

11. Map of southeastern Florida showing directions of surficial drainage - and trends of bar-and-swale topography.

12. Topographic-ecologic map of southern Florida.

13. Map, showing the Silver Bluff Pleistocene shoreline and marine terrace, Dade County.

14. Map of Everglades and Atlantic Coastal Ridge, showing canals and their levels and discharges in a drought period, March 30 to April 2, 1943.

15. Map of area west of Hialeah, showing discharges and water levels in a wet period, June 29 to July $1,1942$.

16. Map of area west of Hialeah, showing discharges and water levels in a dry period, April 24-26, 1946.

17. Map of Miami area, Florida, showing isochlors for ground water in wells at depths of 40-60 feet and 80-130 feet, January 1947.

18. Chart, showing comparison of driller's logs and chloride logs with resistivity interpretations, Fort Lauderdale. 
Plate 19. Well index map of southern Florida.

20. Well index map of southeastem Broward County.

21. Well index map of Miami metropolitan area.

22. Well index map of Miami well-field area.

23. Well index map of eastern Dade County.

24. Well in $x$ map of southeastarn Palm Beach County.

Figure 1. Map of southern Florida showing areas of investigation............................. 6

2. Schematic representation of the hydrologic cycle......................................... 16

3. Map showing average annual precipitation, in inches, for southern Florida,

4. Graph showing seasonal distribution of rainfall at selected locations in southern Florida.

5. Chart showing relation of amount of precipitation to duration of storms in southern Flotida.....

6. Graph showing characteristics of evaporation from selected pans in southeastern Florida.

7. Study of pan evaporation in relation to temperaturf and wind movement at Belle Glade.

8. The Floridan Plateau.

9. Generalized NNW-SSE geologic cross section from vicinity of Ocala to Florida City..

10. East-west cross section along North. New River Canal from 20 -Mile Bend to Fort Lauderdale.

11. Dredge-cut in Caloosahatchee River showing small undulations in Fort Thompson formation.

12. View of contact of Miami oolite and Fort Thompson formation....................

13. Block diagram of the Miami area.

14. Cores from test wells in Dade County.

15. Cores from test well S 394 at Delray Beach ....................................................

16. Anastasia formation in road cut at south side of West Palm Beach golf course.

17. Details in the Miami oolite, Dade County..

18. Lake Flirt marl

19. Miami oolite in cut at Florida Power and Light Company's Cutler plant....

20. Idealized geologic cross section at type locality of the Fort Thompson formation

21. Natural limestone bridge over Arch Creek.

22. Rock pinnacles resulting from solution of Miami oolite.

23. Silver Bluff, a Climatic Optimum sea cliff.

24. Sea undercutting coralline limestone of Key Vaca.

25. Close-up view of one of the larger solution holes in Dade County.

26. Borrow pit in Miami oolite at Fort Lauderdale,

27. Typical view of western part of the Everglades showing tree islands.........

28. Contour map of rock floor of Everglades.

29. Idealized block diagram showing relationship of water table to land surface.

30. Idealized cross section showing relationship between water table and piezometric surface of artesian water in an area with geologic structure similat to that of Kissimmee valley.

31. Index map of southern Florida showing areas for which information on shallow nonartesian aquifers is given.

32. Map of area west of Hialeah showing water table at high level on July 1, 1942 .

33. Map of area west of Hialeah showing water table at intermediate level on April 26, 1946.

34. Map of area west of Hialeah showing water table at low level on May 19, 1945

35. Piezometric map of the Floridan aquifer in 1944

36. Generalized east-west cross section through Fort Pierce municipal well field showing shallow strata and water table on August $3,1944 . .$.

37. Generalized north-south cross section through Fort Pierce municipal well field showing shallow strata and ground-water levels on June 6, 1944.

38. Hydrographs showing average monthly water levels in key observation wells $G 3, G 10$, and $G 72$.

39. Hydrographs showing average monthly water levels in key observation wells F 179 , F 210 , and S 182 . 
Figure 40. Hydrographs showing average monthly water levels in key observation wells S 18 , S 19, and S 329 .

41. Hydrograph showing average monthly water levels in well S 196, Univ. of Florida Expt. Sta., Homestead, 1932-46.

42. Water-table map of the Biscayne aquifer in the Miami area showing low stage, February 3, 1942

43. Water-table map of the Biscayne aquifer in the Miami area showing medium stage, July 26, 1941

44. Water-table map of the Biscayne aquifer in the Miami area showing high stage, September $30,1940$.

45. Water-table map of the Biscayne aquifer in southeastern Dade County showing low stage, May 19, 1945 ...

46. Water-table map of the Biscayne aquifer in southeastern Dade County showing medium stage, March 17,1941 .

47. Water-table map of the Biscayne aquifer in southeastern Dade County showing high stage, September 23, 1940 .

48. Graph showing fluctuations of water level in well $G 72$ following periods of heavy rainfall.

49. Graph showing fluctuations of water level in well G 86 following periods of heavy rainfall

50. Graph showing fluctuations of water level in well $S 182$ following periods of heavy rainfall.

51. Graph showing total yearly rise of water level in well S 182 compared with precipitation at Peters for 1943-46.

52. Typical fluctuations of water levels in wells $G 72$ and G 218 during rainless periods.

53. Graph showing rate of decline of water level in well S 182 versus stage of water table correlated with average evaporation rate for preceding 5 days....

54. Recession curves for five wells in the coastal ridge..

55. Pumpage from Miami well field at Hialeah, 1925-46.

56. Map of the Miami well-field area

57. Generalized cross section through wells $S 1$ to $S 68$ in the lower Miami well field

58. Graph showing transmissibility coefficient as determined by distancedrawdown relationships from $S 1$ pumping test.

59. Time-drawdown graphs for pumping test of $S 1$, for wells 75 and 150 feet distant.

60. Time-drawdown graphs for pumping test of S 1, for wells 300,500 , and 900 feet distant.

61 . Index map showing generai location of wells G $551, \mathrm{G} 552$, and $G 553 . . .$. ..

62. Reading the mercury manometer of the pitometer used to measure discharge from the pumped well.

63. Sketch showing locations of well G 551 and observation wells.

64. Drawing showing method of construction of $G 551$, and logs of $G 551$ and observation wells.

65. Pump used in aquifer tests.

66. Water discharging at a rate of $5 \mathrm{mgd}$ from G 551 at the end of the 2,000-ft Transite line.

67. Time-drawdown graph for pumping test of $\mathrm{G} 551$.

68. Distance-drawdown graph for pumping test of $\mathrm{G} 551$

69. Sketch showing location of well $\mathrm{G} 552$ and observation wells........................

70. Drawing showing method of construction of G 552, and logs of $G 552$ and observation wells.

71. Time-drawdown graph for pumping test of $\mathrm{G} 552$.

72. Distance-drawdown graph for pumping test of $G 552$.

73. Sketch showing location of $\mathrm{G} 553$ and observation wells.

74. Drawing showing method of construction of G 553, and logs of G 553 and observation wells..

75. Time-drawdown graphs for pumping tests of G 553 .

76. Distance-drawdown graphs for pumping tests of $\mathrm{G} 553$..

77. Map of Opa Locka and vicinity showing water-table contours and ground-water drainage areas on August 29, 1940.

78. Stabilized profiles of water table between shoreline and center of proposed well field. 
Figure 79. Theoretical drawdowns in relation to distance from pumped well and time after start of pumping.

80. Graph showing drawdowns resulting from pumpage within and beyond a circle of 7 -mile radius.

81. Map of proposed well-field area showing theoretical cone of depression ater drawdowns for a uniformly recharged circle of 7 -mile radius are superimposed on the average water table..

82. Curve showing estimated evapotranspiration salvage resulting from lowering the water table.

83. Profiles of the water table and plan of the stabilized cone of depression in an ideal aquifer of semi-infinite extent with reduced recharge from a canal

84. Recording gage at stream-gaging station on Miami Canal at Water Plant, Hialeah.

85. Staff gage graduated in feet and hundredths of a foot at streamgaging station on Miami Canal at Water Plant, Hialeah.

86. Graph of discharge of Kissimmee River near Okeechobee, 1928 -46.........

87. Stage-area, and storage capacity curves for Lake Okeechobee..

88. Graph showing stages of Lake Okeechobee, 1915-46.

89. Protective levee around Lake Okeechobee.

90. Hurricane gate no. 6, located at the mouth of Taylor Creek near Okeechobee.

91. Control and lock in Hillsboro Canal near Deerfield Beach, a typical Everglades installation.

92. Water control facilities in the upper Everglades.

93. Diagram of water relationships in typical farmed area of the upper Everglades during dry and wet periods.

94. Top of wall of lock in South New River Canal at South Bay...

95. Aquatic growth in Everglades canals.

96. Graphs showing stage and discharge of West Palm Beach Canal, $1939-42$

97. Graphs showing stage and discharge of West Palm Beach Canal, 1943-46.

98. Runoff pattem and stage profile of West Palm Beach Sanal on September 22, 1945 .

99. Graph of stage and discharge in the eastern one-third of West Palm Beach Canal, October-December 1946.

100. Graphs of stage and discharge of Hillsboro Canal, 1939-42.

101. Graphs of stage and discharge of Hill sboro Canal, 1943-46.

102. Graph of monthly mean stage of Hillsboro Canal at Shawano, $1929-46 . .$.

103. Graph showing discharge of Hillsboro Canal at Dixie Highway, Deerfield Beach, December 10, 1941

104. Graphs showing stage and discharge of North New River Canal, 1939-42

105. Graphs showing stage and discharge of North New River Canal, 1943-46

106. Graph of discharge and seepage rates of North New River Canal on May 1 and November 2, 3, 1944

107. Graph of stage of South New River Canal about 8 miles west of Snake Creek Canal, 1941-46.

108. Graph of stage and discharge of South New River Canal near Davie, $1939-41$

109. Map of lower New River basin showing principal discharges on February 15, 1941

110. Graphs of stage and discharge in lower New River basin on February 15, 1941.

111. Graphs of stage and discharge of Miami Canal at Lake Harbor, 1939-43

112. View of Miami Canal upstream from junction with South New River Canal

113. View upstream in bed of Miami Canal; shallow excavation above head of deep channel.

114. Lower Miami Canal above County Line Dam.

115. Upstream side of County Line Dam showing top of control gates, temporary irrigation-pump installation, and diversion to the borrow pit along the west side of Dade-Broward Levee. 
Figure 116. Miami Canal at Broken Dam.

117. Graphs of stage and discharge of lower Miami Canal, 1939-40

118. Graph of stage and discharge of lower Miami Canal, 1941

119. Graph of stage and discharge of lower Miami Canal, 1942

120. Graph of stage and discharge of lower Miami Canal, 1943.

121. Graph of stage and discharge of lower Miami Canal, 1944

122. Graph of stage and discharge of lower Miami Canal, 1945.

123. Graph of stage and discharge of lower Miami Canal, 1946.

124. Map of Miami Canal reservoir area showing the flow pattern and water conditions in a wet period, June $24,1942$.

125. Graph of actual tidal variation in Biscayne Bay for a short period and predicted tidal variation for 1948

126. Graph of annual mean el evation and range of Atlantic Ocean at Miami Beach, 1931-46.

127. Diagram of tidal backwater in a canal and progressive changes of slope, directions of flow, and changes in storage of a tidal canal.........

128. Hydrographs of stages at selected locations along Miami Canal, April 10-17, 1942

129. Graph of tidal variation in stage and discharge at stations along Miami River and Canal, February 17, 1941 .

130. Graph of tidal variation in stage and discharge of Miami Canal at Water Plant, Hialeah, December 7, 1942, and June 23, 1943

131. Graph of stage of Miami Canal at Pennsuco, 1926-46.

132. Graph of annual maximum stage of Miami Canal at Pennsuco, 1926-46.... -462

133. Graphs of stage profiles of Miami Canal for selected dates and map of lower reaches of canal.

134. Profile of Miami Canal during hurricane of September 15, 1945, and stage graphs for stations along the canal for the storm period...

135. Graphical determination of the tide-corrected gage height of Miami Canal at Water Plant, Hialeah

136. Graph of relationship between tide-corrected gage height and discharge for Miami Canal at Water Plant, Hialeah.

137. Graph of available storage in reservoir area of Miami Canal above County Line Dam and rating of control gates in dam

138. Graph of cumulative discharge, seepage rates, and profiles of Miami Canal from County Line Dam to Water Plant, Hialeah, on selected dates.

139. Graph of stages, tidal fluctuations, and profiles along lower Miami Canal, November and December, 1945.

140. Map of Miami well-field area showing distribution of canal flow on March 28, 1946.

141. Graph of tidal variation in stage and discharge at two locations on Miami River, June 28, 1946.

142. Graphs of stage and discharge of Tamiami Canal, 1939-42.

143. Graphs of stage and discharge of Tamiami Canal, 1943-46

144. Graph and map of flow distribution and profiles of Tamiami Canal outlets during a wet period, October 5,1945

145. Middle reaches of Tamiami Canal near 40-Mile Bend in severe

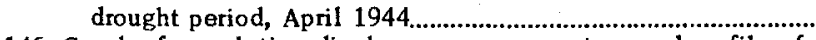

146. Graph of cumulative discharge, seepage rates, and profile of Tamiami Canal from Dade-Broward Levee to Red Road, September 16,1941

147. Graph of discharge of Boynton Canal at Boynton Beach, 1941-43.............

148. Graph of stage and discharge of Cypress Creek Canal at Pompano, $1940-43$.

149. Map of drainage basins of southern Florida showing mean annual

149. Map of drainage basins of southern Florida showing mean annual

150. Hydrograph of Kissimmee River near Okeechobee, 1937.

151. Lower part of depletion rating curve, Kissimmee River near Okeechobee......

152. Average depletion hydrograph, Kissimmee River near Okeechobee.

153. Relation between rate of base flow and base storage, Kissimmee River near Okeechobee.

154. Recession rating curve of direct runoff, Kissimmee River near Okeechobee. 
Figure 156. Annual rainfall-runoff relation, Kissimmee River near Okeechobee,

157. Monthly rainfall-runoff relations, Kissimmee River near Okeechobee,

158. Monthly change in base flow, Kissimmee River near Okeechobee.

159. Study of the relation between base flow and total storage, Kissimmee

160. Stotige basind cumulative precipitation and runoff during average year, Kissimmee River near Okeechobee.

161. Study of the relation between rate of outflow and storage in the Everglades area, 1940-46.

162. Rainfall-runoff diagram, Everglades area...

163. Location of sampling stations in Biscayne Bay..

164. Analyses of uncontaminated and contaminated ground water.

165. Deviation of cation concentrations in contaminated ground water from computed cation concentrations.

166. Rapids of the Miami River before dredging of Miami Canal.

167. Looking upstream from the mouth of the Miami River before dredging of Miami Canal.

168. Map of metropolitan Miami area showing isochlors for $1928-29$, based on samples of ground water from drainage wells.

169. Maps showing progressive salt-water encroachment in the Miami area, 1904-50.

170. Map of Silver Bluff area, Miami, showing the location of wells used in studies of salt-water encroachment.

17. Graph showing relation between specific gravity and chloride concentration in artificial mixtures of ground water and sea water.

Composite profile for salt-water encroachment study of July 26, 1941, Silver Bluff area, Miami.

173. Composite profile for salt-water encroachment study of February 4 , 1942, Silver Bluff area, Miami.

174. Composite profiles for salt-water encroachment studies of July 26, 1941, and February 4, 1942, Silver Bluff area, Miami.

175. Graph showing correlation between fluctuation of water level in well F 179 and chloride content in 12 wells of the Silver Bluff area, Miami, 1940-46.

eneralized cross section showing isochlor pattern in the Silver

176. Generalized cross section showing isochlor patter
Bluff area, October 1940 and December 1946 . area, Miami, February 4, 1942.

178. Schematic profile to illustrate method of computing theoretical bulk change in ground-water storage due to tides.

179. Profile of Miami Canal above NW. 36th Street Dam showing chioride concentrations on May $15,1945$.

180. Cross sections of Miami Canal at NW. 36th Street and at the Miami Springs-Hialeah bridge showing approximate horizontal layering of salty water on May 15, 1945.

181. Graph of vertical variations of chloride concentration in Biscayne Canal at four phases of a tide cycle.

182. Variations of stage, velocity, and chloride concentration in Snapper Creek Canal during one tidal cycle.

183. Profile of Biscayne Canal showing isochlors at high and low tide on March 24, 1948.

184. Map of Miami area showing maximum observed chloride concentrations in the tidal canals, May-July 1945 .

185. Graph of chloride concentrations in lower Miami Canal during drought period of 1939.

186. Graph of location of 1,000 ppm chloride concentration and discharge of Miami Canal, $1940-46$.

187. Map showing chloride concentrations at sampling stations in lower New River basin, April 30, 1946.

188. Map of Homestead area, showing chloride concentrations in canals, February 22, 23, 1941, and June and July 1945

189. Map of Miami well-field area showing shape of typical cones of depression in the water table.

190. Geologic cross section near the Miami well field: $A$, prior to saltwater intrusion; $L$, the beginning of the intrusion; $C$, several months later; $D$, a late stage. 
Figure 191. Geologic cross section under North New River Canal showing residual salty ground water contaminating fresh canal water.

192. Graph showing variation of chloride in: $A$,Miami Canal at NW. 54th Street; $B$, wells F $1, \mathrm{~F} 2, \mathrm{~F} 3$, and S 68 , Miami well-field area.

193. Isochlor map of the Miami well-field area: $A$, December 1939; $D$, June 1940; C, January $1941 ; D$, February 1942

194. Isochlor map of the Miami well-field area: $A$, J anuary 1943; $B$, March 1943; $C$, May 1943; $D$, September 1943.

195. Isochlor map of the Miami well-field area: $A$, May 1944; $D$, July 1944; $C$, September 1944; and $D$, November 1944

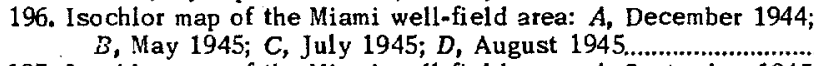

196. Isochlor map of the Miami well-field area: $A$,
B. May 1945; $C$, July 1945; $D$, August 1945 .

197. Isochlor map of the Miami well-field area: $A$, September 1945 ; $B$, November 1945; $C$, January 1946; and $D$, April 1946

198. Isochlor map of the Miami well-field area: $A$, May 1946; $D$, June 1946; C, September 1946; and D, December 1946

199. Map and cross section of the Coconut Grove well-field area showing location and depth of wells and infiltration gallery, isochlor pattern, and water-table profile for June 20,1940

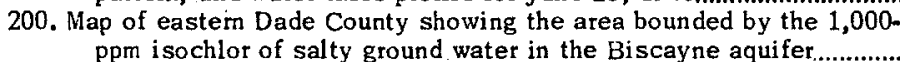

200. Map of eastem Dade County showing the area bounded by the
ppm isochlor of salty ground water in the Biscayne aquifer. showing locations and depths of wells, isochlor pattern, and water-table profile.

202. Specific conductance of salty water for low ranges of chloride content.... 713

203. Specific conductance of salty water for high and low ranges of chloride content.

204. Resistivity curves obtained in the Cutler area

205. Location of resistivity lines and related wells, Silver Bluff area, Miami.

206. Comparison of driller's logs and chloride logs with resistivity interpretations, Silver Bluff area, Miami

207. Location of resistivity lines and related wells, Cutler area.....

208. Comparison of driller's logs and chloride logs with resistivity interpretations, Cutler area.

209. Comparison of driller's logs and chloride logs with resistivity interpretations, Cutler area.

210. Comparison of driller's logs and chloride logs with resistivity interpretations, Cutler area and near Goulds.

211. Location of resistivity lines and related wells, Fort Lauderdale area....

212. Correlation of resistivity layers near Fort Lauderdale

213. Graph showing discharge and dissolved solids in the Kissimmee River near Okeechobee, 1940-41.

214. Location of sampling stations in Lake Okeechobee..

215. Graph showing analyses of waters of the Kissimmee River, Fisheating Creek, and Lake Okeechobee.

216. Graph showing analyses of water from Caloosahatchee and St. Lucie Canals.

217. Graph showing discharge and dissolved solids in North New River Canal at 26-Mile Bend and near Fort Lauderdale, 1941-42.

218. Graph showing chloride concentrations in North New River Canal between South Bay and State Highway 7 .

219. Graph of discharge and dissolved solids in Miami Canal at Water Plant, Hialeah, 1941-42.

220. Graph showing analyses of waters of Miami and North New River Canals.

221. Maps showing chloride concentrations in ground water at different
depths in the Everglades: $A$, wells less than $20-\mathrm{ft}$ deep; $B$, wells 21-50 ft deep; $C$, wells 51-100 ft deep.

222. Map showing hardness of public water supplies in southeastern Florida, 1941.

223. Index map showing municipal water supplies in southern Florida, 


\section{TABLES}

Table 1. Population of 12 counties in area of investigation.

2. List of rain gages in southern Florida showing locations and periods of record

3. Annual precipitation (in inches) in vicinity of Kissimmee-Everglades drainage basin, 1932-46.

4. Amounts of 24-hour rainfall to be expected at rare intervals.

5. Precipitation deficiency and temperature in relation to normal during periods of drought at Miami and Kissimmee.

6. Precipitation deficiency and temperature in relation to normal during periods of drought in southern Florida.

7. Location, description, and period of record of selected evaporation pans operated in southeastem Florida,

8. Monthly and annual evaporation, in inches, for ventilated pan at Belle Glade.

9. Monthly and annual evaporation, in inches, for sunken pan at Moore Haven, Glades County..

10. Monthly and annual evaporation, in inches, for floating pan at West Palm Beach, Palm Beach County.

11. Geologic formations of southeastem Florida,

12. Macrofaunas from U. S. Geological Survey Station 15112 (USGS test well G 188), Krome Road and the Tamiami Trail, 19 miles west of Miami.........

13. Cenozoic time correlations...

14. Tentative correlation of Pleistocene and Pliocene formations in southern Florida.

5. Pleistocene terraces of Southeastem United States.

16. Values of $S$ computed from drawdowns in deep wells.

17. Values of $S$ computed from drawdowns in shallow wells.

18. Drawdown, in feet, for well G 553 and observation wells at end of 5hour pumping test.

19. Computed values of $S$ based on drawdowns after 5 hours of pumping and a value of $T$ equal to $3.5 \mathrm{mgd}$ per $\mathrm{ft}$.

20. Principal datum planes used in the Everglades and in the Miami area,

21. Index of discharge and stage records in Lake Okeechobee and Everglades basins as of Jan. 1, 1947.

22. Runoff of Kissimmee River at outlet of, and below, Lake Kissimmee.

23. Summary of discharge and water-level data at stations in Kissimmee River basin for selected periods

24. Runoff of Reedy Creek near Loughman.

25. Runoff of Kissimmee River near Okeechobee.

26. Runoff from lower Kissimmee River basin.

27. Runoff of Arbuckle Creek near DeSoto City.

28. Runoff of Istokpoga Canal near Comwell

29. Runoff of Fisheating Creek at Palmdale,

30. Runoff of Indian Prairie Canal near Okeechobee.

31. Runoff of Taylor Creek at Okeechobee.

32. Runoff of Caloosahatchee Canal.

33. Runoff of St. Lucie Canal at Lake Okeechobee..

34. Runoff of West Palm Beach Canal at Canal Point.

35. Runoff of West Palm Beach Canal at West Palm Beach,......................................3354

36. Runoff of Hillsboro Canal at Belle Glade...............................................................368

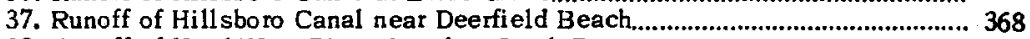

38. Runoff of North' New River Canal at South Bay.................................................. 379

39. Runoff of North New River Canal near Fort Lauderdale ............................... 379

40. Discharge measurements, in cubic feet per second, and elevations, in feet above mean sea level, of South New River, Flamingo, and Snake Creek Canals at intersection.

41. Runoff of South New River Canal near Davie................................................... 396

42. Runoff of Miami Canal at Lake Harbor. 
Table 43. Discharge, in cubic feet per second, and elevation, in feet above mean sea level, at selected points principally in headwater storage area of lower Miami Canal and the upper South New River Canal.

44. Discharge, seepage, and water-level tata on Miami Canal in storage inflow reach, County Line Dam to Pennsuco,

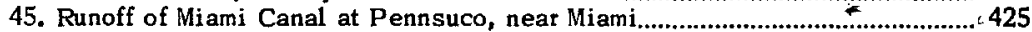

46. Discharge measurements of Pennsuco Lateral at Pennsuco, near Miami....... A26

47. Runoff of Miami Canal at Water Plant, Hialeah................................................... 427

48. Comparison of discharges for Miami Canal at Pennsuco and Water Plant gaging stations.

49. Runoff of Tamiami Canal outlets (between Monroe and the DadeBroward Levee) west of Miami

50. Annual summary of discharges, in cubic feet per second, for gaging stations on Tamiami Canal.

51. Runoff of Tamiami Canal near Coral Gables........................................................... 494

52. Runoff of Tamiami Canal at Red Road, Miami.................................................. 494

53. Runoff of Boynton Canal at Boynton Beach......................................................... 504

54. Cypress Creek Canal at Pompano..................................................................... 507

55. Annual summary of hydrologic data for southeastern Florida .......................... 512

56. Summary of runoff, in inches, for selected drainage basins in southern Florida for calendar years $1930-46$.

57. Weighted average precipitation in Kissimmee River basin above Okeechobee, by months, computed by the Thiessen method from rainfallstation records.

58. Number of rain gages used to determine precipitation in given drainage basins.

59. Monthly runoff analyses, Kissimmee River near Okeechobee, 1930-46........ 533

60. Average monthly and annual hydrologic data, Kissimmee River near Okeechobee, 1931-46

61. Annual summary of hydrologic data, Kissimmee River basin ........................ 550

62. Hydrologic summary of Lake Okeechobee, 1940-46........................................ 552

63. Hydrologic summary of Everglades area south and east of Lake Okeechobee.

64. Annual summary of hydrologic data, Everglades area......................................... 570

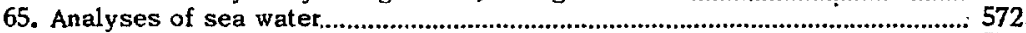

66. Chloride concentrations at sampling stations in Biscayne Bay, May 1940... 576

67. Canals in the Miami area and periods of their construction........................... 587

68. Specific gravity of sea water samples diluted with uncontaminated ground water.

69. Salt-water encroachment data for Silver Bluff area, Miami; July 25, 26, 1941, and February 3, 4, 1942

70. Data and computations for adjusting water-table elevations at two selected sites in Silver Bluff area, February 4, 1942

71. Chloride in Miami Canal during spring and summer of 1939.

72. Chloride concentrations in Snake Creek Canal, Miami.

73. Chloride concentrations in Biscayne Canal, Miami

74. Chloride concentrations in Little River Canal, Mig

75. Chloride concentrations in Tamiami Canal, Miami.................................... 653

76. Chloride concentrations in Coral Gables Canal, Miami.......................................6. 668

77. Chloride concentrations in Snapper Creek Canal, Miami.................................... 674

78. Analyses of ground and surface water at Miami, January 21, 1919................ 689

79. Analyses of water from infiltration gallery and shallow wells in the Coconut Grove well field.

80. Resistivities of layers in the Silver Bluff area, Miami...................................... 718

81. Resistivities of layers in the Cutler area...................................................... 720

82. Analyses, in parts per million, of water from the Kissimmee River near Okeechobee.

83. Analyses, in parts per million, of water from Lake Okeechobee.

84. Analyses, in parts per million, of water from St. Lucie Canal at lock 1 , Lake Okeechobee.

85. Analyses, in parts per million, of water from Caloosahatchee Canal at Moore Haven.

86. Analyses of water from Lake Okeechobee floodway channel near Moore Haven, October 27, 1941

87. Analyses, in parts per million, of water from West Palm Beach Canal at West $\mathrm{Palm}$ Beach. 
Table 88. Analyses, in parts per million, of water from West Palm Beach Canal from Canal Point to West Palm Beach.

89. Analyses, in parts per million, of water from Hillsboro Canal near Deerfield Beach.

0. Analyses, in parts per million, of 10-day composite samples of water from North New River Canal near Fort Lauderdale,

91. Analyses, in parts per million, of water from North River Canal near Fort Lauderdale. Analyses, in parts per million, of water from North New River Canal

92. Analyses, in parts per million, of water from North New Rive
from South Bay to State Highway 7 near Fort Lauderdale

93. Analyses, in parts per million, of water from South New River Canal west of bridge on State Highway 25 .

94. Analyses, in parts per million, of 10-day composite samples of water from Miami Canal at Water Plant, Hialeah.

95. Analyses, in parts per million, of water from Miami Canal at Water Plant, Hialeah. Analyses, in parts per million, of water from Miami Canal north of dam

96. Analy ses, in parts per million, of
at Dade-Broward County line.

97. Analyses, in parts per million, of water from Miami Canal between Royal Palm Dock in Biscayne Bay and Pennsuco, near Hialeah.

98. Analyses, in parts per million, of water from Cypress Creek Canal, at Pompano.

99. Analyses, in parts per million, of water from Tamiami Canal at Krome Road, near Miami.

100. Analyses, in parts per million, of water from Tamiami Canal, near Coral Gables.

101. Analyses, in parts per million, of miscellaneous surface waters in southeastern Florida, 1939-42

102. Analyses, in parts per million, of miscellaneous surface waters in southeastern Florida, May and September 1945.

103. Analyses, in parts per million, of nonartesian waters in the Miami metropolitan area.

104. Analyses, in parts per million, of nonartesian waters in Dade County, outsi de Miami metropolitan area.

105. Analyses, in parts per million, of nonartesian waters in Broward County.

106. Analyses, in parts per million, of nonartesian waters in eastern Palm Beach County

107. Analyses, in parts per million, of nonartesian waters in Glades County..

108. Analyses, in parts per million, of nonartesian waters in Hendry County..

109. Analyses, in parts per million, of nonartesian waters in western Palm Beach County.

110. Analyses, in parts per million, of nonartesian waters in Martin County......
111. Analyses, in parts per million, of nonartesian waters in Okeechobee County.

112. Analyses, in parts per million, of nonartesian waters in Collier County....

113. Analyses, in parts per million, of artesian waters in southeastem Florida,

114. Analyses, in parts per million, of public water supplies in southern Florida, 1941-42

115. Analyses, in parts per million, of public water supplies in southern Florida, 1948

116. Records of wells in Broward County

117. Records of wells in Collier County

118. Records of wells in Dade County.

119. Records of wells in Glades County.

120. Records of wells in Hendry County.

121. Records of wells in Highlands County...

122. Records of wells in Martin County.

123. Records of wells in Okeechobee County.

124. Records of wells in Palm Beach County.

125. Record of well in St. Lucie County..

126. Logs of wells in Broward County.

127. Logs of wells in Dade County.

129. Logs of wells in Hendry County 
Page

Table 130. Logs of wells in Highlands County........................................................ 906

131. Logs of wells in Martin County........................................................................ 908

132. Logs of wells in Okeechobee County............................................................... 909

133. Logs of wells in Palm Beach County.......................................................... 911

134. Log of well in St. Lucie County...................................................................... 917

135. Municipal water supplies in Broward County................................................. 919

136. Municipal water supply in Collier County........................................................ 923

137. Municipal water supplies in Dade County.......................................................... 924

138. Municipal water supply in Glades County............................................................ 928

139. Municipal water supplies in Hendry County......................................................... 929

140. Municipal water supplies in Martin County........................................................ 930

141. Municipal water supply in Monroe County ......................................................... 932

142. Municipal water supply in Okeechobee County................................................. 933

143. Municipal water supplies in Palm Beach County......................................... 934

144. Municipal water supply in St. Lucie County..................................................... 940

145. Interpretations of apparent resistivity curves at Silver Bluff...................... 941

146. Interpretations of apparent resistivity curves at Cutler.............................. 942.

147. Interpretations of apparent resistivity curves at Fort Lauderdale................ 946 


\title{
WATER RESOURCES OF SOUTHEASTERN FLORIDA
}

\section{WITH SPECIAL REFERENCE TO THE GEOLOGY AND GROUND WATER OF THE MIAMI AREA}

\author{
By Garald G. Parker, G. E. Ferguson, S. K. Love, and others
}

\section{AIBS THACT}

The circulation of water, in any form, from the surface of the earth to the atmosphere and back again is called the hydrologic cycle. A comprehensive study of the water resources of any atea must, therefore, include data on the climate of the area.

The humid subtropical climate of southeastem Florida is characterized by relatively high temperatures, alternating semi-annual wet and dry seasons, and usually light but persistent winds.

The recurrence of drought in an area having relatively large rainfall such as southeastem Florida indicates that the agencies that remove water are especially effective. Two of the most important of the agencies associated with climate are evaporation and transpiration, or "evapotranspiration". Evaporation losses from permanent water areas are believed to average between about 40 and 45 inches per year. Over land areas indirect methods must be used to determine losses by evapotranspiration; necessarily, these values are not precise.

Because of their importance in the occurrence and movement of both surface and ground waters, detailed studies were made of the geology and geomorphology of southern Florida.

As a result of widespread crustal movements, southern Florida emerged from the sea in late Pliocene time and probably was slightly tilted to the west. At the beginning of the Pleistocene the continent emerged still farther as a result of the lowering of sea level attending the first widespread glaciation. During this epoch, southern Florida may have stood several hundred feet above sea level.

During the interglacial ages the sea repeatedly flooded southern Florida. The marine members of the Fort Thompson formation in the Lake Okeechobee-Everglades depression and the Caloosahatchee River Valley apparently are the deposits of these interglacial invasions by the sea. The fresh-water marls, sands, and organic deposits of the Fort Thompson formation appear to have accurnulated during glacial ages when sea level was low and the area was a land surface partly occupied by fresh-water lakes and marshes. Elsewhere in southem Florida the deposits are mainly marine limestones and sandy terrace deposits.

The Pliocene surface upon which these Pleistocene sediments were deposited was highest to the north and west of the present Everglades and Kissimmee River basin, and it sloped gently to the south, southeast, and east. On this slightly sloping floor, alternately submerged and emerged, the later materials were built; these materials, modified by wind, rain, and surface and ground waters, have largely determined the present topographic and ecologic character of southem Florida.

The most important aquifer in southern Florida, and the one in which most of the wells are developed, is the Biscayne aquifer. It is composed of parts of the Tamiami formation (Miocene), Caloosahatchee marl (Pliocene), Fort Thompson formation, Anastasia formation, Key Largo limestone, iliami oolite, and Pamlico sand (Pleistocene). In some parts of southem Florida, the Pamlico sand and the Anastasia formation are not a part of the Biscayne aquifer; however, they are utilized in the development of small water supplies. Most of the Caloosahatchee marl and the Fort Thompson formation in the Lake Okeechobee area is of very low permeability. In the northern Everglades their less permeable 
parts contain highly mineralized waters, which appear to have been trapped since the invasions by the Pleistocene seas. These waters have been modified by dilution with fresh ground water and by chemical reactions with surrounding materials.

Sea-level fluctuations, starting at the close of the Pliocene with highest levels and progressing toward the Recent with successively lower levels, have built a series of nearly flat marine terraces abutting against one another much like a series of broad stairsteps. Erosion and solution have defaced and, in places, have obliterated the original surficial forms of these old sea bottoms, shores, and shoreline features, but their remnants today are widespread and, in some places, are easily recognizable.

Ice-age terraces higher than 100 feet above present sea level are not present in southeastem Florida. The terraces recognized and their approximate shoreline elevations are as follows: Wicomico, 100 feet; Penholoway, 70 feet; Talbot, 42 feet; Pamlico, 25 feet; and Silver Bluff, 5 feet.

Southeastern Florida contains few major streams; 'the two largest are the Kissimmee, which empties into Lake Okeechobee, and the Caloosahatchee, which empties into the Gulf of Mexico. The flow in these streams is maintained largely by ground-water seepage from the aquifers underlying the higher terrace lands. Most of the rainfall in southeastem Florida evaporates or is utilized by plant transpiration; most of the remainder enters the permeable soils and percolates downward to the water table where it joins in a slow seaward or stream ward underground flow.

The action of downward and laterally moving ground water has modified land forms and has produced sinkholes, vertical solution pipes (natural wells), and innumerable small rounded ponds aligned with the trend of underground solution channels. Intermingling channels and honeycomb-like holes in the underlying rocks cause extremely high permeabilities in some of the limestone aquifers and produce conditions favorable for the development of wells with exceptionally high yields and extremely low drawdowns.

Ground water occurs under both artesian and nonartesian conditions in southeastem Florida. Nonartesian water is by far the most important because it occurs at shallow depths and is therefore more economical to develop; also, except in the upper Everglades, the quality of this water is the best obtainable for domestic use.

The Biscayne aquifer is composed mainly of sandy limestone and calcareous sandstone with beds and pockets of quartz sand. The aquifer is riddled with solution holes generally filled with the sand, but numerous cavities of considerable size and extent occur. It is one of the most permeable aquifers ever investigated by the U. S. Geological Survey, and ranks with clean, well-sorted gravel in its capacity to transmit water. North of Dania, in Broward County, the aquifer contains considerable amounts of fine sand; this causes a lower coefficient of transmissibility. In the Fort Lauderdale well-field area the transmissibility is about $1,200,000$ gpd per $\mathrm{ft}$, but nearer the coast it is probably higher.

The Biscayne aquifer underlies eastern Dade County to depths ranging from about 70 to 125 feet, but it becomes thinner to the west, and is of lower transmissibility beginning about 15 miles west of Biscayne Bay. In the Everglades, in the latitude of Fort Lauderdale, and along the coastal ridge near Delray Beach, the Fort Thompson formation is finally displaced as the major unit of the aquifer by the Anastasia fomation and the Caloosahatchee marl.

Wells developed in the Biscayne aquifer are usually of open-hole, rock-wall construction, having from 1 foot to about 15 feet of open hole below the bottom of the casing. An average well, 6 inches in diameter and 50 feet deep, will yield 1,000 to 1,500 gpm with a drawdown of less than 4 feet, and it will recover almost immediately. Small wells, 10 to 30 feet deep, are commonly obtained by manually driving a pipe $1 \frac{1 / 4}{4}$ to $2 \frac{1}{2}$ inches in diameter into the ground and developing either an open-hole, a rock-wall, or a sandpoint well. 
The principal artesian aquifer of Florida is here named the Floridan aquifer. It includes most or all of the middle Eocene (Avon Park limestone), upper Eo cene (Ocala limestone), Oligocene (Suwannee limestone), and Miocene (Tampa limestone, but only a minor part of the Hawthom formation). It is found at depths of 800 to 1,200 feet in the southem part of the State where it yields water that is sulfurous, saline, hard, and cormsive. The water in wells penetrating the Floridan aquifer will rise as much as 40 feet bbove see level. The typical well yields about $750 \mathrm{gpm}$ by natural flow.

In the past, water from the Floridan aquifer has had very limited use in southem Florida. It is expensive to develop, and it generally is of poorer quality than shallow ground water. Recently a few artesian wells have been used for cooling purposes; the water is circulated through special cormsion-resistant systems. Also, some wells have been used for irrigation.

In addition to the Floridan aquifer, there are several shallow artesian aquifers in some areas of southern Florida. Chief among these are the Miocene aquifer at Everglades, Collier County, and the Miocene and Pliocene aquifers at Fort Pierce, St. Lucie County, in the Kissimmee River valley. Locally, these are very important aquifers and have not been fully explored and evaluated.

Detailed quantitative studies of the Biscayne aquifer have resulted in the following conclusions:

1. In the Miami area, the aquifer averages about 100 to 125 feet in thickness and is wedge shaped with the blade inland. Around Miami and to the south under the Atlantic Coastal Ridge, the coefficient of transmissibility ranges from about $3,000,000$ to $20,000,000$ gpd per $\mathrm{ft}$ and has a median value of about $5,000,000 \mathrm{gpd}$ per $\mathrm{ft}$. The transmissibility becomes smaller to the north and to the west of Miami because of larger quantities of fine sand in the aquifer. The storage coefficient of the aquifer ranges from about 0.10 to 0.35 and averages about 0.20 .

2. Recharge to the aquifer is chiefly from rainfall, which at times is so localized that ephemeral ground-water mounds often build up under the Atlantic Coastal Ridge to heights considerably above the water level in the Everglades. Under these conditions, ground water flows outward in all directions from the mounds and large quantities of water flow westward into the Everglades as well as eastward into Biscayne Bay.

Studies in the coastal ridge south of Miami indicate that of the average annual rainfall (approximately 60 inches) about 38 inches reach the water table directly, and about 22 inches is lost through evapotranspiration; direct runoff is quite small in relation to these quantities. In general, the canal system in southeastem Florida is not effective in recharging the aquifer; instead, it is highly effective in draining away ground water stored in the aquifer. Only in areas of localized lowering of the water table adjacent to a canal (as in a cone of depression around a well field) do canals contribute a large amount of. recharge to the aquifer. In such places recharge from canals may account for a considerable portion of the total amount pumped from the well field.

3. Discharge from the aquifer is by ground-water flow into drainage canals and Biscayne Bay, evapotranspiration loss to the atmosphere, and pumpage. Of these, discharge into canals and the bay account for about 15 to 25 inches of the rainfall, and the total evapotranspiration loss accounts for about 35 inches. Total pumpage from wells in Dade County is very difficult to estimate, but in 1945 it amounted to about $58.4 \mathrm{mgd}$ or 21,300 million gallons a year.

The limits of the southeastem Florida drainage unit àre not clearly definable because the land is so nearly flat, but the total area drained covers about 9,000 square miles. The physical features and flow characteristics of the drainage system from the Kissimmee River basin to the Miami area are described in detail from north to south. Records of stage and discharge for the period 1940-1946 are presented in tabular and graphical form. 
The northernmost drainage basin in the area is the Kissimmee River valley. Many lakes occupy the northem and westem parts of the basin, but generally it is characterized by low undulating hills and flat, wide, swampy valleys. The altitude varies from about 16 to 325 feet, although most of the basin is below 100 feet.

Lake Okeechobee, south of the Kissimmee River basin, receives natural runoff from the north and northwest and also functions as a disposal reservoir for natural and artificial drainage of excess water from the farm lands to the south and east. Prior to development of the Everglades, Lake Okeechobee overflowed its south shores at high stages, and water moved overland across the Everglades in broad sheets. At present, runoff from the Everglades is largely through the canal system, which serves generally both for irrigation and drainage.

During the period 1940-1946, rainfall ovet the entire southeastem Florida drainage unit averaged about 50 inches. Runoff, as measured in the canals draining to the sea, was equivalent to 7.5 inches over the area. The difference between rainfall and runoff averaged 42.6 inches; this loss was caused by evapotranspiration and changes in storage. There is also an unknown amount of subsurface percolation (ground-water flow) out of the Everglades. However, evapotranspiration is by far the most important factor in the removal of water from the area.

Effective drainage of the coastal ridge, which started about 1909, lowered the freshwater head of the Biscayne aquifer in the Miami area and permitted a wedge of salt water to move inland at depth in the aquifer. It advanced on a broad front all along the shore zone, with tongue-like extensions pushing inland from the wedge under and along each of the tidal drainage canals. The most extensive and most rapid movement occurred in the Silver Bluff area because of the more effective drainage provided by the Miami', Tamiami, and Coral Gables Canals, which surmound it on the landward side. This salt wedge may continue to move slowly inland, interrupted by periods of high water conditions, and it may gradually contaminate new areas. If the Ghyben-Herzberg principle is the goveming factor, the inland movement may be expected to continue until the wedge reaches a place, determined by the average height of the water table, where the weight of fresh water above mean sea level will prevent the salt water from rising above the bottom of the Biscayne aquifer. This limiting height of the water table will probably be about $2 \frac{1}{2}$ feet above the average level of Biscayne Bay or about 3 feet above U. S. Coast and Geodetic Survey mean sea level datum. Salt-water encroachment via the canals can be rather effectively controlled by installing lock-and-dam structures as far downstream as is feasible.

In the coastal areas near Miami and Fort Lauderdale it is possible to map the approximate extent of subsurface salt-water encroachment by making surface electrical resistivity surveys. However, in urban areas some difficulty is caused by interference from power lines, buried pipes, and cables.

The surface waters that discharge into Lake Okeechobee from the north and west are soft, low in dissolved mineral matter, and rather highly colored. The surface waters to the south and east of Lake Okeechobee, which usually flow away from the lake, are variable in chemical character but are usually hard, contain moderate to large amounts of dissolved mineral matter, and are rather highly colored. The amount of dissolved matter in Lake Okeechobee is intermediate between the soft inflowing waters of the north and west and the hard water flowing seaward to the south and east.

Nonartesian waters along the Atlantic Coastal Ridge in Dade and Broward Counties are generally moderately hard, the dissolved mineral matter consisting largely of calcium and bicarbonate. Hardness ranges from about 150 , to $300 \mathrm{ppm}$. Usually, the waters are colored by organic materials. Iron is frequently present in objectionable amounts and, when in combination with organic substances, contributes to the color of the water. The temperature averages $76^{\circ} \mathrm{F}$. Shallow ground water in the Everglades is generally harder and more concentrated than the ground water along the coast because of the presence of saline residues left from former invasions of the sea. The high concentrations of bicarbonate found in some of the shallow ground water may be explained by the phenomenon of cation exchange, largely through the medium of organic matter, which colors practically all the waters in the area.

Artesian water in southeastern Florida is brackish, and generally it is unfit for domestic use and most other purposes. The average temperature is $72^{\circ}$ to $73^{\circ} \mathrm{F}$. 


\section{INTRODUCTION}

By Garald G. Parker

\section{AREA OF INYESTIGATION}

The afore-mentioned water-resources and geologic investigations cover most of southern Florida in a general way. However, it is those parts of southeastern Florida considered to be a present or future source of water supply for Dade County and the cities of Miami, Miami Beach and Coral Gables that is the principal area of investigation covered by this report. It includes most of Dade County, the Everglades, Lake Okeechobee, and parts of Kissimmee River basin and Big Cypress Swamp (see fig. 1).

Investigations of surface-water supply were most intensive in Kissimmee River basin, around Lake Okeechobee, and along the drainage canals because the well-defined surface channels were limited mostly to those areas. Likewise, the investigations of ground-water supplies, with their attendant geologic studies, were concentrated in the Miami area where the promising Biscayne aquifer was found early in the investigation to be of prime importance.

As a result of the war emergency, water-resources investigations (including comprehensive geologic studies) were made in other areas in southern Florida extending along the Atlantic Coastal Ridge from Cocoa on the north to Key West on the south and along the Gulf coast north to and beyond Sarasota. The cooperative studies with the cities of Fort Pierce, Lake Worth, Delray Beach, Fort Lauderdale, Dania, and Fort Myers were of considerable help in filling in local details of the investigation.

\section{PURPOSE OF THE INVESTIGATION}

The rapid increase in population of southern Florida during the past two decades has been phenomenal. As a concomitant of this large population growth there has been increased usage of the natural resources of the area, and various attempts have been made to develop these resources.

The result has been a radical change in the natural hydrologic balance; some changes, which were not anticipated, have had deleterious effects. To study these changes, present conditions, and possible future changes, the U. S. Geological Survey, in cooperation with the cities of Miami, Miami Beach, Coral Gables, and Dade County, began an investigation of the water resources of southeastern Florida in the fall of 1939 (some records of stage and discharge of streams were started in 1930). Particular emphasis was placed on the geology and ground water of the Miami area. 
Table 1.- Popuiation of 12 counties in area of investigation

[From United States Census and Florida State Census]

\begin{tabular}{|c|c|c|c|c|c|c|c|c|c|}
\hline County & 1890 & 1900 & 1910 & 1920 & 1930 & $\begin{array}{l}1935 \\
\text { State } \\
\text { Censts }\end{array}$ & 1940 & $\begin{array}{c}1945 \\
\text { State } \\
\text { Census }\end{array}$ & 1950 \\
\hline $\begin{array}{l}\text { Broward } \\
\text { (Created in } 1915 \text { from Dade and Palm Beach) } \\
\text { Collier } \\
\text { (Created in } 1923 \text { from Lee) } \\
\text { Dade } \\
\text { (Created in } 1836 \text { ) } \\
\text { Glades } \\
\text { (Created in } 1921 \text { from DeSoto) } \\
\text { Tendyy } \\
\text { (Created in } 1923 \text { from Lee) } \\
\text { Htghlands } \\
\text { (Created in } 1921 \text { from DeSoto) } \\
\text { Lee } \\
\text { (Created in } 1887 \text { from Momroe) } \\
\text { Martin } \\
\text { (Created in } 1925 \text { from St Lucle and Palm Beach) } \\
\text { Mouroe } \\
\text { (Created in } 1824 \text { ) } \\
\text { Okeechobee } \\
\text { (Created in } 1917 \text { from Osceola, Palm Beach, St. Lucie) } \\
\text { Palm Beach } \\
\text { (Created in } 1909 \text { from Dade) } \\
\text { \$t. Iucie } \\
\text { (1905 recreated) } \\
\text { Total of the } 12 \text { counties } \\
\text { State of Florida } \\
\text { Proportion of the } 12 \text { counties to the State total, } \\
\text { in percent } \\
\text { Metropolitan Miami area }\end{array}$ & $\begin{array}{r}21,061 \\
391,442 \\
5.4\end{array}$ & $\begin{array}{r}26,032 \\
528,542 \\
4.9 \\
1,681\end{array}$ & $\begin{array}{r}5,577 \\
4,057 \\
49,424 \\
752,619 \\
6,6 \\
5,471\end{array}$ & $\begin{array}{r}19,550 \\
2,132 \\
18,654 \\
7,886 \\
105,650 \\
968,470 \\
10,9 \\
30,215\end{array}$ & $\begin{array}{r}20,094 \\
2,883 \\
142,955 \\
2,762 \\
3,492 \\
9,192 \\
14,900 \\
5,111 \\
13,624 \\
4,129 \\
51,781 \\
7,057 \\
277,980 \\
1,468,211 \\
18.9 \\
126,588\end{array}$ & $\begin{array}{r}23,042 \\
4,790 \\
180,998 \\
2,673 \\
3,711 \\
10,912 \\
16,351 \\
5,214 \\
13,354 \\
3,484 \\
53,194 \\
9,044 \\
326,767 \\
1,606,842 \\
20,3 \\
154,411\end{array}$ & $\begin{array}{r}39,794 \\
5,102 \\
267,739 \\
2,745 \\
5,237 \\
9,246 \\
17,468 \\
6,295 \\
14,078 \\
3,000 \\
79,989 \\
11,871 \\
462,584 \\
1,897,414 \\
24.4 \\
218,000\end{array}$ & $\begin{array}{r}50,442 \\
4,957 \\
315,138 \\
2,281 \\
5,066 \\
16,224 \\
23,593 \\
6,094 \\
19,018 \\
2,919 \\
112,311 \\
12,958 \\
571,001 \\
2,250,061 \\
25,4 \\
254,154\end{array}$ & $\begin{array}{r}83,933 \\
6,488 \\
495,084 \\
2,199 \\
6,051 \\
13,636 \\
23,404 \\
7,807 \\
29,957 \\
3,454 \\
114,688 \\
20,180 \\
806,881 \\
2,771,305 \\
29.1 \\
1458,647\end{array}$ \\
\hline
\end{tabular}

${ }^{1}$ Metropolitan Miami area has grown at expense of rural areas. 
Prior to the entrance of the United States into World War II, the coastal ridge was principally a resort area, with agricultural; commercial, and business interests of only secondary importance; very little manufacturing was done. However, war-time activities created a tremendous stimulus to air, rail, and water transportation, and to agriculture, business, and commerce. Light manufacturing, shipbuilding and repairing, and service industries became important. As a result of these activities the once marked seasonal fluctuation of the population has noticeably diminished.

West of the coastal ridge, and on the southern end of the ridge beyond South Miami, the principal development is agriculture; on the higher limestone areas, citrus fruits, avocados, mangoes, guavas, and other subtropical fruits are grown. The lower lands of the coastal marshes and the Everglades produce truck vegetables and sugarcane.

The principal soils of the Everglades are organic (peats and mucks) and cover 1,900,000 acres (Jones, 1948, p. 63) of which about 100, 000 acres (Allison, 1939, p. 37) was intensively cultivated in 1939. Under the stimulus of World War II, low-water conditions for several years, and the refinancing of Everglades Drainage District, this acreage was about doubled by 1946. The largest development is in the northern part of the Everglades where the soil is thickest (about 8 feet) and where water control can be most effectively practiced. The important crops are sugarcane and truck vegetables; ramie, a fiber plant, shows promise of becoming a valuable crop in the Everglades organic soils, and the fattening of beef cattle is becoming increasingly important.

\section{PROBLEMS RESULTING FROM DEVELOPMENT}

Among the most serious problems resulting from the development of southern Florida are those that arose in part, at least, from the superimposed hydrologic effects of the drainage canals, first constructed about the turn of the century in the interest of reclamation of the Everglades. The construction of the drainage canals has lowered the average water level several feet, not only in the Everglades but also in the coastal ridge. As a result, during times of drought the organic soils dry out almost to the water table, which may fall several feet below the land surface (see figs. 127a and 152); in places beneath the coastal ridge the water table may even fall below sea level, especially during a protracted drought (see figs, 42 and 45 ).

Among the effects of this network of drainage canals on the land, crops, and wildlife of the Everglades have been the following:

1. Shrinkage, compaction, oxidation, burning, and general subsidence of the organic soils. This loss is reported by Jones $(1948$, p. 
79) to be much as 5 feet over extensive areas of the cultivated or: ganic soils; the soil has disappeared in some areas where it was thin.

2. Development of shallow "subsidence valleys". along each major canal extending laterally for 3 to 4 miles (Evans and Allison, 1942, p: $34-46)$.

3. Increase in damage due to frosts, which formerly had been held in check by the large body of water in the Everglades (Clayton, Neller, and Allison, 1942, p. 5).

4. Reduction of much of the original capacity of the canals, owing to loss of vertical section. This condition results from lowering of the land surface; sedimentation of the canal bottoms; slumping of canal banks especially in sand cuts; and blocking by water weeds (such as water hyacinths), fallen trees, and other debris.

5. Cessation of deposition of the organic material that has built the peat and muck soils.

6. Changed ecologic conditions seriously affecting wildlife of the drained areas. This has brought about the migration of some species and the extinction, or near extinction, of others-one of these is the Everglades kite, now almost extinct because of the drainage of the swamps and the destruction of a certain species of fresh-water snails upon which the kite feeds solely (O'Reilly, 1940, p. 129 131-134).

Water problems have become of prime importance. Among these are:

1. The development and protection from salt-water contamination of adequate perennial water supplies for the populous cities and agricultural areas along the coast. It was noted in 1940 that the consumption was about $50 \mathrm{mgd}$ during the winter season for the communities from West Palm Beach to Key West, and that Miami consumed a maximum the previous year of about $33 \mathrm{mgd}$. It was estimated that in 1946 , because of the greatly increased population, approximately 50 percent more water was used. In Miami alone, monthly consumption during the last 6 months of 1946 averaged 56 mgd; this is 171 percent of the monthly consumption for the same period in 1940 .

2. Unregulated flow in the canals during droughts, which allows salty water to move inland in and along the canals (even beyond the coastal ridge in some places), thus contaminating the fresh ground water in adjacent areas. Salty water was observed 11 miles inland in the Miami Canal in 1939. 
3. Changing the naturally established equilibrium that had existed between fresh- and salt-water bodies, by a lowering of the freshwater head in the Biscayne aquifer, which brought about general encroachment of salt water at depth in the aquifer all along the coastal strip. In the Silver Bluff area of Miami this salt-water movement extended inland for a distance of more than 2 miles from Biscayne Bay in 1946.

4. Regulation of the water level in Lake Okeechobee and the canals leading oceanward from it. The St. Lucie and Caloosahatchee Canals form links of the cross-state waterway between Stuart and Fort Myers, on which the Federal Government maintains navigation. The lake is usually held at levels between 12.6 and 15.6 feet above mean sea level, U. S. Coast and Geodetic Survey datum, or 14 and 17 feet, Okeechobee datum. This regulation has been deemed necessary in order to supply adequate water for transportation and, at the same time, to maintain the lake level at a point low enough to prevent hurricane waves from overtopping the flood levee and inundating the adjacent lands. In normal years such control is not difficult, but following a prolonged drought, or a series of exceedingly wet months, it is much more difficult. Regulation to meet the needs of navigation alone would not be too difficult, but the additional consideration of agricultural needs complicates the regulation considerably.

5. Shortage of water for irrigation, municipal supplies, and all other needs in drought periods. Distribution of rainfall is uneven, and means have not been found to store excess water in wet periods.

6. Overloading of the main canals because of added drainage works that facilitate rapid runoff.

7. Flooding of urban developments that have been built in natural floodways during extended periods of low water levels.

\section{SCOPE OF THE INVESTIGATION}

The general scope and objectives of the investigations by the U. S. Geological Survey were largely determined during conferences with representatives of cooperating agencies prior to the beginning of work in the fall of 1939. The local motivating interest was the need for one or more sources of water supply sufficient for present and future municipal needs of the metropolitan area of Miami and for agricultural and industrial purposes of Dade County. These interests were stimulated by the loss to salt-water encroachment of two former well fields of the city of Miami and thousands of private well supplies along the coast of Dade County, and by the recurring threats to the principal existing source of municipal supply. Accordingly, U. S. Geological Survey activities throughout the period 
of study have included the investigation of factors pertinent to an evaluation of all significant sources of water supply that could possibly be utilized by the residents of the cooperating county and municipalities.

As originally planned however, this cooperative program with the above objectives was only a part of a broader concurrent activity by other Federal and State agencies and was known as The Southeastern Florida Joint Investigation. This investigation, initially sponsored and coordinated by the National Resources Planning Board in cooperation with the Florida State Planning Board, also included work programs for the Soil Conservation Service, the Bureau of Agricultural Economics, and the Fish and Wildlife Service. The Corps of Engineers agreed to supply data from its files as needed by the other agencies during the period of investigation. The main objective of the joint investigation was a general study of the natural resources of southeastern Florida for the benefit of future development in the area.

Prior to the termination of its activities on April 1, 1941, the National Resources Planning Board, cooperating with the Florida State Planning Board, coordinated the operations of the several participating agencies through its local representative, Stanley $B$. Wright. Therefore, although the Southeastern Florida Joint Investigation did not continue as such beyond this date, the several agencies have continued to work together in the interests of greatest benefit to the citizens of the area.

It was recognized that an evaluation of possible development of water supply would require the collection of basic geologic, hydrologic, hydraulic, and chemical data over a wide area in southern Florida. For example, the study of existing and possible future ground-water sources in Dade County necessarily included an investigation of the rockstructure, not only in the immediate vicinity but over most of southern Florida, to determine and evaluate basic geologic controls and general characteristics of recharge and ground-water movement. Likewise, studies of possible surfacewater sources necessarily included the evaluation of such fairly distant supplies as Kissimmee River and Lake Okeechobee; the nature of recharge to and discharge from the lake, and the hydraulic and geologic characteristics of all major waterways in the Everglades and the coastal ridge. Determinations of chemical quality of water were made of samples from all water sources investigated.

This report therefore is a compilation of basic information relating to the quantity, chemical quality, and availability of the water resources, and the method of utilization most practicable for development by the cooperating county and municipalities. Most of the data were collected from field observations and research in 
geology and hydrology made during the period of investigation, beginning in the fall of 1939 and extending through the fall of 1946 . Considerable additional data were collected either by the U. S. Geological Survey during other programs of observation, including war-service-connected work, or furnished by other interested parties. A minor amount of information collected by the Survey as late as 1950 has been incorporated into the report.

No attempt is made herein to recommend or specify the details of development of any water supply, because this is not within the Survey's authorized activities. Instead, it is intended that the report should serve as a comprehensive and convenient reference for those charged with the responsibility of both developing and protecting water supplies and for those who use or control water in significant quantities. The data are such as to be useful not only in municipal water-supply development but also in all developments in the southern Florida area that are in any way dependent upon or affected by water.

\section{PREVIOUS INVESTIGATIONS}

Information concerning the geology and water resources of southern Florida is contained in numerous published and unpublished reports. Prior to the present investigation no intensive study of the water resources of southern Florida had been made; Matson and Sanford's 1913 report and Stringfield's 1933 and 1936 reports are among the most important contributions. Significant reports are included in the selected bibliography which appears at the end of this report. 


\section{CLIMATE}

By G. E. Ferguson

\section{INTRODUCTION}

The climate of southern Florida reflects strongly the influence of dominant features of its geographical position. This area is nearer to the equator than any other part of continental United States, and all parts of it are within 60 miles of the coast on either the Gulf of Mexico or the Atlantic Ocean side. The effects of this low latitude and marine exposure make the general climatic conditions markedly dissimilar from other areas in the United States. Its distinctive climate is a major contributing factor to development of both the coastal and inland areas of southeastern Florida. Both tourists and more permanent residents are attracted to the coastal areas by the comparatively warm sunny weather that prevails during the winter months. This weather also favors the successful growing of off-season truck produce and semitropical crops in the interior agricultural areas.

This climate is characterized by warm weather, usually ample rainfall, and usually light but persistent winds. Each of these climatic elements has a distinct influence on the hydrology and water resources of the area and is treated separately below. Climatic data for areas adjacent to, as well as within, the area of study are presented for the purpose of better definition and understanding.

\section{THE HYDROLOGIC CYCLE}

Water evaporating into the atmosphere as vapor from the oceans and other open bodies of water, or from the land surface, is joined with water that is transpired (breathed) into the air from plants, and ascends to form clouds, which, when conditions are right, release the moisture as precipitation upon the earth below. This circulation of water from the surface of the earth to the atmosphere and back again is called the hydrologic cycle. Figure 2 is a schematic representation of this cycle.

The permeable nature of the geologic materials in most of southern Florida allows the rainfall to sink into the ground and become stored in the aquifer. However, not all of the rain contributes to these underground reservoirs. Some of the rain is evaporatedagain. before it sinks into the ground, some reaches the sea through river and canal flows, some remains temporarily in storage in lake basins, some that has entered the ground is caught by plant rootlets and returned to the atmosphere through the leaves of plants as transpired water; the remainder of the rainfall may eventually per- 


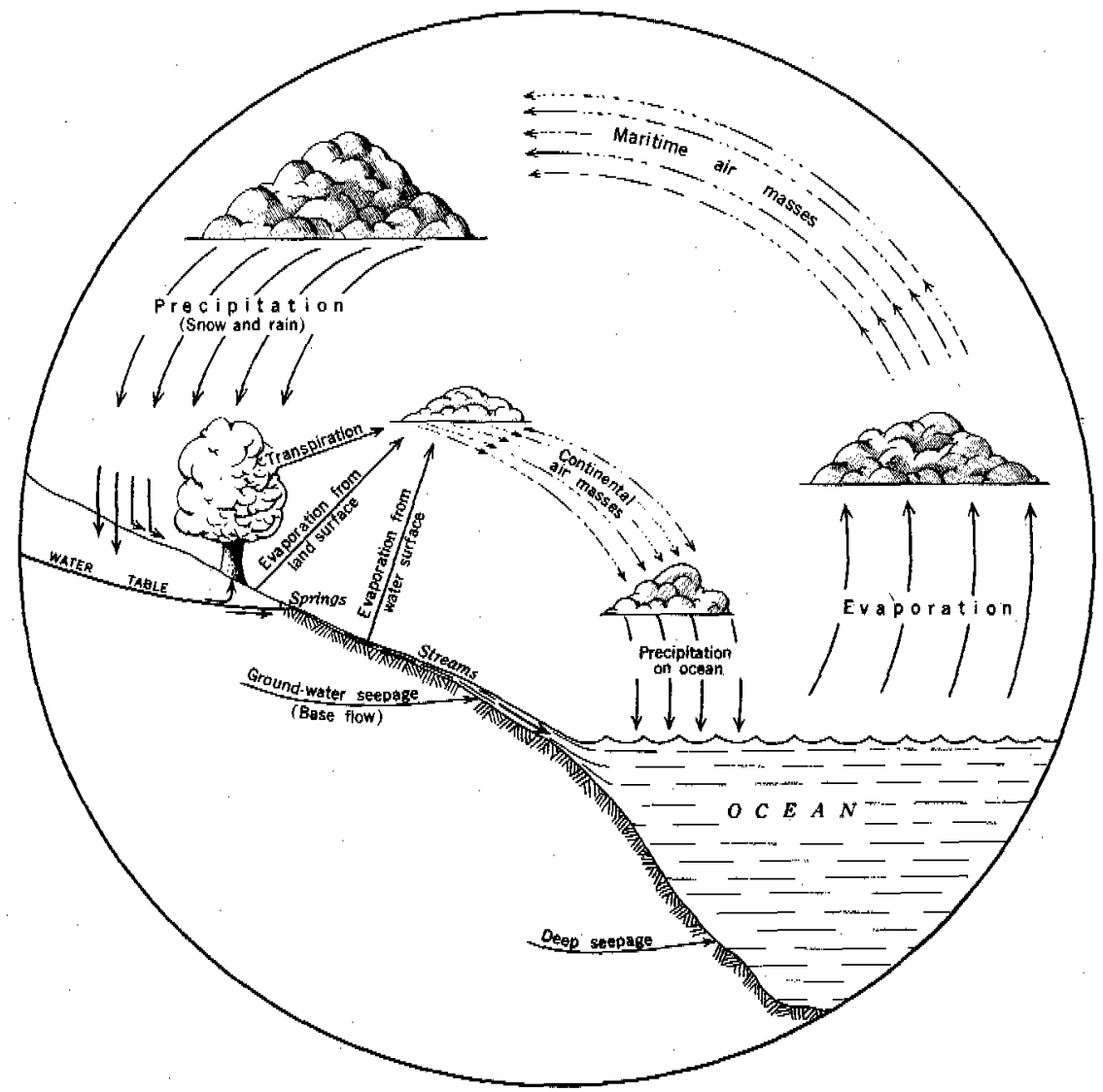

Figure $2,-$ Schematic representation of the hydrologic cycle.

colate through the soil and contribute to the ground water. Thus, the hydrologic cycle is rather complex, because although some water returns to the clouds very soon after precipitation, some returns again only after long periods spent in geologic formations, or in the ocean, and some, through chemical combination with minerals, may never return.

\section{PRECIPITATION}

Of all the climatic elements, precipitation has the greatest and most direct effect upon the water resources of southeastern Florida. Figure 2 illustrates the importance of the role that precipitation plays in the hydrologic cycle. The characteristics of the water supplies in the area are dependent to a large degree on recharge from rainfall during the preceding few weeks or months. Successful evaluation and further development of water supplies, therefore, necessitate a knowledge of the characteristics and amounts of rainfall that are likely to occur. 
In southeastern Florida, the study of precipitation is restricted to rain only, because snow is practically unknown, and light hail occurs only at rare intervals.

\section{RAINFALL RECORDS}

The characteristics of rainfall of a place or region are largely determined from actual measurements at rain gages established at points within and adjacent to the area in question.

The locations of rain gages in southern Florida are shown on plate 1. The recording and nonrecording types are shown by different 'symbols. An index number shown for those gages in and adjacent to the areas under direct study, facilitates reference to a description of that gage given in table 2. This table gives the location, length of record, and operating agency for each gage.

In the fall of 1939 the United States Geological Survey established and started operating 18 recording-type rain gages in areas (principally in the Everglades) without adequate means of investigating water resources.

\section{AVAILABILITY AND PUBLICATION OF RECORDS}

Nearly all of the records of rainfall collected in the area under study were published by the U. $S$. Weather Bureau in its current reports. For this reason, no complete rainfall tabulations are included in this report. The U. S. Weather Bureau's "Climatological Data, Florida section," which is published monthly, includes daily and monthly precipitation at all gages in the area except at a few privately operated stations. A special annual issue of "Climatological Data" contains a summary of monthly and annual totals. Temperature, evaporation, wind, and other current climatic data are included in this publication.

Daily and hourly rainfall at recording rain-gage stations are listed for Florida in the monthly "Hydrologic Bulletin" by the Weather Bureau which are open for inspection at Weather Bureau offices. The "Climatic summary of the United States, section 105, southern Florida 1930" (Martin, 1930) contains valuable compilations and average values of monthly and annual precipitation for the period prior to 1931 . 
Table 2. - List of rain gages in southern Florida showing locotions and periods of record

[Includes stations pertinent to study of water resources of southeastern Florida. Refer to U. S. Weather Bureau publications for names of observers or parties furnishing current records published therein. See reference notes for parties collecting unpublished records and for govemmental agencies operating gages as part of their research programs. Type of data collected as of Dec. 31, 1946. is explained on pl. 1. Records for many older stations are not continuous, but breaks in record of 2 years, or less, are not indicated herein. Absence of termination date indicates station was in operation at end of 1946. HGS is abbreviation for Hurricane Gate Structure]

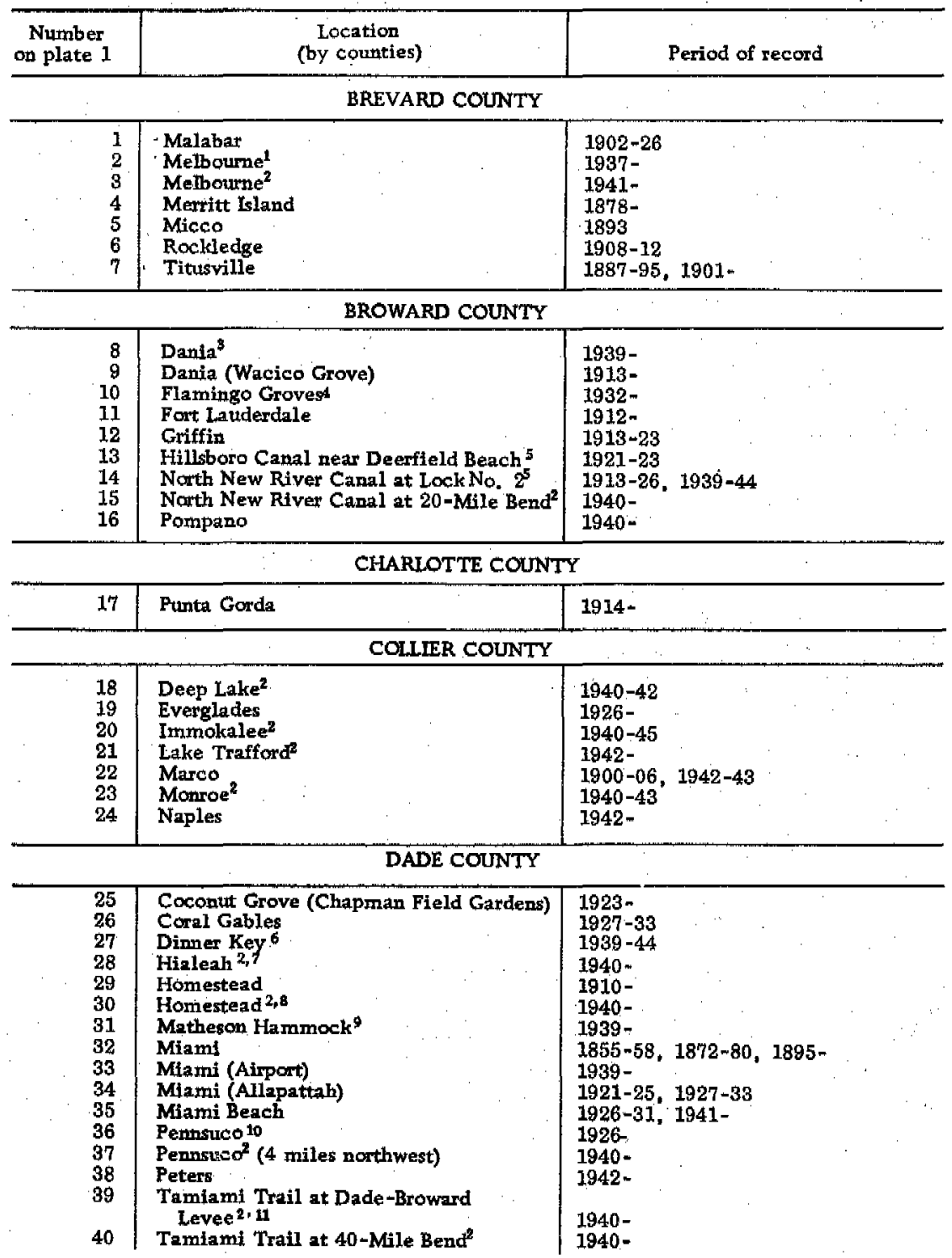


Table 2. - List of rain gaf es in southern Florida showing locations and periods of record-Continued

DE SOTO COUNTY

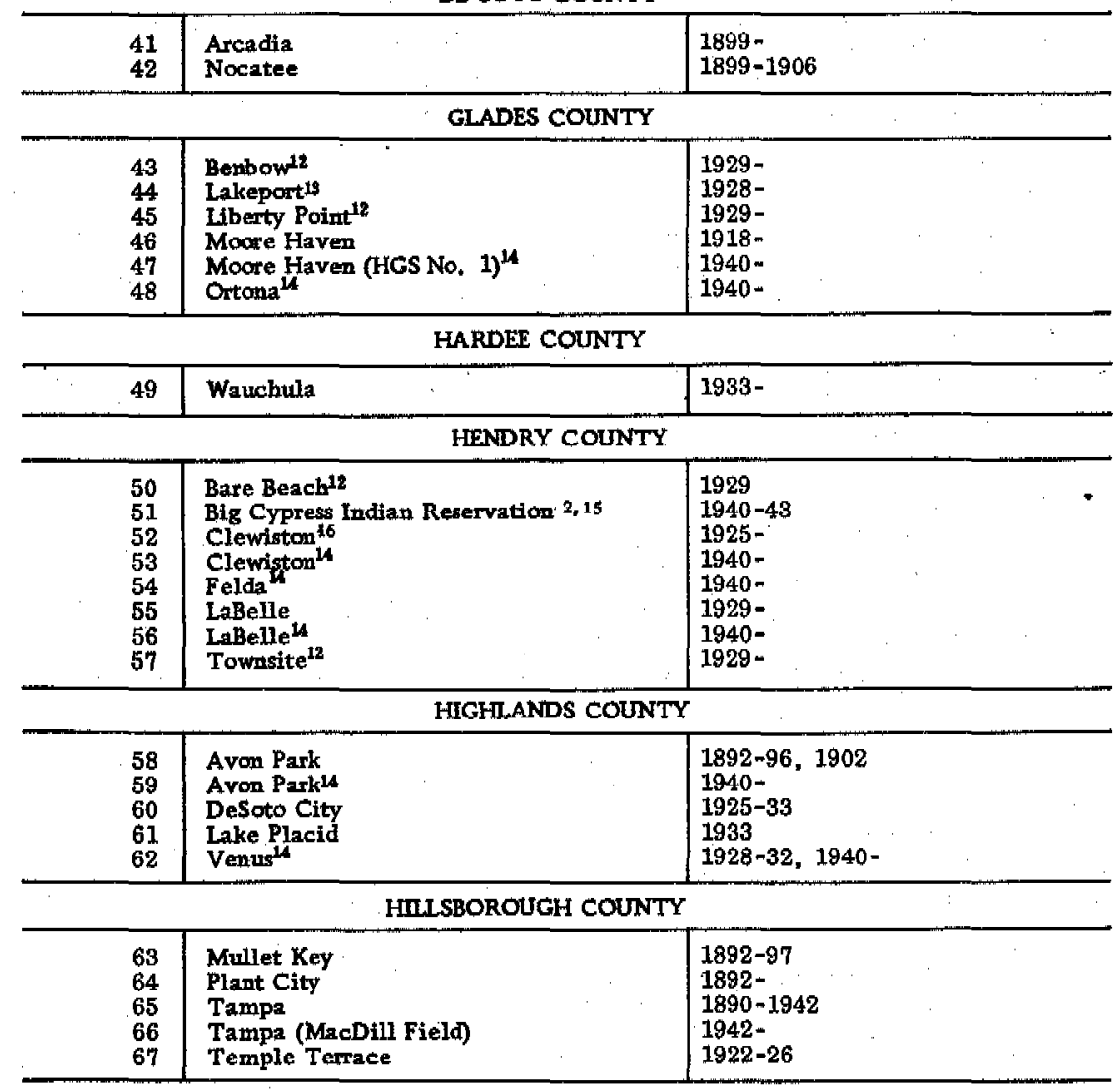

INDIAN RIVER COUNTY

\begin{tabular}{|c|c|c|}
\hline $\begin{array}{l}68 \\
69 \\
70 \\
71\end{array}$ & $\begin{array}{l}\text { Fellsmere } \\
\text { Sebsstian } \\
\text { Vero Beach } \\
\text { Vero Beach } 1\end{array}$ & $\begin{array}{l}1911- \\
1897-1901 \\
1923-26 \\
1940-\end{array}$ \\
\hline \multicolumn{3}{|c|}{ LAKE COUNTY } \\
\hline 72 & Clermont & $1892-$ \\
\hline \multicolumn{3}{|c|}{ LEE COUNTY } \\
\hline $\begin{array}{l}73 \\
74 \\
75 \\
76\end{array}$ & $\begin{array}{l}\text { Bonita Springs } 2 \\
\text { Captiva } \\
\text { Fort Myers } \\
\text { Fort Myers }\end{array}$ & $\begin{array}{l}1942 \\
1939- \\
1851-58,1871-83,1886-1940 \\
1940-\end{array}$ \\
\hline \multicolumn{3}{|c|}{ MANATEE COUNTY } \\
\hline 77 & Bradenton & $1869-$ \\
\hline \multicolumn{3}{|c|}{ MARTIN COUNTY } \\
\hline $\begin{array}{l}78 \\
79 \\
80 \\
81\end{array}$ & $\begin{array}{l}\text { Indian Town } \\
\text { Poet Mayaca14 } \\
\text { Saint Lucie Lock No. } 2^{14} \\
\text { Stuart }\end{array}$ & $\begin{array}{l}1929-34 \\
1940 \\
1940= \\
1935=\end{array}$ \\
\hline
\end{tabular}


Table 2. - List of rain gages in southen Flotida showing locations and periods of record - Continued

\begin{tabular}{|c|c|c|}
\hline \multicolumn{3}{|c|}{ MONROE COUNTY } \\
\hline $\begin{array}{l}82 \\
83 \\
84 \\
85 \\
86 \\
87 \\
88 \\
89\end{array}$ & $\begin{array}{l}\text { Flamingo } \\
\text { Key West } \\
\text { Key West } \\
\text { Ligmumvitae Key } \\
\text { Long Key } \\
\text { Pinecrest } \\
\text { Sand Key } \\
\text { Tavemier }\end{array}$ & $\begin{array}{l}1901-08 \\
1832-38,1843-45,1849-65,1870- \\
1941- \\
1941- \\
1916-35 \\
1928-30 \\
1903-25 \\
1936-\end{array}$ \\
\hline \multicolumn{3}{|c|}{ OKEECHOBEE COUNTY } \\
\hline $\begin{array}{l}90 \\
91 \\
92 \\
93 \\
94\end{array}$ & $\begin{array}{l}\text { Bassenger } \\
\text { Fort Drum } \\
\text { Kissimmee River at State Route } 70^{2} \\
\text { Okeechobee } \\
\text { Okeechobee (HGS No, 6) }\end{array}$ & $\begin{array}{l}1913-17 \\
1942- \\
1931- \\
1913- \\
1940-\end{array}$ \\
\hline \multicolumn{3}{|c|}{ ORANGE COUNTY } \\
\hline $\begin{array}{l}95 \\
96 \\
97 \\
98 \\
99\end{array}$ & $\begin{array}{l}\text { Hart Lake } \\
\text { Isleworth } \\
\text { Lake Hiawassee } \\
\text { Orlando } \\
\text { Orlando (Airport) }\end{array}$ & $\begin{array}{l}1942- \\
1916- \\
1939= \\
1892-1944 \\
1940-\end{array}$ \\
\hline & OSCEOLA COUNT & \\
\hline $\begin{array}{l}100 \\
101 \\
102 \\
103 \\
104 \\
105\end{array}$ & $\begin{array}{l}\text { Hatchineha } \text { Lake }^{2} \\
\text { Holopaw } \\
\text { Kissimmee } \\
\text { Kissimmee } \\
\text { Nittaw } \\
\text { St. Cloud }\end{array}$ & $\begin{array}{l}1942- \\
1941- \\
1888-89,1892- \\
1940- \\
1942- \\
1913-33\end{array}$ \\
\hline \multicolumn{3}{|c|}{ PALM BEACH COUNTY } \\
\hline $\begin{array}{l}106 \\
107 \\
108 \\
109 \\
110 \\
111 \\
112 \\
113 \\
114 \\
115 \\
116 \\
117 \\
118 \\
119 \\
\\
120 \\
121 \\
122 \\
123 \\
124 \\
125 \\
126 \\
127 \\
128 \\
129 \\
130\end{array}$ & 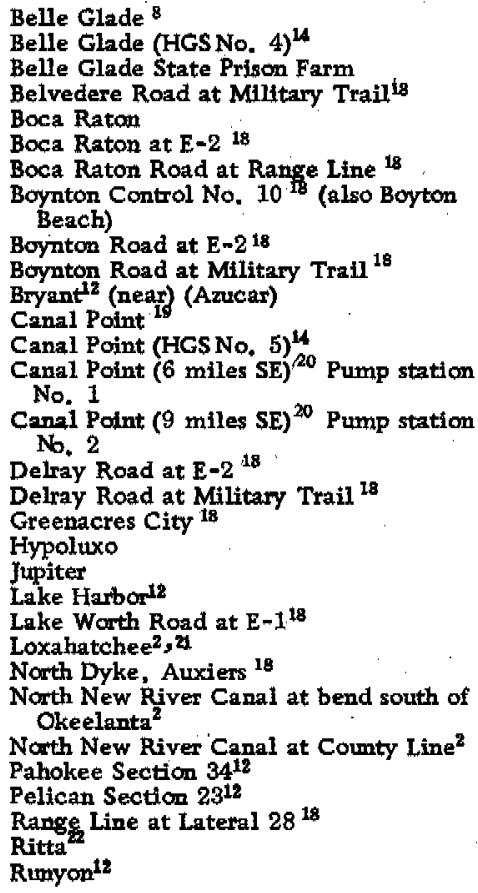 & $\begin{array}{l}1924- \\
1940- \\
1936- \\
1940-42 \\
1941- \\
1928- \\
1940- \\
1928- \\
1928= \\
1940= \\
1929= \\
1922= \\
1940= \\
1939- \\
1941- \\
1928- \\
1940- \\
1928- \\
1890-96,1900- \\
1888-1911,1920-29 \\
1929- \\
1940= \\
1940- \\
1928= \\
1940- \\
1940- \\
1939- \\
1931- \\
1940- \\
1913-32,1937- \\
1942-\end{array}$ \\
\hline
\end{tabular}


Table 2.- List of tain gages in sotthem Florida showing locations and periods of record-Continued

\begin{tabular}{|c|c|c|}
\hline \multicolumn{3}{|c|}{ PALM BEACH COUNTY-Continued } \\
\hline $\begin{array}{l}137 \\
138 \\
139 \\
140 \\
141 \\
142 \\
143\end{array}$ & $\begin{array}{l}\text { Shawano Plantation } \\
\text { South Bay } \\
\text { South Shore } \\
\text { West Palm Beach } \\
\text { West Palm Beach } \\
\text { West Palm Beach } \\
\text { West Palm Beach }\end{array}$ & $\begin{array}{l}1929- \\
1929- \\
1940- \\
1920-32 \\
1927- \\
1929- \\
1938-\end{array}$ \\
\hline \multicolumn{3}{|c|}{ PASCO COUNTY } \\
\hline 144 & St. Leo & $1895-$ \\
\hline \multicolumn{3}{|c|}{ PDELLAS COUNTY } \\
\hline $\begin{array}{l}145 \\
146 \\
147 \\
148\end{array}$ & $\begin{array}{l}\text { Clearwater } \\
\text { Pinellas Park } \\
\text { St. Petersburg } \\
\text { Tarpon Springs }\end{array}$ & $\begin{array}{l}1931- \\
1911-37 \\
1891-94,1914- \\
1891-\end{array}$ \\
\hline \multicolumn{3}{|c|}{ POLK COUNTY } \\
\hline $\begin{array}{l}149 \\
150 \\
151 \\
152 \\
153 \\
154 \\
155 \\
156 \\
157 \\
158 \\
159 \\
160 \\
161 \\
162\end{array}$ & $\begin{array}{l}\text { Bartow } \\
\text { Davenport } \\
\text { Fort Meade } \\
\text { Ftostproof } \\
\text { Grape Hammock }{ }^{14} \\
\text { Haines City } \\
\text { Homeland } \\
\text { Kissimmee River at State Route } 60^{2} \\
\text { Lake Alfred } \\
\text { Lake Wales } \\
\text { Lakeland } \\
\text { Mammoth Groves } \\
\text { Mountain Lake } \\
\text { Winter Haven }\end{array}$ & $\begin{array}{l}1887- \\
1923-45 \\
1851-54,1885-1920 \\
1895-97 \\
1940- \\
1942- \\
1893-95 \\
1932-43 \\
1924- \\
1921-37 \\
1915- \\
1921-32 \\
1935- \\
1941-\end{array}$ \\
\hline \multicolumn{3}{|c|}{ SAINT LUCIE COUNTY } \\
\hline 163 & Fort Pierce & $1852-58,1901-$ \\
\hline \multicolumn{3}{|c|}{ SARASOTA COUNTY } \\
\hline $\begin{array}{l}164 \\
165\end{array}$ & $\begin{array}{l}\text { Sarasota } \\
\text { Venice }\end{array}$ & $\begin{array}{l}1930- \\
1941=\end{array}$ \\
\hline
\end{tabular}

${ }^{1}$ Operated by U. S. Civil Aeronautics Authority,

${ }^{2}$ Operated by U. $\mathrm{s}$. Geological Survey.

${ }^{3}$ Operated by Florida Power \& Light Co.

Operated by Flamingo Groves, Inc.

5 Operated by Everglades Drainage District.

${ }_{7}^{6}$ Operated by Pan American Alrways.

${ }^{7}$ Operated by city of Miami.

Operated by State Agricultural Experiment Station.

Operated by Dade Coumty.

${ }^{10}$ Operated by Graham Dairy.

11Prior to July 1942 located 2 miles west.

${ }^{12}$ Operated by U. \$. Sugar Cotp.

${ }^{13}$ Operated by J. L. Beck.

14 Operated by Corps of Engineers.

15 Observations by Bureau of Indian Affairs.

16Operated by Clewiston Drainage District.

17 Operated by Soll Comservation Service.

18Operated by Lake Worth Drainage District.

190 perated by Department of Agriculture and U. S. Sugar Corp.

200perated by Pahokee Drainage District.

21 Also Loxahatchee Groves record from 1929.

${ }^{22}$ From 1937, location 1 mile west and operation changed to U, S. Sugar Corp.

23. Operated by Shawano Plantation, Inc.

${ }^{4}$ Operated by West Palm Beach Water Co. 


\section{CHARACTERISTICS OF RAINFALL}

\section{ANNUAL RANFAL,}

The average annual rainfall in southeastern Florida varies from a maximum of more than 60 inches along the east coast in the vicinity of Miami and Fort Lauderdale to less than 50 inches in the interior areas in the vicinity of Lake Okeechobee, and along the Florida Keys off the southern end of the peninsula. The areal distribution for the State is shown in figure 3 , on which is plotted average annual rainfall at the several stations for the number of years of record indicated. Isohyetal lines were not drawn, because it is believed that additional years of record will be needed to define the areal distribution of rainfall in the Everglades. There are wide areas in the Everglades where rainfall is as yet unmeasured. Even without isohyetal lines figure 3 can provide a satisfactory illustration of the general areal distribution of rainfall in southern Florida by. scanning the annual averages shown in their respective positions, as qualified by the indicated period or number of years of record. A study of this map indicates that the mean rainfall over the southeastern Florida area is somewhat greater than the 53-inch average for the entire State and that it is nearly twice as great as the 29 -inch average for the entire continental United States.

The variations in annual values from the mean or average for the period of record can be illustrated from a study of the rainfall records, for Miami, where the record since 1901 shows a mean deviation from average of 12,1 inches (equal to 21 percent of the 57. 3-inch average). The minimum annual rainfall was 28,66 inches in 1944, and the maximum rainfall was 85.36 inches in 1908. During the past 7 calendar years of study (1940-46) the average annual rainfall was 46.7 inches (about 11 inches below the long-term average).

An examination of the 51-year continuous record of rainfall at Miami reveals two 6-year below-normal sequences (1913-1918 and 1941-46) and a 6-year sequence above normal (1929-1934). These sequences may encourage inquiry in regard to the persistence of rainfall to continue an above-normal or below-normal trend, A count of the rainfall of the 51-year Miami record indicates that the rainfall for 28 years continued the same in relation to normal as the preceding year. The ratio $28 / 50=0.56$ is slightly above the 0,50 ratio for simple chance. A count of total precipitation in 2-year successive groups (e.g., $1896+1897 ; 1897+1898$, etc.) gives a persistence ratio of $26 / 48=0.54$, and of 3 -year groups $26 / 46=0,57$; the tendency for rainfall to continue the same in relation to normal is probably not significant.

There is a record of rainfall at Okeechobee near the mouth of the Kissimmee River that began in 1913 (there is no record for 


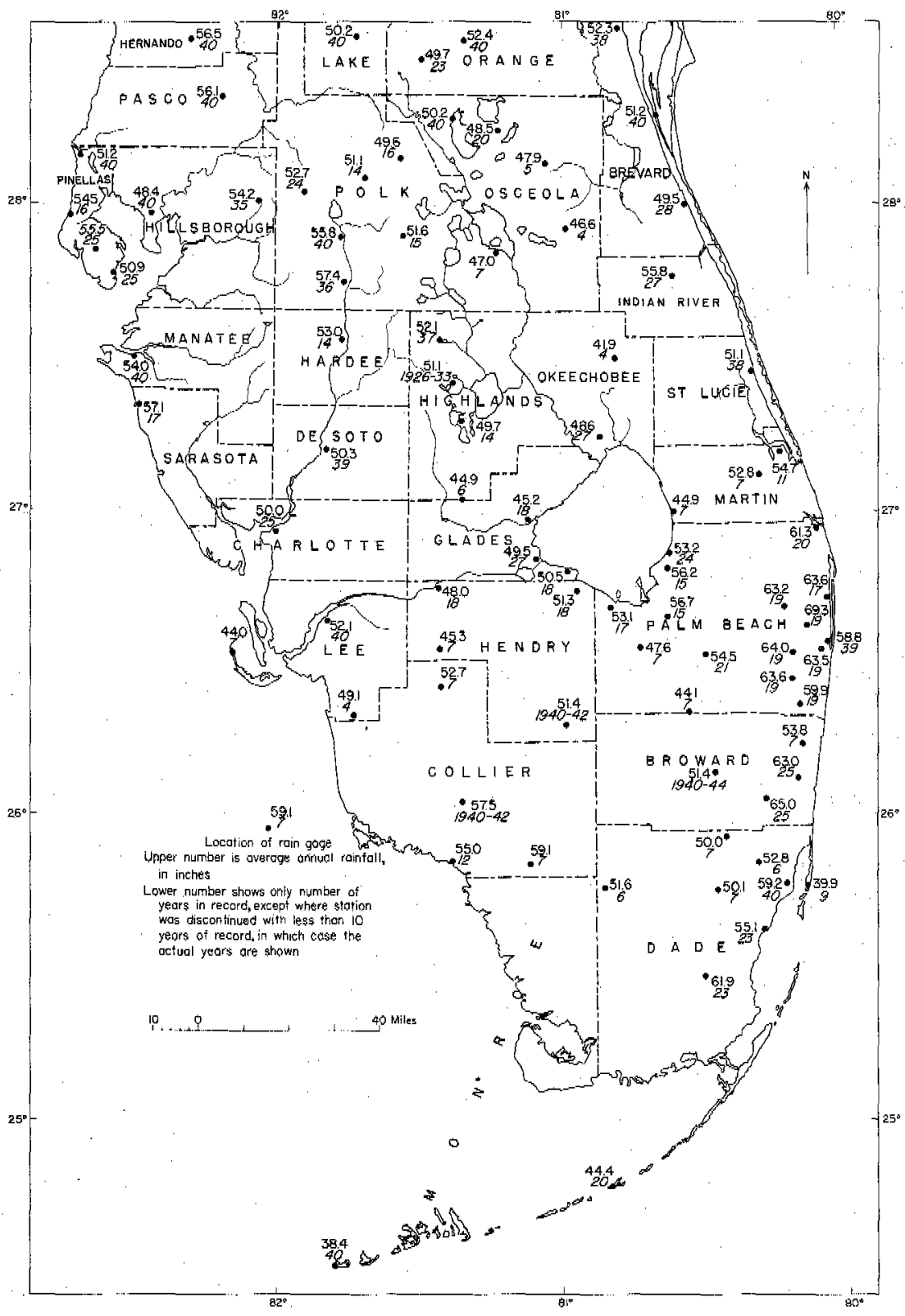

Figure 3. -Map showing average annual precipitation, in inches, for southern Florida. 
Table 3.- Annual precipitation (in inches) in vicinity

\begin{tabular}{|c|c|c|c|c|c|c|}
\hline \multicolumn{2}{|l|}{ Statíon } & \multirow[b]{2}{*}{ County } & \multirow[b]{2}{*}{$\begin{array}{c}\text { Length } \\
\text { of } \\
\text { record } \\
\text { (years) }\end{array}$} & \multirow[b]{2}{*}{$\begin{array}{l}\text { Average } \\
\text { annual } \\
\text { precipi- } \\
\text { tation }\end{array}$} & \multicolumn{2}{|c|}{1932} \\
\hline Location & $\begin{array}{l}\text { No, on } \\
\text { plate } 1\end{array}$ & & & & Depth & $\begin{array}{l}\text { Percent } \\
\text { of } \\
\text { normal }\end{array}$ \\
\hline 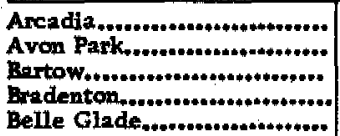 & $\begin{array}{r}41 \\
59 \\
149 \\
77 \\
106\end{array}$ & 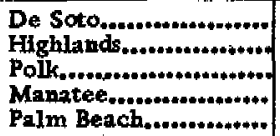 & $\begin{array}{l}47 \\
50 \\
60 \\
64 \\
23\end{array}$ & $\begin{array}{l}50,30 \\
52,12 \\
55,78 \\
54,00 \\
56,70\end{array}$ & $\begin{array}{l}33.52 \\
38.67 \\
52.74 \\
46.32 \\
65.09\end{array}$ & $\begin{array}{r}67 \\
74 \\
95 \\
86 \\
115\end{array}$ \\
\hline 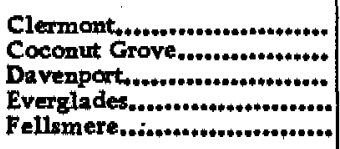 & $\begin{array}{r}72 \\
25 \\
150 \\
19 \\
68\end{array}$ & 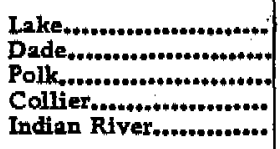 & $\begin{array}{l}54 \\
23 \\
23 \\
21 \\
35\end{array}$ & $\begin{array}{r}50.20 \\
455,10 \\
49.63 \\
55.05 \\
55.75\end{array}$ & $\begin{array}{l}38.16 \\
64.75 \\
41.11 \\
60.20 \\
50.26\end{array}$ & $\begin{array}{r}76 \\
83 \\
109 \\
90\end{array}$ \\
\hline 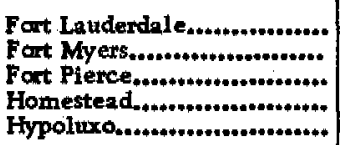 & $\begin{array}{r}11 \\
75 \\
163 \\
29 \\
124\end{array}$ & 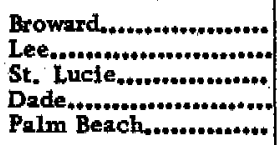 & $\begin{array}{l}34 \\
63 \\
52 \\
37 \\
54\end{array}$ & $\begin{array}{l}62.98 \\
52.06 \\
51.06 \\
61.88 \\
58.75\end{array}$ & $\begin{array}{l}64.97 \\
52.85 \\
49.91 \\
69.75 \\
69.85\end{array}$ & $\begin{array}{r}103 \\
101 \\
98 \\
113 \\
119\end{array}$ \\
\hline 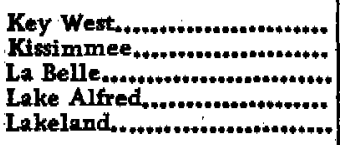 & $\begin{array}{r}83 \\
103 \\
55 \\
157 \\
159\end{array}$ & 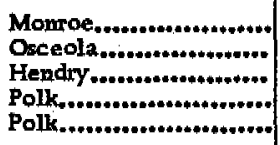 & $\begin{array}{l}99 \\
56 \\
16 \\
24 \\
32\end{array}$ & $\begin{array}{r}38.36 \\
50.24 \\
446.87 \\
51.14 \\
52.70\end{array}$ & $\begin{array}{l}40.42 \\
47.11 \\
51.57 \\
38.90 \\
41.32\end{array}$ & $\begin{array}{r}105 \\
94 \\
110 \\
76 \\
78\end{array}$ \\
\hline 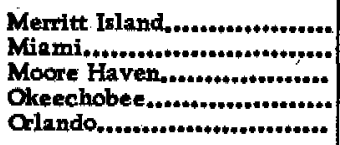 & $\begin{array}{r}4 \\
32 \\
46 \\
93 \\
98,99\end{array}$ & 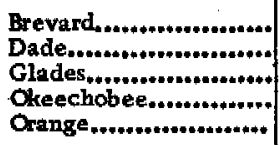 & $\begin{array}{l}68 \\
55 \\
29 \\
28 \\
55\end{array}$ & $\begin{array}{l}51.20 \\
59.18 \\
49.52 \\
48.61 \\
52.45\end{array}$ & $\begin{array}{l}56.27 \\
79.90 \\
54.97 \\
45.78 \\
39.90\end{array}$ & $\begin{array}{r}110 \\
135 \\
111 \\
94 \\
76\end{array}$ \\
\hline 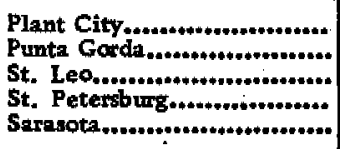 & $\begin{array}{r}64 \\
17 \\
144 \\
147 \\
164\end{array}$ & $\begin{array}{l}\text { Hillsborough............. } \\
\text { Charlotte................. } \\
\text { Pasco } \\
\text { Pinellas........................ } \\
\text { Sarasota.t................ }\end{array}$ & $\begin{array}{l}50 \\
33 \\
54 \\
36 \\
17\end{array}$ & $\begin{array}{r}54.24 \\
49.98 \\
56.12 \\
50.90 \\
44.89\end{array}$ & $\begin{array}{l}42.64 \\
43.69 \\
40.49 \\
50.19 \\
46.56\end{array}$ & $\begin{array}{l}79 \\
87 \\
72 \\
99 \\
85\end{array}$ \\
\hline 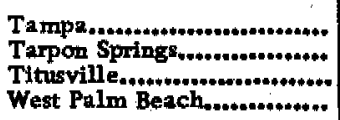 & $\begin{array}{r}65,66 \\
148 \\
7 \\
142\end{array}$ & 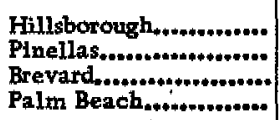 & $\begin{array}{l}57 \\
56 \\
54 \\
17\end{array}$ & $\begin{array}{r}48.35 \\
51.18 \\
52.31 \\
463.03\end{array}$ & $\begin{array}{l}44.72 \\
45.85 \\
47.19 \\
63.38\end{array}$ & $\begin{array}{r}92 \\
89 \\
90 \\
101\end{array}$ \\
\hline
\end{tabular}

See footnotes at end of table. 
of Kissimmeo-Everdlades drainabe basin, 1932-46

\begin{tabular}{|c|c|c|c|c|c|c|c|c|c|c|c|}
\hline \multicolumn{2}{|c|}{1933} & \multicolumn{2}{|c|}{1934} & \multicolumn{2}{|c|}{1935} & \multicolumn{2}{|c|}{1936} & \multicolumn{2}{|c|}{1937} & \multicolumn{2}{|c|}{1938} \\
\hline Depth & $\begin{array}{c}\text { Percent } \\
\text { of } \\
\text { normal }\end{array}$ & Depth & $\begin{array}{c}\text { Percent } \\
\text { of } \\
\text { normal }\end{array} \mid$ & Depth & $\begin{array}{c}\text { Percent } \\
\text { of } \\
\text { nommal }\end{array}$ & Depth & $\mid \begin{array}{c}\text { Percent } \\
\text { of } \\
\text { noxmal }\end{array}$ & Depth & $\begin{array}{c}\text { Percent } \\
\text { of } \\
\text { nommal }\end{array}$ & Depth & $\begin{array}{c}\text { Percent } \\
\text { of } \\
\text { normal }\end{array}$ \\
\hline $\begin{array}{l}47.71 \\
57.42 \\
68.02 \\
50.93 \\
65.26\end{array}$ & $\begin{array}{r}95 \\
110 \\
122 \\
94 \\
115\end{array}$ & $\begin{array}{l}42.27 \\
44.95 \\
65.64 \\
56.23 \\
62.24\end{array}$ & $\begin{array}{r}84 \\
86 \\
118 \\
104 \\
110\end{array}$ & $\begin{array}{l}50.08 \\
53.47 \\
52.35 \\
54.28 \\
48.81\end{array}$ & $\begin{array}{r}100 \\
102 \\
94 \\
101 \\
86\end{array}$ & $\begin{array}{l}56.29 \\
65.77 \\
51.73 \\
57.32 \\
64.57\end{array}$ & $\begin{array}{r}112 \\
126 \\
93 \\
106 \\
114\end{array}$ & $\begin{array}{l}61.16 \\
53.02 \\
59.38 \\
52.04 \\
58.44\end{array}$ & $\begin{array}{r}121 \\
102 \\
106 \\
96 \\
103\end{array}$ & $\begin{array}{l}42.78 \\
37.12 \\
44.77 \\
46.11 \\
40.99\end{array}$ & $\begin{array}{r}85 \\
71 \\
80 \\
85 \\
72\end{array}$ \\
\hline $\begin{array}{l}65.12 \\
51.28 \\
62.37 \\
49.63 \\
62.66\end{array}$ & $\begin{array}{r}130 \\
126 \\
90 \\
112\end{array}$ & $\begin{array}{l}54.43 \\
55.45 \\
59.15 \\
56.88 \\
65.85\end{array}$ & $\begin{array}{c}108 \\
\ldots \ldots \ldots \\
119 \\
103 \\
118\end{array}$ & $\begin{array}{l}54.89 \\
50.82 \\
38.84 \\
55.36 \\
62.72\end{array}$ & $\begin{array}{r}109 \\
78 \\
101 \\
112\end{array}$ & $\begin{array}{l}48.88 \\
79.09 \\
47.88 \\
65.52 \\
67.00\end{array}$ & $\begin{array}{r}97 \\
96 \\
119 \\
120\end{array}$ & $\begin{array}{l}53,34 \\
55,16 \\
48,92 \\
51.68 \\
60.88\end{array}$ & $\begin{array}{r}106 \\
99 \\
94 \\
109\end{array}$ & $\begin{array}{l}37.06 \\
47.39 \\
34.57 \\
48.89 \\
41.00\end{array}$ & $\begin{array}{l}70 \\
89 \\
74\end{array}$ \\
\hline $\begin{array}{l}75.23 \\
46.36 \\
69.92 \\
70.33 \\
67.48\end{array}$ & $\begin{array}{r}119 \\
89 \\
137 \\
113 \\
115\end{array}$ & $\begin{array}{l}64.78 \\
46.20 \\
41.32 \\
65.18 \\
52.45\end{array}$ & $\begin{array}{r}103 \\
89 \\
81 \\
105 \\
89\end{array}$ & $\begin{array}{l}52.85 \\
50.21 \\
46.44 \\
69.73 \\
54.39\end{array}$ & $\begin{array}{r}84 \\
96 \\
91 \\
113 \\
93\end{array}$ & $\begin{array}{l}76.49 \\
67.13 \\
73.86 \\
84.12 \\
57.01\end{array}$ & $\begin{array}{r}121 \\
129 \\
145 \\
136 \\
97\end{array}$ & $\begin{array}{l}-44.22 \\
69.17 \\
65.10 \\
43.00\end{array}$ & $\begin{array}{r}85 \\
135 \\
105 \\
73\end{array}$ & $\begin{array}{r}41.05 \\
42.00 \\
38.22 \\
40.42 \\
40.32\end{array}$ & $\begin{array}{l}65 \\
81 \\
75 \\
65 \\
69\end{array}$ \\
\hline $\mid \begin{array}{l}52.02 \\
65.44 \\
45.55 \\
54.52 \\
58.89\end{array}$ & $\begin{array}{r}136 \\
130 \\
97 \\
107 \\
112\end{array}$ & $\begin{array}{l}31.50 \\
58.50 \\
43.86 \\
64.43 \\
58.89\end{array}$ & $\begin{array}{r}82 \\
116 \\
93 \\
126 \\
112\end{array}$ & $\begin{array}{l}39,62 \\
40,45 \\
44.63 \\
42.11 \\
55,23\end{array}$ & $\begin{array}{r}103 \\
81 \\
95 \\
82 \\
105\end{array}$ & $\begin{array}{l}50.46 \\
45.59 \\
53.64 \\
53.97 \\
49.78\end{array}$ & $\begin{array}{r}131 \\
91 \\
114 \\
106 \\
94\end{array}$ & $\begin{array}{l}44.29 \\
54.88 \\
43.83 \\
53.32 \\
51.52\end{array}$ & $\begin{array}{r}116 \\
109 \\
93 \\
104 \\
98\end{array}$ & $\begin{array}{l}22.58 \\
33.03 \\
41.26 \\
37.50 \\
44.70\end{array}$ & $\begin{array}{l}59 \\
66 \\
88 \\
73 \\
85\end{array}$ \\
\hline $\begin{array}{l}56.01 \\
66.05 \\
41.45 \\
54.42 \\
57.42\end{array}$ & $\begin{array}{r}109 \\
111 \\
84 \\
112 \\
109\end{array}$ & $\begin{array}{l}52.84 \\
68.79 \\
48.20 \\
49.16 \\
50.30\end{array}$ & $\begin{array}{r}103 \\
116 \\
97 \\
101 \\
96\end{array}$ & $\begin{array}{l}48.40 \\
47.91 \\
40.87 \\
51.46 \\
49.27\end{array}$ & $\begin{array}{r}95 \\
81 \\
83 \\
106 \\
94\end{array}$ & $\begin{array}{l}58.33 \\
77.30 \\
57.30 \\
55.46 \\
52.18\end{array}$ & $\begin{array}{r}114 \\
131 \\
116 \\
114 \\
99\end{array}$ & $\begin{array}{l}44,98 \\
57,50 \\
60,33 \\
50,96 \\
59,10\end{array}$ & $\begin{array}{r}88 \\
97 \\
122 \\
105 \\
113\end{array}$ & $\begin{array}{l}42.79 \\
43.74 \\
33.78 \\
43.31 \\
34.55\end{array}$ & $\begin{array}{l}84 \\
74 \\
68 \\
89 \\
66\end{array}$ \\
\hline $\begin{array}{l}71.76 \\
51.96 \\
64.97 \\
51.10 \\
64.66\end{array}$ & $\begin{array}{l}132 \\
104 \\
116 \\
100 \\
118\end{array}$ & $\begin{array}{l}56.37 \\
52.61 \\
69.85 \\
52.37 \\
47.61\end{array}$ & $\begin{array}{r}104 \\
105 \\
125 \\
103 \\
87\end{array}$ & $\begin{array}{l}49.49 \\
47.36 \\
57.55 \\
45.75 \\
57.18\end{array}$ & $\begin{array}{r}91 \\
95 \\
103 \\
90 \\
104\end{array}$ & $\begin{array}{l}55,21 \\
56.55 \\
55.85 \\
52.87 \\
65.48\end{array}$ & $\begin{array}{l}102 \\
113 \\
100 \\
104 \\
119\end{array}$ & $\begin{array}{l}56,19 \\
50,27 \\
60.73 \\
58,91 \\
46.99\end{array}$ & $\begin{array}{r}104 \\
101 \\
108 \\
116 \\
86\end{array}$ & $\begin{array}{l}44.41 \\
43.98 \\
49.16 \\
39.93 \\
57.41\end{array}$ & $\begin{array}{r}82 \\
88 \\
88 \\
78 \\
105\end{array}$ \\
\hline $\begin{array}{l}50,07 \\
48,81 \\
58,67 \\
86,46\end{array}$ & $\begin{array}{r}103 \\
95 \\
112 \\
137\end{array}$ & $\begin{array}{l}56,48 \\
52,22 \\
47.79 \\
53,72\end{array}$ & $\begin{array}{r}117 \\
102 \\
91 \\
85\end{array}$ & $\begin{array}{l}53.71 \\
48.25 \\
66.36 \\
59.13\end{array}$ & $\begin{array}{r}111 \\
94 \\
127 \\
94\end{array}$ & $\begin{array}{l}49.35 \\
55.90 \\
53.91 \\
71.48\end{array}$ & $\begin{array}{l}102 \\
109 \\
103 \\
113\end{array}$ & $\begin{array}{l}55.00 \\
64.25 \\
49.31 \\
62.98\end{array}$ & $\begin{array}{r}114 \\
125 \\
94 \\
100\end{array}$ & $\begin{array}{l}41.93 \\
46.81 \\
35.18 \\
44.34\end{array}$ & $\begin{array}{l}87 \\
91 \\
67 \\
69\end{array}$ \\
\hline
\end{tabular}


Table 3.- Annual precipitation (in inches) in vicinity

\begin{tabular}{|c|c|c|c|c|c|c|c|c|}
\hline \multicolumn{2}{|l|}{ Station } & \multirow[b]{2}{*}{ County } & \multirow[b]{2}{*}{$\begin{array}{c}\text { Length } \\
\text { of } \\
\text { recard } \\
(\text { years) }\end{array}$} & \multirow{2}{*}{$\begin{array}{l}\text { Average } \\
\text { ammal } \\
\text { precipi- } \\
\text { tation }\end{array}$} & \multicolumn{2}{|c|}{1939} & \multicolumn{2}{|c|}{1940} \\
\hline Location & $\begin{array}{l}\text { No, on } \\
\text { plate } 1\end{array}$ & & & & Depth & $\begin{array}{l}\text { Percent } \\
\text { of } \\
\text { nermal }\end{array}$ & Depth & $\begin{array}{c}\text { Petapht } \\
\text { of } \\
\text { normal }\end{array}$ \\
\hline 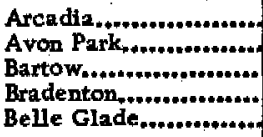 & $\begin{array}{r}41 \\
59 \\
149 \\
77 \\
106\end{array}$ & $\begin{array}{l}\text { De So } \\
\text { Highi } \\
\text { Polk. } \\
\text { Manat } \\
\text { Palm }\end{array}$ & $\begin{array}{l}47 \\
50 \\
60 \\
64 \\
23\end{array}$ & $\begin{array}{l}50.50 \\
52.12 \\
55.78 \\
54.00 \\
56,70\end{array}$ & $\begin{array}{l}59.32 \\
62.51 \\
54.21 \\
54.63 \\
55.49\end{array} \mid$ & $\begin{array}{r}118 \\
120 \\
97 \\
101 \\
98\end{array}$ & $\begin{array}{l}57.55 \\
57.27 \\
45.83 \\
48.05 \\
54.94\end{array}$ & $\begin{array}{r}114 \\
110 \\
82 \\
89 \\
97\end{array}$ \\
\hline 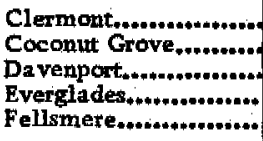 & $\begin{array}{r}72 \\
25 \\
150 \\
19 \\
68\end{array}$ & 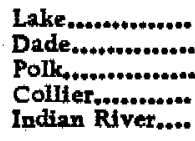 & $\begin{array}{l}54 \\
23 \\
23 \\
21 \\
35\end{array}$ & $\begin{array}{r}50.20 \\
455.10 \\
49.63 \\
55.05 \\
55.75\end{array}$ & $\begin{array}{l}51.30 \\
51.87 \\
61.77 \\
50,70 \\
60.23\end{array}$ & $\begin{array}{r}102 \\
124 \\
92 \\
108\end{array}$ & $\begin{array}{l}47.88 \\
56.15 \\
49.32 \\
54.69 \\
58.58\end{array}$ & $\begin{array}{r}95 \\
99 \\
99 \\
105\end{array}$ \\
\hline $\begin{array}{l}\text { ort Lauderdale......... } \\
\text { ort Myers................ } \\
\text { ort Pierce............... } \\
\text { lomestead............... } \\
\text { lypoluxo.................. }\end{array}$ & $\begin{array}{r}11 \\
75 \\
163 \\
29 \\
124\end{array}$ & 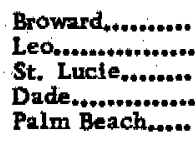 & $\begin{array}{l}34 \\
63 \\
52 \\
37 \\
54\end{array}$ & $\begin{array}{l}62.98 \\
52.06 \\
51.06 \\
61.88 \\
58.75\end{array}$ & $\mid \begin{array}{l}48,46 \\
65,33 \\
44,13 \\
64,04 \\
49,53\end{array}$ & $\begin{array}{r}77 \\
125 \\
86 \\
103 \\
84\end{array}$ & $\begin{array}{l}70.75 \\
56.55 \\
50.29 \\
70.37 \\
62.42\end{array}$ & $\begin{array}{r}112 \\
109 \\
99 \\
113 \\
106\end{array}$ \\
\hline 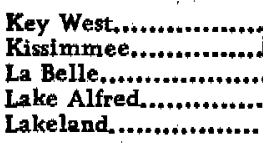 & $\begin{array}{r}83 \\
103 \\
55 \\
157 \\
159\end{array}$ & $\begin{array}{l}\text { Monroe............ } \\
\text { Osceola..........* } \\
\text { Hendry............ } \\
\text { Polk............... } \\
\text { Polk,............. }\end{array}$ & $\begin{array}{l}99 \\
56 \\
16 \\
24 \\
32\end{array}$ & $\begin{array}{r}38.36 \\
50.24 \\
46.87 \\
51.14 \\
52.70\end{array}$ & $\begin{array}{l}42.12 \\
54.85 \\
43.10 \\
58.91 \\
57.98\end{array}$ & $\begin{array}{r}110 \\
109 \\
92 \\
115 \\
110\end{array}$ & $\begin{array}{l}41.50 \\
49.58 \\
50.49 \\
40.03 \\
44.22\end{array}$ & $\begin{array}{r}108 \\
99 \\
108 \\
78 \\
84\end{array}$ \\
\hline 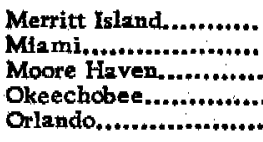 & $\begin{array}{r}4 \\
32 \\
46 \\
93 \\
98,99\end{array}$ & $\begin{array}{l}\text { Brevard............ } \\
\text { Dade............... } \\
\text { Glades............. } \\
\text { Okeechobee..... } \\
\text { Orange............. }\end{array}$ & $\begin{array}{l}68 \\
55 \\
29 \\
28 \\
55\end{array}$ & $\begin{array}{l}51.20 \\
59.18 \\
49.52 \\
48.61 \\
52.45\end{array}$ & $\begin{array}{l}57.39 \\
49.74 \\
56.20 \\
52.42\end{array}$ & $\begin{array}{r}97 \\
100 \\
116 \\
100\end{array}$ & $\begin{array}{l}54.31 \\
71.65 \\
58.50 \\
52.97 \\
54.02\end{array}$ & $\begin{array}{l}106 \\
121 \\
118 \\
109 \\
103\end{array}$ \\
\hline 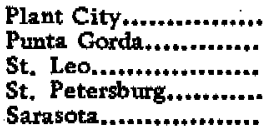 & $\begin{array}{r}64 \\
17 \\
144 \\
147 \\
164\end{array}$ & $\begin{array}{l}\text { Hillsborough.... } \\
\text { Charlotte......... } \\
\text { Pasco.............. } \\
\text { Pinellas.......... } \\
\text { Sarasota.......... }\end{array}$ & $\begin{array}{l}50 \\
33 \\
54 \\
36 \\
17\end{array}$ & $\begin{array}{r}54.24 \\
49.98 \\
56.12 \\
50.90 \\
454.89\end{array}$ & $\begin{array}{l}60.64 \\
55.79 \\
50.90 \\
61.41 \\
62.81\end{array}$ & $\begin{array}{r}112 \\
112 \\
91 \\
121 \\
114\end{array}$ & $\begin{array}{l}43.61 \\
55.50 \\
43.87 \\
43.49 \\
44.05\end{array}$ & $\begin{array}{r}80 \\
111 \\
78 \\
85 \\
80\end{array}$ \\
\hline 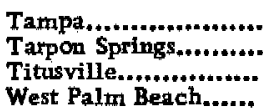 & $\begin{array}{r}65, \quad 66 \\
148 \\
7 \\
142\end{array}$ & $\begin{array}{l}\text { Hillsborough.... } \\
\text { Pinellas........... } \\
\text { Brevard......... } \\
\text { Palm Beach..... }\end{array}$ & $\begin{array}{l}57 \\
56 \\
54 \\
17\end{array}$ & $\begin{array}{r}48.35 \\
51.18 \\
52.31 \\
463.03\end{array}$ & $\begin{array}{l}51.71 \\
55.05 \\
48.42 \\
46.57\end{array}$ & $\begin{array}{r}107 \\
108 \\
98 \\
72\end{array}$ & $\begin{array}{l}42.98 \\
46.67 \\
55.68 \\
87.52\end{array}$ & $\begin{array}{r}89 \\
91 \\
106 \\
139\end{array}$ \\
\hline
\end{tabular}

1Through 1946.

2Except as noted, normals given are as publlshed in "Climate and Man," Yearbook of Dept. of Agr. 1941 .

November and December 1945 rainfall estimated.

4Computed from 1943 "Climatological Data," U. S. Weather Bureau.

5 December 1941 rainfall estimated.

${ }^{\circ}$ Record incomplete.

7 February 1938 rainfall estimated.

A April 1941 rainfall estimated.

- Station relocated.

${ }^{10}$ November and December 1942 rainfall estimated. 
of Kissimmee-Everglades drainage basin, 1932-46-Continued

\begin{tabular}{|c|c|c|c|c|c|c|c|c|c|c|c|}
\hline \multicolumn{2}{|c|}{1941} & \multicolumn{2}{|c|}{1942} & \multicolumn{2}{|c|}{1943} & \multicolumn{2}{|c|}{1944} & \multicolumn{2}{|c|}{1945} & \multicolumn{2}{|c|}{1946} \\
\hline Depth & $\begin{array}{c}\text { Percent } \\
\text { of } \\
\text { not }\end{array}$ & Depth & $\begin{array}{c}\text { Percent } \\
\text { of } \\
\text { normal }\end{array}$ & Depth & $\begin{array}{c}\text { Percent } \\
\text { of } \\
\text { nornal }\end{array}$ & Depth & $\begin{array}{c}\text { Percent } \\
\text { of } \\
\text { normal }\end{array}$ & Depth & $\begin{array}{c}\text { Percent } \\
\text { of } \\
\text { nomal }\end{array}$ & Depth & $\begin{array}{c}\text { Percent } \\
\text { of } \\
\text { normal }\end{array}$ \\
\hline $\begin{array}{l}55.68 \\
55.53 \\
56.13 \\
48.01 \\
63.53\end{array}$ & $\begin{array}{r}111 \\
106 \\
101 \\
89 \\
112\end{array}$ & $\begin{array}{l}53.82 \\
53.67 \\
56.30 \\
47.81 \\
65.82\end{array}$ & $\begin{array}{r}107 \\
103 \\
101 \\
89 \\
116\end{array}$ & $\begin{array}{l}57.08 \\
51,01 \\
53,61 \\
68,52 \\
43,20\end{array}$ & $\begin{array}{r}113 \\
98 \\
96 \\
127 \\
76\end{array}$ & $\begin{array}{l}41,57 \\
47,68 \\
48,99 \\
29,45 \\
52,12\end{array}$ & $\begin{array}{l}83 \\
91 \\
88 \\
55 \\
92\end{array}$ & $\begin{array}{l}53,55 \\
54,66 \\
58,08 \\
53.89 \\
50,65\end{array}$ & \begin{tabular}{r|}
106 \\
105 \\
104 \\
100 \\
89
\end{tabular} & $\begin{array}{l}49,55 \\
50,70 \\
50,22 \\
42.04 \\
70,94\end{array}$ & $\begin{array}{r}99 \\
97 \\
90 \\
78 \\
125\end{array}$ \\
\hline $\begin{array}{c}52.66 \\
59.32 \\
62.09 \\
51.6 \\
78.83\end{array}$ & $\begin{array}{r}105 \\
108 \\
125 \\
94 \\
141\end{array}$ & $\begin{array}{l}47.11 \\
54.90 \\
50.72 \\
36.50 \\
60.60\end{array}$ & $\begin{array}{r}94 \\
100 \\
102 \\
66 \\
109\end{array}$ & $\begin{array}{l}49.20 \\
50.77 \\
47.78 \\
40.64 \\
61.20\end{array}$ & $\begin{array}{r}98 \\
92 \\
96 \\
74 \\
110\end{array}$ & $\begin{array}{l}56.11 \\
43.34 \\
55.36 \\
42.24 \\
64.70\end{array}$ & $\begin{array}{r}112 \\
79 \\
112 \\
77 \\
116\end{array}$ & $\begin{array}{l}59,6 \\
55,15 \\
67.74 \\
57.42 \\
52,44\end{array}$ & $\begin{array}{r}119 \\
100 \\
136 \\
104 \\
94\end{array}$ & $\begin{array}{l}49.00 \\
62.64 \\
56.27 \\
56.44\end{array}$ & $\begin{array}{l}102 \\
101\end{array}$ \\
\hline $\begin{array}{r}55.01 \\
62.92 \\
73.43 \\
76.47 \\
64.87\end{array}$ & $\begin{array}{r}87 \\
121 \\
144 \\
124 \\
110\end{array}$ & $\begin{array}{l}53.05 \\
53.92 \\
47.46 \\
63.31 \\
67.45\end{array}$ & $\begin{array}{r}84 \\
103 \\
93 \\
102 \\
115\end{array}$ & $\begin{array}{l}47.38 \\
62.45 \\
49.63 \\
56.80 \\
46.37\end{array}$ & $\begin{array}{r}75 \\
120 \\
97 \\
90 \\
79\end{array}$ & $\begin{array}{l}41,61 \\
34,17 \\
48.34 \\
51,15 \\
34,70\end{array}$ & $\begin{array}{l}66 \\
66 \\
95 \\
83 \\
59\end{array}$ & $\begin{array}{c}\left({ }^{6}\right) \\
52,58 \\
51,88 \\
54,28 \\
56,41\end{array}$ & $\begin{array}{r}101 \\
102 \\
88 \\
96\end{array}$ & $\begin{array}{c}(6) \\
42.45 \\
43.59 \\
64.27 \\
53.34\end{array}$ & $\begin{array}{r}82 \\
85 \\
104 \\
91\end{array}$ \\
\hline $\begin{array}{l}52.01 \\
63.10 \\
55.97 \\
57.30 \\
59.76\end{array}$ & $\begin{array}{l}136 \\
125 \\
119 \\
112 \\
113\end{array}$ & $\begin{array}{l}29.03 \\
45.50 \\
43.88 \\
44.99 \\
39.57\end{array}$ & $\begin{array}{l}76 \\
91 \\
94 \\
88 \\
75\end{array}$ & $\begin{array}{l}36.53 \\
41.50 \\
47.65 \\
53.64 \\
49.40\end{array}$ & $\begin{array}{r}95 \\
83 \\
102 \\
105 \\
94\end{array}$ & $\begin{array}{l}31.93 \\
43.34 \\
48.60 \\
58.02 \\
40.70\end{array}$ & $\begin{array}{r}83 \\
86 \\
104 \\
113 \\
77\end{array}$ & $\begin{array}{l}40.93 \\
50.13 \\
62.74 \\
60.55 \\
52.24\end{array}$ & $\begin{array}{r}107 \\
100 \\
134 \\
118 \\
99\end{array}$ & $\begin{array}{l}31.68 \\
48.75 \\
50.40 \\
51.89 \\
47.05\end{array}$ & $\begin{array}{r}83 \\
97 \\
108 \\
101 \\
89\end{array}$ \\
\hline $\begin{array}{l}59.79 \\
51.34 \\
61.64 \\
53.42 \\
59.65\end{array}$ & $\begin{array}{r}117 \\
87 \\
124 \\
110 \\
114\end{array}$ & $\begin{array}{l}39.10 \\
56.80 \\
44.74 \\
44.03 \\
41.29\end{array}$ & $\begin{array}{l}76 \\
96 \\
90 \\
91 \\
79\end{array}$ & $\begin{array}{l}40.09 \\
44.82 \\
39.54 \\
39.81 \\
49.40\end{array}$ & $\begin{array}{l}78 \\
76 \\
80 \\
82 \\
94\end{array}$ & $\begin{array}{r}47,34 \\
28,66 \\
42.70 \\
36.38 \\
94.85\end{array}$ & $\begin{array}{l}92 \\
48 \\
86 \\
75 \\
93\end{array}$ & $\begin{array}{l}49.61 \\
34.54 \\
45.48 \\
43.41 \\
55.95\end{array}$ & $\begin{array}{r}97 \\
58 \\
92 \\
89 \\
107\end{array}$ & $\begin{array}{l}51.55 \\
39.04 \\
40.88 \\
37.45 \\
50.13\end{array}$ & $\begin{array}{r}101 \\
66 \\
83 \\
77 \\
96\end{array}$ \\
\hline $\begin{array}{r}61.20 \\
45.44 \\
60.05 \\
45.77 \\
55.83\end{array}$ & $\begin{array}{r}113 \\
91 \\
107 \\
90 \\
102\end{array}$ & $\begin{array}{l}48.82 \\
51.77 \\
60.09 \\
44.64 \\
46.14\end{array}$ & $\begin{array}{r}90 \\
104 \\
107 \\
88 \\
84\end{array}$ & $\begin{array}{l}57.98 \\
48,90 \\
63.30 \\
56.20 \\
75.93\end{array}$ & $\begin{array}{r}107 \\
98 \\
113 \\
110 \\
138\end{array}$ & $\begin{array}{l}45.41 \\
38.89 \\
54.30 \\
38.40 \\
35.75\end{array}$ & $\begin{array}{l}84 \\
78 \\
97 \\
75 \\
65\end{array}$ & $\begin{array}{l}59.78 \\
56.54 \\
81.93 \\
62.66 \\
55.38\end{array}$ & $\begin{array}{l}110 \\
113 \\
146 \\
123 \\
101\end{array}$ & $\begin{array}{l}44.89 \\
50.07 \\
51.79 \\
45.75 \\
39.03\end{array}$ & $\begin{array}{r}83 \\
100 \\
92 \\
90 \\
71\end{array}$ \\
\hline $\begin{array}{l}54.25 \\
62.46 \\
66.38 \\
66.64\end{array}$ & $\begin{array}{l}112 \\
122 \\
127 \\
106\end{array}$ & $\begin{array}{r}38.66 \\
9.1068 .8 \\
48.63 \\
\cdot 66.36\end{array}$ & $\begin{array}{r}80 \\
124 \\
93 \\
105\end{array}$ & $\begin{array}{l}44.89 \\
59.59 \\
47.57 \\
50.69\end{array}$ & $\begin{array}{r}93 \\
116 \\
91 \\
80\end{array}$ & $\begin{array}{c}34.87 \\
(6) \\
65.57 \\
44.91\end{array}$ & $\begin{array}{r}72 \\
125 \\
71\end{array}$ & $\begin{array}{l}66.65 \\
58.75 \\
60.55 \\
73.02\end{array}$ & $\begin{array}{l}138 \\
115 \\
116 \\
116\end{array}$ & $\begin{array}{l}59.12 \\
61.53 \\
51.21 \\
66.93\end{array}$ & $\begin{array}{r}122 \\
120 \\
98 \\
106\end{array}$ \\
\hline
\end{tabular}


1923). Average rainfall at Okeechobee for a 33 -year period is 47.9 inches. The average deviation is 6.8 inches, or 14 percent of the average, indicating a slightly less variable rainfall regimen than at Miami. During the 7-year study period, rainfall averaged 43. 9 inches, 4 inches less than the long-term average. Persistence of precipitation trends is about the same as at Miami; $18 / 31 \quad(=0.58)$ for 1 -year period, $9 / 14(=0.64)$ for 2 -year groups, and $4 / 8(=0.50)$ for 3-year groups, indicating little, if any, persistence in rainfall trends at Okeechobee.

\section{AREAL DISTRIBUTION}

Annual rainfall variations in southern Florida during the 15-year period 1932-46 are shown by figures in table 3 and are indicated on the maps in plate 2. Every year shows areas of above-normal rainfall and areas of below - normal rainfall. Although quite definite areas of above- and below-normal precipitation may be delineated, it seems unusual that factors producing rainfall in Florida would not have been sufficiently uniform, in any of the 15 years, to produce rainfall either entirely above, or entirely below, normal for the entire southern part of the peninsula. Some examples of great contrast between stations can be noted. In 1932, precipitation at Miami totaled 135 percent of normal (third highest of the record), whereas at Arcadia it totaled only 67 percent of normal (lowest of record).

In 1945 the difference in annual precipitation between two stations (Coconut Grove and Miami), only about 11 miles apart, was 20.61 inches. The difference in rainfall between Miami and two nearby stations (with short records and therefore not listed in table 3 ) is even more pronounced. In 1944 it was 27.8 inches in Pennsuco (about 19 miles distant), and in 1946 it was 27.95 inches in Peters (15. 5 miles distant).

There are also considerable variations in the monthly rainfall for stations only a few miles apart. For example, Miami and Miami Airport gages are about 5 miles apart, yet some of the monthly rainfalls have differed by more than 11 inches, and it is not uncommon for the daily rainfall at the se two stations to differ by more than 2 inches.

No detailed studies of rainfall patterns have been made, but it is apparent that there is usually a considerable variation in both daily and annual rainfall within distances of a few miles; most of the precipitation occurs as local showers, which have a high intensity over only a few square miles or over a few city blocks. 
The seasonal distribution of rainfall at selected stations in southern Florida is shown in figure 4. The concentration of a large part of the annual rainfall during the summer months is a characteristic common to all of the Florida peninsula; this rainfall distribution coincides to some extent with the demands of evapotranspiration, and therefore it tends to maintain a more nearly uniform moisture condition. During the 5-month period, June to October, southern Florida usually receives more rain than any other section of the country. Aside from this general characteristic, monthly distribution of rainfall over southern Florida is not uniform; rather, the contrasts that occur in short distances are remarkable when compared with the coastal plain of the country immediately to the north. On the west coast of the peninsula June and July are the rainiest months. On the lower east coast (illustrated by Miami and Key West) there are two high points, one in spring and the other in fall-September and October are the rainiest months of the year. At inland stations there is an intermediate distribution (see graph for Kissimmee, fig. 4).

The contrast between the distribution of rainfall during July and during October is of special interest. During July, the average rainfall exceeds 9 inches in the region about Tampa Bay. In the Miami region, July precipitation is about 6 inches. Normal October precipitation exceeds 9 inches along a narrow coastal fringe between

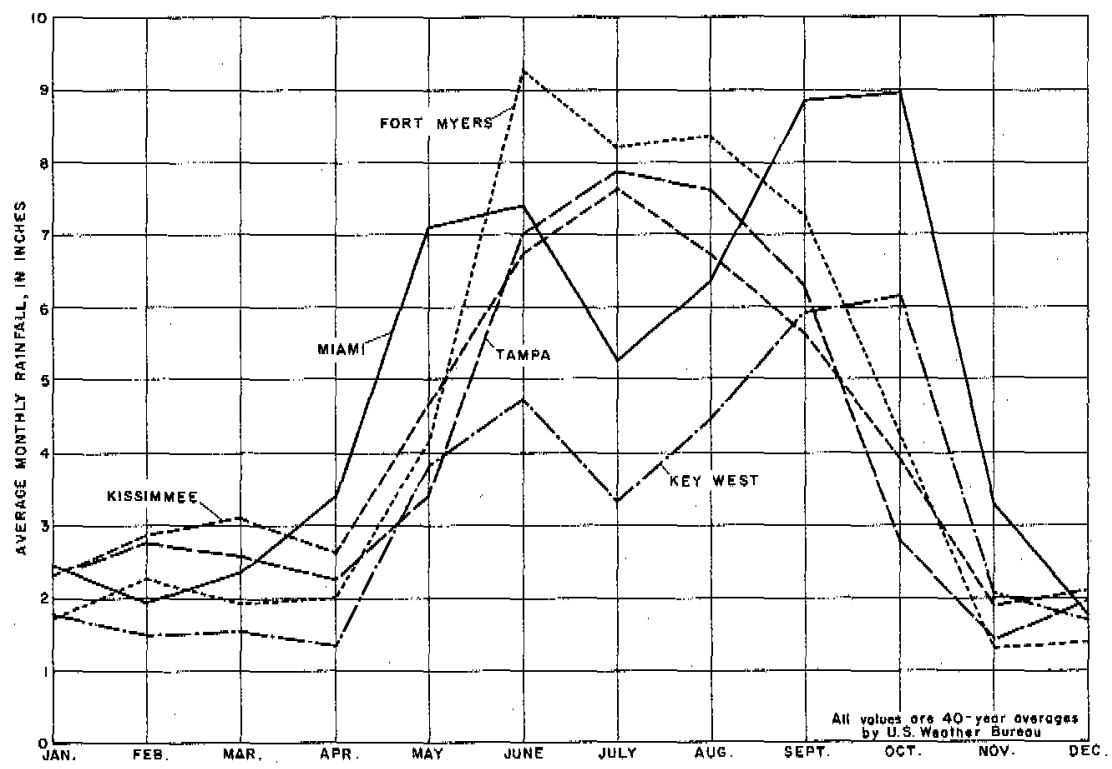

Figure 4. - Graph showing seasonal distribution of rainfall at selected locations in southem Florida, 
Homestead and Jupiter. Thirty miles inland, October rainfall averages about 5 inches, and on the west coast, notably in the Tampa Bay region, it is only about 3 inches. The high July rainfall on the west coast probably reflects the activity of convectional or airmass thunderstorms, which are common over the Gulf during that month. The high October rainfall on the east coast doubtless arises from the influence of the West Indian hurricanes that are particularly active in the early fall. The rainfall regimen at Miami seemingly has more in common with that at Nassau in the Bahamas (about 150 miles to the east) than it has with the regimen at Fort Myers (about 115 miles to the northwest on the Gulf coast of the peninsula).

The usual long dry winter and spring seasons, as clearly illustrated by all graphs on figure 4 , are closely associated with the recurring droughts in the area. Little recharge to water supplies can be expected after the end of October; therefore, the lowest water levels generally occur in the spring and following a year in which the precipitation of both the summer and fall seasons was below average. Successful development of water supplies and operation of water-control projects require careful consideration of this seasonal distribution of rainfall.

Actual seasonal behavior in rainfall at the water plant at Hialeah during the 7 years of this investigation is illustrated in plate 3 . The graph illustrates the vagaries in seasonal distribution that may take place from year to year and suggests that normal distribution of rain among the months rarely occurs at a given place in any one year. See pages 215-221 for a discussion of rainfall characteristics in the Miami area and pages 511-569 for a discussion of the relationship between rainfall and runoff.

\section{STOZM RAINFALL}

Periods of storm rainfall are usually associated with the tropical disturbances that generally occur during the fall months. Not all of these disturbances produce heavy rainfall, but some produce rainfall amounts that approach, if not equal, the greatest recorded anywhere in continental United States. The 24-hour rainfall recorded at Canal Point, Palm Beach County, on November 6-7, 1932 , as 21.92 inches (Clayton, Neller, and Allison, 1942, p. 27) is believed to be the heaviest on record in southeastern Florida. This compares with a 24-hour recorded maximum for Florida of 23. 22 inches-at New Smyrna Beach on October 10-11, 1924 (Theaman, 1943)-and for the continental United States of 38.2 inches at Thrall, Tex., Sept. 9-10, 1921 (U. S. Corps of Engineers, 1945).

The Gulf coast is noted for its frequency of thunderstorms, which occur on the average on 80 to 90 days annually, a greater number than 


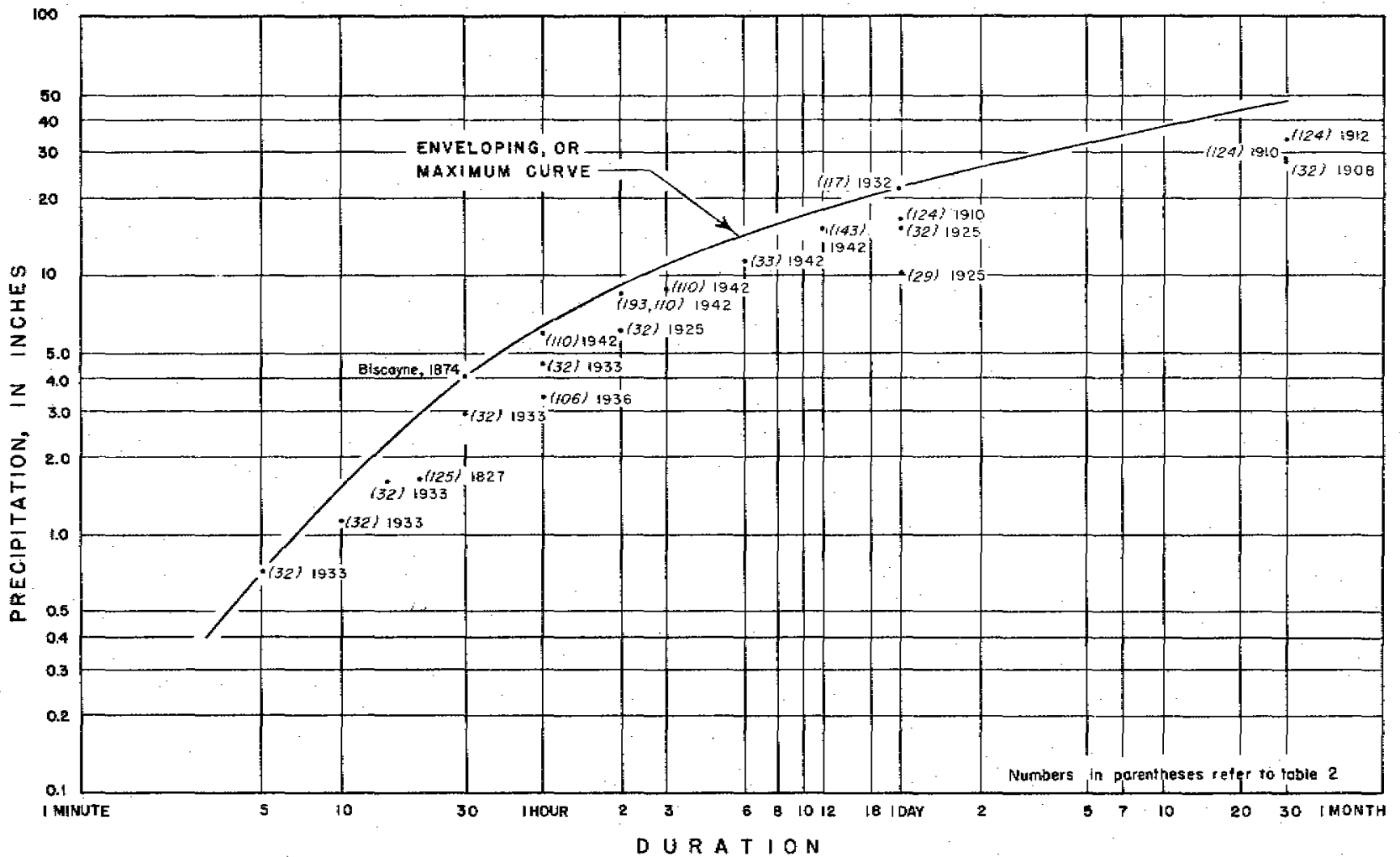

Figure 5. - Chart showing relation of amount of preclpitation to duration of storms in southern Florida. 
Table 4.-Amounts of 24hour raintall to be expected at rare intervals

\begin{tabular}{|c|c|c|c|c|c|c|c|c|}
\hline \multirow[t]{2}{*}{ Station } & \multirow[t]{2}{*}{ County } & \multirow{2}{*}{$\begin{array}{l}\text { Average } \\
\text { annual } \\
\text { precipi- } \\
\text { tation1 } \\
\text { (inches) }\end{array}$} & \multirow{2}{*}{$\begin{array}{l}\text { Years } \\
\text { of record } \\
\text { used for } \\
\text { frequency } \\
\text { array }\end{array}$} & \multirow{2}{*}{$\begin{array}{l}\text { Average of } \\
\text { ammual } \\
\text { maximum } \\
24-h o u r \\
\text { rainfalls } \\
\text { (inches) }\end{array}$} & \multicolumn{3}{|c|}{$\begin{array}{c}\text { 24-hour rainfall, in inches, which } \\
\text { probably will be equaled or } \\
\text { exceeded once in: }\end{array}$} & \multirow{2}{*}{$\begin{array}{l}\text { Maximum } \\
\text { recorded } \\
\text { 24-hour } \\
\text { rainfall } \\
\text { (inches) }\end{array}$} \\
\hline & & & & & 5 years & 10 years & 25 years & \\
\hline $\begin{array}{l}\text { Miami } \\
\text { Belle Glade } \\
\text { Orlando } \\
\text { Okeechobee } \\
\text { Avom Park } \\
\text { Kissimmee }\end{array}$ & $\begin{array}{l}\text { Dade } \\
\text { Palm Beach } \\
\text { Orange } \\
\text { Okeechobee } \\
\text { Highlands } \\
\text { Osceola }\end{array}$ & $\begin{array}{l}59.18 \\
56.70 \\
52.45 \\
48.61 \\
52.12 \\
50.24\end{array}$ & $\begin{array}{l}42 \\
19 \\
43 \\
23 \\
40 \\
42\end{array}$ & $\begin{array}{l}6.20 \\
4.26 \\
3.57 \\
3.32 \\
3.70 \\
3.64\end{array}$ & $\begin{array}{l}8.3 \\
5.4 \\
4.3 \\
4.2 \\
4.5 \\
4.3\end{array}$ & $\begin{array}{r}10.0 \\
6.8 \\
5.3 \\
4.7 \\
5.6 \\
5.5\end{array}$ & $\begin{array}{r}12.1 \\
9.2 \\
6.8 \\
5.4 \\
7.1 \\
7.3\end{array}$ & $\begin{array}{r}15.10 \\
10.90 \\
8.02 \\
6.02 \\
8.52 \\
11.60\end{array}$ \\
\hline
\end{tabular}

${ }^{1}$ Climate and Man, Yearbook of Agriculture:

U. S. Department of Agriculture, p. 809-810, 1941. 
at any other place in the country. Thunderstorms are most frequent in July and August when they occur on the average of about 20 days each month on the Gulf coast. Graphic records of rainfall from the automatic recording rain gages verify casual visual observations that the greatest part of the rain falls during heavy showers of a few minutes' duration. The exception is the prolonged and generally widespread.rainfall during the disturbances of tropical origin. Fallseason hurricanes in particular bring torrential rainfalls over the relatively narrow bands they traverse.

The outstanding torrential rainstorms in southern Florida are plotted in figure 5 to show the depth of rainfall in relation to its duration. A curve has been drawn showing the highest limits of intensity on record as defined by the plotted points. Rainfall shown by this enveloping curve has occurred but rarely in southern Florida; the record on which it is based is equivalent to a great many station years. No estimate can be given of the frequency with which rainfall of the extraordinary depths shown can be expected at any given place. Nevertheless, the recurrence of such rainfall is a distinct possibility.

The frequency of 24-hour rainfall at several of the long-term stations in southeastern Florida was studied to find the depth of 24-hour rainfall expected to be equaled or exceeded once in 5,10 , and 25 years on the average. The results are given in table 4 for six stations.

The data in table 4 indicate somewhat greater depths of 24-hour rainfall at Miami and at Belle Glade (possibly the same is true in the intervening Everglades) than at any of the other stations listed, which are in the Kissimmee basin. This difference in intensity is associated with corresponding differences in annual rainfall.

The reliability of the frequency data in table 4 , especially for the 25-year interval, is open to speculation because of the errors arising from the relative shortness of the record as well as deficiencies in the statistical theory available. The data in the table, however, probably are a fair appraisal of the frequency of storm rainfall to be expected in southeastern Florida.

\section{DROUGHT RAINFALL}

The sufficiency of water supplies in southeastern Florida depends as much on the nature and frequency of droughts as on the average or normal supply. In general, an economy (agricultural or urban) is adapted most easily to a climatic regimen that remains fairly uniform from year to year. Wide fluctuations from the normal result in stress, and unless facilities are available to store supplies, droughts may impose a limit to possible development. 
In a general sense, a drought may be defined as a period in which rainfall has been so deficient as to hinder the growth of native vegetation and to affect water supplies adversely. It is difficult to define a drought precisely because various things are affected to different degrees by any given deficiency in rainfall. This is true even with respect to native vegetation (a drought, in this case, exists when vegetation wilts or defoliates unseasonally), because vegetation may be situated variously with respect to available water supplies. Shallow-rooted plants may be affected by even ephemeral shortages, whereas deep-rooted species in the same area may be affected adversely only after months of sustained deficiency. Water supplies, too, are variable in their response to deficiencies in rainfall. Deep ground water, especially in artesian aquifers, responds only to changes in rainfall over long periods, and it is almost unaffected by month to month variations. Headwater streams, on the other hand, vary frequently in rate of discharge and respond to vagaries in daily or even hourly rainfall. Furthermore, during development of a region, if unreasonable demands are made for water, a situation will be created that may simulate drought.

Although deficiency in precipitation is the prime cause of drought, its effects may be aggravated or ameliorated by variations of tem perature. Above-normal temperature would tend to increase transpiration of vegetation and evaporation from the land and so accelerate the loss in soil moisture. Below-normal temperatare would tend to conserve soil moisture.

Degree of drought is best measured by the effect upon activities directly concerned; for example, soil moisture with respect to agriculture, and streamflow and ground-water levels with respect to water supplies. However, there are no records of soil moisture, and records of streamflow and ground water are relatively short in comparison with the available records of rainfall. Even though it is difficult to measure a drought in terms of precipitation deficiencies alone, for the purpose of this discussion it may be presumed that the intensity of a drought would be proportional to the amount and duration of the deficiency.

Table 5 lists cumulative deficiency in precipitation at Miami and at Kissimmee during outstanding periods of subnormal rainfall. There are 18 periods listed for Miami and 14 for Kissimmee, but the variability between these stations is such that only about half are common to both. Deficiencies during the other periods were apparently local in extent. For example, the drought of 1944-45 was worse in the record at Miami, but its influence was rather localized (see also pl. 2). Large deficiency in rainfall at one station does not necessarily indicate a drought, because its areal effects may be mitigated by a smaller deficiency or even by a normal rainfall at a nearby station; therefore,table 6 has been prepared to show the cumulative deficiency of average rainfall at all stations in the southern part of the State. 
Mean-temperature deviation from normal during the indicated periods is also shown in tables 5 and 6 . Plus and minus signs are about equally numerous, thus suggesting that there is no tendency for periods of droughts to be associated with either above- or belownormal temperatures.

At Miami, droughts listed in approximate order of magnitude occurred in 1944-45, 1906-07, 1927-28, 1897-98, and 1913-14. At Kissimmee, the five most severe droughts of record were respectively 1897-98,1942-43,1906-07, 1931-32, and 1938-39. The ranking five droughts in southern Florida as a whole are 1931-2, 1906-07, 1942-43,1897-98, and 1927-28. Three ranking droughts (1931-32,1942-43, and 1944-45) have occurred since some records of lake and river stages are available. It is fortunate indeed that the intensive study of the water resources of the area was under way during the droughts of 1942-43 and 1944-45 (two of the five most severe droughts in more than 40 years). Significant conditions were recorded, which might otherwise have been unavailable for future guidance.

Climatic analyses by some means that will evaluate the effectiveness of precipitation in terms of the temperature with which it is associated are helpful in a study of droughts. Thornthwaite (1931, p. 635-655) has devised a formula for such an evaluation. Briefly, Thornthwaite has assumed that the rate of evaporation from freewater surfaces is a measure of the characteristics of a region with respect to the natural water loss, or consumption of water through evaporation from land, and through the transpiration of vegetation. He then expresses the effectiveness of the precipitation as a ratio of precipitation to evaporation; his findings are based on anempirical formula which involves precipitation and temperature as factors. Using the results of his formula, he also devised a system of climatic classification and later published a series of maps, one for each calendar year from 1900 to 1939 , showing the distribution of the climatic types in the United States (Thornthwaite, 1941).

Normally, southeast Florida, like most of the eastern United States, has a humid climate and adequate rainfall for tree growth. However, the precipitation effectiveness falls toward the lower boundary of the humid classification; ther efore, the moist-subhumid type is of frequent occurrence (between 25 and 50 percent of the years), and indeed, much of the central peninsula (including the upper Kissimmee River basin) normally falls within the moistsubhumid classification. The moist-subhumid climate is typical of a lush grassland vegetation (such as the prairies of east Texas). Dry-subhumid, the next lower classification, is typical of a shortgrass region (as incentral Texas) and would correspond to serious drought in Florida. Thornthwaite demonstrates that this type occurred over scattered and limited areas 10 times in 40 years (19001939), but only in 1907 and in 1938 were large areas affected. During 
Table 5. - Precipitation deficiency and temperature in relation

\begin{tabular}{|c|c|c|c|c|c|c|c|c|}
\hline \multicolumn{3}{|c|}{12 months } & \multicolumn{3}{|c|}{6 months } & \multicolumn{3}{|c|}{4 months: } \\
\hline Period & 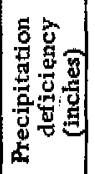 & 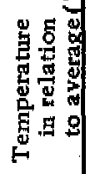 & Period & 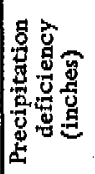 & 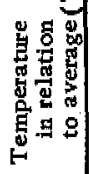 & Period & 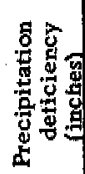 & 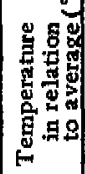 \\
\hline
\end{tabular}

MIAMI

Aug. 1875-July 1876

Oct. 1897-Sept. 1898

Nov. 1901-Oet. 1902

Dec. 1906-Nov, 1907

Sept. 1913-Aug. 1914

June 1916-May 1917

Oct, 1917-Sept, 1918

July $1919-J u n e$ 1920

July 1923-June 1924

May 1927-Apr, 1928

1928-29

1931

Aug. 1934-July 1935

Oct. 1937-Sept, 1938

Oet. ${ }^{+} 1937-$ Sept. 1938

July $1942-$ Jume 1943

Aug. 1944-July 1945

May 1945-April 1946

\begin{tabular}{|c|c|c|c|c|c|c|c|}
\hline $\begin{array}{l}16.28 \\
25.19 \\
22.78 \\
28.42 \\
23.13\end{array}$ & $\begin{array}{l}(1) \\
+0.4 \\
\cdots \ldots \ldots \\
+.5 \\
-1.2\end{array}$ & $\begin{array}{l}\text { Aug. -Jan. } \\
\text { Jan.-June } \\
\text { Mar.-Aug. } \\
\text { May-Oct. } \\
\text { May-Oct. }\end{array}$ & $\begin{array}{l}13.44 \\
16.70 \\
15.08 \\
19.31 \\
18.86\end{array}$ & $\begin{array}{l}\text { (t) } \\
-1.0 \\
+.9 \\
+.5 \\
-.7\end{array}$ & $\begin{array}{l}\text { Sept. -Deg } \\
\text { Apr. -July } \\
\text { Apr. -JuIy } \\
\text { July-Oet. } \\
\text { May-Aug. }\end{array}$ & $\begin{array}{l}12.01 \\
14.52 \\
11.31 \\
17.02 \\
14.06\end{array}$ & $\begin{array}{l}(1) \\
-0.6 \\
+1.6 \\
+.3 \\
+\ldots+\ldots .+4\end{array}$ \\
\hline $\begin{array}{l}22.27 \\
22.77 \\
18.54 \\
19.11 \\
30.61\end{array}$ & $\begin{array}{r}-.8 \\
-1.6 \\
-.5 \\
-1.0 \\
-.1\end{array}$ & $\begin{array}{l}\text { Sept. -Feb. } \\
\text { Oct. -Mar. } \\
\text { July-Dec. } \\
\text { July-Dec. } \\
\text { Mar.-Aug. }\end{array}$ & $\begin{array}{l}15.39 \\
12.55 \\
13.29 \\
14.43 \\
17.90\end{array}$ & $\begin{array}{r}-.6 \\
-2.1 \\
+.4 \\
-1.1 \\
+.6\end{array}$ & $\begin{array}{l}\text { Sept. -Dec } \\
\text { Oet. -Jan. } \\
\text { July-Oet. } \\
\text { Sept. -Dec. } \\
\text { May-Ang. }\end{array}$ & $\begin{array}{l}11.17 \\
11.89 \\
13.89 \\
13.40 \\
14.26\end{array}$ & $\begin{array}{r}-.6 \\
-4.0 \\
+.3 \\
-1.3 \\
+1.0\end{array}$ \\
\hline $\begin{array}{c}(2) \\
(2) \\
22.72 \\
20.68 \\
20.68\end{array}$ & $\begin{array}{r}\ldots \ldots \ldots \\
\ldots \ldots \ldots \\
+.4 \\
+.1 \\
+.2\end{array}$ & $\begin{array}{l}\text { Oct. -Mar, } \\
\text { Mar. -Aug. } \\
\text { Oct.-Mar. } \\
\text { Oct.-Mar. } \\
\text { Mar. "Aug. }\end{array}$ & $\begin{array}{r}9.63 \\
9.74 \\
13.98 \\
11.56 \\
13.39\end{array}$ & $\begin{array}{r}+1.0 \\
-1.1 \\
+.2 \\
+.1 \\
+.6\end{array}$ & $\begin{array}{l}\text { Oct, -Jan. } \\
\text { May-Attg. } \\
\text { Oct.-Jan. } \\
\text { Oct.-Jan. } \\
\text { May-Aug. }\end{array}$ & $\begin{array}{r}10.73 \\
14.68 \\
9.83 \\
8.40 \\
8.21\end{array}$ & $\begin{array}{r}+.2 \\
+.4 \\
+.3 \\
-1.1 \\
+.1\end{array}$ \\
\hline $\begin{array}{l}20.61 \\
35.28 \\
23.85\end{array}$ & $\begin{array}{l}+.2 \\
-.7 \\
-.8\end{array}$ & $\begin{array}{l}\text { July-Dec. } \\
\text { Jume-Nov, } \\
\text { Mar.-Aug. }\end{array}$ & $\begin{array}{l}15.44 \\
22.90 \\
17.67\end{array}$ & $\begin{array}{r}+1.5 \\
-.8 \\
.0\end{array}$ & $\begin{array}{l}\text { July-Oct. } \\
\text { Aug.-Nov, } \\
\text { May-Aug. }\end{array}$ & $\begin{array}{l}14.85 \\
17.77 \\
14.77\end{array}$ & $\begin{array}{l}+1,4 \\
-1,3 \\
-1,0\end{array}$ \\
\hline
\end{tabular}

Oct. 1897 -Sept. 1898

Oct. 1901-\$ept. 1902

July 1906-June 1907

Nov. 1910-Oct. 1911

Nov. 1913-Oct: 1914

Jan. -Dec, 1917

fume 1921-May 1922

Dec. 1926-Nov. 1927

Feb. 1929-Jan. 1930

May 1931-Apr. 1932

Nov. 1934-Oct. 1935

Apr. 1938-Mar. 1939

July 1942-June 1943

Sept. 1943 -Aus. 1944

\begin{tabular}{|c|c|c|c|c|c|c|c|}
\hline $\begin{array}{r}12.40 \\
12.00 \\
22.93 \\
15.83 \\
9.89\end{array}$ & $\begin{array}{l}(1) \\
(1) \\
(1) \\
+3.3 \\
+2.4\end{array}$ & $\begin{array}{l}\text { Jat. - Jume } \\
\text { Mar. -Aug. } \\
\text { Oct. - Mar. } \\
\text { Feb. July } \\
\text { June-Nov: }\end{array}$ & $\begin{array}{r}14.76 \\
9.08 \\
13.86 \\
10.75 \\
11.05\end{array}$ & $\begin{array}{l}(1) \\
(1) \\
(1) \\
+6.4 \\
-.4\end{array}$ & $\begin{array}{l}\text { Feb. -May } \\
\text { Mar. -June } \\
\text { Dec. -Mar. } \\
\text { Apr.-July } \\
\text { June-Sept. }\end{array}$ & $\begin{array}{r}11.69 \\
7.34 \\
10.20 \\
8.52 \\
6.83\end{array}$ & $\begin{array}{l}(1) \\
(1) \\
(1) \\
+3.0 \\
=.3\end{array}$ \\
\hline $\begin{array}{r}12.54 \\
11.48 \\
6.09 \\
12.95 \\
19.76\end{array}$ & $\begin{array}{r}+1.9 \\
-3.6 \\
+5.4 \\
+5.0 \\
+2.9\end{array}$ & $\begin{array}{l}\text { Feb. -July } \\
\text { June-Nov. } \\
\text { Dec. -May } \\
\text { Aug.-Jan. } \\
\text { May-Oct. }\end{array}$ & $\begin{array}{r}11.68 \\
6.74 \\
8.41 \\
8.44 \\
13.40\end{array}$ & $\begin{array}{r}+5.2 \\
+7.5 \\
-.7 \\
-.9\end{array}$ & $\begin{array}{l}\text { Mar. -June } \\
\text { June-Sept. } \\
\text { Dec:-Mar. } \\
\text { Aug. -Nov. } \\
\text { May-Aug. }\end{array}$ & $\begin{array}{r}9.33 \\
10.46 \\
5.95 \\
6.31 \\
8.50\end{array}$ & $\begin{array}{r}+5.2 \\
=.2 \\
+8.3 \\
-1.2 \\
-1.2\end{array}$ \\
\hline $\begin{array}{l}12.82 \\
17.84 \\
20.77 \\
11.66\end{array}$ & $\begin{array}{r}-3.3 \\
+2.3 \\
+2.1 \\
+.5\end{array}$ & $\begin{array}{l}\text { Mar. -Aug. } \\
\text { Apr. - Sept. } \\
\text { July Dec. } \\
\text { Apr. - Sept. }\end{array}$ & $\begin{array}{r}9.63 \\
9.96 \\
13.59 \\
6.79\end{array}$ & $\begin{array}{r}+3.5 \\
+.2 \\
+.9\end{array}$ & $\begin{array}{l}\text { May-Aug. } \\
\text { June-Sept. } \\
\text { July-Oct. }\end{array}$ & $\begin{array}{r}8.11 \\
8.73 \\
12.02\end{array}$ & $\begin{array}{r}+.8 \\
-1.9 \\
-.4\end{array}$ \\
\hline
\end{tabular}

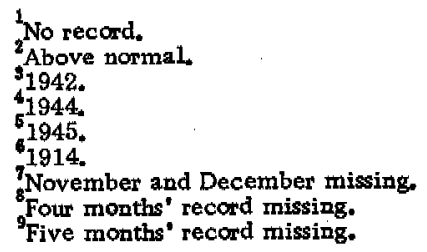


to normal during periods of drought at Miami and Inissimmee

\begin{tabular}{|c|c|c|c|c|c|c|c|c|}
\hline \multicolumn{3}{|c|}{3 months } & \multicolumn{3}{|c|}{2 months } & \multicolumn{3}{|c|}{1 month } \\
\hline Period & 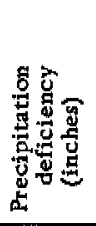 & 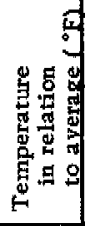 & Period & 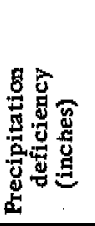 & 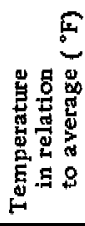 & Period & 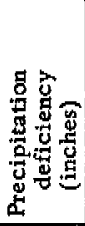 & 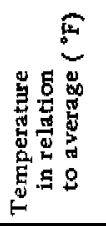 \\
\hline \multicolumn{9}{|c|}{ MIAMI } \\
\hline $\begin{array}{l}\text { Sept. - Nov. } \\
\text { Apr, -June } \\
\text { Apr. - June } \\
\text { Aug. -Oct. } \\
\text { May-July }\end{array}$ & $\begin{array}{r}10.49 \\
14.40 \\
8.55 \\
14.76 \\
11.30\end{array}$ & $\begin{array}{l}(1) \\
-0.8 \\
+1.8 \\
+.3 \\
+.1\end{array}$ & $\begin{array}{l}\text { Sept, Oct. } \\
\text { May-June } \\
\text { Apr. -May } \\
\text { Sept, -Oct. } \\
\text { May-June }\end{array}$ & $\begin{array}{r}8.30 \\
11.82 \\
7.34 \\
11.83 \\
9.78\end{array}$ & $\begin{array}{l}(1) \\
-0.4 \\
+1.6 \\
+.25 \\
+.5\end{array}$ & $\begin{array}{l}\text { Sept. } \\
\text { June } \\
\text { May } \\
\text { Oet, } \\
\text { May }\end{array}$ & $\begin{array}{l}4.06 \\
6.52 \\
6.01 \\
6.27 \\
5.13\end{array}$ & $\begin{array}{l}\text { (1) } \\
+0.7 \\
+2.7 \\
-.8 \\
+.1\end{array}$ \\
\hline $\begin{array}{l}\text { Sept. -Nov. } \\
\text { Oct. - Dec. } \\
\text { Aug. - Oct. } \\
\text { Sept. -Nov. } \\
\text { May-July }\end{array}$ & $\begin{array}{r}9.50 \\
10.04 \\
13.75 \\
11.94 \\
12.13\end{array}$ & $\begin{array}{r}-.8 \\
-3.6 \\
+.7 \\
-2.4 \\
+1.1\end{array}$ & $\begin{array}{l}\text { Sept. -Oct. } \\
\text { Oct. -Nov, } \\
\text { Sept. -Oct. } \\
\text { Sept, -Oct. } \\
\text { May-June }\end{array}$ & $\begin{array}{r}88.56 \\
9.58 \\
10.95 \\
9.42 \\
11.09\end{array}$ & $\begin{array}{r}-1.0 \\
-2.9 \\
+.8 \\
-1.5 \\
+1.5\end{array}$ & $\begin{array}{l}\text { Sept. } \\
\text { Oct. } \\
\text { Sept. } \\
\text { Oct. } \\
\text { May }\end{array}$ & $\begin{array}{l}4.45 \\
7.03 \\
5.54 \\
6.37 \\
6.27\end{array}$ & $\begin{array}{r}-1.5 \\
-.3 \\
-.7 \\
-1.9 \\
+1.0\end{array}$ \\
\hline $\begin{array}{l}\text { Oct. -Dec. } \\
\text { May-July } \\
\text { Oct. -Dec. } \\
\text { Oct. -Dec. } \\
\text { June-Aug. }\end{array}$ & $\begin{array}{r}9.06 \\
13.17 \\
7.48 \\
8.12 \\
6.84\end{array}$ & $\begin{array}{r}-.5 \\
+.2 \\
+.6 \\
-1.3 \\
-.1\end{array}$ & $\begin{array}{l}\text { Oct. -Nov. } \\
\text { Jume-July } \\
\text { Oct. -Nov. } \\
\text { Oct. -Nov. } \\
\text { July-Aug. }\end{array}$ & $\begin{array}{r}7.88 \\
10.56 \\
6.53 \\
6.60 \\
5.27\end{array}$ & $\begin{array}{r}-.1 \\
+.6 \\
+1.0 \\
-1.1 \\
+.2\end{array}$ & $\begin{array}{l}\text { Oct. } \\
\text { June } \\
\text { Oct. } \\
\text { Oct. } \\
\text { Aug. }\end{array}$ & $\begin{array}{l}5.51 \\
7.15 \\
6.00 \\
4.14 \\
5.38\end{array}$ & $\begin{array}{r}+.5 \\
+.2 \\
+2.0 \\
+.7 \\
+1.1\end{array}$ \\
\hline $\begin{array}{l}\text { July-Sept. } \\
\text { Aug. -Oct. } \\
\text { May-July }\end{array}$ & $\begin{array}{l}10.98 \\
14.74 \\
13.04\end{array}$ & $\begin{array}{l}+1.7 \\
-1.0 \\
-1.0\end{array}$ & $\begin{array}{l}\text { July-Aug. } \\
\text { Sept. - Oet. } \\
\text { May-June }\end{array}$ & $\begin{array}{r}7.97 \\
10.34 \\
11.45\end{array}$ & $\begin{array}{r}+1.9 \\
-1.4 \\
-.8\end{array}$ & $\begin{array}{l}\text { Mays } \\
\text { Sept. } \\
\text { May }\end{array}$ & $\begin{array}{l}5.21 \\
5.77 \\
6.33\end{array}$ & $\begin{array}{r}+.8 \\
+.2 \\
-1.4\end{array}$ \\
\hline
\end{tabular}

KISSIMMEE

\begin{tabular}{|c|c|c|c|c|c|c|c|c|}
\hline $\begin{array}{l}\text { Mar. -May } \\
\text { Mar. -May } \\
\text { Jan. -Mar. } \\
\text { May-July } \\
\text { June-Aug. }\end{array}$ & $\begin{array}{l}9.93 \\
6.45 \\
8.14 \\
7.62 \\
6.31\end{array}$ & $\begin{array}{l}(1) \\
(1) \\
(1) \\
+1.0 \\
+.2\end{array}$ & $\begin{array}{l}\text { Apr. -May } \\
\text { Apr, -May } \\
\text { Feb,-Mar, } \\
\text { June-July } \\
\text { July-Aug. }\end{array}$ & $\begin{array}{l}6.83 \\
5.23 \\
5.93 \\
4.86 \\
5.10\end{array}$ & $\begin{array}{l}(1) \\
(1) \\
(1) \\
+.2 \\
-1.5\end{array}$ & $\begin{array}{l}\text { May } \\
\text { May } \\
\text { Mar. } \\
\text { July } \\
\text { July }\end{array}$ & $\begin{array}{l}4.33 \\
4.34 \\
3.10 \\
3.40 \\
3.44\end{array}$ & $\begin{array}{l}(1) \\
(1) \\
(1) \\
-3.3 \\
-3.5\end{array}$ \\
\hline $\begin{array}{l}\text { Apr. -June } \\
\text { July-Sept, } \\
\text { Pec. -Feb. } \\
\text { Aug. -Oct. } \\
\text { May-July }\end{array}$ & $\begin{array}{l}7.42 \\
8.62 \\
5.30 \\
5.62 \\
8.29\end{array}$ & $\begin{array}{r}+3.1 \\
+.8 \\
+12.5 \\
-1.5 \\
+.7\end{array}$ & $\begin{array}{l}\text { May-June } \\
\text { Aug. - Sept. } \\
\text { Dec. -Jan, } \\
\text { Aug. -Sept. } \\
\text { May-Jume }\end{array}$ & $\begin{array}{l}5.74 \\
7.06 \\
3.82 \\
4.97 \\
6.56\end{array}$ & $\begin{array}{r}+1.8 \\
+.6 \\
+3.2 \\
-1.2 \\
-.1\end{array}$ & $\begin{array}{l}\text { June } \\
\text { Sept. } \\
\text { Jan. } \\
\text { Aug. } \\
\text { June }\end{array}$ & $\begin{array}{l}4.29 \\
5.03 \\
2.11 \\
3.98 \\
4.17\end{array}$ & $\begin{array}{r}+.8 \\
+.8 \\
+7.3 \\
-.7 \\
-.4\end{array}$ \\
\hline $\begin{array}{l}\text { May-July } \\
\text { Aug.-Oct. } \\
\text { puly-Sept. } \\
\text { Apr. -June }\end{array}$ & $\begin{array}{l}5.52 \\
6.73 \\
8.45 \\
5.73\end{array}$ & $\begin{array}{r}+.6 \\
-1.3 \\
+.7 \\
\\
\end{array}$ & $\begin{array}{l}\text { May-June } \\
\text { Aug.-Sept. } \\
\text { July-Aug. } \\
\text { May-June }\end{array}$ & $\begin{array}{l}5.27 \\
7.09 \\
7.04 \\
5.77\end{array}$ & $\begin{array}{r}+3.3 \\
-1.0 \\
+.8 \\
+1.0 \\
\end{array}$ & $\begin{array}{l}\text { June } \\
\text { Sept. } \\
\text { July } \\
\text { lune }\end{array}$ & $\begin{array}{l}3.36 \\
3.72 \\
5.95 \\
4.31 \\
\end{array}$ & $\begin{array}{r}+1.6 \\
+1.6 \\
+1.7 \\
+1.2 \\
\end{array}$ \\
\hline
\end{tabular}


Table 6. Precipitation deficiency and temperatute in telation

\begin{tabular}{|c|c|c|c|c|c|c|c|c|}
\hline \multicolumn{3}{|c|}{12 months } & \multicolumn{3}{|c|}{6 months } & \multicolumn{3}{|c|}{4 months } \\
\hline $\begin{array}{l}\text { Period } \\
\therefore\end{array}$ & 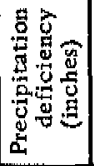 & 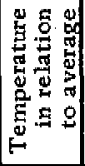 & Period & 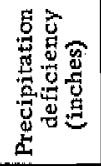 & 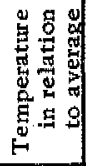 & Period & 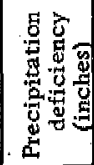 & 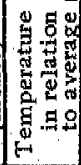 \\
\hline . & & & & & & & \multicolumn{2}{|c|}{ SOUTHERN } \\
\hline $\begin{array}{l}\text { Dec. 1891-Nov, } 1892 \\
\text { June 1895-May } 1896 \\
\text { Oct. 1897-Sept. } 1898 \\
\text { Oct. 1901-Sept. } 1902 \\
\text { Dec. 1906-Nov. } 1907\end{array}$ & $\begin{array}{r}6.51 \\
9.20 \\
10.20 \\
11.02 \\
14.08\end{array}$ & $\begin{array}{r}-1.0 \\
-8.0 \\
+.1 \\
-1.6 \\
+.1\end{array}$ & $\begin{array}{l}\text { Dec. -May } \\
\text { June-Nov. } \\
\text { Jan. -June } \\
\text { Mar. -Aug. } \\
\text { Nov, -Apr. }\end{array}$ & $\begin{array}{r}6.07 \\
5.72 \\
13.97 \\
8.85 \\
9.71\end{array}$ & $\begin{array}{r}-0.5 \\
-.8 \\
-.1 \\
-.2 \\
+.3\end{array}$ & $\begin{array}{l}\text { Feb. -May } \\
\text { Jwe-Sept. } \\
\text { Mar. -June } \\
\text { May-Aug. } \\
\text { Dec. -Mar. }\end{array}$ & $\begin{array}{r}5.25 \\
6.51 \\
10.59 \\
7.06 \\
7.99\end{array}$ & $\begin{array}{r}-0.7 \\
-.1 \\
+.5 \\
+1.9 \\
-.6\end{array}$ \\
\hline $\begin{array}{l}\text { Dec. 1910-Nov, } 1911 \\
\text { Apr. 1913-Mar, } 1914 \\
\text { Nov. 1915-Oct. } 1916 \\
\text { Jan.-Dec, } 1917 \\
\text { May 1921-April } 1922\end{array}$ & $\begin{array}{r}11.62 \\
8.58 \\
8.71 \\
8.95 \\
7.38\end{array}$ & $\begin{array}{r}+.3 \\
-1.4 \\
-.4 \\
-.6 \\
+1.3\end{array}$ & $\begin{array}{l}\text { Nov. -Apr. } \\
\text { Apr. -Sept. } \\
\text { Jan. -June } \\
\text { Jan. -June } \\
\text { Nov. -Apr. }\end{array}$ & $\begin{array}{l}7.60 \\
6.92 \\
6.07 \\
7.87 \\
5.59\end{array}$ & $\begin{array}{r}-.8 \\
-1.1 \\
-.2 \\
+.6 \\
+2.8\end{array}$ & $\begin{array}{l}\text { Dec. -Mar. } \\
\text { Apr. -July } \\
\text { Jan. -Apr. } \\
\text { Jan. -Apr. } \\
\text { June-Sept. }\end{array}$ & $\begin{array}{r}6.20 \\
5.43 \\
5.02 \\
4.68 \\
11.62\end{array}$ & $\begin{array}{r}-.7 \\
-1.1 \\
-.3 \\
+1.2 \\
+.2\end{array}$ \\
\hline $\begin{array}{l}\text { Mar. 1927-Feb. } 1928 \\
\text { May 1931-Apr. } 1932 \\
\text { July 1934-June } 1935 \\
\text { Apr. 1938-Mar. } 1939 \\
\text { July 1942-June } 1943 \\
\text { June 1944-May 1945 }\end{array}$ & $\begin{array}{l}14.51 \\
15.90 \\
12.67 \\
11.53 \\
11.76 \\
12.22\end{array}$ & $\begin{array}{r}+.8 \\
+1.5 \\
+.8 \\
+.9 \\
+1.0 \\
+1.1\end{array}$ & $\begin{array}{l}\text { Apr.-Sept. } \\
\text { May-Oct. } \\
\text { Oct,-Mar. } \\
\text { Dec. -May } \\
\text { July-Dec. } \\
\text { Dec.-May }\end{array}$ & $\begin{array}{r}8.67 \\
10.29 \\
8.79 \\
7.29 \\
10.14 \\
8.92\end{array}$ & $\begin{array}{r}+1.3 \\
+1.1 \\
+1.0 \\
+1.0 \\
+1.6 \\
-1.6\end{array}$ & $\begin{array}{l}\text { Mar. -June } \\
\text { May-Aug. } \\
\text { Oct. -Jan. } \\
\text { Jan. -Apr. }{ }^{2} \\
\text { July-Oct. } \\
\text { Feb. -May }\end{array}$ & $\begin{array}{l}6.40 \\
8.84 \\
5.80 \\
5.85 \\
9.54 \\
7.81\end{array}$ & $\begin{array}{r}+1.6 \\
+ \\
+++.8 \\
+1.7 \\
+.8 \\
+3.2\end{array}$ \\
\hline
\end{tabular}

1906 .

21938 :

$31937-1938$. 
to nomal during periods of drought in southem Florida

\begin{tabular}{|c|c|c|c|c|c|c|c|c|}
\hline \multicolumn{3}{|c|}{3 months } & \multicolumn{3}{|c|}{2 months } & \multicolumn{3}{|c|}{1 month } \\
\hline Period & 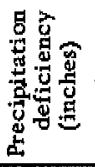 & 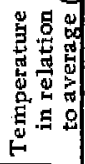 & Period & 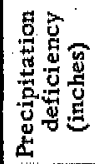 & 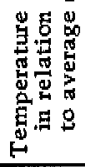 & Period & 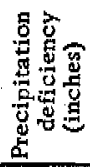 & 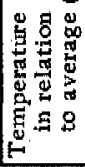 \\
\hline
\end{tabular}

\section{FLORIDA}

\begin{tabular}{|c|c|c|c|c|c|c|c|c|}
\hline $\begin{array}{l}\text { Mar. -May } \\
\text { Mar, -May } \\
\text { Apr. -June } \\
\text { June-Aug. } \\
\text { Jan. -Mar. }\end{array}$ & $\begin{array}{l}4.55 \\
4.78 \\
8.96 \\
5.14 \\
6.07\end{array}$ & $\begin{array}{r}-0.9 \\
-.9 \\
+.1 \\
+.7 \\
+2.4\end{array}$ & $\begin{array}{l}\text { Apr.-May } \\
\text { Apr. -May } \\
\text { May-June } \\
\text { Oct. -Nov, } \\
\text { Sept. -Oct) }\end{array}$ & $\begin{array}{l}3.62 \\
3.68 \\
6.88 \\
4.21 \\
5.04\end{array}$ & $\begin{array}{r}+.4 \\
+.7 \\
+.8 \\
-2.6 \\
+.1\end{array}$ & $\begin{array}{l}\text { july } \\
\text { June } \\
\text { June } \\
\text { Oct. } \\
\text { Oct. }\end{array}$ & $\begin{array}{l}3.69 \\
3.17 \\
4.12 \\
2.99 \\
2.99\end{array}$ & $\begin{array}{r}+0.5 \\
+.1 \\
+1.0 \\
+.3 \\
-1.4\end{array}$ \\
\hline $\begin{array}{l}\text { Dec, -Feb. } \\
\text { May-July } \\
\text { Jan.-Mar. } \\
\text { Jan. -Mar. } \\
\text { fuly-Sept. }\end{array}$ & $\begin{array}{l}5.31 \\
5.24 \\
4.82 \\
3.73 \\
7.82\end{array}$ & $\begin{array}{r}-1.2 \\
-1.0 \\
+.4 \\
+2.1 \\
+.1\end{array}$ & $\begin{array}{l}\text { June-July } \\
\text { June-July } \\
\text { Feb. -Mar. } \\
\text { Jan, -Feb. } \\
\text { Aug. -Sept. }\end{array}$ & $\begin{array}{l}4.18 \\
4.70 \\
3.42 \\
2.88 \\
8.21\end{array}$ & $\begin{array}{r}+.1 \\
-.9 \\
-2.2 \\
+1.7 \\
+.6\end{array}$ & $\begin{array}{l}\text { june } \\
\text { July } \\
\text { Mar. } \\
\text { Jan. } \\
\text { Sept. }\end{array}$ & $\begin{array}{l}2.60 \\
2.44 \\
1.93 \\
1.71 \\
4.95\end{array}$ & $\begin{array}{r}+.8 \\
-.1 \\
-3.7 \\
+4.4 \\
+1.4\end{array}$ \\
\hline $\begin{array}{l}\text { Apr. -June } \\
\text { June-Aug. } \\
\text { Oct. -Dec. } \\
\text { Feb. -Apr. } \\
\text { July-Sept. } \\
\text { Mar. -May }\end{array}$ & $\begin{array}{l}6.07 \\
8.19 \\
4.47 \\
4.94 \\
6.33 \\
5.91\end{array}$ & $\begin{array}{r}+2.0 \\
+.5 \\
+.9 \\
+2.4 \\
+1.4 \\
+3.0\end{array}$ & $\begin{array}{l}\text { May-June } \\
\text { June-July } \\
\text { Oct. -Nov. } \\
\text { Aug. - Sept. } \\
\text { July-Aug. } \\
\text { Apr. -May }\end{array}$ & $\begin{array}{l}5.16 \\
7.09 \\
3.16 \\
5.29 \\
5.21 \\
3.81\end{array}$ & $\begin{array}{r}+2.0 \\
+.5 \\
+1.4 \\
+.1 \\
+1.5 \\
+2.1\end{array}$ & $\begin{array}{l}\text { May } \\
\text { June } \\
\text { Mar. } \\
\text { Aug. } \\
\text { Oct. } \\
\text { May }\end{array}$ & $\begin{array}{l}3.18 \\
5.36 \\
2.03 \\
4.08 \\
3.21 \\
2.88 \\
\end{array}$ & $\begin{array}{r}+1.7 \\
-.2 \\
+3.3 \\
+.5 \\
+.2 \\
-.3\end{array}$ \\
\hline
\end{tabular}


such years, the maintenance of a state of development predicated on a humid or moist-subhumid climate can be accomplished only by a withdrawal of water stored from previous years.

\section{TEMPERATURE}

A knowledge of temperature conditions in southeastern Florida is pertinent to a study of its water resources because of the dominating influence of temperature on rates of water losses throughout the area by evaporation and transpiration. This relationship is discussed in more detail under "Evaporation and transpiration."

The modifying effect of the marine exposure on Florida temperatures can be seen by comparing the area under study with the only other area in continental United States of similar latitude, the extreme southern part of Texas. With similar average annual temperature existing in both areas, in Florida the mean July average is about $2^{\circ}$ to $3^{\circ} \mathrm{F}$ cooler, and the January average is $3^{\circ}$ to $5^{\circ} \mathrm{F}$ warmer than in Texas.

The mean annual temperatures increase gradually southward from $72^{\circ} \mathrm{F}$ in the upper Kissimmee River basin to about $75^{\circ} \mathrm{F}$ at the southern tip of the peninsula and $77^{\circ} \mathrm{F}$ at Key West. This variation is apparent in a north-south direction only; in an eastwest direction there is little difference between points on the Gulf and Atlantic coasts or between coastal and inland stations.

Mean January temperatures average about $10^{\circ} \mathrm{F}$ below the annual mean in the Kissimmee basin. The variation from the mean is less along the lower east and west coasts; January temperatures are generally somewhat higher along the coasts than at inland stations. The areal variation in mean July temperatures is only about onehalf that for January and does not conform to any definite trend over the area. This variation seems to be part of the general temperature gradation in the East, where the contrast between north and south is great in winter and small in midsummer.

Record-low temperatures vary from $18^{\circ} \mathrm{F}$ in the upper Kissimmee River basin to from $26^{\circ}$ to $28^{\circ} \mathrm{F}$ along the southern tip of the peninsula and approximately $40^{\circ}$ along the Florida Keys. Frost conditions sufficiently severe to kill vegetation have been observed over the entire mainland of the peninsula, but not along the keys. These killing frosts are rare, and the damage to vegetation, although severe from the standpoint of agriculture, seldom is great enough to affect hydrologic factors pertinent to water supplies. On the contrary, the presence of sizeable supplies of water on, or near the surface, has the effect of limiting damage by low temperatures on the vegetation in the immediate locality. 
On the basis of normal monthly temperatures, August is the warmest month of the year in southern Florida, July is a close second, and September and June follow in order. January is the coldest month, and December and February are almost as cold (see pl. 3).

\section{WIND}

The wind plays a part in the hydrologic processes as a factor in the determination of evaporation from lake or stream surfaces, from the soil, and from the surfaces of vegetation. Other factors remaining the same, the rate of evaporation increases with the rate of movement of the air or wind. Wind movement is commonly expressed as a rate in miles per hour or as an accumulated quantity in a longer unit of time, as miles per month, and ordinarily it is measured by an anemometer, either the revolving-cup type or the orifice type. Variations of the former type are commonly used, although the Corps of Engineers operates several of the pitot or orifice type in the vicinity of Lake Okeechobee to obtain accurate recording of the high hurricane winds. A simple weather vane operated as a part of, or in conjunction with, the anemometers, indicates wind direction by compass bearing.

To be of greatest value in hydrologic studies, records of wind should be observed at or near the ground, and these records should be representative of the general area. Unfortunately, few wind records satisfy both requirements because in urban or wellsettled areas, where most of the gages are installed, wind velocities near the ground usually are affected by nearby buildings or trees, and they do not accurately represent the general area. To avoid this difficulty, anemometers are commonly placed high above the ground. The resulting wind-movement records effectively show variations and trends that are usable in hydrologic studies, but these records may not be representative of the slower movement of winds at plant height and at ground and water surfaces where evaporation and transpiration take place.

On the basis of a 30-year record at Miami (Carson, 1940)anemometer 168 feet above ground surface-the monthly average air speeds varied from 8.1 miles per hour (mph) in July to 10.8 $\mathrm{mph}$ in November, with an average for October to March of 9.9 mph as compared to $8.8 \mathrm{mph}$ for April to September. The general average speed of $9.3 \mathrm{mph}$ is more than twice the general average speed inland at Belle Glade. The anemometer at Miami is 19 feet higher than the anemometer at Belle Glade.

Monthly averages for stations at Belle Glade (Palm Beach County) and at Lake Hiawassee (Orange County), as shown graphically in 
plate 3 , illustrate the seasonal variation shown by the Miami records above. It is significant that the season of greatest wind movement coincides with the usual period of greatest water-supply deficiencies. According to the record at Belle Glade, wind movement is greatest in March (when it averages $6.1 \mathrm{mph}$ ) and least in August (2. $9 \mathrm{mph}$ ).

Other older wind records are available in U. S. Weather Bureau records for Key West (since 1871), Jupiter (1907), and Tampa (1890).

Because of the variations in types, elevations, and exposures of the few anemometer stations in southeastern Florida, it is not practicable to attempt to define areal variation in wind movement. On the basis of the comparison between the Miami and Belle Glade records, it is logical to assume, however, that average wind movement decreases from coastal to inland areas.

The prevailing winds are easterly, especially during the summer and fall; direction of wind movement varies during the rest of the year. Winds of high intensity, which usually accompany the tropical storms in this area, are usually confined to the storm paths, and although they probably have an effect on evapotranspirationlosses at that time, they are not important to hydrologic studies of water problems in the area.

\section{EVAPORATION AND TRANSPIRATION}

\section{GENERAL STATEMENT}

The frequent recurrence of drought in the heavy rainfall area of southeastern Florida indicates that the agencies for removal of water are especially effective. In addition to runoff and deepseepage, these agencies include the evaporation of water into the atmosphere from open water surfaces, from the soil, and from the surfaces of plants. The last named, which involves the escape of water from plant organisms into the air, is known as transpiration. The total of these losses over land areas is usually designated as total evaporation or evapotranspiration, and its role in the hydrologic cycle is important. Unlike rainfall, over which man has little or no control, the natural losses from evapotranspiration may be susceptible to change, especially by drainage developments in the almost level Everglades. Removal of water in the Everglades by evaporation can be either beneficial or detrimental depending upon whether the loss is from excess water during wet periods or from much needed and perhaps deficient supplies during drought periods. Studies of the characteristics and magnitude of these losses have been a pertinent part of the study of the water resources of the area. See pages 222-231 for a discussion of ground-water discharge in relation to evapotranspiration in Dade County. 
Temperature, wind, relative humidity, and solar-radiation determine the rate at which the air at a given point takes up water from a wet or moist surface. Temperature generally is regarded as the most important factor. On the basis of data (Williams, 1940, p. 53) from representative river basins over the Eastern and Central United States, a general relationship is indicated between the water loss by evaporation from an area and its mean annual temperature. Because mean annual temperature is generally higher in southern Florida than in other parts of the United States, it follows that evaporation should also be comparatively large.

The effect of wind on evaporation is in the replacing of the moisture-laden air at the water ground, or plant surface with usually drier air capable of continuing the evaporation process and inducing vertical mixing. Therefore, total evaporation from any given surface increases with the air movement or wind.

The relative humidity of the atmosphere is likewise a factor to be considered because it is a measure of the extent to which the air can hold additional water. Because the relative humidity is usually high during, before, and after periods of rainfall, the evaporation losses are decreased during these times.

Solar radiation increases the evaporation processes principally through its effect in raising the temperatures of bodies of water, of the soil, and of vegetation. Direct radiation is especially effective when the temperatures of water-surfaces are raised above that of the surrounding air.

Evapotranspiration from land areas is a more complex process than evaporation from open-water surfaces. Total loss from the former is the sum of losses both from vegetation (transpiration) and from the ground (or water surface when the ground is inundated). Furthermore, the losses over longer periods of time from evaporation pans and open-water areas are fairly uniform because of the continuous supply of water. Losses from land areas, however, may vary more widely because of the greater variations in the amount of water available for evaporation.

To illustrate the complexities and the characteristics of total evaporation losses in southeastern Florida, the process of evapotranspiration in a typical section of the open Everglades will be analyzed. This area is assumed to be covered with a growth of sawgrass and other vegetation rooted in several feet of peat or muck over a rock floor. During the summer months the heavy rains usually cover the surface of the muck with several inches of water. The temperatures are high, the sun is bright, and the shallow, standing water warms rapidly. Water vapor moves from the water surface into the air which circulates, perhaps by convection 
currents, to the top of the vegetation, and then it is carried away by a gentle wind to be replaced by the drier air. Air turbulence produced by the wind serves to diffuse the vapor towards higher levels. At the same time, the processes of transpiration are active. Water absorbed through the roots of the vegetation is also being given to the atmosphere, both from the moist outer membranes and from the pores of the plants. This combination of conditions is conducive to large water losses.

As a rain storm approaches, the relative humidity of the air increases, and its evaporative capacity is correspondingly decreased. The direct solar radiation is intercepted by clouds, and the air and standing water become cooler. The rate of water loss is greatly reduced as a result of this change. During the period of rainfall it may stop entirely. The rate of loss is likewise lessened at night when somewhat similar conditions of lower temperature, lack of direct solar energy, and increased relative humidity prevail.

As summer passes a lowering of the levels of the standing water takes place during the drier fall and winter months, but because of lower temperatures and shorter periods of sunlight, the evaporation qualities of the atmosphere likewise decrease. The water level then declines below the surface of the ground. Transpiration continues as long as adequate water remains available to the root systems, but the loss from the soil now moistened by capillarity from the lower water level is less than that from free water surfaces. Still later, in some areas the water declines to a level where it can no longer be drawn to the surface and lost by evaporation, and all or part of the vegetation approaches a dormant condition with arrested transpiration losses. Thus, the opportunity for evaporation varies greatly even under natural conditions. Total loss depends as much upon availability of water for evapotranspiration as it does upon weather and air conditions.

\section{EVAPORATION}

The direct measurement of evaporation from land and water surfaces meets fundamental obstacles and is subject to many practical limitations (Thornthwaite and Holzman, 1942). The measurement of evaporation losses from small water areas can be made much more rapidly in open tanks called evaporation pans, but it is also beset with difficulties in practical application. Coefficients deter mined experimentally may be applied to these losses to indicate approximately the losses over natural water surfaces of varying size, depth, and exposure. A list of some of the evaporation pans operated in southeastern Florida is given in table 7. These pans are of three general types, the ventilated pan, the sunken pan, and 
Table 7.-Location, description, and period of record of selected evoporation pans operated in southeastern Florida

\begin{tabular}{|c|c|c|c|c|c|}
\hline Location & County & Latitude & Eongitude & Operator & Years of Record \\
\hline \multicolumn{6}{|c|}{ Standard U. S. Weather Bareau Class A ventilated land pans, 48 inches in diameter and 10 inches deep } \\
\hline $\begin{array}{l}\text { Loxahatchee } \\
\text { Big Cypress Indian Reservation } \\
\text { Hialeah }\end{array}$ & $\begin{array}{l}\text { Palm Beach } \\
\text { Hendry } \\
\text { Dade }\end{array}$ & $\begin{array}{l}26^{\circ} 41^{\prime} \\
26^{\circ} 19^{\circ} \\
25^{\circ} 50^{\circ}\end{array}$ & $\begin{array}{l}80^{\circ} 16^{\prime} \\
81^{\circ} 00^{\prime} \\
80^{\circ} 18^{\prime}\end{array}$ & $\begin{array}{l}\text { U. S. Geological Survey } \\
\text { U. S. Geological Sturvey } \\
\text { City of Miami water plant in cooper- }\end{array}$ & $\begin{array}{l}1940- \\
1940-43 \\
1940-\end{array}$ \\
\hline Tamiami Canal (40-Mile Bend) & Dade & $25^{\circ} 45^{*}$ & $80^{\circ} 49^{\prime}$ & U. S. Geological Survey & $1940-$ \\
\hline
\end{tabular}

Colorado type sunken pans, 3 feet square and 18 inches deep with bottoms about 1 foot below grotmd surface

\begin{tabular}{|c|c|c|c|c|c|}
\hline $\begin{array}{l}\text { Moore Haven } \\
\text { Clewiston } \\
\text { Belle Glade } \\
\text { Canal Point } \\
\text { Port Mayaca } \\
\text { Okeechobee }\end{array}$ & $\begin{array}{l}\text { Glades } \\
\text { Hendry } \\
\text { Palm Beach } \\
\text { Palm Beach } \\
\text { Martin } \\
\text { Okeechobee }\end{array}$ & $\begin{array}{l}26^{\circ} 50^{\prime} \\
26^{\circ} 45^{\prime} \\
26^{\circ} 42^{\prime} \\
26^{\circ} 52^{\prime} \\
26^{\circ} 59^{\prime} \\
27^{\circ} 13^{\prime}\end{array}$ & $\begin{array}{l}81^{\circ} 05^{\prime} \\
80^{\circ} 55^{\prime} \\
80^{\circ} 43^{\prime} \\
80^{\circ} 38^{\prime} \\
80^{\circ} 37^{\prime} \\
80^{\circ} 48^{\prime}\end{array}$ & $\begin{array}{l}\text { Corps of Engineers } \\
\text { do } \\
\text { do } \\
\text { do } \\
\text { do } \\
\text { do }\end{array}$ & $\begin{array}{l}1926^{1-}- \\
1937^{2}- \\
1937^{2}- \\
1937^{2} \\
1937^{2}- \\
1937^{2}-\end{array}$ \\
\hline
\end{tabular}

U. S. Weather Bureau Class A floating pan

\begin{tabular}{|c|c|c|c|c|c|}
\hline West Palm Beach & Palm Beach & $26^{\circ} 42^{\prime}$ & $80^{\circ} 04^{\prime}$ & Everglades Drainage District & $1916-31^{3}$ \\
\hline
\end{tabular}

${ }^{1}$ Records prior to 1926 destroyed. Prior to 1937 operation by Everglades Drainage District (about 1918 to 1930 ) and Fred A. Flanders (1930-37).

${ }^{2}$ Subject to change when additional data are available.

${ }^{3}$ Original records available only from 1920-28. 
the floating pan. The water temperatures in the first type are approximately those of the surrounding air; in the second and third types the water temperatures are approximately those of the soil and water surfaces, respectively.

The only other evaporation pans in the area were operated by the Everglades Drainage District in the vicinity of West Palm Beach and Lake Okeechobee for varying periods between 1915 and 1932 . Original records for these pans are not available.

The evaporation loss in pans is determined by differences between successive water-level readings with corrections for rainfall as measured in an adjacent rain gage. Readings are usually made daily to the nearest thousandth of an inch. Surplus water from rainfall is removed from the pan, and water lost by evaporation is replaced at intervals as necessary to maintain the surface within operational limits.

Values as determined from the ventilated standard U. S. Weather Bureau pans would be representative of evaporation losses from natural, small isolated shallow pools of water in the general vicinity of the pan, where similar exposure conditions prevailed. Studies extending over a long period of time have shown that coefficients, if carefully chosen, may be applied to pan values to give approximate natural losses in large bodies of water. According to Harding (1942, p. 75-76), coefficients of 0.70 and 0.78 are generally recommended to be applied to measured evaporation from ventilated and sunken pans, respectively, in order to obtain values of evaporation from extensive water areas.

Such coefficients represent the results of comparison of evaporation from large water bodies as deduced from records of inflow and outflow with evaporation from pans nearby. Even cursory examination of the se comparisons will reveal wide variations in the ratios, which approach the above values only when evaporations over long periods of time are considered. For individual months, estimates of evaporation based on reference to a pan may be in error as much as 100 percent, andfor days the error may be even greater. Assigning reasons for such variations is beyond the scope of this report; possibly, however, much of the difference may arise from differences in exposure and water temperatures.

For methods used in the evaluation of total evaporation losses from several areas by subtracting runoff from rainfall, see pages $524-531$.

Records from three of the listed evaporation pans (ventilated pan at Belle Glade, a sunken pan at Moore Haven, and a floating pan at West Palm Beach) are sufficiently long to permit a determination of seasonal and other characteristics. The fact that each of these 
Table 8. - Monthly and annual evaporation (in inches) for ventilated pan at Belle Glade, Palm Beach County

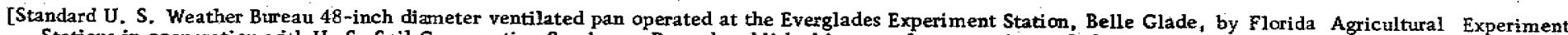

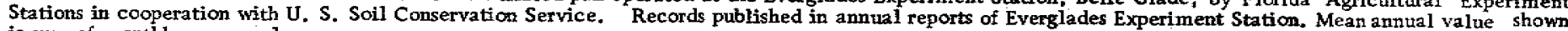
is sum of monthly averages]

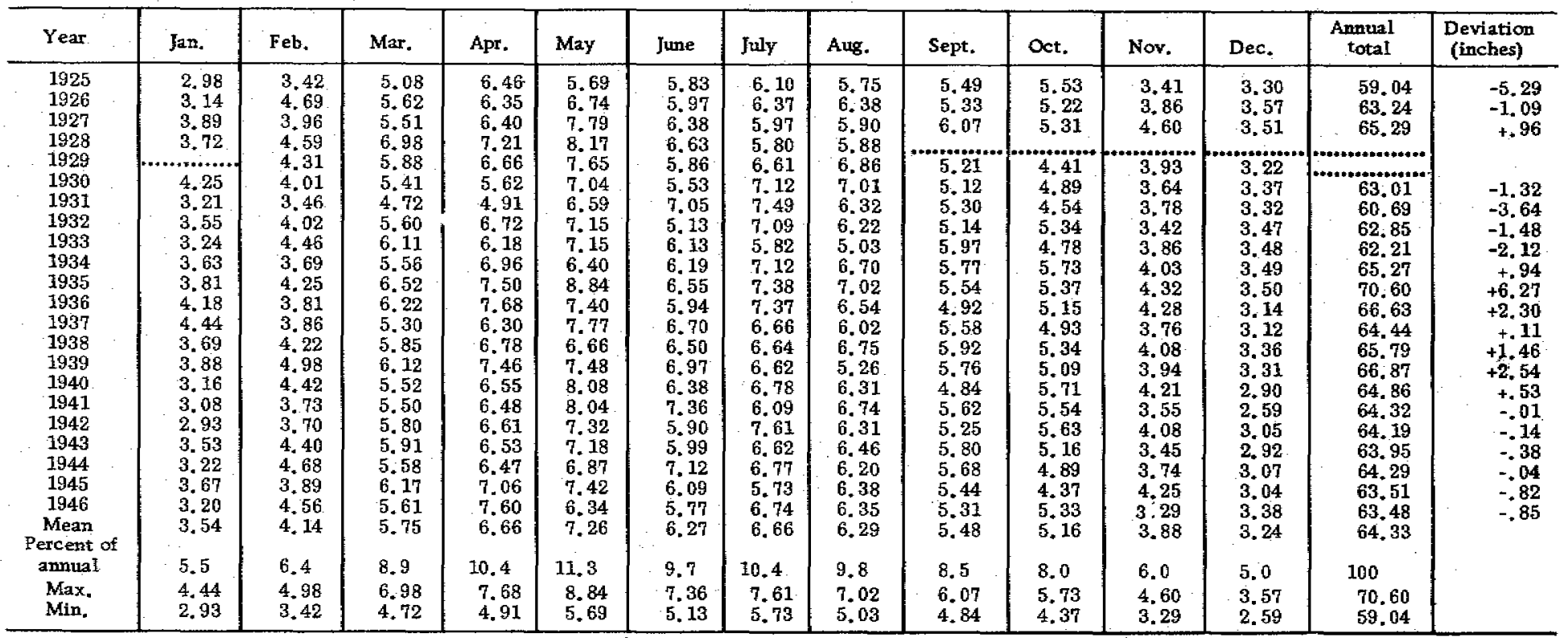


Table 9. - Wonthly and annual evaporation (in inches) for sunken pan at lfoore Ilaven, Glades County

[Colorado type sunken pan, 3 feet square and 18 inches deep with bottom 15 inches below ground surface. Station operated by Everglades Drainage District (about 1918 to November 1930), by Fred A. Flanders (November 1930 to January 1937) and by Corps of Engineers, U. S. Army (beginning January 1937). Records, December 1926 to December 1940, furnished by Fred A. Flanders (observer since 1921); those beginning January i941 published in U. S. Weather Bureau Climatological Data-Florida section. Mean annual value shown is sum of monthly averages]

\begin{tabular}{|c|c|c|c|c|c|c|c|c|c|c|c|c|c|c|}
\hline Year & Jan. & Feb. & Mar. & Apr. & May & Jume & July & Aug. & Sept. & Oct. & Nov. & Dec. & $\begin{array}{l}\text { Annual } \\
\text { total }\end{array}$ & $\begin{array}{l}\text { Deviation } \\
\text { (inches) }\end{array}$ \\
\hline \begin{tabular}{c|}
1926 \\
1927 \\
1928 \\
1929 \\
1930 \\
1931 \\
1932 \\
1933 \\
1934 \\
1935 \\
1936 \\
1937 \\
1938 \\
1939 \\
1940 \\
1941 \\
1942 \\
1943 \\
1944 \\
1945 \\
1946 \\
Mean \\
Percent of \\
annual \\
Max. \\
Min.
\end{tabular} & $\begin{array}{l}2.67 \\
2.58 \\
2.11 \\
2.91 \\
1.92 \\
2.98 \\
3.22 \\
3.07 \\
3.07 \\
2.01 \\
3.00 \\
2.82 \\
2.88 \\
2.63 \\
2.50 \\
3.07 \\
3.18 \\
2.91 \\
3.13 \\
2.72 \\
2.77 \\
5.3 \\
3.22 \\
1.92\end{array}$ & $\begin{array}{l}2.35 \\
2.81 \\
2.58 \\
2.93 \\
2.34 \\
3.56 \\
3.10 \\
2.76 \\
3.20 \\
2.63 \\
3.11 \\
3.28 \\
3.34 \\
3.00 \\
2.38 \\
3.17 \\
3.93 \\
4.08 \\
3.31 \\
3.71 \\
3.08 \\
5.9 \\
4.08 \\
2.34\end{array}$ & $\begin{array}{l}4.69 \\
4.86 \\
4.04 \\
3.59 \\
3.56 \\
3.88 \\
5.12 \\
4.18 \\
4.78 \\
4.97 \\
4.02 \\
4.33 \\
5.01 \\
3.67 \\
3.90 \\
4.56 \\
5.35 \\
5.17 \\
5.46 \\
4.87 \\
4.50 \\
8.7 \\
5.46 \\
3.56\end{array}$ & $\begin{array}{c}6.16 \\
5.92 \\
5.10 \\
4.35 \\
4.12 \\
4.74 \\
4.95 \\
5.96 \\
5.72 \\
5.77 \\
4.11 \\
5.68 \\
4.79 \\
5.15 \\
4.45 \\
4.93 \\
6.28 \\
5.79 \\
6.64 \\
6.50 \\
5.36 \\
10.3 \\
6.64 \\
4.11\end{array}$ & $\begin{array}{l}6.14 \\
6.83 \\
5.54 \\
6.01 \\
5.52 \\
5.95 \\
6.17 \\
4.86 \\
6.84 \\
7.16 \\
5.45 \\
5.34 \\
4.98 \\
5.83 \\
6.03 \\
5.72 \\
6.83 \\
6.00 \\
7.28 \\
5.30 \\
5.99 \\
1.6 \\
7.28 \\
4.86\end{array}$ & $\begin{array}{l}7.00 \\
5.43 \\
4.20 \\
4.40 \\
6.27 \\
4.73 \\
4.75 \\
5.91 \\
5.17 \\
5.48 \\
4.97 \\
4.85 \\
4.67 \\
4.32 \\
5.47 \\
4.25 \\
5.40 \\
5.55 \\
5.13 \\
4.73 \\
5.13 \\
9.9 \\
7.00 \\
4.20\end{array}$ & $\begin{array}{c}5.91 \\
5.23 \\
4.74 \\
5.54 \\
6.08 \\
6.00 \\
4.97 \\
5.01 \\
4.80 \\
6.99 \\
4.94 \\
4.62 \\
3.76 \\
4.95 \\
4.86 \\
6.36 \\
4.76 \\
5.40 \\
4.38 \\
4.72 \\
5.21 \\
10.1 \\
6.99 \\
3.76\end{array}$ & $\begin{array}{l}4.93 \\
4.92 \\
5.24 \\
5.15 \\
4.79 \\
4.93 \\
4.82 \\
5.04 \\
4.83 \\
6.46 \\
6.32 \\
5.70 \\
3.51 \\
3.98 \\
5.34 \\
5.98 \\
5.47 \\
4.31 \\
4.59 \\
4.49 \\
5.04 \\
9.7 \\
6.46 \\
3.51\end{array}$ & $\begin{array}{l}4.72 \\
3.76 \\
3.54 \\
4.06 \\
4.27 \\
4.81 \\
4.64 \\
4.78 \\
4.47 \\
4.39 \\
4.72 \\
3.45 \\
4.50 \\
3.29 \\
4.33 \\
4.70 \\
4.60 \\
5.18 \\
3.76 \\
4.52 \\
4.33 \\
\\
8.4 \\
5.18 \\
3.29\end{array}$ & $\begin{array}{l}4.03 \\
4.08 \\
3.20 \\
4.29 \\
4.00 \\
4.04 \\
4.64 \\
4.36 \\
3.94 \\
4.19 \\
3.83 \\
4.57 \\
4.10 \\
4.71 \\
4.54 \\
5.65 \\
4.91 \\
4.50 \\
3.86 \\
4.67 \\
4.31 \\
8.3 \\
5.65 \\
3.20\end{array}$ & $\begin{array}{l}3.33 \\
2.92 \\
3.53 \\
3.12 \\
3.17 \\
3.75 \\
3.62 \\
2.92 \\
3.12 \\
4.13 \\
3.27 \\
3.45 \\
3.75 \\
3.72 \\
3.16 \\
3.62 \\
3.66 \\
3.61 \\
3.83 \\
2.92 \\
3.43 \\
\\
6.6 \\
4.13 \\
2.92\end{array}$ & $\begin{array}{l}2.67 \\
2.67 \\
2.70 \\
3.13 \\
2.26 \\
2.57 \\
2.64 \\
2.97 \\
2.66 \\
2.74 \\
2.56 \\
2.59 \\
2.67 \\
2.47 \\
2.27 \\
2.55 \\
2.80 \\
3.04 \\
3.11 \\
2.58 \\
2.99 \\
2.69 \\
5.2 \\
3.13 \\
2.26\end{array}$ & $\begin{array}{c}54.60 \\
52.04 \\
46.95 \\
48.61 \\
48.61 \\
52.01 \\
52.97 \\
51.51 \\
52.68 \\
56.74 \\
50.33 \\
50.76 \\
47.76 \\
47.52 \\
49.51 \\
54.81 \\
57.41 \\
55.61 \\
53.95 \\
52.14 \\
51.84 \\
100.0 \\
57.41 \\
46.95\end{array}$ & $\begin{array}{r}+2.76 \\
+.20 \\
-4.89 \\
-3.23 \\
-3.23 \\
+.17 \\
+1.13 \\
-.33 \\
+.84 \\
+4.90 \\
-1.51 \\
-1.08 \\
-4.08 \\
-4.32 \\
-2.33 \\
+2.97 \\
+5.57 \\
+3.77 \\
+2.11 \\
+.30\end{array}$ \\
\hline
\end{tabular}


Table 10. - Monthly and anrual evaporation (in inches) for floating pan at West Palm Deach, Palm Deach County

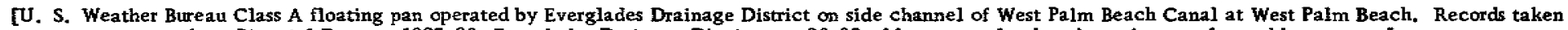
from Biennial Report, 1927-28, Everglades Drainage District, p. 36-38. Mean annual valufe shown is sum of monthly averages]

\begin{tabular}{|c|c|c|c|c|c|c|c|c|c|c|c|c|c|c|}
\hline Year & Jan. & Feb. & Mar. & Apr. & May & June & July & Aug. & Sept. & Oct. & Now. & Dec. & $\begin{array}{l}\text { Amual } \\
\text { total }\end{array}$ & $\begin{array}{l}\text { Deviation } \\
\text { (inches) }\end{array}$ \\
\hline $\begin{array}{l}1920 \\
1921 \\
1922 \\
1923 \\
1924 \\
1925 \\
1926 \\
1927 \\
1928 \\
\text { Mean } \\
\text { Percent of } \\
\text { anmual } \\
\text { Max. } \\
\text { Min. }\end{array}$ & $\begin{array}{l}3.7 \\
4.2 \\
3.3 \\
3.7 \\
1.9 \\
2.7 \\
2.4 \\
3.8 \\
2.9 \\
3.2 \\
5.9 \\
4.2 \\
1.9\end{array}$ & $\begin{array}{l}4.0 \\
4.5 \\
4.0 \\
3.8 \\
2.9 \\
3.6 \\
3.2 \\
4.0 \\
2.9 \\
3.7 \\
6.8 \\
4.5 \\
2.9\end{array}$ & $\begin{array}{l}4.5 \\
4.3 \\
5.6 \\
4.7 \\
4.6 \\
2.8 \\
3.6 \\
5.6 \\
4.5 \\
4.5 \\
8.3 \\
5.6 \\
2.8\end{array}$ & $\begin{array}{r}5.3 \\
7.7 \\
6.3 \\
4.9 \\
5.0 \\
5.2 \\
3.5 \\
6.2 \\
5.8 \\
5.5 \\
10.2 \\
7.7 \\
3.5\end{array}$ & $\begin{array}{r}6.6 \\
8.3 \\
4.2 \\
5.6 \\
5.1 \\
3.4 \\
4.9 \\
7.8 \\
6.2 \\
5.8 \\
10.7 \\
8.3 \\
3.4\end{array}$ & $\begin{array}{r}6.2 \\
8.9 \\
3.6 \\
6.4 \\
4.9 \\
4.6 \\
3.4 \\
6.4 \\
5.6 \\
5.6 \\
10.3 \\
8.9 \\
3.4\end{array}$ & $\begin{array}{l}6.0 \\
5.2 \\
3.8 \\
2.4 \\
4.7 \\
4.7 \\
3.0 \\
5.8 \\
6.0 \\
4.6 \\
8.5 \\
6.0 \\
2.4\end{array}$ & $\begin{array}{l}6.9 \\
6.4 \\
2.6 \\
4.9 \\
5.9 \\
3.8 \\
4.9 \\
5.8 \\
5.8 \\
5.2 \\
9.6 \\
6.9 \\
2.6\end{array}$ & $\begin{array}{l}4.3 \\
5.5 \\
2.6 \\
3.8 \\
3.9 \\
4.8 \\
5.6 \\
6.0 \\
4.8 \\
4.6 \\
8.5 \\
6.0 \\
2.6\end{array}$ & $\begin{array}{l}5.8 \\
3.8 \\
2.2 \\
4.9 \\
2.9 \\
3.7 \\
5.5 \\
5.5 \\
4.9 \\
4.4 \\
8.1 \\
5.8 \\
2.2\end{array}$ & $\begin{array}{l}3.9 \\
3.7 \\
3.3 \\
2.6 \\
4.7 \\
3.4 \\
4.5 \\
4.7 \\
3.7 \\
3.8 \\
7.0 \\
4.7 \\
2.6\end{array}$ & $\begin{array}{l}3.5 \\
3.6 \\
3.9 \\
2.9 \\
2.3 \\
2.1 \\
4.8 \\
3.6 \\
3.2 \\
3.3 \\
6.1 \\
4.8 \\
2.1\end{array}$ & $\begin{array}{r}60.7 \\
66.1 \\
45.4 \\
50.6 \\
48.8 \\
44.8 \\
49.3 \\
65.2 \\
56.3 \\
54.2 \\
100.0 \\
66.1 \\
44.8\end{array}$ & $\begin{array}{r}+6.5 \\
+11.9 \\
-8.8 \\
-3.6 \\
-5.4 \\
-9.4 \\
-4.9 \\
+11.0 \\
+2.1\end{array}$ \\
\hline
\end{tabular}



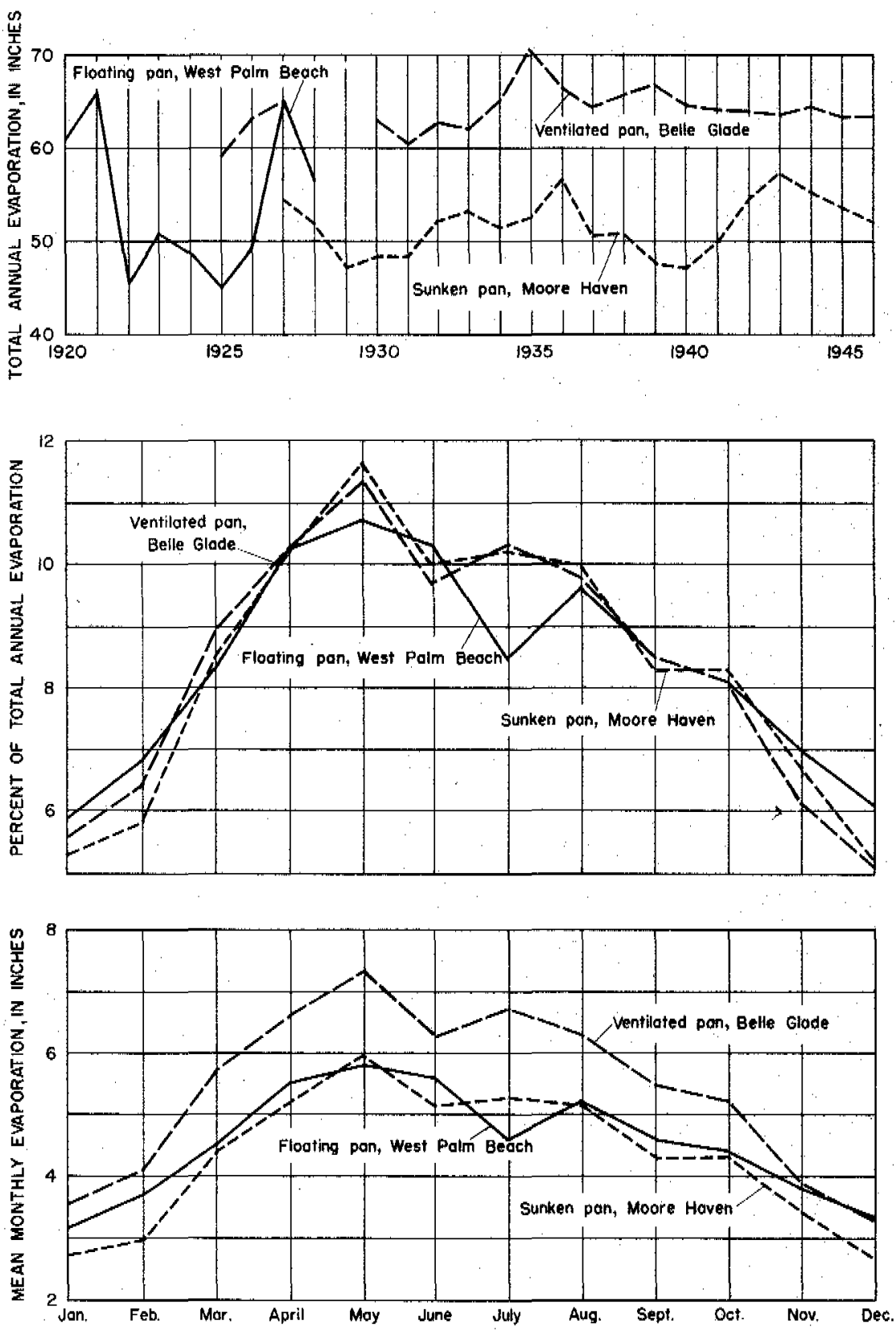

Figure 6. -Graph showing characteristics of evaporation from selected pans in southeastern Florida. 
records is for a different type of evaporation pan permits comparative studies of the losses from each pan. Monthly values for each pan for the period of available record are given in tables 8-10, and from these records the mean, maximum, and minimum monthly values and total annual. values were computed. Beginning with January 1941, nearly all current evaporation records in the area are published in U. S. Weather Bureau Climatological Data, Florida section. The source of the earlier records is indicated in a note with each tabulation.

It will be noted that the periods of record for the sunken pan at Moore Haven are nearly the same as for the Belle Glade ventilated pan. As a test of the local applicability of the coefficients cited above for determining losses over large bodies of water from records for ventilated (coefficient, 0.70) and sunken (coefficient, 0.78) pans, the mean annual values for the similar years of record (1927, 1930-43) for each pan were calculated. The mean evaporation from the ventilated pan was about 25 percent greater than from the sunken pan. However, after application of the coefficients, the calculated annual loss from Lake Okeechobee would be about 11 percent greater on the basis of ventilated-pan values $(64.7 \times$. $70=$ 45.3 inches) than for the sunken-pan values $(51.7 \times .78=40,4$ inches). The generally recommended coefficient for a floating pan, such as the one at West Palm Beach, is 0,80, which, multiplied by the average annual evaporation for the 1920-28 period of record (54. 2 inches) equals 43.4 inches. This is believed to be a reasonably close agreement, and it indicates an average annual loss over Lake Okeechobee of 40 to 45 inches.

Figure 6 illustrates graphically certain characteristics of the losses from these pans and permits ready comparison between them. The values plotted are taken from tables 8,9 and 10. The most outstanding evaporation characteristics, important because of their relationship to natural evaporation losses over the area, are shown by figure 6 to be as follows:

1. Seasonal variation: May is the month of greatest loss for all pans. Averages show April and June to be next in that order. The total monthly values for the floating and sunken pans generally agree closely; those for the ventilated pan are larger throughout the year and greater differences exist during the summer than durthe winter months.

An average of mean monthly values for the three types of pans shows the evaporation to be lowest for December, followed closely by January, and with February and November next lowest in that order. The evaporation during the months of December, January, and February average about 0.55 of the evaporation during the three months of April, May, and June. 
2. Annual variation: The range in total annual values throughout the period of record is approximately 10 inches for both the ventilated and sunken pans. The range for the values for the floating pan is about twice as great, but direct comparison is difficult because this record covers an earlier period. The annual values for the ventilated and sunken pans have only a slight similarity.

The deviations of annual evaporation from the average annual are listed in tables 8,9 , and 10 . The average of these deviations (signs disregarded) is a statistical measure of the year-to-year tendency of evaporation to vary. For Belle Glade the average deviation is 1.80 inches, or 2.8 percent of the average annual; at Moore Haven, 2.55 inches, or 5 percent of the average annual; and at West Palm Beach, 7.1 inches, or 13 percent of the average annual evaporation. The average deviations vary greatly for the three sets of observations. It is notclear whether these deviations are caused by differences in the three pans and their exposures or whether they are caused by differences in climatic factors. However, it may be noted that, in general, the variability is less than that of rainfall (for which the mean deviation at Miami has been reported as 19 percent and at Okeechobee, 13 percent).

Total monthly losses from the ventilated pan at the Hialeah Water Plant, operated by the U. S. Geological Survey during the period of study, are shown in graphical form on plate 3 , which also includes other climatological data helpful to a better understanding of the reasons for the seasonal trend of evaporation values. The seasonal distribution of evaporation and the effect of temperature and wind is further illustrated in figure 7 , where the observed evaporation has been adjusted as a result of a correlation analysis to a constant value of wind movement so as to bring out the relation of evaporation to temperature. The rate of evaporation reaches a seasonal minimum in December and January. Increases, until about March, are associated with increases in wind movement and temperature; thereafter, although the wind decreases, evaporation losses continue to increase until rising temperatures reach a peak in May. During the summer, evaporation decreases moderately mostly because of a decrease in wind movement. The tendency towards lower relative humidity in April and May and higher relative humidity in September and October may also be an influence, but the seasonal variation in relative humidity is not marked. After the end of the summer rainy season the rate of evaporation continues to decrease with lowering temperatures until the end of the calendar year.

From January until May, as shown on figure 7, the observed evaporation exceeds the amount of evaporation due to temperature alone. During this period, it may be noted that wind movement is about average (3,000 miles per month). From June to December 


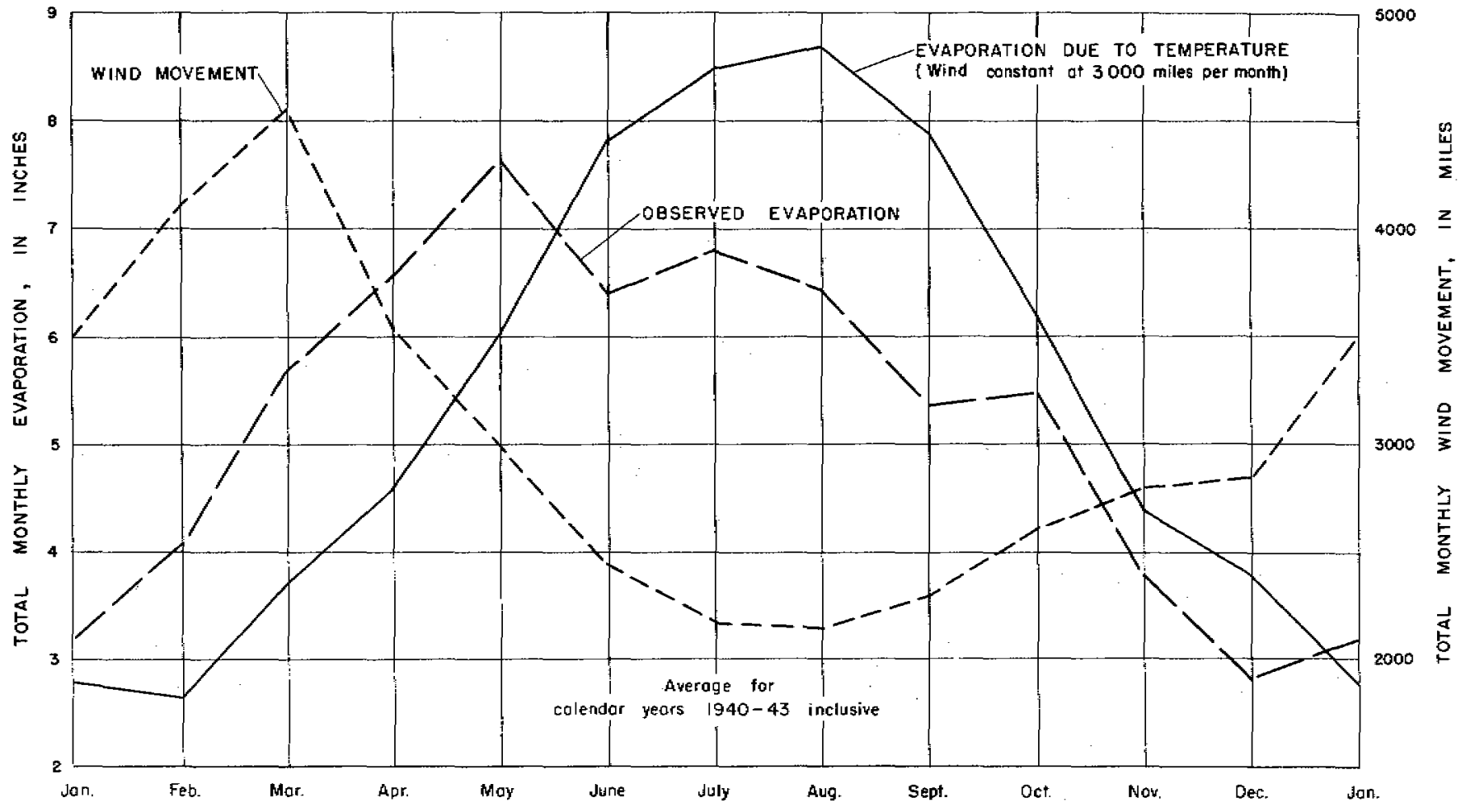

Figure 7. - Study of pan evaporation in relation to temperature and wind movement at Belle Glade. 
(the period of less-than-average wind movement) observed evaporation is below that due to temperature. The high wind movement during the January-May period of low rainfall creates a condition that tends to intensify loss of soil moisture during this critical period.

Unlike precipitation, evaporation in the Everglades appears, from a study of the records collected so far, to have no appreciable areal variation. Any observed differences may be due partly to variations in the equipment, its exposure, the method of taking observations, or other causes.

Although the characteristics of seasonal variation in evaporation from natural bodies of water are thought to be somewhat similar to those shown for the pans, it cannot be inferred that such is generally true for evaporation over land areas, where the water supplies vary widely during the year and where the seasonal variation in evaporation may be quite different. The months of greatest evaporation normally would be during the usually wet summer season, when water stands over extensive areas.

\section{EVAPOTRANSPIRATION}

Experiments on evapotranspiration were conducted and reported (Clayton, Neller, and Allison, 1942, p. 35) by soil scientists of the University of Florida and the U. S. Department of Agriculture, in 1937 and 1938, at the Everglades Experiment Station near Belle Glade, Fla. The station is southeast of Lake Okeechobee and about 75 miles nor th-northwest of Miami. The experimenters attempted to determine values for evapotranspiration losses from sawgrass lands. The tanks used were 4 feet wide, 12 feet long, and 4 feet deep; they contained 3 feet of muck soil placed on a 3-inch layer of crushed limestone in the bottom of the tanks. The tanks were set into the ground to a depth of $3 \frac{1}{2}$ feet.

After making due allowance for differences between conditions in the tanks and those in the Everglades near Belle Glade, the experimenters estimated the mean annual evapotranspiration from sawgrass land to be about 60 inches. This estimate assumed a water table ranging throughout the year from the land surface to 4 feet or morebelow the surface and averaging about 2 feet below. For the 2 complete years that the experiment was conducted, the average evapotranspiration loss during the months of May, June, and July was about twice as great as the loss for the months of December, January, and February.

The sawgrass in the glades near Belle Glade has a denser and more vigorous growth than the vegetation in the glades west of 
Miami, owing largely to the greater thickness of muck overlying the limestone in the lake area. The muck is approximately 8 feet thick there, whereas it ranges from a few inches to about 3 feet in thickness in the glade areas near Miami. Because of drainage of the glades and recurring muck fires, the sawgrass in the southern glades and near the coastal ridge has been stunted, and in some areas it has been and is being replaced by several species of grasses, sedges, and reeds. These factors probably make the transpiration losses in the glades near Miami and in southern Dade County appreciably less than losses in the glades near Belle Glade. See p. 229 for additional information on evapotranspiration from pine- and grass-land areas south of Miami, obtained from groundwater investigative methods, which indicate approximately 35 inches of annual evapotranspiration, and to pages 544 and 545 which indicate about 42.4 inches average annual evapotranspiration from the Kissimmee River basin.

Experiments were also conducted in a tank at Belle Glade during 1934-36 to determine the amount of evaporation from bare muck soil. The evaporation rates for the 3 years were, respectively, $42.65,39.21$, and 35.97 inches of water; the average yearly depths to the water table were $1.76,1.33$ and 1.43 feet below the muck surface in the tank.

During 1937 and 1938 , experiments were conducted with the bare soil in a tank covered with 3 to 4 inches of cane trash. The evaporation rates were, respectively, 12.2 and 9.1 inches of water; the average yearly depth to the water in the tank was 1.4 feet. This shows that the addition to the bare soil of a 3-inch layer of dead cane trash reduced the annual evaporation approximately 30 inches.

The rate of decline of the water table in tanks containing sawgrass was reported not appreciably affected by the depth to water below the land surface so long as the water level remained in the 3-foot thickness of muck. This indicates that the depth to the water table, within this range, did not have a noticeable effect on the total evapotranspiration loss.

The Everglades Drainage District conducted experiments on rates of evapotranspiration loss from tanks operated at West Palm Beach. Of these, Fred M. Elliot, former chief drainage engineer of the District, states that large differences were found in annual total evaporation losses from similar types of vegetation under different water levels. Losses were measured concurrently from two tanks having stands of Para grass growing in muck carefully transplanted from the Everglades. In one of the tanks, water levels were maintained between the top and 12 inches below the top of the muck. In the other, the water was held at considerably lower levels from 30 to 36 inches below the top of the muck. The total evaporation for a year from the former tank was about 110 inches, but during 
the same period the tank containing the lower water levels showed a loss of 50 to 60 inches. Elliot states further that under comparable water levels the stands of Para grass showed the greatest total evaporation of all types of vegetation under observation. The rate of water loss from corn during its growing season was next highest, with a stand of sawgrass somewhat below that for corn.

\section{CONCLUSION}

Because of their great magnitude, a thorough knowledge of the characteristics of evaporation and transpiration losses is highly desirable for the successful study of the water resources of southeastern Florida. Evaporation losses from permanent water areas can be determined with a fair degree of accuracy and are believed to average about 40 to 45 inches per year. Over land areas, however, less-direct methods must be used to determine evaporation and transpiration values, and it has been found practicable to attempt this only for the total rather than for the individual losses. 


\section{GEOLOGY}

By Garald G. Parker, N. D. Hoy, and M. C. Schroeder

\section{RELATIONSHIP OF GEOLOGY TO STUDY OF GROUND-WATER RESOURCES}

The occurrence of ground water is governed by the geology, and any attempt toward its evaluation is therefore dependent upon a thorough knowledge of the structure, stratigraphy, and lithology of the area. Studies of outcrops aid in the correlation of the for mations and give clues concerning their stratigraphic relations.

In areas where the rocks are hidden, exploratory test-well drilling must be done in order to determine formations present at any given depth and to determine the lithologic, hydrologic, and paleontologic characteristics of the formations. With this information the geologist can then prepare maps and cross sections showing graphically the relationships of the formations, the aquifers, and the aquicludes. Thus, the width, thickness, and general distribution of all formations and water-bearing rocks can be determined, and by constructing water-table maps the movement of water can be traced from the time it enters the rocks until it is finally discharged.

\section{METHODS OF INVESTIGATION}

GENERAL STATEMENT

The study of geology in southern Florida is not only difficult to perform, but it is slow and costly. This is because of the combination of low-lying land with little relief; the thick cover of mantling sands, marls, and soft organic soils; the thick growth of vegetative cover; and the large area of swamps and marshes.

These conditions were almost insurmountable to early geologists, whose work was necessarily confined to observation of outcrops around the margins of the peninsula and along the low banks of the few shallow rivers. Only a few water wells had beendrilled, and few cuttings had been saved; therefore, adequate studies of the underlying rocks were impossible.

Later, the building of roads, railroads, canals, and cities brought about conditions that made geological research easier. Cuts for roads and railroads in southern Florida are practically nonexistent, but the excavation of borrow pits, ditches, and 
quarries, and the drilling of thousands of wells have helped. The miles of spoil banks have revealed the surficial distribution of the formations, and the fine state of preservation of the fossils found therein has aided greatly in working out the stratigraphy and paleontology.

The construction of roads, which crisscross hitherto inaccessible portions of the area, has been of inestimable value, and the development of new means of transportation, such as the "gladesbuggy," "air-boat," wide-cleated tractor, helicopter, and airplane, has made it possible to explore these trackless wilds. Then, too, the development of efficient drilling machinery has been a relatively recent accomplishment. Light portable drilling equipment can now be utilized in areas where previously only Seminoles or white hunters ventured, and heavy equipment can be hauled over roads to sites where deep exploratory test wells are needed.

The present investigation has been conducted along two main lines of research: 1. study of outcrops and tracing of formations in the field, and 2. study of subsurface conditions by means of samples from exploratory test wells.

\section{GEOLOGIC STUDIES FROM OUTCROP DATA}

Natural rock outcrops are very limited in southeastern Florida. Only a few occur in the 4,000 square miles of the Everglades and these are principally lacy solution remnants, which are isolated and widely scattered in the southwestern parts. North and west of the Everglades, except. in parts of the Big Cypress Swamp, the rocks are generally covered by sandy marine terrace deposits, and to the east the rocks of the Atlantic Coastal Ridge crop out in a narrow strip bordering the ocean. This strip is likewise largely covered by sand north of Miami, but the sand gradually thins out to the south, and beyond Coral Gables the rocks form the land surface almost everywhere. In the Caloosahatchee River banks west of Ortona the rock exposures (since the dredging of the river and the installation of Ortona Lock) are better than ever before. Recent widening, straightening, and deepening of the river have madefresh cuts through the strata, and the installation of the lock at Ortona has lowered the water level several feet in the stretch of the river west of the locks.

The present areal geologic map (pl, 4) has been worked out largely by tracing formational contacts along canal and borrow excavations during extreme low water of the dry season; it checks fairly closely with that of earlier workers (Cooke and Mossom, 1928). This work has been described in part by Parker (Cross, Love, Parker, and Wallace, 1940; Parker, 1942, p. 47-76; Parker and Hoy, 1943, p. 77-94; Parker and Cooke, 1944) in previous reports. 


\section{EXPLORATORY TEST-WELL DRILLING}

Various methods of gathering subsurface geologic and hydrologic data were used in this investigation; these methods depended upon the funds available, the data required, and the area in which the data were to be collected. For example, in instances where the area was not directly accessible by road, light portable equipment was transported by special vehicles adapted to that particular area. If a shallow well was installed principally to test the quality of ground water (as were the wells through the heart of the Everglades along Miami Canal), a well $1 \frac{1}{4}$ inches in diameter was put down manually. If the purpose was to gather more complete data, portable mechanical drilling equipment was moved in, and wells $2 \frac{1}{2}$ to 4 inches in diameter were drilled (a good sampling of the rocks, fossils, and waters can be obtained from wells of this type). If the area was directly accessible by good road, anykind of equipment, from light to very heavy, could be used, and in most instances wells 6 inches in diameter we re put down. From an exploratory test well of this size, good to excellent cuttings, fossils, and hydrologic data can be obtained, and it was this kind of well that was principally used in this investigation. Occasionally, where conditions permitted, $2 \frac{1}{2}$-inch wells were jetted down; the main advantage of such wells is their relative inexpensiveness. Rock and water samples are satisfactory, but macrofossil data are likely to be poor, and hydrologic data are not so good as from wells of larger diameter.

Most of the test wells were installed by the standard cable-tool method and were drilled in such a manner that the bit was clopsely followed by the casing, thus shutting off the upper rock and water that had been passed through and assuring the collection of valid samples for any given depth. Samples of the cuttings were collected every few feet, stored in containers, and taken to the laboratory for study. Macrofossils were screened out of the cuttings 'at the drilling site; later, in the laboratory, microfossils were separated and mounted on faunal slides for identification. Water samples were collected for analysis as of ten as practicable, although sometimes the formations were essentially without recoverable water and no sample could be obtained.

In drilling by the cable-tool method it is necessary to have enough water in the hole to keep the cuttings continuously immersed. This makes it easier to remove the cuttings, it speeds up drilling, and when the hole is nearly full of water, it helps prevent caving of the soft, unconsolidated materials by maintaining nearly equal hydrostatic pressure inside and outside the well.

Often, however, the deeper formations lacked enough water to supply the well with sufficient drilling water, and it was necessary 
to add water from the surface. Before collecting a water sample, therefore, it was necessary to bail out all this added water to insure the collection of a sample truly representative of the ground water at that depth. In the relatively impervious materials it required many hours for enough water to seep into the test well for sampling purposes. All samples were collected in 12-ounce botthes and were taken to the laboratory for analysis.

In all, 167 exploratory test wells were drilled in southeastern Florida during the $1940-46$ period. Of these, 30 were installed jointly by the U. S. Geological Survey and the Soil Conservation Service. The rest were installed either by the U. S. Geological Survey or, under its supervision, by the Army, Navy, or Defense Plant Corporation. Logs for many of these wells are given in tables $126-134$.

\section{THE FLORIDAN PLATEAU}

The peninsula of Florida is the emerged part of a much wider projection from the continental mass of North America, called by Vaughan (1910, p. 99-185) the Floridan Plateau (fig. 8). ${ }^{1}$ The

'Vaughan spelled it "Floridian," but the simpler and etymologically correct spelling is "Floridan," the spelling herein adopted.

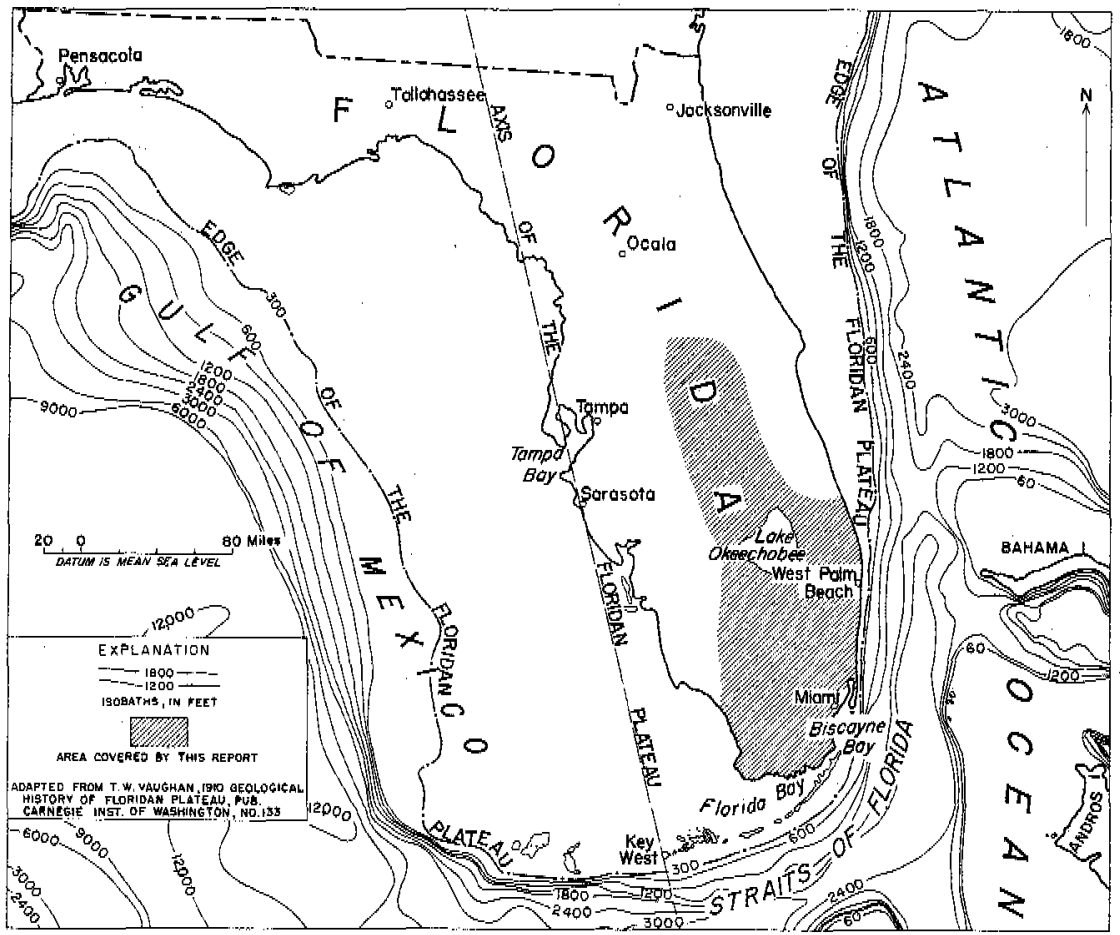

Figure 8. -The Floridan Plateau. 
plateau has the appearance of a huge horst, and it separates the deep water of the Atlantic Ocean from the deep parts of the Gulf of Mexico. Its core is composed of metamorphic and igneous rocks similar to those underlying the Piedmont region of the eastern United States, of which, according to Mossom (1926, p. 174-256), it seems to be a southern extension. Campbell (1939c, p. 87-105) has suggested that Paleozoic and Mesozoic rocks may underlie the sedimentary formations and comprise a part of the core of the plateau. The steep submarine slopes that mark its boundaries on the east, south, and west presumably represent fault scarps or monoclinal folds in the original basement rocks, though their outlines may have been modified by solution and erosion and the accumulation of sediments upon them. Pressler (1947) mapped the faults involved in the structure on the east and south, and he suggested that downwarping caused the form of the plateau.

The core or bedrock of the Floridan Plateau is covered with sediments that range in thickness from about 4,000 feet in northcentral Florida to more than 15, 000 feet in southern Florida. The deepest well drilled in Florida before 1942, located in Monroe County, was started in calcareous sandstone of the Tamiami formation of Miocene age and ended, at a depth of 10,000 feet, in limestone and anhydrite assigned by Campbell (1939b, p. 1713-1714) to the Lower Cretaceous. Cole (1941, p. 16-17) agreed that the rocks are Cretaceous but found- no evidence that they are Lower Cretaceous. The rocks penetrated were dominantly limestone and marl. No sand or clay is reported below the Hawthorn formation of Miocene age-an indication that southern Florida was for a long time remote from sources of such sediments.

Since 1942 several deep wells have been drilled in southern Florida in an attempt to discover new oil fields. The deepest of these wells, drilled at Big Pine Key in Monroe County, (about 30 miles east-northeast of Key West) is reported by Campbell (personal communication) to have penetrated more than 15,000 feet and to have ended in undoubted Lower Cretaceous sediments. The materials penetrated were dominantly limestones, dolomites, and anhydrite.

Only the eastern part of the plateau stands above sea level; the western half slopes gently out beneath the waters of the Gulf of Mexico, where it plunges to greater depths. This suggests tilting to the west. Moreover, the trend of the boundaries between successive geological formations is to extend farther out beneath the Gulf. This, however, might indicate merely that the western half of the plateau was eroded more deeply than the eastern half when the sea stood lower with respect to land surface than it does now. More likely, however, it represents tilting that took place largely at the close of the Pliocene epoch and possibly during the early 
part of the Pleistocene epoch. The sloping surface of the plateau may, in some degree, reflect the contour of the ancient core, or it may be the result of the deposition of a greater thickness of sediments on the eastern side. Since early Pleistocene time no noticeable tilting has taken place-Pleistocene shorelines apparently remain horizontal throughout their distribution in Florida. Cooke (1931, p. 503-515) has traced discontinuous and eroded shorelines from New Jersey into Florida and finds that they are approximately level, thus indicating that this area has been relatively stable for a considerable length of time.

Southern Florida occupies the southeastern corner of the Floridan Plateau. The edge of the plateau lies only a few miles off the Atlantic coast and sweeps closely around the crescent of the Florida Keys, but it lies many miles to the west off the Gulf coast. The shallow waters of the Florida Baylie upon the plateau.

\section{THE OCALA ANTICLINE}

In his geologic cross section, extending from Alabama through Florida to Cuba, Pressler (1947, p. 1851-1862) shows the Ocala uplift underlain by a dome of schist and granite constituting the principal geologic structure of the State, and high-angle faults bounding the southern tip of the Floridan Plateau. The Straits of Florida is shown as a huge graben. He also says that "on the basis of present data, anticlines are probably the most prevalent structure *** though faulting is undoubtedly present, and conditions are favorable for the formation of stratigraphic traps $*_{* *}^{*}$ :"

Overlying the crystalline rocks at the crest of the Ocala uplift are rocks of Late Cretaceous, Tertiary, and Quaternary age. Lower, off the flanks of the uplift, rocks of Early Cretaceous age occur. The Tertiary and Quaternary rocks form a broad elongate dome, or anticline, that trends in a southeastern direction and plunges to the southeast in southern Florida. On its crest, in northwestern peninsular Florida, this huge arch is breached by erosion (see fig. 9), and Ocala limestone of Jackson age (upper Eocene) is exposed at altitudes as much as 150 feet above sea level. In northeastern Monroe County the top of the Ocala limestone lies 1,200 feet below sea level, indicating an average dip southward of about 5 feet per mile. However, because the surface of the Ocala limestone has been modified by faulting, erosion, and solution, this slope probably is not uniform throughout. A slope of 5 feet per mile is less than the slope of many sea bottoms on the continental shelves; nonetheless, it is believed that some deformation is involved. 


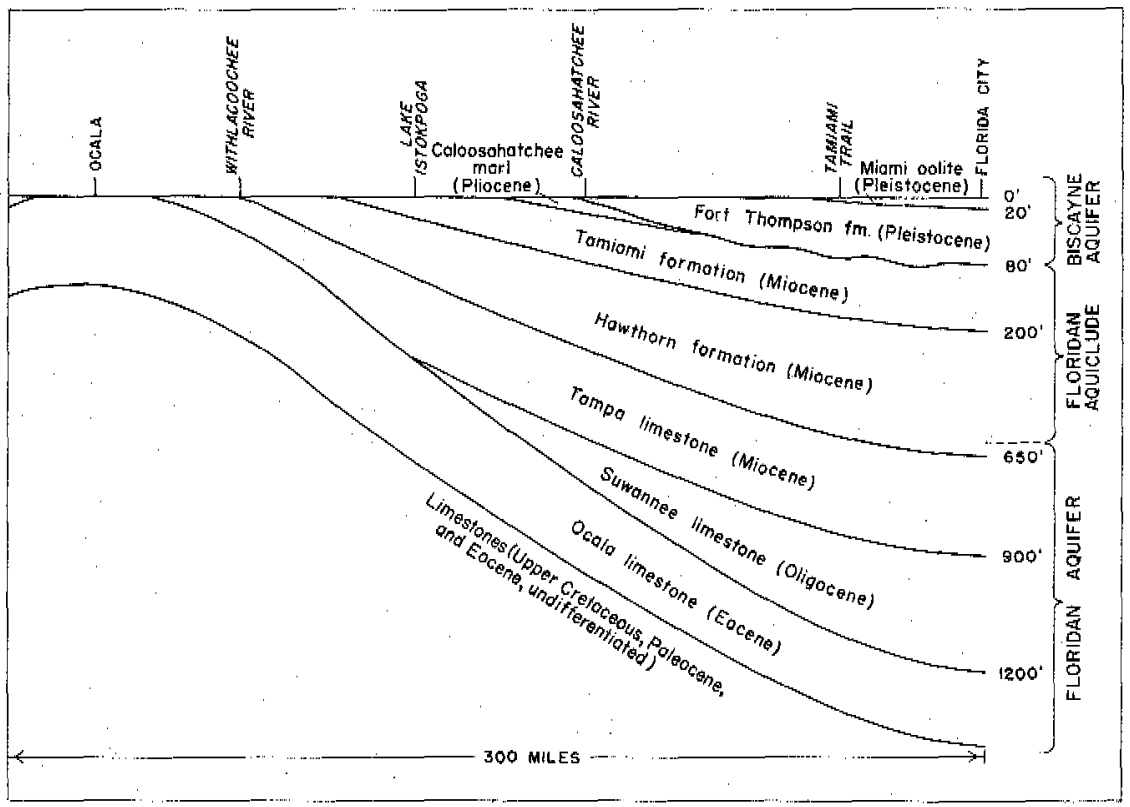

Figure 9. -Generalized NNW-SSE geologic cross section from vicinity of Ocala to Florida City.

Younger geologic formations of Oligocene and Miocene age flank the Ocala anticline and slope away in all directions from the crest of the dome, thickening seaward. Because of their structure and the capacity of some of them for transmitting water, the water-bearing formations constitute notable artesian aquifers. They crop out near the shoreline along Citrus; Levy, and Dixie Counties on the Gulf coast, and at the edge of the continental shelf on the Atlantic coast. Some of their ground-water discharge takes place through submarine springs, such as the one near Saint Augustine, about $2 \frac{1}{2}$ miles east of Crescent Beach (Stringfield, 1936, p. 157; Ferguson, Lingham, Love, and Vernon, 1947, p. 9-10), but most of the natural discharge is probably accomplished through unnoticed submarine seepage.

The younger formations of Pliocene, Pleistocene, and Recent age lie more nearly flat. They do not carry artesian water under high pressure as do the older Tertiary formations, but in local instances water is carried under low artesian head, especially in the Pliocene rocks. 


\section{STRATIGRAPHY AND WATER-BEARING CHARACTERISTICS OF THE FORMATIONS}

\section{GENERAL STATEMENT}

The stratigraphic succession of formations in southern Florida was formed, with few exceptions, under a marine environment. The exceptions occur in the lacustrine and swamp deposits of the Lake Okeechobe-Everglades depression and the connecting Kissimmee River valley. These deposits include the fresh-water beds of the Fort Thompsonformation, the fresh-water Lake Flirt marl, and organic soils, mostly peats and mucks. In west-central Florida there are deltaic, lacustrine, and alluvial deposits that are believed to be contemporaneous with certain of the Pliocene marine beds (Parker and Cooke, 1944, p. 21, 60, 61).

Most of the geologic materials of southern Florida are limestones, marls," silts, clays, shells, sand, gravel, and various mixtures of these materials; very deep wells penetrate great thicknesses of limestone, anhydrite, and gypsum, with minor amounts of halite. Generally the coarser materials, such as coarse sand and gravel, are scarce, but some occur in the Hawthorn and Tamiami formations (Miocene) and in the Caloosahatchee marl (Pliocene). The clays of southern Florida (except the laterite of the Redlands district-mee p. 110) are commonly greenish and calcareous; of marine origin, they usually contain a shallow-water fossil fauna indicative of warm subtropical seas.

This area has long been one of shallow-water conditions with an adjacent low-lying land mass whose usually sluggish streams carried relatively small amounts of suspended or bed-load materials to the sea. Shoreline processes were the major factors in dispersing detrital materials. Conditions such as these have been generally operative at least since the opening of the Tertiary period. Whether they were operative prior to this time, also, remains to be seen from the research now being made by oilcompany geologists engaged in deep-well drilling programs.

In the southeastern Florida ground-water investigations no wells were drilled deeper than 812 feet, and very little original

2Marl is generally considered to be an unconsolidated earthy material consisting of particles of clay size with considerable calcium carbonate included, In Florida almost any unconsolidated material containing variable quantities of calcium carbonate is called a marl, although the term may be qualified by use of an appropriate adjective. Deposits consisting largely of shells plus detrital materials are called "shell marls"; mixtures of peat and calcareous silt or clay are called "peaty marls"; those composed of sand and calcareous silt or clay are called "sandy tiarl"; and there are many other possible variations, depending upon the character of the dominant constituents. 
data have been obtained on formations deeper than the Hawthorn. Therefore, in this report the major emphasis will be placed on the late Cenozoic strata from the Miocene through the Recent epoch).

\section{PRE-TERTIARY ROCKS}

Rocks of pre-Tertiary age are not penetrated for water supplies in southern Florida for two principal reasons: (1) they are deeply buried and thus costly to reach, and (2) they contain only highly mineralized water. Campbell (1939a) gives the following laboratory analysis of water from a depth of 3,000 feet in well S 396 (Cory No. 1).

\begin{tabular}{|c|c|}
\hline Constituents & Constituents \\
\hline 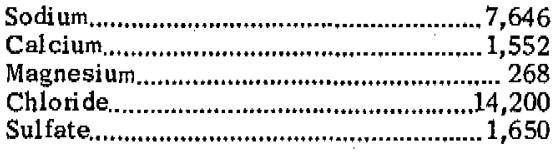 & 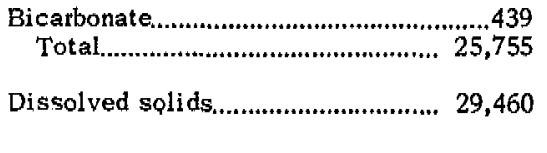 \\
\hline Comparison data & Comparison data \\
\hline 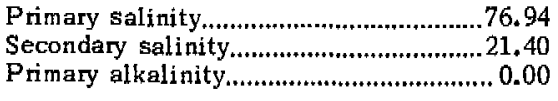 & 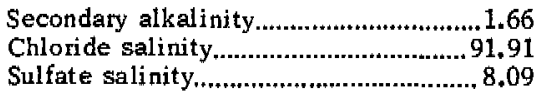 \\
\hline Constituents & Constittents \\
\hline 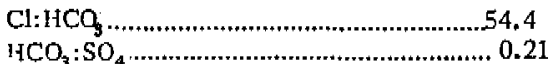 & $\begin{array}{l}\mathrm{Ca}: \mathrm{Mg} \\
\mathrm{Na} \\
\mathrm{Ca}\end{array}$ \\
\hline
\end{tabular}

Chloride analyses of deeper water from this same well, made by the U. S. Geological Survey, are as follows:

\begin{tabular}{|c|c|}
\hline $\begin{array}{l}\text { Depth } \\
\text { (feet) }\end{array}$ & $\underset{(p p m)}{\text { Cóloride }}$ \\
\hline $\begin{array}{l}9,500 \ldots \\
9,550 \ldots \\
9,772 \ldots \\
9,987 . .\end{array}$ & $\begin{array}{l}\ldots .11,200 \\
\ldots . . .24,600 \\
\ldots . .15,000 \\
\ldots .17,100\end{array}$ \\
\hline
\end{tabular}

Cooke (1945, p. 21-32), Applin and Applin (1944, p. 1673-1753), and Pressler (1947, p. 1851-1862) have amply discussed the structure and stratigraphy of these deeper rocks, most of which are limestones, dolomites, anhydrite with minor amounts of gypsum, and some halite; therefore, it is believed unnecessary to give another description in this report. 
TERTIARY SYSTEM

GENERAL STATEMENT

In southeastern Florida, water wells do not penetrate rocks deeper than those of Eocene age, and most of the deep wells end in the Ocala limestone of upper Eocene (Jackson) age. Some of the deep wells terminate in middle Eocene rocks, some in Oligocene, and others in lower Miocene. All, however, produce only mineralized artesian water too salty and too corrosive for most uses (see section on Quality of ground and surface waters, p. $824-826)$.

The following table lists formations encountered in drilling water wells in southeastern Florida.

Table 11.-Geologic formations of southeastern Florida

\begin{tabular}{|c|c|c|c|}
\hline Age & Formation & Characteristics & $\begin{array}{l}\text { Thickness } \\
\text { (feet) }\end{array}$ \\
\hline $\begin{array}{l}\text { Recent } \\
\text { and } \\
\text { Pleisto- } \\
\text { cene }\end{array}$ & $\begin{array}{l}\text { Soils } \\
\text { Lake Flirt marl }\end{array}$ & $\begin{array}{l}\text { Peat and muck, all Recent in age; laterite. } \\
\text { White to gray calcareous mud rich with shells of } \\
\text { Heli soma sp. a fresh-water gastropod. In places } \\
\text { case-hardened to a dense limestone. Relatively } \\
\text { impermeable. }\end{array}$ & $\begin{array}{l}0-12 \\
0-6\end{array}$ \\
\hline $\begin{array}{l}\text { (Contem- } \\
\text { porane- } \\
\text { ous in } \\
\text { part) }\end{array}$ & $\begin{array}{l}\text { Miami oolite } \\
\text { Anąstasia } \\
\text { formation } \\
\text { Key Largo } \\
\text { limestone }\end{array}$ & $\begin{array}{l}\text { Quartz sand, white to black or red, depending upon } \\
\text { nature of staining materials, very fine to coarse, } \\
\text { averaging medium. Mantles large areas underlain } \\
\text { by oolite and the Anastasia formation. Occurs in } \\
\text { sand dunes and old beach ridges in elevations up to } \\
\text { about } 60 \text { feet. Yields water to sand-point wells. } \\
\text { Principally unconsolidated quartz sand with interca- } \\
\text { lated clay and silt beds in places, especially the } \\
\text { Kissimmee River area. Locally consolidated to } \\
\text { scabby ferric sandstone. Generally permeable. } \\
\text { Yields water to sand-point wells. } \\
\text { Limestone, soft, white to yellowish, containing } \\
\text { streaks or thin layers of calcite, massive to cross" } \\
\text { bedded and stratified; generally perforated with } \\
\text { vertical solution holes. Fair to very high } \\
\text { permeability. } \\
\text { Coquina, sand, calcareous sandstone, sandy lime } \\
\text { stone, and shell marl. Composed of deposits equiv- } \\
\text { alent in age to the marine members of fort } \\
\text { Thompson formation. Fair to high permeability. } \\
\text { Coralline reef rock, ranging from hard and dense to } \\
\text { soft and cavernous. Probably contemporaneous with } \\
\text { the marine members of the Fort Thompson forma - } \\
\text { tion. Outcrops along southeastern coastline of } \\
\text { Florida from Soldier Key in Biscayne Bay to Bahia } \\
\text { Honda. Highly permeable. } \\
\text { Alternating marine, brackish, and fresh-water marls, } \\
\text { limestones, and sandstones. Very low permeability } \\
\text { in the upper Everglades-Lake Okeechobee area, but } \\
\text { it is the major component of the highly permeable } \\
\text { Biscayne aquifer (see p. 160) of coastal Dade, } \\
\text { Broward, and Palm Beach Counties, which yields } \\
\text { copious supplies of ground water. }\end{array}$ & $0-100$ \\
\hline
\end{tabular}


Table 11.-Geologic formations of southeestem Florida-Continued

\begin{tabular}{|c|c|c|c|}
\hline Age & Formation & Characteristics & $\begin{array}{c}\text { Thickness } \\
\text { (feet) }\end{array}$ \\
\hline Pliocent & $\begin{array}{l}\text { Caloosahatchee } \\
\text { marl }\end{array}$ & $\begin{array}{l}\text { Sandy marl, clay, silt, sand, and shell beds. Yields } \\
\text { some water, in places under low artesian head, but } \\
\text { is little used because of low permeability and gen- } \\
\text { erally poor quality of water, especially in the } \\
\text { Everglades-Lake Okeechobee area. Not pearly so } \\
\text { widely spread as was once believed but occurs chief - } \\
\text { ly as erosion remnants. }\end{array}$ & $0-50$ \\
\hline Mtoce & $\begin{array}{l}\text { Tamiami } \\
\text { formation } \\
\text { Hawthorn } \\
\text { formation } \\
\text { Tampa } \\
\text { limestone }\end{array}$ & $\begin{array}{l}\text { Creamy-white limestone, and greenish-gray clayey and } \\
\text { calcareous marl locally hardened to limestone, silty } \\
\text { and shelly sands, and shell marl. Upper part, where } \\
\text { permeability is high, is only a few feet thick, and, } \\
\text { forms the lower part of Biscayne aquifer. Lower, and } \\
\text { major part of the formation, is of low to very low } \\
\text { permeability and forms the upper part of the Floridan } \\
\text { aquiclude. } \\
\text { Sandy, phosphatic marl, interbedded with clay, shell } \\
\text { marl, silt, and sand. Greenish colors predominate. } \\
\text { Contains beds of flattened, well-worn quartxite and } \\
\text { phosphate pebbles up to half an inch in greatest diame- } \\
\text { ter. Water is generally scarce, of poor quality, and in } \\
\text { the permeable beds is confined under low pressure head. } \\
\text { Comprises the major part of the Floridan aquiclude. } \\
\text { White to tan, soft to hard, ofter partially recrystallized } \\
\text { limestone. Yields artesian water but not so freely as } \\
\text { lower parts of the Floridan aquifer. }\end{array}$ & $\left\{\begin{array}{c}50-500 \\
150-250\end{array}\right.$ \\
\hline Oligoc & $\begin{array}{l}\text { Suwannee } \\
\text { limestone }\end{array}$ & $\begin{array}{l}\text { Creamy, soft to hard limestone, similar lithologically } \\
\text { to underlying Ocala limestone and often included } \\
\text { with it in some earlier reports. With the Ocala, is } \\
\text { part of the Floridan aquifer. }\end{array}$ & $0-450$ \\
\hline Eocene & $\begin{array}{l}\text { Ocala } \\
\text { limestone } \\
\text { Avon Park } \\
\text { limestone }\end{array}$ & $\begin{array}{l}\text { White to cream, porous and cavernous to dense, in } \\
\text { part cherty, in part highly foraminiferal, limestone. } \\
\text { An excellent water-bearing formation, although the } \\
\text { water is saline in large areas, especially south of } \\
\text { Lake Okeechobee and along the Atlantic and Gulf } \\
\text { coasts some distance northward. Principal compo- } \\
\text { nent of the Floridan aquifer. } \\
\text { White to cream, foraminiferal limestone, with dark } \\
\text { brown to tan crystalline to saccharoidal dolomite, } \\
\text { Generally an excellent water-bearing formation and } \\
\text { a part of the Floridan aquifer. } \\
\text { Dark-brown dolomite and chally limestone. Hydrologic } \\
\text { characteristics imperfectly loown. Probably a part } \\
\text { of the Floridan aquifer. }\end{array}$ & $150-350$ \\
\hline
\end{tabular}

\section{EOCENE SERIES}

\section{LAKE CITY AND AVON PARK LIMESTONES}

In the last few years, older Eocene rocks have been differentiated from the late Eocene Ocala limestones mainly on the basis of the microfossils. In 1937, Stubbs (1937, p. 24-36) tentatively assigned a middle Eocene age to those rocks which underlie typical Ocala limestone but which lack typical Ocala fossils and contain an abundance of the foraminifer Dictyoconus cookei (Moberg), mistakenly identified by Stubbs as Coskinolina sp. Stubbs gave these rocks the name "Coskinolina Zone." Since then, Cole (1941) has 
divided the entire middle Eocene into seven zones, the youngest of which he calls the Dictyoconus cookei zone; and the Applins (1944, p. 1673-1753) have divided the middle Eocene into two parts, late middle and early middle, and have assigned several geologic formational names to these units.

The Avon Park limestone of the Applins includes the Dictyoconus cookei zone of Cole, and their Lake City limestone includes his Lictyoconus americants zone.

On the basis of subsurface data, Cole $(1944$, p. 25-26) has referred the Avon Park limestone to the Lisbon formation; Erickson $(1945$, p. 234$)$ has correlated surficial outcrops of a limestone in southern Levy and northern Citrus Counties with the Avon Park and has proposed the new name "Gulf Hammock formation, " to replace "Avon Park limestone."

The Eocene rocks older than the Ocala limestone contain a large amount of dolomite and dolomitic limestone with colors ranging from cream through tan to dark brown. Solution activity by circulating ground water in these calcareous rocks has developed caverns and a network of smaller channels, thus giving these formations a high coefficient of transmissibility (see section on Ground water, Quantitative studies, p. 237). Until more deep wells are drilled in southeastern Florida and the data therefrom studied, the thickness of middle and lower Eocene rocks in this area will remain unknown.

\section{OCAL A LIMESTONE}

The Ocala limestone, and most deeply buried of all formations ordinarily penetrated for water in southern Florida. It was present in the Campbell well, S 396 at 1, 220 feet below land surface. (See pl. 19.) According to Mossom (1926, p. 236-237) it was penetrated at about 900 feet below land surface in well S 353 at Belle Glade (about 60 miles north of $S 396$ ) and at about 600 feet below land surface in well $\mathrm{S} 432$, at Okeechobee City. The Ocala limestone is exposed at the land surface about 150 miles north of Okeechobee Gity in Citrus, Sumter, and Marion Counties. From these data it is apparent that the Ocala limestone, within a distance of 250 miles, dips about 1,220 feet. This is at a rate of about 5 feet to the mile. However, it is believed that this rate is not uniform because the upper surface of the Ocala limestone is eroded by weathering and solution processes, and according to $R$. O. Vernon (personal communication), it is faulted in numerous places; thus, the few control points may be somewhat $m$ isleading. The Ocala limestone is not present everywhere in southern Florida. Evidence obtained from study of deep wells in this area by the Applins (1944,

3According to Robert O. Vernon, Florida Geological Survey (oral communication), the Ocala limestone can be differentiated into two formations. 
p. 1684-1685) indicates that the Ocala limestone is missing in a part of eastern Dade and Broward Counties and in Monroe County at Key West.

The Ocala is essentially a soft, white, foraminiferal limestone, in places a coquina, and, in addition to the Forminifera, it also contains a varied fauna of other marine fossils. In places, beds of chert are present. The formation generally thickens in all directions away from the outcrop area and attains a maximum thickness of 350 feet. In southeastern Florida it averages about 100 feet, but in places, as noted above, it seems to be missing entirely.

The Ocala limestone is an excellent water-bearing formation, widely used, and well known. It is the principal component of the Floridan aquifer (see p. 188-189). Large springs, such as Silver Springs in north-central Florida, and Wakulla Spring in northwestern Florida, issue from the cavernous rocks of the Ocala limestone. Silver Springs alone, as measured by the U. S. Geological Survey (Ferguson, Lingham, Love, and Vernon, 1947, p. 124-125; Stringfield, 1936, p. 155), flows at times more than 31 million gallons per hour, or $756 \mathrm{mgd}$, and averages $500 \mathrm{mgd}$; by comparison, a city the size of Miami used about $40 \mathrm{mgd}$ in 1946 .

Rainwater enters the Ocala limestone both in the outcrop area and in areas where permeable materials overlie it and permit downward percolation. The part of the water that does not return to the surface as a spring or seep, or is lost by evapotranspiration or by some other means (pumping from wells etc.), flows slowly through the aquifer and becomes highly mineralized. By the time the water has progressed to southern Florida, some of it is so highly mineralized that it is unsatisfactory for most uses. All wells penetrating the Ocala limestone in southern Florida are artesian.

\section{OLIGOCENE SEEIES}

SUWANNEE LIMESTONE

The southernmost known exposure of the Suwannee limestone is in the northeastern part of Hillsborough County, in the banks of Blackwater Creek. Mansfield (1937, p. 46) describes the rock as *** a granular to dense, compact, usually cream-colored, rather pure limestone." The Applins (1944, p. 1681-1683) describe the Suwannee: "Throughout most of its underground extent, the Oligocene has a rather uniform lithologic character: white, finely porous limestone composed chiefly of fragmental tests of Bryozoa and miliolid Foraminifera.*** In southern Florida the Oligocene thickens gradually toward the south and southwest from its updip limits, attaining a thickness of about 350 feet in wells near the coast and 450 feet in a well at Key West ***: 
The Suwannee unconformably overlies the Ocala limestone and, in turn, is overlain and generally overlapped by younger geologic formations, so that it has a relatively small outcrop area. Its relation with the underlying Ocala limestone in southern Florida is such that artesian water occurs in both formations under essentially the same conditions. Thus, they are components of a single hydrologic underground unit-the Floridan aquifer.

\section{MOCENE SERIES}

\section{GENERAL CONSIDERATIONS}

In peninsular Florida, Cooke (1945, p. 109-111) recognizes deposits of early Miocene time (Tampa limestone), middle Miocene time (Hawthorn formation), and late Miocene time (Duplin marl). The Tampa and Hawthorn formations have long been recognized in Florida, but 'only recently has the name Duplin been extended to Florida. Cooke $(1945$, p. 181$)$ discontinued the use of the name "Choctawhatchee marl" and regards the four Choctawhatchee zones as parts of two other formations: the Yoldia and Arca zones (the lower two) are part of the Shoal River formation, and the Ecphora and Cancellạia zones are part of the extended Duplin marl.

Recently, F. Stearns MacNeil and C. Wythe Cooke (personal communications) have stated that studies of fossils (gathered by themselves, Parker, Schroeder, and others) show that the Tamiami formation, previously regarded as of Pliocene age (Mansfield, 1939), is actually of upper Miocene age.

In southern and southeastern Florida the great bulk of the Miocene formations are buried and can be studied only through the medium of well cuttings and their enclosed fossils. Although numerous wells have penetrated geologic materials (mainly silts, clays, fine sands, or limestones) that are, on the basis of fossil assemblage, Miocene, it has been exceedingly difficult to separate the sediments into the units recognized farther north and west.

In Cooke's correlation chart $(1945$, p. 110) an erosion interval is indicated between the middle Miocene Hawthorn formation and the late Miocene Duplin marl. This is based on field relationships in northern Florida. There are no significant changes in either lithology or fossil faunas in southern Florida to indicate such an interval. However, without a decided change in lithology such a break would be difficult to detect in well cuttings, and fossils of ten are of little help; in many instances both microfossil and macrofossil assemblages, collected from carefully controlled test wells, seem to indicate that in this area little reliance can be placed on them for precise age and stratigraphic correlations. It is quite apparent that ecologic conditions are a prime factor in these studies and that the reworking of previous sediments and their 
enclosed fossils by an encroaching sea and the filling of deep sink holes and solution cavities with younger deposits may be the main reasons for the difficulty in definitely separating the Miocene for mations that probably are present in this area, either from one another or from the Pliocene.

There is no doubt that some geologic materials of southeastern Florida, which in the past have been called Miocene (Hawthorn) or Pltocene (Caloosahatchee marl and Tamiami limestone), are in reality of Duplin age and are present beneath the Caloosahatchee marl and younger formations everywhere in southeastern Florida. This belief is based largely upon lithologic correlation of cuttings from numerous wells of this area (in which indeterminate faunas, possibly of Pliocene or Miocene age, occur) with that of test well G 188, 19 miles west of Miami at Krome Road (State Route 27) and Tamiami Trail (U. S. Route 41), where upper Miocene (Duplin) faunas undoubtedly occur. (See pls. 8 and 9 , index map, and geologic cross sections for correlation interpretations.)

According to Julia Gardner, who studied the larger fossils from this well, "No age determinations could be made upon the faunas from the four upper levels, $-26.2^{\prime},-32.1^{\prime},-46.6^{\prime}$, and $-51.0^{\prime}$ (all depths refer to mean sea level). The faunas from:-57.3' and $-61.8^{\prime}$ are referred to the lower Pliocene, and they more closely resemble the mollusca from eastern Florida than they do from the Caloosahatchee region. All the shells from -67.81 are small; they have much less in common with the Pliocene faunas above than with the Miocene below. The finest, the most abundant, and the best characterized assemblages are those from $-71.1^{\prime}$ and -76. 7'. These include several species which characterize the Cancellatia zone of the Duplin marl. The collections from-80. 2* through $-136^{\prime}$ are meager and there is nothing new in them. The lower faunas, $-140.3^{\prime},-144.9^{\prime}$, and the lowest of all, $-155.3^{\prime}$, are much better but only in the lowest is there a new element of any significance and that indicates nothing more than a slightly lower horizon in the Duplin [upper Miocene]. The resemblance of the faunas from the Miocene section of the well to those of the Duplin marl of North and South Carolina is marked, and there. is no reason to suppose that any fauna older than that of the Duplin is represented. The faunas from top to bottom of the well are conspicuously shallow water faunas with no evidence of marked ecologic changes. This is indicated by the wide distribution of the limpets and barnacles, inter-tidal groups such as otiva and olivella, and reef-making forms such as the oysters, pectens, and anomias. The temperature in the late Miocene was probably not unlike that of the Recent Floridian seas.

The faunal assemblages upon which Dr. Gardner based the above interpretation are given in table 12 . 
Table 12.-Macrofaunas from $U$. S, Geolobical Survey Station 15112 (USGS test well $G$ 188), Krome Road and the Tamiani Trail. 19 miles West of Miami, Dade County

\begin{tabular}{|c|c|c|}
\hline Collection & $\begin{array}{l}\text { Depth } \\
\text { (feet) }\end{array}$ & Macrofaune \\
\hline 15112 & -26.2 & $\begin{array}{l}\text { Chl amys sp. ind. } \\
\text { Chione sp. ind. } \\
\text { Indet erminate gastropod } \\
\text { Age: Indeterminate. }\end{array}$ \\
\hline 15112-b & -32.1 & $\begin{array}{l}\text { Indeterminate bivalve } \\
\text { Planorbid? } \\
\text { Age: Indeteminate. }\end{array}$ \\
\hline $15112-\mathrm{c}$ & .46 .6 & $\begin{array}{l}\text { Bryozoa } \\
\text { "Pecter" sp, ind. } \\
\text { Ostres sp. ind. } \\
\text { Age: Indeteminate. }\end{array}$ \\
\hline $15112-d$ & -51.0 & $\begin{array}{l}\text { "Pecten" sp, ind. } \\
\text { Age: Indeteminate. }\end{array}$ \\
\hline $15112-6$ & -57.3 & 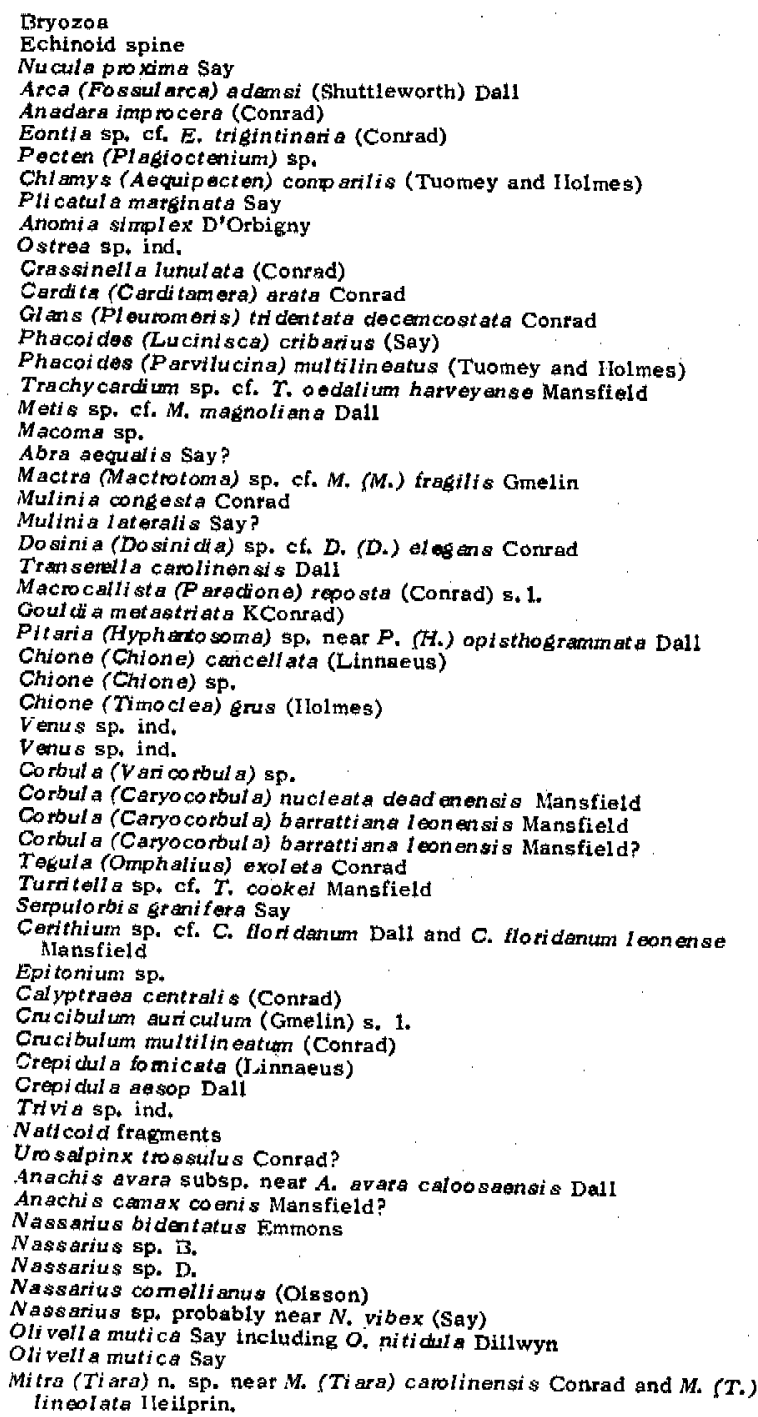 \\
\hline
\end{tabular}


Table 12.-Macrofaunas from U. S. Geological Survey Station 15112 (USGS test well G 188), Krome Road and the Tamiami Trail, 19 miles west of Miani, Dade County-Con.

\begin{tabular}{|c|c|c|}
\hline Collection & $\begin{array}{l}\text { Depth } \\
\text { (feet) }\end{array}$ & Macrofauna \\
\hline 15112e & $-57,3$ & 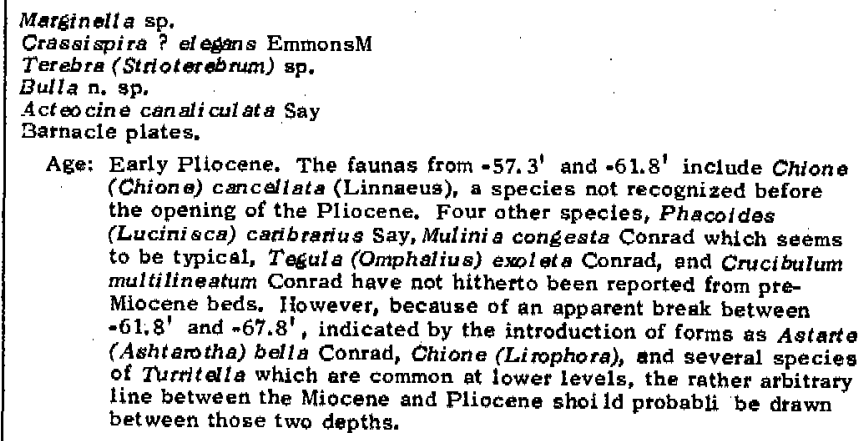 \\
\hline $15112 \mathrm{f}$ & -61.8 & 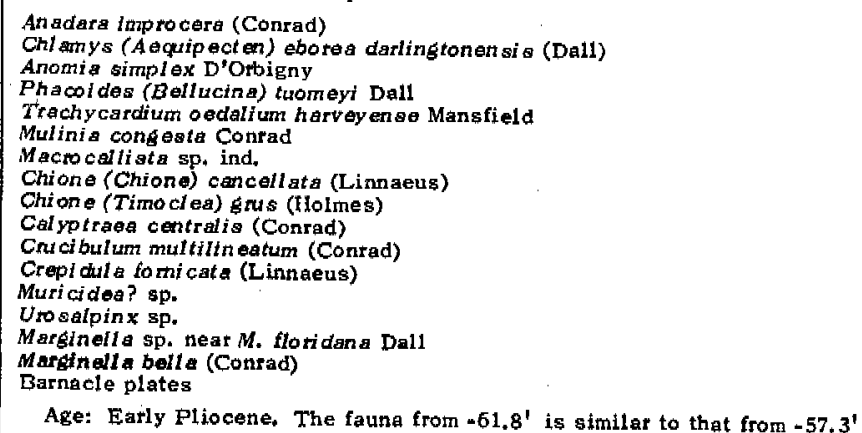 \\
\hline $15112-g$ & +67.8 & 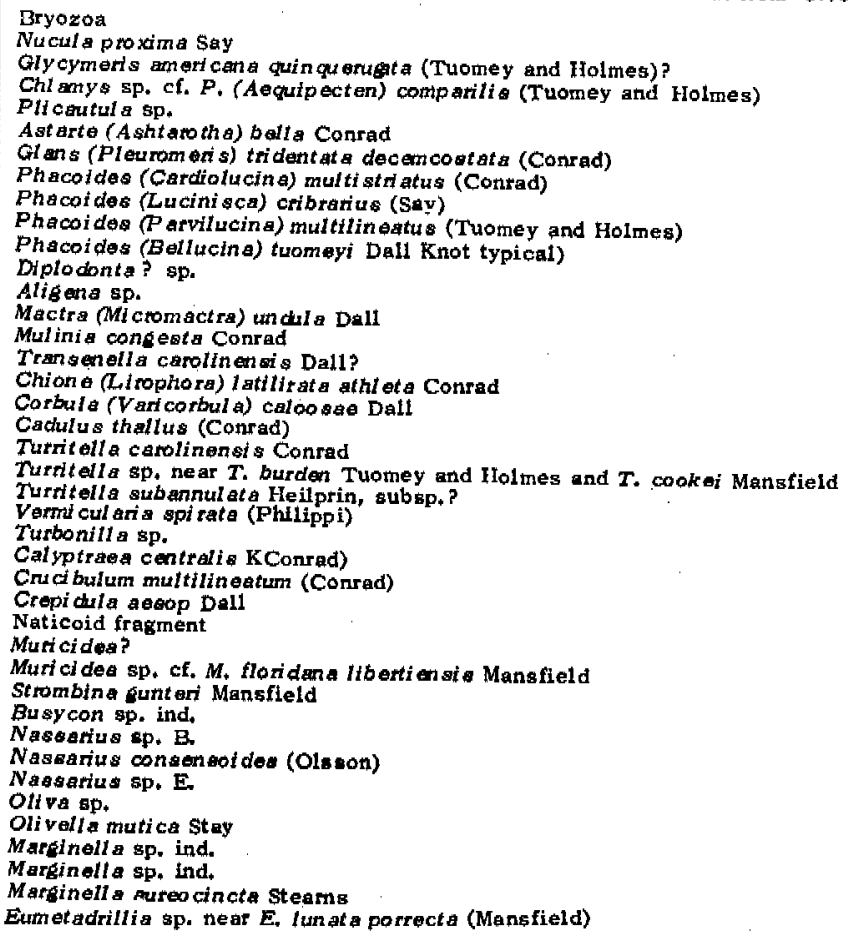 \\
\hline
\end{tabular}


Table 12. - Macrofatnas from U. S. Geological Strvey Station 15112 (USGS test well G 188); Irome Road and the Tantani Trail, 19 miles West of Miani, Dade County-Con.

\begin{tabular}{|c|c|c|c|}
\hline Collection & $\begin{array}{l}\text { Depth } \\
\text { (feet) }\end{array}$ & Macrofatina & \\
\hline 15112-g & -67.8 & 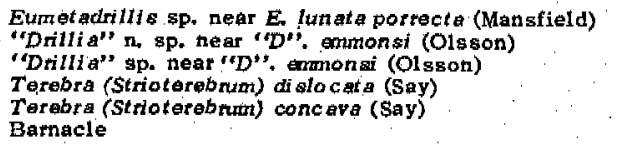 & $\therefore$ \\
\hline
\end{tabular}

Age: Late Miocene. Chione (Chione) cancellats (Linnaeus), the characteristic Pliocene species, present in the faunas from $-57.3^{\prime}$ and $-61.8^{\prime}$, is absent in the fauna from $-67.8^{\prime}$, and of probably greater significance is the first appearance of a number of foms including Astarte (Ashtatotha) balla Conrad, Chione (Li nophota) latilirata Conrad, Cadulus thalfus (Conrad), Turritell a carolinensis Conrad, and Tumitell a subannulat lieflptin, subsp.?, which are common at the three next lower levels from which faunas have been taken. To be sure, C. (C.) cancellata has not bean feported from the lowar bed of the Caloosahatchee matl in Volusita County, Florida, and is presumably absent, but so are the charact ertstic Miocene species recorted from $-67, Q^{\prime}$ 
Table 12.-Macrofanas from U. S. Geological Survey Station 15112 (USGS test well G 188), Krome Road and the Tamiani Trail, 19 miles west of Miami, Dade County -Con,

\begin{tabular}{|c|c|c|c|}
\hline Collection & $\begin{array}{l}\text { Depth } \\
\text { (feet) }\end{array}$ & Macrofauna & \\
\hline $15112-\mathrm{h}$ & $=71.1$ & 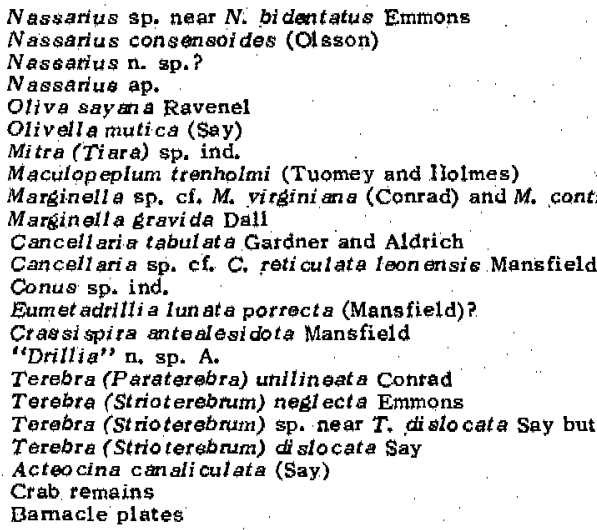 & axials not bisected \\
\hline
\end{tabular}

Age: Upper Miocene, Duplin mart, probably the Cancallaria zone The three faunas from the depths $-71.1^{\prime}$ are the most prolific of those takenffrom the well and obviously are to be included within a single unit. They are characterized by large pectens, Astarte (A shtatotha) bella Contad, common Mulinia congesta and chione (Lirophora latilizata athlet a Conirad, and by two of the characteristic species of the Cancellaria zone. Chione (Chione) procancel$t$ at a Mansfield. The diversified Turritella fauna, first recorded at $67,8^{\prime}$, is best developed at this level and at the two immediately succeeding.

Arca (Cunearca) scalaris Contad

Anadara lienosa (Say)

An acla ra impro cera (Conrad)

Glycymeris anterican quinguentata (Tuomey and lloimes)

Glycymert s pectinata (Gmelin)

Glycymerts sp. ind.

Pegten (Pecten) sp. cf. P. (P.) achlockoneentensi st Mansfield

Chlamy's (Alequipecten) eborea darlingtonensis (Dalt)?

Ostrea sculpturata Conrad

Astarte (Ashtarotha) bell a Conrad

Crassatellites (Crassatellites) abbesil (Tuomey and Holmes)

Cardita (Carditamera) arata Conrad.

Gl ans (Pleurontetis) thi dentata decencostata Conrad

$V$ en ert cardi a (Cy clo cardl a) granulata Say

Phacotdes (Cardiolucina) sp. of. C. (C.) multi striatus (Conrad)

Phacot des (Lucitis sa) ctibarius (Say)

Phacoides (Callucina) radians (Conrad)

Phacoldes ( $P$ atvitucina) multilineatus (Tuomey and Holmes)

Phacoides (Bellicitha) tuomeyl Dalt Phacoi des (Bellucina) sp. cf. $P$. (B.) tuomeyl Dall and $P$. (B) waccama
wani a Dall.

Cerastodema spl near C. taprium Dall

Cerastodema? sp. of. C. Acutil aqueatum Conrad

Trachycardiun o edalitum harveyense Mansfield

"Carditum" sp. ind.

Tellina (Eurytallina) alternata Say

Tellina (Noetella) possibly th. sp. near $T .(M$.$) . duplini an a Dall$
Tellinid

Metis sp.

Ensis sp. ind.

Mulini a congesta Conrad

Dosinia (Dosini dia) sp. of. D. (D.) acetabulum blountana Mansfield
Gouldia n, sp.?

Macrocallista ?p.

Callocardia? sp.

Ohione (Chione) procancellata Mansfield

Chiore (Litophota) latilirata athleta Conrad

Venus sp.

Corbula (Varicorbula) ap. ef. C. (V.) caloosae Dall

Corbula (Vari corbula) sp.

Cotbula (Caryo co rbula) thucleata Dall?

Cadtulus thalles Conrad

Calliostoma? sp. 
Table 12. - Macrofanas from U. S. Geological Survey Station 15112 (USGS test well G 188), Krome Road and the Temiani Trail, 19 miles west of Mizani, Dade County-Con.

\begin{tabular}{|c|c|c|}
\hline Collection & $\begin{array}{l}\text { Depth } \\
\text { (feet) }\end{array}$ & Macrofauna \\
\hline $15112-i$ & & 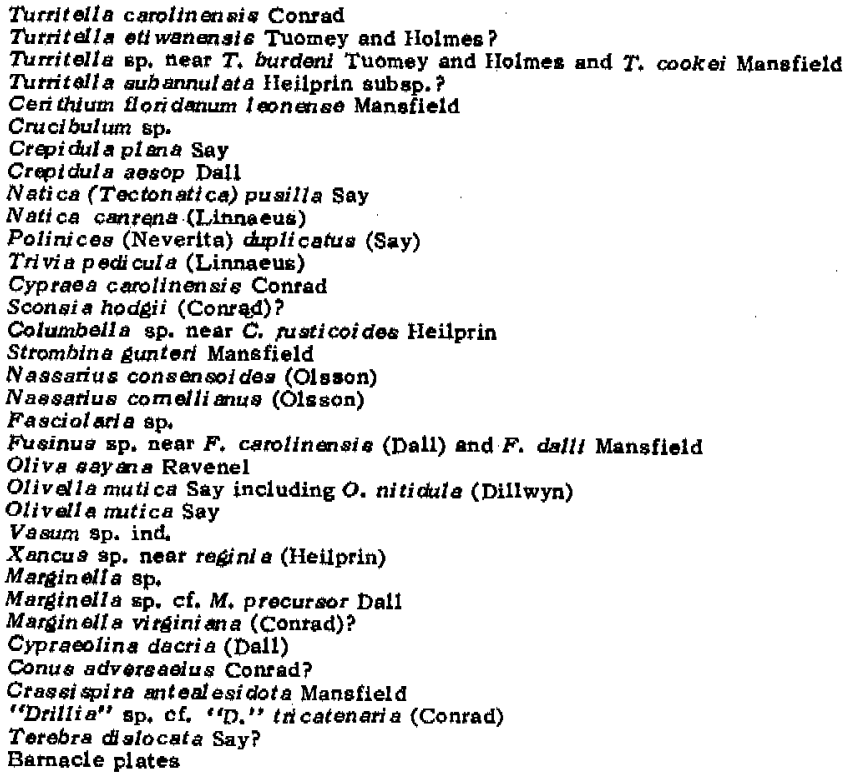 \\
\hline
\end{tabular}

Age: Upper Miocena, Duplin marl, probably the Cancellarla zone. The fauna is similar to those from $-71.1^{\prime}$ and $-76,7^{4}$

Boring sponge

Coral

Bryozoa

Nu Eut a proxima Say

Nu cul a taphri a Dall

Sacella trochilia coensis (Mansfiel d)

Sacella trochili a henlithen ia (Mansfield)

Arcal (Fossularca) adansi (Shuttleworth) Dall

Arca (Cunearca) sp. near A. (C.) al cinta Dall

An adara impro cera (Conrad)

GIycjmert pectinata (Gmelin)

Pecten (P ecten) sp.

Chl anys (Aequipecten) eborea (Conrad)?

Chlamys (Adquipecten) eborea daríntonengis (Dall)
Plicatula mardinata Say

Anoml a simplex D'Orbigny

O strea sculpturata Contad

Pondora (Kennetlia) atenos Conrad

Astarte (Aehtarotha) bella Consad

Crassatellitas (Crassat allites) ap.

Crassatellites (Crassatellites) op.

Cardita (Carditamera) $\mathrm{sp}_{4}$ ind.

ol ans (P terometis) perplana Conrad

Anodontia sp. ind.

Phacoldes (Lucind sca) cribrarius (Say)

Phacoldes (Callucina) radians (Conrad)

Phacoides (P arvilucina) multill heatus (Tuoney and flol mes)

Phacoides (Bellucina) tuoneyi Dall

Divari cella quacti sulcata (D'Orbigny)?

$P$ seudoch ama straite (Emmons)

Cerasto demta $\mathrm{sp}$, ind.

Trachycarci um oedalium harveyense Mansfield

Tellina (Mori sca) aequistriata Say

Tellina (Eurytollina) elt emata (Say)
Tellinid

Tellina (Moeralla) poseibly n. ap. near $r . M_{*}$ ) dupliniana Dall
Semele petl amelloga Heilprin

Multini a consegta Conrad

Ensis directus Contad?

Do sinia sp.

Dosinita (Dosinidia) sp.

Trensenella carolinensia Dall 
Table 12. - Macrofatnas from U. S. Geological Strvey Station 15112 (USGS test well G 188), Krome Road and the Tamiani Trail, 19 milas west of Miami, Dade Cotunty-Con.

\begin{tabular}{|c|c|c|}
\hline Collection & $\begin{array}{l}\text { Depth } \\
\text { (feet) }\end{array}$ & Macrofauna \\
\hline $15112 * j$ & -76.7 & 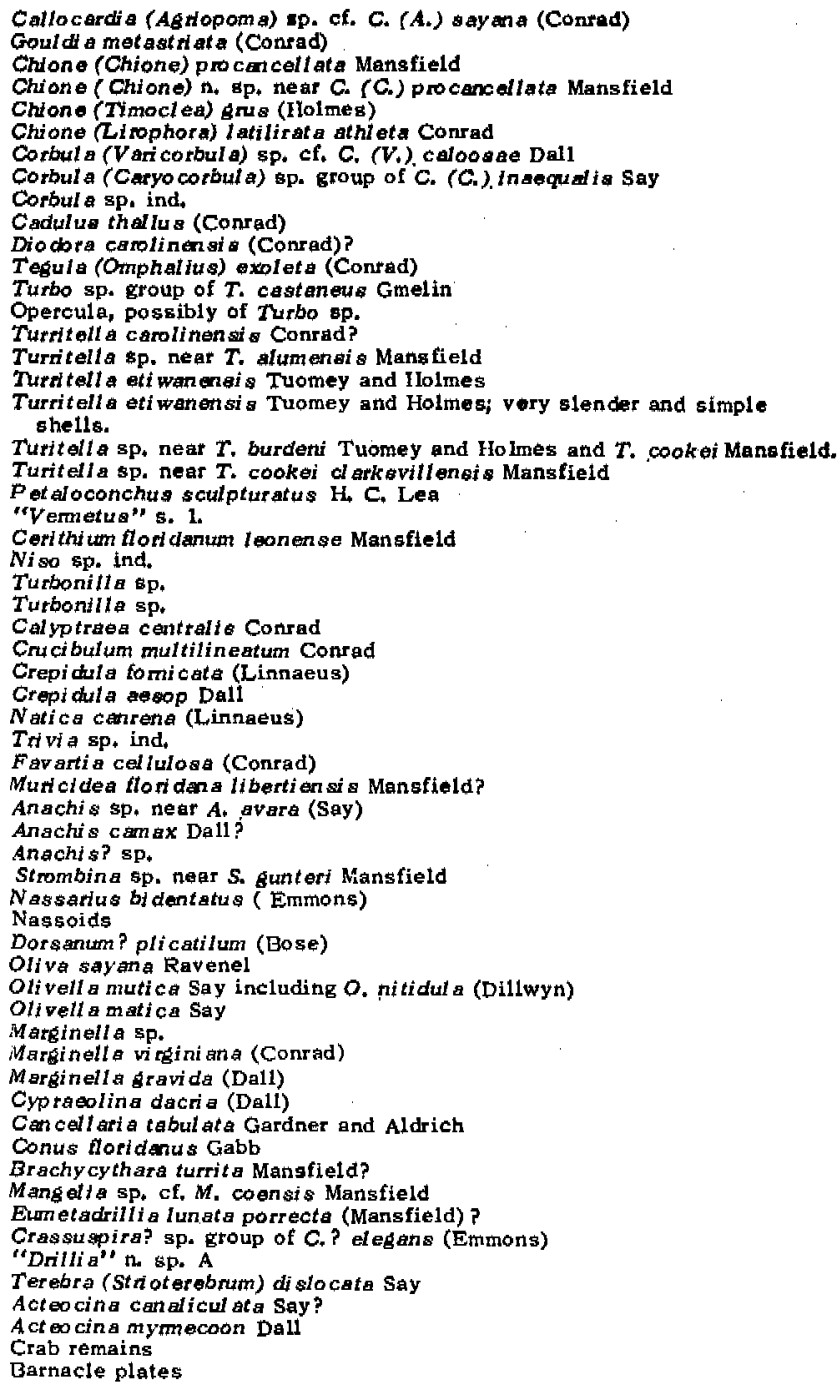 \\
\hline
\end{tabular}

Age: Upper liocene; Duplin marl, probably the Cancellaria zone. The fauna is amilar to those from $-71,1^{\prime}$ and $75.1^{\prime}$.

$O$ strea sp. ind.

Ostrea? sp, ind,

Ast arte sp.

Turritella sp. cf, T. eti wanenais Tuomey and Ilolmes

Caecum flori danum compacturi Dall

Uro salpinx $\$$ p. cf. U. trossulus Conrad

Oliva sp.

Terebro (Strioterebrun) dI slo cata Say?

Age: Probably upper Miocene because of the character of the gastropod fautia, 
Table 12. -Macrofatns from $U . S$. Geological Survey Station 15112 (USGS test well G 188), Irome Road and the Tamiani Trail, 19 miles west of Miani, Dade County- Con.

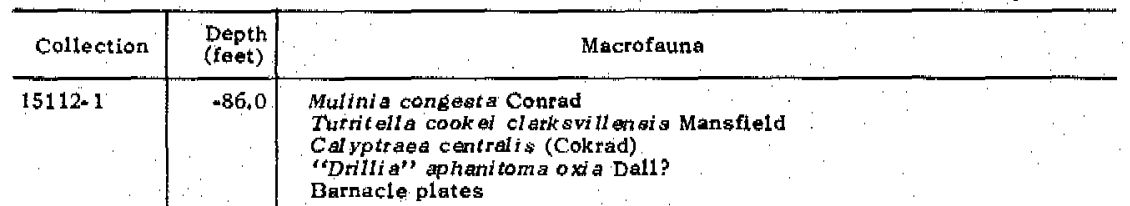

$15112-m$

$15112 \mathrm{n}$

$15112-0$

$15112-p$

$115112 \cdot \mathrm{q}$

$15112-\mathrm{r}$
Age: Probably upper Miocene but there is not sufficient evidence to place it mote accurately.

"Pecten" sp. ind.

Plicatula? sp.

Anomia simplex D'Orbigny

Ostrea sp. ind.

Mulinta congesta Conrad

Chione (Li rophora) sp.

Turnitella sp. cf. T. eti wariensis Tuomey and Holmes

"Vematus" s. 1 .

Age: Probably upper Miocene but the evidence is slight.

"Pectern" sp.

Ostreg sp. ind.

Chione (Chione) sp.

Age: Indeterminate.

"Pecten".sp.

Cht anys sp. cf. C. (A tquipect en) comparilis (Tuomey and Ilolmes)

Ostrea sp. ind.

Lucinoids

Corbula sp.

"Vemetus" s. 1.

Barnacle plates

Age; Indeterninate.

Einchinold spine

Nucul a proxitha Say

Chlanys (Aequipecten) comparilis (Twomey and Holmes)

Ostrea sp. ind.

Glans (Pleuromeris) tridentata decencostata Conrad

Phacoides (Parvilucina) multilineatis (Tuomey and Holmes)

Mulinia congesta Conrad

Transenell a carolinenst s Dall

Turtitella subannulata Heiprin subsp.

Sepulorbia? sp.

Nas sariug bidentatus (Emmons)?

Brachycythara sp. cf. 13. turrita Mansfield

"Drillia" n. sp. A.

Age: Upper Miocene, probably the Duplin marl.

Pecten (Plagioctenium) sp.

Ostrea sp. ind.

Ano cbntia sp. cf. A. chryso stoma (Meuschen)

Dosinia (Dosinidia) sp.

Chione (Chione?) sp.

Turritells sp. \&f. $T$, cookel clarkovillensis Mansfield

Anachis? sp cf. 15112 f

Margitnells sp.

Barnacle plate

Age: Probably the Duplin marl.

Bryozoa

Glycymeris pectinata (Gmelin)

"Pecten" sp.

Ostrea sp, ind

Cardita (Carditamera) sp. ind.

Cerasto dema sp. ind.

Multinia consesta Conrad?

Turritalla ati wanterists Tuomey and Holmes?

Calyptrea sp.

Crab claw

Barnacle plate

Age: Probably upper Mlocene.

Cht anys sp, ind.

Anoml s bp. ind.

Phacoides (Belluclna) tuomeyi Dall

Macra calli sta (Patadione) tepo at a (Conrad) n, subsp. ?

Corbula sp.

Natica cantera (Linnaeus)

Olivella mutica Say

Barnacle plates

Age: Probably upper Miocene. 
Table 12.- Macrofauras from U. S. Geological Survey Station 15112 (USGS test well G 188), Krome Road and the Temismi Trail, 19 miles west of Miami, Dade County-Con.

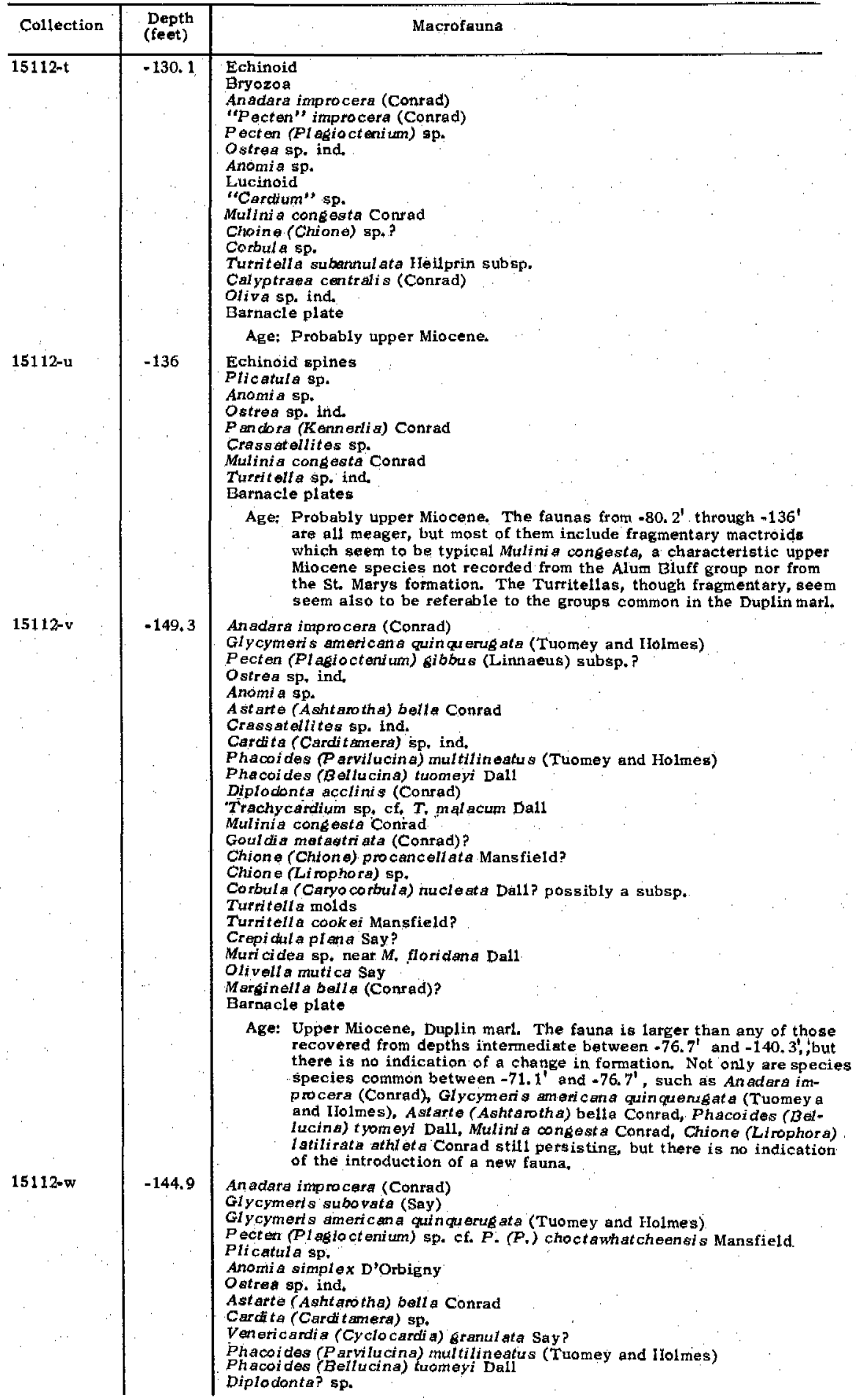


Table 12.-Macrotaunas from U. S. Geological Survey Station 15112 (USGS test well G 188), Kronte Road and the Tamiami Trail, 19 miles west of Miami, Dade County-Con.

\begin{tabular}{|c|c|c|}
\hline Collection & $\begin{array}{l}\text { Depth } \\
\text { (feet) }\end{array}$ & Macrofauna \\
\hline $15112-w$ & -144.9 & 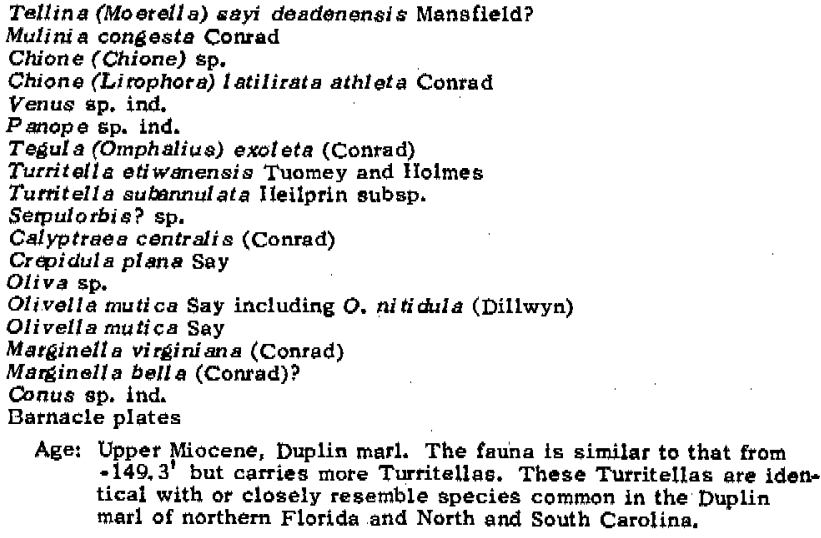 \\
\hline $15112-x$ & -150.3 & 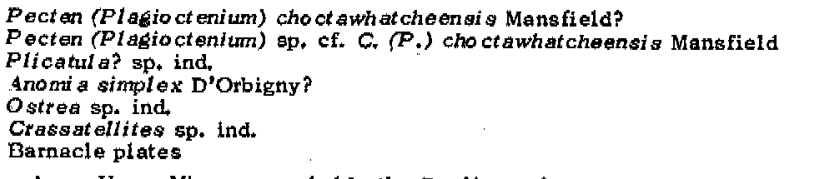 \\
\hline & & Age: Upper Miocene, probably the Duplin marl. \\
\hline $15112-y$ & $-155,3$ & 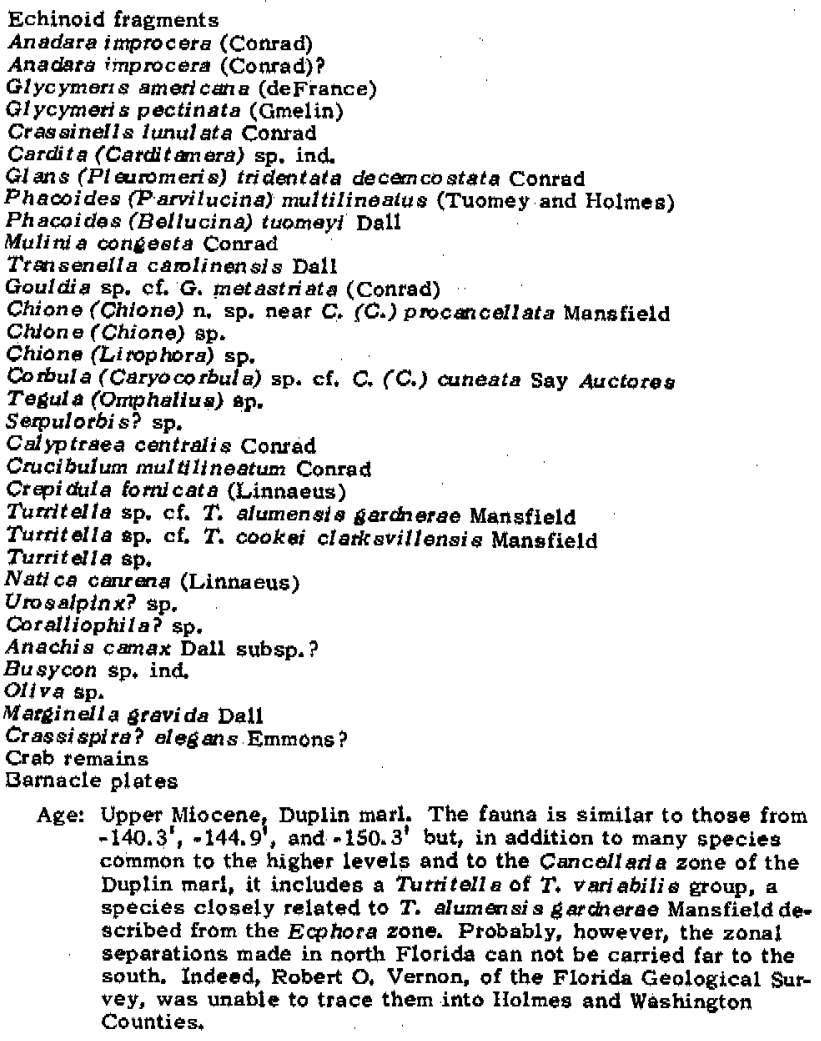 \\
\hline
\end{tabular}


Microfossils from this well (G 188) were studied by Lloyd G. Henbest and Joseph A. Cushman. Henbest, reporting in 1942 upon a sample from -51 to $-57.3 \mathrm{ft}$ (relative to mean sea level), says:

Among the Foraminifera in this sample I find the following species:

Peneroptis aff. $P$. protens D'Orbigny. Lower Miocene, Chipola (western Florida) is the only recotd so far as I know for this particular form.

Elpizidium poeyanum D'Orbigny. Miocene to Recent.

Ouinqueloculine costata? D'Orbigny. Miocene and Pliocene.

Q. lamarckiana D'Orbigny. Oligocene to Pliocene.

Rotalia beccarii var, tepide Cushman. Pliocene to Pleistocene.

Amphisorus sp., fragments, Very closely tesembles the form called "Sorites" by Cushman fron the Chipola. Range above the lower Miocene is unknown to me.

$R$. becarii var. parkinsoniang Cushman. Miocene to Pliocene.

Discorbis orbicularis? Miocene to Recent.

Cibicides americanus (Cushman). Oligocene to Miocene. The specimen at hand resembles the variety reported by Cushman in 1918 (U. S. Geol. Surv. Bull. 676) from the Duplin marl at Mayesville, South Carolina.

Amphistegina chipolensis Cushman. Lower Miocene.

As the stratigraphic notes after each species indicate, the sample includes Miocene and Pliocene foms and appears to contain mixed faunas *** If the method of determining the age by the oldest fauna, which is used where drill cuttings are contaminated or mixed, is followed here, the age is lower Miocene. Inasmuch as the evidence is not extensive, the determination as lower Miocene must be qualified with corresponding reservations.

Thus, in the same well and at the same depth, Henbest finds a fauna of Foraminifera that, from limited data, appears to be lower Miocene where Gardner finds a macrofauna of probably lower Pliocene age. This rather anomalous situation is not at all unusual in southern Florida. Cushman found the foraminiferal faunas so baffling that in many instances, including well $G 188$, he could not, with any degree of certainty, separate the Pleistocene andPliocene from the Miocene.

After detailed and painstaking study of microfaunal slides from various test wells in southern Florida, Cushman stated in 1942: "The material from well $G 188$ is apparently the most nearly complete and therefore has been taken as the basis for the shallower part of the section in all the wells. As the faunas change with increasing depth of the well, ten zones may be recognized *** The tops or first occurrences of the (key) species downward in the well are taken as the indication that the particular zone has been reached. The various species may have long or short vertical ranges, but the first occurrence is an important factor in the correlation. Gaps in the occurrence of many of the species as plotted are probably due to loss of specimens or failure to find the $m$ by the person picking out the material ** The relative abundance of certain species is of ten a very excellent indicator of certain zones but it is evident that, except in well $G 188$, this can be little used here (in southeastern Florida) *** It is also evident from a study of the samples that changes in ecologic conditions aredefinite factors to be reckoned with in such work. The great abundance of Rotalia beccarii (possible var,tepida) might indicate very shallow, almost brackish water, especially where accompanied as it is by 
other species known also to have similar preferred habits. Even a short distance away the constituents of this fauna $m$ ight be deeidedly changed. This must be allowed for in all such work with samples of shallow origin. "

Despite all the study given these samples from well $\mathbf{G} 188$, Cushman did not feel justified in marking the boundaries between Miocene, Pliocene, and Pleistocene but, instead, marked off the 10 faunal zones. As later studies showed, these zones could not be used successfully because they seldom could be recognized in other wells.

The list of specimens, prepared by Cushman from samples of the formation that Gardner identified as being of Duplin age, contains species that have either, or both, Miocene and Pliocene ranges. This evidence, along with that of Henbest (p. 114-115), and the overwhelming evidence of the macrofossils as listed by Gardner (table 12), leads the writers to the conclusion that Duplin deposits of upper Miocene age, herein assigned to the Tamiami formation, are present at a relatively shallow depth in $G 188$, probably at 51 feet below mean sea level or, at the most, at 62 feet (pls. 8 and 9 ).

Similar data, though'sometimes with the foraminiferal evidence stronger than the macrofaunal evidence, have been found in other wells of southeastern Florida. All this, together with the great similarity in the lithologic character of the materials in question, is evidence pointing to a Duplin age for some of the materials heretofore called Caloosahatchee marl and for a part of the sediments called Hawthorn (silty and sandy phase) in southeastern Florida. The deeper Miocene clays and marls that lie between the Tamiam iformation and the Tampa limes tone belong to the Haw thorn formation, but it is practically impossible to separate them. For the study of the occurrence of ground water this is not necessary, because in southeastern Florida all these deeper Miocene materials are of low to very low permeability; they act as a thick, relatively impervious layer (the Floridan aquiclude, p. 188-189), which separates the deep, saline artesian water in the Floridan aquifer from the permeable Pliocene and Pleistocene rocks that comprise the Biscayne aquifer in southeastern Florida (p. 160 et seq.).

TAMPA LIMESTONE

The oldest Miocene formation in southeastern Florida is the Tampa limestone. Surficial deposits of that formation occur in west-central Florida, 40 to 50 miles west of the upper Kissimmee River valley, in Hillsborough, Pinellas, and Pasco Counties. In its outcrop area, the Tampa formation is a yellow to cream lime- 
stone, hard to soft, and in some places (as at Ballast Point in Tampa Bay) siliceous. In the outcrop area and along the Gulf coast it is permeable and a component of the Floridan aquifer (p. 188-189).

In southeastern Florida the Tampa limestone is present in most areas, underlying the Hawthorn formation and overlying the Suwannee limestone. Parker and Hoy, and others (Parker and Hoy, in press; Stringfield, 1933a; Mossom, 1926) have found the Tampa limestone as far north as the Lake Okeechobee area but have not found it in the Kissimmee valley. In table 2 of their publication Parker and Hoy show correlation studies made on the bas is of paleontologic and lithologic data from well cuttings. Cooke (1945, fig. 14, p."112) shows the probable position of the shoreline of the Tampa (early Miocene) sea and indicates the area of known Tampa deposits. All southeastern Florida except the Kissimmee River valley, is thus shown to contain Tampa deposits at depth.

Much remains to be learned of the water-bearing characteristics of the Tampa limestone. It is believed that in southeastern Florida, as in upstate areas, the Tampa is a part of the Floridan aquifer, but the yield and artesian pressure are both somewhat lower than in the underlying Ocala limestone; the quality of the water, however, is essentially the same-hard, saline, and corrosive.

\section{HAWTHORN FORMATION}

Parker and Cooke (1944, p. 96-112) referred to the Hawthorn formation as greenish marine clay marls, and silty, shelly sands underlying the highly permeable limestones of the Biscayne aquifer (p. 160 et seq.). The bulk of the limestones of the Biscayne aquifer are now considered to be of Pleistocene age and are assigned to the. Fort Thompson formation. They were formerly correlated with the Tamiami limestone, which Mansfield (1939) referred to the Pliocene. Materials of upper Miocene age had never been recognized in southern Florida, and because of the lithologic similarity between the Hawthorn formation in outcrop areas and the sediments underlying the Biscayne aquifer, and the Miocene appearance of the faunas, the correlation with the Haw thorn formation was made. These materials are here referred to the upper Miocene and to the Tamiami formation.

Separation of the greenish clays, silts, and marls of "the Tamiami formation (upper Miocene) and those of the Hawthorn formation (lower and middle Miocene) is impossible unless an adequate macrofossil collection can be gathered from each well penetrating the boundary. Because faunal collections are inadequate, no attempt has been made to place the separating boundary. However, the fauna from several wells was studied by Julia Gardner and later examined by F. Stearns MacNeil, who states 
(in a personal communication): "I agree essentially with Miss Gardner"s determinations. The wells" in which the middle Miocene appears to be penetrated are:
G 190 Probably middle Miocene at 190 feet
G 220 Possibly middle Miocene at 189 feet
G 101 Probably middle Miocene at 206-220 feet

Wells with good samples that did not penetrate the middle Miocene are:

G 219 Still in upper Miocene at 180 feet (lower sample)

G 188 Still in upper Miocene at 155 feet (lowest sample)."

In general, the Hawthorn formation contains more clay than does the Tamiami formation. Both are characterized by greenish marine sediments: clay, silt, sand, (all more or less marly and phosphatic, and having a large and varied fauna); the permeability is generally low to very low and is controlled by the finer rather than by the coarser detritals.

Quartzite and phosphate pebbles, some as much as half an inch in greatest diameter, are not uncommon in the Hawthorn formation and were distributed throughout a vertical range of 52 feet in G 223 (from 214 to $266 \mathrm{ft}$ below mean sea level). In well HE 4, near Clewiston, the top of the zone bearing these pebbles was 76 feet below mean sea level, and the bottom was $127 \mathrm{feet}$; thus, this zone had a total thickness of 51 feet. The thickness is almost identical in these two wells, which are 63 miles apart. Based on this zone, the dip in the Hawthorn formation between Lake Okeechobee and the Tamiami Trail is 2.2 feet per mile.

In southeastern Florida, the Hawthorn formation is generally relatively impermeable. Except in shell beds, occasional "shoestring deposits of coarser sand, and some of the limestone layers, water either is not available, or it is obtainable only in very limited quantities. Most of the available water occurs under low artesian pressure. In southwestern Florida, in coastal Collier County, some of the artesian wells of the Hawthorn formation have piezometric heads similar to those found in the Ocala limestone, which are as much as 25 feet above mean sea level and yield as much as $150 \mathrm{gpm}$. Although the water is hard and somewhat saline, it is usable and far superior to that of the Floridan aquifer (see section on Quality of ground and surface waters, $p$. 823 , table of analysis of water for Collier County).

\section{TAMIAMI FORMATION}

The name Tamiami limestone was proposed by Mansfield (1939, p. 8) for "a limestone penetrated in digging shallow ditches to

\footnotetext{
4All depths referred to mean sea level.
} 
form the road of the Tamiami Trail over a distance of about 34 miles in Collier and Monroe Counties, Florida." Mansfield considered that the faunas, which include 6 genera of gastropods, 15 genera of pelecypods and 2 genera of echinoids collected mainly from spoil banks, were possibly of Pliocene age (older than that of the Caloosahatchee marl). Parker and Cooke (1944, p. 62) traced the surficial outcrops of the non-oolitic, permeable, sandy limestone eastward from the type locality into western Dade County, where the formation gently dips eastward beneath younger materials (pl. 9. sec. $\left.f-f^{\prime}\right)$. From this area, near the EvergladesBig Cypress Swamp border, they correlated the Tamiami limestone by subsurface data obtained from test wells, drilled by cabletool or jet rigs (percussion-type drills), with the highly permeable rocks that unconformably underlie the Miami oolite (of Pleistocene age) in the Miami area (see p. 94). Core borings, unavailable until 1947 and later, have since revealed thin (a few inches to severalfeet), fresh-water, Pleistocene, limestone beas intercalated with marine limestone to depths of 55 feet below sea level. Such limestones are unrecognizable in the comminuted cuttings from percussion-type drilling. Most of this section of permeable rocks in the Miami area is tentatively assigned to the Pleistocene Fort Thompson formation, and the remainder, the Tamiamilimestone of Mansfield, was restricted by Parker (1951), and by Hoy and Schroeder (1952), to the basal part of the highly permeable rocks below the lowest fresh-water bed. The total thickness of the restricted Tamiami limestone is probably less than 15 feet.

Beds of hard, cream to tan, sandy limestones and calcareous sandstone ( 1 to 3 feet in thickness, which in many instances contain abundant Chione cancellata) overlie and fill depressicns in the Tamiami formation in the areas along, and adjacent to, the Tamiami Trail (U. S. Route 94). One such bed, as described by Mansfield (1931, p. 2), overlies a sand containing shells of upper Miocene age. A similar eream, calcareous sandstone overlies the Tamiami formation unconformably in a pit $1 \frac{1}{2}$ miles south of Sunniland, Collier County. Obviously, these sandstones and limestones are not a part of the Tamiami formation and are here as signed to the Anastasia formation of Pleistocene age.

The Tamiami formation, as seen at the type locality along the Tamiami Trail, unfortunately is not typical of the formation as a whole. As here defined, the formation is composed of the thin Tamiami limestone of Mansfield and of a thick section underlying the Biscayne aquifer (consisting chiefly of greenish clay marl, silty, and generally very shelly sand, and calcareous marl locally indurated to impure limestone). The formation includes all the upper Miocene materials in southern Florida and has a maximum thickness of about 150 feet. The detritals are characterized by greenish colors. 
F. Stearns MacNeil reports (personal communication) the accumulated macrofossil collection from two Tamiami formation localities as follows:

Locality 1. Borrow pit at junction of U. S. Route 41 and Florida Route 29 (Carnestown), about 4 miles north of Everglades, Collier County,

Molltusca:

Ostrea tamianiensis Mansfield

Ostrea lochlini Gardner

Pecten (Nodipecten) pittieri collierensis Mansfield

Pecten (Plagioctengitum) evergladensis Mansfield

Modiolus sp. (large)

Eucrassatella sp.

Cardita (Carditanera) cf. C. tamiemiensis Mansfield

Chione ulocyma Dall

Chiotie aff. C. cortimaria Rogers

Echinodermata:

Encope macrophota tamiamiensis Mansfield

Cassidulua evergladensis Mansfield

Locality 2. Two borrow pits west of Florida Route 29, respectively $1 \frac{1}{2}$ miles south and $\frac{1}{2}$ mile north of Sunniland, Collier County.

Mollusca:

Turritella pontoni Mansfield

Tutritella aff. $T$, perattenuata Heilptin

Cerithium n. sp. aff. C. floridenuth Morch

Calyptraea sp.

Stronbits sp.

Cypraea sp.

Busycon mazzmum Conrad var.?

Dorsanum? aff. D. plicatilum (Bose)

Fasciolaria sp.

Contus adversaritus Conrad

Glycymeris sp. aff. G. subovata Say

Glycymeris cf. G. quinquirugata Conrad

Glycymeris sp. aff. G. Pectinatus (Gmelin)

Arca (Arca) sp.

Anadara cf. A. improcera Conrad

Anadara sp. aff. A. lienosa Say

Anadara (Cunearca) sp.

Calloarca sp.

Modioltus sp. (large)

Plicatula aff, $P$. marginata Say

Amusium mortoni (Ravenel)

Pecten (Pecter) ochlochomeensis violse Tucker

Pecten (Plasioct enitur) evergladensis Mansfiel di:

Pecten (Plagioctenium) eboreus Conrad

Pecten (Nodipecten) pittieri collierensis Mansfield

Chlamys (Chlanys) exasperatus (Sowerby)

Anonita simplex d'Orbigny

Ostrea lochlini Gardner

Ostrea disparilis Conrad

Ostrea tamiamiensis Mansfield

Placunanomia plicata Tuomey and Holmes ( $P$. aclinica Tucker and Wilson)

Cardita (Carditamera) arata Conrad

Miltha sp. (large)

Cardium (Trachycardium) sp. aff. C. dalli Heilprin

Cardiun (Trachycardium) sp, aff. C. isocardia Linne

Dosinia sp. 
Chione sp. aff, $C$, cancellata Linne

Chione athleta Conrad

Chione tulocyma Dall

Semele sp. aff. S. leana Dall

Large tellenied or semilid with Quidnipagus-like sculpture

Cyatholdonta sp.

Echinodermata:

Encope macrophora tamiantiensis Mansfield

Cessidulus evergladensis Mansfield

Ci rripedia:

Balanus concavas Bronn

MacNeil states that:"*** the faunas contained in the beds at these two localities are of upper Miocene age" and that "Ostrea cisparilis, Chione ulocyma, and Turritella pontoni are not only characteristic upper Miocene species, but they represent groups that have no known post-Miocene relatives, at least in this part of the world. The two echinoids are not known outside of the Tamiamiformation."

The Caloosahatchee marl, the Buckingham marl, and the Tamiami formation when they were all referred to the Pliocene were considered by Parker and Cooke (1944, p. 56-65) to be equivalent and to grade one into another. There is a striking similarity of the macrofauna of the Buckingham formation in Lee and Hendry Counties as described by Mansfield (1939, p. 11-12) to that of the Tamiamiformation in Collier County. Lithologically, the white, silty marl locally hardened to a soft limestone near Sunniland, Collier County, and the cream, clayey marl at Buckingham, Lee County, are nearly identical. It is concluded that the Buckingham marl is merely a facies of the Tamiami formation.

Exposures observed during traverses along the Caloosahatchee River suggested a transition of Buckingham marl to Caloosahatchee marl. The typical shell beds of the Caloosahatchee marl with their characteristic Pliocene fauna were not noted at any place in contact with clay marls containing a characteristic Buckingham fauna; therefore, the exact relationship could not be established.

The recent discovery by Parker of a key gastropod, and further detailed checking of the stratigraphic section in southern and southwestern Florida, indicates that beds formerly called the Buckingham marl do not grade into the Caloosahatchee marl but probably underlie it with a masked unconformity. The gastropod, Ecphora quadricostata umbilicata (Wagne $\mathrm{r}$ ), is from beds formerly known as the Buckingham marl, 2 feet above low tide at station 24 of Parker and Cooke (1944, p. 84). F. Stearns MacNeil states (personal communication) concerning this fossil:

\footnotetext{
"Upper Miocene: The genus Ecphora is not known in beds younger than Miocene. The species Ecphora quadricostata is known from the St. Marys formation to the Duplin formation in Virginia, North Carolina, and South Carolina, and from the Ecphora zone of the
} 
Choctawhatchee formation of western Florida. As fat as is known, the variety umbilicata has no stratigraphic significance, but merely includes those individuals with low nonoverhanging spiral ribs.

"I suggested [to Mr. N. D. Hoy] recently that even though the Buckingham limestone is
older than the Caloosahatchee, it stili might be younger than the Duplin formation of North
Carolina and possibly, therefore, of "lower Pliocene" age. In view of the fossil herein re-
ported on, I am inclined to concur in Mansfield's earlier deternination of an uppermost
Miocene age for the Buckingham- and for the equivalent Tamiami limestone."

The permeability of the thick detrital section of the Tamiami formation is generally very low, but the thin, upper, solutionriddled limestone (the Tamiami limestone of Mansfield) part of the formation is extremely permeable. The lower and major part of the formation is generally very silty and clayey and comprises the upper part of the Floridan aquiclude (see p. 189).

\section{PLIOCENE SERIES}

\section{CALOOSAHATCHEE MARL}

The Caloosahatchee marl discontinuously underlies much of the Everglades and the Big Cypress Swamp and, extends northward beneath the Pleistocene terraces of the Kissimmee Rlver area (see pl. 4). Its distribution at the north end of the Kissimmee valley, in the Orlando area, caused Unklesbay (1944, p. 11-12) some concern. He was attempting to work out the stratigraphy of the Miocene to Recentformations in the Orlando area, but he concluded that because of the lack of data it was not possible to do so. He says: "A few of the wells in the County (Orange) penetrate 30 to 40 feet of shell marl immediately under the surficial sand. This marl contains mollusks and foraminifera which appear to be contemporaneous with Choctawhatchee forms, but proof of this age relationship will require detailed examination of many well cuttings. The shell marl may represent highly fossiliferous portions of the Hawthorn, or it may actually be a deposit of Choctawhatchee time. As the shell marl has been reported in only a few wells, its areal extent is not known."

Unklesbay tentatively assigned this marl to the Hawthorn formation.

From the outcrop area in the Caloosahatchee River and Lake Okeechobee region the Caloosahatchee marl gently dips to the south and southeast under the Everglades and Atlantic Coastal Ridge. It probably never was a thick deposit, possibly not more than a maximum of 50 feet, and now it is considerably thinner be cause of erosion and solution. In fact, in many places in southeastern Florida the Caloosahatchee marl is absent, and in others it appears only as isolated reefs, or as lenticular bodies preserved in depressions in the underlying Tamiamiformation (upper Miocene). 
The Caloosahatchee marl is dominantly a grayish-green or greenish-gray silty, sandy, shell marl with interbedded layers and lenses of sand, silt, clay, and marl. In some areas of the Everglades it includes carbonaceous zones containing remnants of roots, stems, and other organic debris that suggest former mangrove swamps. In some places the Caloosahatchee marl is composed of cemented shells or sandy shell marl that has been changed to a sandy, shelly limestone which, by solution of percolating ground water, has been made highly permeable.

Generally, however, the Caloosahatchee marl is of low to very low permeability, and of ten it is difficult to develop small wells finished with a sand point. However, wells that end in the sandy limestone may have a high yield when the loose sand is cleared from the aquifer in the area surrounding the intake portion of the wells.

In some parts of the northern Everglades, south of Lake Okeechobee, there are shallowly buried Pliocene reefs and shoestring" deposits of permeable sand. These ancient reefs are composed of calcareous sandstone or sandy shelly limestone and were carved out of the Caloosahatchee marl by erosion during early Pleistocene time. Although now overlain and hidden by younger and denser materials, these reefs and "shoe-string" sands are permeable and yield water freely to wells.

Where the Caloosahatchee marl is more permeable, and near the coast, it contains hard, but potable, water; inland, around Lake Okeechobee and in the upper part of the Everglades, the water is hard, in places highly colored, and of ten it is so highly mineralized that it is unfit for use. These variously mineralized bodies of ground water near the lake are probably the result of Pleistocene (Ice Age) invasions of the Everglades area by the sea during the several interglacial ages. Partial flushings or dilution by fresh percolating ground water occurred duringsubsequent glacial ages, and various chemical reactions, especially the cation-exchange variety (Love, 1945, p. 951-955), took place with the surrounding rock materialsm-this action is still taking place.

\section{QUATERNARY SYSTEM}

\section{PLEISTOCENE SERES}

\section{GENERAL STATEMENT}

The Pleistocene rocks of southern Florida are of particular interest because they record several oscilliations of sea level, due in part to continental glaciation and deglaciation during the Pleistocene or "Great Ice Age." This record appears to be most 
nearly complete in the Fort Thompson formation along the upper Caloosahatchee River, but rocks of this epoch are widespread in southern Florida. They include marine, brackish, and freshwater marls, limestones, sandstones, coquinas, and sands, as well as a fringing coral reef (bioherm) that grew along the southern edge of the Floridan Plateau from Miami at least as far south as Big Pine Key, and possibly farther. These formations have been most difficult to correlate, but during the ground-water geology investigation a working hypothesis was reached and published by Parker and Cooke (1944).

\section{FORT THOMPSON FORMATION}

The Fort Thompson formation takes its name from the type locality at Fort Thompson, the site of an army outpost of the Seminole Indian Wars, about $1 \frac{3}{4}$ miles east of La Belle on the Caloosahatchee River. The formation there is about 6 feet thick and is composed of alternating fresh-water, marine, and brackish-water marls, limestones, shell beds, and sand (see fig. 11). The beds differ in thickness from place to place as the formation is traced out into the Lake Okeechobee-Everglades depression or westward toward the Gulf of Mexico, and in some places individual beds may be missing entirely or preserved only in solution holes or cavities in lower beds. In the Lake Okeechobee area its thickness averages less than 10 feet, whereas in the Miami area it averages about 80 feet, and the maximum thickness there may be about 200 feet (pl. 8 , sect. $\left.G-C^{\prime}\right)$.

The Fort Thompson formation forms the floor of the Lake Okeechobee-Everglades depression as far east as the Atlantic Coastal Ridge, where its marine beds merge with, and appear to be extensions of, the main mass of the Anastasia formation. This relationship has been well demonstrated by subsurface studies in the vicinity of Fort Lauderdale (see fig. 10).

The Fort Thompson formation appears to have suffered little deformation although many small undulations in the beds are present. Many of these probably represent almost equal deposition over the uneven floor on which the formation lies; some, however, appear to be due to sagging where solution by percolating ground water has removed the soft calcareous marl from beneath the hard limestone layers (see fig. 11).

The Fort Thompson formation can be separated into two parts on the basis of its hydrologic characteristics. The northern part of the formation underlies the upper Everglades area, which includes northwestern Broward County; its rocks are generally of low permeability, and it averages less than 10 feet in thickness. The southern part of the formation is extremely permeable and forms the major part of the Biscayne aquifer (p. 160). 


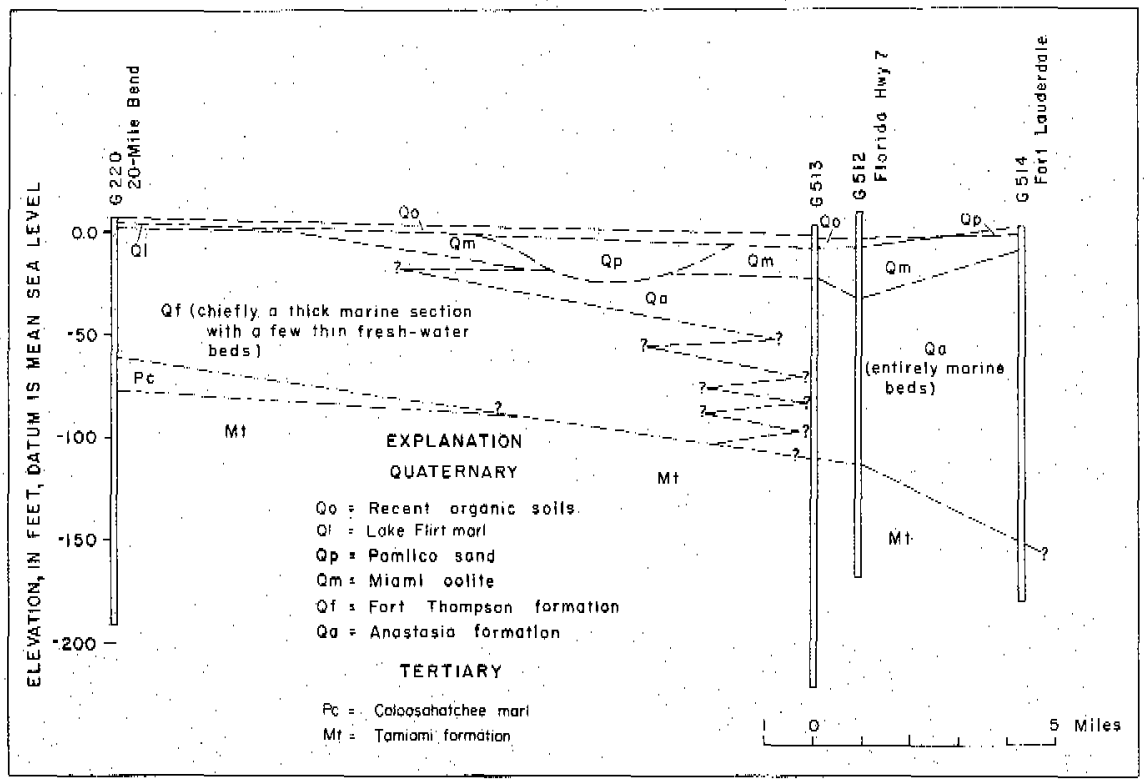

Figure 10. -East-west cross section along North New River Canal from 20-Mile Bend to Fort Lauderdale.

The southern part of the Fort Thompson formation is composed principally of white to eream sandy limestone, calcareous sandstone, beds and pockets of quartz sand and thin beds of dense, hard, fresh-water limestone, perforated by numerous solution holes, many of which are filled with younger materials. Where

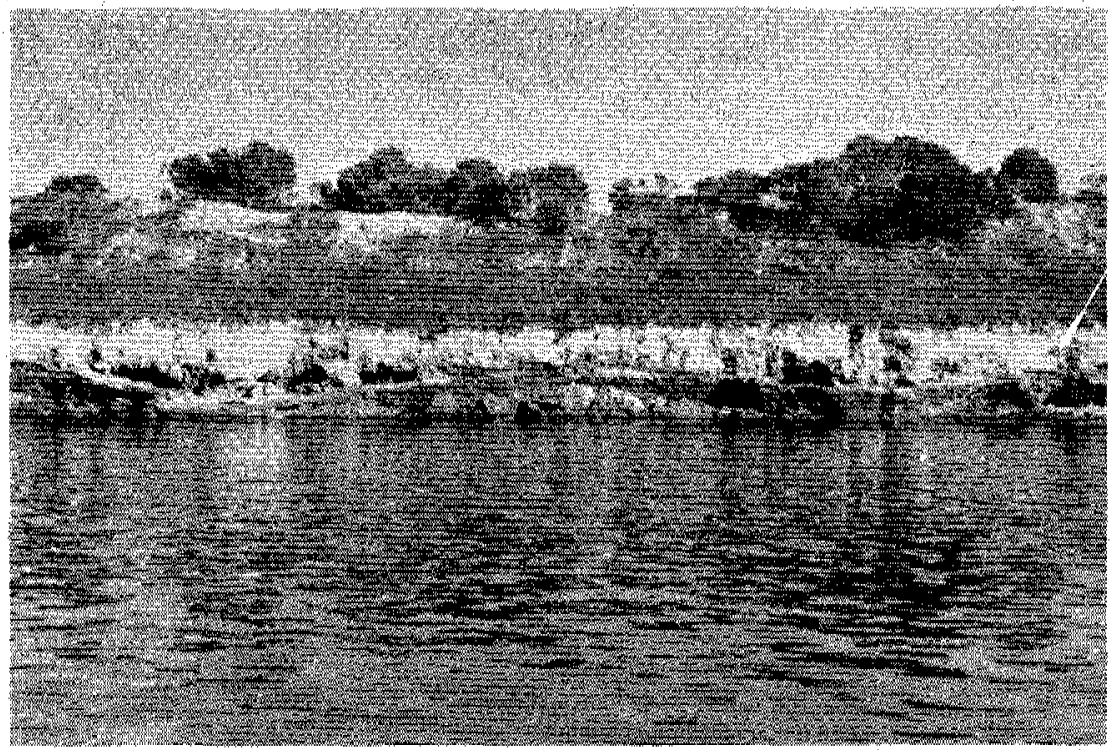

Figure 11. -Dredge-cut in Caloosahatchee River showing small undulations in Fort Thompson formation. 
exposed on the surface in eastern Collier County, the Fort Thompson formation is a grayish-white to tan calcareous sandstone containing an abundance of Chione cencellats shells. It is riddled with solution holes commonly filled with marly soil. To the east and south of the outcrop area (see pl. 4), beds of the Fort Thompson formation slope gradually under the Miami oolite, and for several miles the contact of these two formations is visible in big pieces of rock dredged from the Tamiami Canal. Similar pieces of rock are visible along the banks of the South New River Canal (see fig. 12) where at times of extreme low water this contact can be seen along the banks west of State Route 25 in western Broward County.

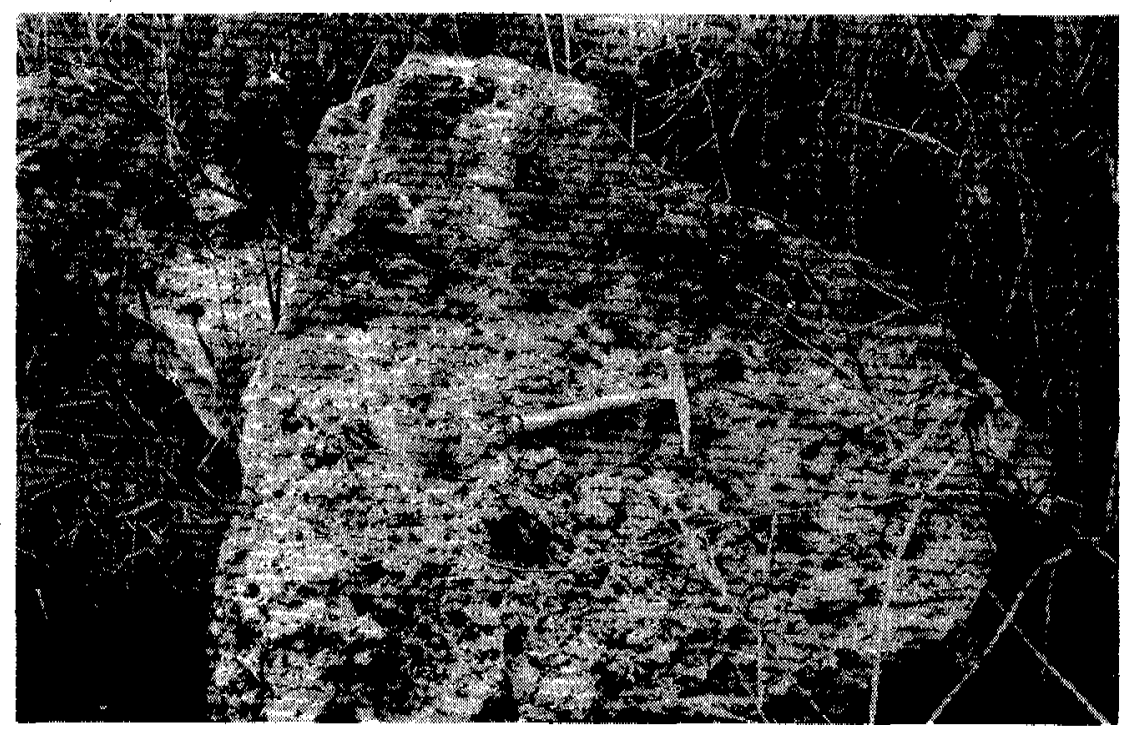

Figure 12. -View of contact of Miami oolite and Fort Thompson formation.

The southern part of the Fort Thompson formation is, in general, a wedge-shaped deposit that thickens toward the Atlantic Ocean. This is graphically shown in some of the following geologic cross sections, especially those trending in an east-west direction. $\mathrm{Plate} 5$ is an index map showing the location of the sections, and plate 8 , section $G G^{\prime}$, and plate 9 , sections $F^{\prime}-F^{\prime}$ and $J \cdot J^{\prime}$, are most illustrative of this eastward thickening.

Three strike sections, $A-A^{\prime}$ (pl. 6), $B-B^{\prime}(\mathrm{pl}, 7)$ and $I-I^{\prime}$ (pl. 8) trend in a direction generally parallel to the coast. These indicate that the Fort Thompson formation thickens somewhat toward the northeast (about 80 feet thick in the Miami area but only about 60 feet thick near Homestead). The block diagram of the Miami area (fig. 13) presents a three-dimensional picture of the Fort 


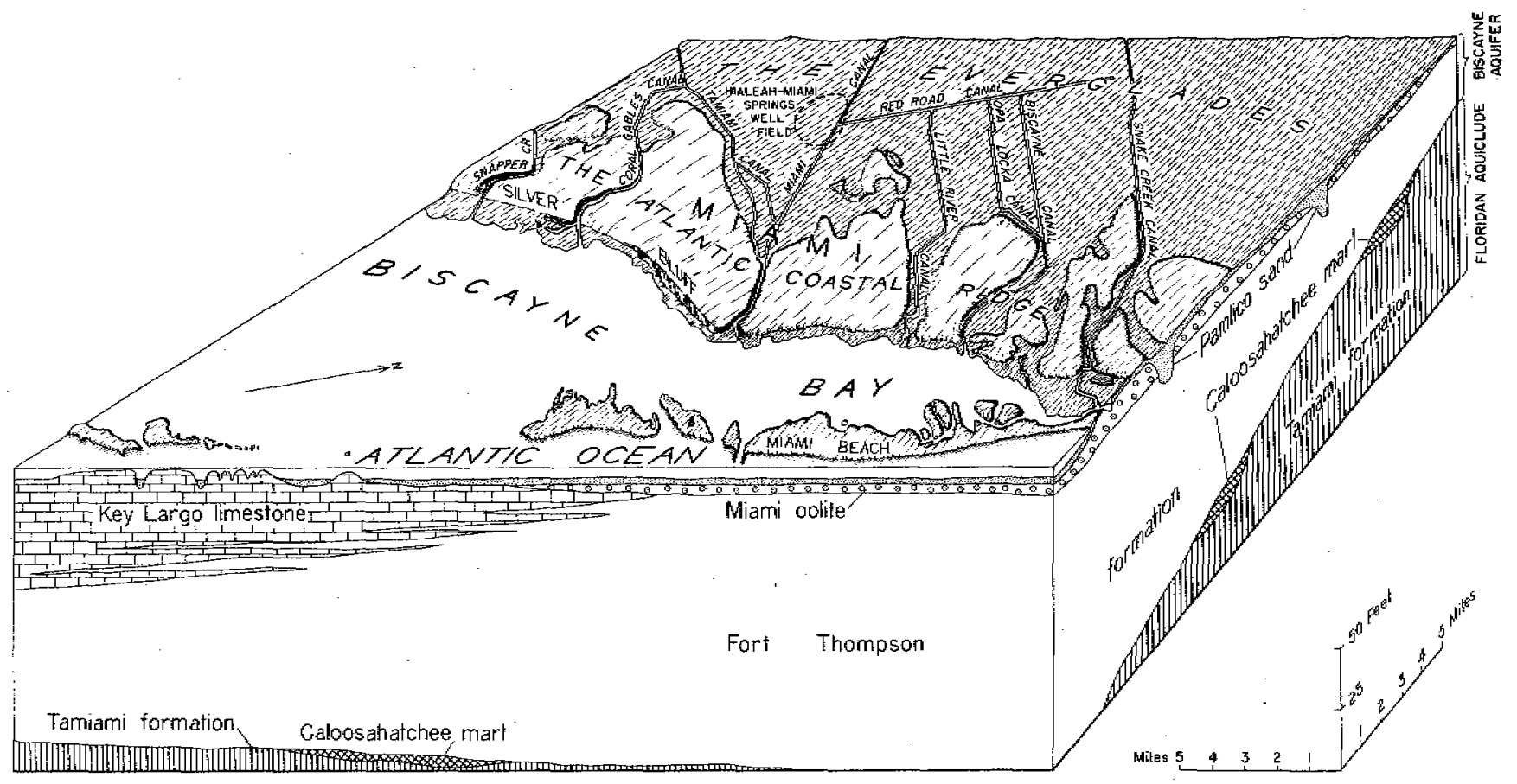

Figure 13, -Block diagram of the Miami area. 
Thompson and associated formations, which together comprise the Biscayne aquifer.

This wedge of Pleistocene marine limestones and intercalated fresh-water limestones was deposited in a topographic depression, whichwas in all probability, bounded on the east by a slightly higher offshore bar and fringing reef composed of the Anastasia formation to the north of Fort Lauderdale, and the coral reefs and their wastage, which now comprise the Key Largo limestone to the south of that area. During the low sea levels of the glacial ages this depression was a land area having one or more large, shallow, fresh-water lakes in which fresh-water deposits, chiefly soft limy muds, were deposited: During the high sea levels of the interglacial ages the depression was flooded with sea water, and marine limestone, sand, and shells were deposited. At the same time, with adjustment to changed sea level, the offshore bars and the Key Largo reefs continued to grow. This concept of Pleistocene sedimentation in southeastern Florida is supported by the occurrence of the fresh-water limestones and by the interfingering of the Anastasia formation and the Key Largo limestone with the Fort Thompson formation along the coastal areas.

The filling of this shallow trough and the contemporaneous development of the bars and reefs along the shore produced a unit of rocks underlying the lower Everglades and the coastal area of southeastern Florida that now forms the major part of the highly permeable part of the Biscayne aquifer. This part of the aquifer was previously correlated with the Tamiami formation by Parker and Cooke (1944), largely on the basis of lithology as interpreted from cable-tool drill cuttings, and partly on the basis of an inconclusive fauna of both microfossils and macrofossils. The comminuted, condition of the cuttings prevented the discernment of fresh-water limestones in which most of the fossils are preserved by casts and molds. Recent core borings, which have been reported by Hoy and Schroeder (1952), indicate that there are several beds, a few inches to a foot or more in thickness, of freshwater limestone intercalated with the very permeable, sandy, marine limestoie. Some of these fresh-water limestones come from depths as greatas 55 feet below present sea level. They are probably the correlatives of the fresh-water beds in the Fort Thompson formation that may be seen in its outcrop area along the Caloosahatchee River east of La Belle and as part of the North New River Canal spoil banks from Lake Okeechobee to 20-Mile Bend.

The fresh-water limestone beds occur in many places at or near the base of the highly permeable limestones and sandstones of the Biscayne aquifer. Only rocks containing upper Miocene fossils occur immediately below this boundary. This knowledge has been used in establishing the boundary between deposits of 
Pleistocene and upper Miocene ages (see pls. 6-9), although it is recognized that possibly there are places where upper Miocene (Tamiami formation) has been included in the base of the Fort Thompson formation. A comparable situation exists in the Kendall area west of U. S. Route 1, where Pliocene materials (Caloosahatchee marl) may be included above the inferred base of the Fort Thompsonformation. A collection of macrofossils from test wells in the interval of 50 to 90 feet below sea level in the Biscayne aquifer west of Kendall includes the following fossils:

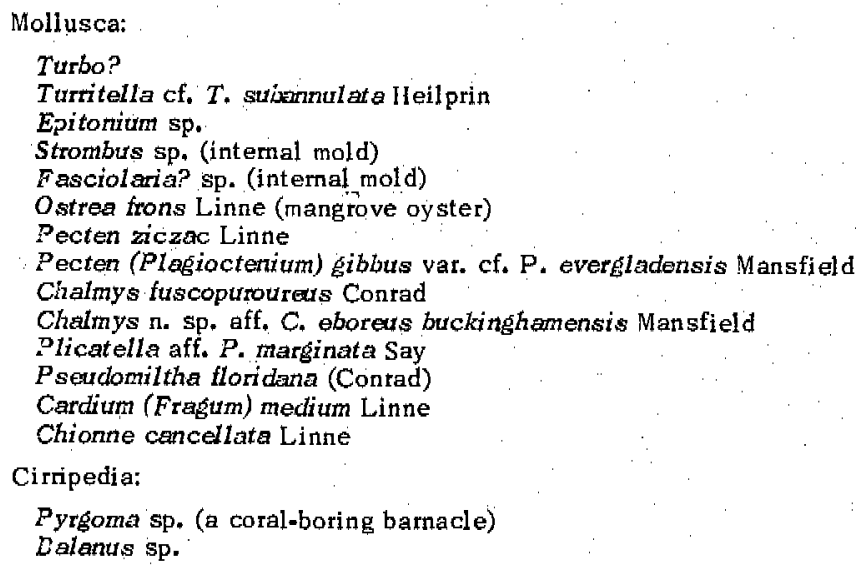

Echinoderm ata:

Metalis cf. $M$. pectoralis Lamark

Other.

Unidentified head coral

Bryozoa (2 genera)

Shark teeth

Concerning this fauna F. Stearns MacNeil (personal communication) states: "There is nothing to indicate an age older than Pliocene. Turritella subanulata Heilprin is believed to be restricted to the Pliocene. If any of this interval is Pleistocene, it is not possible to say so definitely on the basis of this material. The presence of reef-building corals may indicate a Pleistocene age for part of this interval, but we have no information that would eliminate Pliocene reefs."

A fragment of an Encope was recovered between 59 and 63 feet below mean sea level in this same area. MacNeil further reports that: "It is not identifiable, but the absence of a depressed area between the petals and the margin suggests that it is not the upper Miocene species. Age - Post Miocene?"”

The paleontological data suggest that in the Kendall area (see cross section $E-E^{i}$, pl. 8) there may be some Pliocene (Caloosahatchee marl) included in the rocks mapped as belonging to the 
lower part of the Fort Thompson formation. Scattered and relatively thin Pliocene materials may also be present elsewhere in southeastern Florida.

Stringfield (1933a) first reported on the water-bearing characteristics of the Fort Thompson formation in the Lake Okeechobee area. As mentioned above, this part of the formation makes a very poor aquifer; its limestones are dense and hard, and the intercalated calcareous mud and fine-sand layers have very low coefficients of permeability. The freest movement of water is in the sand and shell beds, but these commonly are of relatively low permeability because of the admixture of fine sand, silt, and clay. The water is likely to be of poor quality because of residual mineralization from the several invasions of this area by the sea during Pleis tocene interglacial ages. (See p. 106-107, and p. 184185 of the section on Ground water occurrence and p. 821-822 of the section on Quality of ground and surface waters.) Chloride ranging from 16 to $3,150 \mathrm{ppm}$ has been found in test wells in the Everglades. As means of comparison, the U. S. Public Health Service standards allow a maximum chloride concentration of 250 ppm in public supplies for common carriers in interstate traffic, and most people can definitely taste 400 to $500 \mathrm{ppm}$ of chloride.

The fact that some wells in the Fort Thompson formation of the Lake Okeechobee area supply usable water is due to their having been drilled in more permeable beds that have been flushed of their highly mineralized waters. Heavy or long-continued pumping of certain of these wells, however, has caused mineralized water to be drawn in from adjacent shallow zones, and some weils have been abandoned.

The Fort Thompson formation in Dade County is the major part of one of the most permeable aquifers (Biscayne aquifer) ever investigated by the U. S. Geological Survey, and it ranks with clean, well-sorted gravel in its ability to transmit water. (See the section on Ground water [Quantitative studies].) This high permeability is due to the solution-riddled nature of the limestone and calcareous sandstone. The development of the cavities is caused by the solvent activity of percolating ground water. Note in the geologic cross sections (pls. 6-9) the numerous cavities found during exploratory test-well drilling. Such cavities are usually partly filled, and sometines are entirely filled, with quartz sand. The sand is of two origins: (1) Residual, left behind when the calcareous materials are removed by solution of either sandy limestone or calcareous sandstone, and (2) introduced from above through connecting vertical cavities. The presence of sand in the cavities diminishes the permeability of the formation.

Numerous cores were taken during late phases of the test-well drilling program. These help greatly in visualizing the reason for the extremely high permeability of calca reous rocks of southeastern Florida. Photographs of a few of these cores are reproduced 


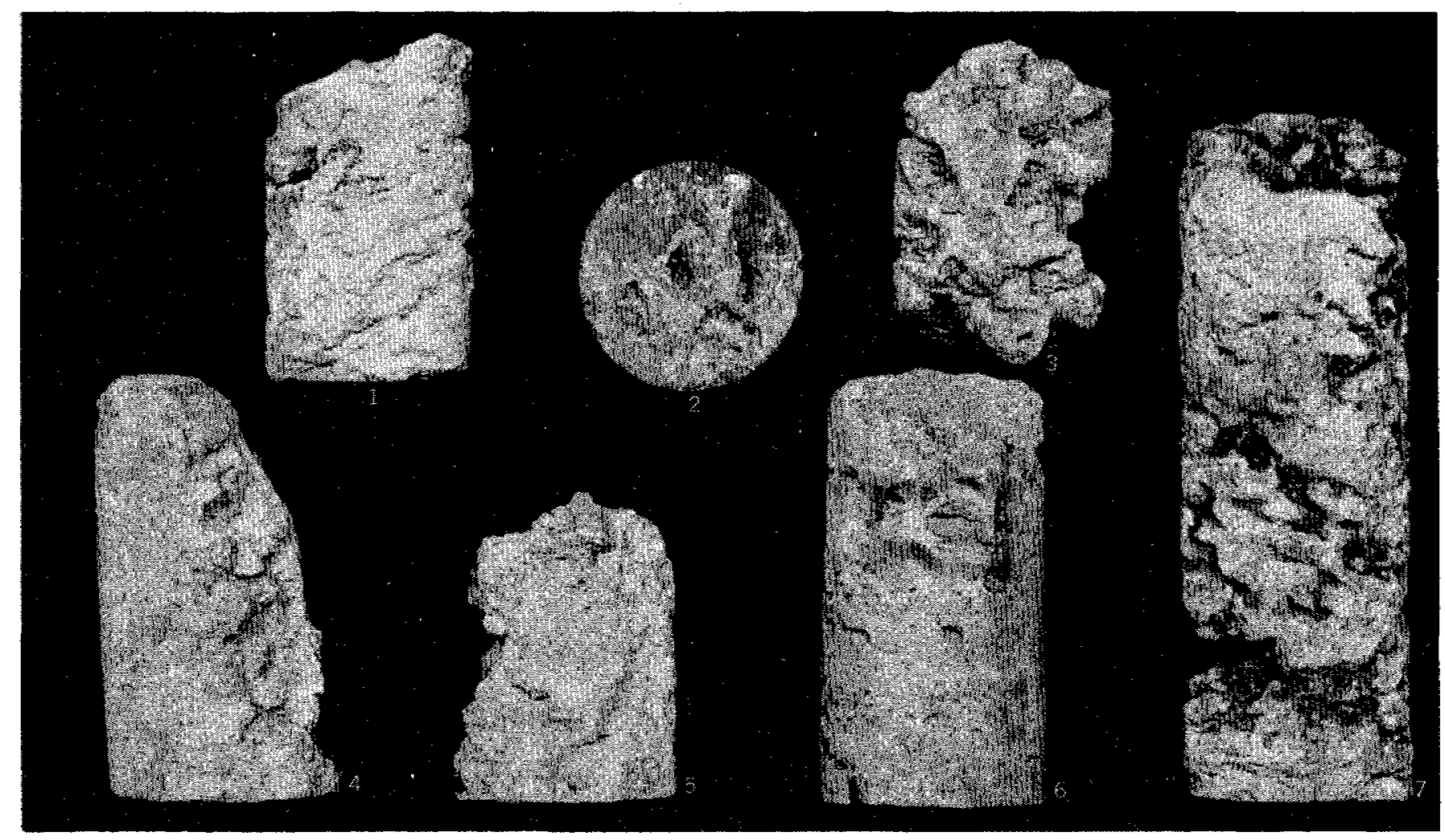




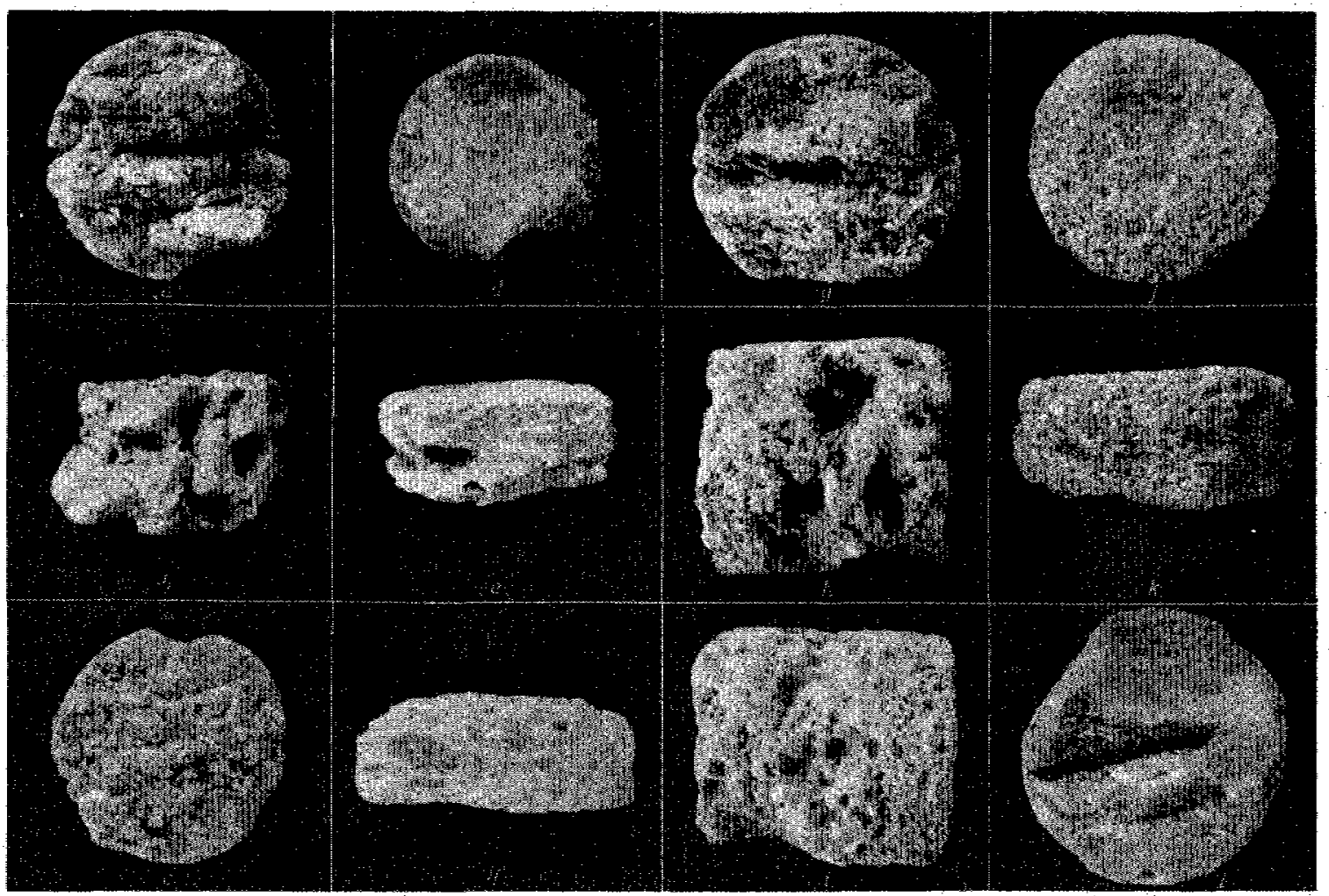


in figures 14 and 15. In figure 14, core Nos. 4 to 7 are from the Fort Thompson formation in Dade County and were selected as being typical of the formation; they were not selected to illustrate extreme or special conditions. Core Nos, 4 and 5 are mediumhard sandy limestone. Each core shows, by a ragged and irregular outline, that it was cut through a part of the formation containing relatively large solution holes. No. 6 is a dense, hard, once fossiliferous limy sandstone from which fossil shells have been removed by solution, thus leaving numerous small cavities. No. 7 is taken from a part of the formation that shows some evi. dence of bedding planes, and it is along the softer of these planes that solution has been most active. The dark color of the solution channels of this core is caused by a deposit of iron oxide. Core Nos. 1 to 3 are from the Miami oolite and will be discussed later.

Without exception, all of the cores in figure 15 are from the Biscayne aquifer at Delray Beach, in Palm Beach County, which is very near the northernmost extent of the aquifer. The cores are chiefly sandy limestone and calcareous sandstone of the Anastasia formation and show by the alinement of solution channels evidence of the solvent activity of percolating ground water moving principally in one direction. Although no means of obtaining oriented cores were available, it is believed that the solution channels developed principally in a west-east direction, because ground-wate movement is now, and probably always has been, directed $r$ sinly toward the Atlantic Ocean on the east.

As in Dade County, the Fort Thompson formation in coastal Broward and Palm Beach Counties is highly permeable, and where thick enough, it yields large quantities of water with very little lowering of the water level.

\section{KEY LARGO LIMESTONE}

The Florida Keys, from Soldier Key, off Miami, to and including Bahia Honda, are parts of a dead coral reef. This reef is about 90 miles long, has a maximum width at sea level of about 3 miles, and is known to be at least 60 feet thick; its base, however, is much wider and possibly much longer.

The Key Largo limestone interfingers in some places with the Miami oolite, and in the Silver Bluff area of Miami it underlies the oolite. It is partly contemporaneous with the oolite, but its lower portion is older and interfingers with the Fort Thompson formation.

This latter relationship is shown by the occurrence of coralline limestone as deep as 48 feet below sea level in well G 189 (see pl. 9), and by fragments of similar marine limestone in the cuttings from wells $G 101$ and $G 224$ as deep as 55 feet below mean sea level. 
Recent core boring in the Kendall area, west of U. S. Route 1 , contained similar limestone (largely reef detrital materials). F. S. MacNeil examined a length of core from about 39 feet below mean sea level that contained a bed of fresh-water limestone. MacNeil states: "The marine limestone with which the freshwater limestone is interbedded is highly coralline and contains Chione cancellata and some other unidentifiable mollusks. Chione cancellata occurs in both the Pliocene and Pleistocene, but the semi-crystalline, coralline nature of this rock does not suggest any Pliocene deposits with which I am familiar. I am inclined to believe that Hoy's assignment (Hoy and Schroeder, 1951) of it (limestone of the Fort Thompson formation formerly referred to the Tamiami formation) to the Pleistocene is correct. The similarity of it to the Key Largo limestone suggests the presence of one or several tongues of the formation."

The Key Largo limestone contains a large amount of coral, and the spaces between and around the coral heads are filled with amorphous limestone or detritus from wastage of the reef. Much limestone breccia is present on the surface of the Keys and is incorporated within former caverns or crevices of the reef. The breccia on the surface is of the same origin as that described on page 102.

On the Florida Keys fresh-water supplies from the Key Largo limestone cannot be obtained except in extremely limited quantities from just above sea level. The formation is so open and permeable that fresh water readily escapes laterally to the sea, and ocean water finds access to the interstices, caverns, and crevices of the rock justas easily. Substantial Ghyben-Herzerg lenses (see section on salt-water encroachment, p. 591-593) of fresh water do not occur in these keys. Wells in the Key Largo limestone of the Florida Keys yield unlimited quantities of salty water with practically no measurable drawdown, but this water is used only for fire-fighting or flushing purposes.

\section{ANASTASIA FORMATION}

On the eastern coast of southern Florida the Anastasia formation comprises the backbone of the Atlantic Coastal Ridge north of Boca Raton, and extends westward into the Lake OkeechobeeEverglades depression, where it forms the marine members of the Fort Thompson formation. Near Boca Raton the upper part of the Anastasia formation grades into the Miami oolite, which forms the southern portion of the Atlantic Coastal Ridge. (See Miami oolite, below.)

The Anastasia formation may exceed 100 feet in thickness and is composed chiefly of sandy limestone, calcareous, sandstone, sand, shells, and coquina. It, like the Miami oolite, is wedge- 
shaped, thick toward the coast and thin toward the interior. Like the oolite, it was formed in a marine environment largely as an offshore bar during times when the Lake Okeechobee-Everglades depression was a wide marine shoal. Many, if not most, of the materials composing these two formations were deposited under water, but at times, and in places, low dunes of calcareous, sandy, and shelly materials were heaped on the surface of the bar above high-tide level. There are many exposures of both the marine and aeolian types of deposits.

One of the thickest outcrops of the Anastasia formation is in a road cut in Palm Beach at the south end of the Palm Beach golf course, one block north of Ridgeview Avenue, where 18 feet is exposed (see fig. 16). Here, an unconformity exists within the Anastasia, separating sediments of twodifferentages in Pleistocene time.

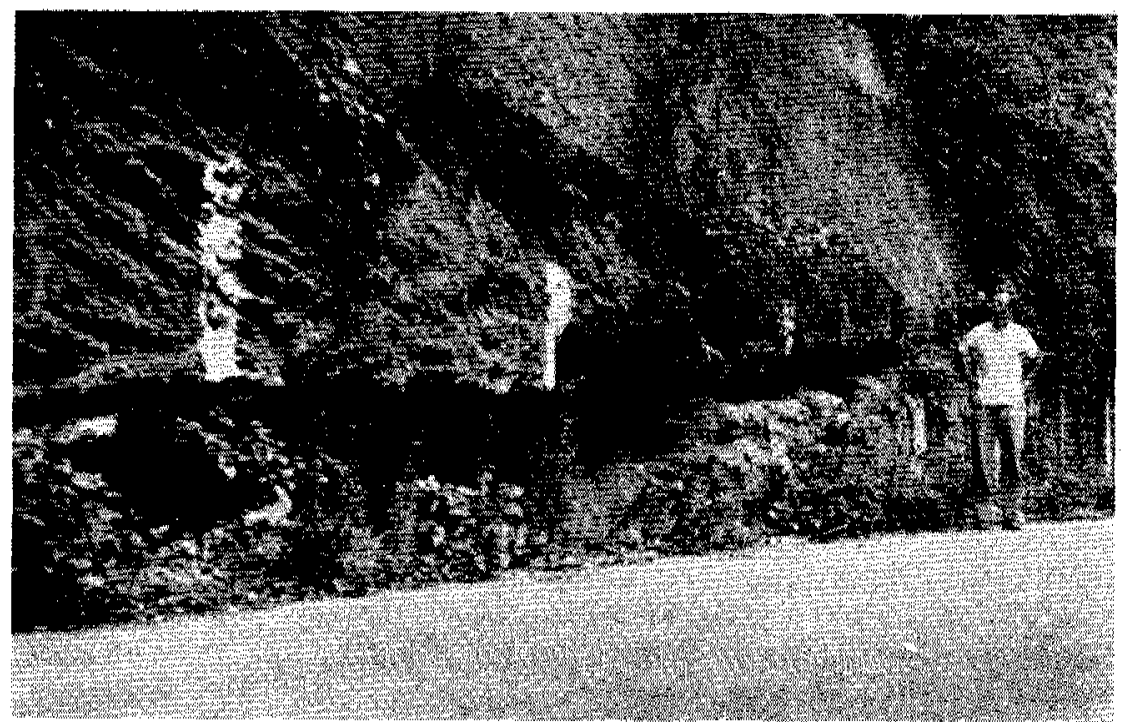

Figure 16. -Anastasia formation in road cut at south side of West Palm Beach golf course.

It is possible that the Anastasia formation contains deposits laid down during most, if not all, of the Pleistocene interglacial ages. Subsurface studies indicate that each of the several marine beds of the Fort Thompson formation, which are possibly representative of the high sea levels of Pleistocene time (Parker and Cooke, 1944, p. 20, 73-74, 89-90), is an extension of the main mass of the Anastasia formation.

Throughout most of its distribution in southern Florida the Anastasia formation yields potable water to wells and may be considered a fair to good aquifer. In the consolidated portions of the formation, open-hole (unsareened) wells of exceedingly high 
yield and low drawdown may be developed. In the sandier portions, wells must be finished with screens, well points, or gravel packs. The yield varies with the lithologic character and can be ascertained locally only by construction of wells.

In those zones within the Anastasia formation that contain old mangrove-swamp or salt-marsh deposits, there is usually so much fine sand, silt, and clay along with black silty muck and organic remains that the yield is very low and the quality of the water is poor. The Anastasia formation along the coast, from southern Palm Beach County to central St. Lucie County, has a considerable amount of these old swamp deposits. To date, not enough exploration has been done to map their boundaries, either a really or vertically.

\section{MIAMI OOLITE}

From a transition zone near Boca Raton, the Miami oolite underlies the Atlantic Coastal Ridge south to, and beyond, Florida City; it floors the Bay of Florida and reappears above water level in the lower Florida Keys from Big Pine Key to Key West. It is thickest along the coast, possibly reaching a maximum thickness of 40 feet, but its base seldom is lower than 20 feet below sea level. Inland from the ocean the oolite thins out, and on the eastern margin of the Big Cypress Swamp it finally disappears entirely. (See geologic map, pl. 4.)

The Miami oolite makes visible contact with the underlying Fort Thompson formation along some of the Everglades canals, as evidenced by rocks in the spoil banks (figs. 11, 12) and in the canal walls. The contact is of ten on a clean, solution-riddled surface of calcareous sandstone, but in many places a limestone breccia or conglomerate separates the two formations. At first glance this breccia appears to be the result of erosion with later sedimentation and consolidation. Closer examination, however, shows it to be the product of differential chemical deposition of water-borne minerals (principally iron oxide and silica) in the limestone. These secondary minerals penetrate the original limestone irregularly, of ten producing angular boundaries within the matrix. Later, solvent action may remove the softer matrix between these harder mineralized areas and leave a rough, irregular surface similar to breccia. Proof that this interpretation is correct is shown by numerous examples of fossils, or original structures, in the limestone that are traceable across boundaries between the angular, hard "fragments" and the matrix.

The oolite is crossbedded to massive, white to yellow, and of ten contains considerable fine to medium quartz sand that fills solution holes and channels. These solution holes occupy so much of the 
total volume of the oolite (figs. 14, 26) that they give it an exceedingly high permeability in a vertical direction. The horizontal permeability, however, is considerably lower.

In some places along the western shore of Biscayne Bay, as at SW. 13 th Street and First Avenue and in the adjacent Florida East Coast Railway cut, large angular blocks and rounded cobbles of oolite, as much as 2 feet long, are embedded in both structureless and crossbedded oolite and lie on old erosion planes (see fig. 17). These erosion planes were formed by wave planation, and

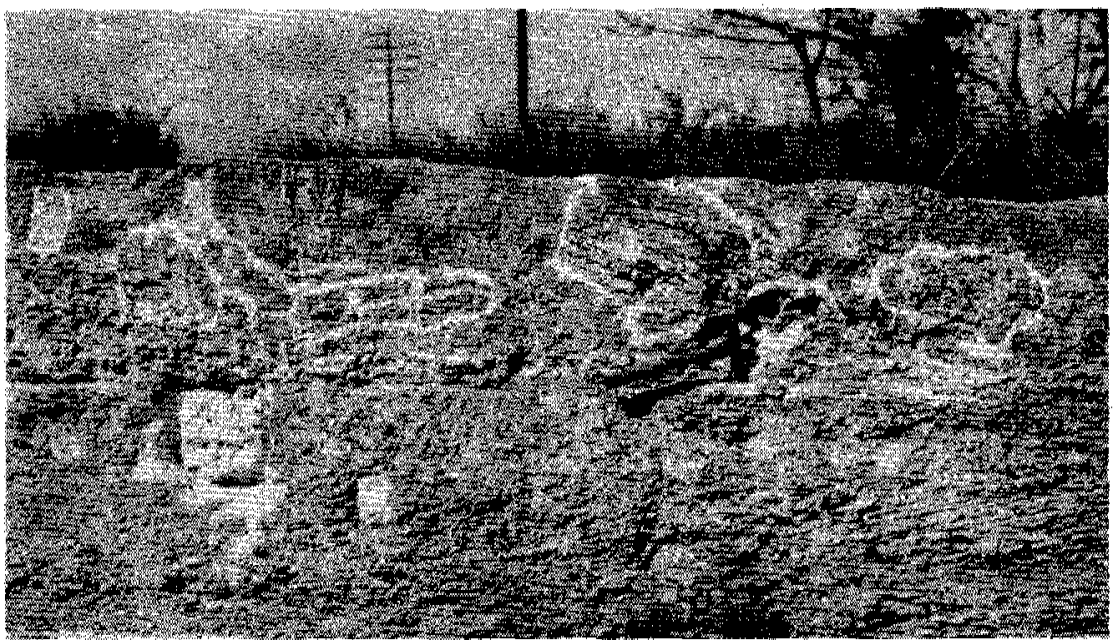

Figure 17. -Details in the Miami oolite, Dade County.

the cobbles are part of the beach shingle that washed back and forth with the tides and waves, aiding the erosion of the previously formed oolite deposit.

There are a number of such erosion planes in the oolite at this locality and elsewhere in southern. Florida, some of which are overlain by a coquina composed mainly of immature forms of shore- or near-shore-dwelling marine pelecypods and gastropods. Commones t among these are Dontax variabilis, Chione cancelleta, Crassatellites sp., Venus mercenaria, Corbula sp., Fasciolera sp., Cerithium 'sp. , Potanides sp., Cardium sp., and others.

The evidence at this locality indicates interrupted deposition of oolite by changing levels of the sea. At times, these changes brought about conditions favorable for the development of a shallow-water, near-shore marine fauna; at other times, beachshingle development occurred and a wave-planed bench was developed in the older part of the deposit; at still other times, dunetype and marine-bar deposits of crossbedded oolite were lald down. 
These changing levels all may have occurred within one interglacial age, but they also may have occurred during other interglacial ages at times when sea level was at the proper elevation. It is likely that conditions that were responsible for development of the oolite at any one time (as during the Sangamon interglacial age) could have been duplicated again and again during the Ple is tocene as the sea level slowly rose and fell, ranging through the altitude at which the oolite is now found; therefore, the problem of dating the oolite is considerably complicated.

The writers are inclined to believe that the Miami oolite, like the Anastasia, Fort Thompson, and Key Largo, formations, may not be entirely the product of one interglacial age, though most of its development may have so occurred.

Core Nos. 1, 2, and 3, of figure 14, were taken from the Miami oolite. Core No, 1 is typical of the crossbedded rock where, for one reason or another, solution by percolating acidic ground water has had little effect. The alternating slanting layers are of hard crystalline limestone containing ooliths, and of soft unconsolidated oolitic sand. The origin of these alternating hard and soft layers, ordinarily developed in crossbedded structure, is not understood. The layers occur both in deposits that appear to be of marine origin (shallow, offshore bar, as judged by the enclosed fossil assemblage) and in those of aeolian (dune) origin.

Core Nos. 2 and 3 are from a part of the formation where solution has been very active and where a large percentage of the original rock material has been leached away, thus altering both the appearance and the water-bearing properties of the oolite. This solvent activity is not confined to the production of small cavities as shown in the cores; instead, it of ten produces underground cavities of considerable size and extent. Biggest of the solution channels found in the Miami area is in well $\mathrm{G} 189$, in the Silver Bluff area of Miami (see pl. 9 section $\left.r-F^{\prime}\right)$, where a vertical cavity 11 feet deep was measured. The length, width, and continuity of these solution channels are not known; however, some probably are of considerable extentand are the cause of foundation failures of many structures-including buildings, houses, roadways, dams, and airplane runways. In certain areas of Miami, for example near SW. 12th Avenue and the Tamiami Trail, apparently solid foundations have been known to give way beneath butldings. The area is one of very active underground solution and erosion. In such a place, after rainstorms, water may be heard trickling underground, and rain water vanishes quickly into the underground channels, sometimes carrying away cubic yards of soil and other surface materials.

Water supplies are of ten developed in the Miami oolite either by driving an "open-hole" well into the limestone, or by driving 
casing equipped with a well point into the sandier portions. Such a screened well driven into the soft limy oolite itself soon becomes clogged, and open-hole wells developed in it of ten produce impractical yields. However, in most instances, high yields of water are obtained by driving or drilling through the oolite into the underlying Fort Thompson formation.

\section{HIGH TERRACE DEPOSITS (PENHOLOWAY AND TALBOT FORMATIONS)}

Cooke (1945, p. 286), in describing the character of the Penholoway terrace deposits, says: "The Penholoway formation is supposed to consist chiefly of sand, but little is really known about its actual composition. The muck and peat associated with the many lakes and swamps on it do not logically form part of the Penholoway but are younger. The formation may, however, include considerable bodies of salt-marsh leposits, for some of it accumulated in lagoons nearly. surrounded by islands, where marshes might be expected to prevail. "In his description of the Talbotformation, Cooke (1945, p. 292) remarks: "Little is known about the detailed composition of the Talbot formation. Presum ably it consists chiefly of fine sand except in former estuaries, where clay or silt may prevail. It probably exceeds 20 feet in thickness only in northwestern Florida, where there was an abundant supply of sand. "

In the geologic map accompanying his report, Cooke (1945) does not attempt to map these two "formations in Florida; instead, he groups them, with deposits of several other Pleistocene terraces, under the heading "Late Pleistocene deposits. "This seems to be a more practical thing to do, because in the field it is impossible to separate these high marine terrace deposits except on the basis of the altitude of their respective shorelines. Parker and Hoys (in press), working with these sands of the Kissimmee River-Lake Okeechobee area in $1943-1944$, discovered the futility of attempting to separate these higher terrace deposits and stated: "Since these terrace sands are all so similar it is believed best to group them together under one heading and consider them as one formation, realizing, however, that several interglacial ages are represented."

Generally, the sands are white to gray at the surface and grade into tan, orange, and red below. In some places enough organic materials are admixed to make a mucky sand, and in other places enough iron oxide (limonite) is deposited around the sand grains to form a scabby ferric sandstone.

Although diligent search has been made in terrace deposits of southern Florida that lie at altitudes higher than the Pamlico ter-

\footnotetext{
${ }^{5}$ Parker, Garald G, and Hoy, N, D, , Geology and ground water of the Kissimmee River-Lake Okeechobee area, Florida: Florida Soil Sci, Soc. Proc., 7-A, (now with publisher).
} 
race (see p. 140-145), no fossils ever have been found. The sand grains are quartz, sharp to subrounded, generally nonfrosted, very fine to coarse in size but averaging less than medium, and have the usual characteristics of marine (not aeolian) sand. If fossils ever were present in these higher terrace deposits-and it seems likely that they were-it is probable that they were leached out by percolating acidic ground water ( $\mathrm{pH}$ values as low as 6 are not uncommon in these siliceous materials today).

In some places, notably the northern end of the Kissimmee River watershed, the terrace deposits contain varying amounts of silt and clay. This reduces the permeability and in some areas makes it difficult to develop shallow wells. Generally, however, small-diameter wells finished with a sand point driven deep enough to be considerably below dry-season low levels of the water table will furnish potable water for domestic use throughout the year. Batteries of such shallow wells will yield water for public supply systems of small communities-Indian Town, Martin County, is a good example, al though the Indian Town wells are developed in a semiconsolidated permeable sandstone and thus require no sereens.

The permeability of these terrace sands has not been intensively investigated. Permeameter tests made in the southern part of the Kissimmee River watershed indicate that coefficients of permeability $(P)$ ranging from 800 to 10 are about average (see footnote, p. 107). Some of the better-sorted sands, however, may exceed the average high value (800) by 3 or 4 times. (See p. 236-237 of section on Ground water [Quantitative studies] for the definition of coefficient of permeability.)

\section{PAMLICO SAND}

The Pamlico sand is composed chiefly of gray-white to black or brown carbonaceous quartz sand locally consolidated to sandstone, and in many places it is highly fossiliferous. It mantles the underlying rocks of southern Florida along the Atlantic Coastal Ridge and along the Gulf coast to about the latitude of Miami. It does not extend far out into the Lake Okeechobee-Everglades depression and seldom is found higher than 25 feet above present sea level, the altitude of the Pamlico seashore (Cooke, 1930, p. 389395). Locally, however, Pamlico sand is heaped into beach ridge and dune deposits at altitudes higher than 25 feet. Pine Island (a dune deposit on the edge of the Everglades southwest of Fort Lauderdale) and Marco Island (northernmost of the Ten Thousand Islands on the Gulf coast) are examples of high dune deposits of Pamlico sand in southern Florida. 
The Pamlico sand is generally of medium to low permeability. Where the sand is clean and well sorted the coefficient of per meability is high; usually, however, the sorting is poor, and the interstices between larger sand grains are filled either with finer grains, or with silt and organic materials intermixed with the sand, thus reducing permeability. A striking example of the effect of low permeability on ground-water flow is shown by studies made in the Lake Okee chobee area.

It had long been a local belief that a considerable amount of water in Lake Okeechobee and the Everglades is derived from ground-water seepage from geologic formations underlying the Kissimmee River watershed. However, Wallace (Cross, Love, Parker, and Wallace, 1940) came to the tentative conclusion, as a result of a brief study of Lake. Okeechobee, that there could be no substantial gain or loss by the lake through underground flow. Furthermore, detailed studies in 1942 and 1943 (Parker and Hoy, in press) in cooperation with the Soil Conservation Service bear out Wallace's conclusions. ${ }^{6}$

The majority of wells developed in the Pamlico sand are smalldiameter driven wells equipped with well points. In some places relatively large supplies are made available by driving numerous wells of this kind as part of a single water-supply system.

\section{LATE PLEISTOCENE AND RECENT DEPOSTS}

LAKE FLIRT MARL

The Lake Flirt marl, principally a light-gray, fresh-water, calcareous mud deposit, has its thickest and most typical development in the basin of now-drained Lake Flirt, between old Fort Thompson and Coffee Mill Hammock on the Caloosahatchee River east of La Belle. There, the formation ranges in thickness from a feather edge to 6 feet. The formation was first named and described by Sellards (1919, p. 73-74) who thought that it "may be quite recent in age. " Sellards did not describe it as occurring

\footnotetext{
${ }^{6}$ The U. S. Geological Survey-Soil Conservation Service studies were designed to check on Wallace's conclusions. Fourteen test wells were sunk in the area of investigation and valuable geologic and hydrologic data were obtained. Coefficients of permeability ranging from about 800 to 10 were common. These were not field coefficients established by pumping tests; instead, they were made with a permeameter on typical samples of the sandy materials.

The nonconsolidated terrace sand borders Lake Okeechobee on the east, west, and north for a total shoreline distance of about 60 miles. Assuming that the coefficient of permeability of the sand bordering Lake Okeechobee is 800 (a generous figure), that the length of the permeable section contributing ground-waterflow around the lake is 60 miles (measured from a point about 6 miles south of Lakeport on the west shore to a point about opposite Lakeport un the east shore), that the average saturated thickness of the permeable sand is 10 feet (based on test-well data), and that the slope of the water table is 1.5 feet to the mile (about equivalent to land-surface slope to the northwest as measured along Indian Prairie Canal), the amount of ground water seeping into Lake Okeechobee was computed by Parker to be about 720,000 gpd or 1.1 cfs per day. This is equivalent to about 730 acre-feet per year-a relatively negligible amount-and bears out Wallace's conclusions.
} 
outside the Lake Flirt basin, which is about 8 miles long. The formation is widely distributed in the Everglades, however, and usually lies in direct contact with the surficial rocks of the underlying Fort Thompson formation; it fills and rather effectively seals the solution holes of these rocks.

Over large areas of southern Florida, particularly in the lower Everglades and in the coastal marshes, deposits of this light-gray calcareous mud, rich in the remains of fresh-water gastropod shells (principally Planobis and Ameria), are present; their thickness ranges from a feather edge to several feet. These marl deposits, valuable as agricultural lands where more than 2 feet thick, are here classed as part of the Lake Flirt marl.

Generally, in its occurrence in the Everglades, the Lake Flirt marl lies between the organic soils and the rock floor, but layers of it of ten are intercalated with layers of organic material, peat or muck. These marl layers pinch out or grade into the organic layers both horizontally and vertically, thus indicating an origin closely related to the deposition of the peat and muck (see fig. 18).

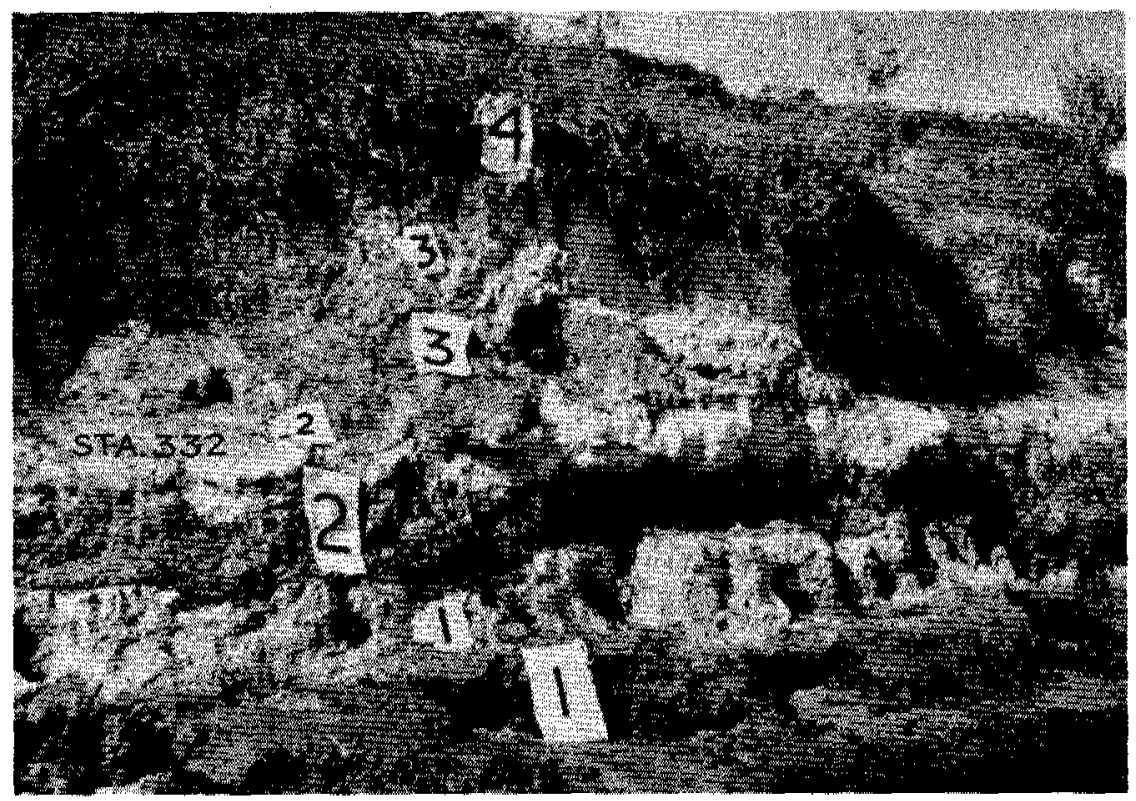

Figure 18, -Lake Flirt marl.

The Lake Flirt marl is relatively impermeable and acts as a seal that prevents movement of water through it to underlying more permeable rock. Where present in thicknesses of a foot or more, it is an importantaid in controlling water levels, especially 
above the highly perm zable parts of the Fort Thompson formation and the Miami oolite.

\section{ORGANIC SOILS}

The peats and mucks of the Everglades range in thickness from a feather edge around the borders and in the south to 8 or 10 feet in the north near Lake Okeechobee.

These organic deposits were formed since the last high-level sea of the Climatic Optimum (see p. 124-125) in marshy areas where large amounts of vegetative matter were annually growing; dying, and sinking below the water surface. Under such conditions the organic material did not decay and dissipate but underwent change slowly. Where little or no inorganic matter was incorporated into the deposit, it became a peat; where considerable amounts of mineral matter were deposited with the organic materials, it became a muck. In the Everglades all types are foundfrom purely aquatic and semiaquatic peats to highly inorganic. mucks.

In order to determine the age of the peat deposits, three samples from the upper Everglades were checked by the Carbon 14 method by J. L. Culp, of Lamont Laboratories, with results given in the following table:

\begin{tabular}{l|c|c|c}
\hline $\begin{array}{c}\text { Survey } \\
\text { No. }\end{array}$ & $\begin{array}{c}\text { Lamont } \\
\text { No. }\end{array}$ & Description & $\begin{array}{c}\text { Age } \\
\text { (years) }\end{array}$ \\
\hline WR 3-4a & $141-A$ & $\begin{array}{l}\text { Peat, south pasture line of Everglades Exp, Sta, 2t miles } \\
\text { southeast of Belle Glade, Fla, Depth, 5, 5 to 6, } \mathrm{ft} \\
\text { below land surface, Peaty muck. }\end{array}$ & $4900 \pm 200$ \\
\hline WR 3-4b & $141-\mathrm{B}$ & Peat, as above area, but north line, Fibrous peat. & $3800 \pm 200$ \\
\hline WR 2-7 & $141-\mathrm{C}$ & $\begin{array}{c}\text { Peat 10 miles south of Lake Okeechobee, Fla, 5, 0 to } \\
5,5 \mathrm{ft} \text { below land surface. }\end{array}$ & $5050 \pm 200$ \\
\hline
\end{tabular}

In the past, under normal conditions, these organic materials were accumulating slowly and building up the body of Everglades soils. At present, with the drainage canals in operation (since about 1909 ), the organic soils are being lost rapidly. This dissipation takes place principally because of drainage that allows fires, natural oxidation, shrinkage, and compaction. As a result of compaction, "subsidence valleys" (Evans and Allison, 1942, p. 38) have developed along all major Everglades drainage canals.

The organic soils of the Everglades have a comparatively low coefficient of permeability. Water moves through them very slowly under the low gradients existing there. In a test pit 5 feet square and 3 feet deep, with the water table standing only about 1 foot below land surface, the ground water seeped in so slowly that the pit could be emptied by slow bailing with a pint can. 


\section{LATERITE OF THE REDL.ANDS DISTRICT}

Harper (1927, p. 57-58) was the first to mention these clayey soils, apparently residually derived from weathering of the Miami oolite. The soil is reddish, contains only a minor amount of quartz sand, and usually fills solution holes and crevices in the oolite (see fig. 19). It is most common on that part of the Atlantic Coastal Ridge near. Homestead, in southern Dade County, but it occurs at least as far nor th as the Miami River. Harper tentatively classified the deposit as a laterite, an interpretation with which the present writers concur.

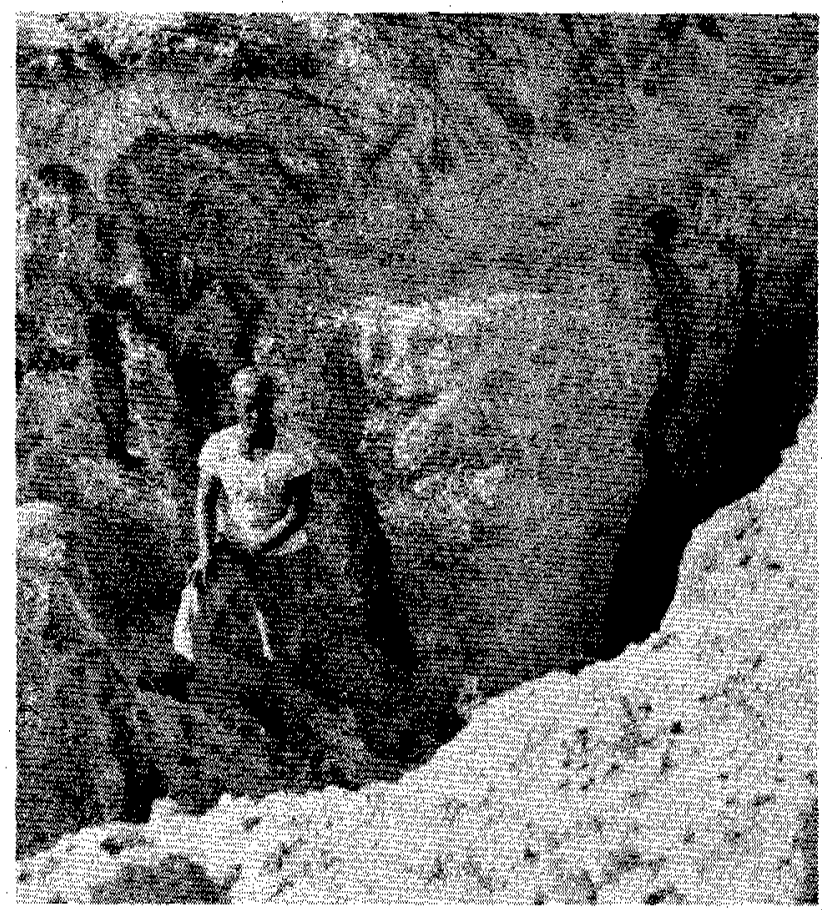

Figure 19. -Miami oolite in cut at Florida Power and Light Company's Cutler plant.

The laterite is not a continuous bedded deposit, nor does it have a wide areal extent; it probably has little effect on ground water, inasmuch as there is an ample amount of bare limestone surface through which rainwater can readily percolate to the water table below. Agriculturally, it is valuable and is used especially for the growing of citrus fruits, avocados, mangoes, papayas, and other subtropical fruits.

\section{BEACH SAND}

Recent sand is confined almost solely to the modern beaches, although in some instances hurricane tides have deposited present- 
day beach and shallow ocean or bay-bottom sand inland beyond the beaches.

Recent sand in southeastern Florida is generally tan to brown and is composed principally of shell particles, possibly derived largely from reworking of coquina deposits (Anastasia formation) near Boca Raton, Jupiter, and elsewhere along the present shore to the north. Generally, the farther south in Florida that beach sands are traced the calcareous content is greater and the silica content is smaller. Beach sand varies in mechanical and chemical character from time to time and from place to place. There is relatively little quartz sand at or south of Miami Beach; and Cape Florida, on Key Biscayne, marks the southern terminus of migrating quartz sand in notable quantities.

Considerable sand is present along the beaches of the Florida Keys; but it is almost entirely calcareous; in many instances it is composed of 75 percent or more of foraminiferal tests. Only minor amounts of true coral sand have been noted on the Florida Keys, though the term is commonly used by local residents in speaking of foraminiferal and shell-fragment sand deposits.

\section{LATE CENOZOIC HISTORY}

GENERAL STATEMENT

In southern Florida only relatively young rocks are penetrated in the drilling of the deepest water wells, and the oldest of these rocks does not antedate the Eocene, which was deposited possibly 50 to 60 million years ago. A minor number of wells reach into the Miocene rocks, some into the Pliocene, but most are developed in the Pleistocene formations.

The following table gives the approximate dates that have been derived from the epoches of the Cenozoic era (National Research Council, 1949-1950).

Table 13.-Cenozoic time correlations

\begin{tabular}{|c|c|c|c|c|}
\hline Era & Period & Epoch & $\begin{array}{c}\text { Duration } \\
\text { in millions } \\
\text { of years }\end{array}$ & $\begin{array}{c}\text { Time since beginning } \\
\text { of each epoch in } \\
\text { millions of years }\end{array}$ \\
\hline \multirow{4}{*}{ Cenozoic } & Quaternary & Recent & 0.01 & 0.01 \\
\cline { 2 - 5 } & Pleistocene & 1 & 1 \\
\cline { 2 - 5 } & Tertiary & Pliocene & 11 & 12 \\
\cline { 3 - 5 } & Miocene & 16 & 28 \\
\hline & Oligocene & 12 & 40 \\
\hline & Eocene and & & \\
\hline
\end{tabular}




\section{THE PLEISTOCENE OR "GIEAT ICE AGE"}

At the close of the Pliocene epoch a marked change took place in the earth"s climate-a change that brought about the development of great systems of continental and alpine glaciers. The continental glacial sheets covered about one-third of the land area in the nor thern hemisphere and a somewhat smaller area in the southern hemisphere. The North American glacial sheets, including the Cordilleran complex, reached from Labrador to Alaska and pushed down from Canada until they covered the part of the northern United States that extends south to an irregularline stretching, roughly, from Long Island, N. Y., through Cairo, Ill, to the southern tip of Puget Sound in western Washington. The Scandinavian sheet extended across the Baltic Sea into the plains of northern Germany and western Russia and covered all of Holland and Belgium and most of the British Isles-an area about half as great as the glaciated region in North America. The extent of the glaciation in the southern hemisphere is not yet well known; at least it covered Patagonia and parts of Australia and New Zealand. In addition to the continental ice sheets, extensive and welldeveloped alpine glacial systems existed. Valley glaciers often extended far beyond the termini of modern glaciers and even spread beyond the foothills to coalesce into piedmont glaciers, often of considerable extent.

The continental ice sheets were tremendously thick. Schuchert and Dunbar (1933, p. 422) estimate the North American sheet to have been "at least 5,000 or 6,000 feet thick at the center of dispersal and it may have been as much as 10,000 feet. It has been found (Wegener, 1933) that the Greenland ice sheet reaches a thickness of 8,800 feet near its center in latitude $72^{\circ}$ north, and averages over 4,500 feet thick over a large area." The North American glacial sheets stripped a large part of Canada to bedrock, and deposited much of Canada's surficial materials as rich soil in north-central United States.

The Pleistocene epoch, however, was not a time of continuous glaciation; rather, it was a time of alternate glaciation and deglaciation as the climate repeatedly changed from cold to warm. The times of glaciation are called glacial ages, and the times of deglaciation are called interglacial ages. The last major change in climate that brought about withdrawal of the major continental ice sheets marks the beginning of the Recent epoch. However, as a. matter of fact, it is probable that our Recent epoch should not be ranked in this manner; instead, it should be regarded as another of the interglacial ages of the Pleistocene, even though large masses of tce on a continental scale (such as the Greenland sheet and the Antarctic sheet) still exist. Lobeck (1939, p. 299) has reckoned the extent of these sheets as totaling approximately $6,000,000$ square miles, and he has stated that enough water is stored in this ice to raise the sea level about 150 feet if it were to 
be released to the ocean. Although all geologists do not agree on this figure, it is generally conceded that the amount is significant. Longwe11, Knopf, and Flint (1932, p. 153) conservatively estimate that "the complete wastage of the polar ice sheets existing today would return enough water to the sea to raise its level about 80 feet. ...

The causes for the waxing and waning of the great ice sheets are not definitely known, but the existence of the several great glacial sheets cannot be doubted. Their distribution of rocks foreign to the regions where they are now found, their terminal and ground moraines, their gouging of deep lake basins, the ir rearrangement of stream patterns, and many other evidences are excellent proof of their existence. Furthermore, their effect on the life of man today, through control of topography, soil types, ground water, surface water, and certain mineral deposits, is of utmost importance. Their influence extended far beyond the confines of the glacial sheets themselves; even tropical areas of the world were influenced, principally as a result of glacial control of sea level. Daly (1934, p. 271) has pointed out that the occurrence of many coral reefs may thus be accounted for.

\section{GENERAL EFFECT OF GLACLAL CONTROL OF SEA LEVEL}

The sea level fell during times of glaciation because of the huge draft on the ocean waters needed to produce the massive continental glaciers; it rose again as the glaciers retreated during the warm interglacial stages and the water formerly stored on the land as ice returned to the sea. This fall and rise occurred several times with worldwide effects.

With each succeeding glacial age the ice front in North America did not advance as far to the south as it had previously; also, with each succeeding interglacial age the high-water mark of the ocean was lower. Whether the difference of ocean level in each succeeding interglacial age is due to successive enlargements in the capacity of the oceanic basins brought about by crustal movements in some distant parts of the earth, or whether it is due to more ice remaining locked on land during each subsequent interglacial age, or both, is not known. However, the changing ocean levels resulted in the formation of shorelines with their characteristic features wherever the ocean halted long enough for their development.

Some of these ancient shorelines are now beneath the surface of the ocean, and therefore they are very difficult to recognize; in some places, however, they have been detected and mapped (Cooke, 1939 , p. 33-58; Stearns and Macdonald, 1942, p. 54-55, 153-154; Veatch and Smith, 1939; Upson, J.. E., 1951). Where the shorelines lie above present ocean level they of ten may be located by 
those familiar with shorelines and shoreline processes despite subsequent modification by weathering, erosion, and solution. Eight such shorelines along the Atlantic seaboard alone have been described (Cooke, 1931, p. 503-515; Parker and Cooke, 1944, p. 21-27); and in Hawaii and the South Pacific, Stearns (Stearns and Macdonald, 1942, p. 54), has de tected four corresponding ones and six others that are not apparent in southeastern United States. In Cuba, Meinzer (1933, p. 256-258) noted and described the occurrence of seven Pleistocene marine terraces, of which the one whose shoreline is about 40 feet above present sea level is the "most persistent and best-preserved throughout the region." Meinzer noted that "the terraces consist largely of benches cut into the older rocks and are mantled with sof $t_{\text {; }}$ massive, coral limes tone

As long ago as 1913 Matson (Matson and Sanford, 1913, p. 31-35) described and named three marine terraces in Florida with shorelines at elevations of approximately 100,70 , and 40 feet, respectively; above present sea level. In the lowest of these terraces, which he called the Pensacola, Matson recognized a second division with a shoreline at about 20 feet. He did not have adequate field data, however, to map this lowest shoreline, so he did little more than mention it. Many other geologists likewise have noted the occurrence of terraces in Florida, and a controversy has developed over whether or not their shorelines reflect westward tilting of the Florida peninsula (Leverett, 1931). Cooke, who has given much time to the study of the Pleistocene shorelines and their associated seafloors (the terraces) along the Atlantic coast, has traced the eroded remnants of the shorelines from New Jersey southward into Florida, has checked their elevations, and finds that they are approximately level. He therefore arrives at the conclusion that no great movements of land with respect to sea level have taken place in this area since the close of the Pliocene epoch. In addition, work of the writers on the younger Pleistocene shorelines in Florida south of Orange County has indicated that they are approximately horizontal, and if any late Pleistocene tilting of the Floridan Plateau is involved, it is of a very minor amount.

\section{EFFECTS OF CHANGNG GEA LEVELS IN SOUTHERN FLORDA}

Geologists have established, by the ir work in the glaciated parts of North America, that there were at least four major glacial ages (time units) and stages (rock units) separated by three major interglacial ages and stages, and possibly five major glacial ages and stages separated by four major interglacial ages and stages (Flint, 1941, p. 22-25). The writers adopt the former view and list them in table 14 . In this interpretation the Iowan is regarded as a subage of the Wisconsin glacial age. 
Table 14. - Tentative correlation of Pleistocene and Pliocene formations in southem Florida

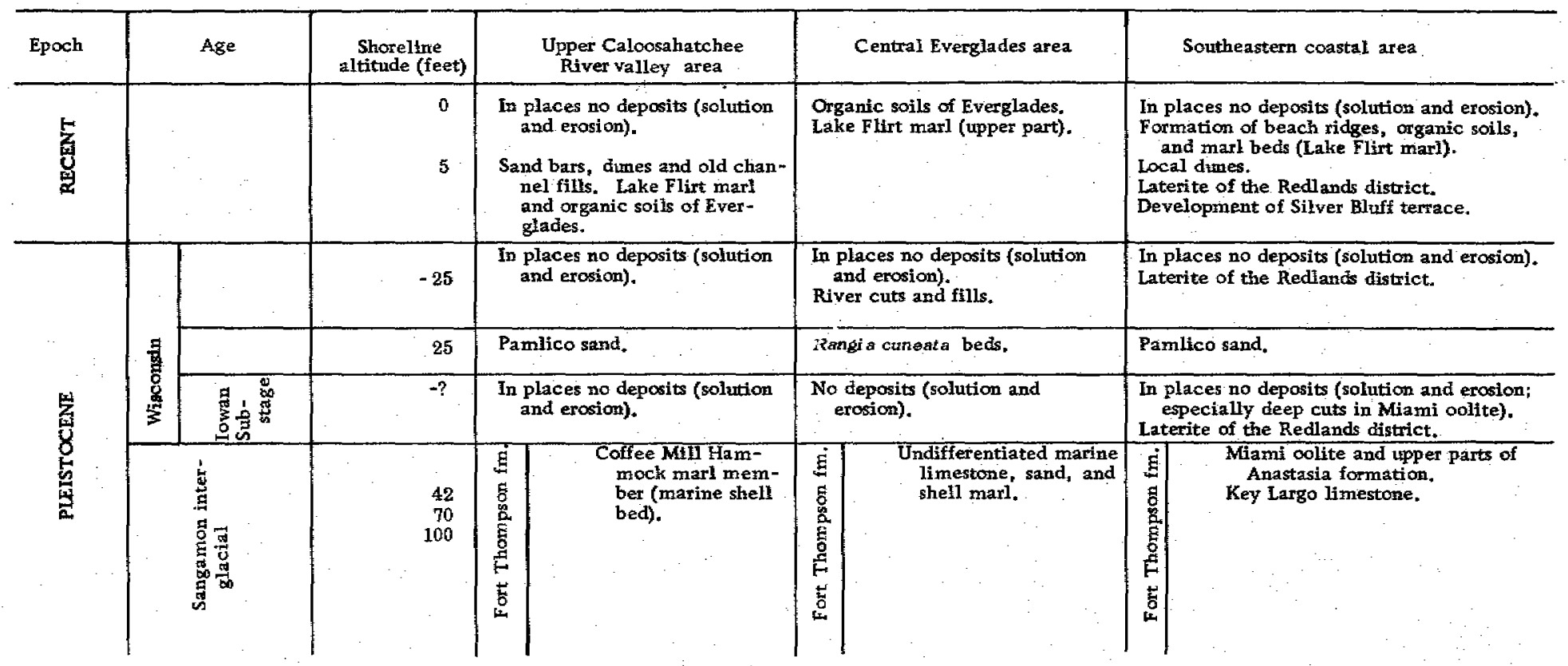


Table 14. - Tentative correlation of Pleistocene and Pliocene formations in southern Florida-Continued

\begin{tabular}{|c|c|c|c|c|c|c|c|c|}
\hline Epoch & Age & $\begin{array}{c}\text { Shoreline } \\
\text { al titude (feet) }\end{array}$ & \multicolumn{2}{|c|}{$\begin{array}{l}\text { Upper Caloosahatchee } \\
\text { River valley area }\end{array}$} & \multirow{2}{*}{\multicolumn{2}{|c|}{$\begin{array}{c}\begin{array}{c}\text { Central Everglades } \\
\text { area }\end{array} \\
\begin{array}{l}\text { Hard fresh-water } \\
\text { limestone. }\end{array}\end{array}$}} & \multicolumn{2}{|r|}{$\begin{array}{c}\text { Southeastern coastal } \\
\text { area }\end{array}$} \\
\hline \multirow{5}{*}{ 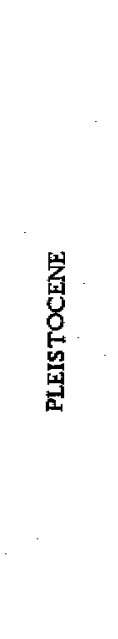 } & 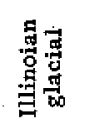 & $-?$ & \multirow{4}{*}{ 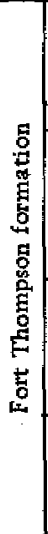 } & $\begin{array}{l}\text { Highest fresh-water lime- } \\
\text { stone ledge, merging } \\
\text { into soft fresh-water } \\
\text { marl below. }\end{array}$ & \multirow{4}{*}{ 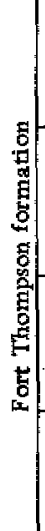 } & & \multirow{4}{*}{ 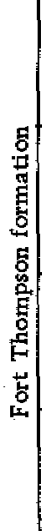 } & $\begin{array}{l}\text { Solution and erosion of } \\
\text { coastal ridge. Deposition } \\
\text { of fresh-water limestone } \\
\text { behind coastal ridge. }\end{array}$ \\
\hline & 点点证 & $\begin{array}{l}170 \\
215\end{array}$ & & $\begin{array}{l}\text { Marine shell marl, } \\
\text { "Pecten horizon." }\end{array}$ & & $\begin{array}{l}\text { Undifferentiated marine } \\
\text { limestone, sand, and } \\
\text { shell marl. }\end{array}$ & & $\begin{array}{l}\text { Undifferentiated, possibly } \\
\text { middle and lower parts } \\
\text { of the Miami oolite. } \\
\text { Anastasia formation. } \\
\text { Key Largo Iimestone. }\end{array}$ \\
\hline & 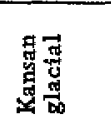 & $-?$ & & $\begin{array}{l}\text { Lowest fresh-water marl, } \\
\text { locally indurated, mak- } \\
\text { ing a shelf. }\end{array}$ & & $\begin{array}{l}\text { Hayd, fresh-water } \\
\text { limestone. }\end{array}$ & & $\begin{array}{l}\text { Solution and erosion of } \\
\text { coastal ridge. Deposition } \\
\text { of fresh-water limestone } \\
\text { behind coastal ridge. }\end{array}$ \\
\hline & 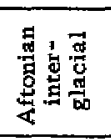 & 270 & & $\begin{array}{l}\text { Marine shelks (local, often } \\
\text { mixed with basal part of } \\
\text { over-lying fresh-water } \\
\text { shells). }\end{array}$ & & $\begin{array}{l}\text { Undifferentiated marine } \\
\text { limestone, sand, and } \\
\text { shell marl. }\end{array}$ & & $\begin{array}{l}\text { Undifferentiated. } \\
\text { Basal part of Anastasia } \\
\text { formation. } \\
\text { Basal part of Key Largo } \\
\text { limestone. }\end{array}$ \\
\hline & 之 & $\Rightarrow$ & & & No d & eposits (solution and erosic & & \\
\hline bi: & & & & Caloosahatchee mar!. & & Caloosahatchee marl. & & $\begin{array}{l}\text { Caloosahatchee marl. In } \\
\text { places no deposits. }\end{array}$ \\
\hline
\end{tabular}


The following correlation of deposits in southern Florida with these glacial and interglacial ages is tentative and is to be regarded as a working hypothesis only. In part it is based upon the work of Cooke (1935, p. 331-333), who previously has assigned tentative ages to the Pleistocene shorelines in Southeastern United States.

Table 15.-Pleistocene terraces of Southerstern United States

\begin{tabular}{|c|c|c|}
\hline Terrace & $\begin{array}{c}\text { Approximate altitude } \\
\text { of shoreline } \\
\text { (feet) }\end{array}$ & Tentative age \\
\hline Brandy wine & 270 & $\begin{array}{l}\text { Aftonian inter - } \\
\text { glacial }\end{array}$ \\
\hline $\begin{array}{l}\text { Coharie } \\
\text { Sunderland }\end{array}$ & $\begin{array}{l}215 \\
170\end{array}$ & $\begin{array}{c}\text { Yarmouth in- } \\
\text { terglacial }\end{array}$ \\
\hline $\begin{array}{l}\text { Wicomico } \\
\text { Penholoway } \\
\text { Talbot }\end{array}$ & $\begin{array}{r}100 \\
70 \\
42\end{array}$ & $\begin{array}{c}\text { Sangamon in - } \\
\text { terglacial }\end{array}$ \\
\hline $\begin{array}{l}\text { Pamlico } \\
\text { Silver Bluff }\end{array}$ & $\begin{array}{r}25 \\
5\end{array}$ & $\begin{array}{l}\text { Interglacial sub " } \\
\text { age of Wisconsin } \\
\text { Climatic } \\
\text { Optimum }\end{array}$ \\
\hline
\end{tabular}

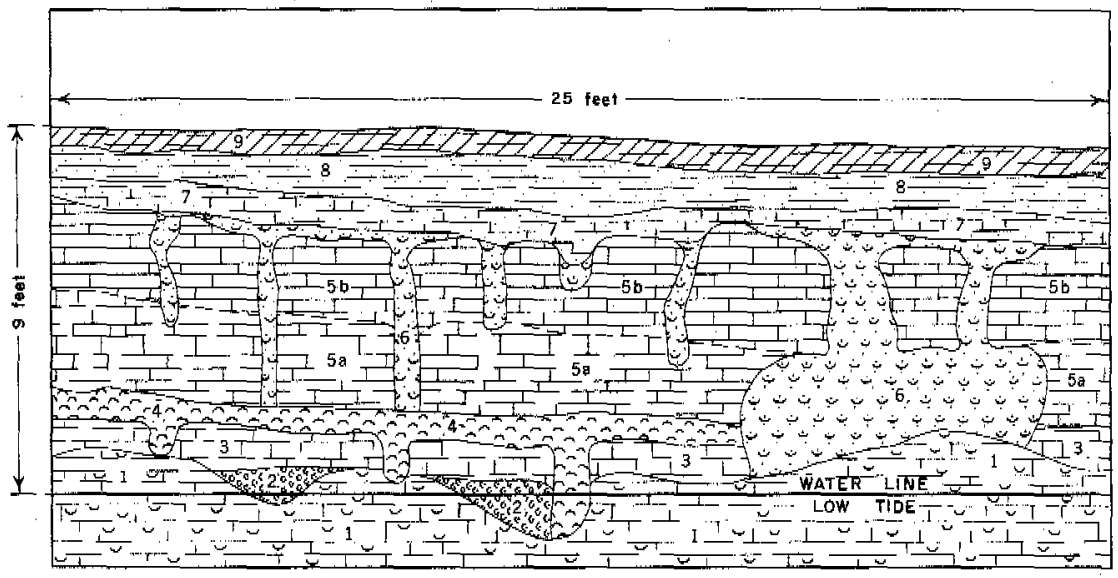

Goology by Gartid G. Parker and C. Wythe Cooke

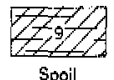

Dradged out in deepening to straightening Caloosahatcheo River

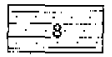

Lake Flirt man

Black carbonaceous sand

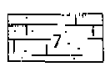

Pamlico sand

Gray calcareous quarti sind witha few fresh-water shells. Helisoma and Ameria so. washed in from nearby land arest

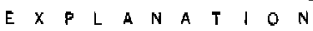

$$
\begin{aligned}
& \text { 岁 } \\
& \text { W }
\end{aligned}
$$

Coffee Mill Hammock marl Marine shell bed. Sangamon interglacial age

$$
\text { 讷 }
$$

Fort Thompscon formation Fresh-waler, gray marl (5a) consolidated in uppef part to make a hard, freshwater limestone (5b). Helisoma and Ameria sp. most common fos sils. Aimeria sp. most commonas interglacial age

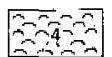

Fort Thompson formation Fort Thompson formation
Marine shell bed with mixture of fresh-water shell at base. Yarmouth interglacial age

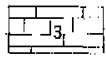

Fort Thompson formation Fresh-water, gray, calcareous marl, locally hardengd in upper part to a hard gray limestone. Helisoma and Amerla so. most common fossils. Kansan glacial age

सe्es ges

Fort Thompson formation Marine shells, found only locally in solution holes of depressions in solution tholes of depressions in bed no. 1 , or lying on, of mixed
with, a thin basal conglomerale. Aftonian interglatial age

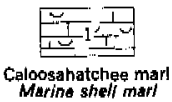

Caloosahatchee mar
Marine shelf marl

Note: Correlations tentative (see text)

Figure 20. -Idealized geologic cross section at type locality of the Fort Thompson formation. 
Inasmuch as the topography of southern Florida offers no opportunity to work on terraces having shorelines higher than 100 feet, the writers offer no suggestions for amending or changing Cooke's age assignment, except to add the Silver. Bluff terrace and shoreline and to tentatively assign their development to the Climatic. Optimum of Recent time - the lower shorelines and deposits appear to fit into Cooke's chronology. If the higher shorelines outside southern Florida are actually the product of Pleistocene marine environments, much of the earlier Pleistocene shoreline record is missing here; therefore, a sequence based on a complete set of Pleistocene shorelines cannot be made from evidence in southern Florida.

However, at Fort Thompson on the Caloosahatchee River, $1 \frac{3}{4}$ miles east of La Belle, there is a sequence of Pleistocene deposits that records the effects of fluctuating sea level; and it is upon this occurrence and upon the tracing of related marine beds elsewhere in southern Florida that much of the correlation is based (see fig. 20).

The Caloosahatchee River section (illustrated in fig. 20) includes four Pleistocene marine beds (three in the Fort Thompson formation and one in the Pamlico sand) separated from one another by erosional unconformities and fresh-water deposits. If each of these marine beds represents an interglacial age and if the erosional unconformities and fresh-water deposits represent glacial ages, then the sequence of major ocean-level changes, postulated as a result of the several glaciations and deglaciations during the Pleistocene, is accounted for. However, there is nothing about these deposits to indicate, with any degree of certainty, the height of the ocean at its maximum altitude when the deposits were being formed. As a matter of fact, these marine beds may well have been laid down when the ocean level was comparatively low, either during advancing or retreating phases in the slow fluctuations of the ocean level at any time during the Pleistocene. Therefore, the marine beds of the Fort Thompson formation throw no light on the problem of the altitude of the shorelines of the higher terraces of the Southeastern United States. Likewise, the other low-lying Pleistocene marine deposits offer no aid in solving the problem of the altitude of the higher shorelines. Their stratigraphic relationships have been the bases for tentatively assigning them to the several interglacial ages listed in this report.

\section{NEBRASKAN GLACIAL AGE}

When the sea withdrew at the beginning of Nebraskan time, a gently southeastward-sloping area existed under the central and 
southern part of the present Everglades. Higher land lay to the west in the present area of the Devil's Garden and the Big Cypress Swamp, and to the north about in the latitude of Tampa Bay (see pl, 12). The deposits of the Pliocene sea were generally shelly, sandy, and silty, although in some places calcareous deposits were laid down.

This Pliocene surface became exposed to weathering and to the attacks of running surface water and percolating ground water. The latter was an especially important factor because it created a network of solution holes in the calcareous deposits and started the action which, repeated in subsequent glacial ages, has produced the best water-yielding parts of the Caloosahatchee marl. The shelly, sandy, and silty parts of the Caloosahatchee marl, however, were not so affected; instead, they were eroded, and in many places the Pliocene deposits were completely stripped away.

Ancestral Lake Okeechobee made its first appearance at this time, and in all probability other smaller lakes existed in the lower parts of the area to the south. If any fresh-water limestones were deposited in these early Everglades lakes they are not recognized as such.

\section{AFTONI AN INTERGL ACIAL AGE}

After the close of Nebraskan time, there ensued a warm period called the Aftonian interglacial age, during which the great continental glaciers retreated, and the sea level may have risen to about 270 feet above its present level, forming the Brandywine terrace and associated deposits (Cooke, 1939, p. 33-35).

Only a few scattered local patches of marine shells, generally found in depressions in the underlying Caloosahatchee marl and often mixed with the basal part of the overlying bed of fresh-water marl, may be seen at Fort Thompson (bed 2, fig. 20). Elsewhere in southern Florida, extensive deposits of the Aftonian stage possibly are included in the lower part of the Fort Thompson and Anastasia formations. These deposits probably were once much thicker than they are now, but they have been thinned and in most places entirely removed by erosion and solution. The fact that the ocean probably was fairly deep here at its maximum during this age and that the sources of detritus were far distant, may be additional reasons in this area for a scarcity of deposits possibly assignable to the Aftonian interglacial stage.

This invasion of southern Florida by the sea during the Aftonian interglacial age probably distributed sand southward along the Atlantic coast, thus building up the early Pleistocene deposits (basal part of Anastasia formation) under the present area of the Atlantic Coastal Ridge. Also, it is likely that the basal portions of the Key Largo limestone were being formed by coral growth as 
a reef at or near the site of the present Florida Keys. The ocean water displaced the fresh ground water in much of the Pliocene and Miocene rocks, and it probably washed enough sand into many of the solution holes (developed during Nebraskan time) to partly or completely fill them.

\section{KANSAN GLACIAL AGE}

The cold Kansan glacial age succeeded the warm Aftonian interval, and again the sea fell below its present level. Once more, southern Florida became a wide land area with rivers, lakes, trees, grass, and strange animals (Simpson, 1929, p. 229-279). The sand, which had been washed southward in the vicinity of the present coastal ridge during Aftonian time, formed a low barrier and allowed a large shallow fresh-water marsh and lake to exist in the upper Everglades and the present Caloosahatchee River Valley. Fresh-water marl accumulated in this marsh.

Once again, fresh percolating ground water was at work flushing out the salt water and creating a network of solution holes in the calcareous marine rocks which were deposited during the Aftonian interval. The Caloosahatchee marl deposits may also have been flushed of salt water, but owing to the low permeability of these sediments and the very slow rate of ground-water movement through them, this flushing may not have been complete.

\section{YARMOUTH INTERGLACIAL AGE}

The Kansan glacial age was succeeded by the warm Yarmouth interglacial age. Cooke (1935, p. 331-333) has postulated that during this time the sea level may have risen to 215 feet above present sea level, that it stood there long enough to establish a definite shoreline and then fell to 170 feet, where it remained until the end of the age. None of these higher (270\%, 215-, and 170-foot) shorelines or terraces are present in southern Florida, but Cooke describes them as occurring along the Atlantic coast from central Florida northward to New Jersey.

In the area of the Fort Thompson type locality the sea laid down a shell marl containing the shells of many scallops (Pecten sp.). marine jet -propelled pelecypods. Without doubt, this deposit was once much thicker than it is now, but, like earlier deposits, it was largely removed by subsequent erosion. In other areas of southeastern Florida the coral reef (Key Largo limestone) once more was being built upon; a very shelly limestone was deposited in the central and lower Everglades area; basal parts of the Miami oolite were probably being formed as a limy shore and bar deposit; and sand, a principal component of the Anastasia formation, continued to work southward, building up the present east-coast ridge, and 
together with the oolite bar and coral reef deposits it enclosed enough of the present Lake Okeechobee-Everglades depression to allow a large shallow lake and marsh to exist there in the succeeding interglacial age. This invasion by the sea once again filled the rocks with salt water and displaced the fresh water of the preceding age.

\section{ILLINOIAN GLACIAL AGE}

As the climate cooled again and the Illinoian glaciers spread far to the south of the dispersal centers, the ocean once more withdrew from the land and fell below present sea level. Land conditions again existed in southern Florida, and once more a wide, shallow lake and marsh came into existence in the Lake Okeechobee-Everglades depression. A widespread fresh-water limestone and marl deposit was laid down; which today is the most easily recognized member of the Fort Thompson formation. Solution and erosion took place on the higher land, and rivers wended their way from this shallow interior lake to the ocean. Fresh ground water again began displacing the salt water; it dissolved the more soluble limy rocks and extended the already existing solution network, thus making the Fort Thompson formation in the lower Everglades and coastal Broward and Dade Counties still more permeable.

\section{SANGAMON INTERGLACIAL AGE}

With the melting of the Illinoian ice the ocean slowly rose during the Sangamon interglacial age. Cooke (1935, p. 331-333) postulates that it reached an elevation of 100 feet above present sea level, then fell to 70 feet, and finally to about 42 feet by the end of the age. In each instance it remained long enough to produce marine terraces with well-preserved shorelines at those elevations. In southern Florida these shorelines show plainly on aerial photographs taken at 14,000 feet. They usually are difficult to see on the ground, but some features along these old shorelines are so little changed by erosion, that they are unmistakable when viewed even at close range. Best preserved of the three shorelines are those at 42 and 70 feet, and least well preserved is the one at 100 feet (the oldest). This is to be expected, because weathering has had more time to efface the features of the older ones.

At the beginning of the Sangamon age and again near its close (when sea level may have ranged between about -20 and +20 feet with reference to present mean sea level), conditions were very similar to those of the Yarmouth age, and an extensive bar of oolite (Miami oolite) was being built up along the eastern shore to 
the south of Boca Raton. North of this place the bar was sandy and shelly, and deposits of coquina, sand, and sandy limestone (the upper part of the Anastasia formation) were laid down (pl, 4). Outside this bar, southward from the latitude of Miami, the coral reef that makes up the present Upper Keys was once again growing (Key Largo limestone), and behind this bar" and reef, in the Lake Okeechobee-Everglades depression, myriads of marine and brackish-water shells were accumulating, which today compose the uppermost member of the Fort Thompson formation (the Coffee Mill Hammock marl). Salt water again gained access to the rocks and displaced the fresh water, and sand worked into the solution holes.

On the higher terraces referred to the Sangamon interglacial age, especially on those that surround and underlie the Kissimmee River basin, the development of sand bars, beach ridges, and dunes took place. These features today dictate land usage through their control of drainage, ground water, vegetation, and soil types.

When the sea withdrew at the close of this interval it left many original depressions which today contain such consequent lakes as Istokpoga, Kissimmee, and the Tohopekaligas. The Kissimmee River is a consequent stream making use of the abandoned late Sangamon sea bottom north of Lake Okeechobee, which, itself, occupies a slightly modified original depression in the Pliocene sea bottom.

It is postulated that the deposits formed during Sangamon time largely gave southern Florida its modern appearance by building up the htgher lands north, west, and east of the Lake OkeechobeeEverglades depression, and by constructing the major part of the coastal ridge along the Atlantic shore.

\section{MISCONSIN GLACIAL AGE}

Following Sangamon time, the Wisconsin glacial age occurred, consisting of early (Iowan) and late Wisconsin glacial subages, and an intermediate interglacial subage. The results, though much more complicated than here outlined, were about as follows: In the Iowan, or first glacial subage, the sea fell below its present level, and solution and erosion were common on the higher land. From the lakes that existed in the interior, cuts were made through low areas and abandoned tidal channels in the newly formed Atlantic Coastal Ridge, especially through the soft oolite between Miami and Fort Lauderdale. Dune building was common along the sandier shore areas, especially in St. Lucie, Martin, Palm Beach, and Collier Counties. Fresh water began to flush out the salt water left from the Sangamon invasion, but the interval was short, and the action may not have progressed very far, especially. 
in the rocks of low permeability inland from the shore where very low water-table gradients probably existed.

Then, during the mid-Wisconsin interglacial subage, the re followed a time of warm weather; the ocean rose to 25 feet above present sea level and remained long enough to produce the Pamlico terrace and formation (Pamlico sand), which, in southern Florida, is mainly quartz sand locally hardened into sandstone. This is the sand that mantles the Atlantic Coastal Ridge as far south as Coral Gables, of ten completely filling the channels cut through the oolite during the previous glacial subage. West of the Everglades this sand mantles the higher land that underlies the Big CypressDevil's Garden area (to as high as 25 feet above mean sea level, and higher where it was heaped into beach-ridge and dune deposits), and to the north it surrounds the higher terraces and generally encloses Lake Okeechobee-except on the southern and southeastern sides where the wide expanse of the Everglades meets the lake shore. Only a minor amount of the Pamlico sand found its way out into the present basin of the Everglades proper. because the longshore currents that carried it south were not effective in the quieter water of this great shoal area. Again, salt water displaced the fresh ground water, and sand worked its way down into solution holes.

Remnants of this Pleistocene salt water are still left in isolated patches in southern Florida; some of the patches are of considerable size, especially in the northern Everglades and around the southeastern side of Lake Okeechobee [see p, 183-185 in the section on Ground water (Occurrence) and p. 818-822 of the section on Quality of ground and surface waters]. This mid-Wisconsin invasion by the sea is believed to be largely responsible for salt water found in other places on the Pamlico terrace in Florida, notably in the St. Johns River valley and along the coast, as at Cocoa and Titusville, in Brevard County. Although these residual bodies of trapped sea water are still quite salty, the waters do not now have the characteristics of modern sea water. This is probably the result of modification by dilution with fresh water and by chemical reactions (mainly of the cation-exchange variety) with organic soils and enclosing calcareous rocks.

This mid-Wisconsin (Pamlico) stand of the sea over southern Florida was the lastextensive one, and its marks are very evident today. The old bars and current-marked sand deposits are still noticeable and are being only partially obliterated by surficial drainage mainly in the vicinity of larger streams, where a dendritic drainage pattern is being imposed on the parallel pattern of old beach ridges, offshore bars, and intervening lagoons that characterizes some areas in the sandy flatlands in southern Florida, especially in St. Lucie, Palm Beach, and Martin Counties. The trend of the bars and swales parallels the present 
Atlantic shoreline and is entirely confined to the sand land; it does not affect the surficial drainage in the organic soils of the Everglades, where one can see, from aerial photographs, a similar ar rangement of the drainage pattern. This latter pattern is entirely conf ined to the peat and muck soils, and has no apparent relationship to the underlying floor of the Everglades.

As this warm mid-Wisconsin interglacial subage waned and as the continental glaciers made a relatively short but significant advance, the ocean level began to fall again. Probably it did not recede uniformly with respect to time but receded by halting stages. It may have remained long enough at 5 feet above present sea level in southern Florida to begin the development of a marine terrace and its associated shoreline, which in places in Dade County presently is marked by a low, wave-cut sea cliff in the Miami oolite. However it is more likely that the se topographic features were developed in Recent time, during the Climatic Optimum. This will be considered subsequently.

In any event, the sea level fell at the close of the Wisconsin, to approximately 25 feet below present sea level (Cooke, 1937, p. 5), and a fresh-water regimen became dominant once again in southern Florida. Once again solution of the calcareous rocks and erosion of channels through the Atlantic Coastal Ridge became active, and it is quite likely that the re-excavation of former channels that had been choked with Pamlico sand was furthered. Fresh ground water began displacing the newly formed salt water body concentrated especially in the Lake Okeechobee-Everglades depression and may have cleared the more permeable and shoreward parts of the Biscayne aquifer of its saline water rather effectively.

During this time of lowered sea level it is likely that there was renewed sand-dune growth along both the Atlantic and Gulf coasts, and the major wind-blown sand deposits assumed in general their modern topographic expression.

\section{RECENT EPOCH}

The beginning of Recent time was marked by the climatic changes that brought about the withdrawal, through melting back, of the great Wisconsin ice sheets. The melt-water released from the continental glaciers partly refilled the oceanic basins, and sea level gradually rose. The rise must not be construed to have been uniform, for the climate is known to have been not uniform. Minor, but none-the-less effective, climatic fluctuations occurred that are revealed in several lines of evidence. Flint (1947, p. 487-535) and Brooks (1949, p. 359-378) have presented especially lucid and comprehensive accounts of the evidence and descriptions of postglacial climates and their general geologic effects. 
In southern Florida the sea level rose to, or very near, its present level and stood there until the interval known as the Climatic Optimum, which is believed to have occurred about 5000 B. C. (Brooks, 1949, p. 364). During the warm period, of which the Climatic Optimum was the peak, the sea rose to 5 , and perhaps 8 feet, above its present level, and remained at this range of elevated stage for about 2,000 or 3,000 years, long enough to complete the carving of the wave-planed Silver Bluff Terrace (see pl. 13 and fig. 23), and to choke with sand the discharge channels through the Coastal Ridge as far south as Miami. During this time the entire present floor of the Everglades was a shoals area, situated between the low-lying Big Cypress-Devil's Garden area on the west and the Coastal Ridge to the east that stood out as a low series of islands and disconnected bars, as indicated by the Silver Bluff shoreline in pl. 13; Lake Okeechobee itself was an extension and slightly deeper part of this great shoal. The semi-diurnal sweep of the tides kept the floor of the shoal swept practically clean of what little sediment occurred there. The lack of marine sediment in such an environment is not at all surprising, because the surrounding low-lying limestone and quartz-sand terrain, under climatic conditions then existing, simply did not provide much detritus.

About 3,000 years ago, as the warm weather of the Climatic Optimum waned, the sea level began falling, and receded to its approximate present level, near which it has remained ever since. This resulted in the establishment, in essence, of our modern shoreline and its related topographic features.

In the great shoal area of the present Everglades, a fresh-water regimen replaced the salt and brackish water regimen of the Climatic Optimum, and in the deeper parts of the area, where the land was always submerged, plant remains accumulated until finally the peat and muck deposits of today were developed (p. 109). Gradually these materials accumulated over a greater and greater area, and as the basin became nearly filled, the water level rose, and some of the higher of the old tidal channels across the Coastal Ridge came into use as discharge channels; thus, modern natural drainage was effected. Short streams such as the Miami River, Arch Creek, New River, and many others established their modern form. The surface waters in the Everglades, slowly moving more or less as a sheet in high-water times and still more slowly in shallow channels in low-water times, came to flow toward these outlets. As they moved, the waters imposed a linearly arranged drainage pattern on the soft organic soils and flotant masses. Trees chose the higher of the areas between the "swales. " and the "bays" or "tree islands" began to take form; sawgrass and the more aquatic plants chose the swales. (See the section on Geomorphology, p. 152-153). 


\title{
GEOMORPHOLOGY
}

\author{
By Garald G. Parker
}

\section{FACTORS AFFECTING LAND FORMS}

The factors that have most to do with shaping land forms in southern Florida are: (1) Materials comprising the land, (2) fluctuating sea level, (3) shoreline processes, (4) climate and vegetation, (5) solution, and (6) erosion.

No attempt has been made to list these factors in the order of their importance; obviously that would be difficult to decide. In the following account they are discussed separately but, as will be noticed, it is impossible to separate them entirely. In nature they are mutually operative and effective.

\section{MATERIALS COMPOSING THE LAND}

The principal geologic materials in southern Florida are limestones, calcareous sandstones, marls, shell marls, sands, silts, and clays. All these are rocks that offer comparatively weak resistance to degradational forces acting in a warm, moist climate such as that of southern Florida.

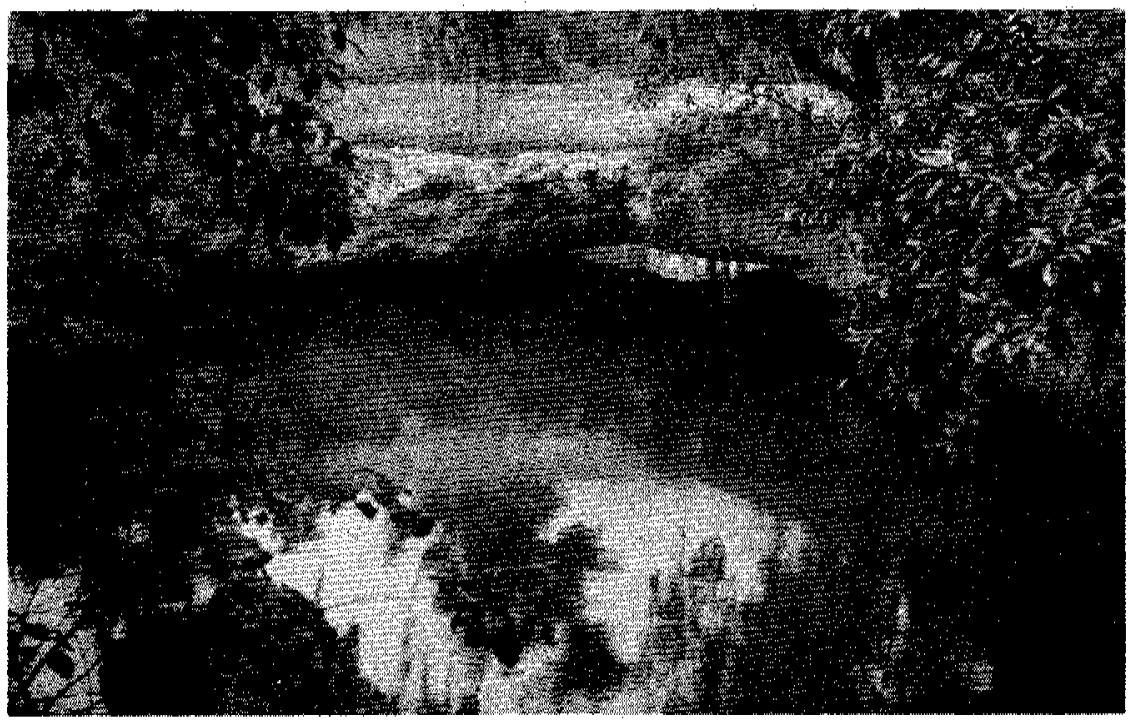

Figure 21. -Natural limestone bridge over Arch Creek. 
The calcareous materials are especially likely to be attacked by percolating ground waters charged with humic or other acids occurring in nature. A terrain developed on calcareous materials is characterized by solution forms, and southern Florida is no exception; solution holes and sinks are common, even a natural bridge is found (fig. 21), and a drowned karst topography is largely responsible for the topographic expression of the Ten Thousand Islands area. Solutional features predominate over erosional features. (See figs. 22 and 25.)

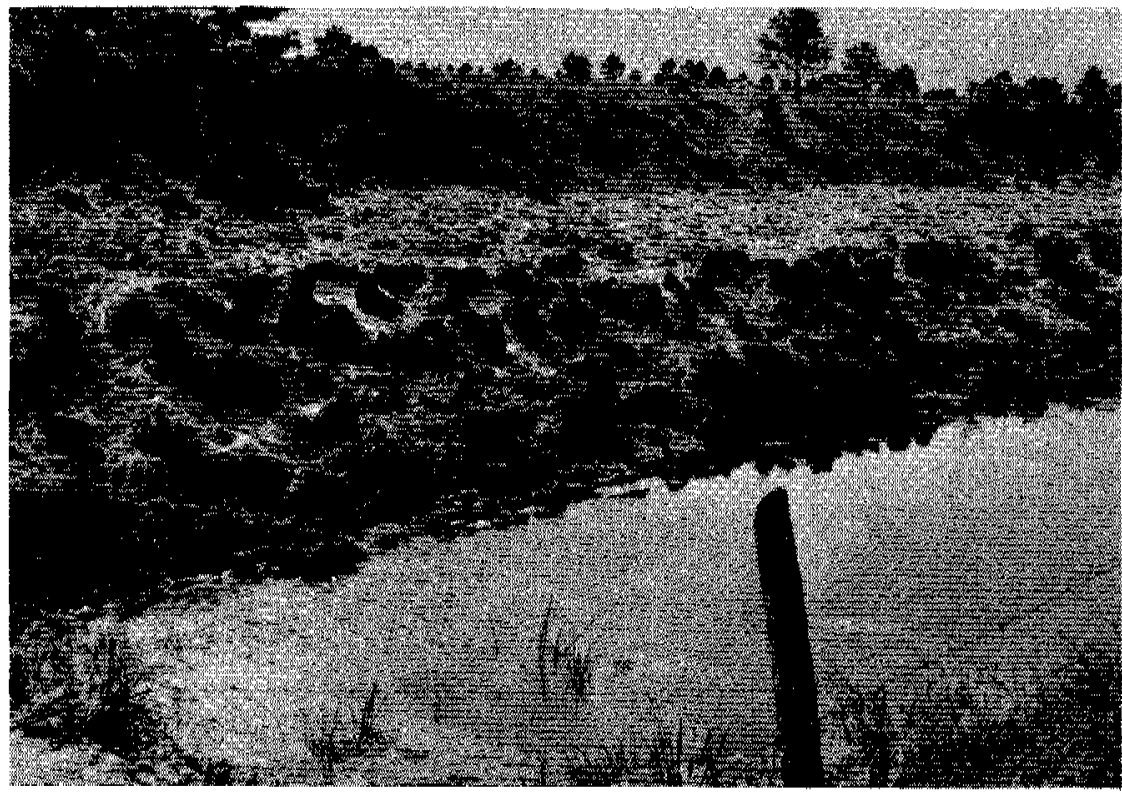

Figure 22. -Rock pinnacles resulting from solution of the Miami oolite,

The sands of southern Florida are principally siliceous (quartz) but present-day beach sands are quite shelly and calcareous. Sand is an excellent absorbent of rainfall, and in areas mantled with fairly thick deposits of sand there is comparatively little surface runoff following storms. This lack of runoff tends to prevent erosion and thus to preserve land forms, such as ancient beaches, beach ridges, or dunes; at the present time, the ir identity is fairly well preserved in many places.

Where sands are uncemented and unaffected by vegetation they tend to drift and to form dunes in areas where wind action is strong. Loose sand will not stand in steep banks, but instead it tends to maintain slopes of low angle with subdued, rounded outlines. The effect of the weathering agents (wind and rain), combined with gravity and animal activities, is to round off and reduce the once steep beach bars, ridges, or dunes to low, flattish heaps. 
The permeable sand of southern Florida permits large amounts of rainfall to be stored as ground water; this water reacts chemically upon the underlying rocks and produces great changes over a long period of time.

Marls are variously defined, both by geologist and laymen. Common usage in southern Florida designates a marl as any unconsolidated rock that contains considerable amounts of carbonate. Most common, perhaps, are the "shell marls" of the Caloosahatchee marland the Tamiamiformation. These are usually sandy shell deposits and may contain little or no silt or clay. However, silty and clayey marls are common in southeastern Florida, although they seldom are found very near the surface and therefore exert little topographic control.

Shell marls are much more permeable than clayey marls, and where exposed to rainfall they are attacked by solution, which increases their permeability and reduces surface runoff. On the other hand, clay marls are relatively impermeable, and wherethey lie near the surface they prevent absorption of rainfall and promote surface runoff.

\section{FLUCTUAT̃ING SEA LEVEL}

A fluctuating sea level has been an important factor in shaping the topography of southern Florida. (See p. 111-125.) The principal topographic effects of the fluctuating sea over the Floridan Plateau were the terracing of the landscape with a veneer of marine sands, the alternate cutting and filling of shallow river valleys, and the development in the underlying calcareous rocks of a system of deep solution passages and sinkholes, many of which later became filled with sediment when the sea rose high enough to cover them. Also, marine features were left, such as spits, bay bars, offshore bars, lagoons, beaches, beach ridges, and flat shallow sea bottoms. These features abound on the marine terraces at the present time, especially on the younger terraces which have not yet been destroyed by solution and erosion. They may be readily observed from the air or studied on aerial photographs. Primarily, they control the natural drainage, and therefore they are important factors in water-resources studies.

\section{SHORELINE PROCESSES}

Waves, tides, and currents along the shoreline are actively engaged in modifying the adjacent land and the shallow sea bottom, and wind-blown spray etches rocks, especially the calcareous ones, beyond the reach of the waves. 
In southern Florida, as the sea has fluctuated over the relatively flat surface of the Floridan Plateau, the shoreline has migrated many miles; each time that the sea halted long enough, it left some present land features as marks of its stand. These features are

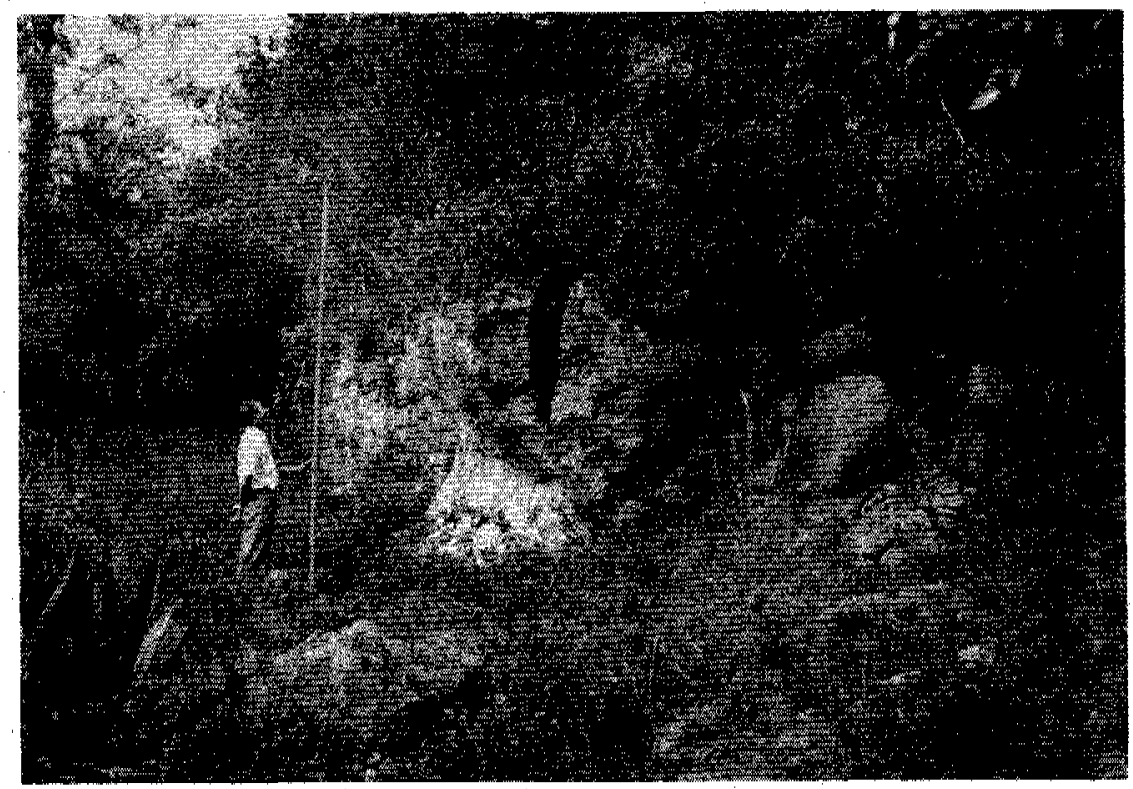

Figure 23, - Silver Bluff, a late Pleistocene sea cliff.

usually beach ridges, inner lagoons, and offshore bars, but they may be wave-cut notches in sea cliffs or wave-cut benches at the bases of sea cliffs. (See figs. 23 and 24.) Because consolidated rocks are rare in southern Florida, sea cliffs are scarce, but old beaches, with their associated bars, ridges, and dunes, are common and widely scattered.

One of the principal effects of shoreline processes in southern Florida has been the building up of the land along the coast. Sand is constantly being fed to the ocean by streams of the Piedmont Region of Alabama, Georgia, the Carolinas, and Virginia, and some of it eventually finds its way along the shore to Florida. Ancient sand deposits formed along the coast in the geologic past are now attacked by waves, and the newly released sand is dragged south by longshore currents and diagonally striking waves, to be incorporated later in new deposits still farther south.

Since the close of Miocene time, sand has not worked very far south of Miami. Calcareous rocks contain progressively less sand as they are traced southward. Today, the southern part of Biscayne Bay has much less sand in it than the northern end. In fact, 


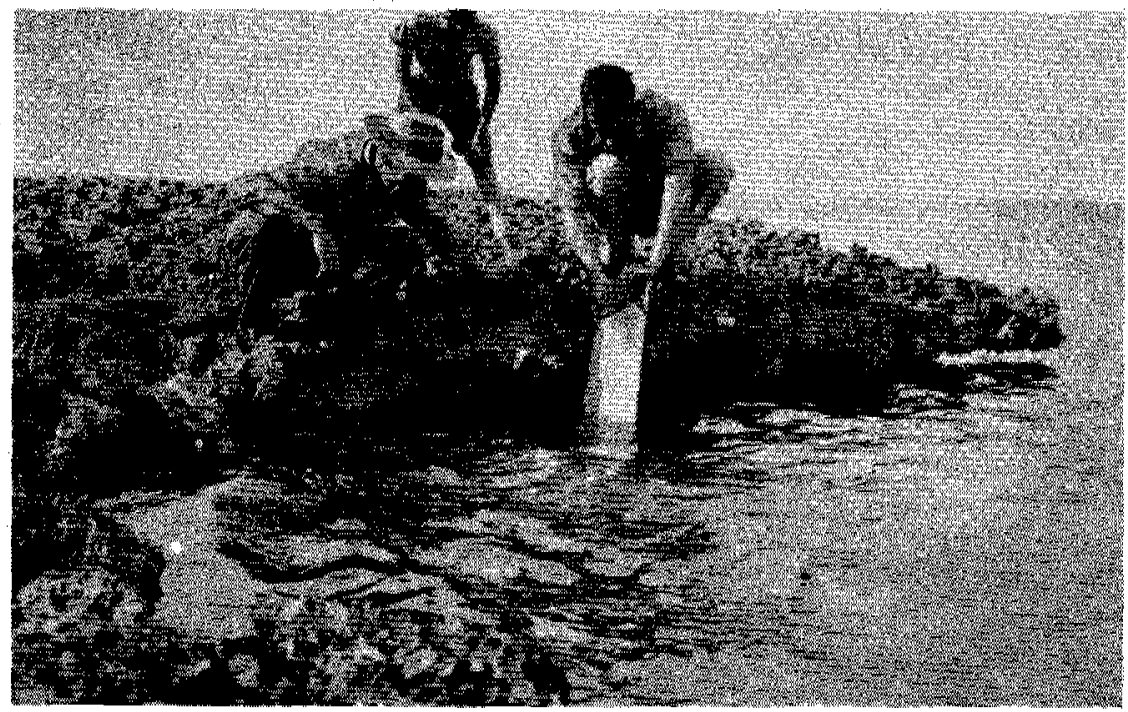

Figure 24. -Sea undercutting coralline limestone of Key Vaca.

Cape Florida, the extreme southern tip of Key Biscayne, off Miami, is now the principal southern terminus of the siliceous sands that wash down the coast.

This lateral movement of sand along the beaches tends to fill in, on the north side, tidal runways that cut through the offshore bar; but the sweep of tides and tidal currents in and out tends to keep the cuts open. The result of these two actions is the down-beach (southward) migration of the tidal inlets, a phenomenon with which all coastal residents are familiar.

Hurricanes may cause storm tides of as much as 16 or 18 feet (Congressional documents, p. 8-9). Waves of tremendous eroding power, which accompany hurricanes, are prime movers of loose materials along the shoreline and may accomplish greater changes during the course of one hurricane than normal shoreline processes would accomplish in many years. Sand bars, spits, and even small islands may be entirely washed away; new tidal cuts may appear across bars that formerly excluded the sea from direct access to inner lagoons; and a new set of bars, spits, and beaches may appear-all these changes are subsequently modified by the usual shoreline processes.

On a land as flat as southern Florida, these shoreline processes and the features they produce have a marked effect on subsequent drainage which, in turn, has a direct effect upon storage of ground water, upon the vegetation, and consequently upon the use that man makes of the land. 


\section{CLIMATE AND VEGETATION}

Climate is an important factor and has a profound effect on both organic and inorganic materials. Southern Florida has a semitropical climate. Rainfall is plentiful (50 to 60 inches per year), humidity is usually high, winds blow most of the time, and an occasional hurricane roars in from the tropical seas. (See section on Climate, p. 15-56.)

The principal effects of climate upon topography in southern Florida are brought about by the plentiful supply of rain that flows over or enters the rocks and attacks them both chemically and mechanically. Solution, a result of chemical attack on carbonate rocks, produces the characteristic karst topography of a limestone terrain.

Running water has carved valleys but in southern Florida its principal effect is solution. (Note on the hypsometric map, pl. 10, the indentations partly brought about by streams working on the marine terraces.)

On the flat terrace lands streams are sluggish and drainage is imperfect. The combination of physical conditions mentioned above has developed one of the largest areas of principally organic soils in the world-the Everglades. Outside the main body of the Everglades-extending up Kissimmee'River, Fisheating Creek, and in old lagoons and swales between ancient beach ridges-other smaller deposits of peat and muck have developed.

These organic deposits would continue to build up even today, but they are prevented from doing so by drainage operations. This problem has been discussed by Evans and Allison (1942, p. 34-46).

Not only is the climate favorable to the growth of swamp plants, but it enables bunch grasses, pines, palmettos, and other semitropical-to-tropical vegetation to grow on the old beach sands and dunes. This vegetation helps to prevent continuous arifting of the sands before prevailing winds and, by preserving their forms, helps the immature drainage pattern to become better established.

\section{SOLUTION}

Southern Florida is underlain by limestone and other calcareous deposits and, because surface waters usually contain natural acids, solution plays a more important role than abrasion in the development of topographic features. At times in the past, when the Floridan Plateau stood high above the sea, few, if any, deep gorges were carved by running water. Instead, both surface and underground rocks were etched and made càvernous by the lateral 


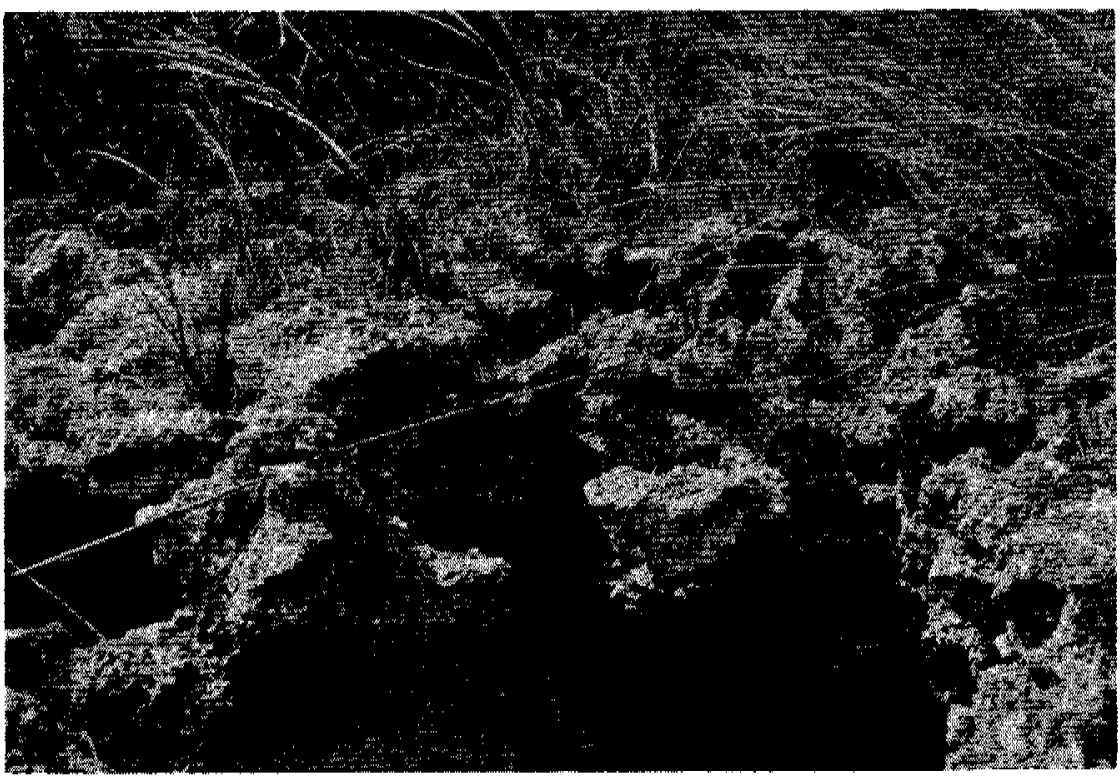

Figure 25, -Close-up view of one o. the larger solution inoles in Dade County.

and downward movement of corrosive waters. (See figs. 15, 25 and 26.)

Apparently, no original cavity is needed to starta solution hole, though the existence of a ready-made hole hastens the process. It has been suggested that many vertical solution holes begin to be dissolved along taproots of trees, and possibly some holes do originate in this fashion, but it is not the most common way. On the surface of hard limestone or soft calcareous clayey marl the first effects of solution appear as small surficial pits resembling raindrop marks in mud. These pits gradually deepen, many retaining their rounded outlines. Without visible outlet along the sides or bottom, they later become tubes which enlarge into holes of various shapes and sizes; but generally they develop vertically.

The work of solution is evident wherever outcrops of rock occur, as on the bare limestone surface south of Miami or in the Big Cypress Swamp, in canals and street cuts, in borrow ditches and rock quarries, or in river and creek banks. In large areas of southern Florida it is evident that at least one-fourth of the total volume of limestone, once more or less solid rock, is now occupied by solution holes, generally filled with sand. (See fig. 26.) Trees blown over by hurricanes rip up rock with their roots, thus leaving a new and localized depression for concentration of rain water and the start of active solution holes. Adjacent holes enlarge, coalesce, and become increasingly effective in draining surface water underground. Many solution depressions of this kind, 


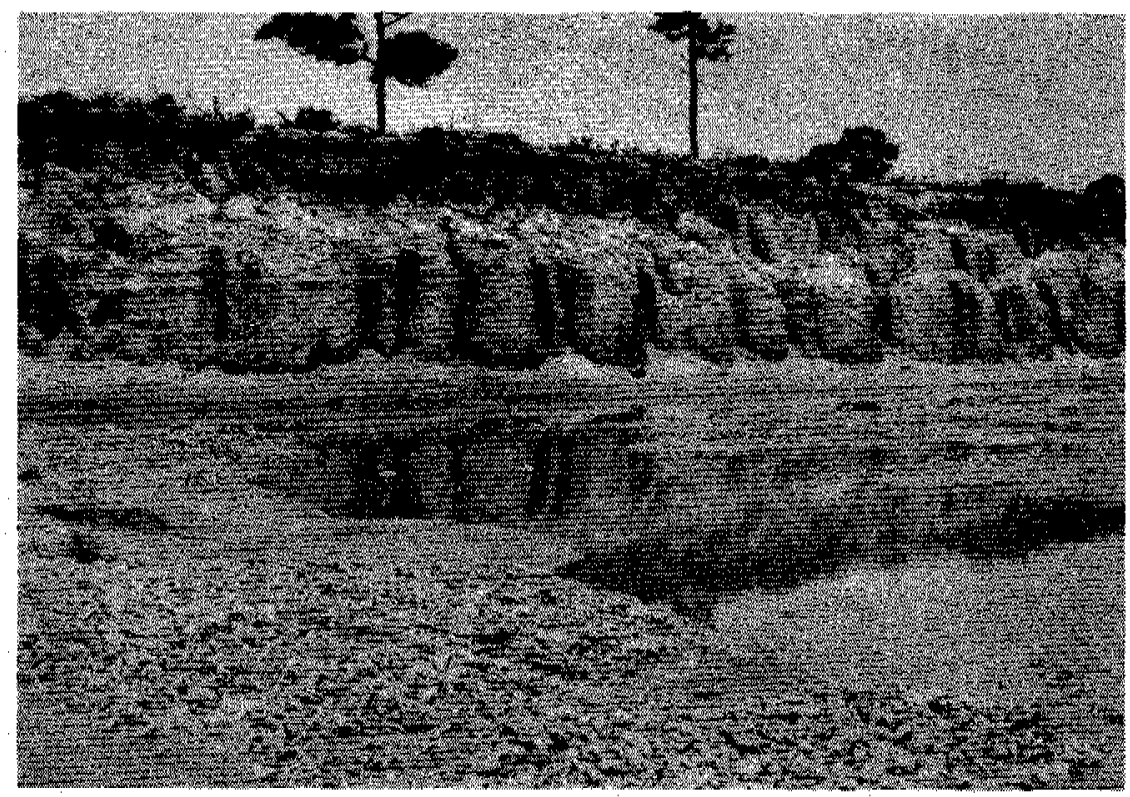

Figure 26. -Borrow pit in Miami oolite at Fort Lauderdale.

some as much as 150 feet in diameter, can be seen in the pineland and wet prairies south and west of Miami.

\section{EROSION}

Erosion by running water has been more effective in the area north of Lake Okeechobee (especially on the higher terrace lands) than it has been to the south of the lake and on the lower terraces, partly because of difference in underlying materials and partly because stream erosion has had a longer time to work on the older terraces.

The veryflatness of the marine terraces, their mantle of relatively permeable sands, the soluble underlying rocks, and the rank growth of vegetation, all play important roles in inhibiting surface flow. During glacialages, when the surface of the Floridan Plateau stood relatively high above sea level, the water level in the ground dropped accordingly, and the principal flow of water was downward to the water table, where it moved laterally to the seas. As a result, shallow valleys usually were carved.

On the higher sandy terraces with underlying shell marls and clayey marls, small streams developed and meandered in their lower courses across the flat land, causing little abrasion, of low gradient, they carried relatively clear water, but during seasonal floods they probably moved considerable quantities of loose sand 
seaward, as Fisheating Creek, the Kissimmee River, and other streams are doing today. Characteristically, they developed broad, shallow valleys.

During subsequent interglacial ages the lower reaches of these valleys were flooded by the sea to a lesser height with each successive age and the valleys then became embayments whose margins were modified by wave action and whose bottoms were leveled by planation and aggradation.

During subsequent glacial ages these lower parts of the former stream courses were partly reexcavated, and the upper reaches continued to work headward, though very slowly and rather ineffectually.

The net result has been the indented terrace pattern shown on the accompanying hypsometric map (pl. 10): Generally speaking, the inner boundaries of the terraces coincide with the shoreline of the sea at the time the terrace was developed, and the almost flat, gradually sloping surface of the terrace was the shallow sea bottom. But these features have been modified by subsequent erosion and solution so that the old shorelines have been changed; the older the shoreline, the more it is modified. However, some of these old shorelines with associated offshore bars and inland dunes are remarkably well preserved and are readily recognized.

Wind erosion, very effective in southern Florida during the Pleistocene glacial (low sea level)ages, has ceased to be a prominent factor. During the later glacial ages, prominent dunes were built in present southern Florida, especially in Palm Beach, Martin, and St. Lucie Counties, atop old beach ridges, and along the Gulf shore near Marco in an area of prominent karst topography; many of the Ten Thousand Islands owe their origin to these Pleistocene dunes, now partly drowned by rise of the sea to its present level.

The old dunes are now held down by vegetation and are quiescent, and even when vegetation is cleared off they remain fixed. They were formed under climatic and sea level conditions that do not now prevail.

\section{MARINE TERRACES}

\section{GENERAL STATEMENT}

Marine terraces are the former bottoms of shallow seas, usually floored with deposits of sand, clay, silt, and shells, and are bounded along their inner margin by shoreline features such as beach ridges, swales, offshore and bay bars, or, in rare instances, by low rocky sea cliffs notched by wave action. Landward, these 
deposits merge with estuarine and fluviatile deposits that were laid down in bays and in rivers emptying into the sea.

The surfaces of the terraces are generally almost featureless, flat, gently sloping plains with an occasional old sand bar or island remaining as very slightly higher land. Old tidal runways are now the sites of rivers, creeks, or swamps, and the land surface is dissected by moving water or pocked by solution holes in underlying calcareous rocks. The wash of small waves, in the water of the shallow ponds that fill these depressions, or the circulation of currents due to prevailing winds tend to produce evenly curved shorelines. Swamps and lakes develop in the lower lying, poorly drained areas of the terraces. (See p. 113-114 for a discussion of the effect of glacial control of sea level.)

Table 15 lists eight Pleistocene terraces in southeastern United States. No description is given in this report for terraces higher than 100 feet. (See pl. 10.)

\section{WCOMICO TERRACE}

The inner boundary and shore of the Wicomico terrace today stands approximately 100 feet above sea level, and its outer margin is bounded by the 70-foot shoreline of the next younger terrace.

The Wicomico terrace forms a narrow fringing band surrounding the higher terrace lands that extend southward between the valleys of Fisheating Creek and the Kissimmee River. In Wicomicotime, this high land was a long, comparatively narrow peninsula, called Highlands Peninsula in this report, after Highlands County in which it occurs. (See pl. 10.)

The greater part of Kissimmee River valley is developed on the Penholoway terrace (the next terrace lower than the Wicomico), which supports two islands of Wicomico deposits. The smaller of these islands called Kissimmee Island in this report, is approximately 27 miles long and 8 miles wide. It separates the larger Kissimmee River valley from the smaller Arbuckle Creek valley, which drains southward into Lake Istokpoga and from there into the Kissimmee River. In Wicomico time, Kissimmee Island was separated from the mainland by a salt-water narrows, called Istokpoga Strait in this report, which is about 27 miles long and averages about 3 miles in width.

The larger of the two islands of Wicomico deposits, called Osceola Island in this report, was an offshore bar during Wicomico time, and its highest parts probably were slightly submerged at high tide. It lay between deep water of the Atlantic Ocean and the shallow body of shoal water that extended about 20 miles west to 
the mainland. For this great Pleistocene shoal area the name "Kissimmee Sound" is here proposed. Osceola Island may have gained much of its modern shape during succeeding Penholoway time when it stood as an island about 70 miles long $w i$ th an average width of about 6 miles. A long narrow spit, about 23 miles long and a mile wide, extended almost due north from the main body of Osceola Island to a point that is now almost midway between Orlando and Titusville. Osceola Island is important today as the drainage divide that separates the upper St. Johns River basin from the Kissimmee River basin.

\section{PENHOLOWAY TERRACE}

The 70-foot shoreline of the Penholoway terrace is fairly well preserved in many places and is usually marked by a scarp, or wave-steepened slope, at its inner boundary. The terrace itself is relatively broad, flat, little dissected, and slopes gently to its outer margin, where another terrace, the Talbot, with a shoreline at approximately 42 feet, borders it.

A tongue of the Penholoway terrace extends northward along the west side of Highlands Peninsula in an embayment (called Fisheating Bay in this report), which in Penholoway time was about 20 miles long and 7 miles wide. It is now occupied by the upper reaches of Fisheating Creek.

During Penholoway time, Highlands Peninsula was lengthened by longshore currents sweeping sand southward as far as Palmdale, in Glades County. Fisheating Creek now turns abruptly eastward around the southern terminus of this extensive Pleistocene sand spit.

The Penholoway terrace narrowly fringes the east side of Highlands Peninsula as far north as the north shore of Lake Istokpoga; the southern boundary then turns eastward across Kissimmee River basin, with deep indentations along Kissimmee River and Taylor Creek. To the south of Osceola Island, the Penholoway terrace extends as a long peninsula (here called Okeechobee Peninsula), northeast of Lake Okeechobee.

From Okeechobee Peninsula the Penholoway terrace extends northward and fringes Osceola Island in a band about 7 miles wide and generally parallel to the modern Atlantic shore. Small headward-working streams, tributary to the upper St. Johns River basin, scallop its outer margin. 
KIBSTMMEE RAVER BASIN

The present drainage system of the Kissimmee River, with its numerous large and small lakes, meandering connecting channels and swampy lowlands, occupies Pleistocene Kissimmee Sound.

Rainfall that becomes ground-water storage in the adjacent higher terrace lands eventually reappears as ground-water discharge into Kissimmee River. The time lag is such that the flow of the river is maintained even during times of drought. (For details on the flow and the drainage-area characteristics of Kissimmee River, the principal tributary of Lake Okeechobee, see p. $301-314$.

Four large consequent lakes, Kissimmee, Hatchineha, Tohopekaliga, and East Tohopekaliga, occupy shallow basins that apparently were original depressions on the floor of old Kissimmee Sound. To what extent they may be impounded because of shallow sand bars is not known, owing to lack of detailed topographic work. Some of the smaller lakes in the Kissimmee River valley result from the damming of the sluggish drainage ways by Recent organic material.

At the extreme northern end of Kissimmee Sound there is a narrow strait connecting with the part of St. Johns drainage system that lies between the northern extremity of Osceola Island and the mainland. At present, surficialflow in this area is unpredictable.

\section{FISTEATING CREEK VALIEY}

Fisheating Creek heads on the Penholoway terrace and occupies Pleistocene Fisheating Bay, which lies just west of Highlands Peninsula; its valley is broad and flat. The stream, like the Kissimmee River, carries highly colored water with little sediment. Reeds, sedges, water hyacinths, and other aquatic and semiaquatic plants choke its channel and reduce abrasion to a minimum, During extended droughts, streamflow in Fisheating Creek, especially along the upper reaches, dwindles to nothing.

\section{TALBOT TERRACE}

Following the stand of the sea at 70 feetand the formation of the Penholoway terrace, the sea level dropped to 42 feet and stayed at that level long enough to establish a definite terrace, which is named the Talbot. Its outer limit is the generally poorly marked 25 -foot shoreline of the next lower terrace, the Pamlico.

The inner shoreline of the Talbot terrace is marvelously well preserved in some places and may be viewed to good advantage 
3 miles east of Childs on Florida Route 70. At that place, it lies at the foot of a noticeable scarp that separates it from the Penholoway terrace. A series of quiescent sand dunes lie inland from the old shore. Just east of the shoreline is a shallow offshore trench, and beyond the trench lies an offshore bar; both of these formations are comparable to those now being formed at the pres ent time of Miami Beach and elsewhere along the Atlantic and Gulf coasts. The old offshore trench is now filled with a woody-peat deposit, and dense swamp vegetation grows there. The old offshore bar is not continuous, but like most offshore bars, it has the higher and lower parts separated by tidal scour channels. It is known locally as the Parker Sand Islands.

The Talbot terrace is usually a narrow fringing area around the wider Penholoway terrace. South of DeSoto County it flares out into a wide lobe, called Glades Peninsula in this report, and a long tongue extends to form the floor of the southern part of Fisheating Bay. North of Lake Okeechobee a wide embayment, called Seminole Bay in this report, is largely floored with Talbot deposits. Seminole Bay lies between Highlands Peninsula on the west and Okeechobee Peninsula on the east. It was a very shallow bay, open to the ocean on the south, and it received the flow of ancestral Kissimmee River in its northern end when that river first came into existence. Lake Istokpoga appears to occupy an original depression on the floor of Seminole Bay.

East and northeast of Lake Okeechobee is the wide projection of the Okeechobee Peninsula, with a long narrow strip of Penholoway terrace as its core. Okeechobee Peninsula seems to have been formed in the same manner as the rest of these old peninsulas; that is, by longshore currents dropping their load of sand in the form of a broad spit.

Across Caloosahatchee Strait from the broad lobe of Glades Peninsula is roughly pear-shaped Immokalee Island, which is surmounted by a very small area that may possibly belong to the Penholoway formation. Immokalee Island still bears noticeable beach ridges in its southwestern quarter. These old beach ridges and intervening swales trend roughly west-northwest to eastsoutheast and parallel the southwestern shoreline of the island. See the map showing directions of surficial flow (pl. 11).

In addition to these old shorelines features, the long nor th-southtrending drainageway of the Okaloacoochee Slough and the eastwest-trending extension known' as the Devil's Garden occur on Immokalee Island. They are probably inherited from old tidal runways and are largely original features on the bottom of the Talbot sea. They have been modified by subsequent erosion and possibly by solution in the underlying shell marl. In places they may be partly blocked by old sand bars. 
The Talbot terrace is remarkably flat, and drainage on it is very sluggish. Sloughs, shallow ponds, and swamps abound, and there are wide'grassy plains with bunch grasses, palmettos, and pines.

\section{PAMLICO TERRACE}

All the land of southern Florida lying below the 25-foot contour, where itskirts the outer boundary of the Talbot terrace, and above the 5 -foot contour which marks the inner boundary of the Silver Bluff terrace (p. 146-147), is a part of the Pamlico terrace. The Pamlico shoreline is generally very difficult to trace because of the nature of the materials and the slope of the land surface upon which the Pamlico sea encroached.

In some places, notably west of the St. Lucie River in St. Lucie County, the shoreline becomes markedly steeper; probably this was caused by wave erosion. In others, southwest of Immokalee, Collier County, for example, the shoreline is marked by fringing swamps developed in the shallow offshore trench, and the shoreline itself can be plainly seen from high in the air. Lake Trafford lies in a re-entrant in the shoreline in this area.

The shoreline of the Pamlico sea is roughly indicated on the hypsometric map, plate 10 . It followed up river valleys developed in previous low stands (glacial stages) of the sea, especially up such streams as Myakka River, Peace Creek, Kissimmee River, and Caloosahatchee River. The Caloosahatchee valley was flooded by 10 to 15 feet of marine water and formed a strait about 7 to 10 miles wide connecting the Gulf of Mexico with Pleistocene Okeem chobee Bay (which was then a shallow shoal area similar to the present Bay of Florida) - this strait was deepest in the area now occupied by Lake Okeechobee.

The Pamlico terrace is remarkably flat and even, except in certain areas where it was made uneven by beach-ridge, swale, and dune deposits. Over most of southern Florida it is so flat lying that the eye can detect no change in slope.

The Pamlico terrace is poorly drained. Few well-established drainage courses cross it, and these are sluggish streams usually choked with aquatic weeds. Most important of these rivers is the northward-flowing St. Johns, lying in an old inner lagoon and separated from the present ocean by beach ridges. Its headwaters lie on the wet prairies and in the marshes at about the latitude of Lake Kissimmee.

Many small streams and canals drain water from the higher terrace lands surrounding Lake Okeechobee. Among them are Fisheating Creek, Harney Pond Canal, Indian Prairie Canal and 
Taylor Creek. The lower courses of both Kissimmee River and Fisheating Creek cross the Pamlico terrace as extended consequent streams.

The largest stream flowing oceanward from the Lake Okeechobee area is the Caloosahatchee River on the west. The St. Lucie River on the east drains an area of beach ridge and swale topography through an old lagoon separated from the ocean by high beach ridges. North of the estuary of the Caloosahatchee River are the estuaries of Peace Creek and Myakkka River emptying into Charlotte Harbor.

Numerous small rivers or creeks are on both the east and west sides of the State. Rivers such as the Estero and Imperial flow from the higher parts of the terrace to the Gulf of Mexico. Streams such as the Jupiter, New, and Miami Rivers flow to the Atlantic Ocean. All these streams carry highly colored swamp waters and accomplish little mechanical erosion.

Regions of special mention developed entirely or mainly on the Pamlico terrace of southern Florida are the sandy flatlands, the Big Cypress Swamp and the Atlantic Coastal Ridge.

\section{THE SANDY FLATLANDS}

The sandy flatlands are developed over most of southern Florida and include deposits of all the Pleistocene marine terraces having shorelines of 100 feet or less above sea level. Most of this area is lower than 25 feet and generally is very flat; the remainder may be slightly rolling, and it is called by Sanford (1909, p. 185-186) the "Rolling Sand Plains."

The sandy flatlands floor most of the lowlands along the Atlantic coast and extend west around the north side of Lake Okeechobee, fringing the central highlands (developed mainly on Wicomico and higher terraces), to the Gulf coast. (See pl. 12.)

They continue south in this western area beyond Naples, where coastal marshes begin. Along the Atlantic coast they are limited on the east by the narrow coastal ridge with its Pleistocene dunes, and on the southwest and west by the eastern border of the Everglades. This strip continues southward between the Everglades and the coastal ridge to Coral Gables, in the Miami area, with an occasional break through the ridge north of Miami, where they form the floor of old drainageways and tidal channels.

Rainfall on the sandy flatlands either sinks directly into the surficial sand or is stored in shallow pools from which evapotranspiration removes most or all of it. The whole flatlands area is-dotted with these circular intermittent ponds, generally only a 
foot or so deep and rarely over 4 feet deep. Diameters of the ponds may reach several hundred feet. Many of these ponds, as seen in aerial photographs, look remarkably like the Carolina bays. The ponds appear over areas' of deep sand as well as over areas where only a thin layer of sand mantles underlying limestones and shell marls. These ponds may be a result of solution of the underlying calcareous rocks, thus creating a local subsidence, or they may result from original inequalities on the sand floor, which were left when the sea withdrew, modified now by the wash of small waves and wind-impelled currents. Many definitely are in alinement, which was caused by underground solution along either horizontal passages or old bars and ridges.

Transpiration and evaporation probably account for the disposal of almost all the rainfall on the sandy flatlands, as they do in the Everglades. Studies described in the section on Surface water (Quantitative studies) and material by Clayton, Neller, and Allison (1942, p. 27-35), have shown that for limited areas transpiration and evaporation may exceed rainfall, the deficiency being accounted for by seepage and runoff from contiguous areas.

Drainage of the flatlands is sluggish and there is generally little or no surface flow, except in the rainy season when lower parts are inundated. Although the surficial sands are permeable, the movement of ground water is very slow because the gradient is almostflat and because the immediately underlying shell marls, calcareous marls, and clayey marls are of low permeability.

In some of the rather well marked areas on the sandy flatlands, drainageways inherited from the past and modified by present conditions are still used by surface waters. Most important of these are the Okaloacoochee Slough and Devil's Garden, the Loxahatchee Marsh, and the Allapattah Marsh. (See pl. 12.)

\section{.THE OKALOACOOCHEE GLOUGH AND DEVIL'S GARDEN}

The Okaloacoochee Slough and Devil's Garden (pl. 12) form a marshy drainageway on the sandy flatlands south of the Caloosahatchee River, west of the Everglades, arid in general, north of the Big Cypress Swamp. The Okaloacoochee Slough extends southward about 50 miles from the vicinity of La Belle into the Big Cypress Swamp. Its average width is little more than 2 miles, but a wide prong, called the Devil's Garden, extends northeastward from Immokalee.

The northern end of the Okaloacoochee Slough has a number of branches, most of which discharge into little creeks flowing into the Caloosahatchee River. The southern end branches out in a similar manner, but it is lost in the maze of intertwining courses in the Big Cypress Swamp. Fahkahatchee Slough is the southwestern branch of the Okaloacoochee Slough. 
The Okaloacoochee Slough drains both northward and southward from about the latitude of the Devil's Garden. The Devil's Garden itself drains westward most of the time to Okaloacoochee Slough, but in times of high water it may overflow in all directions-into the flatlands on the north, the Everglades on the east, and into the Big Cypress Swamp on the south. (See pl. 12; arrows indicate directions of surficial flow.)

The Okaloacoochee Slough and Devil's Garden occupy poorly drained depressions on the former Pamlico and Talbot sea bottom. The depressions may have been inherited from an earlier age and are now partly obstructed by old beach bars. When the Pamlico sea was withdrawing from its high-water shoreline, 25 feet above present mean sea level, it left many low beach ridges and bars. These have since been modified by erosion, but many are still noticeable and show plainly on aerial photographs.

Drainage from the Okaloacoochee Slough and Devil's Garden and from the Allapattah and Loxahatchee Marshes is retarded by a rank growth of vegetation and by an accumulation of organic peat and muck that clogs the channels; therefore, at times the movement of water is difficult to discern. Moreover, the direction of flow in the channels may be changed by local rains. "Spot showers, "which typify the rainfall in southern Florida, may cover only a fraction of a square mile or several square miles, but they may be so intense that surface-water gradients are temporarily reversed in the sluggish drainageways.

\section{ALLAPATTAY MARSI, LOXAHATCHEE MARSH, AND HUNGRYLAND SLOUGH}

The Allapattah Marsh occupies a poprly drained depression on the sandy flatlands east and nor theast of Lake Okeechobee. To the south it splits into two prongs, one that discharges its water to Lake Okeechobee north and west of Indian Town, and another that drains almost due south of that city into the Everglades.

The Loxahatchee Marsh and Hungryland Slough together form a wishbone-shaped marshy area with the apex pointed toward Jupiter Inlet and with prongs leading to the Everglades. Drainage is in both directions from a low divide in the middle of Hungryland Slough, and from a divide in Loxahatchee Marsh west of Kelsey City: Part of Loxahatchee Marsh drains directly into the Hillsboro Lakes Marsh at a point a few miles southeast of Loxahatchee. (See pl. 12.)

\section{SANDY HLATLANDS SOUTH OF LOXAHATCHEE MARSI}

Southward from the Loxahatchee Marsh the sandy flatlands extend just past Coral Gables, where they abut against the coastal 
ridge of oolitic limestone and are overlapped by Everglades soils. Apparently the sand never extended farther south because the currents that swept the sand southward became ineffective there.

Between Fort Lauderdale and Miami are several low, shallow valleys, floored with Pamlico sand, that reach to the present shore. These valleys are called transverse glades because of their orientation and their characteristic soils and vegetation. They occupy old drainage courses cut through the Miami oolite, probably in early Wisconsin time, and subsequently partly filled with sand during later Wisconsin and Recent time.

Outside the Atlantic Coastal Ridge, a strip of Recent sand extends southward to Miami as beach, beach-bar, and lagoon areas.

\section{TIE AG CYPRESS SWAMP}

The Big Cypress Swamp (pl. 12) is an indefinitely defined area. In general, it is bounded on the east and southeast by the Everglades, a region distinguished by its organic soils, sedges, and lower lying area. The sandy flatlands adjoin it on the north (where they are higher) and on the west (where they are lower). On the southwest and south, the Big Cypress Swamp merges into the lowlying coastal marshes and mangrove swamps. In marked contrast to the surrounding areas of mucky, sandy, and marly soils with no outcropping rocks, the Big Cypress Swamp has large areas with solution-riddled limestone at the surface, or with thin marly soil lying in shallow pockets in the rock. This marly soil in old drainageways is suitable for truck farming if the water table is adequately controlled by ditches, dikes, dams, and pumps.

Natural drainage is very defective, and in the rainy season the larger part of the Big Cypress Swamp usually is flooded; but even under flood conditions the only discernible movement of water is in shallow, poorly defined drainage courses, locally called sloughs, rivers, or creeks. Near the Gulf of Mexico these courses are better defined; however, they are so intricate that the service of a guide is required by a stranger traversing them.

The Big Cypress Swamp is not a vast morass of huge mossshrouded cypress trees, as is supposed by many people unfamiliar with the area. Instead, it is an area of alternating swampy and higher land (hammocks), with the former prevailing. Davis (1943) describes these relationships and.lists the principal components of the flora. The differences in the heights of aerated ground above the water table cause a marked diversification in the distribution of plants. The higher areas support bunch grasses, palmettos, and pines, whereas the lower areas are covered with cypress, much of it stunted, and with willow, bay, reeds, sedges, and other marsh plants. This relationship is especially noticeable near the borders, 
where strips of coastal marsh, of sandy flatland, or of Everglades may invade the Big Cypress Swamp for several miles. In general, there is no sharp line of demarcation between areas; instead, they merge into each other.

\section{THE ATLANTC COASTAL RJDE}

The Atlantic Coastal Ridge extends along the Atlantic shore as an irregularly shaped higher strip between the sandy flatlands and the Everglades on the west, and the ocean on the east. It has no sharp crest and appears to rise almost imperceptibly from the Everglades and descend gently to the ocean. Along several short stretches of shore (the most notable at Silver Bluff in Miami), there are several low sea cliffs. Silver Bluff is notched by wave action at a former higher stand of the sea, 5 feet above present mean sea level (fig. 23).

The greatest altitudes on the coastal ridge (about 50 feet) are found on the summits of sand dunes formed during the Pleistocene epoch. These dunes lie in a series of nearly parallel and broken rows inland from the present shoreline. The most southern dunes are found in the region west of Fort Lauderdalel", but here the dunes are much lower and broader than in the vicinity of West Palm Beach, Jupiter, and Hobe Sound, Northward from Hobe Sound. and extending into St. Lucie County, the belt of dunes surmounts old beach ridges and is better developed. These dunes are now quiescent and largely overgrown with bunch grasses, low shrubs, pines, and palmettos.

South of the Fort Lauderdale area there are no dunes on the coastal ridge, although large amounts of sand are present as far south as Coral Gables. This veneer of Pamlico sand was spread out over the limestone bedrock by ocean currents during midWisconsin time.

The coastal ridge almost everywhere has a rock foundation; north of Boca Raton it consists of sandy limestone and calcareous sandstone of the Anastasia formation, and south of Baca Raton it is the Miami oolite. The oolite lies at or near the surface almost everywhere from Miami southward to the point where the ridge finally dies out on the mainland southwest of Florida City. The height of the coastal ridge south of Fort Lauderdale averages about 8 feet above sea level; maximum altitudes of about 21 feet occur on the western shore of Biscayne Bay at Coconut Grove, Miami.

The coastal ridge disappears southwest of Florida City in a series of low "islands, " of ten called "Everglades Keys," sur-

1 Pine Island, so called from the fact that prior to drainage of the glades this large, pinecovered dune was entirely surrounded by water, is the best developed of these ice-age cunes. 
rounded by lowlands of Everglades soils. The coastal ridge reappears once again in the lower Florida Keys, from Big Pine Key to Key West, where Miami oolite is again the bedrock. Maximum altitude measured on Big Pine Key is less than 7 feet, and on Key West it is about 13 feet.

Marly or mucky strips, called by Harper (1927, p. 176) "transverse glades, " cut across the coastal ridge in several places. The plants of these glades are unlike those of the higher ridge land and are very distinctive. Some of the transverse glades, especially south of Miami, head on the ridge itself and merge seaward with the coastal prairie developed on the Silver Bluff terrace. They are generally floored with gray marl soils, and when the water table is properly controlled they form excellent agricultural lands.

\section{SILVER BLUFF TERRACE}

The Silver Bluff terrace has not previously been described in detail, although the shoreline that borders it has been partly described (Parker and Cooke, 1944, p. 22-44; Parker, 1945b, p. $130,138-139$ ) and the terrace adjacent to Silver Bluff (a wave-cut bench) was called the "Miami bench."

Since then, this wave-cutbench and its bordering shoreline have been found to be quite extensive. They have been traced and mapped with considerable accuracy in Dade County, but with less accuracy in adjoining counties. The Silver Bluff terrace has been found to underlie most of the Everglades and the coastal marshes. A map, plate 13, shows the Silver Bluff terrace in Dade County, the approximate location of the old shoreline, and the areas that were dry land, mostly islands, in the time of Silver Bluff deposition.

Not only are the islands and surrounding terraces now distinguishable by physiographic mean'; they support an entirely different assemblage of plants (reeds, sedges, willows, wax myrtle, on the terrace, and pines, bunchgrasses, and saw palmetto, on the islands) and thus aid field mapping. The area shown in plate 13 has been mapped by leveling and by studying aerial photographs.

Modern shorelines are not uniformly level throughout their distribution, nor was that of the Silver Bluff in Pleistocene time. In Florida, along the open ocean this Pleistocene shoreline now averages about 5 feet above sea level, but in protected places and areas where the oolite is harder it may be several feet higher. Thus, it does not everywhere coincide with the 5 -foot contour line.

Nor does the terrace have a perfectly smooth surface. It shows shallow undulations, trenches, and low ridges caused by differen- 
tial erosion of oolite varying in hardness and whose original depositional surface was not level. However, as a whole it is fairly uniform. It slopes gently seaward along the Atlantic Ocean; and inland, between the islands and the mainland that existed in the time of Silver Bluff deposition, the terrace slopes gently toward a broad, shallow groove that is oriented in a northeast-southwest direction and connects with outlets on the northeast at Miami and Fort Lauderdale, and on the southwest with the Bay of Florida.

Most of the Everglades and coastal marshes in Dade County are developed on the Silver Bluff terrace. The shoreline is traceable in Broward County (northward from Dade County on the eastern side of the Atlantic Coastal Ridge), but it loses its identity near Pompano where the geologic materials that compose the Atlantic Coastal Ridge are not consolidated-sand, not limestone, occurs there. On the western side of the Coastal Ridge the Silver Bluff shoreline follows a sinuous path beneath the Everglades soils and connects with the Lake Okeechobee basin. From here, the shoreline follows southward in a line roughly parallel to the EvergladesBig Cypress Swamp border.

MacNeil (1950, p. 104) has recognized the Silver Bluff shoreline in northern Florida and Georgia. However, the fact that the Silver Bluff shoreline and terrace are easily traceable only in southeastern Florida is not at all surprising. Elsewhere along the A tlantic and Gulf coasts there are few areas of consolidated rocks in which the record of this latest Pleistocene shoreline could be either developed or preserved.

Sands and other unconsolidated materials soon weather, creep, and slump, reducing a once-prominent sea-cut scarp to a mild change in slope of the land surface. Although very hard rocks may not even. be noticeably cut in a relatively short stand of the sea at a given level, softlimestones develop a noticeable and lasting cut.

At the present time, southeastern Florida presents an outstanding example of the development and preservation of the modern shoreline. If present sea level starts to recede, it would not be long, geologically speaking, until most recognizable features of the present shore elsewhere along the Atlantic and Gulf coasts would be so nearly obliterated that they would be recognizable only to the trained eye.

\section{THE EVERGLADES}

The Everglades, a region of organic soils (pl. 12), occupies an irregularly defined area of about 4,000 square miles, lying between slightly higher areas on all sides, except on the south and southwest, and developed principally on the Silver Bluff terrace. (See p. 118-125 for the geologic history of the Everglades.) 
An arm of the Everglades borders the western side of Lake Okeechobee, and a narrow tapering arm extends northward along the eastern side, where it merges with the Allapattah Marsh and cypress swamps. The Everglades extends southward and southwestward from the lake in a vast sweep about 40 miles wide and 100 miles long, merging near the Bay of Florida and the Gulf of Mexico into salt-water marshes and mangrove swamps. The boundary between the Everglades and surrounding areas is very indefinite. It may be regarded as the place where the sedges of the Everglades give way to true grasses and pines or cypress, or to salt-marsh plants and mangroves.

Large areas in the northern and eastern parts of the. Everglades are almost treeless expanses of sawgrass (Mariscusiamaicensis) -a sedge, growing as tall as 10 or 12 feet. Low shrubs of wax myrtle, willow, bay, and custard apple appear on slightly higher areas, generally in isolated clumps called tree islands, which are generally in alinement with the general drainage pattern (fig. 27).

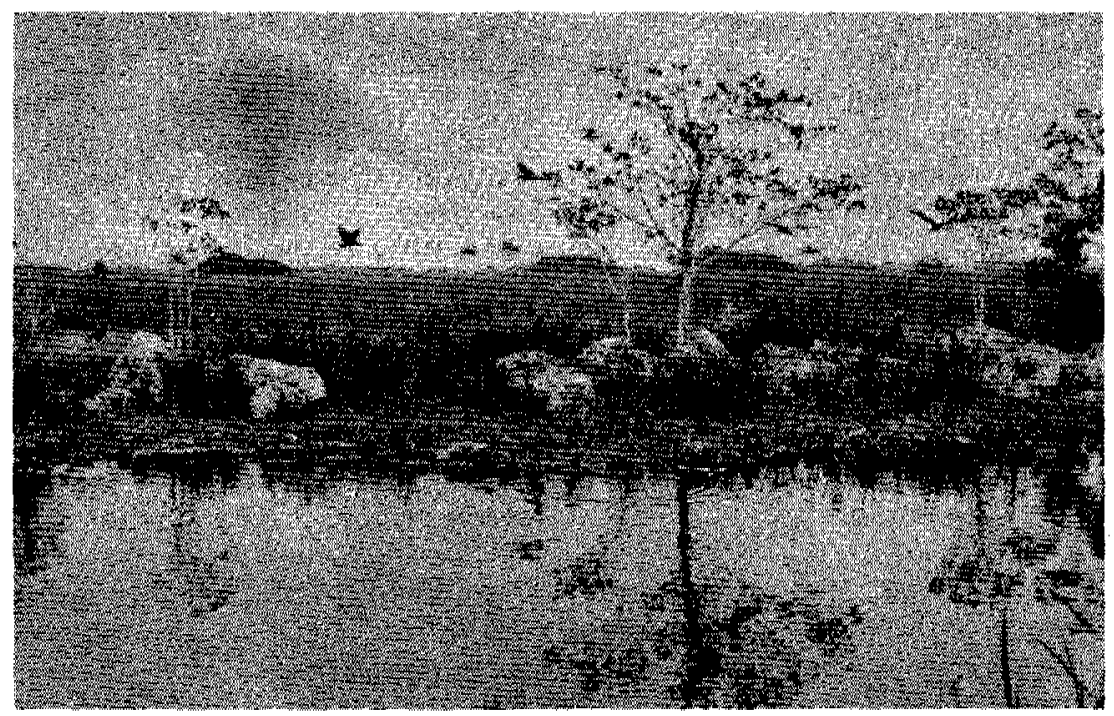

Figure 27. - Typical view of western part of the Everglades showing tree islands.

Trees grow in the Everglades where there is enough height above the perennial water table to allow aeration of the soil. Conditions are very favorable along spoil banks, and trees and shrubs grow there in rank profusion.

The accumulation of peat and muck is still continuing in certain undeveloped areas of the Everglades where each year's growth of plants dies and sinks below the surface of the shallow water and is incorporated in the organic mass below. And it would continue 
at a much faster rate except for man's interference by drainage and farming.

\section{FLOOR OF THE EVERGLADES}

The floor of the Everglades is chiefly comprised of rocks of the Fort Thompson formation, except in the south where the Miami oolite is prevalent. A thin gray blanket of relatively impermeable Lake Flirt marl covers vast areas of the rocky floor, and along the west and east margins of the Everglades (as far south as the latitude of Miami) a thin mantle of Pamlico sand occurs. Over these materials are several kinds of peat and muck (Evans and Allison, 1942, p. 34-46).

Sanford (1909, p. 192-193) thought that the rock floor in the northern part of the Everglades slopes to the west more steeply than in the southern part, that depth to bedrock 5 miles west of the eastern rim back of Fort Lauderdale is probably not less than 20 feet, and that the Everglades probably occupies a series of comparatively shallow rock hollows. He states, "Whether these hollows were as deep when the Everglades first occupied them as they now are, that is, whether they have been deepened by solution through underground drainage, whether they represent original inequalities of deposition of the lime rock, or whether they are buried shallow valleys cannot be determined from the evidence at hand. It is probable, however, that the deepening and enlarging effect of underground solution has been exaggerated."

Subsequent writers have added little to this concept because of lack of specific information. Of the rock floor, Fenneman (1938, p. 63) writes: "Under it (the organic soils) is a floor of limestone believed to be nearly level. Rarely, if ever, does it fall below sea level, and nowhere in the Everglades proper does it reach the surface. The fact that it reaches the surface on all margins, exceptalong the shore to the southwest, suggests that the Everglades may owe their existence to an original rock basin. The rock floor is slightly more uneven in the north than in the south, and various explanations have been offered, based on erosion, solution, and deformation."

Data gathered by the U. S. Geological Survey while drilling numerous exploratory test wells, and by the Soil Conservation Service while making soil surveys in the Everglades, show that Sanford's and Fenneman's observations were fairly accurate. Beginning along the eastern rim of the Everglades (fig. 28), from Lake Okeechobee to the latitude of the Palm Beach--Broward County boundary, there is a rapid descent from the Atlantic Coastal Ridge to the shallow basin that contains the Hillsboro Lakes Marsh in its southern end (pl. 12 and fig. 28). Elevations drop from about 10 feet to about 3 feet (mean sea level, U. $S$. 


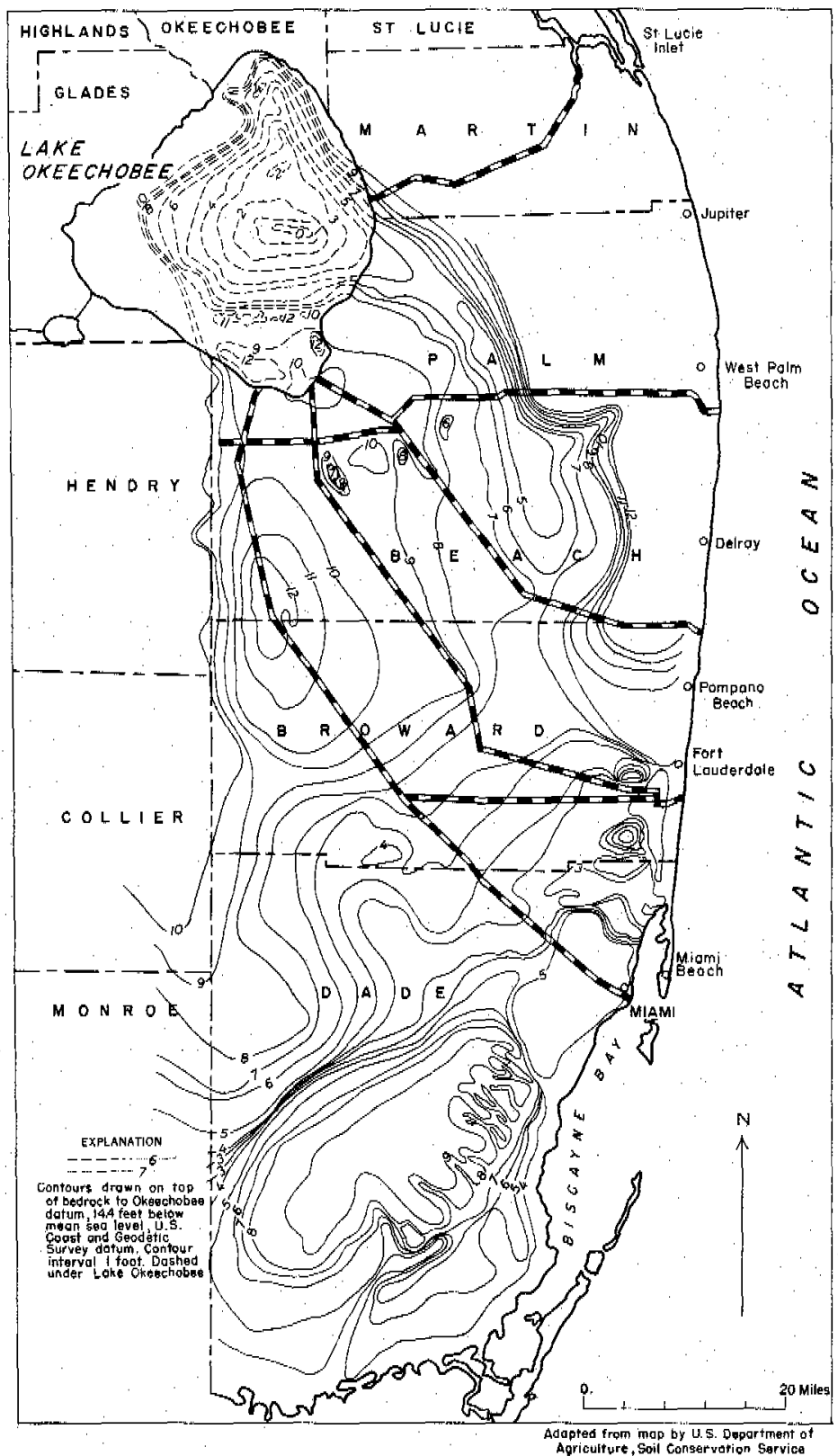

Figure 28. - Contour map of rock floor of Everglades. 
Coast and Geodetic Survey datum) within a distance of about 1 mile-a change in elevation that is distinctly scarplike. There is a shallow trough leading into the shallow basin of the Hillsboro Lake Marsh from the southeastern side of Lake Okeechobee. Southward from the Hillsboro Lakes Marsh this trough continues to connect with old spillways and tidal channels emptying into the Atlantic Ocean between Fort Lauderdale and Mlami. Some of these old channels have been deeply eroded in the rock and later filled with sand; Sanford referred to these sand-filled channels when he said that depth to bedrock west of Fort Lauderdale is not less than 20 feet. However, he did not know that these depths exist only in channels, because sufficient data were not available to him.

West of this trough, which lies along the eastern margin of the Everglades, the rock floor forms a domelike surface (an erosion remnant) with its top about 10 feet above mean sea level. This "high" centers on the Palm Beach-Broward County line about 6 or 7 miles east of the Palm Beach-Hendry County line, and due south of Lake Okeechobee. From the top of this low dome the floor slopes gently northward and southward. To the north the slope is quite gentle until the basin of Lake Okeechobee is reached; then the drop is abrupt. To the south, also, the slope is slight. To the west the slope increases and the floor drops about 3 feet in 4 miles to where a narrow trough (with floor elevation about 8 feet above mean sea level) lies along the eastern margin of the Big Cypress Swamp and the sandy flatlands north of the Big Cypress. (See pl. 12 and fig. 28.)

Farther south, beyond the domelike area and between the Big Cypress Swamp on the west and the Atlantic Coastal Ridge on the east, the floor of the Everglades slopes gently from the sides. toward the center where a low, broad, flat valley swings gently to the southwest.

These major features of the floor of the Everglades are locally marked by smaller basins and higher areas. In general, the floor slopes from the Silver Bluff shorelines at the sides toward the middle, but the slope is interrupted by local ridges and basins, none higher than the lands surrounding the Everglades and few deeper than sea level.

Solution is actively engaged in etching out the floor of the Everglades at the present time, deepening the hollows and roughening the ridges. Deposition, too, is taking place in some parts, especially in the soils of the hammocks where calcium carbonate is being deposited, making a carbonaceous marl that locally hardens to friable, impure limestone. 
DRANAGE PATTEAN OF THE EVERGLADES

In the Everglades there are many elongate tree islands, arranged more or less in parallel rows and separated from one another by shallow "swales," "runs," "sloughs, "or "lakes," as they are variously called locally. These tree islands and swales trend nor thwest-southeast in the upper part of the Everglades as far south as the old spillways through the coastal ridge between Miami and Fort Lauderdale, then they begin to bend to the south, and finally, about $18 \mathrm{miles}$ south of Miami, they swing abruptly to the southwest.

The linear arrangement of this pattern is most noticeable from the air, from which, as Dickerson (1942, p. 136-139) says, "They reveal a decided 'grain' to a broad sweep of country *** as if a great coarse broom had been rudely brushed over the low-lying Everglades region. "Such an arrangement of alternate strips of tree islands and sawgrass is developed best toward the western side of the Everglades in the vicinity of the Tamiami Trail (fig. 27).

Dickerson postulates that this "grain" may be the result of ocean currents during Pamlico time when this whole area was a shallow sea bottom. He notes, "Off the east coast of Florida a strong south-flowing inshore current prevails, and this current drags the quartz sands from the north and mixes them with the coral sands of the Florida Keys as it sweeps westward in a great arc. The marked parallelism between these Everglades groovings and the present east and south shorelines of Florida suggests that the same agents-ocean currents-shaped both."

Dickerson's hypothesis, which is based entirely on photographs taken from an altitude of 14,000 feet, fails on closer examination. The "grain" of the Everglades, interpreted by him as traces of ocean current, is believed to be developed entirely onfresh-water peat and muck and apparently does not reflect an underlying pattern of marine bars. It merely represents a drainage pattern produced on a very gentle sloping surface of organic deposits. The "grain" is composed of tree islands and swales that trend parallel to the regional slope, just as one would expect in an area of consequent drainage. Streams flowing across the Sunderland terrace into Okefenokee Swamp in Clinch and Warren Counties, Ga., show a similar pattern of parallel lines. On certain parts of the Pamlico terrace, especially in St. Lucie and Martin Counties, a parallel arrangement of old dunes, beach ridges, bars, and lagoons is noticeable. This pattern is a direct product of the lowering of a sea level in a shoreline environment but is not the same as that of the organic Everglades soils.

The drainage pattern in the Everglades is gradually being changed by man's operations. "Subsidence valleys", according to 
Evans and Allison (1942, p. 38), have developed along the principal drainage canals, and the flow in the northern end of the Everglades at certain times of the year is northward into the lake, exactly opposite to the original condition.

\section{LAKE OKEECHOBEE}

Lake Okeechobee occupies the northermost and largest of the interconnected series of basins and shallow troughs that comprise the Lake Okeechobee-Everglades lobe of the Silver Bluff terrace (fig. 28). The lake basin is an original hollow in the Pliocene sea floor that has been modified by solution, erosion, and deposition of sediments during the Pleistocene and Recent epochs.

The lake averages a little less than 30 miles in diameter, and its area usually varies between 650 and 725 square miles, depending on the stage. (See section on Surface water for detalled information on the lake.)

The lake is very shallow; the deepest parts are approximately at sea level (fig. 28). It is saucer-shaped, and because of its physical characteristics it is subject to violent wind tides and wave action during storms. According to House Document 469, 76th Congress, 1st session, pages 8-9: "The hurricane of 1933, with a maximum wind velocity of about $80 \mathrm{mph}$, caused a hurricane tide of approximately 5. 6 feet. The hurricane of 1926, with a maximum wind velocity of about $90 \mathrm{mph}$, caused a hurricane tide of 6.8 feet. The hurricane of 1928 , with a maximum wind velocity of 135 to $150 \mathrm{mph}$, caused a hurricane tide of 13.2 feet. This hurricane caused such great loss of life and property damage that it was the primary cause of the Federal Government undertaking the present flood-control project. Past records show that hurricanes with much greater wind velocity than that of 1928 have occurred, notably that of the Florida Keys in 1935, which had an estimated wind velocity of approximately $200 \mathrm{mph}$ and a maximum hurricane tide of 16 to 18 feet."

From these data it is easily understood that the bottom of the lake is rather thoroughly scoured by the action of storm waves, and because these waves effectively cast out detrital material, loose sand is scarce on the bottom. Around portions of the lake, especially on the northeastern, eastern, and southeastern borders, a definite sand ridge has been built up. This is a beach ridge, probably built by storm waves, and it lies outside the hurricane levee. It is the dwelling place of most of the rural families who live around the eastern margin of the lake. Shallow sand-point wells driven into this deposit furnish domestic water supplies. For information on ground-water inflow into the lake see p. $106-107$. 
HILLSBORO LAKES MARSH

Hillsboro Lakes Marsh (pl. 12) is a boggy area of about 55 square miles in Palm Beach County. It lies nor th of the Hillsboro Canal, south of the West Palm Beach Canal, west of the strip of sandy flatlands that borders the Atlantic Coastal Ridge, and, in general, east of a north-south line through the junction of the Cross Canal and the West Palm Beach Canal.

It occupies one of the large and deeper basins in the floor of the Everglades - a basin now nearly filled with peat and muck. These organic soils are being constantly built up over the greater part of this area by aquatic and semiaquatic vegetation. Expanses of open water, dotted with small tree islands on peat and muck and flotant masses of "floating islands," existover large areas. In shallower parts, sawgrass grows thickly; in deeper water, pond lilies and pickerel weed are the commonest plants.

Since the excavation of the Hillsboro Canal and the resultant lowering of the water table, rejuvenation of the better-established drainage courses has occurred, and at the present time, some of them have become small streams in which the underlying organic deposit has been stripped away in their channels and the bedrock exposed. Indian Run is a good example.

\section{COASTAL MARSHES AND MANGROVE SWAMPS}

The coastal marshes and mangrove swamps are developed on the seaward margin of the Silver Bluff terrace and along the border of the present seashore. In southeastern Florida their greatest development is in southern and eastern Dade County, but they continue as an irregular narrow band along much of the Atlantic coast behind the sandy beach ridge.

The mangrove swamps are generally floored with a black peaty deposit, often with considerable inorganic material (quartz sand, chiefly) admixed. The coastal marshes are characterized by marly soils mixed locally with sand and muck. In the area bordering salt water the vegetation consists of the usual salt-marsh subtropical assemblage, which gives way to fresh-water marsh plants at the outer edge of the sandy flatlands, the Everglades, or the Atlantic Coastal Ridge. The general relationship of these plants has recently been presented by Davis (1943). The coastal marshes have yielded excellent-truck crops in areas where aproperly controlled water table has been maintained. 


\section{THE FLORIDA KEYS}

The Florida Keys are low-lying islands that extend about 140 miles to the southwest in a gently curving arc from Soldier Key (in Biscayne Bay) to and including Key West.

The keys are divisible into two groups, distinguishable both by their difference in rock characteristics and by their shape. The "upper keys" include the group lying between Soldier Key and Bahia Honda. They are of coral-reef origin and are elongated in a direction parallel to the coastline along which the reef grew during the Pleistocene epoch. They average about a quarter of a mile in width and range in length from a few hundred yards to many miles-Key Largo, the longest, is almost. 30 miles long. All are low; land surface in excess of 5 feet above sea level is rare.

The "lower keys" are merely an extension of the oolitic limestone reef or bar on which Miami and other mainland cities of southeastern Florida are built. These lower keys begin with Big Pine Key, and are generally elongated at $r$ ight angles to the elongation of the upper keys. This northwest-southeast elongation of the lower keys is caused largely by the direction of movement of the tidal scour produced by differences in time and height of the tides in the Gulf of Mexico and the Strait of Florida, but it is also influenced by the original shape and differences in altitude of the surface of the oolitic bar from which the rocks of the lower keys are formed.

The shape of the keys is also modified by agencies other than the tides. The work of the waves along the shorelines (especially during hurricanes) is important, and solution of the limestone by percolating water is another vital factor. The latter is especially noticeable in the so-called potholes or natural wells which occupy a large part of the total volume of the rock. On both Big Pine Key and Key West these open vertical solution holes are commonly called springs, although they do not flow. Some of the larger solution areas, produced by coalescense of a group of small, adjacent potholes, create ponds, or depressed areas reaching near the water table. These latter depressions become centers of extremely lush vegetation. 


\section{GROUND WATER}

By Garald G, Parker

\section{OCCURRENCE}

\section{INTRODUCTION AND GENERAL PRINCIPLES}

\section{DEFINIITION OF GROUND WATER}

Water that occurs beneath the surface of the earth in the zone of saturation where it fills the interstices, joints, crevices, fissures, solution holes, and any or all other voids, is called ground water (Meinzer, 1923a; 1923b, p. 5). It is the water that supplies springs and wells, and that seeps into lakes and streams to maintain their stages and flows between rains. The geologic formations whose interstices or openings are filled with water, and from which water is collectible for use; are called aquifers.

\section{NONARTESIAN WATER AND THE WATER TABLE}

The water that infiltrates the ground and fills the voids between rock particles makes a water-saturated zone whose upper surface is under atmospheric pressure; this surface is called the water table. To most laymen the term "water table" denotes a flat or plane surface; actually it seldom is that: A glance at figure 29 will show plainly what the term means.

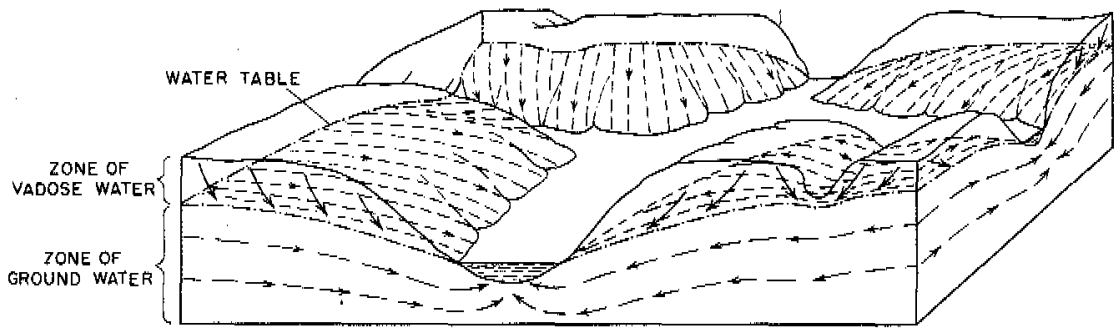

Figure 29. - Idealized block diagram showing relationship of water table to land surface,

The water table is higher beneath uplands than beneath lowlands, and in general it reflects the topography of the land in a subdued fashion. The water table is an unconfined air-water surface, acted upon mainly by gravity and atmospheric pressure; in a well that penetrates the water table, water ordinarily will not rise above the water level in the surrounding aquifer, which contrasts with the 
water of artesian aquifers (see following section). Where the water table intersects the land surface, seeps or springs form; and, accórding to topography, a marsh, lake, or stream results.

Vadose water is water held in suspension in the zone of aeration above the water table. In areas where the ground-water resources are carefully studied, maps of the water table may be prepared for selected times. Such maps show by contours the altitude of the water table with reference to a common datum plane (such as mean sea level) and indicate the direction of ground-water flow, which is normal to the contours. Such maps may indicate the source of water of a given well field, the area influenced by pumping from the well, and other valuable and pertinent data. Several water-table maps are given elsewhere in this report (see, for example, figs. 32 , $42,46,77$, and 189 ).

\section{ARTESIAN WATER AND THE PIEZOMETRIC SURFACE}

When water completely fills an aquifer whose upper surface is relatively impermeable, it is under pressure both from the water entering the aquifer at a higher level (where there is no confining upper surface) and from the weight of the overlying beds. A well drilledinto such an artesian aquifer will relieve the pressure, thus locally allowing the water to rise in the well to a distance necessary to balance the pressure. Such a well is an artesian well regardless of whether or not it will flow. Figure 30 is a cross section of a

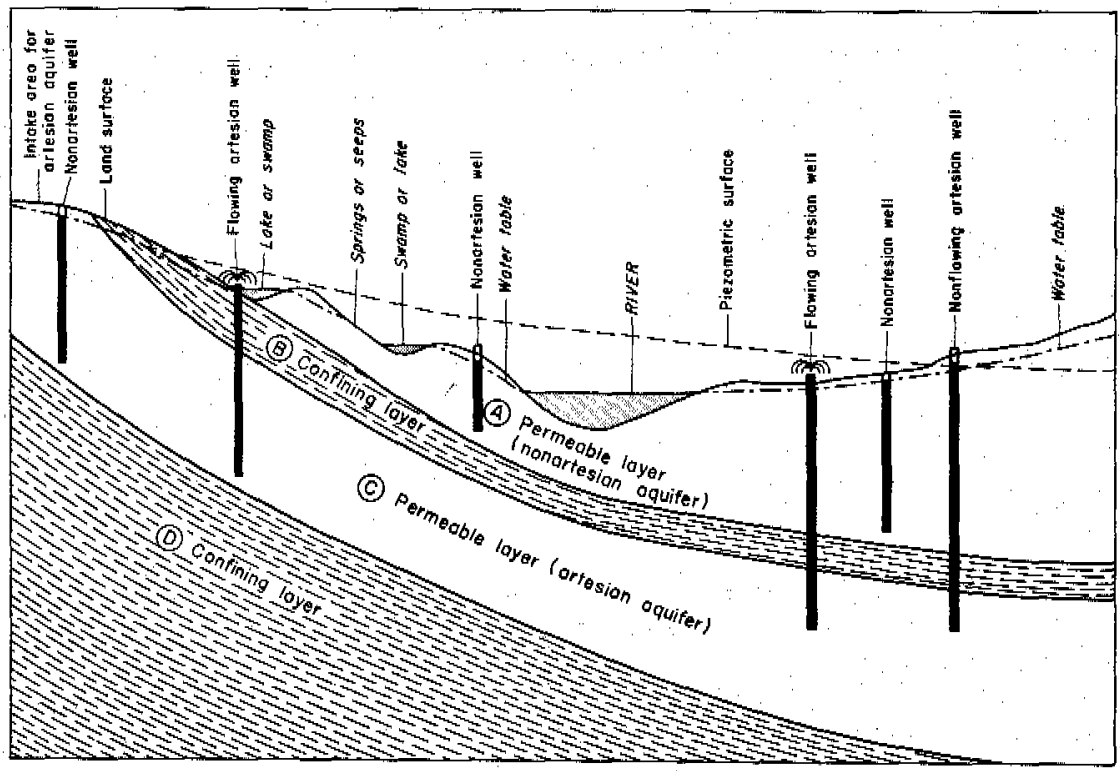

Figure 30. - Idealized cross section showing relationship between water table and piezometric surface of artesian water in an area with geologic structure similar to that of Kissimmee valley. 
hypothetical area with a geologic structure similar to that of the Kissimmee River valley. Aquifer A contains only nonartesian water or water that occurs under water-table conditions. Layer B, a bed of relatively impermeable marl or clayey material, separates aquifer $A$ from aquifer $C$, which, down slope from the intake area, contains water under artesian pressure.

In the highland area, where permeable beds crop out, aquifer $C$ has a water table, and the water there is not confined. Such an area is termed a "recharge area", because it is there that the aquifer naturally receives its water. An artesian aquifer is both an underground reservoir and a conduit operating under natural pressures, and the water in it behaves in a manner similar to water in a city water-supply distribution system.

When water is withdrawn from an artesian well, no unwatering of the aquifer occurs unless the water level is drawn down below the bottom of the overlying confining beds; instead, the space formerly occupied by the removed water is taken up by a combination of both the expansion of the water remaining, and the compression of the aquifer resulting from the lowered pressure. Unwateringmay eventually occur in the recharge area where the water level declines when the effect of well-discharge reaches it. On the contrary, when water is withdrawn from an aquifer under water-table conditions an actual unwatering of the aquifer occurs in the area surrounding the well.

The lowering of pressure in an artesian system, caused by discharge from a well, is somewhat comparable to that in a city watersupply system when a faucet is opened. In the city water-supply system the pipes are rigid and comparatively nonexpanding; thus, the pressure changes in the distributionsystem are readily transmitted to the elevated tank where the water level drops when faucets discharge. In artesian aquifers such rigidity is not known; most aquifers are more or less elastic and may eventually suffer some compaction and a certain amount of permanent loss of capacity through development. For further information on elasticity of artesian aquifers the reader is referred especially to two papers by Meinzer $(1928$, p. 263-291; 1937, p. 715).

An imaginary surface indicating the height to which water will rise in tightlycased artesian wells represents the artesian head in any given artesian aquifer; it is called the piezometric surface, and is to an artesian (confined) aquifer what the water table is to a nonartesian aquifer.

By mapping the piezometric surface much can be learned of the occurrence and behavior of wate $r$ in an artesian aquifer. This was first done by Stringfield (1936, p. 134) for the Floridan aquifer, the principal artesian aquifer of the State (see fig.35). 


\section{METHODS OF INVESTGATION}

The methods of investigating ground-water occurrence and behavior under varying conditions in southern Florida are those in general use by the U. S. Geological Survey and were, in large part, developed by this Survey (Meinzer, 1931).

Inasmuch as the occurrence and behavior of ground water is in large part dependent upon the geology of the area, many of the methods and procedures of investigation are geologic in nature. See pages $57-58$, in the section on Geology.

Behavior of the water in the aquifers is studied by a variety of means and methods; these include both qualitative and quantitative approaches. The latter are described in considerable detail later under Quantitative studies in the Miami area (p. 197-290).

In addition to the problems of determining occurrence and behavior of water in the aquifers there have been other problems requiring special methods. Chief among these is the problem of saltwater encroachment. Test and observation wells were installed, water-table and isochlor maps were prepared periodically, and electrical resistivity studies were made (see the section on Saltwater encroachment, especially p. 712-725). Studies of tides, rainfall, evaporation, transpiration, wind effects, and other conditions involved special methods, most of which are described later in the Quantitative studies in the Miami area.

\section{NONARTESIAN WATER}

THE RISCAYNE AQUIFER

The Biscayne aquifer, named after Biscayne Bay, is the source of the most important water supplies developed in southeastern Florida. It is the most productive of the shallow nonartesian aquifers in the area and is one of the most permeable in the world. The aquifer extends along the eastern coast from southern Dade County into coastal Palm Beach County as a wedge-shaped underground reservoir having the thin edge to the west. It underlies the Everglades as far north as northern Broward County, though in that area it is comparatively thin, and the permeability is not as high as it is farther east and south.

The Biscayne aquifer is a hydrologic unit of water-bearing rocks ranging in age from upper Miocene through Pleis tocene. The aquifer is comprised, from bottom to top, of parts or all of the following 


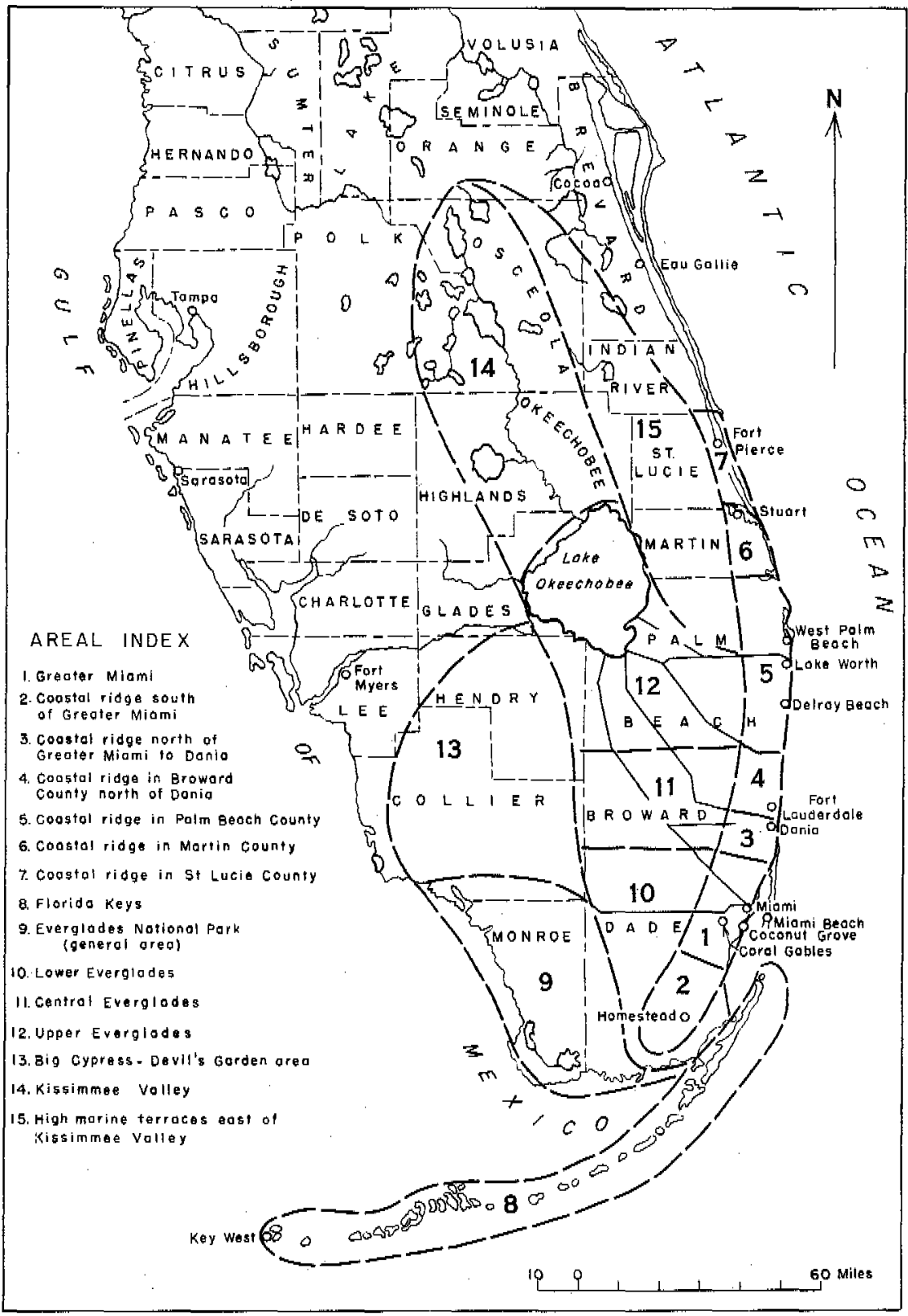

Figure 31, -Index map of southern Florida showing areas for which information on shallow nonartesian aquifers is given 
formations: (1) Tamiami formation (including only the uppermost part of the formation-a thin layer of the highly permeable Tamiami limestone of Mansfield); (2) Caloosahatchee marl (relatively insignificant erosion remnants and isolated reefs); (3) Fort Thompson formation (the southern part); (4) Anastasia formation; (5) Key Largo limestone; and (6) Pamlico sand.

The boundaries of the Biscayne aquifer seldom follow formational boundaries, but instead, they cut across according to the geohydrologic properties. Additional information on the geographic distribution of the aquifer and on the parts of the formations comprising the unit is presented throughout in the section on geology and in following. sections. The Biscayne aquifer rests upon the Floridan aquiclude (p. 189).

Several other shallow nonartesian aquifers exist in southern Florida, but they are of lesser importance. All aquifers will be discussed by areas in the sections that follow. (See fig. 31.)

\section{GREATER MIAMI AREA}

In a comprehensive report dealing with all aspects of the watersupply and related geologic factors, it is not possible to avoid some duplication of information; neither is it possible to bring together in one section all the data bearing on a particular subject. Thus, it will be noted that additional information on the early history and development of Miami's water supply will be found in the section on Salt-water encroachment.

\section{DEVELOPMENT OF WELLS}

Generally, wells are easily developed in the Biscayne aquifer. They are either of open-hole, rock-wall construction, or they are finished with a sand point. Most wells are of the former type and are from $1 \frac{1}{4}$ to 18 inches in diameter. They are used for domestic, industrial, and public supply, or for drainage. A common well in this area is 6 inches in diameter and from 50 to 65 feet deep (with 3 to 10 feet of open hole in highly permeable sandy limestone below the bottom of the casing). The yield ranges from 1,000 to 1,500 gpm with a drawdown during pumping of less than 4 feet; recovery occurs almost immediately after pumping ceases. Such wells can usually be drilled in 1 or 2 days by a crew using a standard cabletool rig.

The upper limestone of the Biscayne aquifer is ordinarily soft enough that pipe can be readily driven into it. Many people have installed their own wells for domestic or irrigation use simply by driving a piece of $1 \frac{1}{4}-$ to 2 -inch casing into the ground with a sledge 
hammer, withdrawing it and emptying the included rock materials, then reinserting the casing in the same hole and driving it deeper. By repeating this process, such a well can be put down to depths of 20 to 40 feet in a day without undue hardship. Of course, this can be accomplished much more easily by machinery. Small drilling. rigs using the jet-percussion method can install such a well in an hour or so.

In some parts of the Miami area, limestone is not present at shallow depths. Therefore it is necessary to use sand-point wells for development of supplies. Such wells can readily be driven either with a sledge hammer or with a light drilling rig.

\section{EARLY Y SUPPLIES}

Most early domestic supplies were obtained by driving casing by hand in the manner just described. As the population increased, wells of larger diameter were needed, and the first well-drilling rigs were built locally to do the work. The first drillers to operate permanently in this area were C. H. Perry, H. E. Kiser, and R. H. Magruder. These three well drillers deserve much credit for furnishing information on early water supplies in Miami. In addition, an interesting, though not entirely correct (geologically and hydrologically), account of these early developments is given by John Sewell (1933), from whose memoirs the following is quoted, with the permission of John Sewell, Jr.

"In starting Miami as a city one of the great problems was getting good water. As the city lies 6 to 18 feet above sea level, at the beginning everyone used a common pitcher pump hitched on a 2 inch pipe driven into the rock 10 or 12 feet. The rock formation being limestone naturally gave us hard water, which made a great many sick when we first began using $i t$.

"Harry Tuttle put down the firstbig well, which was about 50 or 60 feet deep, with 4-inch pipe and hitched a steam pump to it to furnish water for the Miami Hotel. [The Miami Hotel of which Mr. Sewell speaks is not the present one. The first Miami Hotel was built in 1896 on Avenue $D$ at what is now 235 South Miami Ave.] That was in the summer of 1896. Then Mr. McDonald had a similar well put down to furnish the water supply for the construction of the Royal Palm Hotel. [Built in 1896 on the north bank of Miami River where it empties into Biscayne Bay. ] But both these wells gave the hard limestone water, Later $\mathrm{Mr}$. Tuttle arranged with Mr. Flagler to put a pump at a big sulfur spring near the head of the Miami River, which was then known as the rapids, about 4 miles above the city, and piped the water to the city through a 6-inch pipe. The power house was built and a station established with a gasoline engine. We would carry the drums of gasoline up the Miami River 
on lighters, then put them on a little push car, and carry them about 200 yards north of the river to the station over a little narrow gauged railroad that we had built for the purpose. The station was located near what is now (1921) the J. W. Watson orange grove. [Exact location cannot be determined but it was not far from what is now NW. 27th Avenue and 22nd Street.] This station was run by Tom Ryan, one of our engineers of the Royal Palm construction force. This station remained for about one year, when it was decided to move the pumping station down to the city and suck the water the 4 miles instead of pushing it and the present (1921) standpipe [10cated at what is now the Florida Power and Light Co.'s steamelectric plant at SW. Second Avenue and the Miami Riverl was built to store the water supply which made conditions much better. The water supply was limited to a 6-inch supply as that was the capacity of the spring. While the water was good, we had to have a greater supply to draw from.

"Mr. Flagler sent a man here in the early part of 1898 to drill an artesian well near Avenue D and Sixth Street [now N. Miami Avenue and Sixth Street. Mr. Henry E. Kiser says that this well was abandoned at 65 feet and that he (Mr. Kiser) was the first driller ever to penetrate the artesian aquifer in this areal, about where the Drake Lumber Company's office now stands. This well was put down about 800 feet. The re was no flow-nothing but salt water-and this well was abandoned.

"Dan Cosgrove, Mr. McDonald's chief engineer, had ideas of his own about a water supply. There was a spring in Wagner's Creek near 4th Street and Avenue L [Avenue $L$ is now NW. Seventh Avenue and Fourth Street is now NW. Eighth Street] which had a larger flow than the one in the Everglades, where we were getting our supply. He figured that there was a subterranean stream running from the spring in the Everglades and this 4 th Street spring, making its way to the ocean. He never had an opportunity to experiment with his idea until 1899, when he was on construction of the Colonial House at Nassau, Bahama Islands, with Mr. MeDonald. While he was constructing this hotel for Mr. Flagler, Mr. Cosgrove's health gave away and he was not able to continue the job. Mr. McDonald sent him back to Miami to let him experiment with his water investigation. I got him up a bunch of men and tools and helped him start. He gothis lines and made his first experiment on what was then the golf grounds and where the present water reservoir now stands, at the east end of the Country Club Golf course [present NW. 11th Street and 10th Avenue]. He had an excavation made about 10 feet square and 5 feet deep, where he struck solid rock. Then he began drilling a 6-inch well and followed up with his iron pipe. He kept drilling until he got his pipe down between 50 and 60 feet in depth. I saw him every day and kept close track of the work. One night he came in and told me that he had struck flint rock, as he had not made an inch the whole day and had been drilling all the time, and he 
seemed terribly worried. But the next day before noon he came rushing in to see me and said he had struck his river. As the roof of the river caved in the water had rushed through the pipe with such a flow that it came very near drowning all of his Negroes before they could get out of the hole in the ground. He was highly elated at the flow of water, clear and pure. This proved that Cosgrove had the right theory. Cosgrove, to prove this theory was right, moved his plant down nearer the city on the same line and drilled a well between 4th and 5th Streets near Avenue L. This water tested out pure also-just as the first. Then he moved his plant still nearer the standpipe, near Avenue $G$ and 14th Street [at what is now SW. Second Avenue and SW. Second Street], where he drilled another well. This well tested out salty, which showed that he was near the outlet of the subterranean stream. He went back to the 4 th Street well and connected up his pipe with the pumping station and that was used for one year. When that well developed salt water from hard pumping it was abandoned and the permanent wells and reservoir were erected near the first well on the golf grounds and several additional wells put down, where we are still (1921) getting our water supply, only now we have a 30-inch supply line from the reservoir to the standpipe.

"In the spring of 1919 some of the wells sprung salt leaks [actually not 'leaks' at all but inland encroachment of the salt-water wedge from Biscayne Bay. See the section on Salt-water encroachment, p. 580-584], which gave the water supply some heavy criticism and caused prosecution of the water company for selling salt water, which they could not help. This case was tried in Key West, where the case was decided in favor of the water company. When these wells were originally put down they [that is, the tops of the well casing] were put below the water level where they flowed in a reservoir, as a regular artesian well, but later they had to connect pumps to these wells to get enough water for the city, and this hard pumping caused the salt water to appear, which created so much trouble with our water supply. After this trouble the water company decided not to get caught again. They started west, putting down wells about 50 feet deep and connecting them up with electric pumps, and now (1921) they have gone back $\frac{1}{2}$ mile farther west and have a number of wells with an electric pump for supply, which is, I think, the best system. Some claim the canal water filtered would be better, but in long dry spells the water gets very low in the canals and we would have to go back to our wells for a supply."

\section{EFFECTS OF DRAINAGE}

Effects of drainage will be rather thoroughly discussed in the section on Salt-water encroachment, p. 580-707, and are mentioned elsewhere in this report (see p. 9-11). The principal effect upon the water supply of the Miami area has been to set in motion a wedge 
of salty water encroaching inland into the fresh-water of the Biscayne aquifer, which has resulted, to date, in the loss of thousands of private supply wells along the coastline in Dade County, and the loss of two of Miami's well fields (Spring Gardens and Coconut Grove). See the section on Salt-water encroachment, p. 580 to 584 .

\section{PRESENT SUPPLIES}

The Biscayne aquifer (see p. 160 and 162) is the chief source of present supplies. Most municipalities in the Greater Miami area are served by the city of Miami's supply, which at present (1946) is obtained from 20 wells, ranging in depth from about 60 to 95 feet, in the Miami Springs-Hialeah area (see the section on Saltwater encroachment, fig. 189). The field was first put into service in 1925 and has been enlarged by the drilling of additional wells from time to time as occasion demanded. The average daily pumpage from this well field in 1946 was $36,600,000$ gallons.

This water is softened and the color is removed in a new and modern water-treatment plant. The water is used not only for domestic supply but also for industrial and commercial purposes, especially for industries and businesses located in areas where ground water was once fresh but is now contaminated by salty water.

Many air-conditioning units and condenser coils of industrial plants are cooled by water from wells at the site; but because of the salt-water encroachment, which has spread under most of the business, commercial, and industrial areas of Miami (see the section on Salt-water encroachment, figs. 168 and 200), treated city water that is used over and over again is generally replacing the salty and corrosive ground water from the supply wells of the salt-contaminated zone.

Some of the adjacent municipalities, such as Opa Locka, North Miami, and North Miami Beach, have their own public supplies. The wells are developed in the Biscayne aquifer and water is pumped from open-hole, rock-wall wells. Some neighboring communities, such as South Miami and Perrine, have no municipal water-supply systems. Instead, each family and building has its own private supply well.

The Miami area makes considerable use of wells for fire-fighting purposes. The Greater Miami area grew so fast that city water mains could not keep pace with the widely scattered and rapidly expanding population. In order to obtain large quantities of water to fight fires, wells have been drilled or dug at strategic locations over most of the settled areas. These wells average 6 inches in diameter and about 65 feet in depth; each will supply a pumper with at least $1,000 \mathrm{gpm}$, with a resulting drawdown that is usually less than 2 feet and rarely as great as 4 feet. 
For detailed information on municipal supplies of this area, for well logs, and for other pertinent data, see the Appendix,

\section{ATLANTIC COASTAL RIDGE SOUTH OF GREATER MIAMI IN DADE COUNTY}

\section{THE AQUIFER AND GROUND WATER}

Ground water with the smallest amount of coloring matter, in Dade County, occurs in the Kendall-Florida City area. The Biscayne aquifer underlies the entire area; it ranges in thickness from 60 to 100 feet and is composed principally of highly permeable sandy limestone that is very cavernous in places (note especially cross sections $A-A^{\prime}, B-B^{\prime}, C-C^{\prime}, D-D^{\prime}$, and $E-E^{\prime}$, in pls. 5, 6, 7, and 8). The hardness of the water is about equal to that of the Miami area, but the color of the untreated water (unless locally affected by iron oxide) compares favorably with the color of the treated water of the present (1946) Miami public supply.

The ground water in the Miami area and to the north under the Atlantic Coastal Ridge usually contains organic color ranging from 80 to 120 on the standard cobalt scale (see p. 730), but in the Kendall-Florida City area the color usually ranges from about 10 to 30. The difference in color of the raw ground water of the two areas is apparently due to the difference of materials comprising the land surface. In the Everglades, south of the latitude of South Miami, there is a deposit of gray to white marl and very little muck on the underlying rock surface, whereas north of this line the muck (decomposed organic materials) becomes progressively thicker toward Lake Okeechobee, until at the south shore of the lake it averages about 8 feet in thickness. The surficial materials of the coastal ridge in both the Miami and the Kendall-Florida City areas are almost identical, and so are the materials that comprise the Biscayne aquifer at depth; it is only on the surface, in the area west of the coastal ridge, that the materials are much different. Rainwater seeping through the black muck becomes highly stained by organic materials, whereas rainwater seeping through the white to gray marl gains only a slight amount of organic color. This is one of the proofs of the local origin of the ground water.

\section{DEVELOPMENT OF WELLS}

Homestead is the only incorporated municipality in the KendallFlorida City area that has a public water-supply system. The other communities (all small) and unincorporated areas are served by individually owned, private supplies. Most of the supply wells in this area are $1 \frac{1}{4}$ to $2 \frac{1}{2}$ inches in diameter, and the majority of these were hand-driven. They do not exceed 15 to 20 feet in depth because throughout much of the southern part of the area very hard layers of limestone are encountered at these depths (see cross sections $A-A^{\prime}, D-B^{\prime}, C-C^{\prime}$, and $D-D^{\prime}$, pls. 5-8). 
Most grove-irrigation and fire wells of the Kendall-Florida City area are 4 to 8 inches in diameter, but some are dug wells, and many are entirely uncased. Most of those put down prior to World War II were manually constructed and were only shallow wells because of the very hard limestone layers mentioned above. However, during the War labor became scarce and costly, a pair of drought years-(1944-1945) reduced the water table in some parts of the area to sea level or below (figure 45, water-table map), and many of these shallow wells thus became dry. Inability to obtain manual laborers, inability to dig through the hard limestone layers, and a shortage of qualified well drillers necessary to drill the deeper wells so urgently needed, forced many of the grove owners to look helplessly on while groves, gardens, and field crops wilted and died, or were seriously damaged.

For detailed information on well logs, pumpage, and other data from the Homestead public supply, the U. S. Navy supply for Key West and for other places in the area, see the Appendix.

\section{ATLANTIC COASTAL RUDGE NORTH OF GREATER MIAMI TO, AND INCLUDNG, DANIA IN BROWARD COUNTY}

\section{THE AQUIFER AND GROUND WATER}

The Biscayne aquifer is much sandier north of Miami than it is to the south, and in several places deep sand-filled channels cut entirely through the Miami oolite into the underlying Fort Thompson formation. These sand-filled cuts are called "transverse glades" because of their characteristic glades-type vegetation. They served as discharge channels for waters from the flooded Everglades prior to man-made drainage, and even yet, in times of heavy and longcontinued rains, they become occupied by shallow sluggish streams.

The ground water of this area is chemically comparable to that in the Miami well-field area, with organic color ordinarily ranging from about 80 to 120 on the standard cobalt seale, but in some cases reaching as high as 220 . In some parts of the area it is difficult to develop raw water that is free from iron oxide, which occurs erratically both horizontally and vertically in the aquifer. Often, changing the depth of a well by about 10 feet, or moving its location from one side of a building to the other, may be all that is needed to obtain water of low iron content.

Prior to drainage, the entire aquifer contained only fresh, potable ground water. Now, along the coastline, and in tongues extending inland varying distances along the tidal canals and streams, saltwater encroachment has taken place. This encroachment is not generally so extensive as in the Greater Miami area and southern 
Dade County, where there are more drainage canals and where the water table has lowered to a greater depth (see the section on Saltwater encroachment, fig. 200, which maps the area of encroachment in Dade County). See also the section on Characteristics of drainage basins and summaries of gaging-station records for seepage studies along North New River Canal.

\section{DEVELOPMENT OF WELLS}

Most of the private supplies in this area are obtained from the Biscayne aquifer through shallow driven wells, $1 \frac{1}{4}$ to $2 \frac{1}{2}$ inches in diameter, equipped with sand points. Most of these wells end in sandy oolitic limestone or quartz sand at depths of only 15 to 30 feet-most of these wells furnish copious supplies of water.

Wells for larger supplies are usually of open-hole, rock-wall construction, with as much as 15 feet of uncased hole below the end of the casing. These wells are finished in sandy limestone or calcareous sandstone and are bailed, surged, and pumped to free them of sand; then, as in the rest of southeastern Florida, they are usually equipped with centrifugal pumps. Depths of these wells range from about 45 to more than 200 feet (the deeper wells are in the northern part of the area). Data on well logs, public supplies, and other pertinent information are given in the Appendix. For data on water analyses, see also the section on Quality of ground and surface waters.

\section{ATLANTIC COASTAL RUGE IN BROWARD COUNTY NORTH OF DANIA}

In this area, the coastal ridge averages about 7 miles in width. It is composed chiefly of sandy oolitic limestone (Miami oolite) riddled with vertical solution holes (see the section on Geology, figs. 22 and 26), and is mantled with white quartz sand of the Pamlico sand. In places the sand is heaped into low, broad dunes probably formed in latest Pleistocene and Recent time.

The New River valley cuts through the coastal ridge between Dania and Fort Lauderdale. It is the widest and deepest of all the sandfilled Pleistocene cuts in southeastern Florida. The maximum depth to hard rock is about 100 feet.

\section{THE AQUIFER AND GROUND WATER}

The Biscayne aquifer in this area is composed chiefly of sandy limestone; beds of marly or clayey sand are common in the western part, and shelly sand or shell marl lenses are common throughout the area. Cementation of the sediments is very irregular, thus 
leading to the occurrence of considerable rock at the site of one well whereas no consolidated materials may be found at corresponding depths at an adjacent site.

The Fort Thompson formation grades into the Anastasia formation in this area (see section on Geology, p. 90-102, and figure 10.)

Because of the greater amount of unconsolidated materials (sand, silt, clay, marl, shells, etc.) in the Biscayne aquifer of this area than in the coastal ridge to the south, wells are not so easily constructed, and yields ordinarily are lower and drawdowns are greater. In the Miami area the coefficient of transmissibility, (T), ranges from about 2 to 20 million gpd per $\mathrm{ft}$, and averages about 5 million gpd per $\mathrm{ft}$ [see the section on Ground water (Quantitative studies), p. 270], whereas calculations of $T$ for the Fort Lauderdale well-field area indicate a value of about 1.2 million gpd per ft (Vorhis, 1948, p. 20-21). This value may not be valid for parts of this area nearer the ocean where the Biscayne aquifer is composed of a greater amount of permeable limestone and of a lesser amount of unconsolidated materials; values of $T$ approaching 3 million gpd per $\mathrm{ft}$ may be more nearly correct there.

See pages 373-374 in the section on Surface water for a study of ground-water inflow in Hillsboro Canal near Deerfield Beach. Water in the aquifer is generally similar in chemical characteristics to that in the coastal ridge from Palm Beach southward-that is, it is typical of limestone areas in southeastern Florida. In some parts of the area highly colored water is found. This color, which may exceed 200 on the standard cobalt scale, is caused by organic stain and is associated with the extensive muck and peat deposits of the vast Everglades. These organic soils lap upon the western shoulder of the coastal ridge and floor the transverse glades that cut into or through the coastal ridge in several places. The water from shallow depths and close to the muck deposits is usually more highly colored than the water from deeper parts of the aquifer and closer to the ocean. Iron oxide, which causes "red water," occurs erratically in the aquifer, and, as explained earlier (p. 168), may sometimes be avoided either by changing the depth of the well or by putting a well down on a different part of the property.

In some places, such as the Fort Lauderdale well-field area, salty ground-water residual from the Pleistocene high-level seas (p. $112-125$ ) occurs at depths as shallow as 165 feet below land surface. There, the salinity increases with depth and is a serious hazard to water supplies because the saline water might be drawn upward into the well field by long-continued and large-scale pumping. (See the Appendix for well logs and other data on supplies of this area; see 
also the section on Quality of ground and surface waters for information on the chemical quality of the ground water.)

\section{EFFECTS OF DRAINAGE}

The only part of the coastal ridge between Dania and the northern border of Broward County where effects of drainage on the ground water are noticeable is in the Fort Lauderdale area. There, the dredging of the North New River, South New River, and Dania Cutoff Canals, as well as numerous smaller channels in the metropolitan area, has effectively lowered the average height of the water table and has, through changing the natural balance between fresh and salt water, caused sea water to migrate inland on a broad front all along the coastal zone from Dania to and slightly beyond Fort Lauderdale.

Also, during times of drought when flow in the canals is reduced, sea water is free to advance inland as far as the control dams in the North New River and South New River Canals. Respectively, these dams are located approximately $7 \frac{1}{2}$ and 9 miles inland from the ocean.

When sea water flows inland in these canals, it seeps out through their sides and bottoms. This action has resulted in the formation of an irregular tongue of salty ground water extending inland from the ocean for a distance of more than 6 miles. This is a different type of encroachment from that mentioned above, although both types are a direct result of the effects of drainage canals and reclamation work in the Everglades.

This tongue of salty ground water is irregular with respect both to time and to place. It is caused by several factors, chief among them being: 1 . Changes in salinity of the canal water itself, which may range from concentrations of sea-water during time of drought to almost no salinity during rainy seasons. 2. Unequal opportunities for salty water to escape from the canals. (This inequality is caused by variable sedimentation of the canal bottoms and sides with respect to both time and place; seepage is small in a section of a canal that has a heavy deposit of sediment.) 3. Variations in permeability of the geologic materials through which the canals are dredged. (In a canal free of sediment, seepage of salty water outward into the aquifer will proceed rapidly in highly permeable materials, slowly in materials of low permeability, and essentially not at all in impermeable materials. Although there are no truly impermeable beds in the upper part of the Biscayne aquifer in New River basin, there are, in places, lenses or layers of fine sand, silty or clayey sand of low permeability, and limestones and sands of high permeability. Thus, the geologic conditions in the aquifer are a controlling factor in the rate of movement of salty water into or out of the aquifer.) 
These several factors are involved in the explanation of irregular occurrence of saline water in the aquifer of New River basin.

\section{DEVELOPMENT OF WELLS}

For general household purposes, or for lawn and garden irrigation, driven sand-point wells, $1 \frac{1}{4}$ to $2 \frac{1}{2}$ inches in diameter and ranging in depth from about 15 to 40 feet, are the most common. Where rock occurs at these shallow depths, sand points are not needed and open-hole, rock-wall wells are constructed. The rock is generally soft enough for well casings to be driven by hand,

For larger supplies, such as for citrus grove or farm irrigation, air conditioning, and fire fighting, most wells are drilled by the standard cable-tool method. Such wells range in diameter from 4 inches to as much as 18 inches and are usually 6 to 8 inches; the depth of the wells depends upon the depth to rock, because most of these wells are of open-hole, rock-wall construction and have 1 to 15 feet of uncased hole below the bottom of the casing. Yields in such wells compare favorably with those from similarly constructed wells in the Miami area-it is not unusual for a 6-inch diameter well to yield 1,000 gpm. Drawdowns, however, are usually greater than in the Miami area, ranging from 2 to about 10 feet.

Public-supply wells of Fort Lauderdale and the new municipalsupply well at Dania are of gravel-pack construction and have an average of about 40 feet of shutter-type screen placed in an enveloping wall of gravel. For detailed data on these and other wells in the area see the Appendix. Details on the quality of water may be found in the section on Quality of ground and surface waters.

\section{atlantic CoAstal RIDGe n PALM BEACH COUNTY}

THE AQUIFER AND GROUND WATER

The Fort Thompson formation, which is a major unit of the Biscayne aquifer in Dade and Broward Counties, grades into the Anastasia formation in the area between Delray Beach and West Palm Beach. The nor thernmost important occurrence of the Fort Thompson formation has been noted in well cuttings from the Delray Beach well field.

The areal and vertical distribution of limestone in this area is not uniform. Well logs for sites within 100 feet of each other may show entirely different figures for depth to rock and for thickness of rock-in fact, some wells may penetratelittle or no rock at all. The absence of rock in some of the areas may be a result of original 
lithologic differences, but generally this situation is caused by solution or erosion of the original limestone, and subsequent filling by sand.

The rock ranges from coquina to dense, hard calcareous sandstone, but ordinarily, it is sandy limestone. Generally, it is riddled with solution holes of varying size and extent, but many of the holes are definitely aligned. Core samples of the limestone from a test well (S 394) at Delray Beach are illustrated in figure 15.

The sand that overlies the rock and fills solution holes in it, or that occurs in beus and pockets beneath the top layer of rock, is composed principally of quartz grains with some worn shell fragments. The grain size ranges from very fine to coarse and averages in most places fine to medium; the degree of sorting in different places ranges from good to poor. Generally the sand is permeable.

In that part of the coastal ridge north of West Palm Beach the Fort Thompson formation disappears entirely, and materials of the Anastasia formation and the Caloosahatchee marl compose the deeper part of the aquifer. These materials range from sand to shell marl and in some places, where cementation has taken place, to irregular local lenses of sandy or shelly limestone.

Water in the aquifer of this part of the coastal ridge is a typical calcium bicarbonate type water, and is very similar to that described for the area immediately to the south. "Iron water" is not uncommon, but generally it can be avoided if care is taken in selecting the depth and location of the well, because it is not uniformly present in the aquifer. Color, other than iron, is of organic origin and usually ranges from about 20 to 110 and averages about 35 (standard cobalt scale).

\section{EFFECTS OF DRAINAGE}

Whereas in Dade and Broward Counties the program of draining the Everglades has had a serious effect on the coastal ground water in the Biscayne aquifer, it has had little effect in Palm Beach County. This is largely because of the maintenance of a higher water table in Palm Beach County through a system of carefully operated water-control districts, such as the Lake Worth Drainage District. Also, the geologic. materials composing the aquifer in Palm Beach County are generally of much lower permeability than in the Miami area, and salt-water encroachment would not be as rapid even if the water table were lowered enough to induce it.

Thus, salt-water encroachment in Palm Beach County to date is not of major importance; wells 80 to 100 feet deep near the 
shoreline of Lake Worth (a salt-water lagoon) can stillobtain potable water, as similar wells once did in Dade and Broward Counties, prior to drainage.

\section{DEVELOPMENT OF WELLS}

In the area from Delray Beach southward, wells 4 to 18 inches. in diameter are commonly of open-hole, rock-wall construction, with 1 foot or more of open hole in the rock below the bottom of the casing. However, in some places the solution-riddled character of this rock is a serious hazard to the development of such wells. Even though the casing is set and firmly seated in the rock, solution holes connecting (either directly or tortuously) with the overlying sand can funnel sand into the well. This will cause land-surface subsidence if the driller bails or pumps too much sand out of the well he is attempting to develop. This occurred in 1947 at the site of an 18-inch well being drilled for the city of Delray Beach by J. P. Carroll. The situation was remedied by installing a screen in the well; thus preventing the sand from entering.

North of West Palm Beach most of the larger wells in the Biscayne aquifer are deveioped with screens and yield large quantities of water with relatively small drawdowns. Gravel-packed wells, which are really screened wells in an enveloping pocket of artificially placed gravel, have been developed in some places and produce excellent yields, Large-diameter, open-hole, rock-wall wells north of West Palm Beach are rare, but many smaller-diameter wells ( 45 to 100 feet deep) are in service and yield copious supplies of potable water.

Shallow, driven or jetted wells, $1 \frac{2}{4}$ to $2 \frac{1}{2}$ inches in diameter, furnish most rural family supplies and are commonly used in the urban areas for garden and lawn irrigation. These wells are generally less than 30 feet deep and can be put down manually, or by light drilling rigs, in a very short time.

\section{ATLANTIC COASTAL RIDGE IN MARTIN COUNTY}

\section{THE AQUIFER AND GROUND WATER}

The aquifer of the coastal ridge area of Martin County is generally not so sandy as in the northern part of Palm Beach County. This is shown by the selected well logs for these areas, given in the Appendix.

In some parts of the area Pamilico sand is heaped in Pleistocene dunes and beach ridges to heights of as much as 50 feet above sea level. Materials of the Anastasia formation underlie these sands 
and range from coquina and shelly limestone to shell and quartz sands. Beneath the Anastasia formation are irregularly cemented sands and shell marls or clayey marls, sand, and silt of the Caloosahatchee marl. Generally, these materials act as one waterbearing unit (aquifer), but locally, layers of hardpan (such as that at Indian Town, see p.193) or dense marly material (such as that at Fort Pierce, see p.195-196), separate the uppermost part of the aquifer and create local low-pressure artesian aquifers. Where these low-pressure artesian aquifers extend seaward beneath Indian River or the Atlantic Ocean it is possible to develop shallow (35 to 100 feet) wells that furnish potable water, even though the water in the overlying materials may be as salty as sea water. Such areas are exemplified at Jensen Beach, Sewell's Point, and Salerno.

The beach ridge and dune sands contain soft, slightly acidic water, as contrasted to the typically hard, alkaline, calcium bicarbonate water in the calcareous rocks of the lower part of the aquifer. The color of the ground water is usually low, ranging from about 10 to 50 (cobalt scale). (See the section on Quality of ground and surface waters, for analyses of typical waters.)

\section{EFFECTS OF DRAINAGE}

Drainage of the Everglades has had no noticeable effect on the ground water of the coastal area of Martin County.

\section{DEVELOPMENT OF WELLS}

Most supplies for homes and for small business or commercial houses are usually obtained through $1 \frac{1}{4}$ - to $2 \frac{1}{2}$-inch driven wells finished with sand points at depths of 15 to 40 feet below land surface. Such wells are easily constructed, either manually or by light drilling rigs, and furnish plentiful supplies of potable water. Some of these small private wells are of open-hole, rock-wall construction, finished with 1 foot or more of uncased hole below the bottom of the casing in the permeable rock.

Larger supplies require bigger wells. Examples of these are the Hobe Sound public-supply wells, which are 12 inches in diameter and range in depth from 78 to 117 feet. They are of open-hole, rock-wall construction. The wells at nearby Camp Murphy are also 12 inches in diameter and average about 100 feet in depth. These wells, however, are of gravel-pack construction. All are capable of yielding large supplies (in excess of $1,500 \mathrm{gpm}$ ). At Stuart, numerous open-hole, rock-wail wells, 4 to 6 inches in diameter, ranging in depth from 47 to 88 feet and averaging about 65 feet, are in use. There are three municipal public-supply wells at Stuart, ranging from 75 to 85 feet in depth. (See Appendix.) 


\section{ATLANTIC COASTAL RUGE IN ST, LUCIE COUNTY}

THE AQUIFER, GROUND WATER, AND DEVELOPMENT OF WELLS

The coastal ridge south of Fort Pierce is generally much flatter, wider, and of lower altitude than the area of high sand dunes and parallel beach ridges north of the city. In this lower southern part a long, shallow, swampy, muck-bottomed swale, called the Savanna, parallels and lies west of the high, narrow beach ridge that borders Indian River. The Savanna is about 13 miles long, averages about $\frac{1}{4}$ to $\frac{1}{2}$ mile wide, and terminates to the nor'th at the southern limits of Fort Pierce. There, the municipal water-supply plant has been built, and the well field has been developed.

A shallow hardpan underlies much of the coastal ridge in St. Lucie County and prevents or retards free movement of water from the land surface to the shallow aquifer. The uppermost part of the shallow aquifer at Fort Pierce is separated from the lower part by a relatively impermeable marly layer about 10 feet thick. This, together with the east-sloping structure of the geologic formations, gives rise to the development of a shallow, low-pressure artesian system (see p. 194-195 and figs. 36 and 37). A similar occurrence was described previously for the coastal area of Martin County (see p. 174-175).

Above this shallow, low-pressure artesian aquifer the ground water occurs under water-table condition's in the pores and interstices between the sand grains, and it can be recovered through shallow, driven, screened wells. In that part of the area lying south of Fort Pierce and west of the Savanna, the water is soft but usually has an objectionably high color (around $200^{\circ}$ on the standard platinumcobalt scale). North of Fort Pierce in the high dune area, and south along the narrow beach ridge that lies between the Savanna and Indian River, similar ground water, with organic color ranging from 10 to 50, can commonly be obtained. To obtain this water, screened wells are usually driven to depths of about 15 to 50 feet, depending upon the elevation at the well site.

\section{THE FLORIDA KEYS}

THE AQUIFER, GROUND WATER, AND DEVELOPMENT OF WELL $\$$

The only fresh water that occurs in the rocks of the Florida Keys floats as a thin lens of varying thickness on the underlying salt water of each of the larger keys-the smaller keys usually lack this freshwater lens. During the rainy seas on the fresh-water lenses increase somewhat in thickness, but during the dry season, even with no pumping, the fresh water tends to disappear rapidly through seepage to the sea and by evapotranspirative processes. The rocks are 
very permeable and the water table of each key undulates with the tides. Thus, rainwater escapes readily to the sea, and salt water finds free access to the permeable rocks.

In order to obtain information about the effect of tides on the ground water of the larger keys, an automatic water-stage recorder was placed in operation during the last week of May 1941 on a fire well (F 628) located near the center and on one of the highest parts, of Key West, where the land is about 10. 5 feet above mean sea level. In this well, the maximum tidal fluctuation was 0,79 foot, whereas in the nearby ocean the maximum fluctuation during the same tide was 1.9 feet. During low tides, water in the well stood an average of 0.69 foot above ocean level, but during high tides, the ocean level stood an average of 0.04 foot above water level in the well. There was a lag of only a few minutes between the time that the maximum high or maximum low occurred in the well and the corresponding high or low occurred in the ocean. Similar results were obtained when a recorder was mounted on the CCC Camp well (S 701), on Big Pine Key.

Samples of water from most wells in the Florida Keys were obtained and brought to the laboratory for analysis. This study showed that even though the sampling period closely followed a period of heavy rains, no supply (even the shallowest) was entirely free of sea-water contamination and some were heavily contaminated.

Key West and Big Pine Key contain the largest quantities of fresh water; they have the greatest potential supplies of any of the Keys. However, these supplies are strictly limited, and pumpage of several thousands of gallons per day, even during the rainy season, would soon exhaust the fresh water.

Deeper wells, including one more than 15,000 feet deep (see section on Geology, p. 61) have not encountered fresh water, nor should any be expected because the piezometric map of the Floridan aquifer (fig. 35 ) indicates that the artesian pressure in the area of the Florida Keys is too low to hold sea water out; or to state it another way, the artesian pressure is toolow to force fresh water into the aquifer in this area.

Fire wells can be easily and quickly made anywhere in the Florida Keys at depths ranging from a few feet to more than a hundred feet. Most fire wells on Key West are entirely uncased and are of openhole, rock-wall construction. These wells range in diameter from 8 to 18 inches and are about 52 to 85 feet deep. Each well will supply several thousand gallons per minute of sea water. 
THE eVERGLades national PARK AREA

\section{AREA DEFINED}

The area included is approximately that now within the Everglades National Park. It is shown as Area 9 on the index map (fig. 31 ) and includes the southwestern part of the lower Everglades and Big Cypress Swamp (see the section on Geomorphology, p. 144-145 and 147-151) and parts of the Mangrove Swamps and coastal marshes (see section on Geomorphology, p. 154). It is one of the last remaining areas of primitive tropical wilderness on the North American continent.

\section{THE AQUIFER AND GROUND WATER}

Information on the artesian aquifers of this area is given on pages 188-197. The Biscayne aquifer in which nonartesian water occurs is composed chiefly of rocks of the Miami oolite and Fort Thompson formation. These rocks are riddled with solution holes and are highly permeable. It is believed that a coefficient of permeability of about 50,000 (see section on Quantitative ground-water studies, p. $236-237$ ) would be proper for these rocks. The aquifer is not thick, however; at the Tamiami Trail it is only about 20 feet thick, and to the south, at the site of test well GS 30,13 miles southwest of Royal Palm State Park (see Appendix) it is about 30 feet thick. No tests have been made to determine its thickness at Cape Sable, but it is believed to be about the same thickness as at well GS 30 .

The quality of the water in the area several miles inland from the Bay of Florida or the Gulf of Mexico, or from tidal canals and ditches connecting with salt water, is good; it is a typical calcium bicarbonate type water. But salt water occurs in the coastal area and in an indefinitely defined zone extending inland along the tidal canals or ditches (such as that along Florida Route 27, the Florida City-Cape Sable Road). Samples from GS 30, taken in September 1943, indicate that, even this far inland, salt-water encroachment has taken place. At 16.3 feet below land surface, the chloride content was 490 ppm;at 28 feet below land surface, it was $2,920 \mathrm{ppm}$; and at 34 feet, it was $3,750 \mathrm{ppm}$.

\section{DEVELOPMENT OF WELLS}

Satisfactory fire wells could be made anywhere in this area at depths of about 10 to 30 feet, and excellent wells for potable water could be developed at similar depths seyeral miles inland from sources of sea water. These wells could be dug, drilled, or driven and finished as open-hole, rock-wall wells capable of yielding as 
much as several thousand gallons per minute. However, if permanent supplies of this magnitude were developed it would be essential to stay as far away from salt-water sources as possible to prevent contamination by encroachment of sea water.

\section{THE LOWER EVERGLADES}

\section{AREA DEFINED}

The area included extends from the arbitrarily chosen southern line of Broward County on the north to the Everglades National Park area and the Bay of Florida on the west and south and to the Greater Miami area on the east. Its boundaries are approximately those shown in Area 10, figure 31 .

\section{THE AQUIFER AND GROUND WATER}

Principal components of the Biscayre aquifer in this area are the Fort Thompson formation and the Miami oolite. Their relations to each other and to the "basement" or relatively impermeable floor of the aquifer are shown in the geologic cross sections of Dade County, especially on plates 8 and 9 , sections $" F, C-G$, and $J-J^{\prime}$. In general, the aquifer is wedge-shaped and is thinnest toward the west. At the western boundary of Dade County the aquifer is about 15 feet thick; in the vicinity of the Dade-Broward levee it is nearly 50 feet thick; and in the area just west of Miami Springs it is about 90 feet thick.

In approximately the eastern third of this area the aquifer is generally highly permeable. The data obtained from a pumping test made on well G 218 (see the section on Ground water, Quantitative studies, p. 272-274) indicates a coefficient of transmissibility of about 4 million gpd per $\mathrm{ft}$. Because the aquifer in this area is only about 50 feet thick, the coefficient of permeability is about 80,000 .

To the west, the Biscayne aquifer becomes thinner and generally less permeable because the rocks of the Fort Thompson formation are denser and the sandy sections are composed of finer grades of sand. The Miami oolite, however, is even more permeable to the west than to the east. It is through this thin layer of oolitic limestone that much of the ground-water flow to the east occurs.

Although it is generally more highly colored, the ground water in this area is very similar in quality to water obtained from the Miami well-field area. 
Wells of open-hole, rock-wall construction can be easily made in this area and, if properly finished, will yield copious quantities of water with very slight drawdowns.

\section{THE AREA WEST OF HIALEAH}

Figures 32, 33, and 34 show contours on the water table representing periods of high, intermediate, and low water stages in the area. west of Hialeah, which is located in the eastern part of the

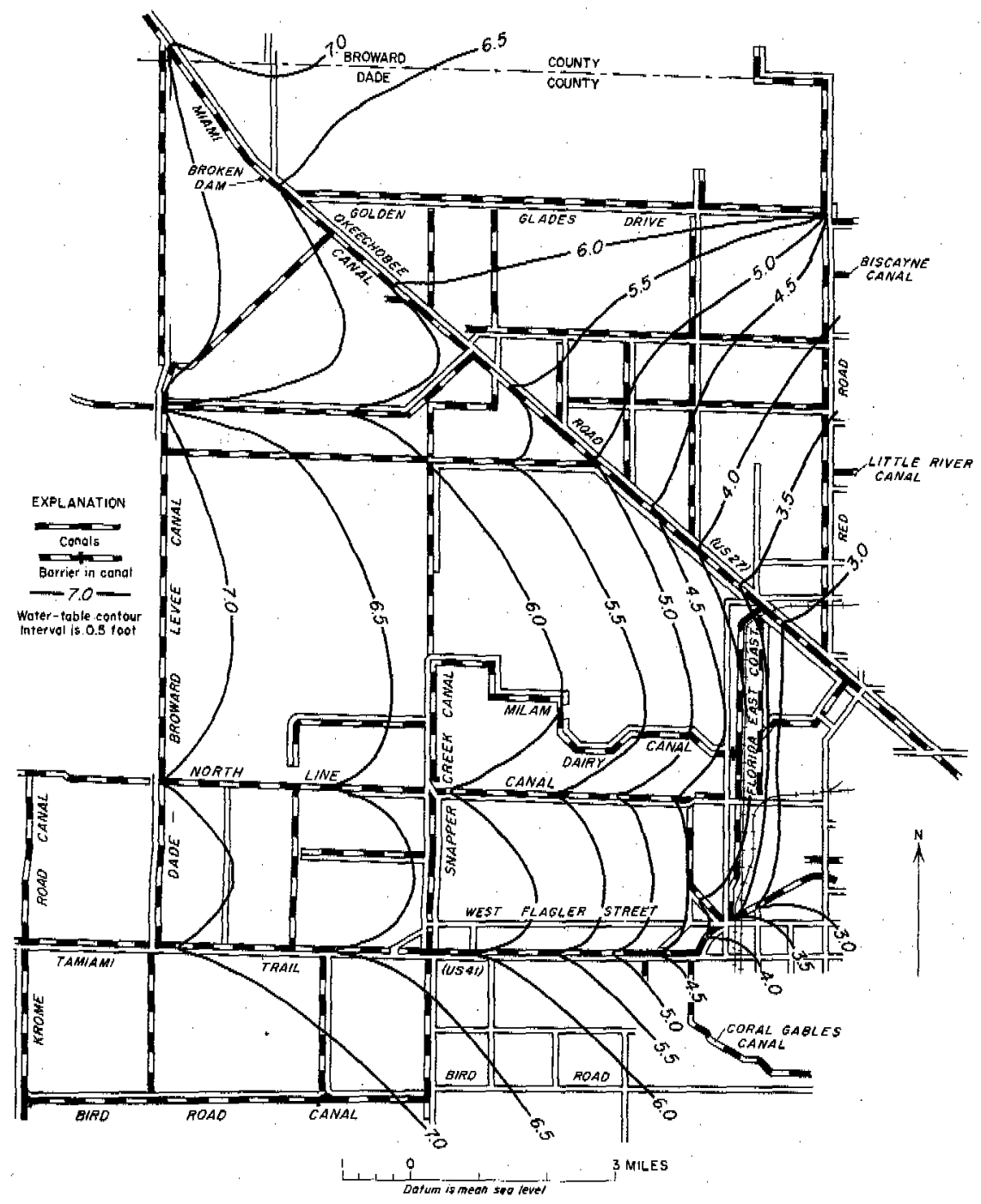

Figure 32. - Map of area west of Hialeah showing water table at high level on July $1,1942$. 


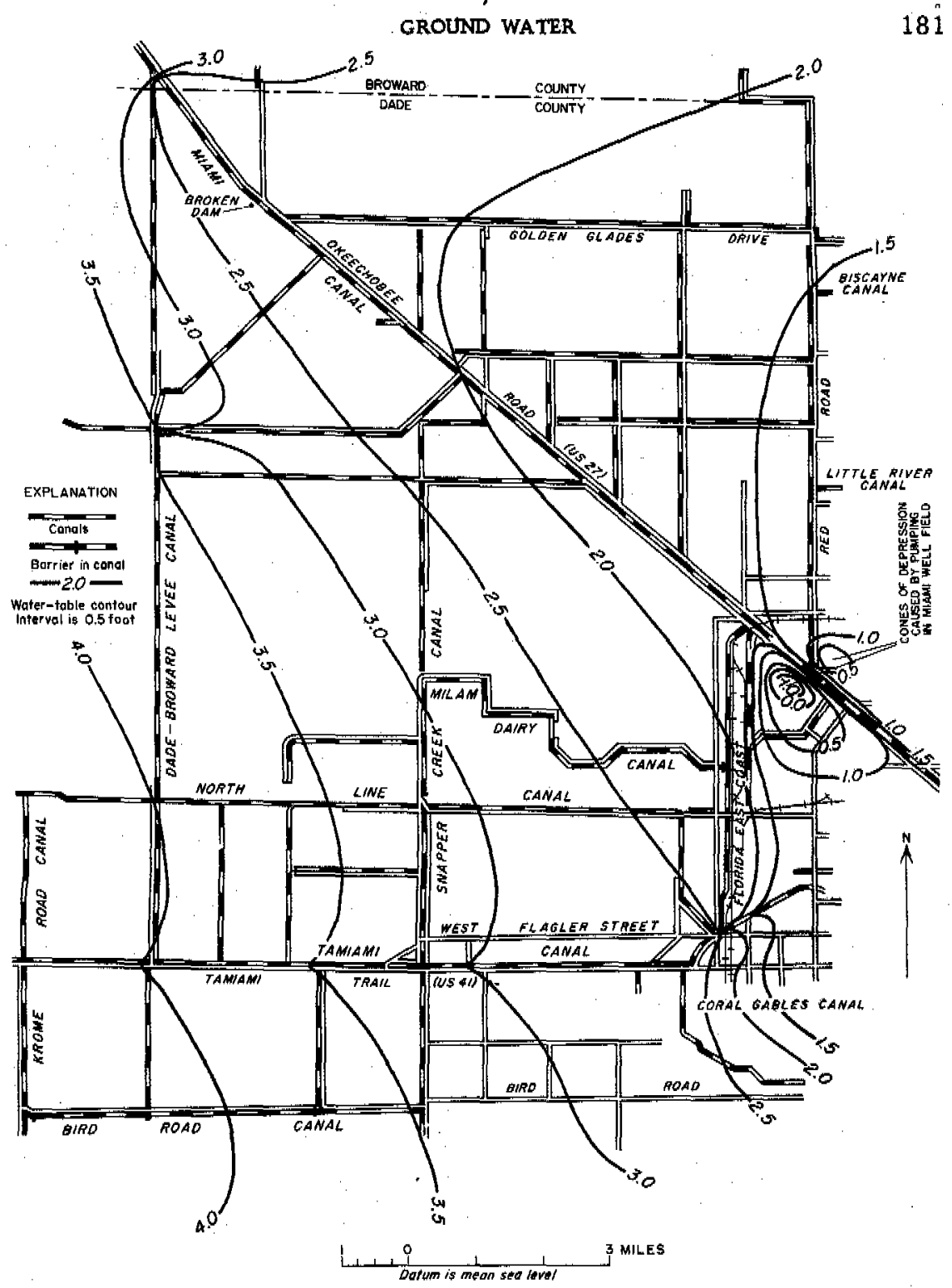

Figure 33. - Map of area west of Hialeah showing water table at intermediate level on April 26, 1946.

lower Everglades area. Lack of flow and stage data on some of the minor canals and ditches has made it necessary to interpolate the relationship of ground-water levels to the stage in the canal in these areas.

Figure 32 shows water-table conditions approximately as they exist during times of high water levels in the area. The water-table contours show that the movement of the ground water is to the east and southe ast, except in areas adjacent to the larger canals. During such a period of high water level (June-July 1942), approximately 
75 percent of the area was inundated and a small amount of overland flow occurred.

Water-table conditions as they exist during times of intermediate water levels are depicted on figure 33. During these periods, water levels are about 3 feet lower than those shown on figure 32 , and the effect of the Miami Canal on ground-water flow is much more pronounced and extends over a considerably larger area. At the time of this study (April 1946), the water table was below the land surface over the entire area.

Figure 34 shows water-table conditions for a period of extremely low water levels, which occurred during the drought in the early

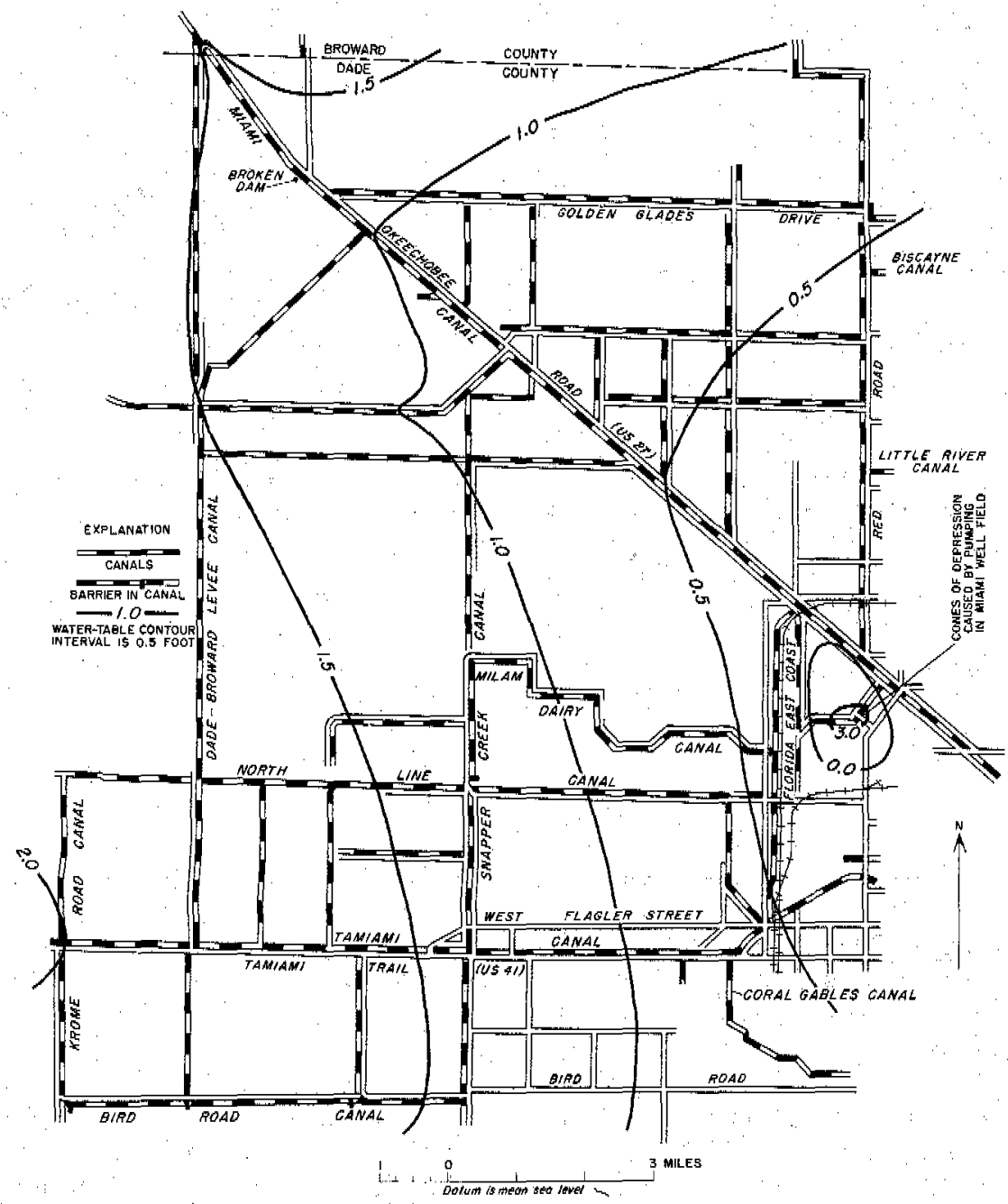

Figure 34. - Map of area west of Hialeah showing water table at low level on May 19, 1945. 
part of 1945. The water level in approximately half the area is less than a footabove mean sea level and the level in the remaining part is less than 2 feet above mean sea level. The direction of ground-water flow is about the same as at higher stages, but owing to the low gradients of the water table, the rate of movement is low. It is readily apparent that because of the low water levels as shown on this map, the western boundary of which is 15 to 20 miles inland from Biscayne Bay, salt water has easy access into the aquifer along the coastal areas and uncontrolled tidal canals.

\section{SEEPAGE}

The rock at, or near, the surface in this area is highly permeable and permits a large amount of seepage through the aquifer beneath levees. The amount of seepage under the levees varies from time to time, and from place to place, and is determined by the difference in head of the water on either side of the levees and by the coefficient of transmissibility of the Biscayne aquifer in the immediate locality.

THE CENTRAL EVERGLADES

AREA DEFINED

The area consists of Broward County west of the coastal ridge; its boundaries are roughly those shown in Area 11, figure 31.

\section{THE AQUIFER AND GROUND WATER}

The aquifer in this area represents a transition zone from very high permeability in the southern part of the area to low permeability in the northern part. The principal components of the Biscayne aquifer in the eastern and southern parts of the area are the Fort Thompson formation and the Miami oolite; in the western and northern sections the aquifer is composed of the Fort Thompson formation and the Caloosahatchee marl. The Fort Thompson formation grades into the Anastasia formation in the latitude of Fort Lauderdale (fig. 10).

The quality of shallow ground water in the central Everglades follows about the same pattern as the areas of high and low permeability; that is, water of better quality is in the areas of higher permeability, and water of poorer quality is in the areas of lower permeability. The quality of water in the eastern and southern parts is similar to that of the coastal ridge; however, the color may be somewhat higher because of the overlying organic soils. In the remainder of the area the water is generally of higher mineral con- 
tent and salinity. This is probably due to the fact that the aquifer. being of low permeability, has not been completely flushed of water deposited there during Pleistocene high-level seas. Well logs and other pertinent information are given in the Appendix; data on water analyses are given in the section on Quality of ground and surface waters.

\title{
DEVELOPMENT OF WELLS
}

Wells of open-hole, rock-wall construction can easily be made in the area, except perhaps in the extreme northern and western parts where, owing to the lack of consolidated rocks, screened wells may be necessary.

\section{SEEPAGE}

The amount of seepage through the aquifer beneath levees in the area is controlled by head differential of the water on either side of the levees, and by the transmissibility of the aquifer in the immediate area involved. In areas underiain by porous oolitic limestone, or by quartz sand, the seepage rate is relatively high, and in areas underlain by the dense limestones of the Fort Thompson formation, or by marl (Lake Flirt Marl), it is comparatively low. In the eastern and southern parts of the area the rate of seepage through the aquifer beneath levees is relatively high, and toward the north and west it becomes progressively lower. (See pages 291 , 375-386, section on Characteristics of drainage basins and summaries of gaging-station records, for seepage studies along North New River Canal.)

\section{TIE UPPER EVERGLADES}

\author{
AREA DEFINED
}

The area included in this description extends from Broward County on the south to, and including, Lake Okeechobee on the north, and from the coastal ridge on the east to the Devil's Garden area on the west. It includes practically all areas of muck and peat soils under cultivation in the Everglades, and it also includes the Hillsboro Lakes Marsh area. The boundaries are roughly those shown in area 12 , figure 31 .

The principal components of the aquifer in this area are the Caloosahatchee marl and the Fort Thompson formation, except in 
the extreme eastern part where the Fort Thompson grades into the Anastasia formation.

The permeability of the Caloosahatchee marl and the Fort Thompson formation varies considerably but, as a whole, the formations in this area are of relatively low permeability, and some wells ending in them yield little or no water. In the upper Everglades area the yield to wells is usually small, and the water is always hard, colored, and often highly mineralized. The high mineralization of the water is probably the result of Pleistocene invasions by the sea during interglacial ages and subsequent partial flushings or dilutions by fresh percolating ground waters. Some wells developed in the more permeable sand and shell beds of the Fort Thompson form ation yield usable water because the rocks have been flushed of sea water. However, long-continued pumping has been known to cause residual mineralized water to be drawn from adjacent unflushed zones of lower permeability, resulting in some instances in the abandonment of wells. (See the section on Quality of ground and surface waters, for data on water analyses; see also the Appendix for well logs and other pertinent information.)

\section{DEVELOPMENT OF WELLS}

Both open-hole and screened wells are constructed in the area. However, most wells are of small diameter and are equipped with a sand point. The large-diameter wells also are usually screened, and sometimes they are gravel-packed. The yields from wells in this area are relatively small compared with yields from wells along the coastal ridge.

\section{SEEPAGE}

The amount of seepage through the aquifer underneath levees in the upper Everglades is small enough that effective and economical water control on producing agricultural lands could be maintained. Likewise, according to preliminary studies, the amount of underground flow from Lake Okeechobee into the Everglades is very small. This fact is partly borne out by the presence of considerable chloride in the ground water at shallow depths adjacent to the lake, while the chloride content of Lake Okeechobee is very low. (See pages 291, and 375-386, section on Characteristics of drainage basins and summaries of gaging-station records, for seepage studies along North New River Canal.) 
THE GG CYPRESS-DEVU'S GARDEN AREA

AREA DEFINED

The area included in this description extends from the Everglades on the east to the low sandy flatlands on the west and from Glades County on the north to the Tamiami Trail on the south. The Big Cypress Swamp is in the southern part of the area and the Devil's Garden, including Okaloacoochee Slough, is in the northern part. The boundaries are approximately those shown in Area 13 , figure 31 .

THE AQUIFER AND GROUND WATER

The principal components of the aquifer are the Pamlico sand, the Anastasia formation, the Fort Thompson formation (northern part of the area), and the Tamiami formation (southern part of the area). Owing to the thinness of the aquifers and the type of material (usually sand, marl, shell marl, shell beds, and solution-riddled limestone filled with sand) the permeability and yield are generally low. The quality of water from wells varies considerably over the area but in general, although most wells yield potable water, it is rather poor. (See the section on Quality of ground and surface waters; see also Appendix for well logs, and p. 810 for water analyses of wells GS 4 and 5.)

\section{DEVELOPMENT OF WELLS}

Because the area is very. sparsely populated, only a limited number of wells have been developed. Practically all are shallow (10 to 30 feet), small-diameter, sand-point wells, which were developed for domestic use. Except in the southern and southwestern parts of the area, yields from the shallow aquifers are small.

\section{THE KISSIMMEE VALLEY}

\section{AREA DEFINED}

The Kissimmee valley, as designated here, is principally the drainage basin of the Kissimmee River; it extends from Lake Okeechobee on the south to the town of Kissimmee on the north and is about 35 miles wide and 80 miles long. Its boundaries are approximately those shown in Area 14, figure 31 . 
The principal shallow aquifer is composed of the marine-terrace sands of Pleistocene age which mantle the entire area and which range from 1 foot to about 25 feet in thickness. Wells, necessarily screened in these unconsolidated sands, yield potable water; however, in many instances a high color makes the water objectionable. It is possible to develop wells of small yield below the surficial sand deposits in some areas, but usually the water is highly mineralized. This mineralization is a result of low permeability of the materials, which has prevented completeflushing of the water that was left when the Pleistocene seas flooded this area. (See the section on Quality of ground and surface waters for water analyses; see also Appendix for well logs and other pertinent data.)

\section{DEVELOPMENT OF WELLS}

Where large yields are required, wells are usually developed in one of the deeper artesian aquifers. Generally, however, smalldiameter sand-point wells, driven deep enough into the terrace sands to be below dry-season low levels of the water table, will furnish potable water for domestic use. Batteries of such wells will yield water for public-supply systems of small communities.

\section{THE HGH MARINE TERBACES EAST OF KISGMMEE VALLEY}

\section{AREA DEFINED}

This area extends from Palm Beach County on the south to the latitude of Melbourne on the north and from the Kissimmee valley area on the west to the coastal ridge and St. Johns valley on the east. Its boundaries are approximately those shown in Area 15, figure 31 .

\section{THE AQUIFER AND GROUND WATER}

The Pleis tocene marine-terrace materials, the surfaces of which range 25 to 100 feet above mean sea level, are the principal components of the aquifer in this area. The aquifer is principally clean quartz sand and sand containing varying amounts of marl and clay. In general, shallow wells, 10 to 30 feet deep will yield small amounts of potable water in areas where the sand does not contain too large a percentage of marl or clay. However, in some areas the water from shallow wells has a very high color, which is caused by organic materials. The materials under the terrace sands are usually of such low permeability that satisfactory wells cannot be developed. (See the section on Quality of ground and surface waters, for water analyses; see also Appendix for well logs and other pertinent data.) 


\section{DEVELOPMENT OF WELLS}

There are relatively few wells in the area. However, in most parts of the permeable sand layers of the marine terraces, screened wells could be developed that would yield potable water for domestic use, and in many instances fairly large supplies could probably be obtained.

\section{ARTESIAN WATER}

\section{GINERAL STATEMENT}

At the present time, very little artesian water is used in southeastern Florida. This is because of the relatively poor quality of the water, and also because the artesian aquifer is deeply buried and therefore expensive to tap. (See the section on Quality of ground and surface waters, table of analyses of artesian waters.) In general, the artesian water is saline, sulfurous, and corrosive. In southwestern Florida, especially in the area adjacent to the city of Everglades, in Collier County, one of the artesian aquifers supplies most of the water used. This is not because the water is of satisfactory quality, but because it is the best obtainable.

In southeastern Florida there is only one productive artesian formation, the Floridan aquifer, but in most of the remainder of southern Florida there may be several productive shallow artesian aquifers, each with its own characteristics. They are described below in the section entitled Shallow artesian aquifers (see p.193-197).

\section{THE FLORIDAN AQUIFER AND AQUICLUDE}

The principal geologic formations carrying artesian water in the Florida peninsula, as described by Stringfield (1936), are the Ocala limestone of Eocene age and the Tampa limestone and Hawthorn formation of Miocene age. Earlier reports (Matson and Sanford, 1913 , p. 67) included the Ocala limestone as part of the Vicksburg group, which is of Oligocene age. In 1928, the Ocala limestone (Cooke and Mossom, 1928, p. 48) was regarded as having a-maximum thickness of about 500 feet, but according to more recent paleontological evidence the maximum thickness of the Ocala limestone is considerably less than that (see p. 69, and table, p, 67).

However, the Avon Park, Lake City, and Suwannee limestones (formations formerly included in the Ocala) have hydrologic and lithologic properties similar to that of the Ocala limestone and, together with the Tampa limestone and the lower limestone part of the Hawthorn formation of Miocene age, act as a hydrologic unit. In discussing this hydrologic unit in northeastern Florida and the 
coastal area of Georgia, Stringfield (Stringfield, Warren, and Cooper, 1941, p. 698-711) refers to it as the Ocala and associated limestones. Parker and Hoy (in press) called it the "principal artesian aquifer." It is here designated the Floridan aquifer and includes parts or all of the middle Eocene (Avon Park and Lake City limestones), upper Eocene (Ocala limestone), Oligocene (Suwannee limestone), and Miocene (Tampa limestone, and permeable parts of the Hawthorn formation that are in hydrologic contact with the rest of the aquifer).

Overlying the Floridan aquifer, and confining its water under artesian pressure, is a wedge-shaped blanket composed of one or more geologic formations of relatively low permeability. This confining unit, which is herein called the Floridan aquiclude, is nonexistent or very thin in the recharge areas of the Floridan aquifer, but it becomes very thick in all seaward directions and is about 600 feet thick in the Miami area.

The term "aquiclude" was proposed by Tolman (1937, p. 36) to describe a geologic unit that, although porous and capable of absorbing water slowly, will not transmit it quickly enough to furnish an appreciable supply for a well or spring.

The Floridan aquiclude, as here defined, is comprised chiefly of clays, silts, marls, dense limestones, and fine sediments with greater or lesser admixtures of sand, fine gravel, and shells-all these are materials of extremely low permeability, chieflybelonging to the Hawthorn and Tamiami formations of Miocene age. In southeastern Florida, the Floridan aquiclude not only caps the Floridan aquifer, it also forms the relatively watertight foundation upon which the Biscayne aquifer rests (p. 160 et seq.).

\section{DISTRIBUTION}

The Floridan aquifer underlies all of Florida and parts of the adjacent States of Georgia and Alabama. In southern Florida it is deeply buried, being about 900 feet below sea level at Miami and 800 feet at Everglades City. The Floridan aquiclude is less extensive because it is absent, or very thin, in the areas of recharge to the aquifer.

\section{ARTESI AN PRESSURE}

The piezometric surface of the Floridan aquifer in Florida was mapped by Stringfield (1936, p. 135; 1938, p. 457-458), and the surface in southeastern Georgia was mapped by Warren $(1944, \mathrm{p}$. 18-a). Later editions of the map were prepared by Cooper (1944, p. 175; Cooper and Warren, 1945). The map in figure 35 is a product 


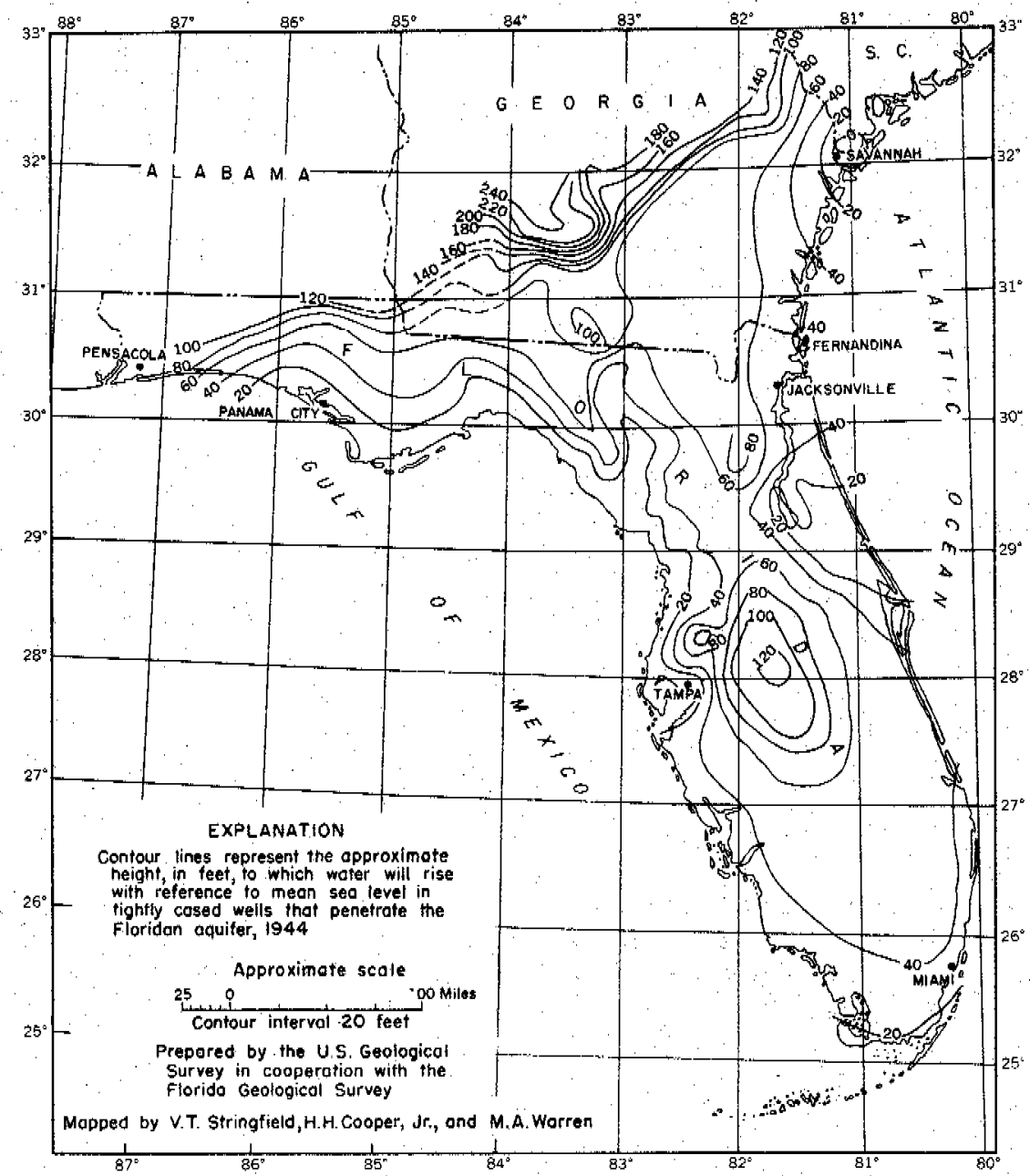

Figure 35. - Piezometric map of the Floridan aquifer in 1944.

of their work and shows by contour lines on the piezometric surface the approximate height, in feet (mean sea level); to which water would rise in tightly cased wells that penetrate the Floridan aquifer. As described by Stringfield (1936), the domed areas of the piezometric surface, such as that in Polk County (central Florida). indicate places of recharge to the aquifer, and depressed areas indicate regions of discharge from it. In general, the water moves from high to low areas and follows along flow lines normal to the contours, because this course gives rise to the steepest gradients.

The artesian pressure varies seasonally at all places: it varies momentarily with changes in atmospheric pressure; it changes in response to discharge from wells or to recharge in areas where 
drainage wells function; in some places it varies with the passage of trains; in places near the seashore it varies with the tides; and it changes in accordance with several other minor variable factors. Obviously, because of fluctuations of the artesian pressure, the position of the piezometric surface is changing constantly. However, the piezometric map (see fig. 35) shows the major features, which do not change except in detail from time to time. For example, the major features of the 1944 edition of the map are essentially the same as those of the 1934 edition. These retained major features indicate recharge, areas of discharge, and the direction of movement of the water.

YIELD TO WELLS

In reporting on yield of wells from the Floridan aquifer, Stringfield (1936, p. 158) states: "The yield of flowing artesian wells under natural flow ranges from a few gallons to more than 1,000 gallons a minute. The largest yields by natural flow are in the eastern and northeastern parts of the peninsula, where the artesian pressure is relatively large and the surface of the ground is only a few feet above sea level. One of the largest yields observed was about 2, 000 gallons a minute from a well 8 inches in diameter at Crescent Beach [well 20, St. Johns County (northeastern Florida)]. The largest reported yield by natural flow is 6,200 gallons a minute from well 2 in Brevard County, a 12-inch well."

Flows from artesian wells ending in this aquifer in southern Florida depend upon the amount of penetration into the aquifer and upon the diameter of the well. Flows range from $75 \mathrm{gpm}$ (well G 101, Dade County) to an estimated 2, $300 \mathrm{gpm}$ (well S 524, Dade County), and they average about $750 \mathrm{gpm}$.

\section{UTILITY}

All artesian water in southeastern Florida is hard, sulfurous, and corrosive. Its temperature ranges from $71^{\circ}$ to $78^{\circ} \mathrm{F}$ but it averages about $72^{\circ}$ or $73^{\circ} \mathrm{F}$. (See the section on Quality of ground and surface waters.)

The temperature, which averages about 4 to 5 degrees lower than that of the shallow nonartesian ground water (average temperature $\left.77^{\circ} \mathrm{F}\right)$; and the pressure, which causes the artesian water to rise to heights ranging between 20 and 40 feet above sea level in the Miami area, are advantages that industrialists, farmers, airconditioning engineers, and others would like to utilize. However, the salinity and corrosiveness of the water, and the much greater cost of obtaining it (as compared with the cost of a well tapping the shallow aquifer), have greatly limited its use. 
Prior to 1939, about 20 artesian wells had been drilled in the Miami area, but nearly all had been abandoned because of the poor quality of the water. Now there are several such wells in use: two are used for ornamental-fountain displays-one on Palm Island, Miami Beach, and the other is used at the Deering Estate off South Bayshore Drive, in Miami; three are used for limited irrigation of golf greens in Miami Beach, and one is used for lawn and garden irrigation in Fort Lauderdale; one (formerly in use, then abandoned) is used for cooling condenser tubes of an ice plant in Miami, and another was completed in 1948 for similar use. Formerly, condenser tubes were too vulnerable to the corrosive action of the artesian water, but now corrosion-resistant tubes are available, and it is possible that other industries will, in the future, make greater use of this flowing artesian water.

CONTAMINATION OF NONARTESIAN AOUIFERS BY LEAKY OR FLOWING ARTESIAN WELLS

Leaky or uncontrolled-flowing artesian wells in an area where the nonartesian aquifers contain only fresh, potable water could do much damage by contaminating the fresh-water aquifers with saline water. At the present time artesian wells in the Miami area are, for the most part, in the downtown area of Miami or on Miami Beach, where the thallow ground water is already contaminated with sea water and is generally more saline than the artesian water. Thus, the Miami area has nothing to fear from these existing wells.

The effects of leaky or flowing artesian wells in southeastern Florida may be illustrated by two examples: (1) Well S 142 is an abandoned artesian well in the downtown area of Miami. The casing is so thoroughly corroded that, although it is capped, the well discharge is practically unhindered, and the volume discharged is great enough that a mappable ground-water mound is always present-as shown for the peninsular area north of the Miami River and just west of Biscayne Bay in figures 42, 43, and 44. (2) Flow through the corroded casing of an abandoned oil-exploratory well (the "Gaston Drake well"), about 44 miles west of Miami near Pinecrest (northeast Monroe County) on Florida Route 94, has been taking place for many years. Over a radial distance of more than 100 feet from the well this water has killed most of the native vegetation and is contaminating fresh ground water for a much greater distance in the adjacent area. It is fortunate that this flowing well (chloride content is $18,800 \mathrm{ppm}$ ) is not nearer Miami. If it were nearer it could do serious damage to the potable water supply.

In Dade, Broward, and Palm Beach Counties there are no intermediate aquifers of low pressure that might be contaminated by the escape of water from an artesian well with higher hydrostatic pressure. The only danger is to the shallow nonartesian aquifers. 
GHALLOW ARTESIAN AQUIFERS

In the past, little attention has been paid by well drillers and by the general populace to shallow artesian aquifers; most of the attention has beengiven to the deep artesian aquifer. However, in southeastern Florida the deep (Floridan) aquifer has been of only limited use (or it is not usable at all), and in many places the shallow nonartesian water is undesirable because of objectionable color, odor, or taste, or because of contamination or pollution. This has led to a search, in some parts of southern Florida, for usable water at intermediate depths, and it has led to the development of more wells in these shallow artesian aquifers during the last few years, especially along the Gulf coast in Lee and Charlotte Counties, where numerous wells are being completed at depths of 100,200 , and 400 feet in the Hawthorn formation of Miocene age.

\section{PLEISTOCENE ARTESIAN AQUIFER AT INDIAN TOWN.}

At Indian Town, in Martin County, the public supply has been developed in Pleistocene marine-terrace deposits at depths of only 16 to 35 feet below land surface. A generalized geologic section follows:

\begin{tabular}{|c|c|c|}
\hline Deposits & $\begin{array}{c}\text { Thickness } \\
\text { (feet) }\end{array}$ & $\begin{array}{l}\text { Depth } \\
\text { (feet) }\end{array}$ \\
\hline 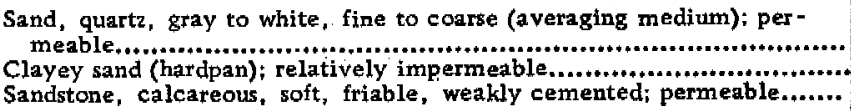 & $\begin{array}{r}12 \\
4 \\
19\end{array}$ & $\begin{array}{l}12 \\
16 \\
35\end{array}$ \\
\hline
\end{tabular}

The hardpan is not present everywhere in western Martin County, but it has sufficient areal extent near Indian Town to act as a confining layer to the water in the friable sandstone beneath. Prior to the pumping tests, the water level in sand-point wells ending above the hardpan stood at the same level as in the open-hole wells ending below the hardpan. When pumping began on the deeper wells, water levels immediately dropped (due to pressure relief), but the water levels in the shallow wells were unaffected. When pumping ceased, water levels in the pumped wells quickly recovered and again stood at the same level as in the shallow wells. If pumping had continued long enough, the water levels in the wells that were screened, above the hardpan, would eventually have been lowered because of the limited areal extent of the hardpan.

It is probable that this shallow artesian aquifer at Indian Town is largely replenished by local rainfall seeping down through discontinuities in the hardpan and that the system itself is compar- 
atively local. There may be similar areas of local shallow artesian aquifers on the Pleistocene marine terraces bordering the Kissimmee valley.

\section{PLIOCENE AND MOCENE AQUIFERS AT FORT PIERCE, ST. LUCIE COUNTY, AND IN}

THE KISSIMMEE VAL,LEY.

At the present time, only a small amount of field research has been made on the shallow artesian aquifers of the Kissimmee valley; however, in the northern. and central parts of the valley numerous shallow-flowing and some nonflowing artesian wells have been investigated. Many of these wells are developed in the Pliocene (Caloosahatchee marl), and it is likely that the rest are developed in the upper Miocene (Tamiami) formation.

Geologic conditions in the Kissimmee valley in the shallow aquifers are idealized in figure 30 . This illustration is greatly simplified; instead of only one confining layer ( $B$ in fig. 30 ) there actually are several (each of unknown, but probably different, areal extent). These confining layers (some are doubtless only lenticular bodies of relatively large areal extent) generally slope toward the center of the valley from the higher lands on either side. Their irregular areal and vertical distribution accounts for the fact that, whereas on one farm an artesianflow can be obtained through a well 100 feet deep, on an adjacent farm, with equal land-surface elevation, water can be obtained only at depths of 120 feet or more. Heads in these shallow artesian wells do not rise much above the land surfacethe average rise is about 3 to 4 feet during years of normal rainfall. Usually, flows can be obtained from similar shallow wells in all parts of the valley where the altitude above mean sea level does not exceed 70 feet.

From the highland area (Pleistocene Osceola Island, pl. 10), which separates the Kissimmee valley from the Atlantic coastal strip, confining layers (similar to, and perhaps of similar origin as, the layers described above for the Kissimmee valley) slope eastward beneath permeable Pleistocene sands to, and beyond, the present shoreline. As a result of these geologic conditions, shallow artesian aquifers exist in most of the coastal zone lying between Melbourne, in Brevard County, and Stuart, in Martin County, and may extend somewhat farther, both north and south.

As in the Kissimmee valley, very little research on the shallow artesian aquifers has been done in this coastal zone. However, an intensive, small-scale study made at Fort Pierce, St. Lucie County, has provided valuable data.

Figures 36 and 37 are generalized cross sections through the Fort Pierce municipal well field showing the shallow strata, the local ground-water conditions, and the arrangement of the wells. 


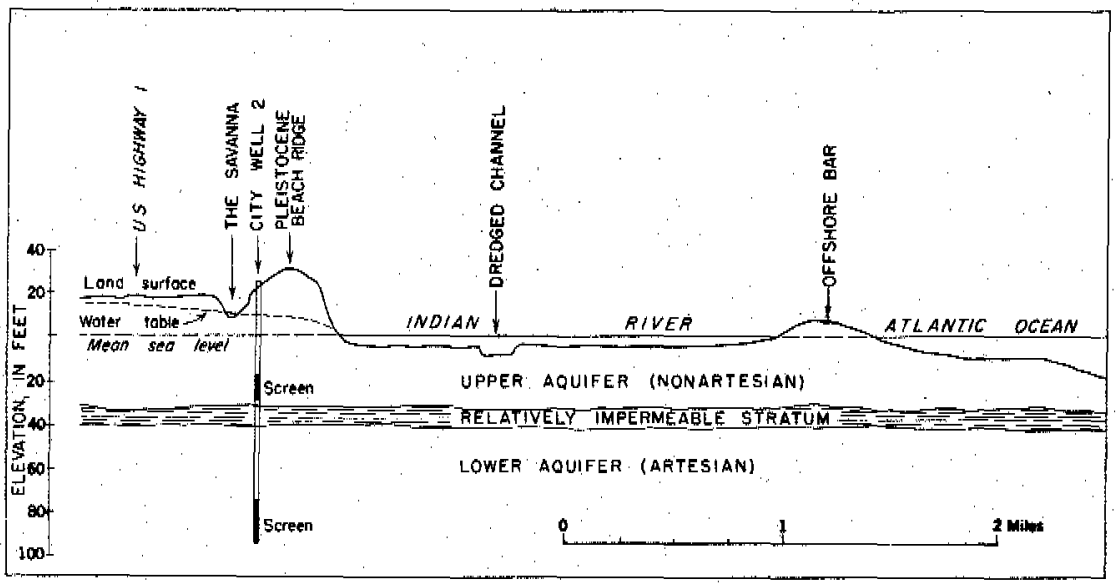

Figure 36. - Generalized east-west cross section through Fort Pierce municipal well field showing shallow strata and water table on August 3,1944 .

Figure 36 is a greatly foreshortened cross section normal to the shore, showing the principal topographic and geologic features and the location of one of the municipal wells. The upper (nonartesian) aquifer is composed chiefly of white quartz sand at the surface, grading through tan to brown below (see log of well St. L 4, in Appendix); it is separated from the lower (artesian) aquifer by a bed of dark-gray sandy and clayey marl which is relatively impermeable. The artesian aquifer is composed chiefly of various grades of quartz sand, shell marl, and shell beds.

Figure 37 is a generalized cross section parallel to the shore and shows the heights of the water table and the piezometric surface during pumping of city wells on June 6,1944 . Note that the water table above the relatively impermeable stratum is unaffected by pumping, but that the piezometric surface is greatly affected. Drawdowns are greatest in the vicinity of each pumped well. The greatest drawdown is in well 3, in which the water level fell from 10 feet above mean sea level, before the pumps were started, to 43 feet below, during pumping; this is a total drawdown of 53 feet. It wotld appear from figure 37 that pumping from city wells 1,2 , and 4 would draw the water table down; however, thin layers of relatively impermeable material in the upper aquifer prevent this action.

In wells distant from the ocean, or distant from Indian River (which is really a salt-water lagoon with direct connections to the open ocean), no serious consequences arise from such depressions in the plezometric surface. However, where the wells are situated as close to salt water as they are in the Fort Pierce well field, such drawdowns could eventually bring about the local ruination of the aquifer through salt-water encroachment. The fact that the municipal well field is not already ruined is due to a combination of several factors: (1) The relatively impermeable stratum probably 


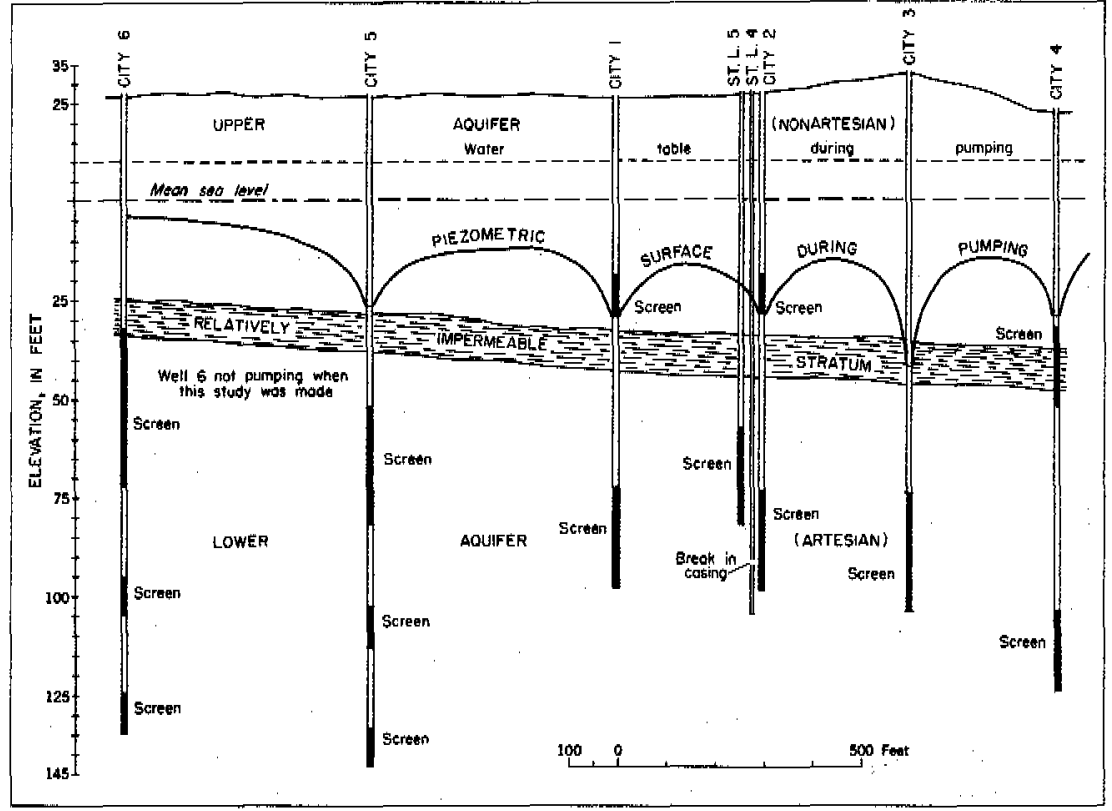

Figure 37. - Generalized north-south cross section through Fort Pierce mumicipal well field showing shallow strata and ground-water levels on June $6,1944$.

extends beneath Indian River and the Atlantic Ocean, thus preventing direct transfer of overlying salt water into the underlying freshwater artesian aquifer; (2) both the piezometric surface and the water table between the Savanna and Indian River are usually relatively high-high enough that the weight of the fresh water above sea level overbalances any inland salt-water movement that would occur because of an upset equilibrium between salt and fresh water caused by pumping or drought conditions; and (3) the wells are not pumped at a very high rate. In fact, most of the Fort Pierce supply is obtained from the ponded water of the Savanna. If, however, it were necessary to pump large quantities of ground water from the existing wells over a period of several years, it is likely that such pumping would result in salt water being drawn into the aquifer.

Geologic and hydrologic conditions of the shallow aquifers as discussed above for Fort Pierce probably prevail along the coastal zone from Brevard into Palm Beach County, and any proposed large-scale development should be preceded by adequate local ground-water studies to determine the importance of thesefactors that relate to the perennial yield of the aquifers and thus to the security of the proposed supply.

Everglades, the county seat of Collier County, is a small fishing and vacationing resort on the shores of the Gulf of Mexico in the Ten Thousand Islands area. The town water supply is obtained from 
three flowing wells, ranging in depth (reported) from 409 to 521 feet, and believed to be developed in limestone of the Hawthorn formation. The water is hard and slightly saline (chloride content is about $250 \mathrm{ppm}$ ) but is of much better quality than either the deeper artesian water from the Floridan aquifer or the shallow unconfined ground water in the coastal area (for analyses see the section on Quality of ground and surface waters).

The quantity of flow from these wells is reported to be $80 \mathrm{gpm}$ from No. 1, $60 \mathrm{gpm}$ from No. 2, and $120 \mathrm{gpm}$ from No. 3 .

No detailed geologic or hydrologic investigation has been made at Everglades, as was done at Fort Pierce (see p. 194-196). However, it is believed that if a heavy draft were placed upon the aquifer near the coast, salt water would soon be drawn into the aquifer and thus ruin the existing supply. Large quantities of usable water might be obtained from this aquifer several miles inland from the shore, but before any large-scale development is attempted a careful study should be made of all the geologic and hydrologic factors involved.

\section{QUANTITATIVE STUDIES IN THE MIAMI AREA}

By M. A. Warren and Garald G. Parker

INTRODUCTION

\section{GENGRAL STATEMENT}

Wherever it is proposed to develop large supplies of ground water it is wise to determine whether or not the project is possible or feasible, and whether or not the perennial yield of the formation will be exceeded by the demand.

The perennial yield of an aquifer may be defined as the quantity of water that can be withdrawn from the aquifer year after year without exceeding the rate of replenishment or causing impairment to the quality of water in the aquifer.

\section{GROUND-WATER INVENTORY}

In making detailed studies of an aquifer it is essential to have thorough knowledge of the ground water. A complete inventory necessitates reliable knowledge of the quantity and quality of the water stored in the aquifer and the changes in storage that take place from time to time. Also it includes information regarding the quantity and quality of the water entering and leaving the aquifer in the area of investigation. 
Water entering the area includes subsurface flow across its boundaries from other areas; surface flow that enters the aquifer in the area from adjacent areas; recharge by precipitation within the area; and recharge by artificial addition of water from other sources, either through drainage wells or galleries, or by application to the land surface from which it seeps to the water table.

Water leaving the area includes subsurface outflow, some of the water that is discharged from wells or galleries, water that percolates into surface streams and canals and flows out of the area, and water that is withdrawn from the aquifer and discharged into the atmosphere by evapotranspiration.

Several methods for estimating ground-water supplies have been used by various investigators (Meinzer 1931). However, some of the methods used by investigators in other areas are not applicable to the Miami area.

\section{THE BISCAYNE AQUIFER}

The Biscayne aquifer, its extent, and its thickness have been discussed in detail in the sections on Geology and occurrence of ground water. Basically, it consists of a permeable limestone, called the Fort Thompson formation, which increases in thickness toward the east and extends under-Biscayne Bay. It has an average effective thickness of about 100 feet under most of the coastal ridge. Recharge to the aquifer is mostly from local rainfall; and the natural outlet for the subsurface flow is Biscayne Bay.

\section{RESPONSE TO SUDDEN PRESSURE CHANGES}

\section{PUMPAGE}

Ground water occurs in the Biscayne aquifer essentially under water-table conditions. In many places, however, there is a section of less permeable material intervening between the upper and lower parts of the aquifer, and when sudden changes in pressure occur in the lower part, such as the lowering caused by heavy pumping from a well that is cased throughout the upper part of the aquifer, the water levels in the nearby deeper wells respond very rapidly to these changes, while those in adjacent shallow wells show a more gradual decline. However, after a period of a few hours to a day or more, the differential head between the upper and lower parts of the aquifer disappears. This difference in the response of the water level in the deep and shallow wells becomes less noticeable as the distance from the pumped well increases, but it may be noticeable 1,000 feet or more from the pumped well. Thus, the deeper part of the aquifer may sometimes have artesian characteristics. 
Sudden changes in pressure caused by earthquake shocks and passing trains are registered in some of the deeper wells, whereas usually no response is indicated in wells less than 20 feet deep (see Parker and Stringfield, 1950). The water table responds to heavy showers almost as quickly in the deep wells as in the shallow wells, because little transfer of water through the less permeable section of the aquifer is required to increase the pressure in the lower part.

\section{VARIABLE HYDROLOGIC FACTORS AFFECTING THE AQU'FER}

A quantitative accounting of ground water in the Miami area is made difficult by the great variation in hydrologic factors. The areas contributing to runoff of streams and canals cannot be determined with any degree of exactness. Neither can the areas of natural ground-water discharge be accurately outlined. This is largely because these areas are cons tantly changing in size according to the intensity and duration of localized rainfall, the stage of the water table, the stage incanals, and tidal and periodic changes in sea level. It is not unusual for the direction of flow of both ground and surface water to be reversed in some areas several times each year. Local rainfall (the source of recharge) varies widelyin a distance of 10 to 15 miles the annual rainfall may differ by 20 to 25 inches (page 28 ).

The coefficient of transmissibility of the aquifer, which is a measure of its ability to transmit water, is very great, but it varies as much as 500 percent or more within relatively short distances. The variability of the specific yield of the upper part of the aquifer, over which the water table fluctuates, makes it difficult to accurately compute the changes in ground-water storage in the aquifer as the water table rises or falls.

The water table is near the surface over most of southeastern Florida, and it is within easy reach of plants. As a result, a large percentage of the precipitation that reaches the water table is returned to the atmosphere by evapotranspiration. The quantity thus returned varies widely with location, depth to the water table,' character of the vegetation, and weather conditions.

The water surface in Biscayne Bay, the base level with regard to canal and ground-water flow, has an average daily tidal range of about 2. 0 feet, and the daily mean level in the Bay may vary a foot within a few days. The highest point on the water table during the rainy seasons rarely exceeds 10 feet above mean sea level. Thus, the variances in sea level are 20 percent or more of the total head affecting ground-water flow toward the sea. 


\section{SALT-WATER ENCROACHMENT}

The history, occurrence, and extent of salt-water encroachment in the Miami area are discussed in detail in the section on Saltwater encroachment (p. 580 et seq.). The contact between the fresh and salt water may be near the shore in some locations and several miles inland in others. In general, owing to the greater density of salt water, the encroaching body of salt water has advanced much farther inland along the bottom of the aquifer than near the top. Thus, there are zones, a mile or more wide, roughly paralleling the shoreline and major canals, in which the depth to the rreshwater-salt-water contact varies. In these zones the shallower wells may obtain fresh water while the deeper wells furnish only salt water. As explained in the section on Salt-water encroachment, a delicate balance exists between the fresh-water head in the aquifer and the average stage in Biscayne Bay. The difference between these two elevations largely determines the extent and rate that salt water either will invade the aquifer or be flushed out by fresh water moving seaward. Because the fresh-water head and sea level are constantly fluctuating (each in a different manner), a condition of static equilibrium for the contact zone between fresh and salt water is never attained.

\section{PERENNIAL YIELD}

The question of primary importance in the Miami area, with reference to the ground-water resources, is the perennial yield. The Biscayne aquifer is known to be permeable enough to yield copious quantities of water without the pumping lift becoming excessive; but the perennial yield is determined by the level that must be maintained to keep salt water out of the wells. The amount of water that can be safely withdrawn under these conditions is deter mined by the several hydrologic factors previously discussed, each related to the other in a highly complex manner. These factors will be discussed and evaluated in the sections that follow.

In working with this problem it is necessary to use average figures for the hydrologic data collected over a period of several years, and the longer the period of time, the better. Trying to integrate the effects of all the factors that enter the problem as they change, or as they go through their cycles or fluctuations, one finds the problem so complex that a strictly mathematical solution is virtually impossible to achieve; however, a practical solution, accurate within allowable working error, is possible. 
THE WATER TABLE

\section{GENERAL STATEMENT}

The water table, in materials permeable enough to permit circulation of ground water, is the upper surface of that body of free (unconfined) water that completely fills all opening and interconnected passages in the rock materials. See p. 157-158.

The water table is seldom stationary; instead, it is constantly changing shape, rising and falling, sometimes so slowly as to be almost imperceptible, but at other times fluctuating very rapidly. The minor fluctuations, many of them being only of momentary duration, are ordinarily unobserved because they are detectable only by measuring and recording devices. Major fluctuations, usually of longer duration, are noticeable, and many of these fluctuations cause alarm when aquifers overfill and the land becomes flooded, or when, during a drought, wells become dry.

All fluctuations of the water table, whether minor or major, are of concern to the hydrologist. Determination of such fundamental hydrologic factors as the coefficients of permeability, transmissibility, and storage; areas of recharge and discharge; direction of ground-water movement; perennial yield; and other pertinent, related factors are based wholly, or in part, upon water-level measurements in wells. But these water-level readings, if not properly understood and weighted, may be entirely misleading. Water levels fluctuate as a result of several factors other than recharge to, and discharge from, the aquifer (principal factors in a quantitative ground-water study). Chief among these other factors are: tides-both oceanic and earth, atmospheric pressure, winds, earthquakes, and passing trains.

In the Biscayne aquifer, all these phenomena have been observed and reported by Parker and Stringfield (1950). It should be noted, however, that the effects of ocean tides, discussed stbsequently in greater detail, were observed only in wells located within a relatively narrow coastal band. In well F 179, for example, in the Silver Bluff area at a distance of $6,680 \mathrm{ft}$ from the bay, the range of tidal fluctuations was $0.01 \mathrm{ft}$. Farther inland, at well $\mathrm{S} 182$ (fig. 39 ) the water level is affected only remotely by fluctuations in Biscayne Bay.

Figures 38-41 are hydrographs showing average monthly water levels in 10 key observation wells tapping the Biscayne aquifer in southern Florida. Because these hydrographs were derived by averaging the daily readings for each month, they do not show either the highest or lowest water levels recorded, and because the records for all wells except $\$ 196$ were obtained largely during a series of dry years, the hydrographs give a picture of low-level, instead 

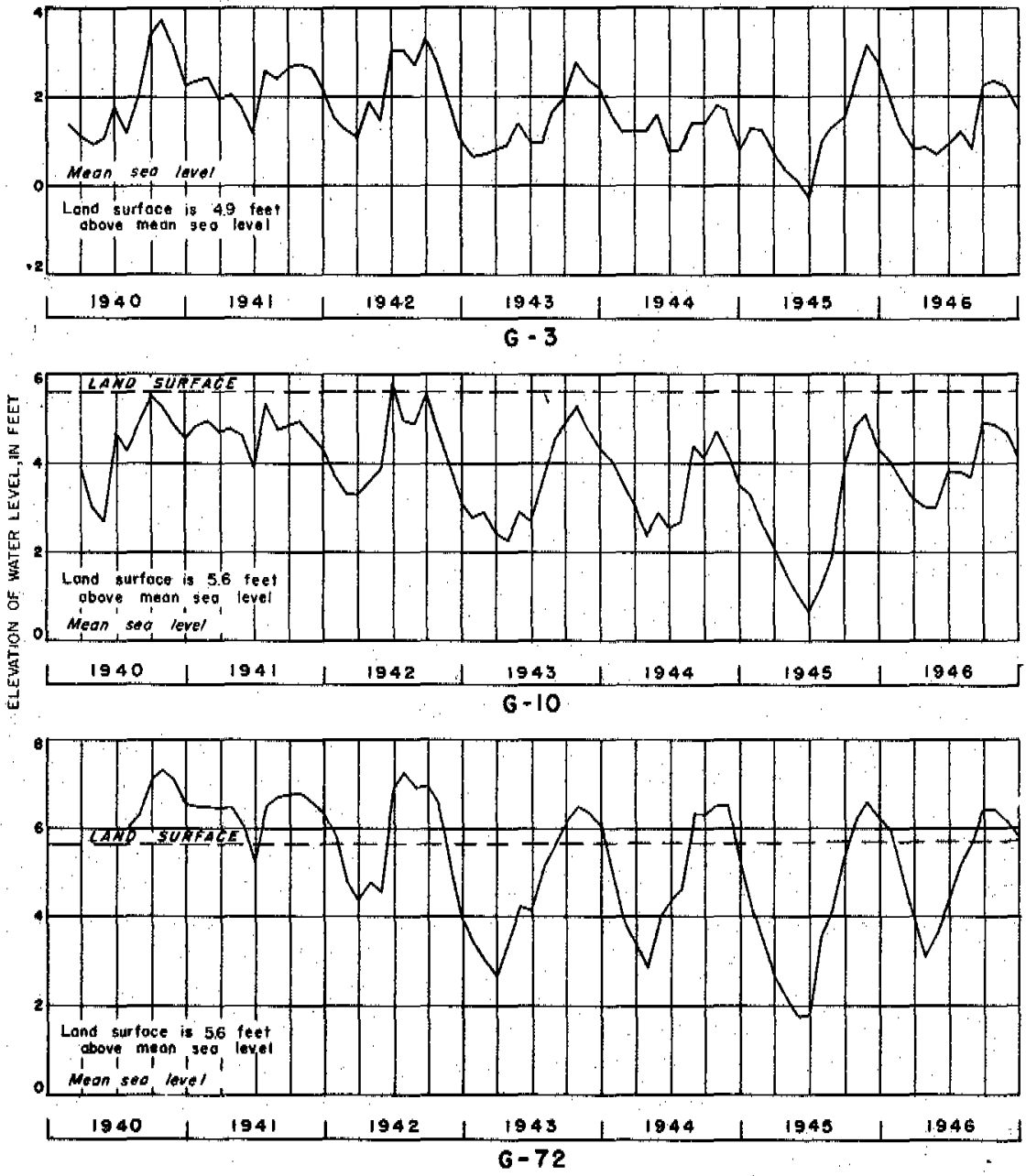

Figure 38, - Hydrographs showing average monthly water levels in key observation wells $G 3$, 610 , and $G 72$.

of high-level, fluctuations of the 10 wells here recorded. Nine are in Dade County and one well, S 329, is in Broward County on the Atlantic Coastal Ridge, at the eastern margin of the Fort Lauderdale well field. Unfortunately, well S 329 was out of commission during the drought of 1945 , so no record is available for that time. Tables 116 and 118 list well locations and other pertinent data.

The fluctuations shown on these four figures are caused largely by changes in aquifer storage brought about by recharge to, and discharge from, the Biscayne aquifer. These factors are of sufficient importance to merit major sections being devoted to them (p. 212-236). 

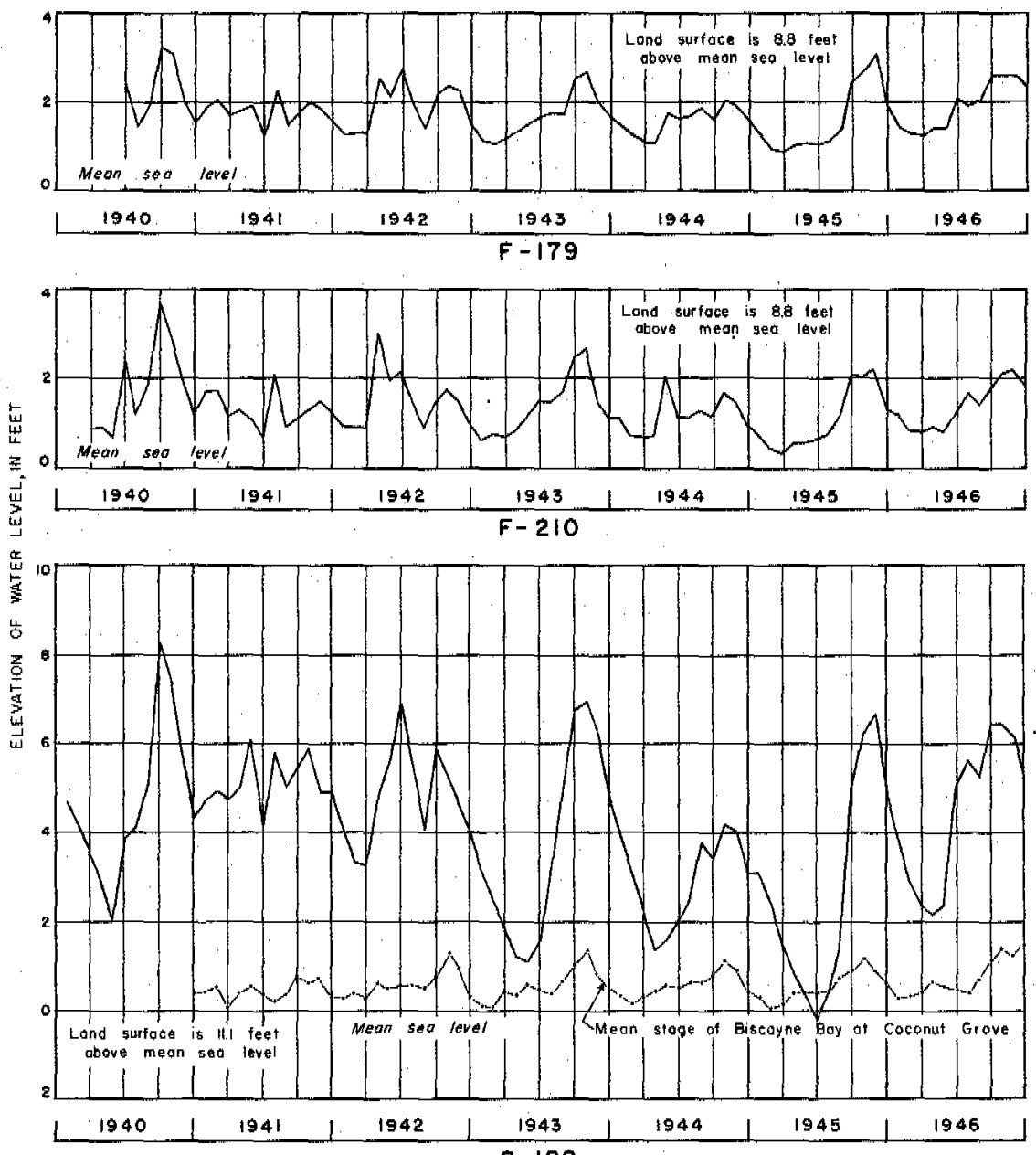

$5-182$

Figure 39. - Hydrographs showing average monthly water levels in key observation wells $\mathrm{F} 179$. $\mathrm{F} 210$, and $\mathrm{S} 182$.

EFFECT OF CANALS ON THE waTER TABLE

Except when heavy and long-continued rainfall results in floods, the canal system of the Miami area is an effective outlet for discharge of ground water; it lowers the water table rapidly after a short, heavy rainfall. However, when the Everglades are flooded and the aquifer is filled to overflowing, the capacity of the canals is not great enough to remove flood waters in time to prevent damage to crops and structures on low lands.

Ground water is free to discharge through the bottoms (provided there is not a thick layer of sediment) and through both sides of drainage canals cut into the aquifer. Ground water can readily discharge directly into Biscayne Bay only along one side of the Bay; 

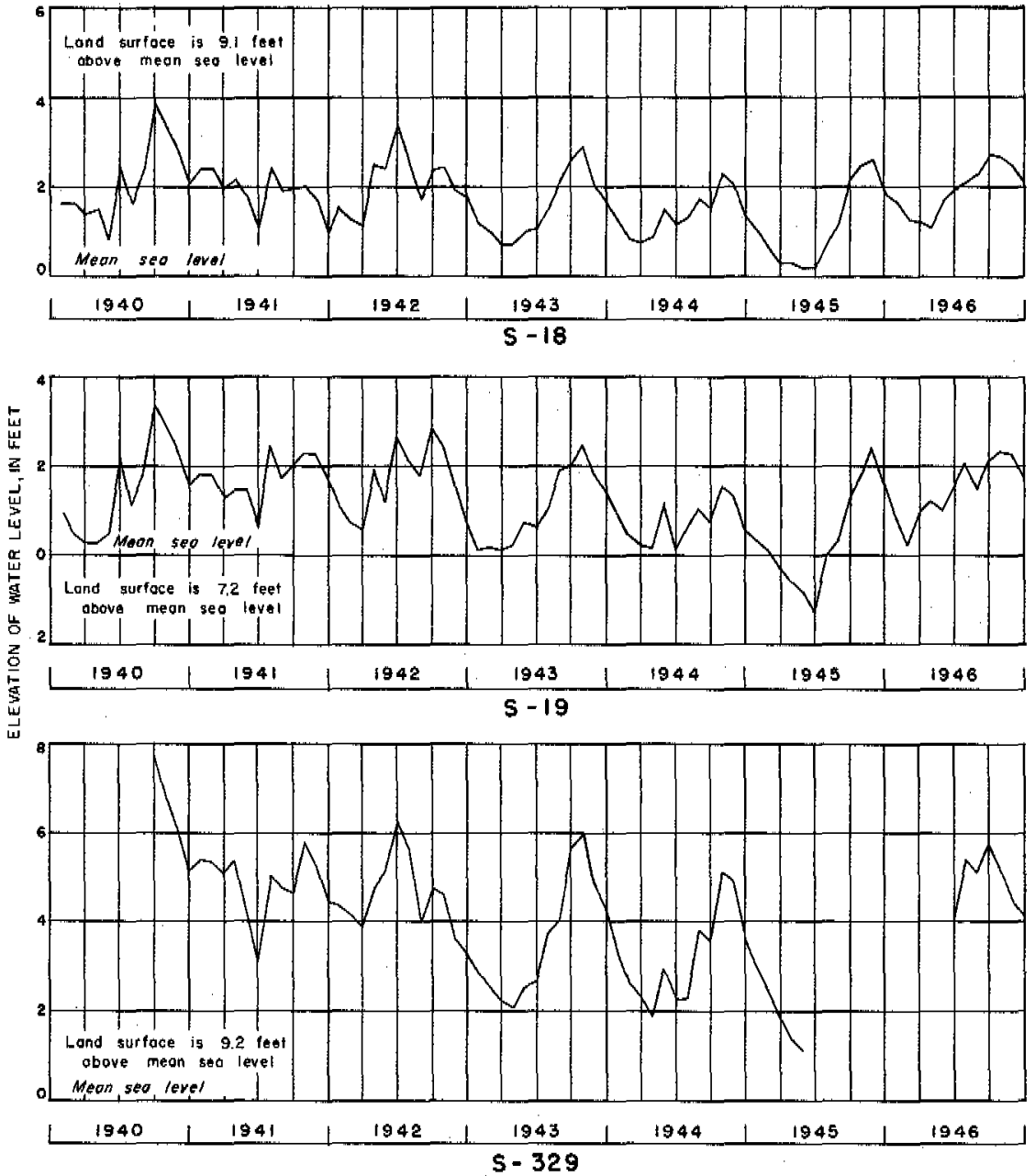

Figure 40. - Hydrographs showing a verage monthly water levels in key observation wells $\mathbf{S} 18$, S 19 , and $\$ 329$.

however, this movement is not as effective as discharge into the canals through their highly-permeable, cut-rock faces. As an outlet for ground-water flow, a mile of deepened canal appears to be more effective than 4 miles of bay shore. A study of the water-table maps, figures $42-44$, will help make this clear. 


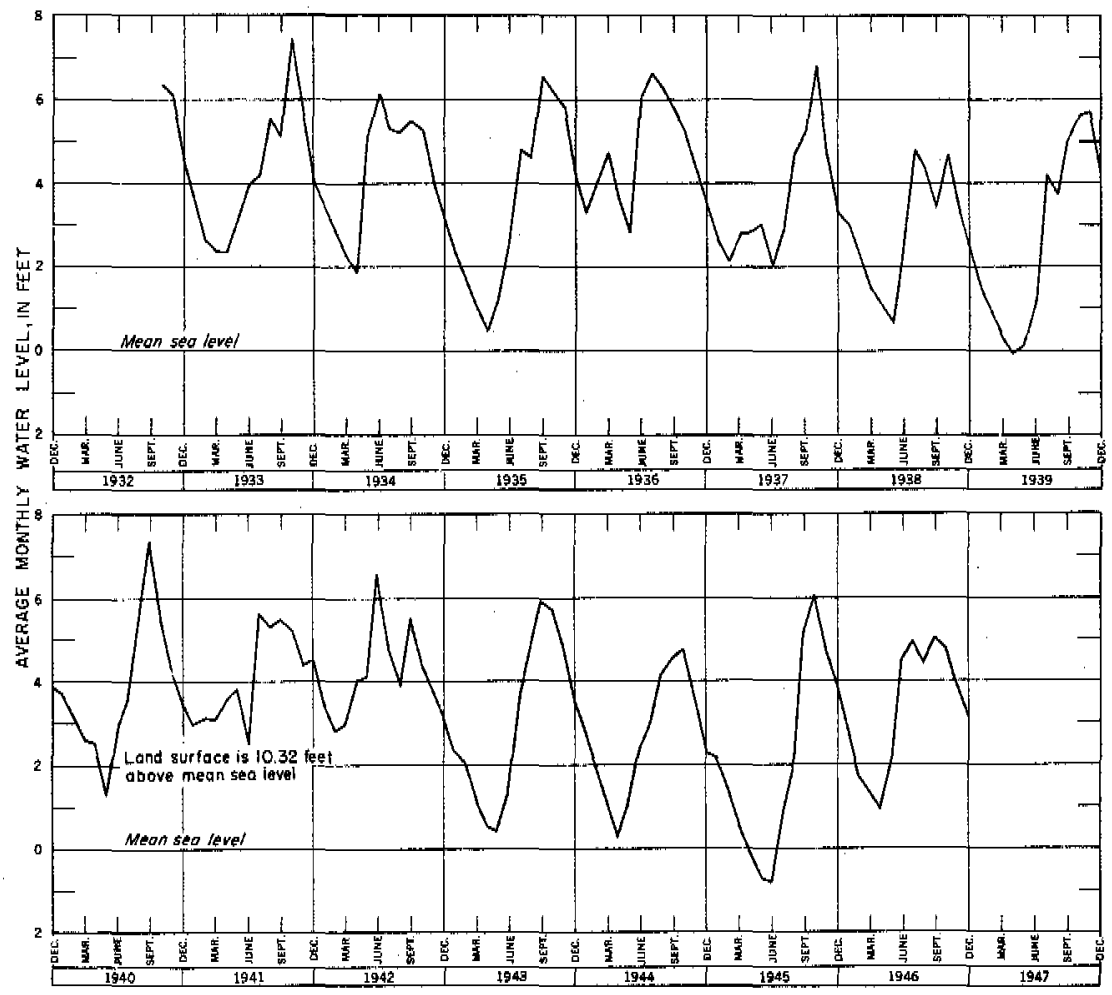

Figure 41, - Hydrographs showing a verage monthly water levels in well S 196, Univ. of Florida Expt. Sta., Homestead, 1932-46.

\section{WATER-TABLE STUDIES OF THE MIAMI AREA}

Contour maps of the water table (also called water-table maps) are very helpful in depicting the shape and position of the water table. These features of the water table are constantly changing in response to several factors, including: the movement of water due to gravity; additions through recharge by rainfall or irrigation; losses due to pumpage, evaporation, and transpiration; and losses or gains due to flow into or out of streams.

Mapping of the water table provides the most reliable method of locating areas of recharge and discharge and of determining the direction of flow. Contours are lines of equal elevations; therefore, the direction of flow is at right angles to the contours because the steepest gradients are in that direction. The fundamental law of 
laminar ground-water flow is that the velocity varies directly as the slope and inversely as the permeability. By application of this law, quantitative values for the amount of ground-water flow may be obtained, provided that reliable average values for permeability are known. The slope may be obtained from water-table maps or profiles.

Figures $42-44$ show the Miami area when the water table is at low, medium, and high stages. Because the gradients are gentle, the area is dissected by a network of canals that radically modify the water table within several miles of the deeper canals, and because heavy local rains change the shape of the water table, it is necessary to have a large number of observation wells and staff gages to get enough points of access to the ground-water body to contour the water table accurately. For the same reason, it is necessary to determine the elevations of the reference points for the observation wells and staff gages by careful instrumental leveling with reference to a common datum plane. Datum used is U. S. Coast and Geodetic Survey mean sea level datum of 1929.

\section{WATER TABLE AT LOW STAGE, FEBRUARY 3, 1942}

February 3, 1942, was a time when the water table was relatively low (fig. 42). The general direction of ground-water flow, which is normal to the contours, is toward the east; but in the vicinity of the canals (particularly the deeper ones, not controlled by locks or dams) the contours indicate a discharge of ground water into the canals (effluent condition). However, during some low stages the canals in places may be influent, thus raising the water table in the influent area. An example of this is the Miami Canal opposite the Hialeah well field. The 0.5 - and $0.0-\mathrm{ft}$ contours encircle the well field, whereas the canal stage opposite the well field is about $1.0 \mathrm{ft}$ above sea level. Under these conditions, a considerable part of the water pumped from the well field was diverted from the canal. The 1. 0-ft contour near Biscayne Bay, enclosing a large part of the Miami residential and business areas, indicates a low ground-water mound, which probably is maintained during dry periods by recharge from used municipal water being returned through the soil to the water table through septic tanks, drainage wells, and by the watering of lawns.

WATER TABLE AT MEDIUM STAGE, JULY 26, 1941

The map for July 26, 1941, shows the water table at an intermediate stage ( $f$ ig. 43). The steeper gradients indicate greater discharge of ground water, but the discharge'areas have not changed greatly from the time when the stage was low. 


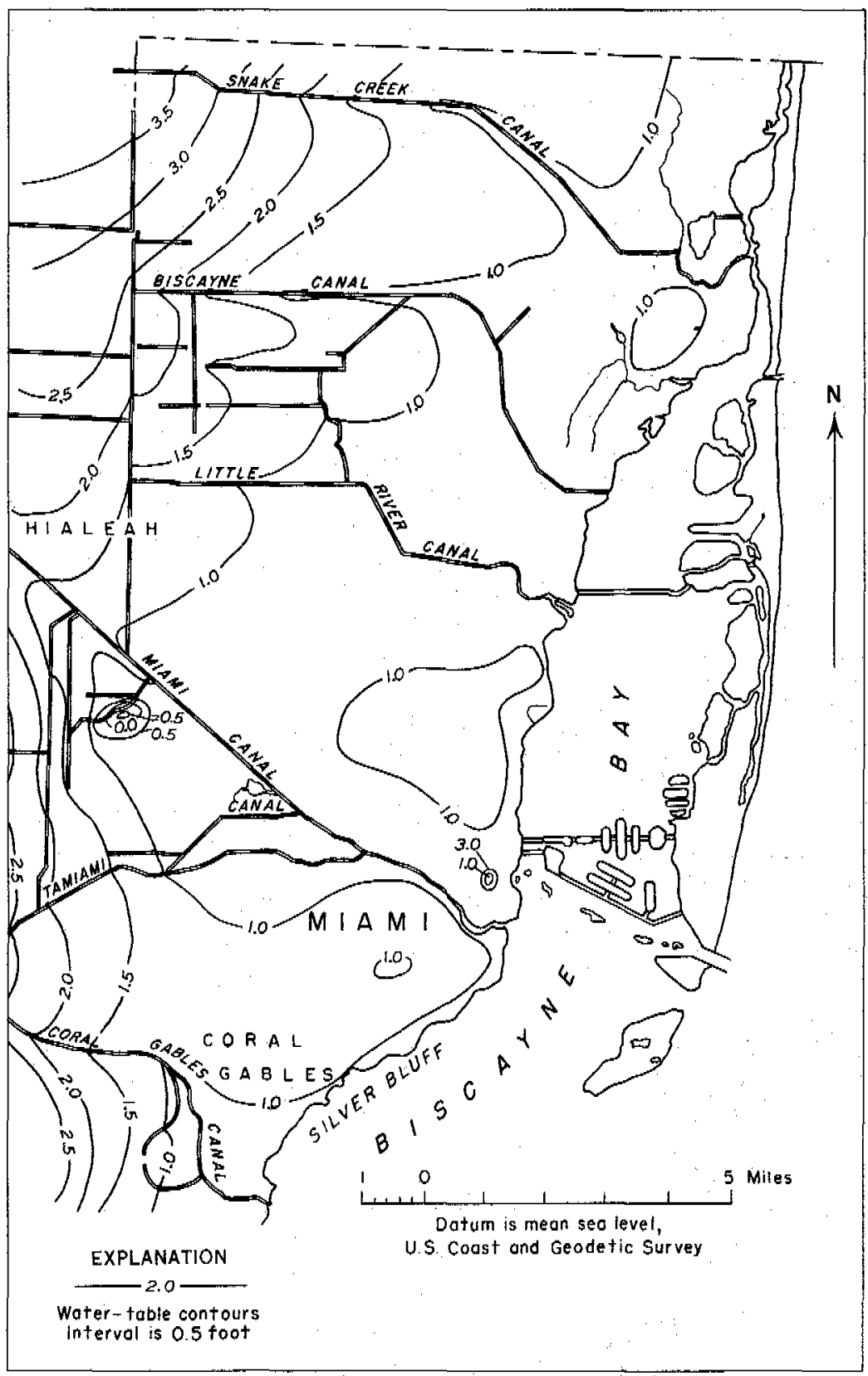

Figure 42. - Water-table map of the Biscayne aquifer in the Miami area showing low stage, February 3, 1942 , 


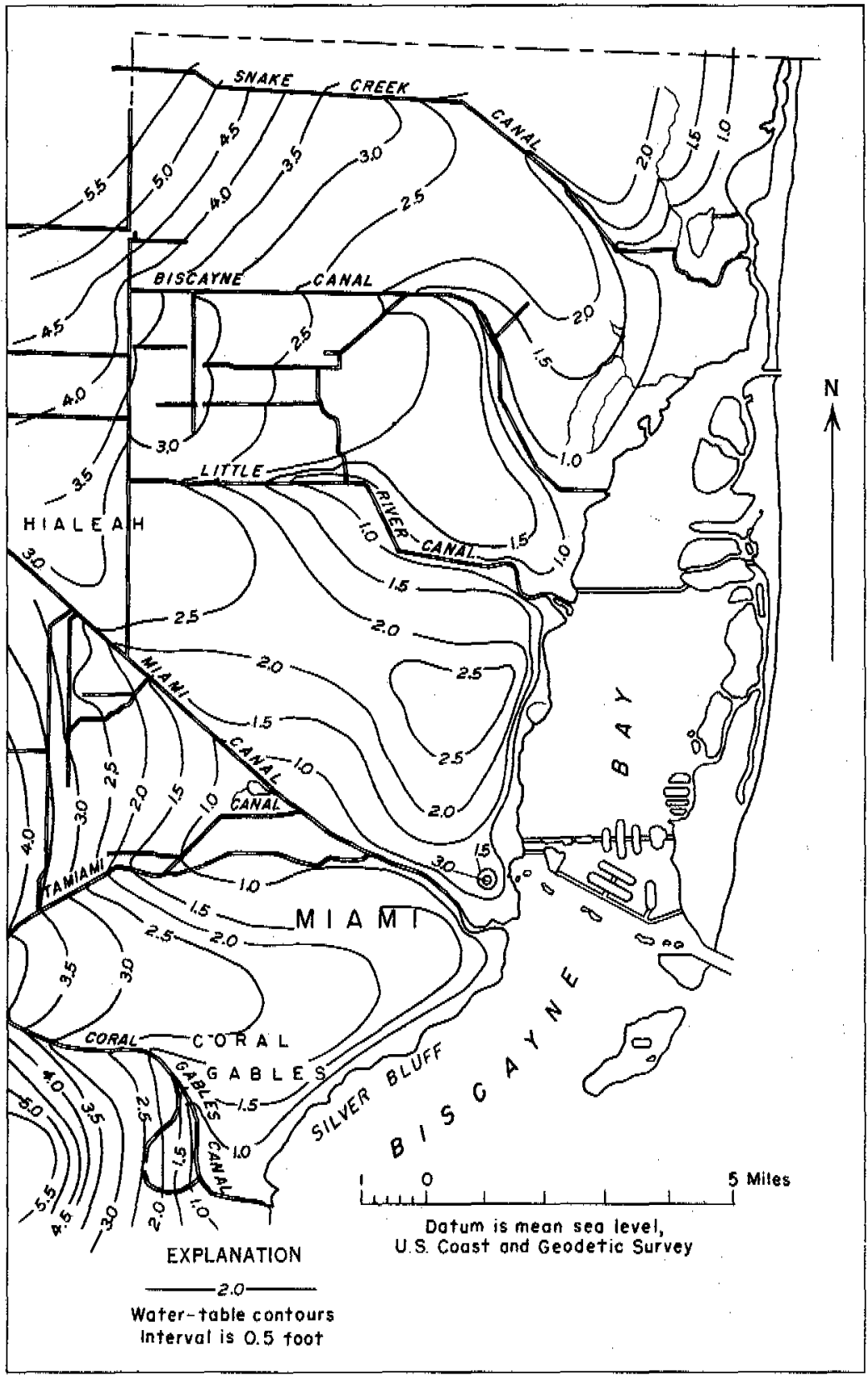

Figure 43. - Water-table map of the Biscayne aquifer in the Miami area showing medium stage, July 26, 1941. 


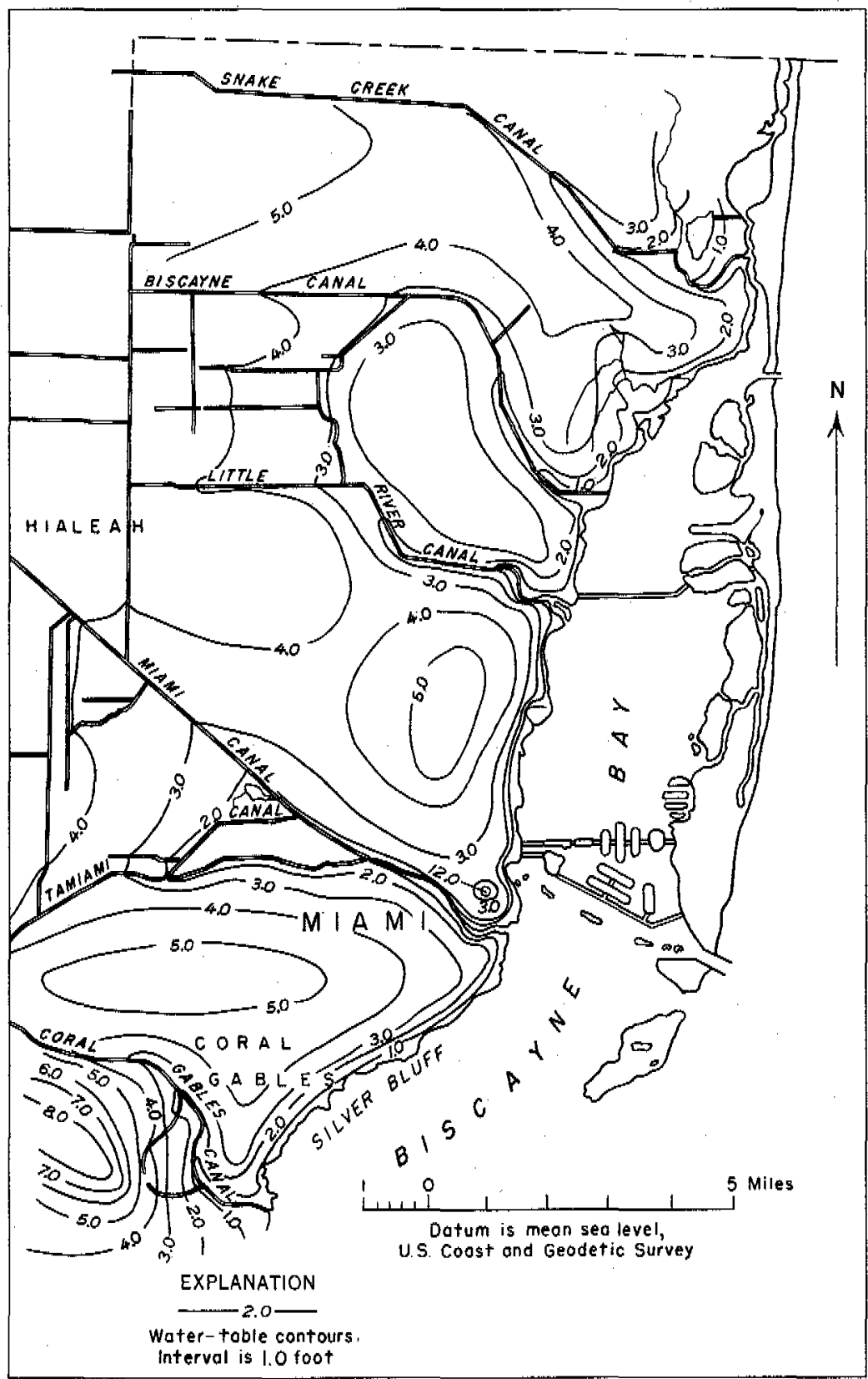

Figure 44. - Water-table map of the Biscayne aquifer in the Miami area showing high stage, September 30, 1940. 
WATER TABLE AT HIGH STAGE, SEPTEMBER 30, 1940

The water-table map for September 30,1940 , is for a time when the water levels were comparatively high (fig. 44). The flow pattern is similar to that for the intermediate and low stages, but the gradients are steeper. The ground-water mounds prove that the recharge is local and that the major part of the ground water does not move in from distances of many miles to the west or north, as has been the popular belief; in fact, ground-water movement on the western sides of these mounds is to the west-toward the Everglades, not toward the ocean.

\section{WATERTARLE STUDIES OF DADE COUNTY}

\section{WATER TABLE AT LOW STAGE, MAY 19, 1945}

Figure 45 shows the water table for May 19, 1945, which was almost the lowest stage that occurred during the period of investigation here reported (1939-1946). In the northern part of the county the water table slopes toward the east. If this low-stage condition were maintained for a long time, the water table would not have sufficient head above sea level to prevent salt water at depth in the Biscayne aquifer from encroaching several miles farther inland than it is at present. However, because of the low velocity of encroaching salt water, lateral movement over a period of a few months is very small.

In the southern part of the county the water table sloped inland toward a low area in the vicinity of Royal Palm State Park, where evapotranspiration loss had lowered the water table to slightly more than $3 \mathrm{ft}$ below average level in Biscayne Bay, which, during this investigation, was about $0,6 \mathrm{ft}$ above U. S. Coast and Geodetic Survey mean sea level datum. The exceedingly low water table developed here mainly because of its geographic location. Evapotranspiration rates are rather uniformly high over the glades area of Dade County. This particular area could not develop closer to the sea because of recharge from the sea, nor could it develop farther inland because of recharge from the normally higher water table in the area to the north and west.

\section{WATER TABLE AT MEDIUM STAGE, MARCH 17, 1941}

Figure 46 shows the water table as mapped for March 17, 1941, and it was selected because it shows the water table when it was very near medium stage for the period of record. At this stage, the water table slopes from the Everglades toward the east and southeast. 


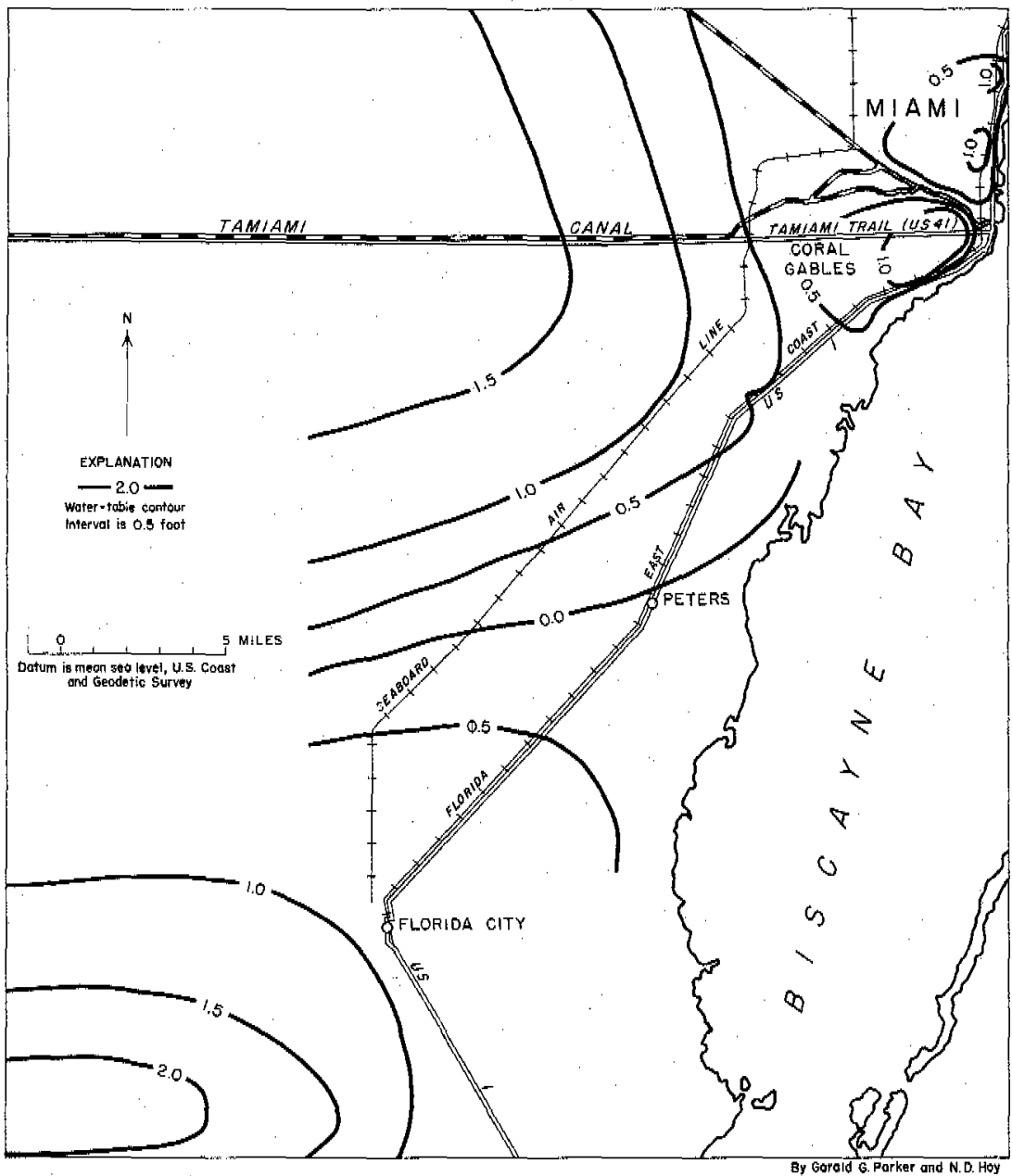

Figure 45. - Water-table map of the Biscayne aquifer in southeastern Dade County showing low stage, May 19, 1945.

WATER TABLE AT HIGH STAGE, SEPTEMBER 23, 1940

Figure 47 shows the water table for September 23, 1940, which was almost the highest stage that occurred between 1939-46. At this stage, the water table in the western part of the coastal ridge south of Miami had been built up by recharge from rainfall until it was above the water level in the adjacent part of the Everglades. Therefore, ground water was flowing in all directions from this mound, part of it being discharged westward into the Everglades. This condition commonly occurred in this area prior to the construction of the drainage canals, as attested by the observations of Sanford (1913, p. 289) who reported that, “*** along the rock ridges of the Biscayne pineland are a number of springs, some of considerable size. The largest noted rises on the west side of the 


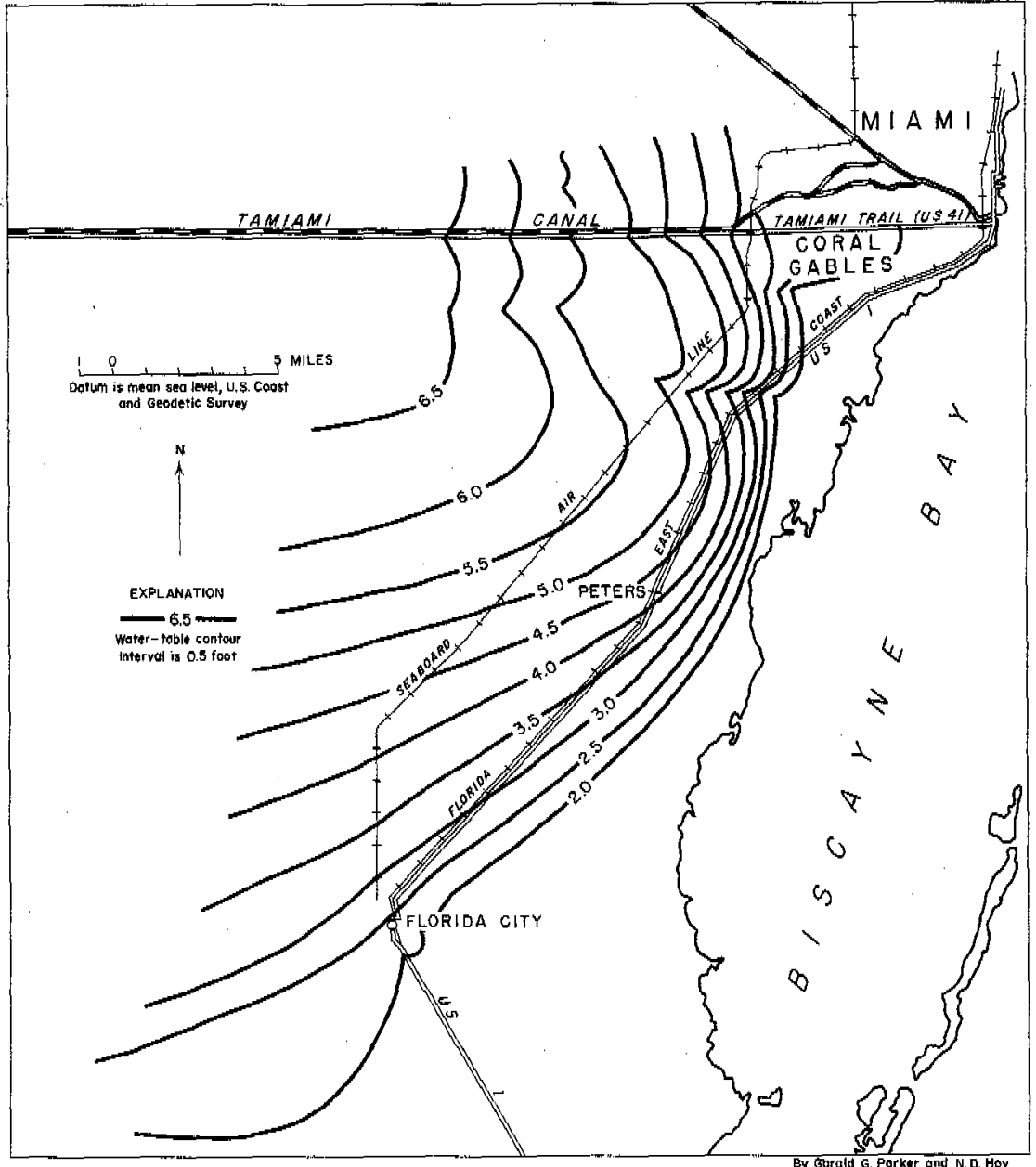

Figure 46. - Water-table map of the Biscayne aquifer in southeastem Dade County showing medium stage, March 17, 1941.

crest of the ridges just north of Miami and flows into a swamp from Miami River. It is supplied by rainfall on the slightly higher ground of the pineland. "The occurrence of this large spring on the west side of the high land required a higher water table to the east, which probably reached a crest under the highest part of the coastal ridge.

\section{GROUND-WATER RECHARGE}

\section{GENERAL STATEMGNT}

Over most of the coastal ridge from Miami southwest to Homestead, the Miami oolite, which underlies the entire area, is at the 


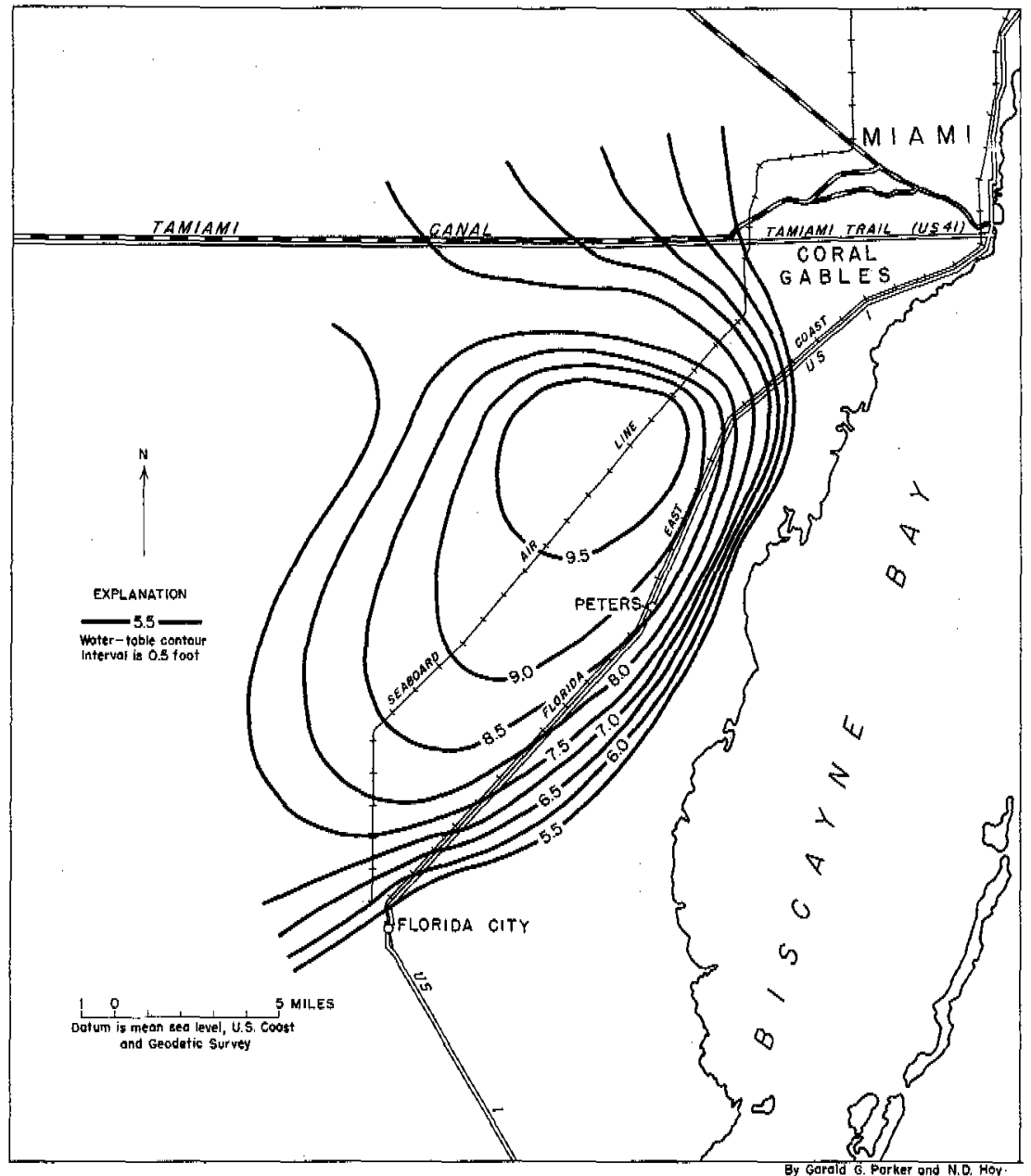

Figure 47. - Water-table map of the Biscayne aquifer in southeastem Dade County showing high stage, September $23,1940$.

surface or is covered with only a thin sandy soil mantle. The oolite has high vertical permeability; rain falling on the surface rapidly percolates downward to join the water table, which is seldom more than $10 \mathrm{ft}$ below the land surface and which, at times of high watertable conditions, is at or near the surface over a considerable part of the area. Thus, there is little opportunity for rainfall to flow into surface drainage channels and reach the ocean without first entering the ground.

Rain falling in the glades recharges the Biscayne aquifer until the water table reaches the surface. Additional rainfall floods the glades, and, as the stage increases, the flow into canals and overland to the south, through the glades, and to the east, through transverse glades, also increases proportionately (see the section on Geomorphology). 
A rapid rise of the water table occurs within a few hours after the rain begins if the rainfall is of sufficient magnitude and intensity to saturate the soil and rock above the water table. The rise of the water table, correlated with the rainfall, gives reliable information in some locations as to the amount of rainfall reaching the water table, and it may give information regarding the porosity and specific yield of the part of the aquifer through which the water table rises.

\section{DEFINITIONS}

Porosity 4 - According to Meinzer (1942, p. 387): "The porosity of a rock is its property of containing interstices. It is expressed quantitatively as the percentage of the total volume of the rock that is occupied by interstices or that is not occupied by solid rock material. A rock is said to be saturated when all its interstices are filled with water. In a saturated rock the porosity is practically the percentage of the total volume of the rock that is occupied by water."

Specific yield-The specific yield has been defined by Meinzer (1923b, p. 28) as the ratio, expressed as a percentage, of (1) the volume of water a rock or soil will yield by gravity to (2) its own volume.

Specific retention. - Specific retention (Meinzer, 1923b, p. 29) has beencalled the ratio, expressed as a percentage, of (1) the volume of water which a rock or soil will retain against the pull of gravity to (2) its own volume.

Under natural water-table conditions the sum of the percentages representing specific retention and specific yield should equal the percent porosity. It should be recognized, however, that during the period following drainage of a zone of saturation, the water retained by the rock or soil, against the pull of gravity, will gradually be dissipated by evaporation and transpiration. Thus, theoretically, in a rock or soil the actual air space available for receiving ground-water recharge can vary from the value given by the porosity minus the specific retention, immediately following complete gravity drainage of the zone of saturation, to the value given by the porosity alone after sufficient time has elapsed to permit complete evaporation and transpiration of all the retained water. Therefore, in any discussion of quantitative analysis of groundwater storage and recharge, due consideration must be given to the elapsed time between the antecedent climatic and hydraulic events. 
WATER TABLE AND RAINFALL CORRELATIONS

\section{RATFALL AND THE WATER TABLE IN MUOK OF THE EVERGLADES}

Figure 48 shows rises of the water table in observation well G 72 correlated with hourly precipitation data from a recording rain gage located about 1.5 miles to the south. Well G 72 is near the DadeBroward County. line on the east side of State Highway 25. This well is in the glades about 12 miles west of the coastal ridge and 20 miles west of the Atlantic Ocean. The well is $4.6 \mathrm{ft}$ deep and the land surface is $6.0 \mathrm{ft}$ above U. S. Coast and Geodetic Survey mean sea level datum. The upper $3 \mathrm{ft}$ consists of muck overlying hard permeable limestone.

Figure 48 shows a $2.25-\mathrm{ft}$ rise of the water table following 4.50 in. $(0.375 \mathrm{ft})$ of rainfall between $12 \mathrm{~m}$. and $6 \mathrm{p}$. m. on April 18, 1943. On this date only a fraction of an inch of rainfall was recorded by gages at, and south of, Miami. Therefore, this was probably a local shower having a high intensity over only a relatively small
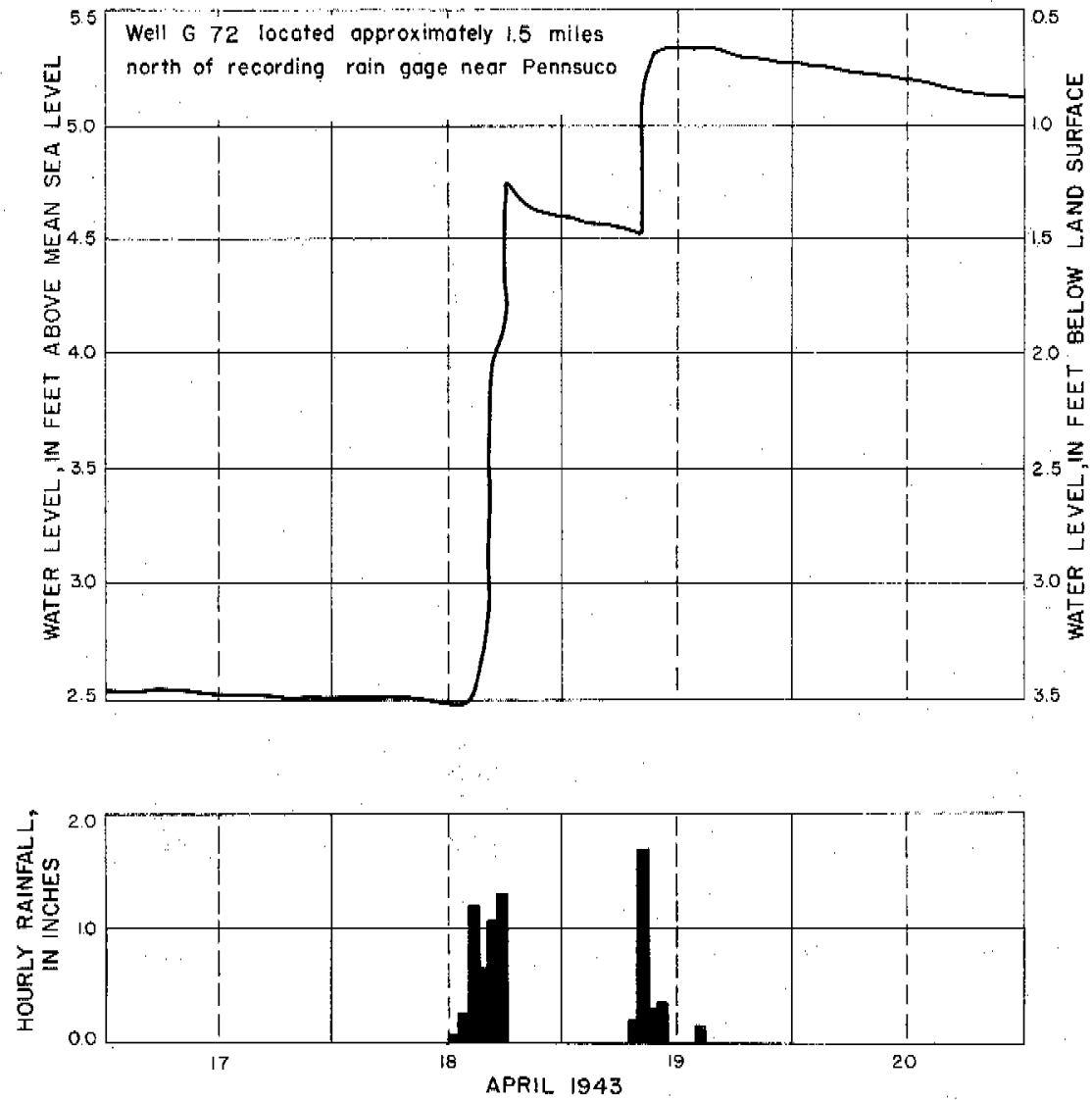

Figure 48. - Graph showing fluctuations of water level in well $\mathrm{G} 72$ following periods of heavy rainfall. 
area, and the rainfall recorded by the Pennsuco gage may even have been appreciably different from the actual rainfall at the well 1.5 miles distant. Another rainfall of $2.70 \mathrm{in.}(0.225 \mathrm{ft})$ between 7 a. m. and 11 a. $m$. the following day, caused a rise of the water table of $0.82 \mathrm{ft}$. These figures give a value of approximately 0.27 for the ratio between precipitation and the water-level rise in the muck between depths of 0.65 and $1.47 \mathrm{ft}$ below land surface.

\section{RATFALL TWD THE WATER TABLE IN SAND OF THE ATLANTTC COASTAL RIDGE}

Figure 49 shows the rise of the water level in well G 86 on April 16 and 17,1942 , following very heavy rainfall. This well is 0.4
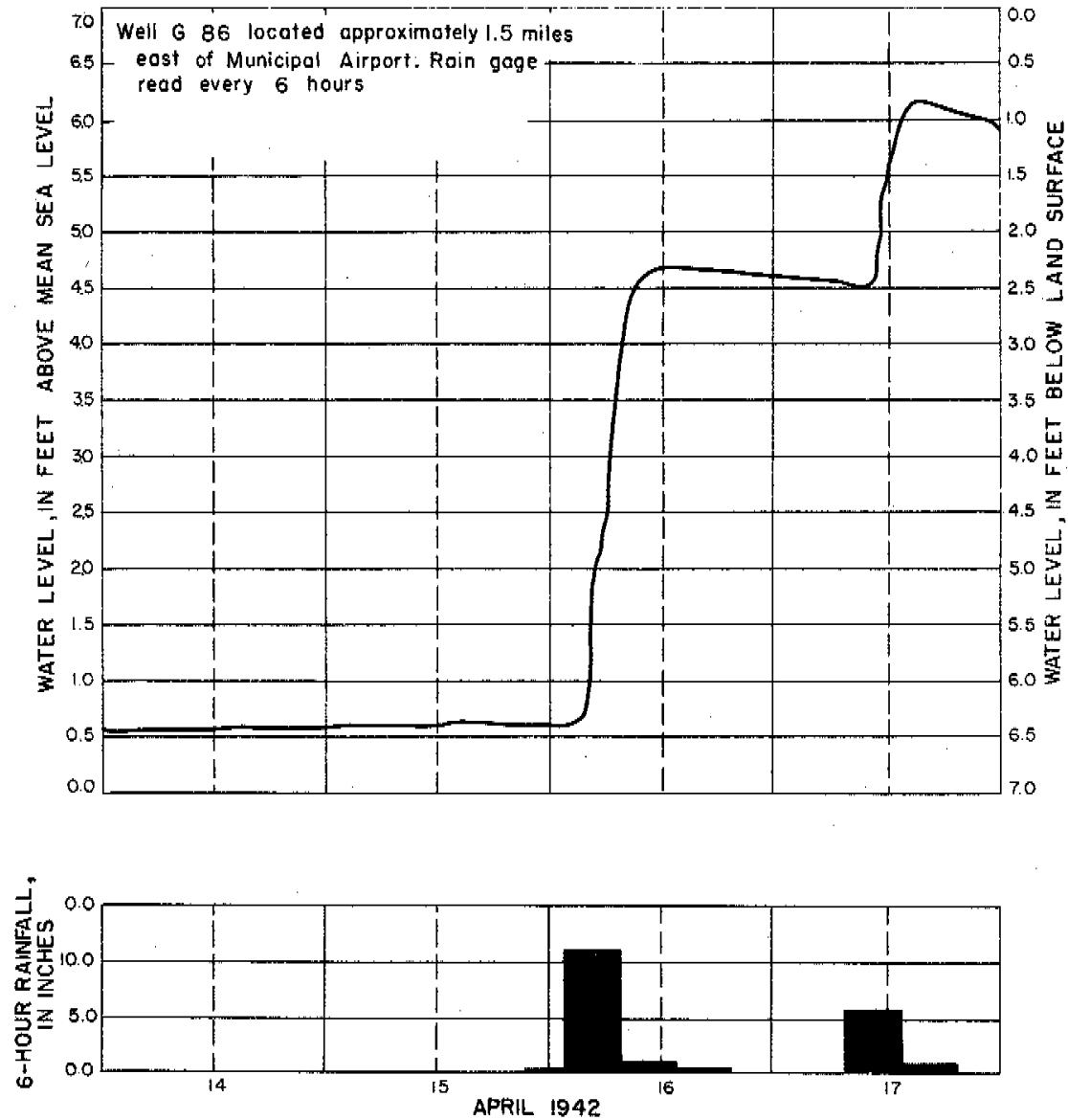

Figure 49. - Graph showing fluctuations of water level in well G 86 following periods of heavy rainfall. 
mile north of Little River Canal on the east side of NW. 27th Avenue, and 1.5 miles southeast of NW. 111 th Street and LeJeune Road, where the Miami Airport rain gage was located (it has since been moved to the NW. 36 th Street Airport). During the morning of April 16, 1942, 12.16 in. of rain caused a $4.1-\mathrm{ft}$ rise in the water table. This well is only $9 \mathrm{ft}$ deep and penetrates fine to medium quartz sand. Previous to April 16, only 0.10 in. of rain had fallen in the preceding 15 days; therefore, the sand above the capillary fringe probably contained little moisture. Assuming that the water table in the area rose about the same amount as in well G 86, that the rainfall at the well was the same as at the rain gage, that the $2 \mathrm{ft}$ of sand above the water table at the end of the first rise retained an estimated $2 / 3 \mathrm{in}$, of rainfall, and that the moisture held in the capillary fringe is the same in both positions of the water table, then the approximate value for the ratio between recharge (water reaching the water table) and the water-level rise due to increased storage in the aquifer, between the depths of 2.4 and $6.5 \mathrm{ft}$ below land surface, is calculated as 0.23 . This ratio is somewhat higher than the specific yield because a part of the water would be retained and would not be released from storage under gravity drainage; also, it is somewhat less than the porosity because the sand probably contained a small amount of moisture before the rain fell and because appreciable amounts of air may have become trapped, thus preventing water from completely filling the void spaces.

A second rainfall in the area, 6.64 in. on April 17, 1942, between 9 a. $\mathrm{m}$. and $3 \mathrm{p}$. $\mathrm{m}$., caused a $1.65-\mathrm{ft}$ rise of the water table. At the peak of this rise the water table was within $0.85 \mathrm{ft}$ of the land surface. Assuming that the soil above the water table had been thoroughly moistened by the heavy rains that ended less than 12 hours previously, and that all the rainfall infiltrated to the water table, a value of 0.34 for the ratio between recharge and watertable rise was calculated for the formation between the depths of 0.85 and $2.50 \mathrm{ft}$ below land surface.

The area surrounding the well is level and sandy, and it is believed that the water table did not get above the surface in the area. After the rain ceased the water table began to drop at the rate of $0.6 \mathrm{ft}$ per day. Probably one of the greatest sources of error in the above line of reasoning is that for individual storms the rainfall in the area near the well may be appreciably different from that recorded by the gage, 1.5 miles away. As the period of observation is lengthened, however, the total precipitation recorded by the rain gage becomes a more reliable measure of total precipitation at the well. 


\section{RATNALL AWD THE WATER TABLE IN THE OOLITE OP THE ATLANTTC COASTAL RIDOE}

Figure 50 shows rises of the water level in response to rainfall at well $\mathrm{S} 182$, near Peters. No recording rain gages were maintained near this well. A standard U. S. Weather Bureau rain gage at Peters, which is read daily, is about 0.5 mile east of well S 182 .

On September 15-16, 1945, the water level in well S 182 rose 2. $54 \mathrm{ft}$, and on these same dates 6.95 in. of rainfall was recorded at Peters. The 10 previous days were without rain, and it is estimated that the $4.5 \mathrm{ft}$ of material above the water table absorbed about $1 \mathrm{in}$. of water from this rainfall. The remainder of the rain, if it is assumed to have caused the rise in water levels, would give a ratio between recharge and water-table rise of about 0.19 on these dates.

All the wells shown in figures 48,49 , and 50 are typical wells of the Miami area, and their water-level behavior indicates that a large percentage of the rain that falls in heavy showers or storms reaches the water table in a very short time.

The amount of rainfall that becomes recharge after any particular storm depends on many factors, most important of which are: the infiltration capacity (ability of water to percolate from the surface

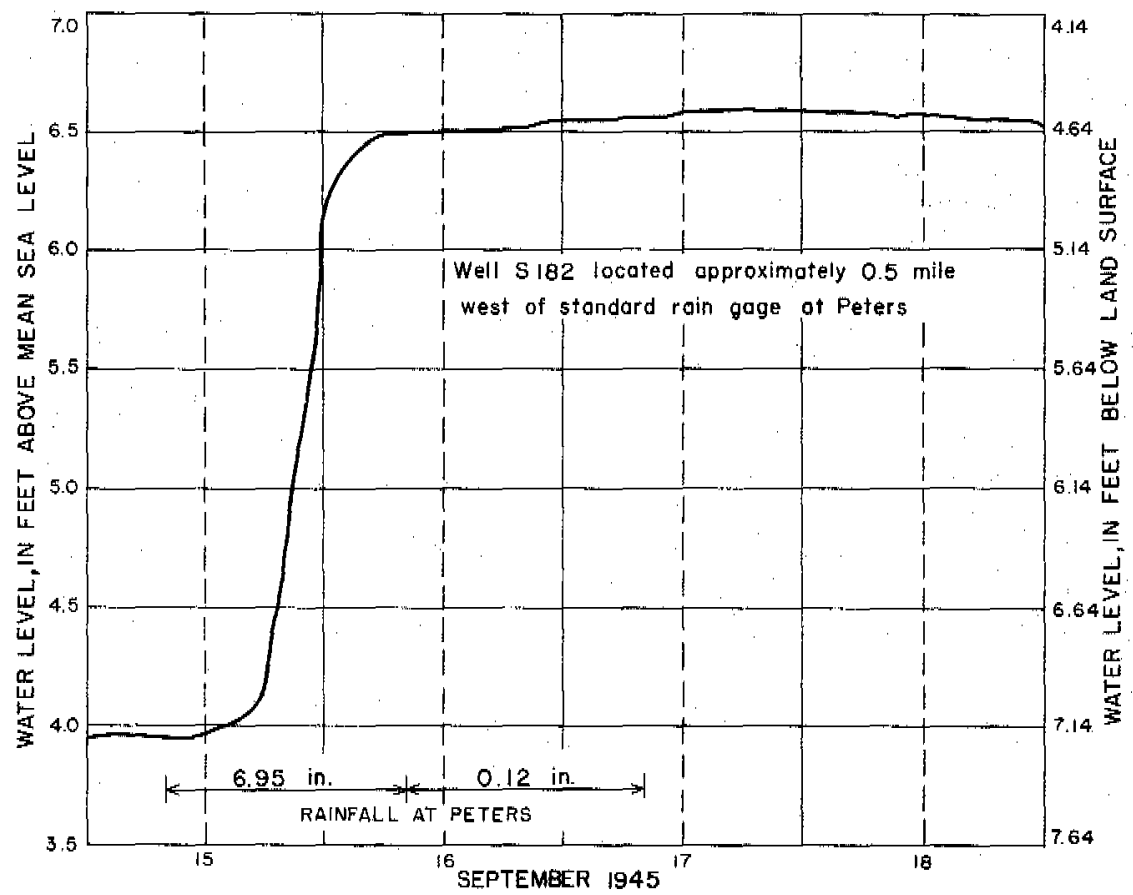

Figure 50. -Graph showing fluctuation of water level in well $\mathrm{S} 182$ following periods of heavy rainfall. 
to the water table), the porosity and the specific retention of the soil and rock above the water table; the intensity and duration of the rainfall; and the antecedent weather conditions, which may result in dry, moist, or wet materials above the water table.

Under certain conditions it is possible to calculate approximately the amount of recharge reaching the water table. The following conditions are important: The area should have a high infiltration capacity, the land surface should be nearly level, and the water table should have a gentle slope and should not be unduly influenced by nearby canals (thus, to limit ground-water discharge during the storm and to make an estimation of discharge possible with a fair degree of accuracy).

It is necessary, of course, to have fairly reliable values for the ratio between recharge and the water-table rise for that part of the aquifer over which the water table fluctuates. Wells S 182, near Peters, and S 196, 3 miles north-northwest of Homestead at the University of Florida Sub-Tropical Experiment Station, are in areas that appear to satisfy these conditions. Well S 182 is equipped with an automatic water-stage recorder, and a rain gage is $0.5 \mathrm{mile}$ east, near the intersection of U. S. Highway No, 1 and Quail Roost Drive. Well S 196 has a float gage that is readdaily; the rain gage is about $100 \mathrm{ft}$ east of the well.

From field work done during the early part of this investigation, Cross (Cross, Love, Parker, and Wallace, 1940, p. 80) estimated the specific yield of the aquifer in the vicinity of Hialeah to be 0.22 and estimated the specific yield near Opa Locka to be 0.15.

Relating amounts of recharge to the response of the water table in well $\mathrm{S} 196$, a ratio of about 0.15 for the Miami oolite was determined by the writers. When a shower followed a dry period, recharge was calculatedas precipitation minus 0.25 in. for each foot of rock above the water table at the end of a rise, thus allowing for water retained by the rock. Recharge was assumed to equal precipitation if heavy showers occurred on succeeding days when the rise caused by the second shower could be correlated with the corresponding rainfall.

Examination of the Miami oolite in borrow pits and canal bank cuts shows that the porosity and permeability of the formation change considerably in relatively short distances, both horizontally and vertically, but even with these changes it is believed that values of 0.15 to 0.20 are the best average figures to use in relating recharge to water-table rises for these parts of the coastal area.

Figure 51 shows the annual sum of the individual rises of the water table in well S 182 during the calendar years 1943-46, plotted against annual precipitation at Peters, about 0.5 mile to the east. Each 


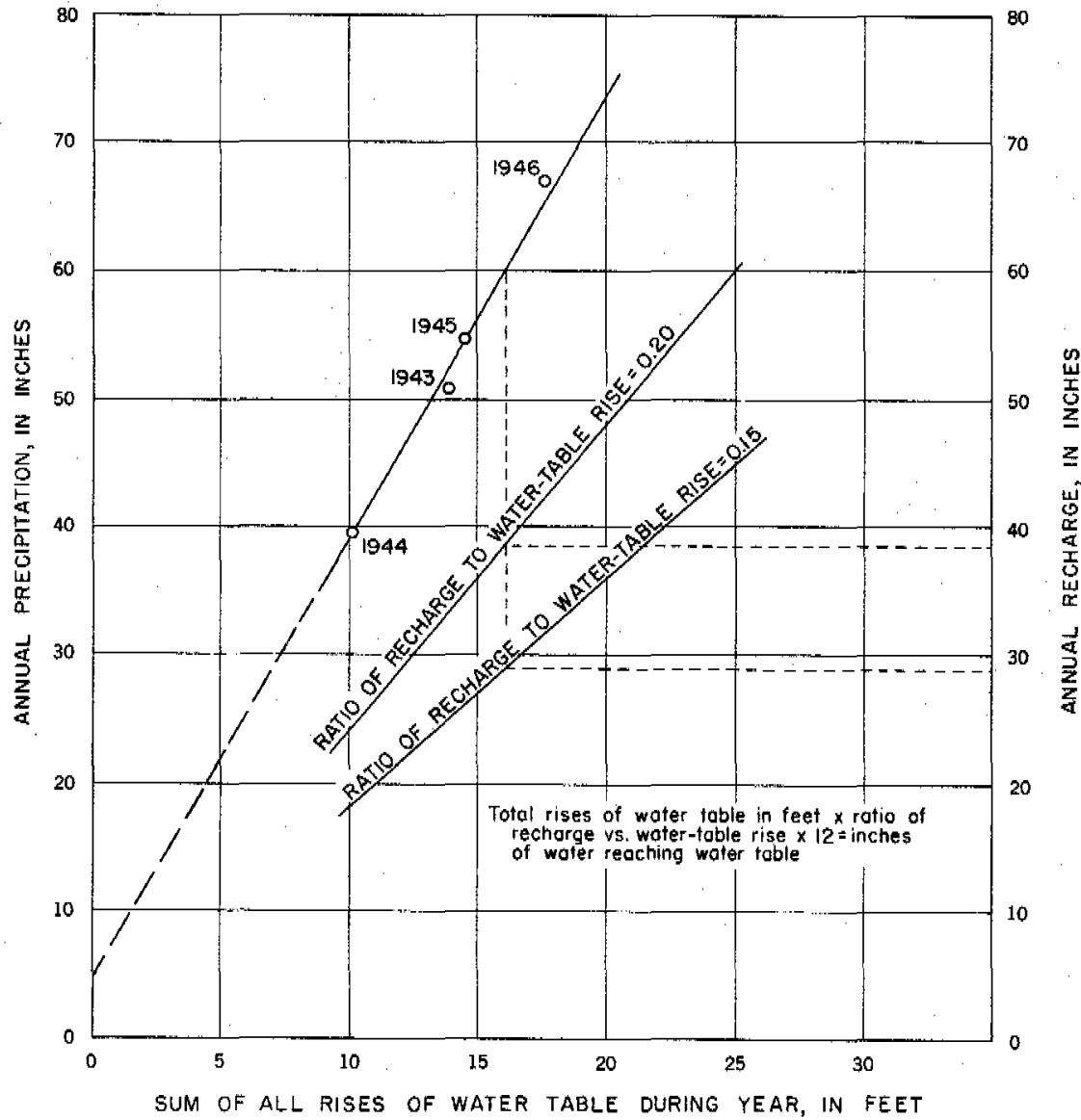

Figure 51. - Graph showing total yearly rise of water level in well $\$ 182$ compared with precipitation at Peters for 1943-46.

point plotted indicates the total rise of the water level for that year. Only the years 1943 to 1946 , inclusive, were used because the rain gage at Peters was not installed until May 1942. A straight line was drawn as closely as possible to the four plotted points, which gave a fair degree of alinement. This graph indicates that, with an average annual rainfall of 60 in., an average total rise of about $16 \mathrm{ft}$ will occur in the water table. If the ratio of recharge to watertable rise for the material saturated by the rising water table were 0.20 , the amount of recharge would be 38.5 in., or 64 percent of the rainfall.

A similar study, made for the 10 years of record for well $S 196$, showed that a 60 -in, annual rainfall would cause a total rise during the year of about $20.5 \mathrm{ft}$. Assuming a ratio of recharge to watertable rise of $0,20,40 \mathrm{in}$. or 81.5 percent of the rainfall would reach the water table. If this ratio were 0.15 the recharge would be 36,8 in., or 61.5 percent. 
It is recognized that results of the above method are of limited accuracy because of the impossibility of accurately determining the true specific yield of the material saturated by the rising water table; but by this method it is possible to obtain relative values of the ratio of recharge to water-table rises, and it shows that about two-thirds of the annual rainfall reaches the water table in southern Dade County.

Wells S 182 and S 196 are between Howard and Homestead in typical areas of the coastal ridge. Well G. 86 , however, is in the north Miami area, where the formation above the water table consists largely of sand; recharge to the water table averaging about 50 percent of the annual rainfall appears to be somewhat less than that of the area to the south.

\section{GROUND-WATER' DISCHARGE}

\section{GENERAL STATIEMENT}

In this discussion, the discharge of ground water refers only to the water that has infiltrated to the water table, although the rate of extraction from the aquifer may, in some instances, be related to the amount of moisture retained in the formation above the water table.

Ground water may be removed from the aquifer by several means. Gravity will cause it to flow into streams, canals, and wells when the water table in the area is above the water surface in these exits. From the stream or canal, it may flow by gravity out of the area; from the well, it may be removed by pumping. The amount of ground water moving by gravity depends on the slope of the water table (also referred to as the hydraulic gradient) and the transmis sibility of the aquifer. Where the water table is at or near the surface, a large percentage of the ground water may be removed by the process of evapotranspiration. If the water table is below the land surface, evaporation may take place where the capillary fringe reaches the land surface or where the air cancirculate through the pores or interstices of the soil to sufficient depth to reach the capillary fringe.

Water rises in the capillary fringe above the water table in response to the same molecular forces that cause a liquid to rise in a wick. In fine-grained geologic materials the capillary fringe may reach to a height of several feet above the water table; in silty or clayey materials it may exceed $10 \mathrm{ft}$; but in coarse sand or gravel it may be only a few inches or even a fraction of an inch. The height of the capillary fringe above the water table also varies with the temperature, and with the rise or fall of the water table itself. 


\section{EVAPORATION AND TRANSPIRATION}

Transpiration is the exhalation of water vapor by organisms, but the ground-water investigator is concerned only with transpiration by plants, whose roots remove water from the soil and whose leaves return most of this water to the atmosphere. Transpiration is a process that is concerned with the metabolism of plants, and if the supply of water becomes too small, the plants wilt, wither, and die. Plants can extract water from the water table only so long as their roots extend into the capillary fringe or to the water table itself.

In many ground-water investigations it is difficult or impossible to separate evaporation from transpiration, and the total of both is referred to as evapotranspiration, or total evaporation. Evapotranspiration varies widely, depending on the topography, soil, weather conditions, depth to water table, height of capillary fringe above the water table, and character of the vegetation.

Over the Everglades and over most of the coastal ridge in Dade County the water table is so close to the land surface that evapotranspiration accounts for a large percentage of the total water removed from the aquifer. The land surface in the glades in Dade County ranges from about 2 to $8 \mathrm{ft}$ above mean sea level, and over most of the coastal ridge it is less than $10 \mathrm{ft}$ above mean sea level. The water table in the coastal ridge ranges from about $10 \mathrm{ft}$ above mean sea level to $1 \mathrm{ft}$ below, varying with location, weather conditions, pumpage, and several other factors.

(See the section on climate for descriptions of experiments on evapotranspiration at Belle Glade and West Palm Beach.)

\section{EVAPOTRANSPIRATION AND DISCHARGE STUDIES IN DADE COUNTY}

An attempt was made by the writers to correlate the rate of decline of the water level in two wells, G 72 and G 218, with the depth to the water table. These two wells are in the eastern part of the Everglades of northern Dade County, where the muck is about $3 \mathrm{ft}$ thick and where the water table seldom drops below the base of the muck. The hydrographs of these two wells indicate that the rate of decline of the water table during rainless periods does not decrease noticeably as the water table drops. This suggests that evapotranspiration rates, for the limited range of water levels considered, do not decrease materially as the water table declines.

Figure 52 shows typical fluctuations of the water table in wells G 72 and G 218 during rainless periods. The maximum daily rate of decline due to evapotranspiration losses appears to be about $0.15 \mathrm{ft}$, and the minimum is about $0.03 \mathrm{ft}$. An average decline of $0.10 \mathrm{ft}$ per day is at the rate of $3 \mathrm{ft}$ per month. Assuming that the 

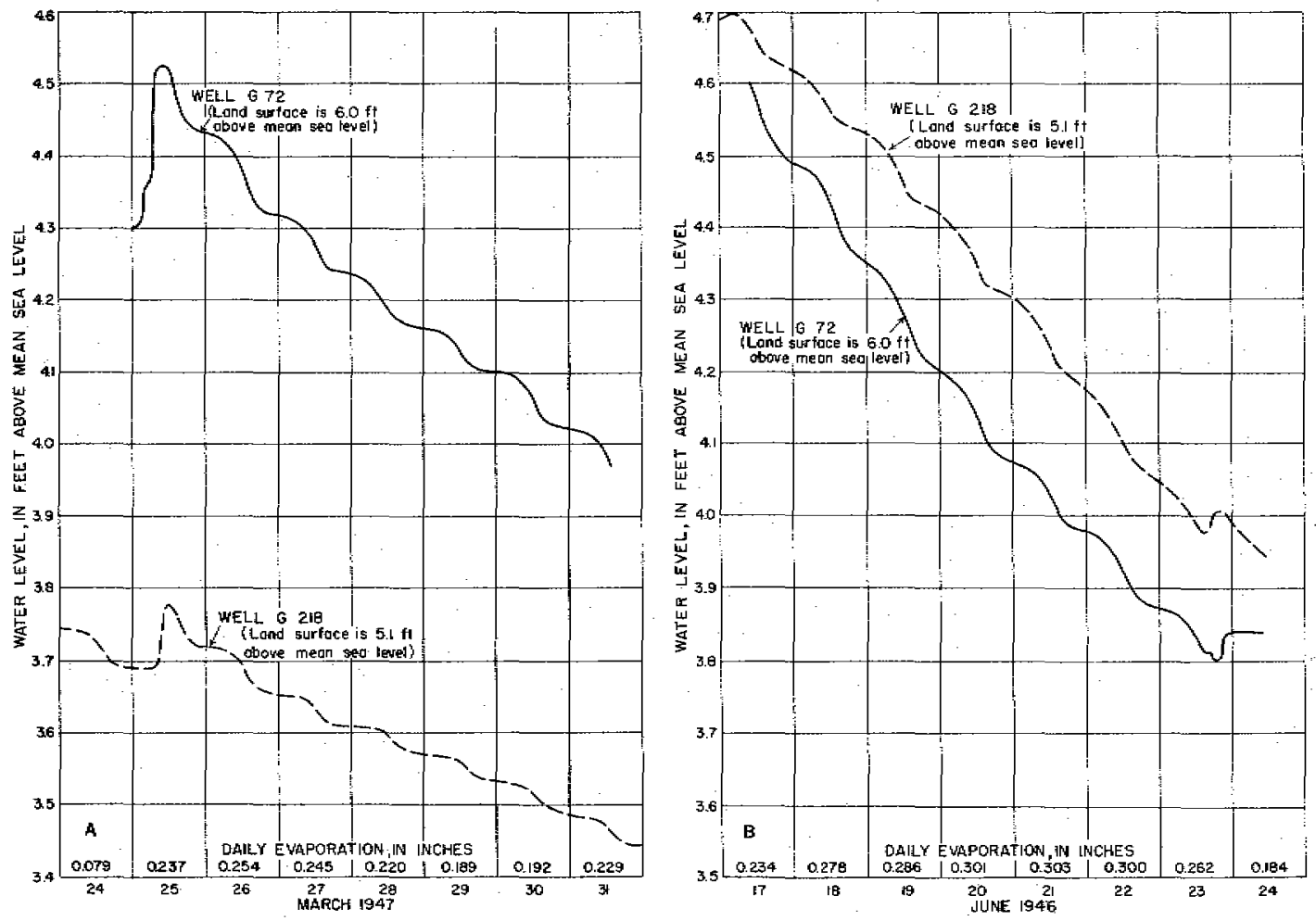

Figure 52. - Typical fluctuations of water levels in wells $\mathrm{G} 72$ and $\mathrm{G} 218$ during rainless periods. 
water coming out of storage occupied 20 percent of the volume of the material dewatered, this would give $0.60 \mathrm{ft}$ or $7.20 \mathrm{in}$. of water per month and 86.4 in. per year. A decline of $0.03 \mathrm{ft}$ per day would be equivalent to 2.16 in. per month or 25.9 in. per year.

The water taken by evapotranspiration from below the water table is only a part of the total evapotranspiration loss from the muck, because the latter has a high specific retention and plants can extract water held against gravity drainage above the water table. From Clayton's published results (Clayton, Neller, and Allison, 1942 , p. 10-14), it is concluded that a saturated cubic foot of muck soil in its original condition is about 80 percent water, but the specific yield is only about 0.20 .

Thus, it appears that in an area where the muck is $2 \mathrm{ft}$ or more thick, the water table could be lowered readily by pumping but very little salvage would be obtained and evapotranspiration losses would be reduced only slightly. While the water table is in the muck, the capillary fringe reaches the land surface and evapotranspiration rates are high; when the water table is lowered below the muck, the moisture content of this material is so high that evapotranspiration rates can be maintained for long periods without appreciable falling off. Subsequent rainfall is largely absorbed by the muck, and only a small part of it percolates through to the water table. Thus, very little can be done to reduce the priority of plants on rainfall.

Where the muck and marl mantle is about $1 \mathrm{ft}$ or less in thickness above the limestone, lowering of the water table would probably produce conditions more favorable for salvaging some water from loss by evapotranspiration.

The hydrographs of wells $\$ 182$ and $S 196$ show rainless periods as smooth curves of decreasing slope similar to the recession curve illustrating runoff for a surface stream. This decline generally starts from an hour to a day or more after the rain ceases, depending on depth to the water table, characteristics of the soil, and formation above the water table. Wells S 182 and S 196 are typical wells for the section of the coastal ridge south of the Tamiami Canal and north of Homestead; they are situated more than 3.5 and 9.5 miles respectively from the nearest Biscayne Bay shore points and thus, as indicated in figures 39 and 41 , they are unaffected by normal variations in Bay levels. Furthermore, these wells are in the general area of weather observation (rainfall) stations (see p. 219). They are the only wells in this area with daily or continuous records of water levels over a period of more than 6 years.

In an attempt to correlate the rate of decline of the water level in well S 182 with the stage of the water table, during rainless periods a graph was made (fig, 53) of rates of decline (obtained from re- 


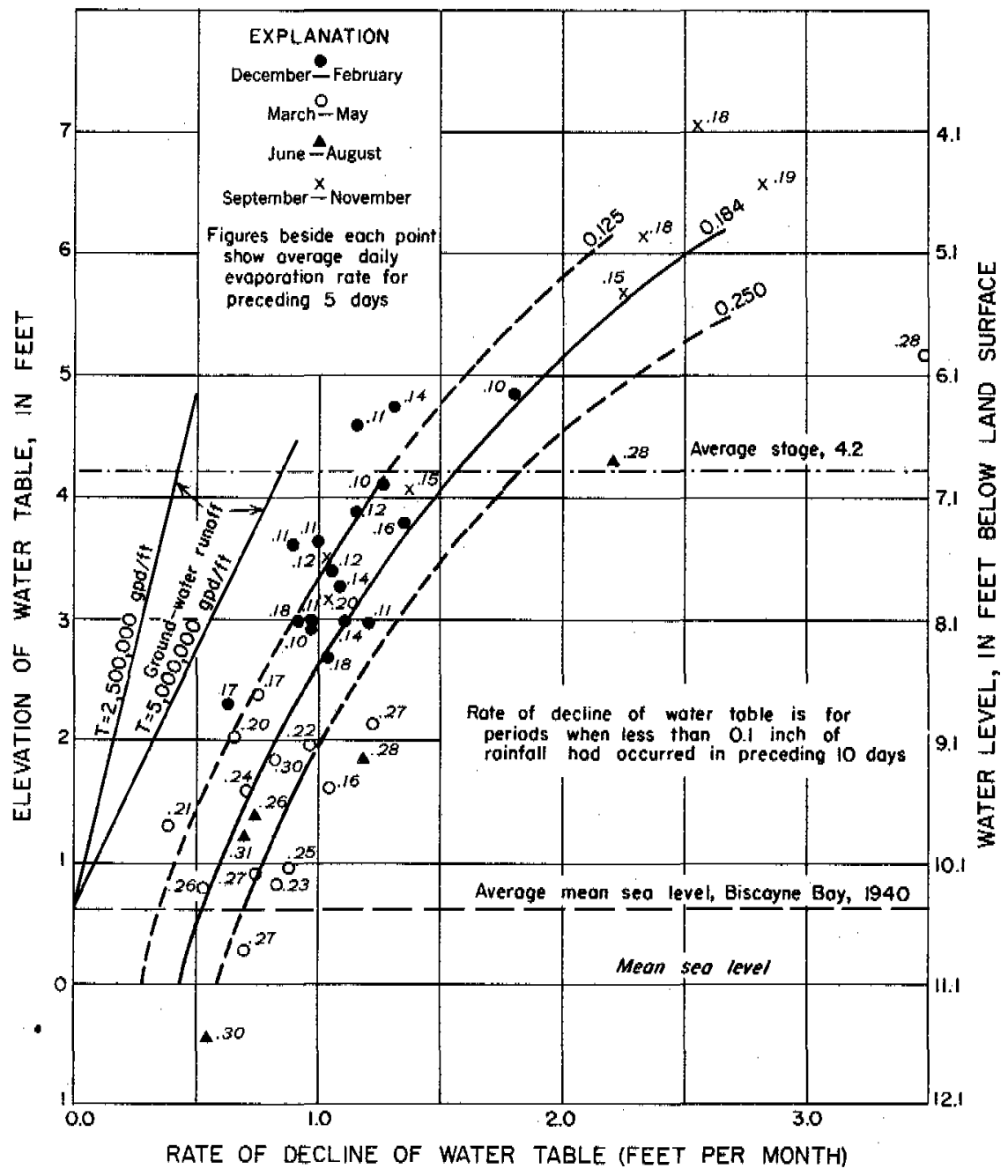

Figure 53, - Graph showing rate of decline of water level in well $\$ 182$ versus stage of water table correlated with average evaporation rate for preceding 5 days.

corder charts) plotted against the corresponding water-level stages for times when less than a total of 0.10 in. of rain had fallen in 10 preceding days. Note that a decline of the water table, indicating removal of water from storage in the aquifer, is evidently accompanied by a decreasing rate of ground-water removal. The daily fluetuations in this well are slight during rainless periods, and the departures from a smooth curve drawn through the water level at noon each day seldom exceed $0.01 \mathrm{ft}$. These small daily fluctuations, superimposed on the recession curve for the well, appear to be due mostly to changes in atmospheric pressure, but at times they may be due partly to transpiration.

Forty-one points are plotted on figure 53, the data having been obtained from records for the period from May 1942 (date rain 
gage was installed) through December 1946. The season of the year when the rainless periods occurred is indicated by symbols. Points for the lower stages, less than $2.5 \mathrm{ft}$ above mean sea level, are for periods that occurred principally during the spring and summer months when evapotranspiration rates were high (pl. 3 ). Above the 2. 5-ft stage, most of the 10-day rainless periods occurred in fall and winter when evapotranspiration rates were somewhat below the yearly average. High water-table stages occurred frequently during the summer but a rainless period of 10 days, or more, did not occur of ten.

The scattering of points on figure 53 shows that the rate of decline of the water table is influenced by factors other than the stage alone. If evapotranspiration processes are effective in withdrawing water from the wate $x$ table, the quantity of water withdrawn will vary with depth to the water table and with plant growth and weather conditions. These factors, together with the character of the soil and the type of vegetation, may cause evapotranspiration to range from zero to as much as $0.4 \mathrm{in}$. of water per day, and it can easily be seen that if water is being extracted from the aquifer by evapotranspiration, then the rate of decline is being influenced by the weather at the same time. Beside each point on figure 53, the average daily evaporation rate is given in inches for the preceding 5 days (from Class A pan at Hialeah). Curves for three arbitrarily selected evaporation rates are drawn to show the general manner in which differences in evaporation rates displace the water-table recession curve.

Another factor affecting the rate of decline is the intensity, duration, and areal distribution of the preceding rainfall. Heavy and highly localized showers build up isolated water-table mounds, which gradually flatten out during the period following the shower. Thus, a higher local rate of decline of the water table occurs in one of these temporary mound areas than would follow a rainfall of nearly uniform intensity and duration over a large area. As a ground-water mound spreads out to other areas, not covered by the shower, it tends to retard the decline of the water table in those areas.

Also shown on figure 53 are the approximate rates of decline of the water table caused by ground-water runoff. These rates were determined for two values of the coefficient of transmissibility by using the average water-table slope and assuming a ratio of 0.20 between recharge and water-table rise (see p. 218). If the entire ground-water loss were by percolation through the aquifer to discharge areas in Biscayne Bay, the rate of decline would gradually approach zero as the water table declined to the same level as that in the bay, after which no further decline would occur. However, other factors are effective, for, as shown in figures 41 and 45 , the water table at times falls below sea level in certain coastal areas. 
The average water level in Biscayne Bay during this investigation (1941-46), as determined from the recording gage at Coconut Grove, was found to be approximately $0.6 \mathrm{ft}$ above mean sea level, U. S. Coast and Geodetic Survey datum, adjustment of 1929 (the plane of reference for this investigation). This average is significant when studying water-level records for observation wells located in areas unaffected by transient tidal variations. The measurable effects of transient variations apparently are restricted to a coastal strip no wider than about 7,000 ft. Thus, for such observation wells as $\mathbf{S} 182$ and $\mathrm{S} 196$, the longer term averages of sea level, or water level in Biscayne Bay, are more significant than daily or monthly tidal variations.

For average, and below average, water-table stages Biscayne Bay is the only natural outlet (other than by evapotransipiration) for the ground water moving from the area in which well $\mathrm{S} 182$ is $10-$ cated. If all the ground-water flow were discharged into the bay, then the average gradient between the well and the bay would vary with the height of the water level in well $\mathrm{S} 182$ above some relatively long-term average water level in Biscayne Bay. However, the data indicate that at a stage of $0.6 \mathrm{ft}$ above mean sea level (using $0.6 \mathrm{ft}$ as the average water level in Biscayne Bay, base level for ground-water flow) the water table is still declining at a rate of about $0.5 \mathrm{ft}$ per month. Assuming that the water coming out of storage occupied 0.20 of the volume of material unwatered, the loss from storage is at the rate of 1.20 in, per month, or 14.4 in; per year, for this stage of the water table.

Above the average stage, the rate of decline increases rapidly as the stage rises. This is due to several causes, among which are the following: (1) As the stage rises, the hydraulic gradient toward the sea steepens and ground-water flow increases in proportion. (2) At higher stages there are additional outlets for ground-water flow. (3) As the water table approaches the land surface, the evapotranspiration loss increases.

Figure 47 shows a high stage of the water table, and the contours indicate discharge from the western part of the coastal ridge toward the Everglades and toward Biscayne Bay. At extremely high, stages, certain springs that formerly flowed perennially commence flowing in places along the shoreline at elevations slightly above sea level. These springs flow only for a short time, but they are additional and somewhat freer exits than those that discharge into the bottom of the bay. Also, at extremely high stages, consider able ground-water flow is directed into the transverse glades (see the section on Geomorphology) that discharge (by surface flow) into the bay or connecting canals.

The recorder charts for well S 182 generally do not show daily fluctuations similar to those for wells in the glades. The land sur- 
face at $\mathrm{S} 182$ is about $11 \mathrm{ft}$ above mean sea level, but within half a mile there are areas less than $7 \mathrm{ft}$ above sea level. Because the Biscayne aquifer is very permeable, the evapotranspiration loss in nearby areas, where the water table is closer to the land surface, would have some effect on the water in this well.

Figure 46 shows contours on the water table for March 17, 1941, at a time when the water table was very near the average stage computed for the entire period of record (1940-46). The rain gages in Dade County show no rainfall other than slight traces for the period March 10-19, inclusive, but on March 8-9 a rainfall ranging from 1.04 in. to 2.28 in. was recorded in all gages (the first 7 days of the month were rainless). The average evaporation rate from the Hialeah pan during the 5 days preceding March 17, 1941, was 0.18 in. per day (about average for the year).

\section{GROUND-WATER DISCHARGE STUDIFS DN THE ATLANTC COASTAL ADGE gOUTh OF KENDALL.}

If an average value for the coefficient of transmissibility (see $p$. 237) for a selected area around wells 182 were known, the groundwater runoff from the area for an average stage, based on the shape of the water table (see fig. 46), could be computed. If a value for the average annual recharge to the aquifer in the area were known, it would be possible to compute evapotranspiration losses from the water table because the part of the recharge not accounted for by ground-water runoff would have to return to the atmosphere. Figure 51 indicates that about $38 \mathrm{in.}$ of an average annual rainfall of 60 in. reaches the water table, assuming that the average ratio between recharge and water-table rise is 0.20 (see p. 218).

Three pumping tests, at locations respectively 4 miles northnortheast, 7 miles north-northwest, and 4 miles west-northwest of well S 182 (fig. 61), gave values for the coefficient of transmissibility $(T)$ of about 4,15 , and $6 \mathrm{mgd}$ per $\mathrm{ft}$ respectively $(\mathrm{p} .270)$. This is a rather wide range for the coefficient of transmissibility, the maximum of the three determinations being about four times the minimum. Therefore, it was decided to compute theoretical ground-water runoff, using an average water-table stage and values of $T$ equaling $2.5,5$, and $10 \mathrm{mgd}$ per $\mathrm{ft}$ in each case. These computations should therefore yield results indicative of orders of magnitude of the ground-water discharge.

The area selected for making these computations centered around well S 182 and lay between the $2,0-\mathrm{ft}$ and the $5.5-\mathrm{ft}$ water-table contours. At the average water-table stage in this area (fig. 46) the location of the 2.0-and 5.5-ft contours on the water table approximately coincides with the boundaries of the coastal ridge, because, at the average stage, the Everglades generally begin west of the $5.5-\mathrm{ft}$ contour on the water 
table and the mangrove swamp and marl flats begin on the east near the $2,0-\mathrm{ft}$ contour on the water table. The width of the selected area was about 5 miles, measured along the $4.0-\mathrm{ft}$ contour, 2.5 miles on each side of well S 182 . The north and south boundaries were arbitrarily chosen flow lines between the 2.0- and 5. 5 - $\mathrm{ft}$ contours.

The average length of, and the average water-table gradient across, each of the contours in the selected area was determined, and by assuming a value of $T$, the ground-water flow past each contour was computed, and the flow into, and out of, the area was obtained.

Because the size of the area enclosed within the contours and the nor th and south boundaries was known, the amount of increase in flow between the two contours could be expressed in inches per year for the area.

This method was used for various combinations of contours to "average-out" errors in mapping the water table and to compensate for variances in the transmissibility. On the basis of these studies, a value of $\tau$ equal to $10 \mathrm{mgd}$ per $\mathrm{ft}$ appeared to be too high, because it would require about 50 in. (of an average annual of 60 in.) of rainfall as ground-water discharge to maintain the water table at the average stage. Given a value of $T$ equal to $5 \mathrm{mgd}$ per $\mathrm{ft}$, the ground-water discharge would be about $25 \mathrm{in}$. per year. Assuming that $38 \mathrm{in}$. per year would reach the water table (fig. $51), 13$ in. would be discharged as evapotranspiration from the water table, and the total evapotranspiration would be 35 in. of water per year, provided that the only other disposition of rainfall were ground-water runoff.

A logical continuation of the above method shows:

38 in. recharge to water table

-25 in. ground-water discharge

$\overline{13}$ in. evapotranspiration from water table

$60 \mathrm{in.}$ average annual rainfall

-38 in. recharge to water table

$\overline{22}$ in. evapotranspiration of rain not reaching water table

22 in. evapotranspiration of rain not reaching water table +13 in. evapotranspiration loss from water table

$\overline{35}$ in. total evapotranspiration loss, or

60 in. annual rainfall

-25 in. ground-water discharge

$\overline{35}$ in. total evapotranspiration loss

Inasmuch as the re are no canals within these selectedareas, surface runoff would be inconsequential. Given a value of $r$ equal to 
$2.5 \mathrm{mgd}$ per $\mathrm{ft}$, the ground-water runoff would be $12.5 \mathrm{in}$. per year; evapotranspiration from the water table would be 25.5 in. , and total evapotranspiration would be 47.5 in.

Assuming that atmospheric conditions causing high evaporation rates from a free water surface are also conducive to high evapotranspiration rates from the water table, there should be some relationship between the rate of evaporation and the rate of decline of the water table. This relationship would hold true only when the water table is close enough to the surface for plants to draw freely upon it.

The water table under most of the coastal ridge appears to decline as a result of evapotranspiration, but at a lower rate than in the glades to the west. Figure 53 shows the water table still declining at the rate of about $0.5 \mathrm{ft}$ per month when the water table is down to $0.6 \mathrm{ft}$ above mean sea level, which is approximately the average level of the water surface in Biscayne Bay (see p. 227). Because ground-water discharge would be zero from a flat water table at this elevation, and because there is no large-scale artificial withdrawal in the area, evapotranspiration must account for the decline below this stage. Even if the evapotranspiration in the immediate vicinity of a well on high ground is small, loss from adjacent lower ground (possibly within a $2-$ or $3-$ mile radius) will affect the water table in the higher area, and it will lower the water level there at a rate in excess of that caused by the local evapotranspiration.

Figure 53 was prepared in an attempt to correlate stage and rate of decline of the water table with evaporation rates for the 5 preceding days from a standard Class A, U. S. Weather Bureau evaporation pan at Water Plant, Hialeah. It is realized that evaporation rates as determined from an evaporation pan cannot be directly applied to evaporation from land surfaces, and in this section the estimates are based on changes in evaporation rates. The average evaporation rates are shown in figure 53.

The highest evaporation rates tend to fall to the right side of the group of points, and the lowest evaporation rates tend to fall to the left side of the group, thus indicating that higher evaporation rates tend to cause a more rapid decline of the water table at a given level. There is a considerable scattering of points for equal evaporation rates. This is probably due to several factors, the two principal ones being: (1) Local rainfall creates water-table mounds (see p. 226), which, even after' 10 to 20 days following a heavy shower, may still be dissipating into the water table. (2) The evaporation pan at Water Plant, Hialeah, is 16.5 miles northnortheast of the well, and average 5-day pan evaporation rates at the two loeations may vary enough to introduce some error. 
This scattering of points makes it impossible to draw curves accurately correlating the rate of decline versus stage for constant evaporation rates. However, lines have been drawn to indicate average evaporation rates of about $0.25,0.184$ (the average evaporation rate for the Hialeah pan for the period of record, $1941-46)$ and 0.125 in. per day.

A study similar to the above was made for well S 196 for the period 1938-46, inclusive. This well is at the University of Florida Sub-Tropical Experiment Station, 3 miles nor th-northwest of Homestead and 10.5 miles southwest of well S 182 .

The evapotranspiration loss in the area of well $\mathrm{S} 196$, at a stage of $0.6 \mathrm{ft}$ above mean sea level (at this stage the water table is nearly flat and at the same level as the average water surface in Biscayne Bay), causes the water to decline at the rate of about $0.85 \mathrm{ft}$ per month. In the vicinity of $S 196$, a ratio of recharge to change in ground-water level of 0.15 seems a reasonable value (see section on Ground-water recharge, p. 219). Using this ratio, the evapotranspiration is equivalent to about 1.5 in. of water per month or $18 \mathrm{in}$. per year. At an average stage of $3.5 \mathrm{ft}$ above mean sea level, the water table declines at the rate of $1.6 \mathrm{ft}$ per month. Using the ratio of 0.15 , this is equivalent to about 35 in. per year.

After deducting losses for evapotranspiration, the ground-water discharge at average wate $x$-table stage is sufficient to cause the water table to drop at the rate of $0.60 \mathrm{ft}$ per month, which is equivalent to about $13 \mathrm{in}$. of runoff per year.

In the area of well S 196 the value of the cofficient of transmissibility required to carry off $13 \mathrm{in.}$ per year, based on the shape of the water table at average stage, appears to be between 15 and 20 mgd per $\mathrm{ft}$. The map of the water table in this area ( $\mathrm{fig}$. 46) shows that the gradients are rather flat; however, the control for mapping the water table in this area is not complete enough to allow accurate contours to be drawn.

The analysis of the behavior of the water levels in wells S 182 and S 196 indicates that, for the coastal ridge between Kendall and Homestead, about 35 to $40 \mathrm{in}$. of the annual rainfall of $60 \mathrm{in}$. reaches the water table, and of this amount, about 15 to $20 \mathrm{in}$. is lost by ground-water runoff and 20 to $25 \mathrm{in}$. is lost by evapotranspiration from the water table.

The coastal ridge area between Kendall and Homestead consists of about 120 square miles. A 15-in, annual ground-water runoff from this area is equivalent to an average daily runoff of $85 \mathrm{mgd}$; and a $20-\mathrm{in}$. runoff is equivalent to $114 \mathrm{mgd}$. It is estimated that, at an average stage of the water table, the ground-water flow past the $2.0-\mathrm{ft}$ contour, which in this area is about $18 \mathrm{miles}$ long, is from 100 to $140 \mathrm{mgd}$. 
TATER-LEVEL DECLNE IN BELECTED WELS OF THE ATLANTIC COASTAL BIDE

Figure 54 shows the recession curves for several wells in the coastal ridge. From these curves may be determined the approximate length of time required for the water table to decline from

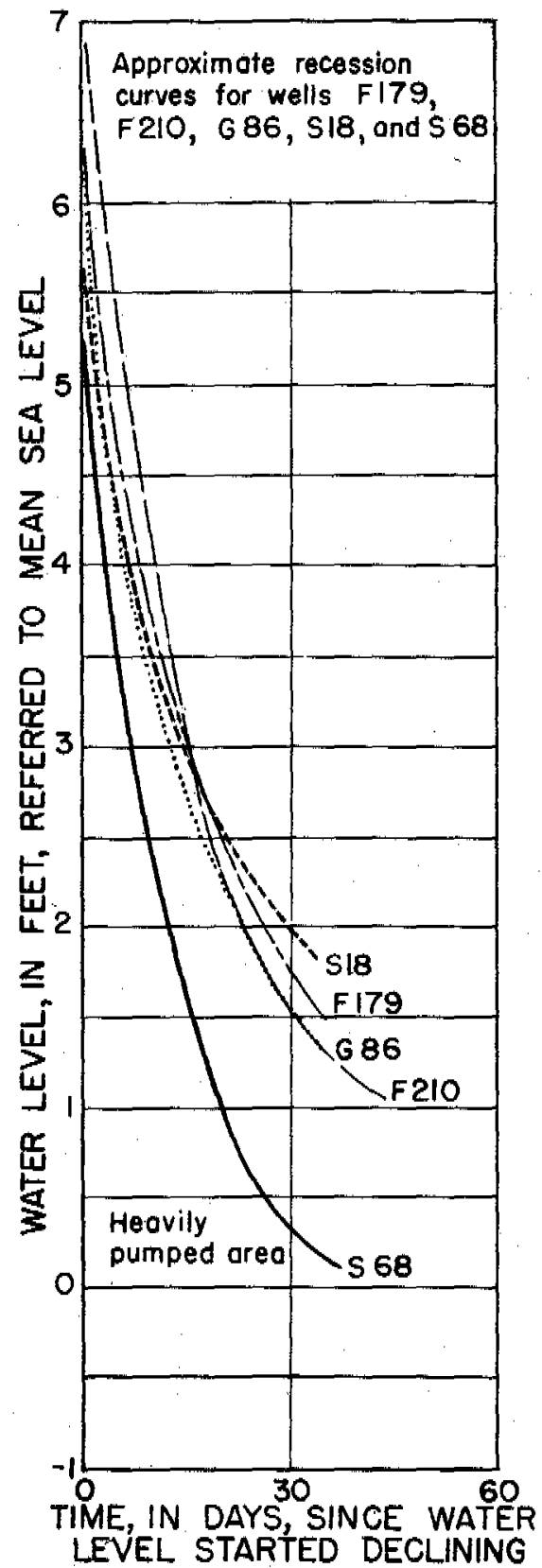

Figure 54. -Recession curves for five wells in the coastal ridge. 
one stage to another during periods of no rainfall. The curves were traced from the hydrographs of wells F 179, F 210, G 86, $S 18$, and $S 68$, following very heavy rainfall on April 16-17, 1942.

On April 14, the water level in these five wells was 0.5 to 0.9 $f t$ below their average stage. Ten to twenty in. of rainfall fell on the area in which these wells are located during April 16 and 17, 1942. At this time, the water levels in the five wells rose to their highest stages on record $(1940-46)$; they reached peak stages of 5.3 to $6.9 \mathrm{ft}$ above mean sea level, 1 to 7 hours after the rainfall stopped. The rise in the five wells during these 2 days ranged from 4.8 to $6.1 \mathrm{ft}$. By May 14, the water level in these wells had declined to stages only 0.1 to $0.6 \mathrm{ft}$ above their average stage. Thus, within a 30-day period the water level had risen from relatively low stages to the highest stages on record and had declined to a stage only slightly above normal.

These five wells are all located within 1,5 miles of either the Biscayne Bay shoreline or a major canal, and the water levels in the wells react accordingly.

Well $\mathrm{S} 68$ is an observation well in the Miami well field near Hialeah, about 0.6. mile southwest of the Miami Canal. On April 14, the stage in the well was about mean sea level, and in the $\mathrm{Mi}$ ami Canal at Hialeah it was $1.2 \mathrm{ft}$ higher, thus indicating influent conditions. After about $18 \mathrm{in}$. of rainfall on April 16 and 17, the water level in the well reached a peak stage of $5.3 \mathrm{ft}$ above mean sea level within an hour after the rain ceased. The corresponding peak stage in the canal was $2.6 \mathrm{ft}$ above mean sea level, a difference of $2.7 \mathrm{ft}$, and the establishment of effluent conditions had tak en place. Fifteen days later, the stage in well $\mathrm{S} 68$ was $1.6 \mathrm{ft}$ above mean sea level, and in the canal it was $1.7 \mathrm{ft}$ above mean sea level. Thirty days after the heavy rainfall, the stage in the well was about $0.4 \mathrm{ft}$ above mean sea level and $0.6 \mathrm{ft}$ below the canal stage, thus indicating that influent conditions had been rees tablished.

Well S 18 is about 0.5 mile north of Biscayne Canal, and well $G 86$ is about 0.5 mile north of Little River Canal; both wells are on, or near, NW. 27 th Avenue. After about 18 in. of rainfall, these wells rose to peak stages of 5.6 and $6.1 \mathrm{ft}$ above mean sea level. Thirty days later, they had declined to stages of 2.0 and $1.6 \mathrm{ft}$ above mean sea level, respectively. The differences between the water levels in the wells and those in the canals probably never exceed $3.5 \mathrm{ft}$. Well F 179 is located at SW, 24th Terrace and $32 \mathrm{~d}$ Avenue, and well F 210 is located at NW. 62d Street and Miami Court. Well F 179 is about 1.3 miles northwest of Biscayne Bay shoreline and 1.7 miles northeast of Coral Gables Canal. Well F 210 is about 1 mile west of Biscayne Bay shoreline and $1.3 \mathrm{miles}$ south of Little River Canal. 


\section{GROUND- WATER DISGHARGE gTULUE IN THE ATLANTIC COASTAL FUDGE NORTB OF} KENDALL

The northern part of the coastal ridge of Dade County is dissected by several tidal drainage canals; the principal ones are Snake Creek, Biscayne, Little River, Miami, Tamiami, Coral Gables, and Snapper Creek. The recession curves for five wells in this area show that these canals quickly drain off water reaching the water table when the area is not flooded. Although no quantitative data are available for ground-water runoff through canals from the coastal ridge, the average discharge was determined for several selected days at two or three locations on each major canal. Continuous discharge records are available for the years since 1940 for several stations on the Miami and Tamiami Canals (see section on Surface water). From these limited data it is impossible to arrive at a figure for total average annual ground-water runoff through canals from the coastal ridge.

From 1 mile below Kendall to the Dade-Broward County line to the north, the coastal ridge includes an area of about 120 square miles. In this area, it is estimated that more than half of the average annual rainfall reaches the water table, and of this amount, the larger part leaves by ground-water runoff. If the average annual ground-water runoff were 25 in., this would be equivalent to an average daily ground -water runoff of $143 \mathrm{mgd}$, or $221 \mathrm{cfs}$. However, this is not the total ground-water runoff, because, in addition to recharge from rainfall on the coastal ridge, there is groundwater runoff due to underground flow into the area from the Hialeah, Opa Locka, and adjacent areas, just west of the coastal ridge. This additional ground-water runoff appears to be less than onequarter of the above figure $(221 \mathrm{cfs})$, but it would be difficult to determine the amount with any degree of accuracy.

A large part of the area just west of the coastal ridge is drained by a network of lateral canals. Most of the discharge from these canals is into the Miami Canal when the 36 th Street dam is open. However, some of it goes into Biscayne, Little River, Tamiami, and Snapper Creek Canals. On the basis of the total area contributing ground-water flow directly to the bay and on the basis of the slope and shape of the water table at the average elevation above sea level, it is estimated that three-quarters, or more, of the ground-water runoff from the northern part of the coastal ridge of Dade County (beginning at the south near Kendall) is discharged into canals and thence finds its way into the sea. The remainder of the ground water discharges directly into the bay. 


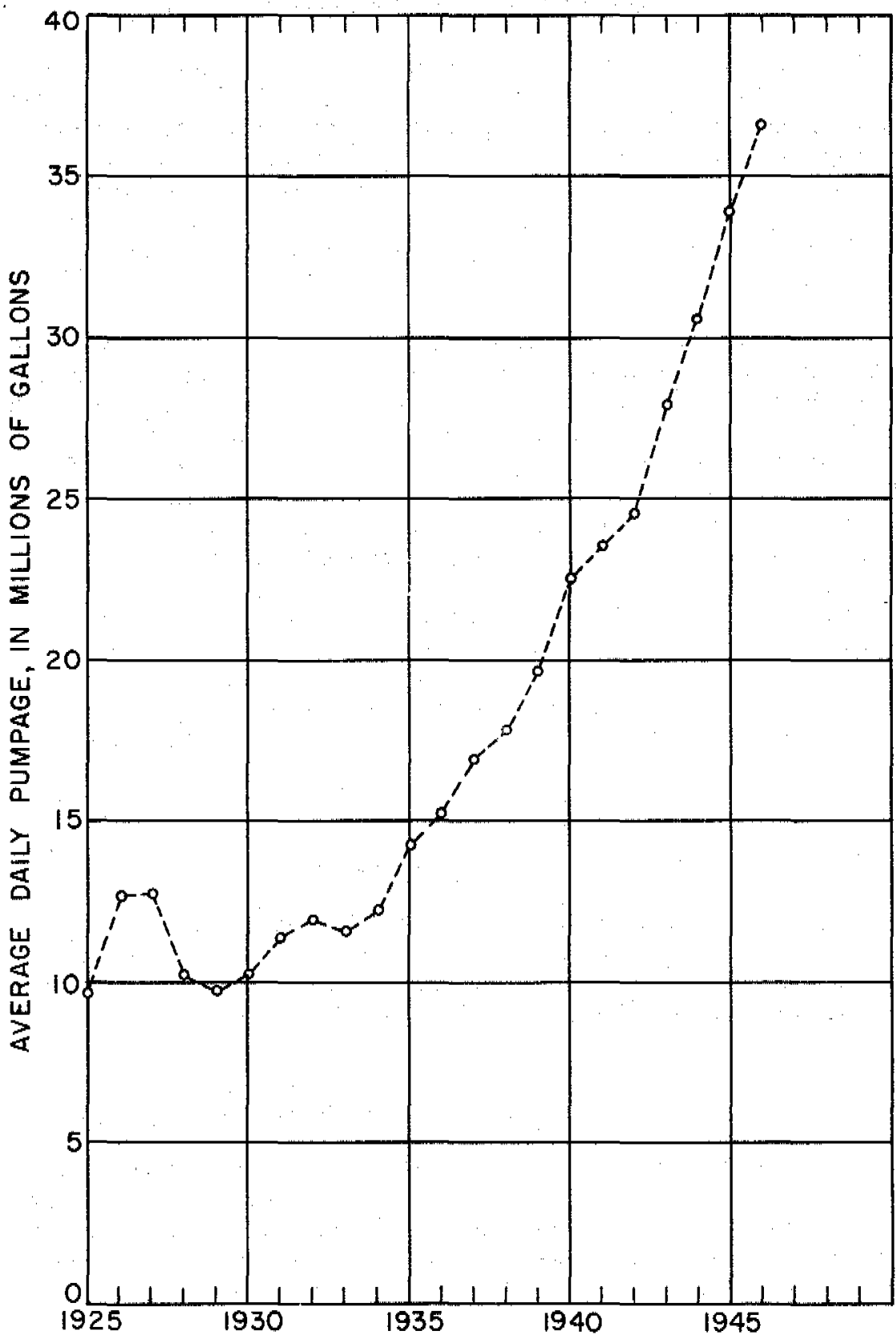

Figure 55, - Pumpage from Miami well field at Hialeah, 1925-46. 


\section{ESTMATED GROUND-TATER PUMPAGE IN DADE COUNTY}

The total amount of water pumped from wells in Dade County during 1945 was estimated (Parker, 1947, p. 72-88) to be 21, 310 million gallons, of which 4,240 million gallons was for industrial use and 4,140 million gallons was for rural and agricultural purposes. The remaining 12,930 million gallons was pumped for the various municipal water supplies in the county. These figures are equivalent to an average daily pumpage of 58 million gallons for all purposes.

The average daily pumpage in 1945 from the Miami municipal well field was about 34 million gallons. The pumpage from this well field has increased steadily from an average of about 11.5 mgd in 1933 to $36.6 \mathrm{mgd}$ in 1946 (see fig. 55 and Appendix). Not all of this water enters the well field as normal ground-water flow. Instead, a large part of the water pumped from the Miami municipal well field percolates into the areafrom nearby canals; the most heavily pumped area is completely surrounded by canals.

Of the more than 21,000 million gallons of ground water pumped annually, a considerable part is returned to the aquifer by seepage from irrigation systems, septic tanks, and drainage wells. As pointed out elsewhere in this report, this recharge helps to maintain high water levels in that part of the coastal ridge near the shore of Biscayne Bay.

\section{HYDROLOGIC PROPERTIES OF WATER-BEARING MATERIALS}

The two principal hydrologic properties of an aquifer are its capacities to store and to transmit water. All aquifers have both properties to a certain extent, but there is a wide range of degree of efficiency among them.

\section{COEFFTCIENT OF PERMEARUITY}

The capacity to transmit water through the pores and interstices of an aquifer is of ten referred to as permeability, and it is expressed by various combinations of units of space and time. It is now commonly referred to as the coefficient of permeability. Meinzer and Wenzel (1942, p. $452-454)$ discuss permeability as follows:

" The standard coefficient of permeability used in the hydrologic work of the United States Geological Survey is defined as the rate of flow of water at $60^{\circ} \mathrm{F}$, in gallons a day, through a cross section of 1 square foot, under a hydraulic gradient of 100 percent. A related coefficient, which may be called the 'field coefficient of permeability,' is defined as the rate of flow of water, in gallons a 
day, under prevailing conditions, through each foot of thickness of a given aquifer in a width of 1 mile, for each foot per mile of hydraulic gradient. The standard coefficient of permeability can generally be computed very closely by multiplying the field coefficient by the ratio of (1) viscosity of the water in the stratum to (2) the viscosity of water at $60^{\circ} \mathrm{F}$."

\section{COEFFICANT OF TRANEMESTBITTY}

Transmissibility is a measure of the capacity of an aquifer to transmit water. To quote further from Meinzer and Wenzel: "Recently Theis (1935, p. 519-52 4) introduced the very convenient term 'coefficient of transmissibility, $[T]$ which is the "field coefficient of permeability" multiplied by the thickness, in feet, of the saturated part of the aquifer. Thus the [standard] coefficient of permeability denotes a characteristic of the water-bearing material, whereas the coefficient of transmissibility denotes the analogous characteristic of the aquifer as a whole.

"Natural earth materials that have been tested in the hydrologic laboratory of the United States Geological Survey have been found to have coefficients of permeability ranging from about 0.0002 to about 90,000 - that is, the most permeable material carries water at a rate about $450,000,000$ times that of the least permeable material. However, most water-bearing materials utilized by wells have coefficients that are whole numbers of two or more figures, generally between 10 and $5,000 .=$

\section{COEFFICIENT OF STORAGE}

The coefficient of storage (s) of an aquifer is defined as the volume of water released from, or taken into, storage per unit surface area of aquifer, per unit change in the component of head normal to that surface. To visualize this concept, imagine a decrease in head on an elemental vertical prism extending from top to bottom of a horizontal elastic aquifer of uniform thickness. The volume of water thereby released from this prism, divided by the product of the cross-sectional area and the decline in head, determines the storage coefficient. For artesian conditions, the water released is attributed solely to the compressibility of the aquifer material and of the water. Obviously, under these conditions, $s$ is dependent on the thickness of the aquifer. For water-table conditions the water released is attributed partly to gravity drainage of the zone through which the water-table declines and partly to compressibility of the water and aquifer material in the saturated zone. Usually, the volume of water attributable to compressibility is a negligible proportion of the total volume of water released and can be ignored. The storage coefficient then is sensibly equal to the specific yield and is independent of the thickness of the aquifer. 


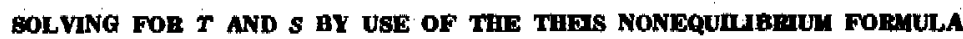

The coefficients of transmissibility $(T)$ and storage (S) may be determined from a mathematical analys is of the shape and rate of expansion, with respect to time since pumping started, of the cone of depression that develops around a pumped well. As in any mathematical analysis, it is necessary to assume certain basic conditions and relationships, and the reliability and accuracy of these coefficients, for practical application, is determined by how closely actual field conditions fit the assumptions on which the formulas are based.

The nonequilibrium formula, now widely used in quantitative studies of ground water was introduced by Theis (1935, p. 519524) in 1935 for determining the coefficients of transmissibility and storage of a theoretical aquifer. It is called the nonequilibrium formula because the element of time (time since well started pumping) enters into it.

This formula is as follows (Wenzel, 1942, p. 87):

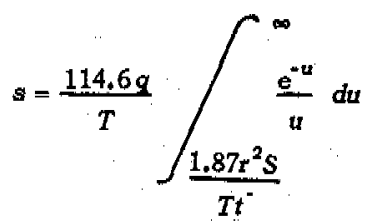

in which:

$s=$ the drawdown in. feet at any point in the vicinity of a well discharging at a uniform rate.

$q$ - the discharge of the well in gallons per minute.

$T=$ coefficient of transmissibility of the aquifer, in gallons per day per foot.

$s=$ coefficient of storage.

$t=$ time the well has been pumped in days.

$t=$ distance in feet from discharging well to the point of observation.

According to Theis and Wenzel, the nonequilibrium formula is based on the following assumptions: (1) The water-bearing formation (aquifer) is homogeneous and isotropic; (2) the aquifer has an infinite areal extent; (3) the discharge well penetrates the entire thickness of the aquifer; (4) the coefficient of transmissibility is constant at all places and times; (5) the discharge well has an infinitesimal diameter; and (6) water taken from storage is discharged instantaneously with the decline in head. The formula also assumes that Darcy's Law is effective; that is, that the velocity of groundwater flow varies directly as the slope of the hydraulic gradient. 
The integral can be called the well function of $y, W(u)$, and can be evaluated by the series:

$$
W(u)=-0.577216-\log _{u} u+u+\frac{u^{2}}{2 \cdot 2 !}+\frac{u^{3}}{3 \cdot 3 !}-\frac{u^{4}}{4 \cdot 4 !} \cdots
$$

in which: $\quad t=\frac{1.87 \pi^{2} S}{T t}$

The nonequilibrium formula may then be written:

$$
s=\frac{114.6 q}{T} W(u)
$$

By means of a special type curve, a graphical solution for values of $T$ and $S$ may be made (Wenzel, 1942, p. 88).

Several attempts were made by pumping tests to determine the coefficients of transmissibility and storage for the aquifer in the Miami area. The four most important of these tests are known as: (1) S 1 ; (2) G 551; (3) G 552; and (4) G 553. They will be discussed on the following pages.

\section{LARGE-SCALE PUMPING TESTS}

\section{S 1 PUMPING TEST}

From November 19 to November 26, 1946, a large-scale pumping test was made in the lower Miami Springs well field. The pumped well was $\mathbf{S} 1$, one of the regular city supply wells; its location with respect to the other wells and the canals in the area is shown in figure 56. An idealized geologic section of the lower well field, with location and depth of the test wells plotted with respect to each other and to land surface, is shown in figure 57.

Well $S 1$, the pumped well, is $61 \mathrm{ft}$ deep and has 14 -in. casing to a depth of $48.5 \mathrm{ft}$. The rated capacity of the pump is about $4,100 \mathrm{gpm}$. The deeper observation wells in the area, which were measured during the test, are approximately the same depth as the pumped well and have about the same amount of casing. The shallow observation wells are 10 to $12 \mathrm{ft}$ deep and have about 2 to $5 \mathrm{ft}$ of slotted casing or open hole at the bottom (see fig. 57).

All the supply wells, S 1 to $S 8$ (see fig. 56), in the lower well field were idle on November 14 , except $S 7$, which was in operation continuously from November 14 through November 26. For the period November 14 to 18 , inclusive, all the Miami water supply was obtained from the upper" well field (wells S 11 to S 22, inclusive), except that supplied by well $S 7$. Well $S .7$ has a rated capacity of $2,600 \mathrm{gpm}$, or $3,744,000 \mathrm{gpd}$. The average daily pumpage from wells $S 11$ to $S 22$ during this period was $30.9 \mathrm{mgd}$. 


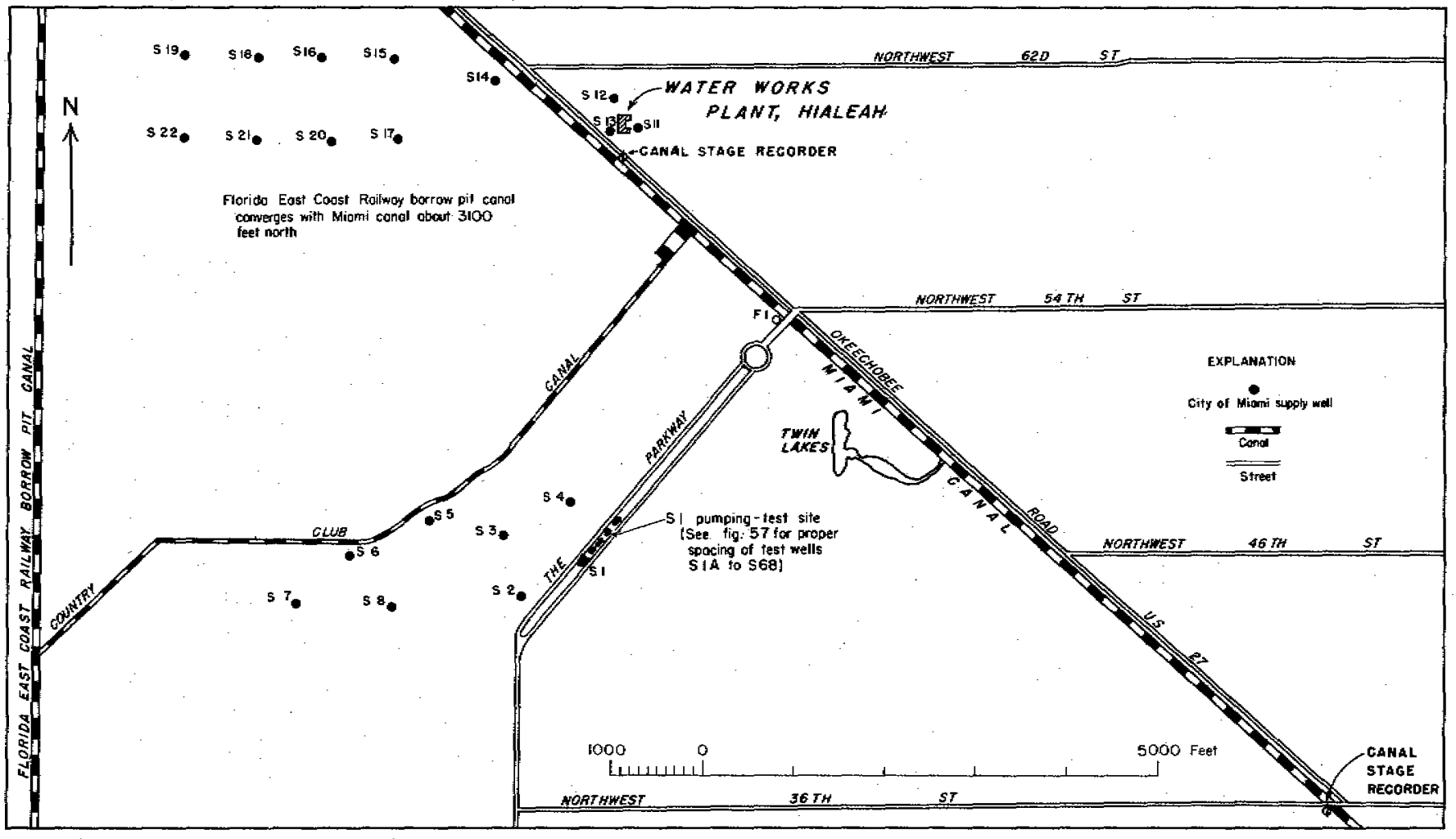




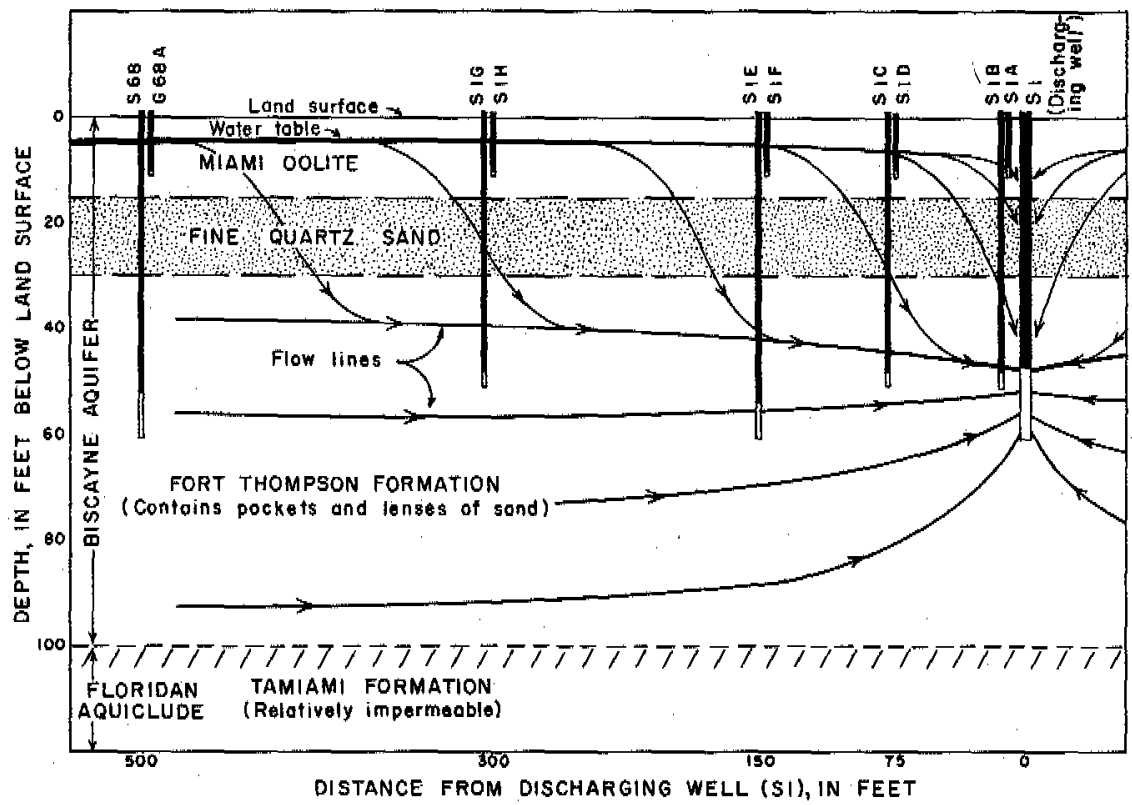

Figure 57. -Generalized cross section through wells S 1 to S 68 in the lower Miami well field,

On November 19 at 10:30 a. m., supply well $\mathrm{S}$ I was placed in operation and continued operating until 11 a. $m$. November 26 . The capacity of this well is $4,030 \mathrm{gpm}$, or $5.8 \mathrm{mgd}$. From November 19 to 25 , inclusive, the total pumpage to the water works plant averaged $36 \mathrm{mgd}$, of which $9.55 \mathrm{mgd}$ was pumped from wells $\mathrm{S} 7$ and $S 1$; the remainder was pumped from wells $S 11$ to $S 22$ in the upper field.

Well $\mathrm{S} 7$ is $3,150 \mathrm{ft}$ west of $\mathrm{S} 1$. Of the supply wells $\mathrm{S} 11$ to $\mathrm{S} 22$, $S 13$ is the closest to $S 1$ and is about 4,750 ft north of the Miami Canal. Wells S $11, S 12$, and S 13 are near the water works plant on the north side of the Miami Canal. Wells $S 14$ to $S 22$, in the upper field, are 5,100 to 7,100 ft from well $\mathrm{S} 1$ and on the opposite side of the Country Club Canal (a shallow canal just northwest of the lower well field). At the closest point, well $S 1$ is about 1,500 ft from the Country Club Canal.

Records from a recording gage on the Miami Canal at the Water Works Plant at Hialeah for the period November 17 to November 25 showed that the daily mean stage of the Miami Canal ranged from 2.6 to $2.5 \mathrm{ft}$ above mean sea level. The average daily range of fluctuation in the canal, during this period, was $0.90 \mathrm{ft}$; this fluctuation was caused mostly by tides. At the upper 36 th Street gage on the Miami Canal, 2.1 miles downstream from the Hialeah gage (fig. 56), the daily mean stage in the canal for the same period ranged from 1.80 to $1.68 \mathrm{ft}$ above mean sea level, and the average 
daily range of fluctuation for the 9 days was $1.75 \mathrm{ft}$ (owing almost entirely to tides).

Well $F 1$; which is $52.7 \mathrm{ft}$ deep and about $80 \mathrm{ft}$ from the southwest bank of the Miami Canal and $3,400 \mathrm{ft}$ northeast of well $\mathrm{S} 1$, was equipped during the test with an automatic water-stage recorder that showed a daily mean stage of $2.26 \mathrm{ft}$ above mean sea level on November 19 , and $1.94 \mathrm{ft}$ above mean sea level on November 26. The average daily range caused by tides was $0.07 \mathrm{ft}$. The daily fluctuations caused by tides in well $\mathrm{S} .68$ (fig. 57) during the period November 17 to November 26 was about $0.03 \mathrm{ft}$.

From a study of the measurements made of the wate $r$ level in all observation wells within $6,000 \mathrm{ft}$ of well $\mathrm{S} 1$ (during, and 6 days prior to, the test), it was concluded that a regional decline of about $0.10 \mathrm{ft}$ in water levels had occurred during the period November 19 to November 26. Three observation wells equipped with automatic water-stage recorders, 4.4 to 6.2 miles from well $\mathrm{S} 1$, showed declines during this period of $0.06,0.08$, and $0.15 \mathrm{ft}$. Therefore, corrections varying from 0.00 to $0.10 \mathrm{ft}$, increasing uniformly with time during the period November 19 to November 26, were applied to the observed drawdowns. The observed drawdowns were then computed on the assumption that no decline of the water level would have occurred if well $\mathbf{S} 1$ had not been pumped.

Pairs of shallow and deep observation wells were constructed at distances of $10,75,150$, and $300 \mathrm{ft}$ northeast from well $\mathrm{S} 1$ (the pumped well) in line with $\mathrm{S} 68$ and $\mathrm{G}$ 68A (a shallow well), which are $500 \mathrm{ft}$ northeast of well $\mathrm{S} 1$ (fig. 57). The shallow wells are numbered respectively $S 1 A, S 1 D, S 1 F$ and $S 1 H$, and the deep wells are numbered $S 1 B, S 1 C, S 1 E$ and $S 1 G$. Shallow wells had been installed about $10 \mathrm{ft}$ from the other supply wells.

In the lower well field the water levels in these supply wells and their companion shallow wells were measured during the test (except for $\mathrm{S} 7$, which had been in continuous operation during and for 5 days before the tests). Wells $\mathrm{S} 2, \mathrm{~S} 3$, and $\mathrm{S} 4$ are the only supply wells within $1,000 \mathrm{ft}$ of well $\mathrm{S} 1$.

Referring to the Theis nonequilibrium formula (p. 239) as long as the values of $u$ are less than 0.02 , values of $W(u)$ versus $a$ will plot as a straight line on semilogarithmic coordinates. This indicates that in the theoretical aquifer, the drawdowns (for a given time in that part of the cone of depression around the pumped well that has stabilized in shape) will vary as the logarithm of the distance from the pumped well. After the shape of the cone of depression has stabilized, the water levels may still slowly decline, but they will decline the same amount in all wells in that part of the cone of depression that has stabilized. This condition makes it pos sible to solve the coefficient of transmissibility ( $T$ ) by a semiloga- 
rithmic plot of drawdown versus distance of observation well from. the pumped well, so long as the observation well used is in that part of the cone of depression that has stabilized in shape. This method has been discussed by Cooper and Jacob (1946, p. 526534). The following formula is used:

in which:

$Q=$ discharge of well.

$$
T=2.3030 / 2 \pi \Delta s
$$

$\Delta s=$ change indrawdown, in feet, for one log cycle on the straightline plot.

Figure 58 shows a solution for $T$. by this method. Using the drawdowns in the deeper wells after 1 day of pumping, the value of $T$ (as obtained from the slope of the straight line fitted to the plotted points as closely as possible) is $3.4 \mathrm{mgd}$ per $\mathrm{ft}$; after 6 days of pumping, the value of $T$ is $3.25 \mathrm{mgd}$ per $\mathrm{ft}$. Using the drawdowns in the shallow wells, the value of $T$, after 6 days of pumping, is $4.3 \mathrm{mgd}$ per $\mathrm{ft}$.

Figures 59 and 60 show semilogarithmic plots of drawdown versus time (after well $S 1$ started pumping) for the five pairs of observation wells at $75,150,300,500$, and $900 \mathrm{ft}$ from $\mathrm{S} 1$. The drawdown in all shallow wells was less than in the deeper wells during the early part of the test, but, after 2 days of pumping, the water level in each pair of shallow and deep wells beyond $300 \mathrm{ft}$ was very nearly the same, and for all pairs the rate of decline of the water level in the shallow and deep wells was about the same. As far as $300 \mathrm{ft}$ from the pumped well, the water level in a given pair

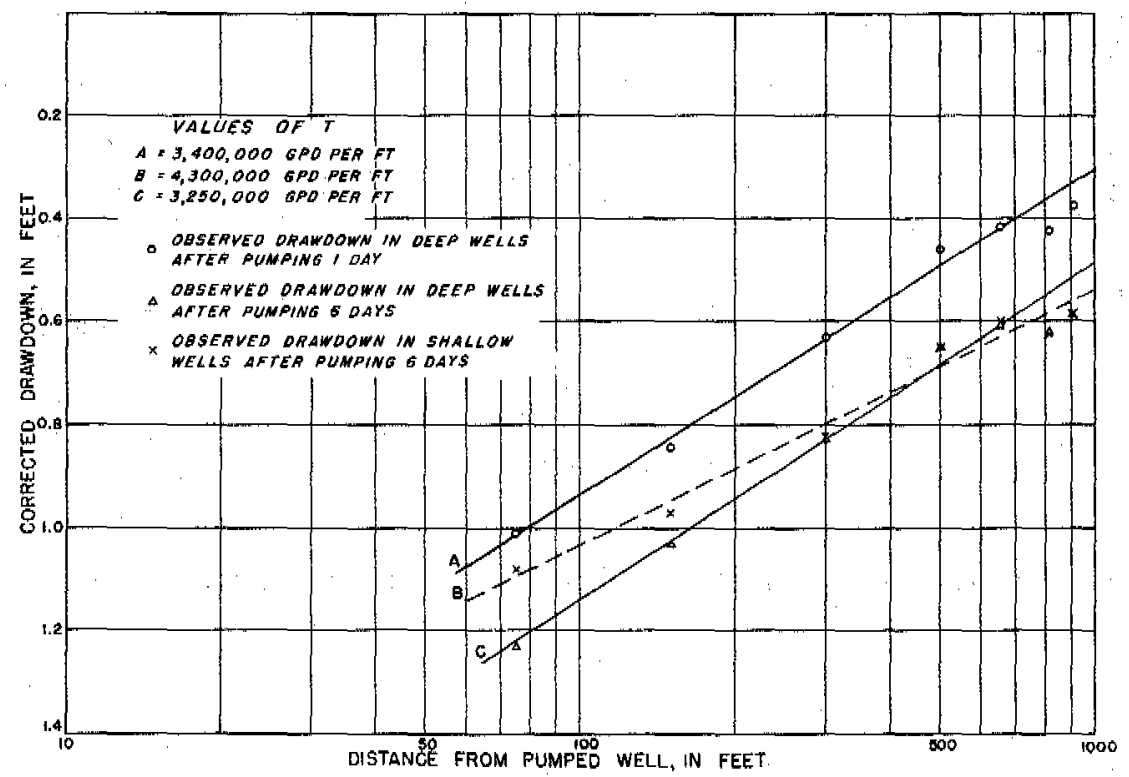

Figure 58. -Graph showing transmissibility coefficient as determined by distance-drawdown relationships from $\$ 1$ pumping test. 

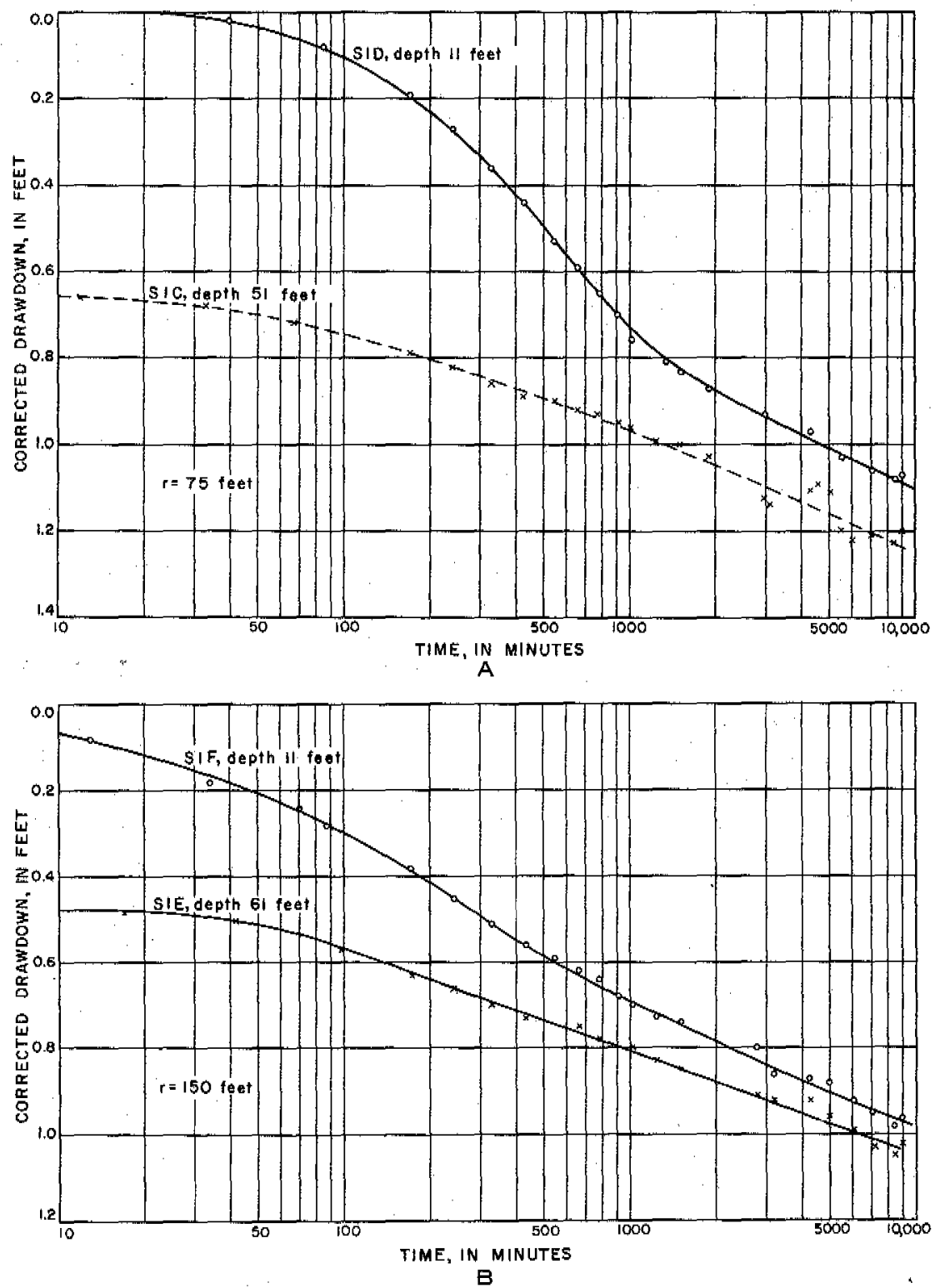

Figure 59. -Time-drawdown graphs for pumping test of $\mathrm{S} 1$ for wells 75 and 150 feet distant. 

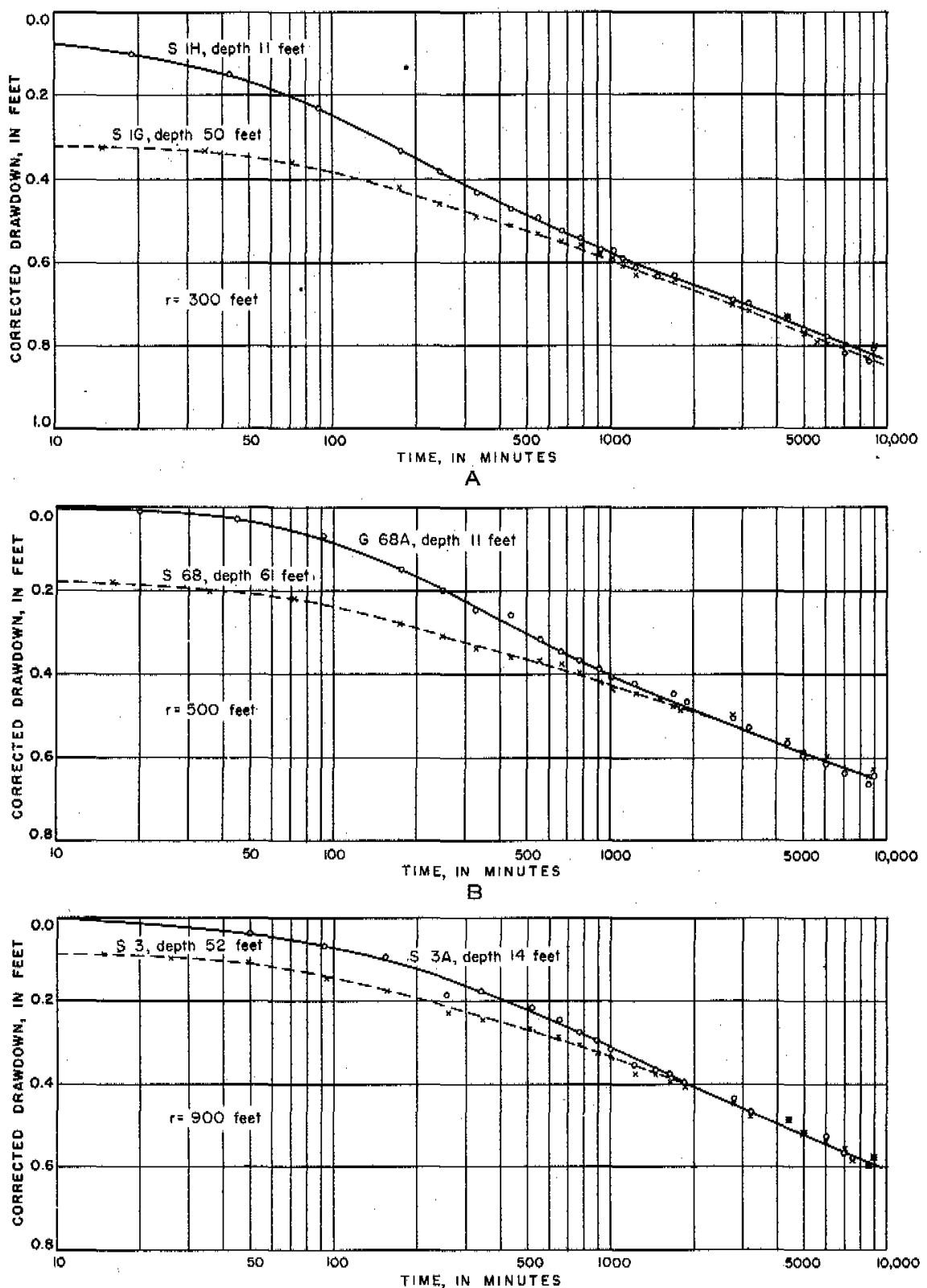

Figure 60. - Time-drawdown graphs for pumping test of $S 1$ for wells 300,500 , and $900 \mathrm{ft}$ distant. 
of deep and shallow wells differed by almost a constant during the last 3 or 4 days of the test. For the wells at 10, 75, 150, and 300 ft from $S 1$ the difference was about $1.08,0.15,0.07$ and 0.015 $\mathrm{ft}$, respectively. This difference was still decreasing slightly in these wells during the latter part of the test, thus indicating that a slight amount of water was still infiltrating from the upper part to the lower part of the aquifer.

The uncased hole in well $S 1$ is between 48.5 and $61 \mathrm{ft}$ below the land surface (fig. 57) and it was through this $12.5 \mathrm{ft}$ of open hole that the pumped $4,030 \mathrm{gpm}$ entered the well. As water approached the pumped well, the flow lines gradually converged to this zone, thus causing higher velocities and greater drawdowns in the deeper wells that are open to the aquifer only in this zone. The deeper observation wells and supply wells are so constructed that they would be subject to this effect, and, near the end of the test, most of the differences in drawdown between the deep and shallow wells of each pair are believed to be due to this cause.

The geologic section of the lower well field (fig. 57) includes a layer of fine quartz sand, 10 to $20 \mathrm{ft}$ thick, between the Miami oolite (in which the water table is located) and the Fort Thompson formation (from which the water is directly pumped). This layer of sand is less permeable than the limestones, and the vertical velocity of water from the upper to the lower part of the aquifer is small compared to the horizontal velocity in the Fort Thompson formation. Thus, during the early part of the pumping test the aquifer manifests temporary artesian characteristics, which allow the cone of decreased pressure to spread more rapidly through the lower part of the aquifer than through the upper part. These same characteristics are also responsible for a more rapid recovery in the lower part of the aquifer immediately after pumping ceases. After a day or two of pumping, enough water infiltrates through the sand from the upper part of the aquifer to supply most of the water pumped by the well; the aquifer then evidences water-table characteristics. Well S 68 responds markedly to sudden shocks (such as those caused by earthquakes) and thus gives further evidence of the semiconfining effect that the sand layer exerts in the aquifer.

Using a value of the coefficient of transmissibility $(T)$, determined by distance-drawdown relationships for that part of the cone of depression that has stabilized (fig. 58), values for the coefficient of storage ( 5 ) may be computed on the basis of the drawdown observed in a well. Values of $s$ computed in this manner will be large for shallow wells that are close to the pumped well during the early part of the test. The value of $s$ computed from drawdown in shallow wells will (in general) decrease with time and distance from the pumped well until the water levels in both the shallow and deep wells are the same. Values of $S$ computed 
from the drawdowns observed in the deeper wells will (in general) increase with time and distance from the pumped well until a fixed value is reached upon stabilization of the cone of depression.

If the water table is recharged from above or by influent canals, the value of $s$, computed in this manner by the The is nonequilibrium formula, may continue to increase indefinitely, rising above 1.00. A value of $s$ greater than 1.00 is a physical impossibility under the conditions assumed for deriving the formula, because more than $1 \mathrm{cu} f t$ of water cannot be extracted from $1 \mathrm{cu} f t$ of saturated material. However, one of the basic assumptions of the formula is that the water pumped by the test well comes entirely from storage in the aquifer and the aquifer receives no recharge during the test.

Another basic assumption of the The is nonequilibrium formula is that the pumped well completely penetrates the aquifer and is capable of receiving water throughout the saturated thickness of the aquifer. In this pumping test, the deeper wells are open and capable of receiving ground water only for a few feet in the pumped zone; the well does not directly receive water from that part of the aquifer in which the shallow wells end. Thus, it is believed that the deeper wells gave greater drawdown and the shallow wells gave less drawdown than if the pumped well had drawn directly from all parts of the aquifer. In making computations for coefficient of storage, therefore, an average value of $3.8 \mathrm{mgd}$ per $\mathrm{ft}$ for $T$ was used.

Table 16 shows values of $s$ computed from drawdown in the deeper wells using a value of $T$ equal to $3.8 \mathrm{mgd}$ per $\mathrm{ft}$ for both 1 and 6 days after the test started. The drawdowns used in the computations were those taken from smooth curves drawn through the plotted points as shown in figures 59 and 60 . Table 17 shows values of $s$ computed from drawdowns in the shallow wells, using a value of $t$ equal to $3.8 \mathrm{mgd}$ per $\mathrm{ft}$ for both 1 and 6 days after the test started.

The coefficients derived from the $\mathrm{S} 1$ pumping test indicate that $T$ is about $4 \mathrm{mgd}$ per $\mathrm{ft}$ and that $s$ is about 0.10 . The coefficient of storage is more likely to be in error because a 10-percent er ror in the value of the coefficient of transmissibility, used in making the computation of $s$, may nearly double or halve the coefficient of storage, depending on whether $T$ is greater or smaller. Also, slight errors or differences in drawdown, due to irregularities in the aquifer, cause relatively large differences in the calculated values for the coefficient of storage. 
Table 16. -Values of $S$ computed from drawdowns in deep wolls

[Coefficient of transmissibility equal to $3.8 \mathrm{mgd}$ per ft]

\begin{tabular}{|c|c|c|c|c|c|c|c|c|}
\hline $\begin{array}{l}\text { Time since } \\
\text { pumping } \\
\text { started } \\
\text { (days) }\end{array}$ & $\begin{array}{c}\text { Well S 1C } \\
t=75 \mathrm{ft}\end{array}$ & $\begin{array}{l}\text { Well S IE } \\
t=150 \mathrm{ft}\end{array}$ & $\begin{array}{l}\text { WeHl S 1G } \\
r=300 \mathrm{ft}\end{array}$ & $\begin{array}{l}\text { Well S } 68 \\
r=500 \mathrm{ft}\end{array}$ & $\begin{array}{c}\text { Well S } 4 \\
s=650 \mathrm{ft}\end{array}$ & $\begin{array}{l}\text { Well S 2 } \\
t=820 \mathrm{ft}\end{array}$ & $\begin{array}{l}\text { Well S 3 } \\
r=900 \mathrm{ft}\end{array}$ & Average \\
\hline $\begin{array}{l}1 \\
6\end{array}$ & $\begin{array}{r}0.050 \\
.047\end{array}$ & $\begin{array}{r}0.048 \\
.068\end{array}$ & $\begin{array}{r}0.071 \\
.083\end{array}$ & $\begin{array}{r}0.105 \\
.130\end{array}$ & $\begin{array}{r}0.090 \\
.107\end{array}$ & $\begin{array}{r}0.052 \\
.063\end{array}$ & $\begin{array}{r}0.063 \\
.066\end{array}$ & $\begin{array}{r}0.068 \\
.080\end{array}$ \\
\hline
\end{tabular}

Table 17.-Values of $S$ computed from drawdowns in shallow wells

[Coefficient of transmissibility equal to $3.8 \mathrm{mgd}$ per ft]

\begin{tabular}{|c|c|c|c|c|c|c|c|c|}
\hline $\begin{array}{l}\text { Time since } \\
\text { pumping } \\
\text { started } \\
\text { (days) }\end{array}$ & $\underset{t=75}{\text { Well } S}$ id & $\begin{array}{l}\text { Well S IF } \\
r=150 \mathrm{ft}\end{array}$ & $\begin{array}{l}\text { Well s } 1 \mathrm{H} \\
\mathrm{r}=300 \mathrm{ft}\end{array}$ & $\begin{array}{l}\text { Well } \dot{\mathrm{C}} 68 \mathrm{~A} \\
\quad=500 \mathrm{ft}\end{array}$ & $\begin{array}{l}\text { Well S } 4 A \\
t=650 \mathrm{ft}\end{array}$ & $\underset{r=820 \mathrm{ft}}{\text { Well S }}$ & $\begin{array}{c}\text { Well S 3A } \\
t=900 \mathrm{ft}\end{array}$ & Average \\
\hline $\begin{array}{l}1 \\
6\end{array}$ & $\begin{array}{r}0.247 \\
.168\end{array}$ & $\begin{array}{r}0.113 \\
.104\end{array}$ & $\begin{array}{r}0.080 \\
.089\end{array}$ & $\begin{array}{r}0.119 \\
.130\end{array}$ & $\begin{array}{r}0.111 \\
.117\end{array}$ & $\begin{array}{r}0.054 \\
.060\end{array}$ & $\begin{array}{r}0.072 \\
.066\end{array}$ & $\begin{array}{r}0.114 \\
.105\end{array}$ \\
\hline
\end{tabular}


One of the chief objectives of the ground-water investigation begun in 1939 was to determine a potentially safe area for the development of future municipal supplies. This area was described and mapped by Parker (Parker, Ferguson, and Love, 1944, p. 26-28), but detailed and large-scale quantitative investigations outside the present well-field area, where test $\mathrm{S} 1$ was made, necessarily awaited the selection of a general area for development. This choice, based on engineering economics as well as on the data collected from the geologic and ground-water investigations, was made in the spring of 1947 by Messrs. W. A. Glass and Frederick Weed, of the Department of Water and Sewers of the city of Miami, and arrangements were made to obtain detailed quantitative ground-water data on the chosen area.

Previous pumping tests in the Miami area were not too successful because of the necessity for pumping and disposing of very large quantities of water. In most parts of the world, pumping tests using quantities of water ranging from about 100 to about $1,000 \mathrm{gpm}$ would suffice. In Dade County, however, the Biscayne aquifer is so permeable that rates of pumping in this range produce a cone of depression too shallow to be used to accurately determine the drawdowns caused by the pumping, or to satisfactorily determine the depth, shape, rate of spread, and decline of the cone of depression. In previous pumping tests, the wells had been pumped at approximately 1,000 and $1,500 \mathrm{gpm}$; these tests had indicated that the coefficients of transmissibility were very high and that exceedingly large volumes of water could be pumped with a very small drawdown, but it was felt that they did not give accurate values of the hydrologic coefficients needed for the planning of a well field. Therefore, it was decided to run tests in the potential well-field area at a rate of approximately 3,500 gpm, or $5 \mathrm{mgd}$. It had been shown in the fall of 1946 (in the lower Miami well-field area, where the pumping test on well S 1 was conducted) that such a quantity would be large enough.

The selected test area lies south and west of Miami (see fig. 61 ). It is of triangular shape and contains approximately 11.3 $\mathrm{sq}$ miles. A test well occupies each angle of this area: G 551 is in sec. $36, T .54 \mathrm{~S} .$, R. $39 \mathrm{E}$, a distance of approximately 5.4 miles nor theast of G 552; G 552 is in sec. 27, T. 55 S., R. 39 E., a distance of approximately 5.8 miles west-southwest of G 553; G 553 is in sec. 16 , T. $55 \mathrm{~S}$, , R. $40 \mathrm{E}$, , a distance of approximately 4.6 miles southeast of G 551 .

Most supply wells in Dade County are drilled or driven. Most drilled wells have solid casing driven into hard, solution-holed limestone, with an open hole extending from 1 or $2 \mathrm{ft}$ to about 15 $\mathrm{ft}$ beyond the end of the casing; driven wells generally have solid 


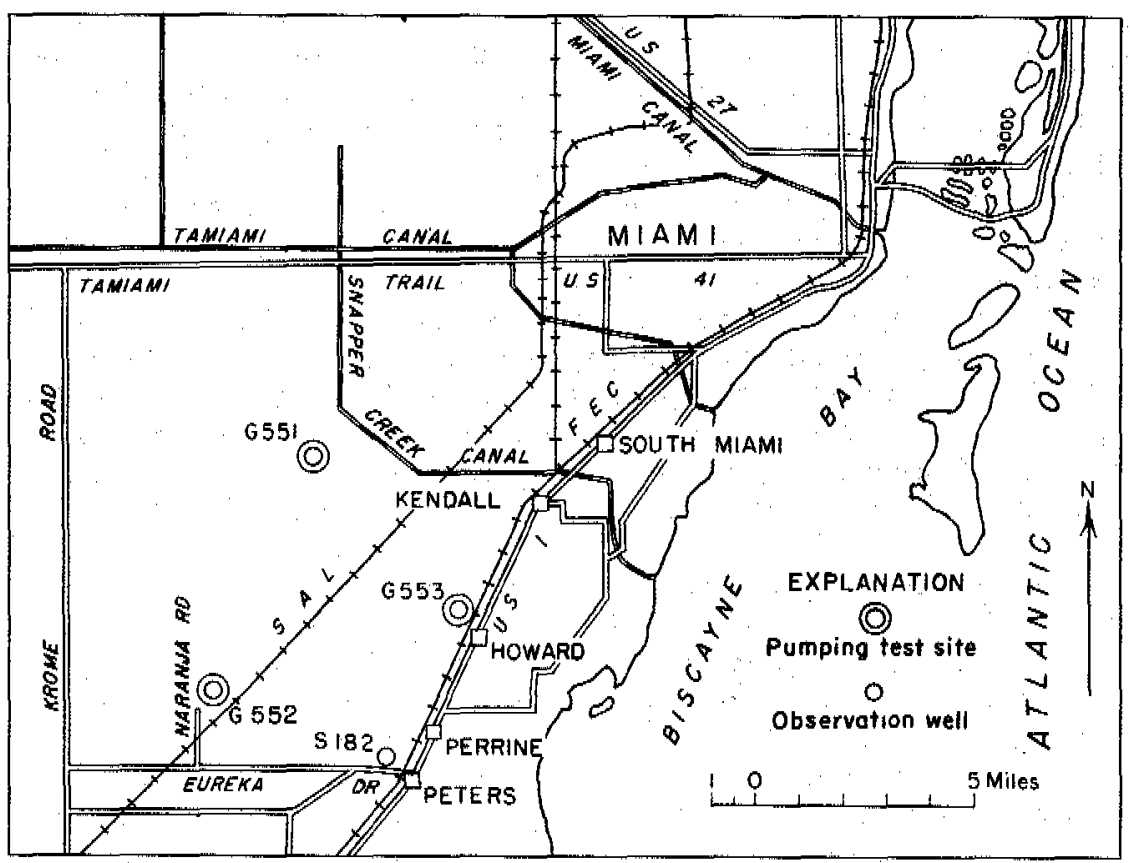

Figure 61 . - Index map showing general locations of wells G 551, G 552, and G 553 .

casing finished with a well point in sand. The driven wells seldom are more than $2 \frac{1}{2} \mathrm{in}$. in diameter and are used chiefly for small domestic,supplies. All large supply wells, most fire wells, and large-capacity drainage wells are drilled wells ranging in diameter from 6 to 18 in. The average $6-i n$. well yields as much as $1,500 \mathrm{gpm}$ with a drawdown of 2 to $4 \mathrm{ft}$.

In these wells, all water must enter the casing only through the open hole or screened parts, thus causing large deflections in the ground-water flow lines, especially near the well (see fig. 57). In order to avoid this condition it was decided to try a type of well construction new to the Miami area, which, insofar as geologic conditions permitted, would minimize the deflection of groundwater flow lines and permit a more nearly horizontal flow through the entire thickness of the aquifer toward the well. 
Such conditions could be fulfilled at the least expense by a slotted well, which would draw water through relatively large openings in the casing at all depths below the water table. However, it was obvious that if such slots were opposite a thick sand layer the well would fill with sand; therefore, the geologic section at the exact site of each test well was explored by core borings before the well was drilled. The placement of the slots then was determined from the geologic interpretation of the cores and cuttings.

The slots, $3 / 8 \mathrm{in}$. wide and $12 \mathrm{kn}$. long, were burned in the 18 in. casing with an acetylene torch; they were cut parallel to the length of the casing and were arranged spirally around the circumference. Enough slots were cut to provide a total intake area through the casing walls of about $10 \mathrm{sq} f \mathrm{ft}$ (see fig. 64).

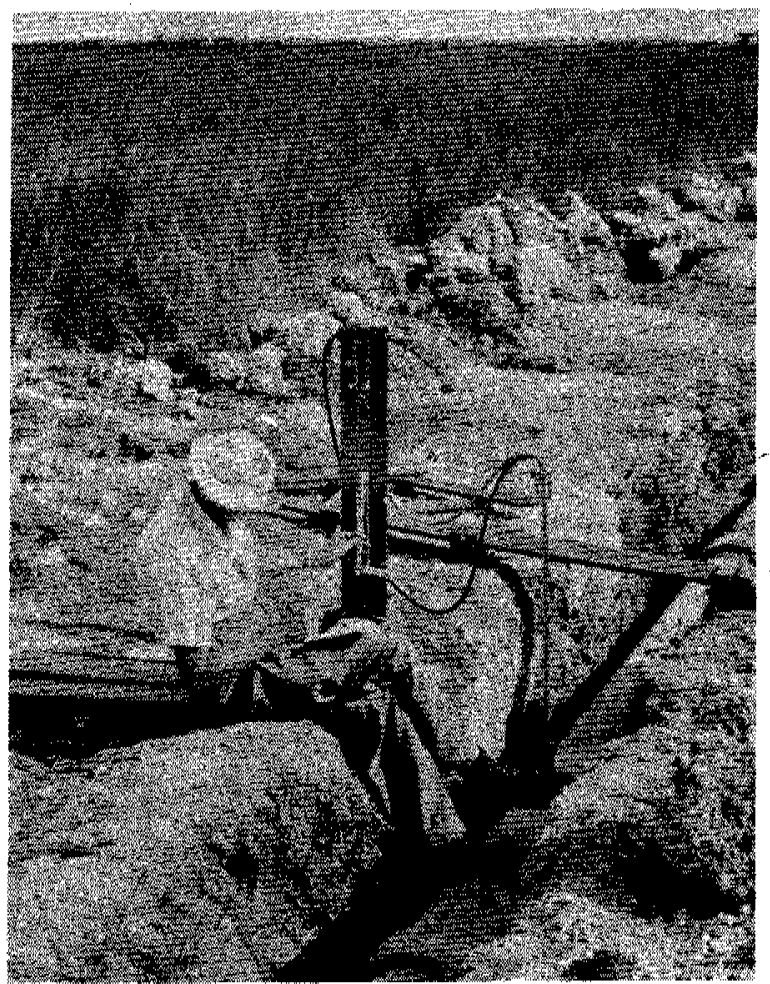

Figure 62. -Reading the mercury manometer of the pitometer used to measure discharge from the pumped well. 
In each of the three pumping tests to be described, several short runs were made, generally on the day preceding the final test run, to ascertain that the physical and mechanical setup was satisfactory and to allow for any necessary repairs or adjustments. Then a 2-hour test run was made to correlate the throttle of the motor with the desired rate of pumping, which was determined by pitometer readings (fig. 62). These were made in a straight section of the Transite discharge line at a point far enough from the pump, valves, and pipe bends so that flow disturbances due to these features would be unimportant. When this rate was established for each well, the throttle was marked to facilitate setting when the actual test run was made. Pitometer readings were made at frequent intervals during the test runs to ascertain that a flow of approximately $5 \mathrm{mgd}(3,500 \mathrm{gpm})$ was maintained.

Descriptions of the tests and results obtained are given in the following sections.

\section{G 551 PUMPING TEST}

On April 9, 1947, a 5-hour pumping test was run on test well G 551, the first of three such wells constructed for test purposes for the Department of Water and Sewers of the city of Miami. Figure 63 shows the location of this well with respect to the neighboring roads and observation wells, and figure 64 shows the method of construction of G 551, and the logs of G551 (prepared from cores, drill cuttings, and the action of the drill) and the five observation wells.

G 551 , the pumped well, has solid $24-i n$. casing to $29 \mathrm{ft}$, slotted 18 -in. casing from 29 to $71 \mathrm{ft}$, and an open hole in the cavernous limestone from 72 to $84 \mathrm{ft}$. The four observation wells, OW 1-10, OW 1-50, OW 1-200, and OW 1-500, at respective distances of 10 , 50,200 , and $500 \mathrm{ft}$ from the pumped well, have solid 4 -in. casing to $72 \mathrm{ft}$ with an open hole in the cavernous rock to $84 \mathrm{ft}$. Well OW $1-10 \mathrm{~S}$, a second well $10 \mathrm{ft}$ north of $\mathrm{G} \mathrm{551}$, is $72 \mathrm{ft}$ deep and has perforated 4-in. casing to $72 \mathrm{ft}$. The casing in this well is perforated with $3 / 8-i n$. holes drilled at $1-\mathrm{ft}$ intervals for the entire length.

The test-well site is relatively free from canals or supply wells that might affect the water table. The nearest waterway of any importance is Snapper Creek Canal, which, at its closest point, is about 1.5 miles northeast of G 551 and is fairly well clogged with debris and water plants; there are no pumped wells of any consequence within several miles. Therefore, there could be no appreciable recharge from canals nor any interference from other pumping wells during a 5 -hour test. 


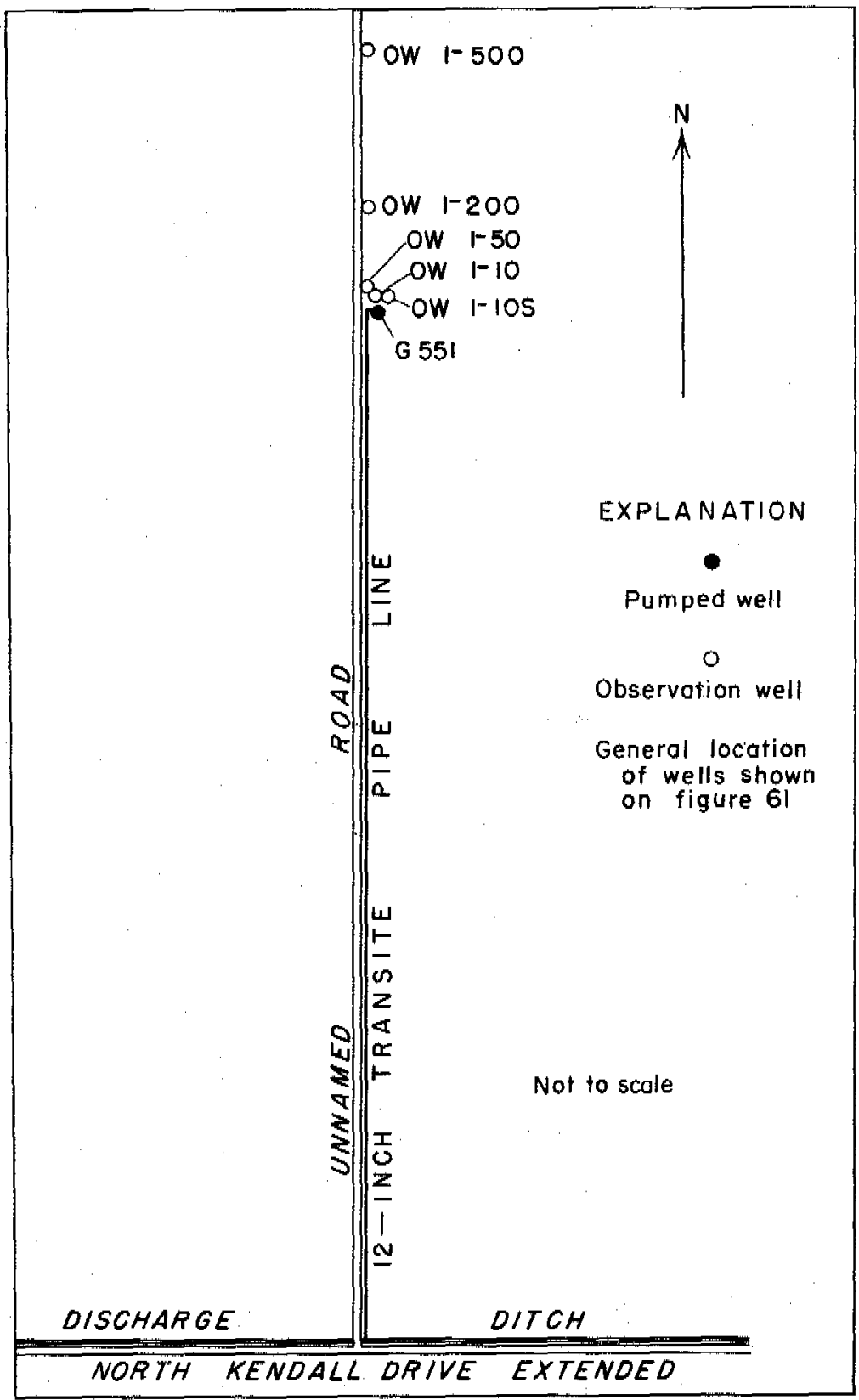

Figure 63, -Sketch showing locations of well G 551 and observation wells. 


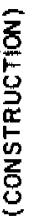
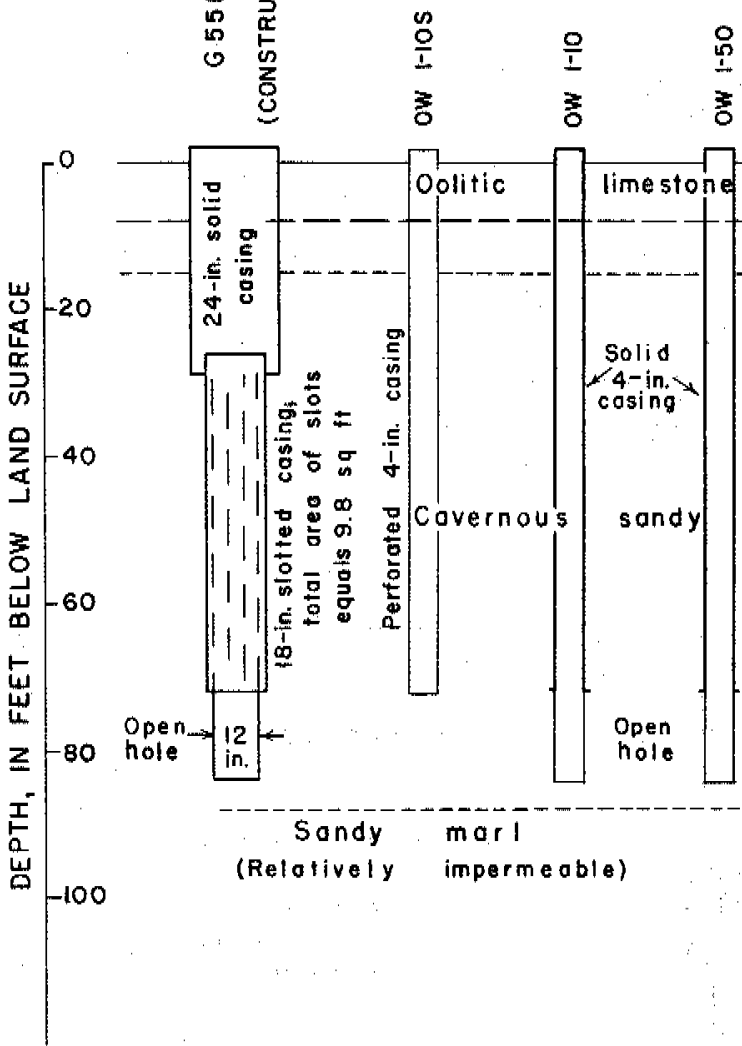

$\stackrel{8}{8}$

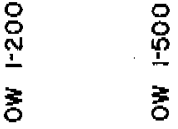
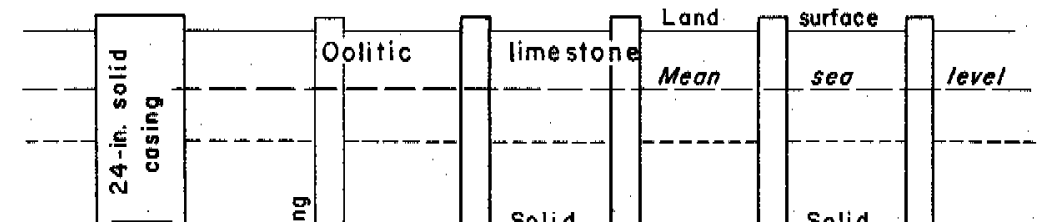

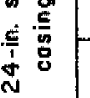

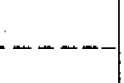

-

$\begin{array}{ll}\text { Open } & =12 \\ \text { hole } \rightarrow & 12 \\ \text { in. }\end{array}$

4

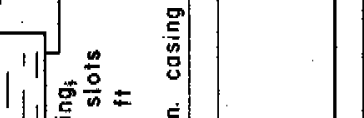

Solid

$4-\sin$
cosing

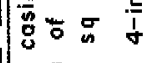

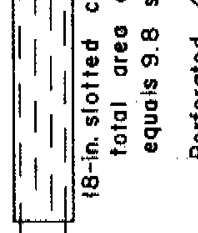

Covernous

sand $y$

limestone

$4-\operatorname{cin} x$
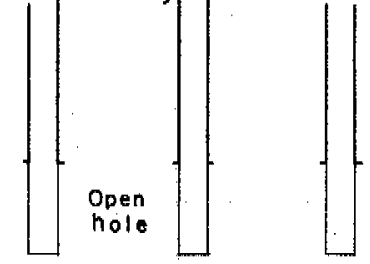

$\sqrt{\text { level }}$
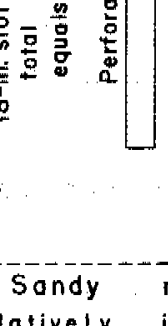

mor 1

(Relatively impermeable)

Horizontal distances not to scale

Numbers following ow

represent distance, in feet from pumped well

Figure 64. -Drawing showing method of construction of $G 551$, and logs of $G 551$ and observation wells.

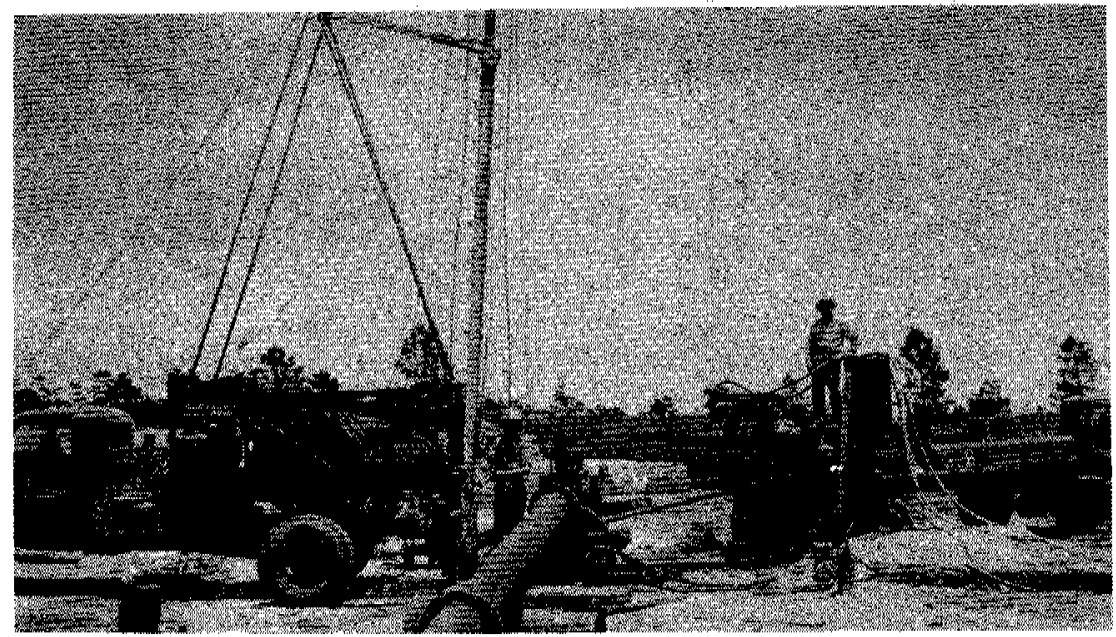

Figure 65. - Pump used in aquifer tests. 


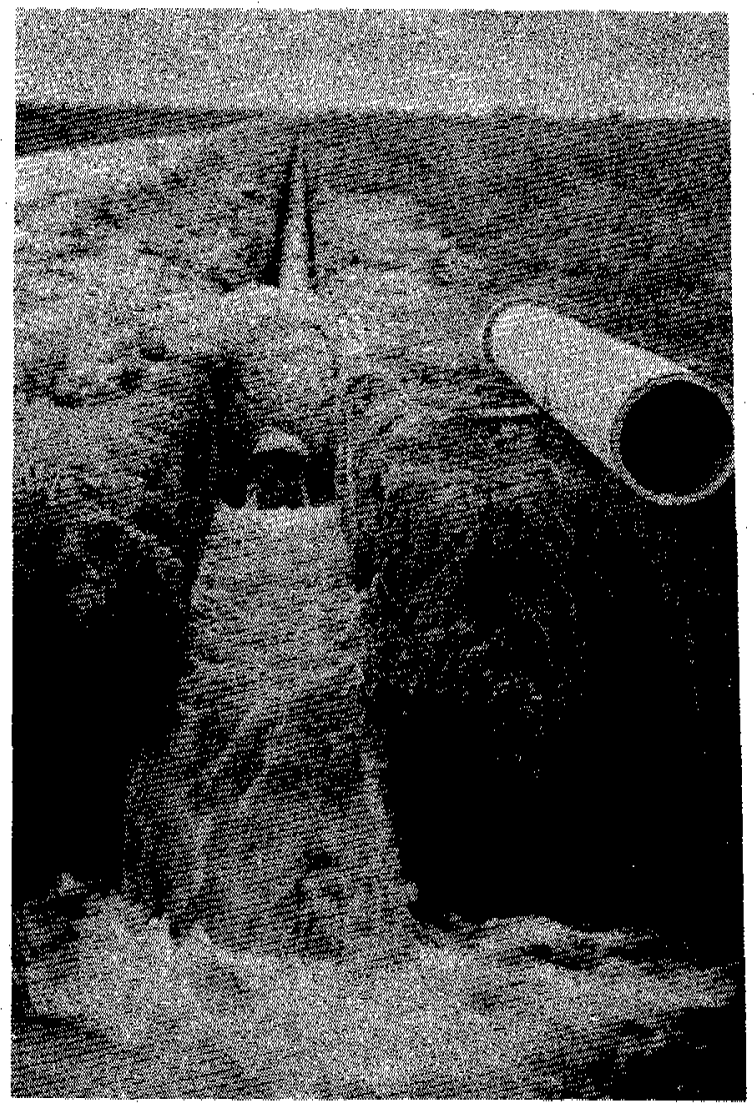

Figure 66. -Water discharging at a rate of $5 \mathrm{mgd}$ from $\mathrm{G} 551$ at the end of the 2,000 $\mathrm{ft}$ Transite line.

The pumped well was equipped with a deep-well turbine pump set at $32 \mathrm{ft}$, having a rated capacity of $3,520 \mathrm{gpm}$ and powered by a 225 -hp diesel motor (fig. 65). The water pumped from the well was discharged to the south through $2,000 \mathrm{ft}$ of $12-\mathrm{in}$. Transite pipe into the western end of a shallow, narrow borrow ditch cut into the Miami oolite (fig. 66). The ditch, extending 1;320 ft east, is closed at both ends, and there was no surface flow into, or out of, the ditch during the test.

The pump was started at 10:05 a. $\mathrm{m}$, and run until 12:05 p. m., when it was necessary to shut it down because of motor trouble. After-waiting for the effects of the pumping to disappear, the test was started again at $2: 15 \mathrm{p} . \mathrm{m}$. This time the pump operated satisfactorily, and at $7: 15 \mathrm{p} . \mathrm{m}$. it was shut down.

The drawdowns used in making the computations were obtained during the period from $2: 15 \mathrm{p} . \mathrm{m}$. to $7: 15 \mathrm{p}$. m. A small adjustment, varying from zero at the start to $0.013 \mathrm{ft}$ at the end of the test, was made to correct for the residual drawdown caused by operating the well (G 551) from 10:05 a. m. to $12: 05 \mathrm{p} . \mathrm{m}$. 


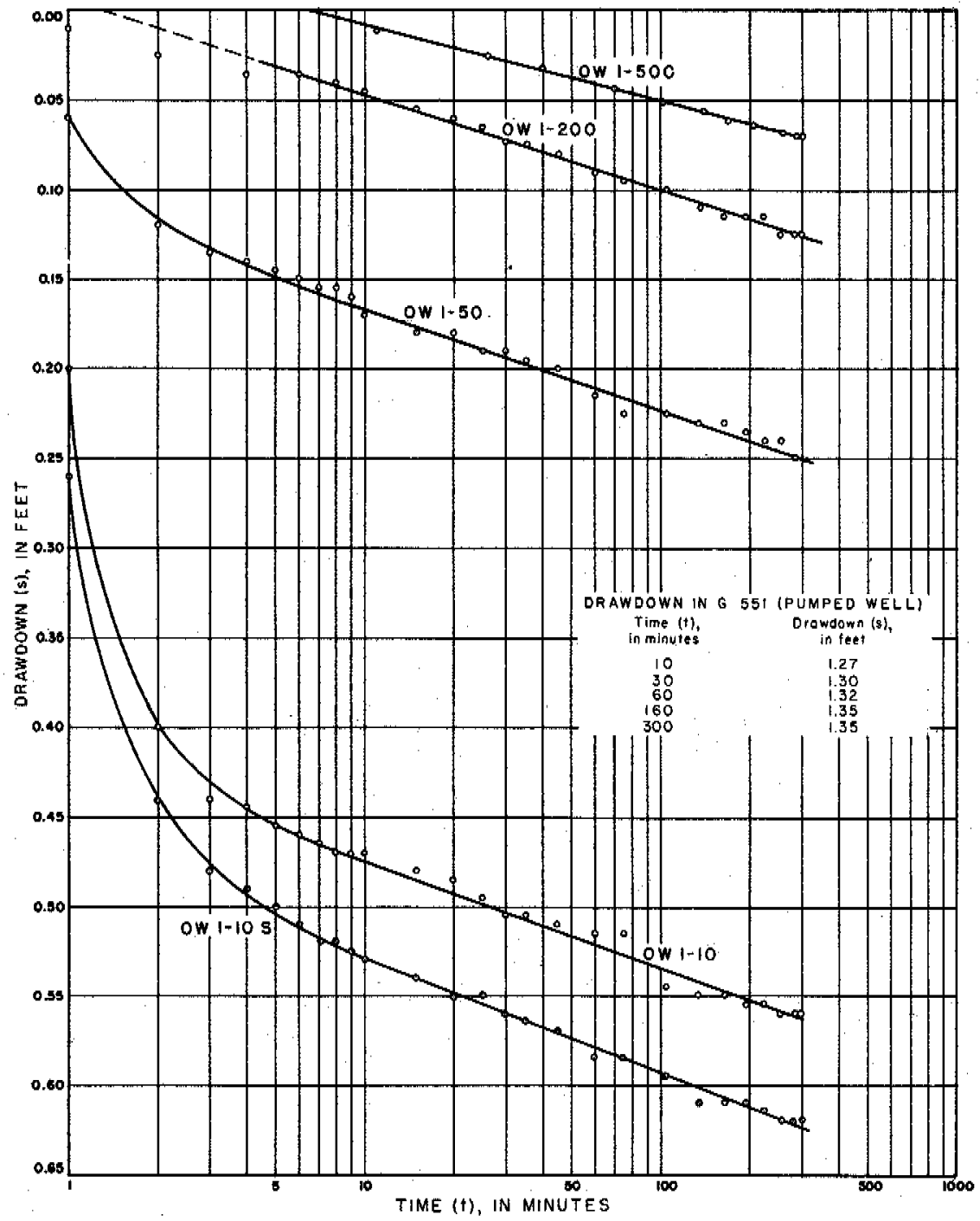

Figure 67. -Time-drawdown graph for pumping test of C 551.

Figure 67 shows a semilogarithmic plot of the corrected drawdowns versus time after pumping started in $\mathrm{G} 551$. The difference in drawdown between wells $O W 1-10$ and $O W 1-500$ remained nearly constant from 20 minutes after the pump was started until the end of the test; this indicates that the cone of depression had approximately stabilized to a distance of at least $500 \mathrm{ft}$ in the first 20 minutes of pumping.

Figure 68 shows a semilogarithmic plot of corrected drawdowns versus distance from the pumped well for 150 and 300 minutes 


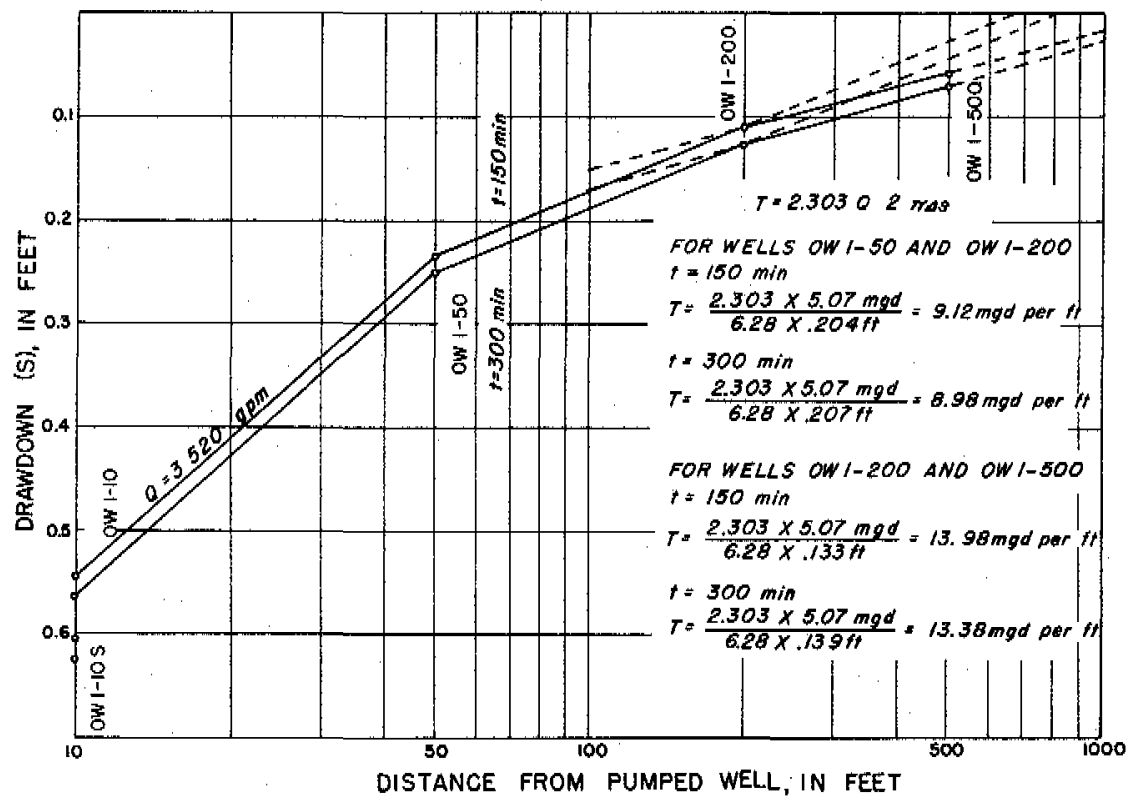

Figure 68. -Distance-dra wdown graph for pumping test of $\mathbf{G} 551$.

after pumping started. The points for the four wells do not fall upon a straight line as they should do for the theoretical aquifer composed of materials that are homogeneous, isotropic, and of indefinite areal extent. This indicates that the field conditions do not closely approximate the conditions upon which the test formula is based. The difference in conditions is believed to be due largely to the following causes: (1) Numerous solution holes and cavities occur in the aquifer, the largest of which is shown by the log of well $G 551$ to have a vertical dimension of $5 \mathrm{ft}$ or more. The shape, size, and extent of these cavities are unknown; however, it is not uncommon for the interconnecting passages or solutional areas to range in cross section from less than a quarter of a square inch to many square feet. These interconnecting passages are rather indirect and tortuous, and many large cavities begin and end abruptly in a series of small tubular ones. Probably, most of the larger ones extend laterally for considerable distances from the pumped well and act as natural pipelines or collectors of ground water in a manner similar to laterals driven out from a collection gallery. Thus, the largest percentage of the pumped water probably moves into the well through the solution channels, not uniformly through the aquifer. Obviously, the location of any well with respect to a large cavity would have a marked effect on the drawdown occurring in the well. (2) Even the small solution holes are sufficiently large, and the velocities in them are so high, relatively, that they cause turbulent ground-water flow in the aquifer. 
Assuming that the water entering the well approaches it through a section of aquifer $60 \mathrm{ft}$ thick, that this section has an effective porosity of 20 percent, and that the flow is radial toward the well, pumping $5 \mathrm{mgd}$ would give $\mathrm{rise}$ to ground-water velocities of about $0.12 \mathrm{ft}$ per minute (nearly $180 \mathrm{ft}$ per day) at a point $50 \mathrm{ft}$ from the well. If the interconnecting passages are indirect and approach the well by tortuous routes, the actual velocities might be several times this amount. As the pumped well is approached the actual observed drawdowns increase at a faster rate than they should for a theoretical aquifer in which laminar flow occurs. These anomalous drawdowns indicate that turbulent flow is probably occurring at distances greater than $100 \mathrm{ft}$ from the pumped well.

Computations based on the drawdowns in wells 50 and $200 \mathrm{ft}$ from G 551 ( $f$ ig. 68) give values for $T$ of 9.12 and $8.98 \mathrm{mgd}$ per $\mathrm{ft}$ after 150 and 300 minutes of pumping. If the difference between the drawdowns in the two wells were as little as $0.01 \mathrm{ft}$ in error the calculated value of $T$ would change about 8 percent. Computations based on the drawdowns in wells 200 and $500 \mathrm{ft}$ from G 551 give values for $T$ of 13.98 and $13.38 \mathrm{mgd}$ per $\mathrm{ft}$ after 150 and $300 \mathrm{~min}$ utes of pumping. An error of $0.01 \mathrm{ft}$ in the drawdown in these two wells would cause an error of 18 percent in the calculated value of $T$.

Using the drawdown in the wells 200 and $500 \mathrm{ft}$ from $\mathrm{G} 551$ and a value of $T$ equal to $13.5 \mathrm{mgd}$ per $\mathrm{ft}$, the value of $s$ after $150 \mathrm{~min}$ utes pumping is 0.27 . This value of $s$ appears to be too high, and for it to fall near the expected value, $T$ would have to be higher.

From an analysis of all the data obtained from this pumping test (G 551 ) the coefficient of transmissibility is about $15 \mathrm{mgd}$ per $\mathrm{ft}$; however, the field conditions appear to differ too much from the assumptions on which the formula is based to allow a precise value of $s$ to be calculated.

\section{G 552 PUMPING TEST}

On April 16, 1947, a 5-hour pumping test was made on well G 552 in an effort to determine the coefficients of transmissibility and storage of the aquifer for the general area in which this well is located.

G 552, constructed for the Department of Water and Sewers of the city of Miami, is about 1.5 miles north of Eureka Drive and about $300 \mathrm{ft}$ east of Naranja Road (see fig. 61). It is in an area that is free from pumping effects of wells, or recharge or dis charge effects from tidal canals. Figure 69 shows the location of this well with respect to nearby roads and observation wells. 


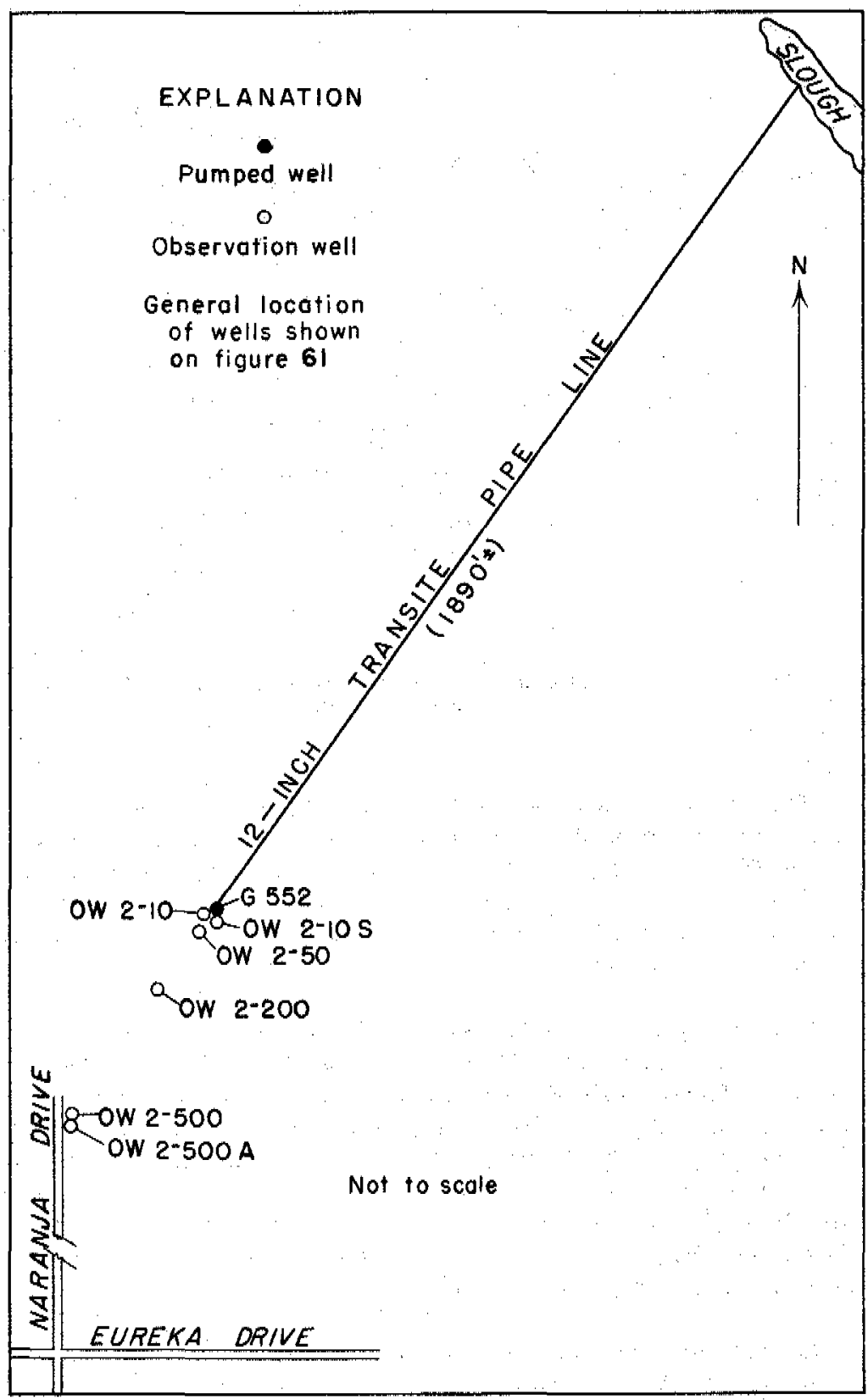

Figure 69. -Sketch showing location of well $\mathrm{G} 552$ and observation wells. 


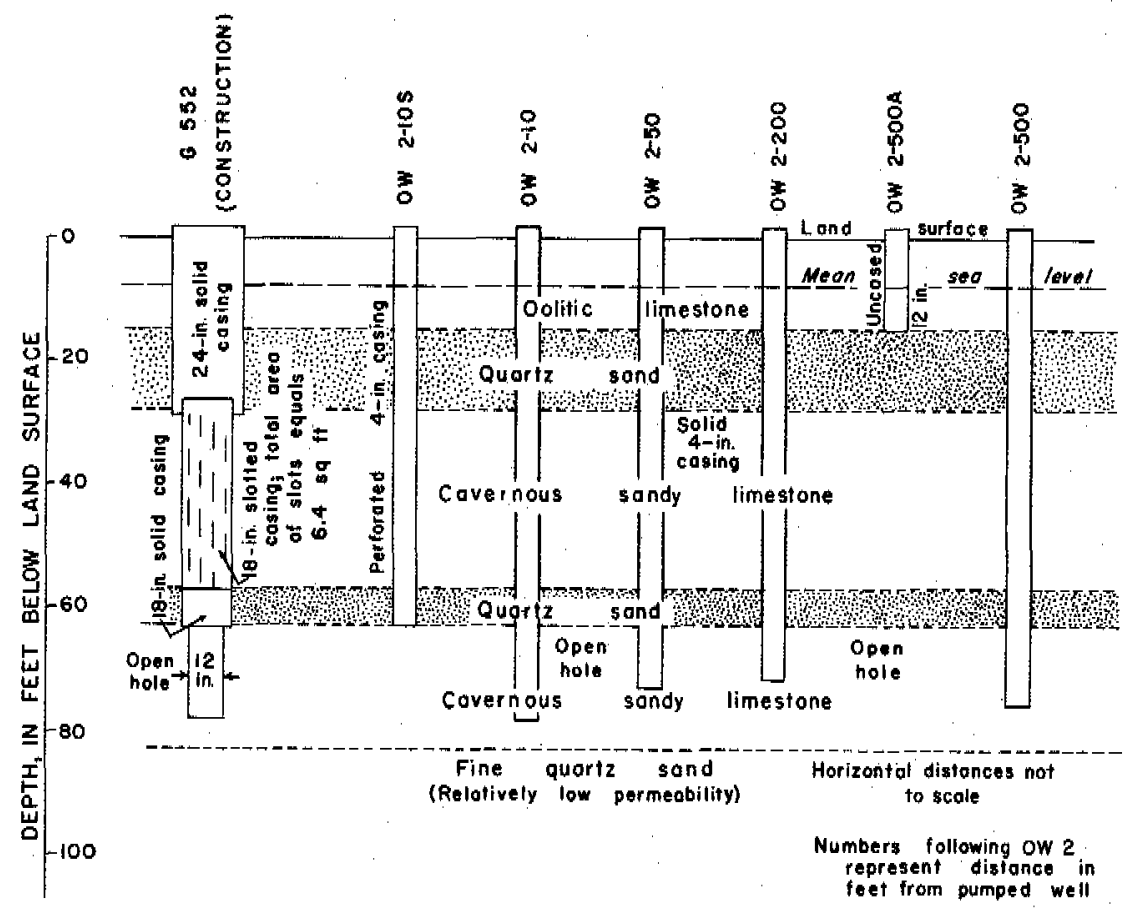

Figure 70. $\rightarrow$ Drawing showing method of construction of G 552, and $\log x$ of $G 552$ and observation wells.

Figure 70 shows the method of construction of well G 552 and contains the logs of G 552 and observation wells. Well G 552 has solid 24-in. casing to $29 \mathrm{ft}$, slotted 18 -in. casing from 29 to $57 \mathrm{ft}$ (the slots have a total area of approximately $6.4 \mathrm{sq} \mathrm{ft}$ ), solid 18in. casing from 57 to $63 \mathrm{ft}$, and about a 12-in. open hole in cavernous limestone fröm 63 to $79 \mathrm{ft}$.

Observation wells OW $2-10$, OW $2-50$, OW 2-200, and OW $2-500$ are respectively $9.8,50.0,199.2$, and $497.1 \mathrm{ft}$ southwest of well G 552. These observation wells have solid 4 -in. casing to $63 \mathrm{ft}$, and below this is 11 to $15 \mathrm{ft}$ of open hole in the limestone. Well OW 2-10 S, $10.3 \mathrm{ft}$ southwest of well G 552, has perforated 4-in. casing to $64 \mathrm{ft}$; the well is open to a depth of $63 \mathrm{ft}$. The $4-\mathrm{in}$. cas ing has 3/8-in, holes drifled at 1-ft intervals. Well OW 2-500 A, $504 \mathrm{ft}$ southwest of $\mathrm{G} 552$, is an uncased hole, about 12 in. in diameter and about $15 \mathrm{ft}$ deep.

G 552 was pumped in the same manner and with the same equipment as G 551; the pump bowl was set at $32 \mathrm{ft}$. The average rate of pumping during the test was $3,540 \mathrm{gpm}$ and the actual rate never varied more than 2 percent from this figure. The water pumped from the well was discharged to the northeast through $1,890 \mathrm{ft}$ of 12-in. Transite pipe into a transverse glade. It is believed that no recirculation of water occurred. 


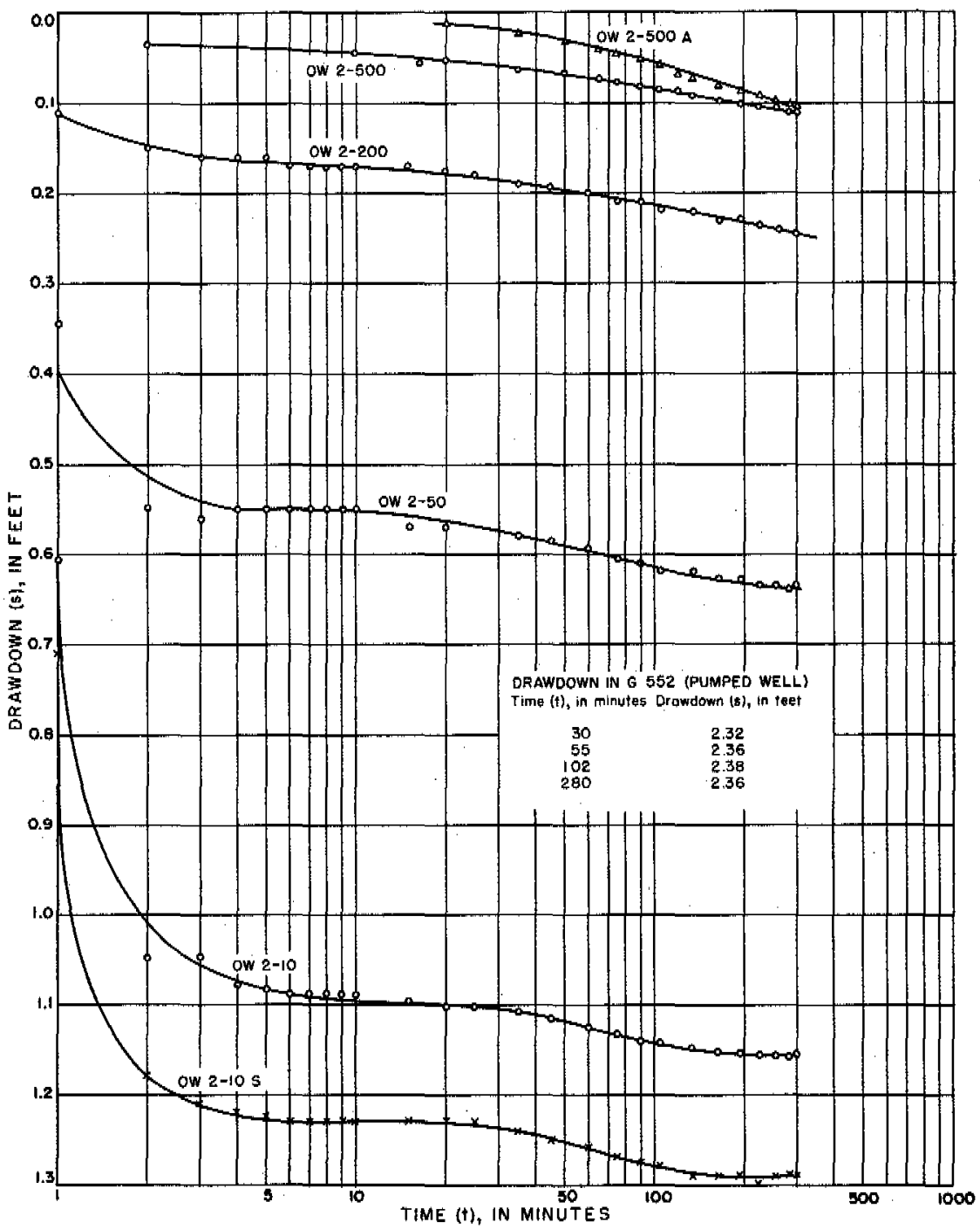

Figure 71, -Time-drawdown graph for pumping test of G 552.

Figure 71 shows a semilogarithmic plot of drawdown in G 552 versus time after pumping was started. The drawdown curves for wells $200 \mathrm{ft}$, and less, from the pumped well show that the water levels were nearly stationary for about 6 to 15 minutes after the test. This may have been caused by the removal of sand from solution channels, which thys increased their capacity to transmit water and decreased the actual drawdown enough to compensate for the anticipated increase in drawdown. 
Figure 72 is a semilogarithmic plot of drawdown versus distance from the pumped well. Drawdowns in wells OW 2-50 and OW 2-200 give a value of $T$ of about 2.84 and $2.85 \mathrm{mgd}$ per $\mathrm{ft}$, but drawdowns in wells OW 2-200 and OW 2-500 give a value of $T$ of about 5.72 and $5.65 \mathrm{mgd}$ per $\mathrm{ft}$. The smaller value of $T$, obtained by using drawdowns in the nearer wells, appears to be too low. This may be due to turbulent flow that develops in the solution channels of the aquifer, and which requires a steeper gradient (greater $\Delta$ s) than would be necessary if the flow were laminar (see p. 257). The values of $T$ required to give a value of $s$ equal to 0.20 (which appears to be the most reasonable value of $S$ for the Miami area in general) for the observed drawdowns in wells OW 2-200, OW 2-500, and $O W 2-500 \mathrm{~A}$, after 5 hours of pumping, range from about 6 to as much as $10 \mathrm{mgd}$ per $\mathrm{ft}$.

The data from this test corroborate the fact that the field conditions do not conform closely to the assumptions on which the test formula is based. Although the aquifer is composed largely of sandy limestone, it is not homogeneous or isotropic; pockets of sand and dense layers of limestone, together with the numerous solution cavities and channels, give rise to conditions impossible to account for mathematically. The solution holes and channels, which give rise to turbulent flow in the aquifer, are especially confusing. It is conceivable that if another line of observation wells had been available, the drawdowns observed (especially in the closer wells) would not have agreed precisely with those used and would have given a different calculated value of $T$.

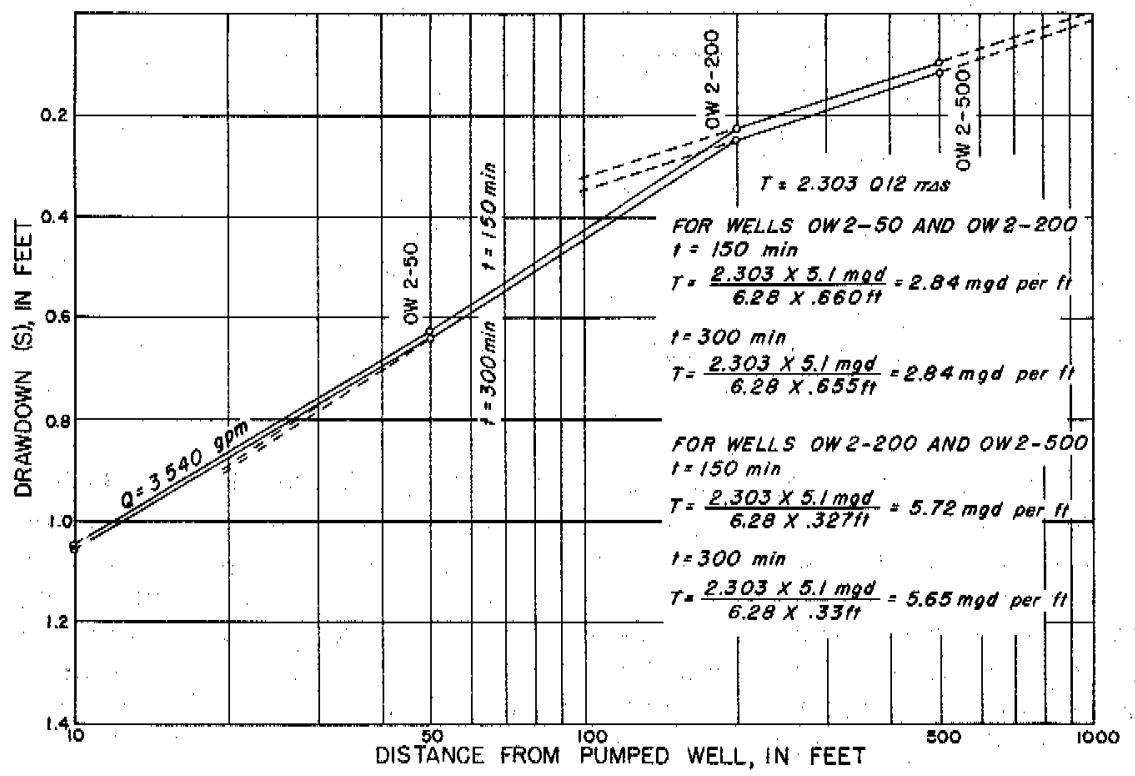

Figure 72. -Distance-drawiown graph for pumping test of $\mathrm{G} 552$. 


\section{G 553 PUMPING TEST}

On May 1, 1947, a 5-hour pumping test was conducted on well G 553 , the third test well constructed for the Department of Water and Sewers of the city of Miami. This well is about 0.4 mile northwest of the little community of Howard (see fig. 61), in an area where no extraneous influences are felt, such as pumping from other wells or recharge or discharge due to canals. Figure 73 shows the location of this well on the south side of Motu Drive with respect to the observation wells. Figure 74 shows the method of construction of $\mathrm{G} 553$, the logs of $\mathrm{G} \mathrm{553}$, and the observation wells.

G: 553 has solid 24 -in. casing to $36 \mathrm{ft}$, a slotted 18 -in. casing from 36 to $80 \mathrm{ft}$, and an open hole about $12 \mathrm{in.} \mathrm{in} \mathrm{diameter} \mathrm{in} \mathrm{the}$ cavernous limestone between 80 and $91 \mathrm{ft}$. The total area of the slots in the slotted casing is approximately $10 \mathrm{sq} f t$. The $4-\mathrm{in}$. observation wells OW 3-10, OW 3-25, OW 3-50, and OW 3-100 are respectively $10,25,50$, and $100 \mathrm{ft}$ east of $\mathrm{G} 553$. These wells were drilled to a depth of $85 \mathrm{ft}$ and have perforated casing to a depth of $81 \mathrm{ft}$. The perforations are $3 / 8 \mathrm{in}$. holes drilled at intervals of $1 \mathrm{ft}$. The observation wells $\mathrm{OW} \mathrm{3-200}$ and $\mathrm{OW} 3-500$, located 200 and $500 \mathrm{ft}$ east of well G 553, respectively, were drilled to a depth of $85 \mathrm{ft}$ and have $4-\mathrm{in}$. perforated casing to 70 ft. The uncased portion of the hole in each of these two wells filled with sand shortly after construction, thus reducing their effective depth to about $70 \mathrm{ft}$. Observation well OW 3-250, located $250 \mathrm{ft}$ east of G 553, was an uncased hole about 12 in. in diameter and about $16 \mathrm{ft}$ deep; it was drilled to a depth of $34 \mathrm{ft}$, but the bottom $18 \mathrm{ft}$ filled with sand.

Well G 553 was pumped in the same manner and with the same equipment as in the two preceding tests (see fig. 65). The water was pumped east from G 553 through $1,700 \mathrm{ft}$ of $12 \mathrm{in.}$ Transite pipe into the eastern end of a ditch emptying into a transverse glade. It is believed that no recirculation of the pumped water occurred.

On April 30, 1947, between 11:30 a, m. and 1:00 p. m., G 553 was pumped at a rate of $3,540 \mathrm{gpm}$ for 90 minutes; then it became necessary to shut down the pump to replace a bearing. The next day, May 1, between 9:30 a. m. and 2:30 p. m., a 5-hour pumping test was made; the pumping rate was $3,540 \mathrm{gpm}$ and did not vary more than 2 percent.

In the area of $G 553$, a layer of fine to medium quartz sand intervenes between the upper limestone (Miami oolite) and the lower limestone (Fort Thompson formation) in a geologic relationship similar to that at the site of S 1 in Miami Springs. (See p. 246.) The permeability of this sandy layer is lower than that of the limestone, and pumping causes a difference in recovery of water levels in deep and shallow wells: 


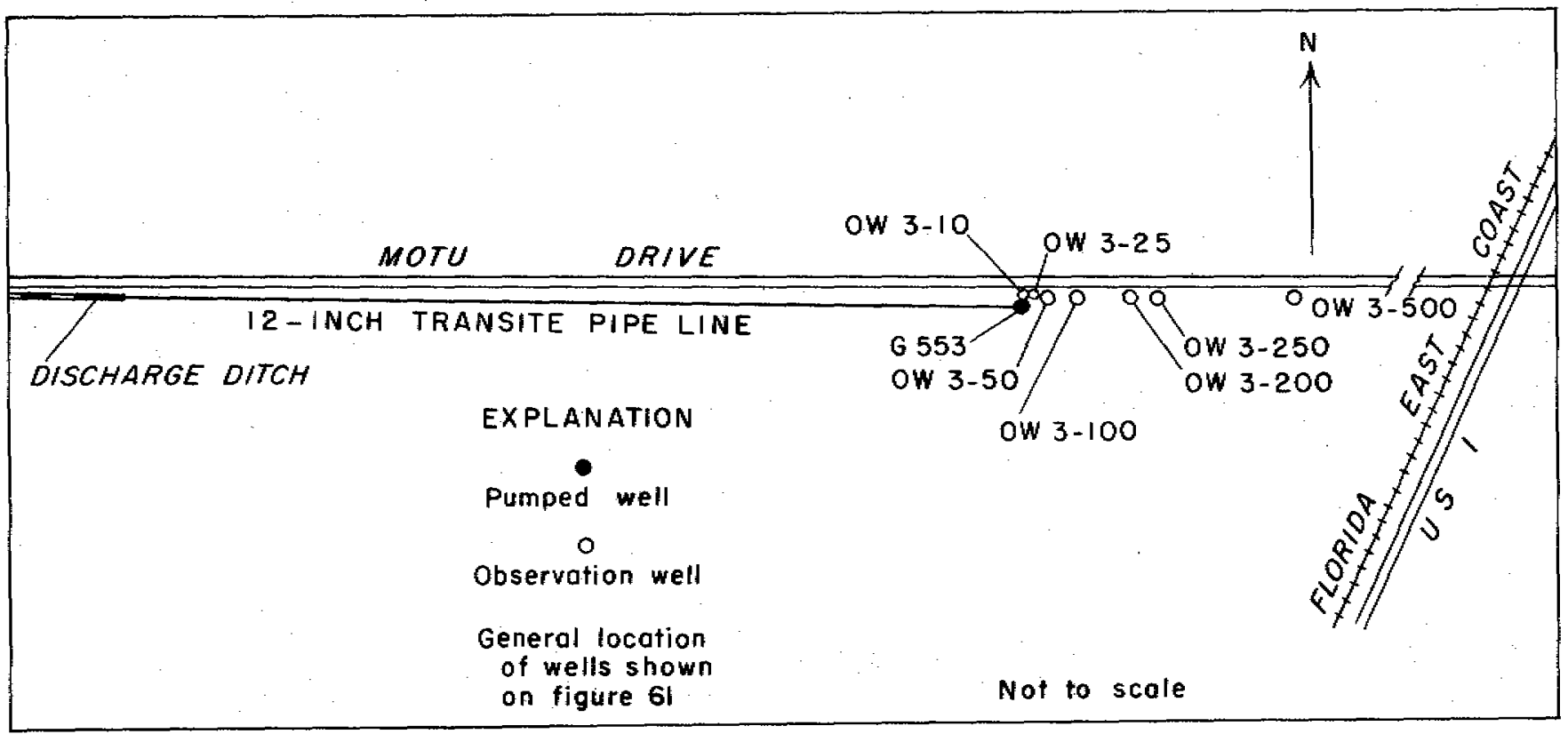




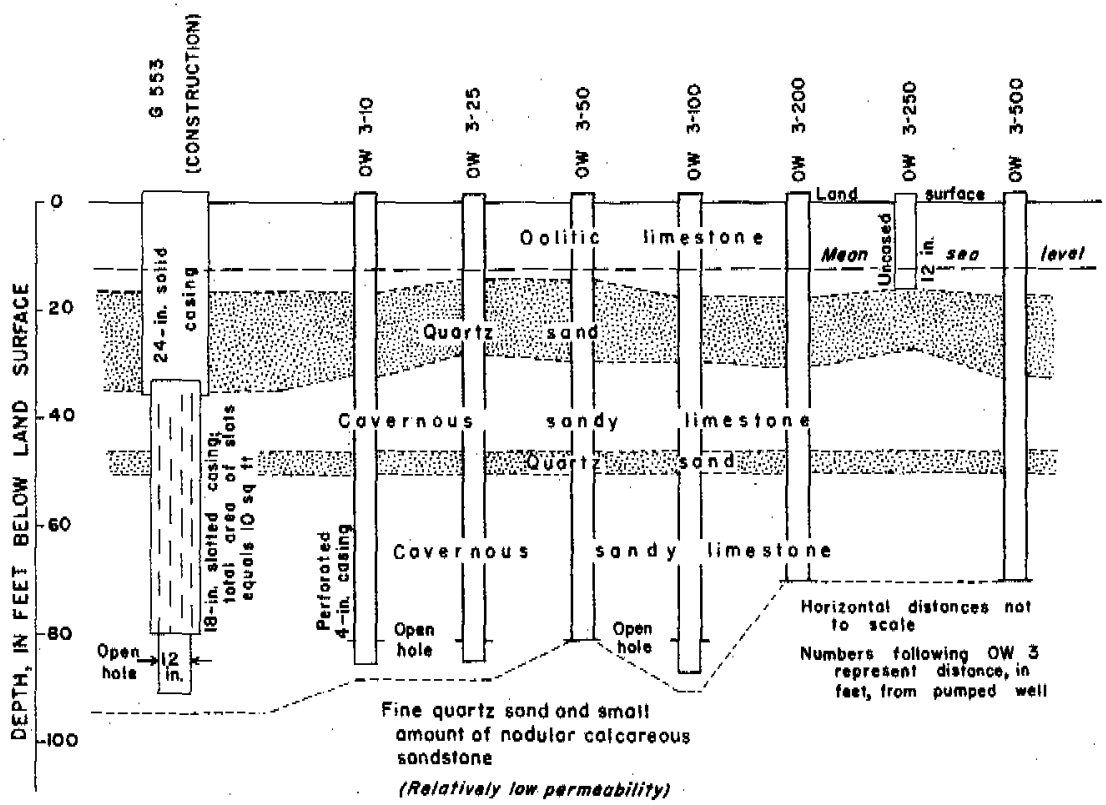

Figuxe 74. -Drawing showing method of construction of $G 553$, and logs of $G 553$ and observation wells.

Inasmuch as well $G 5.53$ was constructed with nonperforated casing to $36 \mathrm{ft}$ (which excludes the sand layer and overlying oolite), all water pumped had to enter the well between depths of 36 and $91 \mathrm{ft}$. Thus, the water in the upper limestone, where the water table was located, reached the pumped well by infiltrating through the sandy layer.

Figure 75 shows a semilogarithmic plot of the drawdown versus time after pumping started for each observation well during the 5 -hour test on May 1. From 10 minutes after the pump started until the end of the test the difference in drawdown between OW $3-10$ and $O W 3-500$ was nearly constant; this indicates that the cone of depression, as observed in the deeper wells, had approximately stablized to a distance of at least $500 \mathrm{ft}$ in the $\mathrm{first}$ 10 minutes of pumping.

The water level in the upper limestone, in which the water table is located, did not decline as much as that in the deeper limestone. The drawdown in the shallow well (OW 3-250) for the first 4 minutes was less than that for the deeper well (OW 3-500), which is twice as far from the pumped well. However, after the first couple of minutes the rate of decline in $O W 3-250$ was greater than that for any of the deeper wells. This indicates that water was still infiltrating from the water table through the sand to the lower part of the aquifer (in this portion of the cone of depresston)at a greater rate than the lateral flow of water through the oolite. 

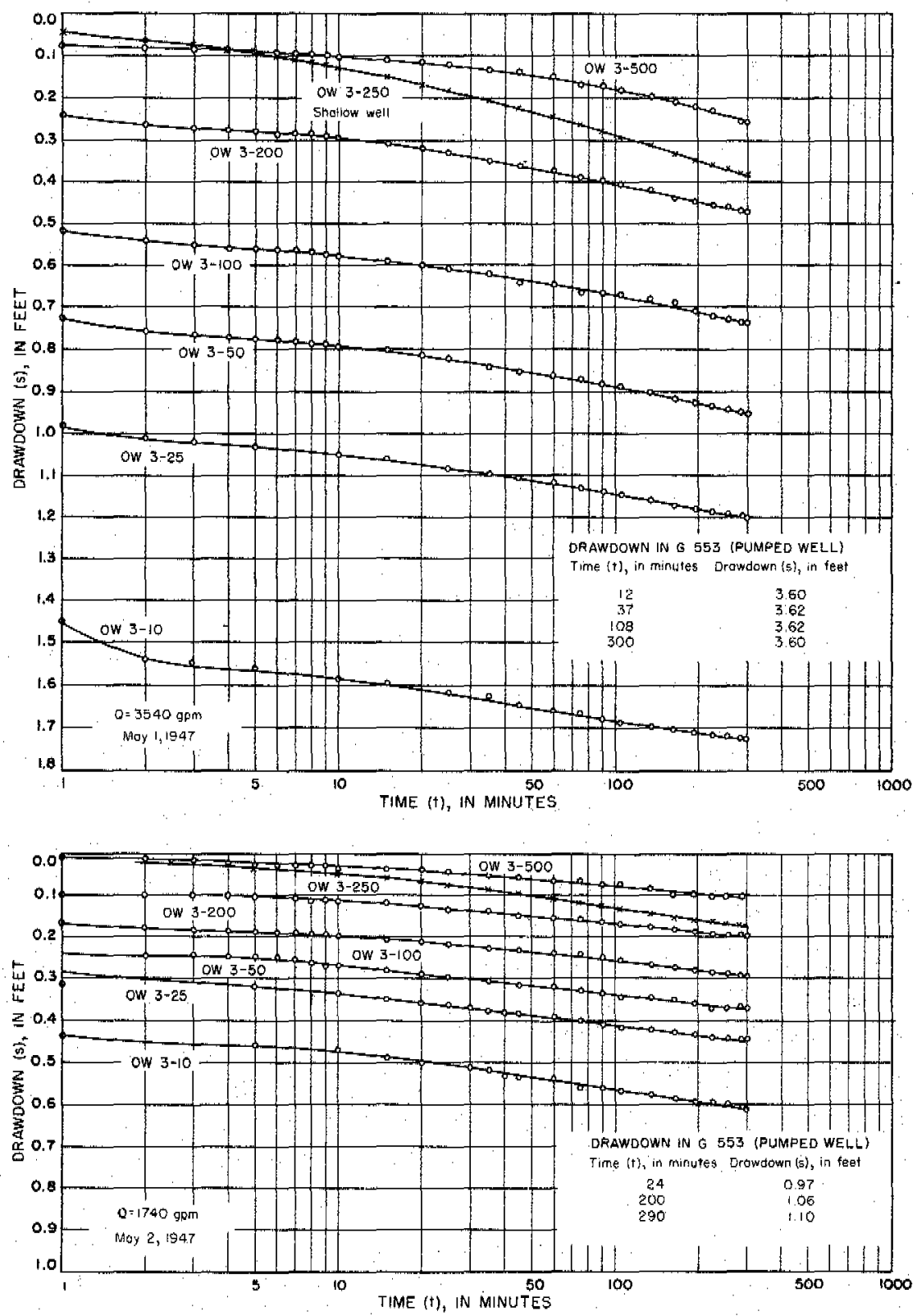

Figure $\mathbf{7 5}$. - Time-drawdown graphs for pumping tests at G $\mathbf{5 5 3}$, 
On May 2, 1947, between 8:00 a. m. and 1:00 p. m., a second 5 -hour pumping test was made on well $G 553$. For this test the rate of pumping was $1,740 \mathrm{gpm}$, or 49 percent of the rate on the preceding day. Figure 75 also shows the drawdown in the observation wells during this test.

The drawdowns at the two rates of pumping for both 5 -hour tests are compared in table 18. The computed drawdowns at $3,540 \mathrm{gpm}$ were obtained by multiplying the observed drawdowns at 1, 740 gem by the ratio of the two rates $(3,540 / 1,740=2.03)$.

Table 18. - Drawdown, in feet, for well G-553 and observation wells at end of 5-hour pumping test

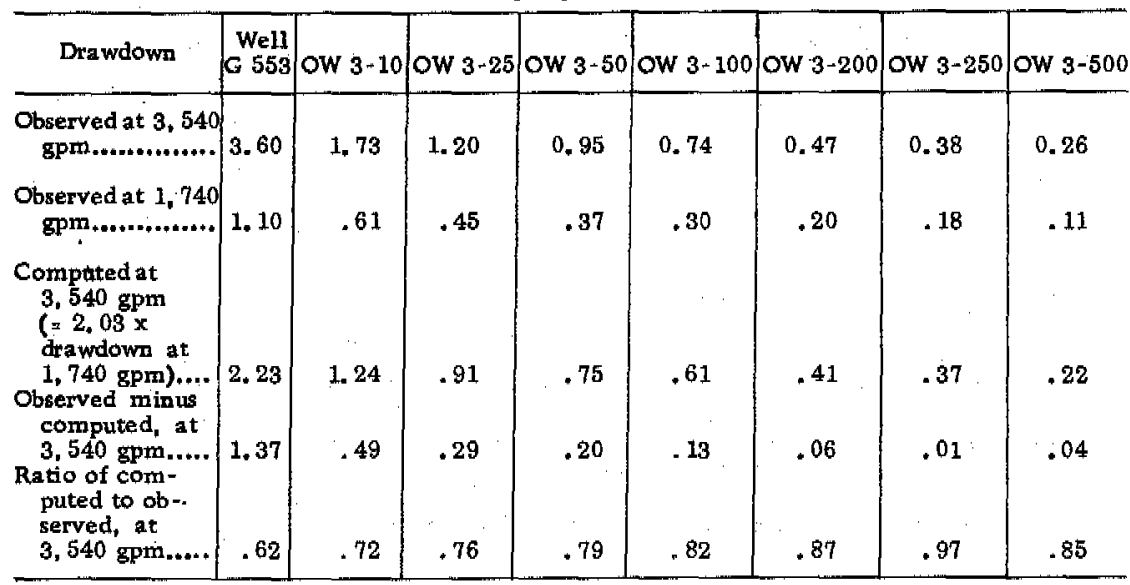

The ratio of computed to observed drawdown increases with distance away from the pumped well, but it is appreciably less than 1.00 at a distance of $500 \mathrm{ft}$ from the pumped well. The fact that the ratio is less than 1.00 indicates that the actual conditions are not in strict accord with the assumptions on which the test formula is based, and it appears to corroborate previous data indicating that the ground-water flow is not strictly laminar, even at distances as great as $500 \mathrm{ft}$ from the pumped well, when the rate of pumping is as high as $3,500 \mathrm{gpm}$.

Figure 76 is a semilogarithmic plot of drawdown versus distance from the pumped well for 150 and 300 minutes after the test started for both the $1,740 \mathrm{gpm}$ rate and the $3,540 \mathrm{gpm}$ rate. The value of $T$ obtained from the $3,540 \mathrm{gpm}$ rate, using all wells 25 to $500 \mathrm{ft}$ from the pumped well, is about $2.5 \mathrm{mgd}$ per $\mathrm{ft}$ and that for the $1,740 \mathrm{gpm}$ rate is about $3.5 \mathrm{mgd}$ per $\mathrm{ft}$. The value of $T$, computed from the drawdowns in OW 3-200 and OW 3-500after 5 hours of pumping at the $3,540 \mathrm{gpm}$ rate, was $3.2 \mathrm{mgd}$ per $\mathrm{ft}$. After 5 hours of pumping at $1,740 \mathrm{gpm}$ rate the value of $T$, determined from the same two wells, was $3.9 \mathrm{mgd}$ per $\mathrm{ft}$. Using a value of $T$ equal to $3.5 \mathrm{mgd}$ per $\mathrm{ft}$, values of the coefficient of storage ( $\mathrm{S}$ ) were com- 


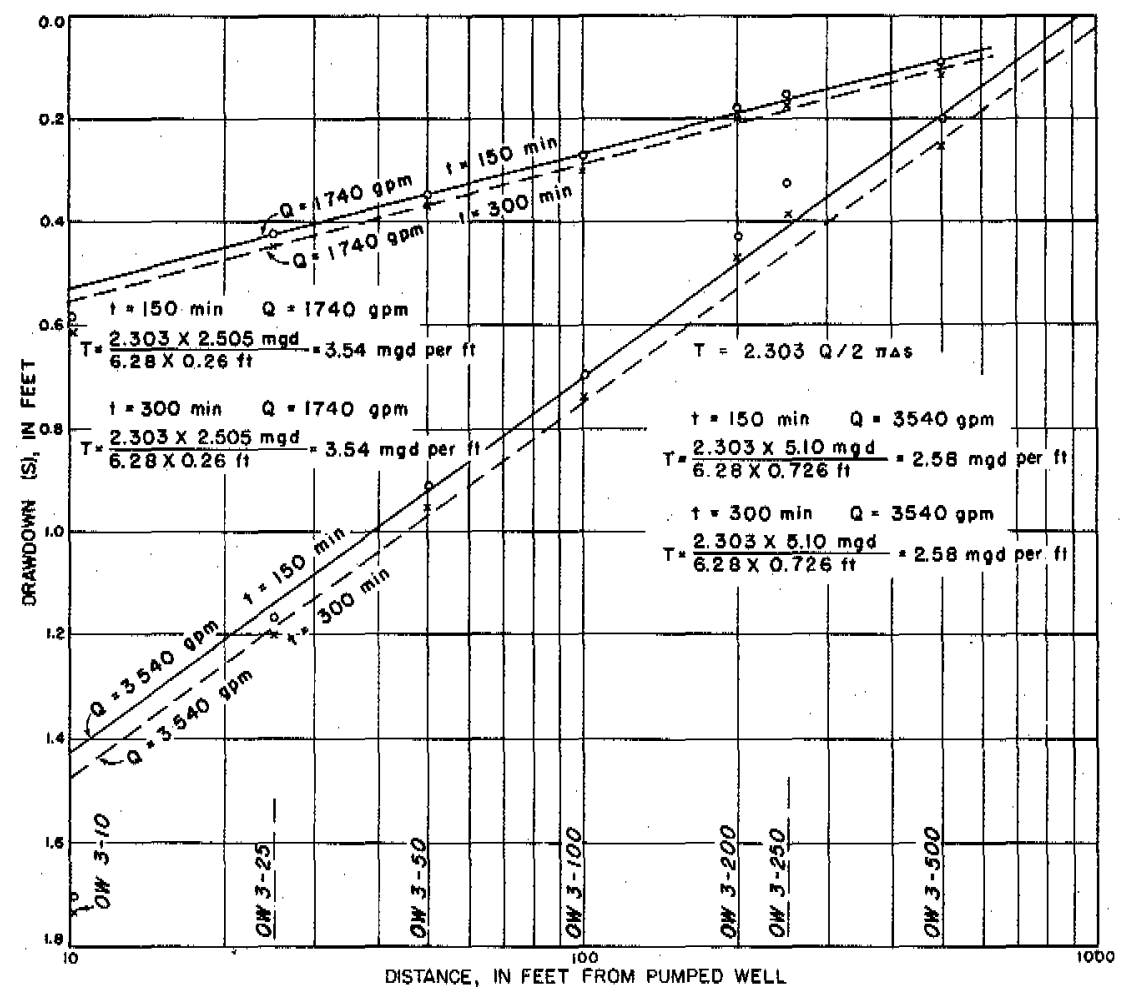

Figure 76. -Distance-drawdown graphs for pumping tests of C 553.

puted from the drawdown in wells located 100, 200, 250, and 500 ft from the pumped well, as shown in table 19 .

Table 19.-Computed values of $S$ based on drawdowns after 5 hours of pumping and a value of $\mathrm{T}$ sizal to $3.5 \mathrm{mgd}$ per $\mathrm{ft}$

\begin{tabular}{|c|c|c|c|c|c|}
\hline $\begin{array}{c}\text { Rate of } \\
\text { pumping } \\
\text { (gpm) }\end{array}$ & $\begin{array}{c}\text { Well } \\
\text { ow 3-100 }\end{array}$ & $\begin{array}{c}\text { Well } \\
\text { OW } 3-200\end{array}$ & $\begin{array}{c}\text { Well } \\
\text { OW 3-250 }\end{array}$ & $\begin{array}{c}\text { Well } \\
\text { OW 3-500 }\end{array}$ & Average \\
\hline 3,540 & 0.037 & 0.089 & 0.131 & 0.103 & 0.090 \\
1,740 & .134 & .166 & .164 & .152 & .154 \\
\hline
\end{tabular}

The analysis of the data obtained from these tests on G 553 indicates that the value of $T$ in that area is about 3.5 to $4 \mathrm{mgd}$ per $\mathrm{ft}$ and that the value of $S$ is equal to about 0.15 . The fact that the full-rate pumping test produced drawdowns considerably more than twice that of the half-rate pumping test indicates that turbulent flow toward the well is occurring through the natural limestone tubes or solution channels in the aquifer, and that this flow is highly complicated and not subject to precise mathematical analysis. Nonetheless, the data are useful and give a general value for hydrologic coefficients. 


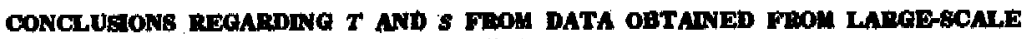 PUMPING TEST}

The pumping tests on wells $S 1, G 551, G 552$, and $G 553$ are of value chiefly in indicating the productiveness of the Biscayne aquifer in several different locations. These tests, and other preceding smaller-scale tests, show that the aquifer in Dade County is highly productive everywhere along the coastal ridge and for a considerable distance into the Everglades; however, its productivity appears to vary considerably from one locality to another within this area.

The pumping tests discussed in the preceding pages indicate that actual field conditions under which the tests were made do not conform closely to the basic assumptions from which the Theis nonequilibrium test-pumping formula is derived. The differences are principally these: (1) The Biscayne aquifer is not homogeneous. Sand pockets or lenses, dense limestone layers, and cavities or solution channels occur. These cavities may extend considerable distances and may influence a pumping well in a manner similar to that of laterals supplying a collection gallery, (2) Even when no large cavities are encountered, the solution passages, common nearly everywhere in the Miami oolite and Fort Thompson formation, are large enough to allow turbulent flow to develop at distances as great as $500 \mathrm{ft}$ from the pumped well (when the rate of pumping is as high as $5 \mathrm{mgd}$ ). (3) In some areas, layers of sand or dense limestone of much lower permeability intervene between the water table in the upper limestone (Miami oolite) and the lower limestone (Fort Thompson formation), from which water is pumped. It is assumed in the formula that the aquifer has the same permeability throughout its entire thickness and that, during pumping, the water level in a well ending in the top of the aquifer is the same as the level in a well ending near the middle or bottom of the aquifer, providing that all wells are the same distance from the pumped well. (4) In the formula it is also assumed that water in storage is released immediately as soon as the water table declines, whereas actually, when there is a sudden lowering of the water table, water may drain for several hours or days from the part of the aquifer that was saturated before pumping began. (5) Also, it is assumed that the pumped well penetrates the entire thickness of the aquifer and is able to receive water throughout the entire saturated thickness of the aquifer. Thus, it is assumed that there is no vertical convergence of flow lines as the pumped well is approached.

These divergences in the Biscayne aquifer from the basic as = sumptions on which the formula is derived make it difficult to obtain reliable values for the coefficient of storage $(S)$. The values derived for the coefficient of transmissibility $(T)$ are approximate, and $T$ appears to range in value considerably from one location to 
another so that it is difficult to determine what the average value of $T$ would be for an area of 100 or $200 \mathrm{sq}$ miles.

From the four pumping tests just discussed $S 1$ and $G 553$ gave values of $T$ equal to about $4 \mathrm{mgd}$ per $\mathrm{ft}$. The values of $T$ at $G 551$ and $\mathrm{G} 552$ are about 15.0 and 6.0 , respectively. The higher value of Tobtained from tests of well G 551 probably is due in large measure to the fact that most of the water moves into the well through solution channels in the limestone that are large enough to more than offset the added resistance of turbulent flow. When high pumping rates are used, water does not move uniformly through the aquifer to the well with laminar flow.

It is estimated on the basis of analysis of the water levels in well S 182 that annual ground-water runoff in that area is about 21 in., which, at an average stage of the water table for the area surrounding the well, gives a computed value of $T$ equal to about $4 \mathrm{mgd}$ per $\mathrm{ft}$. This figure compares closely with the value obtained from the G 553 test, which was conducted about 3.8 miles away.

In view of the wide ranges in value of $T(4$ to $15 \mathrm{mgd}$ per $\mathrm{ft}$ ) obtained from these tests, the median ( $5 \mathrm{mgd}$ per $\mathrm{ft}$ ) was adopted as the best single value of $T$ to use for the coastal ridge from Peters north to Hialeah.

A coefficient of transmissibility of $5 \mathrm{mgd}$ per $\mathrm{ft}$ indicates a highly productive aquifer, which would compare favorably with an aquife $x$ of the same thickness composed of clean, coarse, wellsorted gravel. As a matter of comparison, an 18-in. well in the Miami area, penetrating less than $100 \mathrm{ft}$ of the Biscayne aquifer and pumping $5 \mathrm{mgd}$, has a drawdown of only about 2 to $3 \mathrm{ft}$; at Jacksonville, a typical well of equal diameter, penetrating about $500 \mathrm{ft}$ of water-bearing limestone in the Floridan aquifer (p. 188), when pumped at the rate of $5 \mathrm{mgd}$, would have a drawdown about 10 times as great as that of the Miami well; and a well of equal diameter at Savannah, Ga., penetrating about $500 \mathrm{ft}$ of waterbearing limestone in the Floridan aquifer where the coefficient of transmissibility is about 250,000 gpd per $\mathrm{ft}$, would have a drawdown of about $50 \mathrm{ft}$. It is concluded that the Biscayne aquifer at Miami compares favorably in productivity with any aquifer in the world.

\section{QUANTITATIVE STUDIES OTHER THAN LARGE-SCALE PUMPING TESTS}

58 RUMPLNG Test

The first effort to determine hydrologic coefficients of the Biscayne aquifer at Miami by means of a pumping test was made February 29, 1940. The well selected was a fire well, F 85, located at NW. 77 th Street and 15 th Avenue. It was 6 in, in diam- 
eter and $58.6 \mathrm{ft}$ deep, with an open hole of unknown length in sandy limestone below the bottom of the casing. The well was pumpedat a rate of $400 \mathrm{gpm}$ over a $7 \frac{1}{2}$-hour interval. Other fire wells in the vicinity were measured periodically, and it was found that the pumping had no effect on water levels in these wells.

As a result of this pumping it was decided that if any appreciable drawdown of the water table were to be measured, a considerably higher pumping rate would have to be employed, and measurements of drawdown would have to be made much closer to the pumped well. Accordingly, plans were made to obtain a pump capable of discharging $1,000 \mathrm{gpm}$ (1.44 mgd) and to install 20 observation wells within a radius of $100 \mathrm{ft}$. Ten of these observation wells were to be of the same depth as the pumped well and the other 10 were to be about $15 \mathrm{ft}$ deep, located beside each of the deeper observation wells. The water was to be discharged through $300 \mathrm{ft}$ of $6-\mathrm{in}$. pipeline into a weir box and thence into a large, rock pit west of the well. Two staff gages were to be installed in the rock pit, and one gage was installed in Little River Canal at the point closest to the pumped well. All measuring points were to be tied by levels into U. S. Coast and Geodetic Survey mean sea level datum.

Preparations were completed so that preliminary readings of water levels in the new observation wells, all fire wells in the vicinity, and staff gages in the rock pit and Little River, could be made on May 8 , beginning at 11:00 a. m. Pumping started on May 9 , but engine trouble caused a shut-down after 20 minutes of operation. Readings were discontinued until pumping started again at 6:00 a. m., May 10. Again the pump did not operate properly and readings were discontinued in the afternoon. On May 11, readings were begun again at 6:00 a. $\mathrm{m}$. , pumping was started at 10:35 a. m. and except for three shut-downs of about 5 minutes each, to allow for pump oiling, continued for 24 hours. Readings were discontinued at noon, May 12.

Discharge from the pumped well was approximately $950 \mathrm{gpm}$ and, except for the period of the three shut-downs, varied only slightly. Vacuum-gage readings on the intake side of the pump fluctuated very little and showed no definite trend, being approximately the same just before pumping ceased as they were just after pumping started.

Drawdown data from all wells were plotted as hydrographs. They indicate that the water table was practically a plane surface in the vicinity of the pumping test and that it fluctuated slightly owing to oceanic tides in Biscayne Canal. The hydrographs also indicate that accidental errors, though small, are highly significant because of the small drawdowns involved. They are especially significant for those wells being used to determine the slope of 
the cone of depression, because the difference in water level (between distances of 50 and $100 \mathrm{ft}$ from the pumped well) was only $0.015 \mathrm{ft}$.

The water levels in the 10 deep observation wells dropped a few hundredths of a foot almost instantaneously when the pump started and they rose the same amount when the pumping ceased. There was no apparent increase in drawdown in the 24 hours of the pumping test. The shallow wells responded more slowly and with even less drawdown. No effect of pumping was noted in any of the other fire wells in the vicinity, nor was there any conclusive evidence that the water discharged into the rock pit raised water levels adjacent to the pit; water-table profiles between the pit and the pumped well (F 85) showed no gradient from the pit.

Recovery at the end of the pumping test was plotted on semilogarithmic paper against distance from F.85. Of the 10 deep observation wells, six of them plotted in approximately straight lines; the other four wells showed such scattered points that they were disregarded. From the recovery curves of these six wells, the coefficient of transmissibility $(T)$ was computed to be approximately 9. $5 \mathrm{mgd}$ per $\mathrm{ft}$. This figure seemed excessively high, but it was realized that even very small observational errors would result in large errors in the computed values. However, largescale pumping tests since that time have shown that considerably higher values for $T$ may be valid for the limestone aquifer of this area (p. 270). Therefore, the $9.5 \mathrm{mgd}$ per $\mathrm{ft}$; obtained at $F 85$ is probably correct.

\section{G 218 PUMPING TEsT}

G 218, an exploratory test well 202. $5 \mathrm{ft}$ deep, had been drilled in August 1941, in the Everglades, 6 miles west of the Miami well field. As with all such test wells, G 218 was pumped at successively deeper levels as drilling proceeded to obtain data on the quality and quantity of water at different depths. The data showed that this well penetrated the Biscayne aquifer at a point where it is typically composed of permeable sandy limestone and calcareous sandstone with occasional beds or pockets of quartz sand. The most permeable partwas between about 60 and $75 \mathrm{ft}$ below the land surface, where the water was very similar, chemically, to that obtained from the Miami well field.

Early in 1945 it was decided that a pumping test should be made in that area, not only to determine the hydrologic coefficients of the aquifer, if possible, but also to pump the well long enough and at a high enough rate that ground water would be drawn in from a considerable distance; thus, if any change in quality were to occur, it could be ascertained by chemical analyses of the collected samples. 
Accordingly, plans were made to plug the well at about $72 \mathrm{ft}$, blast the casing open slightly above that depth, then surge and pump the well to develop maximum efficiency. This was done in March 1945, and an excellent well was obtained. Following this, 10 observation wells, $2 \frac{1}{2}$ in. in diameter, were drilled to the same depth as G 218, that is, to a depth of $72 \mathrm{ft}$. All wells were finished with open holes below the casing, ranging from about 5 to $10 \mathrm{ft}$. One line of wells extended north-south along the east bank of Snapper Creek Canal, which was then practically dry. These observation wells were drilled at the following distances from the

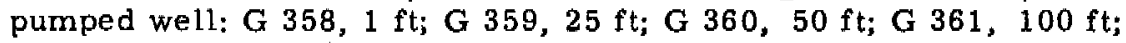
$G 362,200 \mathrm{ft}$; and $G 363,2,200 \mathrm{ft}$. The other line of wells extended east-west through G 218 with one well, G 364 , being $25 \mathrm{ft}$ west of G 218 in Snapper Creek; the rest of the wells of this line extended east of $G 218$ as follows: $G 365,25 \mathrm{ft}$; $G 366,50 \mathrm{ft}$; and G $367,100 \mathrm{ft}$.

To make certain that no recirculation of pumped water occurred, a solid earth dam was constructed across Snapper Creek

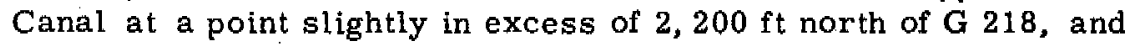
a 12 -in. Transite pipeline was laid to discharge the water beyond (north of) the dam. Staff gages were then set in Snapper Creek Canal on both sides of the dam and these, together with all observation wells, were tied by levels to U. S. Coast and Geodetic Survey mean sea level datum.

A 6 -in. centrifugal pump, rated at $1,450 \mathrm{gpm}$ when $20 \mathrm{ft}$ above water and pumping against a total head of $50 \mathrm{ft}$, was attached to the well casing. Discharge was into the 12 -in. pipeline where it was measured by a pitometer located far enough from the pump that flow disturbances would be unimportant.

Pumping began on April 7, 1945, at 9:50 a. m., and continued, except for occasional interruptions due to engine trouble, until April 25 at 9:30 p. m. During this period, the pump operated efficiently for a total of 189 hours and pumped a total of approximately 14.2 million gallons. The average rate of pumpage was $1,250 \mathrm{gpm}$, although at times the rate was as high as $1,350 \mathrm{gpm}$.

Because the pump operated discontinuously, the frequent starts and stops probably did not always allow the water table to regain equilibrium, and because the observed drawdowns were very small, and because occasional light showers had some recharging effect on the water table, it is believed that the values obtained for the coefficient of transmissibility are not precise, even though corrections were applied.

The most satisfactory part of the testoccurredfrom 9:50 a. m., April 16, to $10: 00$ p. m. , April 18. During this time, pumping was continuous for 60 hours and 10 minutes. Nopumping had been done previously since 6:00 p. m., April 13, and the water table on 
April 16 was a plane surface apparently not affected by previous pumping. Distance-drawdown graphs gave values for $r$ equal to $4.4 \mathrm{mgd}$ per $\mathrm{ft}$ for the north-south leg between wells $\mathrm{G} 359$ and G 361 , and $3.9 \mathrm{mgd}$ per ft for the east-west leg between wells G 365 and $G 367$. Thus, it is believed that $T$ is about equal to 4.0 mgd per $f t$ in the $G 218$ area. No satisfactory value for $s$ could be computed.

The chemical analyses of the water, made by chemists of the city of Miami Department of Water and Sewers, showed that no change in the quality of the water occurred with pumping. The dissolved chemical constituents, temperature, $\mathrm{pH}$, and color remained essentially uniform throughout the test and were very similar to those of raw water from the Miami well field in Miami Springs.

\section{STUDAES OF CONE OF DEPRESGON IN MAMI FELL FIELD}

Pumping from the Miami well field in Miami Springs produces a rather wide, shallow cone of depression averaging about a mile in radius and 2 to $2 \frac{1}{2} \mathrm{ft}$ in depth at the center during the dry season. (See figures $32-34$.) Water from this field is measured by venturi meters in the Water Works Plant in Hialeah, and a record of pumping time is kept for each individual well. By use of average water-table slopes at different distances from the center of the cone, the coefficient of transmissibility was computed using the Thiem formula (Wenzel, 1942, p. 81). These computations were made throughout the year, under both wet and dry conditions, so that deep, intermediate, and shallow cones of depression were represented. Values of $T$ ranged from 2.35 to $4.9 \mathrm{mgd}$ per $\mathrm{ft}$ and averaged about $3.5 \mathrm{mgd}$ per $\mathrm{ft}$. This compares with the value for $T$ equal to about $4 \mathrm{mgd}$ per $\mathrm{ft}$ obtained from data gathered at the S 1 pumping test (p. 239-248). S 1 is one of the wells in the Miam $\mathrm{i}$ well field. These values give a check on the methods used for determining $T$ in this area and indicate a fairly close correlation.

\section{CANAL INELOW STUDUES}

Darcy's law states that the rate of flow through porous media is directly proportionate to the hydraulic gradient. This law is utilized in the expression $Q=P I A$, in which $C$ equals the quantity of water discharged in unit time, $P$ equals the permeability factor, $I$ equals the hydraulic gradient, and $A$ equals the cross-sectional area through which the water is discharged.

In field conditions, discharge through an aquifer past a line, such as a water-table contour, may be reckoned by the formula $Q=T I W$. In this formula; $Q$ equals the ground-water discharge in 
gallons per day; $T$ equals the coefficient of transmissibility; $l$ equals the hydraulic gradient in feet per mile; and $W$ equals the length, in miles, of the line across which the ground-water flow is measured.

A reach of canal suitable for an inflow study would be one that is fairly straight, with an appreciable. inflow between upstream and downstream measuring points, and with all the inflow contributed by ground-water seepage. In the Miami area, suitable sitesfor such studies are very limited because of lateral canals, surface inflow, small ground-water inflow, and tidal influences. The only suitable area is in the vicinity of Opa Locka between LeJeune Road and NW.

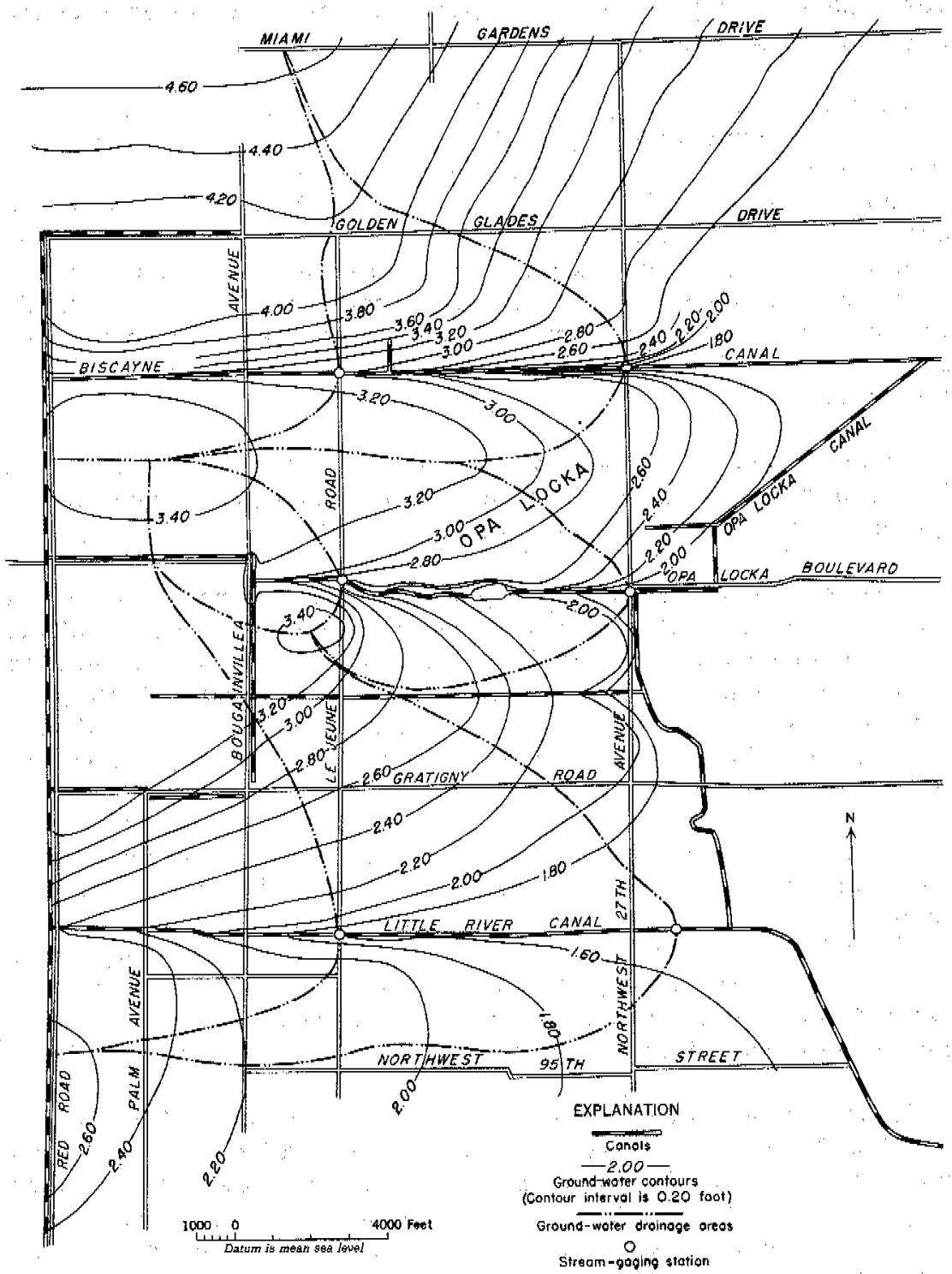

Figure 77. - Map of Opa Locka and vicinity showing water-table contours and ground-water drainage areas on August 29, 1940. 
27th Avenue on the Biscayne, Opa Locka, and Little River Canals. However, this area is not ideal (see fig. 77) because low flow; tides, and weeds in the canals make stream gaging difficult; furthermore, these canal stretches occur in an area that is largely underlain by quartz sand instead of the usual highly permeable limestone. Such materials would have a lower value of $T$ than would be found elsewhere in the Miami area.

All observation wells, measuring points, and staff gages were tied in to mean sea level datum and were measured at hourly intervals over a 13-hour tidal cycle. Streamflow measurements were made hourly at both the upper and lower ends of each of the canal reaches used in these studies.

Mean flow past each gaging station was computed. Water-table maps were constructed (fig. 77), based on mean water-level readings over the tidal cycle corrected to mean sea level datum. Drainage boundary lines, located by means of contours on the water table, were then drawn on the water-table map. These delineated drainage areas were then planimetered, and areas between the contours of each drainage area also were determined. The average distance of each contour from the canal was measured and the length of each contour with in the drainage areas was mieas ured also.

From these data, an average profile of each drainage area was drawn, and diagrams of the width of the drainage areas were plotted against distances from the canal.

Studies of these ground-water profiles indicate large head losses near the canals. These losses are the tangible evidence of the crowding of the flow lines as ground water moves from the aquifer out into the canals. It should be recalled that the water-table profile used is not an actual one taken normal to a given canal, but instead, it is built up by using average distances of each watertable contour from the canal.

The flow past any given contour is: $Q=T I W$. From the profile and width diagrams, the water-table slope, $l$, and the element of drainage area width, $: W$, can be determined, and a diagram of slope-width factor can be drawn. Since the total discharge, $Q$, is known only at the canal, it is necessary to assume that groundwater discharge is uniform throughout the area. This assumption makes the slope-width factor related linearly to the drainage area.

These studies give values of $T$ ranging from $1,458,000$ to $1,970,000 \mathrm{gpd}$ per $\mathrm{ft}$. It is believed that these values may be fairly reliable for the areas tested; they are somewhat lower than values for. $T$ of the highly permeable limestone areas. However, this is to be expected because the sand is not so permeable as the limestone. 


\section{FACTORS TO BE CONSIDERED REGARDING THE PROPOSED WELL FIELD IN THE MIAMI AREA}

\section{GENERAL ANALYES}

The Department of Water and Sewers of the city of Miami plans to develop a well field with a capacity of $50 \mathrm{mgd}$ in sec. $36, T, 54$ S., R. $36 \mathrm{E}$. This site is about $\frac{1}{2}$ mile west of the western border of the coastal ridge on the eastern border of the Everglades. The center of the proposed well field will be about 1.5 miles southwest of Snapper Creek Canal near the site of well G 551 (see fig. 61). In this area, an average stage for Snapper Creek Canal is approximately $5 \mathrm{ft}$ above sea level. In its present condition, the canal just west of the Seaboard Air Line Railroad is not very effective as a drainage canal because it is relatively shallow and contains a heavy growth of aquatic plants (mosses and rushes) that offer considerable resistance to the flow of water. From the vicinity of Miller Drive, Snapper Creek Canal flows northward into the Tamiami Canal, and from the vicinity of the Seaboard Air Line Railroad the canal flows eastward into Biscayne Bay.

The land surface in the area of the proposed well field averages about 6 to $8 \mathrm{ft}$ above mean sea level and is about 3 to $5 \mathrm{ft}$ lower than the coastal ridge to the east. At an average stage, the water table is about $5 \frac{1}{2} \mathrm{ft}$ above mean sea level and about $1 \frac{1}{2}$ to $2 \mathrm{ft}$ below the land surface.

It appears that the water pumped from a well field in this area would be derived from the following sources: (1) Water salvaged from evapotranspiration due to lowering of the water table substantially below the base of any muck present; (2) water supplied to the well field by infiltration from canals and by salvaging ground water that would have been discharged into canals, and thence into the sea, if the well field had not been in existence; and (3) water diverted from natural ground-water discharge areas. A part of the water pumped will be putback into the ground through drainage wells, septic tanks, and irrigational uses in the areas in which it is consumed. This will tend to decrease part of the total quantity of water diverted from natural discharge and will assist in maintaining a fresh-water head to prevent salt-water encroachment.

The question of primary importance is whether sufficient freshwater head can be maintained in the Biscayne aquifer between the bay and the well field, at an average stage of the water table, to prevent salt water encroaching westward at depth in the aquifer.

Under conditions of high water levels (shown by fig. 47) when the glades are flooded, water will be readily available to recharge the aquifer because more than half the cone of depression created by pumping in the well field will be under the flooded glades area. 
As there are no impermeable layers to prevent this surface water from recharging the aquifer, the cone of depression cannot expand to any great extent, because, as the water near the well field moves downward, water from adjacent flooded areas will flow in to replace it. It appears obvious that if the glades were continuously flooded, the water table would be high enough (because of a continuously high recharge to the aquifer) to prevent any encroachment of salt water from the sea. If a wet period followed a dry period, when the water taken from storage in the aquifer would cause the cone of depression to expand for a distance of several miles, most of the water taken from storage would be quickly replaced by downward infiltration from the flooded glades. The recharge of the aquifer in this manner would result in the salvage of some surface water that otherwise would have been discharged in to the sea.

During times of drought, such as occurred in 1945 (see fig. 45), the water table over most of southern Dade County did not have sufficient fresh-water head above the average water level in Biscayne Bay to prevent sea water from encroaching inland at depth in the aquifer (see Ghyben-Herzberg principle, section on Salt-water encroachment, p. 591-592). Although the salt water moves inland at depth in the aquifer under low water-table conditions, the rate of advance, owing to the extremely low gradient causing encroachment, is so slow that the total advance of the salt-water front during 3 or 4 months of extremely low water-table conditions is not likely to exceed several hundred feet. As the water table rises (a result of recharge from rainfall), the rate of advance is decreased, and if recharge continues, the advance of the salt-water front will be ștopped; if high water-table conditions are maintained for several months, the salt-water front may be flushed seaward beyond its original position. Thus, so long as hydrologic conditions are not greatly changed by artificial means, the inland and seaward movements of the salt-water front in the permeable limestone aquifer probably will be restricted to a zone less than $\frac{1}{2}$ mile wide. However, ground-water conditions can be changed by artificial means, such as the construction of new canals or the deepening of existing ones (which would drain off additional large quantities of ground water into the sea), or by heavy pumpage from wells. Under the new conditions, if the average yearly stage of the water table becomes appreciably lower, the salt-water front will move inland until it reaches a new position that will be in equilibrium with the average water-table stage.

The water table in the area of the proposed well field ranges between 1 and $9 \mathrm{ft}$ above mean sea level. As the stage changes, the balance between the fresh - and salt-water heads changes, thus causing the salt-water front tofluctuate back and for th through its mean position. Because of the slow movement of water through the Biscayne aquifer (estimated to be about 2, $000 \mathrm{ft}$ per year when 
the gradient is $1 \mathrm{ft}$ to the mile), the salt front never has sufficient time to attain a position of equilibrium for either the high or the low water-table stages. Figure 78 indicates the position of the contact between fresh and salt water for the average water-table stage, according to the Ghyben-Herzberg principle.

Figure 78 also illustrates estimated average conditions af ter the well field has been in operation for several years. This profile was obtained by subtracting from the average water-table profile,
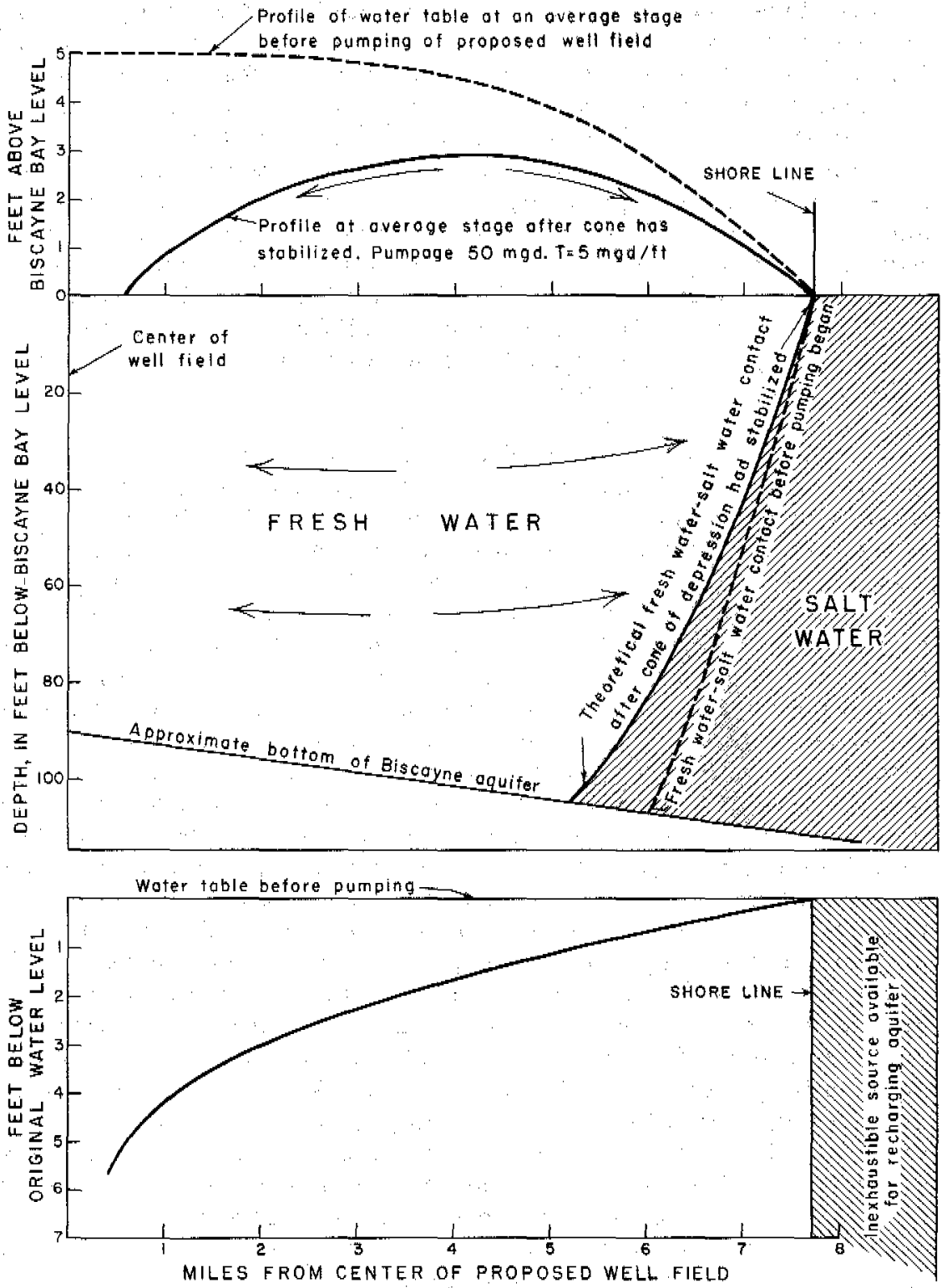

Figure 78, - Stabilized profiles of water table between shoreline and center of proposed well field. 
prior to the development of the proposed well field (dashed line), the equilibrium drawdowns due to pumping $50 \mathrm{mgd}$ in an aquifer having a coefficient of transmissibility of $5 \mathrm{mgd}$ per $\mathrm{ft}$. The center of pumping is a perpendicular distance of 7.7 miles from an infinite line source of recharge (Theis, 1935, p. 519-524; Muskat, 1937, p. 175), which is approximated in reality by Biscayne Bay water level (see p. 227) along the shoreline. This is illustrated by diagram in the lower portion of iigure 78 .

Under these conditions, which were es tablished by pumping from the proposed well field, the maximum fresh-water head above Biscayne Bay level (between the well field and the shore) is about $3 \mathrm{ft}$ and occurs about halfway between these two locations. A fresh-water head of $3 \mathrm{ft}$ is sufficient to displace the salt water to a depth of $120 \mathrm{ft}$. At a depth of $100 \mathrm{ft}$, relatively impermeable material (Floridan aquiclude), which offers much greater resistance to the movement of water, is encountered in this area. Figure 78 shows the theoretical position of the contact between fresh and salt water that would be in equilibrium with the average water-table profile after the proposed well field has been operating for several years. The dashed line shows its position prior to development of the well field.

For several reasons it is believed that the drawdowns shown are greater than would occur in actuality: (1) The center of the well field is approximately 1.5 miles from Snapper Creek Canal at its nearest point. As mentioned previously, the flow in Snapper Creek Canal is to the north and southeast from this area, but after the new well field is in operation it is expected that the water table will average 1 to $1.5 \mathrm{ft}$ lower in the vicinity of the bend in Snapper Creek Canal. The water surface in the canal will lower as the area water table lowers, and thus the canal will salvage much of the water that formerly flowed out of the area and probably it will reverse its flow. Because Snapper Creek Canal is part of an extensive network of canals, water can be fed into the area by canal flow from considerable distances. It is essential however, that the re be suitable gates and locks on these canals to prevent inland flow of salt water from the bay during dry periods when the water table is below that in Biscayne Bay. If Snapper Creek Canal should be cleaned out and deepened, it is especially important to prevent salt water from flowing into the eastern part of the canal from the bay or ocean. (2) A second reason for smaller drawdowns than are shown in figure 78 is that lowering of the water table, by pumping, substantially below the base of any muck present, will reduce evapotranspiration losses. (3) During periods of drought the cone of depression about the well field continues to expand. The rainy periods that follow must refill the cone of depression before glades in this area can become flooded; this will salvage, some of the water that formerly flowed out of the area by surface runoff through transverse glades and canals. 
It is believed that the water salvaged from evapotranspiration, water salvaged from out-flowing canals, and water now being fed into the area through the canal system, will account for more than 50 percent of the $50 \mathrm{mgd}$ that is expected to be pumpedfrom the new well field, thus requiring less than half of this amount to be diverted from natural discharge areas in Biscayne Bay. Drawdowns in figure 78 are based on the total pumpage being diverted from natural discharge areas in Biscayne Bay. Therefore, the drawdowns would be expected to be considerably less than those indicated, which should increase the maximum fresh-water head (as shown by the profile) from 3 to $5 \mathrm{ft}$, or more, above the average Biscayne Bay water level.

\section{THEORETICAL DRAWDOWNS IN AN INFWITE AQUIFER}

It is possible by means of the Theis nonequilibrium formula (p. 238) to compute the theoretical drawdowns that would occur for a pumpage of $50 \mathrm{mgd}$ in an aquifer of infinite extent having a coefficient of transmissibility of $5 \mathrm{mgd}$ per $\mathrm{ft}$ and a coefficient of storage of 0.20 . As discussed on p. 270 , the above coefficients appear to be about average values for the general area of the proposed well field.

Figure 79 shows the theoretical drawdowns at various distances from the pumped well and for various times after pumping has started. This figure may be of value in estimating the drawdown that would occur during a rainless period after pumping starts, before the cone of depression has spread out to recharge areas (canals and flooded-glade areas). If turbulent flow develops in the aquifer as the pumping well is approached, the drawdowns will exceed those shown. Turbulent flow may develop as far as $500 \mathrm{ft}$ from a well pumped at the rate of $5 \mathrm{mgd}$. For a single well with a capacity of $5 \mathrm{mgd}$, the drawdown would be one-tenth of those indicated by figure 79 .

\section{CONE OF DEPRESEON IN AN AREA IN WHCH THE AQUTFER IS UNIFORMLY RECAARGED}

It is possible to compute the theoretical drawdown for a stabilized cone of depression in an ideal aquifer that is continuously recharged at a uniform rate. The transmissibility of the aquifer, the pumpage from the well, and the rate of recharge will determine the shape and extent of the cone of depression. The cone will spread until its circle of influence has expanded sufficiently to divert toward the well a quantity of water equal to that pumped from the well. For conditions to stabilize, the effective recharge within the circle of influence must equal the pumpage from the well. The effective recharge may be defined as the recharge to the water table minus evapotranspiration from the water table. For a given 


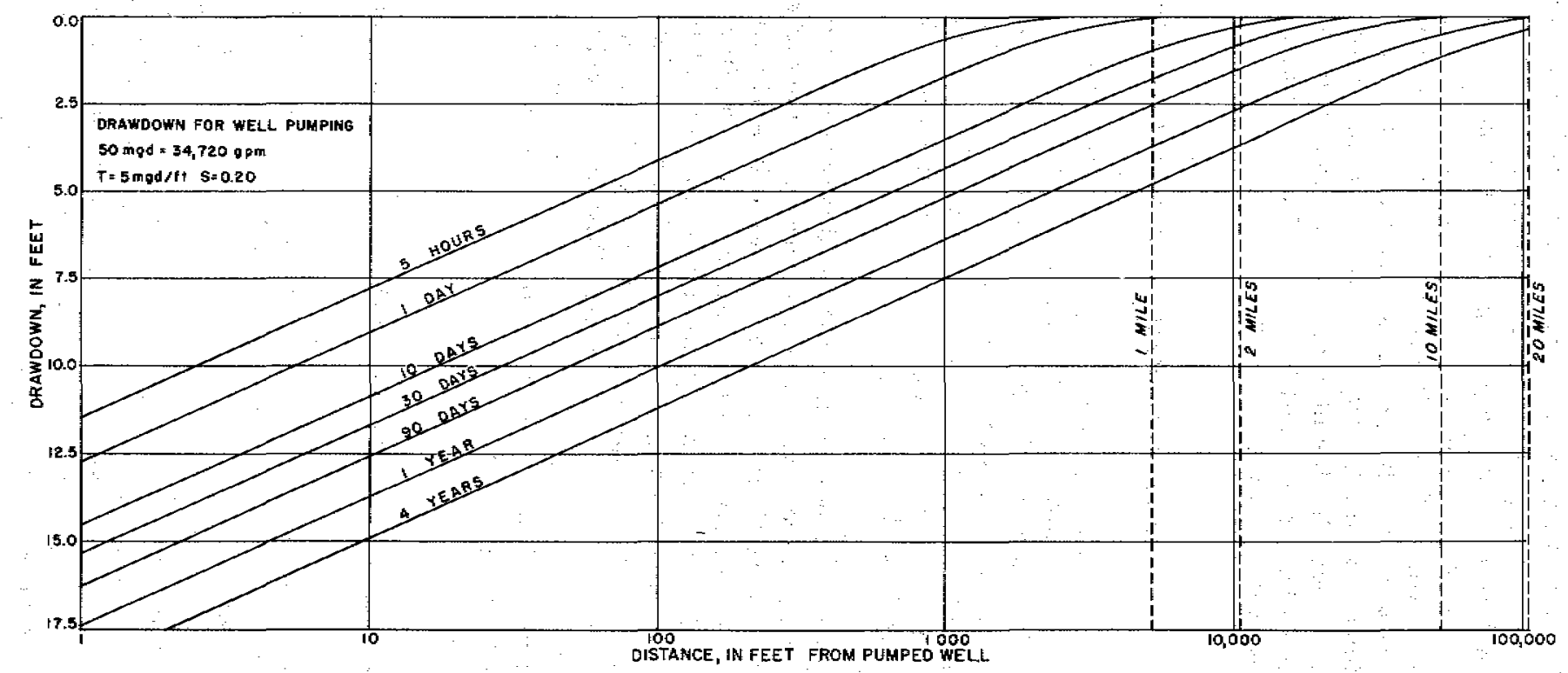

Figure 79. - Theoretical drawdowns in relation to distance from pumped well and time after start of pumping. 
pumpage, the size of the circle of influence may be assumed and the recharge (in inches per year) may be calculated, or, if the effective recharge is known or assumed, the size of the circle of influence may be calculated.

As the radius of the cone of depression is increased from a well that has been continuously pumped at a steady rate for a long time, a point is reached at which the drawdown, due to pumping from this well, is zero. This distance is said to be the radius of influence. Beyond the circle of influence the drawdown is zero, but within this circle of influence the drawdown increases as the well is approached. A level water table, prior to the time pumping began, is assumed.

This drawdown curve may be approximated by the following method. Determine the increase in drawdown for various decrements in radius from the pumping well, using the following formula and a decrement that is a small percentage of the radius of influence.

$$
s_{1}-s_{2}=\frac{527.7 q \log \frac{r_{2}}{r_{1}}}{T} \cdot\left[\frac{R_{0}{ }^{2}-r_{1}{ }^{2}}{R_{0}{ }^{2}}\right]
$$

where:

$r_{2}=$ the distance in feet from the pumping well to point in question on the cone of depression;

$r_{1}=$ the distance in feet from the pumping well to a point on the cone of depression such that $t_{1}$ is less than $r_{2}$;

$R_{0}=$ radius of influence in feet;

$s_{2}=$ drawdown in feet at $r_{2}$;

$s_{1}=$ drawdown in feet at $r_{1}$;

$q=$ well discharge in gallons per minute;

$T=$ coefficient of transmissibility in gallons per day per foot (assumed to be constant);

$s_{1}-s_{2}=$ equals the increase in drawdown between $r_{2}$ and $t_{1}$, $\frac{R_{0}{ }^{2}-r_{1}{ }^{2}}{R_{0}{ }^{2}}$ equals the percentage of the circle of influence, over which recharge is uniformly occurring, that is farther from the well than $r_{1}$. By starting with $r_{2}$ equal to $R_{0}$ and making the increment between $r_{2}$ and $r_{1}$ equal to $1 / 10$ or $1 / 20$ of $R_{0}$, the drawdown curve to the point in question may be closely approximated by summation of the increments of drawdown from $R_{0}$, to the point in question.

Assuming a circle of influence 7 miles in radius, the drawdowns for various distances from the pumping well or well field were 


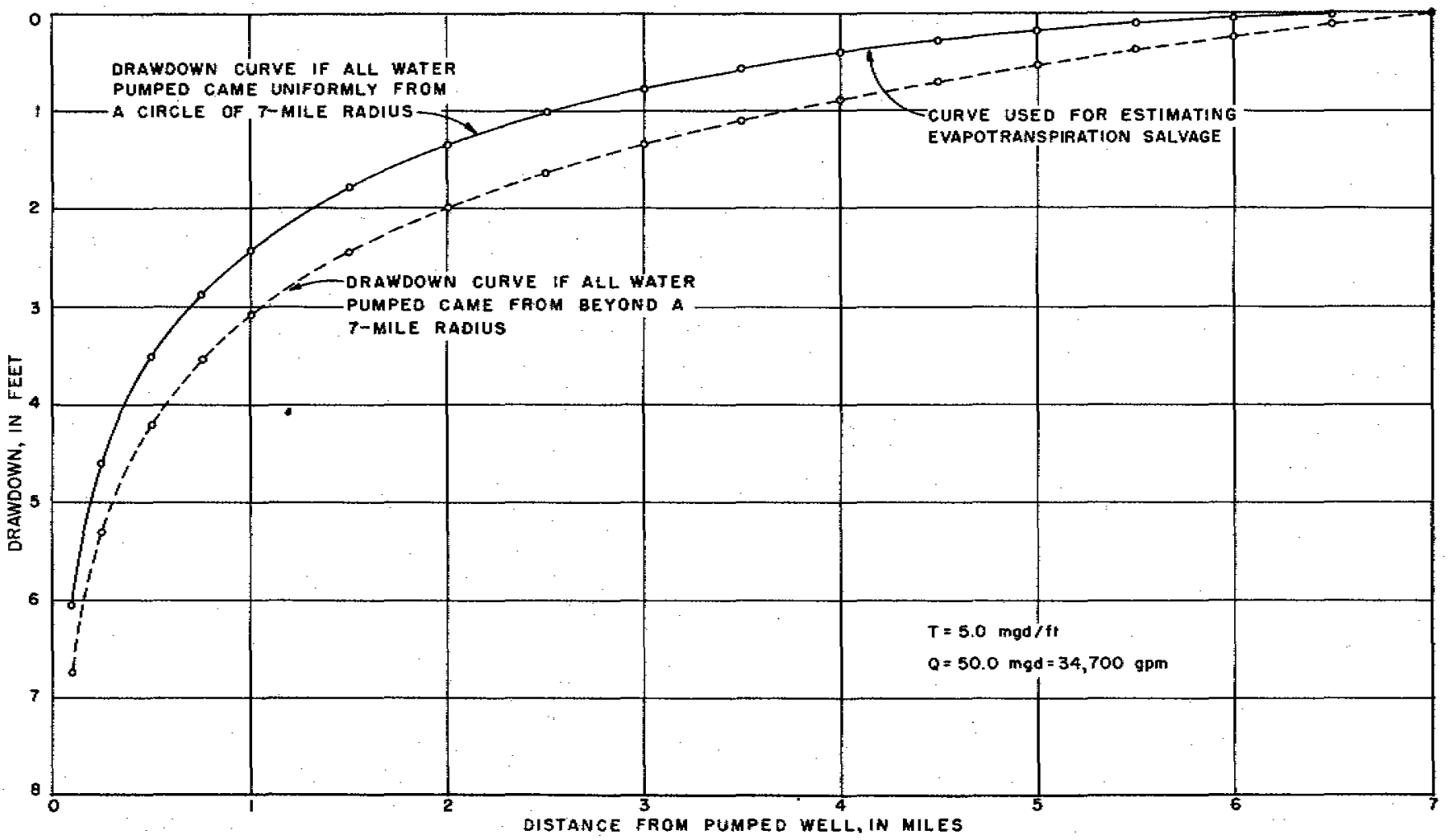

Figure 80. - Graph showing drawdowns resulting from pumpage within and beyond a circle of 7 -mile radius. 
computed for a coefficient of transmissibility of $5 \mathrm{mgd}$ per $\mathrm{ft}$ and a pumpage of $50 \mathrm{mgd}$. The curve resulting from a plot of these drawdowns is shown as a solid line in ligure 80 , and for comparison there is also shown, as a dashed line, the drawdown curve that would have occurred if all the water pumped from the well had moved in from distances greater than 7 miles. The decrement of change for the radius was $0: 5$ mile. A well field pumping $50 \mathrm{mgd}$ continuously, having a circle of influence 7 miles in radius, would require an effective recharge of 6.82 in, of water per year. A 6-mile radius of influence would require an effective recharge of 9.28 in. per year, and a 5 -mile radius of influence would require 13.36 in. of water per year.

From studies of the glades area (see section on Surface water, Hydrologic studies), it has been determined that the runoff through canals and transverse glades has averaged 5 to 14 in. of water per year. It is possible that $6.82 \mathrm{in}$. of water per year could be salvaged by decreased runoff through canals and transverse glades, and by reduction of evapotranspiration loss due to lowering of the water table. The salvage of water over the area would not be uniform; near the center of the cone of depression, conditions would be favorable for salvaging a larger percentage of the water than could be salvaged near the border of the cone of depression. Also, the size of the cone of depression would vary with the rainfall over the area and with the elevation of the water level in the glades.

Figure 81 shows the estimated cone of depression in the proposed well-field area resulting from superimposing the drawdowns caused by a uniformly recharged circle of influence of 7 -mile radius (see fig. 80) upon the water table of March 17, 1941, when the stage was about average for this area.

\section{EVAPOTRANSPLRATION GALVAGE}

Declines of the water table due to evapotranspiration were discussed on pages 222-231. Figure 53 indicates that evapotranspiration is less at lower stages of the water table than at higher stages. This would generally be expected, because, as the water table declines farther below the surface, more energy is required to raise the water to the surface. Also, the water table and the capillary fringe may be beyond the reach of some plant roots. The middle curve on figure 53 is for average atmospheric conditions, which would cause about 0.19 in. of water per day to evaporate from a standard class $A$ evaporation pan.

Figure 82 shows the estimated reduction in evapotranspiration under average atmospheric conditions for stages below average, as indicated by the decline of water levels in wells S 182 and S 196 (see fig. 53). Using the evapotranspiration salvage curve, devel- 


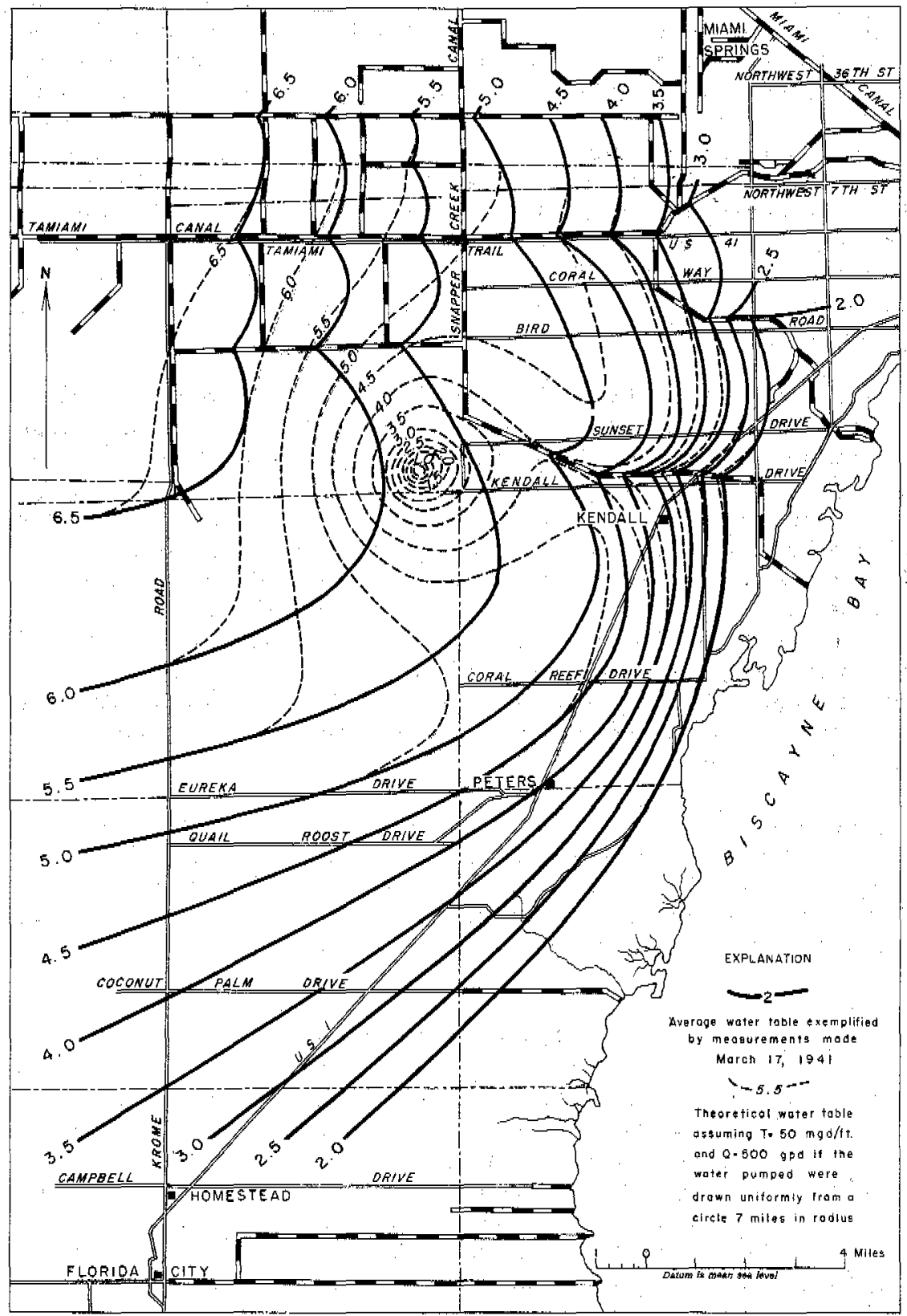

Hydralógy by N. O. Hoy

Figure 81. -Map of proposed well-field area showing theoretical cone of depression after drawdowns for a uniformly recharged circle of 7 -mile radius are superimposed on the average water table. 


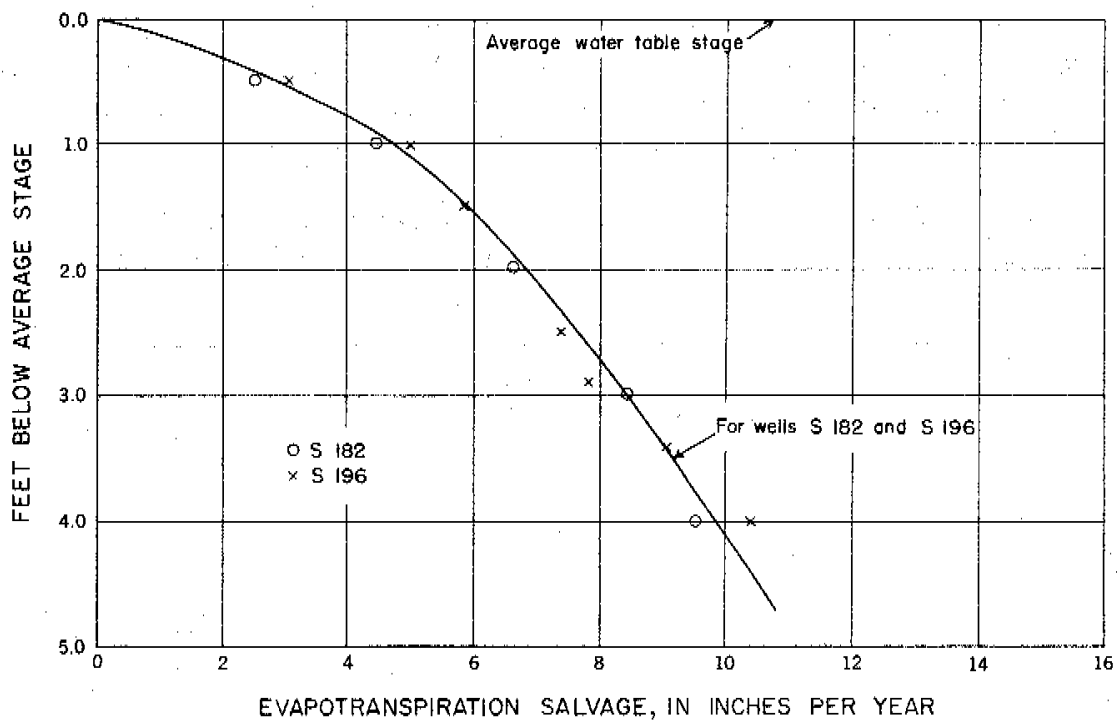

Figure 82, -Curve showing estimated evapotranspiration salvage resulting from lowering the water table.

oped for wells S 182 and S 196 (fig. 82), and the drawdown curve for a pumping well that has developed a cone of depression of 7 miles" effective radius under uniform recharge conditions (upper curve, fig. 80), it is possible to compute, by the summation process, what the apparent evapotranspiration salvage would be. The computation suggests that about $15 \mathrm{mgd}$ could be salvaged. The average stage of the water table in the area in which the proposed well field is to be established is only $1 \frac{1}{2}$ to $2 \mathrm{ft}$ below the surface; this places the stage 2 or $3 \mathrm{ft}$ closer to the surface here than in the coastal ridge. It is believed that this would make the evapotranspiration salvage in the proposed well-field area greater than that indicated by wells S 182 and S 196.

However, in areas of permanently lower average water-table conditions, the roots of some plants may tend to grow deeper and thus somewhat offset potential salvage. The writers know of no way to determine this effect, but it is believed that evapotranspiration salvage might be about $10 \mathrm{mgd}$ where the well field is surrounded by a cone of depression 7 miles in radius.

\section{WFI.TRATION FROM CANALS}

By assuming certain conditions it is possible to approximate the amount of induced recharge to an aquifer from a canal using the principle of recharge from an infinite line source, as outlined by Muskat (1937, p. 175). It is assumed that the canal is freely connected with the water-bearing formation, that the water level in the aquifer bordering the canal is the same as the water level in 
the canal, and that these water levels will rise and fall together, even though the change is rather rapid. It is further assumed that the canal is long and straight, and that canal flow into the area is sufficient to maintain a constant water level in the canal.

Figure 83 shows the stabilized cone of depression and the watertable profile for a well pumping $50 \mathrm{mgd}$ in an ideal aquifer that has

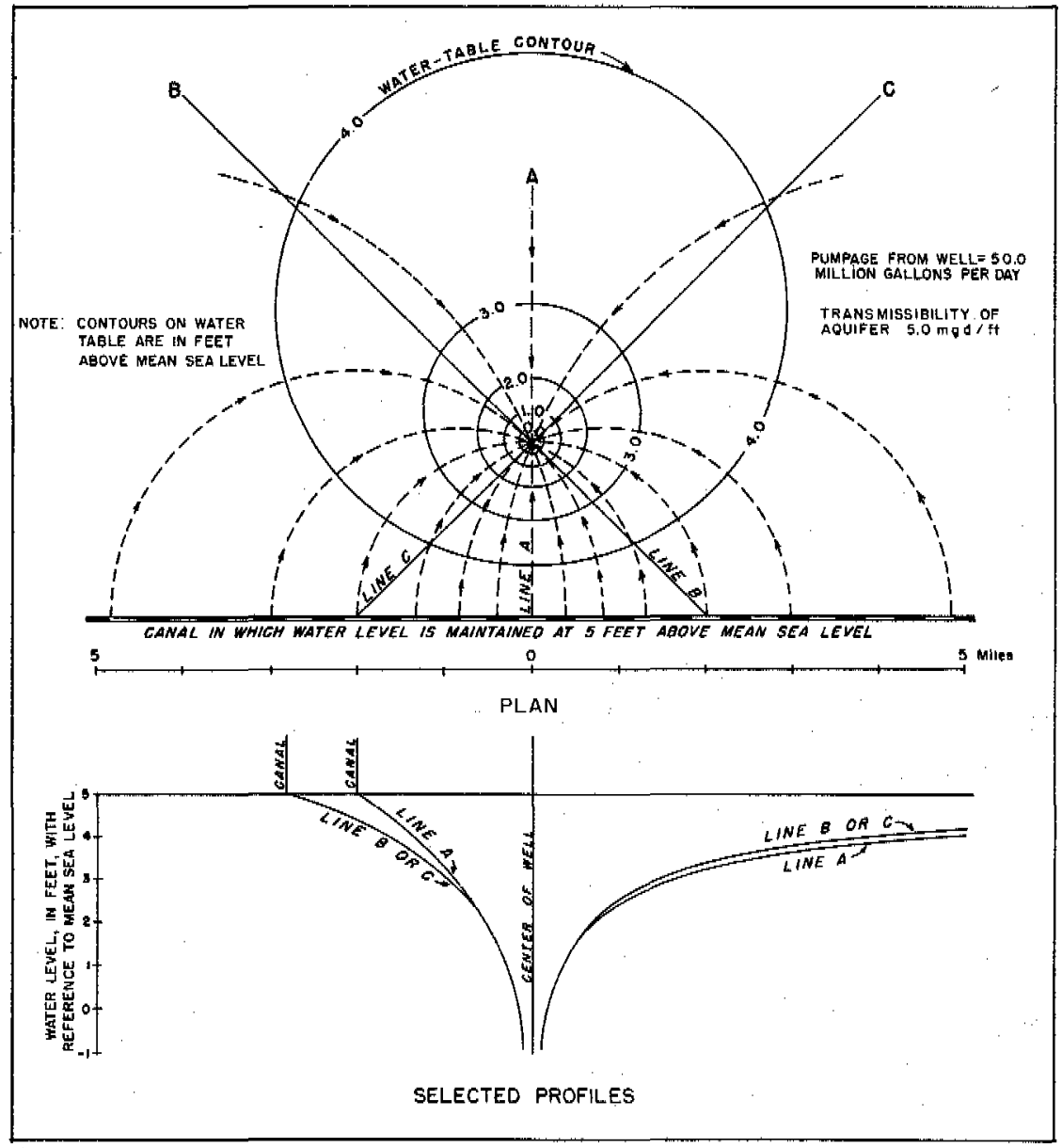

Figure 83. - Profiles of the watertable and plan of the stabilized cone of depression in an ideal aquifer of semi-infinite extent with reduced recharge from 2 canal.

an infinite areal extent away from the canal. A long straight canal, 2 miles from the well and freely connected to the aquifer along its entire length, supplies essentially all the water pumped by the well. The water level in the canal is maintained at $5 \mathrm{ft}$ above mean sea level throughout its entire length. The dashed flow lines show that influent seepage from the 4 miles of canal nearest the well 
supplies 50 percent of the water pumped by the well, and the 10 miles of canal nearest the well supply 75 percent of the water. The water-table profile along lines A, B, and C show the steepness of the gradients between the canal and the pumping well.

Snapper Creek Canal passes within 1.5 miles of the center of the proposed well field, and Bird Drive extension canal is 2.5 miles to the north. It appears that the effect of these canals would be approximated by a straight canal trending northwest-southeast and passing at a perpendicular distance of 2.0 miles from the center of the proposed well field. Pumping test data for well G 551 (p. 252-258) indicate that the Biscayne aquifer is very permeable in this area; the test gives a value of $T$ equal to about $15 \mathrm{mgd}$ per $\mathrm{ft}$. The limestone in this vicinity is rather cavernous, and the layer of quartz sand present in some areas between the Miami oolite and the limestone of the Fort Thompson formation is absent or much less prominent. There appear to be no layers with low permeability to restrict the movement of the water from the Miami oolite to the Fort Thompson formation, from which the wells will draw their water. The rock walls of the canals are cut into the Miami oolite.

The average water level in Snapper Creek Canal is about $5 \mathrm{ft}$ above mean sea level in that part of the canal nearest to the proposed well field. At the junction of Snapper Creek Canal and Tamiami Canal the average water level is about $4.5 \mathrm{ft}$ above mean sea level. If the water table should decline 1 or $1 \frac{1}{2} \mathrm{ft}$ in the area bordering the canal at its nearest point to the well field, the direction of flow in this part of Snapper Creek Canal would reverse, and the water surface would have a slope of about $0.2 \mathrm{ft}$ per mile toward the well field and away from the Tamiami Canal. It is believed that this slope would cause a sufficient flow of water in the canal to replenish the water that would infiltrate to the aquifer from the canal. A lower water surface in the canal would tend to lower the whole cone of depression (to a lesser degree) and would cause the infiltration from the canal to be a little less effective. During severe dry periods, as in 1945, Snapper Creek Canal can become dry and no water will be delivered from other areas for infiltration to the well field. In such periods, simple water-table conditions will prevail. Infiltration from the canal to the aquifer will not account for all the water pumped from the well field, be cause the southern part of the cone of depression will intercept considerable quantities of ground water moving toward the natural discharge area of Biscayne Bay. In view of the high permeability of the limestone in this area, it is believed that the water salvaged (including that which formerly flowed into canals and out of the area), plus the influent seepage from canals caused by pumping, will amount to a minimum of 25 to 50 percent of the total pumpage (data for 1 day, Mar. 28, 1946, p. 484, indicate that 78 percent of pumpage can come from seepage from canals). Water-table maps of the Miami area and the northern part of the coastal ridge 
(figs. 42-44) show the effectiveness of deepened sections of canals in the lowering of the water table. If the situation were reversed, so that the water table was lower than the stage of the canal, the canals would be just as effective in raising the water table.

\section{CONCLUSIONS}

Because of variations in water-bearing properties of the Biscayne aquifer within relatively short distances, because the network of canals that intersect the area have a pronounced effect upon the water table, and because of the delicate balance between the fresh- and salt-water heads, it is not possible to obtain exact mathematical solutions to hydrologic problems. After carefully analyzing the data available, it is believed that about one-half or more, of the desired quantity of $50 \mathrm{mgd}$ will be obtained through infiltration from canals to the cone of depression, by the reduction of runoff to canals from the area, and by evapotranspiration salvage due to lowering of water levels by pumping. It is believed that the remaining amount of water that is diverted from natural discharge areas in Biscayne Bay will not lower the fresh-water head sufficiently to allow salt water to encroach into the well field at depth in the aquifer. During a series of dry seasons, or years, the salt-water front may advance slowly inland, but this advance should be compensated by the seaward movement during wet periods.

Particular attention should be given to the control of canals to insure that they do notallow salt water to flow inland from the bay or from areas where the aquifer is salty. If the new well field is established at the location proposed, and if Snapper Creek Canal is cleaned out or deepened between Biscayne Bay and Tamiami Canal, special attention should be given to the eastern section of these canals to protect against inland flow of salt water, because the canals would provide a direct access for salt water into the well-field area. 


\title{
SURFACE WATER
}

By D. B, Bogart and C. E. Ferguson

\section{CHARACTERISTICS OF DRAINAGE BASINS AND SUMMARIES OF GAGING- STATION RECORDS}

\author{
METHODS OF INVESTIGATION AND EXPLANATION OF DATA
}

\section{COLLECTION OF FTELD DATA}

Characteristics of the surface waters of an area can be defined only after a period of observation can provide data of extreme conditions of both flood and drought and recorded values from which the most probable regimen for the future can be estimated; 10 years usually is considered to be a desirable minimum length of record, although much can be learnedfrom shorter records. A few observation stations were established by the Geological Survey in the Kissimmee River basin and in the Lake Okeechobee area in 1930 and 1931 , but many stations used in this report were started as late as 1939 and 1940, and others are even more recent. Only 7 years of record (through 1946) are available for some stations, but fortunately, wide variations of conditions occurred.

A relatively wide range of hydrologic conditions occurred in southeastern Florida during the period of more intensive investigation (1939-46). The drought of 1939 was the principal cause for the establishment of the enlarged program by the Geological survey in the Everglades area. The year 1940 was ordinary, but 1941 and 1942 were moderately wet, and conditions culminated in the fairly high water of June 1942. After that, rainfall decreased markedly and the accompanying drought reached what may have been an alltime extreme in the middle of 1945. Conditions returned to about normal in 1946 after heavy rains caused a large amount of recharge. Because of the close areal interrelationships of surface waters in southeastern Florida, the study necessarily covered all basins contributing to the Miami area. The longer records for Kissimmee River basin and Lake Okeechobee supplemented the more recent work in the Everglades and the coastal area.

Streamflow records, and records of stage along the streams and canals, were obtained through the operation of stream-gaging stations. At certain locations in southern Florida, water levels at these gaging stations were read from staff gages to hundredths of a foot by local observers. At other points, where tidal fluctuations or rapid changes in stage existed, or where the site was not readily 


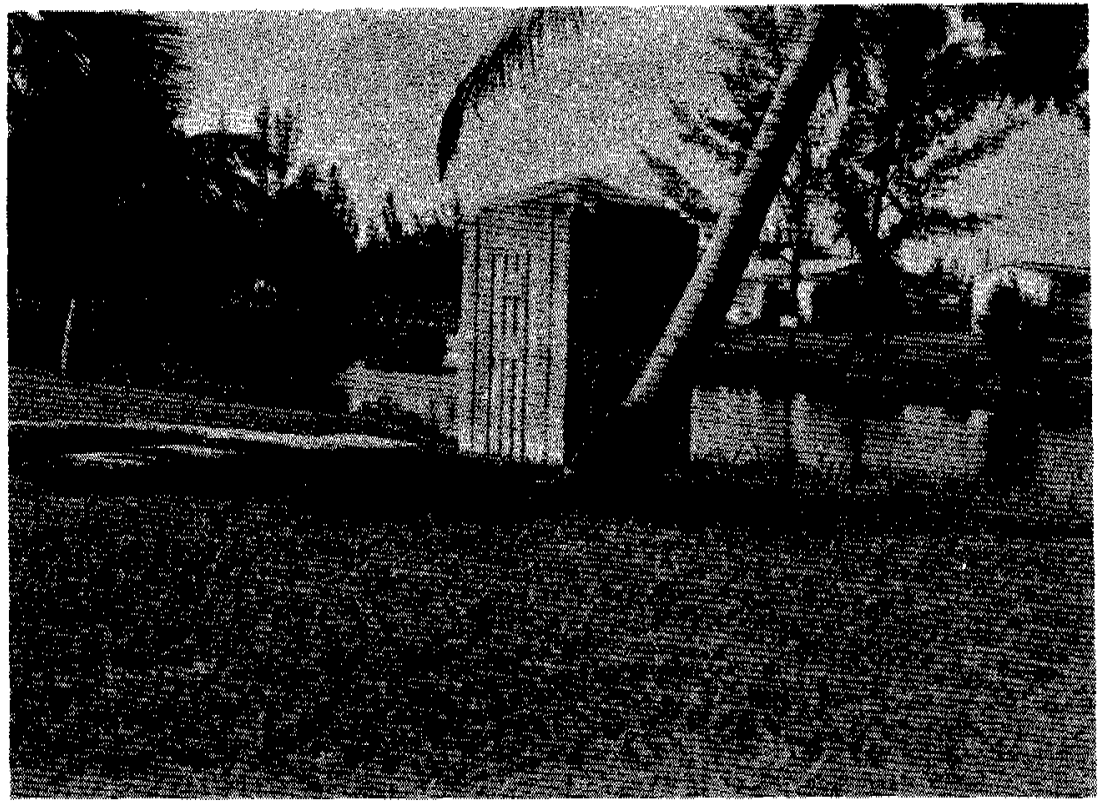

Figure 84-Recording gage at stream-gaging station on Miami Canal at Water Plant, Hialeah. Well is connected to canal by two 2-inch pipes,

accessible to local observers, continuous records of stage were registered mechanically by use of water-stage recorders. Typical gages at a stream-gaging station are shown on figures 84 and 85 .

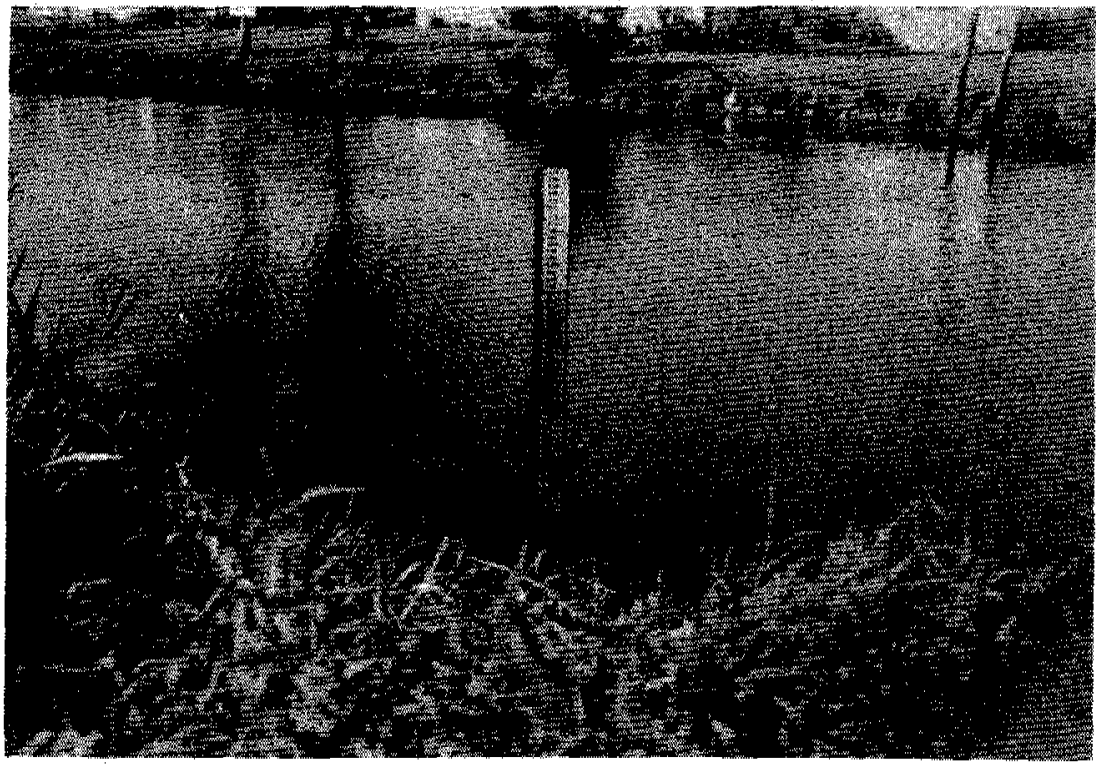

Figure 85. - Staff gage graduated in feet and hundredths of a foot at stream-gaging station on Miami Canal at Water Plant, Hialeah. 
Discharge records were collected by various methods. (See Corbett and others, 1943, for general discussion of this subject.) At gaging stations immediately above control structures in Everglades canals the flow through the spillway openings was measured periodically by use of current meters, and daily discharge was computed from records of stoplog positions and head. (Figure 91 shows a typical control in the Everglades with the recording gage at the left, just above the lock.) The spillway openings, or bays, have vertical slots on each side in which planks, known as stoplogs, may be placed in a horizontal position. Stoplogs are placed or removed (manually), according to the stage that is wanted above the control; the top logs act as the crest of the spillway.. The difference between the upstream stage and the average crest elevation is the head on the spillway, which is used to compute flow over the spillway. The relationship between the head and discharge was determined by making discharge measurements by current meter under a wide range of flow conditions. Allowances were made for obstructions in the spillway openings caused by hyacinth growth and for leakages both under and through the structures. Atcertain locations on the canals, where the control structures could not be used, observations of velocity along measured reaches were made twice daily, or oftener, by local observers by means of floats. The velocity data were used, together with stage records and current-meter measurements, to compute rates of flow. At stations on the few natural streams in the area, it was usually possible to compute flow by means of a continuous record of stage and a relationship between the stage and the discharge developed by means of occasional measurement of discharge. At stations on tidal reaches of canals where single discharge measurements would not represent the flow for other parts of the day, series of discharge measurements were made to define the flow variations during tide cycles (see detailed data for lower Miami Canal).

\section{WNTERPRETATHON OF DATA}

Stages and discharges in streams and canals seldom remain stationary, instead, they fluctuate with rainfall, evaporation, wind, tide, and regulation of control structures. The fluctuations in levels and discharges, when systematically observed at the gaging stations, are most effectively analyzed when plotted in the form of hydrographs having time scales selected to show the fluctuation being studied. Records of stages and discharges on a tidal stream, for example, are presented on hydrographs having an expanded time scale to illustrate fluctuations during a single tidal cycle, but they also are plotted on a greatly contracted time scale to show the seasonal or annual trends. In the first instance, the individual observations are used, but in the second instance, the plotted values are usually daily or monthly averages. Hydrographs containing 
daily or monthly average values do not, of course, indicate instantaneous, extremes in stage or discharge, and this limitation should be recognized in the use of these illustrations.

\section{STAGE RECORDS}

All Geological Survey gages in southeastern Florida were either set, or tied in, to mean sea level, and thus all the water levels in the report are given in feet and hundredths of feet above mean sea level. The use of a common datum permits simple comparisons between water levels at different locations, and slopes or gradients in the water surface are clearly indicated.

Okeechobee datum, occasionally referred to here, was originally established by levels run from Punta Rasa datum, which was obtained from measurements made near the mouth of Caloosahatchee River on the west coast of Florida. The U. S. Coast and Geodetic Survey has corrected and reestablished the elevation of these datum planes; Okeechobee datum (as used for years in the vicinity of Lake Okeechobee) is $1.44 \mathrm{ft}$ below mean sea level. Okeechobee datum was extended by the Corps of Engineers and Everglades Drainage District along all the major Everglades canals, and gages were set to it even in tidal waters along the east coast.

In the Miami area, the matter is further complicated by the use of two other principal datum planes: mean low water, Biscayne Bay datum-used by the Corps of Engineers for tidal waterway projects; and city of Miami precise datum-used by Miami for municipal improvements. Other datum planes are usedlocally, particularly along the coast, but these four are the planes most extensively used in the Everglades area. The use of the several datum planes, and a lack of general knowledge of their interrelationships, often causes confusion in discussion of water problems.

Table 20.-m-Principal datum planes used in the Everglades and in the Miami area

\begin{tabular}{|l|c|}
\hline Datum plane & $\begin{array}{c}\text { Adjustment to be made } \\
\text { to elevations to convert to } \\
\text { mean sea level, U. S. Coast } \\
\text { and Geodetic Survey datum (ft) }\end{array}$ \\
\hline City of Miami & -0.269 \\
Sewall Point & -0.49 \\
Mean low water, Biscayne Bay, & -0.779 \\
U. S. Corps of Engineers & -0.88 \\
Mean low water, Punta Rasa & -1.44 \\
\hline
\end{tabular}

The relationship of the four principal datum planes is shown in table 20. This information can be used toconvert elevations given

\footnotetext{
${ }^{1}$ On July 1, 1947, the Corps of Engineers adopted mean sea level datum for work in the Everglades area and reset all their inland gages to that daturn.
} 
with respect to one of the datums to any of the other three. The Punta Rasa and Sewall's Point datums are used in connection with the navigation canal across Florida from Fort Meyers to Stuart. This canal is the outlet, both to the east and to the west, for water released from Lake Okeechobee.

\section{DEFINITION OF TERMS}

Rate of flow is expressed in this report both in cubic feet per second and in millions of gallons per day. A flow of 1 cubic foot per second (secondfoot) is the rate of discharge equivalent to that of a stream or canal with a channel 1 square foot in cross-sectional area and with an average velocity of 1 foot per second. The unit million gallons per day is equivalent to 1.547 cubic feet per second. These terms are abbreviated "cfs" and "mgd,"

Acre-feet and thousands of acrefeet are commonly used as units of runoff because of convenience in storage and irrigation calculations. An acre-foot is the quantity of water required to cover an acre to the depth of 1 foot and is equal to 43,560 cubic feet. Water flowing at the rate of 1 cubic foot per second for 1 day is equivalent to 1.983 acre-feet, or approximately 2 acre-feet,

In agricultural areas where pumping for drainage and for irrigation is extensively practiced, as in the upper Everglades, rate of flow is also expressed in gallons per minute, abbreviated "gpm." The rate of $1,000 \mathrm{gpm}$ is equivalent to $2.23 \mathrm{cfs}$, and if continued for 1 day, amounts to about 4.4 acre-feet.

Other useful terms for flow are: inflow, outflow, and seepage. In this report, inflow into a canal or an area principally refers to water entering by a connecting channel or by overland movement, but it may also include seepage flow. Outflow, of course, is the same process in the opposite direction. Seepage is the movement of water through soils or rock formations into, or out of, a canal or an area. It is either inseepage or outseepage, depending upon the direction of the movement with respect to the canal or the area. The distinctions involved are useful because of the changing water relationships in the Everglades area.

When discussing the direction of flow in a channel, or the direction of a current, it is customary toidentify the movement with the compass reading of the direction toward which the water is moving; as, a southerlyflow, or a southerly current, is moving toward the south. Familiarity with this definition is important because it is diametrically opposed to usage with respect to the wind.

In most of the United States, the area contributing water to a stream can generally be identified and mapped and is referred to 
as thedrainage basin of that stream. The term is applicable to any point on a stream, but it is usually applied to the whole. In flat terrain like the Everglades, however, and in much of the central part of Florida, drainage basins cannotbe identifiedas such. The drainage divides are too subtle for practical means of delineation and even vary, with different conditions of rainfall. The term contributing area therefore is generally used in this report although besin may occasionally be employed to make easier reading.

\section{INDEX OF GAGING STATONG}

Plate 1 shows the locations of all gaging stations in southern Florida with the type of data collected indicated by symbols. Each station in southeastern Florida is referred by number to a descriptive entry in table 21 , in which all station records in that area are listed (cataloged by basin), beginning on the west shore of Lake Okeechobee and continuing clockwise around the shoreline. Within each basin, the stations are listed in downstream order, with those along the main tributary presented first. The month and year of beginning of records are included, and because many of the early records were not collected by the U. S. Geological Survey, the source of all other data is explained in the footnotes.

Practically all the discharge records collected in southern Florida since 1930 are published in U. S. Geological Survey.Water-Supply Papers. Daily, monthly, and yearly discharges are listed for the regular gaging stations. Stage records are unpublished with the exception of those for Lake Okeechobee.

In addition to records collected at the regular gaging stations, listed in table 21, many observations of stage and measurements of discharge were made at miscellaneous locations. Most of the stage readings are unpublished, but the results of most of the discharge measurements made since 1930 are published in $U$. $S$. Geological Survey. Water-Supply Papers. 
Table 21. - Index of discharge and stage records in Lake Okeechobee and Everglades basins as of Jan, 1, 1947

[D, daily discharge record; $\mathrm{PD}$, periodic discharge measurements; $S$, daily on continuous stage record]

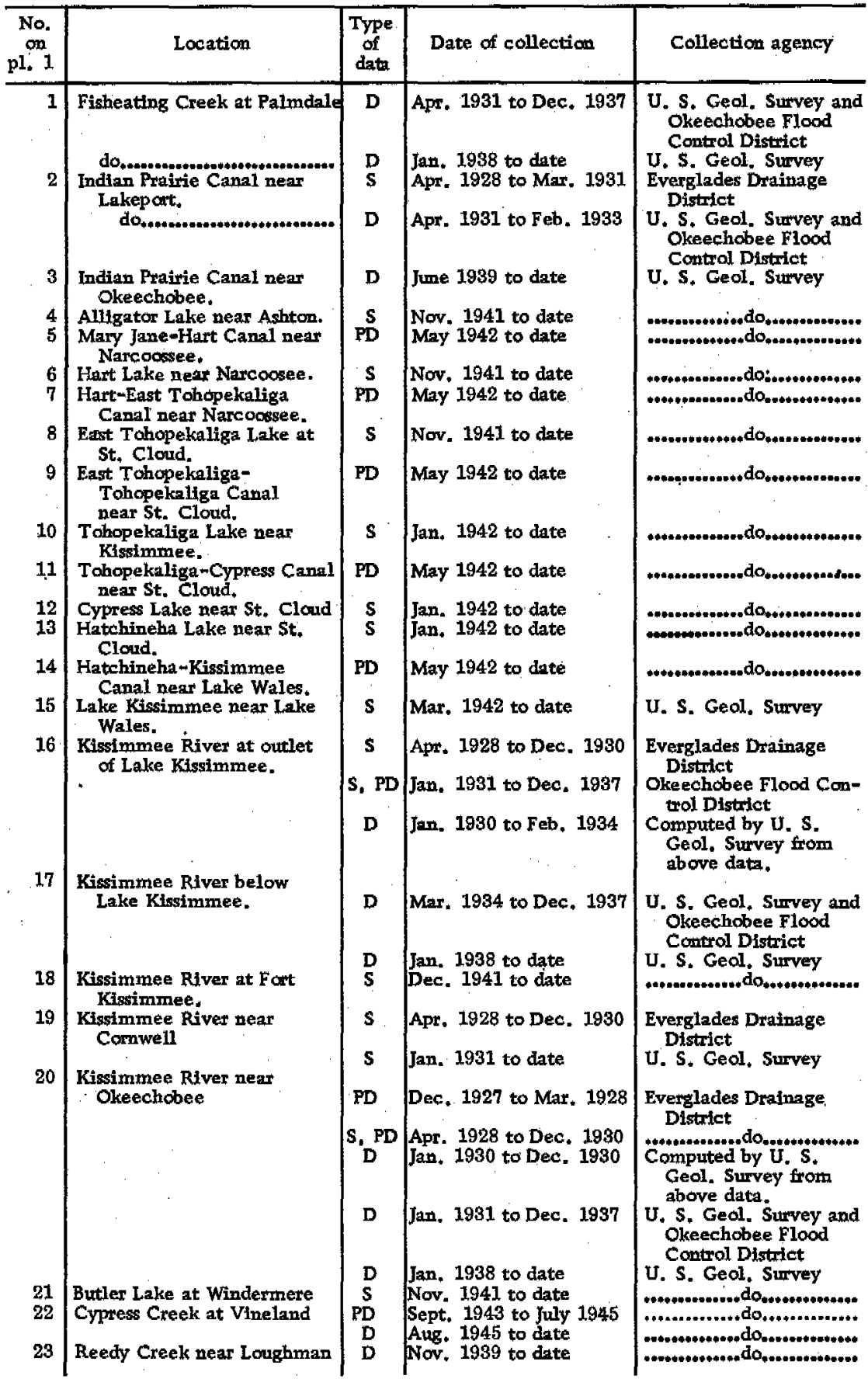


Table 21. - Index of discharge and stage records in $L$ ake Okeechobee and Everglades basins as of Jan. 1,1947 - Continued

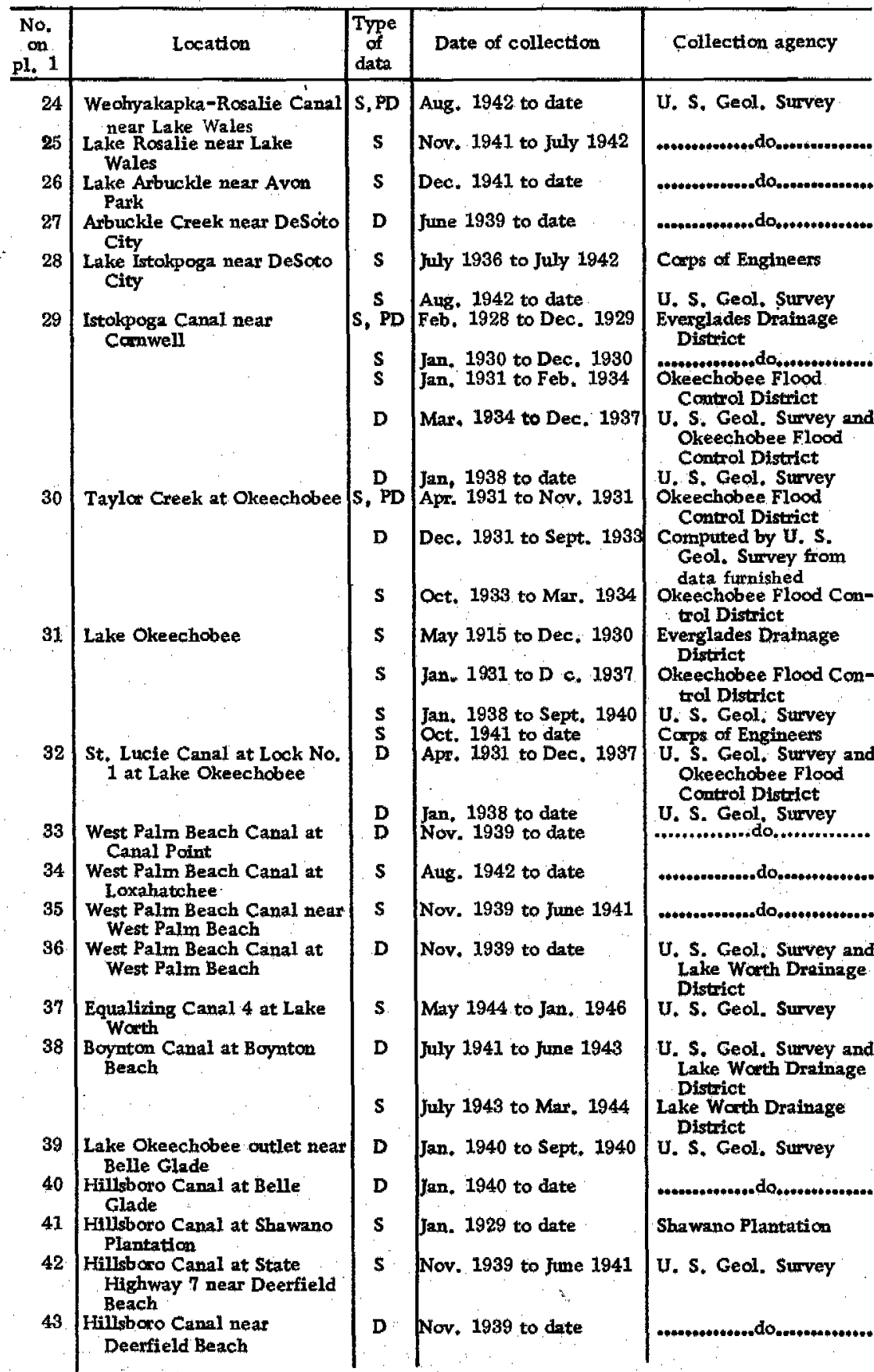


Table 21. - Index of discharge and stage records in Lake Okeechobee and Everglades basins as of Jan. 1, 1947-Continued

\begin{tabular}{|c|c|c|c|c|}
\hline $\begin{array}{l}\text { No, } \\
\text { on } \\
\text { pl. } 1\end{array}$ & Location & $\begin{array}{l}\text { Type } \\
\text { of } \\
\text { data }\end{array}$ & Date of collection & Collection agency \\
\hline 44 & anal at & D & Feb. 1940 to June 1943 & U. \\
\hline 45 & $\begin{array}{l}\text { North New River Canal at } \\
\text { South Bay }\end{array}$ & D & Nov. 1939 to date & ...*n..n........do. \\
\hline 46 & $\begin{array}{l}\text { North New River Canal at } \\
26 \text {-Mile Bend near Fort } \\
\text { Lauderdale }\end{array}$ & $s, \mathrm{PD}$ & June 1942 to date & $\ldots$ \\
\hline 47 & $\begin{array}{l}\text { North New River Canal at } \\
20 \text {-Mile Bend near Fort } \\
\text { Lauderdale }\end{array}$ & s & Sept. 1940 to Jan. 1941 & $\ldots$ \\
\hline 48 & $\begin{array}{l}\text { Nonth New River Canal near } \\
\text { Fort Lauderdale }\end{array}$ & D & Nov. 1939 to date & .......4\% \\
\hline 49 & keelanta & $\mathbf{P D}$ & Jume 1939 to Feb. 1944 & ...............do, \\
\hline 50 & $\begin{array}{l}\text { South New River Canal at } \\
\text { Highway } 25\end{array}$ & s & Mar. 1942 to June 1942 & ...... \\
\hline 51 & River Canal near & $\begin{array}{l}\text { S } \\
\mathrm{D}\end{array}$ & $\begin{array}{l}\text { Apr. } 194 \\
\text { Nov. } 193\end{array}$ & (n)..... \\
\hline 52 & $\begin{array}{l}\text { Snake Creek C } \\
\text { Minmi Beac }\end{array}$ & $\mathbf{s}$ & Mar. 1946 to date & $\cdots \cdots$ \\
\hline 53 & $\begin{array}{l}\text { Biscayne Canal at NW. } \\
\text { 27th Ave., Miami }\end{array}$ & $\mathbf{s}$ & Aug. 1940 to Dec. 1942 & ......... \\
\hline 54 & $\begin{array}{l}\text { Biscayne Canal at North } \\
\text { Miami }\end{array}$ & $\mathbf{s}$ & Nov, & $\omega$ \\
\hline 55 & Canal at Miami & s & $\begin{array}{l}\text { Nov. } 1940 \text { to Sept. } 1941 \\
\text { Sept } 1945 \text { to }\end{array}$ & 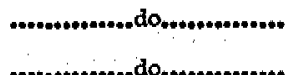 \\
\hline 56 & $\begin{array}{l}\text { Little River Canal at } \\
\text { NW. 27th Ave., Miami }\end{array}$ & $\mathbf{s}$ & $\begin{array}{l}\text { Sept. } 1945 \text { to date } \\
\text { Aug. } 1940 \text { to Dec. } 1942\end{array}$ & 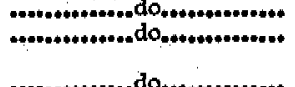 \\
\hline 57 & $\begin{array}{l}\text { Little } \\
\text { NW }\end{array}$ & $\mathbf{s}$ & & $\cdots$ \\
\hline 58 & Little & $\mathrm{s}, \mathrm{PD}$ & $\begin{array}{l}\text { Sept. } 1941 \\
\text { date }\end{array}$ & \\
\hline 59 & anal at Lake & 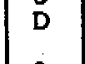 & Nov. 193 & \\
\hline 60 & $\begin{array}{r}\text { Miam } \\
\text { and }\end{array}$ & $\mathbf{S}$ & Apr, 1946 to date & do \\
\hline 61 & $\begin{array}{l}\text { Miami Canal below junction } \\
\text { with South New River } \\
\text { Canal near Miami }\end{array}$ & $|S, P D|$ & Apr. 1941 to May 1943 & ....t...........do, \\
\hline 62 & $\begin{array}{l}\text { Miami Canal a } \\
\text { Line Dam ne }\end{array}$ & $\mathbf{s}$ & Mar. 1942 to Aus. 1943 & \\
\hline 63 & $\begin{array}{l}\text { Miami Canal at broken dam } \\
\text { near Miami }\end{array}$ & PD & $\begin{array}{l}\text { May } 1940 \text { to date } \\
\text { Sept, } 1940 \text { to date }\end{array}$ & ......do \\
\hline 64 & $\begin{array}{l}\text { Miami Canal at } \mathrm{F} \\
\text { near Miami }\end{array}$ & $\mathrm{D}$ & $\begin{array}{l}\text { Nov. } 1939 \text { to July } 1943 \\
\text { July } 1943 \text { to date }\end{array}$ & $\ldots$ \\
\hline 65 & Haleah & $\mathbf{s}$ & & \\
\hline 66 & $\begin{array}{l}\text { Miami Canal at F.E.C. } \\
\text { Canal, Hialeah }\end{array}$ & $\mathbf{s}$ & Aug. 1941 to July 1943 & \\
\hline 67 & $\begin{array}{l}\text { Miami Canal at Water Plant, } \\
\text { Hialeah }\end{array}$ & D & Jan. 1940 & \\
\hline 68 & $\begin{array}{l}\text { Miami Canal at } 36 \text { th Street, } \\
\text { Miami }\end{array}$ & $\mathbf{s}$ & & .... \\
\hline 69 & $\begin{array}{l}\text { Miami Canal } \\
\text { 27th Ave. }\end{array}$ & $\mathbf{s}$ & Oct. 1945 & ...............do \\
\hline 71 & $\begin{array}{l}\text { Miani Canal la teral at } \\
\text { Pennsuco } \\
\text { Tamiami Canal outlets } \\
\text { west of Miami }\end{array}$ & $\begin{array}{r}\mathrm{PD} \\
\mathrm{D}\end{array}$ & $\begin{array}{l}\text { Feb. } 1940 \text { to Aug. } 1943 \\
\text { Nov. } 1939 \text { to date }\end{array}$ & +..............do do \\
\hline
\end{tabular}


Table 21. - Index of disciarge and stage records in Lake Okeechobee and Everglades basins as of Jan. $1,1947-$ Continued

\begin{tabular}{|c|c|c|c|c|}
\hline $\begin{array}{l}\text { No. } \\
\text { on } \\
\text { pl. } 1\end{array}$ & Location & $\begin{array}{l}\text { Type } \\
\text { of } \\
\text { data }\end{array}$ & Date of collection & Collection agency \\
\hline 72 & ni Canal at $40-$ Mile & $\mathbf{S}$ & July 1940 to date & U. S. Geol. Survey \\
\hline 73 & $\begin{array}{l}\text { ni Canal at Krome } \\
\text {, near Miami }\end{array}$ & s & Nov. 1939 to July 1942 & $\ldots \ldots \ldots+\ldots * * *$ do \\
\hline 74 & $\begin{array}{l}\text { Tamtami Canal at Dade- } \\
\text { Broward Levee near } \\
\text { Miami }\end{array}$ & $\mathbf{s}$ & July 1942 to Jan. 1946 & 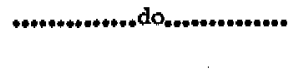 \\
\hline 75 & i Canal near Coral & $\mathbf{D}$ & Jan, 1940 to Jume 1943 & .......do.... \\
\hline 76 & $\begin{array}{l}\text { Tamiami Canal at Red } \\
\text { Road, Miami }\end{array}$ & D & Jan. 1940 to June 1943 & ................do...............* \\
\hline 77 & North Line Canal near Coral & PD & $\begin{array}{l}\text { July } 1943 \text { to date } \\
\text { Jan. } 1940 \text { to May } 1943 .\end{array}$ & \\
\hline 78 & $\underset{\text { Roal }}{\operatorname{Cotap}}$ & $\mathbf{s}$ & Jan. 1946 to date & ............... do \\
\hline 79 & $\begin{array}{l}\text { Snapper Creek Canal at } \\
\text { Coral Gables }\end{array}$ & $\mathbf{s}$ & Nov, 1945 to date & $\ldots$ \\
\hline 80 & $\begin{array}{l}\text { Biscayne Bay at Coconut } \\
\text { Grove }\end{array}$ & $\mathbf{s}$ & Nov. $1940 \mathrm{t}$ & d \\
\hline 81 & $\begin{array}{l}\text { Biscayne Bay near } \\
\text { Homestead }\end{array}$ & $\mathbf{s}$ & & da \\
\hline 82 & $\begin{array}{l}\text { Caloosahatchee Canal at } \\
\text { Mocre Haven }\end{array}$ & D & & H.................................. \\
\hline 83 & $\begin{array}{l}\text { Caloosahatchee River at } \\
\text { Citrus Center }\end{array}$ & D & Apr. 1934 to Sept. 1936 & $\begin{array}{c}\text { Okeechobee } \\
\text { trol Distric } \\
\text { Geol. Sur }\end{array}$ \\
\hline 84 & $\begin{array}{l}\text { Trafford Lake near } \\
\text { Immokalee }\end{array}$ & $s$ & Mar, 194 & rvey \\
\hline
\end{tabular}

Note. - Measurements of discharge made at several points along Hillsboro, North New River, South New River, Miami, and Caloosahatchee Canals during 1913 by Everglades Engineering Commission and published in U, S, Geol. Survey Water-Supply Paper 352.

Additional stage and discharge measurements made by Everglades Drainage District and Corps of Engineers, U. S. Army; some of these measurements are published in reports by these agencies.

Non-continuous observations of stage and measurements of discharge made by $U$. $S$. Geol. Survey at numerous locations not indicated above. A portion of these are included in following sections of this report.

All records collected by $U_{*}, S$, Geol. Survey were in cooperation with one or more of the following: Corps of Engineers, U. S. Army; State Geologist; Trustees of Intemal Improvement Fumd, Everglades Drainage District, Dade County; cities of Miami, Miami Beach, and Coral Gables.

\section{BASINS TRIBUTARY TO LAKE OKEECHOBEE}

\section{GENERAL DRANAGE SYSTEM}

The waters of south-central Florida collect in several basins and drain into Lake Okeechobee, and in their natural regimen they passed through the Everglades and Into the sea. (See p. 138, 145, 149 and $\mathrm{pl}$. 12.) The lake forms a narrow place in a drainage system that is shaped somewhat like an hour-glass. It receives runoff from the north and northwest and distributes the excess water (artificially, since the lake has been controlled) to the east, south, and west. This relationship of river source to ultimate outlet is unique and is in part the cause for the unusual water problems of southeastern Florida. 
Kissimmee River is the largest tributary of Lake Okeechobee, but the lesser tributaries furnish a substantial part of the flow. It is not possible to clearly define the boundaries of the drainage basins because of the nearly level and indeterminate divides; the direction of flow over these divides varies according to the distribution of rainfall. Detailed topographic maps are lacking, therefore the divides and $d$ ainage areas given in this report represent average conditions established from available maps and field observation. (Locations where measurements of flow and stage have been made in the basins tributary to Lake Okeechobee are shown on $\mathrm{pl} .1$ and in table 21.)

The area contributing to Lake Okeechobee is about 4, 200 square miles, of which 80 percent is drained by the Kissimmee River. The remaining areas, considered individually, are small in comparison with Kissimmee River basin; the largest, Fisheating Creek basin, northwest of the lake, is roughly one-eighth the area of Kissimmee River basin. Taylor Creek, which lies immediately east of Kissimmee River, is next largest. Small natural sloughs and drainage canals, mainly along the northeast and northwest shores of the lake, provide courses for runoff from the remainder of the contributing areas. The aggregate runoff from these lesser basins is about 20 percent of the inflow to Lake Okeechobee and must be evaluated in an inventory of the water resources of southeastern Florida.

\section{KISEMMEE RMER}

The uppermost tributary, or source, of the system which drains southeastern Florida is Kissimmee River, with a drainage area of approximately 3, 300 square miles. The basin of Kissimmee River is very similar to those of many other coastal streams, with low undulating hills and flat, wide, swampy valleys. The northern and western parts of this basin, in which there are a myriad of lakes, forin a part of the well-known Lake Region of central Florida and include some of the highest land in Florida. The altitude of the basin ranges from $16 \mathrm{ft}$ at Lake Okeechobee to about $325 \mathrm{ft}$ at Iron Mountain near Lake Wales; most of the basin is below $100 \mathrm{ft}$ in altitude, land slopes are flat, and drainage is imperfect.

Prior to settlement and development of the area the drainage regimen was characterized by the high degree of natural detention of the water in the various lakes, with overflow across wide, shallow marshes into lower lakes during the normally wet summer months and during periods of heavy rainfall. Some water probably flowed north into St. Johns River basin. More recently, construction of canals for reclamation of many of the principal headwater lakes and their connecting channels ha's reduced detention, has increased 
runoff, and has lowered the seasonal high-water levels. The drainage is still characterized, however, by its relatively slow runoff rate and its high proportion of storage.

Kissimmee River basin occupies the part of Polk County that, according to Stringfield (1936), is the recharge area for the Floridan aquifer.

Floods in Kissimmee basin are characterized by slow changes of stage and low velocities of water. They do not resemble the spectacular and destructive floods of hilly regions. The towns and villages in the basin suffer very little from inundation, but homes in outlying districts may be damaged. The principal aspect of the floods is the shallow flooding of large areas of sandy prairie and intermittent marsh. Livestock suffers, but no real danger to humans occurs. In the upper and middle parts of the basin, roads become flooded at low places. Flood conditions may last for several weeks because of the slow rates of runoff. The watersare relatively clear and little silt is left after the floods pass.

In an attempt to simplify description and to conform with significant physical differences, the basin has been divided into two parts of nearly equal size, which are referred to as the upper basin and the lower basin. The upper basin is the part that, in general, drains southward into Lake Kissimmee. The lower basin is the part extending to Lake Okeechobee. Kissimmee River and its principal tributaries are discussed in a north to south order in the following sections. Miscellaneous points of observation in the basin are listed in table 21 and selected discharge and stage data at these locations are listed in table 23.

\section{UPPER KISSIMMEE BASIN}

The distribution of runoff in the upper basin (above the outlet of Lake Kissimmee) is influenced by storage in the chain of large lakes, which, with the interconnecting canals, make up the main headwaters tributary to the Kissimmee River. The area of the lakes in the upper basin total about 200 square miles, or about 10 percent of the basinarea. Plate 1 shows the canals that carry the flow from Alligator Lake north through Lake Hart and then generally south through East Tohopekaliga, Tohopekaliga, Cypress, Hatchineha Lakes, and Lake Kissimmee. In wet periods a large amount of water flows into these lakes through small natural tributaries and secondary drainage canals. A principal tributary, Reedy Creek, discharges runoff from a large area to the northwest into the chain at Hatchineha Lake. Water also crosses the natural divide, shown on plate 1, northward through Lakes Weohyakapka and Rosalie into Lake Kissimmee. From Lake Mary Jane, just upstream from Lake Hart, a canal diverts some water Northeast- 
Table 22.-Runoff of Kissinnie River at outlet of, ard below, Lake Kissimnee

[Drainage area 1,850 square miles]

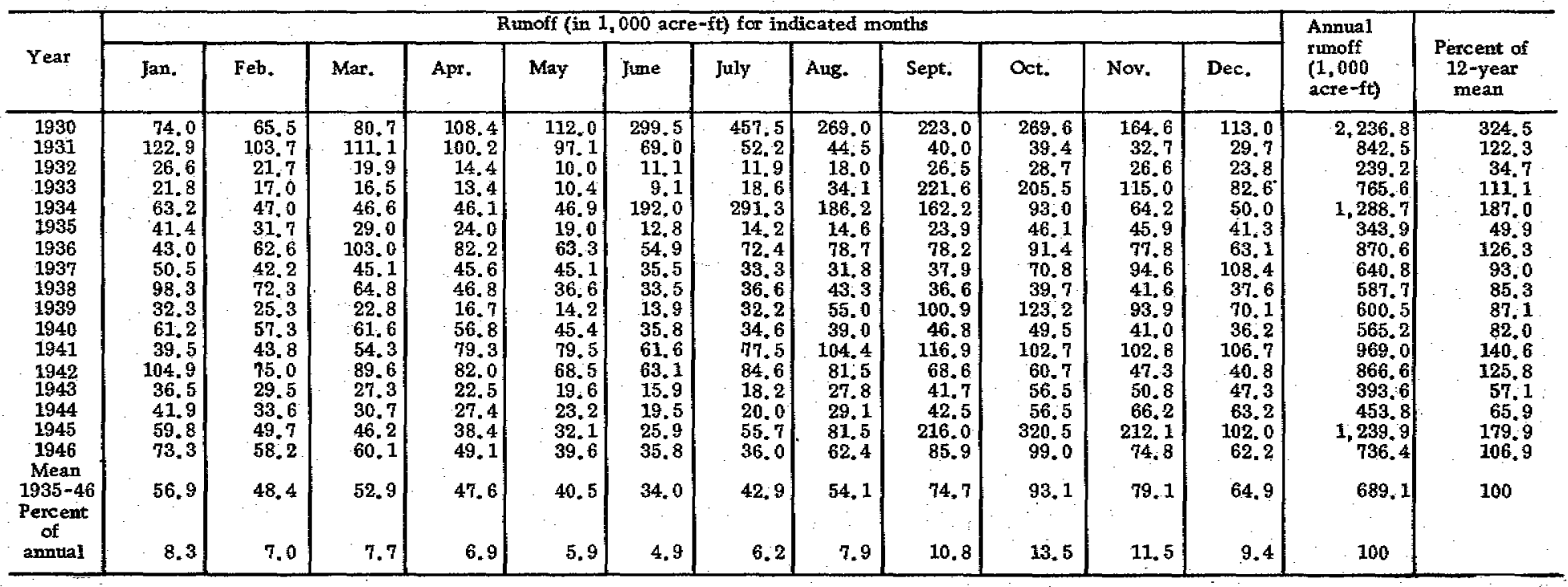

Note. -Daily stage records from January 1930 to December 1930 by Everglades Drainage District, and January 1931 to December 1937 by Okeechobee Flood Control District. Single discharge measurements made during 1931 and 1932, and at semimonthly to monthly intervals from 1933 to 1937 . Unpublished estimates of daily discharge for January 1930 to September 1933 made by the Geological Survey; daily discharge published for October 1933 to December 1937. Records subsequent to January 1938 based on discharge measurements ustally made at bridge and gage-height record 3 miles below bridge. 
Table 23, - Strmury of discharge and water-level date at stations in Kissintmee River basin for selected periods

[Listed in downstream order]

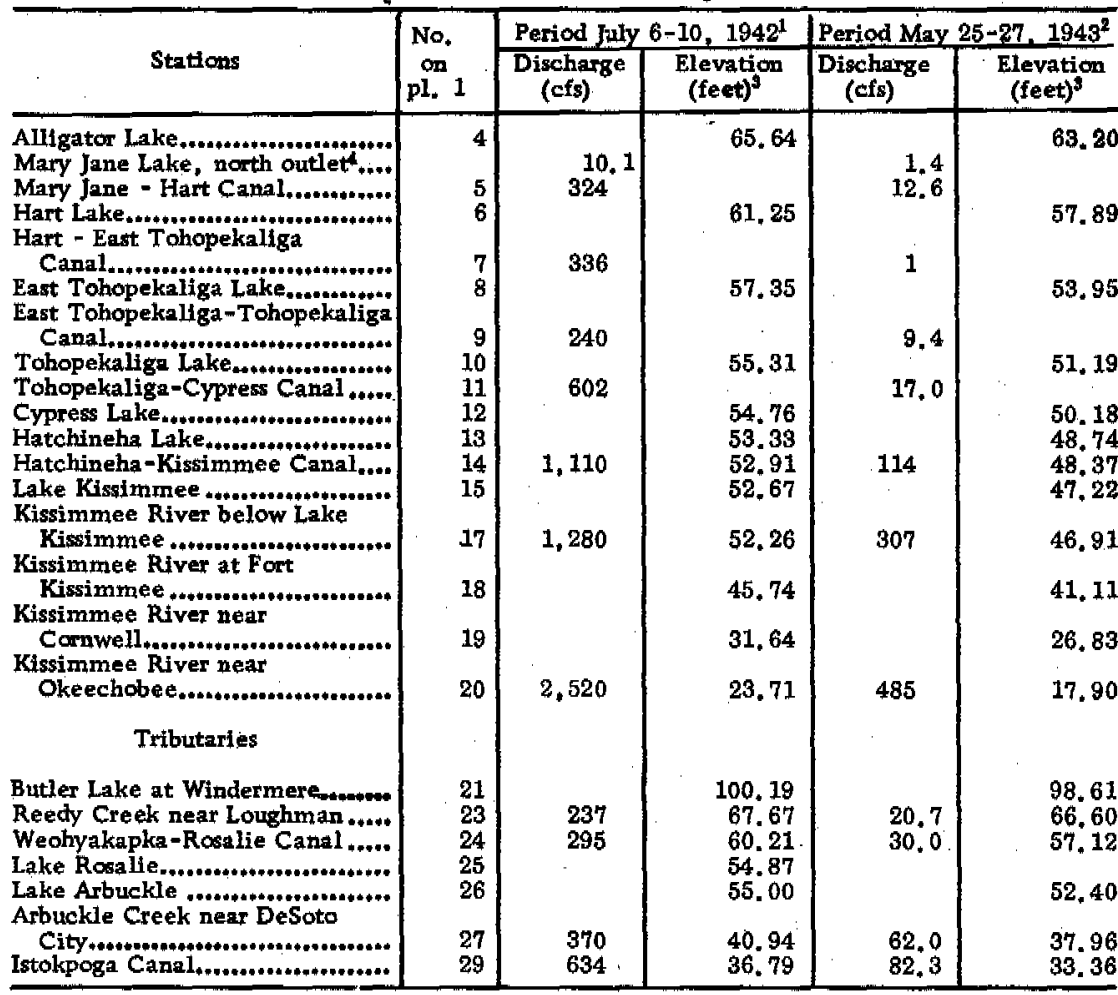

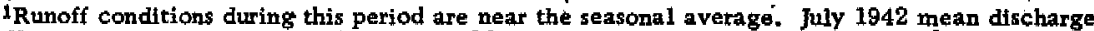
of Kissi mmee River near Okeechobee was 126 percent of the 22-year July mean (1924-45). Single measure ments and observations at various locations were made on different days during the period, but slow rate of change makes all values comparable. For stations at which continuous records are collected, discharge and stage values represent average for period.

2Represents rumoff tuder drought conditions.

3Elevations are for mean sea level daturn. Levels by U. S. Geol. Survey and Corps of Engineers, U. S. Army.

4Flows northeast into Econlockhatchee River (St. Johns River basin).

ward out of Kissimmee basin into Econlockhatchee River headwaters (St. Johns River basin).

The runoff from the upper basin (an area of 1,850 square miles) is measured at a gaging station on Kissimmee River at the outlet of Lake Kissimmee, (no. 17, pl. 1) where records have been collected since 1930. The monthly runoff for this station is listed in table 22. The minimum ordinaryz discharge of $150 \mathrm{cfs}$ occurred in June 1933 during a drought period. The maximum flow of 8,750 cfs occurred on June 24-30, and July 5, 6, 1930 (a rate 58 times as great as the minimum). The fact that both extremes were in June shows the wide range of runoff conditions that are possible in the critical spring and summer months. The mean annual discharge (12-year base period, 1935-46) was $950 \mathrm{cfs}$, equivalent to $6.98 \mathrm{in}$.

2No flow occured September 3-4, 1935, when hurricane winds blew upstream-a special condition. 
of water over the entire tributary area, or about 14 percent of the average annual rainfall. The stage ranged between 44.6 and $55.2 \mathrm{ft}$, a difference of $10.6 \mathrm{ft}$.

Monthly measurements of discharge of canal stations, and daily measurements of stage in 10 lakes along the headwater tributaries, have been collected since January 1942. However, the se limited records can provide only an approximate definition of runoff and stage characteristics. Stage and discharge observations for selected periods are given in table 23.

\section{FLOOD FREQUENCY}

A study of the frequency of flood discharges at the gaging station below Lake Kissimmee was made by the following method: The maximum discharge in each year of record was listed according to size; the greatest discharge was designated as no. 1. The mean recurrence interval in years (interval in which a given discharge will be equaled or exceeded on the average) was computed by the formula $\frac{N+1}{M}$, where $M$ is length of record in years and $M$ is its relative magnitude. A graph was then prepared on probability paper (Gumbel) with discharge as ordinate and its corresponding mean recurrence interval as abscissa. This graph shows the flood discharge that may be expected to be equaled, or exceeded, once in any period of years, on the average. The results are summarized below:

\footnotetext{
Average annual flood.............2, $750 \mathrm{cfs}$. (17 years of record)

5 -year recurrence interval..... 6, $300 \mathrm{cfs}$

10 -year recurrence interval.... 7, $300 \mathrm{cfs}$

15 -year recurrence interval.... 8, $240 \mathrm{cfs}$

Maximum flood observed....... 8, 750 cfs (June 24-30, July 5, 6,

1930); this figure probably was exceeded in August 1928.
}

On a square-mile basis these discharges are less than those observed downstream at the station near Okeechobee, as reported in the section on the lower Kissimmee basin. This relationship is contrary to the typical downstream decrease in flood discharge per square mile of drainage area. The comparatively low unit rate of flood discharge just below Lake Kissimmee is probably due to the attenuation by storage in the many lakes in the upper basin.

\section{REEDY CREEK}

The gaging station on Reedy Creek near Loughman (no, 23, pl. 1), where runoff from an area of 190 square miles is measured, has been in operation since November 1939. Records show a minimum discharge of $2.6 \mathrm{cfs}$ on June $2,3,1945$, and a maximum of $706 \mathrm{cfs}$ 
Table 24. - Runoff of Reedy Creek near Loughman

[Drainage area 190 square miles. Unit 1,000 acre-feet]

\begin{tabular}{|c|c|c|c|c|c|c|c|c|c|c|c|c|c|}
\hline Yeax & Jan. & Feb: & Mar. & Apr. & May & June & July & Aug. & Sept. & oct. & Nov. & Dec. & Annual \\
\hline $\begin{array}{l}1939 \\
1940 \\
1941 \\
1942 \\
1943 \\
1944 \\
1945 \\
1946\end{array}$ & $\begin{array}{l}1.8 \\
6.6 \\
4.7 \\
1.1 \\
2.1 \\
6.1 \\
4.4\end{array}$ & $\begin{array}{r}3.0 \\
4.5 \\
2.9 \\
1.3 \\
.9 \\
2.6 \\
2.5\end{array}$ & $\begin{array}{r}2.0 \\
5.5 \\
9.5 \\
3.3 \\
1.2 \\
1.0 \\
4.2\end{array}$ & $\begin{array}{r}1.8 \\
9.5 \\
5.7 \\
1.3 \\
2.1 \\
.4\end{array}$ & $\begin{array}{r}0.5 \\
2.7 \\
1.5 \\
.7 \\
.7 \\
.2 \\
1.1\end{array}$ & $\begin{array}{r}1.9 \\
1.8 \\
8.5 \\
.6 \\
2.5 \\
4.9 \\
1.6\end{array}$ & $\begin{array}{r}5.9 \\
13.6 \\
9.2 \\
8.3 \\
14.4 \\
16.1 \\
7.9\end{array}$ & $\begin{array}{r}2.5 \\
8.4 \\
2.7 \\
9.6 \\
18.7 \\
11.5 \\
15.4\end{array}$ & $\begin{array}{r}5.8 \\
4.3 \\
7.1 \\
10.2 \\
10.3 \\
16.2 \\
11.5\end{array}$ & $\begin{array}{r}2.7 \\
3.1 \\
2.7 \\
5.8 \\
14.2 \\
8.4 \\
7.0\end{array}$ & $\begin{array}{r}0.8 \\
6.1 \\
.5 \\
1.5 \\
7.3 \\
3.7 \\
3.8\end{array}$ & $\begin{array}{l}1.3 \\
1.8 \\
3.9 \\
1.0 \\
1.5 \\
3.1 \\
2.9 \\
2.1\end{array}$ & $\begin{array}{l}30.5 \\
70.0 \\
56.0 \\
45.2 \\
75.5 \\
74.0 \\
62.4\end{array}$ \\
\hline
\end{tabular}


on October $22,23,1944$. Neither of the se extremes is satisfactorily representative for design purposes because of the short period of record. A tabulation of monthly runoff is given in table 24. The average annual runoff for the 7 complete years of record (to 1946) was 59,100 acre-feet.

\section{LOWER KISSIMMEE BASIN}

The lower basin comprises an area of approximately 1,450 square miles and may logically be considered in two distinet parts. The greater part includes Kissimmee River proper, which begins at the outlet of Lake Kissimmee and flows through a nearly flat valley. During low water stages the river follows a meandering clearly defined channel, but at flood stages it inundates a marshy flood plain several miles wide. The normal fall from Lake Kissimmee to Lake Okeechobee is $30 \mathrm{ft}$ over a $98-$ mile stretch of the river channel. Lakes and well-defined tributary channels are few-lakes cover only 15 to 20 square miles, or about 2 percent of the area.

The lesser part of the basin includes the western half of the lower basin and drains an area of about 700 square miles by means of Arbuckle Creek, Lake Istokpoga, and Is tokpoga Canal (which flows into Kissimmee River at a point 49 miles above Lake Okeechobee). Outflow from Lake Istokpoga to Kissimmee River, most of which originally passed through Istokpoga Creek, was facilitated by the reclamation development that canalized and partially relocated Istokpoga Creek. This part of the lower basin contains about 30 lakes having an aggregate area of about 100 square miles, or about 14 percent of the area.

Runoff from Kissimmee River basin is measured at a gaging station directly west of the town of Okeechobee. The drainage area, 3,260 square miles, comprises over 98 percent of the entire basin. Discharge records collected at this key location since January 1930 are tabulated by months in table 25 and are illustrated graphically in figure 86. Both the minimum and maximum known discharge occurred in 1928; the minimum was $206 \mathrm{cfs}^{3}$ on May 21 and the maximum was $20,000 \mathrm{cfs}$ during August. The mean annual discharge (over a 12-year period) was $1,647 \mathrm{cfs}$, or the equivalent of 6.87 in. of water over the entire tributary area of 3,260 square miles, or about 14 percent of the average annual rainfall. A comparison of this record with that for Kissimmee River below Lake Kissimmee (the upper Kissimmee basin) indicates that the average volume discharged by the upper basin was 58 percent of that for the entire basin. The stage ranged between 16.4 and $29.0 \mathrm{ft}$, a difference of $12.6 \mathrm{ft}$.

\footnotetext{
${ }^{3}$ From discharge measurement made by Everglades Drainage District at point near mouth of, river. Minimum discharge since October 1930 , when daily discharge computations were begun by U, S. Geol. Survey, was 231 efs on May 18, 1932.
} 
Table 25, - Runoff of Kissimmee River near Okeechobee

[Drainage area 3,260 square miles]

\begin{tabular}{|c|c|c|c|c|c|c|c|c|c|c|c|c|c|c|}
\hline \multirow[b]{2}{*}{ Year } & \multicolumn{12}{|c|}{ Runoff (in 1,000 acre $-f$ ) for indicated months } & \multirow{2}{*}{$\begin{array}{l}\text { Annual } \\
\text { runoff, } \\
1,000 \\
\text { acre-ft }\end{array}$} & \multirow[b]{2}{*}{$\begin{array}{c}\text { Percent } \\
\text { of } 12 \text {-year } \\
\text { mean }\end{array}$} \\
\hline & Jan. & Feb. & Mar. & Apr. & May & Jume & Juty & Aug. & Sept. & Oct. & Nor. & Dec. & & \\
\hline
\end{tabular}

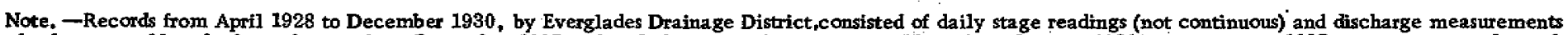

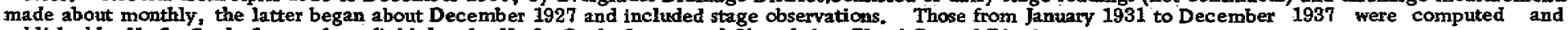
published by U. S. Geol. Survey from field data by U. S. Geol. Survey and Okeechobee Flood Control District. 
Table 26. - Runoff from lower Kissimmee River basin

[Drainage area 1,410 square miles]

\begin{tabular}{|c|c|c|c|c|c|c|c|c|c|c|c|c|c|c|}
\hline \multirow{2}{*}{ Year } & \multicolumn{12}{|c|}{ Run off (in 1,000 acre-ft) for indicated months } & \multirow[b]{2}{*}{$\begin{array}{c}\text { Ammul } \\
\text { runoff, } \\
1,000 \\
\text { acre-ft }\end{array}$} & \multirow[b]{2}{*}{$\begin{array}{c}\text { Percent of } \\
12 \text {-year } \\
\text { mean }\end{array}$} \\
\hline & Jan. & Feb. & Mar. & Apr. & May & Jume & July & Aug. & Sept. & Oct. & Nov. & Dec. & & \\
\hline $\begin{array}{c}1930 \\
1931 \\
1932 \\
1933 \\
1934 \\
1935 \\
1936 \\
1937 \\
1938 \\
1939 \\
1940 \\
1941 \\
1942 \\
1943 \\
1944 \\
1945 \\
1946 \\
\text { Mean } \\
\text { 1935 46 } \\
\text { Percent } \\
\text { of } \\
\text { anmual }\end{array}$ & $\begin{array}{r}52.0 \\
18.7 \\
22.4 \\
38.1 \\
31.5 \\
32.9 \\
39.5 \\
33.8 \\
17.8 \\
37.5 \\
52.5 \\
69.6 \\
18.8 \\
29.5 \\
39.8 \\
80.7 \\
39.6 \\
7.8\end{array}$ & $\begin{array}{r}49.9 \\
12.7 \\
17.0 \\
31.9 \\
29.4 \\
43.6 \\
32.6 \\
23.3 \\
11.8 \\
28.8 \\
52.7 \\
69.0 \\
12.4 \\
20.8 \\
23.6 \\
43.7 \\
31.9 \\
6.3\end{array}$ & $\begin{array}{r}80.1 \\
11.0 \\
17.0 \\
30.8 \\
14.4 \\
77.1 \\
32.6 \\
19.1 \\
7.3 \\
28.7 \\
41.4 \\
144.0 \\
18.7 \\
14.4 \\
20.2 \\
39.7 \\
38.1 \\
7.5\end{array}$ & $\begin{array}{r}68.3 \\
8.3 \\
19.3 \\
31.5 \\
10.2 \\
41.4 \\
37.4 \\
12.7 \\
8.0 \\
32.2 \\
30.6 \\
68.8 \\
11.0 \\
30.7 \\
9.0 \\
20.5 \\
26.0 \\
5.1\end{array}$ & $\begin{array}{r}48.3 \\
10.2 \\
13.2 \\
32.6 \\
7.5 \\
29.9 \\
21.4 \\
4.8 \\
8.9 \\
23.4 \\
37.8 \\
42.3 \\
7.8 \\
16.4 \\
2.1 \\
21.8 \\
18.7 \\
3.7\end{array}$ & $\begin{array}{r}30.4 \\
36.6 \\
11.2 \\
44.0 \\
5.9 \\
56.8 \\
22.8 \\
11.8 \\
5.1 \\
26.2 \\
25.8 \\
92.6 \\
12.8 \\
12.4 \\
2.4 \\
23.9 \\
24.9 \\
4.9\end{array}$ & $\begin{array}{r}26.1 \\
21.9 \\
42.8 \\
151.1 \\
14.2 \\
35.8 \\
28.5 \\
28.5 \\
30.4 \\
51.0 \\
99.5 \\
63.7 \\
44.8 \\
17.7 \\
55.5 \\
22.4 \\
41.0 \\
8.1\end{array}$ & $\begin{array}{r}25.7 \\
34.3 \\
118.9 \\
132.3 \\
17.6 \\
39.1 \\
27.1 \\
51.6 \\
66.5 \\
70.6 \\
104.6 \\
55.5 \\
55.6 \\
29.5 \\
116.4 \\
20.0 \\
54.5 \\
10.8\end{array}$ & $\begin{array}{r}36.5 \\
99.7 \\
238.7 \\
87.2 \\
52.7 \\
48.1 \\
24.3 \\
36.0 \\
109.4 \\
114.3 \\
28.3 \\
58.7 \\
60.6 \\
31.1 \\
150.2 \\
36.6 \\
62.5 \\
12.4\end{array}$ & $\begin{array}{r}7.8 \\
32.6 \\
49.1 \\
102.6 \\
88.3 \\
138.4 \\
49.9 \\
73.0 \\
43.7 \\
70.4 \\
113.7 \\
80.2 \\
48.9 \\
132.0 \\
26.5 \\
56.2 \\
34.4 \\
72.3 \\
14.3\end{array}$ & $\begin{array}{r}35.2 \\
28.5 \\
40.2 \\
66.2 \\
60.6 \\
57.4 \\
49.2 \\
62.8 \\
38.3 \\
48.8 \\
51.3 \\
70.7 \\
31.8 \\
51.7 \\
37.4 \\
48.4 \\
32.0 \\
48.3 \\
9.6\end{array}$ & $\begin{array}{r}49.0 \\
23.9 \\
30.0 \\
51.6 \\
41.9 \\
41.6 \\
44.4 \\
108.2 \\
24.2 \\
41.0 \\
38.7 \\
40.7 \\
26.7 \\
37.7 \\
35.1 \\
101.1 \\
32.6 \\
47.7 \\
9.4\end{array}$ & $\begin{array}{l}502.3 \\
372.7 \\
720.9 \\
770.3 \\
411.8 \\
548.2 \\
510.2 \\
327.8 \\
425.4 \\
616.4 \\
664.8 \\
771.6 \\
463.9 \\
301.5 \\
615.8 \\
408.3 \\
505.5 \\
100\end{array}$ & $\begin{array}{r}99.4 \\
73.7 \\
142.6 \\
152.4 \\
81.5 \\
108.4 \\
100.9 \\
64.8 \\
84.2 \\
121.9 \\
131.5 \\
152.6 \\
91.8 \\
59.6 \\
121.8 \\
80.8 \\
100\end{array}$ \\
\hline
\end{tabular}

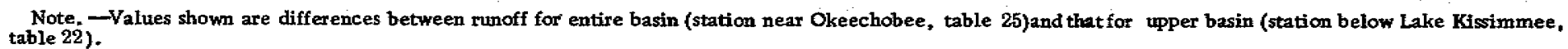




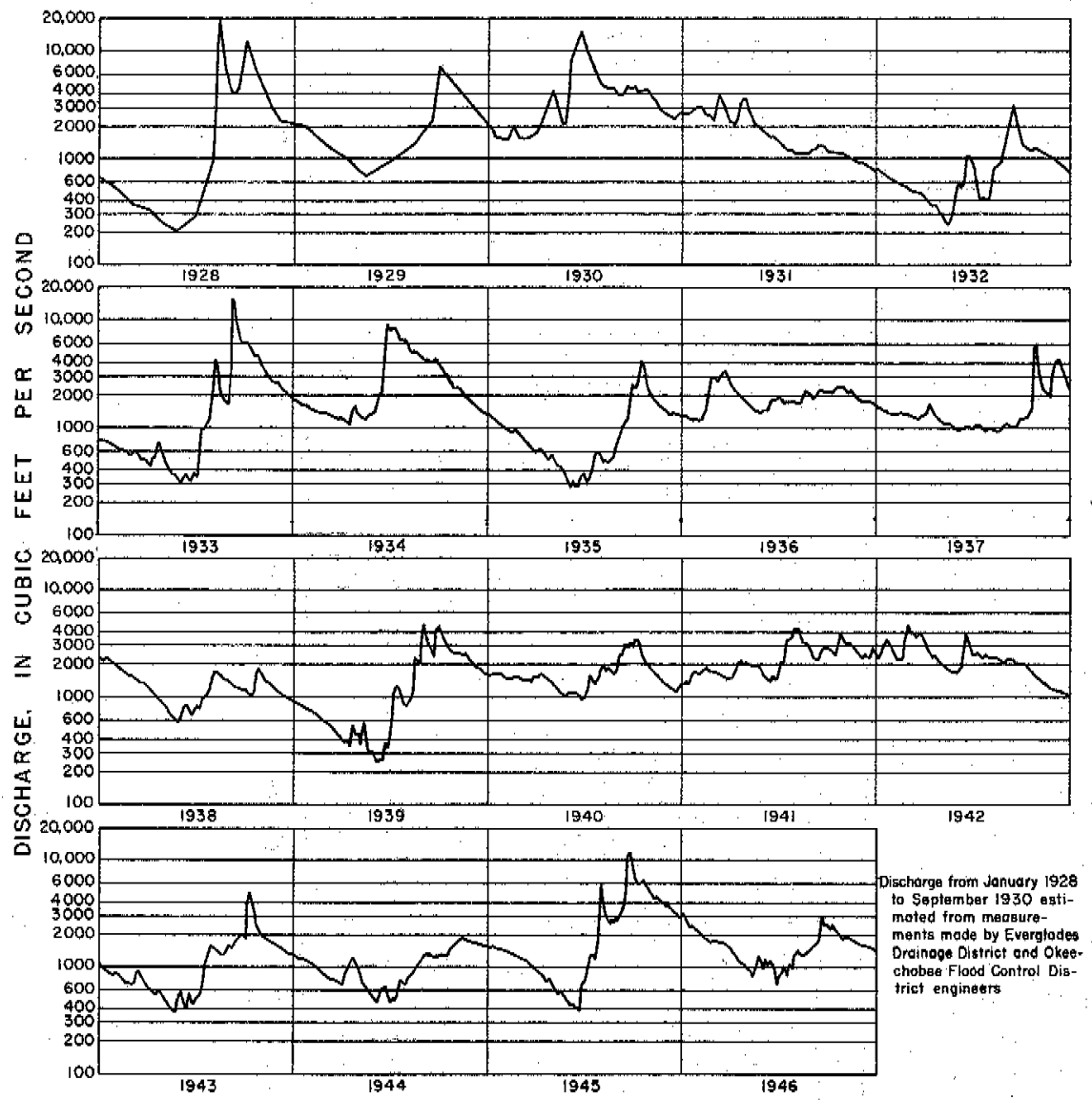

Figure 86. - Graph of discharge of Kissimmee River near Okeechobee, 1928-46.

Runoff from the lower basin, which was taken separately, is listed in table 26, which is a tabulation of the difference between the runoff near Okeechobee and the runoff below Lake Kissimmee (table 25 minus table 22). The mean annual runoff for 12 years of record was $698 \mathrm{cfs}$. This figure shows that the yield of the lower basin was about 74 percent of that from the upper basin, although the lower basin comprises about 78 percent of the entire area.

FLOOD FREQUENCY

A determination of the frequency of flood discharge at the gaging station near Okeechobee was made by the same method used for the station below Lake Kissimmee (see p. 305). The results are summarized below:

Average annual flood............ 5, $380 \mathrm{cfs}$ (16 years of record).

5 -year recurrence interval.... 10,000 cfs 
10-year recurrence interval....13,400 cfs

15 -year recurrence interval.... 15,000 cfs

20-year recurrence interval.... 18, $700 \mathrm{cfs}$

Maximum flood known............20, 000 cfs (August 1928, prior to period of record).

\section{ARBUCELE CREEK}

The discharge of Arbuckle Creek, with a drainage area of 390 square miles, was measured, starting in June 1939, at the highway bridge just upstream from Lake Istokpoga. The monthly runoff is listed in table 27. A minimum discharge of $6.3 \mathrm{cfs}$ occurred on June 21,1945 and a maximum of 3,560 cfs occurred on September 17, 1945. The average annual runoff for the 7 complete years of record ending in 1946 was 202,000 acre- $f$. The stage ranged between 36.4 and $44.0 \mathrm{ft}$, a difference of $7.6 \mathrm{ft}$.

Arbuckle Creek is the principal tributary of Lake Istokpoga. Prior to the canalization of Istokpoga Creek, the lake overflowed along the southeast shore seasonally in much the same manner as Lake Okeechobee overflowed to the south before the drainage pattern was changed by reclamation projects. The overflow from Lake Istokpoga moved overland and by minor waterways to the southeast into the area now known as the Harney Pond and Indian Prairie Canal drainage areas, and it ultimately flowed into Lake Okeechobee. This procedure now occurs only in exceptionally wet years, and drainage is normally by way of Istokpoga Canal. 
[Drainage area 390 square miles. Unit, I, 000 acre-feet]

\begin{tabular}{|c|c|c|c|c|c|c|c|c|c|c|c|c|c|}
\hline Year & Jan, & Feb. & Mar. & Apr. & May & June & July & Aug. & Sept. & Oct. & Nov. & Dec. & Ammual \\
\hline $\begin{array}{l}1939 \\
1940 \\
1941 \\
1942 \\
1943 \\
1944 \\
1945 \\
1946\end{array}$ & $\begin{array}{r}14.5 \\
17.0 \\
18.8 \\
3.8 \\
6.1 \\
7.8 \\
9.9\end{array}$ & $\begin{array}{r}17.0 \\
16.6 \\
16.0 \\
3.6 \\
4.5 \\
5.2 \\
5.9\end{array}$ & $\begin{array}{r}20.9 \\
13.6 \\
27.2 \\
5.0 \\
3.7 \\
3.4 \\
5.2\end{array}$ & $\begin{array}{r}18.4 \\
22.2 \\
14.3 \\
2.9 \\
6.8 \\
1.6 \\
3.4\end{array}$ & $\begin{array}{r}6.4 \\
13.6 \\
8.7 \\
2.6 \\
6.2 \\
.8 \\
2.8\end{array}$ & $\begin{array}{r}11.1 \\
12.4 \\
23.2 \\
3.1 \\
4.2 \\
2.4 \\
4.1\end{array}$ & $\begin{array}{r}18.8 \\
30.7 \\
55.0 \\
23.8 \\
40.1 \\
11.6 \\
59.2 \\
8.9\end{array}$ & $\begin{array}{l}32.8 \\
28.8 \\
27.1 \\
16.3 \\
32.6 \\
34.1 \\
43.8 \\
17.7\end{array}$ & $\begin{array}{l}72.2 \\
53.9 \\
21.0 \\
16.6 \\
35.2 \\
17.6 \\
87.3 \\
26.7\end{array}$ & $\begin{array}{l}43.5 \\
27.8 \\
19.8 \\
14.0 \\
33.5 \\
17.1 \\
44.1 \\
25.1\end{array}$ & $\begin{array}{r}18.4 \\
8.3 \\
17.5 \\
5.1 \\
11.7 \\
11.3 \\
17.6 \\
12.9\end{array}$ & $\begin{array}{r}9.2 \\
7.8 \\
12.2 \\
4.9 \\
7.7 \\
6.9 \\
11.3 \\
8.1\end{array}$ & $\begin{array}{l}245.6 \\
248.0 \\
188.9 \\
186.8 \\
130.1 \\
284.5 \\
130.7\end{array}$ \\
\hline
\end{tabular}


ISTOKPOQA CANAL

The principal outlet of Lake Istokpoga is Istokpoga Canal. Its discharge has been measured starting in March 1934 at the highway bridge 1.5 miles upstream from Kissimmee River. The monthly runoff from the 660-square-mile basin is shown in table 28. A minimum discharge of $4.2 \mathrm{cfs}$ occurred on June 17, 1945, and a maximum of $1,640 \mathrm{cfs}$ occurred on September 20, 1945. The average annual runoff for the 12 complete years of record ending in 1946 was 284,000 acre-ft.

The average annual runoff for the 7 years ending in 1946 was 296,000 acre-ft, which compares with 202,000 acre-ft from Arbuckle Creek for the same period. It is likely that some water overflows the southeastern shore of Lake Istokpoga in periods of high water and thus bypasses Istokpoga Canal. This is shown by the greater runoff from Arbuckle Creek in 1945 than from Istokpoga Canal, 284, 500 and 267,900 acre-ft, respectively. Despite the severe drought ending in the summer of 1945 , the rainy season, marked by the passage of a hurricane, apparently supplied enough rain to cause the runoff of Arbuckle Creek in 1945 to be the greatest of the 7 years of record. 
Table 28. - Runoff of Istokpoga Canal near Comwell

[Drainage area 660 square miles]

\begin{tabular}{|c|c|c|c|c|c|c|c|c|c|c|c|c|c|c|}
\hline \multirow{2}{*}{ Year } & \multicolumn{12}{|c|}{ Runoff (in 1,000 acre $-f t$ ) for indicated months } & \multicolumn{2}{|c|}{ Annual runoff } \\
\hline & Jaen. & Feb. & Mar. & Apr. & May & June & July & Aug. & Sept. & Oct. & Nov. & Dec. & $\begin{array}{l}1,000 \\
\text { acre-ft }\end{array}$ & $\begin{array}{c}\text { Percent of } \\
12 \text {-year } \\
\text { mean }\end{array}$ \\
\hline $\begin{array}{c}1934 \\
1935 \\
1936 \\
1937 \\
1938 \\
1939 \\
1940 \\
1941 \\
1942 \\
1943 \\
1944 \\
1945 \\
1946 \\
\text { Mean, } \\
1935-16 \\
\text { Percent of } \\
\text { annual }\end{array}$ & $\begin{array}{r}15.0 \\
29.2 \\
26.2 \\
26.3 \\
13.0 \\
27.4 \\
31.1 \\
33.1 \\
12.9 \\
24.1 \\
14.2 \\
28.9 \\
23.4 \\
8.2\end{array}$ & $\begin{array}{r}12.0 \\
34.4 \\
21.9 \\
18.7 \\
8.7 \\
23.8 \\
29.0 \\
29.5 \\
10.6 \\
16.6 \\
10.0 \\
21.5 \\
19.7 \\
6.9\end{array}$ & $\begin{array}{r}9.3 \\
49.2 \\
23.5 \\
15.0 \\
6.1 \\
23.5 \\
29.2 \\
42.6 \\
10.8 \\
12.9 \\
6.9 \\
19.4 \\
20.7 \\
7.3\end{array}$ & $\begin{array}{r}16.3 \\
7.3 \\
40.9 \\
24.1 \\
7.4 \\
3.8 \\
24.2 \\
27.8 \\
34.3 \\
7.1 \\
14.2 \\
2.4 \\
11.4 \\
17.1 \\
6.0\end{array}$ & $\begin{array}{r}19.3 \\
4.8 \\
29.4 \\
19.4 \\
3.3 \\
3.5 \\
17.6 \\
26.0 \\
28.2 \\
5.1 \\
9.1 \\
.9 \\
8.0 \\
12.9 \\
4.5\end{array}$ & $\begin{array}{r}36.9 \\
3.0 \\
28.3 \\
17.4 \\
5.0 \\
3.0 \\
16.3 \\
21.6 \\
35.5 \\
7.2 \\
5.7 \\
.9 \\
9.5 \\
12.8 \\
4.5\end{array}$ & $\begin{array}{r}40.4 \\
6.3 \\
36.6 \\
19.0 \\
10.5 \\
10.2 \\
24.2 \\
37.2 \\
39.4 \\
15.2 \\
7.1 \\
14.8 \\
8.6 \\
19.1 \\
6.7\end{array}$ & $\begin{array}{r}36.6 \\
8.9 \\
38.1 \\
18.5 \\
21.9 \\
17.1 \\
38.1 \\
50.7 \\
38.0 \\
28.2 \\
19.0 \\
29.4 \\
15.2 \\
26.9 \\
9.5\end{array}$ & $\begin{array}{l}37.3 \\
23.7 \\
35.4 \\
17.9 \\
17.8 \\
38.8 \\
53.3 \\
40.7 \\
33.7 \\
38.5 \\
23.0 \\
57.8 \\
18.4 \\
33.2 \\
11.7\end{array}$ & $\begin{array}{l}30.2 \\
46.4 \\
49.8 \\
21.0 \\
19.6 \\
48.0 \\
53.5 \\
37.2 \\
32.5 \\
56.0 \\
19.4 \\
56.3 \\
22.5 \\
38.5 \\
13.6\end{array}$ & $\begin{array}{l}22.9 \\
42.0 \\
41.3 \\
25.5 \\
20.4 \\
39.2 \\
37.8 \\
34.6 \\
22.2 \\
40.4 \\
20.6 \\
40.8 \\
21.1 \\
32.2 \\
11.3\end{array}$ & $\begin{array}{l}18.1 \\
31.6 \\
34.2 \\
36.9 \\
16.9 \\
31.0 \\
28.7 \\
31.5 \\
16.3 \\
32.8 \\
17.2 \\
33.5 \\
17.5 \\
27.3 \\
9.6\end{array}$ & $\begin{array}{l}210.3 \\
446.8 \\
271.3 \\
182.8 \\
222.4 \\
368.4 \\
396.6 \\
385.3 \\
264.8 \\
188.9 \\
267.9 \\
202.0 \\
289.8 \\
100\end{array}$ & $\begin{array}{r}74.1 \\
157.4 \\
95.6 \\
64.4 \\
78.4 \\
129.8 \\
139.7 \\
135.8 \\
93.3 \\
66.6 \\
94.4 \\
71.2 \\
100\end{array}$ \\
\hline
\end{tabular}

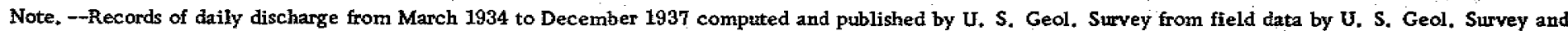
Okeechobee Flood Control District. 


\section{FISH EATING CREDK}

Fisheating Creek drains a basin of about 400 square miles. The headwaters adjoin Peace Creek basin on the west and are separated from Kissimmee River basin by the higher lake region on the north and east. Along its upper course the creek flows from north to south with an average gradient of about $\frac{1}{2} \mathrm{ft}$ per mile, generally through cypress swamp. The low-water channel meanders, and at high stages the water overflows the swamp areas. Runoff is sluggish because of the large amount of natural storage in the basin. During droughts there is little or no flow in the creek; this is probably due to high evapotranspiration rates and lack of sustained ground-water inflow. The only sizable tributary heads in the low plateau southwest of Lake Childs.

In its lower course Fisheating Creek flows in an easterly direction for about 20 miles and enters Lake Oke echobee on the western shore at the settlement of Lakeport. The lower part of the basin slopes generally to the lake, rather than to the creek, thus making drainage boundaries indeterminate. Natural drainage features were changed some what in 1932 by construction.of a levee roughly parallel with, and a few miles south of, the lower reaches of the creek. This levee is a part of the main levee system of the lake.

Runoff from the upper 305 square miles of the drainage area of Fisheating Creek was measured at the gaging station at Palmdale. Records collected since April 1931 show a period of no flow in nearly every year, usually in the spring; this period lasted nearly 5 months in 1935. The maximum discharge observed was 8,980 cfs on September 17, 1945, and the average rate of runoff during the period of record was $227 \mathrm{cfs}$ or about 450 acre- $\mathrm{ft}$ per day. A tabulation of monthly and annual runoff for this station is given in table 29. The average yearly runoff for 12 years of record, 1935-. 46 , was 168,900 acre- $f t$ and the stage ranged between 27.1 and 36.4 $\mathrm{ft}$, a difference of $9.3 \mathrm{ft}$. 
Table 29. - Runoff of Fisheating Creek at Palndale

[Drainage area 305 square miles]

\begin{tabular}{|c|c|c|c|c|c|c|c|c|c|c|c|c|c|c|}
\hline \multirow{2}{*}{ Yeas } & \multicolumn{12}{|c|}{ Rumoff (in 1,000 acre-ft) for indicated months } & \multicolumn{2}{|c|}{ Annual runoff } \\
\hline & Jan. & Feb. & Mar. & Apr. & May & June & July & Aug. & Sept. & Oct. & Nov. & Dec. & $\begin{array}{l}1,000 \\
\text { acre-ft }\end{array}$ & $\begin{array}{c}\text { Percent of } \\
12-\text { year } \\
\text { mean }\end{array}$ \\
\hline 1931 & & & & & 10.8 & 0.8 & & 0.6 & 3.5 & 3.8 & 0.1 & 0 & & \\
\hline 1932 & 0.1 & 0 & 0 & 0 & 0 & 1.4 & 2.7 & 34.9 & 100.6 & 20.4 & 6.9 & 1.8 & 168.8 & 99.9 \\
\hline 1938 & .3 & .1 & .9 & 3.2 & .4 & 0 & 4.9 & 38.3 & 87.4 & 8.4 & 2.6 & .8 & 147.3 & 87.2 \\
\hline 1934 & .3 & $0^{3}$ & .8 & $\therefore 2$ & 1.1 & 4.5 & 4.8 & 21.0 & 14.6 & 7.8 & 1.0 & 1 & & 33.5 \\
\hline 1935 & $0_{4}$ & 00 & $\begin{array}{c}0 \\
22 \\
5\end{array}$ & 90 & & & 0 & .7 & 34.1 & 8.4 & 1.0 & .3 & 44.5 & 26.3 \\
\hline $\begin{array}{l}1936 \\
1937\end{array}$ & $\begin{array}{l}2.4 \\
1.3\end{array}$ & $\begin{array}{r}40.0 \\
2.9\end{array}$ & $\begin{array}{r}2.0 \\
1.0\end{array}$ & .0 & 2.0 & $\begin{array}{r}72.6 \\
1.8\end{array}$ & $\begin{array}{l}24.1 \\
43.3\end{array}$ & 20.3 & $\begin{array}{l}25.8 \\
37.7\end{array}$ & $\begin{array}{l}44.0 \\
398\end{array}$ & $\begin{array}{r}7.8 \\
17.6\end{array}$ & $\begin{array}{r}3.1 \\
23.9\end{array}$ & & $\begin{array}{l}156.8 \\
105\end{array}$ \\
\hline 1938 & 8.2 & 1.8 & .1 & $0^{\circ}$ & 0 & 1.6 & 30.5 & 23.6 & 3.2 & 20.9 & $\begin{array}{r}3.5 \\
3.5\end{array}$ & 1 & 93.5 . & 55.4 \\
\hline 1939 & .1 & 0 & $.0^{\circ}$ & 0 & 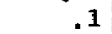 & .2 & 31.2 & 66.2 & 75.4 & 36.7 & 10.7 & 3.4 & 224.0 & 132.6 \\
\hline 1940 & 4.2 & 5.7 & 9.6 & 6.7 & & 0 & 27,0 & 31.7 & 93.8 & $0=$ & 3.9 & 3.9 & 212.4 & 125.8 \\
\hline 1941 & 18.0 & 19.4 & 7.4 & 30.0 & 3,5 & 6.3 & 64.3 & 29.6 & 38.3 & 17.3 & 24.0 & 10.2 & 268.3 & 158.9 \\
\hline 1942 & 24.8 & 23.6 & 33.8 & 7.7 & .9 & 26.4 & 14.2 & 6.9 & 12.1 & 8.5 & 1.1 & 1.4 & 161.4 & 95.6 \\
\hline 1943 & .9 & .3 & 2.4 & .4 & 1.2 & 6.2 & 17.9 & 14.0 & 61.8 & 56.9 & 8.0 & 2.4 & 172.4 & 102.1 \\
\hline 1944 & 9 & .2 & 0 & 0 & 0 & 2.2 & .8 & 14.5 & 29.7 & 4.0 & 1.6 & .2 & 54.1 & 32.0 \\
\hline 1945 & .3 & 0 & 0 & 0 & 0 & .1 & 71.5 & 28.4 & 117.3 & 55,0 & 13.5 & 1.9 & 288.0 & 170.5 \\
\hline $\begin{array}{l}1946 \\
\text { Mean }\end{array}$ & 1.5 & 0 & 1.3 & 0 & a & & 90 & 22.5 & 25.6 & 9.1 & 2.8 & & 66.2 & 39.2 \\
\hline $1935-46$ & 5.1 & 7.9 & 6.5 & 4.0 & .7 & 9.8 & 27.2 & 22.5 & 45.7 & 27.2 & 8.0 & 4.3 & 168.9 & 100 \\
\hline $\begin{array}{l}\text { Percent } \\
\text { of }\end{array}$ & & & & & & & & & & & & & & \\
\hline anmual & 3.0 & 4.7 & 3.8 & 2.4 & .4 & 5.8 & 16.1 & 13.3 & 27.1 & 16.1 & 4.7 & 2.5 & 100 & \\
\hline
\end{tabular}

Note. - Reconds prior to January 1938 computed and published by U. S. Geol. Survey from stage record and a part of the discharge measurements by Okeechobee Flood Control District. 


\section{MINOH THIBUTARIES}

Numerous small streams on the northeast and northwest shores of Lake Okeechobee discharge into the lake mainly through culverts in the hurricane levee. To facilitate drainage of adjacent areas under cultivation many of the streams were deepened (especially along the lower reaches), and some were interconnected by drainage ditches. In areas where no natural channels exist, drainage canals were excavated and passed through the levee by means of culverts. The culverts are equipped with check gates to prevent water from passing out of the lake into the leveed areas during hurricanes and other periods of high stage.

Runoff from each of the basins is relatively small, but the combined total runoff contributes a substantial amount of water to the lake. Estimates based on periodic measurements by the Corps of Engineers show that the runoff from these small basins for the 7year period ending December 31, 1946, was approximately onethird of the amount contributed by Kissimmee River. Estimates of their combined discharge are given for this period by months in table 62 .

Indian Prairie Canal, Harney Pond Canal, and Taylor Creek are sizable secondary tributaries to Lake Okeechobee.

\section{INDIAN PRAIRIE CANAL.}

Indian Praixie Canal enters Lake Okeechobee from the northwest; it is about 20 miles long and drains the gently sloping prairie as far as Lake Istokpoga. The drainage area is indeterminate. In periods of exceptionally high water, overflow from Lake Istokpoga enters the upper part of the basin. The efficiency of the canal has been reduced considerably by the formation of sand bars at the mouths of lateral canals.

Stage and discharge records have been collected at the gaging station at Highway No. 78, close to Lake Okeechobee, since June 1939. A period of no flow was observed nearly every year, and during some years the period lasted as long as 6 months. The maximum discharge during the period of record was $1,540 \mathrm{cfs}$ on September 16,1945 . The monthly and yearly runoffs listed in table 30 show that the average annual runoff for the 7 consecutive years of record, 1940-46, was 74,000 acre-ft. The severity of the 194345 drought is indicated by the runoff of 7,200 acre-ft in 1944 , less than 10 percent of the average annual runoff.

Stage at the gaging station ranged between 12.1 and $18.0 \mathrm{ft}$, a difference of $5.9 \mathrm{ft}$. When runoff is small, or zero, the stage is essentially the same as that of Lake Okeechobee. No levee exists along the northwest shore of the lake, and the canal is subject to varying degrees of backwater, depending upon the amount of runoff, the stage of the lake, and wind effect. 
Table 30. - Runoff of Indian Prairie Canal near Okeechobee

[Drainage area indeterminate. Unit, 1,000 acre-feet]

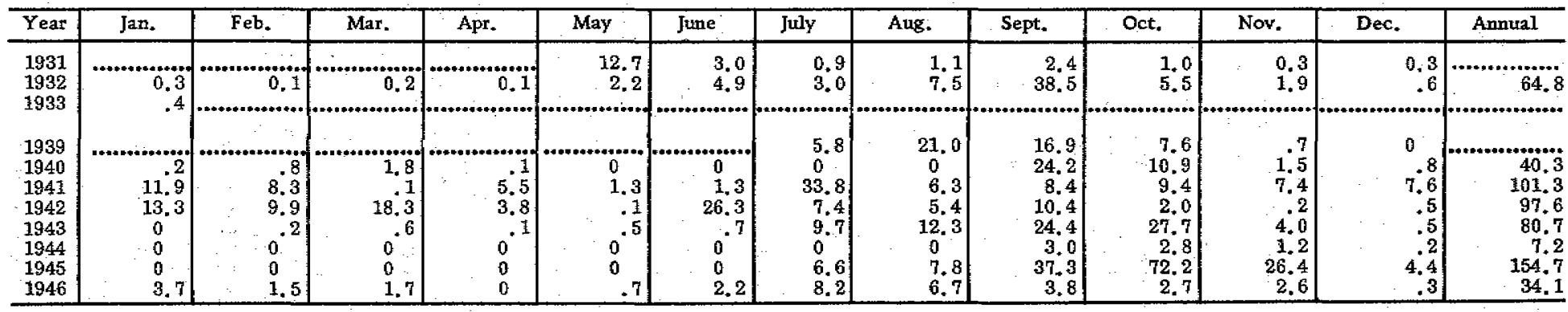

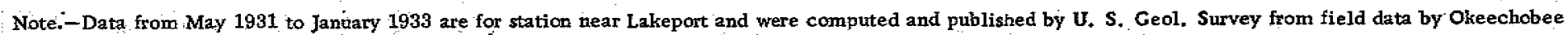
Flood Control District. 


\section{HARNEY POND CANAL}

Harney Pond Canal is located 6 miles southwest of Indian Prairie Canal and roughly parallel to it. This waterway is nearly 20 miles long, and it drains the prairie as far as Lake Istokpoga. A large sand bar at its mouth on the west shore of Lake Okeechobee restricts its flow to a considerable degree. No regular records were kept on Harney Pond Canal andits runoff is included in the "north-shore creeks, etc" in table 62. Although it is smaller in cross section than Indian Prairie Canal (and therefore of smaller capacity) the flow characteristics are probably much the same. The drainage basin merges with adjoining basins and its area is indeterminate.

\section{TAYLOR CREEK}

Taylor Creek flows into Lake Okeechobee at the northern shore at a point about 4 miles south of the town of Okeechobee; it drains a basin having an area of less than 200 square miles. The upper courses of the stream pass through swampland with adjacent areas of sandy pine prairie at elevations of 40 to $50 \mathrm{ft}$ above mean sea level. This basin, like that of Fisheating Creek, has a low gradient and a slow runoff; during dry periods the runoff ceases. The channel was dredged for navigation from the mouth of the stream to the town of Okeechobee. The channel passes through a hurricane gate at the lake (HGS-6), and the gate is kept open at all times, except during open hurricanes and accompanying high lake stages, when it is closed to protect the developed areas in the basin.

Daily runoff from the upper 109 square miles of the basin was measured at a gaging station at the town of Okeechobee during the period December 19.31 to September 1933. This short record does not permit satisfactory evaluation of runoff characteristics, but it does indicate that flow ceases during droughts. The monthly runoff for the period of record is shown in table 31 . 
Table 31.-Rumoff of Taylor Creek at Okeechobee

[Drainage area 109 square miles. Unit, 1,000 acre-feet]

\begin{tabular}{|c|c|c|c|c|c|c|c|c|c|c|c|c|c|}
\hline Year & Jan. & Feb. & Mar. & Apr. & May & June & July & Aug. & Sept. & Oct. & Nov. & Dec. & Annual \\
\hline $\begin{array}{l}1932 \\
1933\end{array}$ & $\begin{array}{l}0.1 \\
0\end{array}$ & 0.1 & $\begin{array}{l}0 \\
0\end{array}$ & $\begin{array}{l}0 \\
1.4\end{array}$ & $\begin{array}{r}0.1 \\
.3\end{array}$ & $\begin{array}{r}19.8 \\
.1\end{array}$ & $\begin{array}{l}1.4 \\
5.2\end{array}$ & $\begin{array}{r}2.2 \\
25.2\end{array}$ & $\begin{array}{r}12.6 \\
30.0\end{array}$ & 2.0 & 2.4 & 0.3 & 41.0 \\
\hline
\end{tabular}

Note, - Records consist of daily discharge computed and published by U. S. Geol. Survey from field data by Okeechobee Flood Control District. 
LAKE OKEECHOBEE AND PRINCIPAL OUTFLOW CANALS

The function of Lake Okeechobee in the drainage system of southeastern Florida is that of a balancing reservoir, which receives the natural runoff from the contributing basins to the north and northwest, and which, within the limits of safe storage capacity, retains a portion of this water. The lake is also used as a disposal reservoir for natural and artificial drainage of excess storm water from the agricultural lands to the south and east. The same canal network and water-control system generally serves for both irrigation and drainage of these lands.

The lake, which is roughly trapezoidal in shape, has an area, depending on the stage, of 650 to '125 square miles. It is the second largest fresh-water lake lying entirely within the United States (Lake Michigan is the largest). At a stage of $13.5 \mathrm{ft}^{4}$ the depth over large areas of the lake is 10 to $14 \mathrm{ft}$, and the deepest part exceeds $15 \mathrm{ft}$. . The bottom of the lake slopes gentiy from shoreline to deep water, especially along the south and west sides, causing great areal variation with change in stage. At low stages, Observation Shoal (an extensive shallow area near Moore Haven) becomes a large grassy island that really is a part of Observation Island. The lands bordering the northern half of the lake rise from the shoreline at a gradient of about 1 to $3 \mathrm{ft}$ per mile. Most of the lower, and more nearly level, lands south of the lake are about 15 $\mathrm{ft}$ above mean sea level and slope gradually to the coast.

Although Lake Okeechobee is comparatively shallow, it stores a considerable quantity of water because of its large surface area. Figure 87 illustrates graphically the relationship of lake area and capacity with stage, plotted from data furnished by the Corps of Engineers. A lake elevation of $8.0 \mathrm{ft}(9.4 \mathrm{ft}$ Okeechobee datum) was chosen as an arbitrary limit for minimum lake depth (the minimum desirable operating stage is $12.6 \mathrm{ft}$ ) and storage below $8.0 \mathrm{ft}$ was not included in the capacity computation. At an ordinary lake stage of $14.0 \mathrm{ft}(15.4 \mathrm{ft}$, Okeechobee datum) the total capacity above the $8.0 \mathrm{ft}$ elevation is about 2.2 million acre- $\mathrm{ft}$.

\section{LAKE-REGULATION PBOGRAM}

Man's development of the Lake Okeechobee region has not greatly affected the characteristics of natural inflow, except for some changes in the regimen of discharge in Kissimmee River caused by canalization of streams connecting lakes in its headwater basins. Levees constructed around the south shore of the lake for flood control and reclamation, however, have interrupted the natural

\footnotetext{
All stages and elevations refer to mean sea level datum unless otherwise stated.
} 
AREA, IN SQUARE MILES

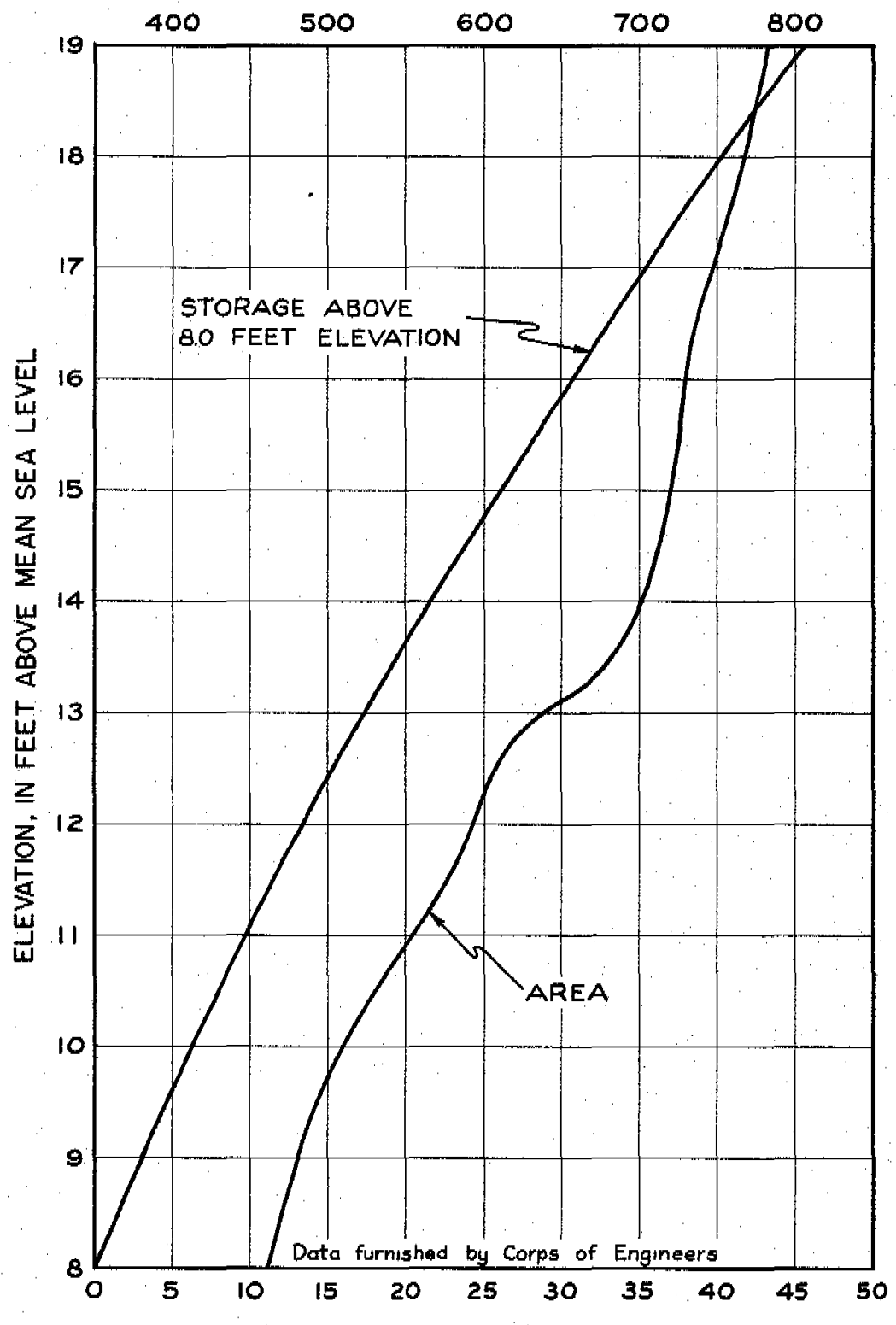

STORAGE, IN HUNDREDS OF THOUSANDS OF ACRE-FEET

Figure 87, - Stage-area and storage-capacity curves for Lake Okeechobee. 
outflow of water over the Everglades to the south and east during high lake stages. The outflow is now controlled and discharged from the lake into the Atlantic Ocean and the Gulf of Mexico by way -of the St. Lucie and the Caloosahatchee Canals, respectively, in the present program of lake regulation by the Corps of Engineers. The stage of the lake is controlled to provide benefits to agricultural activities through water-control operations, to furnish protection to residents and property from hurricane wind tides, and to provide adequate depth for navigation in the channels in the lake and in the St. Lucie and Caloosahatchee Canals.

The objective of the present control program is to maintain lake elevations between the narrow limits of 12.6 and $15.6 \mathrm{ft}(14.0$ and $17.0 \mathrm{ft}$, Okeechobee datum). The difficulties of accurately forecasting the amounts of inflow, as well as to forecast the relatively long period of time required to lower the lake through outflow channels, make the procedure difficult and intricate. An especially critical period exists late each summer, near the end of the rainy season, when the lake must be lowered sufficiently to provide for recharge and for protection during hurricanes, but at the same time, sufficient water must be retained in the lake to provide for all activities through the following normally dry winter and spring months. The magnitude of the problem may be realized by noting that the storage represented by the working range of stage (12.6 to $15.6 \mathrm{ft}$ ) is about 1.25 million acre- $\mathrm{ft}$. . The two outlet canals, disregarding all other factors, would take about 55 days at the maximum observed rates to discharge that volume of water.

Figure 88 shows graphically the variations in the stage of Lake Okeechobee since records were begun in 1915, and it shows the sources of the records from which these stages are plotted. According to Herr (1937) and Schrontz (about 1936) the natural drainage characteristics of the lake were essentially unchanged during the first few years of this record, because the drainage works were incomplete and their influence was small. Above a stage of about $14.6 \mathrm{ft}$ the lake overflowed the low shoreline "between Bacom Point and a point some distance east of Clewiston" (Herr, 1937) into the Everglades to the south; overflow also occurred. along the shoreline near Moore Haven into Lake Hicpochee and the headwaters of Caloosahatchee River.

During 1921 the construction of low muck levees was begun on the south and east sides of the lake to protect agricultural lands developed during the several comparatively dry years prior to 1920, when stages remained relatively low. By 1926 these levees were continuous along the south shores, from a point near Pahokee to about 8 miles north of Moore Haven, with crest elevations varying from about 20 to $24 \mathrm{ft}$. The realization of the need for an outflow capacity greater than that provided by the early Everglades drainage canals and the Caloosahatchee Canal led to the construction of 

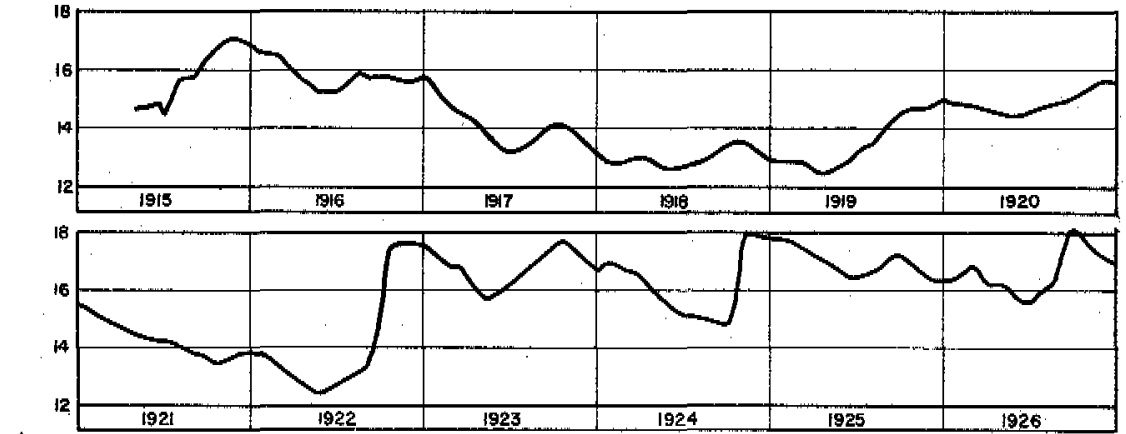

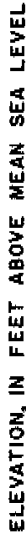
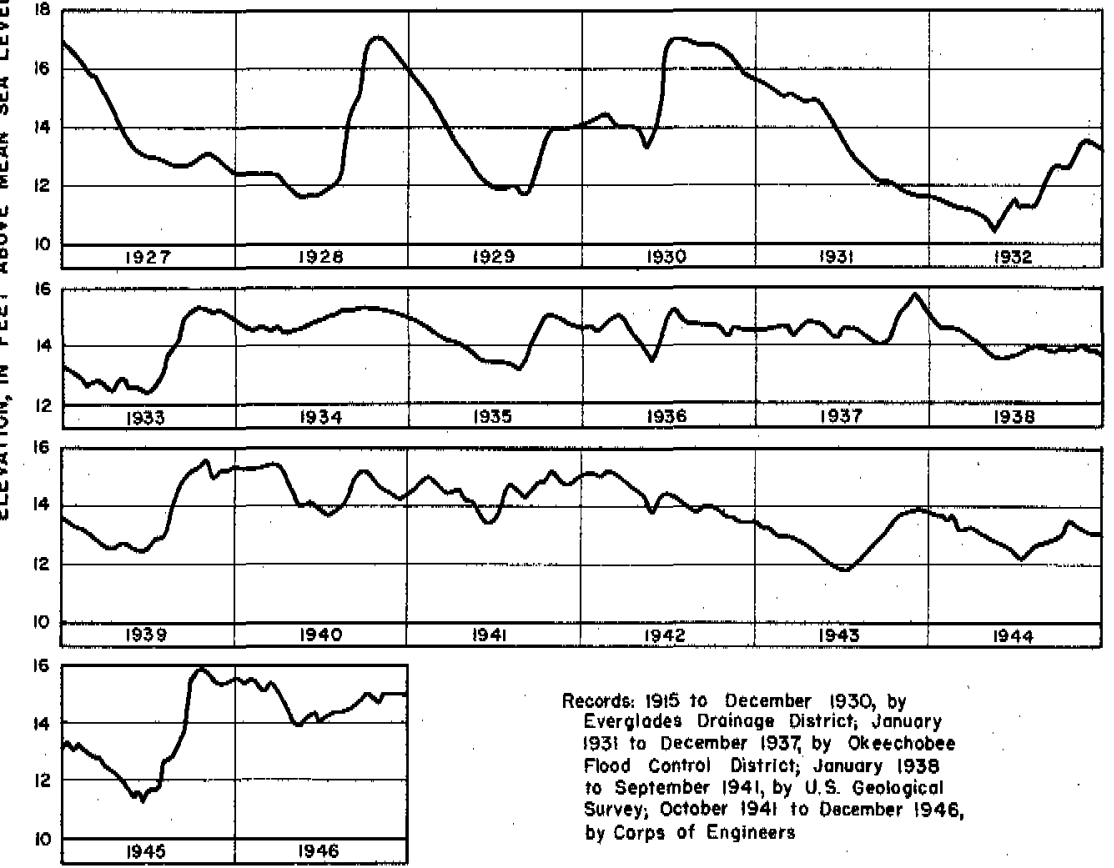

Figure 88, -Graph showing stages of Lake Okeechobee, 1915-46.

the St. Lucie Canal. Although work was begun in 1916, water was not passed through the St. Lucie Canal until 1924. By 1926 the flow reached 70 percent of the planned capacity, and in 1928 full-capacity operation was achieved (Schrontz, about 1936).

Hurricane winds and rains caused the high stages in 1926 and 1928. The great destruction and loss of life accompanying the hur ricanes brought a keen realization of the inadequacy of the existing levee and the catastrophe was largely responsible for the more adequate present levee system, which was constructed by the Corps of Engineers from 1932 to 1938. Herr (1943) describes this levee in detail, stating in part: "The total length of the levee is 85 miles and it forms a high rugged shore on the north, southeast, south, and southwest shores of the lake. The bottom width is from 125 to 150 feet and the top width from 10 to 30 feet. The top elevation 


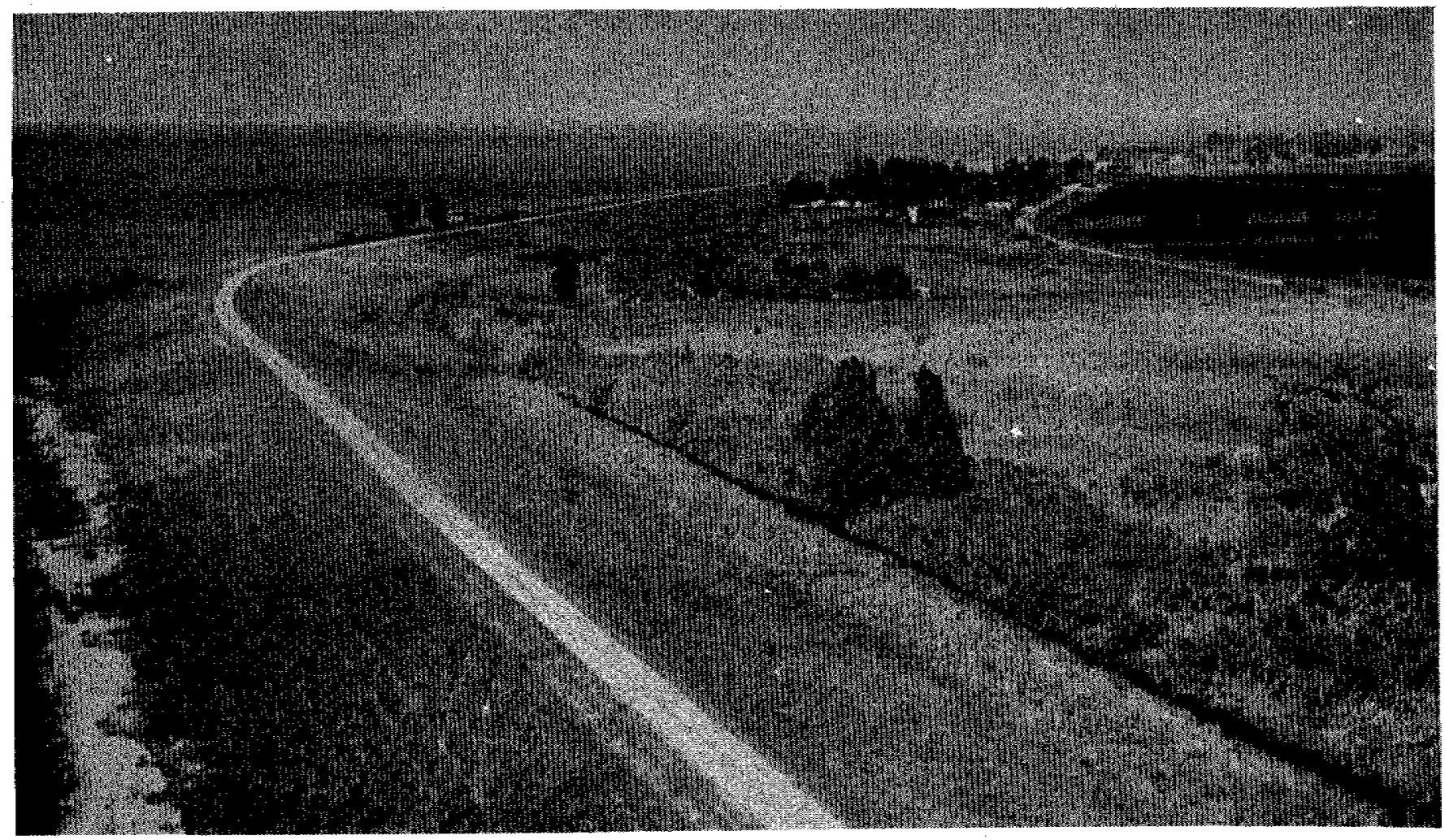

Figure 89. - Protective levee around LakeOkeechobee. Section of hurricane levee near Pahokee. A portion of the lake is in the left background; the far shore is never visible from the top of the levee. Photo by Corps of Engineers. 


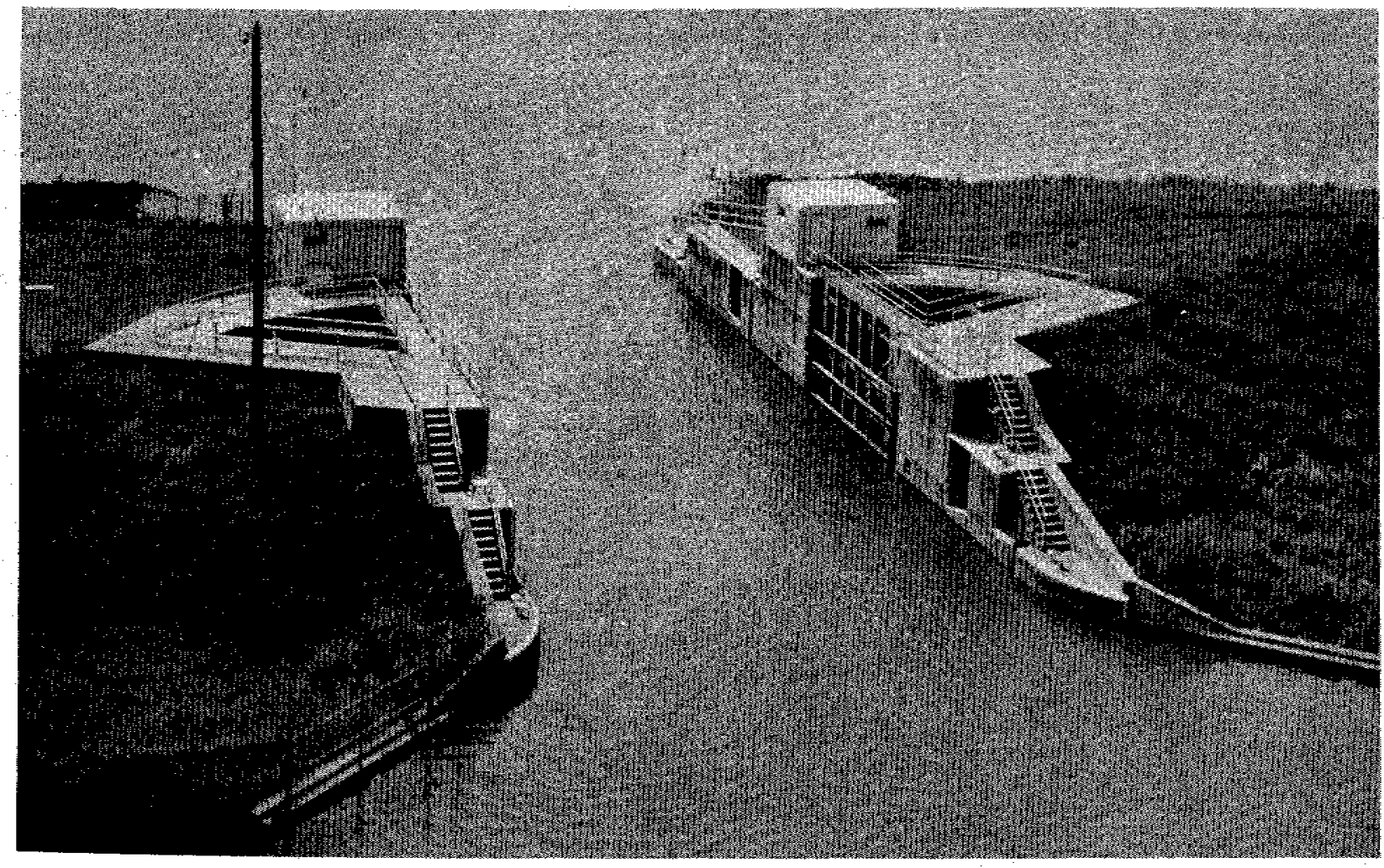

Figure 90. - Hurricane gate no. 6, located at the mouth of Taylor Creek near Okeechobee. The sector gates pivot at the near corners and can be swung together to close the 50-ft opening when a storm tireatens. Operating, weather, and radio equipment are housed in the huricane-proof shelters, Photo by Corps of Engineers. 
varies from 34 to 38 feet above sea level or from 18 to 22 feet above the usual lake level. The levee effectively prevents the overflow of water from the lake along its location under any conceivable conditions, including hur ricane tides." (See fig. 89.)

Six major structures were built in the levee to provide control facilities at the ends of waterways connecting with the lake. At Moore Haven a combined hurricane gate, spillway, and navigation lock was constructed (HGS-1) at the head of Caloosahatchee Canal. Other hurricane gates (occasionally used as controls at times other than during hurricane periods) were built at the following points: HGS-2, Industrial Canal, at Clewiston; HGS-3, Miami Canal, at Lake Harbor; HGS-4, Hillsboro and North New River Canals, at Chosen; HGS-5, West Palm Beach Canal, at Canal Point; and HGS-6, Taylor Creek, at Okeechobee. The gates are manned and closed when a hurricane threatens, and the protective levee stands as a bulwark between the land and the lake. Figure 90 (an aerial view of one of the hurricane gates) gives an indication of the large size of these works.

Figure 88 shows that until 1932 the stage of Lake Okeechobee ranged rather widely. The extreme low, in 1932, was caused by the lake level being purposely brought down to facilitate construction of the protective levee. After 1933, lake levels were controlled for 10 years. The drought, starting in 1943, caused successively lower stages, which culminated in the 11.3-ft stage of June 1945; this drought period was followed by a period of considerable recharge. It was determined that during periods of extended drought or heavy rainfall control of the lake between the desired limits was not entirely possible. However, control of Lake Okeechobee proved to be feasible most of the time, and farming in the muck lands was greatly facilitated.

\section{CaroosaitatcheE Canal}

Caloosahatchee Canal carries controlled amounts of water from Lake Okeechobee to Caloosahatchee River which empties into the Gulf of Mexico. This waterway serves in controlling the stage of Lake Okeechobee, in providing navigation between the gulf and the lake (a portion of the cross-state waterwaybetween Stuart and Fort Myers), and in providing water control to the areas adjacent to the canal and the upper reaches of the river.

The head of the canal is at Moore Haven, on the southwest shore of Lake Okeechobee, where lake water is released through acombined hurricane gate and navigation lock (HGS-1). The canal follows a southwesterly course for about 5 miles through a nearly level 
overflow basin into Lake Hicpochee, which is a shallow natural body of water about 4 miles long (east-west direction) and $2 \frac{1}{2}$.miles wide. Caloosahatchee Canal passes through Lake Hicpochee and then continues in a westerly direction through a gently sloping natural basin to connect with Caloosahatchee River, which is canalized in its upper reaches. At Ortona, 15 miles by canal from Moore Haven, a second navigation lock aids in controlling water levels on adjacent lands upstream. The remaining 55 miles of waterway is canalized in the upper reaches, and channels are dredged in the comparatively wide lower reaches. The mean range of tide is $0.7 \mathrm{ft}$ (U. S. Coast and Geodetic Survey, 1947, P. 304) at Fort Myers, about 15 miles above the mouth, and tidal fluctu+ ations extend as far upstream as the Ortona Lock during periods of low water. Below Ortona, several canals and natural tributaries drain the lands to the north and south.

Prior to development, some of the natural overflow from Lake Okeechobee probably passed slowly overland along the approximate route of the canal into Caloosahatchee River. Improvement of this natural flood channel to facilitate navigation began at a comparatively early date, as Dovell (1942, p. 139) states:

"In late 1881 the Disston Company began operations with the employment of several engineers, J. M. Kreamer, R. E. Rose, and others, who set about constructing dredges to be used in draining lands in south Florida. Rose, later.state chemist for many years, built the first dredge at Cedar Keys and assembled it at Fort Myers. The dredge required three months to reach old Ft. Thompson on the Caloosahatchee, due to trees in the river. The dredge worked from July 1882 until January 1883 cutting a canal to Lake Okeechobee. Disston and a party of his associates made the first steamboat trip from Fort Myers to Kissimmee City in February 1883."

It is apparent, however, that Caloosahatchee Canal had little effect upon the control of Lake Okeechobee until around 1936, after a period of gradual improvement be ginning about 1909. The primary importance of Caloosahatchee Canal to the water resources of southeastern Florida arises from its relationship to the stage and control of Lake Okeechobee. Records of discharge of the canal were collected at a gaging station at Citrus Center during 1934-36 and at Moore Haven since 1938 and are summarized in table 32 . The maximum daily mean discharge recorded was $5,390 \mathrm{cfs}$ on July 8, 1942. Periods of several months of no flow, except for the negligible amount of water released to pass boats through the locks, are common during the normally dry winter and spring months.

The runoff in 1941 was 130 times as great as that in 1944-this is an unusual range for annual runoff, and it illustrates how flow in Caloosahatchee Canal is directly associated with control of Lake Okeechobee. The average annual runoff for the period 1939-46 was 
Table 32. - Runoff of Caloosaliatchee Canal

[Unit, 1,00u acre-féet]

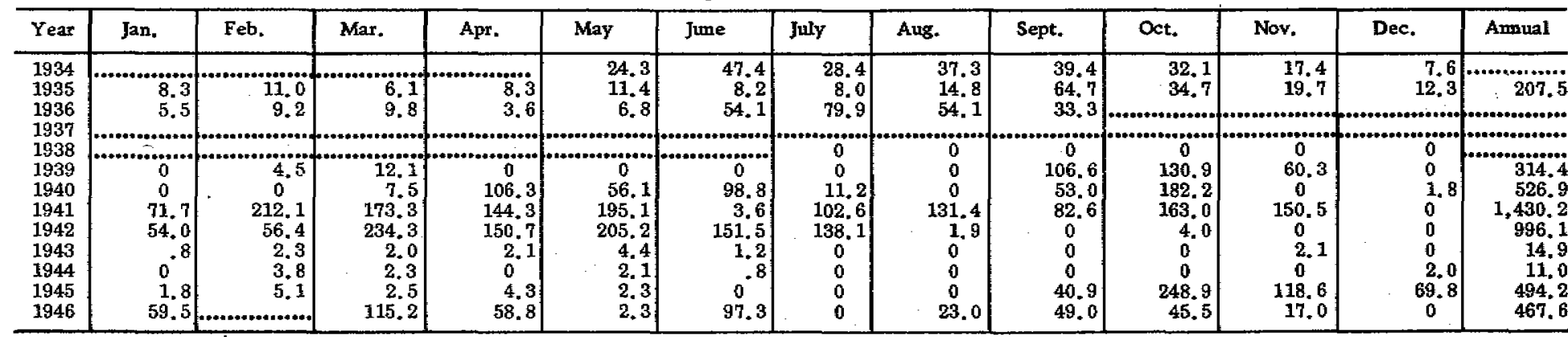

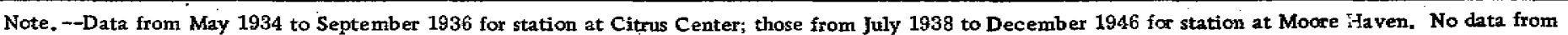
October 1936 to June 1938. Program of improvement beginning October 1936 increased capacity of channel. 
532,000 acre- $\mathrm{ft}$, which is equivalent to $1.2 \mathrm{ft}$ of lake storage at a stage of about $15 \mathrm{ft}$.

When no water is released from the lake, conditions in the reach between Moore Haven and Ortona become almost pool-like, but in periods of large lake discharge, the difference in water elevations in that reach may be as much as $6 \mathrm{ft}$. At Moore Haven, where the elevation of the ground is 14 to $15 \mathrm{ft}$, the lowest stage in the canal in the period 1939-46 was about $5.8 \mathrm{ft}$, and the highest stage was $14.8 \mathrm{ft}$.

\section{ST. LUCIE CANAL}

St. Lucie Canal, an important waterway in the drainage system of southern Florida, is the major channel used for control of water levels in Lake Okeechobee. The canal heads on the east shore of the lake and flows generally northeastward for about 40 miles to the Atlantic Ocean. The upper reaches constitute a true canal but the lower channel follows the canalized courses of South Fork St. Lucie River, which flows in a northerly direction for several miles to its confluence with St. Lucie River at Stuart, then it flows southeastward to St. Lucie Inlet and the Atlantic Ocean. This canal serves also as the eastern link in the cross-state navigation canal between Fort Meyers and Stuart.

The canal proper was dug across a relatively high (maximum altitude about $30 \mathrm{ft}$ ) sandy ridge. The banks are high and are not subject to overflow. The lands along the eastern, natural reaches are lower and are marshy in some areas, notably where Loxahatchee Marsh connects from the south. Some water is pumped from the channel in the upper reaches to.irrigate farms and groves, but the amounts so diverted are small in comparison with the total flow and quantities available as channel storage (in 1949). The lands adjacent to the canal also contribute large quantities of runoff through numerous channels during, and after, rainy periods.

The discharge from Lake Okeechobee through St. Lucie Canal is completely controlled at the lock and dam about 25 miles downstream from the lake. The lock and dam, which was opened to traffic in March 1941, replaces two similar, older structures, one at the same site and one close to the lake. During periods of little or no flow, stages above the lock are essentially the same as those in the lake, but during periods of heavy flow, slopes of as much as $0.3 \mathrm{ft}$ per mile occur. Water levels downstream from the lock are scarcely above mean sea level, and tidal fluctuations are normally present over the entire lower reach. St. Lucie Canal began to contribute effectively to lake-level control in October 1926 (Elliott, 1927), although construction began early in 1916. 
Table 33. - Runoff of St. Lucie Canal at Lake Okeechobee

\begin{tabular}{|c|c|c|c|c|c|c|c|c|c|c|c|c|c|c|}
\hline \multirow{2}{*}{ Year } & \multicolumn{12}{|c|}{ Runoff (in 1,000 acre-ft) for indicated months } & \multicolumn{2}{|c|}{ Anmual rumoff } \\
\hline & Jan. & Feb. & Mar. & Apt: & May & June & faly & Aug. & Sept. & Oct. & Now. & Dec. & $\begin{array}{c}1,000 \\
\text { acre-t }\end{array}$ & $\begin{array}{c}\text { Percent of } \\
12-\mathrm{mear} \\
\text { me }\end{array}$ \\
\hline $\begin{array}{c}1931 \\
1932 \\
1933 \\
1934 \\
1935 \\
1936 \\
1937 \\
1938 \\
1939 \\
1940 \\
1941 \\
1942 \\
1943 \\
1944 \\
1945 \\
1946 \\
\text { Mean } \\
1935-46 \\
\text { Percent } \\
\text { of } \\
\text { anmual }\end{array}$ & $\begin{array}{r}64.0 \\
31.3 \\
7.5 \\
9.9 \\
14.6 \\
158.9 \\
19.2 \\
22.6 \\
52.3 \\
25.8 \\
22.8 \\
15.6 \\
13.0 \\
31.4 \\
32.8 \\
\\
3.9\end{array}$ & $\begin{array}{r}33.8 \\
23.4 \\
23.6 \\
134.3 \\
30.0 \\
18.8 \\
18.1 \\
35.1 \\
160.9 \\
59.7 \\
9.7 \\
17.4 \\
9.6 \\
15.1 \\
44.4 \\
44 \\
\\
5.3\end{array}$ & $\begin{array}{r}21.5 \\
18.5 \\
8.8 \\
276.3 \\
28.1 \\
15.7 \\
19.5 \\
55.5 \\
115.6 \\
227.7 \\
13.5 \\
17.3 \\
16.5 \\
129.4 \\
77.0 \\
\end{array}$ & $\begin{array}{r}268.7 \\
25.8 \\
21.2 \\
5.7 \\
255.1 \\
32.5 \\
21.0 \\
17.6 \\
221.7 \\
146.1 \\
202.2 \\
14.8 \\
14.8 \\
16.8 \\
86.9 \\
86.3 \\
\\
10.4\end{array}$ & $\begin{array}{r}275.1 \\
10.8 \\
31.2 \\
25.3 \\
14.2 \\
211.3 \\
21.7 \\
18.8 \\
6.5 \\
77.9 \\
200.6 \\
153.1 \\
11.6 \\
20.9 \\
18.0 \\
10.6 \\
63.8 \\
\\
7.7\end{array}$ & $\begin{array}{r}235.0 \\
31.6 \\
34.0 \\
231.9 \\
7.0 \\
166.0 \\
15.8 \\
16.1 \\
6.6 \\
102.4 \\
5.9 \\
179.1 \\
15.9 \\
14.5 \\
24.2 \\
17.6 \\
47.6 \\
\\
5.7\end{array}$ & $\begin{array}{r}213.5 \\
69.8 \\
52.0 \\
243.1 \\
9.4 \\
284.6 \\
59.0 \\
24.7 \\
10.6 \\
37.0 \\
108.8 \\
227.8 \\
10.7 \\
17.4 \\
14.5 \\
7.9 \\
67.7 \\
8.1\end{array}$ & $\begin{array}{r}191.6 \\
73.4 \\
147.0 \\
257.0 \\
10.9 \\
285.3 \\
130.7 \\
11.1 \\
15.9 \\
17.8 \\
219.6 \\
168.8 \\
10.4 \\
14.1 \\
16.1 \\
7.8 \\
75.7 \\
9.1\end{array}$ & $\begin{array}{r}168.9 \\
12.4 \\
234.5 \\
251.3 \\
49.4 \\
251.1 \\
155.2 \\
25.0 \\
42.8 \\
167.9 \\
164.6 \\
65.6 \\
12.7 \\
17.4 \\
90.2 \\
9.8 \\
87.6 \\
10.5\end{array}$ & $\begin{array}{r}164.5 \\
55.7 \\
276.8 \\
228.5 \\
212.6 \\
279.6 \\
67.9 \\
8.0 \\
160.6 \\
191.2 \\
156.0 \\
34.0 \\
14.0 \\
11.6 \\
340.6 \\
124.2 \\
133.4 \\
16.0\end{array}$ & $\begin{array}{r}23.6 \\
72.9 \\
216.5 \\
11.9 \\
154.2 \\
83.6 \\
53.5 \\
12.2 \\
87.7 \\
40.3 \\
154.8 \\
15.4 \\
22.4 \\
11.5 \\
255.6 \\
10.4 \\
75.1 \\
\\
9.0\end{array}$ & $\begin{array}{r}88.0 \\
89.9 \\
17.9 \\
16.6 \\
15.5 \\
278.9 \\
9.5 \\
13.7 \\
35.1 \\
41.5 \\
24.1 \\
16.3 \\
14.1 \\
15.4 \\
15.2 \\
41.3\end{array}$ & $\begin{array}{r}1,227.0 \\
1,361.3 \\
519.9 \\
2,252.6 \\
897.9 \\
339.8 \\
418.8 \\
1,004.5 \\
1.526 .7 \\
1,384.2 \\
174.8 \\
186.6 \\
830.5 \\
466.3 \\
832.7\end{array}$ & $\begin{array}{r}147.4 \\
163.5 \\
62.4 \\
270.5 \\
106.6 \\
40.8 \\
50.3 \\
120.6 \\
183.3 \\
166.2 \\
21.0 \\
22.4 \\
99.7 \\
56.0 \\
100\end{array}$ \\
\hline
\end{tabular}

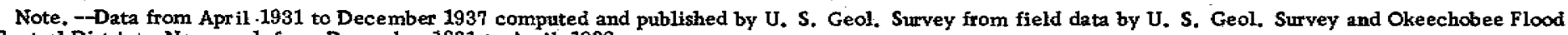
Control District. No records from December 1931 to April 1932. 
Records of the discharge of St. Lucie Canal near its head at Lake Okeechobee have been collected since 1931 and are summarized in table 33. During the period 1931-46, the flow ranged between a maximum daily mean rate of $6,120 \mathrm{cfs}$ on October $25,26,1945$, to periods of no flow for several weeks, except for the negligible amount of water required for passing boats through the locks. These periods of slack flow occurred usually during winter and spring, when water was being conserved in the lake. When the canal was not discharging, wind effect on the lake sometimes caused short periods of small reverse flow; however, these periods had no appreciable effect on the daily flow records.

The maximum annual runoff in the period of record was 13 times as great as the minimum. This ratio is much less than the similar ratio for Caloosahatchee Canal (page 328), which indicates that St. Lucie Canal was used more regularly for controlling the stage of Lake Okeechobee. The procedure was for St. Lucie Canal to be used for the main control outlet while Caloosahatchee Canal was to be used in periods when greater discharge was desired, or, occasionally, to provide irrigation supplies to the upper and middle reaches. The average annual runoff of St. Lucie Canal for the $1935-46$ reference period was 832,700 acre $-\mathrm{ft}$, which is equivalent to $1.8 \mathrm{ft}$ of lake storage at a stage of about $15 \mathrm{ft}$.

A comparison of the records of discharge of St. Lucie and Caloosahatchee Canals shows that although St. Lucie Canal had a slightly smaller recorded maximum daily mean discharge, its total outflow was considerably greater. During the 8 years ending in 1946. St. Lucie Canal discharged 41 percent more water than Caloosahatchee Canal (see tables 32 and 33 ).

THE EVERGLADES AND THE ATLANTIC COASTAL RIDGE

\section{general dRainage features}

\section{EVERGL ADES HYDROLOGIC UNIT}

Prior to development in that part of the Everglades bordering Lake Okeechobee, water from the lake overflowed the south shores in periods of higher stages and fanned out overland in the southern quadrant of the horizon. The first overflow probably occurred in two places, at a stage of about $15 \mathrm{ft}$, with part of the water moving west into the headwaters of the Caloosahatchee River and part drifting south in the Everglades proper. Overflow of the south shore became general at stages of 17 to $18 \mathrm{ft}$, and sizable volumes of water moved slowly in flat, broad sloughs toward tidewater. The largest slough (known as the Everglades) extend's as a grassy marsh, 35 to 50 miles wide, from the south and southeast shores of the lake to the end of the Florida peninsula, 100 miles to the south (see the more detailed description under Geomorphology). 
Two principal branches of the Everglades, Hungryland Slough and Loxahatchee Marsh, extend northeastward toward the coast at Jupiter (see pl. 12). These sloughs probably once operated as floodways, but drainage developments have reduced their principal function to local drainage. Numerous small transverse (northwestsoutheast) sloughs or glades dissect the coastal ridge from Pompano to Homestead and connect the Everglades with the tidal estuaries along the coast. Except in periods of exceptionally high water, these handle principally local drainage. The Everglades also receives runoff from the higher areas of mineral soils on the east and west, particularly from the west. Plate 12 illustrates the directions of surficial drainage in the area.

In its natural state, only a minor, part of the rainfall and the overflow from Lake Okeechobee left the Everglades as surface drainage. Overland flow was extremely slow, because land slopes generally averaged about $0.2 \mathrm{ft}$ per mile, and interconnecting natural drainage channels were extremely shallow and were choked with vegetation. During and after the rainy season, water stood at varying depths over the surface of the organic soils. These conditions naturally led to large losses through evaporation and transpiration. Data on p. 570 show that, because of the present stage of development and the existing network of canals, the runoff amounts to only about one-fifth of the rainfall on the area.

Extensive reclamation activities in the Everglades during the period 1905 to 1927 included the excavation of more than 400 miles of arterial canals, which were equipped with control structures for the primary purpose of draining adjacent lands for agricultural development. Little additional excavation was accomplished subsequent to 1927. These arterial canals consist, in part, of four principal channels, which head on the southeast shore of Lake Okeechobee and flow generally southeastward to the Atlantic Ocean. (See pl. 14.) Another major canal flows eastward and westward across the State from the interior and drains an area west of Miami. The other arterial canals are comparatively short; they flow generally to the east and drain principally coastal areas. Excavation of these canals was started from the coastal ends; hence it is logical that the lower reaches generally follow the channels of short coastal streams, which were outlets for the narrow sloughs connecting with the Everglades.

The major canals in the Everglades were constructed by the Everglades Drainage District, a political subdivision of the State of Florida that was established in 1905 (Dovell, 1942, p. 132-161). The boundaries enclose about 7,500 square miles, which comprises most of the Everglades, an extensive area of sand on the west, much of the sand and rock coastal ridge, and Lake Okeechobee. The primary purpose of the Everglades Drainage District was to provide principal drainage ways for the reclamation of a vast area 
of organic soils, all of which was believed to be suited to agriculture. The four large canals dug from Lake Okeechobee to the east coast of Florida were West Palm Beach Canal, Hillsboro Canal, North New River Canal and Miami Canal (see pl, 1). These radiate from the southeast shores of the lake and cut across a wild section of fresh-water marsh. Because of economic difficulties the canals were never completed as originally designed and are inadequate for the flood load imposed on them. In local areas, where more intensive drainage was desired, provision was made for landowners to establish drainage subdistricts. Pumping facilities for water control were usually installed in the subdistricts and more stable conditions for farming were achieved.

The characteristics of runoff from the Everglades at the present time are greatly changed from the original conditions. The land along the shore of Lake Okeechobee has subsided several feet as a result of the reduction in soil volume since drainage operations were started. Thus, at the same stages, the lake now stands much higher with respect to the land and, for extended periods, is above the land surface. The lake is separated from the farm areas by the hurricane levee, and overflow no longer occurs along these shores. However, the relationship of lake level to land level is important to the water control of the area, and, as the land subsides, the problems become more acute.

When the lake rises to the stage that gravity discharge is no longer possible from the major drainage canals to the lake, the hurricane gates in the main levee between Lake Harbor and Canal Point are closed to prevent flow from the lake. Under such highwater conditions, Kissimmee River basin and Lake Okeechobee and its other tributaries are cut off from the Everglades area, and no significant water movement between the two principal basins occurs. The possible seepage through, and beneath, the hurricane levee has not been completely evaluated, but it is believed to be small. The Caloosahatchee Canal area is effectively separated from the Everglades proper by pumped drainage districts, and St. Lucie Canal is contained between high banks at all stages. Therefore, under moderate- to high-water conditions, all waters south of Lake Okeechobee originate within the Everglades area and consideration must be given to this fact in the future development of southern Florida.

The flow of water out of the Everglades after a heavy rainfall is now largely through the canal system, and it is relatively rapid, compared with predevelopment conditions. It follows that the total runoff is greater, because water now stands on the surface of the glades for shorter periods of time, thus furnishing less opportunity for evaporation. Overland flow to the south still occurs seasonally, but it is considerably less in total volume than that of the several canals. A knowledge of the drainage characteristics of the canals 
is of primary importance to the water problems-not only to those of the Everglades but also to those of the populous and extensively developed Atlantic Coastal Ridge to the east. Each of the canals is discussed in a general north to south order in succeeding sections.

\section{WATER CONTROL FACILITIES}

In the developed area of organic soils south and southeast of Lake Okeechobee, the water in the canals may flow either from, or toward, the lake. The direction of flow in the major canals depends upon the stage of the lake and the amount of water pumped into the canals. Some diked areas, favorably located close to the lake, pump directly to, or from, the lake through culverts in the protective levee and are relatively independent of canal capacity limitations.

A control and lock was constructed in the period of principal development at each end of the four major Everglades canals connecting Lake Okeechobee with the sea. The dual-type structures were designed in such a manner that the lock could be opened and the spillway could be entirely removed (in most of them) to pass large flows. Figure 91 shows a typical installation with the lock

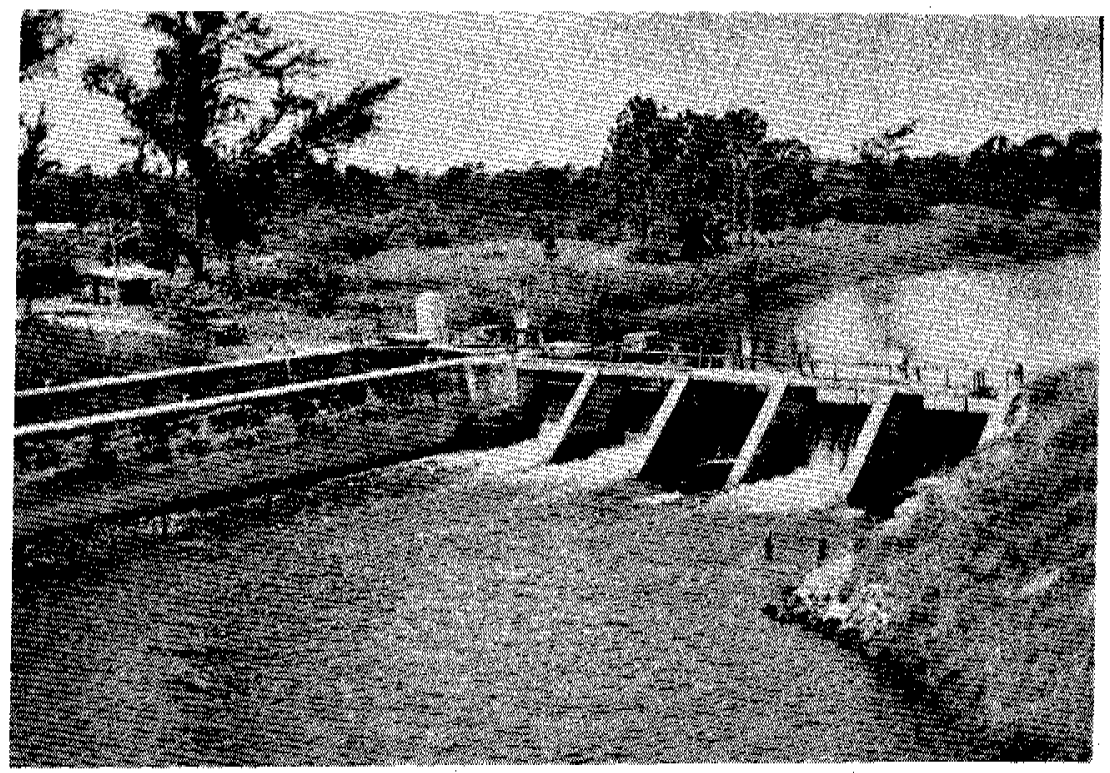

Figure 91. - Control and lock in Hillsboro Canal near Deerfield Beach, a typical Everglades installation. This is close to the coast, and the downstream pool is tidai. The U. S. Geological Survey recording gage in at the upstream end of the lock. Head on the control is about $10 \mathrm{ft}$. 
closed and with stoplogs in the spillway bays to provide a controlled upstream stage. One of these controls has been removed, ${ }^{5}$ two are essentially inoperative, ${ }^{6}$ but the other five are still in active use. The locks at the control structures have seldom been used for navigational purposes since the highways and railroads have replaced the earlier water-borne traffic in the canals. Similar structures were placed in Caloosahatchee, St. Lucie, and South New River Canals, but of these, only the control and lock in South New River Canal still exists (1949).

At the lake ends of the major canals, three hurricane gates also occasionally serve as controls (HGS-4 serves both North New River and Hillsboro Canals, which reach a junction close to the lake levee). When the hurricane gates are completely closed the nearby old controls are ineffective, except for passing local pump discharge. The hurricane gates are closed under the following conditions:

1. When a hurricane threatens-to prevent wind-driven lake water from inundating the communities and farm lands of the upper Glades (the primary function of the gates).

2. When the lake rises higher than the canal levels during flood periods-to prevent outflow from the lake which would augment flood conditions; the old structures, because of their poor condition and high rates of leakage, are not effective enough in preventing lake discharge into the canals.

3. Partly closed, occasionally in drought periods, to control the release of irrigation water and stage-maintenance flow from the lake.

4. For maintenance, the gates may be closed for as long as 2 weeks; time is selected by Corps of Engineers to cause a minimum of interference with normal operations.

5. Partly closed, occasionally, to stop masses of hyacinth from drifting into the canals.

The major canals are interconnected in the upper Everglades by two large secondary canals, Bolles and Cross Canals; these major canals drain and irrigate through a multitude of local canals and ditches. The principal farming area is divided into drainage subdistricts, which are individually diked off from adjoining areas. Except for those close to the lake and a way from the canals, the subdistricts pump extensively into, or from, the canals according to need. The pumps are of low-lift type and may range in capacity from several thousand gallons per minute to $60,000 \mathrm{gpm}$ (134 cfs,

\footnotetext{
${ }_{6}^{5}$ Miami Canal at Miami, just above confluence with Tamiami Canal.

6 Hillsboro Canal at Chosen, between Belle Glade and Lake Okeechobee; Miami Canal at

Lake Habor.
} 
or 266 acre-ft per day). One pump house may contain several pumps. Most of the pumps of the drainage subdistricts were designed to remove 0.5 to 1 in. of water per day from their service areas. Many of the small farm pumps are arranged to pump in either direction, and many of the large units can be used as siphons for irrigating.

The size of the pumps utilized in the lake area is related to a somewhat common misconception about the capacity of the canals for storage of discharged water or for sources of irrigation supplies. Apparently, many persons believe the storage capacity of the canals is a significant factor in water control of the Everglades; however, this is true only in a negative manner. A mile of canal, $70 \mathrm{ft}$ wide, has a surface area of 8.5 acres, and therefore it has a storage capacity of 8.5 acre-ft per mile for $1 \mathrm{ft}$ change in level. In a canal 30 miles long, this would mean a storage of 255 acreft per ft change, which is approximately, the discharge for 1 day of one 60,000 gpm pump. When it is considered that a single pumphouse installation may have two or three such pumps, and that there will be numerous other pumps operating along a typical canal, it becomes obvious that the storage capacity can be occupied in a short time. Unless the pumped discharge moves along the canal at fast-enough rates, the water level rises rapidly and dikes may be overtopped. In the case of irrigation supplies, large demand will draw the canal down excessively unless seepage from reservoir areas, or direct infliow from other surface supplies, furnish some replacement. In either situation, additional discharge or supply capacity must be available for satisfactory operation of facilities. A principal canal in a subdistrict is shown under construction in figure 92 (note the neat trapezoidal cross section).

A schematic diagram of the water relationship in canals, farms, pumps, and open lands is presented in figure 93 , which shows two sets of water conditions. In dry periods, evaporation and transpiration from farms is large, and the pump canals and laterals are maintained at high levels to hold up the water table in the fields. Seepage losses occur to the open lands and then back into the main canal, which may be at a fairly low level because of the irrigation demand.

In wet periods, the main canal is full and levels are above ground surfaces in the open lands. The farm ditches are held at low levels by pumping into the main canal to encourage seepage from the fields. Seepage occurs in some degree under the dikes, and a certain amount of recirculation occurs.

Figure 93 was drawn to be representative of the principal farming area near Lake Okeechobee, but the principles therein apply to installations in the entire Everglades area. The amount of seepage under dikes and canals can vary widely, depending upon the per- 


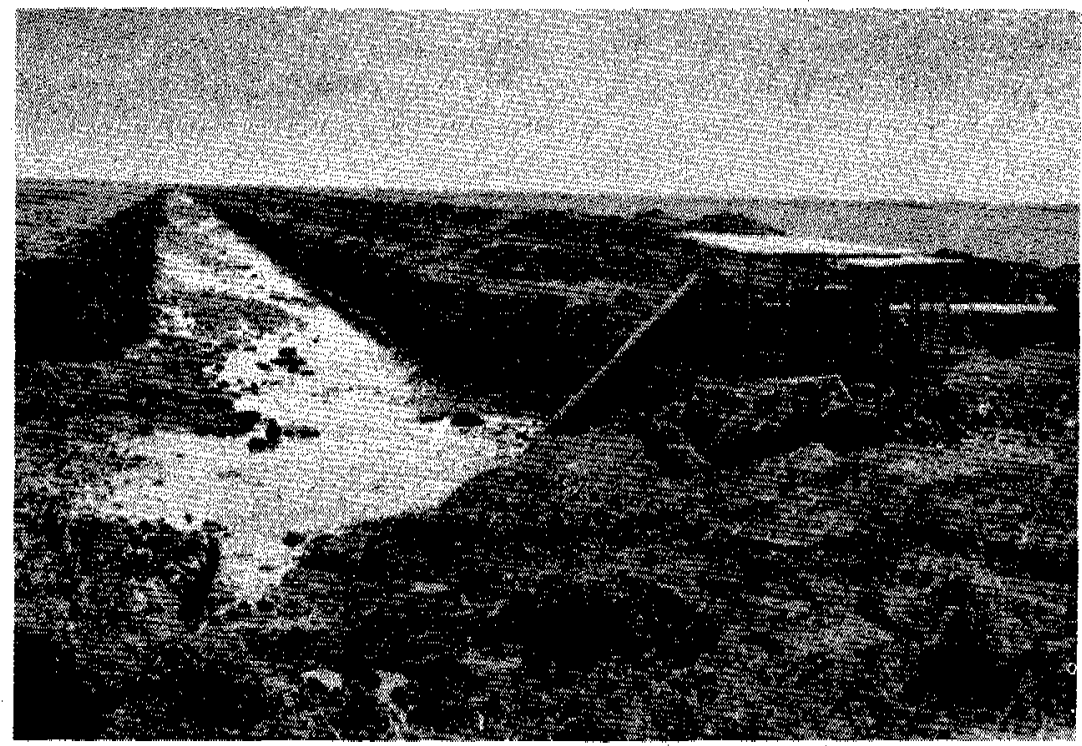

Figure 92, - Water control facilitles in the upper Everglades. Main canal of East Shore Drainage District, under construction near Belle Glade; part of chamel still to be excavated and spoil material to be graded to form a dike. Canal was excavated to the rock surface in 9 ft of muck soil; pump was a temporary installation for construction period; August 1944.

meability of the upper rock formations. The diagrams show that farming in the muck areas of the middle and lower Everglades generally has been uneconomical, because pumping costs are excessive due to the large amount of seepage and recirculation of pumped water.

Although the dry-winter periods of $1943-45$ resulted in an increased interest in pumping for irrigation (which is being practiced more widely each year), the major emphasis is still on pumping for drainage. The pumps are started in anticipation of, or following, excessive rainfall, and the surplus water is drawn through the multiplicity of channels to the pumps to be lifted into the canals.

\section{FACTORS AFFECTING CANAL CAPACITY}

\section{SOI SUESIDENCE}

The subsidence of the muck and peat soils, particularly in the intensively farmed areas, is an important factor that has changed the nature of runoff in the Everglades. Organic soils continue to build up in swamp areas when natural conditions (especially water conditions) are undisturbed but are subject to losses when dry. These losses occur principally in three ways:

1. Compaction-by vehicles and machinery in farming operations; may be as great as 12 in. during the first year of use. 


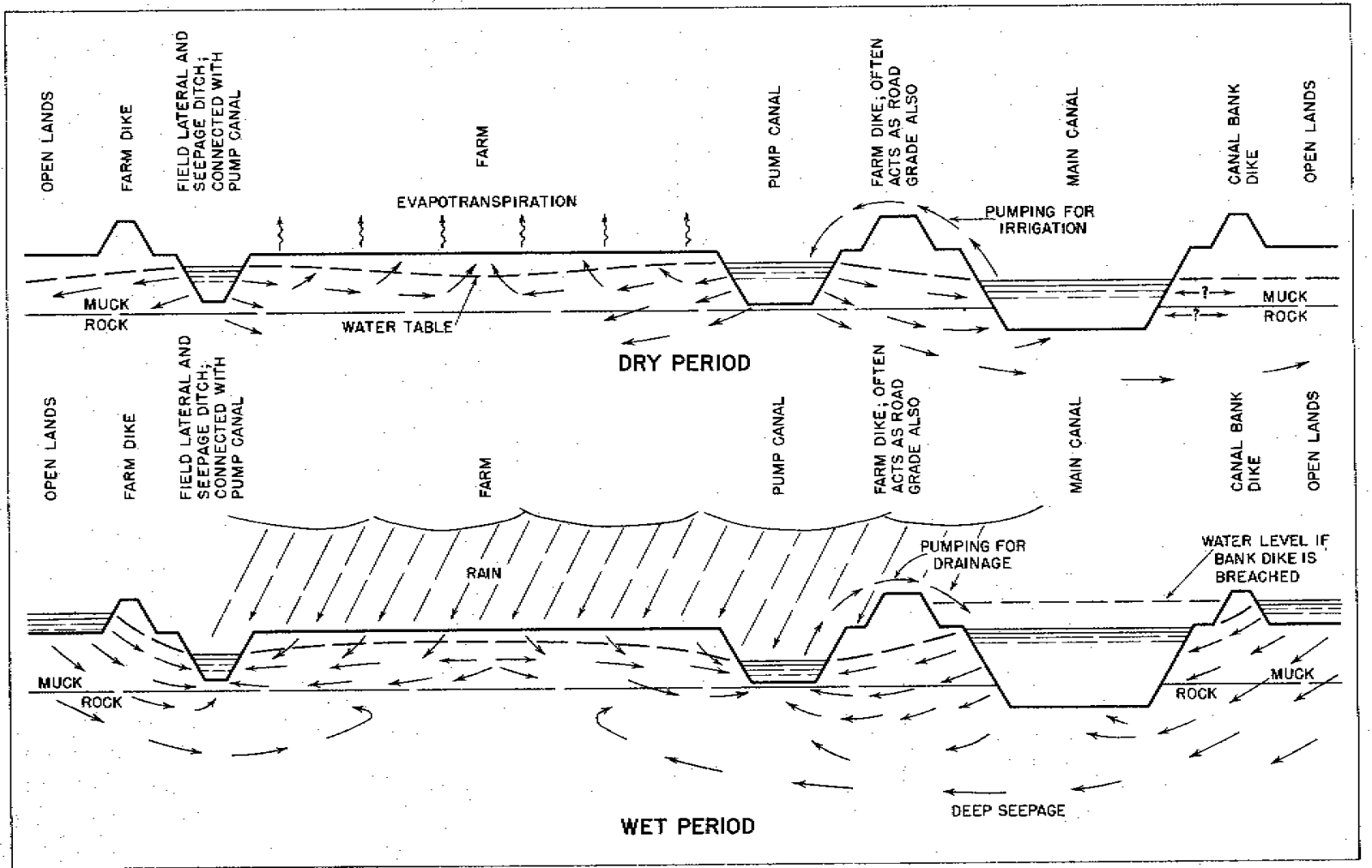

芴

Figure 93. - Diagram of water relationships in typical farmed area of the upper Everglades during dry and wet periods. 
2. Slow oxidation-when dry, by chemical and bacterial action; insidious, because it is not apparent except by elevation loss over a number of years.

3. Fire-when dry, the organic soils ignite readily and may smoulder for months; in the years 1943-1945 most of the Everglades was burned over (several times in some areas).

The nature of the subsidence of organic solls has been discussed in detail by Evans and Allison (1942, p. 34-46) and Clayton and Neller (1943, p. 118-123).

Clayton, Neller, and Allison (1942, p. 15) state: "Most of the cultivated lands of the northern Everglades have subsided approximately 5 feet since drainage was begun about 25 years ago." This process is continuing, and its effect on canal efficiency is considerable. Where the land surface has lowered as much as $5 \mathrm{ft}$, it means that the canals have lost $5 \mathrm{ft}$ of effective depth. And, as the spoil banks subsided with the land, an actual loss of cross section has occurred-44-percent reduction for a canal originally excavated to $12 \mathrm{ft}$ below the land surface. Figure 94 shows a control and lock that, in effect, has been raised above the land because of subsidence of the soils around it.

The loss of storage capacity in the canals is sizable, although it is not a controlling factor. The loss of conveyance capacity,

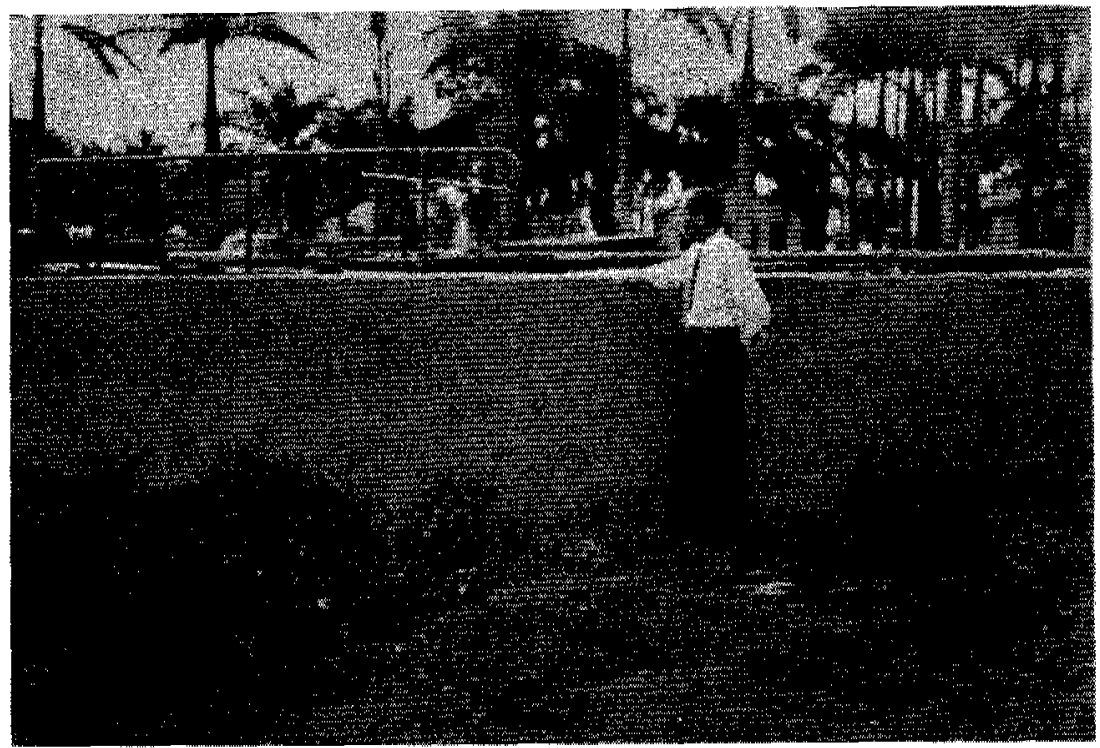

Figure 94. - Top of wall of lock in South New River Canal at South Bay was once close to the ground surface; loss of the inuck soil by oxidation and bacterial action in Lry periods has caused surface to subside about 4,5 feet. 
however, is extremely important, because this is a measure of the efficiency of the canals as water movers. Reduction of conveyance capacity by reduction of depth is a result of changes involving several basic factors:

1. Reduction of cross-sectional area; 40 to 50 percent in some cases.

2. Reduction of the hydraulic radius; this is a hydraulic function derived from the shape of the channel. The smaller the hydraulic radius, the lower the velocity of the water, providing that other factors remain constant.

3. Reduction of height to which water can be pumped to develop the slope that produces flow; for canals that drain into Lake Okeechobee the effect is quite large.

For a typical canal (trapezoidal in section, $70 \mathrm{ft}$ wide at the top and $12 \mathrm{ft}$ deep), a reduction in depth of $5 \mathrm{ft}$, plus an assumed halving of the water slope, would reduce its efficiency to 30 percent of original capacity. This rough computation is furnished only to show the possible magnitude of the loss of conveyance capacity in the canals, a consideration that also involves the cost of such facilities. Some of this loss of capacity has been offset by increasing the height of bank dikes, but the relationship of canal stage to land elevation has not been improved. Costs of moving water have risen because of increased pump lift, an increase in the amount of water to handle (because of additional seepage from the canals to the fields), and because of continual dike maintenance.

\section{BARS AWD SHOALS}

Among other causes for reduced canal efficiency have been the accretion of organic material and the formation of bars and shoals on the bottoms of the canal. Aquatic weeds, both floating and rooted, deposited a steady amount of organic debris in their natural cycles. Weeds along the banks were cut and dumped into the canals, branches from trees and other material entered the canals and impeded flow. Fortunately, much of this material was carried out of the canals when higher velocities occurred during periods of medium and high water. A small amount of this material was removed by maintenance operations, but the net result was an appreciable reduction of the area of the canals.

Bars, which are composed of sand, muck, or debris (or of all three), form in the canals under three general conditions:

$+$

1. Where uncontrolled laterals intersect the canals. This is particularly bad in the sandy areas where, in some cases, lateral inflow developed naturally and unconfined flood waters were able to convey and deposit large amounts of sand as the velocity of the flow 
is reduced upon entrance to the main canal-this happens to a lesser degree in areas of organic soils.

2. Where pump discharges enter the canals. Deltas and bars form on the discharge side of pumps, and because the pumps are usually close to the canals, thus the bars form in the canals. The suspension of heaviex particles in the water results from the relatively high velocities that occur in the field ditches and in the pump-feeder laterals.

3. Where organic material, consisting of decomposed weeds or miscellaneous trash, accumulates (this is usually caused by a reduction of velocity in canals). These shoals tend to be relatively low, but they may cover extensive areas.

Probably no single shoàl has any great effect on flow in a canal, because a reduction of cross section for a short distance does not cause a proportional reduction of capacity. In the aggregate, however, bars and shoals restrict flows appreciably, and they should be removed to increase efficiency. The dire financial plight of the Everglades after 1930 prevented necessary maintenance of the major canals, but in 1946 the Everglades Drainage District (1946) issued a set of regulations in an attempt to stop further blocking of the canals. Aside from a prohibition against disposal of any material except water in the canals, the principal pertinent regulation concerned the laterals, both controlled and uncontrolled. It was stated that in the future all pumps and lateral controls were to be located not less than $300 \mathrm{ft}$ from the main canals, and that a sump was to be provided in that $300-\mathrm{ft}$ reach for the purpose of detaining most of the material suspended in the water; furthermore, the connection from the sump to the canal was to be of such proportions, and to be so protected, that no appreciable amount of material would be carried into the canal. It was stated that existing installations less than $300 \mathrm{ft}$ from the canal (and most of them are closer) must have a sump close to the field side for the same purpose. It was also ruled that uncontrolled laterals must be provided with similar settling basins.

\section{AQUATIC WEEDS}

Another important cause of canal inefficiency has been obstruetions of aquatic weeds, an example of which is shown in figure 95 . The bottom-rooted types are found principally in the secondary canals and field laterals (except in the lower Everglades-see data on Miami Canal) and may block flow almost completely. Fortunately, they seem to have a seasonal characteristic (they are affected by temperature or water velocity) and leave the channels comparatively clear at times. Without doubt, however, the water hyacinth, that beautiful but obnoxious floating plant, is the acknowledged champion among weed pests in canals. 


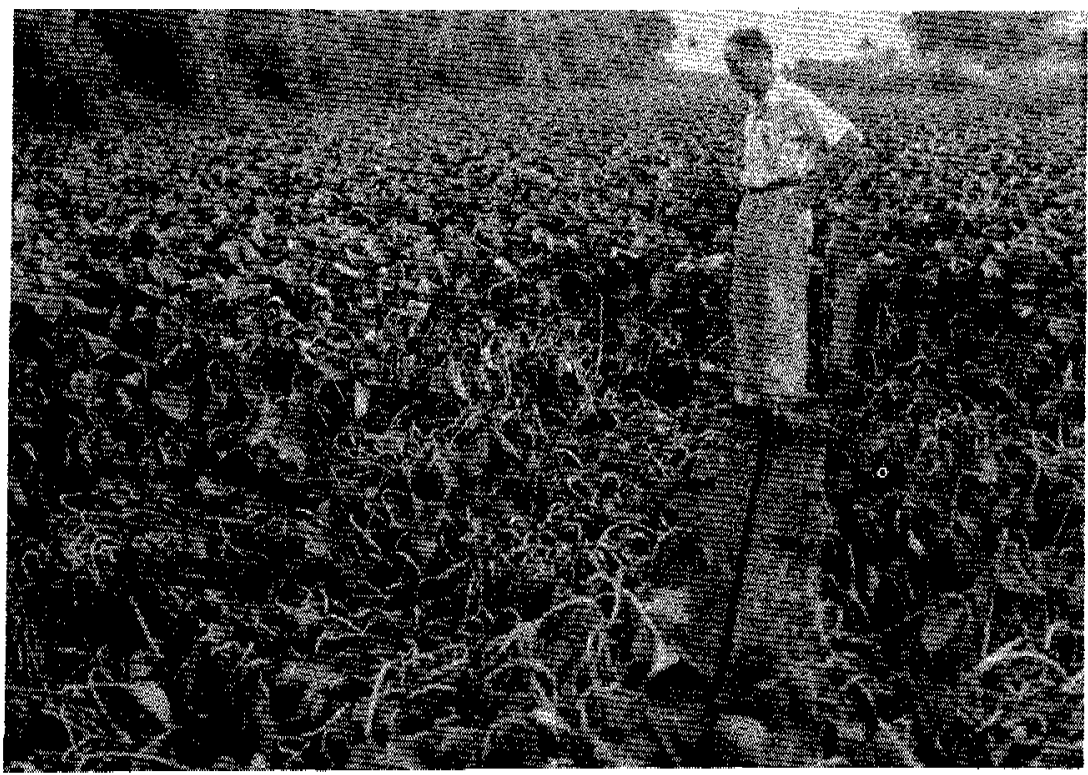

Figure 95, - Aquatic growth in Everglades canals. Dense cover of water hyacinth on North New River Canal at South Bay; view along centerline of canal in September 1946; the trampledappearing area shows the affect of spray-application of 2-4, D, a herbicide that is effective in killing hyacinth.

Johnson (1948) states that contamination of the arterial canals began as soon as they were connected with Lake Okeechobee, about 1918. Regular operations and navigation maintained some degree of control, but by 1925, mechanical methods were being employed. After 1930, with the economy of the Everglades tottering, this work was halted, and the canals were soon covered completely with hyacinth. Between 1935 and 1943 , sporadic attempts were made to clear parts of several of the main canals but no proper followup program was instituted, and regrowth occurred rapidly. Everglades Drainage District resumed active hyacinth control in 1943, but the scale of operations was limited.

In 1946, it was demonstrated that the new herbicides known generally as 2,4-D were effective in killing the waterhyacinth, and in July of that year an ambitious program of hyacinth removal on 178 miles of major canals was started. The 2, 4-D was sprayed in oil or water from planes, boats, and trucks and the results were, on the whole, satisfactory. It may be stated that 162 miles of canal were cleared so completely by July 1948 that only occasional patrol spraying was necessary thereafter. After this program the water in the Everglades canals was seenfor the first time in many years. It is safe to say that the hyacinth problem has been solved, although the solution has not been applied as yet (1949) to all channels in the Everglades. Removal of hyacinth cover is probably the least expensive procedure for obtaining significant improvement in channel efficiency. 
The retarding effect of water hyacinth on flow of water is not merely a matter of a certain part of the channel cross section being occupied. The roots hang 10 to $12 \mathrm{in}$. below the plants, and the net obstruction averages possibly a foot-which would be 10 percent of a canal $10 \mathrm{ft}$ deep. It is the restriction of flow by increased friction that reduces capacity. Because, not only is there the usual friction caused by the bottom and sides of the channel, but also, where complete hyacinth cover exists (see fig. 95), a large amount of friction occurs at the top, and the canal is, in effect, a closed conduit with rough surfaces all around. Bogart and Clayton (1948) show that, because of complete hyacinth cover, North New River Canal (which was $70 \mathrm{ft}$ wide at the point of observation) was only 57 percent efficient. The efficiency of Cross Canal, about $45 \mathrm{ft}$ wide, was found to be about 53 percent. Such efficiencies, of course, vary with the stage-the higher the stage of any canal, other factors being equal, the higher the efficiency will be, and conversely. Loss of conveyance capacity caused by hyacinth cover increases as the size of the channel decreases, until the point is reached (in small farm ditches) where flow efficiency may approach zero.

Loose hyacinth drifting with the current has a tendency to lodge on bridge piers and controls. Large' jams may form and may cause sizable amounts of backwater. Often, plants are removed by means of long-handled choppers, but 6-ft ice saws sometimes are used by workers standing on the matted plants, and even dynamite has been used to break up the jams.

It is ironical that, in spite of the concern over the adverse effect of weeds and hyacinth in canals, these aquatic plants were beneficial at times. When water levels and discharges fell so disastrously low in the drought periods of 1943, 1944, and 1945, the plants, by their blocking action, held water to only small flow on relatively steep slopes-thus holding up levels locally and preventing excessive wastage. In the Miami area, weed growth retarded inland movement of salty water in the tidal canals. As a further paradox in the situation, the highly undesirable salty water killed the weed in the canals and cleaned long reaches that had been clogged for many years.

\section{TOROGRAPHC AND GEOLOGIC FACTOES OF WATER CONTROL}

In very general terms, the organic soils of the upper Everglades (as far south as the latitude of Fort Lauderdale) are underlain by the Fort Thompson formation, which, in this area, is relatively impermeable to water movement and is frequently capped by a thin layer of Lake Flirt marl (also an impermeable formation). (See plate 4.) In this area, canals can be dug in the muck and rock-seepage into, or out of, the canals is small, and water control can be established. Because the muck soil is more permeable in a vertical 
direction than in ahorizontal direction, drainage of the farm lands occurs via the network of mole drains, farm ditches, and laterals, which resembles the arrangement of capillaries and veins of the human body (Clayton, Neller, and Allison, 1942, p. 17, 60; Allison, 1928 , p. 117).

East of the upper Everglades, the Anastasia formation underlies the Pamlico sand in the coastal ridge as far south as Deerfield Beach. The consolidated portions of the formation are quite permeable, but water control in the area is successful mainly because the canals and laterals are dug almost entirely in the sand, and rock is not of ten encountered. Seepage rates are likely to be somewhat greater than in the organic soils, but the higher altitude of the area, much of which is in the Lake Worth Drainage District, makes gravity drainage and pumped irrigation economically feasible.

South of the latitude of Fort Lauderdale, the highly permeable part of the Fort Thompson formation and the Miami oolite underlie muck and peat soils and the shallow marls farther to the south. To obtain the necessary cross section and slope, lateral canals in this area must be dug through the shallow soils and into the rock. When water levels in such channels are held higher, or lower, than those in the adjoining ground, the seepage usually is very large. Pumping has been unsuccessful, for, in effect, the whole countryside was being drawn upon because of the free movement of water through the rock. The creation of dikes around pumped areas was found to be impracticable.

The coastal ridge south of Deerfield Beach is composed principally of the Fort Thompson formation and the Miami oolite and is overlain in places by a generally thin layer of sand, which becomes thinner to the south. Water control by pumping is impractical here, except in isolated areas, and water control must be considered in terms of large areas rather than by arbitrarily limited basins adjacent to a waterway.

Because of the wide range of geologic factors, the capacity of the canals to convey water from one area to another also ranges widely. Where the canals are dug in relatively impermeable materials, water movement (other things being equal) is dependent upon tight and continuous dikes and upon simple hydraulic factors. However, canals cut into the permeable materials present much more complex problems. The adjoining ground water has free access through innumerable small openings, and, depending upon the relationship of the canal and the ground-water stages, it can seep into, or out of, the canal. When the ground water is the higher, inseepage occurs; when the canal is the higher, outseepage occurs. The processes can go on simultaneously at different locations along one canal, particularly near artificial controls. The condition of in- 
seepage on one side of a canal and outseepage on the other side can occur where a canal cuts across the ground-water slope of an area and the canal stage is at the ground-water level. Under these conditions the canal has little effect on ground-water movement.

The flat topography of the Everglades permits control structures to be effective in controlling water levels in the canals and basins over extensive area's upstream. However, this can be a liability as well as an asset; because, in the areas of permeable materials, it means that the canals may collect water from one area haphazardly and at the expense of another area, and, by the very nature of the problem, this process can hardly be stopped, although the effect can be reduced. Fortunately for the economy of the Everglades area as a whole, the highly permeable formations are located at the lower end of the basin, although that part is adversely affected in considerable degree.

Studies at water-control structures in permeable areas show that retention of water upstream from the controls may be a very difficult problem. Under a head of 2 or $3 \mathrm{ft}$, and with the control completely closed, a considerable amount of water will seep through the formations below, and on each side of, the control and will return to the channel farther downstream. Hence, in order to hold heads of water effectively at such points, sizable volumes of water must be continuously provided from an upstream source to replenish losses from this leakage.

The drainage areas contributing water to the canals are indeterminate, and in some areas, the canals cut across the slope of the ground and the direction of natural drainage. Because of the flat topography, the direction of flow over an area may vary; the flow will be away from the center of heavy natural recharge (rainfall) or artificial recharge. In a similar manner, water summits may occur in a canal reach under high-water conditions-the flow may divide and move both ways at a point of large inflow from a pumped or uncontrolled lateral (see fig. 98). In general, the canals drain a considerably larger area to the north of the channels than to the south because of the natural south to southeast drainage and because of the predominantly southeast to east direction of the channels.

During ordinary wet periods, overland flow occurs principally in the open Everglades west of North New River Canal and stretching from Bolles Canal south to the Tamiami Trail and Cape Sable. Such flow is modified in other areas by the canals and road fills. Under maximum flood conditions, however, the old drainage pattern is reestablished, and the water moves overland in large volume; this flow is still modified by development, but to a much lesser degree. 


\section{THE COMBNED NATURAL AND ARTIFICIAL CONTROL REGIMEN}

The natural regimen of the weather is obviously the background for water-control operations in the Everglades, but the relationship is not quite as simple as such a statement may imply.

Each year has been divided by Johnson (1944) inco four periods to cover general conditions that may occur during that year, For a given year, the limits of each period are not precise, but the subdivision is essentially valid. (See section on Climate for detailed weather information.). These periods are discussed below, starting with low water condition:

February 1 to May 15: nomally low water conditions. - Rainfall is usually scanty, although sizable amounts often fall after April 1. This period is the end of the truck-farming season in the Everglades. Water levels decline steadily, particularly in Dade County, and are above ground only in small areas; the Everglades is subject to uncontrolled grass fires and burning of the soil in particularly dry years; soil loss by slow oxidation is at maximum rates; pumping for irrigation is at a maximum; and, salt-water contamination of the tidal canals reaches farthest inland. Water is released from Lake Okeechobee into the major canals to provide irrigation supplies; and controls at the outlet ends of the canal are kept closed to reduce fresh-water runoff to a minimum and to combat salt-water intrusion. Depending upon prior conditions and light rainfall in this period, extreme drought conditions may develop which, as in 1945, can extend into June and July.

May 15 to September 1: rainy seasont.-Many small and intense squalls occur; these squalls are interspersed with more general storms, which may have heavy rainfall. Farmlands, where the truckfarming period is finished, may be allowed to become flooded (good agricultural practice); the soil becomes saturated and, in the open lands, inundation occurs; moderate overland flow may develop; the canals rise considerably; and most pumping is done for drainage. Ordinarily, the outflow from Lake Okeechobee is reduced, and, in wet years, reverse flow to the lake may occur; the controls at the coastalends of the canals are partly opened to provide local relief, but, at the same time, levels are kept high enough to divert, or to keep, as much water as possible on the open lands; and reserve capacity is maintained for the larger rains by keeping the canal stage below certain maximums.

Septonber 1 to Vovenbor 15: possible stom season. - This is the most critical period of the year. Very often, the summer rains are over by late September, and it is desirable to conserve a maximum of stored water. At the same time, the area is subject to hurricanes, which are often accompanied by extremely heavy rainfall, making it desirable to have reserve capacity in the water-control facilities. The coastal controls are opened wider to keep levels down in the canals, 
but efforts are made to keep all possible storage on open lands. The problem of reserve capacity is complicated by the heavy pump discharge in connection with preparations for the farming season. If a tropical storm develops, all the controls are opened wide at the coast and at other locations (as indicated) to remove as much water as possible from the canals and developed areas. When heavy rains occur from such a storm, the facilities are usually inadequate for the quantities of water to be moved, and varying degrees of flood conditions exist.

November 15 to Februery 1: dry season.-Normally, rainfall is scanty, and levels decline steadily. If hurricane floods occurred in the previous period, the controls are maintained in an open position until the excess water has been removed. If the storm period passed with only moderate rains, the controls are closed as far as possible to conserve water for the growing season. Pumping changes from drainage discharge to irrigation as the growing season advances. Low storage during the rainy and stormy periods, and a period of no rain at this time, can set the stage for drought conditions.

The water regimen outlined above is in marked contrast to conditions over most of the United States, where. the period of dry conditions and possible drought usually occurs from July to October. Over most of the country, streamflow is greater in the winter than in the fall, and it generally reaches a maximum in the spring; however, in southern Florida, the peaks usually occur in September and October.

\section{WEST PALM BEACH CANAL}

\section{PHYSICAL DESCRIPTON}

West Palm Beach Canal extends 42 miles from the southeast shore of Lake Okeechobee at Canal Point to Lake Worth and the Intracoastal Waterway in the vicinity of West Palm Beach and passes through an area embracing the northern limits of the Everglades proper. In its western half, a straight reach, 19 miles long, extends in a southeasterly direction and connects to a second straight reach of about the same length, which runs in an easterly direction to the coastal ridge and enters Lake Worth between the cities of West Palm Beach and Lake Worth. The total length of channel is 42 miles. (See plate 14 for the general features of the West Palm Beach Canal basin.)

West Palm Beach Canal was dug in deep muck soil from Canal Point to where the muck grades into sand (about 4 or 5 miles east of 20-Mile Bend). The edge of the sand land is the point where the canal intersects the edge of a low sand upland, which extends 
northwestward and roughly parallel to the west half of the canal and 4 to 6 miles away from it. This higher ground has an important part in the drainage regimen of the canal, because it is from this area that large quantities of water move overland in wet periods into the immediate canal basin.

State Highway 716 (formerly Highway 194 and known as Connor's Highway) serves as a dike along the southern side of the canal from Canal Point to 20-Mile Bend, and it is a part of the principal dike system of three drainage subdistricts: Pelican Lake, Pahokee, and Highland Glades Drainage Districts. The northern bank is effectively diked for 5.5 miles southeast of Canal Point as a part of Pelican Lake Drainage District. (In 1946-47 the northern bank dikes were extended as far east as Big Mound Canal.) East of that point, the original spoil banks (composed mostly of muck) subsided by slow oxidation, or by fire, and became ineffective as dikes. Thus, when water levels rise above ground surface in that area, West Palm Beach Canal is vulnerable to uncontrolled overland inflow from the north. A small dike, known as Old State Dike, once existed parallel to, and about 3 miles north of, West Palm Beach Canal; it extended from near the lake to Loxahatchee. This dike has subsided, and it has little effect on water events. At the present time, it is marked only by a shallow borrow ditch.

- It is in the area of the drainage subdistricts near Canal Point that most of the pumps along West Palm Beach Canal are located. A control and lock regulates flow most of the time at the lake end of the canal. Under certain conditions (see page 336 ), the hurricane gate (HGS-5) in the protective levee at Canal Point is closed, thus canceling the effect of the old control.

Between Canal Point and 20-Mile Bend three large lateral canals enter West Palm Beach from the north: Lateral A, Lateral B, and Big Mound Canal. These are uncontrolled, serve little useful purpose at present, and increase the high-water problems of the area. Cross Canal, an important tributary, extends west from 20-Mile Bend to Hillsboro Canal. A control was constructed in Cross Canal at 20 -Mile Bend in 1945, replacing a temporary wood control built in 1944.

The main highway across the State in the latitude of Lake Okeechobee, State Highway 80 (formerly Highway 25), crosses West Palm Beach Canal at 20-Mile Bend and continues east along the north bank almost to the seaward end of the canal, serving as a dike for a considerable distance into the sand area. Three bridged highway openings east of 20-Mile Bend permit uncontrolled inflow seasonally from the north. The south bank is low and uneven for a considerable distance into the sandy area and is subject to overflow at high stages. Several uncontrolled laterals exist in this reach. The sandy ridge is essentially continuous from west of 
Loxahatchee to the coast, except for a slough (Loxahatchee Marsh) crossing east of range line $41-42$ (pl. 1), and the coastal slough near the east end of the canal. Both banks are high throughout this eastern reach and are not subject to overflow.

Loxahatchee Drainage District, on the north bank, 8 miles east of 20-Mile Bend, drains into, or irrigates from, the West Palm Beach Canal by gravity or pump. At range line $41-42$, a principal tributary, known locally as Rangeline Canal, but of ficially designated as Equalizing Canal $1(E-1)$, connects from the south and marks the western limit of Lake Worth Drainage District, which is the largest subdistrict in the Everglades area. Rangeline Canal extends southward to an intexsection with Boynton Canal and connects with Hillsboro Canal, west of Deerfield Beach. It was originally used only for gravity drainage, but a pump of $20,000 \mathrm{gpm}$ capacity was installed in 1944 at West Palm Beach Canal to irrigate the high sandy lands of Lake Worth Drainage District. State Highway 7 (formerly Highway 199) occupies the west bank of Rangeline Canal and forms a continuous levee, with culverts at regular intervals.

East of range line $41-42$, the principal connections are the equalizing canals of Lake Worth Drainage District: E-2 and E-3, from the north; E-3 and E-4, from the south; and Stub Canal, from the north, in the westernenvirons of the city of West Palm Beach. The sizable pumping plant at Morrison Field, constructed during World War II for local drainage, has little effect on West Palm Beach Canal because it is seldom operated. Several other minor laterals in the eastern 10 miles of the canal also have little effect.

At U. S. Highway 1, the canal discharges into tidal waters at a control and lock. The control structure is larger than most controls in the major Everglades canals, and it was designed to operate under heads as great as 12 feet. A unique feature is the wide highway bascule bridge built across the lock. The canal extends approximately half a mile farther east and discharges into Lake Worth, which is a narrow tidal estuary running parallel wi th the coast. The ultimate connection to the sea probably is via the inlet, 7 miles to the south at Boynton Beach, although during heavy discharge the flow may divide, and part of it may reach the sea by way of Lake Worth Inlet, 9 miles to the north.

The principal features along West Palm Beach Canal with cumulative mileage from Lake Okeechobee are listed below: 
Lateral $B$, from north....................................... $8: 1$

Lateral A, from north.......................................... 10, 7

Big Mound Canal................................................... 11. 7

Cross Canal, bend..................................................19.4 20-Mile Bend bridge. ............................................. 19.5 Loxahatchee, main lateral of Loxahatchee Drainage District, 26. 6 Bridge, Canal E-1, State Highway 7, range line 41-42....... 31,0 Canal E-2, north and south (connection south made in 1947). 32.8

Canal E-3, north and south...................................... 35. 6

Bridge, Military Trail, State Highway $809 . . \ldots \ldots \ldots \ldots \ldots \ldots \ldots . . . . .36 .6$

Bridge, at Morrison Field........................................ 38. 1

Stub Canal........................................................... 38. 2

Bridge, Seaboard Railway...................................... 40.6

Canal E-4........................................................ 40.8

Bridge, F. E. C. Railway,...................................41. 3

Control and lock, U. S. Highway 1 (gaging station). ..........41.4

Bridge, U. S. Highway 1 (Alternate)............................41. 7

Lake Worth..........................................................42, 0

\section{RECORDS AVAILABLE}

Records obtained for various points in the area of investigations are as follows (records were continued after period of this investigation):

\section{Canal Point}

Stage, nor thwest of control: Nov. 7, 1939, to Dec. 31, 1946; staff gage read two and three times daily; stage essentially the same as in Lake Okeechobee except for wind surges and periods when HGS -5 was closed.

Stage, southeast of control: June 30, 1940, to Dec. 31, 1946; continuous recorder graph; daily mean plotted in figures 96 and 97 . Maximum: $16.40 \mathrm{ft}$, on Oct. 15, 1945. Minimum: $9.40 \mathrm{ft}$, on May 24, 1944.

Discharge: Nov. 7,1939 , to Dec. 31, 1946; daily mean plotted in figures 96 and 97 ; monthly and annual runoff listed in table 34 . Maximum: $610 \mathrm{cfs}$, daily mean, to southeast, on Nov. 20, 1939; $1,760 \mathrm{cfs}$, to northwest (into Lake), on June 15, 1942. Periods of no flow were common at times of reversal of flow and when HGS-5 was closed.

\section{Loxahatchee}

Stage: July 7, 1941, to Aug. 27, 1942; staff gage read once weekly. Aug. 28, 1942, to Dec. 31,1946 ; staff gage read once daily. Maximum observed: greater than $14.6 \mathrm{ft}$, on Sept. 22, 1941, and June 16, 1942 .

Minimum observed: $8.02 \mathrm{ft}$, on June $30,1944$. 

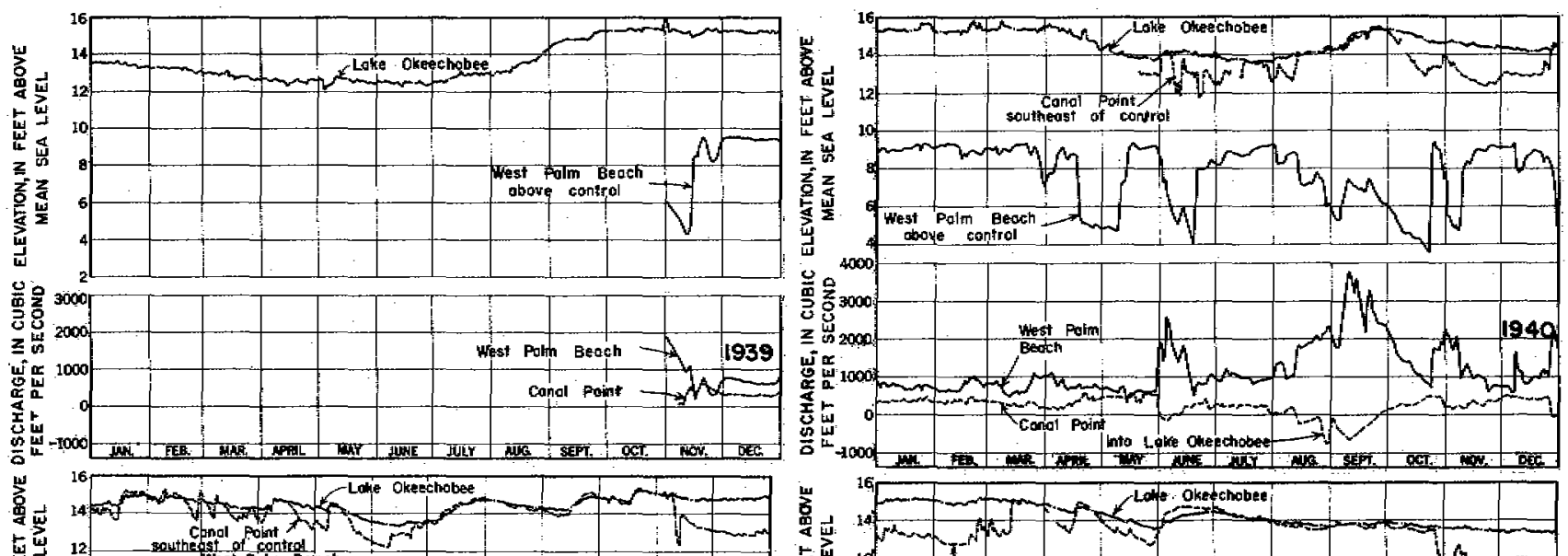

s. - southessis of controd

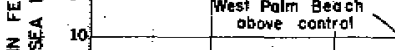

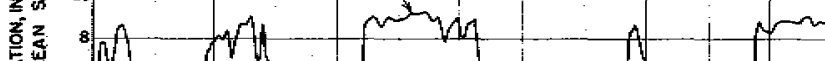

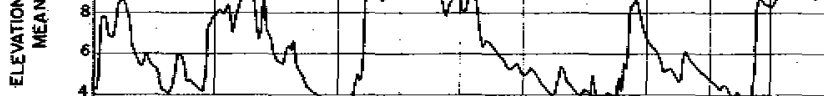
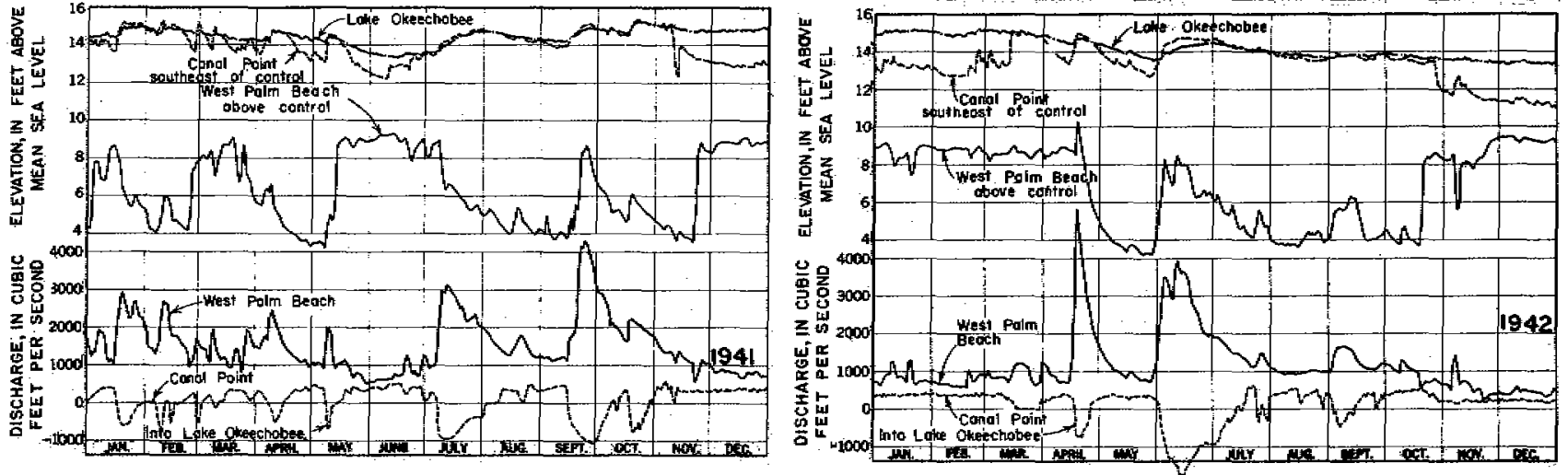

Figure 96, -Graphs showing.stage and dtacharge of West Palm Beach Canal, 1939-42. 

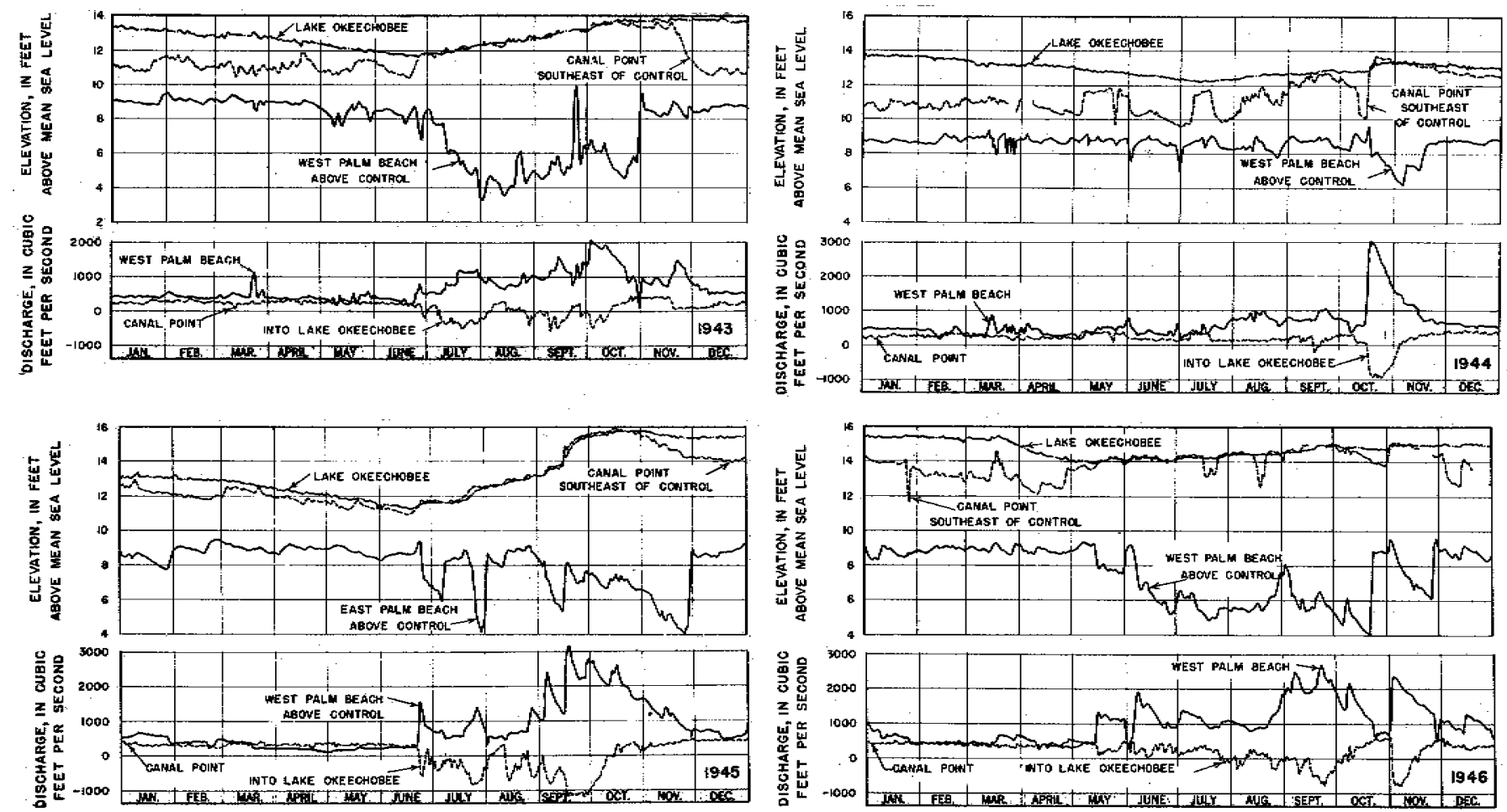

Figure 97. - Graphs showng stage and discharge of West Palm Beach Canal, 1943-46. 
Table 34. - Rtinolf of West Palm Beach Canal at Canal Point

[Unit, 1,000 acre-feet]

\begin{tabular}{|c|c|c|c|c|c|c|c|c|c|c|c|c|c|}
\hline Year & Jan. & Feb. & Mar. & Apr. & May & June & July & Aug. & Sept. & Oct. & Nov. & Dec. & Anneial \\
\hline $\begin{array}{l}1939 \\
1940 \\
1941 \\
1942 \\
1943 \\
1944 \\
1945 \\
1946\end{array}$ & $\begin{array}{r}22.6 \\
-.8 \\
23.1 \\
15.2 \\
15.3 \\
20.2 \\
25.4\end{array}$ & $\begin{array}{l}21.4 \\
-4.5 \\
20.8 \\
15.7 \\
16.8 \\
16.1 \\
23.5\end{array}$ & $\begin{array}{r}17.2 \\
8.6 \\
10.9 \\
14.2 \\
15.6 \\
21.4 \\
24.7\end{array}$ & $\begin{array}{r}19.0 \\
7.6 \\
3.1 \\
16.9 \\
12.6 \\
19.6 \\
24.2\end{array}$ & $\begin{array}{l}29.0 \\
12.3 \\
19.7 \\
17.0 \\
20.1 \\
21.1 \\
22.3\end{array}$ & $\begin{array}{r}7.5 \\
23.9 \\
-67.2 \\
11.2 \\
9.5 \\
9.1 \\
16.9\end{array}$ & $\begin{array}{r}13.3 \\
-29.4 \\
-9.6 \\
-13.9 \\
13.3 \\
-24.9 \\
11.6\end{array}$ & $\begin{array}{r}-8.2 \\
12.5 \\
23.6 \\
1.9 \\
8.7 \\
-11.3 \\
-.5\end{array}$ & $\begin{array}{r}-17.2 \\
-12.7 \\
6.3 \\
-6.0 \\
8.6 \\
-48.4 \\
-17.7\end{array}$ & $\begin{array}{r}19.7 \\
-14.9 \\
25.4 \\
4.3 \\
-17.7 \\
-2.0 \\
21.5\end{array}$ & $\begin{array}{r}18.6 \\
16.7 \\
20.7 \\
12.4 \\
16.5 \\
12.2 \\
20.1 \\
-.2\end{array}$ & $\begin{array}{l}19.8 \\
23.3 \\
22.3 \\
13.7 \\
11.2 \\
23.6 \\
26.4 \\
23.2\end{array}$ & $\begin{array}{r}164.3 \\
45.6 \\
82.2 \\
104.2 \\
138.6 \\
67.4 \\
174.9\end{array}$ \\
\hline
\end{tabular}

1 For period November 7-30.

Note. - Negative discharge indicates flow into Lake Okeechobee.

Table 35.-Runoff of West $P$ aln Beach Cenal a West $P$ alm Deach

[Unit, 1,000 acre-feet]

\begin{tabular}{|c|c|c|c|c|c|c|c|c|c|c|c|c|c|}
\hline Year & $\operatorname{Jan}$. & Feb. & Mar. & Apr & May & June & July & Aug. & Sept. & Oct. & Nov. & Dec. & Amnual \\
\hline $\begin{array}{l}1939 \\
1940 \\
1941 \\
1942 \\
1943 \\
1944 \\
1945 \\
1946\end{array}$ & $\begin{array}{r}46.0 \\
119.5 \\
52.3 \\
25.5 \\
29.4 \\
34.7 \\
39.2\end{array}$ & $\begin{array}{l}44.2 \\
94.2 \\
39.9 \\
23.1 \\
21.9 \\
21.4 \\
24.8\end{array}$ & $\begin{array}{l}46.6 \\
84.4 \\
56.5 \\
30.1 \\
25.6 \\
20.1 \\
32.3\end{array}$ & $\begin{array}{r}47.1 \\
89.7 \\
117.0 \\
22.8 \\
21.9 \\
11.6 \\
24.4\end{array}$ & $\begin{array}{l}41.8 \\
62.6 \\
61.0 \\
21.5 \\
26.4 \\
12.9 \\
51.6\end{array}$ & $\begin{array}{r}78.0 \\
46.1 \\
169.9 \\
23.0 \\
23.0 \\
28.1 \\
68.8\end{array}$ & $\begin{array}{r}60.2 \\
136.4 \\
90.2 \\
53.5 \\
27.4 \\
47.7 \\
68.5\end{array}$ & $\begin{array}{r}102.4 \\
93.1 \\
59.7 \\
51.5 \\
48.4 \\
44.8 \\
66.0\end{array}$ & $\begin{array}{r}161.7 \\
131.3 \\
77.8 \\
68.3 \\
48.6 \\
122.9 \\
128.1\end{array}$ & $\begin{array}{r}88.5 \\
132.3 \\
56.5 \\
89.4 \\
92.0 \\
128.9 \\
79.2\end{array}$ & $\begin{array}{l}52.2 \\
69.5 \\
71.2 \\
34.9 \\
58.1 \\
58.7 \\
64.7 \\
97.2\end{array}$ & $\begin{array}{l}42.1 \\
68.2 \\
49.1 \\
26.8 \\
35.1 \\
35.6 \\
37.1 \\
60.6\end{array}$ & $\begin{array}{r}854.2 \\
1,109.9 \\
842.5 \\
501.9 \\
459.9 \\
574.9 \\
740.7\end{array}$ \\
\hline
\end{tabular}

Note. - Lake Worth Drainage District furnished record of gate and lock openings and daily supplementary stage record. 
West Palm Beach

Stage: west of control, Nov, 1, 1939, to Dec. 31, 1946; continuous recorder graph; daily mean plotted in figures 96 and 97. Maximum: $10.33 \mathrm{ft}$, on Apr. 18, 1942 .

Minimum: $2.97 \mathrm{ft}$, on May 7,1941 .

Discharge: Nov. 1,1939 , to Dec. 31,1946 ; daily mean plotted in figures 96 and 97 ; monthly and annual runoff listed in table 35 . Maximum: daily mean, 5, $320 \mathrm{cfs}$, on Apr. 18, 1942. Minimum: daily mean, 124 cfs (leakage only), on May 1, 1945. Maximum known: 8,570 cfs, on Oct. 23, 24, 1924, computed from data by Everglades Drainage District.

Profile gages

Stages: at 10 locations from Canal Point to West Palm Beach, March 1944 to December 1946, about monthly. See figure 98 for typical profiles.

\section{Miscellaneous}

Discharge: at intermediate locations on the main canal and at many laterals, 1939 to 1946 ; occasional; usually in connection with special basin studies; see figure 98 for type of observations.

\section{FLOW CRARACTERISTCS}

Under low and moderate water conditions, West Palm Beach Canal is controlled as far as possible to satisfy a variety of needs, some of which conflict. During the winter and spring the extensive irrigation needs of the lake farming area require a relatively high canal level and a sizable amount of continuous recharge. This is met by releasing water from Lake Okeechobee at the Canal Point control at lake level. Part of the water moves down the canal for irrigation of land along the east half of the canal, particularly in the Lake Worth Drainage District. Except in anticipation, or as a result, of the infrequent heavy rains of that time of the year, the controlled laterals are usually closed. Flow in the larger uncontrolled laterals continues in small volume while most of the smaller ones are dry.

To satisfy the irrigation needs of Lake Worth Drainage District by gravity yia canal E-4 and Lake Osborn, the stage at the coastal control is maintained at about 8.5 to $9.0 \mathrm{ft}$. This stage provides gravity flow southward to some of the main east-west feeders where pumps lift the water for use on the higher lands of the subdistrict. Stages in excess of $9.0 \mathrm{ft}$ are detrimental to the inhabited areas of West Palm Beach adjacent to Stub Canal, and cause damage to small truck-farming operations in the mucky areas just west of the heavily settled areas. 
The two stage needs at the opposite ends of the canal require that it be operated at an appreciable slope, which is accomplished by releasing a sizable volume of water at the coastal control. Complete closure of the control to avoid this apparent waste in the dry months would result in excessively high stages, followed by local damage. Cutting off the inflow at the Canal Point end of the canal would cause excessively low stages in the upper reaches, with resultant crop loss and a possible soil loss because of dryness. Consideration is also given to keeping the unused lands along the middle reaches as wet as possible.

During the latter part of a normal spring, rainfall starts to increase and irrigation demand falls off sharply, except in the highersandy lands. The canals rise toward ground level, and the soils in the unused lands become saturated. In anticipation of, or during, heavy rains, most of the pumps are discharged at full capacity into the canal and are continued in operation until water levels in the diked areas are satisfactory for farming.

If the rains inundate the sand lands, the Lake Worth Drainage District controls along West Palm Beach Canal are opened and large volumes of water are dumped into the canal. This necessitates further opening of the main control at the coast, and occasionally the lock also is opened to act as a spillway. The runoff from the sand lands then has first demand on the early capacity of the canal and thus reduces the amount of runoff capacity available to the lands in the western part of the basin. In addition, heavy overland flow (originating on the higher lands north of the canal and west of Loxahatchee) sweeps down into the canal, where no spoil banks exist, or at the uncontrolled bridge openings in State Highway 80 . This inflow prevents the large pumped discharge west of Big Mound Canal from moving east, a water summit is established, and the stage in most of the western reach becomes higher than Lake Okeechobee. Flow is then established into the lake in a direction opposite to that existing prior to the rains. The water divide in the main canal has been observed as far as 1 mile east of 20-Mile Bend, a condition resulting from particularly heavy rainfall in the middle of the basin. Generally, however, the location of the divide is at or near Big Mound Canal, and the flow from that tributary has been observed to divide and flow both to the east and to the west for extended periods. Later, when overland flow from the north decreases, the watex summit may shift northwestward to the first large subdistrict pump. Still later, as outflow from both ends of the canal exceeds inflow, the divide moves farther westward until it disappears, and continuous flow to the east is reestablished.

In the meantime, the higher lands to the east drain more rapidly and may even take water for irrigation while the muck lands are still emerging from flood conditions. Then, most of the lower canal capacity is available for runoff from the west. However, it has 
been observed that changes of several feet in stage at the coastal control have very little effect on the discharge of the main canal at range line $41-42$, thus indicating that a controlling condition exists east of range line $41-42$ that prevents larger runoff from the west.

At higher stages, the low south bank east of 20-Mile Bend is subject to overflow from the canal for a distance of several miles. Thus, although the canal acts as a collecting channel, it is also a distributing agent; therefore, part of the old overland flow from northwest to southeast is reestablished across the line of the canal.

Cross Canal, at the intersection with West Palm Beach Canal at 20-Mile Bend, would ordinarily flow into the main canal under low and moderate water conditions, unless prevented by the control. In flood periods, the typical flow is strongly westward (then southward), and the control is sometimes opened to permit this measure of relief. State Highway 716, on the south bank of the west half of West Palm Beach Canal, is subject to overflow, under maximum flood conditions, for a distance of several miles east and west of Big Mound Canal.

Examination of the stage and discharge hydrographs, figures 96 and 97, will disclose a number of significant characteristics of West Palm Beach Canal. The stage of Lake Okeechobee was plotted from the weighted daily mean stage computed by the Corps of Engineers. The actual stage at Canal Point varied because it was affected by wind on the lake. The discharge graphs show a negative section, which is a device for indicating that flow in West Palm Beach Canal at Canal Point was into the lake. This reverse flow occurred 16.1 percent of the time in the period of record and ranged between 0 and 25 percent yearly.

Head on the Canal Point control exceeded $2 \mathrm{ft}$ only a small percentage of the time and was less than $1 \mathrm{ft}$ for extended periods. Large stage changes at the lower control often had no appreciable effect on stage at Canal Point. Perhaps the most striking feature of the graphs is the opposing relationship of the discharge at the two gaging stations-when discharge at the West Palm Beach station rose in response to rainfall or control changes, the discharge at Canal Point decreased or reversed itself; an opposite action took place during drought. In the first halves of the dry years, 1943-45, the discharge at both stations was very similar, thus indicating only a moderate gain or loss in discharge between them.

Note the stage-discharge relationship at West Palm Beach, AprilMay 1940.(and at other times). The stage dropped about $4 \mathrm{ft}$ because of control operation and rose sharply several weeks later. The discharge, however, did not vary to a great extent, except for the brief change at the time of the rise in mid-May. This is an out- 
standing example of the phenomenon observed frequently in Everglades canals - under conditions of uniform flow, changes in the crest elevation of a control often cause no significant change in the amount of flow. Once the stage adjusts to a stable condition (following control changes), the discharge stabilizes close to the rate that existed prior to the change. The canal basins thus have a relatively fixed drainage rate, within reasonable limits of operation-although this statement probably is valid for periods of moderate flow, it would not apply during periods of heavy runoff or during drought, when other factors would be involved.

West Palm Beach Canal, the shortest of the four major canals in the Everglades, was not completed as planned; however, it is the largest water carrier. Tables 34 and 35 list the monthly and annual runoff, in thousands of acre-feet, at Canal Point and West Palm Beach, respectively. The average annual discharge for the period 1940-46 was 726,100 acre-ft at the coastal control (West Palm Beach) - an average flow of $1,003 \mathrm{cfs}$, two to three times as great as the flow of any of the other canals. The average annual discharge at Canal Point, 111,000 acre-ft, represents net flow from the lake into the west end of the canal, which makes an overall net runoff of 615,100 acre-ft from the canal basin. This apparent reduction of runoff capacity by diversion from the lake is mitigated by the fact that in high-water periods and with low-enough lake stages, the flow reverses and runs strongly into the lake at rates two to three times greater than the typical flow toward the eastthus causing a maximum discharge condition of flow from both ends of the canal during the more critical periods.

\section{SPECIAL STUDIES}

Special studies of West Palm Beach Canal consisted principally of areal studies of inflow from tributaries and discharge increase in the main canal. A few other studies were made-some of these studies covered too short a period of time to be conclusive by the end of 1946 .

\section{INFLOW AND PROFILE}

A hurricane moved up the center of Florida on a northerly course on September 15, 16, 1945. The storm caused about 5 in. of rain in the West Palm Beach Canal basin, which, added to previous sizable rains, caused the high-water conditions shown in figure 98. By September 22 (the date of the study), peak stages in the eastern half of the basin had passed, and a recession had startedmost of the lateral inflows probably were less than those that occurred a few days earlier. In the western half of the canal, however, water levels were still rising, and near-peak stages were observed. 


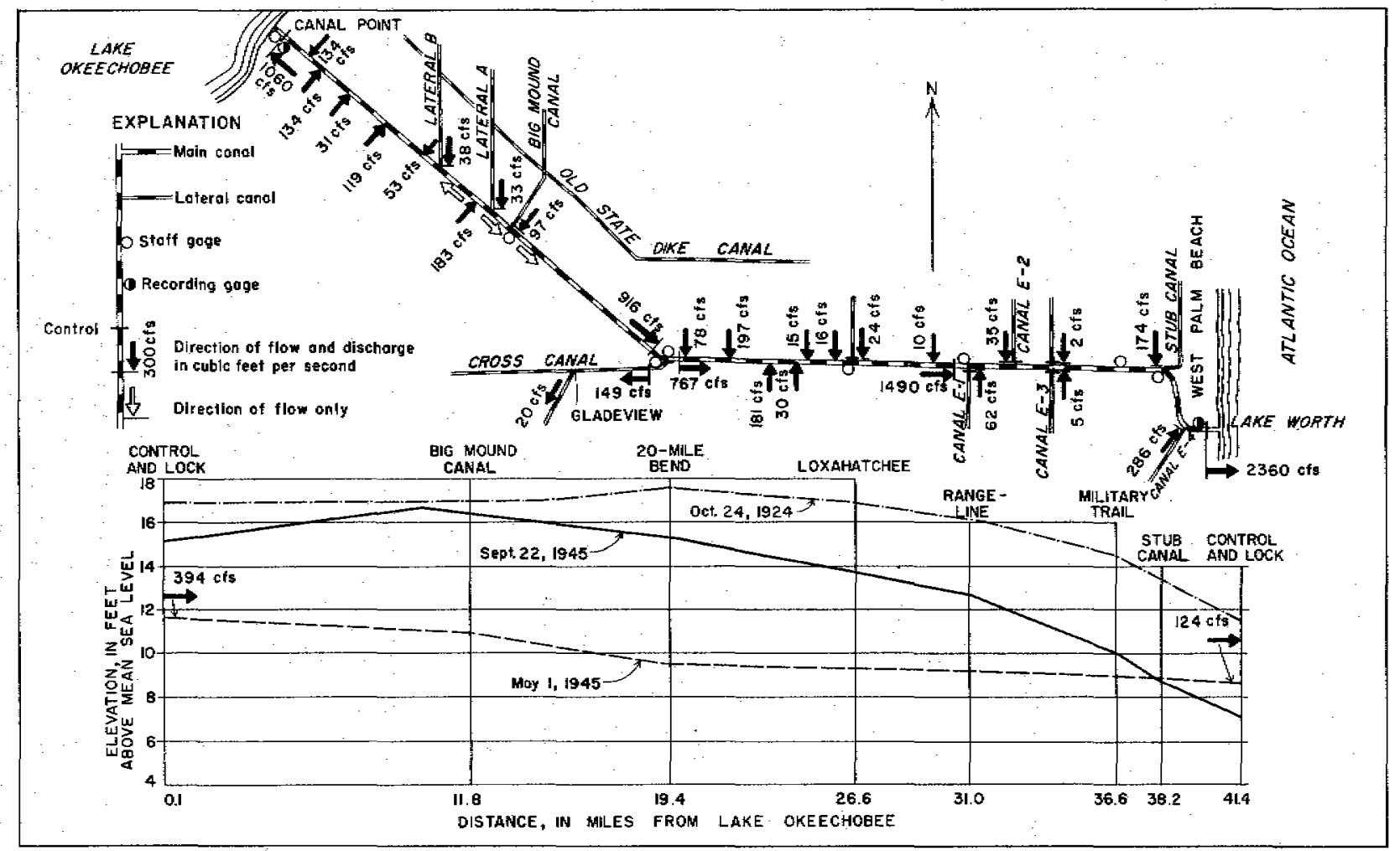

Figure 98. - Runoff pattern and stage profile of West Palm Beach Canal on September 22, 1945; flood condition following near-passage ot a hurricane. 
The inflows, shown along the western half of the canal, were from pump installations, except for the flows from the three laterals on the north side. The high point in the stage profile (the water summit) was between Laterals $A$ and $B$, where the discharge from a large drainage subdistrict pump was divided. The flow at Canal Point was strongly into Lake Okeechobee; furnishing the anomalous situation (common to the Everglades) of a canal discharging at both ends.

The difference between the $916 \mathrm{cfs}$ in the main canal at 20-Mile Bend and about $220 \mathrm{cfs}$ inflow from laterals east of the water summit indicates about $700 \mathrm{cfs}$ of discharge increment (pickup) in the reach. This large increase in canal discharge is a measure of the unimpeded overland inflow from the north (p. 349). Some relief was afforded by the outflow into Cross Canal, but this was offset by the two large uncontrolled inflows from the north, just east of 20-Mile Bend.

The inflows from Stub Canal and Canal E-4 show the sizable proportion of the discharge at the control and lock that can originate close to the coast-about 20 percent in this case. The larger part of the discharge of Stub Canal likely was overflow from Clear Lake, which is located several miles to the north.

The water-surface profile for May 1, 1945, shows the comparative condition of a low-water period. Slopes were flat and were below the surface of the ground at all locations. Only about onethird of the water released from Lake Okeechobee reached the coastal control; the remaining two-thirds was pumped out of the canal for irrigation or seeped out in areas where the canal stage may have been higher than the adjoining ground-water stage. Also shown is the highest profile known, which is that of October 24, 1924.

DISCHARGE AT RANGE LINE $41-42$

West Palm Beach Canal at range line $41-42$ is considered an intermediate key location in evaluating the flow characteristics of the canal. The station is at the west edge of Lake Worth Drainage District, and the discharge, as measured just above Canal E-1, originates in the Everglades proper, plus runoff and seepage from the intervening sand lands. Most of the flow increment east of the station originates in Lake Worth Drainage District.

The daily mean stage at the coastal control was plotted in figure 99 , with the daily stage reading at Loxahatchee. The several miscellaneous stage readings at range line $41-42$ show that the stage at Loxahatchee, 4.4 miles to the west, is valid as a general reference for range line 41-42. This graph demonstrates that the stage at range line $41-42$ was not affected by large changes of stage at the coastal control. 

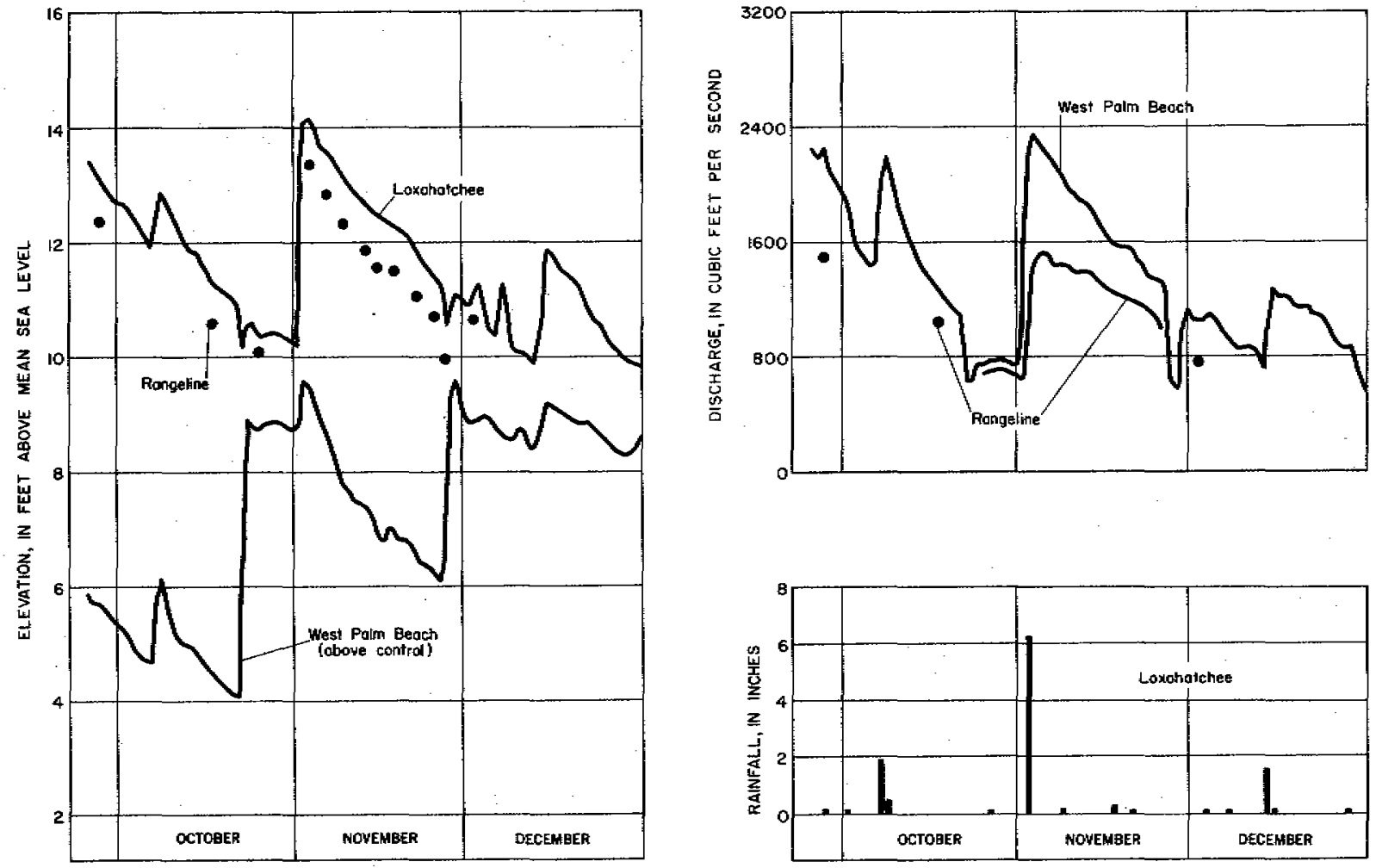

Figure 99. - Graph of stage and discharge in the eastern one-third of West Palm Beach Canal, October-December 1946. 
Figure 99 also shows the discharge at the coastal control and at range line 41-42 plotted above the significant daily rainfall at Loxahatchee. The rainfall-discharge relationship is evident. The marked similarity between the two discharge graphs and the stage at Loxahatchee, and the dissimilarity with the stage at the control, suggest that water events, in periods of moderate to high flow in the lower West Palm Beach Canal basin, are considerably independent of the operation of the control.

\section{HILLSBORO CANAL}

\section{PHYSical description}

Hillsboro Canal heads at the south end of Lake Okeechobee and extends, in a series of straight reaches, in a generally southeasterly direction to the coast at Deerfield Beach-a total length of 51 miles. It lies principally in the area known as the "upper Glades" and may be roughly divided into three sections. Plate 14 shows the general features of the basin.

The first section cuts across the heart of the winter producefarming area of the Everglades and extends from the lake to Shawano. This 18-mile reach was dug in deep (as much as $12 \mathrm{ft}$ ) organic soils; some of the most fertile land is in this area. The canal connects with Lake Okeechobee through the protective levee at a hurricane gate (HGS-4), a few hundred yards west of the junction with North New River Canal. At Chosen, $1 \frac{1}{2}$ miles to the east, the control and lock is in poor condition and has not been used since 1939 (at least). The control and lock is kept open and causes essentially no interference with flow. Nearby, a large pump of the South Florida Conservancy District has a considerable effect on water movement in the main canal. Nine miles from the lake is 6-Mile Bend and the junction with the westernend of Cross Canal, which connects with West Palm Beach Canal at 20-Mile Bend, 13 miles to the east by canal.

About 1 mile southeast of 6-Mile Bend, a junction is made with Bolles Canal, which extends to the west and connects with both the North New River and the Miami Canals. The culverts connecting Bolles Canai to Hillsboro Canal are relatively small and have been so completely obstructed in recent years that flow through them has been negligible.

Shawano is the center of operations in Brown Drainage District and is the eastern limit of development along the upper Hillsboro Canal. From Belle Glade to Shawano, many farms pump directly into, or from, the canal. Until 1948, the banks were continuous from the lake to a point about 4 miles southeast of 6-Mile Bend; beyond 6-Mile Bend a bank existed only on the southwestern side 
to the end of the development at Shawano. In 1948, the nor theastern bank was extended to Shawano. State Highway 80 runs along the southern bank from Belle Glade to 6-Mile Bend, and the canal is accessible by road from close to the lake to Shawano. The Everglades Experiment Station is located on the southern side of the canal, 2.5 miles east of Belle Glade.

The second, or middle, section of Hillsboro Canal comprises the reach southeast from Shawano to Elbow Bend and the reach continuing on an easterly course to the edge of the Everglades proper, about 4 miles west of Equalizing Canal No. 1. The area crossed by this reach of the canal is uninhabited and undeveloped, and it is one of the least accessible parts of the Everglades. Shawano is on the western edge of a large open area covered, for the most part, with the well-known Loxahatchee peat-one of the more extensive soils of the Everglades (Florida Agr. Exper. Sta., 1948, p. 62-70), noted for its instability for travel by foot or vehicle.

Several natural streams enter Hillsboro Canal from the north near Elbow Bend. Two miles east of the Bend is Indian Run, a natural tributary that connects with the Hillsboro Lakes area (see pl. 12). Late in 1943, the U. S. Soil Conservation Service constructed an adjustable control in Indian Run at the line of the north spoil bank of the canal. Another control, with fixed crest, was built in Gandy Run, 1 mile farther east.

The Hillsboro Lakes area, or Hillsboro Marsh, is a wild region, which is normally wet, and which includes some perennial lakes. The innumerable small islands and interconnecting sloughs make this region well suited to wildlife preservation. However, it is also important to the water regimen of the Hillsboro Canal basin as a storage reservoir. Here, the Loxahatchee peat is in a semiliquid state, and the area can be traveled only by shallow-draft boats, which usually are driven by airplane propellors.

From a point about 4 miles northwest of Elbow Bend, to a point $\frac{1}{2}$ mile east of the bend, Hillsboro Canal never was completed as planned. The muck and some rock were removed from the southwest half of the channel; in the northeast half, only the muck was excavated, thus making an inefficient channel section. The banks are discontinuous in this reach, particularly in the vicinity of Elbow Bend, thus affording flow-ways across the line of the canal. East of Elbow Bend, the banks are high and continuous, except for four breaks in the north bank, three of which were closed in the period of observation. A very poor road has been leveled along the top of the high south spoil bank from the edge of the farm lands on the east to near Elbow Bend.

The third, or eastern, section of Hillsboro Canal reaches from the eastern edge of the Everglades to the coast. The canal enters 
higher sandy land 3 miles west of Equalizing Canal No. 1, and the south bank is farmed along the 3-mile reach. About six farm pumps furnish water for irrigation or frost control, but drainage is principally by gravity. A poor road runs parallel with the south spoil bank.

State Highway 7 is on range line $41-42$, which marks the western boundary of Lake Worth Drainage District. Equalizing Canal 1 enters Hillsboro Canal from the north and extends northward along the east side of the highway to connections with Boynton Canal and with West Palm Beach Canal. A 20,000-gpm pump, installed in 1944 to replace an older pump, supplies water to Canal E-1 for irrigation of the high sands lands of the district. Gravity drainage into Hillsboro Canal is regulated by a control. A similar lateral canal extends southward along State Highway 7 to Cypress Creek Canal. Irrigation pumps, with a total capacity of about $80,000 \mathrm{gpm}$, can furnish water to this lateral.

Two miles east of State Highway 7, Canal E-2 connects from the north. Canal E-2 was extended $\frac{1}{2}$ mile south to this location in 1944 , and a 40,000-gpm pump was installed, replacing two pumps with a combined capacity of about $8,000 \mathrm{gpm}$. Several other pumps are located in the reach from State Highway 7 to the control and lock, $4 \frac{1}{2}$ miles to the east.

The control and lock, which is typical of the older structures (see fig. 91), is the discharge point for Hillsboro Canal. At times, head on the control may be as much as $12 \mathrm{ft}$. Tide effect extends inland to the control under all conditions, except during floods, occasionally, tide effect has been observed above the control when it was open at low stages. Canal E-3 connects from the north, 1/10 mile east of the control. Canal E-4 enters from the north, just west of the Florida East Coast Railway bridge.

Hillsboro Canal follows the meandering course of a natural stream in its lower 2 miles and ends in Deerfield Beach at the Hillsboro River (now canalized for the Intracoastal Waterway). Flow from the mouth of the canal moves in the waterway, either north 2 miles to Boca Raton Inlet, or south 4 miles to Hillsboro Inlet, and joins the sea. There is limited access to the canal, east of State Highway 7 , by means of occasional connections from State Highway 810 , which runs parallel with, and about $\frac{1}{2}$ mile south of, the canal.

The following tabulation lists the principal features along Hillsboro Canal, with cumulative mileage from Lake Okeechobee. 
Centerline of lake levee and HGS $-4 \ldots \ldots \ldots \ldots \ldots \ldots \ldots \ldots \ldots \ldots \ldots, 0$

Junction with North New River Canal........................... . 2

Control and lock, Chosen........................................ 1. 5

Bridge, F. E. C. Railway..................................... 2.5

Bridge, State Highway 15, Belle Glade (gaging station)....... 3.2

6-Mile Bend; junction with Cross Canal....................... 9.4

Bolles Canal. ......................................................... 10. 5

Shawano, bridge................................................. 17. 1

Elbow Bend................................................... 31.7

Indian Run........................................................ 34. 1

Bridge, Canal E-1, State Highway 7, range line 41-42,..... 42. 7

Canal E-2....................................................44. 8

Control and lock (gaging station) ...........................47.4 4

Canal E-3..................................................... 47. 5

Bridge, Seaboard Railway....................................... 48.0

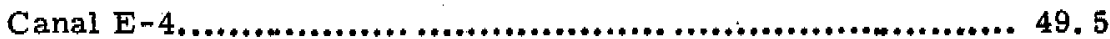

Bridge, F. E. C. Railway................................... 49.7

Bridge, U, S. Highway 1.................................... 50.3

Hillsboro River and Intracoastal Waterway.................. 51.2

\section{RECORDS AVAM.ABĹE}

[Records continued after period of this investigation]

Belle Glade

Stage: May 11, 1940, to Dec. 31, 1946; continuous recorder graph; daily mean plotted in figures 100 and 101 .

Maximum: $17.48 \mathrm{ft}$, on Sept. 26, 1940.

Minimum: $10.78 \mathrm{ft}$, on June $19,1945$.

Discharge: Jan. 11, 1940, to Dec. 31, 1946; daily mean plotted in figures 100 and 101 ; monthly and annual runoff listed in table 36.

Maximum; 481 cfs to east, measured, on Feb. 14, 1940. 289 cfs to west (toward lake), measured, on Sept. 9, 1940. Periods of no flow are common at times of reversal of flow. Shawano

Stage: Jan. 1. 1929, to Dec. 31, 1946; gage read once daily; daily mean stage plotted in figures 100 and 101 ; monthly mean plotted on figure 102 .

Maximum observed: $16.19 \mathrm{ft}$ on June 23, 24, 1930.

Minimum observed: $8.73 \mathrm{ft}$ on May 4, 1945.

Deerfield Beach (near)

Stage: west of control, Nov. 1, 1939, to April 14, 1940; gage read once daily; daily mean stage plotted in figures 100 and 101. 

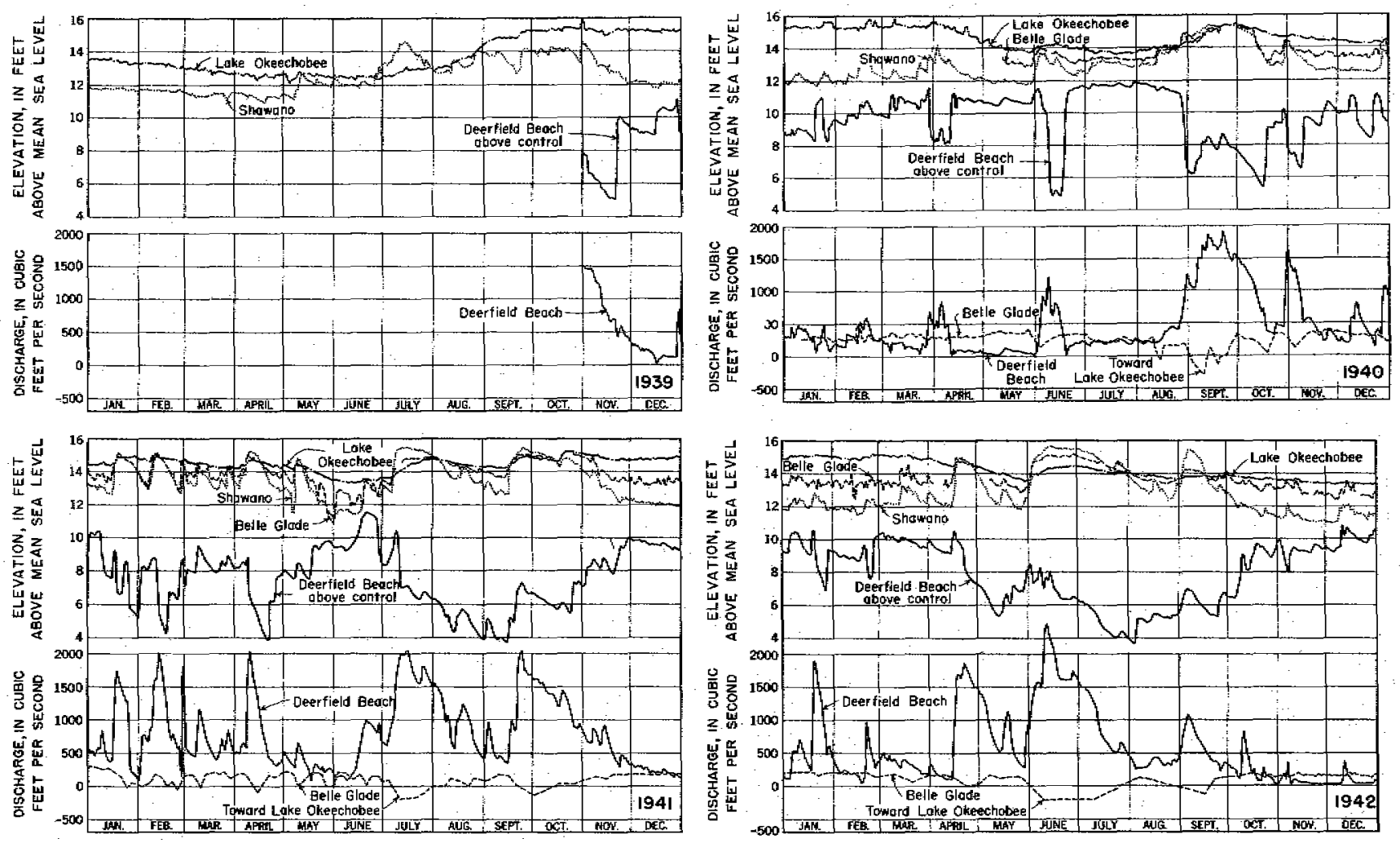

Figure 100. -Graphs of stage and discharge of Hillsboro Canal, 1939-42. 

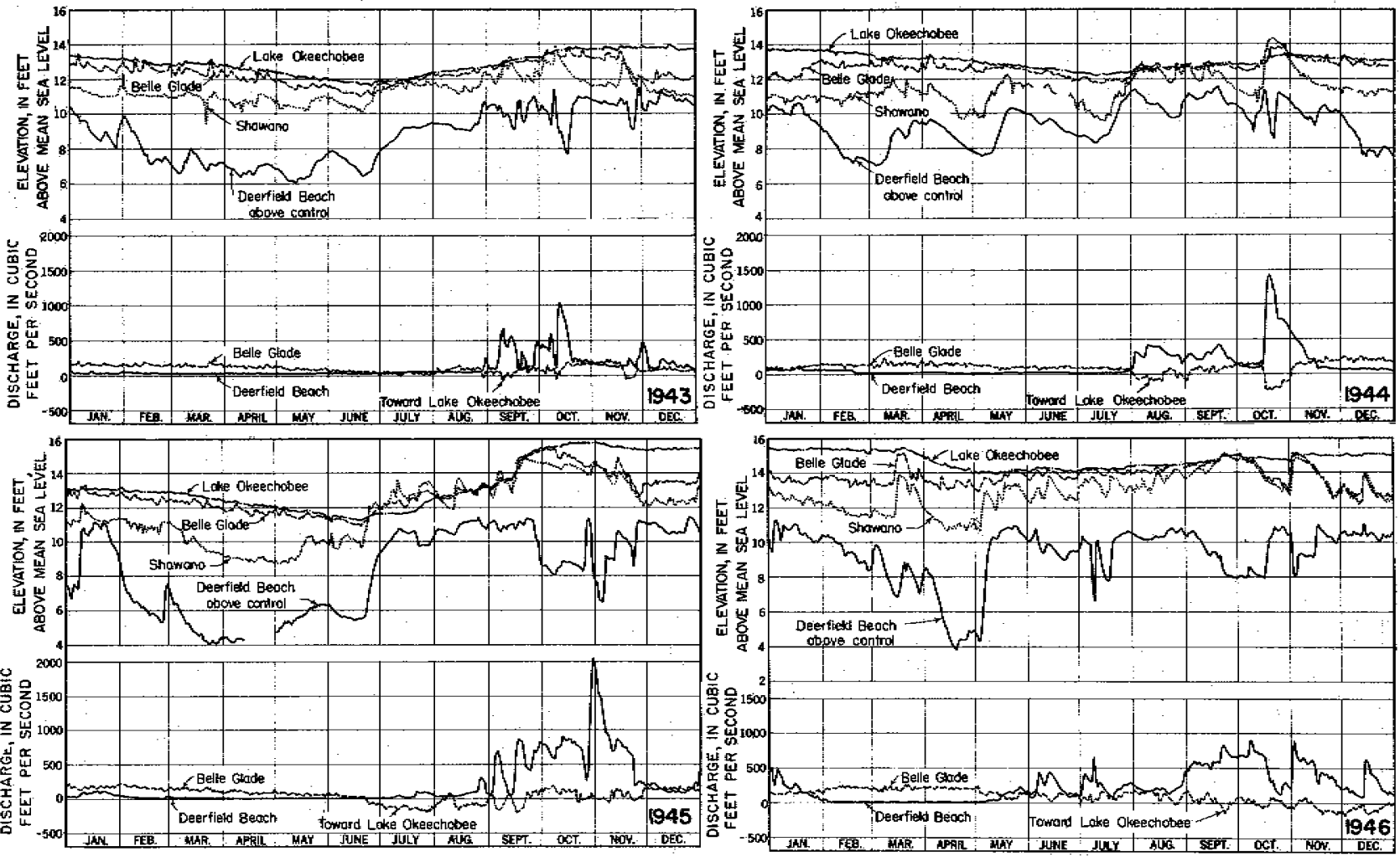

Figure 101. -Graphs of stage and discharge of Fillsboro Canal, 1943-46. 
[Unit, 1,000 acre-feet]

\begin{tabular}{|c|c|c|c|c|c|c|c|c|c|c|c|c|c|}
\hline Year & Jan. & Feb. & Mar. & Apr. & May & Jure & July & Aug. & Sept. & Oct. & Now. & Dec. & Annual \\
\hline $\begin{array}{l}1940 \\
1941 \\
1942 \\
1943 \\
1944 \\
1945 \\
1946 \\
\end{array}$ & $\begin{array}{r}17.0 \\
10.4 \\
12.3 \\
9.9 \\
6.2 \\
10.9 \\
8.8 \\
\end{array}$ & $\begin{array}{r}16.5 \\
3.0 \\
10.2 \\
9.0 \\
7.9 \\
9.4 \\
11.8 \\
\end{array}$ & $\begin{array}{r}19.6 \\
9.2 \\
8.3 \\
9.2 \\
9.2 \\
8.5 \\
12.6 \\
\end{array}$ & $\begin{array}{r}17.3 \\
6.2 \\
5.5 \\
7.9 \\
9.1 \\
5.9 \\
12.2 \\
\end{array}$ & $\begin{array}{r}21.8 \\
7.4 \\
6.9 \\
6.1 \\
6.5 \\
6.4 \\
4.4 \\
7.4 \\
\end{array}$ & $\begin{array}{r}17.0 \\
8.0 \\
-10.4 \\
3.8 \\
5.6 \\
.5 \\
6.5 \\
\end{array}$ & $\begin{array}{r}14.8 \\
-5.2 \\
-6.7 \\
2.5 \\
4.8 \\
-8.0 \\
6.0 \\
\end{array}$ & $\begin{array}{r}9.5 \\
3.7 \\
3.2 \\
5.3 \\
-1.8 \\
-3.8 \\
6.8 \\
\end{array}$ & $\begin{array}{r}0 \\
3.4 \\
-.3 \\
3.9 \\
4.1 \\
-1.2 \\
1.7 \\
\end{array}$ & $\begin{array}{r}14.2 \\
-.1 \\
9.7 \\
7.4 \\
-.9 \\
5.3 \\
1.0 \\
\end{array}$ & $\begin{array}{r}17.6 \\
8.7 \\
9.4 \\
7.2 \\
9.7 \\
2.5 \\
-2.8 \\
\end{array}$ & $\begin{array}{r}18.4 \\
11.1 \\
9.5 \\
5.2 \\
12.4 \\
8.7 \\
-4.1 \\
\end{array}$ & $\begin{array}{r}183.7 \\
65.8 \\
57.6 \\
77.4 \\
72.8 \\
43.1 \\
67.9 \\
\end{array}$ \\
\hline
\end{tabular}

Note. - Negative discharge indicates flow toward Lake Okeechobee.

Table 37.-Rumoff of Hillsboro Canal noer Devrfield Beach

[Unit, 1,000 acre-feet]

\begin{tabular}{|c|c|c|c|c|c|c|c|c|c|c|c|c|c|}
\hline Year & Jan. & Feb. & Mar. & Apr. & May & June & July & Aug. & Sept. & Oct. & Nov. & Dec. & Annual \\
\hline $\begin{array}{l}1939 \\
1940 \\
1941 \\
1942 \\
1943 \\
1944 \\
1945 \\
1946\end{array}$ & $\begin{array}{r}18.1 \\
44.9 \\
40.9 \\
2.8 \\
4.7 \\
4.6 \\
12.9\end{array}$ & $\begin{array}{r}17.9 \\
57.6 \\
16.5 \\
2.1 \\
2.6 \\
1.3 \\
.6\end{array}$ & $\begin{array}{r}13.2 \\
38.6 \\
20.3 \\
1.9 \\
1.2 \\
1.0 \\
.5\end{array}$ & $\begin{array}{r}13.7 \\
47.7 \\
52.6 \\
-2.0 \\
1.4 \\
.3 \\
.4\end{array}$ & $\begin{array}{r}3.4 \\
20.7 \\
46.9 \\
2.1 \\
1.4 \\
.4 \\
5.9\end{array}$ & $\begin{array}{r}26.1 \\
29.8 \\
103.4 \\
2.2 \\
1.5 \\
19.5\end{array}$ & $\begin{array}{r}13.4 \\
94.8 \\
55.6 \\
3.1 \\
1.7 \\
2.7 \\
15.6\end{array}$ & $\begin{array}{r}24.8 \\
58.6 \\
20.7 \\
4.2 \\
18.2 \\
5.0 \\
13.1\end{array}$ & $\begin{array}{l}92.5 \\
60.3 \\
34.8 \\
16.8 \\
15.9 \\
27.8 \\
36.5\end{array}$ & $\begin{array}{l}53.2 \\
79.7 \\
13.9 \\
25.2 \\
32.2 \\
51.5 \\
30.8\end{array}$ & $\begin{array}{r}53.0 \\
36.2 \\
36.0 \\
4.2 \\
10.6 \\
12.6 \\
44.4 \\
28.8\end{array}$ & $\begin{array}{r}12.9 \\
29.1 \\
14.2 \\
4.2 \\
10.0 \\
3.5 \\
9.7 \\
15.0\end{array}$ & $\begin{array}{r}341.6 \\
582.9 \\
414.0 \\
83.0 \\
96.9 \\
149.2 \\
173.1\end{array}$ \\
\hline
\end{tabular}


April 15, 1940, to Dec. 31, 1946; continuous recorder graph; daily mean plotted in figures 100 and 101 .

Maximum: 12.10-ft, on Oct. 17, 1944.

Minimum: 3.50 ft, on Apr. 21, 1941.

Discharge: Nov. 1, 1939, to Dec. 31, 1946; daily mean, plotted in figures 100 and 101 ; monthly and annual runoff listed in table 37.

Maximum daily mean: $2,460 \mathrm{cfs}$, on June 11, 1942. No flow, on Dec. 16, 1939, Apr. 11, June 18, 1940.

Miscellaneous

Discharge: at intermediate locations on the main canal and at many laterals, 1931 to 1946; occasional; usually in connection with special studies; see figure 98 for type of observations.

\section{FLOW CIAARCTEHSTYCS}

Because of the restricted channel in the middle reaches, the control of Hillsboro Canal is effected almost separately for the lake and coastal sections. The control and lock west of Belle Glade is in poor condition and has been open for the entire period of observations. One of the limited control operations has been the occasional closing and partial closing of the hurricane gate (HGS-4) in the protective levee "around Lake Okeechobee. Hillsboro Canal makes a junction with North New River Canal, and it also is affected by the control and lock in North New River Canal at South Bay. Another control factor, of equal importance, has been the operation of the two large pump installations of South Florida Conservancy District-one in each canal. The discharge from each of the pumphouses often divides at the pump and flows both towards the sea and towards the lake. Because the two canals join and have a common connection to the lake, the directions of flow in the reaches near the pumps and the junction of the canals can be a combination of several possibilities. When both pumps are operating, flow at HGS-4 is usually into the lake.

When rainfall necessitates heavy pumping along upper Hillsboro Canal, a water summit may occur in the reach between Belle Glade and 6-Mile Bend. Flow becomes sluggish, and as the canal stage increases, the amount of seepage returning to the fields may become significant.

Prior to the construction of the control at the east end of Cross Canal in 1944, flow was generally to the nor theast into Cross Canal from Hillsboro Canal at 6-Mile Bend. In the spring of 1943, this flow ranged from 60 to 95 cfs which was about 65 percent of the flow at the Belle Glade gaging station, but which probably wa's considerably less than the maximum flow into Cross Canal. After the eastend control was built, flow of Cross Canal was generally into Hillsboro Canal at 6-Mile Bend. Water summits also were observed in Cross Canal as a result of pumping and control manipulation. 
The water does not rise out of the banks of Hillsboro Canal west of 6-Mile Bend, although there have been high-water periods when emergency dike repairs were necessary. Southeast of 6-Mile Bend the road and dike on the southwest side are subject to shallow inundation. In the Shawano area the nor theast bank becomes inundated at moderately high stages, and the canal water spreads out freely overland; at times, the canal acts as an interceptor of overland flow from the north. In either case, however; water slopes become extremely flat, and no large effective flow occurs in the canal. It is this lack of flow capacity to the east that causes water in the area east of Belle Glade to become essentially stagnant in flood periods.

In periods of low and moderate water levels, flow in the reach of Hillsboro Canal and Shawano to Elbow Bend is small. Because of the small channel and excessive weed conditions, very little flow is possible; during periods of extreme drought, essentially no flow occurs (this was observed in 1944). In the vicinity, and east, of Elbow Bend, a considerable amount of inseepage from the north is. obtained from the Hillsboro Marsh area.

Under high-water conditions, the effectiveness of Hillsboro Canal is reduced considerably by the discontinuous spoil banks in the middle reaches. Overland flow from north to south can enter and leave the canal through breaks in the banks, and it cannot be stated positively that any water from the Belle Glade area actually reaches the sea via the canal. However, some flow continues east from the Elbow Bend area, whatever the source.

The several pumps for irrigation along the lower reaches of Hillsboro Canal have a combined capacity of about $280 \mathrm{cfs}$ (1946). The daily pumping in dry seasons causes the canal stage to drop at an excessive rate. (See p. 373. )

East of Elbow Bend, the canal is within its banks at all stages, although one break in the north bank and several low spots in the south bank permit inflow and outflow in high-water periods. When heavy rain threatens or occurs, the controls in Canals E-1 and E-2 are opened, and a large runoff load is suddenly imposed on the canal. The control near Deerfield Beach is opened or closed in response to the needs of the area, and the lock is opened under flood conditions to act as a spillway. Because it is constructed in sand, the control is vulnerable to possible washouts around the ends, and efforts are made to keep the stage below $12 \mathrm{ft}$ (the top of the structure is a little higher than $13 \mathrm{ft}$ ).

When the control and lock are both wide open under flood conditions, the stage drop through the structure may be only a few tenths of a foot. Then the stage and flow are controlled by the discharge limitations of the canal and other structures farther downstream in the normally tidal reach. 
Examination of the stage and discharge hydrographs, figures 100 and 101, will disclose a number of significant characteristics of Hillsboro Canal. The stage at Belle Glade in most of the years of record had a range of only about $2 \mathrm{ft}$; the greatest change within a year was $4 \mathrm{ft}$ in the period of recovery from the extreme drought condition in 1945. This stage reacted with general water conditions and was affected relatively little by control operations. The relationship to Lake Okeechobee, which also reacts slowly, probably was the principal factor in the stage regimen.

It will be noted that the stage at Shawano of ten was close to the stage at Belle Glade, but in the dry-spring periods the stage difference was greater (exceeding $3 \mathrm{ft}$ at times). This relatively steep slope reflects the pumping for irrigation and the limited capacity of the canal to convey water.

Records of water levels in the Everglades are extremely useful in showing the nature and the trends in water conditions over the immediate surrounding area. When such a record is collected on a canal, the stages usually are representative of a large area. For this reason, the record of daily stage of Hillsboro Canal at Shawano, collected since January 1, 1929, is worthy of special attention because it is the longest continuous period of record known in the Everglades. The daily readings for $1939-46$ are shown in figures 100 and 101, and the monthly mean stages for the period of record, 1929-46, are plotted in figure 102. Note the typical large rise each year in the summer or fall, except in 1931, and the small rises in 1943 and 1944. The extreme low that occurred in 1945 is outstanding, particularly because of the fact that the ground surface at Shawano was about $15 \mathrm{ft}$ above mean sea level. This was at the trough of the 3-year drought that ended in 1945. The lowest individual reading was $8.73 \mathrm{ft}$.

Stage changes at the control and lock near Deerfield Beach were considerably larger than changes near the lake, as might be expected, because of control operations. The typical annual stage range was 6 to 7 feet, and changes of several feet in a few days were common. Comparison of the graphs (fig. 100 and 101) will show that extensive stage changes at Deerfield Beach had little or no effect on stage at Belle Glade. The steep declines at Deerfield Beach, shown in the spring of the year, beginning with 1943, were caused by heavy pumping for irrigation; an inspection of the discharge graphs for those periods reveals that discharge at the control was small-actually, it was all leakage.

The discharge graphs at Belle Glade and Deerfield Beach tend to oppose-one graph rose when the other fell-although this effect was not pronounced because of the relatively small discharge at Belle Glade. ${ }^{7}$ The effect of the several dry years starting in 1943

\footnotetext{
${ }^{7}$ Compare with discharge of West Palm Beach Canal, figures 96 and 97.
} 


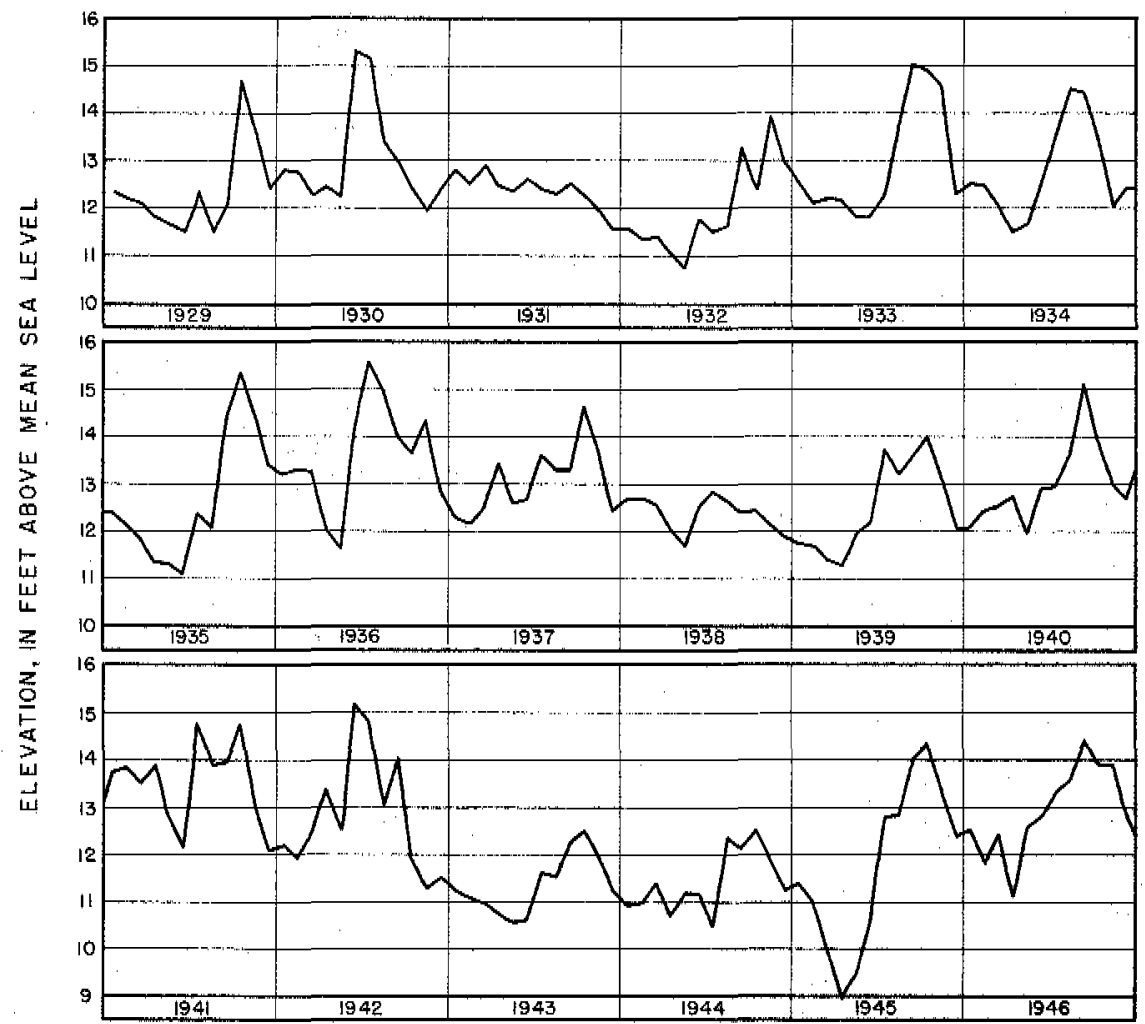

Figure 102. - Graph of mionthly mean stage of Hillsboro Canal at Shawano, 1929-46.

and the realization of the poor carrying capacity of the middle reaches of Hillsboro Canal is reflected in the discharge graph for Deerfield Beach for the spring periods. In the drought years 194345 , discharge was kept to a minimum and no water was purposely released to the sea. However, although 1946 was a relatively normal year, no water was released until the first heavy rains (early in May). This compares with prior years, when. large quantities of water were released in the spring.

Discharge of Hillsboro Canal at Belle Glade was not large at any time, ranging between $481 \mathrm{cfs}$ to the southeast and $289 \mathrm{cfs}$ toward Lake Okeechobee. Flow toward the lake is shown on the discharge graphs as a negative value below the zero line. Reverse flow occurred 10.0 percent of the time and ranged between 1.4 and 25.0 percent yearly. The net flow, however, was to the southeast, and it averaged 81,200 acre-ft yearly. An unknown volume of this water came from the lake. The monthly and annual runoff is listed in table 36.

The average annual runoff to the sea at Deerfield Beach was 262,900 acre-ft, an average of $363 \mathrm{cfs}$, which was the least amount of any of the four major Everglades canals. Table 37 shows the 
monthly and annual runoff. Most of this runoff entered the canal in the eastern half; only a small part originated in the Lake Okeechobee area and moved eastward in the canal proper. Operation of the control and lock near Deerfield Beach caused a wide range of discharge rates (depending upon need imposed by general water conditions). In many dry periods, the control was closed to conserve water and the flow then consisted of leakage only.

\section{SPECIAL GTUDIES}

Special studies in the Hillsboro Canal basin were sometimes part of the large studies covering the Everglades in general, which are reported in a later section of this chapter under Areal studies, page 509 .

\section{PUMPING IN LOWER REACHES}

One of the special studies of Hillsboro Canal was the evaluation of pumping along the lower reaches, in 1944. More than a dozen pumps are used for irrigation of the high sand lands bordering the canal, and the demand is greatest in the late winter and early spring, when conditions ordinarily are dry. Occasionally, a large amount of water is pumped to raise levels in truck-farming areas for frost prevention. Most of the pumping is intermittent and usually occurs in the daylight hours. Daily drawdowns of the canal level, as observed above the control and lock near Deerfield Beach, were as much as 0.6 to $0.8 \mathrm{ft}$. Recovery during the night was about 0.4 to $0.6 \mathrm{ft}$, thus causing a net daily loss of about $0.2 \mathrm{ft}$. This rate continued for several weeks and resulted in excessive drawdown, which forced some of the pumps to stop, because the water level declined below the ends of the intakes.

The capacity of the pumps was evaluated at about $280 \mathrm{cfs}$. It may be assumed that the pumps ope rated about 9 hours a day at full capacity, thus averaging $105 \mathrm{cfs}$ per day. The net storage change in the 16mile reach $(90 \mathrm{ft}$ wide, from the control to the constriction at Elbow Bend), for a decline of $0.2 \mathrm{ft}$, would amount to an average removal of $17 \mathrm{cfs}$. Therefore, about $88 \mathrm{cfs}$ was obtained from other sources. Because about $50 \mathrm{cfs}$ may have been coming from the constricted middle reaches of the canal, the remainder ( $38 \mathrm{cfs}$ ) must have been obtained by seepage. Most of the seepage probably came from the Hillsboro Marsh, on the north side of the canal west of the farming area. The marsh plays an important part in the water economy of the lower Hillsboro Canal, and its capacity and limitations as a storage basin must be considered in plans for further development. Excessive pumping from the canal would deplete the storage in the marsh and would shorten the period that it can effectively provide irrigation supplies. The salient fact emerges that Hillsboro Canal, 
in its present condition, cannot supply sufficient water for the irrigation needs of the lower basin-this fact was emphatically demonstrated in the drought of 1943-45.

\section{SEEPAGE IN TIDAL REACH}

An evaluation was made, December 10, 1944, of the ground-water inflow into Hillsboro Canal between the control and lock near Deerfield Beach and the Dixie Highway bridge-a reach of 2.4 miles. The several intermediate lateral canals were inspected and were found to have only negligible amounts of flow; low-water conditions prevailed, and the controls in the laterals were closed. The discharge at the control and lock was 290 cfs on the day of the study. Because the canal was affected by tide below the control, resulting in a constant change in the amount of flow in the tidal reach, it was necessary to make a series of discharge measurements over a tide cycle at Dixie Highway. The discharge hydrograph is shown in figure 103. The mean discharge for the tide cycle was $388 \mathrm{cfs}$, which puts the variable flow in the tidal reach on a basis comparable to the relatively steady nontidal flow of $290 \mathrm{cfs}$ at the control. The difference between the two discharges, $98 \mathrm{cfs}$, represents the ground-water inflow in the tidal reach. Surface inflow was negligible, and, although the data are subject to moderate degrees of error, it may be stated that the 98 cfs represents a fair evaluation of the inseepage. The rate was $41 \mathrm{cfs}$ per mile of canal.

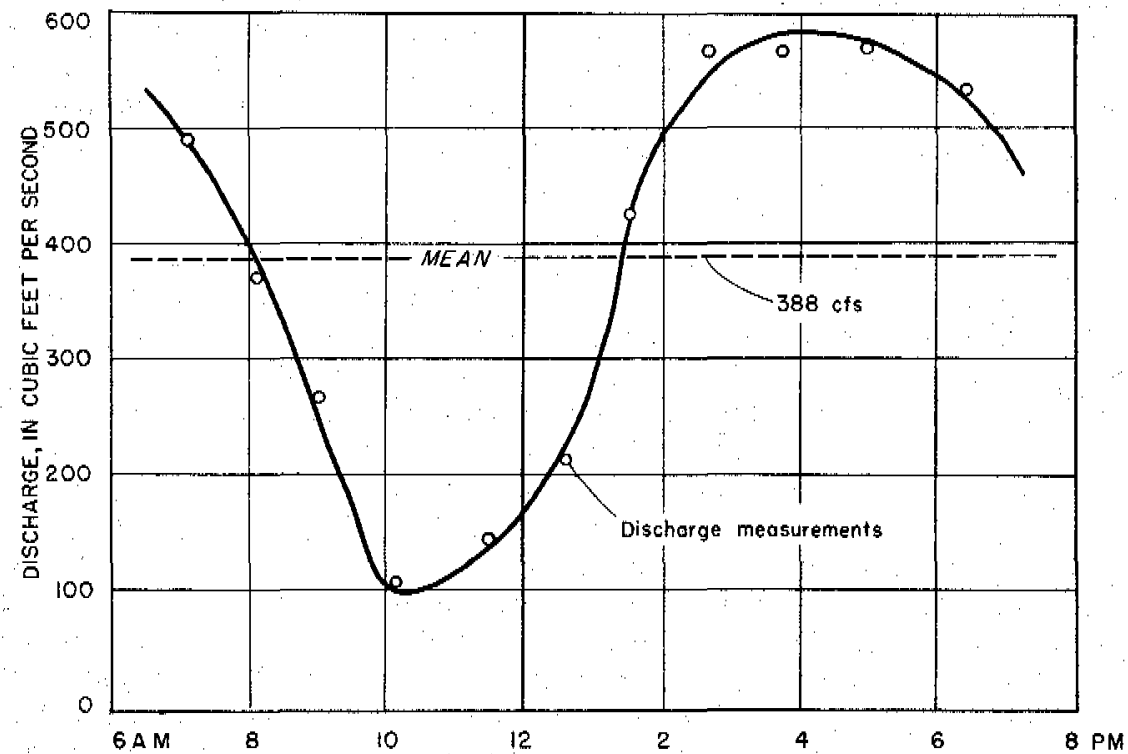

Figure 103, - Graph showing discharge of Hillsboro Canal at Dixie Highway, Deerfield Beach, December 10, 1941. Period of measurements is one tide cycle. 
NORTH NEW RIVER CANAL

PHYSICAL DESCRTtion

As far as effective or working length is concerned, North New River Canal is the longest major canal in the Everglades and is the only canal that carries large amounts of water from the Lake Okeechobee farm area to the Middle Everglades. (See pl. 14.) From its connection with Hillsboro Canal near the lake, it extends south and east 60 miles in a series of straight reaches, ranging between 6 and 25 miles in length, to the tidal waters of New River near Fort Lauderdale. Like Hillsboro Canal, it may be divided into three sections. Plate 14 shows the general features of the North New River Canal drainage area.

The northern, or upper, section of North New River Canal cuts across the area of intensive farming near Lake Okeechobee for 10 miles in a north-south course. The head of the canal is at Hillsboro Canal, several hundred yards east of the hurricane gate (HGS-4) near Chosen and Belle Glade. The first 2 miles has a double channel excavated to about twice the size of the normal channel farther to the south. Near the southern end of this 2-mile reach, a large pumphouse of the South Florida Conservency District is located on the east bank. The town of South Bay and a control and lock is located 2.5 miles south of the head of North New River Canal. The tiny settlement of Okeelanta is located 3.5 miles farther to the south, where Bolles Canal connects both from the east and from the west. The east branch of Bolles Canal extends eastward 9 miles to Hillsboro Canal. The west branch connects with Miami Canal, about 8 miles to the west. Neither branch of Bolles Canal. is controlled.

The bend to the southeastward, 10 miles from the lake, roughly marks the limit of the principal agricultural area, although about 1946 farms were developed south of the bend. Numerous small farm pumps are located along the upper reach; the canal is accessible by road, except for the first 2 miles, and the banks are continuous.

The middle reaches of North New River Canal extend about 42 miles in a southeasterly direction from the bend south of Okeelanta to Flamingo Road, about 8 miles east of 20-Mile Bend. The canal is easily accessible from State Highways 25 and 84 (formerly Highways 26 and 26-A), which are located on, and usually form part of, the southwest and south bank. Concrete culverts were constructed on State Highway 25 about every 2.5 to 3 miles from Okeelanta to 20-Mile Bend. These culverts are 10 feet wide and about 6 feet deep and are fitted with stop-logs at the western ends; thus, they can be controlled. The eastern spoil bank is in poor condition because of burning and subsidence, and at some locations, where 
grading was not completed, it is discontinuous. The middle reach of the canal is cut through a vast sawgrass plain, and the adjoining area is essentially undeveloped except for some farms between the bend and the Palm Beach-Broward County line.

Ten miles northwest of the county line and at the county line, controls with stop-logs were constructed about 1940 by the U. S. Soil Conservation Service and the Everglades Fire Control District. In addition to these controls, which seldom were used and thus were removed in 1946, two low dikes (dike $B$ and dike $C$ ) were constructed, extending 4 and 3 miles, respectively, west from North New River Canal. The purpose of the dikes was to retard and impound the souther lyoverland flow in the Everglades, and thus to preserve organic soils and reduce damage from fires. When new, the dikes were only partly effective, and at the present time, because of subsidence and fire, they are completely ineffective. The borrow ditches, from which the material for the dikes was obtained, remain and act as collecting and distributing channels.

Another stop-lcg control, constructed by the Soil Conservation Service at 26-Mile Bend, has been operated to good advantage. Water can be diverted to the west, above the control, through a bridge on State Highway 25 by manipulation of a low control 50 yards west of the highway. ${ }^{8}$ Dike $E$ extends 3 miles east from the canal and is similar to dikes $B$ and C. Flow into, or out of, the borrow canal for the dike passes through a control at the east bank of the main canal.

At 20-Mile Bend, State Highway 25 continues to the south and North New River Canal turns to the east. The highway-fill forms a continuous dike, extending south to the Miami Canal, and it is an important factor in water control of the area. Five miles east of 20-Mile Bend is 15-Mile Dike, which was constructed south to South New River Canal. Three miles farther east is Flamingo Road, which marks the end of the middle reach of North New River Canal.

The third, or lower, section of North New River Canal starts at Flamingo Road, about 8 miles east of 20-Mile Bend. This is essentially at the western edge of the intensively developed area lying south of the canal. Except along the lines of the original transverse glades to the coast, the muck soil thins out, and areas of sand become the dominant type of soil farther east. Flamingo Canal is on the west side of Flamingo Road and extends south to South New River Canal. A gate in the culvert under State Highway 84 controls flow from the main canal into Flamingo Canal.

Atrange line 40-41, about 1 mile east of Flamingo. Road, a stoplog control was constructed in $1946^{\circ}$. as part of a plan to keep a max-

\footnotetext{
${ }^{8}$ The lateral control was removed late in 1947 to provide a maximum channel for water diverted from the canal.

9 The control has been operated at full-open position to date (early 1949), because of water needs in the area.
} 
imum amount of water stored on the unused lands to the north and west. West Holloway Canal connects from the north just below the control and extends northward 3.5 miles and then turns eastward. Both banks of West Holloway Canal are composed principally of fine sand; they are vulnerable to wave action during periods of high. wind and during periods of area inundation. The west bank forms part of the range line 40-41 dike, which is being extended north to Hillsboro Canal (1948-49). A similar, but smaller, control is located on the north bank of North New River Canal, just above the main control where the borrow pit and canal for the dike connects with the canal. The borrow pit originally was Holloway Canal until the construction of the dike relocated Holloway Canal. Because the west bank of the borrow canal is low and discontinuous, the canal intercepts overland flow from the undeveloped plain to the northwest.

A small number of gravity and pumped laterals extend southward into the intensive citrus development in the 5-mile reach east of Flamingo Road. The principal control facility of North New River Canal is the lock and dam, north of the town of Davie and 2 miles west of State Highway 7 (formerly Highway 149). This is the old coastal control and is the point where the canal discharges into tidal waters. Just downstream, East Holloway Canal (which is not controlled) enters the main canal from the north. East Holloway Canal extends north 4 miles and then turns westward to connect with West Holloway Canal.

A little more than 1 mile east of State Highway 7, North New 'River Canal ends at South Fork New River, which is a natural waterway. Flow from the canal ultimately finds its way to the Intracoastal Waterway and to the sea, via South Fork New River or Dania Cutoff Canal, or by both routes-this is discussed in a subsequent section on the lower New River basin.

All except the last $\frac{1}{2}$ mile of the lower reach of North New River Canal is readily accessible from State Highway 84 , which is on, or close to, the south bank.

The following listing gives the principal features along North New River Canal, with cumulative mileages from its head at Hillsboro Canal. Additional locations are listed to show distances to the tidal waterways at the coast.

Head, Hillsboro Canal (0.2 mile east of HGS-4),............... 0

Bridge, F. E. C. Railway....................................... 2. 1

Bridge, Highway 80 , South Bay..................................... 2. 4

Control and lock (gaging station)................................. 2, 5

Bolles Canal, Okeelanta, 


\section{Location}

Miteage

Bend (south of Okeelanta)......................................... 9, 8 Control, dike B.................................................... 18. 5

Control, dike $C$, county line......................................28,5

Control, dike E, 26-Mile Bend (gaging station)...............37.0

20-Mile Bend........................................................42, 8

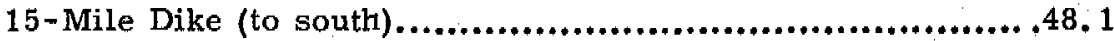

Flamingo Canal, Flamingo Road,...............................5 51.3

Control, range line 40-41 dike (to north), West Holloway

Canal................................................................52.4

Control and lock (gaging station), East Holloway Canal........56.7

Bridge, State Highway 7......................................... 58.6

South Fork New River, south of canal........................... 59. 8

\section{Via South Fork New River and New River}

Bridge, S. A. L. Railway.......................................61.0

New River, North Fork New River.............................63,0

Tarpon River................................................... 63.1

Bridge, F. E. C. Railway....................................63.7

Bridge, Andrews Avenue, Fort Lauderdale.................... 63.8

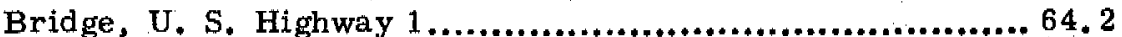

Tarpon River............................................................6 64.8

Intracoastal Waterway...........................................65. 4

\section{RECORDS AVALABLE}

[Records continued after period of this investigation]

South Bay

Stage (north of control): July 19, 1943, to Dec. 31, 1946; staff gage read twice daily; stage often the same as in Lake Okeechobee.

Maximum observed: $15.58 \mathrm{ft}$, on Mar. 18-20, 1946.

Minimum observed: $9.56 \mathrm{ft}$, on June 15,1945 .

Stage (south of control): Oct. 28, 1939, to Dec. 31, 1946; staff gage read twice daily; daily mean of readings plotted in figures 104 and 105.

Maximum observed: $14.98 \mathrm{ft}$, on July $20,25,1941$.

- Minimum observed: $8.78 \mathrm{ft}$, on June 15, 16, 1945.

Discharge: Nov. 8, 1939, to Dec. 31,1946 ; daily mean of readings plotted in figures 104 and 105; monthly and annual runoff listed in table 38.

Maximum daily mean: 445 cfs to north on June 10, 17, 1942; $365 \mathrm{cfs}$ to south, on Dec. 15, 1946. No flow for long periods and at times of reversal of flow. 
Table 38.- Runoff of Worth . Vew River Canal at South Bay

[Unit, 1,000 acre-feet]

\begin{tabular}{|c|c|c|c|c|c|c|c|c|c|c|c|c|c|}
\hline Year & Jan. & Feb. & Mar. & Apr. & May & June & July & Aug. & Sept. & Oct. & Nov. & Dec. & Anmual \\
\hline $\begin{array}{l}1939 \\
1940 \\
1941 \\
1942 \\
1943 \\
1944 \\
1945 \\
1946\end{array}$ & $\begin{array}{r}8.9 \\
8.2 \\
5.2 \\
8.8 \\
10.4 \\
11.2 \\
4.6\end{array}$ & $\begin{array}{l}5.8 \\
6.1 \\
4.7 \\
8.7 \\
8.7 \\
7.5 \\
5.8\end{array}$ & $\begin{array}{l}3.4 \\
7.3 \\
6.1 \\
9.4 \\
8.4 \\
4.8 \\
7.8\end{array}$ & $\begin{array}{r}2.6 \\
5.7 \\
4.9 \\
7.2 \\
5.9 \\
8.0 \\
11.6\end{array}$ & $\begin{array}{r}6.9 \\
7.2 \\
2.7 \\
5.8 \\
8.8 \\
5.9 \\
11.7\end{array}$ & $\begin{array}{r}7.7 \\
1.4 \\
-10.9 \\
3.4 \\
3.2 \\
4.3 \\
5.7\end{array}$ & $\begin{array}{r}9.3 \\
-12.3 \\
-.2 \\
4.8 \\
7.6 \\
1.5 \\
5.4\end{array}$ & $\begin{array}{r}9.5 \\
2.6 \\
10.6 \\
5.3 \\
1.0 \\
5.6 \\
5.1\end{array}$ & $\begin{array}{l}5.1 \\
5.7 \\
6.2 \\
1.4 \\
3.8 \\
5.1\end{array}$ & $\begin{array}{r}4.8 \\
6.9 \\
10.9 \\
10.9 \\
3.8 \\
3.1 \\
3.9\end{array}$ & $\begin{array}{r}4.6 \\
11.1 \\
5.2 \\
11.9 \\
11.6 \\
4.9 \\
3.3 \\
4.9\end{array}$ & $\begin{array}{r}8.1 \\
8.9 \\
8.1 \\
12.3 \\
10.6 \\
4.8 \\
3.8 \\
11.6\end{array}$ & $\begin{array}{r}85.6 \\
51.5 \\
62.3 \\
92.7 \\
68.9 \\
62.8 \\
83.2\end{array}$ \\
\hline
\end{tabular}

Note. - Negative discharge indicates flow toward Lake Oke echobee.

Table 39.- - Runoff of "7orth IVew River Cand near Fot Laxderdale

[Unit, 1,000 acre-feet]

\begin{tabular}{|c|c|c|c|c|c|c|c|c|c|c|c|c|c|}
\hline Year & Jan. & Feb. & Mar. & Apr. & May & June & July & Aug. & Sept. & Oct. & Nov. & Dec. & Annual \\
\hline $\begin{array}{l}1939 \\
1940 \\
1941 \\
1942 \\
1943 \\
1944 \\
1945 \\
1946\end{array}$ & $\begin{array}{r}16.7 \\
44.8 \\
30.7 \\
6.6 \\
8.2 \\
4.3 \\
14.3\end{array}$ & $\begin{array}{r}26.8 \\
43.6 \\
21.2 \\
6.8 \\
1.8 \\
2.0 \\
2.5\end{array}$ & $\begin{array}{r}21.6 \\
46.4 \\
20.0 \\
3.4 \\
2.7 \\
.7 \\
1.7\end{array}$ & $\begin{array}{r}18.1 \\
66.5 \\
30.7 \\
2.5 \\
2.4 \\
.3 \\
.5\end{array}$ & $\begin{array}{r}9 . \\
31 . \\
22 . \\
5 . \\
6 . \\
3 .\end{array}$ & $\begin{array}{r}38.4 \\
30.5 \\
86.7 \\
5.2 \\
1.9 \\
15.6\end{array}$ & $\begin{array}{r}30 . \\
94 . \\
85 . \\
18 . \\
1.5 \\
1 . \\
24 .\end{array}$ & $\begin{array}{r}50.3 \\
81.3 \\
53.1 \\
22.4 \\
8.4 \\
2.4 \\
34.0\end{array}$ & $\begin{array}{r}63.8 \\
64.8 \\
54.6 \\
30.4 \\
8.1 \\
25.4 \\
52.0\end{array}$ & $\begin{array}{l}52.0 \\
71.6 \\
39.4 \\
26.8 \\
29.0 \\
50.8 \\
38.9\end{array}$ & $\begin{array}{r}121.9 \\
41.2 \\
39.9 \\
15.0 \\
8.9 \\
16.8 \\
69.0 \\
35.0\end{array}$ & $\begin{array}{r}13.2 \\
33.3 \\
23.0 \\
12.8 \\
11.1 \\
7.3 \\
20.8 \\
8.7\end{array}$ & $\begin{array}{r}401.4 \\
638.2 \\
472.2 \\
148.0 \\
94.4 \\
178.0 \\
231.3\end{array}$ \\
\hline
\end{tabular}

For period November $8-30$. 

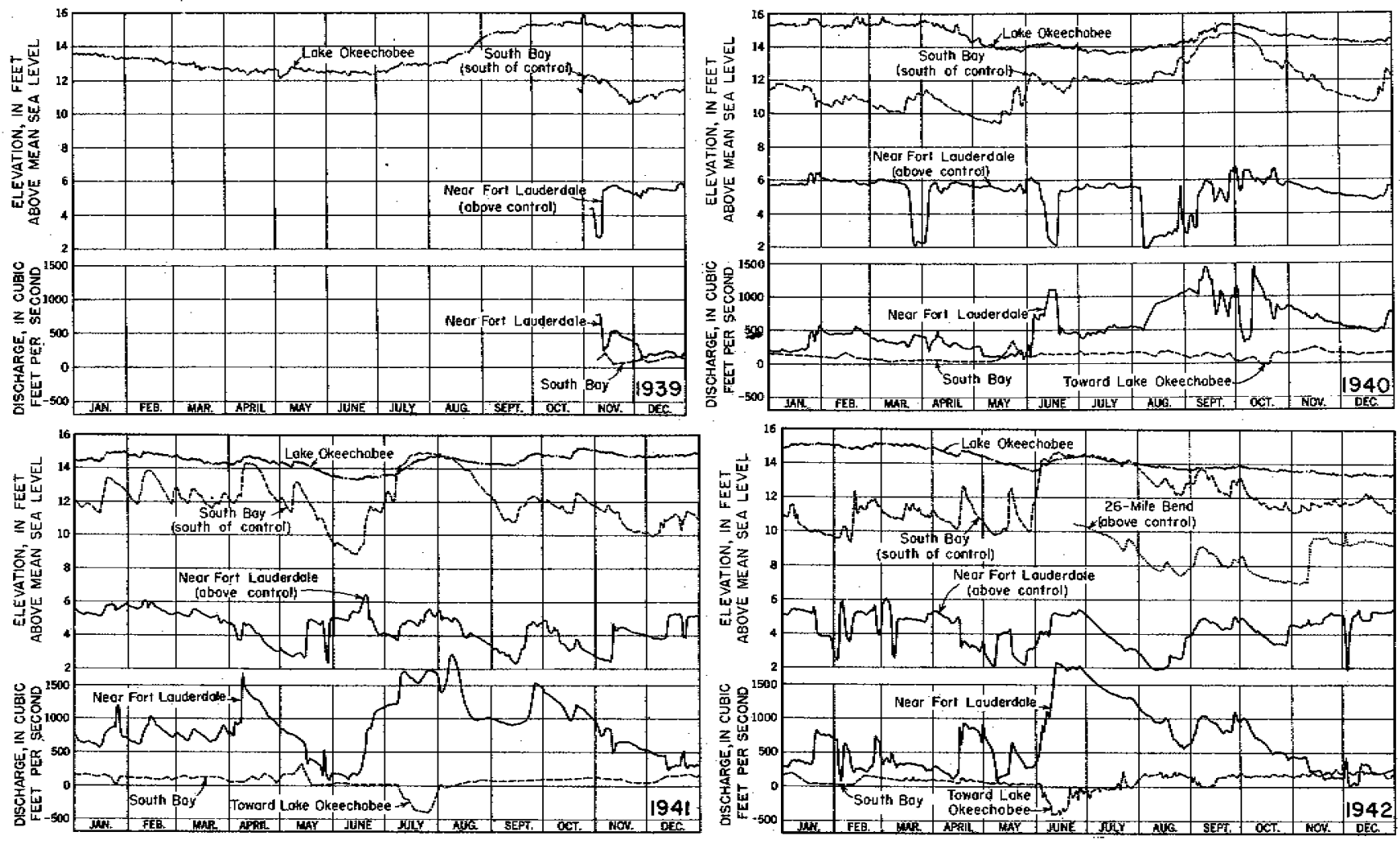

Figure 104. - Graphs showing stage and discharge of North New River Canal, 1939-42. 

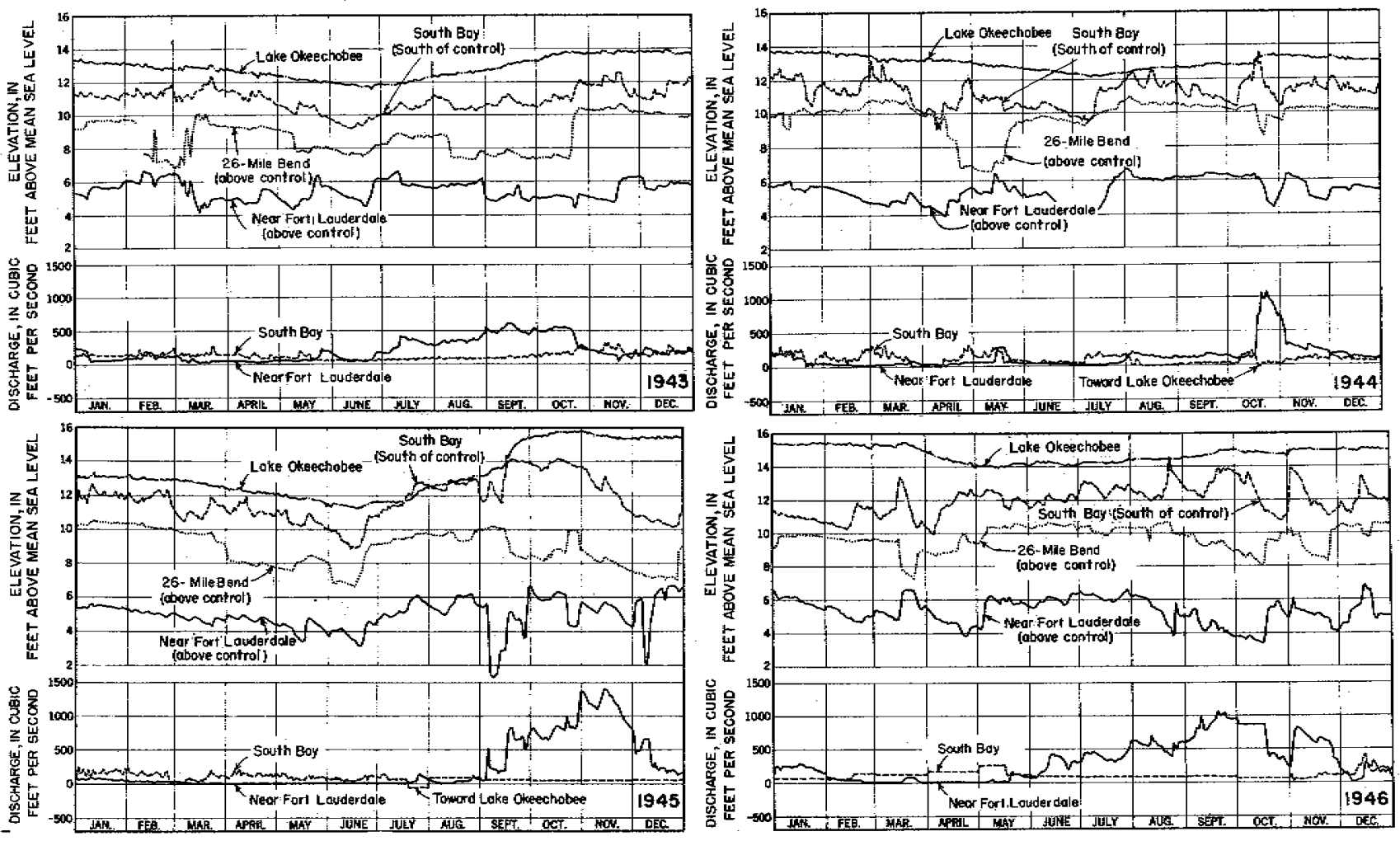

Figure 105. - Graphs showing stage and discharge of North New River Canal, 1943-46. 
26-Mile Bend

Stage, north of control; June 23, 1942, to Dec. 31,1946 ; continuous recorder graph; daily mean plotted in figures 104 and 105.

Maximum: $11.05 \mathrm{ft}$, on Aug. 4, 1944.

Minimum: 6. $42 \mathrm{ft}$, on Mar. 6, 1943.

Discharge: Aug. 1, 1941, to Dec, 31, 1946; through main control; about twice-monthly discharge measurements. Maximum measured: 1,170 cfs, Aug. 1, 1941. Minimum measured: 9,4 cfs, on Dec. 15, 1944 .

Fort Lauderdale, near, Lock No. 2

Stage, west of control: Nov. 4, 1939, to Dec. 31, 1946; continuous recorder graph; daily mean plotted in figures 104 and 105. Maximum: $6.93 \mathrm{ft}$, on Dec. $16,1946$. Minimum: $0.78 \mathrm{ft}$, on Dec. 3, 1942. Maximum known: $7.66 \mathrm{ft}$, on Oct. 15, 1929, from records by Everglades Drainage District.

Discharge: Nov. 8, 1939, to Dec. 31, 1946; daily mean plotted in figures 104 and 105; monthly and annual runoff listed in table 39 .

Maximum daily mean: 1,970 cfs, on Aug. 8, 1941. Minimum daily mean: $3 \mathrm{cfs}$, several days in May and June 1945; leakage only.

Maximum known: $5,400 \mathrm{cfs}$, on Oct, 15, 1929, from records by Everglades Drainage District.

Miscellaneous

Discharge: at intermediate locations on the main canal and at laterals, 1939 to 1946; occasional; usually in connection with special basin studies; see figure 106 for type of observations.

\section{FLOW CHARACTERISTCS}

Conditions of flow in North New River Canal near Lake Okeechobee are necessarily associated with the regimen of the upper Hillsboro Canal because the two canals join and form a continuous reach. The control and lock at South Bay was in poor condition during the period of observations by the Geological Survey, but it was operated to hold varying small heads. Thus, Hillsboro Canal, in which the control near the lake does not function, is the semidependent waterway and is controlled in part by North New River Canal. Under certain conditions (see p. 336), the hurricane gate (HGS-4), in the protective levee west of the junction of the canals, acts as a control.

The large pump north of the control at South Bay and the similar puinp in Hillsboro Canal at Chosen (near Belle Glade) have a considerable effect on the direction and distribution of flow in the upper 
reaches of the canals. The pump discharge often divides at the pumps, and thus all combinations of flows result. Ordinarily, when both pumps are discharging, flow at HGS- 4 is into Lake Okeechobee, although flow in the two canals at the gaging stations may be away from the lake.

In periods of heavy rainfall, flow at the South Bay control may be to the north (toward the lake), partly because of heavy pumping at farms south of the control. Although at one time the water summit was found at Bolles Canal, this may not always be true. The maximum discharge to the north exceeds the maximum to the south (based on 7 years of record). The lock at the South Bay control is not operated as a discharge channel.

Between South Bay and the bend south of Okeelanta, the east bank of North New River Canal overflows at several locations during flood periods. Numerous farm pumps discharge into, or irrigate from, the canal. Water in the east and west branches of Bolles Canal flows into the main canal, but it may reverse when irrigation demand exceeds the ordinary flow. Bolles Canal is a poor water carrier because it flows through the area of greatest soil subsidence in the Everglades- $6.4 \mathrm{ft}$ of soil was lost near Okeelanta between 1913 and 1946 (Florida Agr. Exper. Sta., 1948, p. 80). Because of a lack of maintenance procedures, the channel area has been reduced by extensive shoals near the pumps.

Flow through culverts in State Highway 25, from the bend south of Okeelanta to the Palm Beach-Broward County line, usually is into North New River Canal. In wet seasons, water from the higher lands along the west side of the Everglades, south of Clewiston, moves overland in a southeasterly direction into the North New River Canal drainage area. The canal is in a definite subsidence valley and acts as a collecting channel. This action continues until drought stages develop, whereupon the water in the canal is held higher than in the land, and outflow to the land by seepage may occur. Except where farm ditches may be connected, stub laterals extend about $50 \mathrm{ft}$ west from the culverts.

From the Palm Beach-Broward County line to 26-Mile Bend, flow in the highway culverts is out of the canal in flood periods, but it may reverse when a return to moderate levelsoccurs.

Water levels above the control at 26-Mile Bend usually are maintained sufficiently high to divert flow through the stub lateral to the west, where it fans out over the open lands. Occasionally, the stage is low enough to permit inflow to the canal, but the control in the lateral was ope rated to prevent such flow (see footnote on page 376 ). Water is also diverted through the control in the east lateral, but this flow is smaller than the flow to the west. Because of the relatively close relationship to the higher water levels of the Hillsboro 
Canal drainage area, flow into the canal from the east lateral occurs in periods of moderate water levels.

Flow in the highway culverts from 26-Mile Bend to 20-Mile Bend, when open, is into North New River Canal.

Under high-water and flood conditions overland flow from the northeast enters the canal at numerous gaps in the eastern spoil bank from Okeelanta to 20-Mile Bend. Flow in the highway culverts may be, and often is, cut off by placing stop-logs in the control ends of the culverts.

The north spoil bank of North New River Canal, from 20-Mile Bend to the control and lock north of Davie, is high and continuous, except for several low places that permit inflow into the canal in extreme flood conditions. The only north-bank lateral is West Holloway Canal which in wet periods pours large quantities of water into the main canal. This 14-mile reach is important to the water economy of what is known as the Davie area, the land lying between North New River and South New River Canals and extending a short distance south of the latter canal.

State Highway 84 (formerly Highway 26A), on the south side of the canal, forms a continuous dike that is topped only in maximum flood conditions; and even then, a temporary low levee of sand and gravel is constructed to prevent overflow. A number of culverts under the highway connect with distribution laterals and farm ditches extending to South New River Canal. Some of the laterals utilize pumps for irrigation or drainage, but most of the water is supplied by gravity flow.

South New River Canal is held at a lower stage than North New River Canal and acts principally as a drainage channel. The relationship between these two large, and roughly parallel, canals is unique because both irrigation and drainage are possible by gravity and sometimes are carried on simultaneously. Seepage rates in the sand and rock of the area are fairly high and necessitate additional pumping and drainage capacity.

The control and lock nor th of Davie is a typical Everglades structure. The spillway and stop-log section is entirely removed and the lock is opened to provide maximum capacity for flood flows. In maximum floods, overflow occurs at the north end of the control, but there is no serious threat of washout because the whole structure is subject to a high degree of submergence; drop in water surface across the control is only a few tenths of a foot, and velocities are relatively low. Tide effect ordinarily extends to the downstream face of the control, but it may occur above the control at moderate and low stages when the control or lock is open. 
The north bank has several large breaks for a distance of 1 mile east of the control and lock, which permit large quantities of overland flow to enter North New River Canal in very wet periods. State Highway 84 on the south bank is subject to overflow, unless it is diked off.

The canal takes a gently meandering course east of State Highway 7 (formerly Highway 149), and it enters the swampy headwaters of New River. A discussion of the lower New River basin is in a subsequent section.

Because of the natural and artificial water regimen of the area, North New River Canal, throughout its length, is inadequate for the water load imposed on it. Although its construction closely followed the original design, it cannot handle the requirements of the upper, middle, and lower reaches. Satisfactory operation of the canal has been prevented by the conflicting needs in the several areas and by a lack of responsibility for operation of the controls.

The stage and discharge hydrographs, figures 104 and 105, show certain significant characteristics of North New River Canal at the principal gaging stations. The intermediate record at 26-Mile Bend aids considerably in studying the regimen of water events in the basin.,

When HGS-4 was open, and flow in the upper canal was small, the stage at the north side of the control at South Bay was much the same as that in Lake Okeechobee. The control was in poor condition, but heads of as much as $4 \mathrm{ft}$ were held. Repairs to the control in July 1945 were reflected in the relatively stable discharge afterward. It will be noted that the greatest discharge at South Bay was reverse flow (toward the lake).

The stage at South Bay was independent of stage changes at the control west of Fort Lauderdale (Lock No. 2), except to the extent that general water conditions affected the whole basin; and it was independent of changes at 26-Mile Bend to a considerable degree. It will be noted that when discharge at Lock No. 2 was large, the discharge at South Bay was small (and in extreme cases, it was reversed).

Stage changes at 26-Mile Bend often were reflected in the stage at Lock No. 2, but at times the changes at the two stations were opposed (as in March 1946). Occasionally, a large stage-change at 26-Mile Bend, with consequent reduction of flow, caused no significant change at Lock No. 2 because control adjustments were made at Lock No, 2 to hold the same stage (see November 1942 and October 1943). 
In common with other Everglades canals, adjustments of stage at the lower control (Lock No. 2) of ten resulted in essentially no change in discharge once the storage behind the control had adjusted. A very low stage occurred in September 1945 when the control was opened to facilitate repairs to the control.

The daily discharge of North New River Canal at South Bay was not large at any time, ranging between $365 \mathrm{cfs}$ to the south and $445 \mathrm{cfs}$ to the north (toward Lake Okeechobee). Flow to the north, or reverse flow, is shown on the discharge graphs below the zero line as a negative value-here, the flow toward the sea is determined to be the positive, or normal, direction. Reverse flow occurred 3.5 percent of the time and ranged between 0 and 11.7 percent yearly, whîch was a shorter period of time than for reverse flows that occurred in West Palm Beach and Hillsboro Canals. The net flow, which was to the south, averaged 72,400 acre-ft yearly. Part of this water came from the lake but the amount is unknown. The monthly and annual runoff is listed in table 38 .

Periodic measurements of discharge from the west reach of Bolles Canal into North New River Canal were made in 1940-42. The maximum discharge measured was 300 cfs, on July $28,1941$. On several occasions no flow was observed during dry periods, and it is believed reverse flow into Bolles Canal occurred when irrigation demand exceeded the flow from the west.

Construction of North New River Canal closely followed the original design, but because of its length and slightly smaller cross section, it was less effective than West Palm Beach Canal in draining the Everglades. The average annual runoff to the sea at the control and lock west of Fort Lauderdale was 309, 100 acre-1 $\mathrm{ft}$, which averages $427 \mathrm{cfs}$. More than three-quarters of this runoff originated to the south of South Bay, and undoubtedly a large part of it drained by seepage and direct inflow from the unused lands to the south of the principal farming area. Table 39 shows the monthly and annual runoff.

The discharge at the lower control varied widely, and in dry periods, when flow was cut off by. closing the control gates, the discharge was as little as 3 cfs. This small flow was leakage through the lock gates and under the structure, and until repairs were made early in 1945, the flow amounted to at least $30 \mathrm{cfs}$.

\section{BEFPAGE RATPS}

A series of 14 studies of North New River Canal was made in the period 1941-45 to determine seepage losses or gains. Because 
of the dense cover of hyacinth on the canal at that time, observations of flow could not be made at all of the desired locations and, necessarily, some studies were incomplete.

Most of the seepage determinations were made under dry conditions, when movement of water was slow and differences of discharge between locations along the canal reached the point of permissible measurement error. Some of the studies, however, were complete enough to furnish significant information. Data obtained along North New River Canal on May 1, and November 2, 3, 1944, are shown in figure 106. Only the lower half of the canal is shown, because the more significant phase of the problem occurred there. Seepage rates are shown as straight lines between observation locations. Discharge in the main canal is shown as a continuous graph with inflows, or outflows, indicated by vertical distances.

The study of May 1, 1944, was made under extremely dry conditions. The level of Lake Okeechobee was low, and flow at the upper end of North New River Canal was only $157 \mathrm{cfs}$. Water levels were below the ground surface throughout the length of the canal, but they were above, and below, the ground-water table at various locations. The most interesting aspect of the study is the loss, or outseepage, in the east-west reach from 20-Mile Bend to 15-Mile Dike. Here, the canal is cut through permeable rock and the soil is shallow, but farther to the east, deep sand is encountered and the seepage rate decreased. In this particular instance, the canal level was above the water table and outseepage occurred at an average rate of 21 cfs per lineal mile.

The study of November $2,3,1944$, was made when water levels were moderate in the upper Everglades and fairly high in the lower Everglades. The water table at most locations along the canal was higher than the level of the canal, and the discharge of the canal progressively increased downstream. The graph shows that the gain in discharge, or inseepage, increased considerably between 20-Mile Bend and 15-Mile Dike and averaged 19 cfs per lineal mile. At the time, it is probable that most of the inseepage was derived from the area north of the canal, where water was stored above the canal level. The vertical jump in the discharge graph at range line 40-41 represents a large inflow from this storage pool.

The two studies furnish an indication of the intricate relationship between water levels and canal flows. The seepage rates are not maxima for North New River Canal, or for any other canal that is dug in porous rock. On the other hand, unpublished data by U. S. Soil Conservation Service shows that, under stable water conditions, the level of a canal can be considerably independent of the water table, which can continue at a uniform slope across the line of the canal. 

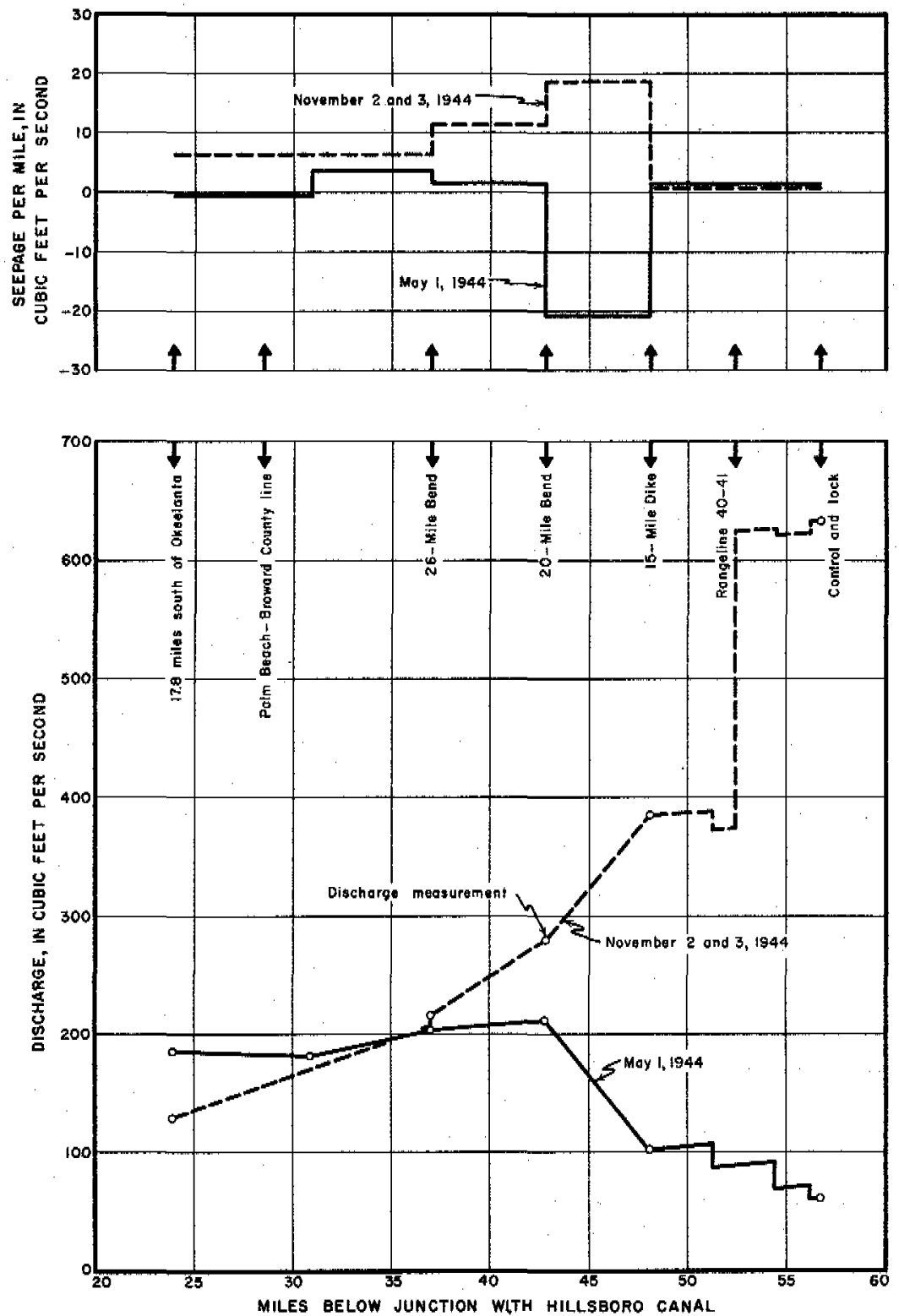

Figure 106. - - Graph of discharge and seepage rates of North New River Canal on May 1 and November 2, 3, 1944. 


\section{SOUTH NEW RIVER CANAL}

\section{PHYSTCAL DESCRIPTON}

South New River Canal, one of the shorter arterial waterways, runs east and west and lies entirely within Broward County. The western end of its 23-mile channel connects with Miami Canal, and the eastern end connects with Dania Cutoff Canal and South Fork New River and thus ultimately enters the sea.

The connection between South New River Canal and Miami Canal is not controlled, and free interchange of flow can occur at all times. State Highway 25 crosses South New River Canal about 8 miles to the east of the junction of these two canals. The south spoil bank is continuous in the reach, but the nor th bank is breached in at least three locations and overland inflow from the north occurs in wet periods.

Fill for the construction of State Highway 25 was obtained from borrow pits along the west side of the highway, and these borrow pits form sizable canals extending north and south. The north borrow pit ends at North New River Canal at 20-Mile Bend, almost 6 miles to the north, but it is not connected with that canal. A low place in the north spoil bank (and later, a culvert pipe) permits flow from the north borrow pit into South New River Canal. The south borrow pit ends at the Dade-Broward County line, a little more than 7 miles to the south; it is not connected with South New River Canal. .

A quarter mile east of State Highway 25 is an earth dam, which makes a pool of the upper reach of South New River Canal. A small pipe culvert is set high in the dam, but in the period 194046, no flow was observed. Moderate flow occurred in 1940-41 through a breach in the dam.

Another earth dam, which was constructed about 1924 and which was extensively breached in 1941 , is located $4 \frac{1}{2}$ miles east of State Highway 25. Head on the dam has been small since the breaching, and it is relatively ineffective as a water control. ${ }^{10}$ A levee, known as 15 -Mile Dike, extends north 4.5 miles from this location to State Highway 84 and North New River Canal.

Snake Creek Canal connects from the south with South New River Canal at a point 3 miles east of 15-Mile Dike. Here, Flamingo Canal extends northward to connect with North New River Canal on the west side of Flamingo Road. This location marks the western edge of the intensive citrus development in the Davie area. Flamingo Canal is controlled at a point $\frac{1}{2}$ mile north of South New River Canal and at its head at North New River Canal.

\footnotetext{
${ }^{10}$ The break in the dam was roughly filled abour December 1947, Later, three 48-inch pipe culverts were installed.
} 
A typical control and lock is located nearly 4 miles east of Snake Creek Canal at the western side of the town of Davie. About 3 miles farther downstream, State Highway 7 (formerly Highway 149) crosses the canal and marks the eastern limit of the Davie area. Numerous north-south uncontrolled lateral canals connect in the reach from Snake Creek Canal to State Highway 7.

South New River Canal ends at the Florida Power and Light Co. plant about 0.4 mile east of State Highway 7. Here the canal connects with Dania Cutoff Canal and the canalized reaches of South Fork New River, both of which connect with the Intracoastal Waterway and ultimately with the sea. Dania Cutoff Canal is the shorter and more direct outlet. Details of the lower New River basin are discussed in the next section.

The banks of South New River Canal are continuous from State Highway 25 to the lower end, except for several breaks. in the south bank, west of Snake Creek Canal. The canal is accessible by roads along the banks from about 2 miles west of Snake Creek Canal to State Highway 7.

The following table lists the principal features along South New River Canal with cumulative mileages from its head at Miami Canal. Additional locations are listed to show distances to the tidal waterways at the coast.

Head, connection with Miami Canal................................ 0

Bridge, State Highway 25 (formerly 26 )........................ 8.4 Earth dam............................................................ 8. 6 Dam (15-Mile Dike)................................................ 12. 8 Bridge, Snake Creek Canal, Flamingo Canal, Flamingo

Road............................................................. 15. 9

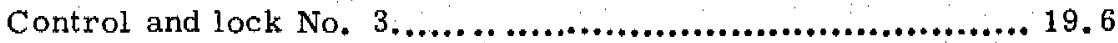
Bridge, Davie.....................................................20. 20. 9 Bridge, State Highway 7 (formerly 149).........................22. 4 Mouth, connection with Dania Cutoff Canal and South Fork

New River.......................................................22.8

Lateral, Florida Power and Light Co. plant intake............. 22.9 Lateral, Florida Power and Light Co, plant return............. 23.8 Bridge, State Highway 84 (formerly $26-$ A) ..................... 24.6 North New River Canal, mouth of .................................24, 8 (for continuation of New River see similar list for North New River Canal on page 377 ). 
via Dania Cutoff Canal

Lateral, powerplant intake...................................... 22, 9

Control............................................................... 22.9

Lateral, powerplant return.........................................2 3.4

Bridge, Ravenswood Road..........................................24, 9

Bridge, Seaboard Railway........................................25. 1

Bend..................................................................25. 3

Bend.....................................................................26. 0

Hollywood Canal.....................................................26. 0

Bridge, F, E. C. Railway....................................26. 7

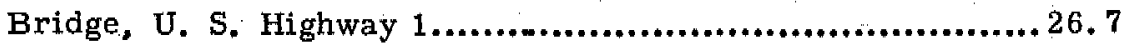

Mouth of Dania Cutoff Canal, Intracoastal Waterway...........28.6

\section{RECORDS AVAILABLE}

[* Record continued after period of this investigation]

Highway 25

Stage: Apr. 12, 1943, to Dec. 31, 1946*; continuous recorder graph; daily mean plotted in figure 107.

Davie, near, (at Snake Creek Canal)

Stage, east of bridge; Nov. 8, 1939, to June 15, 1941; staff gage read twice daily; daily mean of readings plotted in figure 108. Maximum observed: $5.68 \mathrm{ft}$ on Sept. 12, 1940. Minimum observed: $0.50 \mathrm{ft}$ on Dec. 17, 18, 1940.

Discharge, including inflow from Snake Creek Canal and Flamingo Canal: Nov. 8,1939 , to June 30,1941 ; daily mean plotted in figure 108; discharge measurements listed in table 40 , including tributary inflow; monthly and annual runoff listed in table 41 .

Maximum daily mean: $337 \mathrm{cfs}$, on Sept, 21, 1940.

Minimum daily mean: $5.8 \mathrm{cfs}$, May $21-28,1940$

Davie, at

Discharge, monthly, January 1940 to December 1942, listed as "other flow" out of the area in table 63. 


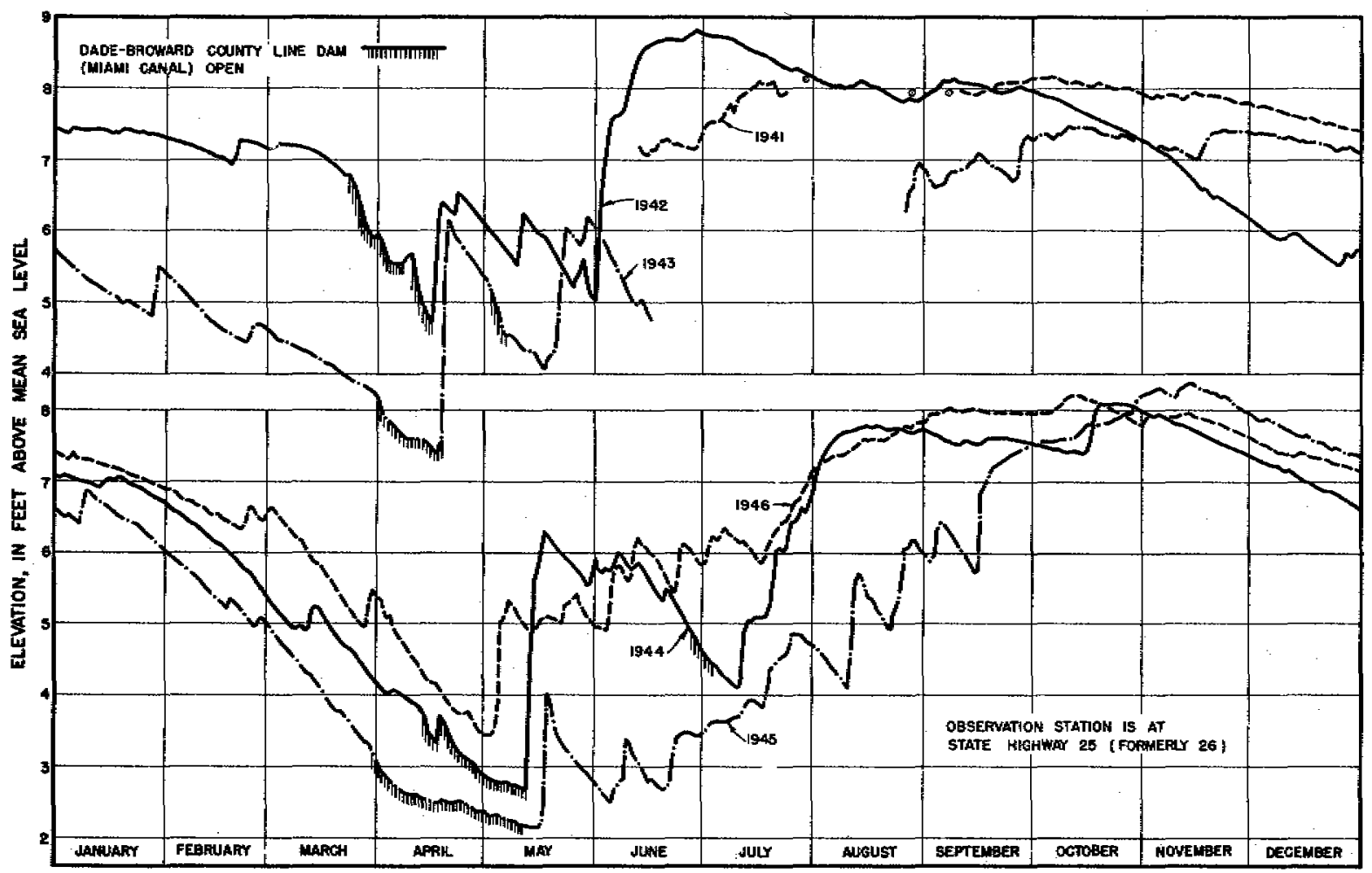

Figure 107. -Graph of stage of South New River Canal about 8 miles west of Snake Creek Canal, 1941-46. 

Table 40.-Discharge measurements, in cutbic feet per second, and elevations, in feet above mean sea level, of South New River, Flamingo, and Snake Creek Canals at intersection

[Measurements of inflow marked by asterisk (") are estimated]

\begin{tabular}{|c|c|c|c|c|}
\hline \multirow{2}{*}{$\begin{array}{l}\text { Date of } \\
\text { measure- } \\
\text { ment }\end{array}$} & \multirow{2}{*}{$\begin{array}{c}\text { Flow of } \\
\text { South New } \\
\text { River Canal } \\
\text { above } \\
\text { intersection }\end{array}$} & \multicolumn{2}{|c|}{ Inflow from } & \multirow{2}{*}{$\begin{array}{l}\text { Elev of water } \\
\text { surface at } \\
\text { intersection }\end{array}$} \\
\hline & & $\begin{array}{l}\text { Flamingo } \\
\text { Canal, } \\
\text { from vorth }\end{array}$ & $\begin{array}{l}\text { Snake Creek } \\
\text { Canal, } \\
\text { from south }\end{array}$ & \\
\hline $\begin{array}{r}1939 \\
\text { Nov, } 8 \\
15 \\
\text { Dec. } 5 \\
13 \\
20 \\
1940\end{array}$ & $\begin{array}{r}54.5 \\
53.6 \\
45.7 \\
46.7 \\
39.0\end{array}$ & $\begin{array}{l}25.6 \\
19.9 \\
13.7 \\
14.6 \\
4\end{array}$ & $\begin{array}{l}* 2 \\
* 2 \\
0 \\
21 \\
*_{1}\end{array}$ & $\begin{array}{l}4.51 \\
4.43 \\
3.40 \\
3.16 \\
3.38\end{array}$ \\
\hline $\begin{array}{lr}\text { Jan. } & 6 \\
12 \\
23 \\
\text { Feb. } \begin{array}{r}1 \\
9\end{array}\end{array}$ & $\begin{array}{l}39.5 \\
50.6 \\
33.9 \\
39.4 \\
39.7\end{array}$ & $\begin{array}{l}16.4 \\
22.6 \\
33.4 \\
36.5 \\
41.0\end{array}$ & $\begin{array}{l}*_{1} \\
+2 \\
+2 \\
0 \\
* 1\end{array}$ & $\begin{array}{l}3.32 \\
3.32 \\
3.21 \\
3.33 \\
3.19\end{array}$ \\
\hline $\begin{array}{r}20 \\
27 \\
7 \\
15 \\
22\end{array}$ & $\begin{array}{l}39.9 \\
35.2 \\
33.7 \\
33.6 \\
22.6\end{array}$ & $\begin{array}{l}29.0 \\
29.6 \\
21.0 \\
15.5 \\
12.0\end{array}$ & $\begin{array}{l}1 \\
* .5 \\
0 \\
0 \\
0\end{array}$ & $\begin{array}{r}3.02 \\
2.76 \\
2.61 \\
+\quad 2.18 \\
2.37\end{array}$ \\
\hline $\begin{array}{r}27 \\
\text { Apr. } \quad 4 \\
9 \\
19 \\
26\end{array}$ & $\begin{array}{l}27.7 \\
41.6 \\
33.2 \\
22.5 \\
19.0\end{array}$ & $\begin{array}{l}9.5 \\
9.5 \\
6.4 \\
.1 \\
1.5\end{array}$ & $\begin{array}{r}0 \\
2 \\
0 \\
0 \\
0\end{array}$ & $\begin{array}{l}2.23 \\
2.29 \\
2.13 \\
1.90 \\
1.71\end{array}$ \\
\hline $\begin{array}{r}26 \\
27 \\
\text { May } 3 \\
10 \\
17\end{array}$ & $\begin{array}{r}7.7 \\
12.7 \\
10.5 \\
7.9 \\
6.4\end{array}$ & $\begin{array}{l}* 1.5 \\
\pm .2 \\
0 \\
0\end{array}$ & $\begin{array}{l}.5 \\
0^{*} \\
0^{*} \\
*-4\end{array}$ & $\begin{array}{l}1.81 \\
2.05 \\
2.28 \\
2.21 \\
2.36\end{array}$ \\
\hline $\begin{array}{r}22 \\
31 \\
\text { June } 4 \\
15 \\
21\end{array}$ & $\begin{array}{r}5.3 \\
10.3 \\
62.5 \\
41.9 \\
32.0\end{array}$ & $\begin{array}{r}0 \\
19.6 \\
61.4 \\
29.6 \\
9.6\end{array}$ & $\begin{array}{l}* .5 \\
10.9 \\
5 \\
2\end{array}$ & $\begin{array}{r}2.38 \\
2.88 \\
3.46 \\
2.94 \\
2.06\end{array}$ \\
\hline $\begin{array}{lr} & 26 \\
\text { July } & 5 \\
12 \\
19 \\
\\
24\end{array}$ & $\begin{array}{l}23.6 \\
27.3 \\
25.2 \\
23.2 \\
17.6\end{array}$ & $\begin{array}{l}25.2 \\
13.6 \\
21.1 \\
21.2 \\
20.7\end{array}$ & $\begin{array}{r}{ }^{*} 4 \\
0 \\
0 \\
0 \\
0 \\
-1\end{array}$ & $\begin{array}{l}2.04 \\
1.86 \\
1.98 \\
1.94 \\
1.87\end{array}$ \\
\hline $\begin{array}{r}31 \\
\text { Aug. } \\
14 \\
22 \\
30\end{array}$ & $\begin{array}{l}28.0 \\
32.4 \\
23.9 \\
28.1 \\
48.2\end{array}$ & $\begin{array}{l}28.3 \\
18.5 \\
13.6 \\
14.1 \\
27.8\end{array}$ & $\begin{array}{r}\quad 3 \\
\quad 3 \\
\quad 45 \\
45 \\
112\end{array}$ & $\begin{array}{l}2.56 \\
2.65 \\
3.17 \\
3.32 \\
4.15\end{array}$ \\
\hline $\begin{array}{lr}\text { Sept } & 3 \\
& 13 \\
17 \\
\\
24 \\
\text { Oct. } \quad 1\end{array}$ & $\begin{array}{l}34,0 \\
163 \\
130 \\
208 \\
196\end{array}$ & $\begin{array}{r}16.8 \\
62.5 \\
84.1 \\
101 \\
61.8\end{array}$ & $\begin{array}{l}* 1 \\
45 \\
48 \\
16.8 \\
14.7\end{array}$ & $\begin{array}{l}3.70 \\
5.65 \\
4.91 \\
4.47 \\
3.73\end{array}$ \\
\hline $\begin{array}{r}8 \\
8 \\
17 \\
22 \\
30\end{array}$ & $\begin{array}{c}146 \\
(2) \\
123 \\
108 \\
114\end{array}$ & $\begin{array}{l}82.2 \\
(2) \\
56.4 \\
57.8 \\
68.9\end{array}$ & $\begin{array}{c}14.8 \\
(2) \\
{ }^{4} 10 \\
12.4 \\
14.3\end{array}$ & $\begin{array}{l}2.81 \\
2.86 \\
2.79 \\
2.00 \\
3.22\end{array}$ \\
\hline Nov. $\begin{array}{r}7 \\
13 \\
20 \\
27\end{array}$ & $\begin{array}{r}145 \\
98.1 \\
81.6 \\
63.9\end{array}$ & $\begin{array}{l}58.2 \\
37.3 \\
38.9 \\
36.5\end{array}$ & $\begin{array}{r}12.5 \\
10.0 \\
10.9 \\
9.0\end{array}$ & $\begin{array}{l}2.49 \\
2.32 \\
1.27 \\
1.83\end{array}$ \\
\hline
\end{tabular}


Table 40.-Discherge measurements, in cubic feet per second, and elevations, in feet above mean sea level, of South New River, Flamintego, and Snake Creek Canals at intersection-Continued

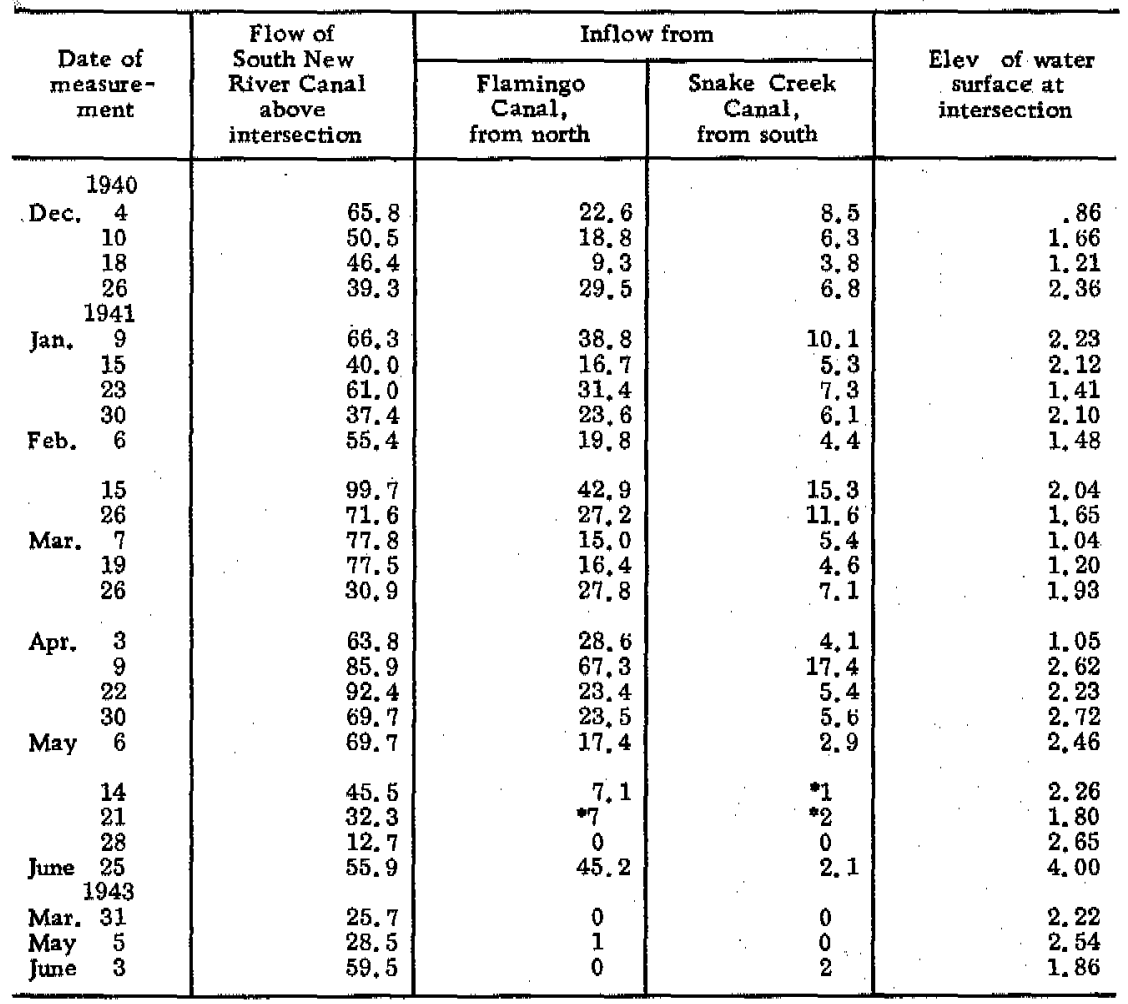

${ }^{1}$ Negative sign indicates flow to south, opposite to normal direction.

2 Flow (235 cfs) measured below intersection of Snake Creek Canal. 
Table 41,-Runoff of South New River Canal new Davie

[Unit, 1,000 acre-feet]

\begin{tabular}{|c|c|c|c|c|c|c|c|c|c|c|c|c|c|}
\hline Year & Jan. & Feb. & Mar. & Apr. & May & June & July & Aug. & Sept. & Oct. & Nov. & Dec. & Annual \\
\hline $\begin{array}{l}1939 \\
1940 \\
1941\end{array}$ & $\begin{array}{l}4.4 \\
5.4\end{array}$ & $\begin{array}{l}4.2 \\
7.1\end{array}$ & $\begin{array}{l}3.0 \\
5.1\end{array}$ & $\begin{array}{l}1.8 \\
7.1\end{array}$ & $\begin{array}{l}0.5 \\
3.2\end{array}$ & $\begin{array}{l}4.5 \\
3.0\end{array}$ & 2.9 & $\begin{array}{c}3.4 \\
.0 .0\end{array}$ & $\begin{array}{l}13.2 \\
\ldots . . . . . . . . .\end{array}$ & 13.0 & $\begin{array}{r}13.3 \\
9.3 \\
\end{array}$ & $\begin{array}{r}3.5 \\
5.2\end{array}$ & $\begin{array}{r}\cdots \\
65.5 \\
\ldots\end{array}$ \\
\hline
\end{tabular}

${ }^{1}$ For period November $8-30$.

Note. - Runoff measured just east of Snake Creek Canal; includes inflow from Snake Creek and Flamingo Canals. 


\section{FLOW CHARACTERISTCS}

The South New River Canal drainage area was not studied intensively, and information on it is relatively meager. Because of the close relationship of the drainage area to adjoining areas, however, it is possible to present certain general characteristics.

The upper reach of South New River Canal, between Miami Canal and State Highway 25, is part of a long pool that is continuous with Miami Canal. The storage pool and its adjoining area has considerable effect on the water regimen of Miami Canal; this is discussed in detail in the section on Miami Canal.

The stage as recorded at State Highway 25 about 8 miles east of Miami Canal, is shown in figure 107. This record is extremely useful because it reflects essentially natural conditions integrated over a large area by the pool formed by the two canals. The annual maximums varied little, and in all except 1 of the 6 years of record a stage of $8.0 \mathrm{ft}$ or higher was reached. The relationship with general water conditions is shown by the varying amounts of decline of water levels in the winter and spring, despite the fairly uniform high levels in the fall.

The accelerated rate of decline below a stage of $7 \mathrm{ft}$ occurs because the ordinary ground elevation in the area is about 6.5 to $7 \mathrm{ft}$. An inch of water lost by runoff, seepage, and evapotranspiration when the area is inundated obviously causes a $1-i n$. decline in water level over the surface area of the canal. An inch of water that is lost when water-table conditions prevail means a decline in the water level of the canal of about 4 or 5 in., depending upon the specific yield of the soil or rock. This accelerated rate of decline in the water level occurs because the rate of loss from runoff, seepage, and evapotranspiration is relatively uniform in the period of transition from inundation to water-table conditions.

State Highway 25 acts as a dike to hold overland flow from moving to the east. Seepage through the porous rock under the highway and under the dam, 1/4 mile to the east, augments the discharge of the middle reaches of South New River Canal. Water movement from the open lands is thus retarded and is spread over a longer period of time, reducing the peak of floods to some degree and also extending favorable water conditions when dry periods develop. The defect in the situation from the viewpoint of water control is that, because of the porosity of the rock and its extent, only limited control can be accomplished.

The breach in the dam at 15-Mile Dike nullifies the effect of that dam, because the head developed there is usually small and often negligible. The reach from State Highway 25 to Snake Creek Canal acts as a collector of ground-water seepage, and surface-water inflow is limited to a few uncontrolled laterals or breaks in the arinil hank 
The bridge opening, just upstream from Snake Creek and Flamingo Canals, is restricted, and in periods of high flow a loss of head, as large as $0.5 \mathrm{ft}$, occurs. Discharge of the main canal and the two tributary canals is often affected by backwater from the control and lock at Davie or by tıdal backwater when the control is open. Table 40 lists the separate flows at the intersection. It is apparent that Snake Creek Canal furnishes only a small part of the gross discharge, while the flow of Flamingo Canal generally, is about half that of the main canal. Taking an average of the weekly discharge measurements in the 1939-41 period of record, the gross discharge is distributed as follows:

South New River Canal, from west.................. 64 percent

Snake Creek Canal, from south..................... 5

Flamingo Canal, from north........................ 31

In extremely dry periods, the flow reverses in Snake Creek and Flamingo Canals, because of irrigation demand or because of outseepage to the water table when it is lower than the level of the canals.

The monthly runoff in acre-feet for the period of record is shown in table 41 . The 65,500 acre-ft of runoff in 1940 is significant in that the runoff of the other large canals was from 5 to 13 times as large in the same year. However, this significance is mitigated by the fact that a sizable amount of additional runoff probably occurred in the 5-mile reach between Snake Creek Canal and the control at Davie, and runoff at the control may have been considerably greater than, although not comparable to, that of the other canals.

The stage and discharge hydrograph, figure 108, shows conditions at South New River Canal near Davie for the period of record. The period is short and covers what might be called a random period of a year and a half. Although the extremes of flood and drought were not observed during this period, the graphs indicate the possibility of a relatively wide range of conditions that may occur in the future. The low stages are significant and are likely to occur in almost every year. The discharge shown includes that from Snake Creek and Flamingo Canals.

The numerous laterals between Snake Creek Canal and State Highway 7 are used mostly for gravity drainage. A moderate amount of gravity irrigation occurs, but only a few irrigation pumps have been installed. In the period of observation by the Geological Survey, the control and lock at Davie was kept open the greater part of the time, and free tide-affected flow occurred. The control is in fair-to-poor condition, and when it was closed, only moderate amounts of head were held. When negative head developed on the control during the early part of the 1943-45 drought-that is, when the tidal downstream stage exceeded the upstream stage with the control closed-the spillway section collapsed, because it was de- 
signed to hold a head of water in only one direction. Rebuilding consisted principally of reassembling and securing the scattered timbers and stop-logs, but the incident is typical of the need for careful planning and designing in this low, flat region.

For the most part, South New River Canal acts as a drainage canal, and its level is kept lower than that of North New River Canal to permit gravity drainage and irrigation in the area between the two canals. Unfortunately, when heavy rains occur and water levels rise, drainage capacity by gravity of South New River Canal and its laterals is reduced. In periods of heavy runoff from the area, some of the discharge from North New River Canal flows southward in South Fork New River and into Dania Cutoff Canal, thus causing a backwater condition in South New River Canal and consequently a reduction inflow upstream. The problem is further complicated by underground seepage from North New River Canal, which is conveyed to, and intercepted by, South New River Canal.

Laterals that enter South New River Canal east of the control and lock at Davie (see fig. 109) have the same drainage advantages as those west of the control, but they are less favorably located for the purpose of supplying water for irrigation. In dry periods, the water levels downstream from the control are tidal, and irrigation demand may draw salty water that occasionally invades the lower reach of the canal. See section on Salt-water encroachment.

\section{LOWER NEW RIVER BASIN}

Consideration must be given to the lower New River basin in arriving at a comprehensive view of the waterways of southeastern Florida. The flow characteristics of this generally tidal area were made more complex by the canalization of the natural channels and by the digging of new channels. The growing urban development of Fort Lauderdale, with resultant, water problems, has shown the need for water research in the area.

\section{PHYSICAL DESCAIPTION}

The principal features of lower New River basin are shown in figure 109. As far as the present waterway system is concerned, it may be considered to head 0.4 mile east of State Highway 7 , at the meeting of South New River Canal, South Fork New River, and Dania Cutoff Canal. The South Fork is a natural stream that has been canalized in part. North New River Canal enters it from the west, 2 miles northeast of the head of South Fork. Three miles farther to the northeast the meandering South Fork meets North Fork and the two branches become New River. 
North Fork New River heads about 2. 5 miles northwest of the junction of the two branches and is the lesser waterway. Just east of the junction, a secondary channel, known as Tarpon River, extends to the south and then to the east, where it rejoins New River near the edge of the mainland.

The lower reach of New River is a relatively deep tidal waterway that meanders through the heart of Fort Lauderdale and is used extensively by yachts and light commercial craft. The easternmost section of the river passes through a series of low-lying islands, located in what was originally a mangrove flat. At the present time, the river ends at the Intracoastal Waterway, but at one time it continued to the east and out to sea at New River Inlet. Since the digging of the entrance channel at Port Everglades, 1 mile south of New River Inlet, the inlet has filled in completely, and connection to the sea is now made by way of Port Everglades entrance.

A shorter connection to the sea from the head of South Fork New River is afforded by Dania Cutoff Canal. This sizable channel extends nearly 6 miles to the east in four straight reaches to the Intracoastal Waterway. A dam is located just east of a coolingwater intake for the Florida Power and Light Co. plant, and the whole junction area makes a complex water pattern that is discussed under flow characteristics. Apart from the powerplant laterals, the only sizable tributary is Hollywood Canal, which enters from the south just west of Dania. Hollywood Canal drains low sloughs and part of the coastal ridge and extends 4 miles southward to the western environs of Hollywood. Dania Cutoff Canal is not actually a part of New River and its tributaries, but it must be included as such because it cannot properly be separated in consideration of the movement of water in the basin.

\section{FLOW CHARACTERISTCS}

The principal tributaries to lower New River, North New River Canal and South New River Canal, have been discussed (p. 375-399) and illustrated in the two preceding sections. Reference to figure 109 will show that water movement below the controls in these canals may occur in several possible patterns. The waterways in the lower basin are tidal throughout under low and moderate runoff conditions, and changes in tidal storage (p. 445) are accompanied by reverse flows. The site of points of flow reversal and divisions of flow result from a complex function of tidal ranges, fresh-water runoff, and the topography of the area. North Fork and South Fork meander through a swamp that has considerable storage capacity.

Flow from North New River Canal is principally toward the northeast in South Fork, but it may turn toward the southwest for several 
hours in each tidal cycle. In periods of large runoff, the flow divides at the end of North New River Canal, and water moves both ways in South Fork. The part that flows toward the southwest enters Dania Cutoff and thus moves to the sea. The volume of flow from North Fork also is a factor in the situation, but detailed information cannot be obtained. It is likely that local runoff east of the end of North New River Canal causes some of the diversion toward the southwest in South Fork,

Tarpon River is restricted at several road crossings by small culverts and does not have much effect on New River. It serves principally as a local drainage channel.

The net discharge of South New River Canal is toward the sea in Dania Cutoff Canal, but flow is often toward the northeast in South Fork New River; this action is a result of tidal reverse flow. In flood periods, all of the flow is into Dania Cutoff Canal, because some water from North New River Canal flows southward in South Fork. The additional flow from the north may be sizable; it occupies a significant part of the capacity of Dania Cutoff Canal, causes an appreciable amount of backwater in South New River Canal, and is a serious problem in drainage of the Davie area. Plans for placing a control in South Fork, near State Highway 84, have met with objections from the Fort Lauderdale area, where residents desire a minimum flow in New River during wet periods.

At maximum load, the powerplant at the head of South Fork New River uses $290 \mathrm{cfs}(130,000 \mathrm{gpm})$ for cooling the condensers. This large quantity of water is obtained from two intakes connecting with Dania Cutoff Canal and South Fork; for practical purposes, they can be considered to be a single intake because they both draw on the same pool. After passing through the condensers, the water leaves the plant in a canal that extends eastward to a north-south canal, where controls at the intersection permit flow southward to Dania Cutoff Canal or northward to South Fork,

Because efficiency of the powerplant depends upon a stupply of cooling water at the lowest possible temperature, efforts are made to prevent recirculation of the warmed water. When the discharge from South New River Canal and South Fork New River is large, no particular problem exists and the water is returned to Dania Cutoff Canal and thus to the sea. When fresh-water discharge is moderate, the water is returned to Dania Cutoff Canal, but the dam at the powerplant is closed near high tide to prevent recirculation.

As runoff decreases and dry conditions develop, however, the demand of the powerplant exceeds the normal discharge of any of the waterways and exceeds the combined fresh-water discharge from North New River Canal and South River Canal. This unbalance 
brings highly saline water inland to the powerplant and creates a series of associated problems (see section on Salt-water encroachment). Although salty water is usable for cooling, it is in the best interests of the area to prevent such encroachment. Thus, during dry periods the control is keptclosed and the warmed water is diverted to South Fork by the north branch of the return channel. The longer distance of travel effects a small amount of cooling, but the water e ventually returns to the plant at a temperature that is higher than normal. The temperature might build up excessively except for the restraining influence of cooler fresh-water discharge from the west and an admixture of sea water.

The problem of salt intrusion and recirculation of cooling water became acute in the period 1943-45. In 1947, the power company extended the outlet canal to the east, thus enabling the warmed water to be routed over a longer distance. The additional travel is partly through a shallow slough area that facilitates cooling. Under moderately dry to dry conditions, the use of water at the powerplant completely changes the seminatural regimen of flow and indicates the need for special consideration in any further development of the area.

The bridges across the principal channels of lower New River basin individually cause only small restriction onflood flows but, taken as a whole, they cause enough head loss to require careful consideration. Most of these bridges are of the horizontal-swing type. The greatest flow restriction occurs in Dania Cutoff Canal where the Florida East Coast Railway and U. S. Highway 1 cross at a short narrow section of the canal on fixed bridges.

\section{SPECIAL STUDIES}

\section{GENERAL FLOW DISTRIBUTION}

Observations of stage and discharge were made in lower New River basin on February 15, 1941. Water conditions were high for that time of the year, and several inches of rain had fallen on the basin about February 10. Runoff was fairly high, and a typical flow pattern existed. The discharges at key locations are shown in figure 109; but the tributary flows were not measured. Dashed arrows show the probable directions of flow, where observations were not made.

North Fork New River undoubtediy contributed a considerable part of the 1,230 cfs flow that was measured in New River at Fort Lauderdale, and thus it may be expected that the flow from North New River Canal divided at South Fork. This is corroborated by the discharge of $225 \mathrm{cfs}$ in South Fork at its connection with South New River and Dania Cutoff Canals. This flow was measured south 


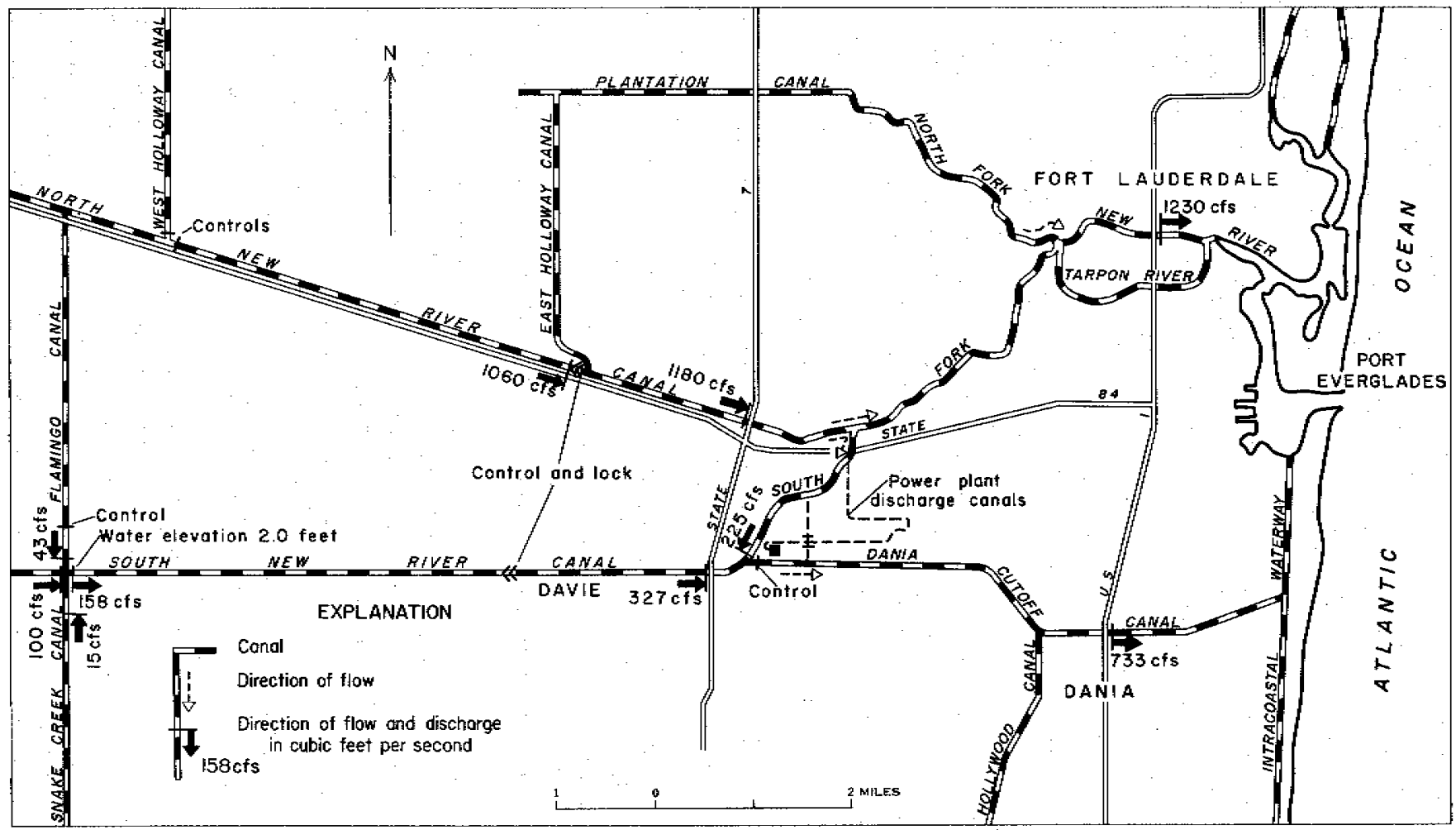

Figure 109. - Map of lower New River basin showing principal discharges on February 15, 1941. 
of one of the powerplant intakes, and it is likely that the total discharge south in South Fork was substantially larger, because the powerplant takes large volumes of water for cooling purposes. This is substantiated by the unusual flow increase indicated in Dania Cutoff Canal between the junction with South Fork and U. S. Highway 1. Part of the increase probably was the cooling water that was returned to Dania Cutoff Canal through the discharge canals after being used in the powerplant. The diversion of water through the plant, under conditions existing in February 1941, had no effect on the hydraulics of lower New River basin (except in the immediate area of the plant). The control at the plant was open during the period of observations.

Increase of discharge in South Fork New River between North New River Canal and Dania Cutoff Canal probably was small, because the intermediate drainage area is relatively small. The sizable increase of flow in South New River Canal, however, can be attributed to the extensive drainage system in the Davie area. (Note the relationship between flow in the main canal and the tributary flow at the intersection 5 miles west of Davie.)

\section{TIDE STAGE AND DISCHARGE RELATIONSHIPS}

The field work for the general flow pattern of lower New River basin involved detailed observations. The basin was affected by tide (tidal backwater) below the controls in the main tributary canals, which meant that simple discharge measurements were not enough to obtain representative data. At the five tide-affected locations in the study on February 15, 1941, stage and discharge observations were made over a period of about 13 hours and covered a complete tide cycle-the basic data are shown in figure 110 .

The tidal range in New River at U. S. Highway 1 was $2.69 \mathrm{ft}$ and in Dania Cutoff Canal at U. S. Highway 1 it was $1.73 \mathrm{ft}$, which reflects the larger and more open channel between New River and the Port Everglades entrance. The mean discharge of New River was $1,230 \mathrm{cfs}$, but the flow varied between almost $3,000 \mathrm{cfs}$ toward the sea and $840 \mathrm{cfs}$ inland. The period of inland, or reverse, flow lasted 3.5 hours. By comparison, Dania Cutoff Canal averaged $733 \mathrm{cfs}$ and varied between 1,160 and $120 \mathrm{cfs}$, with no reverse flow.

The tidal range in North New River Canal at State Highway 7 (formerly 149) was $1.23 \mathrm{ft}$; and in South New River Canal at State Highway 7, it was $1.29 \mathrm{ft}$; the relationship was the reverse of that of the downstream stations. The discharge of North New River Canal, however, varied only a small amount, while that of South New River Canal varied between 55 and $540 \mathrm{cfs}$. Reverse flow did not occur in this part of the basin. 

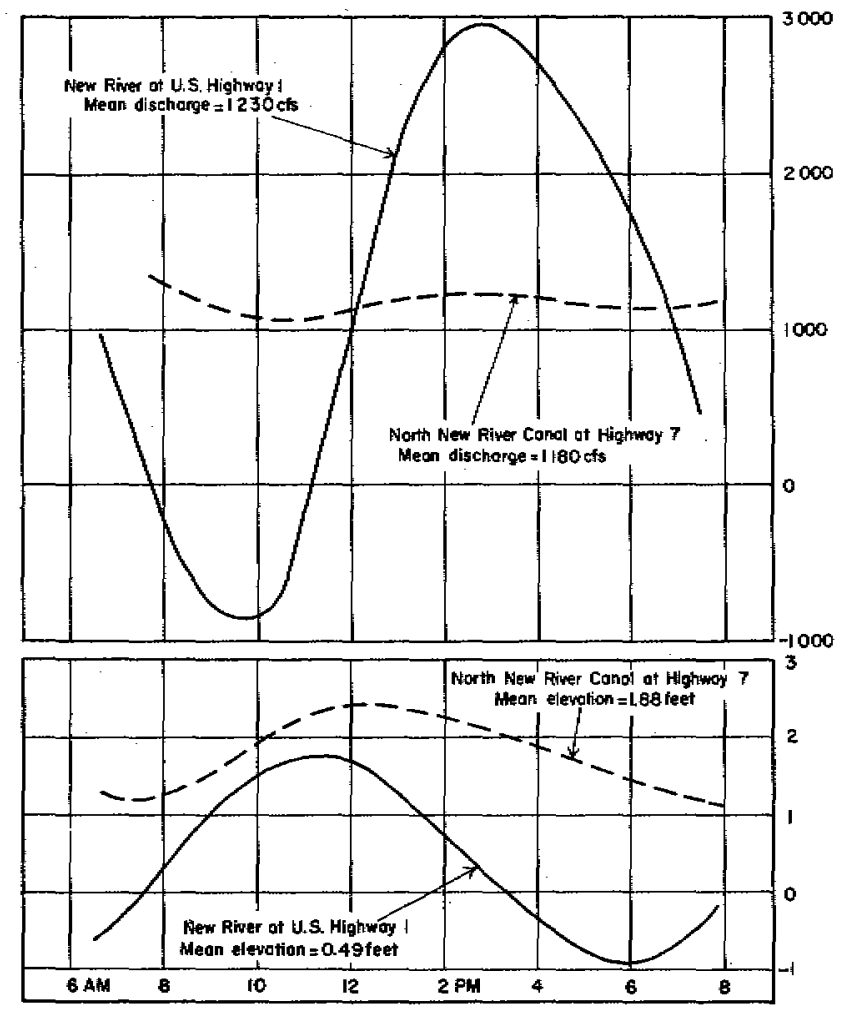

Figure 110. - Graphs of stage and discharge in lower New River basin on February 15, 1941.
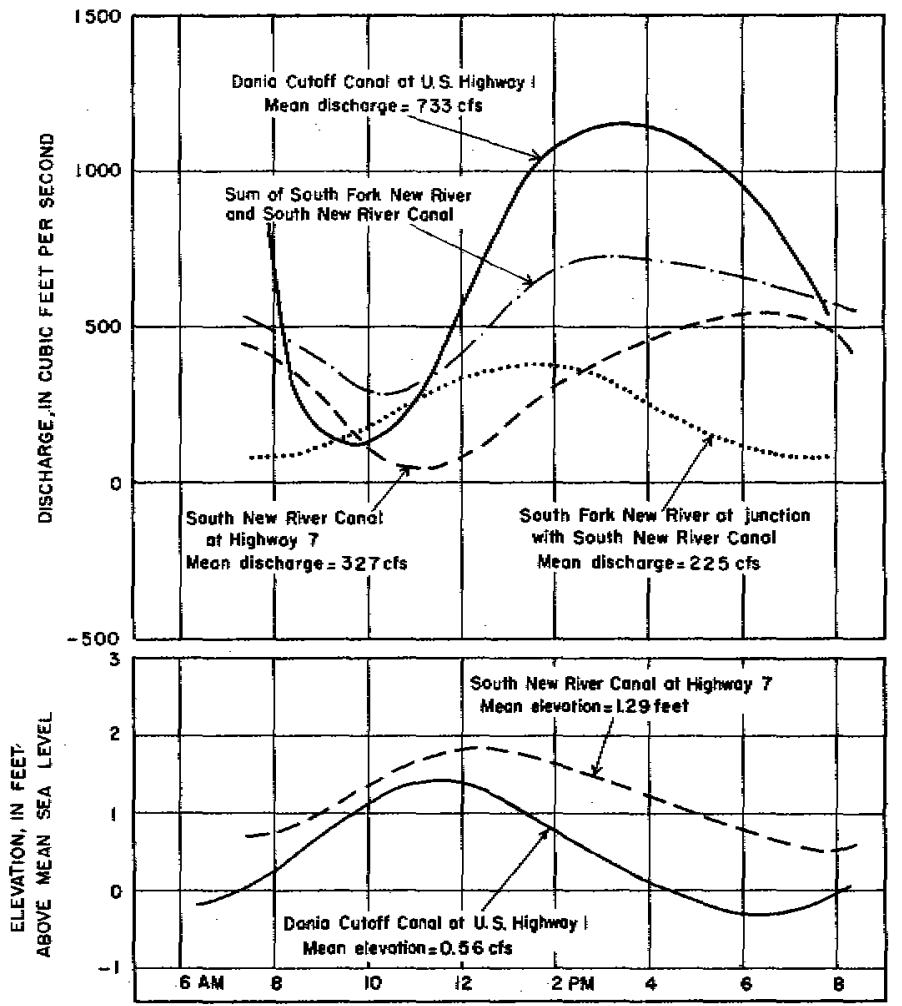
The minimum discharge of South New River Canal at Highway 7 was less than the minimum discharge of Dania Cutoff Canal at Highway 1 , which is contrary to the usual relationship in tide-affected waterways. Also, the discharge cycle of South Fork New River at the junction with South New River Canal was out of phase with the cycles at other locations in spite of the fact that both the stage and discharge of South New River Canal at Highway 7 were in nearly normal phase and that the stage there should be fairly representative of conditions at the junction, only a short distance away.

A comparison of the stage graphs for North New River Canal at Highway 7, and for South New River Canal at Highway 7, shows that the two stages were uniformly only 0.5 to $0.6 \mathrm{ftapart}$ throughout the cycle, with North New River Canal being the higher. This continuous slope tcward the south accounts for the southward flow in the upper reach of South Fork New River. The relative timing of the tidal cycle propagated up South Fork New River and Dania Cutoff Canal to the ends of this connecting reach of South Fork New River caused the discharge cycle at the junction end of the South Fork to be unusual. However, by combining the flows of the South Fork and South New River Canal to obtain net flow to the east at the junction, it is possible to obtain a graph of normal shape and phase (as shown in fig. 110).

\section{MIAMI CANAL—UPPER AND MIDDLE REACHES}

Miami Canal is shown on most maps as a continuous waterway, heading at Lake Okeechobee and extending 81 miles southward and southeastward to Biscayne Bay at Miami. From the standpoint of effectiveness as a waterway, however, the upper and lower reaches are essentially independent of each other and are connected by a middle reach that permits the passage of only small amounts of water. In discussing the canal, therefore, the upper and middle reaches are treated separately from the lower reaches. Plate 14 shows the general features of Miami Canal drainage area.

\section{PHYSICAL DESCRTPTION}

Miami Canal heads at the hurricane gate (HGS-3) in the protective levee at Lake Harbor, where Ritta Island lies just to the north in Lake Okeechobee. (See pl. 1.) A short distance south of the hurricane gate a large pumphouse of South Shore Drainage District connects with the canal. A typical control and lock of the Everglades is located at Lake Harbor proper.

The canal runs on a south-southwest course for 8.5 miles from the lake, following the alinement of an old canal (Disston), which 
extends 2.5 miles beyond. Bolles Canal intersects Miami Canal 6. 5 miles from the lake, connecting to the east with North New River Canal at Okeelanta and extending west 3 miles. At the bend 2 miles farther south, Miami Canal swings to the south-southeast.

Upper Miami Canal was dug in deep muck, some rock was removed, and the channel was largely completed to Bolles Canal, which marks the end of the upper reach. South of Bolles Canal, only the muck was removed (except near the bend, where the rock surface rises a little and a small amount of rock was removed). Disston canal was dug in muck only and is quite shallow.

From the bend, Miami Canal runs for 40 miles in two straight reaches south-southeastward to the head of the deep section just above the junction with South New River Canal. This location near the junction is considered to be the end of the middle reach.

The channel in the middle reach was excavated only in the muck and is shallow. Because of lack of maintenance, it has filled with weeds and brush and has become useless. The spoil banks, which have subsided as a result of fire and slow oxidation, are marked principally by woody growth.

Upper Miami Canal is accessible by road from the lake to several miles south of Lake Harbor, and the spoil banks are continuous in the reach. South of that region, the banks are broken or obliterated. The canal follows the natural slope of the land, and the depth of excavation gradually becomes less as the layer of muck and peat thins to the south.

The principal features along the upper and middle reaches of Miami Canal with cumulative mileage from Lake Okeechobee are listed below:

\section{Location}

Mileage

Centerline of lake levee and HGS-3............................ 0

Control and lock, Lake Harbor, (gaging station)............... . 4

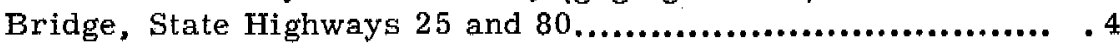

Bridge, Atlantic Coast Line Railroad............................ .9

Bolles Canal............................................................ 6.5

Bend, Disston Canal............................................... 8.6

Bend......................................................................24, 6

Beginning of deep channel,......................................48, 7 


\section{hECORDS AVAILABLE \\ [ * Record continued after period of this investigation]}

Lake Harbor

'Stage, north of control: Oct. 29, 1939, to June 30, 1943; staff gage read Oct: 29,1939 , to May 15, 1942, twice daily; May 16,1942 , to June 30,1943 , thrice daily; daily mean plotted in figure 111; stage essentially the same as in Lake Okeechobee, except for wind surges and periods when HGS-3 was closed, Maximum obseryed: $16.64 \mathrm{ft}$, on Nov, 2, 1939 . Minimum observed: $11.10 \mathrm{ft}$, on May 23, 27, 1943.

Stage, south of control: April 25, 1946 to Dec. 31, 1946*; continuous recorder record.

Oct. 29, 1939 to June 30, 1943; control not effective and stage essentially the same as that north of control.

Discharge: Nov. 7, 1939, to June 30, 1943; daily, mean plotted in figure 111; monthly and annual runoff listed in table 42. Maximum daily mean: $572 \mathrm{cfs}$, to south, on Jan. 6, 1942. 808 cfs, to north (into lake), on July $22,1941$.

No flow, on many days, at times of reversal of flow and when HGS - 3 was closed. 
Table 42.-Runoff of Mtimi Conal at Lake Harbor

[Unit, 1,000 acre-feet]

\begin{tabular}{|c|c|c|c|c|c|c|c|c|c|c|c|c|c|}
\hline Year & Jan. & Feb. & Mar. & Apr. & May & Jure & July & Aug. & Sept. & Oct. & Now. & Dec. & Annual \\
\hline $\begin{array}{l}1939 \\
1940 \\
1941 \\
1942 \\
1943\end{array}$ & $\begin{array}{r}7.4 \\
-6.4 \\
8.7 \\
2.0\end{array}$ & $\begin{array}{r}-.06 \\
-8.8 \\
8.5 \\
1.6\end{array}$ & $\begin{array}{r}4.4 \\
-3.8 \\
8.1 \\
1.1\end{array}$ & $\begin{array}{r}3.0 \\
-15.6 \\
1.8 \\
.9\end{array}$ & $\begin{array}{r}2.6 \\
-12.2 \\
.5 \\
.2\end{array}$ & $\begin{array}{r}-3.7 \\
-5.0 \\
-17.7 \\
-.1\end{array}$ & $\begin{array}{r}-2.2 \\
-39.1 \\
-7.5 \\
-7\end{array}$ & $\begin{array}{r}-7.9 \\
-25.5 \\
-.9\end{array}$ & $\begin{array}{r}-25.9 \\
-12.4 \\
-4.5\end{array}$ & $\begin{array}{r}-16.0 \\
-10.7 \\
-7\end{array}$ & $\begin{array}{r}-.5 \\
.4 \\
-.5 \\
2.1\end{array}$ & $\begin{array}{r}5.7 \\
.7 \\
1.5\end{array}$ & $\begin{array}{r}-37.3 \\
-135.3 \\
1.3\end{array}$ \\
\hline
\end{tabular}

Note, -Negative discharge indicates, llow toward Lake Okeechobee. 


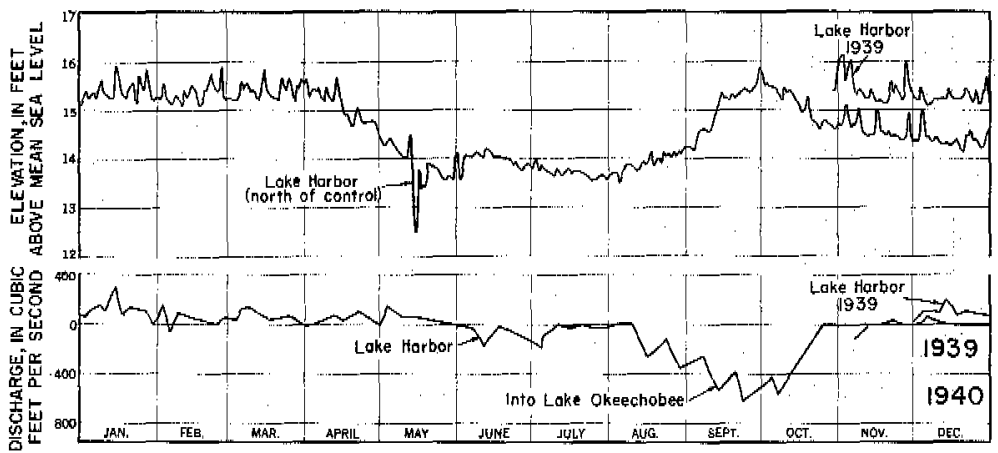

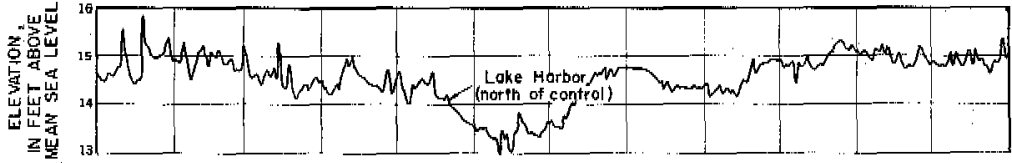

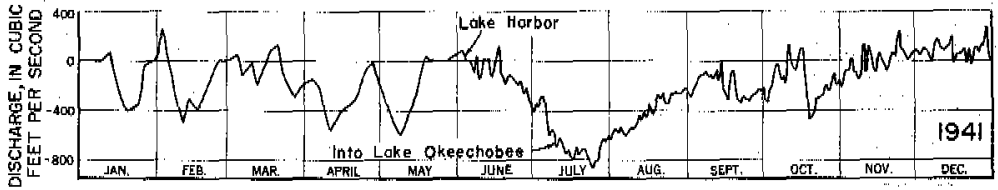

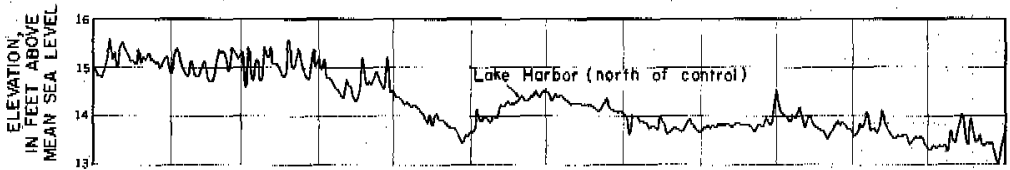
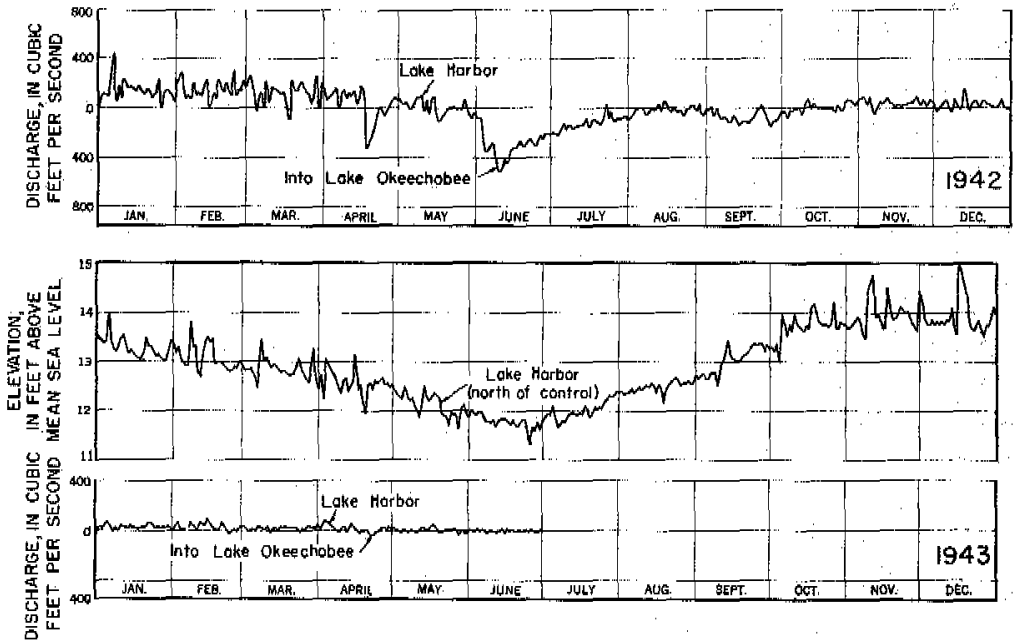

Figure 111. - Graphs of stage and discharge of Miami Canal at Lake Harbor, 1939-43, 


\section{FLOW CHARACTERISTICS}

During the period of observation (1939-43) the control and lock in Miami Canal at Lake Harbor was kept open and essentially uncontrolled flow occurred. The hurricane gate (HGS-3) was closed occasionally - at times of hurricanes, to prevent passage of hyacinth into the canal, and to control the releasing of water from Lake Okeechobee in dry periods. Direction of flow, therefore, was generally subject to the vagaries of rainfall and water conditions as well as to the surges and changes in the level of Lake Okeechobee, which were caused by wind.

The large pumphouse just south of the head of Miami Canal undoubtedly had some effect on the direction of flow and the discharge at the control and lock, because the maximum output of the pumps (268 cfs) was often greater than the discharge of the canal. At times, the flow from the pump was seen to divide and flow both north and south in the main canal. Smaller farm pumps in the several miles south of Lake Harbor purnped into, or from, Miami Canal, but they had no important effect on the flow.

The water of the upper several miles of Miami Canal stays within banks under all conditions. In the vicinity of Bolles Canal and.farther south, however, the canal overflows in wet periods and is lost in the general inundation. Overland flow of ten occurs there because the spoil banks are in such a poor condition that they cannot hold or divert much water. Water in large quantities moves overland from the higher. sand and muck lands to the west and passes in a southeasterly direction across the middle reach of Miami Canal; some of it drains into North New River Canal. In the dryer periods, the water in the middle reach of Miami Canal is within the banks, but because of the vegetation-choked condition of the channel, little or no flow occurs. In drought periods, the channel in the middle reach becomes completely dry.

As a practical water carrier, upper Miami Canal consists of the first 6 miles (less in flood periods) and the branch of Bolles Canal to the east. It serves a relatively small area, but it is not very effective even for that area because of the lack of control operations ${ }^{\mathbf{}}$. and the runoff from the open lands. It must be considered as an unusually large local canal.

Stages and discharges of upper Miami Canal are shown in figure 111. The stage north of the control was essentially the same as that of Lake Okeechobee except for wind surges and thus did not range as widely as the stage of the other major canals. Because the control and lock were generally open, head loss through it was usually very small and the stage south of the control was much the same as that north of it.

\footnotetext{
${ }^{11}$ The control and lock at Lake Harbor was put back in service in 1946 and a fair measure of control was provided.
} 
The discharge shown in the graphs is that at the control and lock and does not necessarily represent the flow into and from Lake Okeechobee. (The discharge of the large pumphouse close to the lake is not included.) Flow toward the lake is indicated on the graphs by a negative sign to differentiate it from flow toward the sea, which is considered the normal, or positive, direction. Reference to figure 111 and table 42 shows that the major part of the flow was toward the lake because of the large amount of runoff from the open lands. Negative, or reverse, flow occurred 47 percent of the time in the period of recordand 38,71 , and 39 percent of the time, respectively, in the 3 years of record. Rates of discharge ranged between 572 cfs away from the lake and 808 ofs toward the lake.

No flow occurred on many days during the period of record, and during late 1942 and the first half of 1943 the flow was very small and indecisive indirection. This was a notably dry period, and the small amount of water movement may be accounted for by the fact that upper Miami Canal was connected only to Lake Okeechobee, and no flow existed in the middle reach or in Bolles Canal.

In flood periods, it is likely that the east branch of Bolles Canal contributes no water to Miami Canal, but instead, it picks up some of the overland flow from the west and diverts it to North New River Canal. In the period between flood and drought, when Miami Canal is flowing south at Lake Harbor, some of this water enters the east branch of Bolles Canal. In drought conditions, the shallow, illmaintained channel of Bolles Canal becomes dry at some locations.

\section{LOWER MIAMI CANAL}

The lower reach of Miami Canal is treated here as a hydrologic unit because it is separate from the upper and middle reaches. In discussing the lower drainage basin, the name "Miami Canal" will be used, and references to upper and lower parts will refer to parts of the lower basin. See plate 14 for the general features of the drainage area.

Because of its key relationship to the Miami metropolitan area, Miami Canal was studied most extensively of all the canals in the Everglades and coastal ridge. It is closely related to the municipal water supply in several ways: as a source of recharge to the present well field; as a source in itself for emergency supply or for future water needs; as a threat to the permanence of the well field because of contamination by sea water; and, paradoxically, as a protection against contamination of the public supply by sea water. The canal is also the principal drainageway of upper Dade County and is closely related to flood problems; it is important to the preservation of the soil and wildlife of a large area of the middle Everglades; its use. 
as a source of industrial water supplies has increased; and it (Miami River) is increasingly used for navigation.

Because the investigations of Miami Canal were so extensive, its discussion has been divided into a number of subtopics, even though a sharp division by subject could not always be effected. Most of the tidal phenomena observed and reported for Miami Canal are common to all tidal waterways in southeastern Florida and can be applied to them.

\section{PHYgCAL DECCDIPTION}

Lower Miami Canal is assumed to begin at the head of the deep excavation just northwest of the junction with South New River Canal (fig. 112). This location, which is also the southern end of the shallow middle reach of the canal, is 49 miles from Lake Okeechobee and 32 miles northwest from the mouth of the canal at Biscayne Bay. It is marked by a line of broken rock across the canal (fig. 113), which has the appearance of a breached dam, but which was left from the dredging operations.

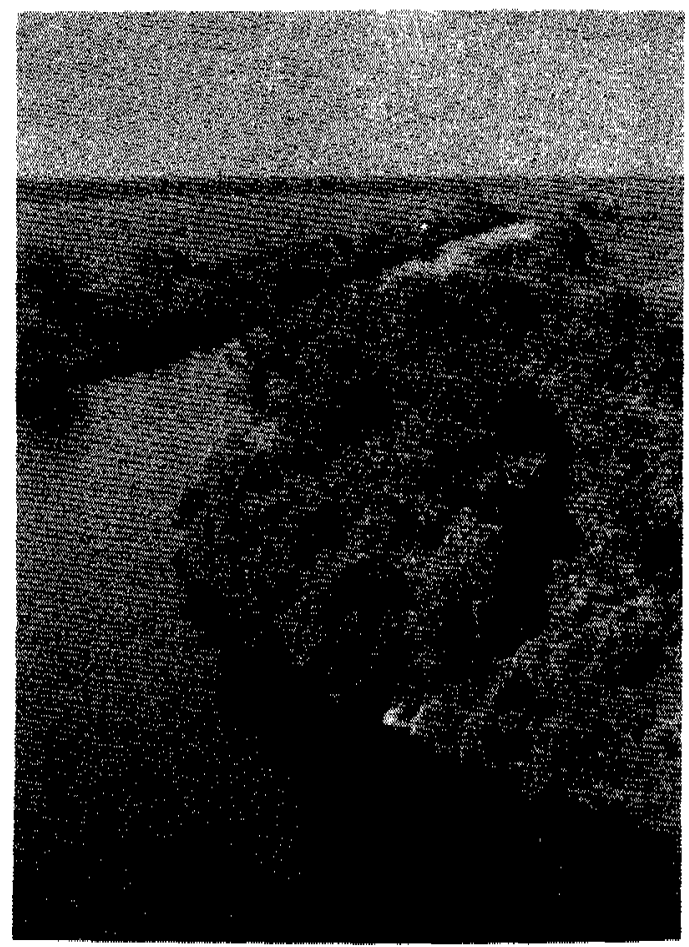

Figure 112, - View of Miami Canal upstream from junction with South New River Canal. End of deep channel and outline of shallow channel shows in background. February 19, 1941. 


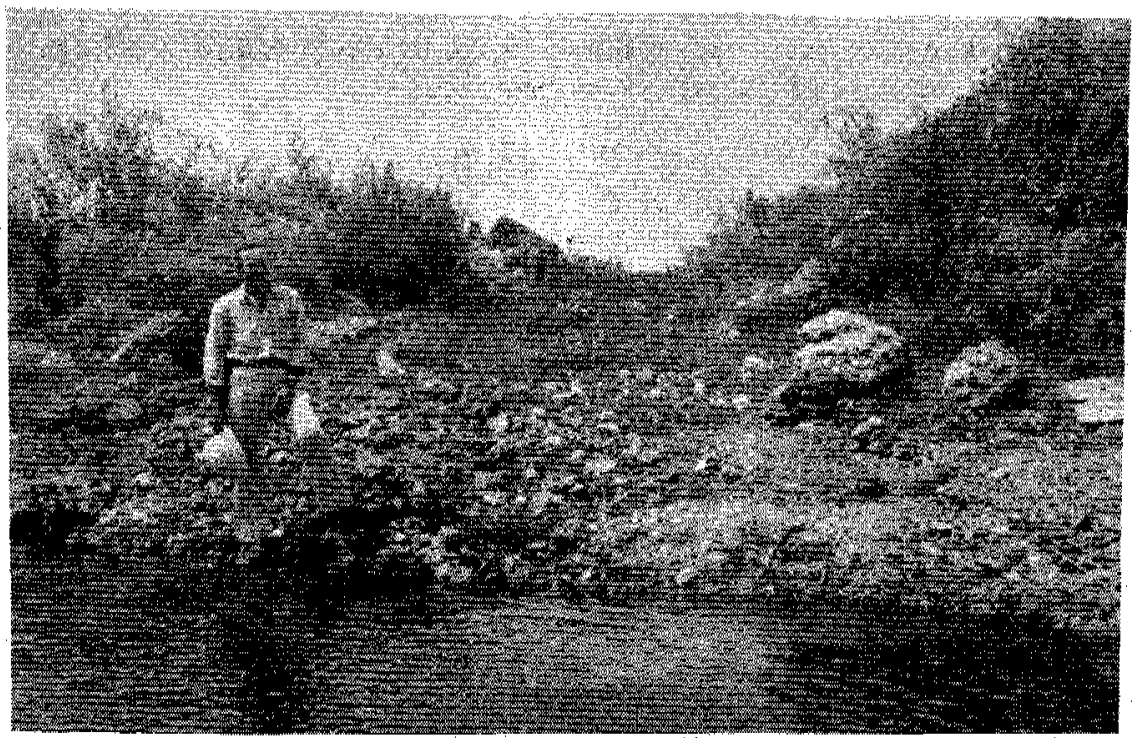

Figure 113, - View upstream in bed of Miami Canal; shallow excavation above head of deep channel. Photograph taken April 13, 1943, in dry period.

South New River Canal, which extends due east to the Fort Lauderdale area, connects with Miami Canal 0.4 mile below the head of the deep channel. No control exists at the junction of the two canals. Miami Canal continues to the southeast through sawgrass terrain for 10 miles to an earth dam. In figure 114 , note

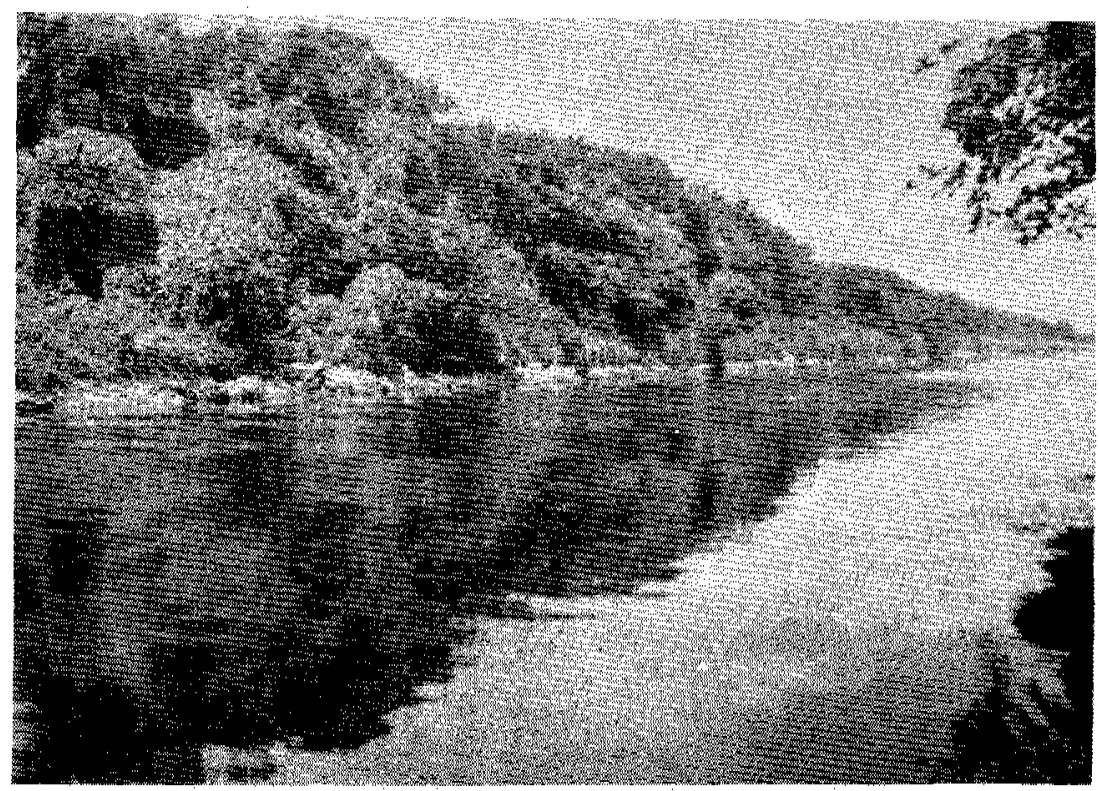

Figure 114. - Lower Miami Canal above County Line Dam, Dense jungle on bank of Miami Canal 2 miles above County Line Dam; trees and brush were not indigenous to the area prior to digging the canal. 
the rank growth of rubber, guava, and other trees on the aerated soil of the spoil banks. These trees do not occur in the adjacent glades soils. Both banks are unevenly graded, breaks in the banks exist at many locations, and no road serves this reach.

County Line Dam, as the earth and rock dam is known locally, is actually in Broward County about 0.4 mile north of the DadeBroward County line at the point where Dade-Broward Levee intersects Miami Canal. The dam has five 36-in. pipe culverts, each equipped with a gate valve at the upstream end (see fig. 115). The culverts and gates were installed late in May 1940 to replace a $35-\mathrm{ft}$ breach that had been cut in the dam a week previously. The gates are opened to release flow for recharge of downstream areas in drought periods, but the dam was placed primarily for flood control.

Dade-Broward Levee extends southward to Tamiami Canal and Tamiami Trail, and northward to South New River Canal. The muck section south of Miami Canal has subsided by oxidation and burning, has been breached extensively at several locations, and during the period of observations by the Survey, was not very effective. ${ }^{22}$ The section of the levee north of Miami Canal was built almost entirely of muck and has subsided to the point where its effect is negligible.

${ }^{12}$ Dade County rebuilt and strengthened the levee in 1947 and 1948 ,

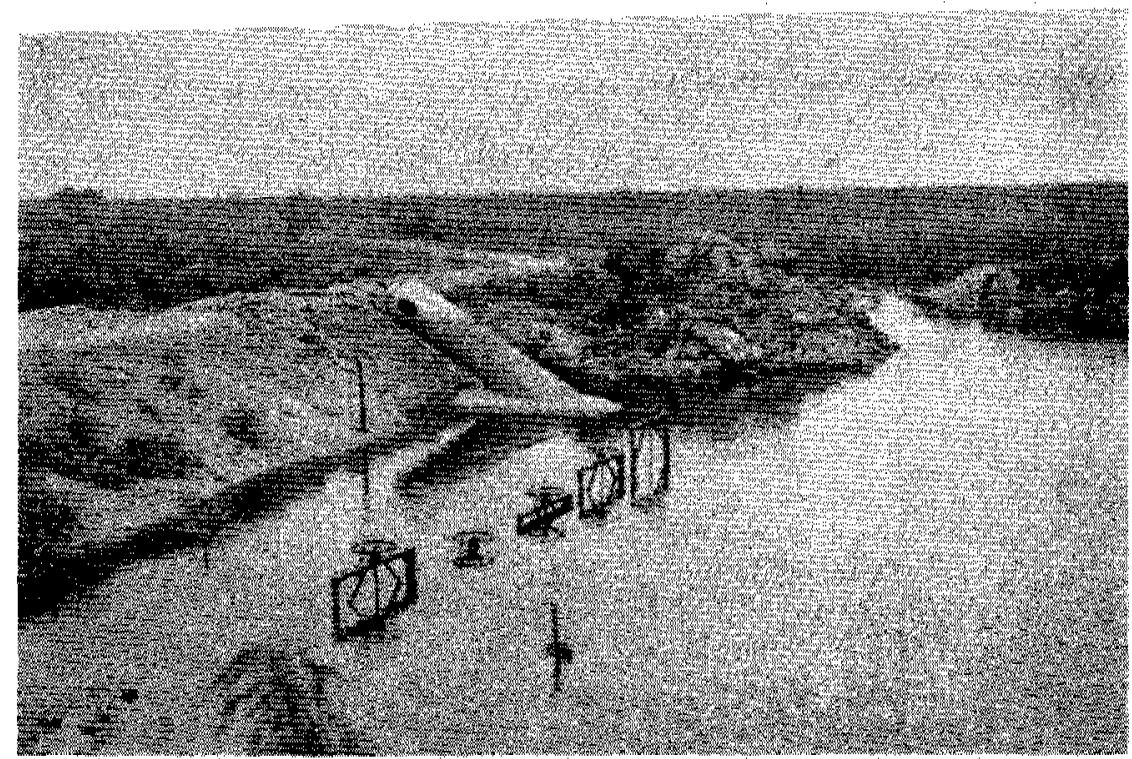

Figure 115. - Upstream side of County Line Dam showing top of control gates, temporary irrigation-pump installation, and diversion to the borrow pit along the west side of DadeBroward Levee. The levee appears in the left background as an extension of the dam. April 20,1943 . 
The borrow ditch along the west side of the south section of DadeBroward Levee has been connected with Miami Canal.in several ways: directly through a breach in the canal bank (see fig. 115); through an uncontrolled $2 \mathrm{ft}$ pipe culvert; and through the same culvert, with a gate valve. Connection with the borrow ditch along the north section of the levee was at a low place in the canal bank, which permitted flow only during higher stages.

Broken Dam, 2. 5 miles downstream from County Line Dam, is an earth and rock dam that was dynamited, and the remnant of the dam is a definite constriction in the canal (see fig. 116). Close by, State Highway 25 (formerly 26) comes in from the north and runs parallel with Miami Canal along the northeast spoil bank toward Miami.

Between Broken Dam and Pennsuco, about 4 miles farther downstream, several small lateral canals and ditches enter Miami Canal from both banks. Half a mile below the dam, Golden Glades Canal enters from the east. A short, but wide, stub canal enters from the west a little more than 1 mile above Pennsuco. The purpose of the stub canal is not known, although its dimensions indicate that an ambitious project was planned. Between Golden Glades Canal and the stub canal, a long lateral is shown entering from the southwest on most maps. This lateral is so shallow and choked with weeds that it can hardly be considered a waterway.

${ }^{13}$ The road parallel with Golden Glades Canal was raised to form a levee by Dade County in 1947 and 1948 .

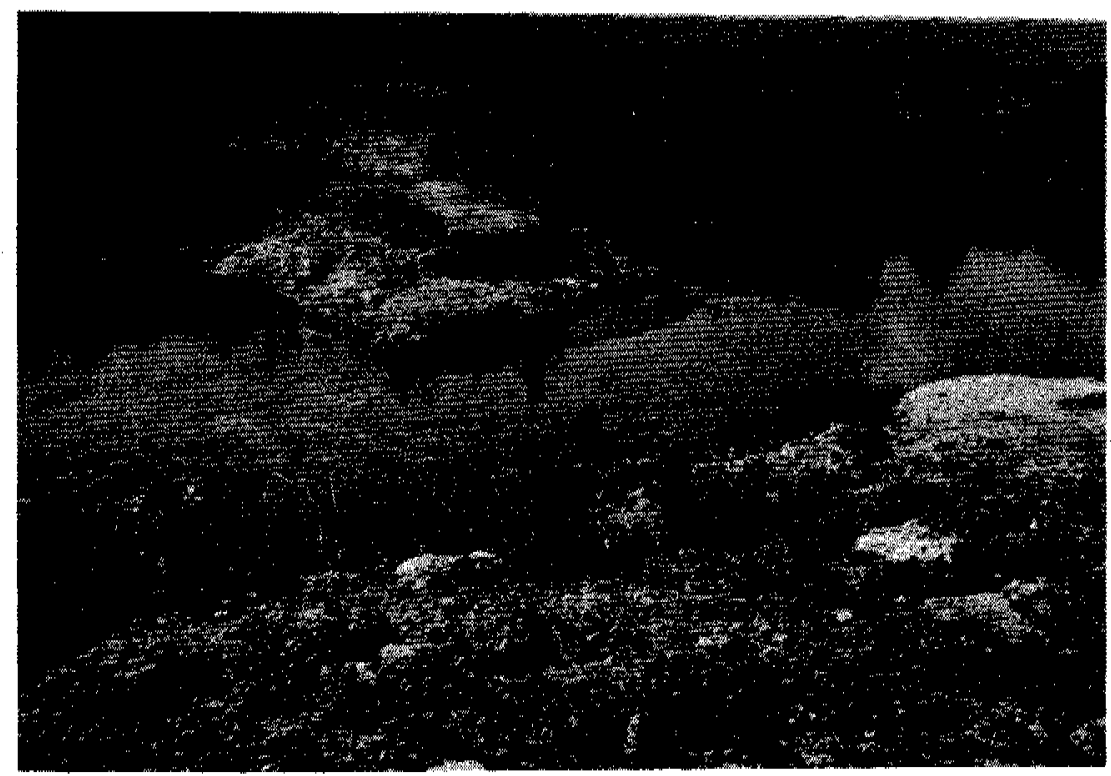


At Pennsuco (contraction of Pennsylvania Sugar Co., now defunct), a principal lateral enters Miami Canal from the southwest. Pennsuco Lateral extends 6 miles to the west and intersects DadeBroward Levee about 5.5 miles south of County Line Dam. On the east side of the levee, the lateral is dammed-off from the levee borrow pit, but on the west side of the levee it is connected with the borrow pit. An earth dam is located about 1.5 miles from Miami Canal, and close to the main canal is a pump and control.

In the 6-mile reach between Pennsuco and the Florida East Coast Railway bridge in Hialeah, three small laterals enter Miami Canal from the north (see pls. 15 and 16). About midway in this reach, Russian Colony Canal connects from the west and extends 2.6 miles to the west to a junction with the north section of Snapper Creek Canal. Shallow canals extend northward and westward from the junction, but they are poor water carriers.

Starting at the Florida East Coast Railway bridge, 1.5 miles above the city of Miami Water Plant, is a series of laterals that have an important relationship to the Miami well field. The interrelationship of these laterals and the well-field area are shown on plates 15 and 16 and in greater detail in figure 140. F. E. C. 4 Canal connects with Miami Canal just upstream from the bridge and extends south along the west side of the railroad about 5 miles to Tamiami Canal. The channel that connects through a culvert on the downstream side of the bridge is known as F. E. C. Borrow Canal and extends south 3 miles to a dead end. This sizable borrow pit provided fill for the railroad's maintenance yards and shop (now abandoned).

The Water Plant in Hialeah is on the northeast bank of Miami Canal 7. 7 miles from Biscayne Bay. This plant supplies water to Miami, Miami Beach, and other communities in the metropolitan area. The original capacity of the plant was $40 \mathrm{mgd}$, which was increased to $60 \mathrm{mgd}$ in 1948 . The wells are located principally in Miami Springs on the southern side of the canal and within a radius of about 1 mile from the plant.

A short distance above the Water Plant, Red Road Canal enters Miami Canal from the north, extends northward 9 miles along the west side of Red Road, and connects with many laterals and canals. The small canal that connects with Miami Canal from the southwest, just below the Water Plant, is important because it passes close to the lower well-field area in the golf course in Miami Springs. This is known as Country Club Canal (also, South Side Canal), and it meanders toward the southwest about 2 miles to a connection with F. E. C. Borrow Canal. A mile downstream from the Water Plant, a small lateral connects Miami Canal with Twin Lakes, which is a small flooded rock pit.

14 The initials "F. F, C." are used locally as a name. 
Two miles southeast of the Water Plant and immediately below the NW. 36th Street bridge is the site of 36 th Street Dam. At this location, which is 5.6 miles from Biscayne Bay, dams were placed in Miami Canal during parts of 1940 and 1943-46. A boatlift was constructed to move boats (as large as about $40 \mathrm{ft}$ long) around the dam. Except for a period of about 2 years the dams were of a temporary nature, constructed from sheet-steel piling. The installation and operation of the dams were necessary to conserve fresh-water supplies and to prevent salty water from contaminating the well fields--see the section on encroachment of salty water in the tidal canals.

Several hundred feet below the darm site, Miami Canal becomes wider and deeper at the head of the channel improvement made in 1932-33. The 4-foot break in depth (approximate) is referred to as the "step", and it plays a part in the water events of the canal.

A little less than 1 mile below the dam site, Palmer Lake connects with Miami Canal from the west through a short connecting channel. Palmer Lake (see fig. 184), which is actually a low-level rock and gravel pit, is tidal and has some importance with respect to the intrusion of salty water in the area.

Tamiami Canal, the principal tributary of Miami Canal, connects from the west $1 / 4$ mile above NW. 27 th Avenue, Miami, and 4.2 miles from Biscayne Bay. (See pl. 14.) A short distance above Tamiami Canal a concrete abutment marks the site of the old control and lock that was removed about 1932, when the channel was enlarged.

For practical purposes, it has been considered that Miami Canal ends, and Miami River begins, a short distance upstream from the bridge at NW. 27th Avenue. This is not strictly accurate, but is appropriate, because Dade County is planning to build a control and locks for the stream at this location, and therefore it will provide a logical dividing point.

About $1 / 4$ mile downstream from NW. 27th Avenue, the natural channel of North Fork Miami River (known locally as Comfort Canal) connects from the west with the present Miami River (fig. 184). Fergusons Mill was located here on a natural riffle in the river during the early settlement days. A natural riffle is a rarity in southern Florida and its existence shows how the rock formations formerly kept water ponded in the Everglades, even in areas now thickly settled. Miami River was one of the overflow channels of the Everglades, and the muck-soil areas of lower Tamiami Canal basin and around Miami springs are actually part of the Everglades.

Miami River is gently meandering in the last 4 miles from North Fork Miami River to Biscayne Bay. A little less than 1 mile south- 
east of NW. 27th Avenue the natural channel of South Fork Miami River enters from the west. This stream extends toward the west for about 1.5 miles to the east end of Comfort Canal, which continues westward through a low slough to a connection with Tamiami Canal. Below South Fork, no other significant tributary enters Miami River, which empties into Biscayne Bay in the heart of Miami.

Miami Canal and Miami River are continuously accessible by road from County Line Dam to Biscayne Bay, a distance of 21 miles. The spoil banks vary considerably in height, and at many locations the parallel road grade is actually the bank and may be subject to overflow during extreme flood conditions. The lower 5.5 miles of the canal and river is used extensively by both pleasure and commercial boats. Many yacht basins and industrial concerns line both banks.

The following tabulation, which is a continuation of the tabulation on page 407, lists the principal features along the lower reaches of Miami Canal, with cumulative mileage from Lake Okeechobee.

Beginning of deep channel........................................48.7

Junction with South New River Canal................................49. 1

Bend.................................................................5 58.2

County Line Dam, Dade-Broward Levee.........................59. 0

Broken Dam, State Highway 25 from north, stage station..... 61.5

Golden Glades Canal..............................................62, 2

Stub lateral...........................................................64. 3

Bridge, Pennsuco lateral, stage station........................65.6

Russian Colony Canal, stage station.............................66.4

F. E. C. Canal, F. E. C. Ry. bridge, F. E. C. Borrow

Canal, stage station.......................................... 71.6

Red Road Canal........................................................ 72.9

Water Plant, Hialeah, gaging station............................ 73.1

Country Club Canal....................................................73.3

Bridge, Hialeah-Miami Springs............................... 73.6

Twin Lakes entrance............................................. 74.0

Bridge, NW. 36 th Street............................................75.1

36 th Street Dam, boatlift, stage stations......................... 75.15

Change in channel depth (step) ....................................... 75. 2

Bridge, Seaboard Railroad........................................... 75. 4

Palmer Lake entrance..............................................76. 0

Tamiami Canal,...................................................76,5

Bridge, NW, 27th Avenue, beginning of Miami River...........76.8

North Fork Miami River.............................................. 77.1 
South Fork Miami River............................................. 77. 7 Bridge, NW. 17th Avenue.......................................78.0

Bridge, NW. 12th Avenue......................................... 78. 6 Bridge, NW. 5th Street..........................................79.2

Bridge, West Flagler Street..................................... 79.7

Bridge, SW. 1st Street.......................................... 79. 8

Bridge, SW. 2nd Avenue............................................ 80. 1

Bridge, F. E. C. Railway...................................... 80.2 Bridge, South Miami Avenue....................................... 80.4 Bridge, SE, 2nd Avenue (U. S. Highway 1).................. 80.6 Mouth, Biscayne Bay.............................................. 80,8

In the early days of the development of the Everglades, Miami Canal was a continuous waterway from Lake Okeechobee to Miami and must have received some water hyacinth from the lake, as did the other major canals. Curiously enough, however, practically no hyacinth exists in the lower reaches, now separated from the lake by the shallow, weedy middle reaches. Pennsuco lateral contains a small amount and some can be found in the tidal river reaches, but the main canal has been exceptionally free, including the connecting pool of South New River Canal. The reason for this has not been evident, because conditions for hyacinth growth in Miami Canal seem to be as favorable as in any other canal. Even the periods of low velocity and negative flow have not spread this pest, and the clumps that seem to be possible breeding centers do not expand very fast.

However, at times a bottom-rooted plant (identified as a naiad) and other aquatic plants have partly blocked the channel of Miami Canal upstream from Hialeah. When the bottom-rooted weed is broken loose by increased flow or temperature changes great masses move with the current and lodge against bridges and other obstructions. The resultant jams may reach sizable proportions, cause appreciable loss of head, and lead to the destruction by scour of pile-supported structures. A case is reported where a mass of weed, rolling as a great amorphous wad in the current, caught on a bridge and caused so much backwater that the water cut a new channel around the bridge.

Except for the last 4 miles, lower Miami Canal is an artificial channel, which extends toward the southeast through an area that originally drained toward the southeast and south. West of Hialeah, it was dug through a shallow layer of peat into very porous limestone. In the coastal ridge, excavation was principally in porous rock, except where a shallow sand cover of varying thickness existed. The limestone is so highly permeable that most of the flow enters the 
canal by seepage through the bottom and banks; this is particularly true in moderately dry to drought periods.

Because of the flatness of the terrain through which Miami Canal passes, the area contributing water to it is indeterminate. Drainage divides, both surface and underground, shift according to control operations and distribution of rainfall. This makes it impossible to determine unit-runoff rates except by treating the Everglades as a hydrologic entity.

In order to discuss the lower reaches of Miami Canal effectively, the channel has been divided into several parts. The principal divisions are the headwaters-reservoir area, the storage-inflow reach, and the tidal reaches. The pertinent hydraulic characteristics of each part are discussed following the tabulation of available records.

\section{RECOHDS AVAILABIE.}

[* Record continued after period of this investigation]

Junction with South New River Canal

Stage: June 11, 1941, to May 17, 1943; continuous recorder graph; essentially the same as that for South New River Canal at State Highway 25-see figure 107 -but was several tenths of a foot lower in wet periods, or when weed growth in the canals was heavy.

Discharge: March 1941 to April 1943; miscellaneous measurements above and below junction made on 23 dates; see table 43.

Reservoir area

Stage and discharge: Feb. 1941 to April 1943; about monthly reconnaissances of the pool from South New River Canal at Highway 25 to Miami Canal at Broken Dam; see figure 124 for the type of data obtained.

County Line Dam

Stage, northwest of dam: Sept. 25, 1942, to Aug. 26, 1943; continuous recorder graph; daily mean plotted in figures 119-123.

Broken Dam

Stage, northwest of dam: Sept. 26, 1941, to Dec. 31, 1946*; continuous recorder graph; daily mean plotted in figures 117123.

Maximum: 7.16 ft, on Sept. 27-29, 1941.

Minimum: $1.02 \mathrm{ft}$, on June 20, 1945.

Discharge: May 1940 to April 1946; miscellaneous measurements made on 50 dates; see table 44.

Maximum measured: $522 \mathrm{cfs}$, Feb. 17, 1941.

Minimum measured: $12.1 \mathrm{cfs}$, June 8, 1945. 
Table 43. - Discharge, in cubic feet per second, and elevation, in feet above mean sea level, at selected points principally in hesdwerer storage area of lower Ifiami Canal and the tpper South New River Canal

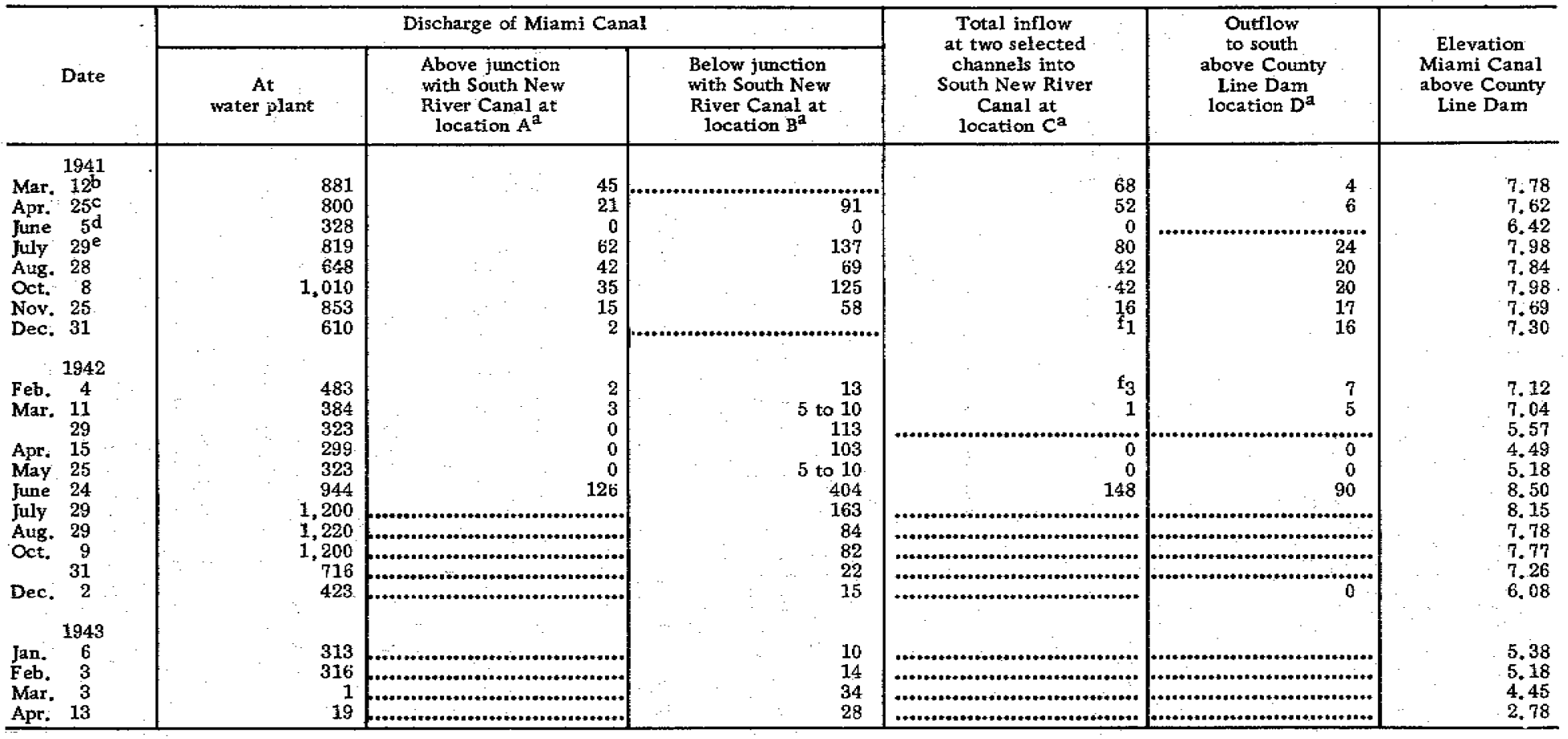

${ }^{\text {a }}$ Location indicated is shown in figure 124 .

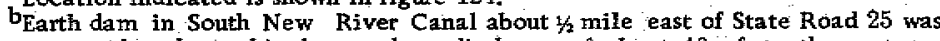
not yet replaced on this date and a discharge of about 40 cfs to the east was measured at the site.

CDischarge of about 43 cfs measured at dam site referred to in footnote "b" above.

Discharge of about 33 cis measured at dam site referted to in footnoce $4 \mathrm{tb}_{\mathrm{b}}$ " above. Gates at County Line Dam open and passing water at a rate of $188 \mathrm{cfs}$. Dani eferred to in footnote "p".

Outflow. 
Table 44.-Discharge, seopage, and water-level data on Miami Canal in storage inflow reach, County Line Dan to Pennsuco

\begin{tabular}{|c|c|c|c|c|c|c|c|c|}
\hline \multirow{3}{*}{ Date } & \multicolumn{4}{|c|}{ Discharge (in cfs) } & \multicolumn{4}{|c|}{ Elevation (in feet above mean sea level) } \\
\hline & \multirow{2}{*}{$\begin{array}{c}\text { Broken } \\
\text { Dam }\end{array}$} & \multirow{2}{*}{$\begin{array}{l}\text { Penn- } \\
\text { suco }\end{array}$} & \multicolumn{2}{|c|}{ Differe } & \multirow{2}{*}{$\begin{array}{c}\text { Above County } \\
\text { Line Dam }\end{array}$} & \multirow{2}{*}{$\begin{array}{c}\text { At Broken } \\
\text { Dam }\end{array}$} & \multirow{2}{*}{$\begin{array}{l}\text { Difference } \\
\text { (in feet) }\end{array}$} & \multirow{2}{*}{$\begin{array}{l}\text { At Penn " } \\
\text { suco }\end{array}$} \\
\hline & & & InIsow & 10w & & & & \\
\hline 1940 & & & & & & & & \\
\hline May 23 & 96 & 48 & ........ & 48 & |.................... & 3.17 & 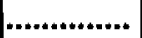 & 1.96 \\
\hline Nov. 27 & $\begin{array}{r}91 \\
439\end{array}$ & $\begin{array}{r}89 \\
928\end{array}$ & ........... & 2 & (b) & 3.20 & $\mid \cdots+\ldots+\cdots+\cdots$ & 2.16 \\
\hline Nov. 21 & & & 408 & & [................... & & |............... & \\
\hline 1941 & & & & & & & & \\
\hline Feb. $\quad 17$ & 522 & 806 & 284 & ...... & an.................... & 5.13 & [................. & 4.14 \\
\hline June 24 & 203 & 297 & 94 & ...... & .......................... & 14 & $\ldots \ldots \ldots$ & 3.04 \\
\hline $\begin{array}{cc}1942 \\
\mathrm{Feb} & 14\end{array}$ & & & & & & & & \\
\hline $\begin{array}{l}\text { Feb. } 14 \\
\text { Mar. } 13\end{array}$ & $\begin{array}{l}175 \\
170\end{array}$ & $\begin{array}{l}245 \\
260\end{array}$ & $\begin{array}{l}70 \\
90\end{array}$ & 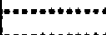 & 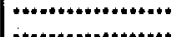 & $\begin{array}{l}2.98 \\
2.84\end{array}$ & …............ & $\begin{array}{l}1.98 \\
1.85\end{array}$ \\
\hline 19 & 178 & 202 & 24 & ....... & 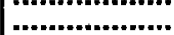 & 2.75 & (...................... & 1.89 \\
\hline 22 & 161 & 240 & 79 & ...... & .......................... & 2.71 & (.................... & 1.81 \\
\hline May 8 & 125 & 172 & 47 & .................. & (4), & 3.40 & 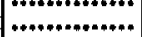 & 2,73 \\
\hline & 118 & 180 & 62 & & .......................... & 3.57 & 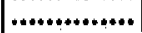 & 2.84 \\
\hline & 200 & 178 & .... & 22 & 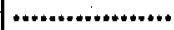 & 4.21 & n................ & 3.14 \\
\hline June 13 & 262 & 320 & 58 & ...... & $\mid$ & 6.52 & $\mid \cdots+\cdots \cdots \cdots \cdots+\cdots$ & 5.74 \\
\hline $\begin{array}{r}27 \\
\text { Dec. } 28\end{array}$ & 296 & 328 & $\begin{array}{l}32 \\
98\end{array}$ & ............. & 5,60 & $\begin{array}{l}6.88 \\
2.58\end{array}$ & 1....... & $\begin{array}{l}6.07 \\
153\end{array}$ \\
\hline & & & & & & & & \\
\hline $\begin{array}{l}1943 \\
15\end{array}$ & & & & & & & & \\
\hline Jan. 15 & 135 & 213 & 78 & • & 5.10 & 2.33 & 2.77 & 1.21 \\
\hline 26 & 117 & 20 & 89 & & 4.78 & 2.26 & 2.52 & 1.33 \\
\hline Feb. 1 & 128 & 196 & 68 & $\ldots . . .$. & 5.35 & 2.54 & 2,81 & 1.57 \\
\hline & 117 & 17 & 58 & P. & 4.93 & 2,34 & 2.59 & 1.27 \\
\hline 15 & 104 & 14 & 41 & [............... & 4.60 & 2. & 2.42 & .97 \\
\hline 22 & 84 & 1t & 20 & & 4.35 & 2. & 2.19 & 1.11 \\
\hline 28 & 100 & 15 & 52 & & 4.55 & $\ddot{2}$. & 2.40 & .97 \\
\hline Mar. 10 & 82 & 65 & ....... & 17 & 4.30 & 2.38 & 1.92 & 1.53 \\
\hline 16 & 74 & 66 & ........ & 8 & & 2.40 & (......... & 1.54 \\
\hline 30 & 51 & 44 & [a.............. & 7 & $3.70^{\circ}$ & 2.31 & 1.39 & 1.52 \\
\hline Apr. $\quad \frac{1}{2}$ & 88 & 82 & ............ & 6 & $b 3.29$ & 2.71 & .58 & 1.60 \\
\hline & $\begin{array}{r}95 \\
110\end{array}$ & $\begin{array}{l}80 \\
82\end{array}$ & …….... & $\begin{array}{l}15 \\
28\end{array}$ & $b_{3} .28$ & $\begin{array}{l}2.78 \\
2.82\end{array}$ & $\begin{array}{r}-40 \\
37\end{array}$ & $\begin{array}{l}1.64 \\
1.70\end{array}$ \\
\hline & 87 & 75 & .................. & 12 & $b_{3} .10$ & 2.78 & .32 & 1.71 \\
\hline 7 & 9] & 112 & 21 & & $b_{2.98}$ & & .18 & 1.72 \\
\hline 8 & 9 & 20 & 1 & .. & & 2. & .1 & 1.74 \\
\hline 10 & 96 & 77 & .... & 19 & & & .1 & 1.71 \\
\hline 13 & 9 & 67 & ................ & 23 & b. & 2. & .06 & 1.67 \\
\hline 17 & 7 & 72 & ..... & 1 & $b_{2.69}$ & & .03 & 1.62 \\
\hline 27 & 10 & 172 & 72 & & 5.60 & & 1.66 & 2.52 \\
\hline May 4 & 13 & 12 & $\therefore$ & 8 & $b_{4.71}$ & & & 2.24 \\
\hline & 57 & 0 & 30 & & 4.41 & & 1.19 & 2.01 \\
\hline 19 & 50 & 1 & 31 & {$[\ldots . . . . . . . .$.} & 4.35 & & $\because$ & 2.43 \\
\hline & 77 & 173 & 96 & $\ldots . .$. & 5.84 & & 1. 22 & 3.27 \\
\hline June 5 & 143 & 114 & $\ldots$ & 29 & 5.59 & & 1,48 & 2.44 \\
\hline & 50 & 75 & 25 & ............... & 4.9 & 3. & 1.4 & 1.96 \\
\hline & 41 & 47 & 6 & $\ldots \ldots \ldots$ & & & & 1.74 \\
\hline $\begin{array}{l}1944 \\
\text { Apr. } 25\end{array}$ & 113 & 106 & .• & 7 & $b_{2.89}$ & 2.65 & .24 & 2.03 \\
\hline 1945 & & & & & & & & \\
\hline Apr. 13 & 59 & 64 & 5 & a.e & $b_{2.26}$ & 2.03 & .23 & 1.61 \\
\hline $\begin{array}{rr}\text { May } & 18 \\
\text { Jume } & 8\end{array}$ & $\begin{array}{l}19 \\
12\end{array}$ & (......... & 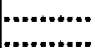 & ........... & 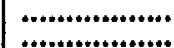 & $\begin{array}{l}1.27 \\
1.30\end{array}$ & a................... & $\begin{array}{r}.69 \\
51\end{array}$ \\
\hline 1946 & & & & & & & & \\
\hline Jan. 14 & 353 & 694 & 341 & $\ldots$ & 7.26 & 4. 71 & 2.55 & 3.88 \\
\hline Mar. 14 & 137 & 152 & 15 & 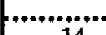 & ..................... & 2.72 & |................. & 2.17 \\
\hline Apr. $\quad 25$ & 50 & .... &... & 14 & (.......... & $\begin{array}{l}2.88 \\
2.38\end{array}$ & 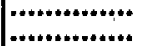 & $\begin{array}{l}2.56 \\
1.96\end{array}$ \\
\hline
\end{tabular}

${ }^{2}$ Discharge for Miami Canal at Pennsuco was computed on basis of a hydrograph through the measurements and does not include inflow from lateral.

County Line Dam open. 


\section{Pennsuco}

Stage: Sept. 28, 1940, to Dec. 31, 1946*; continuous recorder graph; daily mean plotted in figures 117-123.

Maximum: 6.13 ft, Sept. 22, 23, 1940, July 4, 1942.

Minimum: $0.24 \mathrm{ft}$, June $18,1945$.

Minimum daily (tidal): $0.27 \mathrm{ft}$, on June 17, 1945.

Discharge, above Pennsuco lateral: Nov. 9, 1939, to July 5, 1943; daily mean, plotted in figures 117-120;monthly and annual runoff listed in table 45.

Maximum daily mean: $956 \mathrm{cfs}$, Nov. 25, 26, 1940.

Minimum daily mean: $44 \mathrm{cfs}$, Mar. 30, 1943. (Reverse flow was observed near high tide on one date in drought period of 1943).

Discharge of Pennsuco lateral: Feb. 12, 1940, to Aug. 2, 1943; about weekly measurements, listed in table 46; daily mean plotted in figures 117-120.

Maximum measured: $186 \mathrm{cfs}$, Oct. $7,1940$.

Minimum measured: $3.1 \mathrm{cfs}$, Apr. 13, 1943.

Russian Colony Canal

Stage: Aug. 13, 1941, to Dec. 31, 1946*; continuous recorder graph; daily mean plotted in figures 118-123.

Maximum: 5, $21 \mathrm{ft}$, June 27, 28, 1942 .

Minimum: $0.21 \mathrm{ft}$, June 17, 18, 1945.

Minimum daily (tidal): $0.22 \mathrm{ft}$, June 17, 1945 .

F. E. C. Canal

Stage: Sept. 28, 1941, to July 5, 1943; continuous recorder graph; daily mean plotted in figures 118-120.

Maximum: $3.89 \mathrm{ft}$, Sept. 4, 1942.

Minimum: $-0.23 \mathrm{ft}$, July 3, 1943 .

Minimum daily (tidal): $0.43 \mathrm{ft}$, July 3,1943 .

Water Plant, Hialeah

Stage: Feb. 24, 1940, to Dec. 31, 1946*; continuous recorder graph; daily mean plotted in figures 117-123.

Maximum: $4.55 \mathrm{ft}$, Sept. 15, 1945.

Minimum: $-0.54 \mathrm{ft}$, July 2, 1943, Mar. 22, 1945.

Minimum daily (tidal): $0.20 \mathrm{ft}$, Mar, 22, 1945.

Discharge: Jan. 24, 1940, to Dec. $31,1946^{*}$; daily mean plotted in figures 117-123; monthly and annual runoff listed in table 47.

Maximum daily mean: $1,670 \mathrm{cfs}$, on Nov. 8, 9, 10, 1940.

Minimum: 390 cfs reverse flow, measured June 23, 1943. No flow, May 16 to June 24, 1945 (dam at NW. 36 th Street closed).

NW. 36th Street Dam

Stage, northwest of dam: Aug. 12, 1941, to Dec, 31, 1946*; continuous recorder graph; daily mean plotted in figures 118123.

Maximum: $5.11 \mathrm{ft}$, Sept. 15, 1945.

Minimum: 0.84 ft, Mar. 22, 1945 (at low tide). Minimum daily (tidal): $0.10 \mathrm{ft}$, Mar. 22, 1945. 
Table 45.-Runotf of Miami Canal a Pennsuco, near Hiani

[Unit, 1,000 acre-feet]

\begin{tabular}{|c|c|c|c|c|c|c|c|c|c|c|c|c|c|}
\hline Year & Jan. & Feb. & Mar. & Apr. & May & June & July & Aug. & Sept. & Oct. & Nov. & Dec. & Annual \\
\hline $\begin{array}{l}1939 \\
1940 \\
1941 \\
1942 \\
1943\end{array}$ & $\begin{array}{l}31.4 \\
44.1 \\
23.4 \\
13.4\end{array}$ & $\begin{array}{r}23.4 \\
41.6 \\
15.5 \\
8.3\end{array}$ & $\begin{array}{r}17.9 \\
42.5 \\
16.6 \\
4.5\end{array}$ & $\begin{array}{r}11.7 \\
40.4 \\
15.2 \\
8.2\end{array}$ & $\begin{array}{r}5.9 \\
27.8 \\
10.6 \\
8.1\end{array}$ & $\begin{array}{r}9.7 \\
15.9 \\
18.1 \\
6.2\end{array}$ & $\begin{array}{r}7.7 \\
21.6 \\
23.6 \\
61.1\end{array}$ & $\begin{array}{l}10.9 \\
23.5 \\
39.2\end{array}$ & $\begin{array}{l}17.9 \\
23.7 \\
43.3\end{array}$ & $\begin{array}{l}44.8 \\
29.9 \\
40.2\end{array}$ & $\begin{array}{r}30.8 \\
54.6 \\
31.7 \\
20.2\end{array}$ & $\begin{array}{l}39.2 \\
47.5 \\
31.1 \\
16.5\end{array}$ & $\begin{array}{r}283.4 \\
373.8 \\
282.4\end{array}$ \\
\hline
\end{tabular}

${ }^{\mathrm{a}}$ For period November $9-30$.

$b_{\text {For period July 1-5. }}$ 
Table 46. - Discharge measurentents of Pennsuco Lateral at Pennsuco, near Miami

\begin{tabular}{|c|c|c|c|c|c|}
\hline Date & $\begin{array}{c}\text { Discharge } \\
\text { (in cfs) }\end{array}$ & Date & $\begin{array}{c}\text { Discharge } \\
\text { (in cfs) }\end{array}$ & Date & $\begin{array}{c}\text { Discharge } \\
\text { (in cfs) }\end{array}$ \\
\hline 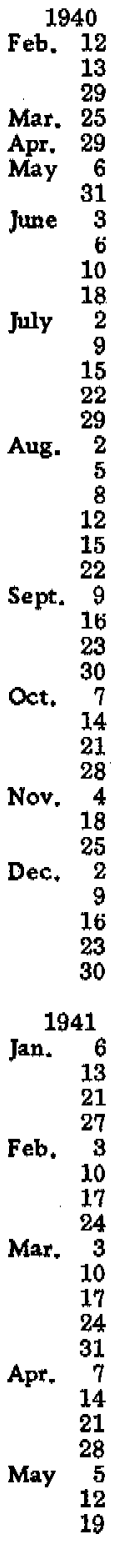 & $\begin{array}{c}78.5 \\
85.5 \\
56.7 \\
38.0 \\
19.5 \\
16.8 \\
5.5 \\
30.4 \\
40.1 \\
42.2 \\
29.7 \\
12.1 \\
17.8 \\
44.8 \\
35.1 \\
28.2 \\
34.1 \\
42.1 \\
19.9 \\
20.5 \\
31.6 \\
48.2 \\
53.8 \\
74.1 \\
123 \\
164 \\
186 \\
162 \\
142 \\
122 \\
133 \\
117 \\
103 \\
96.1 \\
107 \\
98.4 \\
88.9 \\
163 \\
\\
123 \\
132 \\
107 \\
160 \\
136 \\
170 \\
131 \\
94.4 \\
113 \\
122 \\
88.8 \\
114 \\
103 \\
96.0 \\
123 \\
84.6 \\
60.8 \\
101 \\
86.4 \\
62.5 \\
\end{array}$ & 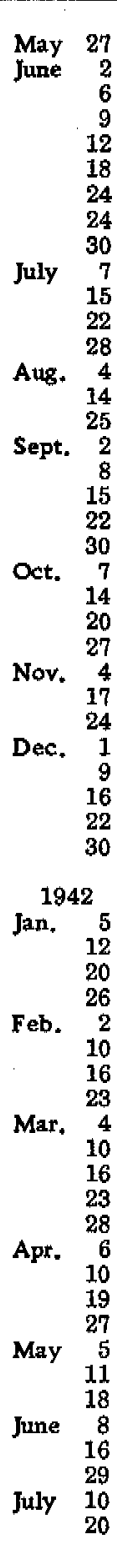 & $\begin{array}{c}34.1 \\
35.5 \\
33.0 \\
30.2 \\
40.1 \\
35.5 \\
38.5 \\
49.1 \\
56.4 \\
84.5 \\
119 \\
120 \\
124 \\
153 \\
128 \\
121 \\
85.4 \\
95.3 \\
113 \\
126 \\
125 \\
153 \\
135 \\
129 \\
118 \\
92.5 \\
99.4 \\
103 \\
94.7 \\
88.3 \\
72.5 \\
63.6 \\
52.2 \\
\\
46.8 \\
47.6 \\
58.5 \\
43.2 \\
35.0 \\
34.3 \\
29.7 \\
32.9 \\
36.6 \\
33.6 \\
24.0 \\
24.3 \\
11.3 \\
22.9 \\
26.4 \\
62.1 \\
57.2 \\
32.5 \\
21.0 \\
20.0 \\
54.2 \\
34.3 \\
50.4 \\
51.1 \\
61.1\end{array}$ & 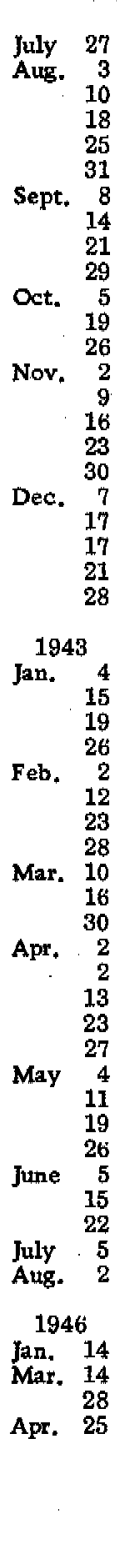 & $\begin{array}{c}73.3 \\
103 \\
84.6 \\
110 \\
99.3 \\
152 \\
144 \\
131 \\
111 \\
140 \\
104 \\
85.5 \\
79.6 \\
65.7 \\
68.4 \\
54.8 \\
32.4 \\
16.7 \\
34.5 \\
35.4 \\
36.0 \\
45.8 \\
24.8 \\
\\
29.5 \\
31.3 \\
26.4 \\
16.7 \\
51.9 \\
20.0 \\
11.0 \\
11.6 \\
8.99 \\
10.9 \\
5.16 \\
4.50 \\
3.42 \\
3.12 \\
28.5 \\
26.7 \\
8.76 \\
6.65 \\
21.9 \\
34.8 \\
23.2 \\
8.82 \\
10.0 \\
25.0 \\
23.8 \\
\\
118 \\
29.2 \\
15.1 \\
10.2\end{array}$ \\
\hline
\end{tabular}


Table 47.-Runoff of Miami Canal at Water Plant, Hialeoh

[Unit, 1,000 acre-feet]

\begin{tabular}{|c|c|c|c|c|c|c|c|c|c|c|c|c|c|}
\hline Year & Jan. & Feb. & Mar. & Apr. & May & June & July & Aug. & Sept. & Oct. & Now. & Dec. & Annual \\
\hline $\begin{array}{l}1940 \\
1941 \\
1942 \\
1943 \\
1944 \\
1945 \\
1946\end{array}$ & $\begin{array}{r}019.7 \\
70.2 \\
35.3 \\
19.1 \\
31.7 \\
19.3 \\
65.7\end{array}$ & $\begin{array}{r}39.4 \\
62.8 \\
26.0 \\
12.3 \\
14.9 \\
4.9 \\
25.9\end{array}$ & $\begin{array}{l}26.5 \\
56.6 \\
23.4 \\
1.8 \\
6.3 \\
2.3 \\
9.4\end{array}$ & $\begin{array}{r}18.8 \\
54.6 \\
34.0 \\
10.0 \\
1.4 \\
.9 \\
3.8\end{array}$ & $\begin{array}{r}3.6 \\
44.0 \\
27.6 \\
17.0 \\
14.7 \\
17.0\end{array}$ & $\begin{array}{r}25.0 \\
25.6 \\
52.4 \\
13.3 \\
9.6 \\
.1 \\
20.3\end{array}$ & $\begin{array}{r}17.4 \\
47.7 \\
64.2 \\
14.1 \\
11.2 \\
5.0 \\
31.6\end{array}$ & $\begin{array}{r}24.2 \\
46.4 \\
73.2 \\
17.4 \\
23.2 \\
4.1 \\
33.6\end{array}$ & $\begin{array}{l}52.6 \\
41.6 \\
86.3 \\
16.2 \\
17.8 \\
23.7 \\
58.2\end{array}$ & $\begin{array}{l}92.6 \\
56.6 \\
63.4 \\
26.3 \\
27.7 \\
49.2 \\
70.6\end{array}$ & $\begin{array}{l}96.8 \\
49.8 \\
35.0 \\
36.3 \\
39.2 \\
85.6 \\
68.6\end{array}$ & $\begin{array}{l}68.5 \\
43.4 \\
24.2 \\
45.3 \\
29.1 \\
81.9 \\
51.3\end{array}$ & $\begin{array}{l}478.6 \\
599.3 \\
545.0 \\
229.4 \\
226.8 \\
277.1 \\
456.0\end{array}$ \\
\hline
\end{tabular}

${ }^{2}$ Based on record for Miami Canal at Pennsuco. 


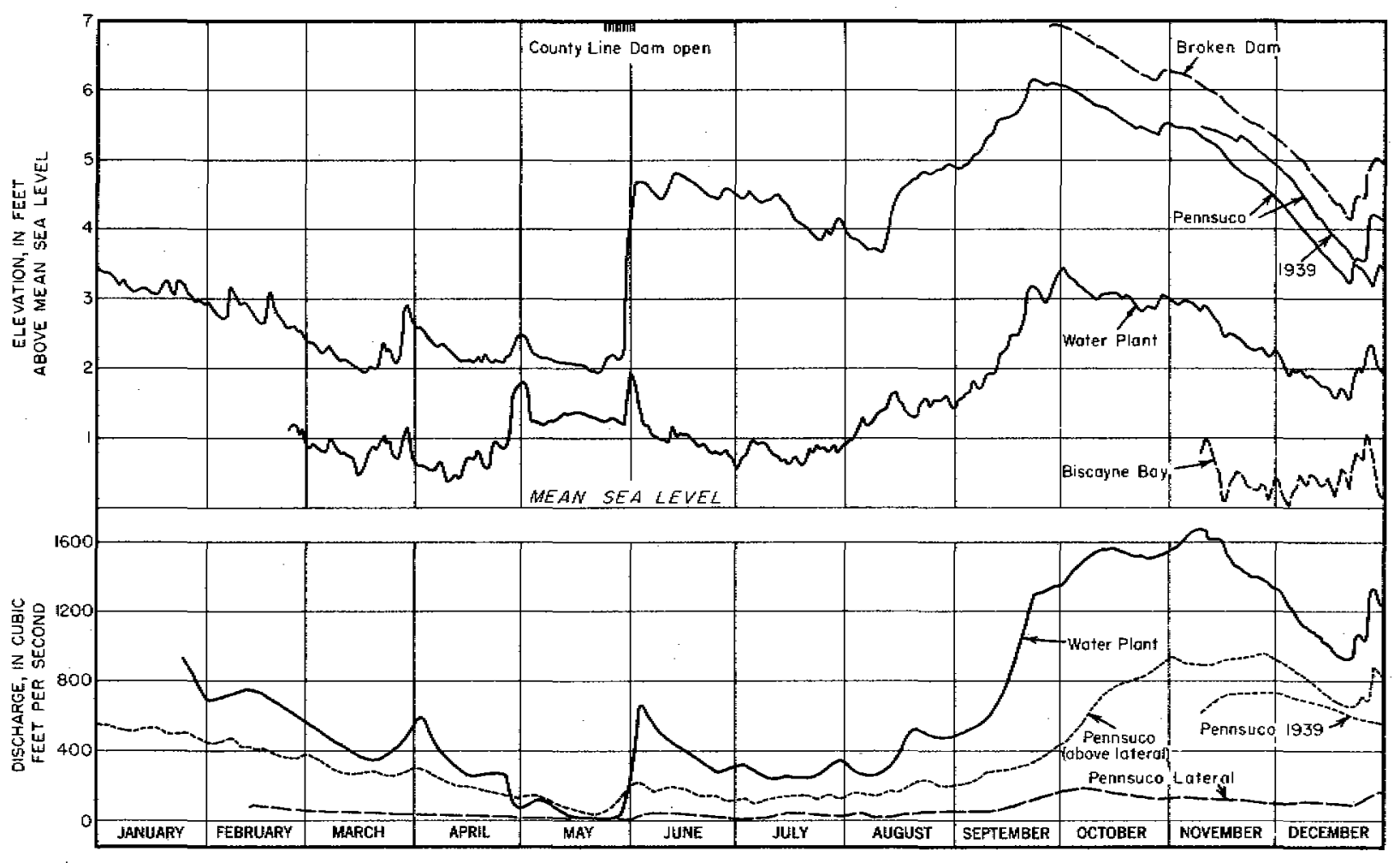

Figure 117. - Graphs of stage and discharge of lower Miami Canal, 1939-40. 


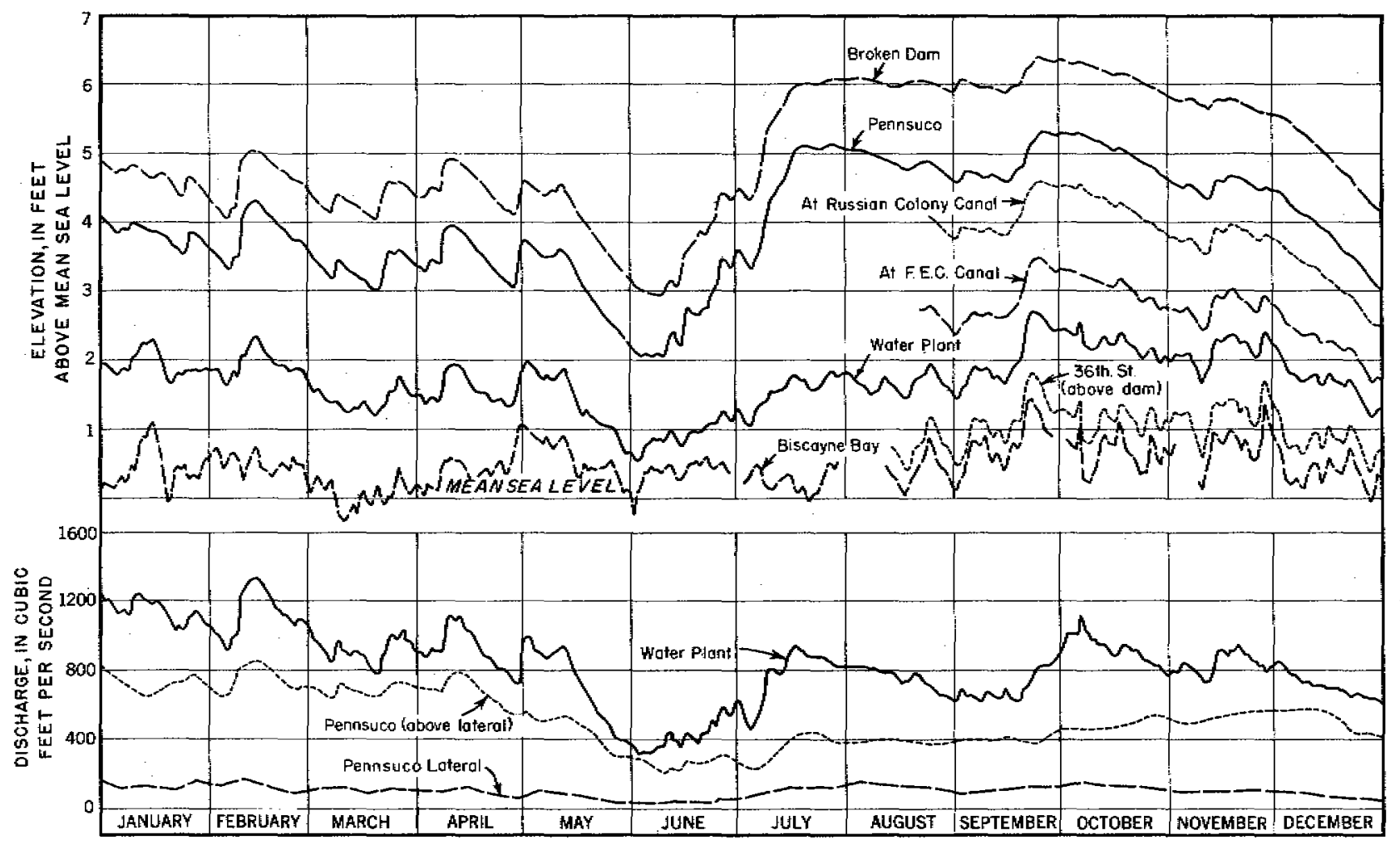

Figure 118. - Graph of stage and discharge of lower Miami Canal, 1941. 


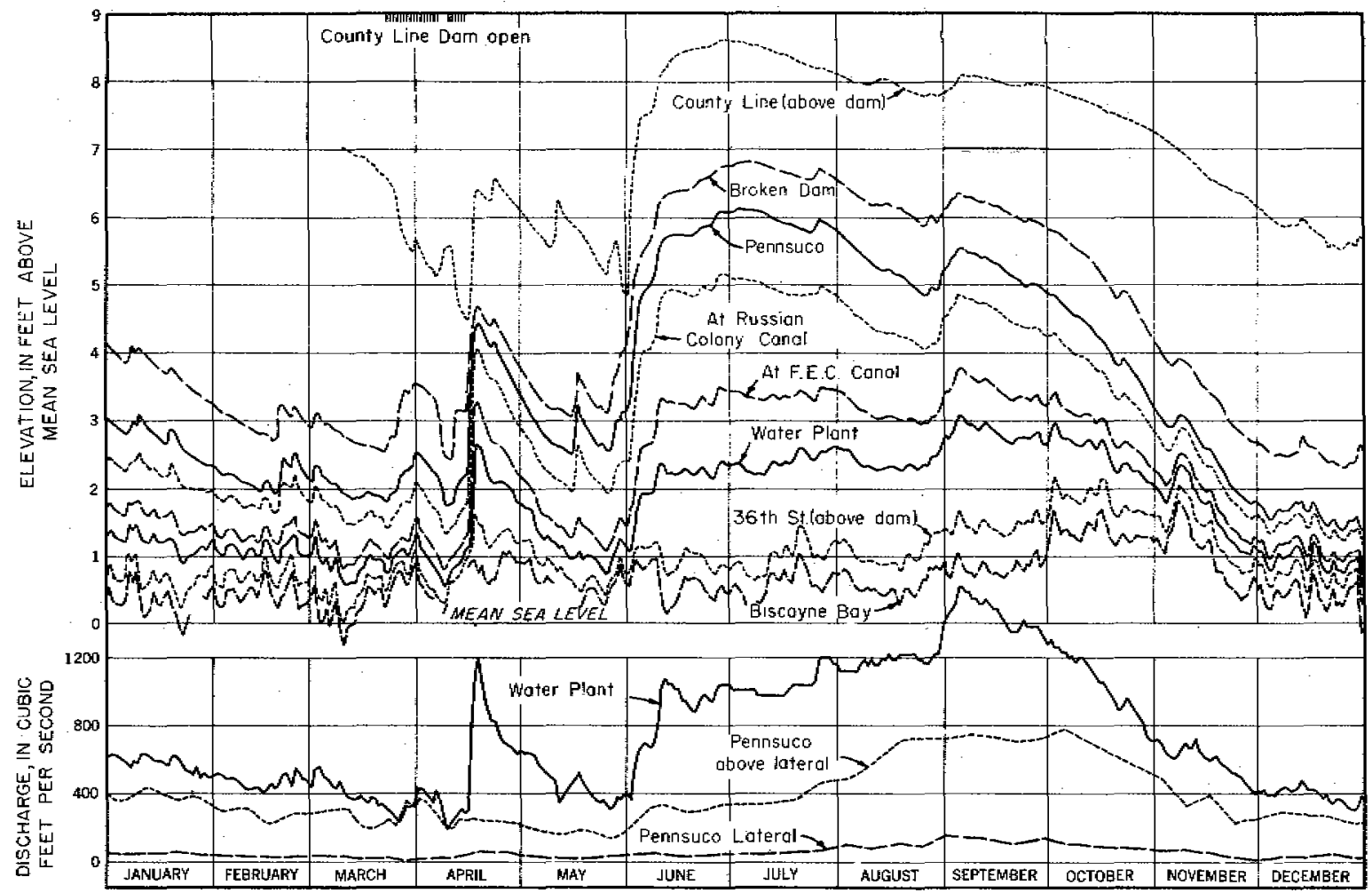

Figure 119. - G1aph of stage and discharge of lower Miami Canal, 1942. 


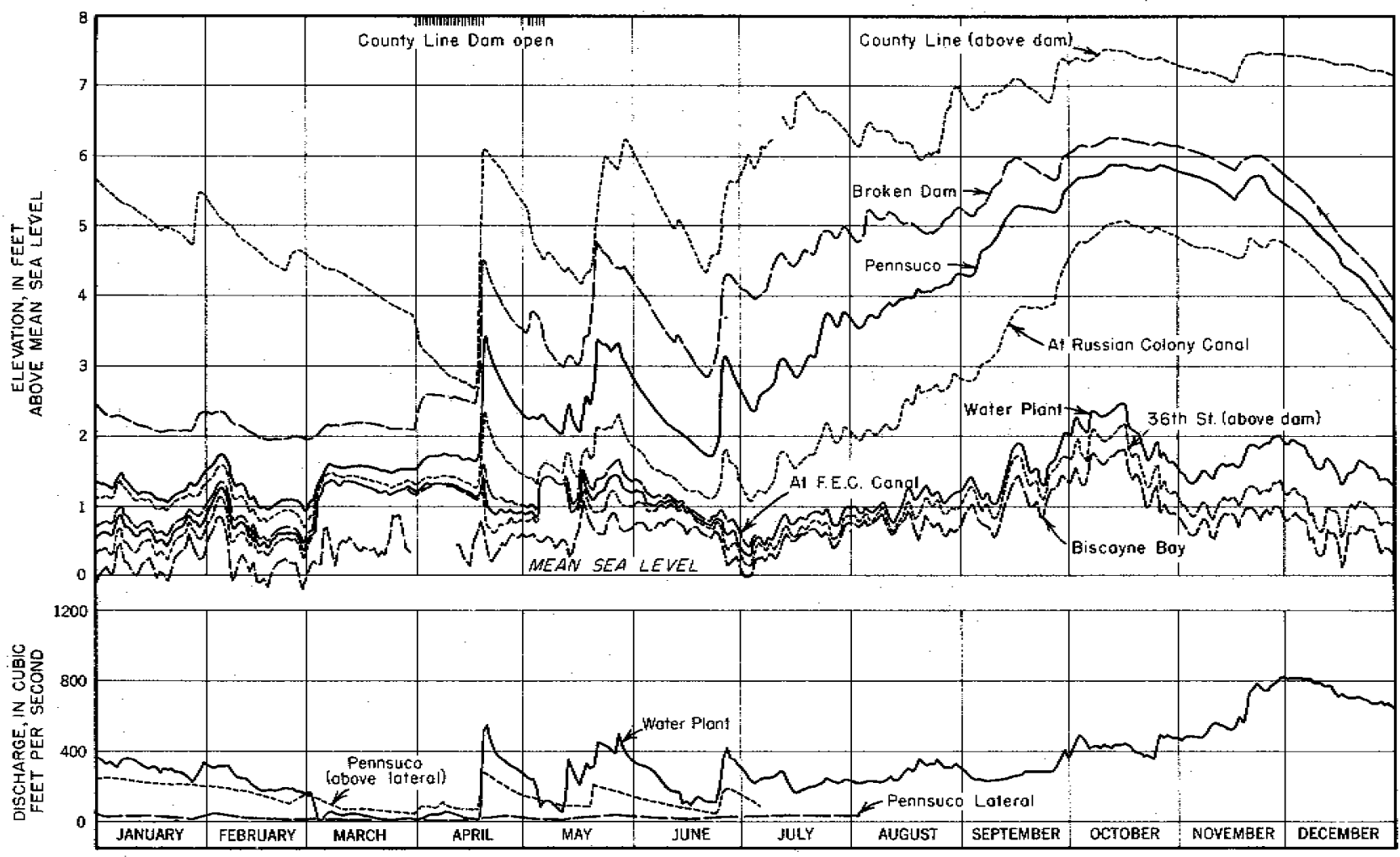

Figure 120. - Graph of stage and discharge of lower Miami Canal, 1943. 


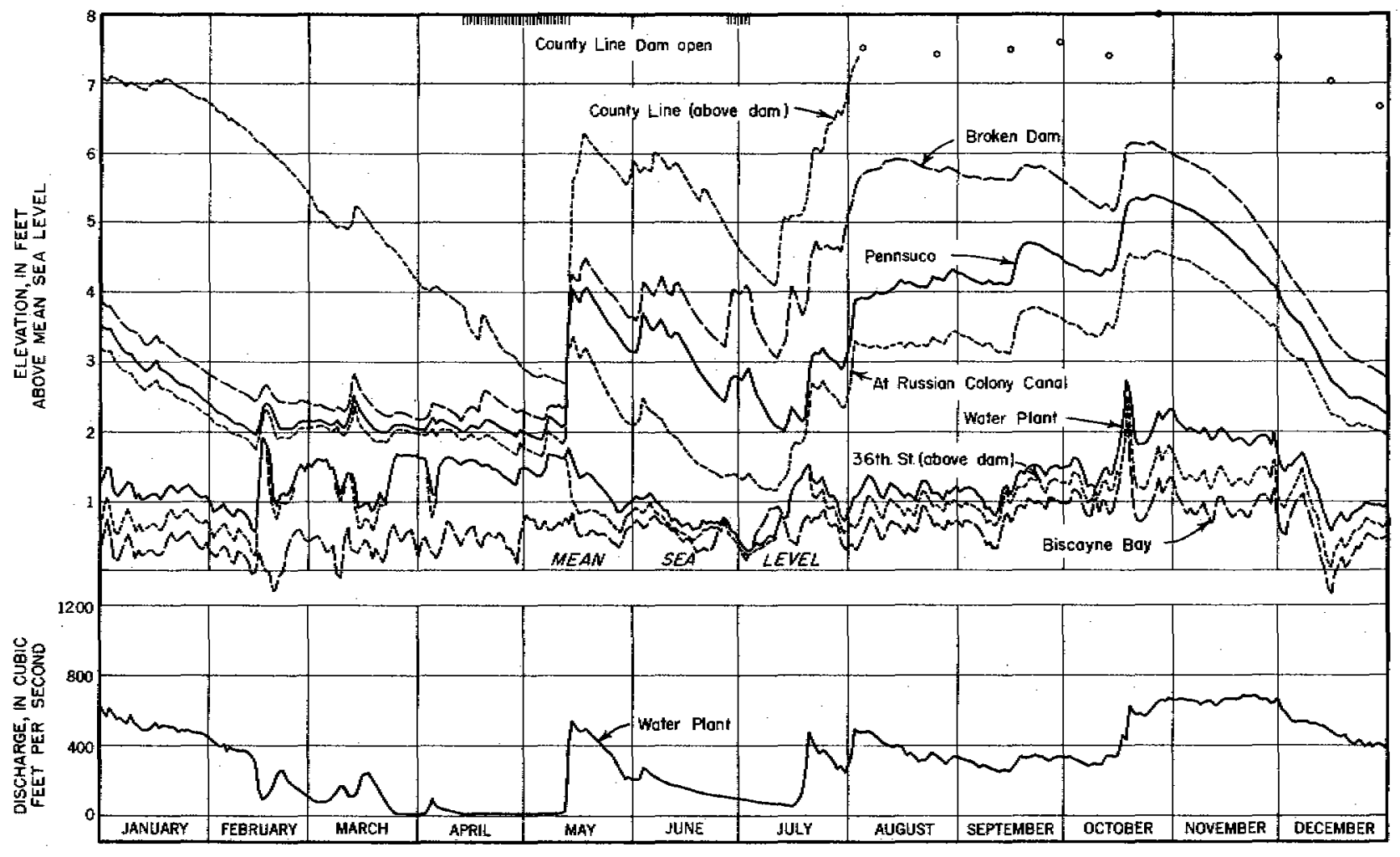

Figure 121, - Graph of stage and discharge of lower Miami Canal, 1944. 


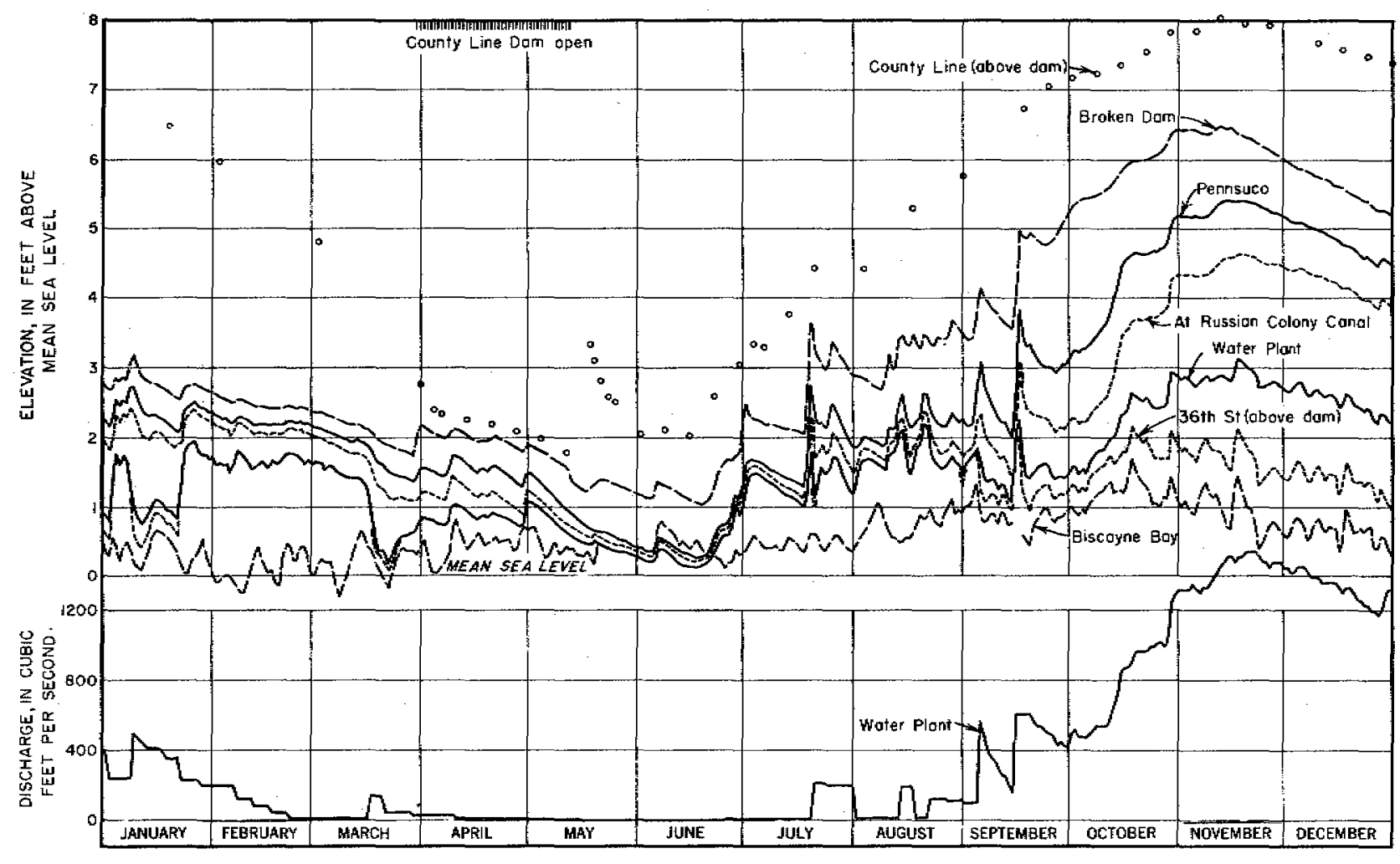

Figure 122.- Graph of stage and discharge of lower Miami Canal, 1945. 


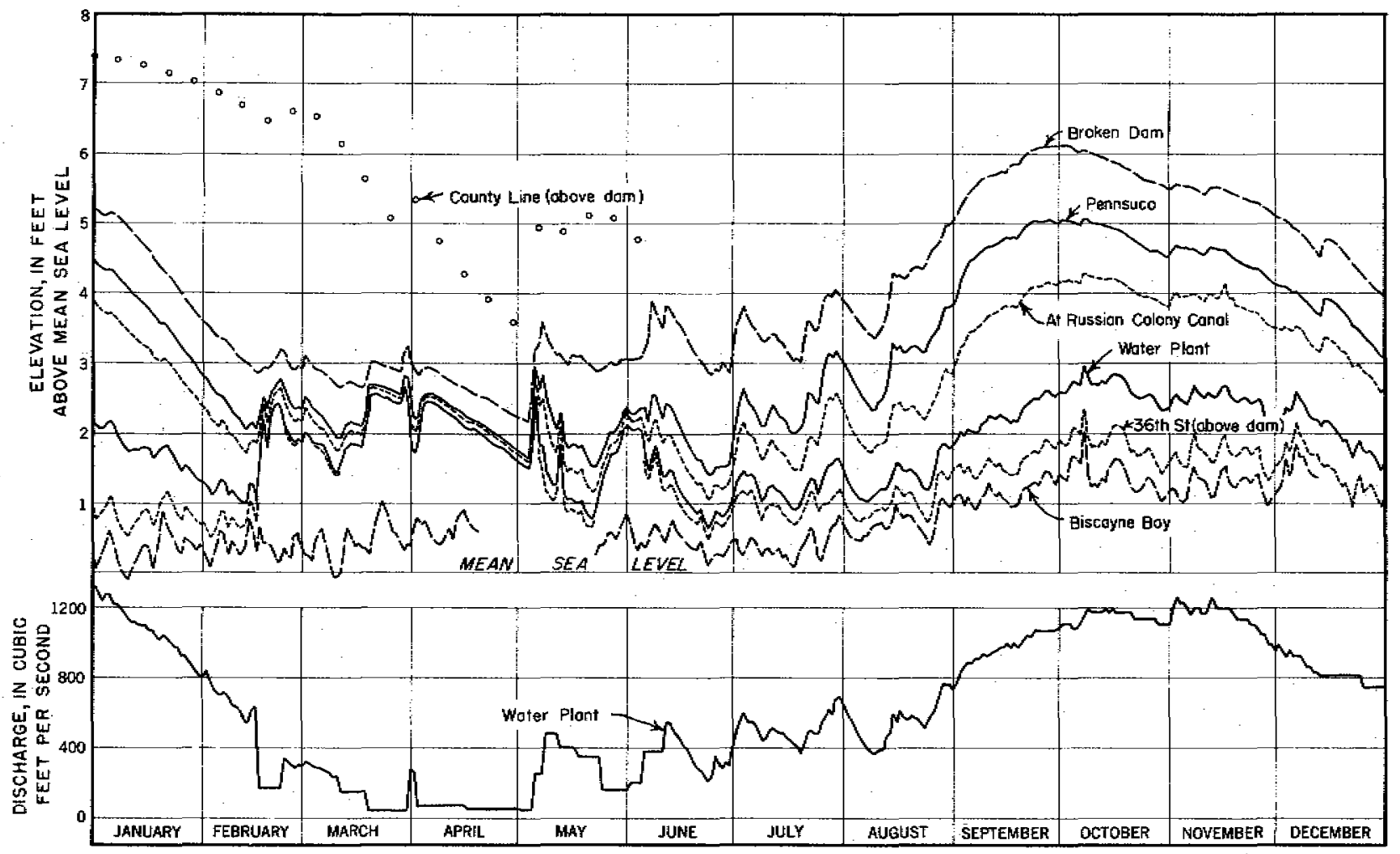

Figure 123. - Graph of stage and discharge of lower Miami Canal, 1946. 
Stage, southeast of dam: Feb. 14, 1942 to June 1, 1942; Jan. 30, 1943 to Dec. 31, 1946 *; continuous recorder graph.

Maximum: $5.31 \mathrm{ft}$, Sept. 15, 1945.

Minimum: $-0.92 \mathrm{ft}$, Mar. 7, 1945 (at low tide).

NW. 27th Avenue, Miami (Miami River)

Stage: Oct. 25,1945 , to Dec. $31,1946 *$; continuous recorder graph.

Maximum: $3.17 \mathrm{ft}$, Oct. 7, 1946.

Minimum: -1.05 ft, June 27, 1946 (at low tide).

Biscayne Bay at Coconut Grove

Stage: Nov. 8, 1940, to Dec. 3.1, 1946*; continuous recorder graph; daily mean plotted in figures 117-123.

Maximum: $9.9 \mathrm{ft}$, Sept. 15, 1945 (hurricane peak).

Minimum: $-1.52 \mathrm{ft}$, Dec. 14, 1944 (at low tide).

Miscellaneous

Stage: southeast of County Line Dam, southeast of Broken Dam, and southwest of control in Pennsuco Lateral; 1940-46*, occasional, usually in connection with special studies.

Discharge: at intermediate locations on the main canal and at many laterals; 1940-46*; occasional, usually in connection with special studies (see plates 15 and 16 for type of observations).

\section{HYDRAULIC CHARACTERISTICS OF HEADWATERS}

\section{RESERVOIR AREA}

The triangle formed by the 10 -mile reach of Miami Canal above County Line Dam, the connecting 8-mile reach of South New River Canal, and the road fill of State Highway 25 is nominally considered to be the reservoir area of lower Miami Canal, but a large area north and west of the canals is also part of the reservoir. See figure 124 and plate 14. Although the re is considerable water impounded in the pool formed by the two canals, the larger part of the water stored above County Line Dam is in the soil and permeable rock of the drainage area. The total storage and drainage area of the canals is indeterminate; it is considerably larger than the triangular area described above, but for reference purposes it is usually called the Triangle.

Overland flow travels slowly southward in the central Everglades, following natural sloughs, but generally moving as a broad sheet of water. Some of the flow enters Miami and South New River Canals at the head of the deep section above the junction, through breaks in the spoil banks, or by seepage through and under the banks. The breached barrier at the head of the deep section retards flow, but it permits the passage of sizable volumes of water in wet periods from the shallow, vegetation-choked middle reaches. South New River Canal, in particular, acts as an interceptor and receives a 
sizable amount of ground-water seepage. In a like manner, these canals act as distributors and recharge the Triangle area. During the normally wet summer and fall seasons, water stands above the ground in the area.

Figure 124 shows one of a series of studies made in 1941-43 under a wide range of conditions. State Highway 25 (formerly 26) acts as a dike, but some water moves toward the east under it.

The usual movement of water within the Triangle is southeastward to a point below County Line Dam, where a considerable quantity returns to Miami Canal by seepage. The flow map shows how the velocity in South New River Canal increases westward as additional increments of flow are received. A maximum velocity is reached in Miami Canal just below the junction with South New River Canal, and then it decreases to the southeast in Miami Canal as water is lost by direct outflow and seepage. Table 43 lists discharges in the storage reach of the canals observed during the studies. The flow of Miami Canal at Water Plant, Hialeah, is also listed to relate the varying water conditions to a useful reference base.

At moderate and low stages, most, or all, direct surface inflow and outflow ceases, although the canal pool still intercepts and

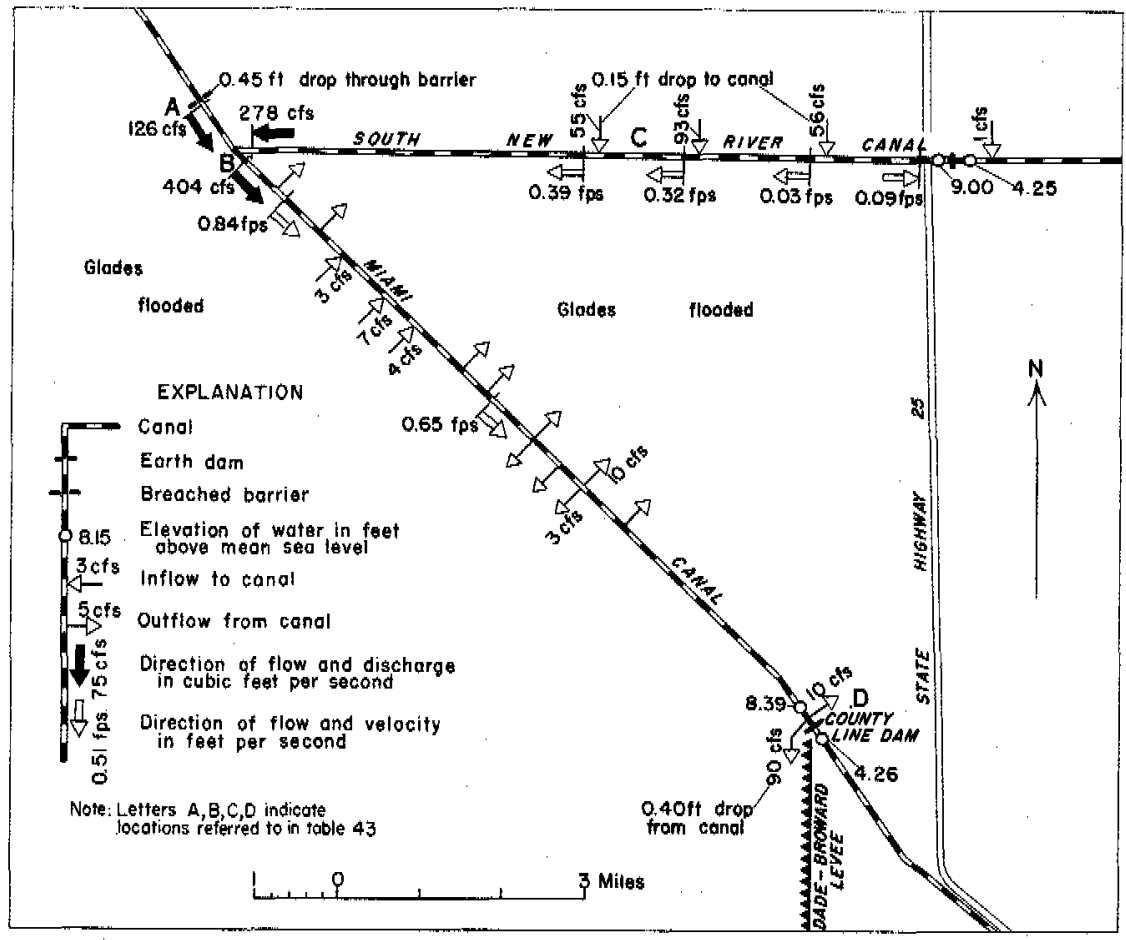

Figure 124. - Map of Miami Canal reservotr area showing the flow pattem and water conditions In a wet period, June 24, 1942 , 
distributes by seepage from the banks. The flow through the breached barrier at the head of the deep section stops as the shallow middle reaches of the canal dry out-see figure 113. Ground-water flow in the Triangle is fairly large, and it continues long after surface inundation and flow have ceased.

Evaporation and transpiration losses are large from this shallow surface and permeable underground reservoir, and together with the ground-water outflow, cause lowering of water levels at rates of as much as $2 \mathrm{ft}$ per month. This maximum rate occurs usually in late winter and early spring. See figure 107, which shows the level of South New River Canal at State Highway 25, a location that serves as a key to the water levels in the Triangle. It is important to appreciate these losses, because the ordinary annual maximum stage in the reservoir is only about $8 \mathrm{ft}$. The rate of decline accelerates after a stage of about $7 \mathrm{ft}$ is reached, because the land surface in the Triangle is 6.5 to $7 \mathrm{ft}$ above sea level. The relationship of the stage in the storage pool to the stages at other locations along Miami Canal can be studied by comparing figures 107 and 117-123.

A part of the water in storage in the reservoir becomes available to South New River and Miami Canals in two ways. The first and principal manner is by uncontrolled seepage. The second manner is by release through culverts or breaches in the earth and rock dams that confine the water in the canal pool.

A breach existed in the dam in South New River Canal, just east of State Highway 25, and discharges of as much as 43 cfs were observed prior to the filling in of the breach in July 1941. The high pipe culvert in the dam has notbeen seen in an open position during the entire period of observations.

The gates that control flow through the five pipe culverts in County Line Dam were opened to augment flow in Miami Canal, as shown in figures 107, 117-123, It will be noted, except for the period in 1942 (for a special evaluation of volume of storage in the reservoir), the gates were opened below a pool stage of $4.0 \mathrm{ft}$, and except for a small immediate drop, the level of the pool declined at a rate no faster than that existing prior to the opening and declined at a decreasing rate as the level fell. It is suggested that the raising of water levels below County Line Dam (because of the opening of the gates) caused a decrease in the amount of ground-water seepage from the reservoir into Miami Canal below the dam, and thus resulted in no particular change in the rate of decline of the reservoir level. In effect, the direct surface outflow from the reservoir replaced part of the seepage outflow. The amount of available storage is discussed in Storage capacity of reservoir in the section on special studies, and data on the rating of the gates in County Line are also given. 
The only other channel that directly carried water from the Triangle was the borrow ditch south from County Line Dam along the west side of Dade-Broward Levee. Outflow from the canal pool as great as $90 \mathrm{cfs}$ was observed through the breached canal bank at that location. About 1944, a 2-ft concrete pipe culvert was placed to close the breach; after this, the maximum flow was about $20 \mathrm{cfs}$.

\section{STORAGE INFI,OW REACH}

The channel of Miami Canal from County Line Dam to Broken Dam, a distance of 2.5 miles, is usually called the storage-inflow reach, because it receives a large amount of water by seepage from the reservoir area, adjoining the northeast bank, and from the pool upstream from County Line Dam. Direct surface inflow occurs only during the greatest floods. The inflow reach probably extends several miles farther southeast toward Pennsuco in periods of high water, but when levels are low above County Line Dam, reductions in discharge, rather than increases in discharge, have been observed in this additional section.

The large volumes of flow measured at Broken Dam are an excellent indication of the porous character of the rock through which the canal was excavated. Despite extensive, although discontinuous, areas of impermeable rock, the seepage in the 2.5 -mile reach below Broken Dam has been found to be as great as $200 \mathrm{cfs}$ per linear mile of canal. As would be expected, the amount of seepage varies with the elevation of the reservoir area. Selected stages and discharge in the inflow reach are listed in table 44.

The water slope in Miami Canal, from below County Line Dam to Broken Dam, is usually quite flat, and even in periods of large flow at Broken Dam, it does not exceed about $0.3 \mathrm{ft}$. The stage graphs, figures 117-123, therefore furnish an indication of head on County Line Dam by the difference between the stages at the two dams. The stage above County Line Dam is usually much the same as that in South New River Canal, at the other end of the storage pool. The stage at Broken Dam reacts with that of the reservoir, but it is also subject to the flow regimen of the tidal reaches of Miami Canal. The more rapid rate of decline at Broken Dam, following the annual wet season, results from the direct drainage to the sea; but the leveling effect in some winter periods results from the operation of 36 th Street Dam in Miami; then, the reservoir declines the more rapidly of the two stages.

When the gates in County Line Dam are opened to augment flow in Miami Canal, the upper pool drops considerably and the lower pool rises, thus resulting in a reduction of the head that existed prior to opening the gates. This was well illustrated during the 
first half of April 1943 (see fig. 120) and should be kept in mind when efforts are made to move more water toward the Miami area-the static head is significantly reduced when the gates are opened.

The constriction at Broken Dam is enough to cause head losses as great as about $0.3 \mathrm{ft}$ during periods of high discharge or at low stages-see figure 116. Velocities are relatively fast for Everglades canals, and the sizable volumes of flow through the gap furnish visual evidence of the nature of water-control problems in this area of highly permeable rock.

\section{TIDAL REACHES}

The bottom of Miami Canal is below mean sea level from County Line Dam to Biscayne Bay, a distance of 20 miles; thus, the canal is subject to tidal backwater. Broken Dam is usually considered to be the inland limit of tidal fluctuations, although during floods the limit is much farther east and during droughts the tide effect extends all the way to County Line Dam.

\section{THE FUNDAMENTAL TIDE}

The Atlantic Ocean along the east coast of Florida is subjected to typical tidal action, as imposed by the moon and the sun. The tide-producing force of the moon is the predominant factor, being a little more than twice that of the sun (Pillsbury, 1940). The fundamental tide is of the semidiurnal type, with two nearly equal cycles in each lunar day of 24 hours and 50.4 minutes and with an essentially sinusoidal pattern. The high waters (the peaks of the cycles) usually follow a smooth trend, alternately higher and lower (see fig. 125), although the relationship may be reversed occasionally.

A few definitions will help to understand references to tidal phenomena. The range of the tide is the vertical distance between the high and low points of a cycle. ${ }^{15}$ As shown in figure 125, the range changes considerably within a short period, as associated with the phases of the moon. The tides with the greatest range in each lunar month, which are known as spring tides, occur at the time of the full or new moon-depending upon the relative declinations of the sun and moon, a complex relationship. The tides with the least range are called neap tides. The amount of tidal range is particularly important in low country like southeastern Florida, where the canals, and therefore the drainage, are considerably affected by tidal backwater.

\footnotetext{
${ }^{15}$ The range is also referred to as the "amplitude"; but amplitude is more commonly identified with "semirange", the departure of a wave from the average position.
} 


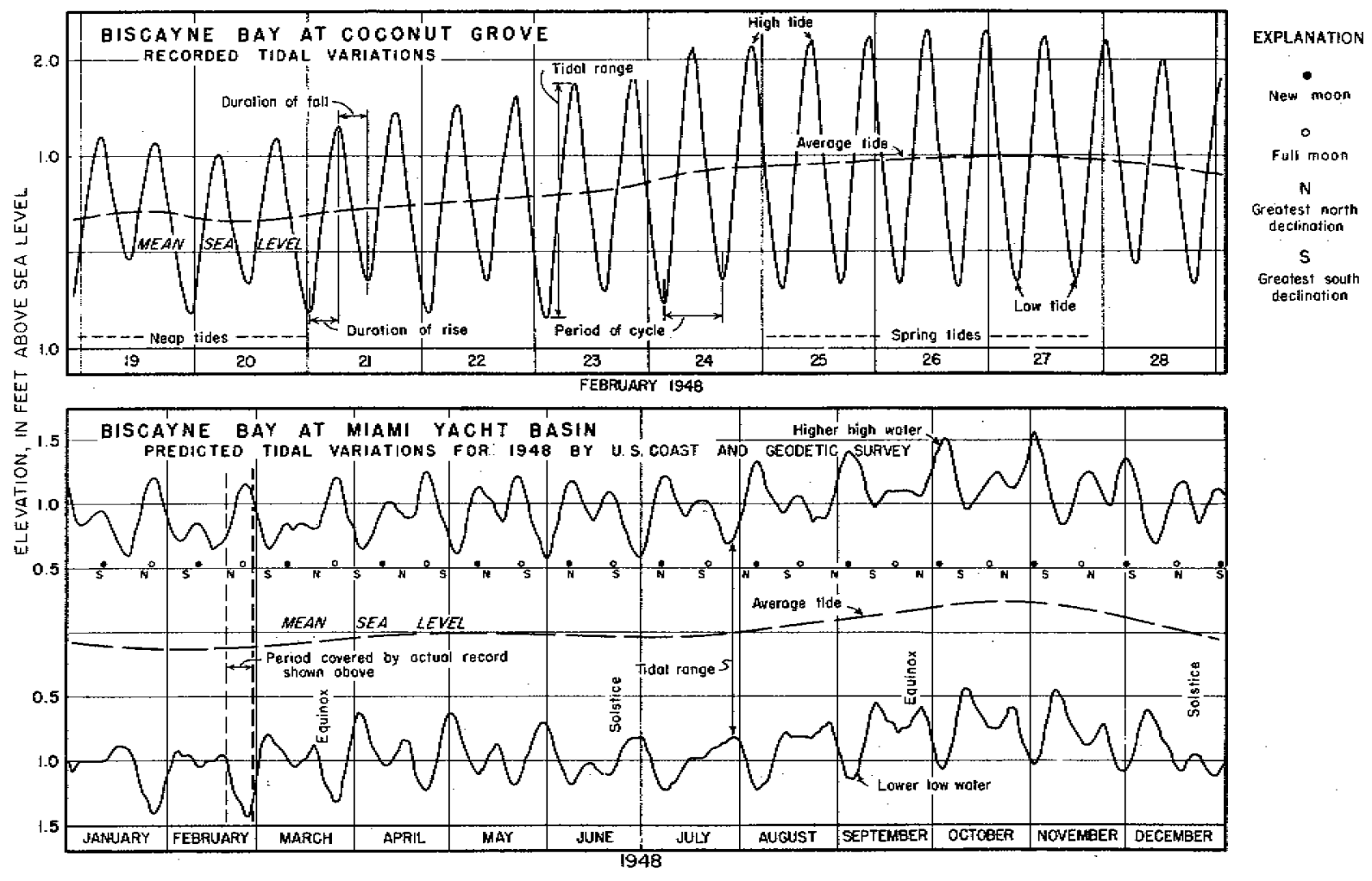

Figure 125. - Graph of actual tidal variation in Biscayne Bay for a short period and predicted tical variation for 1948. 
The monthly (lunar) pattern of variation is superimposed on an annual cycle of a more subtle nature, which slowly but steadily raises and lowers the pattern. This cycle, which is caused by the change in the sun's declination, is shown by the dashed line that represents the mean tide on the prediction graph. In turn, the entire pattern is affected by a further cycle (longitude of the moon's node) having a period of about 19 years. A number of other factors are involved in the forces producing the tides, which make them highly complex and a special field of study.

A distinction should be made between tide and current, which are often loosely interchanged. Tide is the vertical change in the surface elevation of a body of water. Current is the horizontal movement of water caused by tidal action, gravity flow in waterways, wind action, or other causes.

When water flows from the sea into a bay, estuary, or river under tidal action, the condition is referred to as the "flood tide," or "flood current." When tidal flow is toward the sea, the term "ebb tide, " or "ebb current," is used. The short period of negligible current, when the flow reverses at the turn of the tide, is called "slack water." For locations close to the ocean, as at inlets, the time of slack water is very closely the same as the time of high and low tide, but this does not hold true in tide-affected rivers, because of runoff and friction.

It will be noted on the graph of tide prediction that the annual pattern is nearly centered about the 0,0 - $\mathrm{ft}$ sea level line, which is to be expected because the prediction is based on observations that established the mean sea level datum. The section of chart from the automatic stage-recorder in Biscayne Bay (fig. 125), however, shows that the water surface was below $0.0 \mathrm{ft}$ only about 30 percent of the time and that the daily mean level ranged between 0.3 and $1.0 \mathrm{ft}$. This is not necessarily a contradiction, because local factors, such as fresh-water runoff and wind effect (particularly in the fall of the year), change the pattern of tidal fluctuation in the bay.

\section{TIDE LEVELS}

Normal tides. - Since May 1931, a tide gage has been maintained by the U. S. Coast and Geodetic Survey on the open coast at Carter's Pier, Miami Beach. The record from this gage shows that from the period 1931-32 to the period 1940-43 there has been a definite increase of about $0.2 \mathrm{ft}$ in the tidal range. (See fig. 126.) The range declined markedly in 1944, 1945, and 1946. This variation in the range is a reflection of a 19-year cycle in the longitude of the moon's node, and therefore it can be expected that the range will decrease until about 1950 or 1951 . 


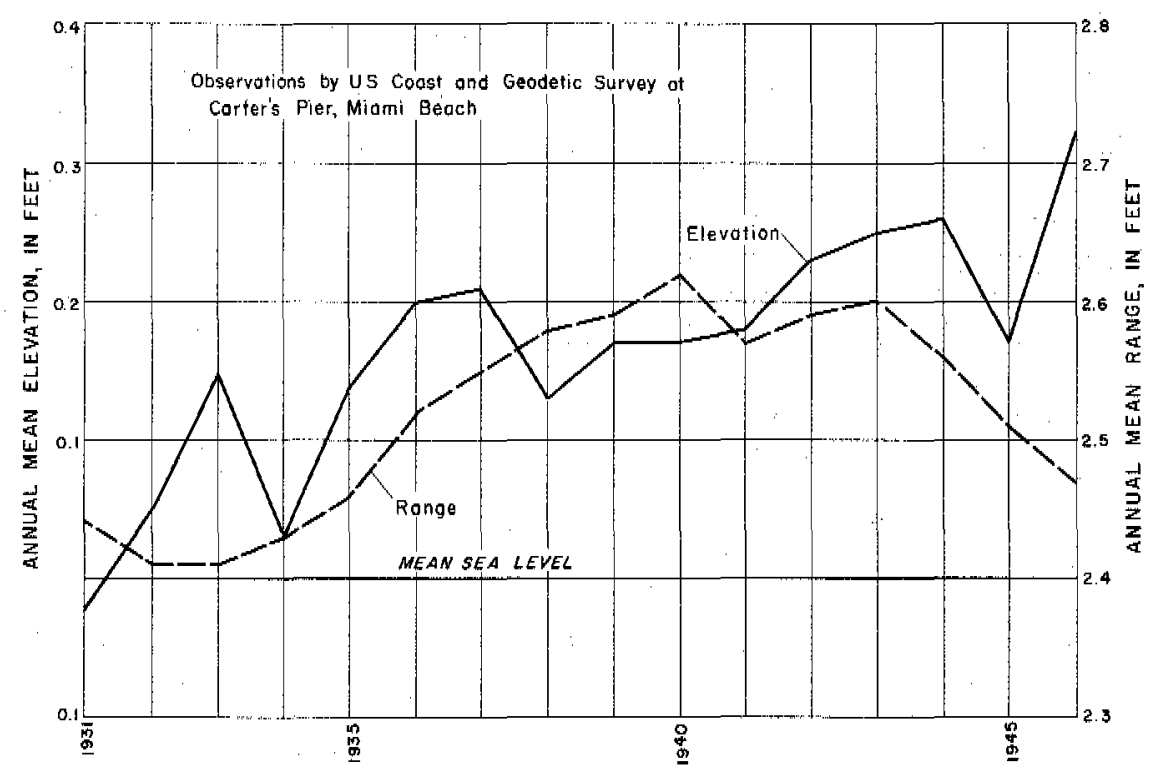

Figure 126. - Graph of annual mean elevation and range of Atlantic Ocean at Miami Beach, $1931-46$.

There has also been a progressive increase in annual mean sea level of about $0.22 \mathrm{ft}$ during the 15 -year period of record, which has also been observed at other places along the Atlantic Coast (Marmer, 1941, p. 620-629).

The combined effect has been to increase high-tide levels at Miami Beach during $1940-46$ by $0.28 \mathrm{ft}$ in comparison with levels in 1931-32. Low-water levels rose only about $0.15 \mathrm{ft}$, because the increase in tidal range tended to counteract the increase in sea level. Throughout the record, sea level remained about halfway between high and low water.

The record from the U. S. Geological Survey recording gage in Biscayne Bay at Coconut Grove furnishes an interesting comparison with that on the open coast. Tidal range in the bay during late 1940 to 1946 varied between 1.0 and $2.7 \mathrm{ft}$, and averaged $1.82 \mathrm{ft}$, which was 70 percent of the range of the ocean at Miami Beach. Therefore, it might be expected that during 1931-46 the rise in high-tide level of Biscayne Bay was $0.22 \mathrm{ft}$, plus 70 percent of the $0.06 \mathrm{ft}$ increase in the semirange, or a total rise of $0.26 \mathrm{ft}$, as compared with 1931-32. This is based on the assumption that the basic rise of $0.22 \mathrm{ft}$ in the mean level of the ocean was also experienced in the bay.

The tidal levels of the bay and ocean are important to the freshwater supply of the Miami area, and particularly to the municipal well fields. The increase in range, together with the rising sea 
level, probably aided the intrusion of sea water during the $1940-46$ period. The mean stage of Biscayne Bay at Coconut Grove during this period was about $0.6 \mathrm{ft}$ above mean sea level datum.

Wind tides. - A sizable body of water, such as Biscayne Bay, is subject to wind tides of considerable magnitude, which have no regular period, but which are associated with wind velocity and direction. Biscayne Bay is shallow, thus augmenting the effect of wind on the water. The prevailing winds are easterly and southeasterly, therefore it is probable that the mean stage of the bay is higher along the west shore than along the east shore (particularly in the nor thwestern corner, where the U. S. Geological Survey tide gage is located). This may account, in part, for the fact that mean stage of the bay at Coconut Grove is higher than the mean stage of the ocean in the period of study; however, it should be kept in mind that fresh-water runoff may also be a factor.

Many small fluctuations of the level of Biscayne Bay are caused by ordinary winds of the area, and, while these fluctuations usually are small, they are associated with the problem of contamination of tidal canals by salty water. The greatest wind tides, of course, are those associated with the hurricanes that occur in southern Florida, The steady high winds of a hurricane tend to raise the level of the bay, and, during the period of maximum wind velocities, they cancause a destructive high stage. Some data (supplied by the U. S. Weather Bureau, Miami) on the three significant hurricanes in the $1940-46$ period are listed below:

Hurricane, track of center:

$\begin{array}{ccc}\text { Oct. 6, } & \text { Oct. } 18, & \text { Sept. } 15, \\ 1941 . & 1944 & 1945\end{array}$

Direction................................. NW N N

Approximate minimum distance from

Miami, miles............................ 13 SW $120 \mathrm{~W} \quad 25 \mathrm{SW}$

Wind velocity, U. S. Weather Bureau,

Miami:

Maximum, 5 minutes, sustained, (miles

per hour)...............................6 63

Maximum, 1 minute (miles per hour) ........ 68

Direction

E SE

86

65

$69 \quad 109$

SE

SE

Stage of Biscayne Bay at Coconut Grove:

Mean, 2 days prior to storm (feet)..........

Maximum during storm (feet)...............

0.7

b. 4

0.8

4. $0 \quad 3.9 \quad 9.9$

astimated 40 tó 60 percent greater at Dinner Key (location of bay gage, 4 miles southwegt of U. S. Weather Bureau office).

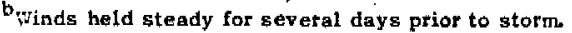

The storm of October 6, 1941, was small, and the wind velocities increased rapidly within a few miles south of Miami. The storm of 
October 18, 1944, was a large storm, and gales were felt in Miami for several days, although the center of the storm was quite a distance away. (Note the comparable maximum wind velocities of the two storms and the resulting wind tide.)

The hurricane of September 15, 1945, was moderate in size, but it was quite intense near the center. The 9.9-ft stage at Coconut Grove was measured in a still pool, and it does not consider wave action that probably was several feet higher. The bay rose from a 4 - $\mathrm{ft}$ stage to a stage of $8 \mathrm{ft}$ in 1 hour and 20 minutes; and from $5 \mathrm{ft}$ to $8 \mathrm{ft}$ in 50 minutes (the time element necessary to rise above 8 $\mathrm{ft}$ is not known, because the stage recorder became submerged and the record is incomplete). The high level of the bay caused a large rush of sea water inland in the tidal canals for several hours. A profile of the peak stages in Miami Canal is shown in figure 134.

The paths of hurricanes have no fixed relationship to the Miami area, and storms may be expected from any direction. The three storms noted above happened to have maximum gales from the easterly quadrant, but this will not always be the case. Therefore, a hurricane could pass near Miami and produce relatively little wind tide along the western shores of upper Biscayne Bay, although other shores might be inundated. The maximum wind tide at Miami will probably occur during periods of spring tides, with the maximum wind velocity occurring from the southeast at the time of high tide.

\section{TIDAL CHARACTERISTICS OF SEALEVEL CANALS}

A waterway directly connected with a tidal body of water usually is affected by tidal variations for some distance above its mouth. The length of the reach affected depends upon the elevation of the bottom of the channel, the amount of fresh-water runoff, and the friction-producing elements in the channel.

The term "backwater," in ordinary stream-gaging usage, is the height that water surface in a channel is raised above its normal, or natural, level by an obstruction retarding its flow. Such an obstruction conceivably could be in the nature of a dam, a bridge, aquatic vegetation, or tides. Regardless of the nature of the ob'struction, the effect on the flow is the same. A backwater curve is the profile of the water surface in the reach that is subjected to backwater. Backwater may also be classified as the volume of water represented by the difference in area of the backwater surface and that of the normal water surface, multiplied by the width of the channel.

The variations in backwater produced in a waterway by tidal fluctuations in the body of water into which the waterway discharges are shown in figure 127 . It will be noted that the effect of tidal 
variations is not simultaneous throughout the waterway, and that the result is a wave that travels upstream. Because the vertical motion of the water affected by the wave is a result of continuous and alternate storage and release of water in the channel, it follows that a tidal impulse can travel upstream against the flow of water in a channel. Therefore, a tidal wave moving upstream does not indicate actual upstream movement of the water, except under certain conditions as described in the following paragraphs.

In figure 127, the line of mean slope (DE) represents the average water surface for the whole tide cycle. The slope of high waters (DF) and the slope of low waters (DA) show the limiting positions of high and low tide as the cycle moves inland. The vertical distance between these two lines at any location is the tidal range, and the height of the water surface above the line DA is the backwater.

The volume of water represented by the triangle DFA is the tidal prism above point $A$. On the other hand, tidal storage is the volume alternately stored and drained by tidal action, and it includes bank storage as well as channel storage. It is always less than the tidal prism because the tidal prism is never filled with water at any one time (see fig. 127). Tidal storage is often expressed in units of cfs-hours, because of the constantly changing ratio of storage, but it may also be expressed in acre-feet or by other volumetric units. Tidal storage is an important factor in the design of channel improvements and canals, in pollution and sewage dilution problems, and in studies of currents.

Tidal storage also may be shown on a discharge hydrograph, as in figures 129 and 130 . With rate of flow as the ordinate, and with time as the abscissa, the area under the curve for any period is a volume. Thus, the area between the curve and the line representing the mean discharge is the tidal storage. There are two such areas in the plot of a tide cycle. The one above the mean line is the period when the tidal storage is being emptied-water is going out of storage. The other is the period when the tidal storage is being filled-water is going into storage.

The tidal range decreases as the wave moves upstream, and it disappears at some point inland. The rate of decrease would be uniform in a perfectly uniform canal, but it varies in the typical waterway because of changes in the channel section and alinement. For a given canal, the limit of tidal backwater varies with the amount of fresh-water runoff in the canal, because runoff has a damping effect-the greater the runoff, the shorter the reach affected by tide.

The wave of the tide cycle in the lower reaches of the canal is usually the same shape as that in the bay, but a change in symmetry 
occurs as the wave progresses upstream. The fresh-water runoff and other factors oppose the upstream propagation of the wave, and they tend to shorten the duration of the rise and to lengthen the duration of the fall, although the period of the wave remains the same. This is the characteristic river-type tide that is common in the upper tidal reaches of coastal streams.

Because of the wave-like variations of water surface caused by tide, the slopes DF and DA in figure 127 actually never occur as shown in the figure. The storage changes that produce the wave take considerable time, thus causing a progressive lag inland for any point on the fundamental cycle. No data are available to prove the amount of lag in an extreme case, but it conceivably could be a full cycle-12 hours and 25 minutes. That is, the bay level could be at high tide and a point far inland could also be at high tide, but the inland high tide could be a result of the preceding high tide in the bay. The lag in progression of high and low tides is shown in figures 128 and 129 .

The progressive changes in slope, directions of flow, and changes in storage of a tidal canal are shown schematically in figure 127. At the right side of the figure is a graph of the fundamental tide in the bay at the mouth of the canal, point $A$. The decreasing range of the tide and the lag in the progression of the wave are shown in the parallel graphs at points $B$ and $C$. At location D the tidal backwater plays out, and the slope of the water surface above $D$ represents the steady fresh-water flow. To make the diagram relatively simple, the fundamental tide has been centered about mean sea level. The several phases of the profile are discussed below, using the circled reference numbers.

1. Slope and direction of flow are positive at all locations; the bay is rising and some of the fresh-water runoff is being stored as the backwater from the bay increases.

2. The bay rises faster than the canal can store water for the increasing backwater, and flow inland occurs from the bay; the point of reversal of flow progresses slowly upstream, because storage is being accumulated at that point from both directions, but at a faster rate from the bay; all of the canal runoff goes into storage (tidal storage).

3. The bay level reaches high tide and starts to decline rapidly; a positive slope is reestablished near the mouth of the canal, a second point of reversal in flow occurs, and some of the stored water flows out. The second reversal moves inland rapidly because water is moving away from it in both directions, and the positive slope to the bay steepens. In this period, flow in the canal occurs in three sections-two positive and one negative. The first reversal is still moving upstream, but at a slower rate than before because 


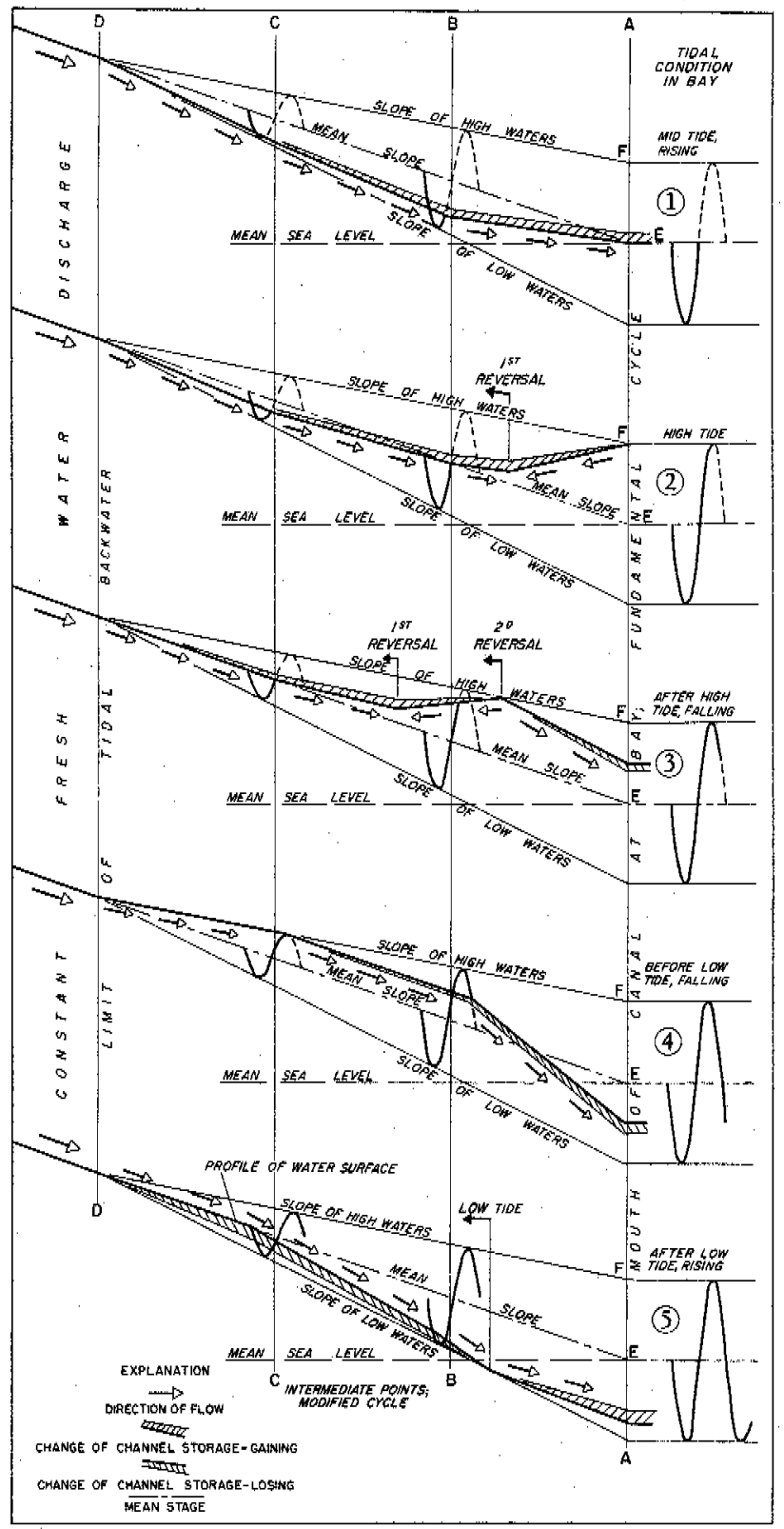

Figure 127. - Diagram of tidal backwater in a canal and progressive changes of slope, direc* tions of flow, and changes in stotage of a tidal canal.

of the decreasing backwater and the filling-in of the low point of the profile; all of the runoff is going into storage; tidal backwater extends upstream beyond the first reversal, but the flow above that point is all positive, and it diminishes toward the reversal point. The second reversal overtakes the first reversal, and all slopes and flow become positive (toward the bay). 
4. The level of the bay is approaching a low condition; the high point of the wave (high tide) has reached point $\mathrm{C}$; the profile and direction of flow is positive, and the fresh-water runoff is augmented by the release of the water stored earlier.

5. The level of the bay has passed low tide and is beginning to rise again; low tide is progressing upstream and has not yet occurred at points $\mathrm{B}$ and $\mathrm{C}$; water is going into storage below the point of low tide and out of storage above it; the point of changeover, from storage release to storage, progresses inland until condition 1 (storage at all locations) is again reached.

The undulating character of the profile shows the reason that tidal slopes are so complex-a steady condition is never achieved. It also shows why computations based on theory are so hard to make and why field studies of tidal phenomena are necessary. The diagrams present only the most simple aspects of the problemactual channels usually have many variations in alinement, in proportions, and in runoff, all of which make the whole problem much more complex.

This discussion omits the further complication imposed by the difference in specific gravity between fresh water and sea water, which involves the problems of divided flow and density head. Additional discussion of this subject will be found in the section on Salt-water encroachment under the heading Contamination of tidal canals.

\section{TIDAL FLUCTUATIONS IN MIAMI CANAL}

The discussion of the fundamentas cide and tidal phenomena can be applied to most tidal waterways, but it is specifically applicable to Miami Canal. Miami Canal plays a very important part in the water events of the greater Miami area, particularly with respect to the protection of the municipal water supply and to the conservation of water in the open lands farther to the west.

Miami Canal is subject to an average tidal variation of $2.0 \mathrm{ft}$ at its mouth in Biscayne Bay (U. S. Coast and Geodetic Survey, 1947, p. 303). Compared with the average range of $2.6 \mathrm{ft}$ in the ocean at Miami Beach and $1.8 \mathrm{ft}$ in the bay at Coconut Grove; it is apparent that the tidal range in the bay diminishes with distance from the ocean. The tidal range also diminishes to the south and becomes very small at the south end of Biscayne Bay and at the upper Keysless than $1 \mathrm{ft}$ in Barnes Sound.

A period of typical tidal variations in Miami Canal is shown in figure 128, which entails tracings from graphs of five water-stage 
recorders. "Because of conflict with the hydrograph of the Water Plant recorder, only a part of the Biscayne Bay record is. shown. No dam was in place in the lower reaches of the canal, and free tide-affected flow occurred throughout the period. The sharp rise at Pennsuco on April 11 resulted from releasing water at County

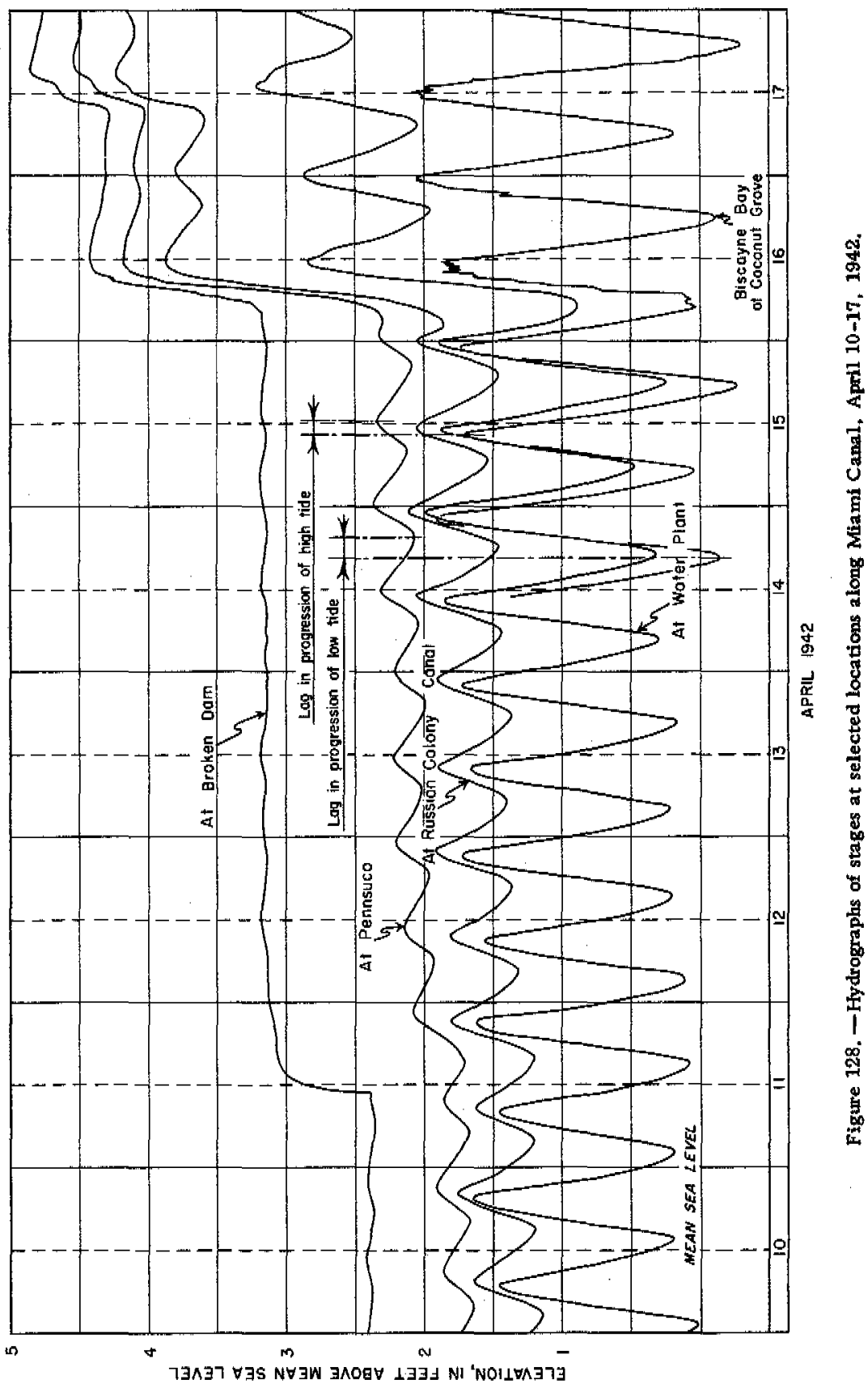


Line Dam, 6.6 miles to the northwest. The large rises on April 16-17 were caused by extremely heavy rainfall. Total precipitation for April 16-18 at Water Plant, Hialeah, was 18.09 in.; at Broken Dam, 6.05 in. was recorded.

The damping of the tide as it moved inland is evident in figure 128. The degree of damping between Water Plant and Russian Colony Canal, during April 10-15, probably resulted from the aquatic weeds in the canal, because discharge at Water Plant was low (ranging between 200 and $300 \mathrm{cfs}$ ). The great storm increased the discharge to $1,200 \mathrm{cfs}$, which is reflected in the upward shift of the several canal stages and in the further damping of the tidal action. Some of the increase in damping may have been offset when some of the aquatic weeds were removed by the greatly increased discharge.

The limit of tidal backwater, prior to the rains, was in the vicinity of Broken Dam, but, as a result of the rains, it was shifted downstream to a point between Broken Dam and Pennsuco.

The progressive upstream lag in the times of high and low tide, between the bay and Broken Dam, is indicated on the figure; this lag amounted to about 5 hours for low tide and to a little more than 3 hours for high tide. This variation in lag is directly associated with the change in symmetry of the waves as they were propagated farther upstream. The stage graph at Pennsuco is a good example of the river-type tide, wherein the duration of the fall becomes longer than the duration of the rise, because of the proportions and friction of the channel, and because of the fresh-water runoff.

The average rate of propagation of the wave on April 14 and 15, 1942, (fig. 128) can be computed from the stage graphs. It is assumed that the time of the tides at the mouth of Miami Canal was the same as that at Coconut Grove on Biscayne Bay. The reach to Pennsuco is 15.2 miles.

$$
\begin{aligned}
\text { Progress of low tide } & =\frac{15.2}{2.8} \\
& =5.4 \mathrm{mph} \\
& =8.0 \text { feet per second }
\end{aligned}
$$

$$
\begin{aligned}
\text { Progress of high tide } & =\frac{15.2}{2.1} \\
& =7.2 \mathrm{mph} \\
& =10.6 \text { feet per second }
\end{aligned}
$$

The theoretical rate of progression of tidal action in an estuary or large channel under frictionless flow is $c=\sqrt{g d}$; where is the rate, $g$ is the acceleration of gravity, and $d$ is the depth of the channel (Pillsbury, 1940, p. 175, 224). 
In this case:

$$
\begin{aligned}
c & =\sqrt{32 \times 8} \\
& =16.0 \mathrm{fps}
\end{aligned}
$$

The difference between the actual and the theoretical rate of progression indicates that depth is not the sole factor involved; probably the size of a canal and its roughness (friction) are important factors.

The simple elements of the rise and fall of the tide are well understood, but the movements of water resulting from that rise and fall are not so widely appreciated. These movements and their variations are discussed below by combining general data with specific data for Miami Canal.

When the ebb flow starts out an inlet, the impounded water being released is not only the tidal storage of the bay, but it is also the storage of all the tidal channels and lakes that are tributary to the bay. Thus, the fall of the tide in Biscayne Bay releases water impounded in Miami River and its tributaries, causing channel velocities and discharges that are comparatively large. The turn of the tide at the inlet starts the flood flow infrom the ocean, water is again stored in the bay, and backwater from the rising bay reduces the discharge of Miami River.

Stage and discharge graphs for stations along Miami River and Canal are shown in figure 129. The most obvious feature is the fact that the stage and discharge graphs both follow essentially the same pattern, disregarding the differences in scale and timing. The wide variation of discharge at NW. 5 th Street, ranging between 430 and 2,840 cfs, caused equally wide variation in the velocity of flow at that location. The fact that all of the discharge at the station was in one direction means that the fresh-water runoff from the drainage area of the canal was great enough to raise the level of the river as fast as Biscayne Bay was rising-which at times exceeded $0.6 \mathrm{ft}$ per hour.

As compared with the discharge at NW, 5th Street, the smaller range of discharge at Water Plant was caused by the large tidal storage area between the two stations (which includes the lower reaches of Tamiami Canal) and by a smaller tidal range than at the lower station. The larger mean discharge at NW. 5th Street $(1,810 \mathrm{cfs}$, as compared with $1,230 \mathrm{cfs}$ at Water Plant) is explained by the additional intermediate runoff, a large part of which (more than 330 cfs) was direct increment from Tamiami Canal.

The shape of the hump in the graph for NW. 5th Street (reflected also on the Water Plant graph) is a characteristic of most tidaldischarge patterns of Miami Canal. The cause is not apparent, 

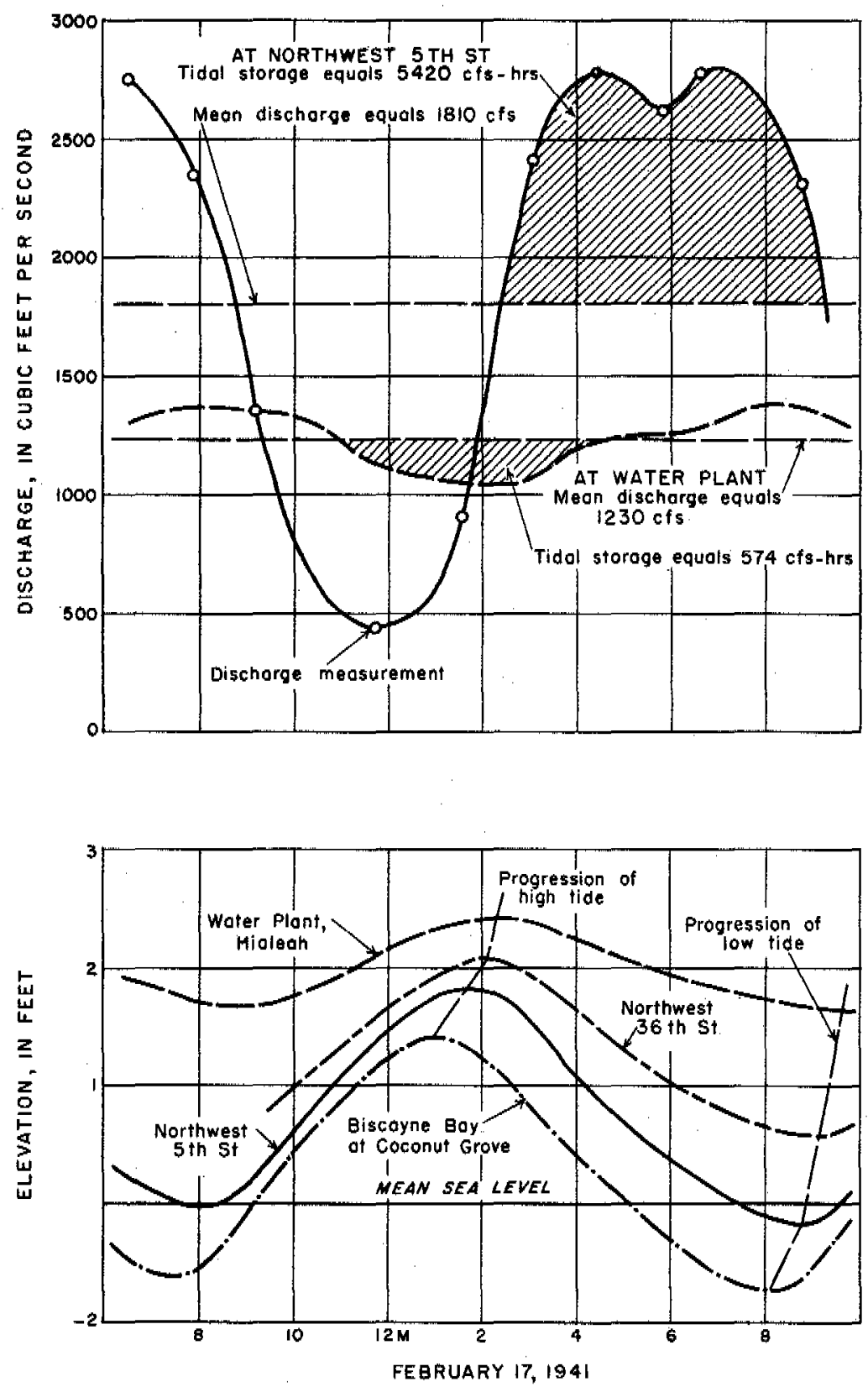

Figure 129. - Graph of tidal variation in stage and discharge at stations along Miamt River and Canal, February 17, 1941. 
although it could be the effect of the timing of tidal release from Tamiami Canal, or it could be the result of some peculiarity of currents in Biscayne Bay.

Concerning the graph for NW. 5th Street, as centered about the line of mean discharge, note that the minimum flow was more divergent from the mean than was the maximum flow-a difference of $1,370 \mathrm{cfs}$, as compared with $1,000 \mathrm{cfs}$. And also, the period of reduced discharge (below the mean) was shorter than the period of increased discharge-5. 6 hours, as compared with 6.8 hours. These features indicate that tidal storage fills more quickly than it empties, because of the combined effect of runoff and the rising bay, coupled with the differences in rates of inland propagation of the high and low tides. The storage and release of the tidal storage can be considered as flood and ebb storage, because it is associated with the flood and ebb of the bay even though flow in the canal may be in only one direction during the entire tide cycle.

The tidal storage at Water Plant on February 17, 1941, was 574 cfs-hours ( 47 acre-ft); at NW. 5 th Street, it was $5,420 \mathrm{cfs-hours}$ (448 acre-ft), or. nearly $1 \mathrm{C}$ times as great, thus illustrating the relatively large amount of tidal storage intermediate between the two locations. Because of the cavernous nature of the limes tone, through which much of the lower reaches of Miami and Tamiami Canal were excavated, water can easily enter or leave the ground through the banks. This change in ground storage was believed to be large. A very rough computation for the NW, 5 th Street location, however, indicates that the surface storage accounts for about 70 percent of the tidal storage (under conditions that existed on February 17, 1941), thus leaving only 30 percent for the bank storage.

The stage graphs of figure 129 show ordinary conditions. The diminishing range of tide, inland from the bay, is well illustrated, as well as the progressive inland lag of the high and low tides.

Another little-understood aspect of tidal action in a canal is the phasing of the discharge cycle (or wave) in a manner similar to the inland progression of the high and low tides. The fundamental tide cycle is approximately a sine wave and can be considered as being divided into $360^{\circ}$, as well as having a time period of 12 hours and 25 minutes.

The cycle of discharge in a tidal system has the same general form as the stage cycle and is a product of the stage cycle, but the extremes occur at different times-that is, the discharge cycle is out of phase with the stage cycle. At the perfect (theoretical) inlet from the sea, the flow through the inlet changes from flood to ebb (reverses) just after high tide in the ocean. The ebb flow reaches a peak as the tide falls to midtide, and it stops when low tide is reached. Thereafter, the flood flow resumes and the discharge 
cycle is completed, but it is later than the stage cycle by a quarter cycle-it lags by $90^{\circ}$, or a little more than 3 hours.

At Government Cut (the principal entrance to Biscayne Bay), the discharge cycle lags behind the stage cycle by about $110^{\circ}$. This lag becomes progressively greater inland from the inlet. The discharge cycle becomes distorted in Miami River, because of freshwater runoff and other factors, and the lag is not constant for all parts of the cycle. At Water Plant, Hialeah, the high discharge occurs about $154^{\circ}$ ( 5 hours, 20 minutes) after high tide, and the low discharge occurs about $135^{\circ}$ ( 4 hours, 40 minutes) after low tide. An example of the phase lag in the canal is shown in figure 129.

Below some critical quantity, the fresh-water runoff in Miami Canal is not able to fill the channel and raise its level as fast as Biscayne Bay rises. Flow inland from the bay then occurs during part of each tide cycle. The mechanics of this reverse (or negative) flow are illustrated in figure 127. The length of the period of reverse flow and the distance inland that it extends are functions of the amount of fresh-water runoff and the tidal range.

Under reverse-flow conditions, salt water from the bay moves up Miami Canal. The existence of an upstream current at any location does not necessarily mean the presence of salt water, however, because salt water from the bay pushes some of the fresh water back inland. Later in the cycle, when all flow is toward the bay (positive), both fresh and salt water flow downstream. During this action, a certain amount of intermixing occurs, and water containing varying amounts of chloride can be found in the canal. The salty water, being heavier than the fresh water, lies in the bottom of the channel and moves inland as fresh-water runoff decreases. In addition to this replacement of the fresh water in the canal, the salty water moves into, and out of, bank storage and tends to contaminate the adjoining ground water. It is during periods of low runoff and at times of maximum tidal range that salty water moves inland at the fastest rates. This phenomenon is more completely discussed in the saction on Salt-water encroachment under the heading Contamination of tidal canals.

Typical and extreme conditions of reverse flow in Miami Canal at Water Plant are shown in figure 130, which was developed from field observations. A series of discharge measurements made over a tide cycle is known as a tidal discharge integration or simply as an integration.

The graphs for December 7, 1942, show conditions during a long steady decline in stage and discharge of the canal. The characteristic shape of the hump near the peak of the integration is not prom inent; instead, it is indicated by a flattening of the curve. The 3hour period of reverse flow, indicated on the graph as negative 
竜

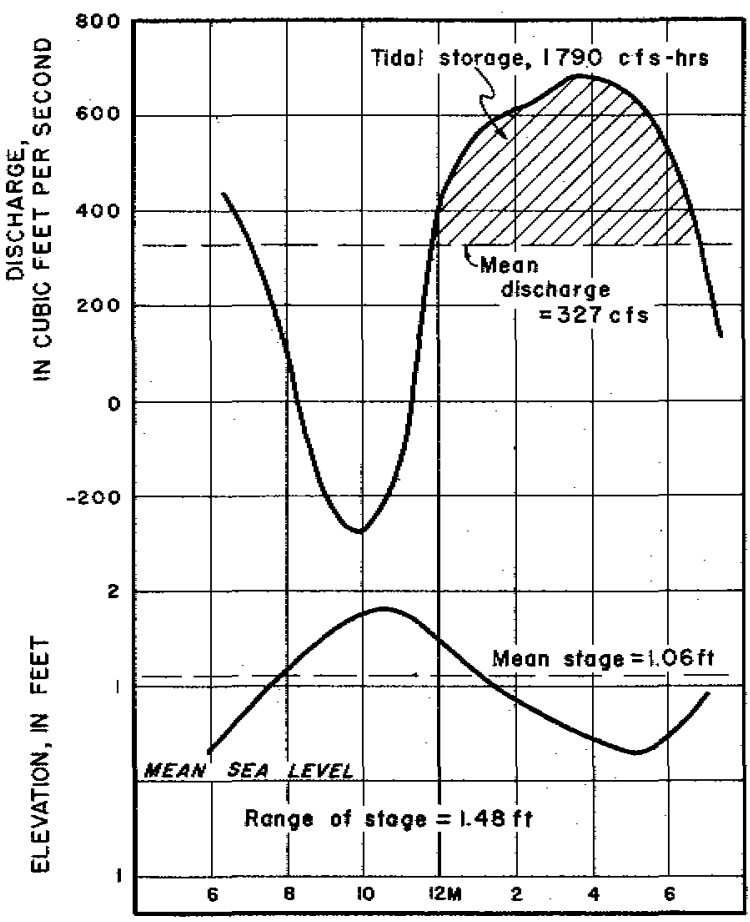

DECEMBER 7,1942

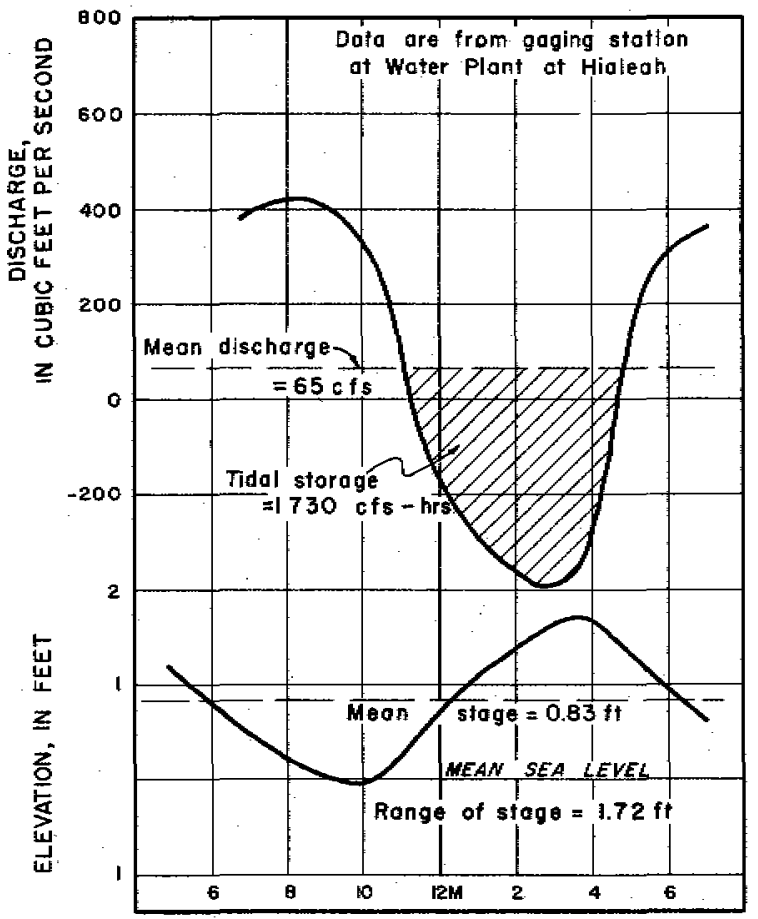

JUNE 23, 1943

Figure 130. - Graph of tidal variation in stage and discharge of Miami Canal at Water Plant, Hialeah, December 7,1942, and June 23, 1943.

co 
flow, means that salty water was progressing inland during part of each cycle. However, the reverse flow measured at Water Plant was fresh water that was forced back by salty water, which had advanced nearly to the entrance to Palmer Lake.

The changing symmetry of the tide cycle as it moves inland is also reflected in the discharge cycle. The upper part of the integration (shaded to show the flow representing the tidal storage) has the typical wider and flatter shape, as compared with the lower part; this shape is the effect of the inland progression and lag of the tide. Note the time relationship between high and low tide and the extremes of discharge. Despite the fairly low mean discharge of $327 \mathrm{cfs}$, the time necessary to fill the tidal storage was about 2 hours less than required to empty it.

The graphs for June 23, 1943, show conditions near the low point of a very bad drought condition. The most notable features are the unusually long period of reverse flow, the large negative flow, and the very low mean discharge. With fresh-water runoff so small, and with the tidal range at the maximum for the month, salty water in the canal was moving inland at a fast rate. The salt front actually passed the point of observation in Hialeah, and some of the water measured during the cycle was salty. Fortunately for the protection of the public water supply, within a short time rains caused increased runoff and forced the salty water downstream. The maximum negative flow of $395 \mathrm{cfs}$ was nearly as great as the maximum positive flow.

If the canal were not controlled, the next event in such a drought period would be the cessation of all fresh-water runoff. Salty water would soon move in under the fresh water and continue inland. The rise and fall of the tide would cause the salty water to move in and out of the banks, and extensive contamination would result. Continued drought effect would result in a net canal flow intand, and contamination of the entire tidal reach would soon occur. This was observed in some of the shorter canals in the Miami area and probably would have occurred in Miami Canal, had it not been for the dam at NW. 36th Street.

Several pertinent factors from the graphs in figures 129 and 130 have been compiled in the following tabulation:

Miami Canal at Water Plant, Hialoah

Feb. 17, Dec, 7, June 32, $1941 \quad 1942 \quad 1943$

Discharge:

Mean............................ efs ... 1,230 
Miani Canal at Water Plant, Hialeah

Feb. 17, Dec. 7, June 23,

$1941 \quad 1942 \quad 1943$

Discharge-Continued

Minimum (or max negative).. cfs.. 1,050

$\begin{array}{rr}-273 & -395 \\ 959 & 810\end{array}$

Range............................... cfs.. $\quad 340$

Volume per eycle........... cfs -hr.. 15, 250

acre-ft.. 1,260

$4,055 \quad 801$

$335 \quad 66.2$

Time:

Period of reverse flow.........hrs..

0

Reverse flow,....percent of cycle..

0

Maximum discharge after maximum stage.....................hrs..

$\begin{array}{lll}5.8 & 5.1 & 4.7\end{array}$

Minimum discharge after minimum stage................... hrs..

$6.0 \quad 4.9 \quad 4.9$

Stage:

Mean..............................ft..
Range............................. ft..
Range at Pennsuco....

2.07

1.06

.83

.73

1.48

1.72

.07

.55

Tidal storage:

Volume.........................efs -hr.. acre-ft. .
574

47.4

5.3

7. 1

3. 8
1,790

148

1,730

143

Time to fill.......................hrs..

Time to empty................. hrs..

Percent of fresh-water runoff......
4.9

5.7

7.1

44

The following interesting relationships are indicated in this listing of data, several of which may be related to the basic factors of decreasing mean discharge and stage in the series presented: 1. The range of discharge increased generally. 2. The length of the period of reverse flow increased markedly-it may be assumed that the maximum period (no runoff) would be around 50 percent of the cycle. 3. The volume of tidal storage compared with the freshwater runoff increased considerably-mathematically, the percent would expand indefinitely as runoff approached zero. 4. The lag of the discharge cycle after the stage cycle apparently decreased with the amount of discharge.

The volume of tidal storage, as shown also by other studies, was closely related to the range in stage. The apparent contrary relationship of range and volume on December 7, 1942, and June 23, 1943, may possibly be explained by the accumulation of aquatic weeds in the canal during the period between the two dates, which would damp the tidal action and thus reduce tidal storage in some 
degree. This is corroborated by comparison of the tidal range at Water Plant with that at Pennsuco. Thus, to arrive at any stagevolume relationship, it is necessary to use stage data from two or more stations.

\section{FLoW characterustics of MAMT CANAL}

The multiple-purpose function of Miami Canal makes its regimen over a period of time important as reference data. The canal helps to collect water for the reservoir area, and at the same time, it is the instrument that excessively drains the area. The drainage needs for farming are met in wet periods, and when dry weather sets in, the canal furnishes the necessary irrigation water. Miami Canal indirectly supplies a considerable part of the municipal wellfield draft, but in dry seasons, when that part is most needed, salty water may move up the canal and contaminate the wells.

One of the best sources for the comparison and evaluation of conditions in the Miami Canal drainage area is the stage record at Pennsuco, shown in figure 131 . This record for the period 1926-46 is the longest available in the Everglades area, and it is the only long record in the lower Everglades. The record is a base reference statistic for the water regimen of a large area from County Line Dam to NW. 36th Street. It has certain weaknesses in the period in which once-daily staff gage readings were made (to November 1939). The readings were discontinuous, particularly in the drier seasons, with breaks as long as 5 months. Also, the readings were made about the same time each day, thus disregarding the twicedaily tidal variation that often existed in the canal and which was greatest at the lower stages. The early record then is increasingly weak below a stage of about $3 \mathrm{ft}$, particularly during the first several years, when pumping for drainage and irrigation occurred. Despite these weaker periods, which are minimized in some degree by the time scale of the graph, the moderate- and high-stage record is valid, and the whole constitutes a most useful record. After November 1939 the graph is plotted from daily mean stages obtained from a continuous recorder.

In studying the record, it is desirable to remember that the ground elevation at Pennsuco of about $4 \mathrm{ft}$ in 1946 was possibly 1.5 to $2 \mathrm{ft}$ lower than in 1926, because of subsidence of the soil from oxidation and fires. This means that during all except about 2 of the 21 years of record the ground was inundated in varying depths and for varying periods.

The seasonal variation is the outstanding characteristic of the graph in figure 131, showing how definite a division exists between the annual wet and dry periods. The maximum stage of $8.77 \mathrm{ft}$ for the 21-year record occurred in 1929, which is remembered as an 

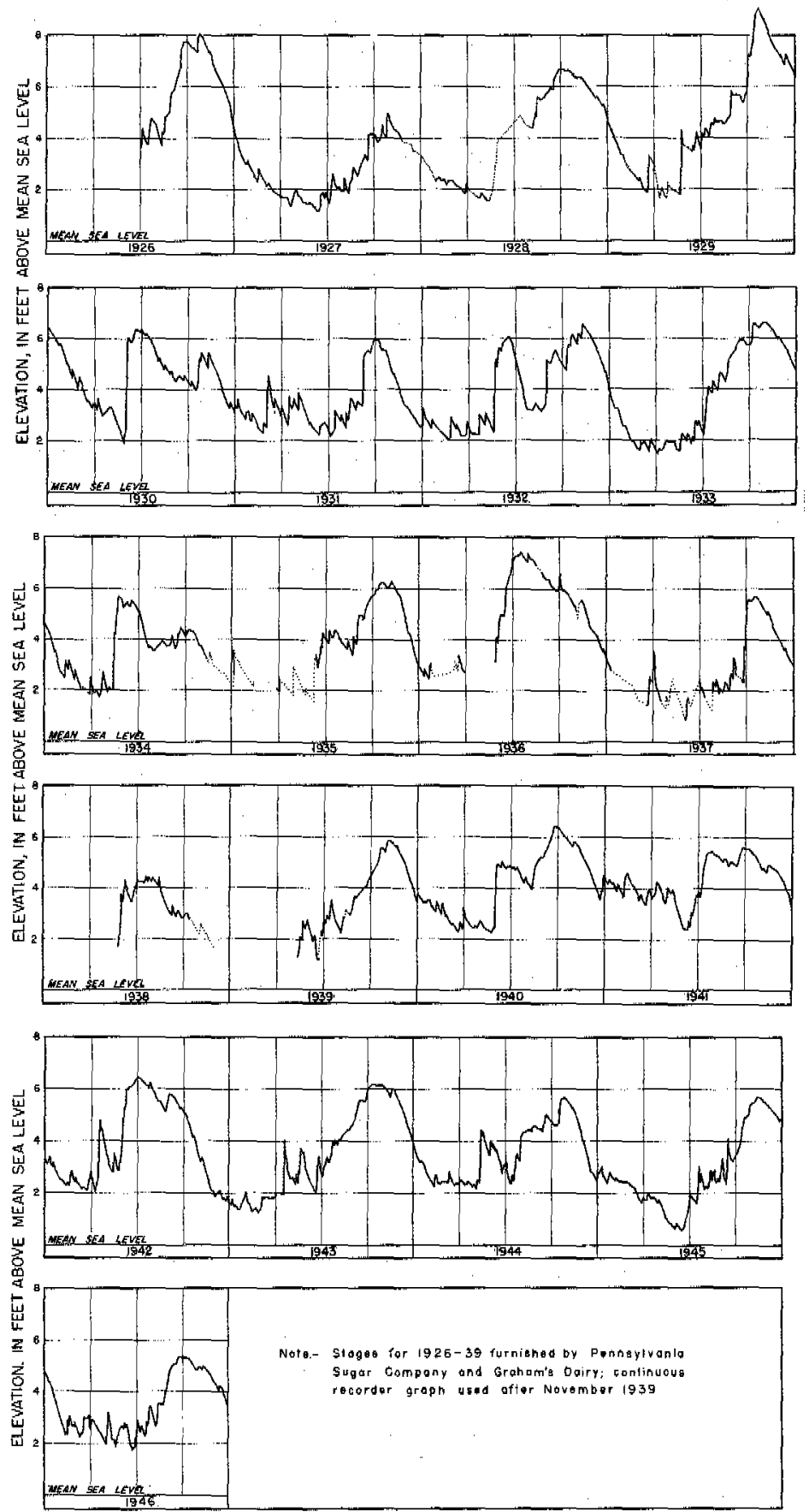

Figure 131, - Graph of stage of Miami Canal at Pennsuco, 1926-46. 
outstanding flood year. The highest stage reached in a year, however, is not the only criterion of water conditions at Pennsuco; the length of the wet, or dry, period must also be considered.

In the winter and spring of 1939 , drought conditions caused salty water to move far inland and contaminate some of the municipal supply wells. All of 1938 was unusually dry, thus setting the condition for early 1939. The year 1927 was also dry, and a serious drought condition probably occurred in the spring of 1928.

A series of very dry winter seasons, starting in late 1942, culminated in the extreme drought condition of June 1945. Although fair amounts of recharge occurred in the wet periods of 1942, 1943, and 1944, the succeeding long periods of little rainfall caused wate $x$ levels to fall excessively. The stage would have been even lower except that NW, 36th Street Dam helped conserve water in the springs of 1943 to 1946 . The effect of the dam shows in the graph, notably in 1944 and 1946.

The over-all range of stage at Pennsuco was nearly 8.5 feet-in an area where some of the land is less than 4 feet above sea level. Some of the fast rates of recharge shown on the graph are noteworthy, as well as the long periods of steady decline. However, a general study of the graph indicates no positive trend in the period of record. The record is duplicated in greater detail with other stage records along Miami Canal for 1939-46 in figures 117-123.

The annual maximum stage at Pennsuco for the period 1926-46 is shown in the following tabulation, in which each peak was assigned a number indicating its order of magnitude-the highest peak listed as No, 1 .

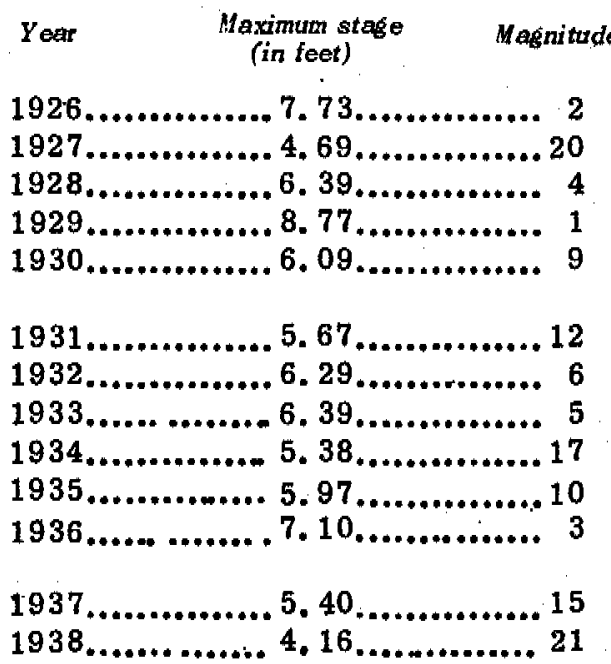




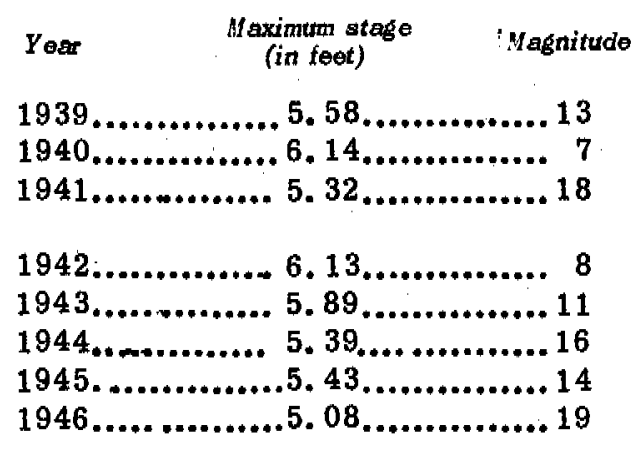

Figure 132 shows the annual peak stages at Pennsuco plotted by date of the year. The seasonal grouping shown would be expected, but certain other features of the graph are outstanding. The early group of 5 peaks is separated from the remainder by a time interval of 67 days (more than 2 months), during which no annual peaks occurred. The main group of 16 peaks all occurred within a period of 56 days (or a little less than 2 months), and no peaks occurred during the succeeding 6 months.

The vertical distribution is also interesting, because 16 of the 21 peaks were in a stage range of 5 to $7 \mathrm{ft}$, and 15 of these 16 peaks, or 71 percent of the total number, were within the narrow range of 5.3 to $6.4 \mathrm{ft}$. The small boxed area on the graph encompasses the concentration of annual peak stages, with 12 , or 57 percent, occurring within the relatively short time of 56 days and within the narrow stage limits of $1.1 \mathrm{ft}$. The over-all stage range was $4.6 \mathrm{ft}$.

The auxiliary graph in figure 132 shows the annual peaks plotted in chronological order. A downward trend seems evident, but it should be accepted and used with caution, because it is not certain that the trend will continue. It may, however, reflect the control of Lake Okeechobee and the increasing practice of water control in the upper Everglades in the later part of the period 1926-46. This would decrease the overland movement of water from the north and possibly show in some degree in lower Miami Canal drainage area. The subsidence of the peat soils also may play a part in the downward trend, because, at a given stage of inundation, more water now is stored above the surface of the soils.

The same procedure as that outlined for the flood frequency computations for Kissimmee River (p, 305) was used for the Pennsuco annual peak record. Based on the period 1926-48, the recurrence interval for the annual peak stage was computed as follows: 
Recurrence interval, Annual stage expected to be (years) equaled or exceeded ${ }^{1}$

(in feet)

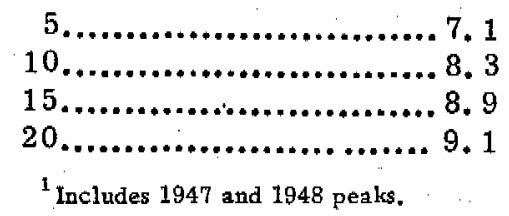

The data shown were chosen from the recurrence-interval graph. Any recurrence-interval data must be used with an appreciation of their limitations.

The discharge and stage of Miami Canal at Pennsuco are affected by conditions in the reservoir upstream, and by backwater from aquatic growth, tidal action, and control operations farther downstream, particularly in dry periods. The discharge pattern from Pennsuco to County Line Dam was discussed in connection with table 44, which shows that, although the discharge increases in the reach under normal conditions, it may decrease in dry periods and when water is released at County Line Dam.

The discharge was measured and computed on a. daily basis during the period $1939-43$ at a point just above the mouth of Pennsuco Lateral. The monthly and annual runoff, listed in table 45 , shows

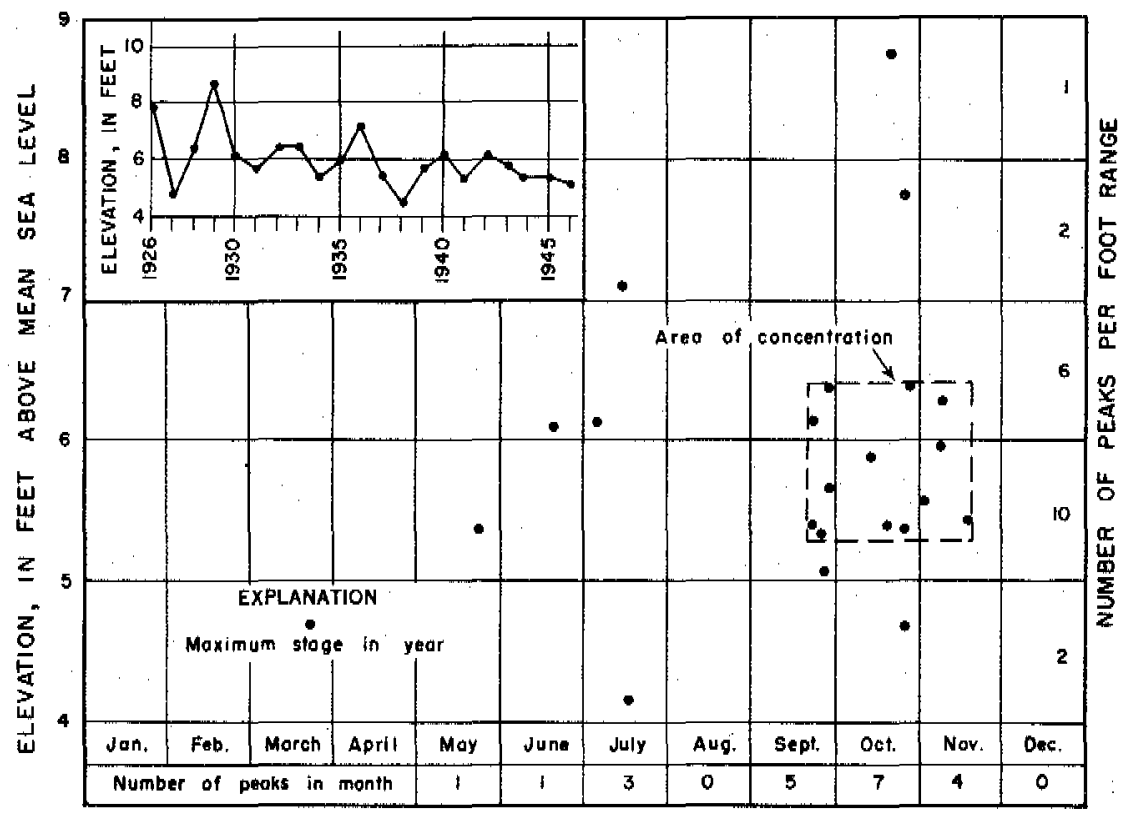

Figure 132. - Graph of annual maximum stage of Miami Canal at Pennsuco, 1926-46. 
a mean annual runoff of 313,000 acre-ft for the 3 complete years of record. The maximum daily discharge was 956 cfs on November 25 and 26,1940 .

Records show that during the period that the sugar development was active, and as late as 1931, the control in Pennsuco Lateral was operated, and the pumps were operated for both drainage and irrigation. After 1931, it is likely that the control was kept open; this was true after 1939, during the period of this investigation. Discharge measurements of PennsucoLateral, made about weekly intervals during $1940-43$, are listed in table 46 . The measured maximum and minimum discharges were 186 and $3.1 \mathrm{cfs}$, respectively. Annual runoff for 3 years of record, 1940-42, averaged 56,000 acre-ft.

Tide effect at Pennsuco has been as much as $0.7 \mathrm{ft}$ during the period of investigations. Strong inland flow was observed during a drought year, showing that, if the dams had not been installed downstream, salty water could have contaminated the entire tidal reach.

The stage and discharge hydrographs of Miami Canal, 1939-46, are shown in figures 117-123. They show the regimen of the canal under a wide range of natural conditions and also under artificial control. Their value is enhanced because they encompass the period of the most severe drought known to the area.

One of the prime unknowns of this investigation was the ability of Miami Canal to provide sufficient discharge along its lower. reaches to prevent salt water from moving upstream to a point where it would endanger the municipal well fields. Unfortunately, the pronounced seasonal variations in rainfall cause equally pronounced variations in runoff. The larger part of the storage accumulated during the wet summer and early fall period drains out and evaporates before the next period of rain occurs, and drought conditions often exist for periods of several months or more. Thus, a discharge of $400 \mathrm{cfs}$, or more, at Hialeah, which has been determined to be necessary to keep salty water below the NW. 36 th Street Dam site, is not available for lengthy periods, even though an excess of water is generally wasted to the sea in the preceding wet periods. Even when dams at NW. 36 th Street were operated to conserve some of the runoff and to fence off the encroaching salty water, the desired flow could not be maintained, because of conflicting water needs along the reach to County Line Dam.

A fairly complete log of the general operation of NW. 36 th' Street Dam may be found in the section on Salt-water encroachment. During various periods, as noted previously; County Line Dam was opened in an effort to augment the flow of Miami Canal in the Hialeah area and to raise water levels that had become dangerously low. The graphs in figures 117-123 show the effect of this operation. 
The graphs also show the obvious response of the canal at the several stage stations to rainfall, or to the lack of rainfall. The relationship between changes in stage and changes in the level of Biscayne Bay can also be observed.

It will be noted that the slope of the water profile, as indicated by the vertical distance between the graphs for adjoining stations on any date, may vary widely, even though the discharge at Water Plant may be the same. This is a direct result of bottom-rooted aquatic plants, which are present at all times above the WaterPlant station, and which sometimes effectively block the channel. The weeds usually tear loose under the impact of larger flows, and thus they cause backwater that has a variable and somewhat seasonal aspect.

In discussing the salient features of figures 117-123, the yearly graphs will be taken in chronological order. The graphs were plotted from dally mean stages and discharges that are averaged from variations at a station for 1 day-including the wide variation often imposed by tidal action. Daily mean figures permit the visualization of the important features of a stage or discharge record without the unnecessary encumbrance of extraneous detail.

1940. - The sharp rise at Pennsuco is noteworthy, because it was not reflected in nearly the same degree at Water Plant, probably owing to the uneven distribution of rainfall. The effect of the first dam to be constructed at NW, 36 th Street can be noted in the levelling-off of the stages in the spring and in May, when it was completely closed.

1941. - The winter and spring rains were abundant; uncontrolled flow existed at all times, and the discharge dropped below $400 \mathrm{cfs}$ for only a short time.

1942. -Declining water levels during the spring resulted in the release of flow at County Line Dam late in March and in the first half of April. The resulting increase in water levels at the lower stations must also be attributed, in part, to a coincidental rise in Biscayne Bay. However, flow at Water Plant was augmented to around $400 \mathrm{cfs}$ (as shown by the discharge graph), although the bay rise probably reduced the amount of increase by causing additional tidal backwater. The heavy rainfall of mid-April stopped further need for control operations during 1942 .

June 1942 was outstanding for the large amount of recharge in the drainage area of Miami Canal. Note that the discharge and stage at Water Plant reached a maximum early in September, even though the highest level in the headwaters area occurred about the end of June. The discharge at Pennsuco reached a maximum in October and, coupled with the flow from the lateral, amounted to nearly three-quarters of the discharge passing Water Plant. 
1943. - The effect of releasing water at County Line Dam in the first half of April can be seen, although it was reduced by the closing of NW. 36 th Street Dam during most of March and early April. As usually happened when water was released at County Line Dam in dry periods, much of the water was absorbed before reaching the critical area near the well fields.

This was the first year of the serious 3-year drought ending in 1945 , and runoff of Miami Canal at Water Plant was the second lowest of record; discharge was notably low throughout the year. An outstanding effect shows in the stage graphs starting in July. The low velocities in the canal encouraged the growth of aquatic weeds, with resultant obstruction of flow, as evidenced by the increasing slope between Water Plant and Russian Colony Canal and the lack of discharge response to the increasing slope. Curiously enough, the problem of salty water did not become critical in late 1943 , and the effect of the weed block was beneficial because it prolonged the period of flow above $400 \mathrm{cfs}$ and probably reduced the severity of the drought during the following dry season.

1944. -Despite the favorable effect of weed growth in 1943, lack of rainfall again caused serious drought conditions. Water was released at County Line Dam from mid-April to mid-May, and again about the end of June, but little effect occurred at Water Plant. The NW. 36 th Street Dam was closed or partly closed, for more than 4 months, and levels above the dam were kept fairly constant. The weed block was considered detrimental to movement of water to the well-field area, and late in the spring, about 2.4 miles of heavy grow th was cut away in the reach above Russian Colony Canal.

The graphs for 1944 (and other years) illus trate one of the principal characteristics of the surface and ground reservoirs of the headwaters area. Whereas the stage graphs from Broken Dam downstream show the steep decline during fall and winter, which is caused by canal runoff and general drainage of the coastal zone, the stage above County Line Dam tends to hold up for a long period and shows a considerable lag in the time of the principal decline. In this period, water is being doled (in effect) from the reservoir by seepage (except when the dam is opened). This characteristic is important to the water regimen of the lower reaches, because without this seepage the problem of drought and salt-water contamination would be more serious.

As a result of the operation of NW. 36th Street Dam and because of the drought, the total runoff for the year was the least of record (see table 47). The sharp rise of Biscayne Bay and the lower reaches of Miami Canal in mid-October was caused by the northward passage of a large hurricane off the west coast of Florida (see p. 443). Note that the stages at the inland stations rose also, 
but they stayed at the peak level because of rainfall recharge associated with the hurricane. Rainfall in the lower reaches was small, and the Water-Plant graph shows the combined effect of the rise upstream and the return of the bay to a normal condition. Note particularly that in July the bay stage was higher than the level above NW. 36 th Street Dam-a condition of the gravest import to the salt-water intrusion problem. Fortunately, this period of net negative head was short.

1945. - This year started with low water levels and marked the culmination of the drought. County Line Dam was open all of April and half of May, but the level of the reservoir was so low that the effect of the additional flow was lost at Water Plant. The dam at NW. 36 th Street was operated throughout the year and was closed for over 4 months." In May and June, the average level of Biscayne Bay was higher than the level of Miami Canal at Water Plant. The occurrence of rain, starting in June, relieved the threat to the municipal water supply. In the worst period, net flow in all the tidal canals in the Miami area probably was inland, and some of the stub canals were highly saline throughout.

The increased rainfall, later in the year, resulted in the first large runoff in Miami Canal since 1942. Note again the effect of a hurricane close to the Miami area in mid-September.

1946. - This year showed a return to more ordinary conditions. More effective operation of NW. 36 th Street Dam resulted from closing the dam earlier in the period of annual decline, thus holding higher stages above the dam. Note the near-pool conditions during April, when the total fall between Broken Dam and NW. 36 th Street was about $0.5 \mathrm{ft}$.

Miami Canal at the Water Plant in Hialeah is considered to be a key station in the investigation of the waters of the Miami area. The evaluation of this discharge is used as a reference base for all other water records of the drainage basin, because the discharge is the resultant of all the factors involved in the uncontrolled runoff in the canal, and it is the key to the protection of the municipal well fields. The Water Plant has an intake from Miami Canal, and the water can be used in an emergency if the other source of supply fails for any reason. The relationship of the gaging station to the well field, and to NW. 36 th Street Dam and the deeper channel below the dam, makes its locaticn strategic.

Table 47 shows the monthly and annual runoff at Water Plant. The totals for the drought years 1943-45 are significant with respect to the more normal years. The mean annual runoff for the $6 \mathrm{com}$ plete years of record was 389,000 acre-ft, which was a little more than half of that for West Palm Beach Canal at West Palm Beach, but it was greater than for any of the other major canals. 
Table 48. - Comparison of discharges for Ufami Canal at Pentusuco and Water Plant gaging stations

\begin{tabular}{|c|c|c|c|c|c|c|}
\hline \multirow[b]{2}{*}{ Calendar year } & \multicolumn{4}{|c|}{ Average discharge (in cfs) } & \multirow[b]{2}{*}{$\begin{array}{l}\text { Inflow between } \\
\text { Pennsuco and } \\
\text { Water Plant } \\
\text { (in cfs) }\end{array}$} & \multirow{2}{*}{$\begin{array}{l}\text { Ratio of discharge } \\
\text { at Pennsuco (incl. } \\
\text { lateral) to discharge } \\
\text { at Water Plant } \\
\text { (in percent) }\end{array}$} \\
\hline & $\begin{array}{l}\text { Miami Canal } \\
\text { above lateral } \\
\text { at Penusuco }\end{array}$ & $\begin{array}{c}\text { Pennsuco lateral at } \\
\text { Penusuco }\end{array}$ & $\begin{array}{l}\text { Miami Canal } \\
\text { below lateral } \\
\text { at Pennsuco }\end{array}$ & $\begin{array}{c}\text { Miami Canal } \\
\text { at Water Plant, } \\
\text { Hialeah }\end{array}$ & & \\
\hline 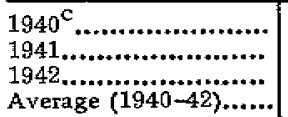 & $\begin{array}{l}390 \\
516 \\
390 \\
432\end{array}$ & $\begin{array}{r}71 \\
102 \\
58 \\
77\end{array}$ & $\begin{array}{l}461 \\
618 \\
448 \\
509\end{array}$ & $\begin{array}{l}707 \\
828 \\
753 \\
763\end{array}$ & $\begin{array}{l}246 \\
210 \\
305 \\
254\end{array}$ & $\begin{array}{l}65 \\
75 \\
60 \\
67\end{array}$ \\
\hline
\end{tabular}

a Sum of two preceding columns.

$\mathrm{b}$ Computed by subtracting discharge at Pennsuco (below lateral) from that at Water Plant.

${ }^{c}$ Partly estimated. 

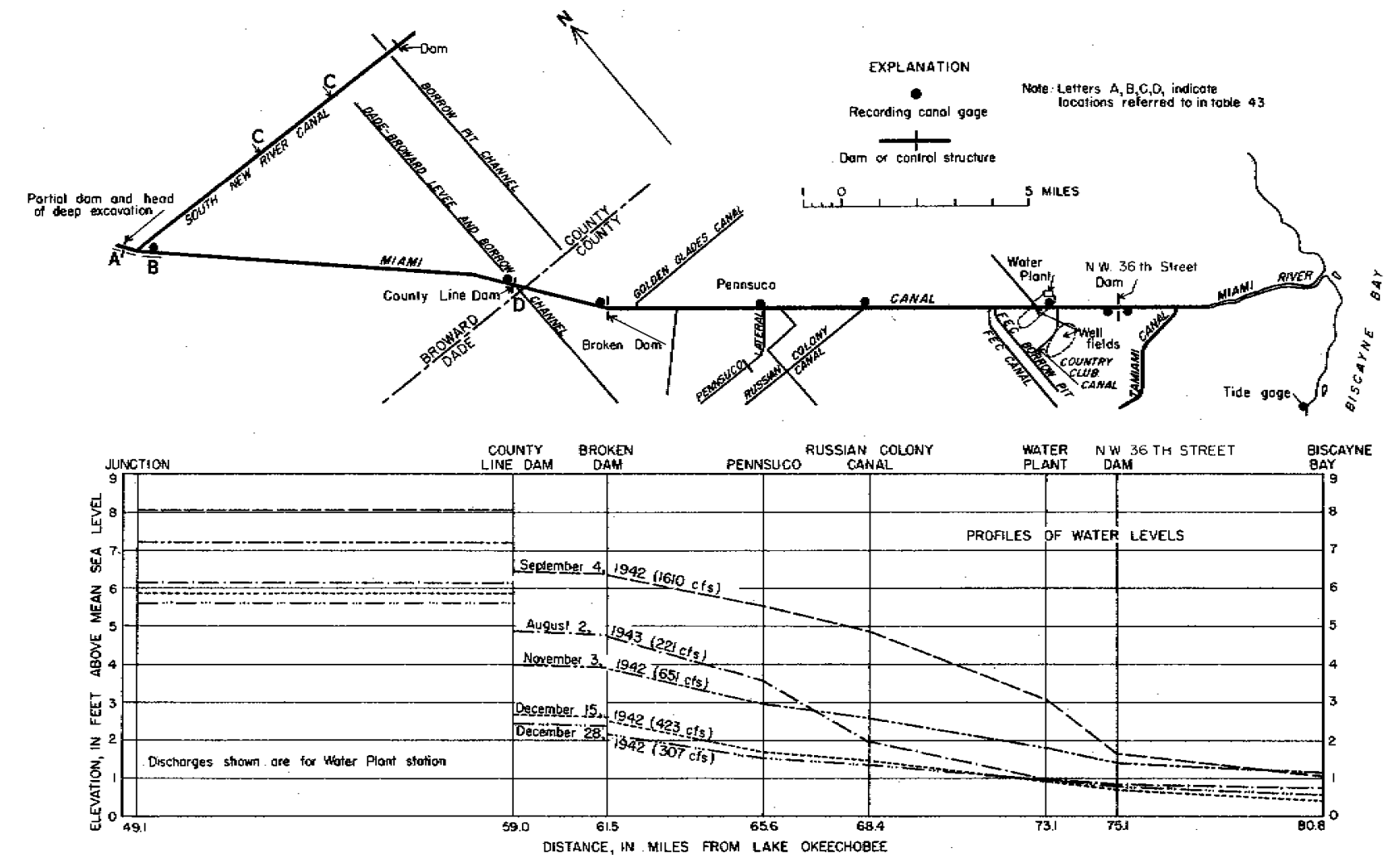

DISTANCE, IN MILES FPOM LAKE OKEECHOBEE

Figure 133. - Graphs of stage protiles of Miami Canal for selected dates and map of lower reaches of canal. 
Table 48 furnishes a useful comparison of annual discharges at Pennsuco and Water Plant, showing the discharge increment between the stations and the comparative runoff. The table indicates that 67 percent of the discharge at Water Plant, during the period $1940-42$, originated in and westward of the Pennsuco area. Although it is true that some of the flow that originated west of the Pennsuco area was useful to the lower reaches, too much of it was necessarily wasted to the sea in wet periods. If part of this runoff could be stored for a longer time, the area would greatly benefit.

The data for plotting water-surface profiles of Miami Canal for any time during the period 1940-46 can be obtained from the stage graphs of figures 117-123. A few selected profiles, however, have been prepared in figure 133 , which also shows a map of the lower reaches. The series of four profiles for dates in 1942 shows a progressive decline of both stage and discharge under typical conditions. The steep gradient between Water Plant and NW. 36 th Street indicates a reduction of channel capacity, as compared with adjoining reaches. The convex profile during periods of large flows is typical, as is the gradual flattening with decreasing discharge and the tendency to become concave.

The profile for August 2, 1943, shows a condition of low discharge during the early phase of the severe weed block that developed that summer. Note the steep gradient for this flow in the reach west of Water Plant and the much steeper slope between Pennsuco and Russian Colony Canal, where the weed block was extreme. Profiles for other dates would show the development and dissipation of the weed block.

The high stage of Biscayne Bay during the hurricane of September: 15, 1945, (see page 443) caused extreme variations in stage upstream in Miami Canal. For a time, at the height of the storm, the inland rush of water must have been impressive. A profile of the maximum height of the hurricane wave is shown in figure 134 for the tidal reaches of the canal. The profile is a limiting curve that did not exist as a whole because the progression of the storm wave inland took an appreciable amount of time, similar to the development of tidal action. However, instantaneous profiles would indicate that even steeper slopes occurred during the storm. Even though NW. 36 th Street Dam was entirely open, the degree of constriction at the site caused a small loss of head and a lag in the movement of the wave.

The average rate of inland propagation of the storm wave can be computed from the time of occurrence (eastern war time) of the peak stage at the several stations listed below, which were taken from recorder charts to the nearest 5 minutes: 
NW. 36 th St. , below dam............. $8: 40$

NW. 36 th 'St. , above dam............. 8:50

Water Plant, Hialeah.................. 9:20

Russian Colony Canal................... 9:55

Pennsuco............................... 10:30

Broken Dam........................... 11:00

Unfortunately, the time of the maximum stage in Biscayne Bay is not known, because the recorder was submerged and the record is incomplete. The average rate of inland travel of the storm wave in the 14.65-mile reach from NW. 36th Street to Broken Dam was 9.2 $\mathrm{fps}$, or $6.3 \mathrm{mph}$. This is at about the same speed as that of tidal action, as discussed on page 450 .

The mean profiles of the canal on the day prior to the hurricane, and on the second day after the hurricane, also are shown in figure 134. The rise in the profile between the two dates represents the recharge of the drainage area by rainfall.

Note the changing characteristics of the storm graph with movement upstream. At NW. 36 th Street, the rise and fall were sudden, and nearly normal tidal action was soon resumed. At Water Plant, a similar hydrograph developed, but the effect of the rainfall upstream is shown in the period following the peak stage. The rainfall effect increased at the upstream stations, and at Broken Dam the stage leveled off with very little recession from the maximum.

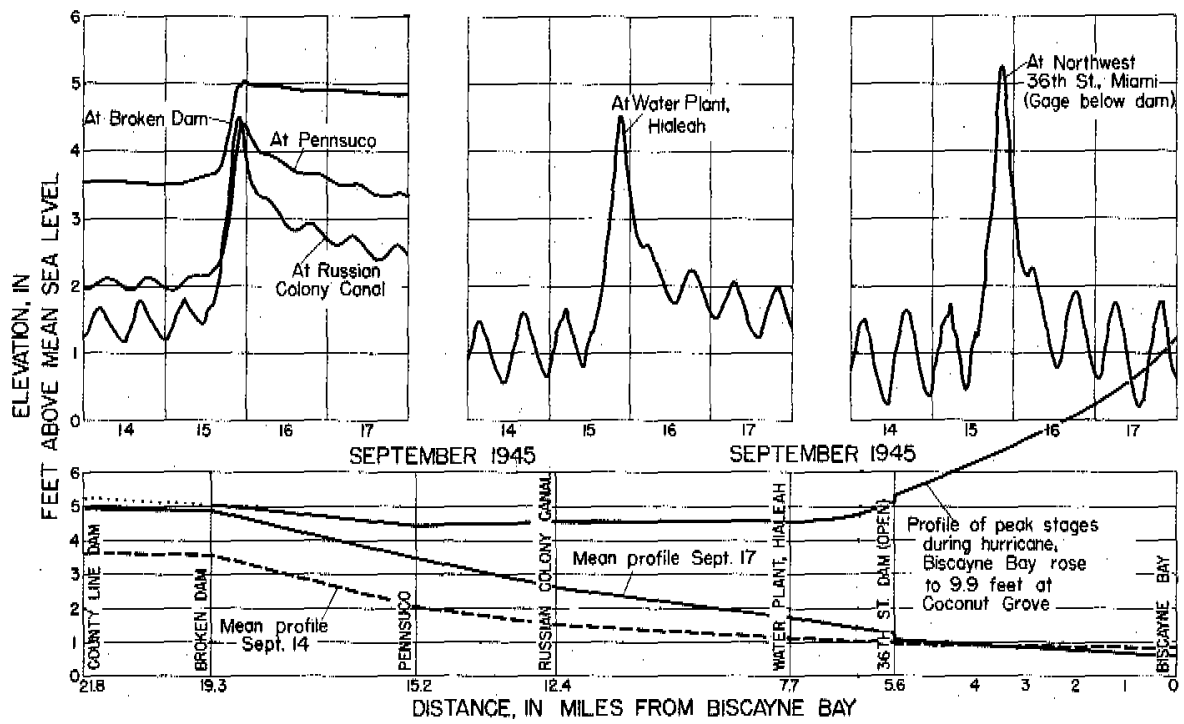

Figure 134. $\rightarrow$ Profile of Miami Canal during hurricane of September 15, 1945, and stage graphs for stations along the canal for the storm period. 


\title{
COMPUTATION OF DISCHARGE BY TIDE-CORRECTON METHOD
}

\author{
By C. C. Yonker
}

The determination of daily mean discharge of Miami Canal at Water Plant at Hialeah, or of any tidal stream, would be a fairly simple problem if the mean tide-cycle eleration at the mouth of the stream were constant. However, the mean elevation of the ocean is not constant; instead it varies from cycle to cycle during the four quarters of the lunar month. Because of these variations in mean elevation, the discharge at any place in the tidal reach of a stream is continually changing, not only because of the rise and fall of the tide, but also because of the rise and fall of the mean tide-cycle elevation at the mouth of the stream. A three-dimensional relationship exists between the mean tide-cycle elevation at the mouth and the mean elevation and discharge at a given place in the tidal reach. Use is made of the tide ranges as a factor in determining the equivalent, or tide-corrected, elevation at a gage in the tidal reach that corresponds to a constant tide-cycle elevation of zero for the mouth of the stream. The discharge rating curve is based on the relationship between the tide-corrected elevation and the discharge.

The station at Water Plant, Hialeah, and the tide station on the west shore of Biscayne Bay at Coconut Grove were selected for this explanation. Water Plant is 7.7 miles upstream from the mouth of Miami River; the tide station is 3.8 miles southwest of the mouth of Miami River and 7.5 miles southeast of the station on Miami Canal (a total separation of 11.5 miles, by water). See figure 133 for relative locations of stations.

\section{PHYSICAL CHARACTERISTICS OF STREAM}

The stream-bed elevation of Miami Canal at Water Plant is 10 feet below mean sea level. Just below NW, 36th Street, 2 miles below Water Plant, the canal becomes broader and deeper, but above and below this point the width and depth are fairly uniform. The canal is straight below Water Plant to the point where it joins the river, a distance of 4 miles. In the last 4 miles, the river meanders slightly. See the section on Physical description (p. 418) for details of the character of the canal.

Two complete tide cycles occur every lunar day (24 hours and 50. 4 minutes). The discharge increases during a falling stage and reaches a maximum at about $1 \frac{1}{2}$ hours prior to the minimum stage. The minimum discharge occurs about $1 \frac{1}{2}$ hours before the maximum stage. Figure 128 shows stage hydrographs covering an 8 -day period for the upper and lower stations and for other upstream stations. 


\section{MEASUREMENTS OF DISCHARGE}

Measurements of discharge are made by a complete discharge integration, consisting of one measurement about every hour during the tide cycle. After certain relationships have been developed, the method involves making one measurement during the tide cycle, or, under certain conditions of flow, a pair of measurements, one at the maximum discharge and the other at the minimum discharge.

Measurements made almost every hour during a tide cycle will, when plotted, define a hydrograph having tidal characteristics similar to the stage hydrograph (as shown on fig. 130), except that the maximum and minimum discharges occur about $1 \frac{1}{2}$ hours in advance of the minimum and maximum stages, respectively. Pairs of measurements, one at the peak discharge and one at the trough, will, when averaged, give too low a discharge for the tidal cycle, because they give equal weight to the narrower trough; therefore, a coefficient is applied to the average of the peak and trough discharge measurements to obtain the mean-cycle discharge. The coefficient at Water Plant varies widely, but when the minimum discharge is greater than $200 \mathrm{cfs}$, the coefficient ranges only from 1.00 to 1.12 .

Use is made of the tide ranges at the upper and lower gages as a factor in developing the Tide-correction method. In a uniform channel that is affected by tide, the tide range at any point in the tidal reach is directly proportional to the tide range at any other point; and, in a nonuniform channel, even though there may be variations in the magnitude of the tide with respect to the distance above the tide source, a very definite relationship exists between the tide ranges for any two points in the tidal reach. It follows then, that if the tide ranges for any two points bear a direct relationship to each other, a given change in mean-cycle elevation at one place will produce a change at another place in the tidal reach that is equivalent to the proportion of the tide ranges for the two places. Therefore, if the mean-cycle gage height at the lower gage is corrected to $0 \mathrm{ft}$, the equivalent correction at the upper gage can be determined from the following relationship:

$\frac{\text { Correction to gage height at upper gage }}{\text { Gage height at lower gage }}=\frac{\text { Tide range at upper gage }}{\text { Tide range at lower gage }}$

The graphical determination of the tide-corrected gage height for the upper gage is based on the following steps:

1. Plot the elevations of the crest of the tide at the upper and lower gages for the tide cycle during which the discharge measurements were made, and connect the two points with a straight line. 
2. Plot the elevations of the trough of the tide at the upper and lower gages, and connect the two points with a straight line.

3. Extend both lines to the point of intersection and draw a straight line through the vertex of the triangle and the point of zero elevation at the lower gage.

4. The point of intersection of the line drawn in step 3 with a vertical line drawn through the position of the upper gage gives the tide-corrected gage height. Figure 135 shows the graphical determination of the tide-corrected gage height of one tide cycle for the discharge measurements that were made on October 12, 1942. The data obtained from the recorder charts at Water Plant (upper gage) and Biscayne Bay (lower gage) stations, upon which the graph is based, are as follows:

Feet

Mean gage height at upper gage (point G).........2.64

Mean gage height at lower gage (point $D) \ldots \ldots \ldots \ldots . . .1 .61$

Tide range at upper gage (BF) ..................... 1.08

Tide range at lower gage $(\mathrm{CE}) \ldots \ldots \ldots \ldots \ldots \ldots \ldots \ldots .2 . \ldots \ldots$

On the basis of the four steps mentioned above, the graphical determination of the tide-corrected gage height at the upper gage is the equivalent stage on figure 135 corresponding to 0 at the lower gage (point $G^{\prime}$ ), or $1.87 \mathrm{ft}$.

An arithmetical determination of the tide-corrected gage height for the upper gage, based on the data that were used in plotting the graph on figure 135 , is as follows:

$$
\begin{aligned}
& \frac{G G^{\prime}}{D D^{\prime}}=\frac{E E}{C E} \\
& G G^{\prime}=\frac{1.61 \times 1.08}{2.26} \\
& G G^{\prime}=0.77
\end{aligned}
$$

The tide-corrected gage height at the upper gage (point $c^{\prime}$ ) then becomes,

$$
2.64-0.77 \div 1.87 \mathrm{ft} \text {. }
$$

Note that the graphical and the arithmetical methods both give a tide-corrected gage height of $1.87 \mathrm{ft}$ at the upper gage. The graphical method is presented only for purposes of illustration and is not used in actual practice. 


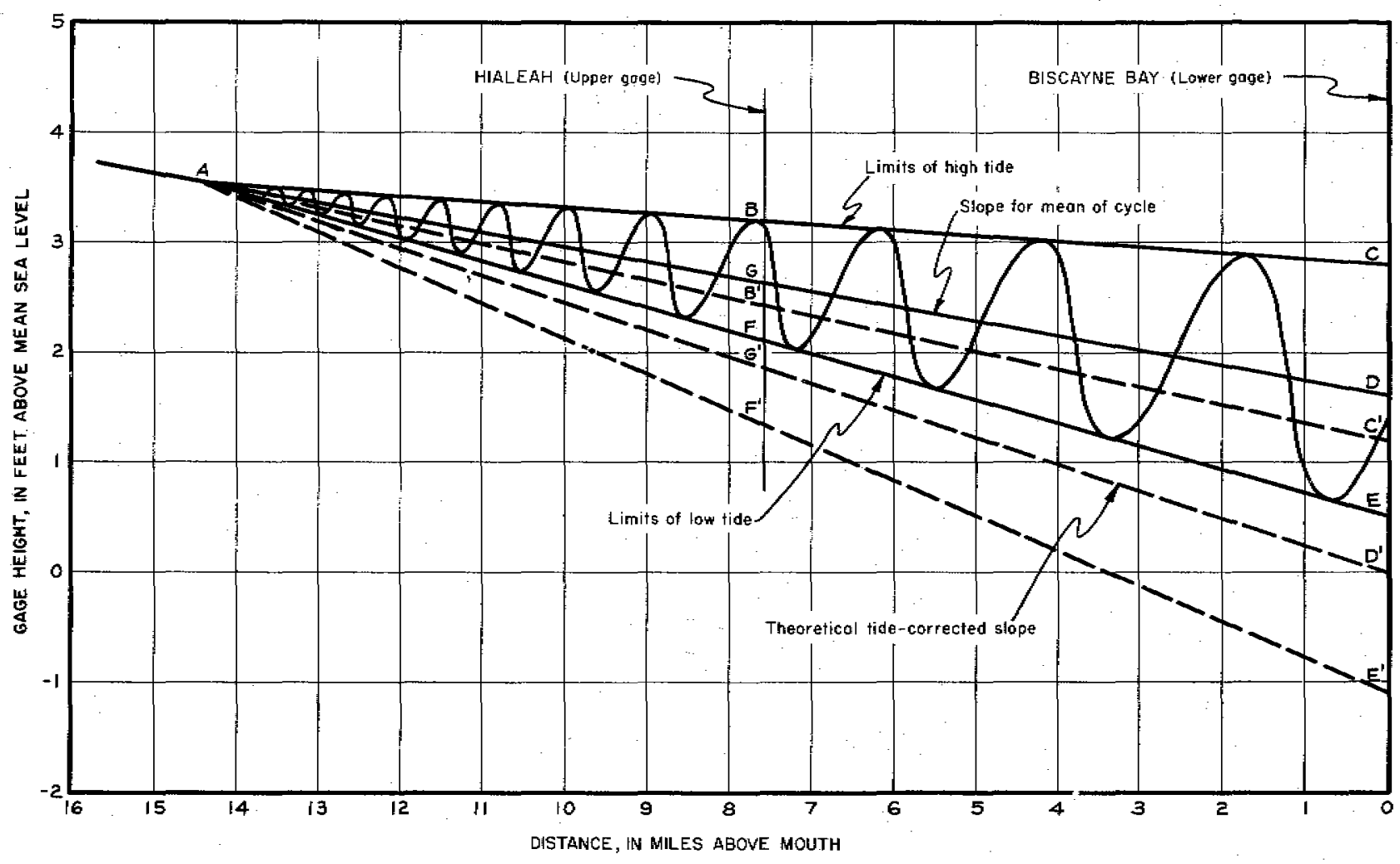

Figure 135. - Graphical determination of the tide-corrected gage height of Miami Canal at Water Plant, Hialeah. 


\section{DEVELOPMENT OF RATING CURVE}

The mean-cycle discharge, as determined from 20 sets of discharge measurements, was plotted against the actual mean-cycle gage height and also against the tide-corrected gage height, as indicated on figure 136. The rating curve shows the relationship between the tide-corrected gage height and the mean tide-cycle dis-

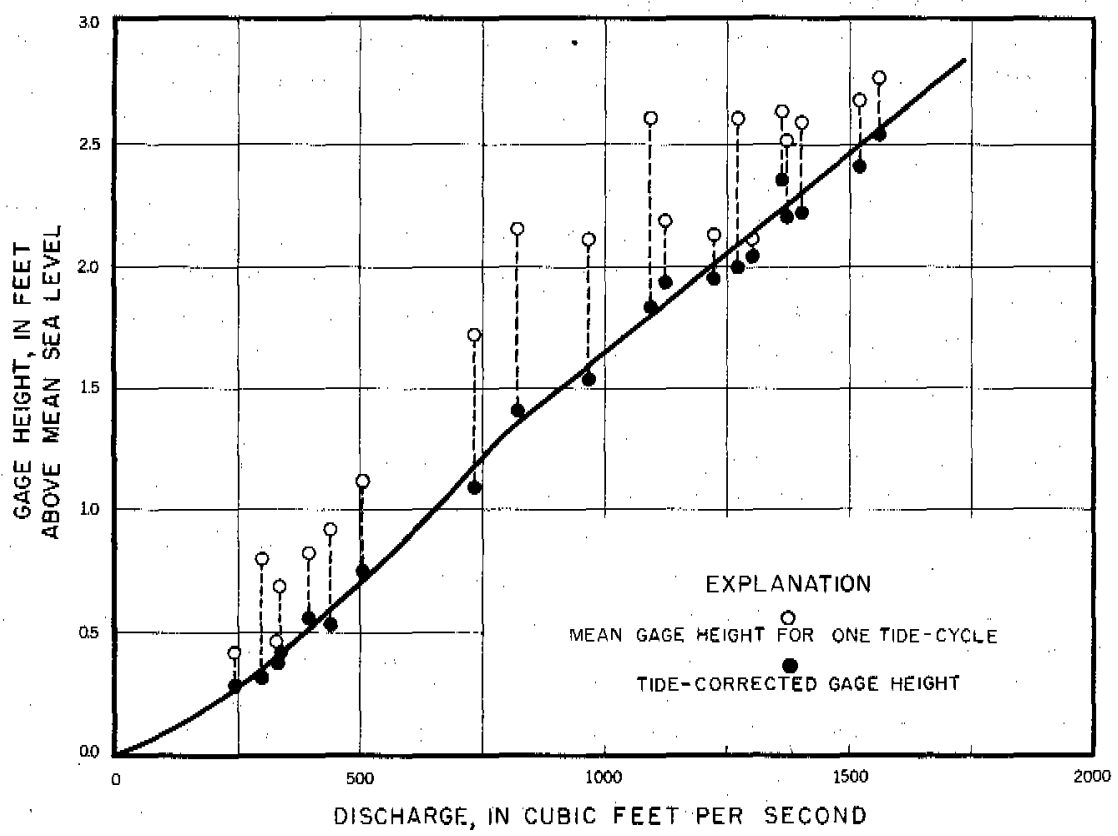

Figure 136. - Graph of relationship between tide-corrected gage height and discharge for Miami Canal at Water Plant, Hialeah.

charge for the upper gage. The discharge plotted against actual mean-cycle gage height shows'a considerable scattering of the plotted points because of variations in channel storage, but the discharge plotted against tide-corrected gage height shows a very close agreement for the numerous measurements. The shape of the rating curve is characteristic of that for a stream having a large initial cross-sectional area at the point of zero flow.

The tide-correction method of rating a tide-affected stream may be used where reverse flows occur during a part of each tide cycle, because the mean discharge for the cycle is the value used in the computation. It is also applicable to a reach of tidal waterway, on which both observation stations are upstream from the mouth of the waterway. The method has been used successfully for computing daily mean discharge of Miami Canal at the Water Plant, Hialeah, since 1940.

A number of comprehensive areal studies were made of Miami Canal from County Line Dam to NW, 36 th Street. These studies included the lower Tamiami Canal drainage area, and they will be 
SPECLAL STUDIES

\section{STORAGE CAPACITY OF RESERVOIR}

In the winter and spring of 1939, drought conditions prevailed, salty water moved far up Miami Canal, and some of the supply wells of the city of Miami became contaminated. Therefore, when drought conditions caused significant inland movement of salty water in March 1942, and when the flow of Miami Canal dropped below 400 cfs (the amount necessary to hold the salty water below NW. 36 th Street), the gates in County Line Dam were opened.

The five gates were opened in the periods March 23-April 7, and April 11-16, 1942. A study was made to evaluate the amount of water released at the dam and to determine how much of the water reached the critical area in Hialeah. It was evident, however, that factors, such as varying tidal backwater, and rainfall, were serious obstacles to an accurate evaluation.

During the period that the gates were open, about 7, 100 acre-ft of water passed downstream (not including basic leakage through the dam). Of this, roughly 3,600 acre-ft, or about half, reached the Hialeah area. This flow increased the discharge at Hialeah to above $400 \mathrm{cfs}$ and caused a small retreat in the salt front. The experiment and associated study came to an abrupt halt April 16, when heavy rainfall drenched the drainage area and thus ended the necessity for augmented flow in Miami Canal for a while.

The experiment started with a stage of $6.6 \mathrm{ft}$ above County Line Dam, which, in view of later drought experiences, was relatively high. At this time, water conditions in the areabelow the dam were moderately low, and the fact that as much as half of the flow reached Hialeah can be attributed to this condition. Most of the remainder of the water released at the dam was lost by outseepage in the 6 -mile reach between the dam and Pennsuco.

When County Line Dam was opened during more serious drought conditions in succeeding years, it was found that very little of the released water reached Hialeah, and it was determined that most of it was dissipated above Pennsuco. The only benefit then was a temporary slow-down of the rate of water-level decline in part of the drainage area.

The experiment at County Line Dam furnished an opportunity to rate the control gates of the dam and to evaluate the quantity of available storage above the dam in the canal channel and in the soils and rocks of the reservoir area. A series of discharge measurements, made while the gates were open, furnished the data evaluated in figure 137. The amount of storage that is shown was computed above an arbitrary base of $2.5 \mathrm{ft}$, with all five gates open. The vertical distance between the two curves of the upper diagram rep- 

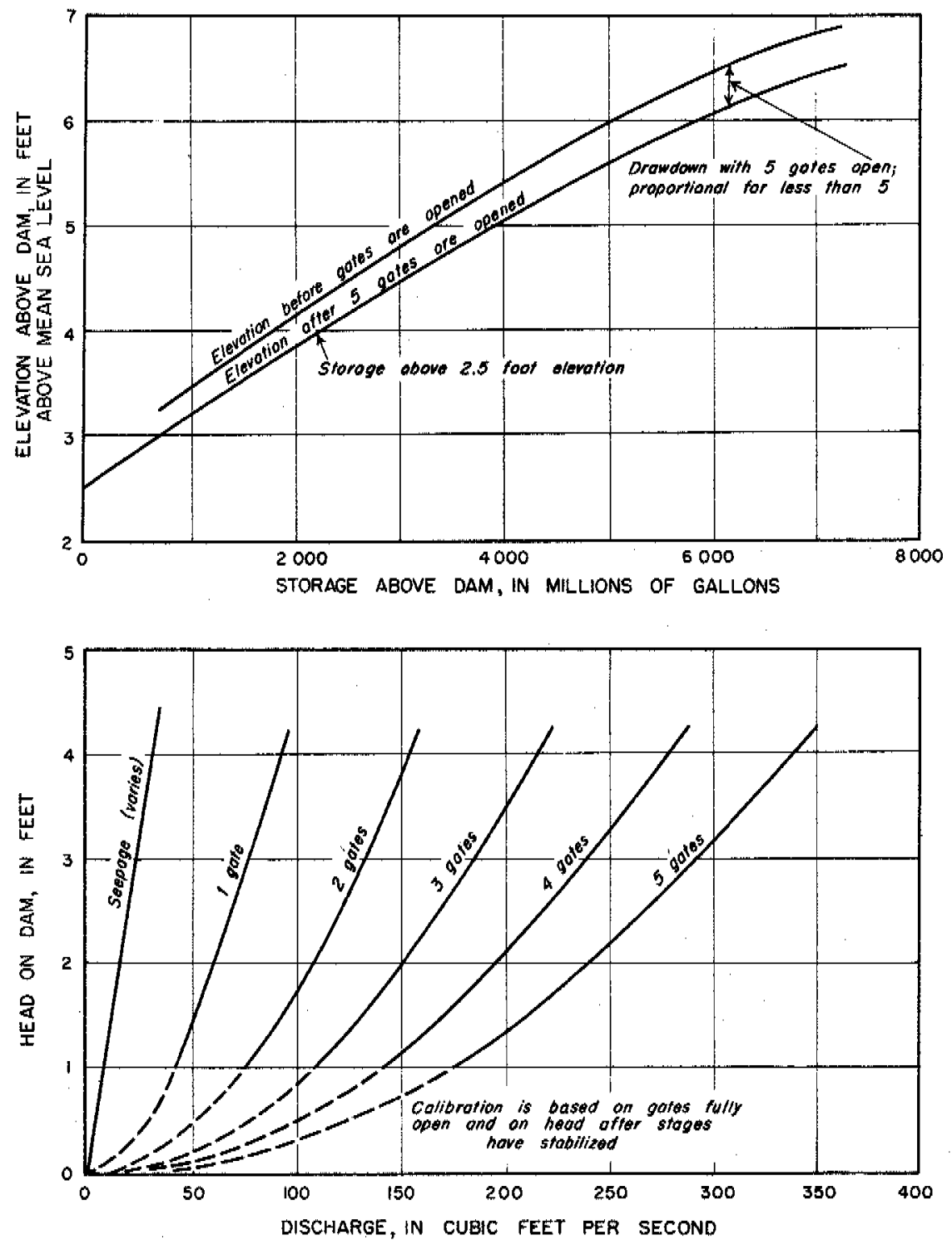

Figure 137. - Graph of available storage in reservoir area of Miami Canal above County Line Dam and rating of control gates in dam.

has stabilized after the gates have been opened. The main achievement of the study was the measurement of the storage magnitude. Prior to this study, an evaluation had been considered to be impossible because of the indeterminate area of the reservoir and the tributary drainage basin.

It will be noted that the storage curve nears the horizontal at a stage of about $7 \mathrm{ft}$, thus indicating a large increase in available storage. Although observations were not made at this higher level, 
the assumption is valid, because the reservoir area becomes inundated at stages of about $7 \mathrm{ft}$. Then the reservoir is replenished from the north and west from the Everglades and is connected with the great shallow river that exists during wet periods. Here, the effect of withdrawals is that of diversions from a large river; while the river exists, the rate of withdrawal from storage is limited only by the capacity of the control gates and of the canal channel above them.

The lower part of figure 137 presents the rating for the gates in County Line Dam. The flow for a given headis that occurring after stages and slopes have stabilized. This adjustment is significant, and to overlook it mey lead to erroneous conclusions as to the discharge that can be expected when only the static head on the dam is considered. In the 1942 study, the static head of $4.1 \mathrm{ft}$ was reduced to $2.2 \mathrm{ft}$ after stabilization with three gates open (the upper pool dropped $0.7 \mathrm{ft}$ and the lower pool rose $1.2 \mathrm{ft}$ ). Again, in a similar study in 1943 , the static head was reduced from 1.50 to $0.66 \mathrm{ft}$ (initial upstream stage was $3.7 \mathrm{ft}$ ) with three gates open (the upper pool dropped $0.41 \mathrm{ft}$ and the lower pool rose $0.53 \mathrm{ft}$ ).

\section{SEEPAGE RATES AND PROFILES IN TIDAL REACHES}

One of the most important factors in the problem of water control in the Miami area is the seepage from, or into, the porous formations through which the canals were excavated. At times, the seepage rate is so high that canal design is an uncertain procedure. Any extension or revision of water-control facilities in the future must take cognizance of this basic problem.

Some of the features of seepage rates along Miami Canal have been discussed under the heading Storage inflow reach. Figure 138 shows graphs of cumulative discharge and seepage rates on two dates, as well as profiles of the stage. The data were obtained during comprehensive studies of the storage inflow and tidal reaches. Stage was recorded as six locations, the main canal discharge was measured at several points, and all tributary flows were measured. The discharge curve is plotted as a continuous line, and the short vertical jumps in the curve show where flow from a tributary enters the canal. The graph of seepage rates was dividedinto three sections, and the breaks in slope occur because the rate was averaged for each section.

The study of December 17, 1941, showed seepage rates of 100 , 40 , and 4.0 cfs per linear mile in the three sections of the reach. Water levels were declining steadily after the fall wet period, and none of the immediate drainage area was inundated. The total flow at Pennsuco was 88 percent of that at Water Plant; most of this flow was runoff from open lands and served no beneficial purpose. 

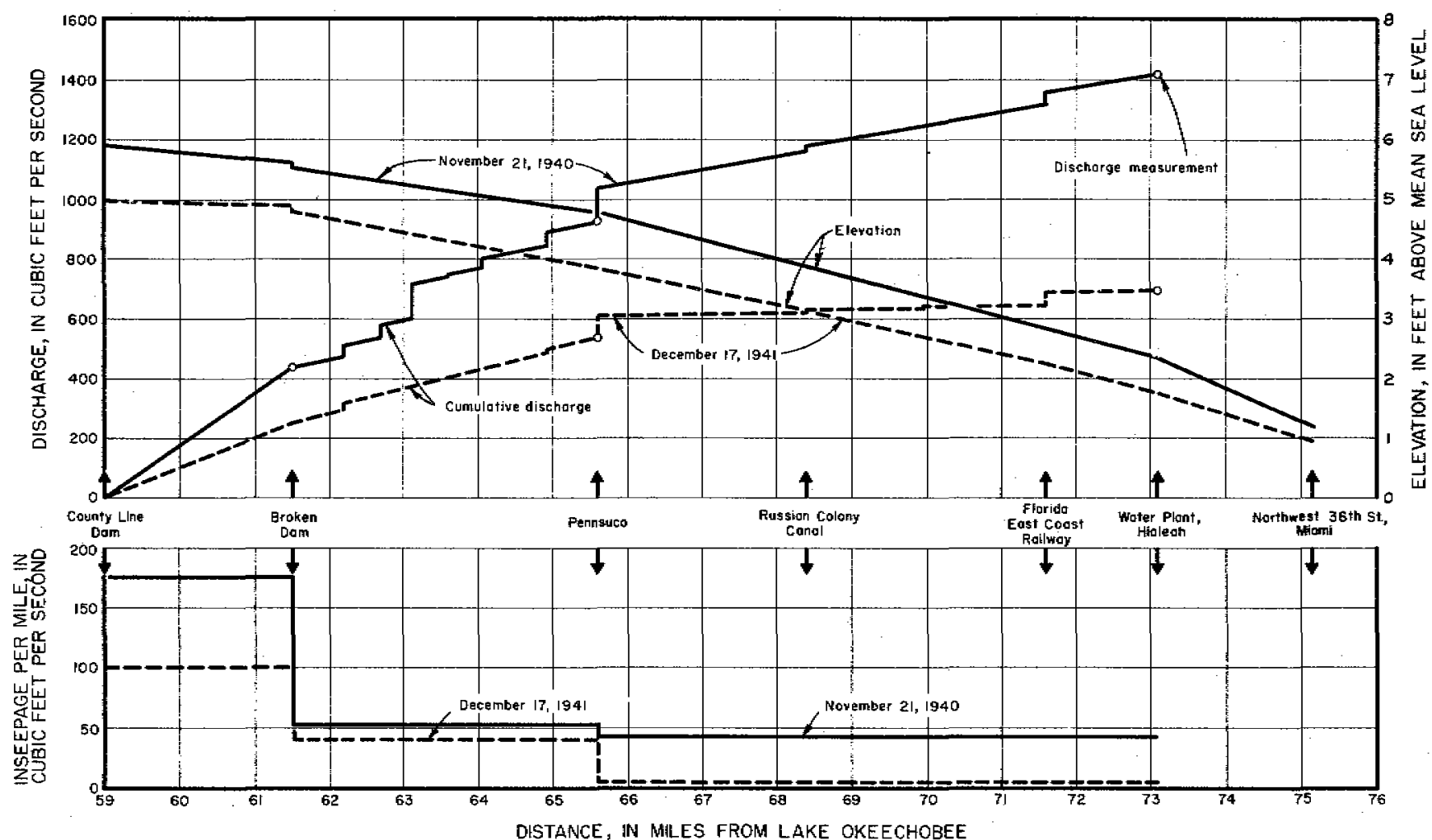

Figure 138. - Graph of cumulative discharge, seepage rates, and profiles of Miami Canal from County Line Dam to Water Plant, Hialeah, on selected dates. 

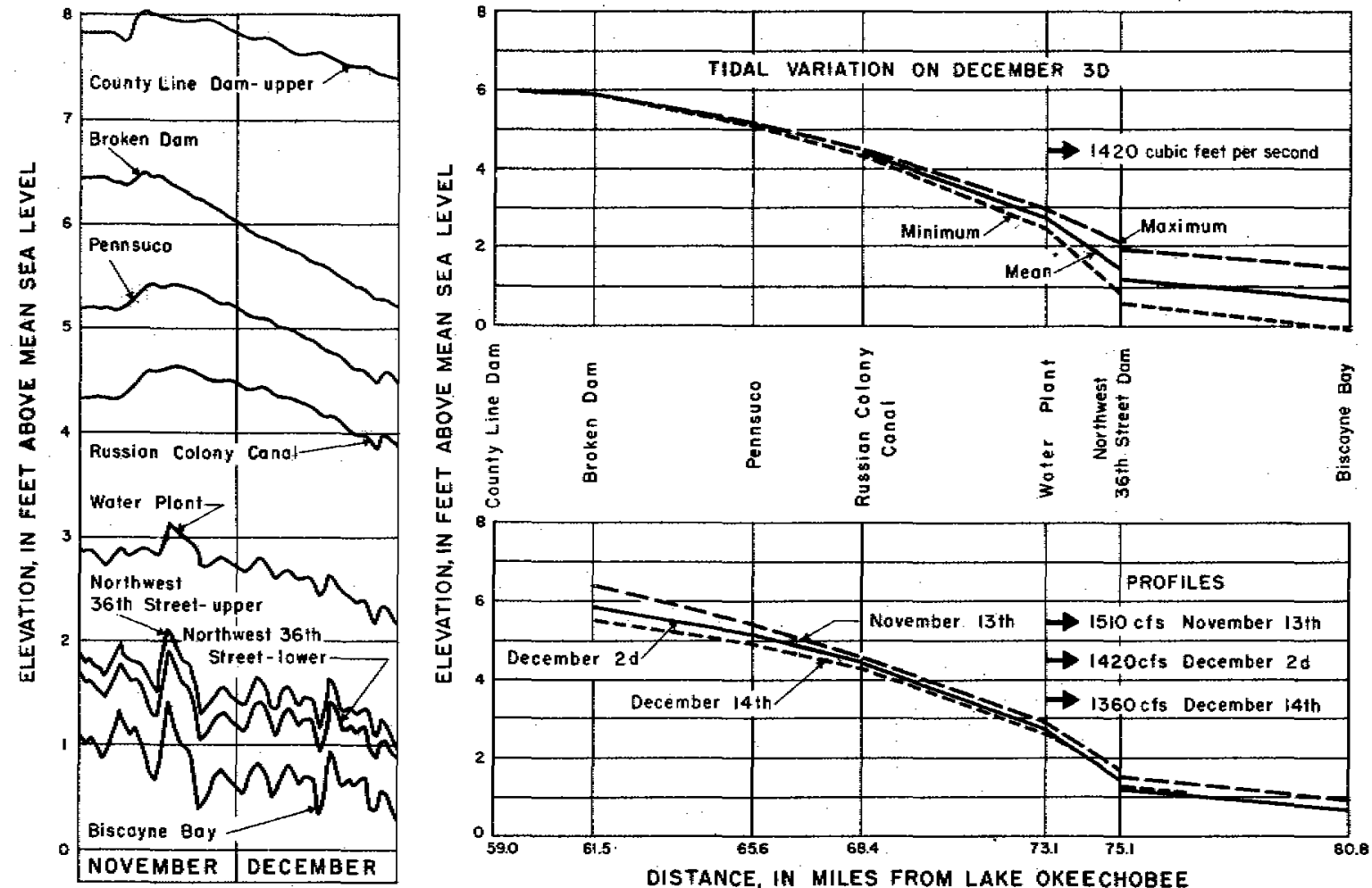

Figure 139. - Graph of stages, tidal fluctuations, and profiles along lower Miami Canal, November and December, 1945. 
Without additional control facilities, this large and useless runoff cannot be reduced.

The study of November 21, 1940, was made during the annual period of principal decline, but water levels generally were about 1 foot higher than during the study in 1941. Conditions were moderately wet, and probably some of the basin was shallowly inundated. The seepage rates were determined at 176,53 , and $43 \mathrm{cfs}$ per linear mile. These values were not the greatest observed during the investigation, but they were large enough to be noteworthy to those concerned with the design of further water-control facilities. It should be noted that 73 percent of the flow at Hialeah originated in the open lands to the west.

\section{BACKWATER EFFECT IN TIDAL REACHES}

A steel-piling dam was in Miami Canal at NW. 36 th Street during most of 1945, and a breach 45 feet wide was opened in the dam in September, when the annual wet period started. The remaining 30 feet of the 75-foot dam caused a visible drop in stage at the dam site. An evaluation was made of the backwater effect of this constriction, with respect to both stage and discharge, at Pennsuco, 9.6 miles upstream.

The data used for the special study were the field observations presented in figure 139.

Fluctuations of Biscayne Bay usually have a considerable effect on the level of Miami Canal in the Hialeah area, and the effect extends to varying distances farther inland, depending upon the amount of runoff and, sometimes, upon the amount of aquatic vegetation in the canal. The series of stage hydrographs for the various locations shows the diminishing inland effect of changes in the bay level and the increasing inland effect of general water conditions. Throughout the 2 months of record (as illustrated), the breach in NW. 36th Street Dam remained the same.

The stage at Pennsuco reached a maximum in mid-November (as it reacted to accumulating rainfall) and then declined steadily to about the end of December. The mean level of Biscayne Bay, in the same period, fluctuated erratically, but this was not reflected at Pennsuco because of the large runoff.

The graph of tidal variation on December 3 shows the diminishing tidal backwater at successive inland locations, The range of tidal backwater in one cycle at the several stations was: 


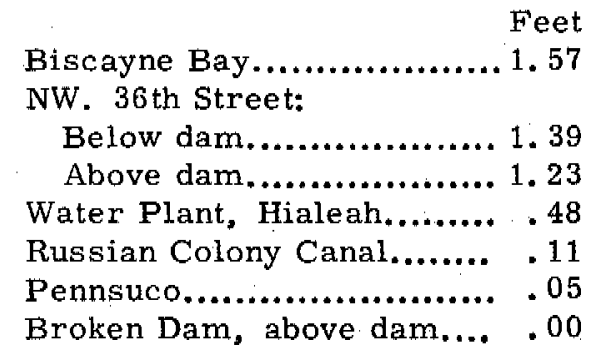

The profiles for the three selected dates, shown in figure 139, demonstrate that the reaches farther inland received a greater amount of drainage in the period than was received by the reaches nearer the coast. This typical relationship is also discussed in the section above on Seepage rates and profiles in tidal reaches. The relatively steep slope that existed between Water Plant and NW. 36 th Street Dam indicates a considerable degree of channel friction, and it was one of the main reasons why tidal backwater was dissipated so rapidly in the reach.

As shown in the stage hydrographs (figs. 117-123), the backwater caused by the remnant of NW. 36 th Street Dam was consistently around $0.20 \mathrm{ft}$. Removal of the dam (thereby reducing the backwater to about $0.08 \mathrm{ft}$ at the site) would probably have had little effect on the stage and discharge at Pennsuco. The several stage records in figure 139 show that sizable variations at NW. 36 th Street Dam caused little stage change at Pennsuco. There would have been a temporary increase in discharge of less than 2.4 pexcent at the site following removal of the dam. As observed in other canals where control changes have been made, this increase would have soon disappeared, and the discharge would have stabilized to the same rate that existed prior to the change.

It is shown from this study that constrictions and loss of head in Miami Canal (and in other waterways) do not affect all parts of the canal to the same degree. Losses do occur at constrictions, but they are not directly proportional to the degree of constriction, and the effect diminishes in an upstream direction.

\section{WELL-FIELD AREA}

As indicated previously, the source of the municipal water supply of Miami is ground water, but the canals near the well fields have very important functions in the supply. One of the most important of these functions is the supply, by seepage, of a considerable volume of recharge to the.wells.

In spite of the probability that the banks and bottoms of the canals have become more or less coated with sediment (and therefore less 
pervious than when first excavated), large outseepage to wells has been observed and evaluated.

In early 1946, as dry winter conditions developed, NW. 36 th Street Dam was closed, and pool conditions existed in the Hialeah-Miami Springs area (site of the municipal well field). Discharge observations on March 28, 1946, showed that water was being lost by outseepage (recharge to the Biscayne aquifer) from Miami Canal between Broken Dam and NW. 36 th Street. The detailed observations made in the vicinity of the well fields are shown in figure 140. A significant reduction of flow occurred in Miami Canal, and flow in most of the secondary canals was toward the well-field area. A ground-water study, made the same date, shows that the cone of depression in the well-field area intercepted the boundary canals. The lowest point of the principal cone was $-1.2 \mathrm{ft}$, as compared with a level of $2.5 \mathrm{ft}$ in Miami Canal.

In the computation of the total amount of water seeping out of the canals in the vicinity of the well fields, it is assumed that most of the $30 \mathrm{cfs}$ in Miami Canal downstream from Country Club Canal passed by leakage and seepage under, around, and through NW. 36 th Street Dam. It is believed that the actual loss at the dam was considerably less than $30 \mathrm{cfs}$, but this figure will cover the unknown quantity of outseepage that did not enter the well field. A summation,

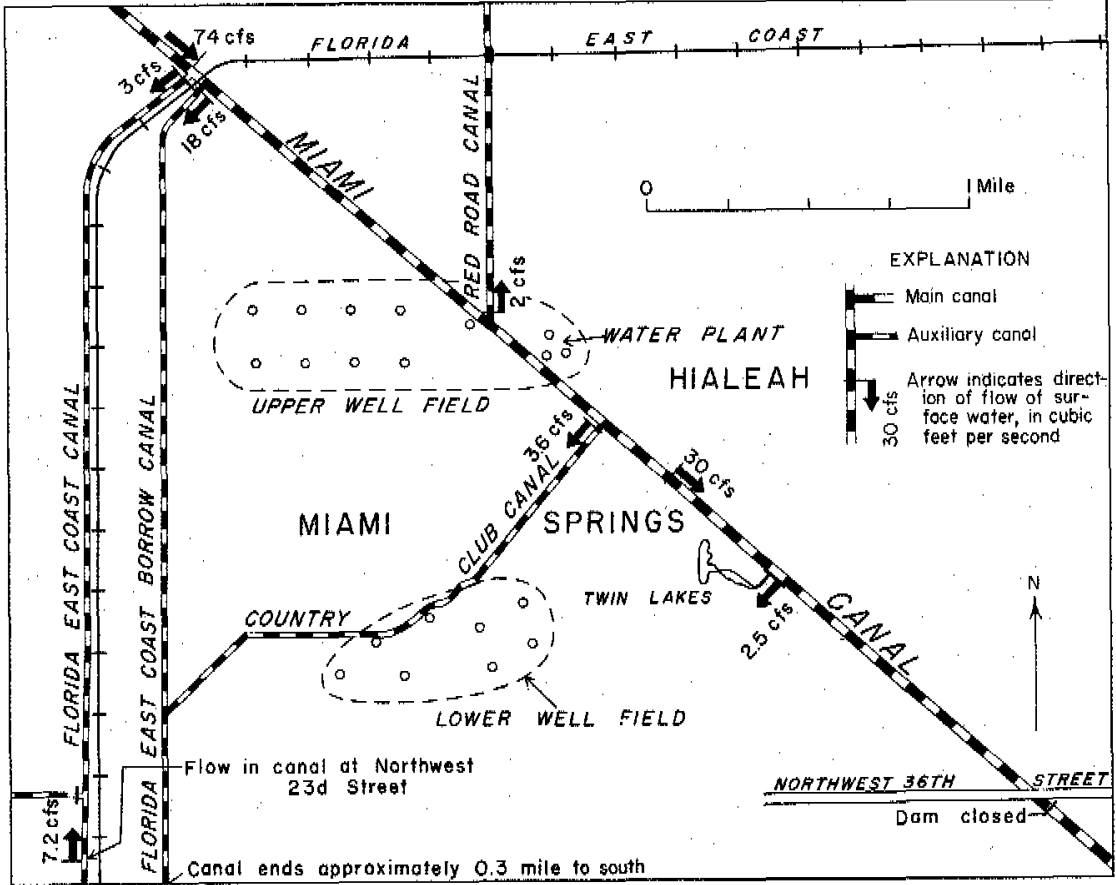

Figure 140. - Map of Miami well-field area showing distribution of canal flow on March 28, 1946. 
then, of all the discharges show that at least $53.7 \mathrm{cfs}$, or $34.7 \mathrm{mgd}$, left the canals by seepage to the well field. This is 78 percent of the 44.4 million gallons that were pumped from the wells on that date.

The study reported above is only for one condition. In flood periods it is likely that the canals contribute relatively little water to the well field. The amount of contribution during drought periods probably is greater than the $\mathbf{7 8}$ percent determined for March 28, 1946.

TIDAL STORAGE OF MIAMI RIVER

In June 1946, the Geological Survey started a study of the tidal storage of Miami River to evaluate the effect of a proposed lock and dam just above NW. 27th Avenue, at the head of the river proper. A study was made on June 28, 1946, at the time of spring tides (when the tidal range was the greatest in the month). The principal data obtained are shown in figure 141 .

The graphs of discharge demonstrate some of the principles of tidal flow developed in the sections on Tidal characteristics in sealevel canals and Tidal fluctuations in Miami Canal. The basic graphs are in the right half of figure 141. The mean discharges at NW. 27th Avenue and SE. 2nd Avenue were nearly the same, indicating relatively small ground-water inflow in the 3.8 miles of river channel. Discharge of Miami Canal at Water Plant was 309 cfs, and that of Tamiami Canal at NW. South River Drive (close to mouth) was about $340 \mathrm{cfs}$; which accounts for most of the $672 \mathrm{cfs}$ measured at NW. 27 th Avenue.

The shaded area on the discharge graphs represents the volume of tidal storage at the two locations (different parts of the tide cycle were used to avoid conflicting shading). Although the mean discharges were about the same, the tidal storage at the upper station (NW. 27th Avenue) was almost two-thirds that of the storage at the lower station, thus showing that the greater volume of tidal storage was above NW. 27 th Avenue.

The same discharge curves are repeated in the left half of figure 141. The shaded area between them represents the volume of tidal storage in the channel and banks between the two locations and is identified as storage or release. Each part of this shaded area also represents the volume of water that would flow in the appropriate direction past $\mathrm{SE}$. 2nd Avenue during one tide cycle if a dam were to cut off all flow (including fresh-water runoff) at NW. 27th Avenue. The net effect is plotted below the other curves. 

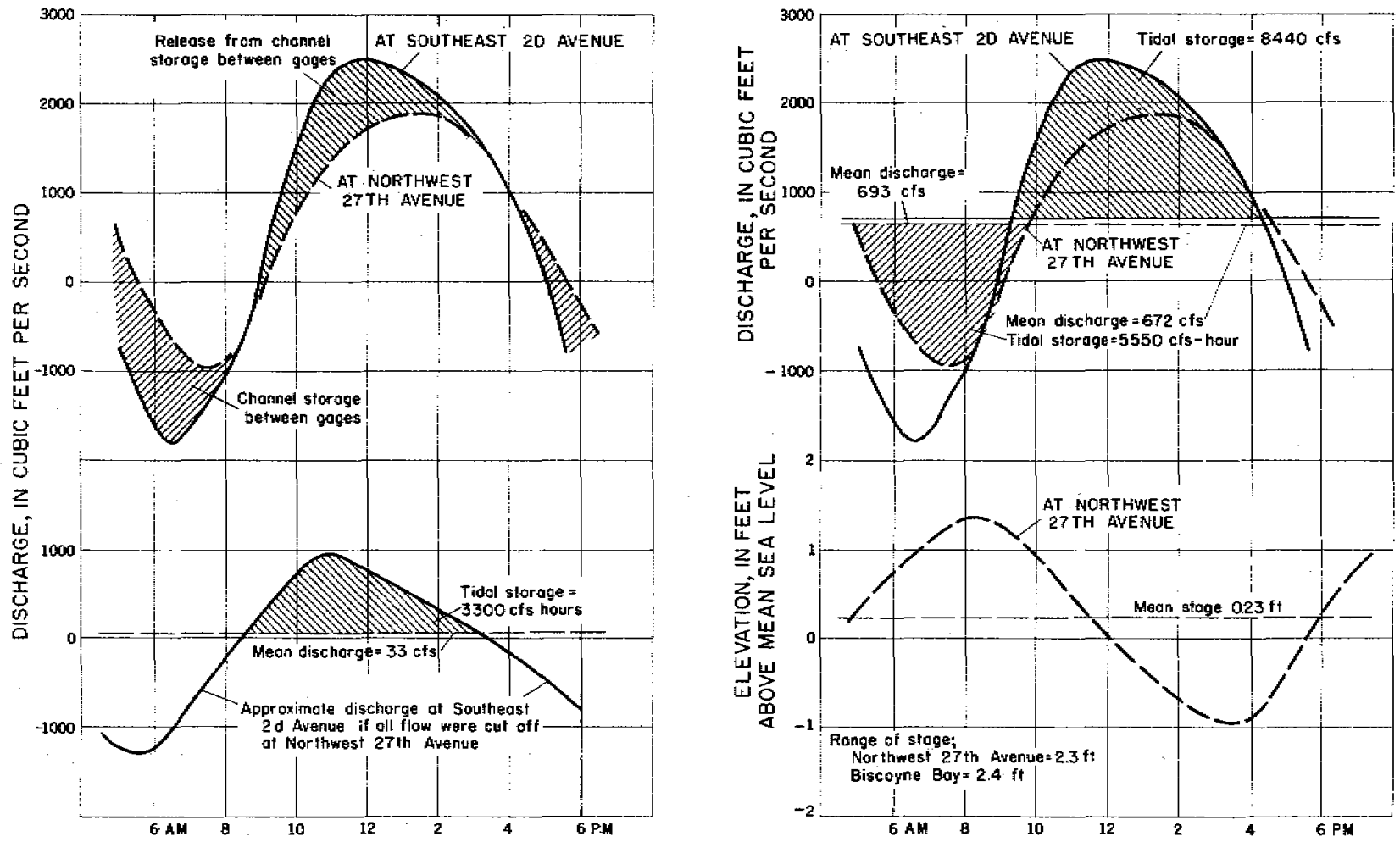

Figure 141: - Graph of tidal variation in stage and discharge at two locations on Miami River. June 28, 1946. 
The computed curve furnishes a good indication of results from damming the river under conditions similar to those of June 28, 1946. The computed curve has a tidal storage that is 39 percent that of the observed storage at SE. 2nd Avenue. The maximum computed discharge is about 40 percent of that of the observed discharge, therefore it can reasonably be expected that maximum current velocities in Miami River would also be reduced in about the same degree. Of course, in wet periods, large fresh-water runoff would cause swifter currents.

The net storage and net mean discharges of the study do not quite balance (a requirement of hydraulic theory), but these minor differences may be ascribed to the errors inherent in the type of observations and their development. Of the basic phenomena of reversing tidal discharge that were observed and measured, possibly the most interesting was the inland progression of the points of reversal. The reader is referred to page 444 for a more detailed discussion. The reversal occurred at three locations, as follows:

\section{Location}

Miami River at SE. 2nd Avenue... Miami River at NW. 27th Avenue. Miami Canal at NW. 36 th Street..
First teversal; positive to negative (a mol)

$4: 42$

$5: 35$

$6: 30$
Second reversal; negative to positive (a m.)

The first reversal of flow took 1.8 hours to travel from the bay to a point 5.5 miles inland, but the second reversal took only 0.4 hour to travel the same distance. This supports the theory presented earlier to the effect that the faster-moving second reversal probably overtakes the first reversal.

\section{TAMIAMI CANAL}

Although it cannot properly be called an arterial canal, part of Tamiami Canal is important to the water events of the lower Everglades. It extends generally east-west across the State and does not connect with Lake Okeechobee. The more important part of Tamiami Canal is the shorter section east of Dade-Broward Levee that drains the western environs of Miami and is closely associated with the water problems of lower Miami Canal. The least important part (hydrologically) is the long reach across the Everglades and into Big Cypress Swamp. Much of the data on Miami Canal can also be applied to the eastern part of Tamiami Canal, including the tidal reaches. The principal features of the drainage area are shown in plate 14. 


\section{PHYsical DEScRaption}

Tamiami Canal is not a drainage entity, because the greater part consists of a borrow pit that was dug to provide fill for the famous Tamiami Trail (U. S. Highway 41). It operates as a typical Everglades canal between its mouth at Miami Canal and Dade-Broward Levee, about 14 miles upstream. The long western part was excavated across the tip of the State, crosses the nominal height of land near the Dade-Collier County line and extends westward along the Trail.

For this report, it will be assumed that the western part of Tamiami Canal begins at Monroe, which is located about 15 miles west of the Dade-Collier County Line. Here, the old grade of Tamiami Trail rejoins the newer alinement and a sizable channel extends southward from the canal to one of the bays on the Gulf of Mexico (Chokoloskee Bay). Tamiami Canal actually continues toward the west, but no observations of flow were made west of Monroe.

From Monroe eastward to Dade-Broward Levee (a 40-mile reach), Tamiami Canal is unique. It is a continuous channel, except in drought periods, but it acts more in the capacity of a collector and distributor. The parallel highway fill of Tamiami Trail south of the canal has 64 bridges in this 40 -mile stretch; these bridges range from 45 to $90 \mathrm{ft}$ in length. The bridges cross shallow stub channels that connect with the canal and extend toward the south for about $100 \mathrm{ft}$ to the edge of the highway right-of-way; however, about a half dozen channels continue farther south.

Tamiami Canal extends 11.5 miles eastward from Monroe to a bend that swings southeastward; then it continues 8 miles more to 40-Mile Bend, where it swings back to an easterly course. This route runs through a sparse cypress area that marks the edge of Big Cypress Swamp. In the vicinity of the bend east of Monroe, the canal cuts through the highest land along its route-elevation $8 \mathrm{ft}$ above mean sea level. The divide is so subtle that it is not noticeable, but contrary to the frequent experience in the Everglades, the water summit in the canal has always been close to it,

East of 40-Mile Bend, which is a principal landmark, the soil is predominantly muck that has burned and oxidized, thus expos ing the underlying eroded rock surface in many areas. From $40-$ Mile Bend to east of Dade-Broward Levee, the terrain is the typical sawgrass plain of the Everglades, with few trees to relieve the flat horizon (see fig. 27). The numerous stub laterals are the principal feature of the canal in this reach.

About 22 miles east of 40-Mile Bend, Krome Road Canal (another borrow ditch) connects from the south and marks the edge of very 
sparse developments (see pl. 15). A branch extends 2.5 miles northward to North Line Canal, an unmaintained shallow canal that is parallel with Tamiami Canal and extends about 12 miles both to the east and to the west from the line of Krome Road Canal.

The southern end of Dade-Broward Levee extends across Tamiami Canal at a point 2 miles east of Krome Road and 13.6 miles above the mouth, thus marking the boundary between the borrow-ditch section and the working section of Tamiami Canal. The levee extends northward about 8 miles to Pennsuco Lateral and continues 5. 6 miles farther to Miami Canal and County Line Dam. Until 1946, pipe culverts (with inverts at an elevation of $6 \mathrm{ft}$ above mean sea level) provided drainage through the levee at higher stages; these culverts have been removed and replaced with solid fill. The borrow pit along the east side of the levee connects with Tamiami Canal and acts as a lateral.

Krome Road and Dade-Broward Levee mark the western limit of a somewhat complicated system of interconnected waterways, which extends to the edge of Miami. Until 1946, little or no maintenance work was done on the canals, but since then, the larger canals have been maintained. Snapper Creek Canal intersects Tamiami Canal 4 miles east of the levee at the location known as Sweetwater. The south branch of Snapper.Creek Canal extends for 12 miles toward the south and southeast to Biscayne Bay at the southeastern corner of Coral Gables. The north branch connects with North Line Canal about 2.5 miles to the north, and a separate section continues 5 miles farther north to Russian Colony Canal (a tributary of Miami Canal), with a break about 2 miles north of North Line Canal.

About 4 miles east of the connection with Snapper Creek Canal and 5.6 miles above the mouth, Coral Gables Canal connects with Tamiami Canal from the south. Coral Gables Canal meanders 7 miles in a southeasterly direction to Biscayne Bay and lies mostly within the city of Coral Gables.

Just east of Coral Gables Canal, Tamiami Canal turns toward the northeast, and about half a mile below the turn, North Line Canal and F. E. C. Canal enter from the north. Comfort Canal branches off toward the east 2.3 miles above the mouth, and the entrance to Seminole Lake (a deep rockpit) connects from the west 0.2 mile farther downstream. (See pl. 22.) The mouth of Tamiami Canal is at Miami Canal 0.3 mile above NW. 27 th Avenue, Miami.

The land through which Tamiami Canal was excavated slopes toward the southwest and south in the western reaches (see pls. 10 and 11). East of 40-Mile Bend, the land slopes mainly toward the southeast. The canal is accessible by roads along, or close to, the south bank (except for several miles of the lower reaches, near Miami). 
The following tabulation lists the principal features along Tamiami Canal, with cumulative mileages from the mouth at Miami Canal.

Mouth, Miami Canal.

Bridge, NW. South River Drive .1

Bridge, Le Jeune Road (NW. 42nd Avenue)...................... 1.3 Seminole Lake entrance.

Bridge, Red Road (57th Avenue), gaging station................ Bridge, F. E. C. Railway....................................... Bridge, Seaboard Railroad, F. E. C. Canal.................... North Line Canal....................................................... Coral Gables Canal.

Krome Road Canal (north and south), State Highway 27

(Krome Road).... 13.6

Lateral south (bridge 50 ), gage.

Lateral south (bridge 45), gage............................... 24.8

Lateral south (bridge 32 ), gage................................... 34.6 40-Mile Bend, gage, meteorological station.................... 37.2 Dade-Collier County line........................................... 41.4 Slough north and south (bridge 115 ), gage....................... 43.4

Bend. 45.2

Slough north and south (bridge 105), gage....................... Monroe, lateral south (bridge 96 ), gage......................... Bridge, State Highway 29 (formerly 164).

\section{RECORDS AVALABLE}

[* Record continued after period of this investigation. ** Slightly lower stages probably occurred June 12-20, 1945, when both gages were reported to be dry]

\section{0-Mile Bend}

Stage: July 1, 1940, to Dec. 31, 1946*; gage read once daily; plotted in figures 142 and 143.

Maximum observed: $8.95 \mathrm{ft}$, on Sept. $22,1945$.

Minimum observed: $4.57 \mathrm{ft}$, on May 3, 4, 1946.

Krome Road

Stage: Nov. 10, 1939, to July 8, 1942; gage read twice daily; daily stage plotted in figure 142 . 
Maximum observed: $7.72 \mathrm{ft}$, on Sept. 30,1940 .

Minimum observed: $4.49 \mathrm{ft}$, on May 28, 1940.

(Compare extremes with those for different period at Dade-

Broward Levee where stages are essentially the same.) Dade-Broward Levee

Stage, west of levee: July 28, 1942, to Jan. 17, 1946; gage read once daily; plotted in figures 142 and 143 (continues where record at Krome Road stops).

Maximum observed: 7.65 ft, on Aug. 9, 1942.

Minimum observed: $1.46 \mathrm{ft}$, on June $11,1945$.

(Compare with extremes at Krome Road.)

Stage, east of levee: July 28, 1942, to Jan. 17, 1946; gage read once daily.

Maximum observed: $7.14 \mathrm{ft}$, on Oct. 10, 11, 1943 .

Minimum observed: $1.42 \mathrm{ft}$, on June 21, 1945.

Outflow to south

Discharge, through 63 connecting laterals in 43 -mile reach from Monroe to Dade-Broward Levee: Nov. 1, 1939, to Dec. 31, 1946 ; daily mean, plotted in figures 142 and 143 ; monthly and annual runoff listed in tables 49 and 50 .

Maximum daily mean: 2, 140 cfs, on Sept. 18, 1945.

No flow, for extended periods in drought years.

Coral Gables, near, (footbridge 0.5 mile west of Coral Gables

Canal)

Stage: Mar. 19, 1940, to June 30, 1943; gage read twice daily; daily mean of readings plotted in figures 142 and 143 .

Maximum observed; $6.05 \mathrm{ft}$, on Sept. 21,1940 .

Minimum observed: $1.84 \mathrm{ft}$, on April 18, 1943.

Discharge: Jan. 16, 1940 to June 30, 1943; daily mean, plotted in table 51.

Maximum daily mean: $346 \mathrm{cfs}$, on Sept. $30,1.942$.

Minimum daily mean: 3.0 cfs, April 7-18, 1943.

Red Road, Miami

Stage: Mar. 9, 1940, to Dec. 31, 1946*; continuous recorder graph; daily mean plotted in figures 142 and 143 .

Maximum: $3.84 \mathrm{ft}$, on Sept. 15, 1945.

Minimum: $-0.52 \mathrm{ft}$, on Mar. 22, 1945.

Minimum daily (tidal): $0.06 \mathrm{ft}$, on Mar. 22, 1945.

Discharge: Jan. 25, 1940, to June 30, 1943; daily mean; plotted in figures 142 and 143; monthly and annual runoff listed in table 52 .

Maximum daily mean: 526 efs, on Sept. 23, 1940. No flow, April 4 to May 22, 1943, (canal flow cut off by dam 1.5 miles upstream).

Miscellaneous

Stage: at about 12 locations from Monroe to Coral Gables Canal in connection with 203 discharge measurements of the outflow to the south, 1939-46*.

Discharge: at 63 laterals from Monroe to Dade-Broward Levee, in connection with 203 discharge measurements of the outflow 
to the south, 1939-46*; at intermediate locations on the main canal and at many laterals, 1940-46*, occasional, usually in connection with special studies; see plates 15 and 16 for types of observations.
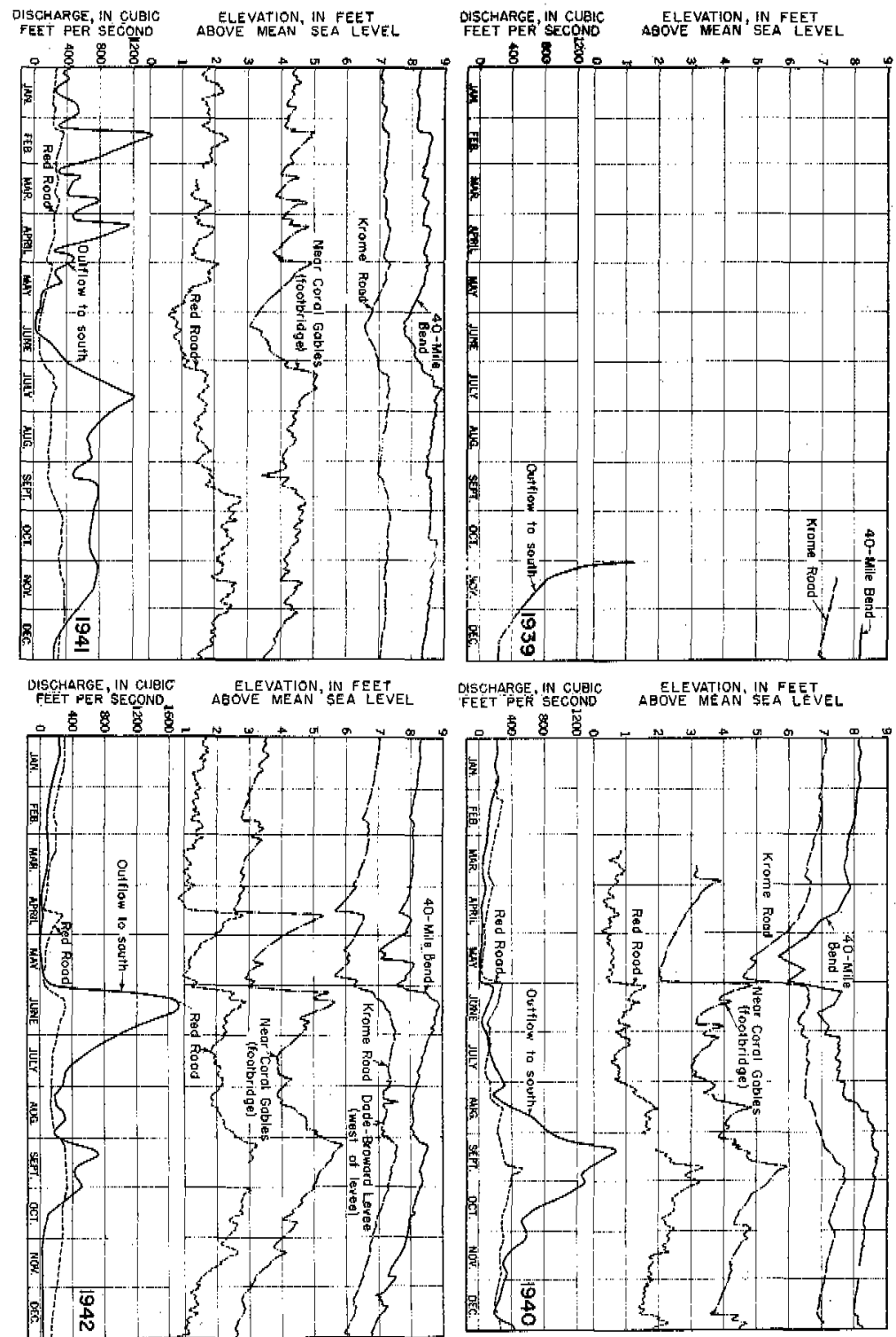

Figure 142. - Graphs of stage and discharge of Tamiami Canal, 1939-42. 

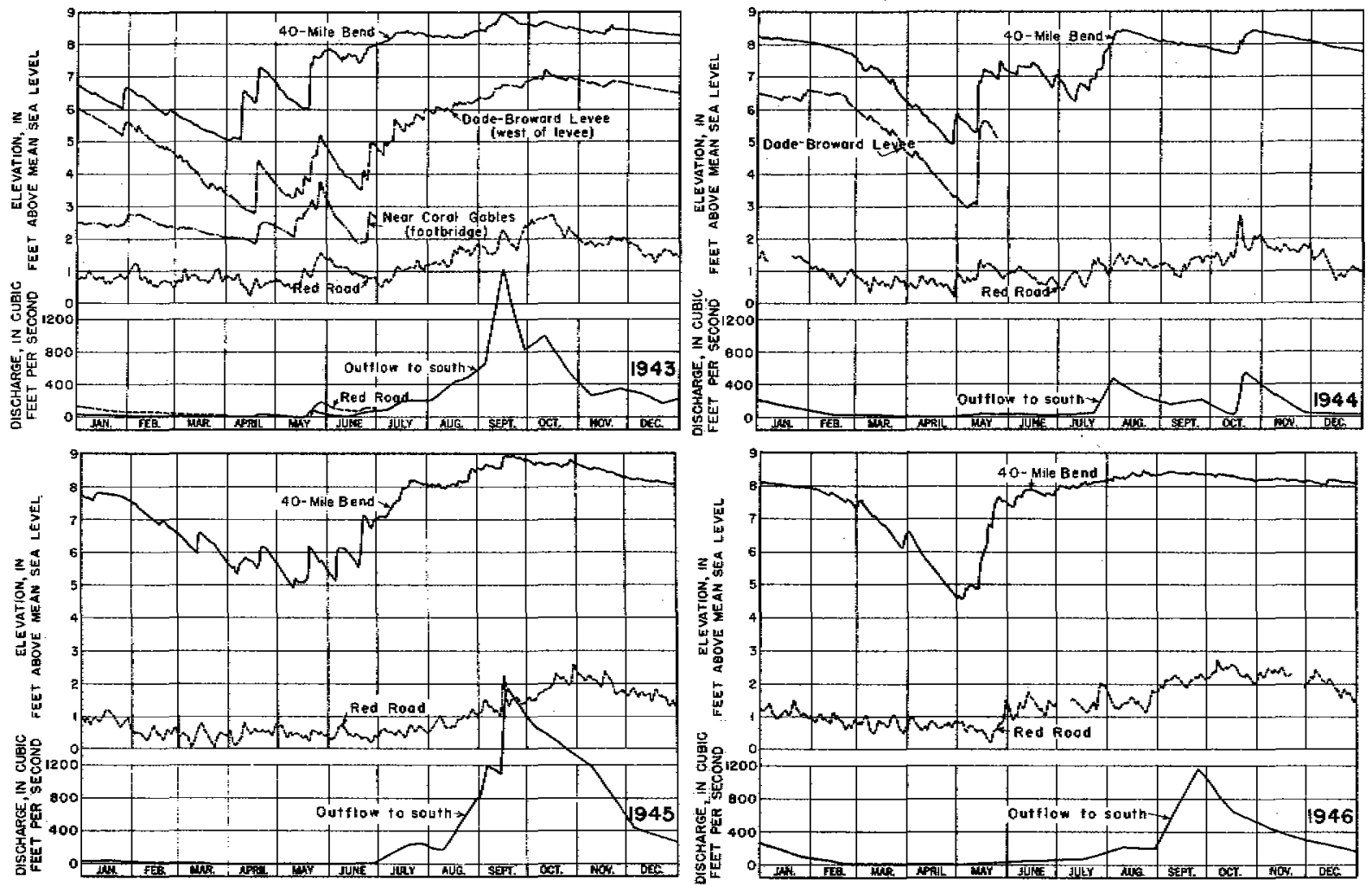

Figure 143. - Grapłs of stage and discharge of Tamiami Canal, 1943-46. 
Table 49.- Runnoff of Tamiani Canal outlets west of Miani

[Between Monroe and the Dade-Broward Levee, unit, 1, 000 acre-feet]

\begin{tabular}{|c|c|c|c|c|c|c|c|c|c|c|c|c|c|}
\hline Year & Jan. & Feb. & Mar. & Apr. & May & June & July & Aug. & Sept. & Oct. & Nov. & Dec. & Annual \\
\hline $\begin{array}{l}1939 \\
1940 \\
1941 \\
1942 \\
1943 \\
1944 \\
1945 \\
1946\end{array}$ & $\begin{array}{r}13.7 \\
25.4 \\
12.9 \\
1.4 \\
9.1 \\
2.1 \\
10.1\end{array}$ & $\begin{array}{r}8.9 \\
48.9 \\
5.7 \\
2.7 \\
2.6 \\
2.9 \\
2.0\end{array}$ & $\begin{array}{r}4.8 \\
31.2 \\
5.7 \\
.5 \\
1.0 \\
.2 \\
1.1\end{array}$ & $\begin{array}{r}3.1 \\
38.5 \\
2.0 \\
.8 \\
.3 \\
(2) \\
.5\end{array}$ & $\begin{array}{r}1.8 \\
12.3 \\
2.2 \\
1.7 \\
1.5 \\
\text { (a) } \\
.8\end{array}$ & $\begin{array}{r}5.9 \\
9.5 \\
80.2 \\
2.2 \\
1.7 \\
.2 \\
2.9\end{array}$ & $\begin{array}{r}10.7 \\
54.8 \\
31.1 \\
10.0 \\
5.7 \\
11.1 \\
5.9\end{array}$ & $\begin{array}{l}29.5 \\
45.1 \\
14.8 \\
24.6 \\
18.8 \\
26.1 \\
12.2\end{array}$ & $\begin{array}{l}80.5 \\
41.1 \\
31.1 \\
69.6 \\
10.8 \\
92.6 \\
47.2\end{array}$ & $\begin{array}{l}50.8 \\
43.7 \\
11.7 \\
47.0 \\
15.4 \\
94.2 \\
44.1\end{array}$ & $\begin{array}{r}50.6 \\
24.0 \\
42.0 \\
2.0 \\
18.8 \\
11.1 \\
58.1 \\
23.9\end{array}$ & $\begin{array}{r}19.2 \\
17.2 \\
20.7 \\
1.9 \\
14.6 \\
2.1 \\
22.9 \\
14.7\end{array}$ & $\begin{array}{r}250.2 \\
413.2 \\
201.3 \\
191.9 \\
80.1 \\
308.4 \\
165.4\end{array}$ \\
\hline
\end{tabular}

aNegligible.

Table 50.-Anmual summary of discharges, in cubic feet per second, for gasing stations on Tamiami Caned

\begin{tabular}{|c|c|c|c|c|c|c|c|c|c|}
\hline \multirow{2}{*}{$\begin{array}{l}\text { Calendar } \\
\text { year }\end{array}$} & \multicolumn{3}{|c|}{ At Red Road } & \multicolumn{3}{|c|}{ At Coral Gables } & \multicolumn{3}{|c|}{ Outflow to south } \\
\hline & Maximum ${ }^{a}$ & Minimum $^{a}$ & Average $b$ & Maximum $^{c}$ & Minimum ${ }^{c}$ & Average $^{b}$ & Maximum ${ }^{d}$ & Minimum $^{d}$ & Average $^{b}$ \\
\hline 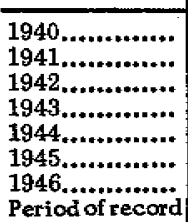 & 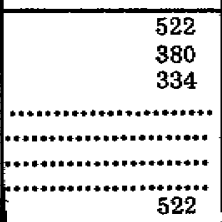 & 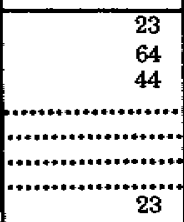 & 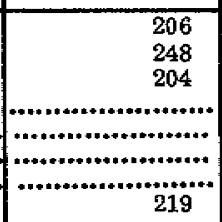 & 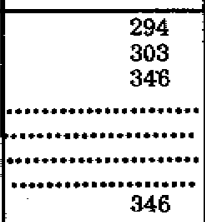 & 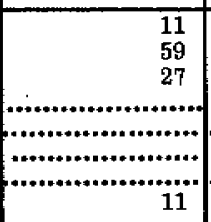 & 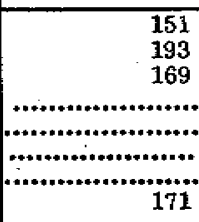 & $\begin{array}{r}1,670 \\
1,430 \\
1,730 \\
1,820 \\
541 \\
2,140 \\
1,160 \\
2,140\end{array}$ & $\begin{array}{l}13 \\
30 \\
4 \\
2.5 \\
. .8 \\
0.5 \\
0\end{array}$ & $\begin{array}{l}345 \\
571 \\
278 \\
265 \\
110 \\
426 \\
229 \\
318\end{array}$ \\
\hline
\end{tabular}

andicates highest value for maximum and lowest value for minimum obtained from means of pairs of discharge measurements usually made weekly and corrected to represent a verage for tidal cycle and approximate average for day. and 143 .

From discharge measurements made about weekly, each of which represents the approximate discharge for that day,

from discharge measurements made about weekly 1940-1942, and semimonthly 1943-1946, each of which represents the approximate discharge for that day. 
Table 51._Runoff of Tamiami Canal near Coral Gables

[Unit, 1,000 acre-feet]

\begin{tabular}{|c|c|c|c|c|c|c|c|c|c|c|c|c|c|}
\hline Year & Jan. & Feb. & Mar. & Apr. & May & June & July & Aug. & Sept. & Oct. & Nov. & Dec. & Annual \\
\hline \multirow{2}{*}{$\begin{array}{l}1940 \\
1941 \\
1942 \\
1943\end{array}$} & \multirow{2}{*}{$\begin{array}{r}14.8 \\
13.6 \\
5.4\end{array}$} & \multirow{2}{*}{$\begin{array}{r}10.8 \\
12.5 \\
8.1 \\
2.3\end{array}$} & \multirow{2}{*}{$\begin{array}{r}7.1 \\
11.8 \\
6.2 \\
.9\end{array}$} & \multirow{2}{*}{$\begin{array}{r}3.3 \\
8.6 \\
5.0 \\
.7\end{array}$} & \multirow{2}{*}{$\begin{array}{l}1.4 \\
7.8 \\
2.7 \\
2.9\end{array}$} & \multirow{2}{*}{$\begin{array}{l}5.1 \\
4.2 \\
7.4 \\
4.1\end{array}$} & $\begin{array}{r}4.1 \\
10.3 \\
6.7 \\
\end{array}$ & $\begin{array}{l}8.4 \\
9.9 \\
9.6 \\
\end{array}$ & $\begin{array}{l}14.7 \\
12.2 \\
18.6\end{array}$ & $\begin{array}{l}16.1 \\
16.8 \\
19.0 \\
\end{array}$ & $\begin{array}{l}14.8 \\
15.5 \\
15.7 \\
\end{array}$ & $\begin{array}{l}13.2 \\
15.1 \\
10.1\end{array}$ & $\begin{array}{r}139.5 \\
122.7\end{array}$ \\
\hline & & & & & & & ant. & itinue & - & & & & $\ldots \ldots+\ldots$ \\
\hline
\end{tabular}

Table 52.-Runoff of Tamiami Canal at Red Raad, Miami

fUnit, 1,000 acre-feet]

\begin{tabular}{|c|c|c|c|c|c|c|c|c|c|c|c|c|c|}
\hline Year & Jan. & Feb. & Mar. & Apr. & May & June & July & Aug. & Sept. & Oct. & Nor. & Dec. & Annual \\
\hline $\begin{array}{l}1940 \\
1941 \\
1942\end{array}$ & \multirow{2}{*}{$\begin{array}{r}18.1 \\
15.6 \\
17.7 \\
6.0\end{array}$} & \multirow{2}{*}{$\begin{array}{r}13.9 \\
16.6 \\
10.9 \\
3.4\end{array}$} & \multirow{2}{*}{$\begin{array}{r}9.9 \\
17.2 \\
9.4 \\
1.6\end{array}$} & \multirow{2}{*}{$\begin{array}{r}6.3 \\
13.0 \\
8.2 \\
.1\end{array}$} & \multirow{2}{*}{$\begin{array}{r}3.2 \\
10.2 \\
4.8 \\
2.7\end{array}$} & \multirow{2}{*}{$\begin{array}{r}11.5 \\
4.7 \\
14.9 \\
5.7\end{array}$} & $\begin{array}{r}7.1 \\
13.4 \\
10.5 \\
\end{array}$ & $\begin{array}{l}12.9 \\
12.2 \\
10.1 \\
\end{array}$ & $\begin{array}{l}19.8 \\
13.5 \\
18.8 \\
\end{array}$ & $\begin{array}{l}20.2 \\
20.7 \\
18.0 \\
\end{array}$ & $\begin{array}{l}16.4 \\
21.3 \\
14.3 \\
\end{array}$ & $\begin{array}{l}14.4 \\
21.1 \\
10.0 \\
\end{array}$ & $\begin{array}{l}153.7 \\
179.5 \\
147.6\end{array}$ \\
\hline 1943 & & & & & & & \multicolumn{7}{|c|}{ 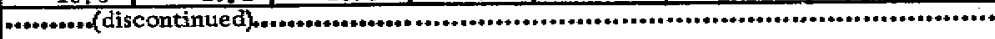 } \\
\hline
\end{tabular}

${ }^{a}$ Computed on basis of comparison with records for Tamiami Canal outlets. 


\section{FLOW CHARACTERISTICS}

In wet periods, overland flow from Big Cypress Swamp and the under Everglades moves slowly toward the south in a broad sheet of water (see pl. 11). This 40-mile-wide "river" (for it is an intermittent river that might aptly be called Everglades River) finds an outlet to the Gulf of Mexico in the complex of channels in the Ten Thousand Islands area between Cape Sable and Everglades, Collier County. The hydraulic characteristics of the river are a product of water conditions over a vast area of undeveloped land stretching from Tamiami Trail to Lake Okeechobee, and their evaluation furnishes an excellent key to the natural water regimen of the Everglades.

The western section of Tamiami Canal, from Monroe to DadeBroward Levee, cuts across and intercepts the flow of the river. The canal also acts as a distributor, because the intercepted water moves to the east or west and flows through the stub laterals and longer laterals that are bridged by Tamiami Trail. Although the river gradually diminishes and disappears in the dry season, Tamiami Canal continues to intercept and distribute a considerable flow of ground water, until the water table has fallen below the bottom level of the outlet channels.

During periods of large discharge, the movement of intercepted water. west of 40-Mile Bend is toward the nearest outlet lateral. The same action occurs east of the bend, but more of ten the water will move toward the east before finding an outlet. During periods of moderate to low flows, the intercepted water west of the DadeCollier County line moves westward in Tamiami Canal and may continue quite a distance in the channel; east of the county line, the direction of flow will be toward the east for a considerable distance. The resultant of components observed in the field show southwesterlyflow in the reach from Monroe to the county line, southerly flow to about 5 miles east of $40-$ Mile Bend, and southeasterly flow in the remainder of the reach to Dade-Broward Levee. The southeasterly trend in the eastern reach shows the route of the river within the actual limits of the Everglades proper-refer to plates 11,12 , and 14. A short distance below the line of Tamiami Canal, the river is shunted toward the southwest by the Atlantic Coastal Ridge.

Figure 144 presents the runoff pattern of Tamiami Canal and the river, as well as profiles of wet and dry conditions. The arrows on the map show the direction of flow in the main canal. The flow in each lateral is indicatedin the bar graph below the map. Note the concentration between bridges 100 and 108 in the slough area, which is not far from the Gulf of Mexico. A much greater concentration occurred east of 40-Mile Bend in the muck-soil area. The western mass of this flow is the effect of water that flows from the 


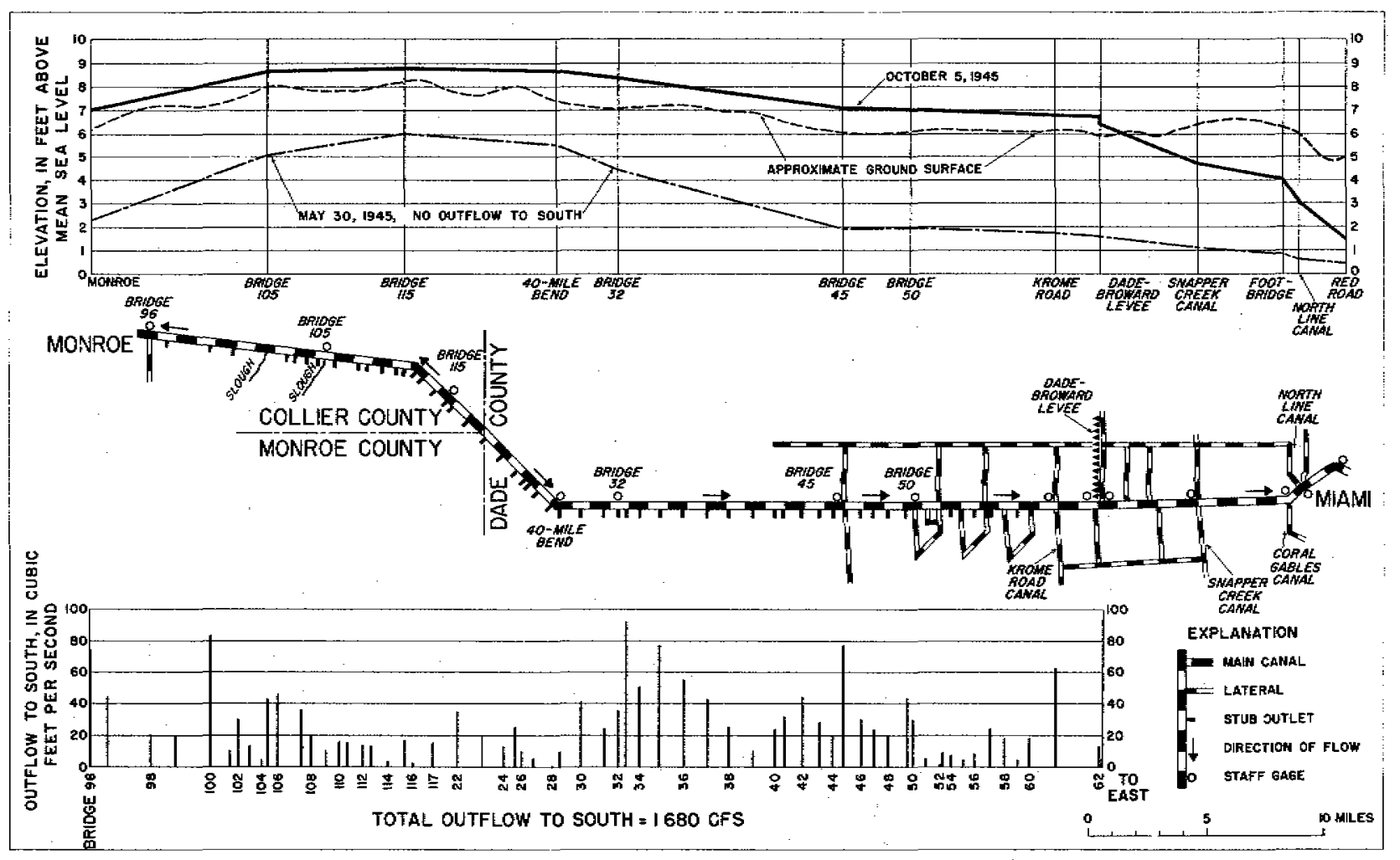

Figure 144. - Graph and map of flow distribution and profiles of Tamiami Canal outlets during a wet period, October 5, 1945. 
higher and steeper area of mineral soils in the Big Cypress Swamp to the northwest. The eastern mass is the principal flow from the upper and middle Everglades.

Flow in Tamiami Canal increases from zero at the Dade-Collier County line to a maximum in the vicinity of bridge 40 and then tapers off to zero again at Dade-Broward Levee (except for the small flows that sometimes occur through the culverts in the levee). West of the county line, the flow is more of the typical canal type, because of the usually large outflow of the lateral at Monroe. It is doubtful, however, that any water traverses the whole reach, because a constant process of interception and distribution of flow occurs. In drought periods, as shown in figure 145, the water level declines so far below the ground surface that the bottom of the canal becomes exposed. The canal then becomes a series of shallow stagnant pools, weed-choked and malodorous from deadfish. Figure 144 shows the water profile on May 30, 1945, when no flow occurred in either the canal or the outlets. The profile is essentially that of the water table.

Water hyacinth ${ }_{4}$ was not much of a problem in Tamiami Canal, although the degree of infestation increased at a point east of bridge 50 late in the period of investigation. Bottom-rooted aquatic weed was a common cause of flow restriction, and at times it reduced east-west distribution to small quantities. Thick masses of weed were observed that were holding water on a slope as great as 4 feet

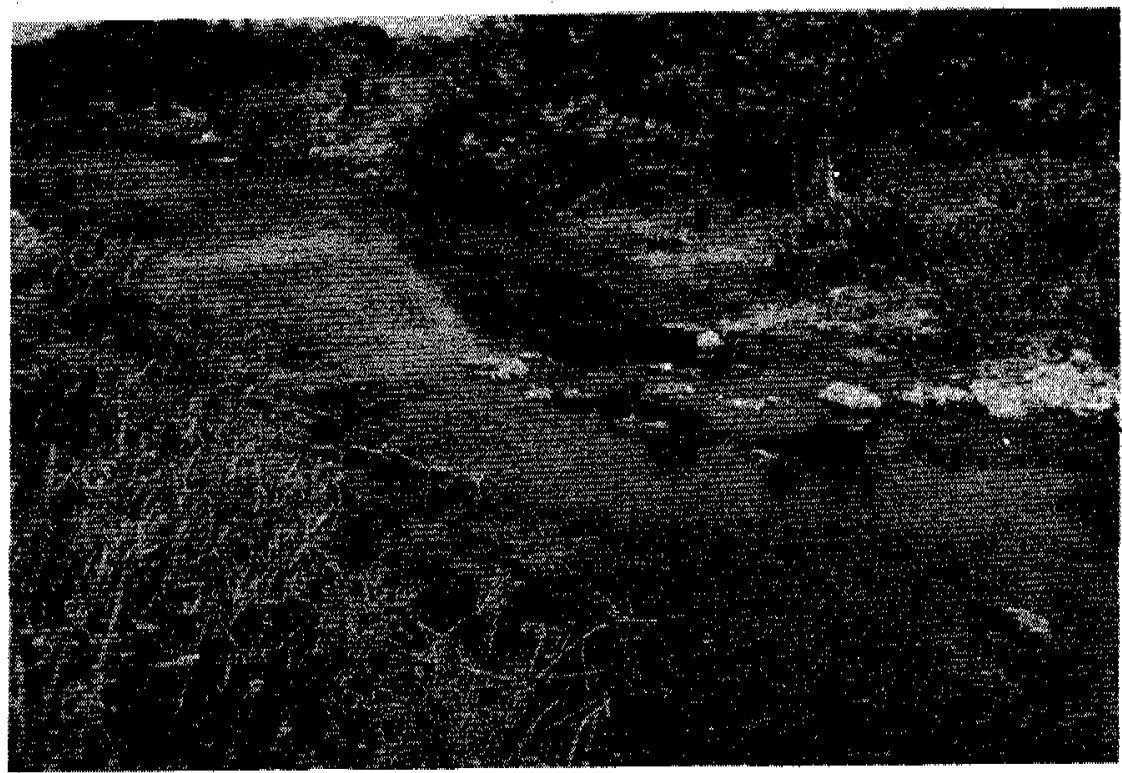

Figure 145. - Middle reaches of Tamiami Canal near 40-Mile Bend in severe drought period, April 1944; bottom of canal exposed and only small weed-choked pools remain. 
in 5 miles near Monroe, and on less steep, but still significant, slopes east of 40 -Mile Bend.

The opinion has been expressed that the road fill of Tamiami Trail causes a significant amount of backwater to the overland flow in the Everglades, in fact, to such an extent that coastal areas are subjected to excessive stages in flood periods. However, this has not been borne out by the 203 detailed observations made by the U. S. Geological Survey during the period 1939-46. Flow under the bridges along Tamiami Trail has been found to be smooth during periods of large discharge, and head loss was ordinarily only a few hundredths of a foot.

It has been observed, however, that a loss of head of as much as $0,3 \mathrm{ft}$ often occurs at the southernends of the stub laterals. The edges of these short channels are partly blocked by material left from dredging operations. Also, debris tends tocatch on the broken rock, and dense vegetation has become established at the outflow ends of many of the stubs. It is doubtful that cleaning the outlets would appreciably affect stages east of Dade-Broward Levee; however, increased flow might shorten the period of higher stages west of the levee. The small loss of head across Tamiami Trail for all reasons probably has no effect on coastal areas.

Most of the runoff in lower Tamiami Canal is derived from ground-water flow, except in dry periods when the connecting canals contribute sizable amounts of water. Some overland inflow also occurs west of Snapper Creek Canal, where the north spoil bank is discontinuous. Flow in Tamiami Canal was not large at any time during the period of study because of weed blocks and lack of maintenance. At times, the bottom-rooted weeds grew so luxuriantly that discharge nearly ceased.

Snapper Creek Canal invariably discharged northward into Tamiami Canal, except for the period in 1942 when an earth dam temporarily blocked all flow. At times, some water flowed northward in the north branch of Snapper Creek Canal, turned eastward in North Line Canal, and then returned to Tamiami Canal, because of weeds and other causes of reduced capacity in the main canal. The situation was difficult to comprehend, however, because weeds were also plentiful in the channels that were followed by this diverted water.

In extreme flood periods, large tributary flow from the south into Tamiami Canal occurred from Snapper Creek Canal and laterals farther west. This flow continued northward in the direction of Miami Canal, at times causing a westerly flow in part of Tamiami Canal. The northward flow during flood periods was the result of heavy rainfall farther south and the relationship to the higher coastal ridge. In ordinary wet periods, the basin usually is inundated as far east as Snapper Creek Canal. 
The vicinity of Coral Gables Canal is considered to be the inland limit of tidal variations in Tamiami Canal. Tidal action would likely extend farther inland in dry periods, except that aquatic vegetation tends to damp it. The channel in the western environs of Miami is relatively narrow, and this also helps to reduce tidal variations.

Coral Gables Canal generally flows into Tamiami Canal, but during extreme floods, it may divert sizable amounts of water to the south. This reversal of the normal (designed) pattern is another example of the limited capacity of the drainage canals to handle larger amounts of runoff.

North Line Canal consistently drains into Tamiami Canal, as observed throughout the study. Just a short distance to the east, F. E. C. Canal usually diverts flow from Tamiami Canal (depending upon the relative water levels in Miami Canal and the municipal well-field area). The nor thward flow in F. E. C. Canal contributes a significant amount of recharge to the well fields. During extreme floods, heavy nor thward discharge in F. E. C. Canal enters Miami Canal and thus reaches the sea by a route longer than via Tamiami Canal.

Tamiami Canal, from Coral Gables Canal to Miami Canal, has a relatively low discharge capacity, because of constrictions, shoals, and shallow sections. Sand-fill dams were placed in Tamiami Canal just downstream from F. E. C. Canal in the years 1943-45, when serious drought conditions developed. These dams prevented further inland contamination by salty water and also helped divert fresh water toward the Hialeah-Miami Springs well field. For a short period in the spring of 1940 a sheet-steel piling dam was placed about 0.5 mile upstream from Red Road for the same purpose.

As in Miami Canal drainage area, the water movement in Tamiami basin is socomplex that data on the main canal do not satisfactorily depict actual water conditions. Consequently, areal studies were made, the results of which appear in the section on Areal studies.

Below F. E. C. Canal, the tidal regimen, imposed by Biscayne Bay through Miami River, increasingly affects Tamiami Canal. Typical tidal discharge occurs, and reverse flows are observed in dry periods.

A short distance below Red Road, Comfort Canal heads at Tamiami Canal and extends to the east to enter South Fork Miami River (see pl. 20). The connection at Tamiami Canal is shallow and weed-grown, and it is probable that not much water is diverted. 
Seminole Lake, the deep rockpit on the north side of the canal, plays an important part in the tidal discharge of Tamiami Canal because of its large area (about 100 acres that is increasing in size as more rock is removed). The tidal storage that must pass in and out of the lower reaches is thus enlarged to the extent of 100 acrefeet for each foot of tidal range $(1,210 \mathrm{cfs}$-hours). Because the storage generally empties in about 5.2 hours, an average of $230 \mathrm{cfs}$ of the canal capacity is utilized by the storage in Seminole Lake for a tidal range of $1 \mathrm{ft}$ (peak flow would be about $370 \mathrm{cfs}$ ). This quantity is an important part of the channel capacity of lower Tamiami Canal and means that runoff from farther inland is reduced. A tidal lake, or an enlargement of a tidal waterway, reduces the volume of runoff from upstream sources. Future improvement of Tamiami Canal must allow for this factor, because Seminole Lake and other rockpits are being enlarged.

The stage and discharge graphs for 40-Mile Bend and the outflow from Tamiami Canal, shown in figures 142 and 143, are especially valuable because they show the most nearly natural water conditions that exist in the Everglades area. The annual stage range at 40Mile Bend is the least for any station observed, ranging from a little more than $1 \mathrm{ft}$ to $4 \mathrm{ft}$. The small range in 1941 reflects the sustained overland flow southward. It will be noted that although the stage at 40-Mile Bend and the discharge southward follow roughly similar trends, the discharge graph fell off much faster proportionately. Generally, the discharge graph did not increase until the stage rose above $7 \mathrm{ft}$, and sometimes it did not reflect large rises at the beginning of the wet period; thus indicating that inundation and overland flow had not occurred.

Table 49 shows that the Tamiami Canal outflow in 1945 was the second highest of the record, despite the fact that the most serious drought known occurred earlier in the year. This demonstrates that care must be exercised in using data based on arbitrary periods. The average annual runoff for the 7 years of record was 230, 000 acre-ft, which was 57 percent of the discharge of Miami Canal at Hialeah. Annual extremes and means for the outflow are given in table 50 together with similar data for the stations farther to the east. According to table 50, which gives an annual summary of the discharges of Tamiami Canal, the outflow to the south was nearly twice as much as the runoff to the east.

The water regimen of lower Tamiami Canal (the section east of Dade-Broward Levee) is much the same as that of lower Miami Canal, and many water events are coextensive in the two adjoining drainage areas.

Stages and discharges of lower Tamiami Canal in the period 193946 are shown in figures 142 and 143 . The response to general water conditions, as described for Miami Canal (p. 454-456), is evident. 
The difference in stage between Red Road and the station near Coral Gables is noteworthy, because the distance between the two stations is only 2.9 miles. The relatively steep slope indicates the limited capacity of the channel in that reach, which is due, in part, to a lack of maintenance. Therefore, the stage at Red Road reacts to a greater degree with changes in Biscayne Bay and the regimen of Miami Canal. The small response at Red Road to large recharge inland is particularly illustrated in the graphs of about May 1944, Note also the very slow rise to the annual maximum stage and the fact that it of ten occurs late in the year.

The monthly and annual runoff of Tamiami Canal near Coral Gables is listed in table 51 . The average runoff for the 2 complete years of record was 131,000 acre-ft, which is probably about average for free-flow conditions, although runoff undoubtedly was considerably lower during the drought years of $1943-45$. The runoff at Red Road is listed in table 52. The mean annual runoff for the 2 complete years of record was 164,000 acre-ft, which shows that the inflow in the reach between Red Road and the station near Coral Gables was 33,000 acre-ft.

\section{SEUPAGE RATES AND PBOFLE IN LOWER REACHES}

Seepage rates (ground-water inflow) along lower Tamiami Canal were found to be not very great, compared with those along Miami Canal. Figure 146 presents the seepage rates computed for September 16,1941 , together with the stage and cumulative discharge profiles. The seepage rates determined for the three principal reaches were $39,8,0$, and $9.6 \mathrm{cfs}$ per linear mile. Note the very steep slope from North Line Canal to Red Road, which is an indication of the poor condition of the channel. Of the total discharge at Red Road, 65 percent originated west of Snapper Creek Canal.

The vertical jumps in the discharge graph represent the inflow or outflow in the connecting canals. A curious combination of flows is shown at the eastern end of the graph, where North Line and F. E. C. Canals flow in opposite directions, even though the two canals are only about $800 \mathrm{ft}$ apart. This unusual condition really indicates a continuous flow from the west in North Line Canal (toward the Miami well field), which enters Tamiami Canal and quickly leaves it by way of F. E. C. Canal; it also indicates the flow of some water from Tamiami Canal. The result is as though North Line Canal were connected directly with F. E. C. Canal. 

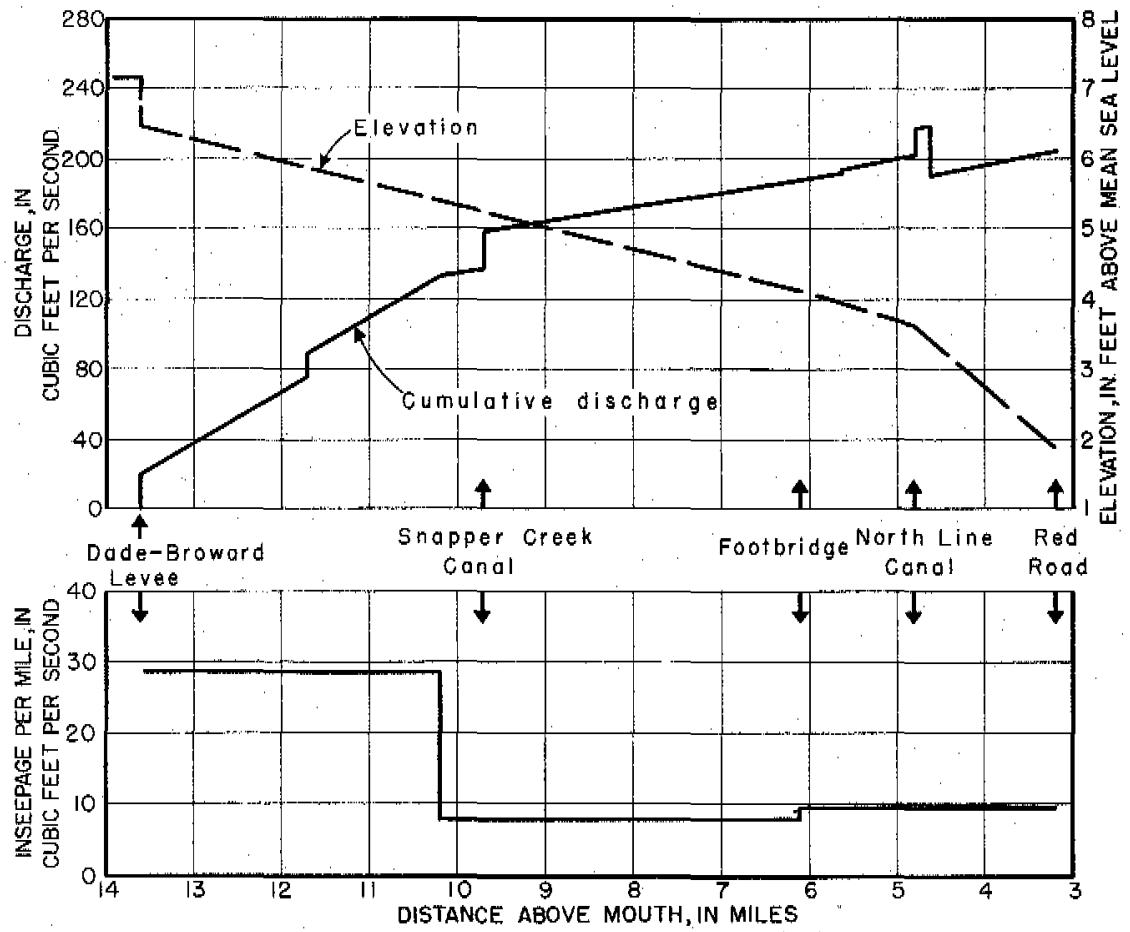

Figure 146. - Graph of cumulative discharge, seepage rates, and profile of Tamiami Canal from Dade-Broward Levee to Red Road, September 16, 1941.

\section{SECONDARY CANALS}

\section{BOYNTON CANAL.}

Boynton Canal is a principal east-west canal of Lake Worth Drainage District, and it is the only canal between West Palm Beach and Hillsboro Canals that drains into tidal waters (pl. 14). It extends westward from Lake Worth and the Intracoastal Waterway at Boynton Beach to range line 41-42 and Equalizing Canal No. 1 (a distance of 9.5 miles). Boynton Canal intersects the other three equalizing canals and supplies irrigation water, or furnishes drainage, according to need. Controls and pumps in the canal make its operation quite flexible.

A gaging station was operated on Boynton Canal just east of U. S. Highway 1 at Boynton Beach from July 1941 to June 1943. Because the principal control on the canal was a short distance west of the station, the stage record which was made below the control, could be used only to compute daily mean discharge. The discharge record in figure 147 shows that the flow regimen was entirely 

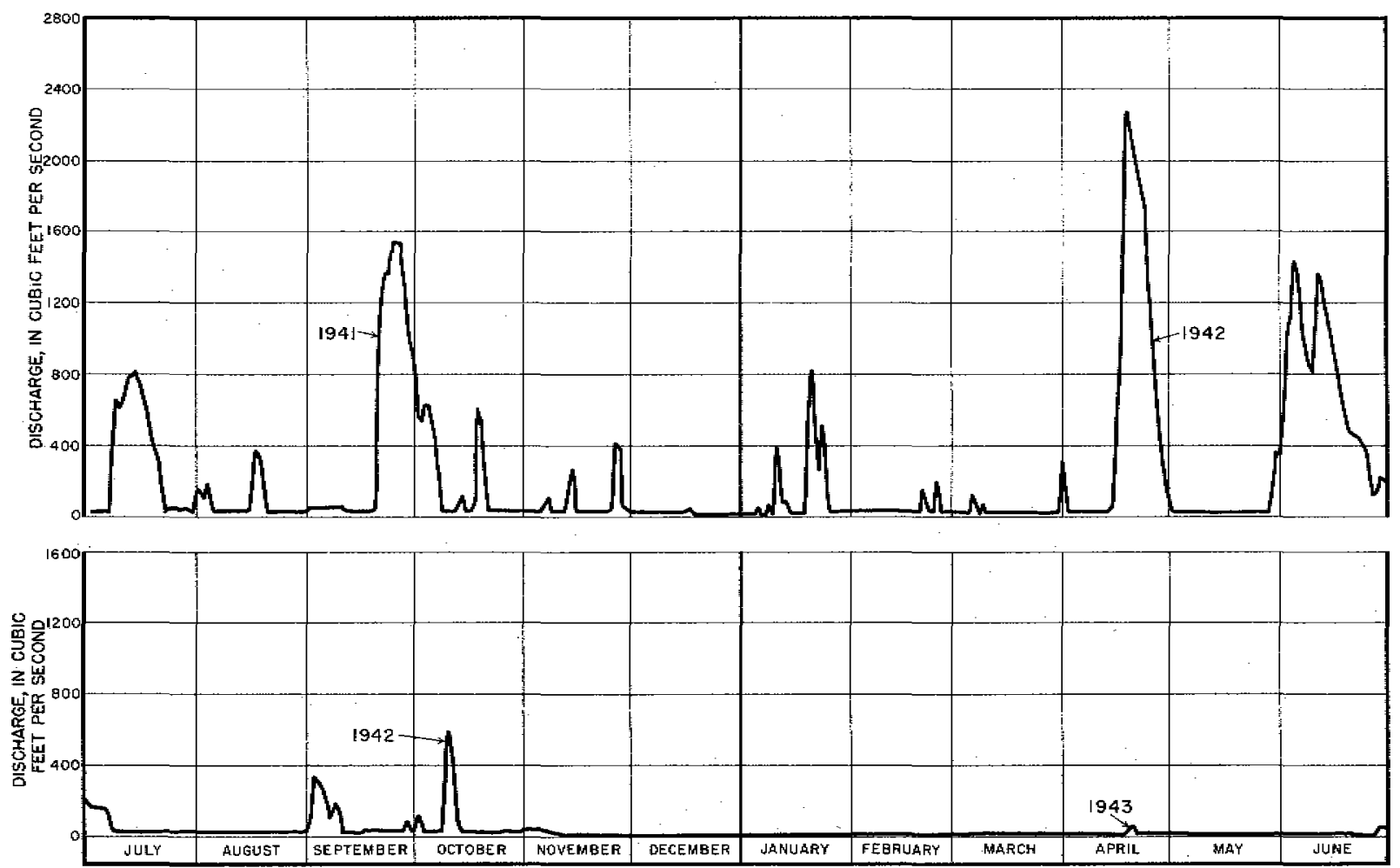

垔

Figure 147. - Graph of đischarge of Boynton Canal at Boynton Beach, 1941-43. 
[Unit, 1,000 acre-feet]

\begin{tabular}{|c|c|c|c|c|c|c|c|c|c|c|c|c|c|}
\hline Year & Jan. & Feb. & Mar. & Apr. & May & June & July & Aug. & Sept. & Oct. & Now. & Dec. & Annual \\
\hline $\begin{array}{l}1940 \\
1941 \\
1942 \\
1943\end{array}$ & $\begin{array}{r}10.5 \\
11.5 \\
7.9 \\
.5\end{array}$ & $\begin{array}{r}10.5 \\
11.1 \\
2.3 \\
.6\end{array}$ & $\begin{array}{r}10.5 \\
1.9 \\
2.5 \\
1.0\end{array}$ & $\begin{array}{r}10.5 \\
11.1 \\
39.2 \\
1.2\end{array}$ & $\begin{array}{r}10.5 \\
1.7 \\
3.3 \\
1.0\end{array}$ & $\begin{array}{r}10.9 \\
1.5 \\
44.3 \\
1.1\end{array}$ & $\begin{array}{r}10.6 \\
18.9 \\
3.7 \\
\end{array}$ & $\begin{array}{r}1.2 \\
4.7 \\
1.9\end{array}$ & $\begin{array}{r}12.3 \\
28.2 \\
4.8 \\
\ldots \ldots \ldots\end{array}$ & $\begin{array}{r}10.9 \\
11.4 \\
5.0\end{array}$ & $\begin{array}{r}10.7 \\
4.5 \\
.8\end{array}$ & $\begin{array}{r}10.7 \\
1.5 \\
.4 \\
\ldots . . .\end{array}$ & $\begin{array}{r}9.8 \\
75.0 \\
116.1 \\
\end{array}$ \\
\hline
\end{tabular}

${ }^{1}$ Computed on the basis of several discharge measurements and on the record for West Palm Beach Canal at West Palm Beach. 
artificial, with only limited indication of seasonal variations. The outstanding peak was caused by discharge following the unusually heavy rain of April 15-17, 1942. Except for a short reach at the eastern end, Boynton Canal is not subject to tidal backwater.

Monthly and annual runoff are listed in table 53, which shows that the runoff for the 2 complete years of record ending in June was 169,000 and 22,000 acre-ft, respectively. This wide variation of runoff reflects the artificial regimen and the very small wastage of water during the 1943 drought period. The record also shows the entirely different water requirements of relatively high lands that are almostentirely sand, as compared with the needs of the mucky areas that are adjacent to the other canals discussed in this report.

\section{CYPRESS CREEK CANAL}

Cypress Creek Canal extends toward the west from the natural tidal slough of Cypress Creek at Pompano to range line 40-41, a distance of 12 miles. It is a local canal that drains a low sandy area characterized by small cypress "heads" or groups of cypress trees. The canal stages are controlled in two pools by two small dams. (See pl. 14.) No cooperative pumping for irrigation occurs; instead, each man operates separately.

A gaging station was operated on Cypress Creek Canal in the center of Pompano from February 1940 to June 1943. The stage and discharge graphs (fig. 148) show a rather natural water regimen because the drainage area is low. This record is in marked contrast with that from Boynton Canal (fig. 147). It will be noted that much of the runoff was in the winter months, because the truck farmers in the area opened the controls for each rain.

The stage graphs are for the principal pool extending from Pompano west to the inland control, just east of State Highway 7. The monthly and annual runoff listed in table 54 shows an average annual runoff of 60,000 acre-ft for the 2 complete years of record. The discharge ranged between 0 and $492 \mathrm{cfs}$, and the stage ranged between 1.02 and $5.64 \mathrm{ft}$.

Cypress Creek Canal has a low efficiency as a water carrier because of weeds and a cover of hyacinth. 

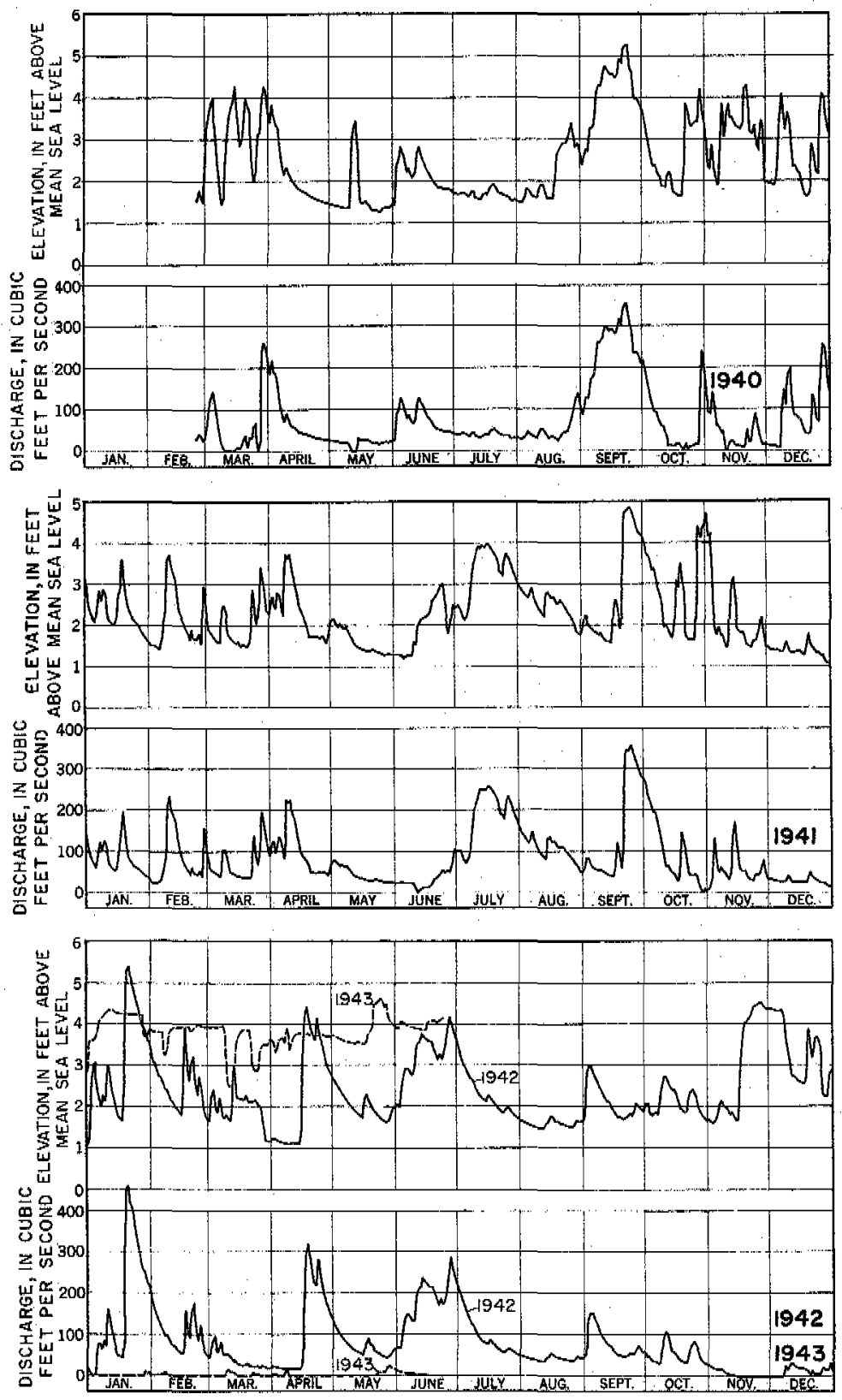

Figure 148, - Graph of stage and discharge of Cypress Creek Canal at Pompano, 1940-43. 
Table 54.-Cypress Creek Canal at Pompano

[Unit, 1,000 acre-feet]

\begin{tabular}{|c|c|c|c|c|c|c|c|c|c|c|c|c|c|}
\hline Year & Jan. & Feb. & Mar. & Apr. & May & June & July & Aug. & Sept. & Oct. & Nov. & Dec. & Annual \\
\hline $\begin{array}{l}1940 \\
1941 \\
1942 \\
1943\end{array}$ & $\begin{array}{r}12.3 \\
5.1 \\
10.6 \\
.08\end{array}$ & $\begin{array}{r}12.2 \\
4.8 \\
5.5 \\
.05\end{array}$ & $\begin{array}{r}4.0 \\
4.4 \\
2.4 \\
.2\end{array}$ & $\begin{array}{l}4.2 \\
6.1 \\
7.1 \\
.07\end{array}$ & $\begin{array}{r}1.2 \\
2.5 \\
4.2 \\
.3\end{array}$ & $\begin{array}{r}4.4 \\
1.9 \\
11.0 \\
.2\end{array}$ & $\begin{array}{r}2.3 \\
11.6 \\
5.6\end{array}$ & $\begin{array}{r}3.1 \\
6.5 \\
2.5\end{array}$ & $\begin{array}{r}14.8 \\
8.9 \\
4.6 \\
\ldots . . . . .\end{array}$ & $\begin{array}{c}4.2 \\
5.8 \\
3.1 \\
. \quad \ldots \ldots . . . . . .\end{array}$ & $\begin{array}{r}2.5 \\
3.4 \\
.3\end{array}$ & 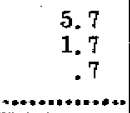 & $\begin{array}{c}50.9 \\
62.7 \\
57.6\end{array}$ \\
\hline
\end{tabular}

${ }^{1}$ Computed on basis of comparison with records for Hillsboro Canal near Deerfield Beach. 
TIDAL CANAIS IN THE MAM AREA

The coastal ridge in the greater Miami area is drained by five short canals-Snake Creek, Biscayne, Little River, Coral Gables, and Snapper Creek-that follow a southeasterly direction to Biscayne Bay and are roughly parallel with Miami Canal (see pl. 22). The major part of their channels was excavated in transverse glades, which were once natural overflow channels of the Everglades. The lower reaches are regularly tidal, and in dry periods tide effect may occur in all reaches. The runoff from the canals was not controlled until 1946, when Dade County started construction of temporary dams to prevent upstream movement of salty water.

The regimen of flow in the short canals is much the same as that in Miami and Tamiami Canals and the tidal phenomena are similar. The principal difference is that the discharge in the short canals is less sustained, because they do not head in reservoir areas.

Records of stage and discharge have been maintained on the short canals in the Miami area, as listed in table 21. Continuous stage recorders were operated for varying periods, but the records have not been developed and plotted. In connection with special areal and basin studies, numerous measurements of discharge were made at many locations along the canals. Results of most of the discharge measurements are published in U. S. Geological Survey Water-Supply Papers 872, 892, 922, 952, 972, 1002, 1032, and 1052 .

Snake Creek, Biscayne, and Little River Canals lie north of Miami proper and drain into the head of Biscayne Bay. The primary purpose of these canals was for suburban development rather than for agricultural purposes.

Snake Creek Canal (also known as Royal Glades Canal) starts at South New River Canal, 5 miles west of Davie. It extends south for about 7 miles, then turns eastward and southeastward to connect with Oleta River at North Miami Beach. The entire channel is in a slough area, and it is inadequate for the area served. Runoff in flood periods is reduced by the obstruction of the channel by two highway and one railroad bridge at the lower end, where head losses in excess of $1 \mathrm{ft}$ have been observed. Tidal action extends at least as far west as Red Road during dry periods.

Biscayne Canal heads at Red Road, west of Opa Locka, and extends 10 miles eastward and southeastward to Biscayne Bay at Miami Shores. A principal branch, Opa Locka Canal (pl, 20), joins Biscayne Canal near the midpoint. The canal was excavated in a slough, except for a short reach close to the bay. The canal is fairly large, but lack of maintenance has reduced its capacity. Several constrictions exist in Miami Shores (at the golf course and 
at several bridges in the vicinity). Except during flood periods, the canal is tidal throughout.

Little River Canal heads at Red Road, north of Hialeah, and extends 8, 4 miles eastward and southeastward to the natural channel of Little River in the northern part of Miami. For the most part, it was excavated in a slough and is about the same size as Biscayne Canal. A narrow section at the F. E. C. Railway bridge reduces the runoff capacity by an appreciable amount. The canal is affected by tides throughout its length, except during flood periods.

Coral Gables and Snapper Creek Canals lie south of Miami and Miami Canal. Both are unusual in that they connect with another canal and usually discharge from both ends.

Coral Gables Canal heads at Tamiami Canal, just west of the Miami City limits, and extends southeastward to Biscayne Bay at Coral Gables. Most of the channel was excavated in a slough, except for about 1 mile of the eastern reaches, which was cut in some of the highest land in the Miami area. The channel is shallow and narrow at several locations east of Red Road. Below U. S. Highway 1 , the canal is larger because it was developed as a scenic attraction. Except during flood periods, tidal action affects all but the upper 3 miles or so.

Snapper Creek Canal extends all the way from Russian Colony Canal (at a point only $1 \frac{1}{2}$ miles from Miami Canal) southward and then eastward to Biscayne Bay, east of South Miami. The branch north of Tamiami Canal is not continuous, and the north-south reaches have a varied pattern of flow. The channel is shallow in the vicinity of the bend toward the southeast, and, as far as the coastal ridge is concerned, flow may be considered to start there. The upper reaches are in the Everglades, and the middle and lower reaches follow a natural slough (except for the last half mile, which was cut through higher land). The channel cross section is generally small and is not adequate to serve the drainage area in the manner intended. Tide effect occurs as far inland as the Seaboard Railroad bridge.

The five short canals do not have the capacity to provide drainage for their drainage areas, and flooding of the old sloughs, particularly in the western reaches, occurs fairly often. During wet years, all the canals in the transverse glades overflow.

\section{AREAL STUDIES}

The hydrology of any drainage area in the Everglades is so intimately related to the hydrology of adjoining areas that records on a single canal, although valuable, do not present a sufficiently broad 
evaluation of water conditions. In order to better understand general water conditions, many areal studies were made. In making these studies, stages and discharges were obtained at the regular gaging stations and at many intermediate locations, as indicated by the pattern of the canals.

\section{GENERAL STUDY OF EVERGLADES}

For one series of studies, the entire Everglades area was considered. Plate 14 shows the results of this study, which was made March 30 to April 2, 1943. Drought conditions were assuming serious proportions at that time, and controls in the canals were closed to reduce wastage to a minimum. All of the open lands were dry, and fires burned over most of the Everglades, causing serious losses of organic soils.

\section{AREA WEST OF MALEAH}

The regular records for Miami and Tamiami Canals in the western environs of Miami were highly useful, but more data were needed to obtain a comprehensive view of local water conditions. The two large canals are interconnected with a network of smaller canals and road ditches that makes the patterns of water movement in the area quite complex.

The study made June 29 to July 1,1942 , when much of the area was inundated and runoff was fairly large, is presented in plate 15. Measurements of ground-water levels were included, and the complexity of the flow pattern is apparent. The contours are, for the most part, surface-water contours because of the general inundation. However, in flat terrain such as this, they may be treated in much the same manner as ground-water contours. (They are shown in greater detail in fig. 32.)

A parallel study on April 24-26, 1946, when conditions were moderately dry, is shown in plate 16. The land surface was dry, and the contours represent ground-water levels (see also fig. 33). Discharges were small at all locations, primarily because dams were closed in Miami and Tamiami Canals. One of the noteworthy features was the fact that all the flows in the canals near the well field were toward the cone of depression. (See the more detailed study in fig. 140.) The relatively close spacing of the contours, west of the well-field area, shows that recharge was being derived from the basin of Tamiami Canal.

Note also that the ground-water contours were generally parallel to Miami Canal, indicating that the principal movement of water was toward the canal and not directly to the sea. 


\title{
HYDROLOGIC STUDIES
}

\author{
By W. B. Langbein
}

\section{INTRODUC'TION}

A comprehensive view of the surface waters of southeastern Florida is a highly desirable, if not an essential, prerequisite to an effective understanding of its complex water problems. The special purpose of the se quantitative studies is to contribute toward such a view, through the general analysis and appraisal of important aspects of the occurrence and behavior of surface waters in the region.

An important objective of a quantitative surface-water study is an accounting, or inventory, of water as it passes through the hydrologic cycle. (See p. 15 for a discussion of the hydrologic cycle.)

Rainfall, after reaching the earth, is disposed of in two ways: 1. The processes of evaporation and transpiration return a major part to the atmosphere as water vapor, and 2. the remainder of the rainfall. drains off, ultimately reaching the sea. Evaporation and drainage from the land are continuous processes, although they are variable in rate and amount. There is an endless sequence of additive and subtractive factors, which, over a long period of time, must balance; that is, total inflow as rainfall must equal total outflow as evapotranspiration and runoff. When short periods are being considered, the gain or loss in storage in the area must be evaluated to balance the equation between inflow and outflow.

Rainfall and runoff can be measured directly. However, evaporation and transpiration were not subject to djrect measurement. at the time of this investigation, and their rates and volumes could only be inferred by reference to measurements of evaporation from suitably placed pans of water and by study of the difference between rainfall and runoff.

Between periods of rainfall and runoff, water is held in temporary storage by various means. There can be no direct accounting of, such volumes and their locations; instead, the investigator must resort to inferences based on seemingly pertinent hydrologic and hydraulic principles. Storage is accounted for as so much bulk, but it is useful to classify it for some purposes with regard to its time characteristics, that is, by its lag, or by the length of time that it remains in the area after the causative rainfall has ended.

If we wish to make an accounting of inflow, outflow, and storage, the hydrologic cycle may be broadly classified as follows: 
1. Rainfall

2. Runoff:
a. Base runoff
b. Direct runoff

3. Storage:
a. Ground
b. Surface:
Streams
Swamps
Lakes

c. Soil moisture

4. Evapotranspiration.

\section{GENERAL HYDROLOGY OF THE AREA}

Introductory to, and as a background for, the detailed analyses to follow, it seems desirable to inquire into the general features of the surface waters of southeastern Florida, with special attention to the following aspects: (1) The amounts of water involved during the period of investigation, and (2) a comparison of these figures with normal amounts.

A condensed inventory of the annual amounts of water involved in the entire southeastern Florida drainage unit (see p. 300) is given in table 55 .

Table 55. -Annual summary of hydrologic "'ata for southeastem Florida

[Drainage area about 9,000 square miles; data measurements given in inches]

\begin{tabular}{|c|c|c|c|c|c|c|}
\hline $\begin{array}{l}\text { Calendar } \\
\text { year }\end{array}$ & $\begin{array}{c}\text { Mean } \\
\text { areal } \\
\text { precip- } \\
\text { itation } \\
\text { (P) }\end{array}$ & $\begin{array}{l}\text { Total } \\
\text { runoff } \\
(R)\end{array}$ & $\begin{array}{l}\text { Precip- } \\
\text { itation } \\
\text { minus } \\
\text { rumoff } \\
(P-R)\end{array}$ & $\begin{array}{l}\text { Total } \\
\text { storage } \\
\text { at end of } \\
\text { year } \\
\text { (S) }\end{array}$ & $\begin{array}{l}\text { Net change } \\
\text { in storage } \\
(\Delta S)\end{array}$ & $\begin{array}{l}\text { Losses } \\
(P-R-\Delta S)\end{array}$ \\
\hline $\begin{array}{l}1939 \\
1940 \\
1941 \\
1942 \\
1943 \\
1944 \\
1945 \\
1946 \\
1940-46\end{array}$ & $\begin{array}{r}53.0 \\
59.8 \\
50.0 \\
45.2 \\
43.9 \\
50.5 \\
48.1 \\
350.5\end{array}$ & $\begin{array}{r}8.7 \\
14.2 \\
11.0 \\
3.1 \\
2.7 \\
6.3 \\
6.1 \\
52.1\end{array}$ & $\begin{array}{r}44.3 \\
45.6 \\
39.0 \\
42.1 \\
41.2 \\
44.2 \\
42.0 \\
298.4\end{array}$ & $\begin{array}{r}7.6 \\
7.4 \\
8.2 \\
4.9 \\
5.8 \\
4.9 \\
9.3 \\
7.5 \\
\ldots \ldots \ldots . .\end{array}$ & $\begin{array}{r}-0.2 \\
+.8 \\
-3.3 \\
+.9 \\
-.9 \\
+4.4 \\
-1.8 \\
-.1\end{array}$ & $\begin{array}{r}44.5 \\
44.8 \\
42.3 \\
41.2 \\
42.1 \\
39.8 \\
43.8 \\
298.5\end{array}$ \\
\hline $\begin{array}{l}\text { 7-year } \\
\text { average }\end{array}$ & 50.1 & 7.5 & 42.6 & & & 42.6 \\
\hline
\end{tabular}

${ }^{a}$ Figures are based in part on estimates of flow. Includes that measured in the canal system only. Percolation from ground water in the Everglades is unmeasurable, and therefore it is not incined.

Rainfall, the primary source of the fresh water, averaged approximately 50 in. during the 7 years of investigation. During the same 7-year period, rainfall in southern Florida averaged about 0.5 in. below a long-term average. The period included 1941, one 
of the wettest in the long-term record, and 1944, one of the driest. The latter part of the 7-year period was markedly drier than the first part. In general, it appears that rainfall during the 7-year investigation was nearly representative of the region.

Runoff from the southeastern Florida drainage unit, as measured in the canals draining it to the sea, was equivalent to 7.5 in. over the 9,000 square-mile area. During the 7-year period (1940-46), runoff of Kissimmee River averaged 7.45 in, per year, only slightly less than the estimated average for the 22-year period (1924-45).

The difference between rainfall and runoff averaged nearly 43 in., which was attributed to evapotranspiration losses. The range in year-end storage indicated in table 55 for the 7-year period (194046) was abopt $5 \mathrm{in}$. This storage includes water stored in Lake Okeechobee and in the waterways, swamps, and lakes in the Kissimmee basin and as ground water and soil moisture in the Kissimmee and other contributing basins and Everglades. Natural storage at the close of the calendar year tends to reach a minimum stage, therefore the actual range in storage during the period was considerably greater.

The atmosphere is by far the most effective agent of land drainage, disposing of several times as much as the waterway systems. Areas in which losses to the atmosphere are great in relationship to the rainfall are frequently classed as moist and subhumid (p. 35). A large relative loss indicates that runoff is subject to large variations during years in which rainfall is less than the average loss (which happened in 2 out of 16 years in the Kissimmee basin). Runoff is then produced only by torrential rains and by drainage of storage from previous years. During such years, the persistent losses to the atmosphere result in marked decrease in storage, and the cumulative effect of 2 or more such consecutive years would be exceedingly unfavorable. In general, physiographic conditions (p. 127155 ) in Florida make it mandatory that swamp and lake storage act as an important regulator of runoff; therefore a single dry year, especially if it follows a wet year, will not necessarily be seriously deficient in runoff.

Table 56 lists the annual runoff of selected drainage basins in southern Florida. Substantial range in runoff may be noted between wet years (such as 1936) and dry years (such as 1938). There were frequent erratic variations from the general pattern of runoff, notably in 1934 when the flow of most streams was above normal, yet the flow of Fisheating Creek was the third lowest in 15 years of record. The table includes runoff of several intervening areas, which were computed by subtracting the volume discharged at the upper station from the volume discharged at the lower station, and expressing the difference in inches over the intervening drainage area. In using such figures, it is well to remember that they are 


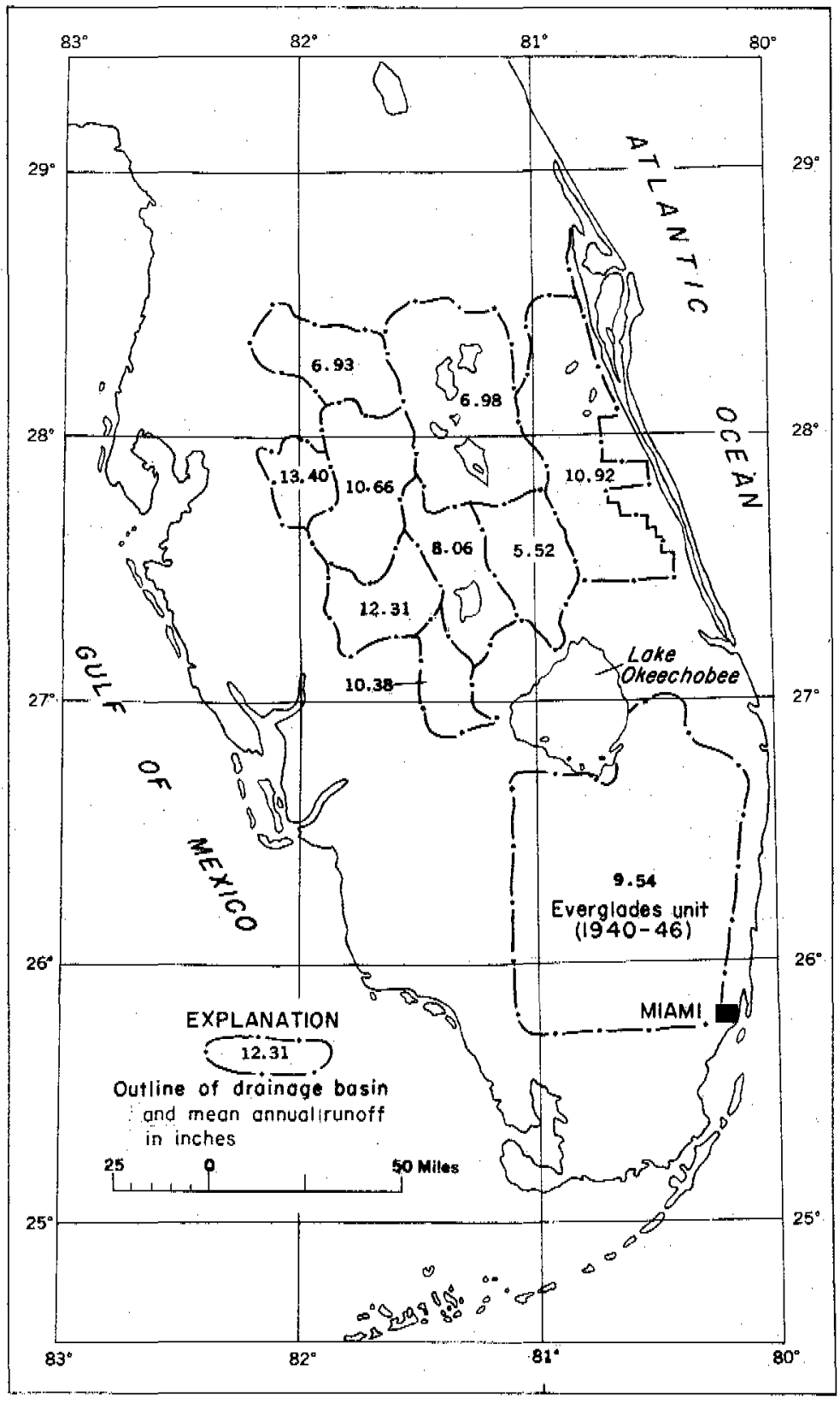

Figure 149. - Map of drainage basins of southern Florida showing mean annual runoff in inches, $1935-46$. 
Table 56. - Sumnary of runoft, in inches, for selected drainage basins in southen Florida for calendat years $1930-46$

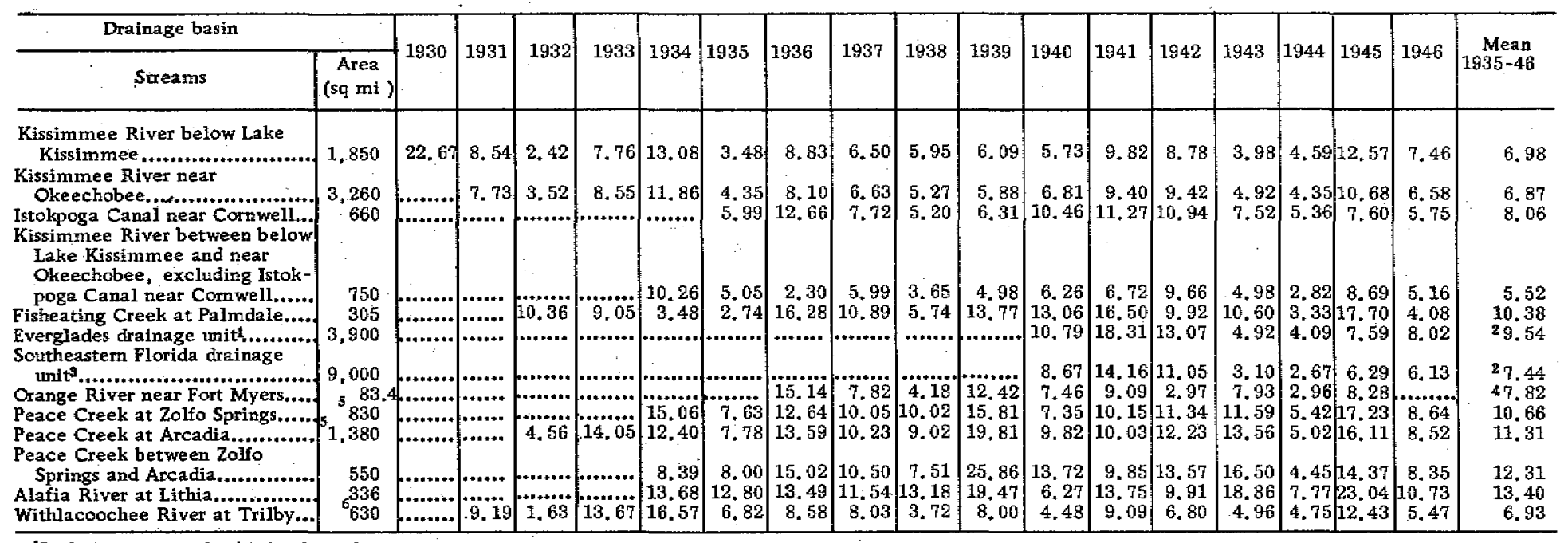

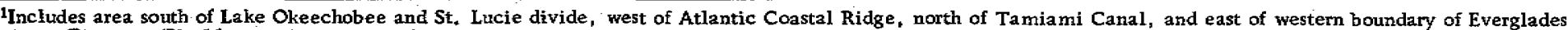

Drainage District. (Pl. 11 shows boundaries of Everglades Drainage District. )

2 Mean $1940-46$

Includes measured canal system only and comprises the runotf from Caloosahatchee and St. Lucie Canals and the runoff from the Everglades unit.

4 Mean 1936-45.

Revised 1940 .

${ }^{6}$ Revised 1938. 
the differences between large quantities and that errors that are small in relation to those quantities may be quite large with respect to the differences. The runoff of Kissimmee River between Lake Kissimmee and Okeechobee for 1936 is especially questionable. Moreover, in using table 56, it is well to bear in mind that where (as in some instances) the sizes of the drainage areas are questionable, the values of the runoff as expressed in inches will be correspondingly uncertain.

The last column lists the average annual runoff for the 12-year period 1935-46, during which most stations were in operation. The average annual runoff of the streams listed ranges from 5.52 to $13.40 \mathrm{in}$.

Figure 149 shows the mean annual runoff of the streams listed in table 56 and their correct geographic position. Conspicuous on the map is the low annual runoff in the lower Kissimmee basin and in the central peninsula. The runoff is highest in the west coast tributaries and in the Everglades where a 7-year mean is shown. The geographic variations in runoff correspond in general to variations in rainfall shown on figure 3 . Losses in lakes and swamps might also affect the volume of runoff.

\section{ANALYSIS OF CLIMATOLOGIC DATA}

The climatologic data gathered were of two kinds: precipitation, representing the volume of supply; and evaporation from observation pans, representing the fate of abstraction of water by the atmosphere.

Rainfall information was obtained principally from U. S. Weather Bureau publications.

Mean areal precipitation (see table 57) was computed by the Thiessen method, using perpendicular bisectors. This method assumes that the precipitation at any point in the basin during a given interval of time is the same as that recorded at the nearest rain gage. The accuracy of the computed mean areal precipitation depends primarily on the number and distribution of rain gages, and secondly, on the characteristics of the distribution of precipitation. The number of rain gages used in these studies is listed in table 58.

The greater density of rain gages in the Lake Okeechobee and Everglades area, and the presumed greater accuracy of the gages, may be credited to the rain gages installed as part of this investigation. Because of the spotty nature of Florida's rainfall, a large number of rain gages are required for detailed determination of 
Table 57. - Weighted average precipitation in Kissinmee River basin above Okeechobee, by months, computed by the Thiessen method tron rainfallstation records

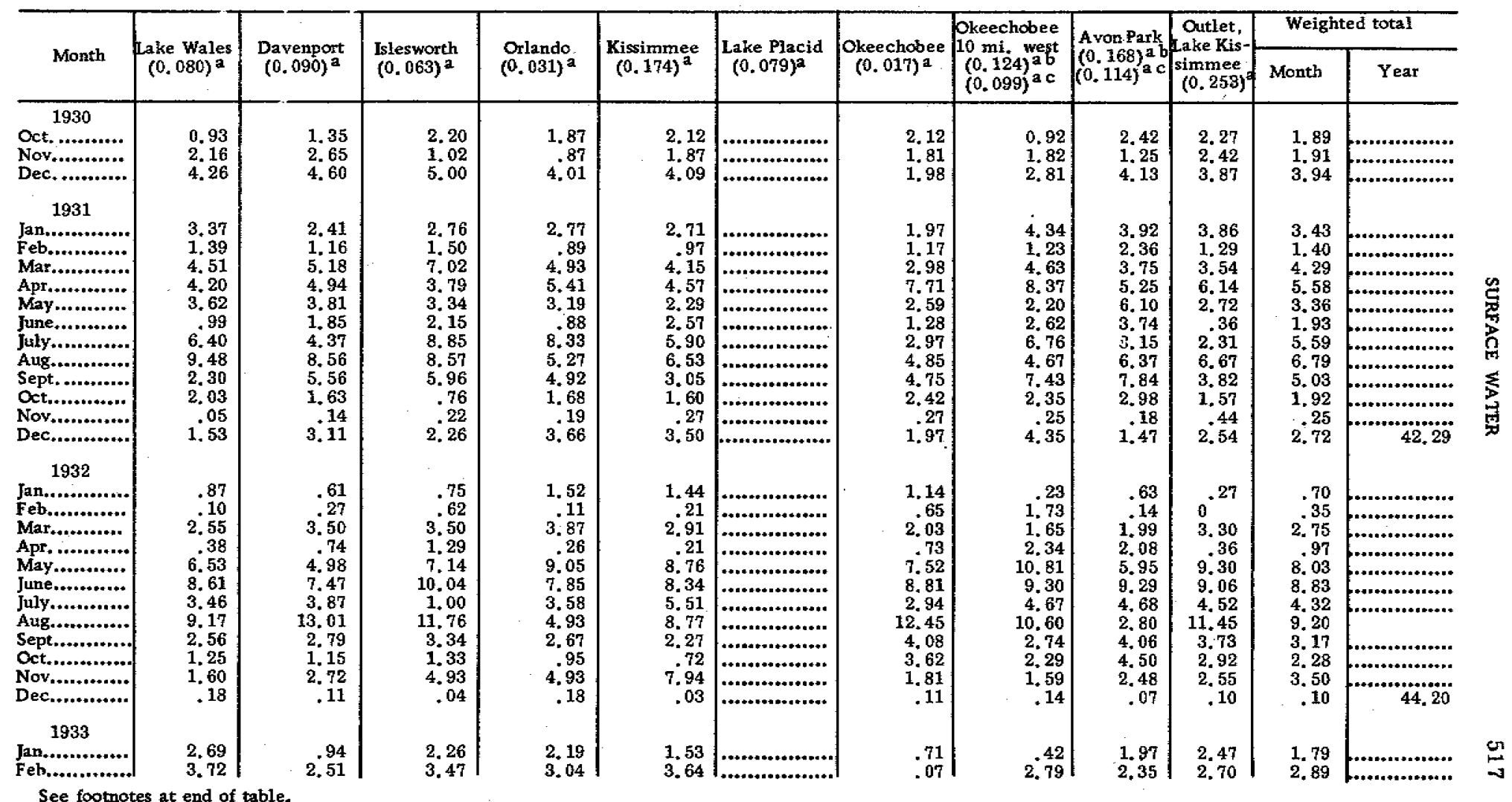


Table 57. Weighted avetage precipitation in Hissirnte River basin above Okeechobee, by months, computed by the Thiessen method from rainfallstation records - Continued

\begin{tabular}{|c|c|c|c|c|c|c|c|c|c|c|c|c|}
\hline \multirow[b]{2}{*}{ Month } & \multirow{2}{*}{$\begin{array}{r}\text { Lake Wales } \\
(0.080)^{a}\end{array}$} & \multirow{2}{*}{$\begin{array}{c}\text { Davenport } \\
(0.090)^{\mathrm{a}}\end{array}$} & \multirow{2}{*}{$\begin{array}{l}\text { Islesworth } \\
(0.063)^{\mathrm{a}}\end{array}$} & \multirow{2}{*}{$\begin{array}{l}\text { Orlando } \\
(0.081)^{\mathrm{a}}\end{array}$} & \multirow{2}{*}{$\begin{array}{l}\text { Kissimmee } \\
(0.174)^{\mathrm{a}}\end{array}$} & \multirow{2}{*}{$\begin{array}{c}\text { Lake Placid } \\
(0.079)^{2}\end{array}$} & \multirow{2}{*}{$\begin{array}{c}\text { Okeechobee } \\
(0.017)^{\mathrm{a}}\end{array}$} & \multirow{2}{*}{$\begin{array}{c}\text { Okeechobee } \\
10 \text { mi. west } \\
(0.124)^{\mathrm{a} \mathrm{b}} \\
(0.099)^{\mathrm{ac}}\end{array}$} & \multirow{2}{*}{$\begin{array}{l}\text { Avon Park } \\
(0.168)^{\mathrm{a}} \\
(0.114)^{\mathrm{a} \mathrm{c}}\end{array}$} & \multirow{2}{*}{\begin{tabular}{|c|} 
Outlet, \\
Lake Kis- \\
simmee \\
$(0.253)^{2}$
\end{tabular}} & \multicolumn{2}{|c|}{ Weighted total } \\
\hline & & & & & & & & & & & Month & Year \\
\hline $\begin{array}{l}1933 \text {-Con. } \\
\text { Mar............. } \\
\text { Apr.............. } \\
\text { May........... } \\
\text { June............ } \\
\text { July............ } \\
\text { Aug............ } \\
\text { Sept........... } \\
\text { Oct............. } \\
\text { Nov........... } \\
\text { Dec............ }\end{array}$ & $\begin{array}{r}1.29 \\
5.22 \\
4.05 \\
5.09 \\
10.39 \\
7.70 \\
17.23 \\
2.20 \\
1.68 \\
.11\end{array}$ & $\begin{array}{r}2.13 \\
3.07 \\
1.68 \\
7.19 \\
15.74 \\
6.52 \\
19.25 \\
1.92 \\
1.06 \\
.36\end{array}$ & $\begin{array}{r}1.61 \\
3.16 \\
4.32 \\
5.90 \\
7.85 \\
8.63 \\
11.50 \\
2.50 \\
1.78 \\
.38\end{array}$ & $\begin{array}{r}2.54 \\
4.33 \\
2.41 \\
8.20 \\
5.46 \\
9.18 \\
14.10 \\
3.84 \\
1.72 \\
.41\end{array}$ & $\begin{array}{r}3.81 \\
4.11 \\
4.80 \\
8.38 \\
13.08 \\
6.45 \\
14.42 \\
2.82 \\
1.99 \\
.41\end{array}$ & $\begin{array}{r}1.85 \\
7.08 \\
2.50 \\
3.81 \\
13.87 \\
7.18 \\
11.64 \\
4.83 \\
1.65 \\
.03\end{array}$ & $\begin{array}{r}2.41 \\
8.82 \\
3.42 \\
2.97 \\
8.69 \\
5.95 \\
13.80 \\
2.88 \\
1.63 \\
.35\end{array}$ & $\begin{array}{r}3.41 \\
7.35 \\
2.16 \\
6.65 \\
19.10 \\
2.75 \\
8.59 \\
2.47 \\
1.58 \\
.18\end{array}$ & $\begin{array}{r}1.70 \\
5.90 \\
3.66 \\
4.77 \\
13.78 \\
6.62 \\
11.71 \\
1.94 \\
3.47 \\
.27\end{array}$ & $\begin{array}{r}0.89 \\
4.73 \\
3.52 \\
7.28 \\
10.63 \\
5.19 \\
15.75 \\
3.43 \\
1.17 \\
.12\end{array}$ & $\begin{array}{r}2.08 \\
5.05 \\
3.42 \\
6.53 \\
12.58 \\
6.16 \\
14.09 \\
2.88 \\
1.76 \\
. .23\end{array}$ & …. \\
\hline 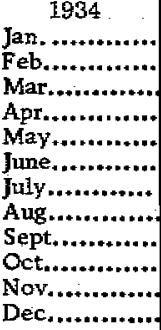 & $\begin{array}{r}1.77 \\
2.73 \\
4.71 \\
4.34 \\
4.11 \\
13.23 \\
11.76 \\
5.97 \\
2.84 \\
4.79 \\
.53 \\
.68\end{array}$ & $\begin{array}{r}.41 \\
3.01 \\
5.84 \\
5.61 \\
5.68 \\
19.91 \\
7.64 \\
5.20 \\
3.95 \\
.89 \\
.22 \\
.79\end{array}$ & $\begin{array}{r}.91 \\
4.47 \\
3.08 \\
4.52 \\
7.80 \\
15.89 \\
9.24 \\
6.57 \\
3.80 \\
3.98 \\
.30 \\
.48\end{array}$ & $\begin{array}{r}1.04 \\
3.37 \\
4.33 \\
4.58 \\
8.08 \\
13.35 \\
9.00 \\
1.27 \\
3.14 \\
1.50 \\
.09 \\
.55\end{array}$ & $\begin{array}{r}1.37 \\
3.25 \\
5.12 \\
5.96 . \\
8.70 \\
15.75 \\
7.03 \\
3.46 \\
4.23 \\
2.54 \\
.43 \\
.66\end{array}$ & $\begin{array}{r}1.94 \\
2.62 \\
2.96 \\
2.36 \\
9.01 \\
9.16 \\
8.03 \\
5.23 \\
4.75 \\
2.13 \\
.40 \\
.50\end{array}$ & $\begin{array}{r}.76 \\
2.47 \\
4.37 \\
4.37 \\
6.69 \\
9.48 \\
6.01 \\
4.41 \\
6.40 \\
2.75 \\
.74 \\
.71\end{array}$ & $\begin{array}{r}1.02 \\
2.36 \\
2.64 \\
3.23 \\
7.47 \\
4.39 \\
2.99 \\
4.11 \\
3.87 \\
.51 \\
.82 \\
.64\end{array}$ & $\begin{array}{r}1.22 \\
2.80 \\
3.58 \\
4.32 \\
7.15 \\
10.94 \\
4.13 \\
4.77 \\
3.17 \\
.11 \\
.93 \\
1.90\end{array}$ & $\begin{array}{r}.98 \\
. .86 \\
2.96 \\
4.98 \\
6.42 \\
14.91 \\
3.11 \\
6.74 \\
3.13 \\
2.12 \\
.81 \\
.36\end{array}$ & $\begin{array}{r}1.16 \\
2.71 \\
3.84 \\
4.64 \\
7.09 \\
13.34 \\
6.00 \\
5.13 \\
3.69 \\
2.02 \\
.58 \\
.59\end{array}$ & (a+k \\
\hline 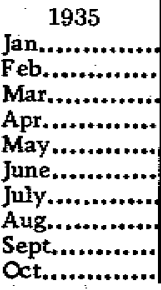 & $\begin{array}{r}.27 \\
.83 \\
.35 \\
4.58 \\
5.30 \\
5.42 \\
7.76 \\
4.37 \\
9.50 \\
1.89\end{array}$ & $\begin{array}{r}.97 \\
.1 .51 \\
.30 \\
1.56 \\
3.51 \\
5.13 \\
7.14 \\
3.96 \\
8.74 \\
.76\end{array}$ & $\begin{array}{r}1.21 \\
3.34 \\
1.45 \\
3.47 \\
4.28 \\
8.73 \\
9.91 \\
4.54 \\
10.68 \\
5.14\end{array}$ & $\begin{array}{r}1.37 \\
2.79 \\
.70 \\
2.26 \\
2.42 \\
2.47 \\
10.13 \\
7.61 \\
9.79 \\
4.07\end{array}$ & $\begin{array}{r}1.43 \\
2.46 \\
1.42 \\
2.78 \\
2.77 \\
3.38 \\
7.38 \\
4.15 \\
9.96 \\
.60\end{array}$ & $\begin{array}{r}.56 \\
1.84 \\
2.14 \\
4.61 \\
2.56 \\
6.64 \\
5.47 \\
9.71 \\
11.00 \\
3.85\end{array}$ & $\begin{array}{r}.39 \\
2.94 \\
.30 \\
11.63 \\
2.14 \\
6.17 \\
3.95 \\
5.54 \\
6.49 \\
9.24\end{array}$ & $\begin{array}{r}.64 \\
1.84 \\
.34 \\
4.47 \\
1.48 \\
4.18 \\
6.24 \\
5.50 \\
10.40 \\
7.18\end{array}$ & $\begin{array}{r}.41 \\
1.15 \\
.81 \\
6.03 \\
2.87 \\
6.87 \\
7.13 \\
9.93 \\
11.35 \\
2.99\end{array}$ & $\begin{array}{r}.93 \\
.63 \\
.25 \\
4.73 \\
1.73 \\
7.96 \\
6.21 \\
3.66 \\
7.39 \\
2.79\end{array}$ & $\begin{array}{r}.88 \\
1.61 \\
.78 \\
4.17 \\
2.73 \\
5.94 \\
6.97 \\
5.42 \\
9.42 \\
2.99\end{array}$ & " \\
\hline
\end{tabular}




\begin{tabular}{|c|c|c|c|c|c|}
\hline $\begin{array}{l}\text { Nov.............. } \\
\text { Dec............ }\end{array}$ & $\begin{array}{r}.64 \\
2.71\end{array}$ & $\begin{array}{l}1.77 \\
3.49\end{array}$ & $\begin{array}{r}.72 \\
3.28\end{array}$ & $\begin{array}{r}.85 \\
4.81\end{array}$ & $\begin{array}{r}.79 \\
3.33\end{array}$ \\
\hline 1936 & & & & & \\
\hline Jan.............. & 2.28 & 2.86 & 4.04 & 4. 11 & 2.07 \\
\hline Feb.............. & 8.72 & 6.08 & 7.65 & 6.29 & 6. 64 \\
\hline Mar.............. & $\begin{array}{r}4.49 \\
.13\end{array}$ & $\begin{array}{l}4.30 \\
1.16\end{array}$ & $\begin{array}{r}3.20 \\
47\end{array}$ & $\begin{array}{l}2.90 \\
1.58\end{array}$ & $\begin{array}{l}4.31 \\
1.58\end{array}$ \\
\hline May........... & 3.98 & 5.27 & 8.56 & 3.58 & 6.40 \\
\hline June............ & 11.18 & 9.65 & 8.97 & 11.28 & 7.30 \\
\hline July........ & 2.38 & 4.81 & 5.76 & 2. 63 & 4.01 \\
\hline Aug. & 6.41 & 3.00 & 4.86 & 4.95 & 4.87 \\
\hline Sept. & 5.77 & 4.17 & 4.77 & 5. 81 & 2.67 \\
\hline Oct......... & 4. 64 & 4. 11 & 3.62 & 5. 97 & 3.42 \\
\hline $\begin{array}{l}\text { Now............. } \\
\text { Dec............. }\end{array}$ & $\begin{array}{l}1.05 \\
1.24\end{array}$ & $\begin{array}{r}1.64 \\
.83\end{array}$ & $\begin{array}{l}1.85 \\
1.00\end{array}$ & $\begin{array}{l}2.21 \\
1.77\end{array}$ & $\begin{array}{l}\text { 1. } 20 \\
1.12\end{array}$ \\
\hline 1937 & & & & & \\
\hline Jan.. & .44 & .01 & .50 & .97 & .51 \\
\hline Feb.......... & 5.52 & 6.13 & 4.95 & 5.00 & 4.83 \\
\hline Mar.............. & 4.20 & 2.60 & 3.37 & 2.97 & 4. 53 \\
\hline Apr............. & 6.38 & 3.71 & 2.45 & 3.78 & 3.61 \\
\hline May....... & 2.19 & .97 & 3.75 & 4.47 & 1.96 \\
\hline June........ & 4.51 & 4.48 & 6.74 & 5.22 & 3.77 \\
\hline July......... & 9.75 & 4.78 & 6.77 & 5.14 & 8,43 \\
\hline Aug........ & 9.87 & T. 19 & 9.95 & 13.14 & 11,34 \\
\hline Sept............. & 4.71 & 5.27 & 4.91 & 9.37 & 3.29 \\
\hline Oct........ & 4.06 & 7.31 & 5.65 & 4.55 & 8.16 \\
\hline Nov......, & 6.67 & 5.49 & 3.59 & 3.67 & 3.75 \\
\hline Dec........ & 1.52 & .98 & 1.23 & .82 & .70 \\
\hline 1938 & & & & & \\
\hline $\operatorname{Jan}, \ldots . . . . . . .$. & 1.65 & .77 & 1.13 & .73 & .64 \\
\hline Feb............. & 1,14 & .79 & .37 & & \\
\hline Mar.... & 1.69 & 2.72 & 2.51 & 1.74 & 1.98 \\
\hline Apr......... & .53 & .19 & .03 & .3 & .34 \\
\hline May...... & 5.38 & 6.88 & 9.29 & 6.30 & 5.73 \\
\hline yline............ & 6.39 & 3.51 & 3.89 & 4.49 & 3.89 \\
\hline July.......... & 9.59 & 5.67 & 7.15 & 9.70 & 8.84 \\
\hline Alug. & 4.65 & 3.85 & 4.09 & 4.36 & 3.37 \\
\hline Sept.. & 6.68 & 4.57 & 5.77 & 5.30 & 1.90 \\
\hline
\end{tabular}

\begin{tabular}{|c|c|}
\hline $\begin{array}{l}1.00 \\
2.89\end{array}$ & $\begin{array}{r}.72 \\
1.95\end{array}$ \\
\hline $\begin{array}{r}3.13 \\
7.12 \\
3.80 \\
2.56 \\
4.23 \\
10.53 \\
5.82 \\
6.71 \\
6.99 \\
3.58 \\
1.65 \\
1.32\end{array}$ & $\begin{array}{r}1.71 \\
6.58 \\
2.70 \\
1.16 \\
5.32 \\
11.58 \\
8.54 \\
5.77 \\
6.24 \\
2.00 \\
2.19 \\
1.67\end{array}$ \\
\hline $\begin{array}{r}.90 \\
4.63 \\
3.47 \\
3.31 \\
.10 \\
6.35 \\
6.98 \\
4.00 \\
3.13 \\
1.88 \\
6.06 \\
.31\end{array}$ & $\begin{array}{r}.90 \\
2.03 \\
3.49 \\
5.21 \\
1.53 \\
6.23 \\
6.38 \\
4.30 \\
6.40 \\
5.59 \\
.8 .27 \\
.63\end{array}$ \\
\hline $\begin{array}{r}.10 \\
.78 \\
.73 \\
2.92 \\
2.38 \\
6.55 \\
12.77 \\
.85 \\
4.18\end{array}$ & $\begin{array}{r}1.45 \\
1.08 \\
1.43 \\
. .55 \\
2.02 \\
10.46 \\
10.08 \\
1.27 \\
7.17\end{array}$ \\
\hline
\end{tabular}

1.66
1.47

2.35
6.28
1.94
.69
4.99
10.07
4.58
3.50
5.96
2.79
2.58
.93
.
1.15
2.83
4.36
3.05
1.01
5.50
5.48
4.20
7.15
3.32
6.75
.78
2.09
.54
. .55
0.89
9.71
12.61
3.39
5.88

.98

\begin{tabular}{|c|c|}
\hline $\begin{array}{l}1.05 \\
2.39\end{array}$ & $\begin{array}{r}.81 \\
2.58\end{array}$ \\
\hline $\begin{array}{r}4.83 \\
8.35 \\
5.52 \\
1.67 \\
2.59 \\
10.87 \\
6.88 \\
7.99 \\
9.99 \\
3.87 \\
1.07 \\
2.14\end{array}$ & $\begin{array}{r}3.93 \\
7.49 \\
3.71 \\
1.45 \\
4.17 \\
4.51 \\
6.46 \\
4.84 \\
10.49 \\
2.73 \\
1.08 \\
1.21\end{array}$ \\
\hline $\begin{array}{r}2.63 \\
5.13 \\
3.31 \\
4.06 \\
1.65 \\
4.70 \\
5.29 \\
6.27 \\
6.47 \\
6.47 \\
5.44 \\
.87\end{array}$ & $\begin{array}{r}1.01 \\
5.27 \\
2.43 \\
4.92 \\
3.16 \\
4.09 \\
7.05 \\
5.22 \\
9.23 \\
10.90 \\
3.52 \\
.82\end{array}$ \\
\hline $\begin{array}{r}1.44 \\
1.43 \\
1.45 \\
.42 \\
3.43 \\
4.64 \\
8.13 \\
4.24 \\
2.81\end{array}$ & $\begin{array}{r}1.75 \\
2.12 \\
1.38 \\
1.48 \\
4.83 \\
8.12 \\
12.46 \\
4.98 \\
5.49\end{array}$ \\
\hline
\end{tabular}

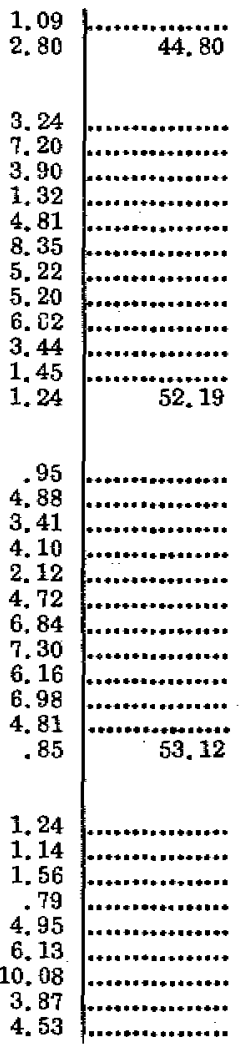

See footnotes at end of table. 
Table 57.- Weighted average precipitation in Kissimme River basin above Okeechobee, by months, computed by the Thiessen method from rainfallstation reconds-Continued

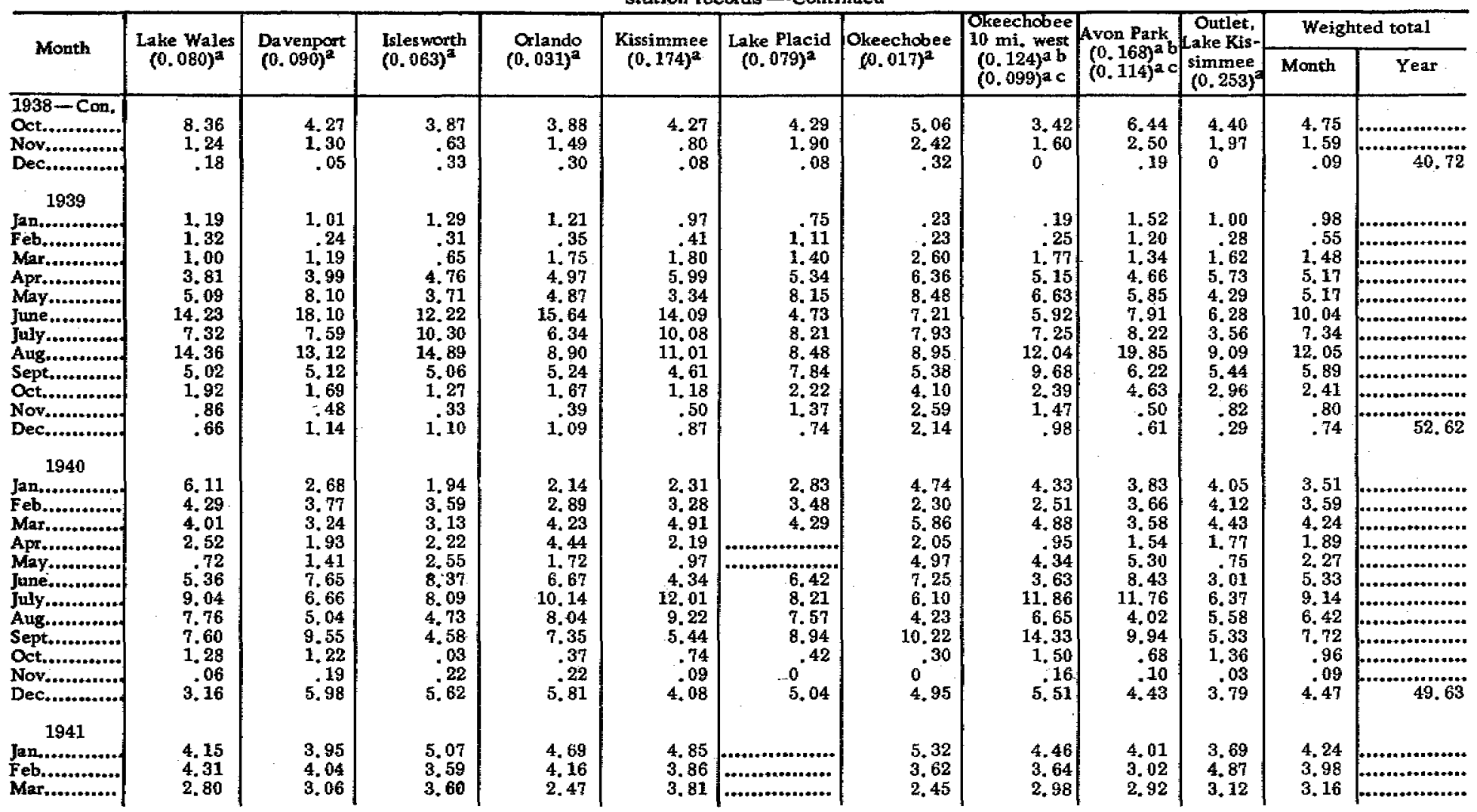




\begin{tabular}{|c|c|c|c|}
\hline $\begin{array}{l}\text { Apr............. } \\
\text { May.......... } \\
\text { June.......... } \\
\text { July............ } \\
\text { Aug........... } \\
\text { Sept.......... } \\
\text { Oct............. } \\
\text { Nov............ } \\
\text { Dec........... }\end{array}$ & $\begin{array}{r}6.35 \\
.81 \\
9.90 \\
10.17 \\
2.44 \\
4.44 \\
2.66 \\
2.87 \\
5.18\end{array}$ & $\begin{array}{r}7.18 \\
1.43 \\
7.74 \\
11.87 \\
6.15 \\
5.23 \\
3.23 \\
3.38 \\
4.83\end{array}$ & $\begin{array}{r}4.76 \\
1.76 \\
9.67 \\
14.50 \\
3.58 \\
5.32 \\
2.71 \\
4.57 \\
2.26\end{array}$ \\
\hline 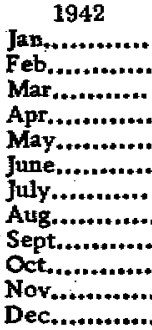 & $\begin{array}{r}2.58 \\
3.48 \\
5.71 \\
2.73 \\
3.26 \\
8.28 \\
5.43 \\
3.88 \\
6.18 \\
.42 \\
.25 \\
4.36\end{array}$ & $\begin{array}{r}2.32 \\
3.51 \\
6.38 \\
2.52 \\
2.61 \\
11.24 \\
9.97 \\
3.51 \\
5.70 \\
.06 \\
.11 \\
2.79\end{array}$ & $\begin{array}{r}2.22 \\
2.95 \\
5.36 \\
1.87 \\
1.31 \\
12.47 \\
6.98 \\
5.03 \\
6.23 \\
.40 \\
.17 \\
2.67\end{array}$ \\
\hline 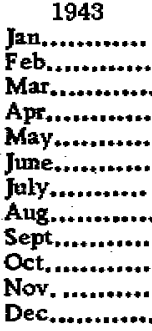 & $\begin{array}{r}.81 \\
.75 \\
4.77 \\
.92 \\
6.34 \\
5.83 \\
11.17 \\
7.72 \\
3.07 \\
2.62 \\
.50 \\
.37\end{array}$ & $\begin{array}{r}1.69 \\
.54 \\
4.34 \\
1.66 \\
5.74 \\
9.25 \\
11.13 \\
5.13 \\
5.98 \\
1.40 \\
.39 \\
.53\end{array}$ & $\begin{array}{r}1.97 \\
.73 \\
5.02 \\
2.21 \\
3.14 \\
8.30 \\
8.80 \\
5.83 \\
10.17 \\
1.50 \\
1.12 \\
1.59\end{array}$ \\
\hline 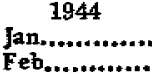 & $\begin{array}{r}.82 \\
.36\end{array}$ & $\begin{array}{r}1.13 \\
.31\end{array}$ & $\begin{array}{r}2.06 \\
.34\end{array}$ \\
\hline
\end{tabular}

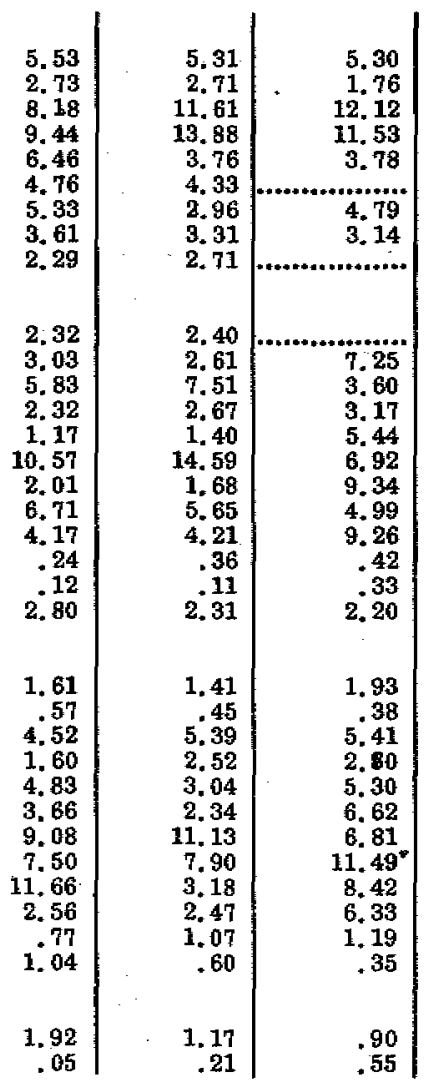

4.90
.90
3.83
12.82
2.24
3.90
6.95
1.95
4.54

1.55
4.30
3.97
2.27
2.67
13.35
4.65
2.53
5.10
.70
.49
2.45

0
.85
4.60
.70
4.90
2.26
6.77
8.20
4.00
3.60
3.67
.26
.44
.25

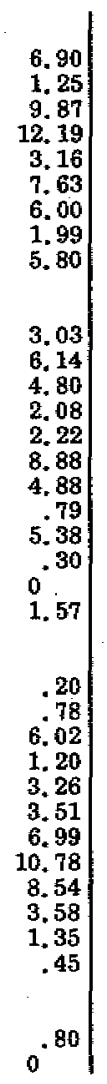

\begin{tabular}{|c|c|}
\hline $\begin{array}{r}4.73 \\
1.04 \\
9.52 \\
15.20 \\
3.11 \\
4.99 \\
2.62 \\
2.49 \\
1.98\end{array}$ & $\begin{array}{r}7.83 \\
.83 \\
9.09 \\
8.02 \\
4.68 \\
6.12 \\
4.04 \\
3.63 \\
3.24\end{array}$ \\
\hline $\begin{array}{l}4.48 \\
4.72 \\
3.86 \\
2.67 \\
6.43 \\
8.52 \\
8.76 \\
5.19 \\
5.37 \\
0.13 \\
3.54\end{array}$ & $\begin{array}{l}2.31 \\
4.06 \\
3.41 \\
2.23 \\
1.40 \\
9.49 \\
4.95 \\
5.04 \\
5.58 \\
1.40 \\
1.16\end{array}$ \\
\hline $\begin{array}{r}1.21 \\
.46 \\
4.94 \\
1.69 \\
8.83 \\
5.76 \\
7.86 \\
10.02 \\
3.98 \\
4.35 \\
1.32 \\
.59\end{array}$ & $\begin{array}{r}1.63 \\
.40 \\
3.81 \\
2.47 \\
4.28 \\
6.75 \\
13.00 \\
5.63 \\
5.34 \\
3.36 \\
1.16 \\
.24\end{array}$ \\
\hline $\begin{array}{r}1.25 \\
.79\end{array}$ & $\begin{array}{r}1.02 \\
.39\end{array}$ \\
\hline
\end{tabular}
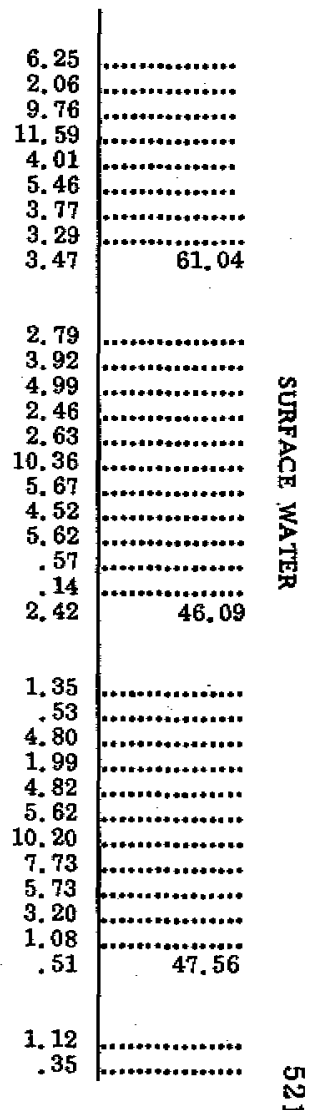
Table 57.- Feighted average precipitation in Kissimmee River basin ajove Okeechobee, by months, computed by the Thiessen method from rainfallstation records-Continued

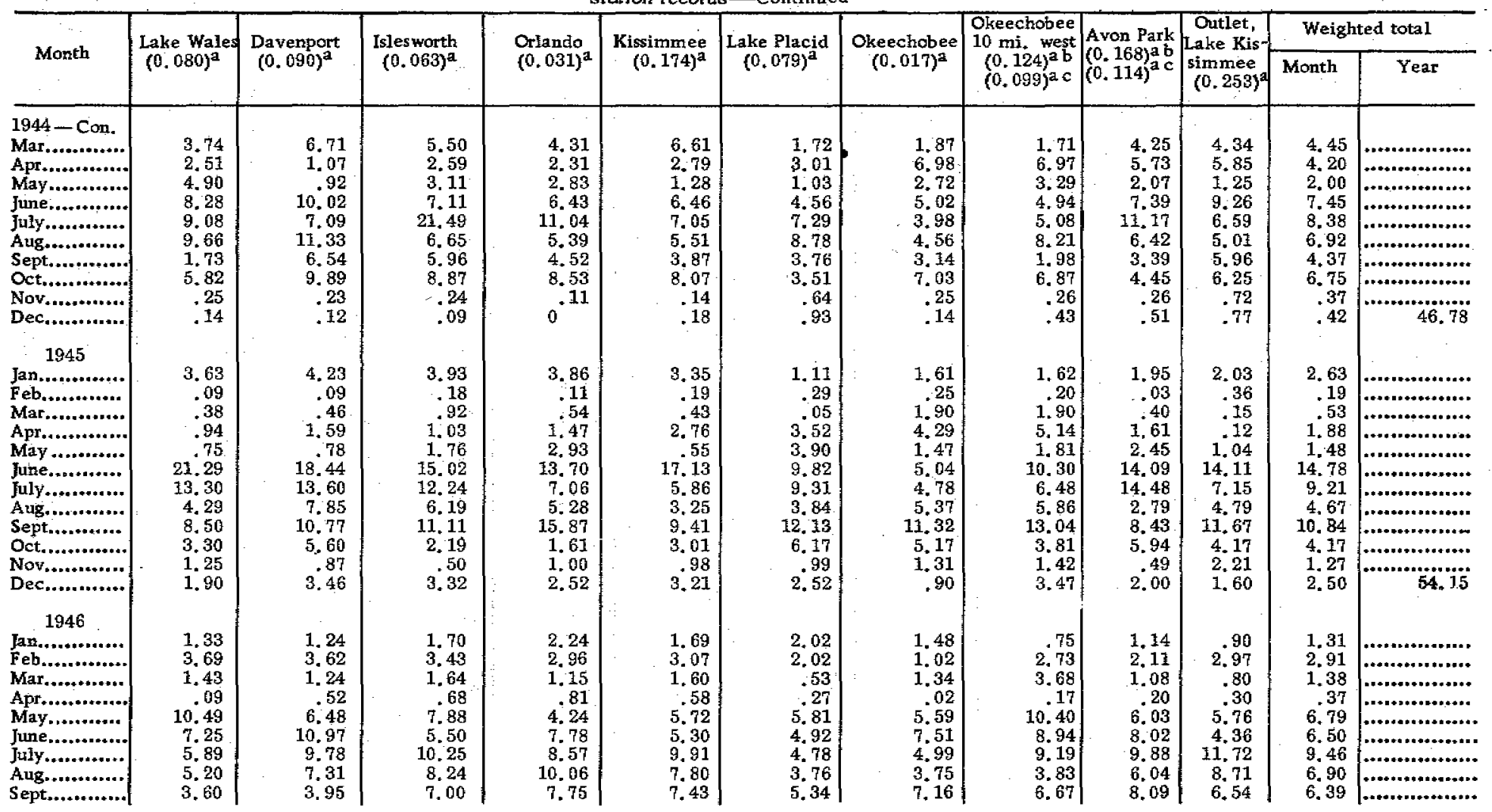




\begin{tabular}{|c|c|c|c|c|c|c|c|c|c|c|c|c|}
\hline $\begin{array}{l}\text { Oct.............. } \\
\text { Nov............. } \\
\text { Dec............ }\end{array}$ & $\begin{array}{r}2.67 \\
1.33 \\
.83\end{array}$ & $\begin{array}{r}2.11 \\
.97 \\
1.89\end{array}$ & $\begin{array}{l}2.58 \\
1.04 \\
2.34\end{array}$ & $\begin{array}{r}3.32 \\
.97 \\
.28\end{array}$ & $\begin{array}{r}2.92 \\
1.75 \\
.98\end{array}$ & $\begin{array}{r}1.99 \\
2.63 \\
.50\end{array}$ & $\begin{array}{l}1.86 \\
1.50 \\
1.23\end{array}$ & $\begin{array}{r}1.92 \\
2.71 \\
.99\end{array}$ & $\begin{array}{l}4.74 \\
2.06 \\
1.31\end{array}$ & $\begin{array}{r}1.93 \\
.44 \\
1.05\end{array}$ & $\begin{array}{l}2.58 \\
1.45 \\
1.15\end{array}$ & $\begin{array}{r}47.19 \\
4\end{array}$ \\
\hline
\end{tabular}

a Proportional weights assigned to precipitation. Sum equals unity.

b Through February 1933 .

CBeginning March 1933 .

dUsed for months of April and May 1940; January, February, March, September, December, 1941; and January 1942.

ERecord at Lake Alfred, June-December 1946.

fRecord at Otiando Airport, May 1944 to December 1946. 
Table 58. Wumber of rain gages used to detemine precipitation in given drainage basins

\begin{tabular}{|c|c|c|c|}
\hline Location & $\begin{array}{l}\text { Number of } \\
\text { rain gages }\end{array}$ & $\begin{array}{c}\text { Area } \\
\text { (square miles) }\end{array}$ & $\begin{array}{l}\text { Square miles } \\
\text { per rain gage }\end{array}$ \\
\hline 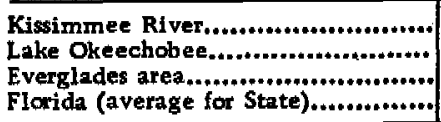 & $\begin{array}{r}a_{10} \\
a_{5} \\
a_{20} \\
b_{119}\end{array}$ & $\begin{array}{r}3,260 \\
800 \\
3,900 \\
54,861\end{array}$ & $\begin{array}{l}326 \\
160 \\
195 \\
461\end{array}$ \\
\hline
\end{tabular}

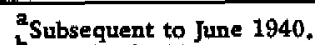

b As published by U. $\$$. Weather Bureau in 1946 climatological summary.

rainfall distribution. Rains of appreciable duration seldom occur; however, during the rainy season, showers of high intensity and narrow width pass across the peninsula at varying speed. Possibly of equal importance is the inadequacy of using mean areal precipitation in studies of rainfall and runoff relations over relatively large areas. For example, a heavy rainfall over the more saturated areas will produce a larger volume of runoff than it will over the relatively absorbent area.

An evaporation pan has been maintained by the Soil Conservation Service and the Florida Experiment Station at Belle Glade since 1924. It is a standard Weather Bureau Class A land pan (Kadel, $1919)$ and is the oldest in the region for which early records are available. Measurements from four sunken pans in the vicinity of Lake Okeechobee were begun by the Corps of Engineers in 1937. During the period $1940-46,10$ evaporation stations were in operation in the area. A compilation of selected evaporation records, including a description of the pans, is given in tables 8,9 , and 10 . For a discussion of the regional climatologic characteristics, see the section on Climate.

KISSIMMEE RIVER BASIN

\section{EXPLANATION OF METHODS}

SEPARATION OF DIRECT AND BASE FLOW

Base flow is the gradually varying or sustained component of streamflow. It responds slowly to seasonal rainfall, and on it are superimposed relatively abrupt peaks, closely associated with periods of rainfall, which represent direct runoff. Rivers, lakes, swamps, and ground water in southern Florida merge to such an extent that it is impossible to ascribe particular sources for base and direct flow, and the distinction between them, which is at times obscure, is one of time-characteristics.

The separation of direct and base flow has been approximated graphically by plotting a hydrograph of daily mean discharges for each year of record. On these graphs the daily precipitation at one 


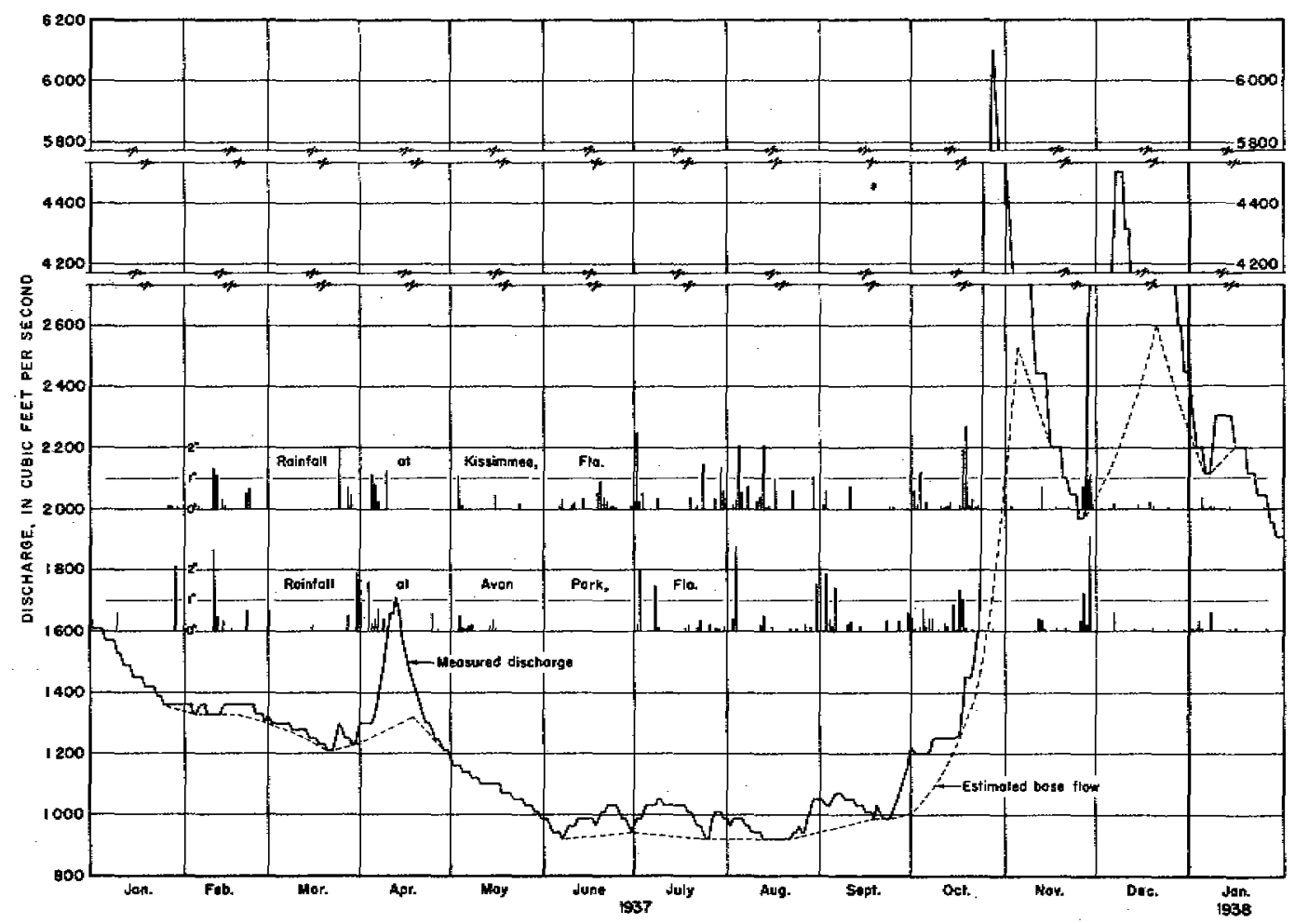

Figure 150. - Hydrograph of Kissimmee River near Okeechobee, 1937. 


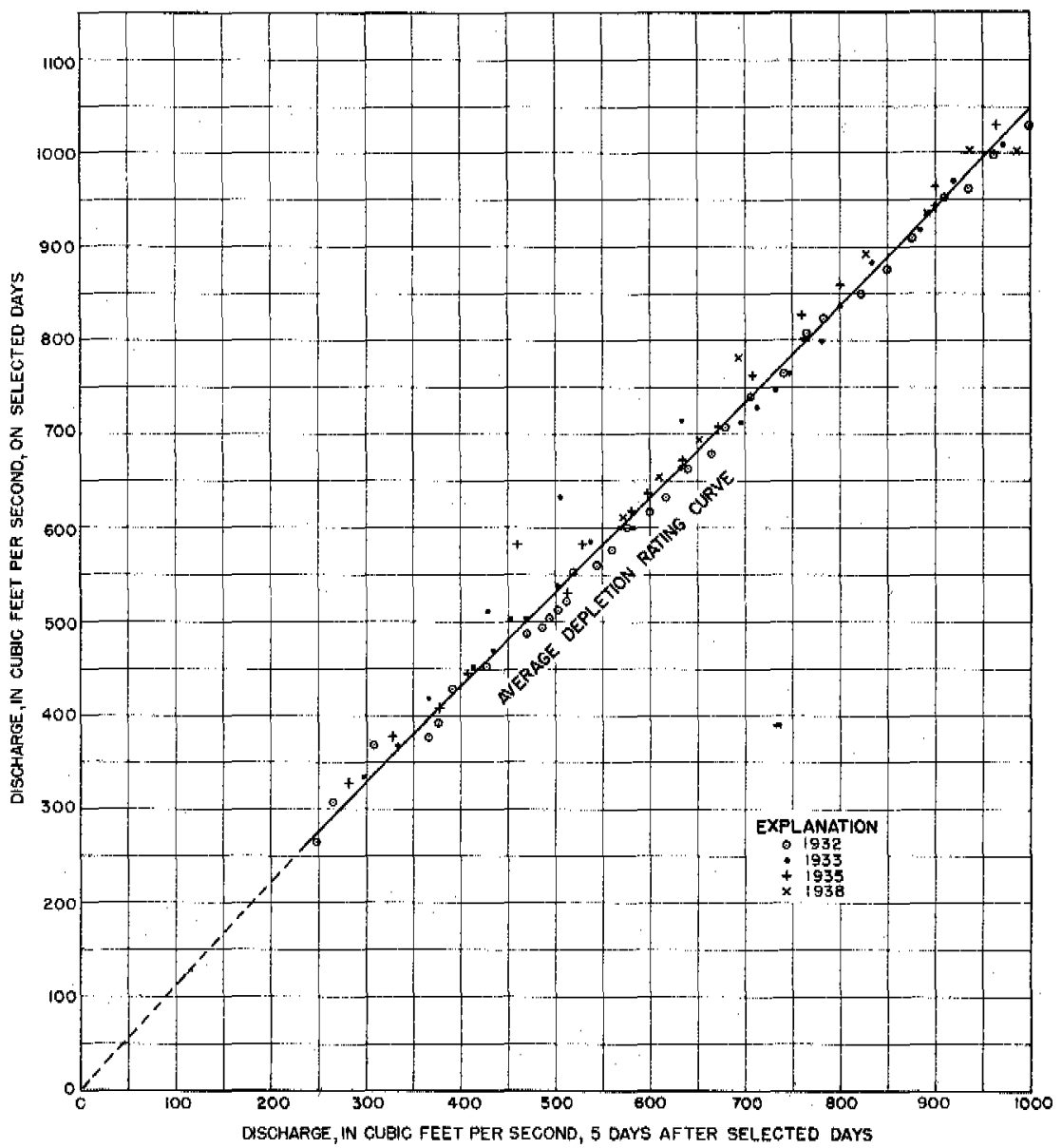

Figure 151. - Lower part of depletion rating curve, Kissimmee River near Okeechobee.

or two places in the basin has also been plotted. Figure 150 is a sample of such a hydrograph.

The basic method was originally described by Houk (1921, p. 165) and later by Meinzer and Stearns (1929, p. 107-116).

The depletion hydrograph, prepared from a study of the decline in stream discharge during rainless periods, is a useful guide for the separation of base flow. However, long rainless periods with an accompanying uninterrupted decline of base flow from high to low flows seldom occur in humid regions, and it is generally necessary to build up a depletion rating curve using segments of hydrographs covering different rainless periods. In selecting these segments of hydrographs, care is exereised to allow sufficient time after rainfall for all direct runoff to be discharged from the basin. In the Kissimmee River basin 10 days was allowed. Having selected hydrograph segments representing apparently normal depletion, discharge at a given time was plotted as ordinate against discharge 


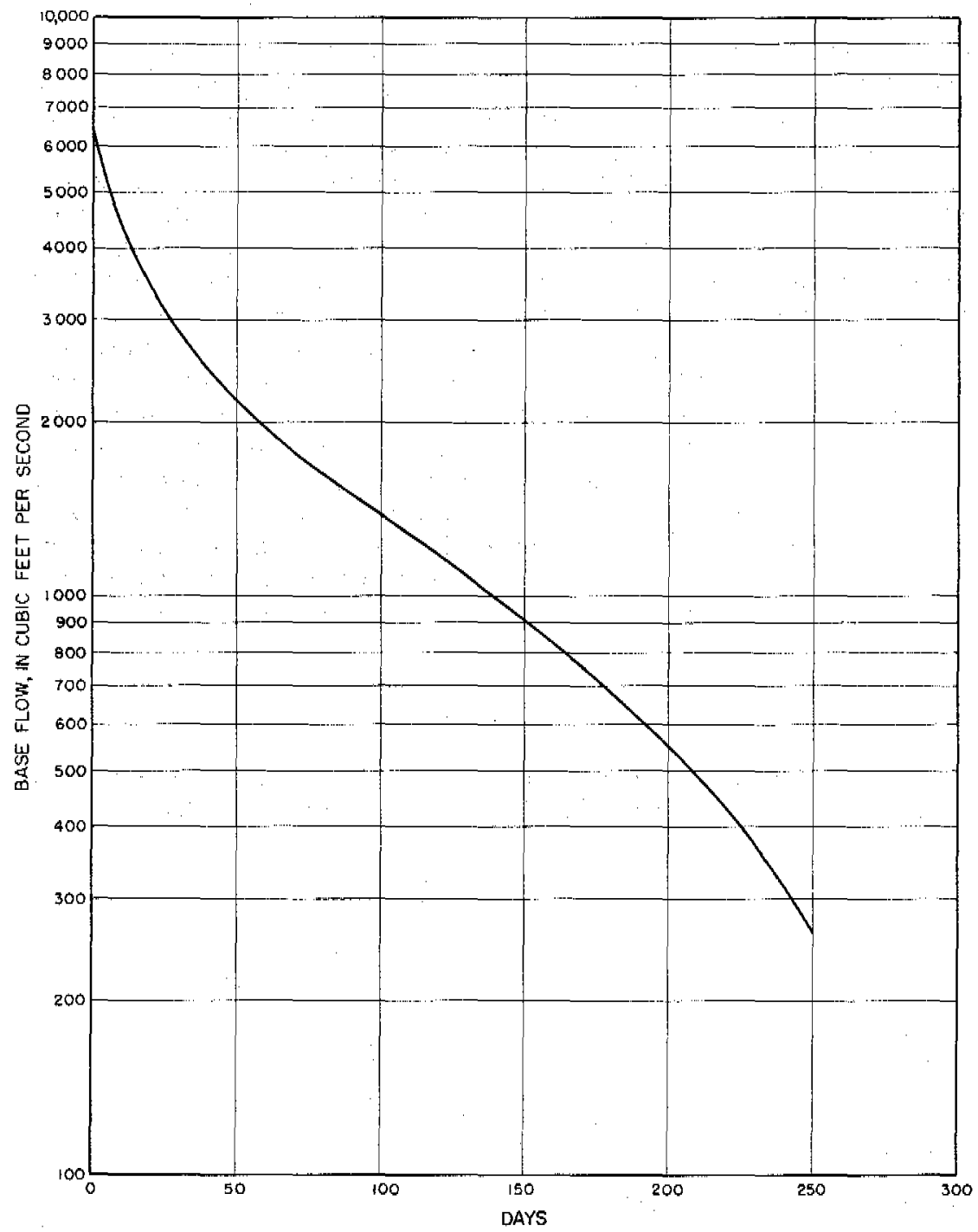

Figure 152, - Average depletion hydrograph, Kissimmee River near Okeechobee.

5 days later as abscissa. A number of points were thereby defined and an average depletion rating curve drawn giving more weight to those points plotting to the right, as it is believed that points that are plotted inconsistently to the left might represent direct flow. The lower portion of this curve is shown in figure 151. From this depletion rating curve a depletion hydrograph was readily prepared by plotting the depletion discharges at 5 -day intervals as obtained from the curve (see fig. 152).

The depletion hydrograph so derived was an important aid in locating the position of the graph of base flow on the basis that segments of the observed hydrograph that conform with the depletion 
hydrograph represent base flow, For example, see figure 150 . The depletion hydrograph (used as a template) was placed along a recession limb of the discharge hydrograph, and a line was drawn to coincide with the lower part of the recession. This line was then extended upward. The difference between the extended depletion hydrograph and the total flow is presumed to represent drainage occurring as direct runoff. A point on the extended depletion hydrograph, generally 10 days after the end of rainfall, was selected as the peak of base flow. This point was then connected, usually by a straight line, with the base flow line at the beginning of the rise. There is considerable uncertainty about base flow during flood periods, and the longer the stream remains at flood stage the greater the uncertainty. During flood, the flow from ground water into the streams or drainage channels may be checked or even reversed because the water level of the streams is likely to be higher than the adjacent water table. On the other hand, floods are also periods of ground-water recharge by direct downward percolation to the water table; therefore, the net effect is problematical.

\section{BASE STORAGE}

The depletion hydrograph, representing drainage from ground water, swamps, and lakes during long rainless periods of no re-

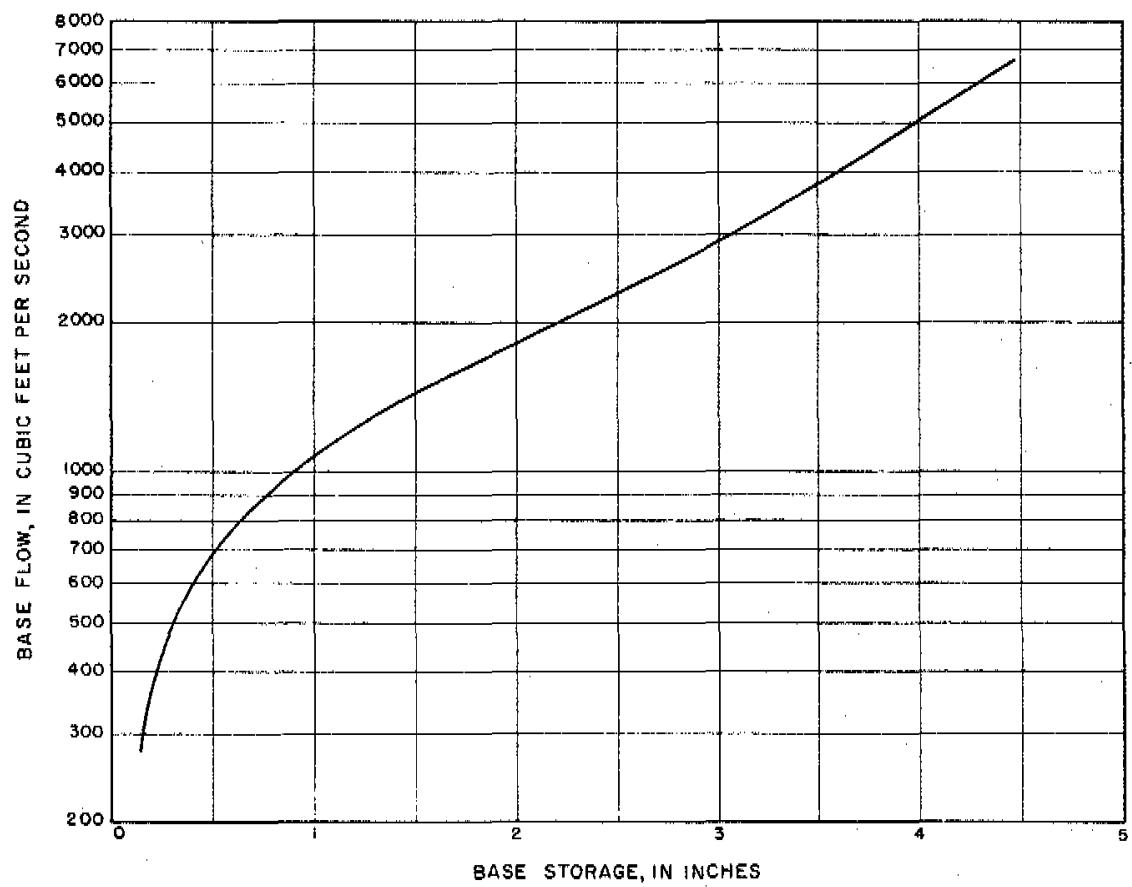

Figure 153. - Relation between rate of base flow and base storage, Kissimmee River near Okeechobee. 


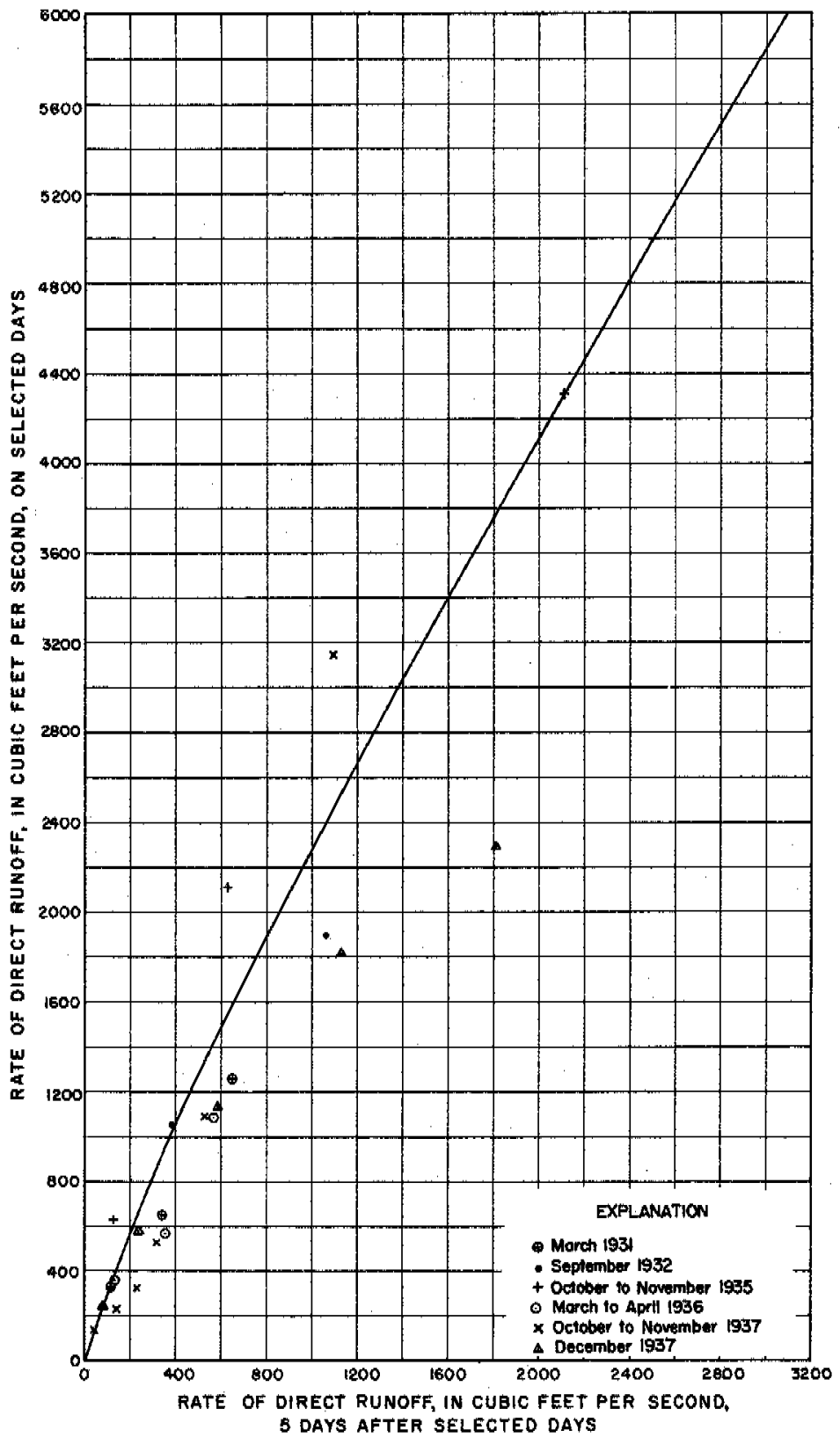

Figure 154. - Recession rating curve of direct runoff, Kissimmee River near Okeechobee. 
charge, is a hydrograph of discharge from the water bodies maintaining base flow. The rate of this drainage is an indication of the rate at which storage in those water bodies is being depleted, and the rate of drainage, as well as storage, decreases with time. Therefore, it seems appropriate to associate rate of drainage with that part of the storage yet remaining that will appear as runofi. This has been done by plotting values of ordinates to the depletion hydrograph against the area under the graph to the right of the ordinate. Figure 153 shows the base-storage curve, as it is called, for the Kissimmee River basin, with the volumes of storage expressed in inches.

\section{DIRECT-RUNOFF STORAGE}

A recession hydrograph for direct runoff, representing water generally in transit during and soon after the cessation of rainfall, was prepared in a manner similar to the depletion hydrograph. Direct runoff is the ordinate between the base-flow line and the hydrograph of total discharge (fig. 150). Only points on the recession limb of the hydrograph were used. In preparing the normal

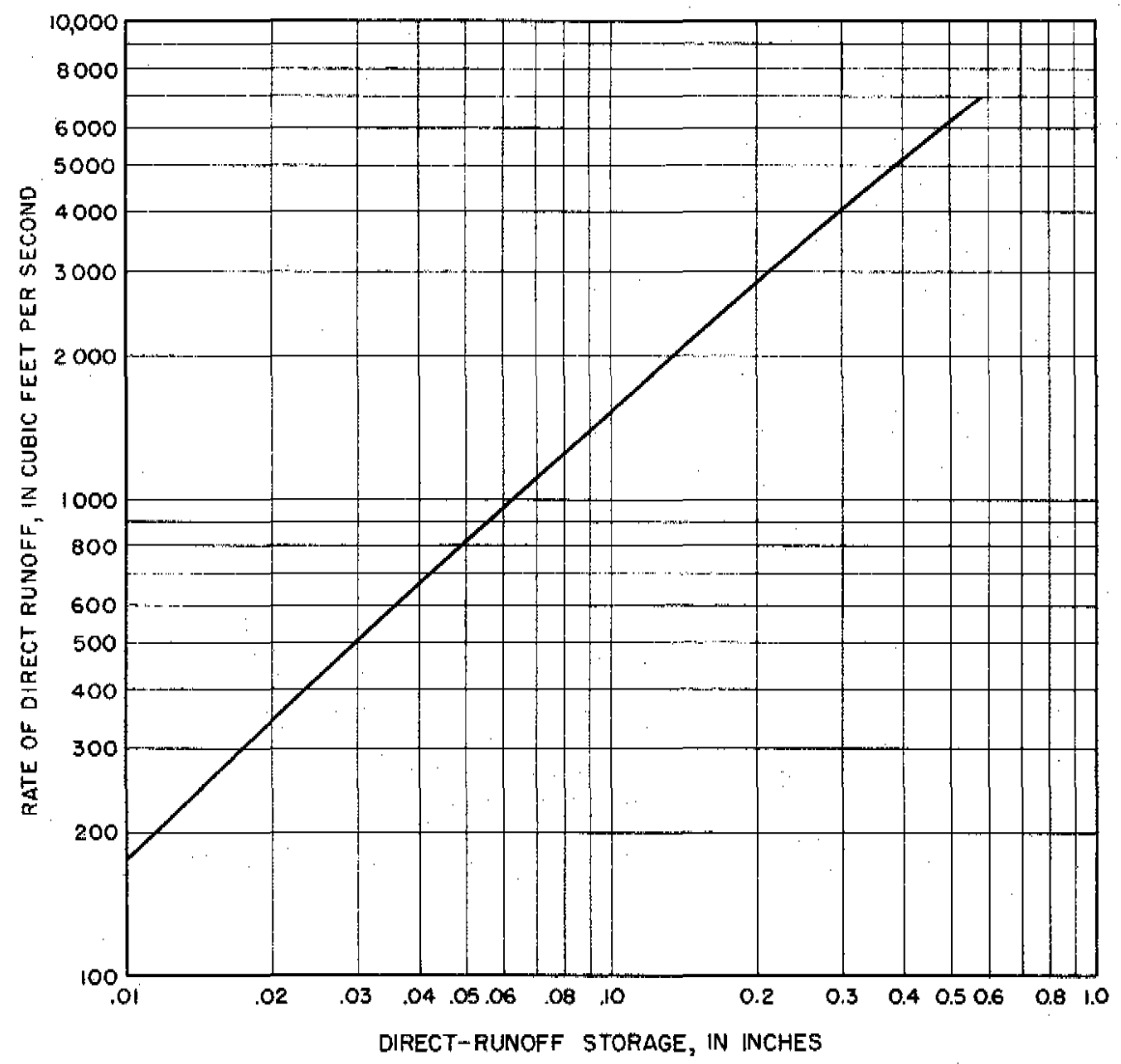

Figure 155. -Direct-runoff storage, Kissimmee River near Okeechobee. 
recession graph (see fig. 154), preference was given to hydrograph segments showing the most rapid rate of drainage; those few hydrographs that declined so rapidly as to be indicative of drainage that occurs in only parts of the drainage basins were disregarded.

A storage curve of direct runoff (see fig. 155) was constructed in the same manner as the base-storage curve described in the preceding paragraphs.

\section{ANNUAL BUNOFF ANALYSES}

The runoff of the Kissimmee River basin $(3,260$ square miles), as measured at the gaging station near Okeechobee, represents about 65 percent of the inflow to Lake Okeechobee. The general characteristics of the basin as they affect the runoff are described in the previous section.

The average annual rainfall for the period $1931-46$ is 49.54 in., and the mean deviation from the average is 4.6 in. (9.3 percent of the average). During this period the annual runoff ranged from $3.52 \mathrm{in.}$ in 1932 to $11.86 \mathrm{in}$. in 1934 (table 61 ), and the average annual runoff is $7.13 \mathrm{in}$. The mean deviation from the average is 1.98 in., 28 percent of the average, in comparison with a 9 -percent mean deviation in precipitation, illustrating the relatively greater fluctuation in runoff.

For the 12-year period 1935-46, annual runoff of the Kissimmee River averaged 6.87 in., broken down as follows: Runoff of Kissimmee River below the outlet of Lake Kissimmee (1,850 square miles), 6.98 in.; runoff of Istokpoga Canal near Cornwell (660 square miles), 8.06 in.; and runoff from the 750 -square mile intervening area just above the gaging station near Okeechobee, only $5.52 \mathrm{in.}$ This reflects in large part the lesser amount of rainfall in the lower part of the basin.

Annual runoff of the Kissimmee River, in inches, has been plotted against mean areal rainfall, as shown on figure 156. As a partial explanation of the scattering of the points there has been indicated, next to each plotted point, the rate of estimated base flow, in second-feet, at the close of the preceding year, as an index of moisture conditions then prevailing. This study shows that the volume of annual runoff is much affected, not only by the amount of precipitation representing the supply but also by antecedent moisture conditions. A correlation analysis showed that annual runoff equals approximately $0.51\left(0.7 P_{0}+0.3 P_{1}\right)-18.32$, in which $P_{0}$ is the total precipitation of the current year and $p_{1}$ is the precipitation during the preceding year. The same study showed that precipitation during the second preceding year had virtually little, if any, influence. The distribution of precipitation among the 


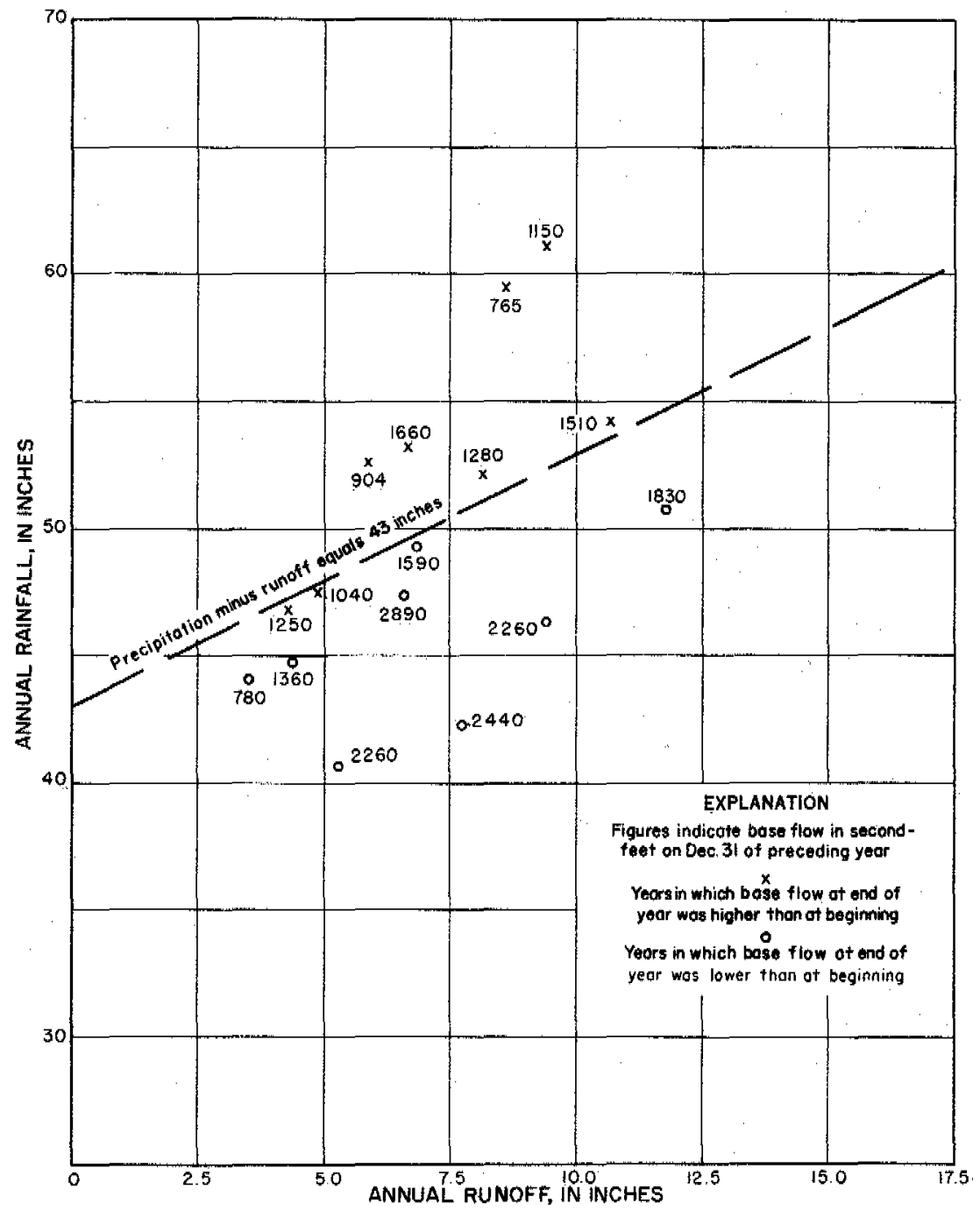

Figure 156. - Annual rainfall-runoff relation, Kissimmee River near Okeechobee.

seasons, also an important factor, is best studied by the preparation of rainfall-runoff diagrams by months.

Base flow, as listed in table 59, averages 88 percent of the total runoff. Comparison of this ratio with that for the adjoining Peace Creek basinillustrates the effect of terrain upon streamflow. Peace Creek, draining a relatively narrow valley, discharges only 62 percent of its runoff as base flow. 
Table 59. - Monthly runoff analyses, Kissimmee River near Okeechobee, 1930-16

\begin{tabular}{|c|c|c|c|c|c|c|c|c|c|c|}
\hline Month & $\begin{array}{c}\text { Total } \\
\text { runoff } \\
\text { (inches) }\end{array}$ & $\begin{array}{l}\text { Discharge at } \\
\text { end of month } \\
\text { (cfs) }\end{array}$ & $\begin{array}{l}\text { Base runoff } \\
\text { (inches) }\end{array}$ & $\begin{array}{l}\text { Base flow at } \\
\text { end of month } \\
\text { (cfs) }\end{array}$ & $\begin{array}{l}\text { Base storage } \\
\text { at end of month } \\
\text { (inches) }\end{array}$ & $\begin{array}{l}\text { Direct-runoff } \\
\text { (inches) }\end{array}$ & $\begin{array}{l}\text { Direct-rumoff } \\
\text { discharge at } \\
\text { end of month } \\
\text { (cfs) }\end{array}$ & $\begin{array}{l}\text { Direct-runoff } \\
\text { storage at end } \\
\text { of month } \\
\text { (inches) }\end{array}$ & $\begin{array}{c}\text { Rainfali } \\
\text { (from table } 56, \\
\text { in inches) }\end{array}$ & $\begin{array}{c}\text { Evaporation } \\
\text { (from Belle } \\
\text { Glade pan, } \\
\text { in inches) }\end{array}$ \\
\hline $\begin{array}{c}1930 . \\
\text { Oct................. } \\
\text { Nov................ } \\
\text { Dec............. }\end{array}$ & $\begin{array}{r}1.60 \\
1.15 \\
.93\end{array}$ & $\begin{array}{l}4,400 \\
2,720 \\
2,640\end{array}$ & $\begin{array}{r}1.16 \\
1.04 \\
.88\end{array}$ & $\begin{array}{l}3,520 \\
2,675 \\
2,440\end{array}$ & $\begin{array}{l}3.34 \\
2.81 \\
2.63\end{array}$ & $\begin{array}{r}0.44 \\
.11 \\
.05\end{array}$ & $\begin{array}{r}880 \\
45 \\
200\end{array}$ & $\begin{array}{l}0.05 \\
0 \\
.01\end{array}$ & $\begin{array}{l}1.89 \\
1.91 \\
3.94\end{array}$ & $\begin{array}{l}4.89 \\
3.64 \\
3.37\end{array}$ \\
\hline 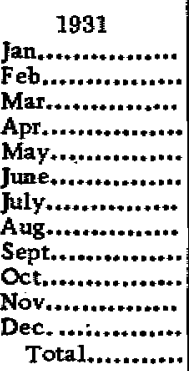 & $\begin{array}{l}1.01 \\
.88 \\
1.10 \\
.97 \\
.84 \\
.57 \\
.45 \\
.40 \\
.44 \\
.41 \\
.35 \\
.31 \\
7.73\end{array}$ & $\begin{array}{r}3,210 \\
2,370 \\
2,250 \\
3,690 \\
1,870 \\
1,480 \\
1,160 \\
1,180 \\
1,260 \\
1,140 \\
935 \\
782\end{array}$ & $\begin{array}{r}.86 \\
.77 \\
.88 \\
.77 \\
.15 \\
.56 \\
.45 \\
.40 \\
.41 \\
.41 \\
.35 \\
.31 \\
6.92\end{array}$ & $\begin{array}{r}2,440 \\
2,360 \\
2,250 \\
2,360 \\
1,810 \\
1,480 \\
1,160 \\
1,150 \\
1,260 \\
1,140 \\
935 \\
780\end{array}$ & $\begin{array}{l}2.63 \\
2.57 \\
2.46 \\
2.57 \\
2.07 \\
1.59 \\
1.13 \\
1.11 \\
1.27 \\
1.10 \\
.82 \\
.62\end{array}$ & $\begin{array}{l}.15 \\
.11 \\
.22 \\
.20 \\
.09 \\
.01 \\
.0 \\
0 \\
.03 \\
0 \\
0 \\
0 \\
.81\end{array}$ & $\begin{array}{r}770 \\
10 \\
0 \\
1,330 \\
0 \\
0 \\
0 \\
30 \\
0 \\
0 \\
0 \\
2\end{array}$ & $\begin{array}{l}.05 \\
0 \\
0 \\
0 \\
0 \\
0 \\
0 \\
0 \\
0 \\
0 \\
0 \\
0\end{array}$ & $\begin{array}{r}3.43 \\
1.40 \\
4.29 \\
5.58 \\
3.36 \\
1.93 \\
5.59 \\
6.79 \\
-5.03 \\
1.92 \\
.25 \\
2.72 \\
42.29\end{array}$ & $\begin{array}{r}3.21 \\
3.46 \\
4.72 \\
4.91 \\
6.59 \\
7.05 \\
7.49 \\
6.32 \\
5.30 \\
4.54 \\
3.78 \\
3.32 \\
60.69\end{array}$ \\
\hline 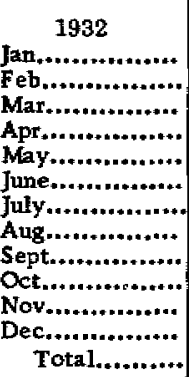 & $\begin{array}{l}.26 \\
.20 \\
.18 \\
.13 \\
.12 \\
.27 \\
.19 \\
.30 \\
.73 \\
.45 \\
.38 \\
.31 \\
3.52\end{array}$ & $\begin{array}{r}656 \\
552 \\
452 \\
308 \\
520 \\
953 \\
418 \\
1,260 \\
1,500 \\
1,250 \\
1,0010 \\
765\end{array}$ & $\begin{array}{l}.26 \\
.20 \\
.17 \\
.13 \\
.10 \\
.16 \\
.15 \\
.28 \\
.45 \\
.45 \\
.38 \\
.31 \\
3.04\end{array}$ & $\begin{array}{r}656 \\
552 \\
440 \\
308 \\
400 \\
485 \\
418 \\
1,120 \\
1,500 \\
1,250 \\
1,010 \\
765\end{array}$ & $\begin{array}{r}.47 \\
.36 \\
.25 \\
.15 \\
.22 \\
.29 \\
.24 \\
1.07 \\
1.61 \\
1.26 \\
.91 \\
.60\end{array}$ & $\begin{array}{l}0 \\
0 \\
.01 \\
0 \\
.02 \\
.11 \\
.04 \\
.02 \\
.28 \\
0 \\
0 \\
0 \\
.48\end{array}$ & $\begin{array}{r}0 \\
0 \\
12 \\
0 \\
120 \\
468 \\
0 \\
140 \\
0 \\
0 \\
0 \\
0\end{array}$ & $\begin{array}{l}0 \\
0 \\
0 \\
0 \\
.01 \\
.03 \\
0.01 \\
0 \\
0 \\
0 \\
0 \\
0 \\
0\end{array}$ & $\begin{array}{r}.60 \\
.35 \\
2.75 \\
.97 \\
8.03 \\
8.83 \\
4.32 \\
9.20 \\
3.17 \\
2.28 \\
3.50 \\
4.10 \\
44.20\end{array}$ & $\begin{array}{r}3.55 \\
4.02 \\
5.60 \\
6.72 \\
7.15 \\
5.13 \\
7.09 \\
6.22 \\
5.14 \\
5.34 \\
3.42 \\
3.47 \\
62.85\end{array}$ \\
\hline
\end{tabular}


Table 59.-Monthly runoff analyses, Kissimmee River near Okeechobee, 1930_46-Continued

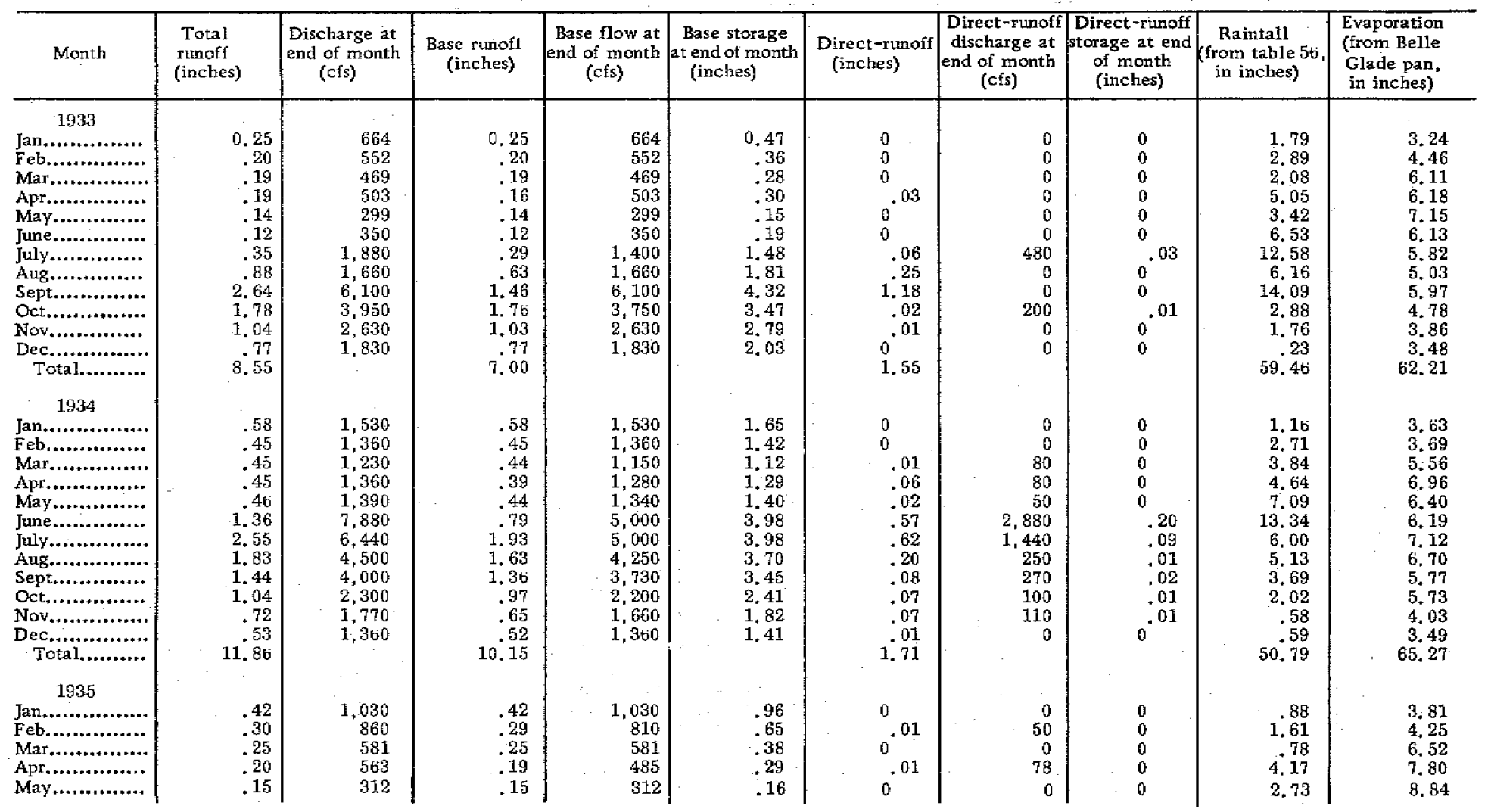




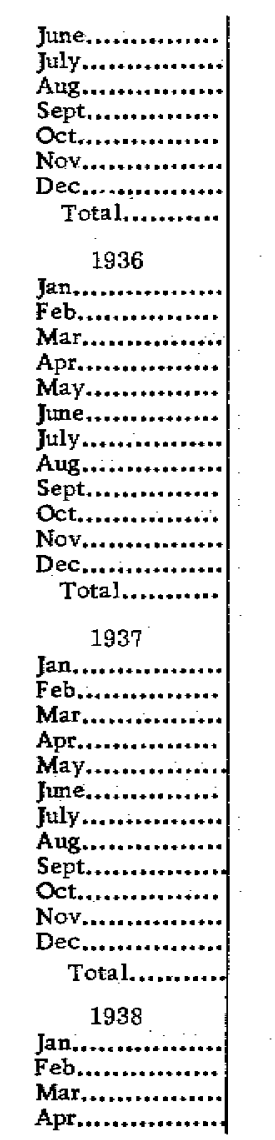

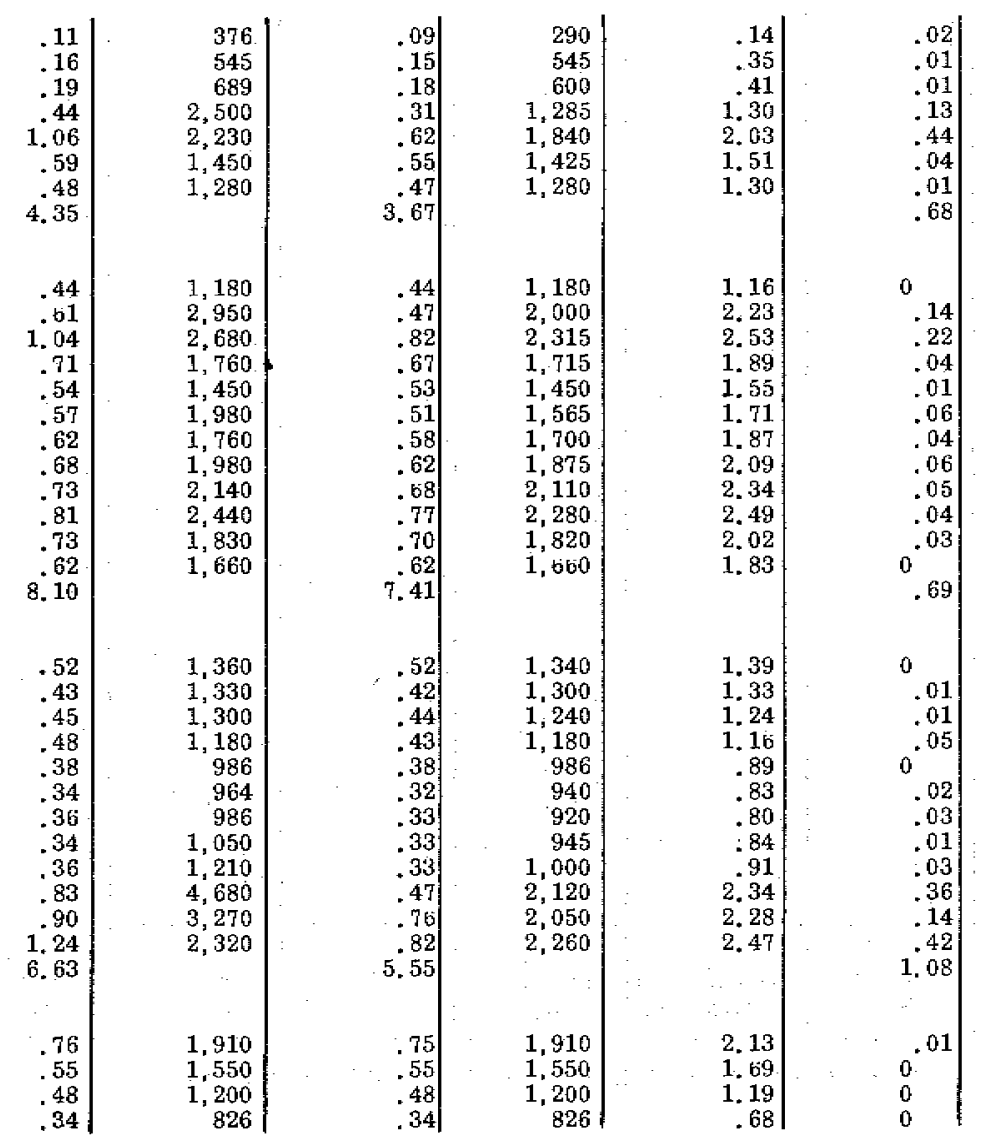

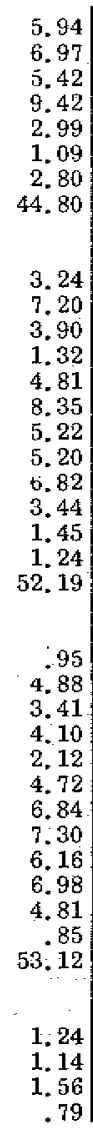

6. 55

7. 38

7.02

5. 54

5,37

4. 32

3.50
70.90

4. 18

3. 81

6. 22

7.68

7.40

5. 94

7.37
6.54

4.92

5. 15

4. 28

3. 14

bo. 63

4. 44

4.44
3,86

5. 30

6.30

7. 77

6. 70

6. bb

6.02

5. 58

4. 93

$3.7 \mathrm{~b}$

3. 12

64. 44

3. 69

4. 22

5.85

ש 
Table 59. - Wonthly runoff analyses, Kissimmee River near Okeechobee, 1930-46-Continued

\begin{tabular}{|c|c|c|c|c|c|c|c|c|c|c|}
\hline Month & $\begin{array}{c}\text { Total } \\
\text { Funoff } \\
\text { (inches) }\end{array}$ & $\begin{array}{l}\text { Discharge at } \\
\text { end of month } \\
\text { (cfs) }\end{array}$ & $\begin{array}{l}\text { Base runoff } \\
\text { (inches) }\end{array}$ & $\begin{array}{l}\text { Base flow at } \\
\text { end of month } \\
\text { (cfs) }\end{array}$ & $\begin{array}{l}\text { Base storage } \\
\text { at end of month } \\
\text { (inches) }\end{array}$ & $\begin{array}{c}\text { Direct-runoff } \\
\text { (inches) }\end{array}$ & $\begin{array}{l}\text { Direct-rimolt } \\
\text { discharge at } \\
\text { end of month } \\
\text { (cfs) }\end{array}$ & $\begin{array}{l}\text { Direct-rumoff } \\
\text { torage at end } \\
\text { of month } \\
\text { (inches) }\end{array}$ & $\begin{array}{l}\text { Rainfall } \\
\text { (from table 56, } \\
\text { in inches) }\end{array}$ & $\begin{array}{l}\text { Evaporation } \\
\text { (fram Belle } \\
\text { Glade pan; } \\
\text { in inches). }\end{array}$ \\
\hline $\begin{array}{l}1938-\text { Con. } \\
\text { May................ } \\
\text { Jure............... } \\
\text { July................ } \\
\text { Autg.............. } \\
\text { Sept.............. } \\
\text { Oct................ } \\
\text { Nov............... } \\
\text { Dec............... } \\
\text { Tota1.......... }\end{array}$ & $\begin{array}{r}0.24 \\
.26 \\
.37 \\
.55 \\
.42 \\
.48 \\
.46 \\
.36 \\
5.27\end{array}$ & $\begin{array}{r}673 \\
826 \\
1,590 \\
1,960 \\
1,180 \\
1,650 \\
1,140 \\
904\end{array}$ & $\begin{array}{r}0.24 \\
.23 \\
.36 \\
.51 \\
.42 \\
.40 \\
.44 \\
.36 \\
5.08\end{array}$ & $\begin{array}{r}590 \\
720 \\
1,350 \\
1,360 \\
1,180 \\
1,400 \\
1,130 \\
904\end{array}$ & $\begin{array}{r}-0.40 \\
1.54 \\
1.41 \\
1.41 \\
1.17 \\
1.46 \\
1.08 \\
.79\end{array}$ & $\begin{array}{c}0 \\
.03 \\
.01 \\
.04 \\
0 \\
.08 \\
.02 \\
0 \begin{array}{r}.02 \\
.19\end{array}\end{array}$ & $\begin{array}{r}83 \\
106 \\
240 \\
0 \\
0 \\
250 \\
10 \\
0\end{array}$ & $\begin{array}{l}0.01 \\
.01 \\
0 \\
0 \\
0.01 \\
0 \\
0 \\
0\end{array}$ & $\begin{array}{r}4.95 \\
6.13 \\
10.08 \\
3.87 \\
4.53 \\
4.75 \\
1.59 \\
.09 \\
40.72\end{array}$ & $\begin{array}{l}6.66 \\
6.50 \\
6.64 \\
6.75 \\
5.92 \\
5.34 \\
4.08 \\
3.96 \\
65.79\end{array}$ \\
\hline 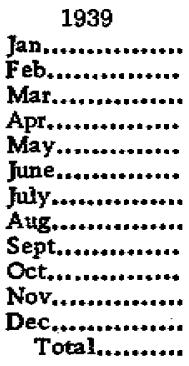 & $\begin{array}{r}.29 \\
.21 \\
.17 \\
.14 \\
.13 \\
.11 \\
.36 \\
.70 \\
1.20 \\
1.11 \\
.82 \\
.64 \\
5.88\end{array}$ & $\begin{array}{r}744 \\
587 \\
406 \\
456 \\
282 \\
586 \\
828 \\
4,510 \\
4,510 \\
2,520 \\
2,070 \\
1,630\end{array}$ & $\begin{array}{r}.29 \\
.21 \\
.17 \\
.13 \\
.12 \\
.10 \\
.25 \\
.46 \\
.89 \\
1.04 \\
.80 \\
.64 \\
5.10\end{array}$ & $\begin{array}{r}744 \\
587 \\
406 \\
380 \\
282 \\
390 \\
828 \\
2,460 \\
2,920 \\
2,520 \\
2,050 \\
1,590\end{array}$ & $\begin{array}{r}.58 \\
.39 \\
.22 \\
.20 \\
.14 \\
.21 \\
.69 \\
2.66 \\
3.00 \\
2.70 \\
2.28 \\
1.74\end{array}$ & $\begin{array}{l}0 \\
0 \\
0 \\
.01 \\
.01 \\
.01 \\
.11 \\
.24 \\
.31 \\
.07 \\
.02 \\
0.78 \\
.78\end{array}$ & $\begin{array}{r}0 \\
0 \\
0 \\
76 \\
0 \\
146 \\
0 \\
2.050 \\
1,590 \\
0 \\
20 \\
40\end{array}$ & $\begin{array}{l}0 \\
0 \\
0 \\
0 \\
0 \\
.01 \\
0^{-01} \\
.14 \\
0 \\
0 \\
0 \\
0 \\
0\end{array}$ & $\begin{array}{r}.98 \\
.55 \\
1.48 \\
5.17 \\
5.17 \\
10.04 \\
7.34 \\
12.05 \\
5.89 \\
2.41 \\
.80 \\
.74 \\
52.62\end{array}$ & $\begin{array}{r}3.88 \\
4.98 \\
6.12 \\
7.46 \\
7.48 \\
6.97 \\
6.62 \\
5.26 \\
5.76 \\
5.09 \\
3.94 \\
3.31 \\
66.87\end{array}$ \\
\hline 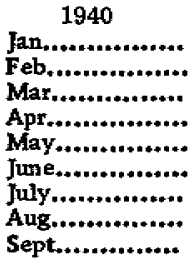 & $\begin{array}{l}.57 \\
.50 \\
.52 \\
.51 \\
.40 \\
.36 \\
.49 \\
.63 \\
.93\end{array}$ & $\begin{array}{l}1,530 \\
1,490 \\
1,580 \\
1,320 \\
1,090 \\
1,000 \\
1,810 \\
1,760 \\
2,940\end{array}$ & $\begin{array}{l}.54 \\
.48 \\
.50 \\
.50 \\
.39 \\
.33 \\
.40 \\
.58 \\
.70\end{array}$ & $\begin{array}{r}1,490 \\
1,430 \\
1,430 \\
1,320 \\
960 \\
970 \\
1,490 \\
1,570 \\
2,520\end{array}$ & $\begin{array}{r}1.59 \\
1.50 \\
1.50 \\
1.34 \\
.85 \\
.87 \\
1.59 \\
1.70 \\
2.70\end{array}$ & $\begin{array}{l}.03 \\
.02 \\
.02 \\
.01 \\
.01 \\
.03 \\
.09 \\
.05 \\
.23\end{array}$ & $\begin{array}{r}40 \\
60 \\
100 \\
0 \\
130 \\
30 \\
320 \\
190 \\
420\end{array}$ & $\begin{array}{l}0 \\
0 \\
.01 \\
0 \\
.01 \\
0 \\
.02 \\
.01 \\
.02\end{array}$ & $\begin{array}{l}3.51 \\
3.59 \\
4.24 \\
1.89 \\
2.27 \\
5.33 \\
9.14 \\
6.42 \\
7.72\end{array}$ & $\begin{array}{l}3.16 \\
4.42 \\
5.52 \\
6.55 \\
8.08 \\
6.38 \\
6.78 \\
6.31 \\
4.84\end{array}$ \\
\hline
\end{tabular}




\begin{tabular}{|c|c|c|c|c|c|c|c|c|c|c|c|}
\hline $\begin{array}{r}\text { Oct.................... } \\
\text { Nov................ } \\
\text { Dec............... } \\
\text { Total........... }\end{array}$ & $\begin{array}{r}.94 \\
.53 \\
.43 \\
6.81\end{array}$ & $\begin{array}{l}1,890 \\
1,320 \\
1,320\end{array}$ & $\begin{array}{r}.77 \\
.53 \\
.42 \\
6.14\end{array}$ & $\begin{array}{l}1,830 \\
1,320 \\
1,150\end{array}$ & $\begin{array}{l}2.04 \\
1.34 \\
1.11\end{array}$ & 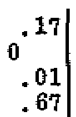 & $\begin{array}{r}60 \\
0 \\
170\end{array}$ & $\begin{array}{l}0 \\
0 \\
.01\end{array}$ & $\begin{array}{r}.96 \\
.09 \\
4.47 \\
49.63\end{array}$ & $\begin{array}{r}5.71 \\
4.21 \\
2.90 \\
64.86\end{array}$ & \\
\hline 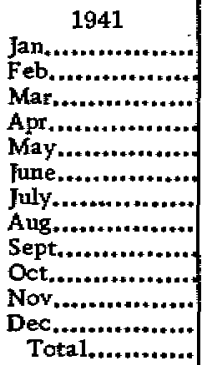 & $\begin{array}{l}.53 \\
.56 \\
.55 \\
.63 \\
.67 \\
.50 \\
1.02 \\
1.20 \\
.84 \\
1.05 \\
1.00 \\
9.85 \\
9.40\end{array}$ & $\begin{array}{l}1,670 \\
1,700 \\
1,500 \\
2,060 \\
1,670 \\
1,530 \\
4,280 \\
2,620 \\
2,800 \\
3,360 \\
2,450 \\
2,450\end{array}$ & $\begin{array}{r}.45 \\
.50 \\
.53 \\
.53 \\
.57 \\
.48 \\
.79 \\
1.06 \\
.75 \\
.85 \\
.95 \\
.82 \\
8.28\end{array}$ & $\begin{array}{l}1,400 \\
1,570 \\
1,470 \\
1,670 \\
1,480 \\
1,490 \\
3,060 \\
2,430 \\
2,250 \\
2,670 \\
2,450 \\
2,260\end{array}$ & $\begin{array}{l}1.46 \\
1.70 \\
1.55 \\
1.83 \\
1.58 \\
1.60 \\
3.04 \\
2.63 \\
2.47 \\
2.82 \\
2.65 \\
2.48\end{array}$ & $\begin{array}{l}.08 \\
.06 \\
.02 \\
.10 \\
.10 \\
.02 \\
.23 \\
.14 \\
.09 \\
.20 \\
.05 \\
.03 \\
1.12\end{array}$ & $\begin{array}{r}270 \\
130 \\
30 \\
390 \\
190 \\
40 \\
1,220 \\
190 \\
550 \\
690 \\
0 \\
190\end{array}$ & $\begin{array}{l}.02 \\
.01 \\
0^{.01} \\
.02 \\
.01 \\
0.08 \\
.01 \\
.03 \\
.04 \\
0^{\circ} \\
.01\end{array}$ & $\begin{array}{r}4.24 \\
3.98 \\
3.16 \\
6.25 \\
2.06 \\
9.76 \\
11.59 \\
4.01 \\
5.46 \\
3.77 \\
3.29 \\
3.47 \\
61.04\end{array}$ & $\begin{array}{r}3.08 \\
3.73 \\
5.50 \\
6.48 \\
8.04 \\
7.36 \\
6.09 \\
6.74 \\
5.62 \\
5.54 \\
3.55 \\
2.60 \\
64.33\end{array}$ & $\xi$ \\
\hline 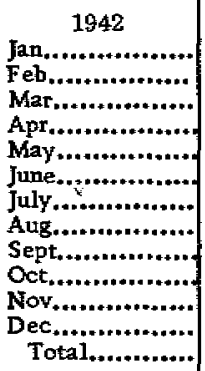 & $\begin{array}{r}1.00 \\
.83 \\
1.34 \\
.87 \\
.64 \\
.90 \\
.85 \\
.79 \\
.73 \\
.63 \\
.45 \\
.39 \\
9.42\end{array}$ & $\begin{array}{l}2,800 \\
4,650 \\
3,360 \\
2,060 \\
1,670 \\
2,450 \\
2,310 \\
2,060 \\
2,060 \\
1,500 \\
1,190 \\
1,040\end{array}$ & $\begin{array}{r}.83 \\
.73 \\
1.06 \\
.82 \\
.64 \\
.73 \\
.80 \\
.77 \\
.71 \\
.63 \\
.45 \\
.38 \\
8.55\end{array}$ & $\begin{array}{l}2,440 \\
2,450 \\
2,890 \\
2,050 \\
1,600 \\
2,360 \\
2,210 \\
2,060 \\
2,060 \\
1,500 \\
1,190 \\
1,040\end{array}$ & $\begin{array}{l}2.64 \\
2.65 \\
2.97 \\
2.27 \\
1.75 \\
2.58 \\
2.44 \\
2.28 \\
2.28 \\
1.60 \\
1.70 \\
.96\end{array}$ & $\begin{array}{l}.17 \\
.10 \\
.28 \\
.05 \\
0.17 \\
.05 \\
.02 \\
.02 \\
0 \\
0 \\
.01 \\
.87\end{array}$ & $\begin{array}{r}360 \\
2,200 \\
470 \\
10 \\
70 \\
90 \\
100 \\
0 \\
0 \\
0 \\
0 \\
0\end{array}$ & $\begin{array}{l}.02 \\
.15 \\
.08 \\
0 \\
0 \\
.01 \\
.01 \\
0 \\
0 \\
0 \\
0 \\
0\end{array}$ & $\begin{array}{r}2.79 \\
3.92 \\
4.99 \\
2.46 \\
2.63 \\
10.36 \\
5.67 \\
4.52 \\
5.62 \\
.57 \\
.14 \\
2.42 \\
46.09\end{array}$ & $\begin{array}{r}2.93 \\
3.70 \\
5.80 \\
6.61 \\
7.32 \\
5.64 \\
7.67 \\
6.31 \\
5.25 \\
5.64 \\
4.08 \\
3.06 \\
64.01\end{array}$ & 莲 \\
\hline 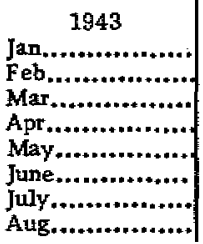 & $\begin{array}{l}.32 \\
.24 \\
.26 \\
.19 \\
.16 \\
.16 \\
.36 \\
.48\end{array}$ & $\begin{array}{r}860 \\
676 \\
632 \\
500 \\
566 \\
500 \\
1,470 \\
1,500\end{array}$ & $\begin{array}{l}.31 \\
.24 \\
.25 \\
.19 \\
.14 \\
.14 \\
.28 \\
.46\end{array}$ & $\begin{array}{r}820 \\
660 \\
632 \\
490 \\
410 \\
460 \\
1,380 \\
1,350\end{array}$ & $\begin{array}{r}.68 \\
.47 \\
.44 \\
.30 \\
.23 \\
.27 \\
1.43 \\
1.41\end{array}$ & $\begin{array}{l}.01 \\
0.01 \\
.01 \\
.02 \\
.02 \\
.08 \\
.02\end{array}$ & $\begin{array}{r}40 \\
16 \\
0 \\
10 \\
156 \\
40 \\
90 \\
150\end{array}$ & $\begin{array}{l}0 \\
0 \\
0 \\
0 \\
.01 \\
0.01 \\
.01 \\
.01\end{array}$ & $\begin{array}{r}1.35 \\
.53 \\
4.80 \\
1.99 \\
4.82 \\
5.62 \\
10.20 \\
7.73\end{array}$ & $\begin{array}{l}3.53 \\
4.40 \\
5.91 \\
6.53 \\
7.18 \\
6.20 \\
6.62 \\
6.46\end{array}$ & $\underset{\omega}{\omega}$ \\
\hline
\end{tabular}


Table 39. - Montily nunotf analyses, Kissinmee River near Okeechobee, 1930-46 - Continued

\begin{tabular}{|c|c|c|c|c|c|c|c|c|c|c|}
\hline Month & $\begin{array}{l}\text { Total } \\
\text { runoff } \\
\text { (tnches) }\end{array}$ & $\begin{array}{l}\text { Discharge at } \\
\text { end of month } \\
\text { (cfs) }\end{array}$ & $\begin{array}{l}\text { Base runoff } \\
\text { (inches }\end{array}$ & $\begin{array}{l}\text { Base flow at } \\
\text { end of month } \\
\text { (cfs) }\end{array}$ & $\begin{array}{l}\text { Base storage } \\
\text { at end of month } \\
\text { (inches) }\end{array}$ & $\begin{array}{c}\text { Direct-runoff } \\
\text { (inches) }\end{array}$ & $\begin{array}{l}\text { Direct-runoff } \\
\text { discharge at } \\
\text { end of month } \\
\text { (cfs) }\end{array}$ & $\begin{array}{l}\text { Direct-runoff } \\
\text { storage at end } \\
\text { of month } \\
\text { (inches) }\end{array}$ & $\begin{array}{l}\text { Rainfall } \\
\text { from table } 56 ; \\
\text { in inches) }\end{array}$ & $\begin{array}{l}\text { Evaporation } \\
\text { (from Belle } \\
\text { Glade pan. } \\
\text { in inches) }\end{array}$ \\
\hline $\begin{array}{l}1943-\text { Con. } \\
\text { Sept................. }\end{array}$ & 0.59 & 1,840 & 0.54 & 1,840 & 2.03 & 0.05 & 0 & b & 5.73 & 5,80 \\
\hline Oct.................. & 1. 08 & 2,000 & .76 & 2,000 & 2.23 & .32 & 0 & 0 & 3,20 & 5.16 \\
\hline Nov................... & .59 & 1,530 & .58 & 1,530 & 1.65 & .01 & 0 & 0 & 1.08 & 3.45 \\
\hline 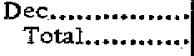 & $\begin{array}{r}.49 \\
4.92\end{array}$ & 1,270 & $\begin{array}{r}.49 \\
4,38\end{array}$ & 1,250 & 1.26 & .54 & 20 & 0 & $47^{.51} .56$ & $\begin{array}{r}2.92 \\
64.16\end{array}$ \\
\hline 1944 & & & & & & & & & . & \\
\hline & .41 & 1,060 & .41 & 1,060 & .98 & 0 & 0 & $\theta$ & 1.12 & 3.22 \\
\hline Feb................... & .31 & 835 & .31 & 835 & .69 & 0 & 0 & 0. & .35 & 4.68 \\
\hline $\begin{array}{c}\text { Mar } \ldots \ldots \ldots \ldots \ldots \ldots \\
\text { Apr................... }\end{array}$ & .26 & $\begin{array}{l}676 \\
960\end{array}$ & .26 & $\begin{array}{r}676 \\
. \quad 750\end{array}$ & $\begin{array}{r}.49 \\
.58\end{array}$ & $\begin{array}{l}0 \\
.08\end{array}$ & 210 & ${ }^{0} .01$ & $\begin{array}{l}4.45 \\
4.20\end{array}$ & $\begin{array}{l}5.58 \\
6.47\end{array}$ \\
\hline May................. & .23 & 478 & .22 & 478 & .28 & .01 & 0 & 0 & 2.00 & 6.87 \\
\hline 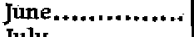 & .18 & 457 & .17 & 457 & .27 & .01 & 0 & 0. & 7.45 & 7. 12 \\
\hline July.................... & .22 & 742 & .18 & 660 & .47 & .04 & 82 & 0 & 8.38 & 6.77 \\
\hline A ug.................. & .34 & 1,210 & .30 & 1,060 & .98 & .04 & 150 & 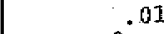 & 6.92 & 6.20 \\
\hline Sept................. & .42 & 1,210 & .40 & 1,190 & 1.17 & .02 & 20 & 0 & 4.37 & 5.68 \\
\hline Oct....................... & .48 & 1,570 & .43 & 1,360 & 1.42 & .05 & 210 & $\therefore$ & 6.75 & 4.89 \\
\hline Nov.................. & 60 & 1,670 & .55 & 1.640 & 1.80 & .05 & 30 & $0^{\circ}$ & .37 & 3.74 \\
\hline Dec.................. & $\begin{array}{r}57 \\
35\end{array}$ & 1,550 & .56 & 1,510 & 1.61 & .01 & 40 & 0 & $46^{\circ} \cdot 42$ & $\begin{array}{r}3.07 \\
64.29\end{array}$ \\
\hline Total................ & 1.35 & & 4.03 & & & .31 & & & 46.78 & 64.29 \\
\hline 1945 & 52 & 1,410 & 51 & 1,410 & 1,48 & 01 & 0 & 0 & 2.63 & 3.68 \\
\hline Feb.................. & .02 & 1,210 & .42 & $\begin{array}{l}1,410 \\
1,210\end{array}$ & $\begin{array}{l}1.40 \\
1.20\end{array}$ & $0^{.01}$ & 0 & 0 & $\begin{array}{r}2.00 \\
.19\end{array}$ & $\begin{array}{l}0.00 \\
3.89\end{array}$ \\
\hline Mar................. & .38 & 930 & .38 & 930 & .82 & 0 & 0 & 0 & .53 & 6.17 \\
\hline Apr................... & .27 & 678 & .27 & 660 & .47 & & 18 & 0 & 1.88 & 7.06 \\
\hline May $\ldots \ldots \ldots \ldots \ldots$ & .20 & 458 & .19 & 458 & .27 & .01 & 0 & & 1.48 & 7.42 \\
\hline June.................. & .16 & $\begin{array}{r}734 \\
5.960\end{array}$ & .14 & $\begin{array}{r}460 \\
1.830\end{array}$ & $\begin{array}{r}.27 \\
2.03\end{array}$ & .02 & $\begin{array}{r}274 \\
4130\end{array}$ & .02 & 14.78 & 6.09 \\
\hline fuly................ & $\begin{array}{r}.64 \\
1.14\end{array}$ & $\begin{array}{l}5,960 \\
2,640\end{array}$ & $\begin{array}{l}.34 \\
.88\end{array}$ & $\begin{array}{l}1,830 \\
2,540\end{array}$ & $\begin{array}{l}2.03 \\
2.71\end{array}$ & $\begin{array}{r}.30 \\
26\end{array}$ & $\begin{array}{l}4,130 \\
100\end{array}$ & $\begin{array}{l}.31 \\
.01\end{array}$ & $\begin{array}{l}9.21 \\
4.67\end{array}$ & 5. 38 \\
\hline Sept.................. & 2.11 & 7,840 & 1.40 & 6,600 & 4,46 & .71 & 1,240 & & 10.84 & 5.44 \\
\hline Oet ..................... & 2.17 & 5.240 & 2.10 & 5,240 & 4.03 & .07 & 0 & 0 & 4.17 & 4.37 \\
\hline Nov................ & 1. 50 & 3,770 & 1.49 & 3,700 & 3.44 & .01 & 70 & & 1.27 & 4.25 \\
\hline Dec................. & $\begin{array}{r}1.17 \\
10.68\end{array}$ & 3,030 & $\frac{1.15}{9.27}$ & $2,890$. & 2.97 & .02 & 140 & .01 & 2.50 & 3.04 \\
\hline Total............... & & & 21 & & & 1.41 & & & 4.15 & 63.52 \\
\hline
\end{tabular}




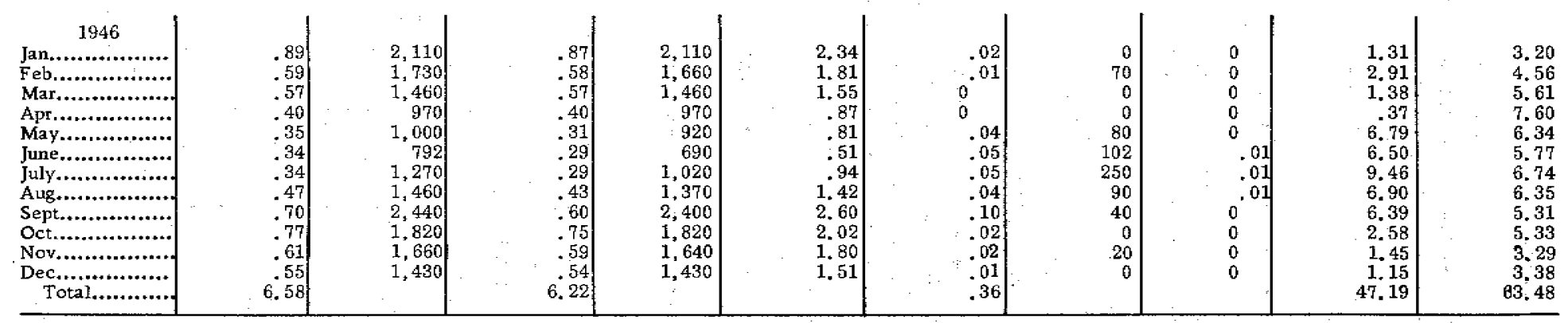




\section{MONTHLY RANFALL-RUNOFF RETATONS}

The discharge of the Kissimmee River varies seasonally in response to the distribution of rainfall and the seasonal variation in temperature. Runoff, in inches, for each month of record (193046), as measured at the gaging station near Okeechobee, is given in table 59. The average discharge near Okeechobee by months for the period $1931-46$ is given in table 60 .

The values of average annual precipitation, runoff, and precipitation minus runoff, given in table 60 , are the average of annual values based on data given in tables 57 and 59 and summarized in table 61; they are not the summation of the monthly values shown in table 60 .

The lowest flows occur in winter and spring, usually in May and June. The highest flows are in September, October, and November, as a result of the rains of those and preceding months.

Runoff during a given calendar month (evaporation losses assumed constant) was analyzed as a function of the following two factors; viz.: (1) Antecedent discharge, which in turn is indicative of the amount of carry-over discharge(drainage of water already in the basin) and the degree of wetness or dryness of the soil, or conditions that determine the portion of the subsequent months' rainfall that will be converted into runoff or added to storage available for runoff during subsequent months. (2) Mean depth of rainfall.

Table 60. - Average monthly and anrual hydrologic deta, Kissimmee River near Okeecho-

[Measurements given in inches]

\begin{tabular}{|c|c|c|c|c|c|c|c|c|}
\hline 壳 & 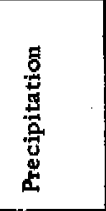 & 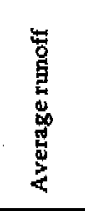 & 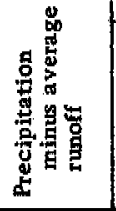 & 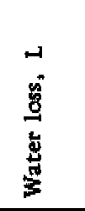 & 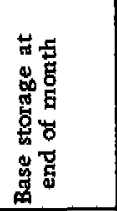 & 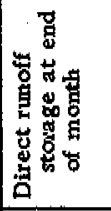 & 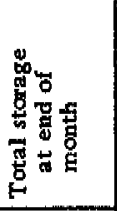 & 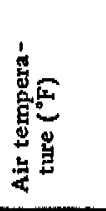 \\
\hline $\begin{array}{l}\text { Jan. } \\
\text { Feb. } \\
\text { Mar. } \\
\text { Apr. } \\
\text { Ray } \\
\text { Juŕé } \\
\text { July } \\
\text { Aug. } \\
\text { Sept. } \\
\text { Oct. } \\
\text { Nov. } \\
\text { Dec. } \\
\text { Annual }\end{array}$ & $\begin{array}{c}1.95 \\
2.4 \\
3.0 \\
3.2 \\
4.0 \\
7.85 \\
8.05 \\
6.4 \\
6.55 \\
3.25 \\
1.45 \\
1.5 \\
a^{4} .5\end{array}$ & $\begin{array}{c}0.55 \\
. .46 \\
.5 \\
.43 \\
.35 \\
.39 \\
.58 \\
.68 \\
.92 \\
.94 \\
.70 \\
.61 \\
7.13\end{array}$ & $\begin{array}{l}1.4 \\
1.95 \\
2.5 \\
2.75 \\
3.65 \\
7.45 \\
7.45 \\
5.7 \\
5.65 \\
2.3 \\
.75 \\
.9\end{array}$ & $\begin{array}{r}2.5 \\
2.9 \\
3.2 \\
3.8 \\
4.8 \\
5.1 \\
4.9 \\
4.2 \\
3.2 \\
2.7 \\
2.9 \\
2.8 \\
\mathrm{~b}_{43.0}\end{array}$ & $\begin{array}{r}1.41 \\
1.31 \\
1.19 \\
1.01 \\
.80 \\
.99 \\
1.49 \\
1.76 \\
2.32 \\
2.21 \\
1.84 \\
1.54\end{array}$ & $\begin{array}{l}0.01 \\
.01 \\
.00 \\
.01 \\
.00 \\
.02 \\
.04 \\
.02 \\
.02 \\
.02 \\
.01 \\
.00\end{array}$ & $\begin{array}{r}10.7 \\
10.2 \\
9.6 \\
8.9 \\
7.9 \\
8.9 \\
11.1 \\
12.3 \\
14.7 \\
14.2 \\
12.7 \\
11.3\end{array}$ & $\begin{array}{c}63 \\
64 \\
67 \\
72 \\
77 \\
80 \\
82 \\
82 \\
80 \\
75 \\
67 \\
68 \\
\mathbf{a} 72.5\end{array}$ \\
\hline
\end{tabular}

Average of annual values, see text.

bsum of monthly values. 
Base flow at the end of the preceding month, as taken from table 59, was used as the index or correlation parameter. Base storage was then obtained by use of figure 153, and direct-runoff storage was obtained in a similar manner from figure 155. Monthly precipitation was obtained as shown in table 57 .

Diagrams similar to figure 156 were prepared, one for each calendar month, with precipitation as ordinate, runoff as abscissa, and antecedent base flow as parameter. Lines of equal antecedent base flow were drawn to conform with the plotted points. A study was made of the 12 monthly charts so prepared to determine the adjustment that could be made to measure precipitation so that all points for all months could be placed on one chart. Figure 157 shows such a chart. The ordinate is precipitation minus $L, L$ being the values of the adjustment just described. A list of the values of $L$ for the several months is given in figure 157 and in table 60. Several points that did not plot satisfactorily may be attributed to improper estimates of base flow or to deficiencies in the analysis of precipitation. The computation of mean areal rainfall based on one rain gage for 326 square miles is subject to large errors of sampling. Moreover, the study does not distinguish between rainfall of a single heavy storm from that of a number of separate storms, nor does it indicate whether the storms occurred at the beginning or at the end of the month. The chart applies only to average conditions. Nevertheless the average error of estimate is only 10 percent.

It was observed that the values of $L$, referred to above, were equal to those values of precipitation minus runoff for which there were no net changes in base flow. In other words, for a month in which precipitation minus runoff exceeded $L$, the base flow at the end of the month was higher than at the beginning; conversely, if precipitation minus runoff was less than $b$, the base flow at the end of the month was less than at the beginning. It was also observed (table 60) that the sum of the values of $L$ for the 12 months is approximately equal to the difference between average annual precipitation and average annual runoff. The difference between this figure and annual figures of precipitation minus runoff segregates years in which there was a net increment or a net decrement in base flow. The line drawn on figure 156 for a value of $L=43.0$ in. (mean annual water loss) approximately separates the group of points in which there was a net rise in base flow from those in which there was a net fall. Accordingly, a diagram (fig. 158) was prepared to show the monthly change in base flow with respect to $P=L$, the values of $R$ being implied by relation to the other factors. The observed points on which the diagram is based are omitted. The ordinate is precipitation minus $L$, the initial or antecedent base flow is given as the abscissa (logarithmic scale), and the final base flow is shown as the parameter. For values of $\vec{p}-L$ equal to 


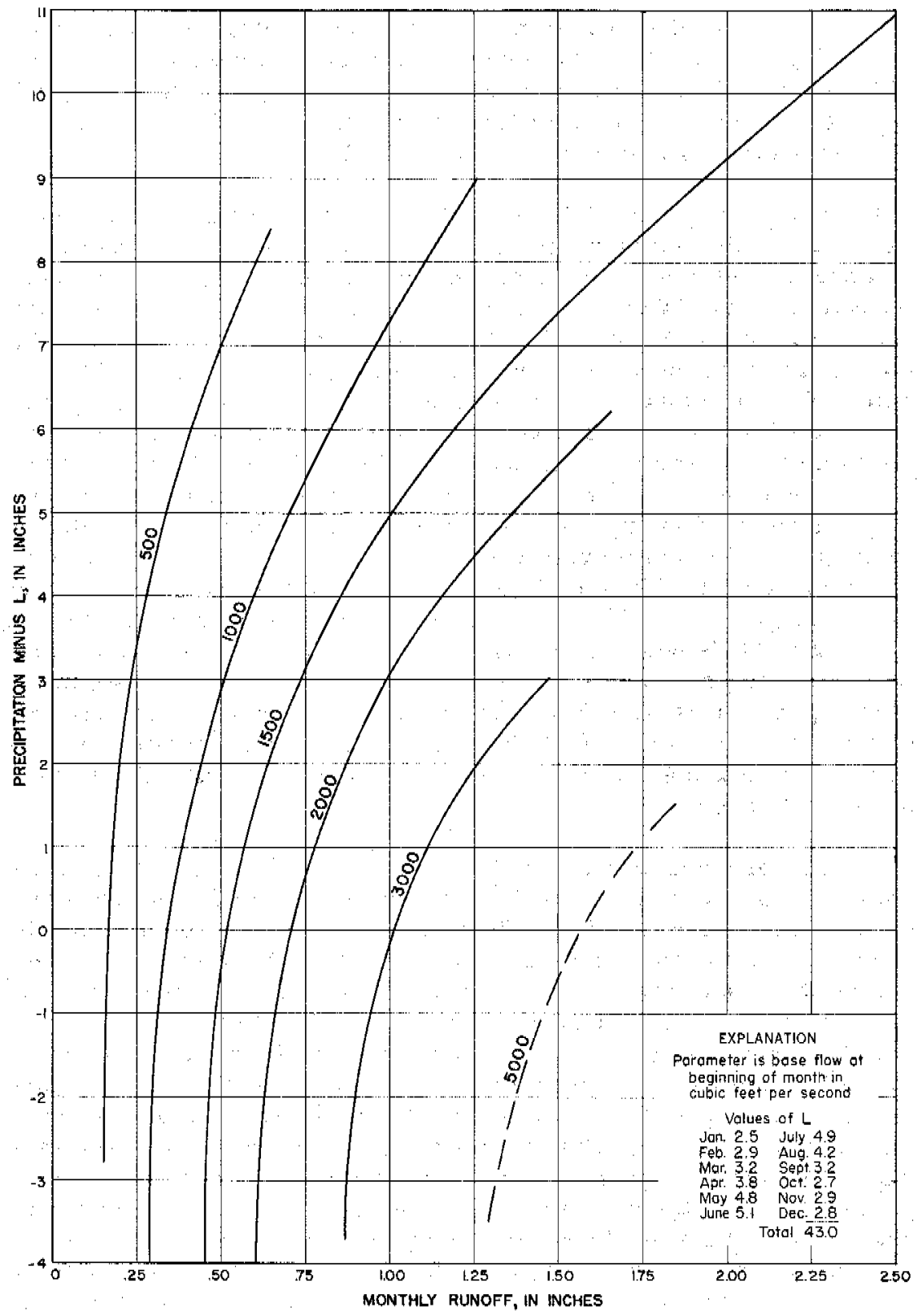

Figure 157. - Monthly rainfall-runoff relations, Kissimmee River near Okeechobee. 


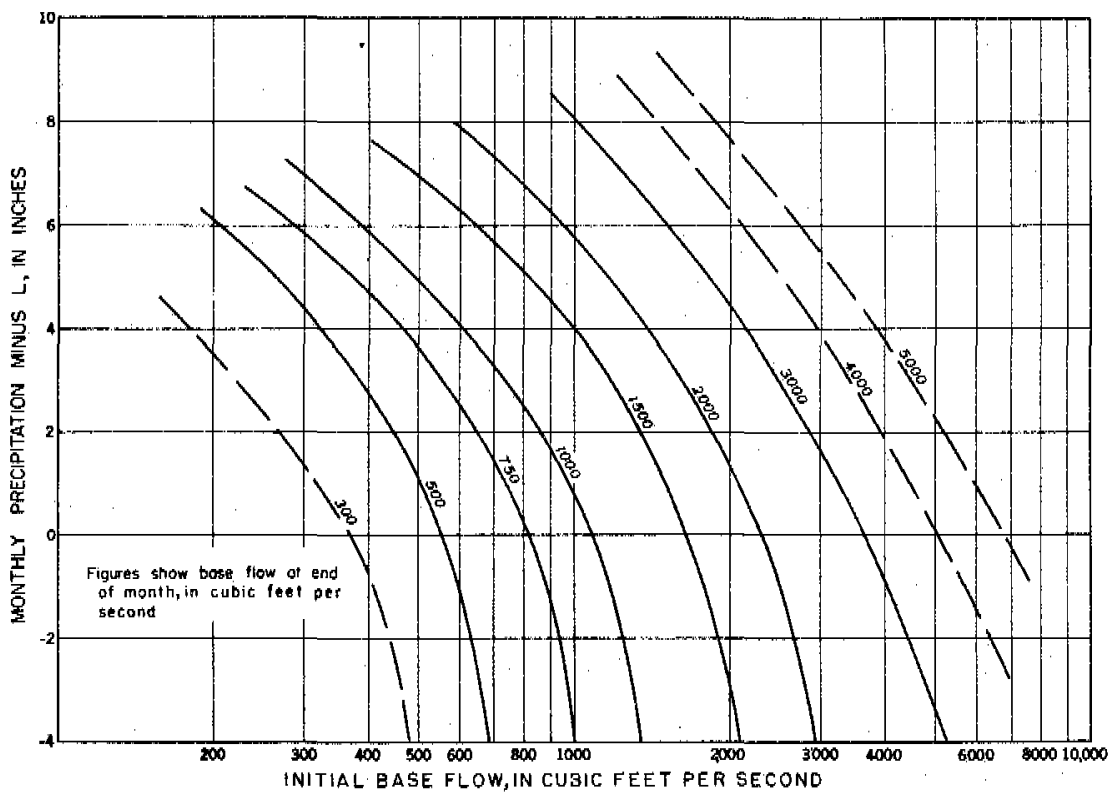

Figure 158. - Monthly change in base flow, Kissimmee River near Okeechobee.

- 3 in, or less, the graphs give results substantially equivalent to the depletion hydrograph (fig. 152) for intervals of 30 days. By using figures 157 and 158 in combination, an estimate of runoff for each month can be made in advance, contingent upon the range in expected precipitation. This may prove of use in the regulation of Lake Okeechobee.

An example of methods of using figures 157 and 158 might be helpful. Consider the wet year 1934. Base flow on December 31, 1933, was 1, $830 \mathrm{cfs}$. Precipitation during January in the period 1931-46 ranged between 0.70 and $4.24 \mathrm{in}$. with a mean of $1.96 \mathrm{in}$. Since $L$ for January is 2.5 in., the corresponding values of $P$ - $L$ are $-1.80,+1.74$, and -0.54 in. According to figure 157, January runoff would range between 0.55 and $0.75 \mathrm{in.}$, with an expected figure of $0.65 \mathrm{in}$, , which corresponds to normal precipitation for January. According to figure 158 , base flow at the end of January should range between 1,400 and $1,800 \mathrm{cfs}$, with an expected figure of $1,600 \mathrm{cfs}$. Precipitation during January 1934 actually was below normal but above the minimum of record, and so runoff experiences was $0.58 \mathrm{in}$. and final base flow, $1,530 \mathrm{cfs}$. The process can be continued from month to month, or projected for 2 or more months. However, if projected for more than 2 months the range widens rapidly.

In projecting the estimates, it is not necessary to base minimum and maximum limits on compounded maximum or minimum precipitation figures for each month; instead, such observed precipitation sequences are used that will give minimum or maximum 
precipitation for the group of months. Thus, continuing through February 1934, we have limiting base flows at the end of January of 1,400 and $1,800 \mathrm{cfs}$. However, it is not likely that January extremes of precipitation would again be followed by February extremes. Nevertheless, it is plausible to use total January plus February precipitation for these limits. These totals are: minimum, 1.05 in.; maximum, 10.44 in; average, 4.35 in. Since we have used $0.70,4.24$, and 1.96 in., respectively, for January, the corresponding quantities for February are $0.35,7.20$, and 2.39 in. Using these figures in conjunction with a value of $L$ of 2.9 in. and with the estimated limits of base flow at the end of January, the February runoff should range between 0.40 and $1.10 \mathrm{in}$., with an expected value corresponding to the occurrence of normal precipitation in January and February of $0.55 \mathrm{in}$.

\section{WATER LOEBES AND STORAGE}

The general hydrologic equation for a basin is $P: R-L=\Delta S$. In this equation $P$ represents the precipitation; $R$, the runoff; $L$, the evapotranspiration loss; and $\Lambda S$, the change in storage in the basin during the period. If the period of time is long enough, the cilange in storage may be neglected and the losses would be approximately $P-R$. For the 16-year period of record, mean annual losses so approximated are equal to $49.5-7.1=42.4 \mathrm{in}$. In the same period, evaporation from the $4-\mathrm{ft}$ ventilated pan at Belle Glade, as listed in table 8 , averaged 64.62 in. per year. The annual water losses of the Kissimmee River basin were therefore about 66 percent of the evaporation from the Belle Glade pan. It has been found (Harding, 1942) that evaporation from lakes and large ponds averages about 70 percent of the evaporation from a ventilated pan. Accordingly, water losses from the Kissimmee basin average about the same as evaporation from equivalent lake areas. This is not surprising because much of the basin is occupied by lakes and swamps. A more accurate value of the mean annual water loss is computedbelow.

To compute monthly water losses, the change in storage must be accounted for. In the basic equation $P-R-L=\Lambda S$, AS refers to the change in total storage of water of all kinds in the basin. The Kissimmee River basin includes extensive areas of swamps and lakes in which surface- and ground-water storage and soil water merge to such an extent as to obscure distinctions between them. However, two broad kinds of storage may be recognized: gravity water (storage available for runoff), which is mainly the water in lakes, rivers, and in the ground under water-table conditions; and capillary water (surface soil-moisture storage), ordinarily referred to as soil moisture or water in the soil-root zone. The storage available for runoff is the source of direct and base runoff. There are no ready measures of storage, except so far as storage can be inferred from records of precipitation and runoff. It is well to emphasize 
that volumes of storage, as computed from analysis of the hydrograph and reported in table 59, represent such portions of the storage in the zone of saturation as were realized in runoff. Volumes of these components of available storage as computed from depletion and recession hydrographs are reported separately as base storage and direct-runoff storage in table 59. The component of base storage (ground storage) is by far the greater, reaching a maximum of more than 4 in. during September 1933 and 1945. Direct-runoff storage within the same period of record did not exceed $0.5 \mathrm{in}$.

Base storage, according to the depletion hydrograph (fig. 152), requires nearly 9 months to change from the highest to the lowest base-flow rates. Furthermore, an average lag of about $3 \frac{1}{2}$ months occurs between the time of recharge and the middle of the period of the mass of outflow. During this interval, variable quantities of ground water are lost by evapotranspiration, depending on the depth. to the water-table. Much swamp water and marsh water is included in the total amount of ground storage, and such water is subject to direct evaporation and transpiration by phreatophytes and hydrophytes. Accordingly, only a small part of the water in the zone of saturation escapes as runoff in the drainage channels and is measured as base storage. Direct runoff is more transient, having an average lag of only about 10 days. It is less subject to loss, although the same principle applies.

Storage in the zone of saturation (including lakes and rivers) in the basin could be determined from ground-and surface-water levels by the formula $V=y_{h}$, where $V$ is volume of storage, $\dot{a}$ is the average areal range of water levels, and $y$ is average specific yield (as determined by laboratory or discharging-well methods; for lake and river areas its value is unity). None of the above factors is known, therefore the equation cannot be evaluated. However, assuming a $7-\mathrm{ft}$ range over the basinduring the period 1931-46 (as inferred from the range in stage observed in several canals) and a specific yield of 20 percent (an average value), the fluctuation in storage is $17 \mathrm{in.}$ For the same period a 4.5-in, range in base storage (available for runoff) was inferred from the hydrograph. According to these assumptions only about 25 percent of the groundwater recharge was realized as base flow in the Kissimmee River. The above figures for range in water levels and specific yield may not be correctly evaluated for theKissimmee basin, but they should serve to illustrate the method that was developed in further detail by Meinzer and Stearns (1929) in relation to the Pomperaug basin in Connecticut. Comparison of recharge, as deduced from observations of ground-water levels, with base flow computed from the hydrograph, indicates that about 56 percent of the recharge becomes available as base flow in the Pomperaug basin. However, this basin is in a climatic and physiographic zone different from that of the Kissimmee. 
The value of $P \cdot R$ for a given calendar month that separates months with increments from those with decrements in base flow is given as $L$ in figure 157 and table 60 . For a value of $P-R=L$, therefore, change in storage ( $\Delta S$ ) may be presumed to be very small and is treated as zero. The values of $L$ were used to compute the monthly changes in basin storage by the formula $\Delta S=P-R-L$, in which $P$ is the monthly precipitation, $R$ is the measured runoff, and $L$ is the average evapotranspiration loss. $\Delta s$ represents the changes in all forms of storage, average monthly values of which are given in table 60 .

Changes in storage have been computed for each month of record and cumulated from the beginning of record. These cumulated totals to the end of each month of record have been plotted on figure 159 against base flow at the end of the respective month. A line has been drawn to average the plotted points, and the scale of cumulative $P$ - R - $L$ chosen so that computed storage is about zero for the lowest observed base flow of record. The range in storage experienced, as indicated by the extreme points shown, is about 24 in., of which about 4 in. represent base storage. Storage reached record-low values in April 1932 and again in the spring of 1939. High values, about $20 \mathrm{in}$. above the minimum, occurred at the beginning of the record during the fall of 1930, and again during the fall of 1933 . The scattering of points might be ascribed either to inadequacy of the theory or to greater variability in monthly loss than has been allowed for herein. However, study of the deviations from the average graph shown failed to reveal any systematic relationship between loss during a given calendar month and other factors such as precipitation or runoff.

Soil moisture has an important role in the hydrologic cycle. A large part of the evapotranspiration losses is from the soil moisture. The soil is recharged during each rain and pumped out by persistent evapotranspiration processes during fair-weather periods. This recharge has first toll on rainfall, penetration to the water table occurring only in those places where soil moisture is near or at capillary capacity. Soil moisture represents storage, and during the growing seasons it is probably subject to greater and more frequent fluctuations in volume than any other item of storage. Storage, as computed in this section, includes only that volume in excess of the minimum recorded during the 1932 and 1939 droughts. It is doubted whether the wilting point was reached over any appreciable area, although the Weather Bureau reported that irrigation was practiced where possible, so there was probably a considerably but indeterminable volume of water in soil moisture in addition to the amount shown. If, however, the range in storage of so-called gravity water (as computed from range in canal and lake stages) is $17 \mathrm{in.}$, and the range in total storage during the same period was $24 \mathrm{in}$., then the difference of $7 \mathrm{in}$. was the soilmoisture storage, assuming that the extremes of soil moisture 


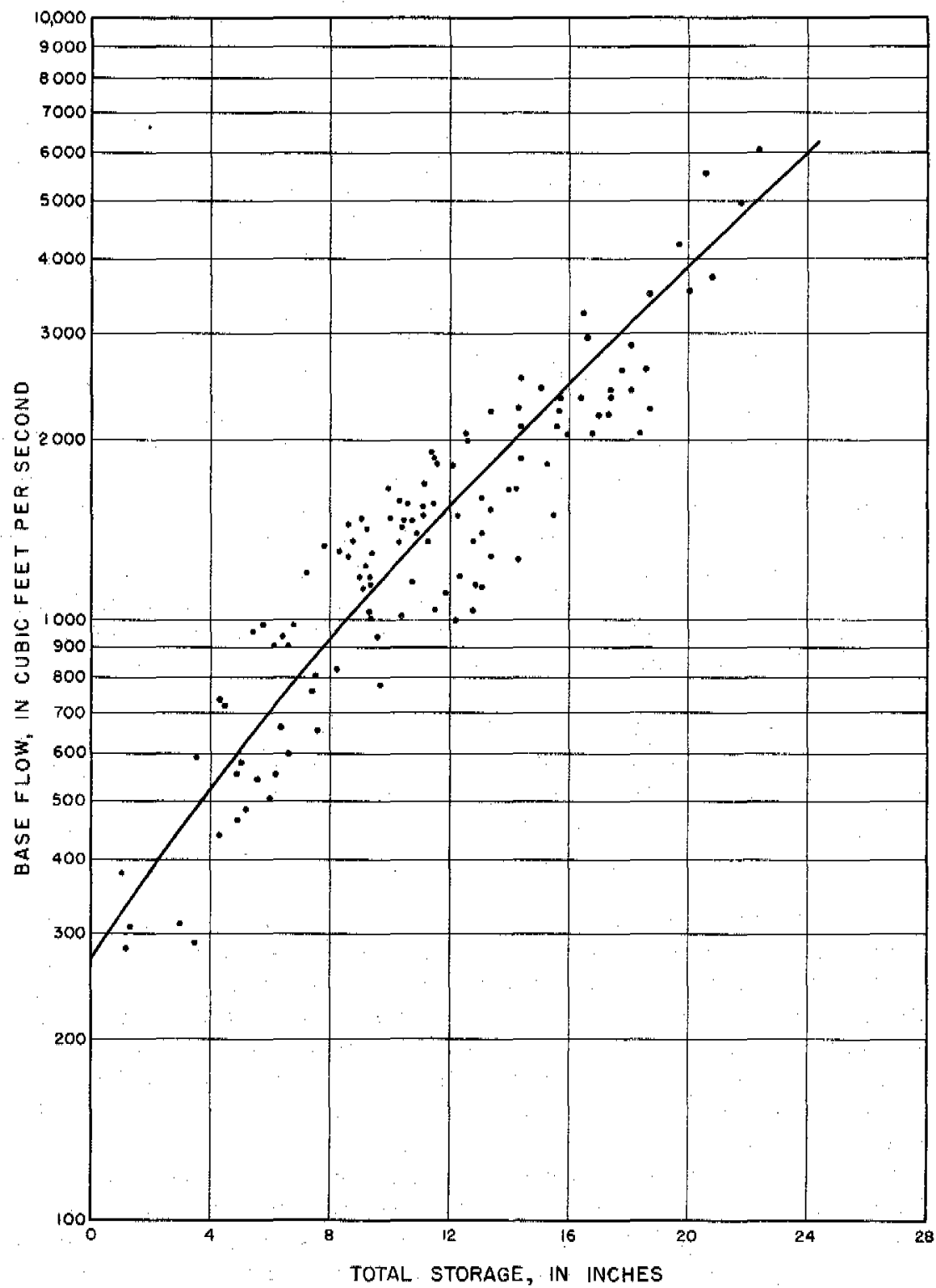

Subject to depletion by evopotranspiration and runoff

Figure 159. - Study of the relation between base flow and total storage, Kissimmee River basin. 
occurred at the same time as the extremes in gravity water, which one would expect.

To summarize, then, the range in storage during the 1931-46 period was about 24 in.; of this, about 17 in. may be gravity water in lakes, streams and ground water, and the remaining 7 in. may be soil moisture, which is directly available only to plants or other evaporative processes. Of the gravity water, only 4 to $5 \mathrm{in}$, is realized as runoff. Therefore, about 20 in. of storage is not available for runoff.

Figure 160 presents a study of rainfall runoff, losses, and storage during an average year. The lowest line shows cumulative runoff based on data in table 60 . Added to this is the computed storage available for runoff, which is the sum of the base storage and storage available for runoff at the end of each month, as given in table 60. The ordinate to this second line at any time is the total water outflow plus water in storage available for outflow. A horizontal line is indicative of no recharge and means that outflow is at the expense of storage. The ordinates to the third line represent total storage plus measured runoff.

At the beginning of the year an average of about $11.5 \mathrm{in.}$ of storage is in the basin. This is the initial point for beginning the line of supply (cumulative precipitation). The difference between the line of cumulative precipitation and the third line represents cumulative evaporation and transpiration $(L)$ from the beginning of the year.

The boundary between total storage and evapotranspiration is indistinct, because if there was an error in the estimates of losses in any month such error would be reflected in the estimate of storage inasmuch as $P-R=L+\Delta S, P$ and $R$ are known and their difference is known, hence the sum of $L+\Delta S$ is known; however, the boundary between them has been based in large part on the assumptions that fluctuations in total storage are reflected by base flow and that losses for any calendar month are the same in each year. Consequently, this boundary in figure 160 is the average of two lines, one defined by adding to the first line the total storage according to the base flow (obtained from base storage in table 60 and by use of fig. 153) as read from figure 159, and the other, by subtracting from the upper line (initial storage plus cumulative precipitation) the cumulative monthly water loss (L).

It will again be noted that evaporation and transpiration make up by far the largest single item in the water budget. This may be nearly the same indry years as in wet years. The largest storage factor is storage not available for runoff, and in this there may be a wide difference in storage between the wet year and the dry year. 


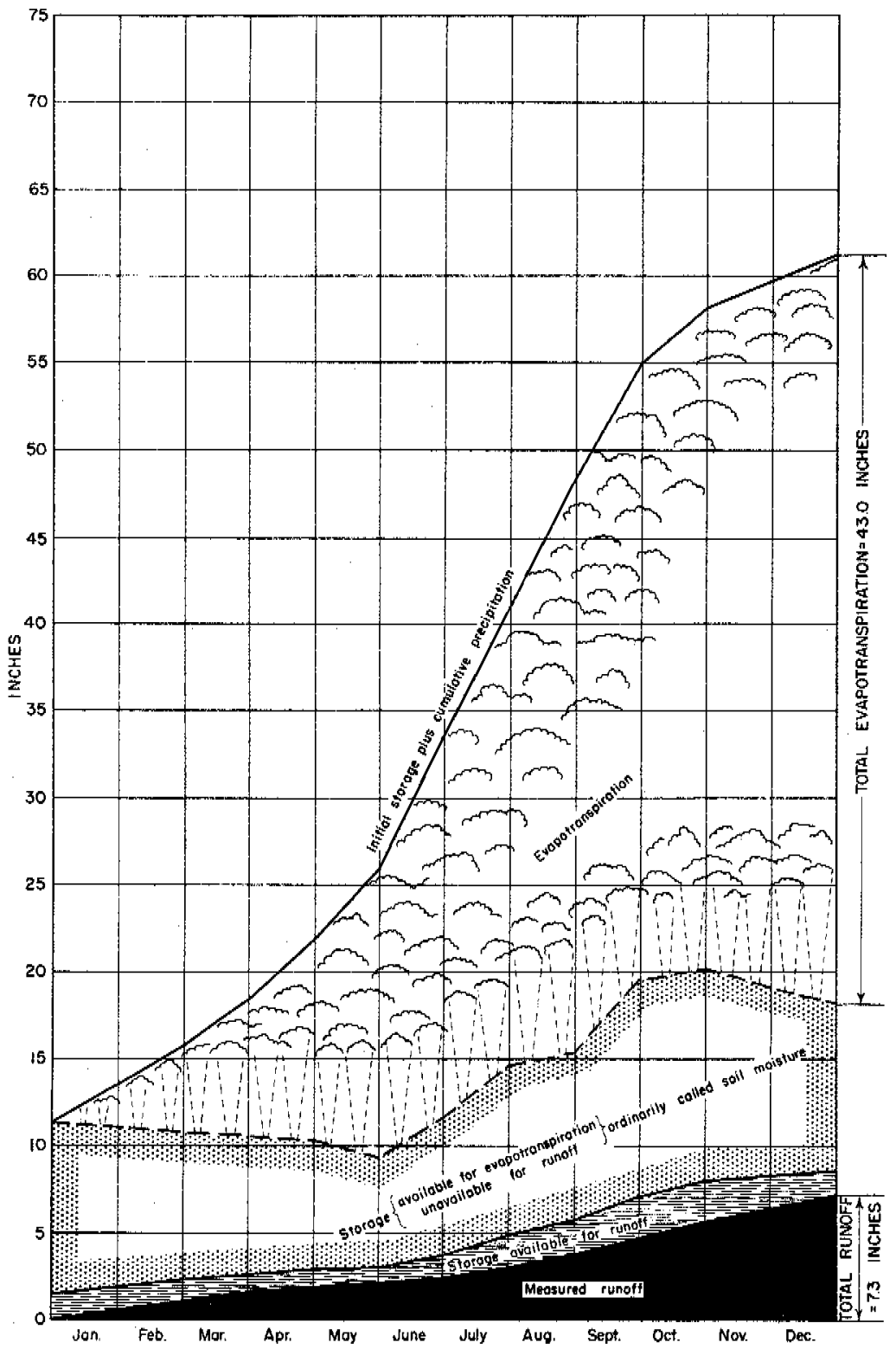

Figure 160. -Storage and cumulative precipitation and rumoff during average year, Kissimmee River near Oke echobee. 
The annual water budget is given in table 61 . For each year the precipitation and runoff measured at Okeechobee, and their difference, is given. The base flow in second-feet at the close of each year is also listed. These data were taken from table 59 .

Analysis of the data in table 61 by the method of least squares indicates that $P-R=0.002 \Lambda B F+[42.54+0.50(P-49.54)]$, in which $P$ is annual precipitation in inches, $R$ is annual runoff in inches, and $\triangle O F$ is net annual change in base flow (in cubic feet per second). The annual difference between rainfall and runoff is equivalent to - water loss only if storage is accounted for. The termin the above equation for change in base flow may be taken as representing changes in storage. Accordingly, it follows that annual water losses equal $P-R-0.002 \Lambda B F$. The values, so computed, are listed in the last column of the table. The annual loss computed in this manner differs from that which would be obtained by using the base storage for the end of December each year, given in column 6 of table 59, by as much as $1.5 \mathrm{in}$. but has been used as being the more probable values. These values of water losses range between 38 and 49 in. , a much smaller range than occurseither in precipitation or in the difference between precipitation and runoff. The average annual water loss of $42.54 \mathrm{in}$. is not exactly the same as the difference between average annual rainfall and runoff for the period of record, as computed from column 4.

\begin{tabular}{|c|c|c|c|c|c|c|}
\hline $\begin{array}{l}\text { Calendar } \\
\text { year }\end{array}$ & $\begin{array}{c}\text { Precipi- } \\
\text { tation } \\
\text { (inches) }\end{array}$ & $\begin{array}{l}\text { Measured } \\
\text { runoff } \\
\text { (inches) }\end{array}$ & $\begin{array}{c}\text { Precipi- } \\
\text { tation } \\
\text { minus } \\
\text { runoff } \\
\text { (inches }\end{array}$ & $\begin{array}{l}\text { Base flow } \\
\text { at end of } \\
\text { year } \\
\text { (cfs) }\end{array}$ & $\begin{array}{l}\text { Change in } \\
\text { base flow } \\
\text { (cfs) }\end{array}$ & $\begin{array}{c}\text { Losses }= \\
P \cdot R 0.002 \wedge B F \\
\text { (inches) }\end{array}$ \\
\hline $\begin{array}{l}1930 \\
1931 \\
1932 \\
1933 \\
1934 \\
1935 \\
1936 \\
1937 \\
1938 \\
1939 \\
1940 \\
1941 \\
1942 \\
1943 \\
1944 \\
1945 \\
1946 \\
1931 \text {-46 } \\
\text { total } \\
16-y \text {-yar } \\
\text { average }\end{array}$ & $\begin{array}{r}42.29 \\
44.20 \\
59.46 \\
50.79 \\
44.80 \\
52.19 \\
53.12 \\
40.72 \\
52.62 \\
49.63 \\
61.04 \\
46.09 \\
47.56 \\
46.78 \\
54.15 \\
47.19 \\
792.63\end{array}$ & $\begin{array}{r}7.73 \\
3.52 \\
8.55 \\
11.86 \\
4.35 \\
8.10 \\
6.63 \\
5.27 \\
5.88 \\
6.81 \\
9.40 \\
9.42 \\
4.92 \\
4.35 \\
10.68 \\
6.58 \\
114.05\end{array}$ & $\begin{array}{r}34.56 \\
40.68 \\
50.91 \\
38.93 \\
40.45 \\
44.09 \\
46.49 \\
35.45 \\
46.74 \\
42.82 \\
51.64 \\
36.67 \\
42.64 \\
42.43 \\
43.47 \\
40.61 \\
678.58 \\
42.41\end{array}$ & $\begin{array}{r}2,440 \\
780 \\
765 \\
1,830 \\
1,360 \\
1,280 \\
1,660 \\
2,260 \\
1,904 \\
1,590 \\
1,150 \\
2,260 \\
1,040 \\
1,250 \\
1,510 \\
2,890 \\
1,430 \\
\ldots \ldots \\
\ldots \ldots . . . . .\end{array}$ & $\begin{array}{r}-1,660 \\
-15 \\
+1,065 \\
-470 \\
-80 \\
+380 \\
+600 \\
-1,356 \\
+686 \\
-440 \\
+1,110 \\
-1,220 \\
+210 \\
+260 \\
+1,380 \\
-1,460 \\
+1,010\end{array}$ & $\begin{array}{r}37.88 \\
40.71 \\
48.78 \\
39.87 \\
40.61 \\
43.33 \\
45.29 \\
38.16 \\
45.37 \\
43.70 \\
49.42 \\
39.11 \\
42.22 \\
41.91 \\
40.71 \\
43.53 \\
680.60 \\
42.54\end{array}$ \\
\hline
\end{tabular}

The stability of the annual losses does not necessarily mean that no runoff will occur during a year with less rainfall than 43 in. Rainfall during 1938 was only $40.72 \mathrm{in.}$, yet there was $5.27 \mathrm{in.}$ of runoff. The runoff and part of the losses were made up by withdrawals 
from storage, mainly from storage remaining from the preceding year.

\section{LAKE OKEECHOBEE}

Lake Okeechobee acts as a sump pit for the runoff of the Kissimmee River and lesser contributors. The total tributary area is about 4,200 square miles. Rainfall on the lake surface is also an important source of supply. However, evaporation from the lake surface and transpiration of littoral vegetation remove most of this supply. At the present time, the surplus of inflow over evaporation is discharged through drainage canals. Before the construction of the canals and levees, the lake discharged most of this surplus by minor percolation and seepage to and from the Everglades (see p. 107 and 185) and by the spilling of water over the southern and southeastern rims at high stages.

Table 62 presents a hydrologic summary of Lake Okeechobee for the 7 years of record of outflow, 1940-1946. For this study, an area that is referred to as the lake basin is used. It consists of approximately 800 square miles, and it includes the lake and surrounding area toward the lake from locations of inflow and outflow measurements.

In preparing a water budget for Lake Okeechobee, frequent use is made of the hydrologic equation arranged as follows: $(P+I)-$ $(O+L+\Delta S)=$ seepage. Precipitation $(P)$ and storage $(\Delta S)$ in the lake are measurable quantities. Although inflow $(I)$ and outflow $(o)$ in the rivers, creeks, and canals are also measurable, the taking of such measurements involved serious practical difficulties. Two items cannot be measured directly, namely, the evaporation and transpiration losses from the lake basin $(L)$, and such minor and relatively insignificant seepage to and from the Everglades as may take place (see p. 107). The equation, therefore, cannot be balanced except by inference.

Table 62 first lists the net discharge from the lake basin measured in the several drainage canals. Although the flow in some of the canals is sometimes to and sometimes from the lake, there was an average discharge from the lake basin of $1,627,000$ acre $-\mathrm{ft}$ per year.

Inflow to the lake basin carried by the Kissimmee River, minor creeks, and a canal, as listed, averaged $1,932,000$ acre-ft per year. Accordingly, the net flow into the lake basin, as measured, averaged 305,000 acre-ft per year. Rainfall over the lake basin, as determined from measurements at rain gages, averaged 44.4 in. a year, equivalent to $1,895,000$ acre-ft a year. 
Table 62. - Hydrologic summary

[All quantities are in thousands of acre-feet, except as noted. Tabulated flow out of lake is New River (table 38), Miami (table 42), and Caloosahatchee (table 32) Canals, Tabulated Indian Prairie Canal (table 30)]

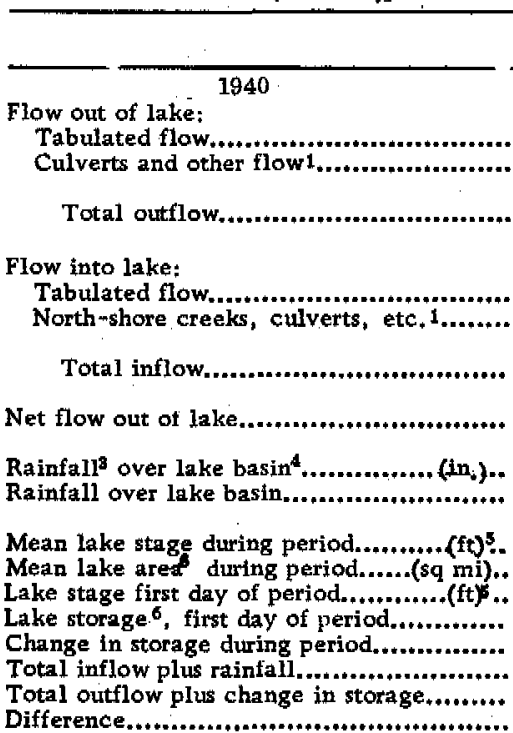

\section{1}

Flow out of lake;

Tabulated flow,

Culverts and other flow ${ }_{+}+\ldots . . . \ldots \ldots . . . . . . .4+.$.

Total outflow

Flow into lake:

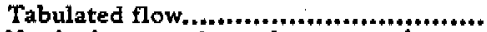

North-shore creeks, culverts, etc. $1_{\text {...+*+*** }}$

Total inflow.

Net flow out of lake

Rainfall $1^{3}$ over lake basin 4 (in, )i.t.

Rainfall over lake basin. (ft)

Mean lake stage during period Mean lake area ${ }^{6}$ during period, $\ldots . \ldots(\mathrm{sq} \mathrm{mi})$.. Lake stage ${ }^{6}$ first day of period............(ft). Lake storage $\mathrm{e}^{6}$, first day of period.......+....... Change in storage during period..........+.+*+.. Total inflow plus rainfall.

Total outflow plus change in storage.......... Difference.

\section{2}

Flow out of lake:

Tabulated flow

Culverts and other flow

Total outflow.

Flow into lake:

Tabulated flow..................................

North-shore creeks, culverts, etc. 1 ..........

Total inflow,

Net flow out of lake

\begin{tabular}{|c|c|c|c|}
\hline Jan. & Feb. & Mar. & Apr. \\
\hline $\begin{array}{l}78.5 \\
1.0\end{array}$ & $\begin{array}{l}78.7 \\
28,0\end{array}$ & $\begin{array}{r}107.6 \\
21.0\end{array}$ & $\begin{array}{r}369.9 \\
21,0\end{array}$ \\
\hline 79.5 & 86.7 & 108.6 & 370.9 \\
\hline $\begin{array}{r}103.1 \\
46.0\end{array}$ & $\begin{array}{r}92.6 \\
262.0\end{array}$ & $\begin{array}{l}101.7 \\
{ }^{2} \\
26.0\end{array}$ & $\begin{array}{r}95.8 \\
223.0\end{array}$ \\
\hline 149.1 & 154.6 & 127.7 & 118.8 \\
\hline-69.6 & -67.9 & -19.1 & 252.1 \\
\hline $\begin{array}{c}2.42 \\
103.3\end{array}$ & $\begin{array}{r}3.21 \\
137.0\end{array}$ & $\begin{array}{r}4.42 \\
188.6\end{array}$ & $\begin{array}{c}1.56 \\
66.6\end{array}$ \\
\hline $\begin{array}{c}16.77 \\
723 \\
16.61 \\
2,518 \\
4 \\
252.4 \\
83.5 \\
168.9\end{array}$ & $\begin{array}{c}16.76 \\
723 \\
16.62 \\
2,522 \\
46 \\
291.6 \\
132.7 \\
158.9\end{array}$ & $\begin{array}{c}16.77 \\
723 \\
16.72 \\
2,568 \\
78 \\
316.3 \\
186.6 \\
129.7\end{array}$ & $\begin{array}{c}16.45 \\
718 \\
16.89 \\
2,646 \\
-476 \\
185.4 \\
-105.1 \\
290.5\end{array}$ \\
\hline $\begin{array}{r}135.4 \\
.6\end{array}$ & $\begin{array}{c}368.8 \\
0\end{array}$ & $\begin{array}{c}310,2 \\
0\end{array}$ & $\begin{array}{r}294.3 \\
.5\end{array}$ \\
\hline 136.0 & 368.8 & 310.2 & 294.8 \\
\hline $\begin{array}{r}121.9 \\
71.4\end{array}$ & $\begin{array}{r}124.2 \\
69.4\end{array}$ & $\begin{array}{r}103.2 \\
19.8\end{array}$ & $\begin{array}{r}145.4 \\
62.6\end{array}$ \\
\hline 193.3 & 193.6 & 123.0 & 208.0 \\
\hline$-57,3$ & 175.2 & 187.2 & 86.8 \\
\hline $\begin{array}{c}4.89 \\
208.6\end{array}$ & $\begin{array}{r}4.31 \\
183.9\end{array}$ & $\begin{array}{r}3.34 \\
142.5\end{array}$ & $\begin{array}{r}7.33 \\
312.7\end{array}$ \\
\hline $\begin{array}{c}16.09 \\
715 \\
15.87 \\
2,178 \\
156 \\
401.9 \\
292 \\
109.9\end{array}$ & $\begin{array}{c}16.21 \\
716 \\
16.21 \\
2.334 \\
-10 \\
377.5 \\
358.8 \\
18.7\end{array}$ & $\begin{array}{c}15.85 \\
708 \\
16.19 \\
2,324 \\
-226 \\
265.5 \\
84.2 \\
181.3\end{array}$ & $\begin{array}{c}15.90 \\
711 \\
15.69 \\
2,098 \\
54 \\
520.7 \\
348.8 \\
171.9\end{array}$ \\
\hline $\begin{array}{c}129,1 \\
0\end{array}$ & $\begin{array}{r}160.3 \\
13.7\end{array}$ & $\begin{array}{c}495,4 \\
0\end{array}$ & $\begin{array}{r}368.2 \\
1.8\end{array}$ \\
\hline 129,1 & 174.0 & 495.4 & 370.0 \\
\hline $\begin{array}{r}212,6 \\
24,1\end{array}$ & $\begin{array}{r}177.5 \\
42.6\end{array}$ & $\begin{array}{r}285.7 \\
53.5\end{array}$ & $\begin{array}{r}162.3 \\
35.6\end{array}$ \\
\hline 236.7 & 220.1 & 339.2 & 197.9 \\
\hline-107.6 & -46.1 & 156.2 & 172.1 \\
\hline
\end{tabular}


of Lake Okeechobee, $1940-46$

combined flow in St. Lucie (table 33), West Palm Beach (table 34), Hillsboro (table 36), North flow into lake is combined flow of Kissimmee River (table 25), Fisheating Creek (table 29),

\begin{tabular}{|c|c|c|c|c|c|c|c|c|}
\hline May & June & July & Aug. & Sept. & Oet. & Nov. & Dec. & Year \\
\hline $\begin{array}{r}194.3 \\
2.0\end{array}$ & $\begin{array}{r}229.7 \\
2.0\end{array}$ & $\begin{array}{r}83.4 \\
2.8\end{array}$ & $\begin{array}{r}20.7 \\
1.9\end{array}$ & $\begin{array}{c}184.5 \\
0\end{array}$ & $\begin{array}{r}396.1 \\
.2\end{array}$ & $\begin{array}{r}86.0 \\
.8\end{array}$ & $\begin{array}{r}88.2 \\
.8\end{array}$ & $\begin{array}{r}1,917.6 \\
21.5\end{array}$ \\
\hline 196.3 & 231.7 & 86.2 & 22.6 & 184.5 & 396.3 & 86.8 & 89.0 & $1,939.1$ \\
\hline $\begin{array}{r}69.0 \\
3.0\end{array}$ & $\begin{array}{l}62.0 \\
25.3\end{array}$ & $\begin{array}{r}112.6 \\
22.2\end{array}$ & $\begin{array}{r}141.3 \\
42.1\end{array}$ & $\begin{array}{l}279.1 \\
126.6\end{array}$ & $\begin{array}{r}199.8 \\
24.2\end{array}$ & $\begin{array}{r}97.7 \\
1.0\end{array}$ & $\begin{array}{r}79.6 \\
5.8\end{array}$ & $\begin{array}{r}1,434.3 \\
407.2\end{array}$ \\
\hline 72.0 & 87.3 & 134.8 & 183.4 & 405.7 & 224.0 & 98.7 & 85.4 & $1,841.5$ \\
\hline 124.3 & 144.4 & -48.6 & -160.8 & -221.2 & 172.3 & -11.9 & 3.6 & 97.6 \\
\hline $\begin{array}{r}3.83 \\
163.4\end{array}$ & $\begin{array}{r}7.22 \\
308.1\end{array}$ & $\begin{array}{r}4.89 \\
208.6\end{array}$ & $\begin{array}{c}7.59 \\
323.8\end{array}$ & $\begin{array}{r}8.78 \\
374.6\end{array}$ & 29.0 & 10.24 & $\begin{array}{r}3.72 \\
158.7\end{array}$ & $\begin{array}{r}48.56 \\
2,071.9\end{array}$ \\
\hline $\begin{array}{c}15.40 \\
697 \\
15.85 \\
2,170 \\
-194 \\
235.4 \\
2.3 \\
233.1\end{array}$ & $\begin{array}{c}15.45 \\
697 \\
15.42 \\
1,976 \\
-90 \\
395.4 \\
141.7 \\
253.7\end{array}$ & $\begin{array}{c}15.11 \\
689 \\
15.22 \\
1,886 \\
-62 \\
343.4 \\
24.2 \\
319.2\end{array}$ & $\begin{array}{c}15.42 \\
697 \\
15.08 \\
1,824 \\
260 \\
507.2 \\
282.6 \\
224.6\end{array}$ & $\begin{array}{c}16.29 \\
717 \\
15.66 \\
2.084 \\
503 \\
780.3 \\
687.5 \\
92.8\end{array}$ & $\begin{array}{c}16.37 \\
718 \\
16.76 \\
2,587 \\
-327 \\
253.0 \\
69.3 \\
183.7\end{array}$ & $\begin{array}{c}15.92 \\
711 \\
16.05 \\
2.260 \\
-118 \\
108.9 \\
-31.2 \\
140.1\end{array}$ & $\begin{array}{c}15.70 \\
705 \\
15.79 \\
2,142 \\
36 \\
244.1 \\
125.0 \\
119.1\end{array}$ & $\begin{array}{c}16.03 \\
713 \\
16.61 \\
2,518 \\
-340 \\
3,913,4 \\
1,599.1 \\
2,314.3\end{array}$ \\
\hline $\begin{array}{r}410.4 \\
.7\end{array}$ & $\begin{array}{r}37.8 \\
6.7\end{array}$ & $\begin{array}{r}125,4 \\
1,4\end{array}$ & $\begin{array}{c}344,3 \\
0\end{array}$ & $\begin{array}{c}230,6 \\
0\end{array}$ & $=\begin{array}{c}300.2 \\
0\end{array}$ & $\begin{array}{c}339.3 \\
0\end{array}$ & $\begin{array}{c}87.7 \\
0\end{array}$ & $\begin{array}{r}2,984,4 \\
9,9\end{array}$ \\
\hline 411,1 & 44,5 & 126.8 & 344.3 & 230.6 & 300.2 & 339.3 & 87.7 & $2,994,3$ \\
\hline $\begin{array}{r}122,1 \\
18,4\end{array}$ & $\begin{array}{r}95,0 \\
6.4\end{array}$ & $\begin{array}{l}275,1 \\
158,9\end{array}$ & $\begin{array}{r}244.9 \\
38.8\end{array}$ & $\begin{array}{r}191.9 \\
65.4\end{array}$ & $\begin{array}{l}209.6 \\
103.7\end{array}$ & $\begin{array}{r}204.9 \\
18.9\end{array}$ & $\begin{array}{r}165.2 \\
9.4\end{array}$ & $\begin{array}{r}2,003.4 \\
643.1\end{array}$ \\
\hline 140.5 & 101.4 & 434.0 & 283.7 & 257,3 & 313,3 & 223,8 & 174,6 & $2,646,5$ \\
\hline 270.6 & -56.9 & -307.2 & 60.6 & -26.7 & -13.1 & 115.5 & -86.9 & 347.8 \\
\hline $\begin{array}{c}2,20 \\
93.9\end{array}$ & $\begin{array}{r}3.83 \\
163.4\end{array}$ & $\begin{array}{c}11.74 \\
500.9\end{array}$ & $\begin{array}{r}4.63 \\
197.5\end{array}$ & $\begin{array}{r}6.63 \\
282.9\end{array}$ & $\begin{array}{r}5.12 \\
218.5\end{array}$ & $\begin{array}{l}1.94 \\
82.8\end{array}$ & $\begin{array}{c}2.14 \\
91.3\end{array}$ & $\begin{array}{r}58,10 \\
2,478.9\end{array}$ \\
\hline $\begin{array}{c}15.50 \\
700 \\
15.81 \\
2.152 \\
-372 . \\
234.4 \\
39.1 \\
195.3\end{array}$ & $\begin{array}{c}14.90 \\
679 \\
14.98 \\
1.780 \\
22 \\
264.8 \\
66.5 \\
198.3\end{array}$ & 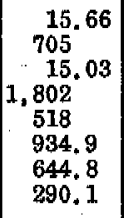 & $\begin{array}{c}15.94 \\
711 \\
16.18 \\
2.320 \\
-204 \\
481.2 \\
140.3 \\
340.9\end{array}$ & $\begin{array}{c}15.93 \\
711 \\
15.73 \\
2.116 \\
241 \\
540.2 \\
471.6 \\
68.6\end{array}$ & \begin{tabular}{|c} 
\\
16.35 \\
718 \\
16.26 \\
2,357 \\
110 \\
531.8 \\
410.2 \\
121.6
\end{tabular} & $\begin{array}{c}16.29 \\
717 \\
16.50 \\
2.467 \\
-161 \\
306.6 \\
178.3 \\
128.3\end{array}$ & $\begin{array}{c}16.24 \\
716 \\
16.15 \\
2,306 \\
87 \\
265.9 \\
174.7 \\
91.2\end{array}$ & $\begin{array}{c}15.90 \\
711 \\
15.87 \\
2,178 \\
215 \\
5,125.4 \\
3,209.3 \\
1,916.1\end{array}$ \\
\hline $\begin{array}{r}388,1 \\
3,0\end{array}$ & $\begin{array}{r}224.4 \\
16.2\end{array}$ & $\begin{array}{r}341.9 \\
6.0\end{array}$ & $\begin{array}{r}207.2 \\
3.8\end{array}$ & $\begin{array}{r}72,8 \\
4,2\end{array}$ & $\begin{array}{r}85.3 \\
2.2\end{array}$ & $\begin{array}{r}50.3 \\
2.5\end{array}$ & $\begin{array}{r}61.1 \\
1.7\end{array}$ & $\begin{array}{r}2,584.1 \\
65.1\end{array}$ \\
\hline 391,1 & 240.6 & 347.9 & 211,0 & 77,0 & 87.5 & 52.8 & 62.8 & $2,639.2$ \\
\hline $\begin{array}{r}111.8 \\
10.0\end{array}$ & $\begin{array}{l}208,4 \\
165,3\end{array}$ & $\begin{array}{r}169.9 \\
42.5\end{array}$ & $\begin{array}{r}149.3 \\
16.7\end{array}$ & $\begin{array}{r}149.8 \\
35.9\end{array}$ & $\begin{array}{c}120,1 \\
12,0\end{array}$ & $\begin{array}{r}80.4 \\
2.1\end{array}$ & $\begin{array}{r}69.4 \\
1.7\end{array}$ & $\begin{array}{r}1,897,2 \\
442,0\end{array}$ \\
\hline 121.8 & 373.7 & 212.4 & 166.0 & 185.7 & 132,1 & 82,5 & 71,1 & $2,339,2$ \\
\hline 269.3 & -133.1 & 135.5 & 45,0 & -108.7 & -44.6 & -29.7 & -8.3 & 300.0 \\
\hline
\end{tabular}


Table 62.-Hydrologic stmmary of

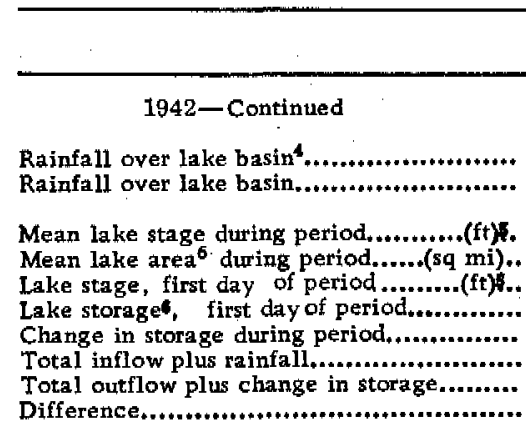

1943

Flow out of lake:

Tabulated flow....................................

Culverts and other flowl.

Total outflow.

Flow into lake:

Tabulated flow....................................

North-shore creeks, culverts, etc.1..........

Total inflow.

Net flow out of lake.

Rainfall ${ }^{3}$ over lake basin 4 ...............(in.)..

Rainfall over lake basin.

$(\mathrm{ft})$.

Mean lake stage during period.

Mean lake area ${ }^{6}$ during period.......(sq mi).

Lake storagef, first day of period.

-Change in storage during period.................

Total inflow plus rainfall.

Total outflow plus change in storage..........

Difference................................................

\section{4}

Flow out of lake:

Tabulated flow.

Culverts and other flowi

Total outflow.................................

Flow into lake:

Tabulated flow.

North-shore creeks, culverts, etc. $1 . . . . .$.

Total inflow,

Net flow out of lake.

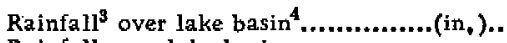

Rainfall over lake basin..........................

Mean lake stage during period..........(ft ${ }^{5}$..

Mean lake area ${ }^{6}$ during period...... (sq mi).

Lake stage, first day of period............(ft) ${ }^{5}$..

Lake storage ${ }^{6}$, first day of period..............

Change in storage during period................

Total inflow plus rainfall.

Total outflow plus change in storage........4.

Difference.

\begin{tabular}{|c|c|c|}
\hline Feb. & Mar. & Apr. \\
\hline $\begin{array}{r}3.21 \\
137.0\end{array}$ & $\begin{array}{r}4.64 \\
198.0\end{array}$ & $\begin{array}{r}4.06 \\
173.2\end{array}$ \\
\hline $\begin{array}{c}16.41 \\
718 \\
16.50 \\
2,467 \\
37 \\
357.1 \\
211 \\
146.1\end{array}$ & $\begin{array}{c}16.46 \\
720 \\
16.58 \\
2,504 \\
-111 \\
537.2 \\
384.4 \\
152.8\end{array}$ & $\begin{array}{c}16.06 \\
715 \\
16.34 \\
2.393 \\
-228 \\
371.1 \\
142 \\
229.1\end{array}$ \\
\hline $\begin{array}{r}47.0 \\
1.3\end{array}$ & $\begin{array}{r}49.4 \\
1.0\end{array}$ & $\begin{array}{r}49.8 \\
2.6\end{array}$ \\
\hline 48.3 & 50.4 & 52.4 \\
\hline $\begin{array}{r}42.4 \\
.7\end{array}$ & $\begin{array}{r}49.0 \\
.6\end{array}$ & $\begin{array}{r}34.0 \\
.4\end{array}$ \\
\hline 43.1 & 49.6 & 34.4 \\
\hline 5.2 & .8 & 18.0 \\
\hline $16,2^{.38}$ & $\begin{array}{c}2.56 \\
109.2\end{array}$ & $\begin{array}{c}2.06 \\
87.9\end{array}$ \\
\hline $\begin{array}{c}14.41 \\
641 \\
14.56 \\
1,601 \\
-139 \\
59.3 \\
-90.7 \\
150\end{array}$ & $\begin{array}{c}14.31 \\
633 \\
14.22 \\
1.462 \\
24 \\
158.8 \\
74.4 \\
84.4\end{array}$ & $\begin{array}{c}13.99 \\
610 \\
14.28 \\
1.486 \\
-186 \\
122.3 \\
-133.6 \\
255.9\end{array}$ \\
\hline $\begin{array}{r}54.6 \\
3.2\end{array}$ & $\begin{array}{r}52.8 \\
4.9\end{array}$ & $\begin{array}{r}42.4 \\
1.1\end{array}$ \\
\hline 57.8 & 57,7 & 43.5 \\
\hline $\begin{array}{r}54.6 \\
3.0\end{array}$ & $\begin{array}{r}45.1 \\
3.3\end{array}$ & $\begin{array}{r}58,1 \\
12,2\end{array}$ \\
\hline 57.6 & 48.4 & 70.3 \\
\hline .2 & 9.3 & -26.8 \\
\hline 5.12 & $\begin{array}{c}4.81 \\
205.2\end{array}$ & $\begin{array}{r}4.00 \\
170.7\end{array}$ \\
\hline $\begin{array}{c}14.98 \\
687 \\
15.14 \\
1.851 \\
-109 \\
62.7 \\
-51.2 \\
113.9\end{array}$ & $\begin{array}{c}14.65 \\
656 \\
14.89 \\
1,742 \\
-116 \\
253.6 \\
-58.3 \\
311.9\end{array}$ & $\begin{array}{c}14.58 \\
656 \\
14.62 \\
1,626 \\
-91 \\
241.0 \\
-47.5 \\
288.5\end{array}$ \\
\hline
\end{tabular}

See footnotes at end of table. 


\begin{tabular}{|c|c|c|c|c|c|c|c|c|}
\hline May & June & July & Aug. & Sept. & Oct. & Nov. & Dec. & Year \\
\hline $\begin{array}{r}3.51 \\
149.8\end{array}$ & $\begin{array}{c}10.07 \\
429.7\end{array}$ & $\begin{array}{r}4.35 \\
185.6\end{array}$ & $\begin{array}{r}3.91 \\
166.8\end{array}$ & $\begin{array}{r}4.57 \\
195.0\end{array}$ & 23.5 & $\begin{array}{c}1.03 \\
43.9\end{array}$ & $\begin{array}{c}1.86 \\
79.4\end{array}$ & $\begin{array}{r}43.58 \\
1,859.6\end{array}$ \\
\hline $\begin{array}{c}15.38 \\
697 \\
15.84 \\
2,165 \\
-345 \\
271.6 \\
46.1 \\
225.5\end{array}$ & $\begin{array}{c}15.65 \\
703 \\
15.07 \\
1,820 \\
368 \\
803.4 \\
608.6 \\
194.8\end{array}$ & $\begin{array}{c}15.64 \\
703 \\
15.89 \\
2,188 \\
-194 \\
398.0 \\
153.9 \\
244.1\end{array}$ & $\begin{array}{c}15.27 \\
695 \\
15.46 \\
1,994 \\
-157 \\
332.8 \\
54 \\
278.8\end{array}$ & $\begin{array}{c}15.25 \\
692 \\
15.11 \\
1,837 \\
112 \\
380.7 \\
189 \\
191.7\end{array}$ & $\begin{array}{c}15.17 \\
692 \\
15.36 \\
1,949 \\
-156 \\
155.6 \\
-68.5 \\
224.1\end{array}$ & $\begin{array}{c}14.96 \\
687 \\
15.01 \\
1,793 \\
-90 \\
126.4 \\
-37.2 \\
163.6\end{array}$ & $\begin{array}{c}14.82 \\
672 \\
14.80 \\
1.703 \\
0 \\
150.5 \\
62.8 \\
87.7\end{array}$ & $\begin{array}{c}15.63 \\
703 \\
16.34 \\
2,393 \\
-690 \\
4,198.8 \\
1,949.2 \\
2,249.6\end{array}$ \\
\hline $\begin{array}{r}45.1 \\
1.8\end{array}$ & $\begin{array}{c}35.4 \\
0\end{array}$ & $\begin{array}{l}4.1 \\
0\end{array}$ & 22.9 & $\begin{array}{c}16.8 \\
0\end{array}$ & $\begin{array}{r}36.6 \\
2.5\end{array}$ & $\begin{array}{r}59.8 \\
4.6\end{array}$ & $\begin{array}{r}43.3 \\
.3\end{array}$ & $\begin{array}{r}469.7 \\
16.0\end{array}$ \\
\hline 46.9 & 35.4 & 4.1 & 22.9 & 16.8 & 39.1 & 64.4 & 43.6 & 485.7 \\
\hline $\begin{array}{r}29.1 \\
1.0\end{array}$ & $\begin{array}{r}35.6 \\
4.8\end{array}$ & $\begin{array}{l}90.6 \\
33.2\end{array}$ & $\begin{array}{r}109.7 \\
33.2\end{array}$ & $\begin{array}{r} \pm 88.5 \\
55.4\end{array}$ & $\begin{array}{r}273.1 \\
46.3\end{array}$ & $\begin{array}{r}114.5 \\
2.5\end{array}$ & $\begin{array}{r}87.9 \\
3.3\end{array}$ & $\begin{array}{r}1,110,6 \\
182,9\end{array}$ \\
\hline 30.1 & 40.4 & 123.8 & 142.9 & 243.9 & 319.4 & 117.0 & 91.2 & $1,293,5$ \\
\hline 16.8 & -5.0 & -119.7 & -120.0 & -227.1 & -280.3 & -52.6 & -47.6 & $-807,8$ \\
\hline $\begin{array}{c}2.84 \\
121.2\end{array}$ & $\begin{array}{r}5.10 \\
217.6\end{array}$ & $\begin{array}{c}7.19 \\
306.8\end{array}$ & $\begin{array}{r}6.44 \\
274.8\end{array}$ & $\begin{array}{c}3.99 \\
170.2\end{array}$ & $\begin{array}{c}2.18 \\
53.0\end{array}$ & $\begin{array}{l}1.74 \\
74.2\end{array}$ & 8.19 & $\begin{array}{r}34.86 \\
1,487.3\end{array}$ \\
\hline $\begin{array}{c}13.58 \\
598 \\
13.81 \\
1,300 \\
-142 \\
151.3 \\
-95.1 \\
246.4\end{array}$ & $\begin{array}{c}13.27 \\
588 \\
13.44 \\
1,158 \\
-45 \\
258.0 \\
-9.6 \\
267.6\end{array}$ & $\begin{array}{c}13.47 \\
594 \\
13.32 \\
1,113 \\
179 \\
430.6 \\
183.1 \\
247.5\end{array}$ & $\begin{array}{c}13.96 \\
610 \\
13.79 \\
1,292 \\
150 \\
417.7 \\
172.9 \\
244.8\end{array}$ & $\begin{array}{c}14.48 \\
649 \\
14.17 \\
1,442 \\
205 \\
414.1 \\
221.8 \\
192.3\end{array}$ & $\begin{array}{c}15.07 \\
689 \\
14.67 \\
1,647 \\
212 \\
412.4 \\
251.1 \\
161.3\end{array}$ & $\begin{array}{c}15.22 \\
692 \\
15.16 \\
1,859 \\
49 \\
191.2 \\
113.4 \\
77.8\end{array}$ & $\begin{array}{c}15.21 \\
692 \\
15.27 \\
1,908 \\
-35 \\
99.3 \\
8.6 \\
90.7\end{array}$ & $\begin{array}{c}14.30 \\
633 \\
14.80 \\
1.703 \\
170 \\
2.780 .8 \\
655.7 \\
2.125 .1\end{array}$ \\
\hline $\begin{array}{r}58.4 \\
6.3\end{array}$ & $\begin{array}{r}33.6 \\
3.9\end{array}$ & $\begin{array}{r}43.1 \\
2.3\end{array}$ & $\begin{array}{r}22.0 \\
2.4\end{array}$ & $\begin{array}{r}31.5 \\
1.5\end{array}$ & $\begin{array}{c}-3.2 \\
0\end{array}$ & $\begin{array}{r}38.3 \\
.1\end{array}$ & $\begin{array}{r}56.9 \\
.3\end{array}$ & $\begin{array}{r}477.9 \\
30.5\end{array}$ \\
\hline 64.7 & 37.5 & 45.4 & 24.4 & 33.0 & -3.2 & 38.4 & 57.2 & 508.4 \\
\hline $\begin{array}{r}39.6 \\
.4\end{array}$ & $\begin{array}{r}34.1 \\
2.3\end{array}$ & $\begin{array}{r}38.5 \\
2.4\end{array}$ & $\begin{array}{l}73.1 \\
33.7\end{array}$ & $\begin{array}{r}106.3 \\
37.3\end{array}$ & $\begin{array}{l}89.8 \\
33.8\end{array}$ & $\begin{array}{r}106.4 \\
3.8\end{array}$ & $\begin{array}{r}98.7 \\
2.0\end{array}$ & $\begin{array}{l}816.6 \\
137.1\end{array}$ \\
\hline 40.0 & 36.4 & 40.9 & 106.8 & 143.6 & 123.6 & 110.2 & 100.7 & 953.7 \\
\hline 24.7 & 1.1 & 4.5 & -82.4 & -110.6 & -126.8 & -71.8 & -43.5 & -445.3 \\
\hline $\begin{array}{r}3.82 \\
163.0\end{array}$ & $\begin{array}{c}3.88 \\
165.5\end{array}$ & $\begin{array}{c}5.84 \\
249.2\end{array}$ & $\begin{array}{l}4.88 \\
208.2\end{array}$ & $\begin{array}{r}4.03 \\
172.0\end{array}$ & $\begin{array}{r}6.16 \\
262.8\end{array}$ & $\begin{array}{l}.16 \\
6.8\end{array}$ & 7.37 & $\begin{array}{r}38.66 \\
1,649.5\end{array}$ \\
\hline $\begin{array}{c}14.26 \\
633 \\
14.40 \\
1,535 \\
-125 \\
203.0 \\
-60.3 \\
263.3\end{array}$ & $\begin{array}{c}13.95 \\
610 \\
14.09 \\
1,410 \\
-126 \\
201.9 \\
-88.5 \\
290.4\end{array}$ & $\begin{array}{c}13.72 \\
601 \\
13.77 \\
1,284 \\
12 \\
290.1 \\
57.4 \\
232.7\end{array}$ & $\begin{array}{c}14.02 \\
610 \\
13.80 \\
1,296 \\
138 \\
315.0 \\
162.4 \\
152.6\end{array}$ & $\begin{array}{c}14.21 \\
626 \\
14.15 \\
1,434 \\
36 \\
315.6 \\
69 \\
246.6\end{array}$ & $\begin{array}{c}14.49 \\
64 . \\
14.24 \\
1.470 \\
212 \\
386.4 \\
208.8 \\
177.6\end{array}$ & $\begin{array}{c}14.70 \\
664 \\
14.75 \\
1.682 \\
4 \\
117.0 \\
42.4 \\
74.6\end{array}$ & $\begin{array}{c}14.54 \\
649 \\
14.76 \\
1,686 \\
-126 \\
108.0 \\
-68.8 \\
176.8\end{array}$ & $\begin{array}{c}14.44 \\
641 \\
15.19 \\
1,873 \\
-313 \\
2,603.2 \\
195.4 \\
2,407.8\end{array}$ \\
\hline
\end{tabular}


Table 62.- Ilydrologic stummary of

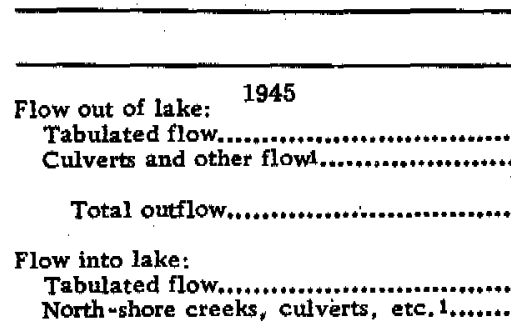

Total inflow.

Net flow out of lake.

Rainfall ${ }^{\text {sover lake basin }} 4$

Rainfall over lake basin

Mean lake stage ditring period

Mean lake area during period ..........(ft)

lake stage, first of day period...........(ft).

Lake storage 6 first day of period.

Change in storage during period.

Total inflow plus raitafall

Total outflow plus change in storage

Difference.

\section{6}

Flow out of lake:

Tabulated flow

Culverts and other how

Total outflow,

\section{Flow into lake:}

Tabulated flow.

North-shore creeks, culverts, etc ${ }^{i}$

Total inflow.

Net flow out of lake.

Rainfall ${ }^{3}$ over lake basint (in.).

Rainfall over lake basin.

Mean lake stage during period $(\mathrm{ft})^{5}$

Mean lake area 6 during period..... (sq. mi)..

Lake stage, first days period..............(ft) ${ }^{\text {5.. }}$

lake storage ${ }^{6}$, first day of period.

Change in storage during period.

Total inflow plus rainfall.

Total outflow plus change in storage

Difference.

Ja

Jan

Jan.

Fe

5.3

44.

\begin{tabular}{l|l|l|} 
Mar. & Apr. \\
\hline
\end{tabular}

May

5.3

\begin{tabular}{c|c}
0 & 56,3 \\
44.4 & 56.3
\end{tabular}

52.8

3.7

53.7

56.5

59.1

0.9

73.3

4.3

1.6

66.

5.2

74.9

69.8

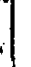

1.3

$-30.5$

1.30

55.5

14.53

649

14.46

1

1,560

71

126.3

$\begin{array}{r}24.4 \\ \hline\end{array}$

.41

$-13.5$

17.5

3.8

641.40

1,631

$-104$

92.4

$-59.6$

152.0

3.8

47.4

34,2

$.9 \quad .5$

48.3

34. 7

8.2

24.4

2.32

2.15

99.0

91.7

14.14

13.66

618

601

14.38

13. 86

1,527

$-208$

73.6

1,319

1,319
-123

$-151.7$

147.3

225.3

213.8

13.26

588

13. 54

.

4

\section{7}

.7
.4

\section{1}

.

159.

9.6

\section{8}

$-38.7$

\begin{tabular}{|c|c|c|}
\hline 168.8 & 109.5 & 120.4 \\
\hline-38.7 & -47.0 & 177.2 \\
\hline 39.9 & $\begin{array}{r}1.46 \\
62.3\end{array}$ & $\begin{array}{r}2.76 \\
117.8\end{array}$ \\
\hline
\end{tabular}

16.81
723
16.83
2,619
-14
208.1
116.1
92

\begin{tabular}{c|c}
16.75 & 16.69 \\
723 & 722 \\
16.80 & 16.79 \\
2.605 & 2,600 \\
-5 & -234 \\
171.8 & 238.2 \\
57.5 & 63.6 \\
114.3 & 174.6 \\
\hline
\end{tabular}

\begin{tabular}{c|c}
15.84 & 15.50 \\
708 & 700 \\
16.28 & 15.46 \\
2,366 & 1,994 \\
-372 & 18 \\
75.4 & 376.3 \\
-167.5 & 85.1 \\
242.9 & 291.2 \\
&
\end{tabular}

\footnotetext{
${ }^{1}$ Records computed from discharges furnished by U. S. Corps of Engineers, Jacksonville, and discharge relationships. Includes Miami Canal at Lake Harbor after July 1, 1943.

2Computed on basis of other records and rainfall data.

3Mean rainfall determined by weighting, by Theissen method, records for five rainfall stations around Lake Okeechobee for period January and February 1940 and six rainfall statioms for period March 1940 to December 1946, on a map furmished b? U. S. Corps of Engineers Jacksonville. Although rainfall values were weighted on basis of a normal lake area, only the values were used for the lake basin themare defined under footnote 4 and that are assumed to represent the conditions in the basin.
} 


\begin{tabular}{|c|c|c|c|c|c|c|c|c|}
\hline June & July & Aug. & Sept. & Oct. & Nov. & Dec. & Year & $\begin{array}{l}\text { 1940-46 } \\
\text { inclusive }\end{array}$ \\
\hline $\begin{array}{r}40.4 \\
1.2\end{array}$ & $\begin{array}{c}-16.9 \\
0\end{array}$ & $\begin{array}{r}6.6 \\
.1\end{array}$ & $\begin{array}{c}85,3 \\
0\end{array}$ & $\begin{array}{r}595.9 \\
2.9\end{array}$ & $\begin{array}{r}400.1 \\
5.2\end{array}$ & $\begin{array}{r}124.1 \\
7.0\end{array}$ & $\begin{array}{r}1,498,0 \\
25,5\end{array}$ & \\
\hline 41.6 & -16.9 & 6.7 & 85.3 & 598.8 & 405.3 & 131.1 & $1,523,5$ & \\
\hline $\begin{array}{r}28.4 \\
6.8\end{array}$ & $\begin{array}{r}189.3 \\
38.9\end{array}$ & $\begin{array}{r}234.1 \\
45.8\end{array}$ & $\begin{array}{l}520.8 \\
290.5\end{array}$ & $\begin{array}{l}503.9 \\
167.8\end{array}$ & $\begin{array}{r}300,4 \\
20.4\end{array}$ & $\begin{array}{r}209.3 \\
4.5\end{array}$ & $\begin{array}{r}2,298,4 \\
585,4\end{array}$ & \\
\hline 35.2 & 228.2 & 279.9 & 811.3 & 671.7 & 320.8 & 213.8 & $2,883,8$ & \\
\hline 6.4 & $-245,1$ & -273.2 & -726.0 & -72.9 & 84.5 & -82.7 & $-1,360.3$ & \\
\hline $\begin{array}{r}6.71 \\
286.3\end{array}$ & $\begin{array}{r}7.42 \\
316.6\end{array}$ & $\begin{array}{r}5.17 \\
220.6\end{array}$ & $\begin{array}{r}9.91 \\
422.8\end{array}$ & $\begin{array}{r}4.40 \\
187.7\end{array}$ & $\begin{array}{l}1.08 \\
46.1\end{array}$ & $40 . .^{.95}$ & $\begin{array}{r}41,91 \\
1,788,1\end{array}$ & \\
\hline $\begin{array}{c}12.90 \\
574 \\
12.84 \\
934 \\
89 . \\
321.5 \\
130.6 \\
190.9\end{array}$ & $\begin{array}{c}13.31 \\
588 \\
13.08 \\
1,023 \\
347 \\
544.8 \\
330.1 \\
214.7\end{array}$ & $\begin{array}{l}14.27 \\
633 \\
13.99 \\
1,370 \\
256 \\
500.5 \\
262.7 \\
237.8\end{array}$ & $\begin{array}{c}15.68 \\
705 \\
14.62 \\
1,626 \\
997 \\
1,234.1 \\
1,082.3 \\
151.8\end{array}$ & $\begin{array}{c}17.08 \\
727 \\
16.84 \\
2,623 \\
157 \\
859.4 \\
755.8 \\
103.6\end{array}$ & $\begin{array}{c}16.94 \\
725 \\
17.18 \\
2.780 \\
-170 \\
366.9 \\
235.3 \\
131.6\end{array}$ & $\begin{array}{c}16.84 \\
723 \\
16.81 \\
2,610 \\
9 \\
254.3 \\
140.1 \\
114.2\end{array}$ & $\begin{array}{c}14.75 \\
672 \\
14.46 \\
1,560 \\
1,059 \\
4,671,9 \\
2,582.5 \\
2,089.4\end{array}$ & \\
\hline $\begin{array}{r}144.0 \\
1.3\end{array}$ & $\begin{array}{r}30.9 \\
.6\end{array}$ & $\begin{array}{c}42.2 \\
0\end{array}$ & $\begin{array}{c}47.9 \\
0\end{array}$ & $\begin{array}{r}196.2 \\
.1\end{array}$ & $\begin{array}{r}29.3 \\
.4\end{array}$ & $\begin{array}{r}45.9 \\
.8\end{array}$ & $\begin{array}{r}1,260.0 \\
41.4\end{array}$ & \\
\hline 145.3 & 31.5 & 42.2 & 47.9 & 196.3 & 29.7 & 46.7 & $1,301.4$ & $11,391,6$ \\
\hline $\begin{array}{l}62.1 \\
21.6\end{array}$ & $\begin{array}{l}68.8 \\
34.2\end{array}$ & $\begin{array}{r}111.6 \\
45.1\end{array}$ & $\begin{array}{r}151.9 \\
83.6\end{array}$ & $\begin{array}{r}145.2 \\
36.9\end{array}$ & $\begin{array}{r}112.2 \\
33.1\end{array}$ & $\begin{array}{l}95.6 \\
13.4\end{array}$ & $\begin{array}{r}1,245.0 \\
320.7\end{array}$ & . \\
\hline 83.7 & 103.0 & 156.7 & 235.5 & 182.1 & 145.3 & 109.0 & $1,565.7$ & $13,523,9$ \\
\hline 61.6 & -71.5 & -114.5 & -187.6 & 14.2 & -115.6 & -62.3 & $-264,3$ & $-2,132,3$ \\
\hline $\begin{array}{r}7.10 \\
303.0\end{array}$ & $\begin{array}{r}\quad 6.85 \\
292.3\end{array}$ & $\begin{array}{r}5.06 \\
215.9\end{array}$ & $\begin{array}{r}7.67 \\
327.3\end{array}$ & $\begin{array}{r}1.57 \\
67.0\end{array}$ & $\begin{array}{r}3.15 \\
134.4\end{array}$ & $\begin{array}{l}1.57 \\
67.0\end{array}$ & $\begin{array}{r}45.14 \\
1,926.3\end{array}$ & $\begin{array}{r}310.81 \\
13,261.6\end{array}$ \\
\hline $\begin{array}{c}15.62 \\
703 \\
15.50 \\
2,012 \\
36 \\
386.7 \\
181.3 \\
205,4\end{array}$ & \begin{tabular}{|c} 
\\
15.68 \\
705 \\
15.58 \\
2,048 \\
108 \\
395.3 \\
139.5 \\
255.8
\end{tabular} & $\begin{array}{c}15.87 \\
711 \\
15.82 \\
2.156 \\
72 \\
372.6 \\
114.2 \\
258.4\end{array}$ & $\begin{array}{c}16.18 \\
716 \\
15.98 \\
2.228 \\
207 \\
562.8 \\
254.9 \\
307.9\end{array}$ & $\begin{array}{c}16.25 \\
716 \\
16.43 \\
2.435 \\
-157 \\
249.1 \\
39.3 \\
209.8\end{array}$ & $\begin{array}{c}16.41 \\
718 \\
16.09 \\
2.278 \\
148 \\
279.7 \\
177.7 \\
102\end{array}$ & $\begin{array}{c}16.43 \\
718 \\
16.41 \\
2,426 \\
4 \\
176.0 \\
50.7 \\
125.3\end{array}$ & $\begin{array}{c}16.17 \\
716 \\
16.83 \\
2,619 \\
-189 \\
3,492,0 \\
1,112.4 \\
2,379.6\end{array}$ & $\begin{array}{c}15,32 \\
695 \\
16,61 \\
2,518 \\
-88 \\
26,785.5 \\
11,303.6 \\
15,481.9 \\
.\end{array}$ \\
\hline
\end{tabular}

4Lake basin refers to lake and surrounding area toward the lake from locations of inflow and outflow measurements and has been measured as approximately 800 square miles.

5 Okeechobee datum $=1.44$ feet below mean sea level.

6rom area and capacity curves by U. \$. Corps of Engineers, Jacksonville. 
The above are the directly measurable quantities of supply to and drainage from the lake. From surveys of the lake a capacity table has been computed by the Corps of Engineers. With this table and a record of its stage, the month to month changes in volume can be taken into account in the inventory. No other quantities are directly known. Evaporation from the lake and transpiration from the littoral vegetation are unmeasurable, and the amounts lost in such manner can only be estimated. The difference between precipitation plus total measured inflow to the lake basin and total measured outflow, with adjustment for storage in the lake, averaged about $2,200,000$ acre- $\mathrm{ft}$ per year, the equivalent of $51.3 \mathrm{in}$, over the lake basin. The monthly differences average as follows:

$\begin{array}{lcc}\text { Month } & \begin{array}{c}\text { Thousends of } \\ \text { acre-feet }\end{array} & \begin{array}{c}\text { Inches over } \\ \text { lake basin }\end{array} \\ \text { Jan. } & 99 & 2.3 \\ \text { Feb. } & 122 & 2.9 \\ \text { Mar. } & 180 & 4.2 \\ \text { Apr. } & 242 & 5.6 \\ \text { May } & 255 & 6.0 \\ \text { June } & 229 & 5.5 \\ \text { July } & 258 & 6.0 \\ \text { Aug. } & 248 & 5.8 \\ \text { Sept. } & 179 & 4.2 \\ \text { Oct. } & 169 & 4.0 \\ \text { Nov. } & 117 & 2.8 \\ \text { Dec. } & 115 & 2.6\end{array}$

These differences range from a maximum of $6.0 \mathrm{in}$. in May and July to a minimum of $2.3 \mathrm{in.}$. January. The seasonal cycle is so strongly developed that evaporation and associated transpiration from hydrophytic vegetation are obviously the controlling factors.

Seepage in and out of the lake is also contained in these figures, but the net quantity is exceedingly small and probably quite uniform throughout the year. Parker (p. 107) has estimated, on the basis of ground-water studies that inflow into Lake Okeechobee is only about 730 acre-ft per year, or about $1.0 \mathrm{cfs}$ per day.

Measurements of evaporation from the pans located about the lake are a further aid in judging the losses from Lake Okeechobee. These measurements, expressed in inches of depth per unit of area, must be multiplied by a coefficient in order to convert them to equivalent evaporation from a lake surface. The location and description of these pans, which are maintained and operated by the Corps of Engineers at Clewiston, are given in table 7 . In this analysis a coefficient of 0.78 was used for the six sunken land pans around the lake, however, the proper application of pan coefficients is a subject open to much question. A value of about 0.7 conforms 
reasonably well to available experience for application to Class $A$ pans, such as those of the Department of Agriculture at Belle Glade and Hiwassee. (See pages 42-54 for a discussion of evaporation.)

Additional losses due to transpiration of hydrophytes occur in a marsh around the shore of the lake. This area, comprising 100 square miles, was measured on an ecologic map furnished by Dr. J. H. Davis, Jr., ecologist of the Florida Geological Survey. These losses are assumed to be in addition to the evaporation from the water surface in the same area, because the losses of this area total 150 percent of those of the water surface area (Calif. Dept. of Public Works Bull., 1942., p. 132-138). Evapotranspiration was studied at the experiment station at Belle Glade during 1937. From a stand of mature sawgrass grown in a tank with water about 11 in. from the surface, the evapotranspiration was measured as 84 in. (Clayton, Neller, and Allison, 1942, p. 32), 131 percent of the losses from a nearby Class A evaporation pan. In calculating total evaporation losses from the lake basin by reference to pans, the computed lake evaporation will be multiplied by $1.00 \times \frac{700}{800}+i$ $1.50 \times \frac{100}{800}=1.06$.

Evaporation from the Class A pans at Belle Glade and Hiwassee averaged 63.2 in. per year during the 7-year period 1940-46. On this basis, evaporation from the lake would be 44.2 in.; with allowance for littoral transpiration, the total losses would be $46.9 \mathrm{in}$. per year. Evaporation from the six sunken pans average 54.2 in. Using a coefficient of 0.78 , lake evaporation would total 42.3 in.; with allowance for littoral transpiration, the total losses would amount to $44.8 \mathrm{in}$.

Since the calculated evaporation from the Lake is 46.9 in. where using the Type-A ventilated pans and $44.8 \mathrm{in}$. where using the sunken pans, the actual evaporation may be between these two values-46 in. per year. This average loss could be reconciled with the average land-water evaporation calculated for the Kissimmee River basin (42. 4 in.), because the opportunity for evaporation would make the lake loss somewhat higher.

All of the above evidence suggests that the losses amount to almost the 51.8-in. difference between precipitation plus total inflow to the basin and total outflow with adjustment for storage. The extent, therefore, that 46 in. represents the annual water loss for the lake basin, the residual between 51.8 and 46 in. represents the net outseepage, a rate of about $6 \mathrm{in}$. per year or $0.042 \mathrm{ft}$ per month. This is equivalent to 250,000 acre-ft per year, whereas ground-water studies (p. 1u7) indicate a flow of less than 1,000 acre-ft. Obviously the pan coefficients are higher than indicated by experience at other lakes. 
Runoff, as it usually occurs in a natural basin, does not occur in Lake Okeechobee, because rain becomes runoff as soon as it falls upon the lake. The lake waters are subject to losses, but the situation is somewhat different from evaporation from the soil and vegetation in other natural basins. Nevertheless, the difference between precipitation and losses is the net increment to the waters passing into and out of the lake basin. As already indicated, rainfall during the 7-year period of record (1940-46) averaged 44. $4 \mathrm{in}$. This figure is about $3 \mathrm{in}$. below a long-term normal. Since evapotranspiration losses are of the same order of magnitude as the rainfall, the lake basin contributes almost nothing to the water supply of southeastern Florida.

During the same period of record, runoff of the Kissimmee River basin averaged 7.45 in. (see table 61), and runoff for the entire southeastern Florida. drainage unit averaged $7.5 \mathrm{in}$. (table 55). The difference between measured rainfall and runoff in these two areas averaged 42.9 in: and 42.6 in., respectively, only slightly less than the estimated loss from Lake Okeechobee. Probably the negligible contribution by Lake Okeechobee to the water supply of southeastern Florida is due as much to low rainfall over the lake as to high losses.

\section{EVERGLADES AREA}

The Everglades area is the most downstream part of the southeastern Florida drainage system, and is the hinterland to the populous Atlantic Coastal Ridge. The distinguishing features of the Everglades proper, although climatic and physiographic in their inception, are basically ecologic (see pls. 11, 12). However, in defining an area from the point of view of its water resources, boundaries must relate to drainage features and points of measurement. Such boundaries will not conform precisely with the limits of the ecologic unit. The Everglades area, as this drainage unit will be called, covers 3,900 square miles and is bounded on the north by the southern levee of the Lake Okeechobee basin (described in the previous section) and by the natural divide that runs from the head of the St. Lucie Canal to West Palm Beach. From West Palm Beach the boundary extends southward along the Atlantic Coastal Ridge to the Tamiami Canal, then westward to the low drainage divide that conforms approximately to the western boundary of the Everglades Drainage District. It follows this divide northward to Lake Okeechobee. The Tamiami Canal forms a suitable boundary because it is used to measure not only the eastward drainage from the area, but also the drainage to the south.

The flows that pass the terminals of all canals crossing the boundaries are summarized for the period $1940-46$, by months, in 
table 63. The difference between total outflow and inflow represents the net increment to visible runoff, produced by precipitation over the area. This quantity averaged 1,985, 000 acre-ft per year, or 9.54 in.

Runoff, a term applied in general to the surface outflow from an area, has complex characteristics in the Everglades. The canals have a flat gradient and are excavated partly in rocks of varying but relatively high permeability to water. As a result, the direction and rate of flow in the canals is influenced by the surrounding water. There is an almost constant movement of water into and out of storage in the rock and, to a more limited extent, in the muck through which the canals are cut. Seemingly, the boundary between the canals and the rock and muck, as far as the movement of water is concerned, is indefinite. Moreover, the flow in the canals is subject to considerable regulation to provide for irrigation and drainage. The control structures at some points are only partially effective however, because of leakage through the adjoining permeable rocks. This situation also affects the measurements of runoff, but to an indeterminable extent.

There is also some seepage flow across the boundaries of the area that cannot be measured. Before the canals were built, overflow and seepage flow from Lake Okeechobee were diffused through the imperfectly drained Everglades. Now, only a very small net seepage flow occurs each year between the lake and the Everglades south and east of the lake. In addition, an indeterminable amount of water percolates out of the Everglades to the sea. Seepage and percolation, if they were of the same magnitude, would compensate one for another, but the latter is probably much the larger. Although both are probably small in relation to the total measured flow, they introduce a measure of uncertainty into all inventories of the water resources of the southeast Florida area and especially of the Everglades.

Other items in the inventory include mean areal precipitation, by months, based on observations at 20 rain gages (subsequent to June 1940). The distribution of gages is on the average of one gage for 195 square miles, the best coverage in the State. However, most of the gages are located along the coast or around the lake, leaving wide interior areas poorly defined. Annual precipitation averaged $50.98 \mathrm{in.}$ during the 7 years $1940-46$. The difference between rainfall and runoff, as given in table 63, equals the sum of the evaporation and transpiration losses and the volume put into, or withdrawn from, storage. If a sufficiently long period of time is considered, changes in storage may be neglected and the difference will equal the portion of the rainfall lost as evaporation and transpiration. This difference, during the 7 years of record, averaged 41.44 in. (subject to minor adjustment for net change in storage). Thus the atmosphere accounts for 82 percent of the total rainfall on the area and is by far the most effective agent for the drainage of the Everglades. 
Table 63.-Iydrologic stmmary of Everglades area

[All quantities are in thousands of acre-feet, except as noted. Tabulated flow out of area for ton Canal (table 53), Hillsboro Canal (table 37), Cypress Creek Canal (table 54), North New outlets (table 49). Tabulated flow out of area for 1943-46 includes discharge at the following (table 39). Miami Canal (table 47), and Tamiami Canal outlets (table 49). Tabulated flow (table 34), Hillsboro Canal (table 36), North New River Canal (table 38), Miami Canal (table Palm Beach Canal (table 34), Hillsboro Canal (table 36), and North New River Canal (table

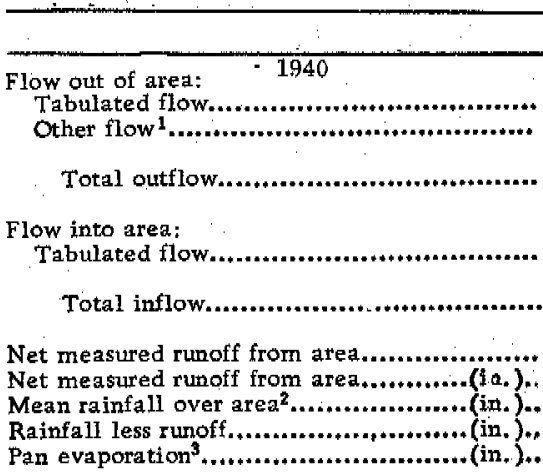

1941

Flow out of area:

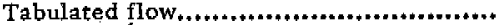

Other flow 1 .

Total outflow.

Flow into area:

Tabulated flow.

Total inflow

Net measured runoff from area

Net meastred runoff from area.............(in.).

Mean rainfall over area ${ }^{2}+\ldots+\ldots+\ldots+\ldots \ldots \ldots \ldots$ (in.)...

Rainfall less runoff.....................+....+(in.)..

Pan evaporation ${ }^{3}$. (iin.).

1942

Flow out of area:

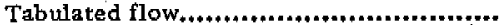

Other flow 1

Total outflow

Flow into area.

Tabulated flow

Total inflow

Net measured runoff from area

Net measured rumoff from aren acasacos (fm,

Mean rainfall over area ${ }^{2}$......................(in.)..

Rainfall less runoff $\ldots+\ldots \ldots \ldots+\ldots \ldots \ldots \ldots \ldots+\ldots . .$. (in.)..

Pan evaporation ${ }^{3}$.

\section{3}

Flow out of area:

Tabulated flow

Other flow ${ }^{1}$.

Total outflow.

Flow into area:

Tabulated flow.

Other flow 1

\begin{tabular}{|c|c|c|c|}
\hline Jan. & Feb. & Mar. & Apr. \\
\hline $\begin{array}{r}135.1 \\
3.2\end{array}$ & $\begin{array}{r}152,9 \\
6,3\end{array}$ & $\begin{array}{r}127.1 \\
4.7\end{array}$ & $\begin{array}{r}111.8 \\
3.6\end{array}$ \\
\hline 138.3 & 159.2 & 131.8 & 115.4 \\
\hline 55.9 & 43.6 & 44.6 & 41.9 \\
\hline 55.9 & 43.6 & 44.6 & 41.9 \\
\hline $\begin{array}{r}82.4 \\
.40 \\
2.86 \\
2.46 \\
3.16\end{array}$ & $\begin{array}{r}115.6 \\
.56 \\
2.93 \\
2.37 \\
4.42\end{array}$ & $\begin{array}{r}87.2 \\
.42 \\
4.26 \\
3.84 \\
5.52\end{array}$ & $\begin{array}{r}73.5 \\
.35 \\
1.52 \\
1.17 \\
6.55\end{array}$ \\
\hline $\begin{array}{r}327.0 \\
12.0\end{array}$ & $\begin{array}{r}329.6 \\
11.9\end{array}$ & $\begin{array}{r}279.7 \\
12.6\end{array}$ & $\begin{array}{r}317.2 \\
19.6\end{array}$ \\
\hline 339.0 & 341.5 & 292.3 & 336.8 \\
\hline 11,4 & -4.2 & 21.3 & 3.9 \\
\hline 11.4 & -4.2 & 21.3 & 3.9 \\
\hline $\begin{array}{r}327.6 \\
1.57 \\
4.48 \\
2.91 \\
3.36\end{array}$ & $\begin{array}{r}345.7 \\
1.66 \\
4.31 \\
2.65 \\
3.65\end{array}$ & $\begin{array}{r}271.0 \\
1.30 \\
4.14 \\
2.84 \\
5.49\end{array}$ & $\begin{array}{r}332.9 \\
1.60 \\
5.75 \\
4.15 \\
6.80\end{array}$ \\
\hline $\begin{array}{r}208.4 \\
7.4\end{array}$ & $\begin{array}{r}128.0 \\
4.7\end{array}$ & $\begin{array}{r}140.0 \\
4.3\end{array}$ & $\begin{array}{r}290.8 \\
7.4\end{array}$ \\
\hline 215.8 & 132.7 & 144.3 & 298.2 \\
\hline 49.3 & 44,2 & 33.4 & 15.3 \\
\hline 49,3 & 44.2 & 33.4 & 15.3 \\
\hline $\begin{array}{r}166.5 \\
.80 \\
2.85 \\
2.05 \\
3.22\end{array}$ & $\begin{array}{r}88.5 \\
.43 \\
2.20 \\
1.77 \\
4.04\end{array}$ & $\begin{array}{r}110.9 \\
.53 \\
3.99 \\
3.46 \\
5.68\end{array}$ & $\begin{array}{r}282,9 \\
1.36 \\
5.67 \\
4,31 \\
6.80\end{array}$ \\
\hline $\begin{array}{r}55.4 \\
6.8\end{array}$ & $\begin{array}{r}45.0 \\
4.3\end{array}$ & $\begin{array}{r}37.7 \\
2.8\end{array}$ & $\begin{array}{r}38.1 \\
1.4\end{array}$ \\
\hline 62.2 & 49.3 & 40.5 & 39.5 \\
\hline $\begin{array}{r}33.9 \\
2.0\end{array}$ & $\begin{array}{r}33.4 \\
1.6\end{array}$ & $\begin{array}{c}32.8 \\
1.1\end{array}$ & $\begin{array}{r}32.0 \\
.9\end{array}$ \\
\hline 35.9 & 35.0 & 33.9 & 32.9 \\
\hline
\end{tabular}


south and east of Lake Okeechobee:

1940-42 includes discharge at the following stations: West Palm Beach Canal (table 35), BoynRiver Canal (table 39), Miami Canal (table 47), Tamiami Canal (table 52), Tamiami Canal stations: West Palm Beach Canal (table 35), Hillsboro Canal (table 37), North New River Canal into the area for 1940-42 includes discharge at the following stations: West Palm Beach Canal 42). Tabulated flow into area for 1943-46 includes discharge at the following stations; West 38)]

\begin{tabular}{|c|c|c|c|c|c|c|c|c|}
\hline May & June & July & Aug. & Sept. & Oct. & Nov. & Dec. & Year \\
\hline $\begin{array}{r}64.5 \\
.9\end{array}$ & $\begin{array}{r}190.2 \\
9.8\end{array}$ & $\begin{array}{r}142.0 \\
7.1\end{array}$ & $\begin{array}{r}248.4 \\
13.8\end{array}$ & $\begin{array}{r}488.0 \\
18.7\end{array}$ & $\begin{array}{r}362.4 \\
14.4\end{array}$ & $\begin{array}{r}280.8 \\
10.7\end{array}$ & $\begin{array}{r}237.1 \\
8.3\end{array}$ & $\begin{array}{r}2,540.3 \\
101,5\end{array}$ \\
\hline 65.4 & 200.0 & 149.1 & 262.2 & 506.7 & 376.8 & 291.5 & 245.4 & $2,641.8$ \\
\hline 60,3 & 28.5 & 35.2 & 2.9 & -36.4 & 22.7 & 45.8 & 51.3 & 396.3 \\
\hline 60.3 & 28.5 & 35.2 & 2.9 & -36.4 & 22.7 & 45.8 & 51,3 & 396,3 \\
\hline $\begin{array}{l}5.1 \\
.02 \\
3.40 \\
3.38 \\
8.08\end{array}$ & $\begin{array}{r}171.5 \\
.82 \\
9.09 \\
8.27 \\
6.38\end{array}$ & $\begin{array}{r}113.9 \\
.55 \\
5.77 \\
5.22 \\
6.78\end{array}$ & $\begin{array}{r}259.3 \\
1.25 \\
9.40 \\
8.15 \\
6.26\end{array}$ & $\begin{array}{r}543.1 \\
2.61 \\
10.18 \\
7.57 \\
4.89\end{array}$ & $\begin{array}{r}354.1 \\
1.70 \\
2.44 \\
.74 \\
5.72\end{array}$ & $\begin{array}{r}245.7 \\
1.18 \\
.65 \\
-.53 \\
4.42\end{array}$ & $\begin{array}{r}194.1 \\
.93 \\
4.22 \\
3.29 \\
3.51\end{array}$ & $\begin{array}{r}2,245.5 \\
10.79 \\
56.72 \\
45.93 \\
65.69\end{array}$ \\
\hline $\begin{array}{r}184.4 \\
7.7\end{array}$ & $\begin{array}{r}148.6 \\
7.4\end{array}$ & $\begin{array}{r}472.0 \\
29.5\end{array}$ & $\begin{array}{r}347.9 \\
24.6\end{array}$ & $\begin{array}{r}389.7 \\
19.0\end{array}$ & $\begin{array}{r}421.8 \\
21.2\end{array}$ & $\begin{array}{r}268.2 \\
10.4\end{array}$ & $\begin{array}{r}174.7 \\
4.9\end{array}$ & $\begin{array}{r}3,660.8 \\
180.8\end{array}$ \\
\hline 192.1 & 156.0 & 501,5 & 372.5 & $408 \cdot-7$ & 443.0 & 278.6 & 179.6 & $3 ; 841.6$ \\
\hline 14.7 & 28.3 & -86.0 & -6.7 & -16.6 & -18.8 & 34.0 & 46.2 & 27.5 \\
\hline 14.7 & 28.3 & -86.0 & -6.7 & -16.6 & -18.8 & .34 .0 & 46.2 & 27.5 \\
\hline $\begin{array}{r}177.4 \\
.85 \\
1.50 \\
.65 \\
8.36\end{array}$ & $\begin{array}{r}127.7 \\
.61 \\
7.54 \\
6.93 \\
7.22\end{array}$ & $\begin{array}{r}587.5 \\
2.82 \\
10.78 \\
7.96 \\
6.34\end{array}$ & $\begin{array}{r}379.2 \\
1.82 \\
4.05 \\
2.23 \\
6.98\end{array}$ & $\begin{array}{r}425.3 \\
2.04 \\
8.83 \\
6.79 \\
5.61\end{array}$ & $\begin{array}{r}461.8 \\
-2.22 \\
4.03 \\
1.81 \\
5.70\end{array}$ & $\begin{array}{r}244.6 \\
1.18 \\
2.70 \\
1.52 \\
3.78\end{array}$ & $\begin{array}{r}133.4 \\
.64 \\
.98 \\
.34 \\
2.70\end{array}$ & $\begin{array}{r}3,814.1 \\
18.31 \\
59.09 \\
40.78 \\
65.99\end{array}$ \\
\hline $\begin{array}{r}172.9 \\
4.9\end{array}$ & $\begin{array}{r}562.8 \\
26.8\end{array}$ & $\begin{array}{r}345,9 \\
26,1\end{array}$ & $\begin{array}{r}236.0 \\
14.8\end{array}$ & $\begin{array}{r}312.8 \\
15.3\end{array}$ & $\begin{array}{r}211.0 \\
10.2\end{array}$ & $\begin{array}{r}106.4 \\
2.8\end{array}$ & $\begin{array}{r}81.0 \\
2.3\end{array}$ & $\begin{array}{r}2,796.0 \\
127.0\end{array}$ \\
\hline 177.8 & 589.6 & 372.0 & 250.8 & 328.1 & 221.2 & 109.2 & 83.3 & $2,923.0$ \\
\hline 29.8 & -106.2 & -24.0 & 36.5 & 7.2 & 46.0 & 34.9 & 37.0 & 203.4 \\
\hline 29.8 & -106.2 & -24.0 & 36.5 & 7.2 & 46.0 & 34.9 & 37.0 & 203.4 \\
\hline $\begin{array}{r}148.0 \\
.71 \\
6.08 \\
5.37 \\
7.26\end{array}$ & $\begin{array}{r}695.8 \\
3.35 \\
14.58 \\
11.23 \\
5.85\end{array}$ & $\begin{array}{r}396.0 \\
1.90 \\
3.33 \\
1.43 \\
7.54\end{array}$ & $\begin{array}{r}214.3 \\
1.03 \\
4.91 \\
3.88 \\
7.18\end{array}$ & $\begin{array}{r}320.9 \\
1.54 \\
6.17 \\
4.63 \\
6.10\end{array}$ & $\begin{array}{r}175.2 \\
.84 \\
1.59 \\
.75 \\
5.76\end{array}$ & $\begin{array}{r}74.3 \\
.36 \\
.97 \\
.61 \\
4.23\end{array}$ & $\begin{array}{r}46.3 \\
.22 \\
2.14 \\
1.92 \\
3.37\end{array}$ & $\begin{array}{r}2,719.6 \\
13.07 \\
54.48 \\
41.41 \\
67.03\end{array}$ \\
\hline $\begin{array}{r}47.9 \\
4.0\end{array}$ & $\begin{array}{r}45.9 \\
7.0\end{array}$ & $\begin{array}{l}99.0 \\
11.8\end{array}$ & $\begin{array}{r}120.1 \\
18.0\end{array}$ & $\begin{array}{r}201.3 \\
27.6\end{array}$ & $\begin{array}{r}214.7 \\
24.5\end{array}$ & $\begin{array}{r}133.0 \\
16.5\end{array}$ & $\begin{array}{r}116.1 \\
17.1\end{array}$ & $\begin{array}{r}1,154.2 \\
141.8\end{array}$ \\
\hline 51.9 & 52,9 & 110.8 & 138 . 1 & 228.9 & 239.2 & 149,5 & 133.2 & $1,296,0$ \\
\hline $\begin{array}{r}28.9 \\
.2\end{array}$ & $\begin{array}{r}18.4 \\
-.1\end{array}$ & $\begin{array}{l}-6.6 \\
-7.9\end{array}$ & $\begin{array}{l}12.5 \\
-6.2\end{array}$ & $\begin{array}{r}4.1 \\
-3,3\end{array}$ & $\begin{array}{r}22,6 \\
2,5\end{array}$ & $\begin{array}{r}35.3 \\
4.6\end{array}$ & $\begin{array}{r}27.0 \\
5.2\end{array}$ & $\begin{array}{r}274.3 \\
.6\end{array}$ \\
\hline 29.1 & 18.3 & -14.5 & 6.3 & .8 & 25.1 & 39.9 & 32.2 & 274.9 \\
\hline
\end{tabular}


Table 63. - Hydrologic summary of Everglades area

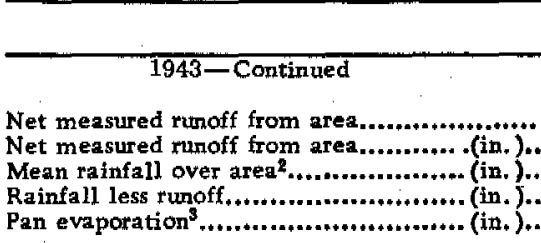

1944

Flow out of area:

Tabulated flow.

Other flow 1 .

Total outflow.

Flow into area:

Tabulated flow

Other flow 1

Total inflow

Net measured runoff from area

Net measured runoff from area..............(in.).." Mean rainfall over area 2 ...................*...(in.)..

Rainfall less runoff...........................(in.)..

Pan evaporation ${ }^{3} . . . . \ldots \ldots+\ldots+\ldots \ldots . . \ldots \ldots+\ldots+\ldots \ldots$ (in.)..

1945

Flow out of area:

Tabulated flow

Other flow'.

Total outflow

Flow into area:

Tabulated flow

Other flow 1

Total inflow

Net measured runoff from area

Net measured runoff from area

Mean rainfall over area ${ }^{2}$......................(in. ...

Rainfall less runoff.......................... (in. )..

Pan evaporation ${ }^{3}$.

(in.).

1946

Flow out of area:

Tabulated flow.

Other flow 1 .

Total outflow

Flow into area:

Tabulated flow.

Other flow 1

Total inflow.

Net measured runoff from area

Net measured runoff from area.

Mean rainfall over area ${ }^{?}$

Rainfall less runoff.

(in.)..

(in.)..

(in

Ja

Jan.

an.

Feb

.13
1.23
1.10
3.64

1.23

1. 10

14.

\begin{tabular}{l|l|l|}
\hline & Mar. & Apr. \\
\hline
\end{tabular}

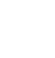

33. 1

10.0

93.1

31.9

3.9
3.6

35.5

57.6

.6
.28

.88

60

3,37

43.
3.

3

07
61

.54

4.49

6.6

.03

1.03

1.00

6.35

6.6

.03

2.27

2.24

6.55

$$
46.8
$$$$
4 .
$$

6.8
4.0

40.8

33.4

2,1

35.5

33.2

$-.8$

32.4

11.3

.05

.06

.01

4.74

\section{4}

.04

2.20

2.16

5.88

27.4

2.0

29.4

27.6

$-3.5$

24.1

5.3

.03

1.60

1.60
1.57

6. 86

65.0
8.0

73.0

42.3

$-2.1$

40.2

32.8

.16

1. 78

1. 62

3.66

.

$$
\text { (1) }
$$

142.2
16.0

158.2

30.5
2.0

(

\footnotetext{
Pan evaporations...

(Ine).

"Other flow" records consist of: 1940-42, records for South New River Canal at lock and dam in Davie computed on basis of two tide discharge integrations made 2 miles below Davie, interpolated as to distance and compared with record of North New River Canal: and 1943 46, records of outflow computed from discharges furnished by Corps of Engineers, Jacksonville, and discharge relation with other stations.
} 
south and east of Lake Okeechobee- Continued

\begin{tabular}{|c|c|c|c|c|c|c|c|c|}
\hline May & June & July & Aug. & Sept. & Oet. & Nov. & Dec. & Year \\
\hline $\begin{array}{r}22.8 \\
.11 \\
5.15 \\
5.04 \\
7.52\end{array}$ & $\begin{array}{r}34.6 \\
.17 \\
6.30 \\
6.13 \\
6.73\end{array}$ & $\begin{array}{r}125.3 \\
.60 \\
8.35 \\
7.75 \\
6.34\end{array}$ & $\begin{array}{r}131.8 \\
.63 \\
6.27 \\
5.64 \\
6.10\end{array}$ & $\begin{array}{r}228.1 \\
1.10 \\
7.21 \\
6.11 \\
6.40\end{array}$ & $\begin{array}{r}214.1 \\
1.03 \\
3.79 \\
2.76 \\
5.35\end{array}$ & $\begin{array}{r}109.6 \\
.53 \\
2.65 \\
2.12 \\
3.94\end{array}$ & $\begin{array}{r}101.0 \\
.49 \\
.39 \\
.10 \\
2.96\end{array}$ & $\begin{array}{r}1,021.1 \\
4.92 \\
45.25 \\
40.33 \\
66.37\end{array}$ \\
\hline $\begin{array}{r}50.5 \\
5.0\end{array}$ & $\begin{array}{r}37.7 \\
3.0\end{array}$ & $\begin{array}{r}47.4 \\
5.0\end{array}$ & $\begin{array}{r}117.0 \\
20.0\end{array}$ & $\begin{array}{r}101,2 \\
17,0\end{array}$ & $\begin{array}{r}196.3 \\
31.0\end{array}$ & $\begin{array}{r}138.4 \\
20.0\end{array}$ & $\begin{array}{r}77.6 \\
9.0\end{array}$ & $\begin{array}{l}957.2 \\
129.0\end{array}$ \\
\hline 55.5 & 40.7 & 52.4 & 137.0 & 118.2 & 227.3 & 158.4 & 86.6 & $1,086.2$ \\
\hline $\begin{array}{r}35.4 \\
2.5\end{array}$ & $\begin{array}{r}18.3 \\
-.3\end{array}$ & $\begin{array}{r}25.7 \\
-.1\end{array}$ & $\begin{array}{r}8.0 \\
-12.8\end{array}$ & $\begin{array}{r}14,1 \\
-18,8\end{array}$ & $\begin{array}{l}-14,8 \\
-15,0\end{array}$ & $\begin{array}{l}26.8 \\
-1.0\end{array}$ & $\begin{array}{r}40.8 \\
.1\end{array}$ & $\begin{array}{l}280.4 \\
-44.0\end{array}$ \\
\hline 37.9 & 18.0 & 25.6 & -4.8 & -4.7 & -29.8 & 25.8 & 40.9 & 236.4 \\
\hline $\begin{array}{r}17.6 \\
.08 \\
5.86 \\
5.78 \\
7.34\end{array}$ & $\begin{array}{r}22.7 \\
.11 \\
3.81 \\
3.70 \\
7.24\end{array}$ & $\begin{array}{r}26.8 \\
.13 \\
8.20 \\
8.07 \\
6.99\end{array}$ & $\begin{array}{r}141.8 \\
.68 \\
8.03 \\
7.35 \\
6.47\end{array}$ & $\begin{array}{r}122.9 \\
.59 \\
4.47 \\
3.88 \\
6.28\end{array}$ & $\begin{array}{r}257.1 \\
1.24 \\
6.95 \\
5.71 \\
5.32\end{array}$ & $\begin{array}{r}132.6 \\
.64 \\
.22 \\
. .42 \\
4.02\end{array}$ & $\begin{array}{r}45.7 \\
.22 \\
.38 \\
.16 \\
3.36\end{array}$ & $\begin{array}{r}849.8 \\
4.09 \\
42.66 \\
38.57 \\
67.87\end{array}$ \\
\hline $\begin{array}{r}13.6 \\
.2\end{array}$ & $\begin{array}{r}29.1 \\
2.8\end{array}$ & $\begin{array}{l}68.4 \\
13.0\end{array}$ & $\begin{array}{l}82.4 \\
16.2\end{array}$ & $\begin{array}{r}292,4 \\
46.0\end{array}$ & $\begin{array}{r}374.6 \\
57.8\end{array}$ & $\begin{array}{r}321 ; 8 \\
40.8\end{array}$ & $\begin{array}{r}172.4 \\
18.8\end{array}$ & $\begin{array}{r}1,487.6 \\
206.6\end{array}$ \\
\hline 13.8 & 31.9 & 81.4 & 98,6 & 338.4 & 432.4 & 362.6 & 191.2 & $1,694.2$ \\
\hline - & & & & & & & & \\
\hline $\begin{array}{r}31.4 \\
. .5\end{array}$ & $\begin{array}{l}13.9 \\
-6.8\end{array}$ & $\begin{array}{r}-31,4 \\
-8,4\end{array}$ & $\begin{array}{r}-9.5 \\
-14.4\end{array}$ & $\begin{array}{l}-45.8 \\
-27.2\end{array}$ & $\begin{array}{r}6.4 \\
-5.3\end{array}$ & $\begin{array}{r}25.9 \\
5.2\end{array}$ & $\begin{array}{r}38.9 \\
4.8\end{array}$ & $\begin{array}{l}173.3 \\
-57.9\end{array}$ \\
\hline 30.9 & 7.1 & -39.8 & -23.9 & $-73,0$ & 1.1 & 31.1 & 43.7 & 115,4 \\
\hline $\begin{array}{r}-17.1 \\
-.08 \\
2.63 \\
2.71 \\
8.13\end{array}$ & $\begin{array}{r}24.8 \\
.12 \\
7.39 \\
7.27 \\
7.20\end{array}$ & $\begin{array}{r}121.2 \\
.58 \\
9.27 \\
8.69 \\
6.40\end{array}$ & $\begin{array}{r}122.5 \\
.59 \\
6.10 \\
5.51 \\
7.04\end{array}$ & $\begin{array}{r}411.4 \\
1.98 \\
10.42 \\
8.44 \\
5.89\end{array}$ & $\begin{array}{r}431.3 \\
2.07 \\
5.62 \\
3.55 \\
4.61\end{array}$ & $\begin{array}{r}331.5 \\
1.59 \\
1.74 \\
.15 \\
4.33\end{array}$ & $\begin{array}{r}147.5 \\
1.71 \\
1.47 \\
3.76 \\
3.12\end{array}$ & $\begin{array}{r}1,578.8 \\
7.59 \\
49.21 \\
41.62 \\
68.32\end{array}$ \\
\hline $\begin{array}{l}78.5 \\
12.3\end{array}$ & $\begin{array}{r}120.6 \\
20.7\end{array}$ & $\begin{array}{r}146.4 \\
23.0\end{array}$ & $\begin{array}{r}158.9 \\
24.4\end{array}$ & $\begin{array}{r}322.0 \\
45.5\end{array}$ & $\begin{array}{r}263.6 \\
34.4\end{array}$ & $\begin{array}{r}253.6 \\
33.4\end{array}$ & $\begin{array}{r}150.3 \\
20.2\end{array}$ & $\begin{array}{r}1,766.5 \\
240.2\end{array}$ \\
\hline 90.8 & 141.3 & 169,4 & 183.3 & 367.5 & 298.0 & 287.0 & 170.5 & $2,006.7$ \\
\hline $\begin{array}{r}41.4 \\
4.2\end{array}$ & $\begin{array}{r}29.1 \\
.9\end{array}$ & $\begin{array}{r}23.0 \\
.3\end{array}$ & $\begin{array}{l}11.4 \\
-4.4\end{array}$ & $\begin{array}{r}-10.9 \\
-2.5\end{array}$ & $\begin{array}{l}26.5 \\
-2.5\end{array}$ & 1.9 & $\begin{array}{r}30.7 \\
.8\end{array}$ & $\begin{array}{r}326.1 \\
16.1\end{array}$ \\
\hline 45.6 & 30.0 & 23,3 & 7.0 & $-13,4$ & 24,0 . & 2.2 & 31.5 & 342.2 \\
\hline $\begin{array}{r}45.2 \\
.22 \\
7.28 \\
7.06 \\
6.53\end{array}$ & $\begin{array}{r}111.3 \\
.54 \\
7.25 \\
6.71 \\
6.42\end{array}$ & $\begin{array}{r}146.1 \\
.70 \\
8.48 \\
7.78 \\
6.10\end{array}$ & $\begin{array}{r}176.3 \\
.85 \\
6.35 \\
5.50 \\
6.23\end{array}$ & $\begin{array}{r}380.9 \\
1.83 \\
7.60 \\
5.77 \\
5.12\end{array}$ & $\begin{array}{r}274.0 \\
1.32 \\
2.04 \\
.72 \\
5.37\end{array}$ & $\begin{array}{r}284.8 \\
1.37 \\
3.62 \\
2.25 \\
3.68\end{array}$ & $\begin{array}{r}139.0 \\
.67 \\
2.20 \\
1.53 \\
3.48\end{array}$ & $\begin{array}{r}1,664.5 \\
8.02 \\
49.48 \\
41.46 \\
64.44\end{array}$ \\
\hline
\end{tabular}

${ }^{2}$ Rainfall computed by Thiessen method by weighting records of 11 stations for period January to May 1940, and 20 stations for period June 1940 to December 1946.

3Values for January to July 1940 are records of Belle Glade station. Values for August 1940 to December 1946 are averages of four stations in the area. 
Table 63 also lists the monthly evaporation from four Class A pans (Kade1, 1919) in the Everglades that is used in the study of the difference between rainfall and runoff.

Rainfall-runoff diagrams might be helpful in the maintenance of an inventory of water needed if the water levels of the Everglades were regulated. However, the available record is short, and only provisional analyses can be obtained.

The relation between monthly rainfall and runoff depends upon the temperature as it affects losses, and upon the storage in the area at the beginning of the month as it affects drainage and soil conditions. This problem is further complicated by regulation of the flow in the canals. The solution involves correlation between the runoff, rainfall, month of the year, and a parameter indicative of storage and soil conditions.

Under certain conditions, as in the Kissimmee basin, the rate of outflow or runoff prior to the period of study may be a satisfactory index of antecedent storage and may yield acceptable correlation. A trial correlation, using monthly mean outflow during the preceding month as the parameter, gave a mean error. of 26 percent; using total outflow in four major canals during the last 5 days of the preceding month, gave an average error of 19 percent. Because these errors appeared high, further study was made.

Storage in the area can be approximated for a given period by reference to the basic equation $P=R=L+\Lambda S$, in which $P$ is precipitation, $R$ is the measured runoff, $L$ is the evaporation Iosses, and $\Delta S$ is the change in storage of all kinds, $P$ and $R$ are known factors; therefore, the sum $L+\Delta S$ can be determined. Over the 7-year period, $P-R$ averaged 41.44 in. (p. 561). If $\Delta S$ is tentatively taken as negligible, then this difference equals the average annual water losses. The average annual pan evaporation loss for the 7-year period was $66.53 \mathrm{in}$. Therefore, the average losses are about $\frac{41.44}{66.53}=0.62$ of the evaporation from a Class A pan in the region. By applying this ratio to the monthly pan evaporation throughout the period of record, the approximate $\Delta s$ can be determined. If the monthly values of $\Lambda s$, with due regard to sign, are accumulated, estimates of variations of total storage in the basin are obtained. The origin point of storage may be taken so that the lowest cumulative value in the record is zero. There is no way of ascertaining just how much storage remains below this lowest value. On figure 161 the cumulative storage, computed against the mean rate of outflow from the Everglades area in second-feet, has been plotted, The plotted points conform well enough to justify the graph as drawn.

The range in storage during the 7 years (1940-46) was about 18 in., which is somewhat less than the range in the Kissimmee River basinduring a 16 -year period. During the 7 -year period, the range 


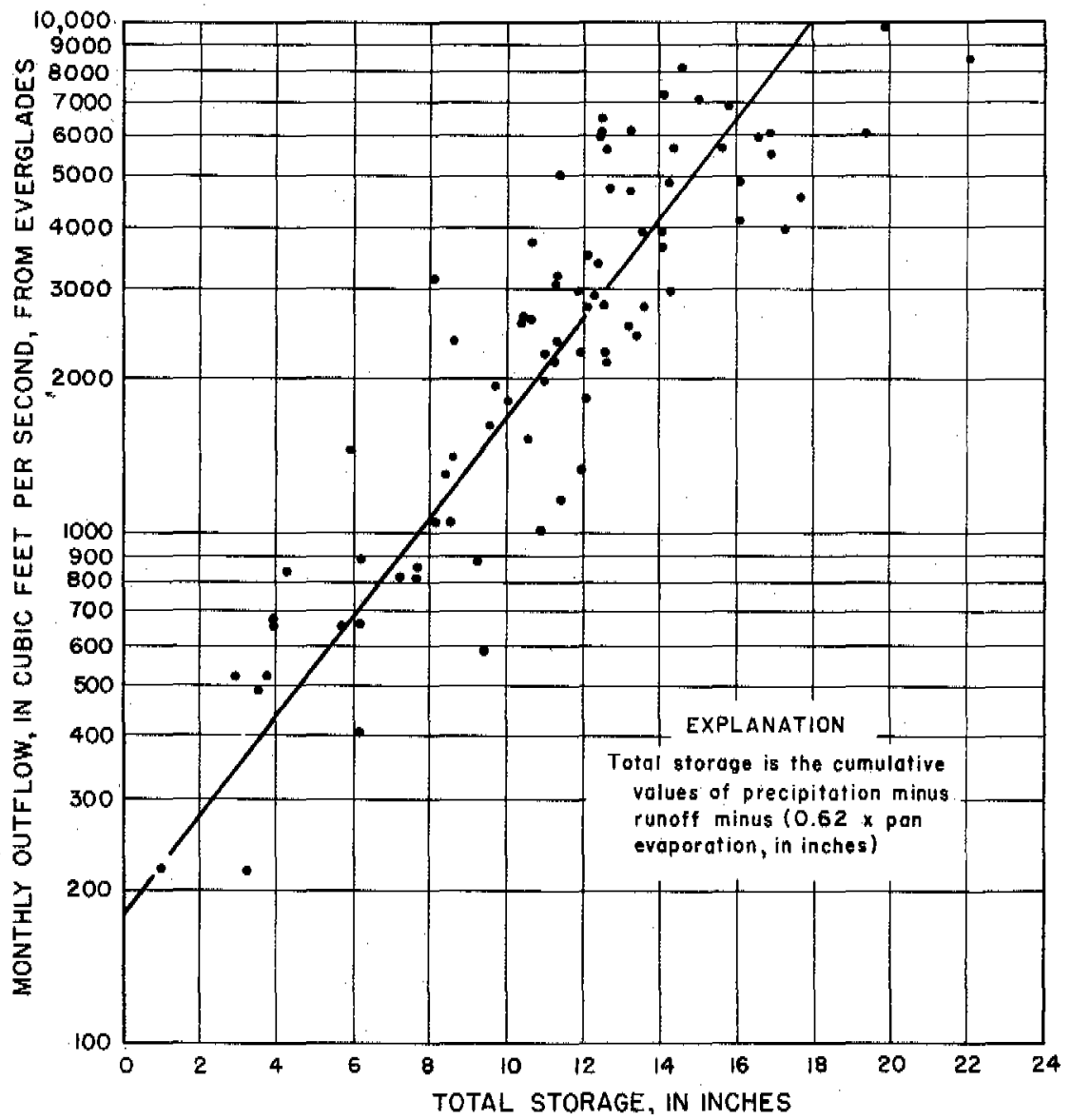

Figure 161. - Study of the relation between rate of outflow and storage in the Everglades area, $1940-46$.

in storage in the Kissimmee River basin was about $22 \mathrm{in.}$ The range in storage in the Lake Okeechobee basin was much greater, of course, being about $44 \mathrm{in.}$, and it was subject to a relatively high degree of control.

Figure 161 indicates a general correlation between rate of outflow and the total storage as computed by cumulating monthly values by the equation $P-R=L+\Delta S$. There is no reason to expect precise correlation; one fault is that the cumulative process gives opportunity for the retention of errors in precipitation. Although the annual value of $L$ may be considered to be known, no such certainty is attached to the respective monthly values, which are estimated by multiplying pan evaporation by a coefficient. On the other hand, the relation shown in figure 161 can be regarded as providing two measures of storage. Total storage can also be computed as cumulative $P-R-L$. The average of the total storage, as obtained by both of these methods, may provide a more stable measure of storage, which might be useful in rainfall-runoff correlations. 
This has been done on figure 162. The ordinate is monthly precipitation minus a correction term, $L$, depending on the calendar month. The appropriate values of the correction term were derived by trial to bring the several months together on one diagram. The sum of the 12 monthly values of $L$ equals the mean annual water losses, and the monthly values are roughly proportional to pan evaporation. The abscissa of figure 162 is net runoff from the area (the difference between measured outflow and inflow), expressed both in inches and thousands of acre-feet.

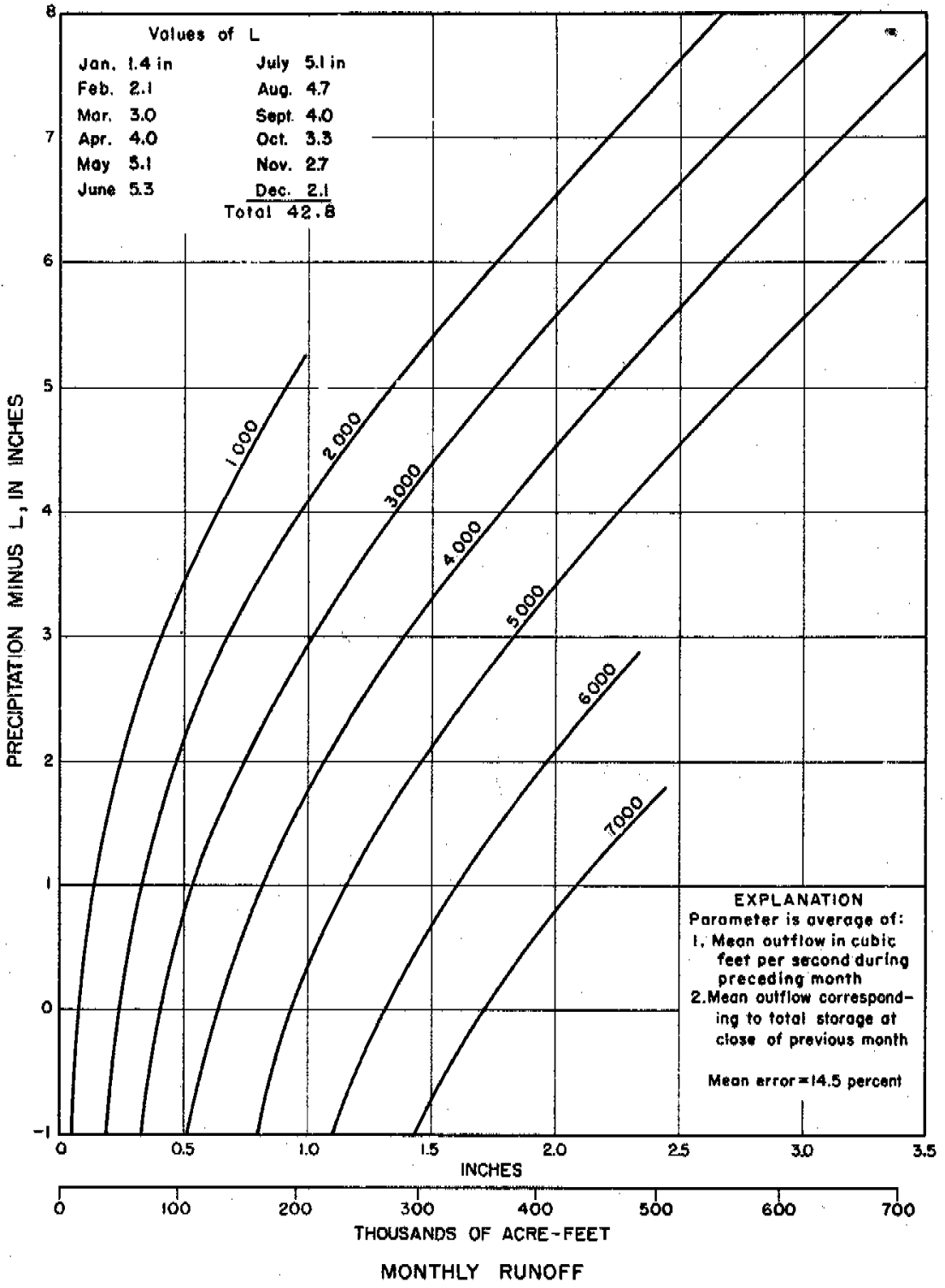

Figure 162, - Rainfall-runoff diagram, Everglades area. 
The correlating parameter is an average of the mean outflow (in cubic feet per second) during the preceding month, and of the equivalent discharge corresponding to the storage at the end of the preceding month (as read from figure 161). The average error of estimate is 14.5 percent, somewhat greater than was obtained in the Kissimmee River basin.

Besides possible use in month to month regulation of water levels in the Everglades, figure 162 can be used in other ways. For example, it might be of interest to estimate the runoff that might have occurred under a combination of highest observed rainfall and highest antecedent storage. The greatest monthly rainfall occurred in June 1942, which followed the highest May of record. This resulted in the highest monthly discharge of record-3.35 in.. But suppose June 1942 had been followed by a wet July, such as July 1941 , with a mean areal rainfall of 11 in. By extrapolation of figure 162 , with a parameter of 8,500 , it is found that about 6 in. of runoff $(1,250,000$ acre $-\mathrm{ft})$ would have been produced, which is nearly twice that of June 1942 .

An annual inventory of the water in the Everglades area is given in table 64. First, the annual precipitation over the area is listed. The runoff listed is the total annual outflow in the canal system minus the total annual inflow. Stubsurface flow was not measured. Second, the difference between the rainfall and the runoff equals the sum of the losses and the change in storage. The mean outflow rate during December is given as a measure of storage in the area. It will be noted that above-average value of $P-R$ in 1940 is associated with a marked increase in base flow, while the below-average value of $P \cdot R$ in 1944 is associated with a marked decrease. The values of base flow were assumed to be associated with storage and were correlated with the deviation of the $P-R$ values from their mean. The annual values of $p-R$ were adjusted by multiplying the change in base flow by 0.001 , as shown by this correlation; the computed losses for each year are shown in the final column of the table. The annual losses average $41.35 \mathrm{in}$.

The average losses, computed above, may be compared with the losses measured from $4-$ by $12-\mathrm{ft}$ tanks containing cut and standing vegetation at the Experiment Station at Belle Glade (Clayton, Neller and Allison, 1942). Annual losses ranged from $9.1 \mathrm{in}$. for a tank with a mulch soil covered with a heavy layer of cane trash to 68 and 84 in. for a thriving growth of sawgrass with water $11 \mathrm{in.}$ from the surface. The results indicated that annual losses from sugar-cane areas are from 42 to 45 in. After making allowances for density and for deeper water and better protection from wind in the Everglades, it was estimated that mean annual losses from sawgrass lands average about $60 \mathrm{in}$. However, water uas always available in the tanks for evaporation-ma condition not representative of the Everglades, which are nearly dry for considerable periods during the average year when the sawgrass defollates. 
Table 54.-Annual summary of hydrologic data Everglades area

\begin{tabular}{|c|c|c|c|c|c|c|}
\hline $\begin{array}{l}\text { Calendar } \\
\text { year }\end{array}$ & $\begin{array}{l}\text { Precipi- } \\
\text { tation } \\
\text { (inches) }\end{array}$ & $\begin{array}{l}\text { Measured } \\
\text { runoff } \\
\text { (inches) }\end{array}$ & \begin{tabular}{|c|} 
Precipi" \\
tation minus \\
runoff \\
(inches)
\end{tabular} & $\begin{array}{l}\text { Mean outtlow } \\
\text { rate during } \\
\text { December } \\
\text { (cfs) }\end{array}$ & $\begin{array}{c}\text { Change in } \\
\text { baseflow } \\
\text { (cfs) }\end{array}$ & $\begin{array}{c}\text { Losses }= \\
P-R=0.001 \Delta L F^{1} \\
\quad \text { (incines) }\end{array}$ \\
\hline $\begin{array}{l}1939 \\
1940 \\
1941 \\
1942 \\
1943 \\
1944 \\
1945 \\
1946 \\
\text { Total }\end{array}$ & $\begin{array}{r}56.72 \\
59.09 \\
54.48 \\
45.25 \\
42.66 \\
49.21 \\
49.48 \\
356.89\end{array}$ & $\begin{array}{r}10.79 \\
18.31 \\
13.07 \\
4.92 \\
4.09 \\
7.59 \\
8.02 \\
66.79\end{array}$ & $\begin{array}{r}45.93 \\
40.78 \\
41.41 \\
40.33 \\
38.57 \\
41.62 \\
41.46 \\
290.10\end{array}$ & $\begin{array}{r}22,100 \\
3,990 \\
2,920 \\
1,360 \\
2,170 \\
1,410 \\
3,110 \\
2,770 \\
\ldots . . . . . . . . . .\end{array}$ & $\begin{array}{r}+1,890 \\
-1,070 \\
-1,560 \\
+810 \\
+760 \\
+1,700 \\
-340 \\
+670\end{array}$ & $\begin{array}{r}44.04 \\
41.85 \\
42.97 \\
39.52 \\
39.33 \\
39.92 \\
41.80 \\
289.43\end{array}$ \\
\hline Average & 50.98 & 9.54 & 41.44 & ; & +95.71 & 41.35 \\
\hline
\end{tabular}

$1_{0.001} \backslash B F$ is adjustment for change in base storage in which $\triangle B F$ is change in base flow.

2Estimated.

The tanks give a result substantially greater than the mean losses from the Everglades computed by analyses of records of rainfall and runoff. Probably this is because of difference in evaporation opportunities between the tanks and the Everglades, unless net subsurface percolation into the Everglades is greater than appears evident. Further investigation, both of tanks and surface and subsurface flow, is required to settle the matter.

However, it is known that during 1940-46, rainfall minus runoff from the 9,000-square-mile area of the Kissimmee-OkeechobeeEverglades unit averaged 42.6 in. (see table 55 ). The runoff to the sea was measured in the canal system. The amount of groundwater flow out of the Everglades is not known; if it were known, it would reduce the difference computed above. A value of a loss of 60 in., except over local areas, appears incompatible with the above result. 


\title{
SALT-WATER ENCROACHMENT
}

\author{
By Garald G. Parker, R. HI. Brown, D. B. Bogart and S. K. Love
}

\section{SOURCE OF SALT-WATER CONTAMINATION}

\author{
GENERAL STATEMENT
}

A critical study of all available information obtained prior to July 1939 and the analysis of all pertinent data collected during the present investigation show without doubt that sea water in the Atlantic Ocean and in Biscayne Bay is the source of salt-water contamination of ground and surface waters in the Miami area." Two other possible sources that were studied and rejected are: the highly mineralized artesian water in the Floridan aquifer, which lies about 600 to $1,000 \mathrm{ft}$ below the surface, and the highly mineralized water found at shallow depths in some areas of the Everglades.

Without exception, the deep artesian wells drilled in the Miami area yield water that contains about 1,000 to $3,000 \mathrm{ppm}$ chloride. This water is unfit for most uses; therefore, most artesian wells in and near Miami have been abandoned. The rocks of the Floridan aquiclude that overlie the Floridan aquifer and confine its water under pressure, are impermeable; the only way that the mineralized artesian water could contaminate the Biscayne aquifer is through leaky well casings. Some leakage is known to occur, but most of the areas affected are within 1 mile of the coast, where the ground water is already contaminated by sea water. Furthermore, the concentration of dissolved mineral matter in wate $r$-table wells close to Biscayne Bay is several times greater than the concentration in the artesian water.

The concentration of dissolved solids in shallow ground water in the Everglades is generally higher in the vicinity of Lake Okeechobee than farther south toward Miami. Except in the encroachment zone along the coast, the large body of shallow ground water in the Miami area is not contaminated. Former invasions of the sea left saline residues in the water-bearing formations underlying large areas in the Everglades. These residues have been only partly flushed out, whereas in and near Miami they have been completely flushed out (Parker, 1945b, p. 119-143). As shown in the section on Quantitative studies in the Miamiarea, the Biscayne aquifer is replenished almost entirely by local rainfall. It is obvious, therefore, that at present the only source of saltwater contamination in and near Miami is the sea water from the Atlantic Ocean and Biscayne Bay. 


\section{ATLANTIC OCEAN}

\section{CHEMTCAL COMPOSTTON OF SEA WATER NEAR MIAMI}

The chemical composition of the ocean water has been determined by analyses of samples collected from many places over the world. The concentration of dissolved mineral matter has been found to vary considerably from place to place and from time to time at a given point. However, the ratios between the more abundant constituents are essentially constant (Sverdrup, Johnson, and Fleming, 1942, p. 165). This fact has an important bearing on the study of ground water contaminated with sea water, in which the chloride content of the samples is taken as an index of the amount of contamination.

The analyses commonly taken to represent the average composition of sea water are those made by Dittmar on 77 samples collected from many parts of the world by the Challenger Expedition in 1884. The average of these analyses is given in table 65 , together with an analysis of water collected on May 23, 1941, from

Table 65.-Analyses of sea water

\begin{tabular}{|c|c|c|c|c|}
\hline \multirow[b]{3}{*}{ 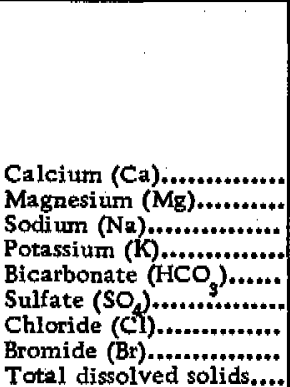 } & \multicolumn{2}{|c|}{$\begin{array}{c}\text { Average of } 77 \\
\text { sample1 }\end{array}$} & \multicolumn{2}{|c|}{$\begin{array}{l}\text { Miami Beach } \\
\text { sample? }\end{array}$} \\
\hline & $\begin{array}{l}\text { Parts per } \\
\text { million }\end{array}$ & $\begin{array}{l}\text { Ratio to Cl } \\
\text { (percent) }^{3}\end{array}$ & $\begin{array}{l}\text { Parts per } \\
\text { million }\end{array}$ & $\begin{array}{l}\text { Ratio to } \mathrm{Cl} \\
\text { (percent) }\end{array}$ \\
\hline & $\begin{array}{r}419 \\
1,304 \\
10,710 \\
390 \\
146 \\
2,690 \\
19,350 \\
70 \\
35,000\end{array}$ & $\begin{array}{r}2.17 \\
6.73 \\
55.35 \\
2.02 \\
.75 \\
13.90 \\
\ldots \ldots . .36 \\
. .3 \ldots\end{array}$ & $\begin{array}{r}423 \\
1,324 \\
10,970 \\
429 \\
147 \\
2,750 \\
19,770 \\
49 \\
35,800\end{array}$ & $\begin{array}{r}2.14 \\
6.70 \\
55.49 \\
2.17 \\
.74 \\
13.91 \\
. .21 \\
. \ldots \ldots \ldots\end{array}$ \\
\hline
\end{tabular}

1 Analyses by Dittmar from samples collected by Challenger Expedition, 1884 .

${ }^{2}$ Atlantic Ocean at Miami Beach, May 23, 1941. 100.

3 Content of indicated fon divided by chloride content and multiplied by

the Atlantic Ocean about $50 \mathrm{ft}$ offshore at 41 st Street, Miami Beach. The concentrations of the different constituents in the sample collected off Miami Beach in 1941 are slightly greater than those reported by Dittmar. However, the percentage of chlo$r$ ide in the two samples is essentially the same.

In the Miami Beach sample the computed chloride concentration was $19,800 \mathrm{ppm}$, which is the value used in this report as an index of the degree of contamination of ground water with sea water. The chloride equivalent to the bromide in that sample was subtracted from the weight of silver halides before combuting the 
chloride concentration. In routine chloride determinations; nowever, total halides were titrated with silver nitrate solution and reported as chloride.

Variations in the chloride concentration of sea water in the vicinity of Miami were studied by Dole and Chambers (1918, p. 299315 ) in 1914-15. Daily samples of sea water were collected at Fowey Rocks Light, $6 \frac{1}{2}$ miles off Cape Florida and about 15 miles southeast of Miami, within 1 or 2 miles of the western edge of the Gulf Stream. It was observed that periods of heavy rainfall were frequently followed by decreases in chloride concentration. Chloride concentrations ranged from about 19,300 to $20,200 \mathrm{ppm}$ and averaged $19,930 \mathrm{ppm}$ during the period of record.

The average chloride content of sea water in the Gulf of Mexico, as determined by Dole $(1914, \mathrm{p}, 69-78)$ on 54 samples collected twice daily between May 20 and June 16, 1913, from Southwest Channel in the Tortugas, was $19,934 \mathrm{ppm}$. Dole and Chambers. concluded, therefore, that the normal chloride concentration of the Gulf Stream off Fowey Rocks is about the same as that of the Gulf of Mexico but that it decreases at times as a result of heavy rainfall and subsequent discharge of surface streams in the Miami area and of ground-water reservoirs along the coast.

Determinations made on several samples collected from the Atlantic Ocean during the present investigation show a range in chloride concentration from $19,180^{\circ}$ to $20,420 \mathrm{ppm}$. It appears that the chloride concentration of $19,800 \mathrm{ppm}$ in the sample collected off Miami Beach on May 23, 1941, represents approximately the average chloride concentration in sea water in the vicinity of Miami.

\section{SPECIFIC GRAVITY OF SEA WATER}

In order that the relationship between milligrams per liter and parts per million may be determined for water samples contaminated with different amounts of sea water, and also in order that corrections may be applied to water-level measurements in wells contaminated with sea water, it is necessary to know the specific gravity of sea water and that of sea water diluted with different amounts of fresh ground water. A full discussion of the determination of these specific gravities is given on pages 598-600. It was found that the average specific gravity of sea water in the Miami area, referred to distilled water at $25^{\circ} / 25^{\circ} \mathrm{C}$., is 1.02680 .

The effect of specific gravity on the factors relating milligrams per liter and parts per million was determined in the following way. Values of chloride were determined gravimetrically on several artificial dilutions of sea water with fresh ground water, and these 
were plotted with milligrams per liter as one coordinate and parts per million as the other. It was found that for dilutions in which the chloride concentration was below 5,000 milligrams per liter, adjustments to the above factors were small enough to be neglected. Above 5,000 milligrams per liter the adjustment increased with increasing concentration. Tables were prepared from which adjusted factors could at once be applied to chloride concentrations in milligrams per liter to obtain concentrations in parts per million. Unless otherwise specified, all concentrations given in this report are expressed in parts per million.

\section{BISCAYNE BAY}

\section{CILORIDE CONCENTRATIONS}

Chloride concentrations at different places in Biscayne Bay of ten differ considerably from those in the ocean nearby and also differ from time to time at a given place. Differences in concentration were observed by Dole and Chambers (1918, p. 313, 315). They state that these differences probably were due to the diluting effect of fresh water from the Miami River and other smaller streams, and to the concentrating effect of evaporation in the shallow expanses of the Bay where circulation is sluggish. The present investigation confirms these conclusions.

During the present investigation, surface and bottom samples were collected in May 1940 from 22 stations in Biscayne Bay (the locations are shown in fig. 163). At some stations, samples were collected at middepth. Chloride concentrations determined on these samples are given in table 66 .

The data in the table show that the chloride concentration in most of the samples was greater than that normally found in sea water. The higher values are the result of concentration of the water in Biscayne Bay by evaporation. Samples from Station 5 contained considerably less chloride than ocean water because of the diluting effect of fresh water discharged from the Miami River. Dilution was also observed in samples from Stations 12 and 13, near the outlet of the Coral Gables Canal, and from Station 15 , near the outlet of Snapper Creek Canal.

Excluding the samples collected from Stations $5,12,13$, and 15, the chloride concentrations in surface and bottom samples ranged from 19,080 to $21,170 \mathrm{ppm}$, and they averaged 20,270 ppm. Thus, the average chloride concentration in Biscayne Bay was $340 \mathrm{ppm}$ greater than the average concentration of the Atlantic 


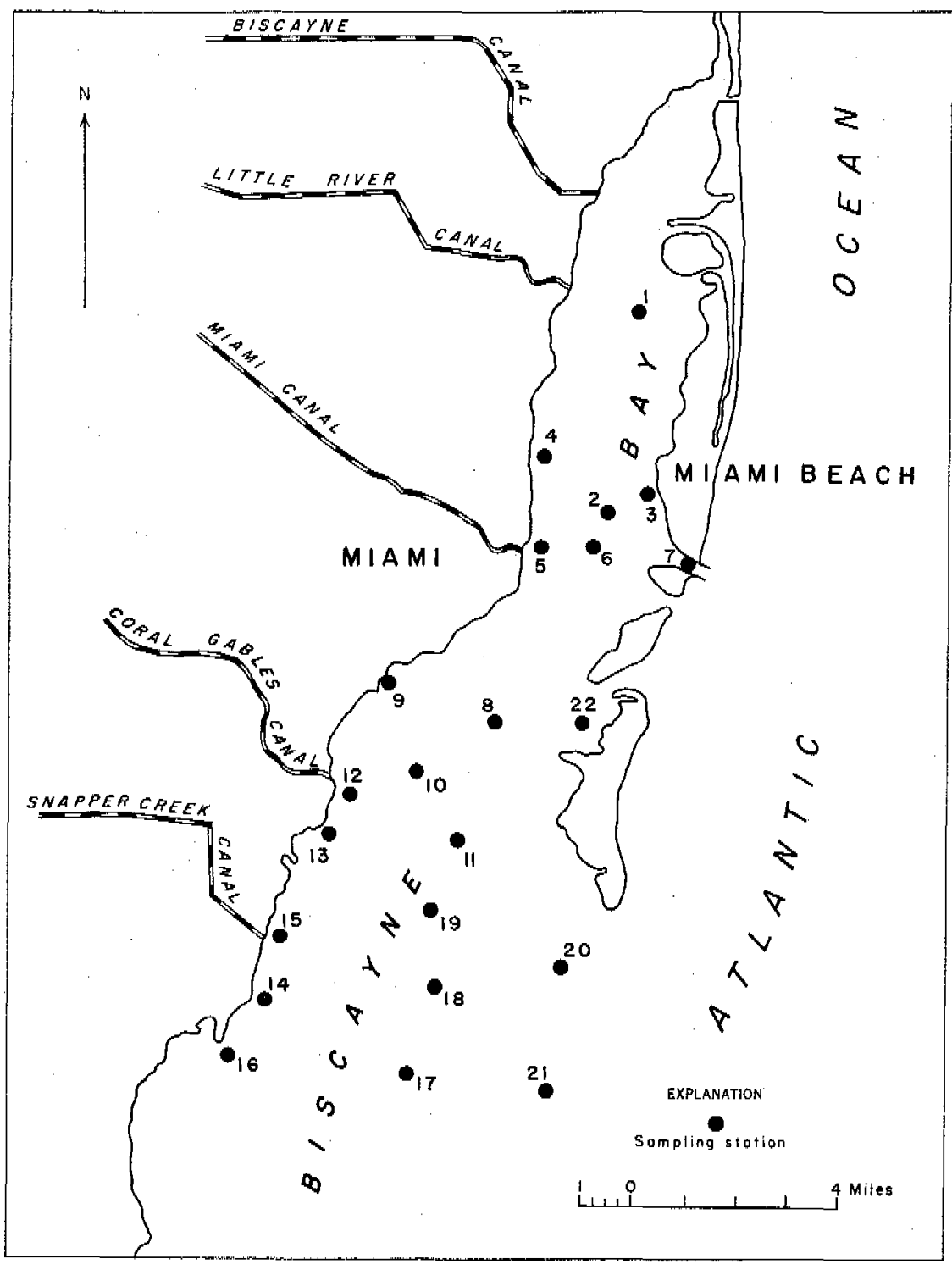

Figure 163. -Location of sampling stations in Biscayne Bay.

Ocean at Fowey Rocks in 1914-15 (Dole and Chambers, 1918, p. $299-315)$, and $500 \mathrm{ppm}$ greater than the concentration determined in the sample collected from the ocean at 41 st Street in Miami Beach in 1941. 
Table 66.-Chloride concentrations at sampling stations in Biscayne Bay, May 1940

\begin{tabular}{|c|c|c|c|c|c|}
\hline $\begin{array}{l}\text { Station No. } \\
\text { (cee fig. 168) }\end{array}$ & Date & Time & $\begin{array}{c}\text { Sampling } \\
\text { point }\end{array}$ & $\begin{array}{l}\text { Depth } \\
\text { (feet) }\end{array}$ & $\begin{array}{c}\text { Chloride } \\
\text { (Ppm) }\end{array}$ \\
\hline $1 \ldots \ldots \ldots \ldots \ldots \ldots . . . . . . . . . . . . . . . . . .$. & May 7 & 11:07 a. m. & $\begin{array}{l}\text { Surface } \\
\text { Bottom }\end{array}$ & $\begin{array}{l}1 \\
4\end{array}$ & $\begin{array}{l}19,230 \\
19,080\end{array}$ \\
\hline 2...................................+ & ......do.......... & 10:13 a. m. & $\begin{array}{l}\text { Surface } \\
\text { Middle } \\
\text { Bottom }\end{array}$ & $\begin{array}{l}1 \\
4.5 \\
9\end{array}$ & $\begin{array}{l}19,890 \\
19,850 \\
19,890\end{array}$ \\
\hline 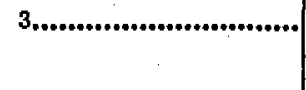 & .....do......... & $9: 50 \mathrm{a}, \mathrm{m}$. & $\begin{array}{l}\text { Surface } \\
\text { Middle } \\
\text { Bottom }\end{array}$ & $\begin{array}{r}1 \\
5 \\
10\end{array}$ & $\begin{array}{l}20,040 \\
20,180 \\
20,180\end{array}$ \\
\hline 4.................................. & .....do......... & $10: 25$ a. m. & $\begin{array}{l}\text { Surface } \\
\text { Middle } \\
\text { Bottom }\end{array}$ & $\frac{1}{7.5}$ & $\begin{array}{l}19,560 \\
19,280 \\
19,560\end{array}$ \\
\hline 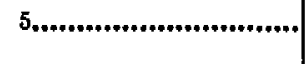 & ......do......... & $11: 28 \mathrm{a}, \mathrm{m}$ & $\begin{array}{l}\text { Surface } \\
\text { Bottom }\end{array}$ & $\begin{array}{l}1 \\
5\end{array}$ & $\begin{array}{l}11,930 \\
15,920\end{array}$ \\
\hline 6................................ & May 17 & $8: 55 \mathrm{a} . \mathrm{m}$. & $\begin{array}{l}\text { Surface } \\
\text { Middle } \\
\text { Bottom }\end{array}$ & $\begin{array}{l}1 \\
4 \\
8\end{array}$ & $\begin{array}{l}19,750 \\
20,800 \\
20,320\end{array}$ \\
\hline $7 \ldots \ldots \ldots+\ldots$ & May 7 & $10: 25 \mathrm{a}, \mathrm{m}$ & $\begin{array}{l}\text { Surface } \\
\text { Middle } \\
\text { Bottom }\end{array}$ & $\begin{array}{r}1 \\
15 \\
30\end{array}$ & $\begin{array}{l}20,230 \\
20,040 \\
20,080\end{array}$ \\
\hline 8................t+................... & May 17 & $9: 30$ a. $\mathrm{m}$. & $\begin{array}{l}\text { Surface } \\
\text { Middle } \\
\text { Bottom }\end{array}$ & ${ }_{11}^{1} 5.5$ & $\begin{array}{l}20,460 \\
20,700 \\
20,610\end{array}$ \\
\hline 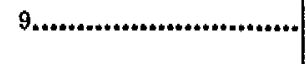 & May 7 & 12:21 p. $\mathrm{m}$ & $\begin{array}{l}\text { Surface } \\
\text { Bottom }\end{array}$ & $\frac{1}{3}$ & $\begin{array}{l}19,130 \\
19,180\end{array}$ \\
\hline 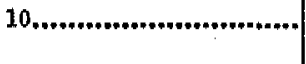 & .....do,........ & $12: 34$ p. m. & $\begin{array}{l}\text { Surface } \\
\text { Bottom }\end{array}$ & $\begin{array}{l}1 \\
4.5\end{array}$ & $\begin{array}{l}19,320 \\
19,280\end{array}$ \\
\hline 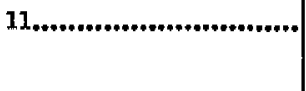 & May 17 & $10: 48$ a. $\mathrm{m}$ & $\begin{array}{l}\text { Sturface } \\
\text { Middle } \\
\text { Bottom }\end{array}$ & $\begin{array}{r}1 \\
5 \\
10\end{array}$ & $\begin{array}{l}20,510 \\
20,420 \\
20,700\end{array}$ \\
\hline $12 . \ldots . .$. & May 7 & 1:00 p. m. & $\begin{array}{l}\text { Surface } \\
\text { Bottom }\end{array}$ & $\frac{1}{5}$ & $\begin{array}{l}17,360 \\
17,270\end{array}$ \\
\hline 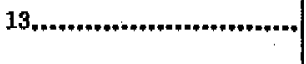 & .....do......... & $2: 43$ p. m. & $\begin{array}{l}\text { Surface } \\
\text { Bottom }\end{array}$ & $\begin{array}{l}1 \\
3\end{array}$ & $\begin{array}{l}18,700 \\
18,610\end{array}$ \\
\hline 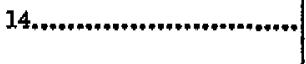 & May 17 & $11: 50 \mathrm{a}, \mathrm{m}$ & $\begin{array}{l}\text { Surface } \\
\text { Bottom }\end{array}$ & $\begin{array}{l}1 \\
2,5\end{array}$ & $\begin{array}{l}20,420 \\
20,460\end{array}$ \\
\hline 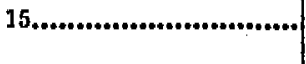 & .....do......... & $12 ; 40 \mathrm{p.m}$ & $\begin{array}{l}\text { Surface } \\
\text { Bottomn }\end{array}$ & $\begin{array}{l}1 \\
2.5\end{array}$ & $\begin{array}{l}15,680 \\
19,700\end{array}$ \\
\hline $16 . . . . \ldots \ldots \ldots \ldots . . . . . . . . . . . . . . . . . . . .$. & .....do......... & $12: 10$ p. $\mathrm{m}$. & $\begin{array}{l}\text { Surface } \\
\text { Bottom }\end{array}$ & $\begin{array}{l}1 \\
4\end{array}$ & $\begin{array}{l}20,980 \\
20,980\end{array}$ \\
\hline $17 \ldots \ldots \ldots \ldots \ldots \ldots \ldots \ldots . . . . . . . . . . . . . .$. & .....do......... & 1:35 p. m. & $\begin{array}{l}\text { Surface } \\
\text { Middle } \\
\text { Bottom }\end{array}$ & ${ }_{11.5}^{1}$ & $\begin{array}{l}20,890 \\
20,840 \\
20,940\end{array}$ \\
\hline 18................................... & .....do......... & $1: 15$ p. m. & $\begin{array}{l}\text { Surface } \\
\text { Middle } \\
\text { Bottom }\end{array}$ & ${ }_{11}^{1}$ & $\begin{array}{l}21,080 \\
21,030 \\
21,170\end{array}$ \\
\hline $19 . . . . . . . . . . . . . . . . . . . . . . . . . . . . .$. & ......do......... & 11:10 a. $\mathrm{m}$. & $\begin{array}{l}\text { Surface } \\
\text { Middle } \\
\text { Bottom }\end{array}$ & $\begin{array}{r}1 \\
5 \\
10\end{array}$ & $\begin{array}{l}20,980 \\
20,980 \\
20,890\end{array}$ \\
\hline $20 . . . \ldots . . . . . . . . . . . . . .$. & .....do......... & $2: 20$ p. m. & $\begin{array}{l}\text { Surface } \\
\text { Middle } \\
\text { Bottom }\end{array}$ & $\begin{array}{c}1 \\
75 \\
15\end{array}$ & $\begin{array}{l}20,700 \\
20,420 \\
20,610\end{array}$ \\
\hline
\end{tabular}


Table 66._Chtoride concentrations at sampling stations in Biscayne Bay, May 1940_Con.

\begin{tabular}{|c|c|c|c|c|c|}
\hline $\begin{array}{l}\text { Station No. } \\
\text { (see fig. 163) }\end{array}$ & Date & Time & $\begin{array}{l}\text { Sampling } \\
\text { point }\end{array}$ & $\begin{array}{l}\text { Depth } \\
\text { (feet) }\end{array}$ & $\begin{array}{c}\text { Chloride } \\
\text { (ppm) }\end{array}$ \\
\hline $21 \ldots \ldots \ldots \ldots$ & .....do,........" & $2: 12 \mathrm{p}+\mathrm{m}_{*}$ & $\begin{array}{l}\text { Surface } \\
\text { Middle } \\
\text { Bottom }\end{array}$ & $\begin{array}{l}1 \\
4 \\
8\end{array}$ & $\begin{array}{l}20,800 \\
20,750 \\
20,650\end{array}$ \\
\hline $22 . . . . . . . . . . . . . . . . . . . . . . . . . . . .$. & ......do.......... & $10: 20$ a. $\mathrm{m}$. & $\begin{array}{l}\text { Surface } \\
\text { Middle } \\
\text { Bottom }\end{array}$ & $\begin{array}{r}1 \\
6 \\
12\end{array}$ & $\begin{array}{l}20,610 \\
20,510 \\
20,610\end{array}$ \\
\hline
\end{tabular}

\title{
EHEMICAL COMPOSITION OF SALT-CONTAMINATED WATERS
}

\author{
SURFACE WATERS
}

Several samples of salt-contaminated water were collected from the MiamiCanal. Analysis of the water showed that its composition was essentially the same as an artificial mixture of uncontaminated canal water and sea water.

\section{GROUND WATERS}

Analyses of samples of ground water collected from wells in and near Miami show that ground water that has been contaminated with sea water differs somewhat in composition from an artificial mixture of the two.

Samples of uncontaminated ground water from the Miami area were found to be relatively uniform in composition. (See the section on Quality of ground and surface waters, p. 727.) An average of 24 analyses of samples from typical wells is assumed to represent the average composition of uncontaminated ground water in the area. Using the chloride concentration as an index of the degree of contamination in other samples containing more than the average amount of chloride, the theoretical concentrations of the other constituents were computed. Typical analyses of uncontaminated and contaminated ground water are shown in figure 164 .

The actual amount of calcium in each sample was more than the computed amount. In order to study the differences between actual and computed concentrations, all data for the chemical constituents in parts per million were converted to equivalents per million. (An equivalent per million means one unit chemical equivalent weight of a chemical constituent per million unit weights of solution. Concentration in equivalents per million is calculated by dividing concentration in parts per million by the chemical combining weight of the chemical constituent.) 


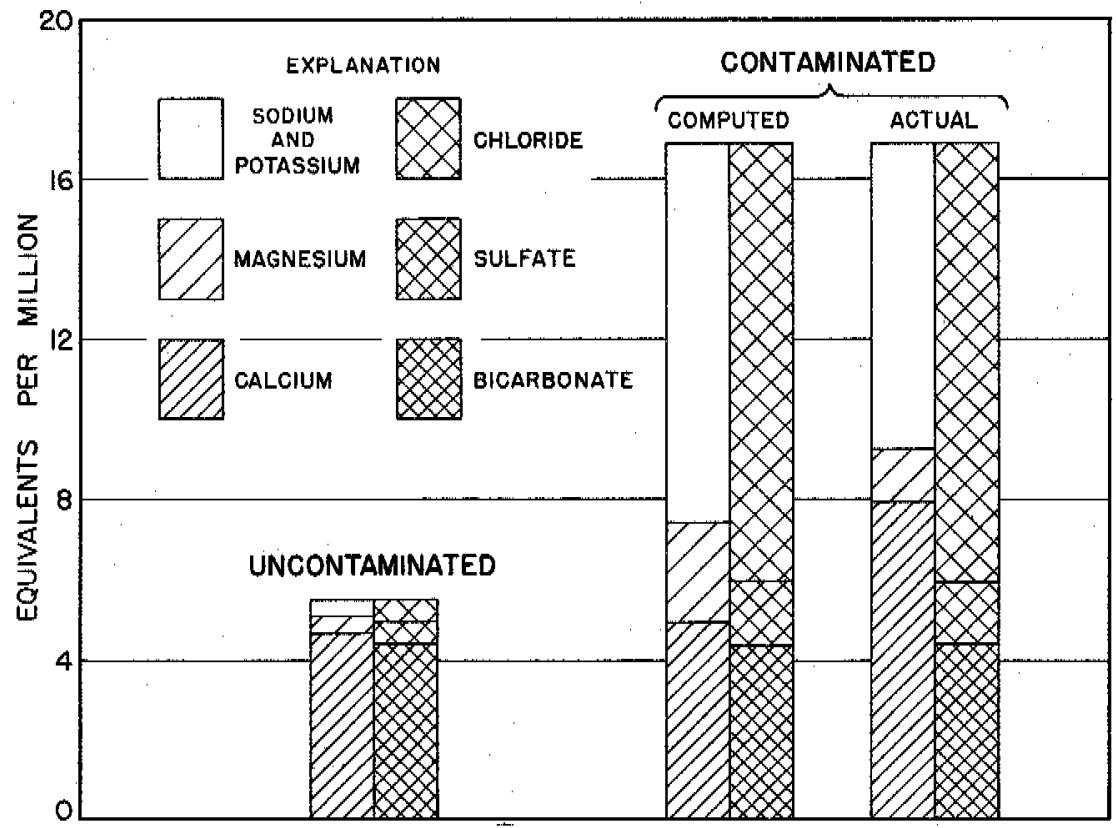

Figure 164, - Analyses of umcontaminated and contaminated groumd water.

Differences in equivalents between actual and computed concen. trations of bicarbonate were usually small and showed no tendency to be consistently positive or negative. Differences between actual, and computed concentrations of sulfate were usually small, but somewhat larger than differences in bicarbonate. About half of the sulfate differences were positive and about half were negative.

The more prominent differences in concentrations occurred among the cations (calcium, magnesium, and sodium). Deviation of actual concentrations from computed concentrations of calcium were plotted against the algebraic sum of deviation of magnesium and sodium as shown in figure 165. In general, increases in calcium concentrations were compensated by losses in magnesium and sodium concentrations. This would suggest that for each equivalent per million of calcium gained, one equivalent of magnesium or sodium, or a mixture of the two, was lost.

A suggested explanation for the differences between actual and computed concentrations of cations in contaminated waters in the Miami area is based on the phenomenon of cation exchange (commonly referred to as base exchange). Many investigations of cation exchange have been made, primarily in the field of soil chemistry (Kelley and Brown, 1924; Chapman and Kelley,1930, p. 391-406). Workers in soil chemistry have long known that soil colloids, usually the aluminum silicate clay components, possess the property of adsorbing one or more cations from water solutions and of releasing them again in exchange for other cations under suitable conditions. The conditions which determine the order and 
MAGNESIUM + SODIUM DEVIATIONS, IN EQUIVALENTS PER MILLION

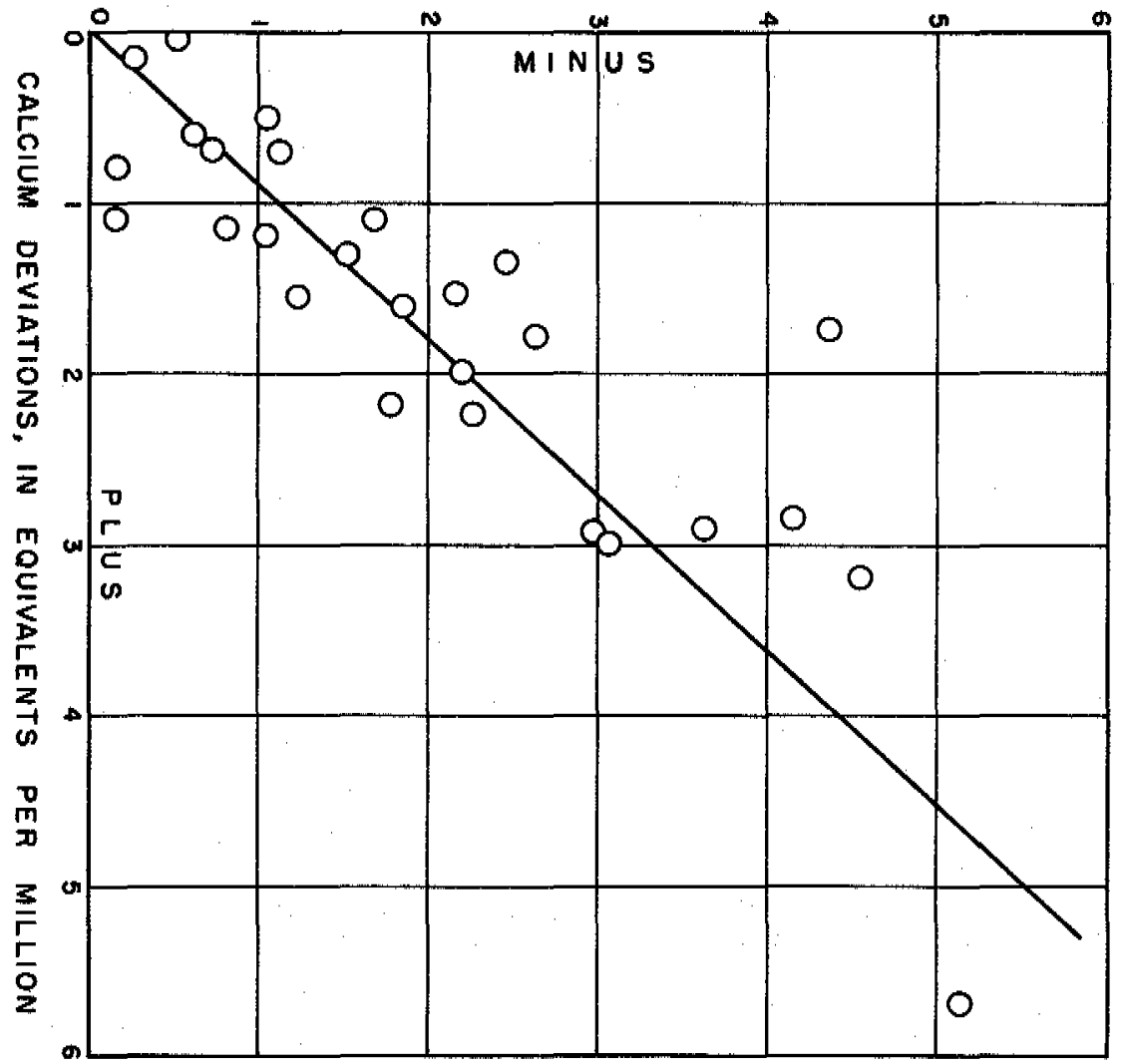

Figure 165. -Deviation of cation concentrations in contaminated ground water from computed cation concentrations.

mechanism of cation exchange have also been investigated (Jenny, 1932 , p. 2217-2258; Walton, 1942, p. 306-337; Bray, 1942, p. 954-963).

It has been found that the cation-exchange capacity of many soils is also associated with the content of organic matter. McGeorge $(1930$, p. 181-312) concluded that the base-exchange capacity of highly organic soils is approximately a linear function of the percentage of carbon in the soil and that the exchange takes place in chemically equivalent proportions. Examination of well cuttings obtained during the drilling of test wells shows no evidence of aluminum silicate clays in the highly permeable Biscayne aquifer in the Miami area. It would appear, therefore, that cation exchange takes place largely through the medium of organic matter, which colors practically all the ground water in the area.

For additional discussion of cation exchange refer to the section on Quality of ground and surface waters, pages 821-822. 


\section{HISTORICAL REVIEW OF ENCROACHMENT IN THE MIAMI AREA}

In the section on Ground water (Occurrence) there is a discus sion of the development of water supplies, from the first supply taken directly from a large spring beside the Miami River near NW. 27 th Avenue and 20th Street to the present (1946) well field in Hialeah and Miami Springs. These discussions indicate the principal conditions for the successive abandonment of supplies for larger ones more remote from salt-water encroachment. In the following discussion these conditions are reviewed, with particular attention given to the manner in which they developed.

\section{EARLY CONDITIONS}

During the latter part of the 19 th century and the early part of the 20th century, geologists and naturalists began scientific explorations of the Florida peninsula. Prominent among them were Alexander Agassiz, Leon S. Griswold, George C. Matson, and Samuel Sanford, all of whom visited Miami and recorded their observations. Notes on early conditions also have been written by others, including Daniel G. Brinton, A. W. Dimock, Hugh L. Willoughby, and Fred C. Elliott. A thorough review and careful interpretation of some of their notes have yielded valuable infor * mation on the relation between fresh water and salt water prior to the construction of drainage canals in the area.

Shaler (1890, p. 144) made extensive geologic investigations along the southeastern coast of Florida in 1887 or 1888. In describing conditions in the Coconut Grove area, he observes **** the waters of the Everglades at a distance of only 3 miles from the shore in their time of lowest level lie 16 feet high above high tide. [Shaler does not indicate the source of his altitude figure. Ecologic, geologic, and topographic studies made during the course of this investigation indicate that Shaler's " 16 feet above high tide" is about equivalent to 10 feet above mean sea level. Thus, an error of several feet in altitude is involved in Shaler's figure, which was probably based on an estimate.] In the rainy season they often rise to such an altitude that they pour over the reef wherever it is less than 20 feet in altitude. [The term "reef" as used here refers to the Atlantic Coastal Ridge.] A sufficiently wide canal, having a depth of 20 feet and a length of not over 4 miles, would drain the waters of the Everglades into Biscayne Bay. The rivers which flow over this part of the reef come down to the sea level over a series of rapids formed upon the harder layers of the reef, and thus the full escape of the Everglade waters is prevented. In the region more to the north, the entanglement of the vegetation about the headwaters of the streams, even where they have no rapids in their beds, likewise hinders the escape of the marsh waters." 
Shaler (1890, p. 146) further describes the "reef" as so thickly covered with sinkholes "that nearly all the rainwater appears to find its way by underground channels to the sea, where we can note its emergence in great springs. "In describing the western side of the "reef," Shaler states, "All portions *** which were so situated as to be exposed to the waves of the lake, which in the rainy season covers this district, were very deeply corroded. * * In the rainy season these waters rise to the height of from 5 to 8 feet above their level during the dry season, when I observed the district***. After the rainy season passes, the water is drained away by the numerous exits to the sea."

In a note appended to Shaler's paper (1890, p. 158), Alexander Agassiz makes the following comment: "To the damming up of the waters in the Everglades, and to the sudden outbursts of gigantic masses of water charged with organic matter and lime, we may trace the immense destruction of fishes which so frequently occurs on the shores of the Florida keys and the waters surrounding them." Griswold (1896, p. 53) mentions "great springs of constant flow" emerging "in large numbers along the shore. Fuller (1904, p. 266) in 1903 observed one of these springs in Coconut Grove flowing at the rate of $100 \mathrm{gpm}$ from the base of a limestone bluff. He indicates that the water was used for drinking and was reported to have supplied the American fleet off Havana in 1898. The water was described as being clear and hard, and as containing sulfur.

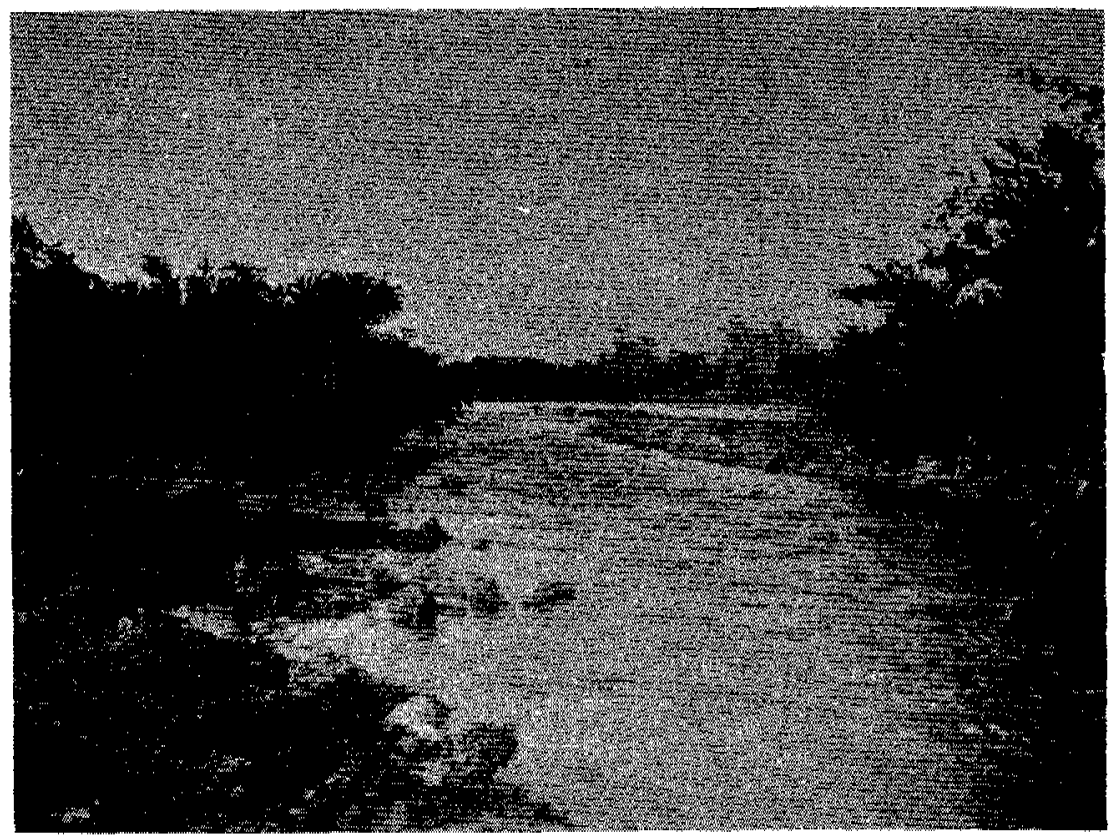

Figure 166. --Rapids of the Miami River before dredging of Miami Canal. 
Likewise, (Matson and Sanford, 1913, p. 179, 256, 289) mentions the existence in 1908 of "springs of some size *** flowing from the low ridges of Miami oolite near Biscayne Bay. "Apparently, a few of the springs were used for domestic supplies and by fishermen.

Griswold (1896, p. 53) mentions the presence of a distinct "fall line in the Miami River just west of the pineland. It has also been reported by Lilburn R. Railey, John W. Watson, and E. J. Sewell (personal communications) as having been near, and slightly west of, the present NW. 27th Avenue Bridge. A rather vivid description of the rapids and flow of the river at this "fall line" (fig. 166) is given by Willoughby $(1898, p .39)$. The discharge of this large volume of fresh water into the Miami River below the falls indicates that comparatively fresh water occurred in the channel within 2 or 3 miles of the salt water of Biscayne Bay.

Willoughby (1898, p. 65) says: "All along this shore [Coconut Grove] there are [Dec. 1896] places where the fresh water comes up through the rocks under the salt water with quite a head. It no doubt comes from the Everglades by subterranean passages."

John Sewell (1933) describes ground-water conditions in early Miami [see the section on Ground water (Occurrence)] and notes that hard limestone water was then obtainable in wells 50 to 60 feet deep at the mouth of the Miami River (fig. 167) and at the old Miami Hotel (now South Miami Avenue between SW. 1st and SW. 2nd Streets). He also describes the flowing fresh-water wells that were drilled 50 to 60 feet deep on the site of the present Miami Country Club (near NW. 11 th Street and 10th Avenue). At first, these wells produced hardfresh limestone water without pumping, but gradually they ceased flowing and had to be pumped. Eventually they became salty and were abandoned.

Munroe (1930, p. 118, 218) says of early ground-water conditions, "The abundant spring water off the shore, while organically pure, and beautifully clear and tasteless, was somewhat hard $* * * *$. He photographed boatmen obtaining fresh water from beneath salt water in Biscayne Bay.

The foregoing quotations, illustrations, and references give valuable background material in regard to early ground-water conditions in the Miamiarea. Shaler's observations are of particular interest because they indicate that a tremendous amount of water was formerly stored in the Everglades to within nearly 3 miles of Biscayne Bay. It is not difficult, therefore, to account for the presence of large fresh-water springs discharging into Biscayne Bay, along the base of the oolite ridge and through the floor of the bay itself. With such relatively high heads of fresh water continuously available in, and west of, the oolite ridge, it is highly improbable that the contact of salt water and fresh water 


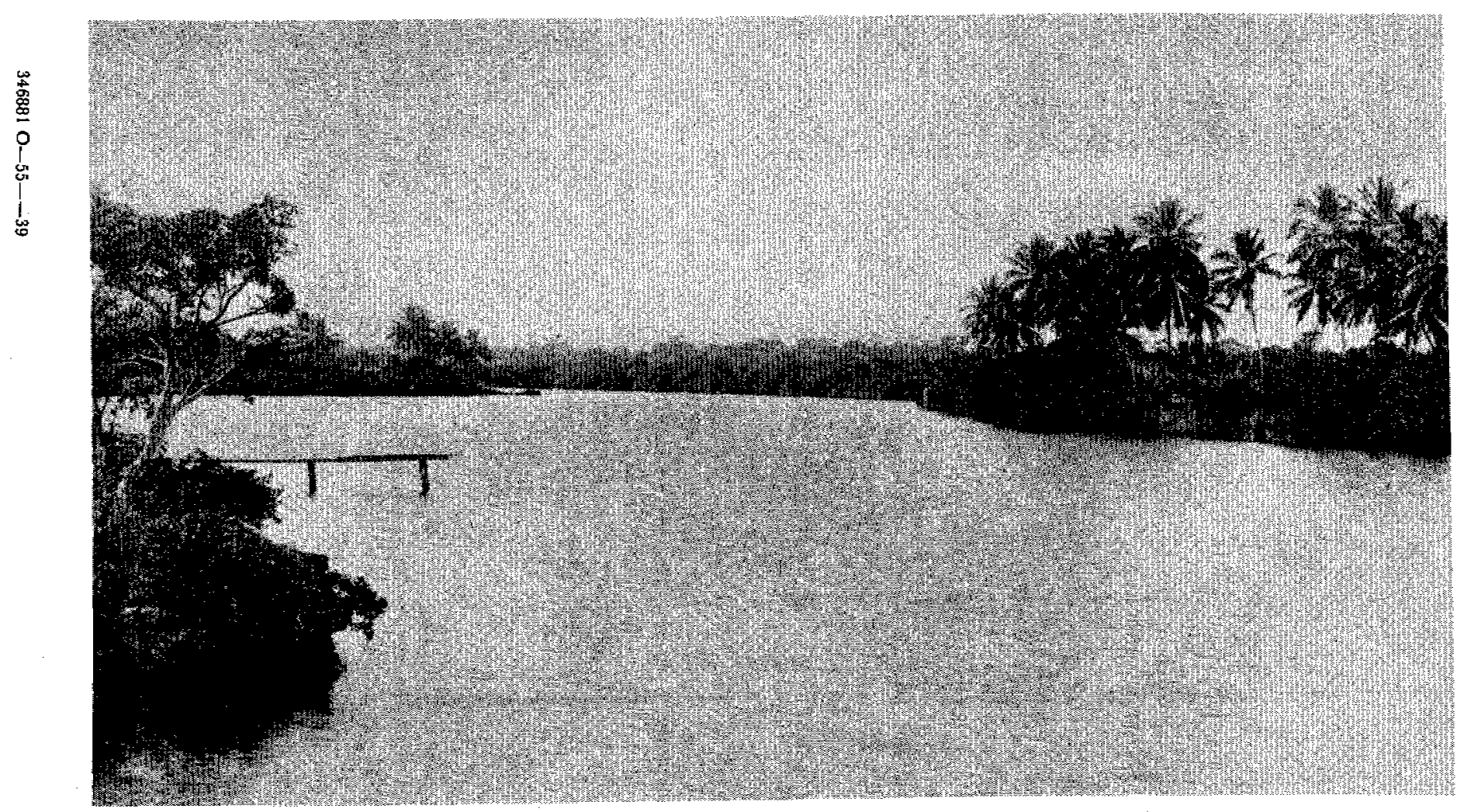

Figure 167. - Looking upstream from the mouth of the Miami River before dredging of Miami Canal. 
was very far inland. Possibly at depths of 200 feet or more below mean sea level the contact might have been farther inland. At shallower depths, however, it appears that no encroachment could possibly have taken place because of the overwhelming weight and flow of fresh water from the land.

\section{CHANGES BETWEEN 1907 AND 1939}

In 1907 the first serious modifications of the natural equilibrium between fresh water and salt water in southern Florida were undertaken by man. Dredging operations, a part of a State-wide drainage program, were started at that time in the New River basin at Fort Lauderdale. However, not until 1909 was dredging begun in the Miami River. By 1910 a channel 10 feet deep had been opened through the "fall line, " or rapids, at the head of the Miami River, and was extended about $4 \frac{1}{4}$ miles into the Everglades. Water that was formerly ponded in the Everglades behind the coastal ridge and stored within the rocks of the coastal ridge itself was now free to waste through the canals into the ocean; and water at sea level, fluctuating with the tides, extended inland as far as the head of the cuts, or to the base of the temporary earth dams placed to form pools deep enough for the dredges to operate.

W. S. Jennings $(1909$, p. 122), in a letter to the trustees of the Internal Improvement Fund of the State of Florida, dated November 19,1907 , tells of his observations during a visit that he and Governor N. B. Broward made to the site of the dredging operations: "The canals reduce the water level from the surface to approximately 6 feet below the surface of the ground as shown by the water in the canal, and the land for a mile on either side of the canal is entirely reclaimed, and is practically ready for preparation for cultivation, and the general influence of the drainage reaches to a much greater distance than one mile. *** Generally speaking, the work is a great success ${ }^{*} *$. The influence on the river has never been and is not perceptible. The reduction of the water level to 6 feet below the surface of the ground is all and more than could have reasonably been expected $* * *$ the superintendent finds it necessary to keep a sufficient quantity of water in the canal to float the dredge, while in front of the dredge is the water pouring over the front of the canal and falling 6 feet over a perpendicular dam to the water level of the canal and thus going on to the ocean.

"The result is that the reclamation of the land is fully demonstrated. We walked for a distance of $\frac{1}{2}$ mile or more along an Indian trail or canoe route through the saw-grass, where 20 days ago the Indians traveled with their boats and canoes, the water having all been drawn off from this territory by the cutting of the canal, thus lowering the water level." 
Nature's original equilibrium between fresh water and salt water, which was based on a high water table, was thus destroyed. As progress was made toward reestablishment of an equilibrium based on a lower water table, the springs along the shores of Biscayne Bay diminished in flow, then disappeared, and swampy areas upstream along the Miami and New Rivers began to dry out.

Clyde P. Ross (1919), of the U. S. Geological Survey, observed that originally the area covered by the Miami well field (the southeast portion of the old Royal Palm Golf Grounds-now the Miami Country Club-near NW, 11 th St. and 10 th Ave.) was swampy, but that it had drained and dried. Sanford (Matson and Sanford, 1913. p. 291) reported that in 1908 the Miami supply was derived from four flowing wells that ranged in depth from 73 to $95 \mathrm{ft}$. These wells were located in a swale underlain by a thick layer of relatively impermeable marl. The swale was partly surrounded by higher land, behind which the waters of the Everglades were impounded. These conditions were ideal for the development of local artesian wells, and therefore flowing wells existed in the Spring Gardens (Penniman Springs) area in those early days.

Twelve years after Sanford's investigation, C. P. Ross reported that the original wells had ceased flowing, that pumps had been installed, and that the wells had been plugged at a depth of 40 to 45 $\mathrm{ft}$ to avoid taking water from the deeper parts of the aquifer, which had become contaminated by salt water. This salt-water movement was further facilitated by drainage operations that began in August 1917 and continued until June 1923. During that period, the Miami Canal was dredged to an average depth of $12 \mathrm{ft}$ from its junction with the Miami River northwestward to a point a quarter of a mile above (northwest of) its junction with the present South New River Canal (about 32 miles from Biscayne Bay).

In 1928 and 1929 , chloride determinations were made on ground water samples collected from a number of drainage wells in the Miami area. The samples were collected at the time of drilling and should, therefore, represent true ground-water conditions. From these data an isochlor map, figure 168, was prepared. (An isochlor is defined as a line on a map connecting points of equal chloride concentration.) Although the data do not give complete areal coverage, they indicate reasons for water from the original Miami Water Company field at Spring Gardens becoming too salty for use. The isochlor representing a concentration of $10,000 \mathrm{ppm}$, based on samples from wells 70 to $100 \mathrm{ft}$ deep, lies northwest of the well field. Thus the field occupied an area of even higher chloride concentration. Inasmuch as the field originally (1907) delivered fresh water, it is obvious that the boundary between fresh and salt water migrated inland largely as a result of dredging operations in the Miami River and construction of the Miami Canal. 


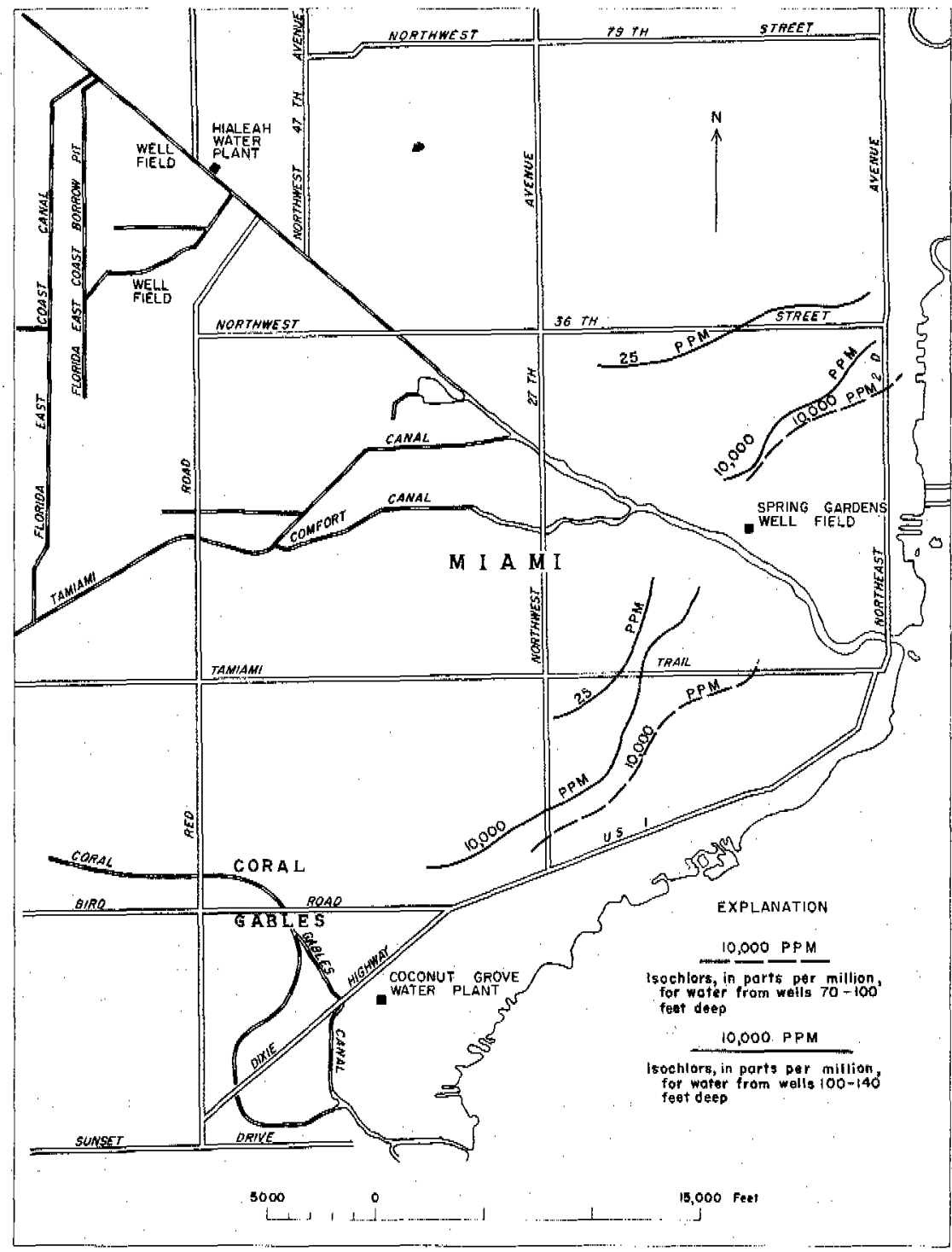

Figure 168. - Map of metropolitan Miami area showing isochlors for 1928-29, based on samples of ground water from drainage wells,

As mentioned previously, earth dams were built in each of the newly dredged canals to give the dredges sufficient water in which to operate. Although they were breached on a few occasions to allow barges and excavating equipment to pass, they were restored each time and remained in place until concrete locks and dams were built in 1912-13. If all these structures had been kept in good condition, they might have prevented many of the damaging results of the breaching of the natural barrier. Operation of the dams and locks has been irregular. Those on the South New River and North New River Canals were most effective and are still in use. The 
Miami Canal lock and dam apparently was not effectively used and was finally removed when the Miami River was dredged to a depth of $15 \mathrm{ft}$ in 1931-32. The deepening of the channel almost to the NW. 36 th Street bridge did not greatly affect ground-water levels; however, it did expose new areas to salt-water contamination. Likewise, the dredging of several supplementary canals, largely during the period 1926-42, further dissected the Miami area and accelerated the drainage of ground water stored during the rainy periods. Table 67 gives the approximate construction periods for each of 10 canals in the Miami area. (See also fig. 184.)

Table 67. - Canals in the Miami area and periods of thcir construction

\begin{tabular}{|c|c|c|c|}
\hline $\begin{array}{l}\text { Name of } \\
\text { canal }\end{array}$ & $\begin{array}{c}\text { Period of } \\
\text { construction } 1\end{array}$ & $\begin{array}{l}\text { Name of } \\
\text { canal }\end{array}$ & $\begin{array}{l}\text { Period of } \\
\text { construction1 }\end{array}$ \\
\hline $\begin{array}{l}\text { Biscayne................ } \\
\text { Comfort............... } \\
\text { Coral Gables.......... } \\
\text { F. E. C................... } \\
\text { Little Rivex........... }\end{array}$ & $\begin{array}{l}1925-26 \\
1925-34 \\
1925-42 \\
\text { No record } \\
1925-27\end{array}$ & 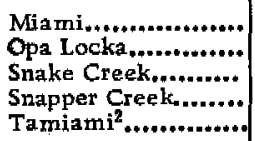 & $\begin{array}{l}1909-32 \\
1925-26 \\
1912-13 \\
1912-13 \\
1919-28\end{array}$ \\
\hline
\end{tabular}

${ }^{1}$ Construction as originally planned. Most canals have been considerably modified during later years.

${ }^{2}$ Five and a half miles completed to 1926; remainder excavated as a borrow ditch for the State Road Department for building of the Tamiami Trail (U. S. Highway 94 ).

During periods of low water these canals provided 10 avenues along which salt water conld move, and from which it could contaminate water-bearing formations.

\section{CONDITIONS SINCE 1939}

In 1933, Charles Morgan, who was then Miami City Chemist, called the attention of V. T. Stringfield, of the U. S. Geological Survey, to the increased salt-water encroachment in the Miami Canal and the salting of wells along that canal. However, it was not until the latter part of 1938 and the early part of 1939 that a severe drought in southeastern Florida forcibly demonstrated how seriously the original equilibrium between salt water and fresh water had been modified. At that time, the ocean level during high tide was above the fresh-water stage in the canals. This was caused by a combination of factors, including overdrainage of the coastal ridge, drainage of the Everglades, and rainfall deficiencies.

As the 1938-39 drought progressed, water that had formerly been stored behind the rock barrier of the coastal ridge wasted into the ocean. Flow reversals in the tidal canals occurred for periods of 2 to 5 hours during each tidal cycle, and salt water migrated farther and farther inland. As the length of the reversal 
periods increased, the salt water migrated more rapidly, until eventually it reached more than 10 miles inland in some canals.

The damaging effects of this inland salt-water movement in the drainage canals were noted when salty water appeared in certain well $\mathrm{s}$ in the Miami well field, which is near the Miami Canal, 7.5 miles inland from Biscayne Bay. Although public concern centered principally around contamination in this field, numerous private supply wells located near the salt water in the tidal canals of Dade and Broward Counties also became contaminated. The damage was widespread and costly, and even in temporarily salted areas it persisted long after seasonal rains reestablished fresh-water stages in excess of the maximum salt-water stages.

Figure 186 shows seasonal variations in the extent of salt-water contamination in the Miami Canal for the period January 1940 through December 1946. On the average, salt water extended up the Miami Canal approximately 4 miles. This is about 2 miles farther than in 1909, before drainage work began.

The general extent of salt-water contamination of the aquifer is shown in figure 169. The map for 1904 indicates the estimated and reported conditions in the area prior to any drainage work. Salty water probably extended only about $1 \frac{1}{2}$ or 2 miles up the Miami River, and fresh-water springs flowed at elevations of as much as $5 \mathrm{ft}$ above mean sea level on the seaward side of the oolite ridge along the west shore of Biscayne Bay. Ground-water levels were high in the Everglades; probably, at times, they were even higher along the coastal ridge, inasmuch as springs were also reported on the western side of the ridge (Matson and Sanford, 1913, p. 289). The stippled areas in the figure represent the estimated zone in which wells about $80 \mathrm{ft}$ deep would tap ground water having chloride concentrations of approximately $1,000 \mathrm{ppm}$ or more.

The map for 1918 (fig. 169) indicates estimated, reported, and known conditions in the area about 5 years after completion of preliminary dredging of the Miami Canal. On the average, salty water probably extended inland about 3 or $3 \frac{1}{2}$ miles up the Miami River. Most of the perennialsprings no longer existed on the east side of the coastal ridge, and certain swampy areas east of the ridge had been drained. Ground-water levels of the Everglades and the coastal ridge were lower, and an increase in chloride concentration had occurred in the areas (stippled) exposed, and already subjected, to salt-water contamination.

The map for 1943 (fig. 169) indicates observed average conditions in the Miami area after the canals had been dredged. Note the greatly increased width of the contaminated zone and its long extensions inland along the drainage canals. Note also that these inland extensions follow up every tidal canal. This map plainly shows why the Coconut Grove field, which lies entirely within the stippled area, had to be abandoned. 

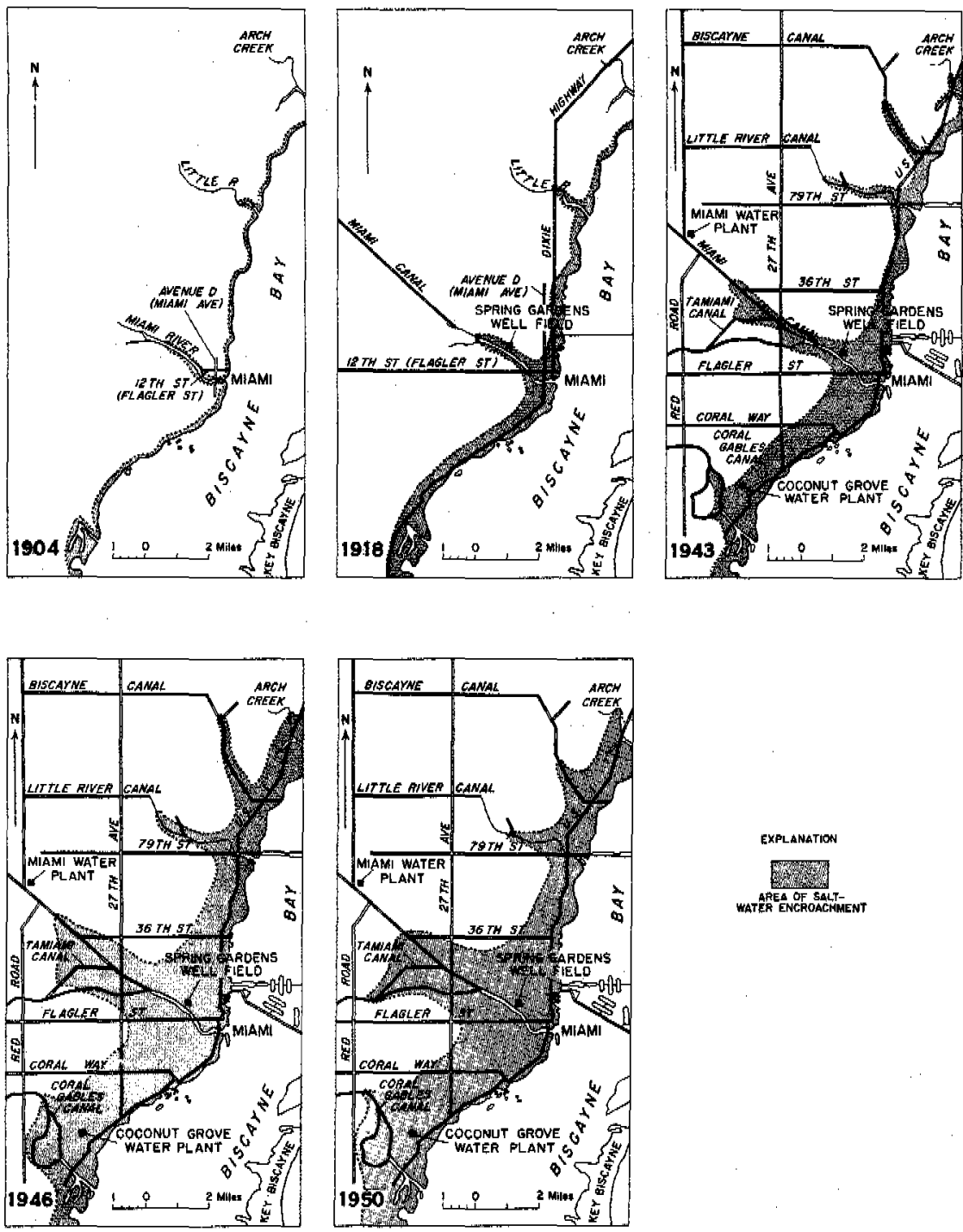

Figure 169. - Maps showing progressive salt-water encroachment in the Miami area, 1904-50.

The map for 1946 shows that the encroachment of sea water upon fresh water was continuing in most canals. (See the section on Encroachment in the tidal canals, p. 618 et seq.) Water levels were exceedingly low during this period, and effective control of them, by regulation of the canals, had not been established. How ever, a start was made by the Dade County Engineering Department in 1945 following a legislative act granting Dade County control over the water levels in canals and waterways within its boundaries.

The map for 1950 indicates the following developments: (1) increased rainfall and greater recharge to the aquifer as compared to the $1943-46$ period; (2) effectiveness of temporary dams in the 
tidal canals in maintaining somewhat higher heads of fresh water in the canals and aquifer upstream from the dams, and in preventing salt-water movement in the canals for any significant distance above the dams.

The five maps in figure 169 show the general pattern of encroachment into the Biscayne aquifer of the Miami area over a period of 47 years. They show that the major spread of contamination probably occurred between 1943 and 1946. During that time a lengthy drought occurred, and in 1945 water levels fell to record all-time lows. Parker (1945a, p. 539) reckoned, on the basis of studies in the Silver Bluff area, that the rate of encroachment until $1943 \mathrm{had}$ been approximately $235 \mathrm{ft}$ per year. In a 27 -month period that overlapped 1943-44, the front of the wedge of encroaching salt water advanced $2,000 \mathrm{ft}$, which is at the rate of $890 \mathrm{ft}$ per year.

To arrest this threat to the water supply, Dade County and Miami cooperated in the building of temporary steel sheet-piling dams in tidal canals. Navigation and other interests prevented the building of dams in the Miami Canal east of the NW. 36th Streetbridge site, and in the Coral Gables and Tamiami Canals east of Red Road. The encroachment pattern shown on the map for 1950, compared with that shown on the map for 1946, clearly describes the results. On the Biscayne, Little River, and Miami Canals actual seaward retreat of the inland ends of the tongues of encroaching salt water has occurred. In each of these areas the temporary dams, although makeshift and leaky, have prevented additional serious intrusion of sea water during the dry seasons and have conserved the fresh-water supply.

By contrast, contamination along the Tamiami and Coral Gables Canals is continuing. The former empties into the Miami Canal downstream from the 36 th Street dam site; therefore, it is vulnerable to salt water movement up the unprotected channel. Both the Coral Gables and Tamiami Canals were dammed at Red Road, but low stage and low flow enabled sea water to penetrate as far as the dams. The continued spread of salt water in these two areas is directly attributable to the lack of downstream salt-water control dams.

In the intercanal areas parallel to the shoreline of Biscayne Bay, the salt water has generally maintained its 1946 position. This condition speaks well for the water-control program, which has not only excluded the sea water above the dams but has also resulted in somewhat higher water levels in the affected areas. This, together with the increased rainfall and recharge to the aquifer since 1947, has slowed the 890-feet-per-year encroachment rate to practically zero. Only in the area of Coral Gables Canal has the intercanal contamination zone migrated inland. This movement is probably caused by the increased opportunity for salt water to gain access from the bay through newly dredged canals in that area. 
Water-table contour maps [see section on Ground water (Quantitative studies)], indicate that even though drainage has lowered water levels considerably, a low ground-water divide still exists in parts of the coastal ridge in the Greater Miami area. It is not a remnant of the original natural divide. In dry weather the present ground-water mounds owe their origin not to natural recharge, but to artificial recharge through irrigation (lawnwatering) systems and waste water from septic tanks, drainage wells, and similar media. In wet weather there is, sufficient natural recharge to create a temporary divide. The artificial recharge is the result of water being taken from the aquifer in the Miami SpringsHialeah area and delivered by the municipal water system to the downtown area and the coastal strip, where it is returned to the aquifer. Although springs no longer exist on either side of the ridge, it is evident from the water-table contours (flow is at right angles to contours) that for short distances, even during the lowest stages of water levels, ground-water flow occurs in some places from the ridge toward the Everglades.

Further details on the present extent of salt-water contamination in the Miamiarea are shown on the isochlor map, plate 17.

If similar maps could have been drawn for the period prior to drainage work, the isochlors would have been much nearer to Biscayne Bay than those shown in plate 17. They would have been parallel to the shore except where it bends inland at the Miami River and other tidal waterways emptying into the bay.

\section{ENCROACHMENT IN THE AQUIFER DIRECTLY FROM THE OCEAN}

\section{HISTORICAL REVIEW OF LITERATURE ON COASTAL GROUND WATER}

Significantstudies of coastal ground water were made independently by Badon Ghyben and A. Herzberg shortly before 1900. The results of their investigations are reviewed by Brown $(1925$, P. 17 19), who points out that their work ** * * appears toapply particularly to small islands and narrow land masses that are made up of freely pervious material, especially sand. It can not be applied to large land bodies or to continents, for it implies that sea water should be found in every locality where the water table is below sea level. There are well-known interior land areas which lie many feet below sea level but in which the ground is entirely free from sea water. The application of the theory is alsogreatly modified by the kind of rocks and their structure. The importance of Herzberg's theory, however, is not to be ignored and has been most convincingly demonstrated by Pennink (Pennink, J. M. K., De "prise d'eau" der Amsterdamsche duin waterleiding: $K$. Inst. Ing. Tijdschr. , 1903-4, p. 183-238, The Hague, 1904) on the Coast. of Holland." 
Pennink's work clearly demonstrates that salt water underlies the land at a depth of 100 to 200 meters below sea level over a belt several miles wide that is adjacent to the Netherlands coast; that the depth to salt water is greatest where the water table is highest, and that the level of salt water rises under areas where the water table is low; that the zone of diffusion between fresh and salt water averages about 20 meters in thickness on the North Sea end of the contact; and that the general zone of contact between fresh and salt water is very regular and its center is occupied by the 1,000 -milligram-per-liter isochlor $(1,000 \mathrm{mg} / \mathrm{l}$ is approximately equivalent to $1,000 \mathrm{ppm}$ ). Irregularities in Pennink's isochlor pattern are readily explained by differences in lithologic character of the water-bearing beds.

Ghyben and Herzberg developed the principle that because salt water is denser and of greater specific gravity than fresh water, under conditions of static equilibrium it would take a column of fresh water $41 \mathrm{ft}$ high to counterbalance a column of normal sea water $40 \mathrm{ft}$ high. Stating it another way, a head of $1 \mathrm{ft}$ of $\mathrm{fresh}$ water above mean sea level indicates a depth of $40 \mathrm{ft}$ of fresh water below mean sea level, or a ratio between fresh-water head above sea level and depth to salt water below sea level of 1 to 40 . This is the familiar ratio commonly used in predicting the depth at which salt water will be found in a given coastal area. Barksdale (Barksdale, Sundstrom, and Brunstein, 1936, p. 25) has aptly likened the manner in which fresh water (in a narrow coastal zone or island structure) "floats" on salt water, to the manner in which an ice mass floats on water, with most of its volume submerged.

Much of the significant early literature concerning coastal ground water has been ably reviewed in Brown's paper (1925). All these studies developed relationships and gave conclusions predicated on the assumption that static conditions were being considered. The Ghyben-Herzberg principle, however, requires the water table to be a convex surface intersecting the shoreline at mean sea level. The fact that the water table slopes toward the shoreline indicates flow-flow that is maintained by sufficient recharge to keep the water table above sea level.

Muskat's treatment (1937, p. 289) of gravity-flow systems offers an explanation of how that outflow takes place. Muskat shows that the water table does not intersect the ground surface at sea level, but that it does so at a higher elevation. The space between is a zone of seepage. Observations appear to confirm this theory in the Miami area, where the profiles made during the investigation indicate a water table sloping gently downward toward Biscayne Bay. Instead of intersecting the bay at mean sea level, however, the trend appears to be such that the intersection will occur above mean sea level and, in fact, even above the high-tide level. The profiles further suggest that the vertical height of the boundary or seepage surface is about $0.5 \mathrm{ft}$. This might suggest discharge by 
springs; however, no visible springs now exist along the shore, although in the early days, before drainage canals lowered the water table, many springs flowed near the base of the limestone cliff along Silver Bluff and elsewhere along the coast.

The wave-cut bench that forms the land surface between Biscayne Bay and the low sea cliff, Silver Bluff, slopes gently down from 5 $f t$ above mean sea level to the water's edge. The water table is never very far below this surface, and the discharge of ground water here through evapotranspiration is much higher than that in adjacent areas inlandfrom the cliff. The land surface of the wavecut bench is always moist and near the shore is quite damp, indicating continuous ground-water discharge.

Wentworth (1942, p. 685) points out that ground water may be discharged in larger quantities by means other than seepage without substantially upsetting equilibrium conditions, if somewhat isolated leakage channels to the sea exist at depths where the hydrostatic pressure of the fresh water is greater than that of the salt water. This condition occurs in the Miami area, and the flow takes place both along a secondary system of vertical and horizontal solution channels in the limestone and through parts of the formation originally more permeable than others. The numerous large and small springs that formerly discharged along the shore and into the bottom of Biscayne Bay and connecting tidal canals gave vivid proof of the existence and operation of these shallowdepth channels of ground-water discharge. It is quite likely that considerable ground-water discharge still occurs in this manner, but owing to the small size of these submerged springs they are not readily noticed. Mention has already been made of the former perennial springs that now flow only during times of extreme high-water level.

These two avenues of discharge probably account for the principal discharge of fresh water moving seaward in this area.

\section{STUDIES IN THE SILVER BLUFF AREA OF MIAMI}

\section{SFLECTION OF THE SITE FOR STUDY}

The Silver Bluff area was selected for intensive investigation largely because it appeared to be a representative area of the coastal ridge in Miami. There, the geologic section is quite similar to that of other areas along the coast of Dade County. Furthermore, this area offered the largest number of wells (points of access to the ground-water body) that could readily be used for observation; the depths of these wells ranged from about 45 to $125 \mathrm{ft}$. Thus, a fairly good observational net was already established. In addition, there were no tidal canals in the immediate neighborhood, although the general area (see fig. 200) is entirely surrounded by 
canals on the sides landward from Biscayne Bay. These canals are the Miami Canal on the northeast, the Tamiami and Comfort Canals on the north, and the Coral Gables Canal on the west and southwest. (See Brown and Parker, 1945.)

\section{PRELIMINARY WORK}

Considerable preliminary work was required before the first study could be attempted. This included a thorough inventory of all available wells to determine the areal and vertical distribution of points of access to the ground-water body.

For purposes of determining the altitude of the water table, 14 additional wells $2 \mathrm{in.}$ in diameter were driven below the water table to insure that they would not go dry during drought periods. Wherever possible, the wells were installed adjacent to existing fire wells to permit a direct comparison between the true water table (as found in the shallow observation wells) and the water level in the deeper fire wells. Where both wells of any pair ended in ground water of normal chloride concentration (about $16 \mathrm{ppm}$ ) or, more properly, where the specific gravity of the ground water in each well was the same, it was expected that the water levels in the two wells would be nearly identical. However, where fire wells tapped ground water of high chloride concentration and where the specific gravity of the water within the well casings was therefore appreciably greater than that of water in the shallow observation wells, it was expected, and later confirmed by field measurements (p, 602-603), that the water level in the deeper wells would be appreciably lower than the true water table. Figure 170 shows the locations of most of the wells used in the Silver Bluff studies.

To obtain complete data on the tides and sea level in Biscayne Bay in order that their effect on the water table could be studied, a water-stage recorder was installed in the bay at the foot of Aviation Avenue. The record shows that the average sea level during the course of this investigation has been higher than the mean sea level established by the U. S. Coast and Geodetic Survey. Also, there has been a tendency for the mean tide stage to increase. See pages $441-443$ for more detailed discussion of this matter.

Following is a summary of the record for the period preceding the studies reported herein: 


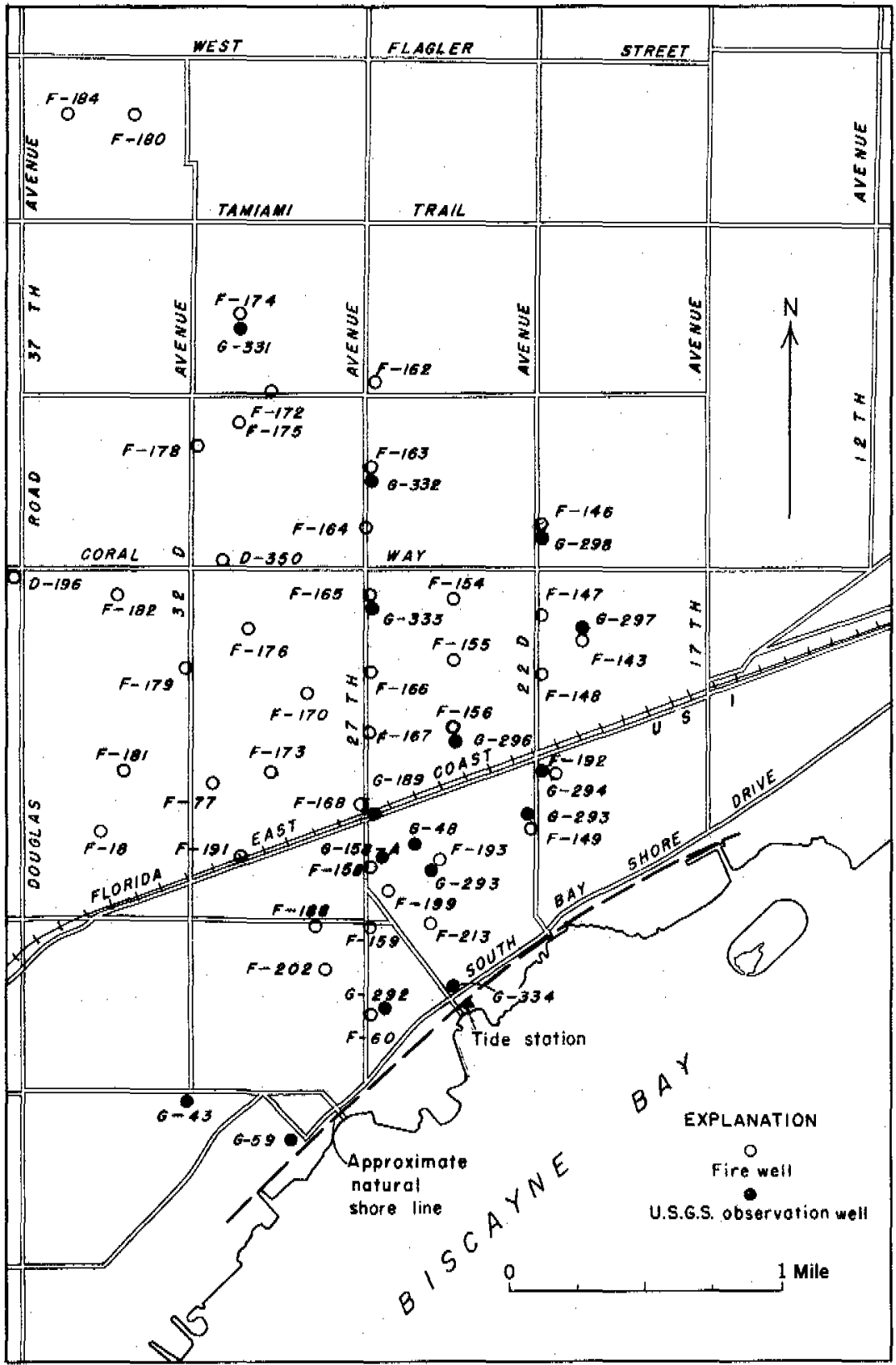

Figure 170. - Map of Silver Bluff area, Miami, showing the location of wells used in studies of salt-water encroachment. 
Tidal elements and sea level

[In feet with reference to U. S. Coast and Geodetic Survey mean sea level datum of 1929]

Nov. 8,1940 , to July 26,1941

229 maximum stages, average............................ +1, 44

229 minimum stages, average............................. -0.66

Average sea level.............................................. + 0.39

Nov. 8, 1940, to Feb. 4, 1942

436 maximum stages, average............................. +1. 48

436 minimum stages, average............................. -0.59

Average sea level............................................. + 45

For the period 1941-1946, average water level in Biscayne Bay was found to be $0.61 \mathrm{ft}$ above $U$. S. Coast and Geodetic Survey mean sea level. Detailed fluctuations in sea level are shown in figures $117-123$.

\section{OANECTVES}

Investigations in the Silver Bluff area inyolved determination of: (1) The horizontal and vertical distribution of salty ground water; (2) the magnitude of cyclic seasonal shifts or changes in the position of the salt-water wedge; and (3) whether or not the salt-water wedge is gradually moving inland and contaminating parts of the aquifer formerly containing only fresh ground water. The first objective could have been reached through a single study; the second and third objectives, however, necessitated repeated studies to cover a variety of seasonal conditions and to be certain of long-term trends. In view of the fact that attempts are being made to control water levels and stop salt-water encroachment, the studies actually need to be continued over a much longer period of time.

\section{PHOCEDURES}

The first intensive study in the Silver Bluff area was made on June 26, 1941. Results of this study were valuable primarily in devising efficient and thorough methods of conducting later studies. The following field procedures were adopted:

1. Selection of a date for conducting a study was based on rainfall records for the preceding several days. Because there are about 17 drainage wells scattered throughout the area (and numerous others in adjoining areas) that receive the discharge from storm sewers and catch basins, it appeared that the water table 
and isochlor pattern near these wells would be distorted for several days following heavy rains. In effect, the drainage wells act as local recharge points for the ground-water body, and, where drainage wells end in salt water, fresh water is injected into the wedge of salty water. This not only dilutes the body of salt water locally but also creates localized mounds on the water table. Therefore, no study was attempted unless 3 or 4 days had elapsed since the last heavy rain.

2. All fire wells in the area selected for observation were pumped on the day preceding the date chosen for a particular study in order to remove the water standing in the casing and to draw in new water. In general, the fire wells were pumped in the approximate order of their estimated chloride concentrations-those in which the concentration was highest were pumped first. This made it certain that if all the fire wells could not be pumped on the day preceding the study, those remaining to be pumped on the day of the study would be low in chloride content. Thus, there would be no appreciable change, due to density differences induced by pumping, in the water level within these wells on the day of the study (see p, 613). Each well was pumped long enough to insure that the casing would be entirely emptied of water standing in the well and would be refilled with water drawn from the aquifer at the known depth of the well. A water sample was collected as soon as the pump had removed the standing water.

3. On the date selected for a study, the water levels in all fire wells and other observation wells were measured at hourly intervals over a 13-hour period to make certain that one complete tide cycle would be obtained for wells responsive to tidal variations. Drainage wells were not used, either for sampling or for observation purposes, because they contained cons iderable amounts of sludge and debris that affect both the quality of the water and the water level in the well.

The field work just outlined supplied data for the preparation of a composite cross section showing the profile of the water table and that of the isochlor pattern in a direction normal to the general trend of the natural shoreline. The profile of the water table was based on observations in the shallow wells and the isochlor pattern on chloride determinations of samples collected from the deep fire wells.

In compiling the results of the first study the shortest distance from each well to the shore was determined, making use of the many man-made irregularities in the shoreline. The composite water-table profile resulting from the use of these distances, however, appeared excessively uneven, so a smooth curve was drawn to represent what was judged to be the original or natural shoreline (fig. 170). The shortest distance from a well to this 
original shoreline then became the length, of the normal, erected to this line, drawn to the well. Using these distances the watertable profile was readily plotted as a fairly smooth curve.

\section{SPECIFIC GRAVITY OF SEA AND GROUND WATER}

Before computations could be made to adjust water levels in wells containing different concentrations of salty water, it was necessary to determine the relation between chloride concentration and specific gravity of sea water, of ground water, and of mixtures of the two.

One of the most exhaustive studies of the relations among specific gravity, temperature, chloride concentration, and salinity of sea water was made under the direction of Knudsen (1901). Empirical equations, based on experimental data, were developed whereby the salinity and specific gravity of sea water can be calculated at any temperature between $-2^{\circ} \mathrm{C}$ and $33^{\circ} \mathrm{C}$ if the chloride concentration in grams per kilogram is known. These equations were developed on the basis of atomic weights of the elements (as known in 1900). More recent investigation by Thompson and Wirth (1931, p. 232-240) indicates that Knudsen's tables are more accurate if the atomic weights of 1930 are substituted for those of 1900. There appears to be a marked relation between specific gravity and chlorinity in samples of sea water collected from many parts of the world. As defined by Thompson and Robinson (1932, p. 107), chlorinity is the number of grams of halides capable of precipitation by silver nitrate, calculated as chloride, contained in a kilogram of sea water. In this report the total halides reported as chloride are considered to be synonymous with chlorinity.

When sea water is diluted with runoff from land areas, the relation of specific gravity to chloride concentration, as well as to other constituents, may vary somewhat. Determinations were made, therefore, of the specific gravity of sea water and of several artificial dilutions of sea water with typical uncontaminated ground water of the Miami area. As the average temperaturc of ground water in this area is close to $25^{\circ} \mathrm{C}\left(77^{\circ} \mathrm{F}\right)$, the specific gravities were determined at $25^{\circ} \mathrm{C}$. Computations are greatly simplified by assuming that such uncontaminated ground water has a specific gravity of 1.00000 at $25^{\circ} \mathrm{C}$; the results are then expressed as specific gravity at $25^{\circ} / 25^{\circ} \mathrm{C}$ in accordance with the usual notation. Table 68 presents these determinations of specific gravity, arranged in order of increasing dilution from sea water to ground water.

A plot (fig. 171) of chloride concentration as abscissa and specific gravity as ordinate illustrates the results given in table 68 . 
Table 68.- Specific gravity of sea water samples diluted with uncontaminated ground water

\begin{tabular}{|c|c|c|c|}
\hline $\begin{array}{c}\text { Sample } \\
\text { no. }\end{array}$ & $\begin{array}{c}\text { Gravimetric } \\
\text { chloride } \\
\text { (ppm) }\end{array}$ & $\begin{array}{c}\text { Specific gravity } \\
\left.\text { (at } 25^{\circ} / 25^{\circ} \mathrm{C}\right)^{\mathrm{a}}\end{array}$ & $\begin{array}{c}\text { Computed } \\
\text { specific gravity } \\
\left(\text { at } 25^{\circ} / 25^{\circ} \mathrm{C}\right)^{\mathrm{b}}\end{array}$ \\
\hline $1^{\mathrm{c}}$ & 19,740 & 1.02680 & $\mathrm{~d}_{1.02643}$ \\
2 & 15,940 & 1.02161 & 1.02124 \\
3 & 13,260 & 1.01803 & 1.01766 \\
4 & 10,070 & 1.01374 & 1.01337 \\
5 & 6,710 & 1.00922 & 1.00886 \\
6 & 5,050 & 1.00700 & 1.00664 \\
7 & 3,340 & 1.00472 & 1.00436 \\
8 & 2,280 & 1.00333 & 1.00297 \\
9 & 1,594 & 1.00239 & 1.00203 \\
10 & 1,132 & 1.00179 & 1.00143 \\
11 & 907 & 1.00148 & 1.00112 \\
12 & 583 & 1.00107 & 1.00071 \\
13 & 353 & 1.00078 & 1.00042 \\
14 & 214 & $\mathrm{e}_{1.00057}$ & $\mathbf{1 . 0 0 0 2 1}$ \\
15 & 122 & 1.00050 & 1.00014 \\
$16^{\mathrm{f}}$ & $\ldots \ldots \ldots \ldots \ldots \ldots$ & $\mathbf{1 . 0 0 0 3 6}$ & 1.00000 \\
\hline
\end{tabular}

Determined in laboratory and referred to distilled water at $25^{\circ} \mathrm{C}$. as unity.

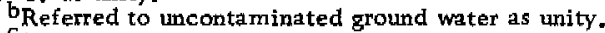

SSea water.

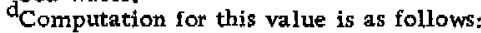

Specific gravity $=\frac{1,02680}{1.00036}=1.02643$

$f_{\text {Ground water. }}$

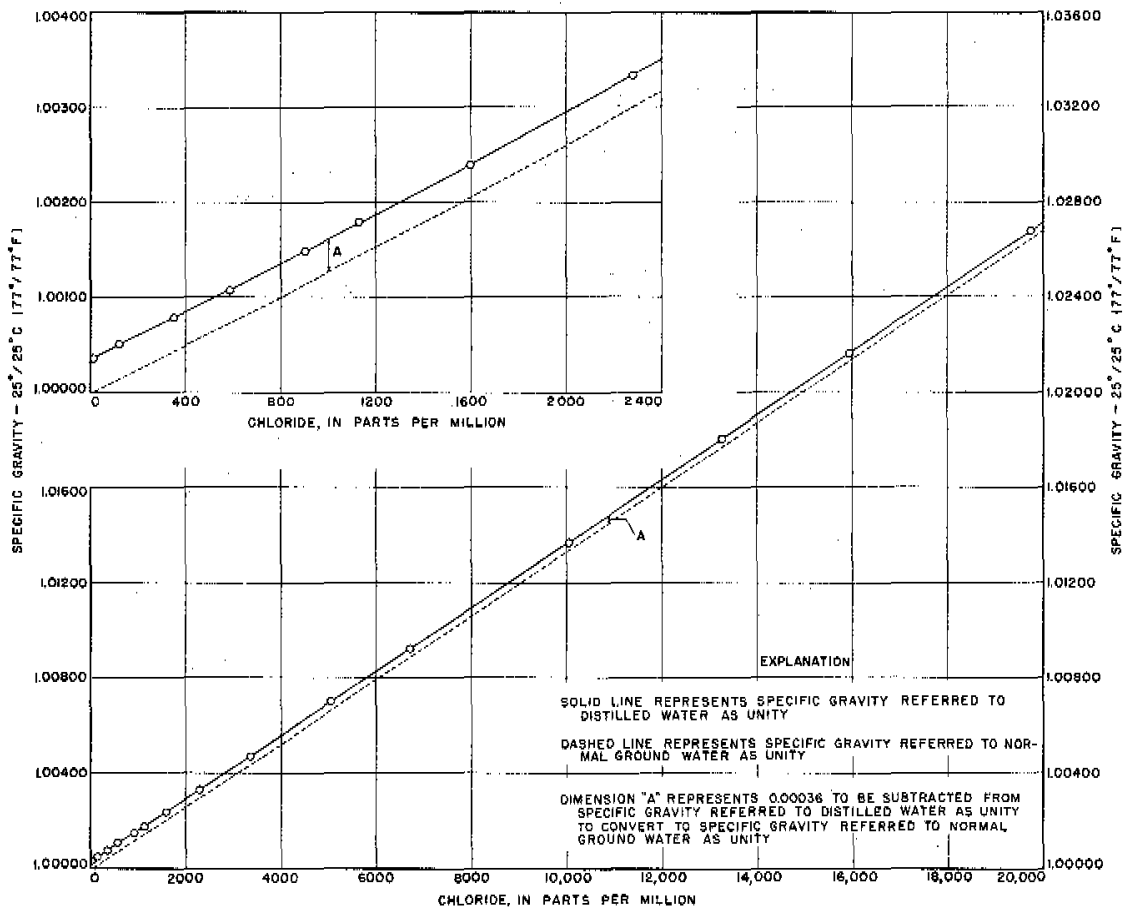

Figure 171. -Graph showing relation between specific gravity and chloride concentration in artificial mixtures of ground water and sea water. 
The solid line resulted from direct plotting of the laboratory determinations of chloride and specific gravity values. As expected, it does not pass through the coordinate origin because, even with a chloride concentration of zero, other dissolved compounds are present and the specific gravity therefore remains greater than the value of the unit assigned to distilled water as a reference. The curve is essentially a straight line above a chloride concentration of about $3,500 \mathrm{ppm}$; below this point the curve is slightly concave upward.

The dashed curve shown in figure 171 was derived from the solid curve by plotting computed specific gravities, referred to normal ground water as unity, against chloride concentrations. It passes slightly to the right of the coordinate origin because a specific gravity of unity now represents normal ground water having a chloride concentration of $16 \mathrm{ppm}$. It is parallel to the solid curve and lies below it by an ordinate amount of 0.00036 .

\section{SILVER BLUFF STUDIFS}

Four complete sets of data concerning salt-water encroachment were collected in the Silver Bluff area following a study of the determinations of June 26, 1941. These data collections were made

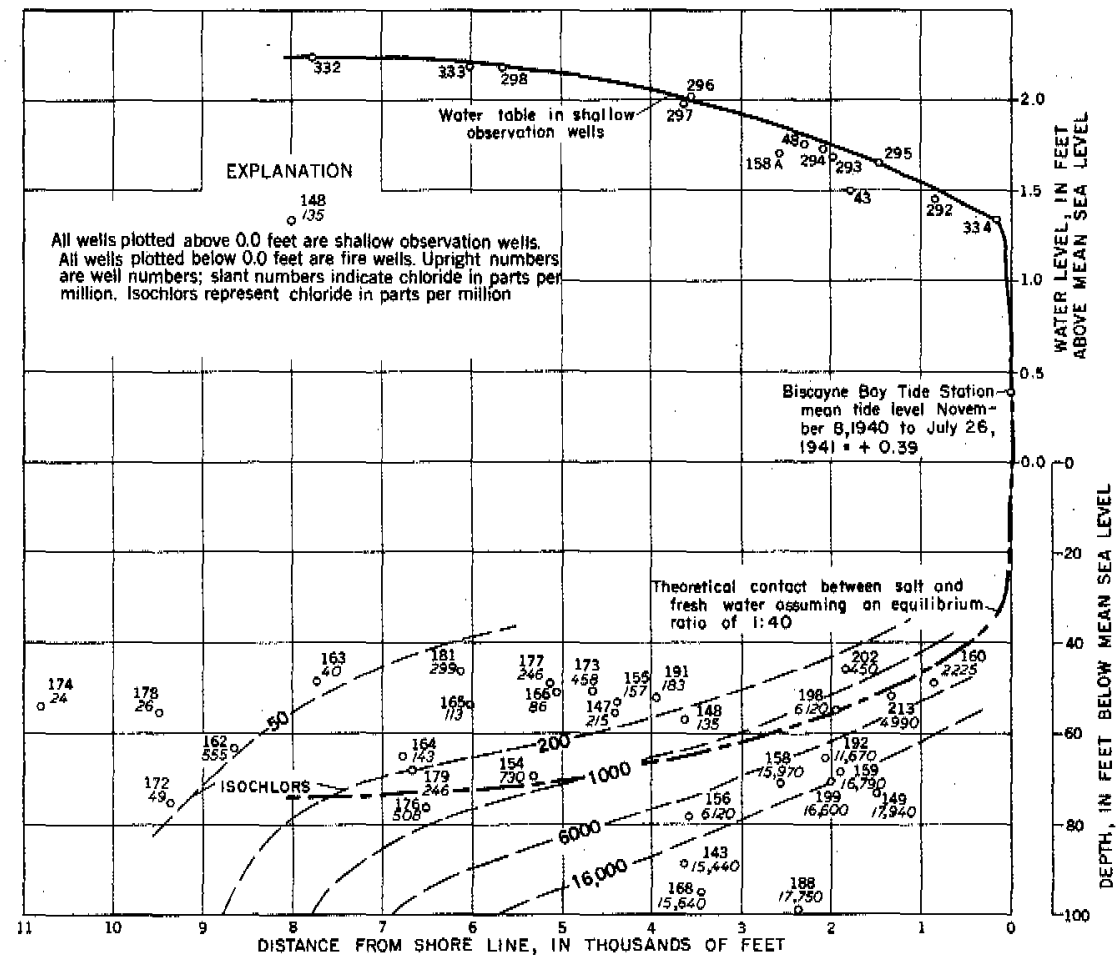

Figure 172, - Composite profile for salt-water encroachment study of July 26, 1941, Silver Bluff area, Miami. 
on July 26, 1941, August 28, 1941, October 25, 1941, and February 4,1942 , and covered periods during which the water-table levels ranged from a stage slightly above average to one that was fairly low. Of the four collections, the one on July 26 , included the highest water-table levels and the one on February 4 included the lowest. Data for these two collections are presented in this report so that the maximum observed seasonal changes in the salt-water encroachment pattern may be noted.

Table 69 gives the data collected at the time of the two watertable extremes, and figures 172 and 173 give the resulting composite profiles indicating isochlors and the water table. A line has been drawn on each of these profiles to represent the theoretical position of the boundary between fresh water and salt water, as suming perfect application of the Ghyben-Herzberg principle. The position of this line was determined by selecting a value of 1.025 as an average specific gravity for sea water (referred to normal ground water as unity), thereby developing a ratio of $1: 40$ for the relation between fresh-water head above mean sea level and depth to which fresh water extends below mean sea level. Using this ratio, computations were then made for enough selected points along the water-table curve to insure that the Ghyben-Ferzberg equilibrium line would be well defined.

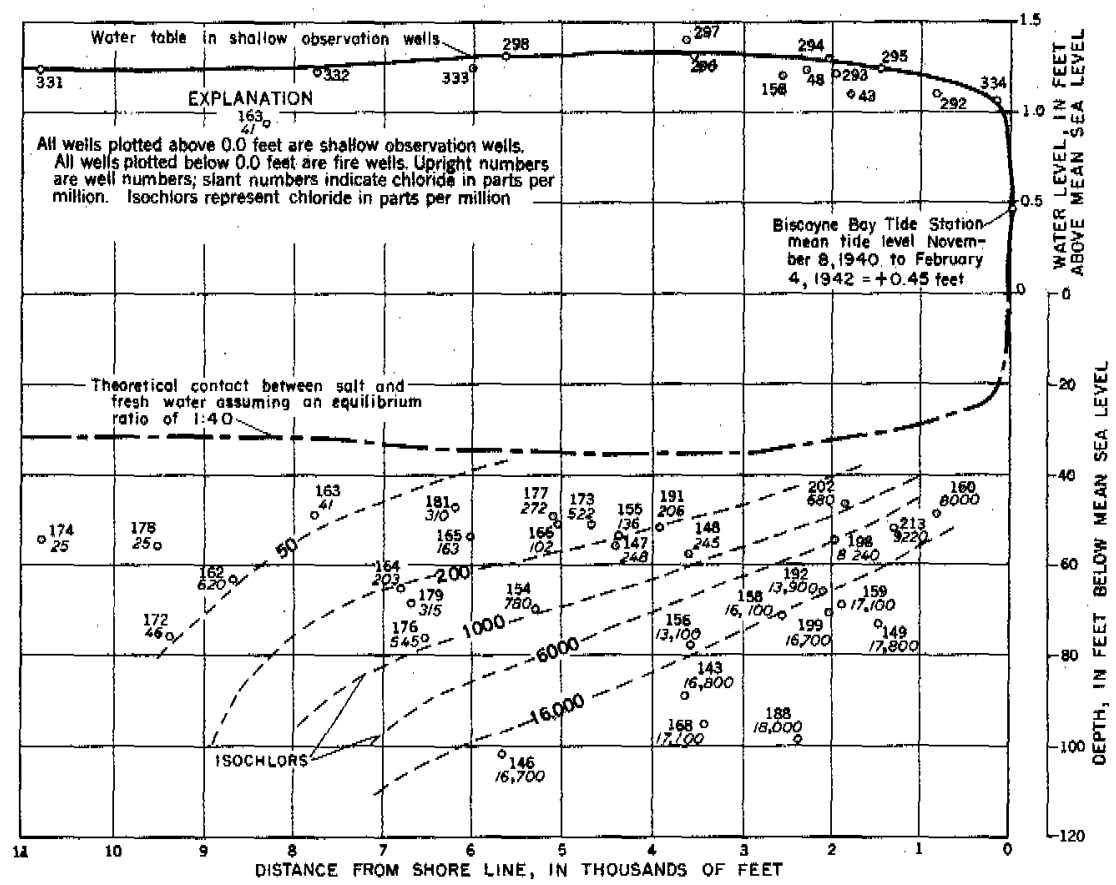

Figure 173. - Composite profile for salt-water encroachment study of February 4, 1942, Silver Bluff area, Miami. 
Table 69.-Salt-water encroachment data for Silver Bluff area, Miami; July 25, 26, 1941, anú February 3, 4, 1942

[Distance from shoreline measured normal to an arbitrary curve drawn to represent the approximate natural shoreline. Parentheses enclose the nos. of wells paired at the same location. Elevations are relative to $U, S$. Coast and Geodetic Survey mean sea level datum. Specific gravity referred to uncontaminated ground wateras unity]

\begin{tabular}{|c|c|c|c|c|c|c|c|c|c|}
\hline \multirow{2}{*}{$\begin{array}{l}\text { Well } \\
\text { no. }\end{array}$} & \multirow{2}{*}{$\begin{array}{l}\text { Distance from } \\
\text { shoreline } \\
\text { (feet) }\end{array}$} & \multirow{2}{*}{$\begin{array}{l}\text { Land-surface } \\
\text { elevation } \\
\text { (feet) }\end{array}$} & \multirow{2}{*}{$\begin{array}{l}\text { Depth of } \\
\text { well below } \\
\text { datum } \\
\text { (feet) }\end{array}$} & \multicolumn{2}{|c|}{$\begin{array}{c}\text { Mean water level } \\
\text { elevation (feet) }\end{array}$} & \multicolumn{2}{|c|}{$\begin{array}{l}\text { Chloride } \\
\text { (ppm) }\end{array}$} & \multicolumn{2}{|c|}{ Specific gravity } \\
\hline & & & & $7-26-41$ & $2-4-42$ & $7-25-41$ & $2-3-42$ & $7-25-41$ & $2-3-42$ \\
\hline 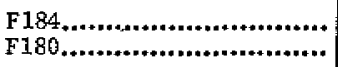 & $\begin{array}{l}14,840 \\
14,240\end{array}$ & $\begin{array}{l}14.7 \\
13.5\end{array}$ & $\begin{array}{l}71.9 \\
48.3\end{array}$ & $\begin{array}{l}0.99 \\
1.45\end{array}$ & $\begin{array}{r}0.40 \\
.83\end{array}$ & $\begin{array}{l}\mathrm{a}_{20} \\
\mathrm{a}_{17}\end{array}$ & $\begin{array}{l}\mathbf{b}_{20} \\
\mathbf{b}_{16}\end{array}$ & $\begin{array}{l}1.0000 \\
1.0000\end{array}$ & $\begin{array}{l}1.0000 \\
1.0000\end{array}$ \\
\hline (F174) & $\begin{array}{l}10,820 \\
10,820\end{array}$ & 12.7 & $\begin{array}{r}54.3 \\
1.1\end{array}$ & $\begin{array}{c}2.24 \\
\ldots \ldots \ldots \ldots\end{array}$ & $\begin{array}{l}1.18 \\
1.22\end{array}$ & $\begin{array}{c}a_{24} \\
\ldots \ldots \ldots \ldots . . . . . . .\end{array}$ & $\begin{array}{l}\mathrm{b}_{25} \\
\ldots \ldots \ldots \ldots \ldots\end{array}$ & $\begin{array}{r}1.0000 \\
\ldots . . . . . . . . . . .\end{array}$ & 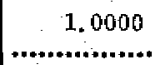 \\
\hline 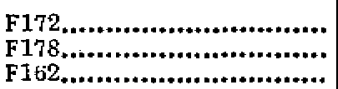 & $\begin{array}{l}9,380 \\
9,500 \\
8,680\end{array}$ & $\begin{array}{l}12.2 \\
10.7 \\
10.7\end{array}$ & $\begin{array}{l}75.3 \\
55.6 \\
62.9\end{array}$ & $\begin{array}{l}2.19 \\
2.22 \\
2.21\end{array}$ & $\begin{array}{l}1.17 \\
1.20 \\
1.18\end{array}$ & $\begin{array}{r}a_{49} \\
a_{26} \\
a_{555}\end{array}$ & $\begin{array}{r}b_{46} \\
b_{25} \\
b_{620}\end{array}$ & $\begin{array}{l}1.0000 \\
1.0000 \\
1.0007\end{array}$ & $\begin{array}{l}1.0000 \\
1.0000 \\
1.0008\end{array}$ \\
\hline 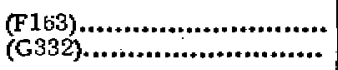 & $\begin{array}{l}7.760 \\
7.760\end{array}$ & $\begin{array}{c}13.1 \\
1 \\
\ldots \ldots \ldots \ldots \ldots \ldots \ldots \ldots \ldots\end{array}$ & $\begin{array}{r}48.6 \\
.7\end{array}$ & $\begin{array}{l}2.23 \\
2.24\end{array}$ & $\begin{array}{l}1.23 \\
1.21\end{array}$ & $a_{40}$ & $b_{41}$ & 1.0000 & 1.0000 \\
\hline 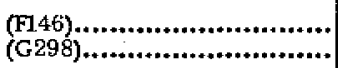 & $\begin{array}{l}5,680 \\
5,680\end{array}$ & 7.7 & $\begin{array}{r}100.8 \\
2.0\end{array}$ & 2.29 & $\begin{array}{l}-.58 \\
1.31\end{array}$ & a16,600 & $\mathrm{b}_{16,700}$ & 1.0222 & 1.0223 \\
\hline F164_................................... & 6,800 & 12.9 & 65.4 & 2.16 & 1.21 & ${ }^{a} 143$ & $b_{203}$ & 1.0002 & 1.0002 \\
\hline 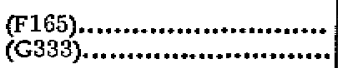 & $\begin{array}{l}6,020 \\
6,020\end{array}$ & $\begin{array}{c}7.7 \\
\ldots \ldots \ldots \ldots \ldots\end{array}$ & $\begin{array}{r}53.6 \\
.9\end{array}$ & $\begin{array}{l}2.14 \\
2.19\end{array}$ & $\begin{array}{l}1.22 \\
1.23\end{array}$ & 113 & $b_{163}$ & 1.0001 & 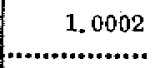 \\
\hline 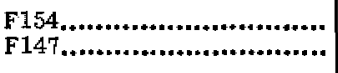 & $\begin{array}{l}5,340 \\
4,420\end{array}$ & $\begin{array}{l}12.2 \\
10.3\end{array}$ & $\begin{array}{l}69.6 \\
55.8\end{array}$ & $\begin{array}{l}2.11 \\
2.10\end{array}$ & $\begin{array}{l}1.22 \\
1.32\end{array}$ & $\begin{array}{l}730 \\
215\end{array}$ & $\mathbf{b}_{248}$ & $\begin{array}{l}1.0009 \\
1.0003\end{array}$ & $\begin{array}{l}1.0010 \\
1.0003\end{array}$ \\
\hline 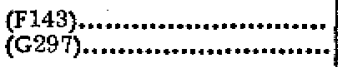 & $\begin{array}{l}3,640 \\
3,640\end{array}$ & 10.5 & $\begin{array}{r}88.7 \\
.9\end{array}$ & $\begin{array}{r}.51 \\
1.98\end{array}$ & $\begin{array}{r}-.14 \\
1.40\end{array}$ & $\begin{array}{l}15,440 \\
\ldots \ldots \ldots \ldots\end{array}$ & $b_{16,800}$ & 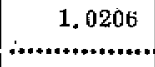 & 1.0224 \\
\hline 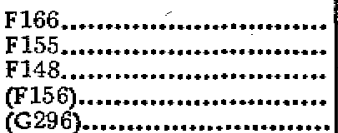 & $\begin{array}{l}5,060 \\
4,380 \\
3,620 \\
3,580 \\
3,580\end{array}$ & $\begin{array}{r}9.9 \\
7.0 \\
11.1 \\
12.4 \\
2 . . . . . .\end{array}$ & $\begin{array}{l}50.9 \\
53.5 \\
57.4 \\
78.1 \\
.8\end{array}$ & $\begin{array}{l}2.10 \\
2.07 \\
2.03 \\
1.43 \\
2.03\end{array}$ & $\begin{array}{l}1.24 \\
1.26 \\
1.34 \\
.22 \\
1.30\end{array}$ & $\begin{array}{r}86 \\
157 \\
135 \\
6,120\end{array}$ & $\begin{array}{r}102 \\
136 \\
245 \\
13,100\end{array}$ & $\begin{array}{l}1.0001 \\
1.0002 \\
1.0002 \\
1.0081\end{array}$ & $\begin{array}{l}1.0001 \\
1.0002 \\
1.0003 \\
1.0175\end{array}$ \\
\hline
\end{tabular}




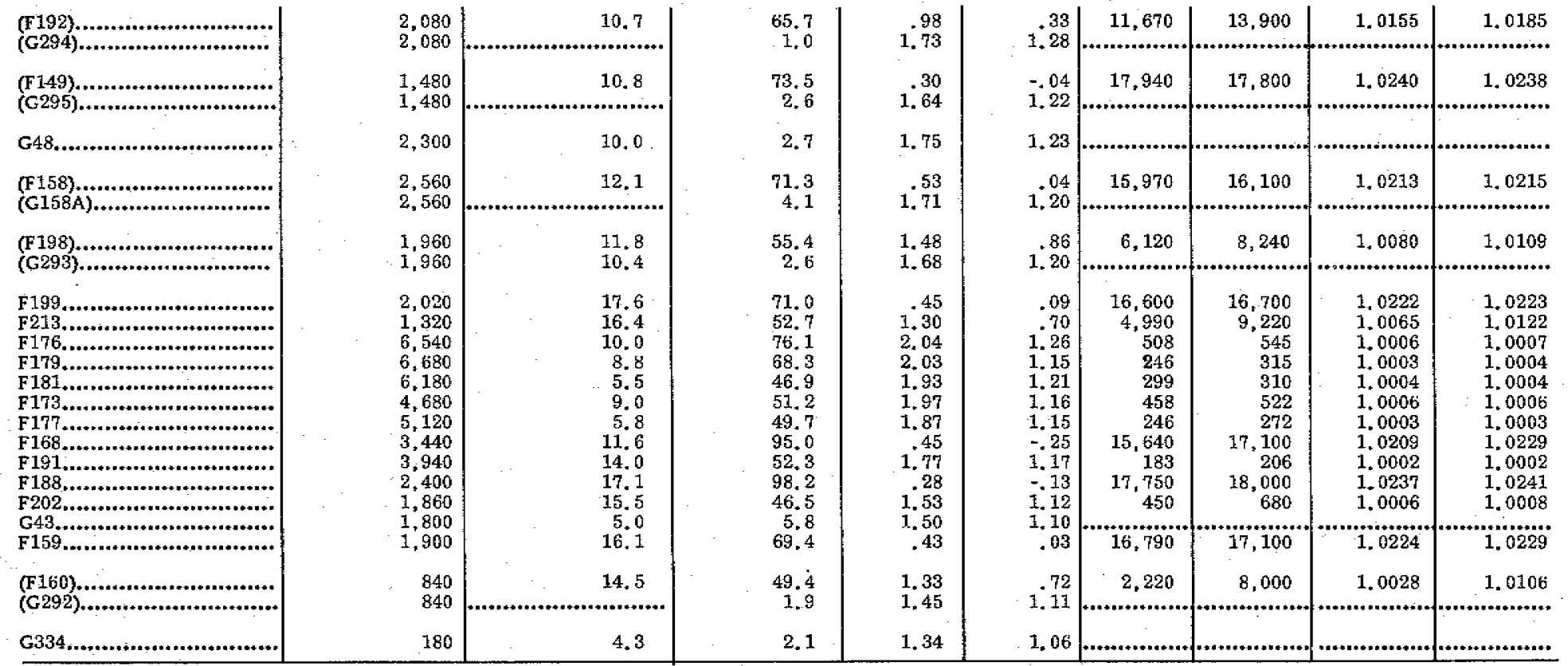

${ }^{a}$ Sample collected July $26,1941$.

$b_{\text {Sample collected February 4, } 1942 .}$ 
In selecting the $1: 40$ ratio the ranges in specific gravity, as observed in the nearby ocean water, in the water of Biscayne Bay, and in the salty ground water of the Silver Bluff area, were taken into account. On the basis of the specific gravity of sea water the ratio would have been $1: 37,8$, but ratios ranging as high as $1: 42$ were noted for the bay and for the encroaching salt-water wedge in the Silver Bluff area. These facts, coupled with ease of computation, prompted use of an average ratio of $1: 40$.

The mean water level in Biscayne Bay for the periods of investigation in each case were above U. $\mathbf{S}$. Coast and Geodetic Survey mean sea level datum. On July 26, 1941, the mean water level was $0.47 \mathrm{ft}$, and on February 4,1942 , it was $0.49 \mathrm{ft}$ above mean sea level. However, the mean gage height for any given day is not satisfactory for use as a datum in correcting for salt waterfresh water balance as of that day; rather, the average sea level for a considerable time preceding the collection of data should be used. Thus, for the July 26 and February 4 data, average bay levels of $+0.39 \mathrm{ft}$ and $+0.45 \mathrm{ft}$, respectively, were used.

Because the ratio of scales used in plotting the water table and the isochlors was $1: 40$, the Ghyben-Herzberg equilibrium curve is very nearly an exact inversion of the water-table curve. The inversion would plot exactly only if the actual observed mean tide level in Biscayne Bay agreed with the established mean sea level. It is significant to note that on the profile for July 26 , the GhybenHerzberg equilibrium line parallels the entire isochlor pattern inland to about 2,500 $\mathrm{ft}$ and lies below the $1,000 \mathrm{ppm}$ isochlor inland to about 4, $800 \mathrm{ft}$; whereas on the profile for February 4, it lies above the entire plotted isochlor pattern. In spite of this great difference there is no proportionate shift in the isochlor pattern. This is a graphical illustration of the fact that a change in elevation of the water table does not immediately cause a change 40 times as great in the elevation of the isochlor pattern. Superimposing the two composite profiles (fig. 174) shows that the elevation of the water table on February 4 ranged from 0.3 to 1.0 ft lower than on July 26. The elevation of the isochlor pattern for February 4, however, averaged only about $4 \mathrm{ft}$ higher than that on July 26. This had been anticipated, for Wentworth (1939) had previously shown that an adjustment of the equilibrium between salt and fresh water, in response to a change in water-table elevation, lags far behind the time of water-level change because it involves actual changes in "bottom storage", which take place slowly.

In figure 174, chloride data are given for three drainage wells drilled in the Silver Bluff area prior to July 26, 1941. Water samples were carefully collected as the wells were being drilled, but we re not obtained as part of the July 26 and February 4 studies. The data for the two drainage. wells, D 196 and $D 350$, indicate sharp downward trends of the isochlors about $8,000 \mathrm{ft}$ from the shoreline. It is therefore evident that, in general, as of the date 


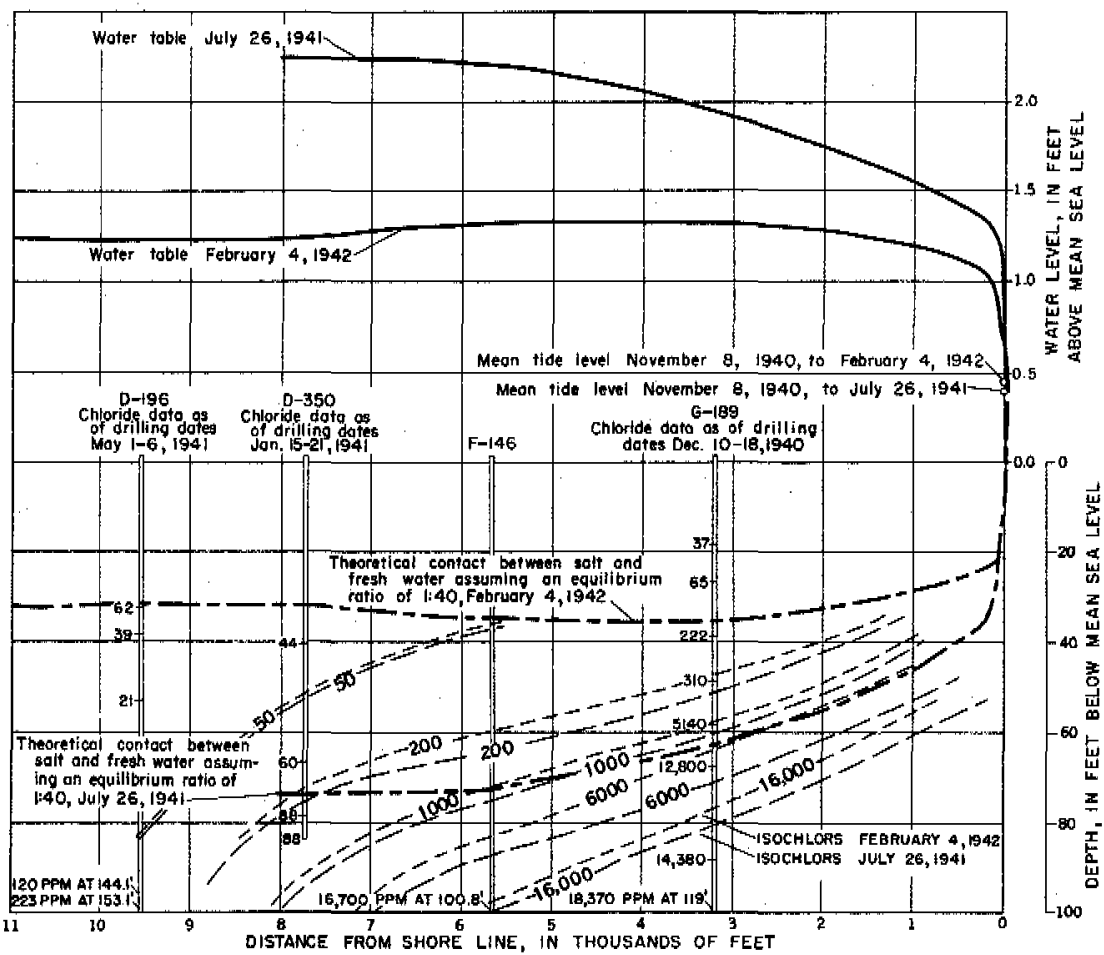

Figure 174, Composite profiles for salt-water encroachment studies of July 26, 1941, and February 4, 1942, Silver Bluff area, Miami.

of these studies, the inland extent of salt-water encroachment in the Silver Bluff area at depths below $80 \mathrm{ft}$ was about $8,000 \mathrm{ft}$. The maximum inland penetration of chloride in a concentration comparable to that of sea water is not known, but on the basis of the data obtained from the drilling of well D 196 it is evident that it is less than $9,600 \mathrm{ft}$, and samples pumped from well $\mathrm{F} 146$ indicate that it is more than $5,600 \mathrm{ft}$. Somewhere between these boundaries, therefore, is the line of maximum inland penetration of high-chloride concentration within the Biscayne aquifer.

The chloride data for test well G 189 fit in satisfactorily with the isochlors as drawn for July 26. Although inspection of these data suggests that, except for the $16,000 \mathrm{ppm}$ isochlor, the isochlors have been drawn at too low an elevation, it should be noted that the test well was drilled in December 1940 , at a time when the water table was lower than on July 26, 1941. Thus the chloride pattern, as indicated by the well samples, would be expected to appear at an elevation slightly higher than shown by the isochlors.

The data collected for the studies of August 28 and October 25 , 1941 (not presented in detail in this report), covered a shift in the 
isochlor pattern from low to high water-table conditions. On October 25 the water table averaged from $0.2 \mathrm{ft}$ to $0.6 \mathrm{ft}$ higher than on August 28, and the isochlor pattern on October 25 averaged about $2 \mathrm{ft}$ lower than on August 28. Although this 2 -ft shift is admittedly slight and could, to some degree, be accounted for by experimental error, it is believed to be significant.

Although only four comprehensive encroachment studies were undertaken in the Silver Bluff area, considerable supplemental data are available through periodic water-level observations and chloride analyses of well water. In figure 175 , chloride results, plotted against time, are given for water samples collected from wells in the Silver Bluff area. Also shown on the graph, for comparison, is a hydrograph of F 179, a well on which a continuous water-stage recorder is maintained. $F 179$ is $6,680 \mathrm{ft}$ inland from the bay. This is the greatest distance, in this area, at which a recognizable tidal effect has been noted in wells. The fluctuation of the water level in $F 179$ may be taken as representative of the other wells in this area.

The record of chloride changes in wells of high salinity $(F 146$, $F 156, F 160, F 198$, and $F 192$ ) during the period of $1940-46$ is shown in figure 175. (Descriptive data for these wells, and all others referred to in this section, appear in table 69.) In general, the trend in chloride concentration in all wells was the same; they rose and fell in unison. Furthermore, these changes in chloride concentration seem to have occurred in response to changes in the water table-that is, when the water table was low, the chloride content tended to rise, and when the water table was high, the chloride content tended to fall. The net trend, however, was for an increase in chloride content.

Figure 175 also shows comparable data for wells of low salinity (F 147, F 162, F 163, F 164, F 165, F 174, and F 202). These wells are more distant from the bay or are shallower than those of the first group; therefore their chloride content was much less. The chloride in the water of these wells also responded to movements of the water table and, as in the wells of high salinity, also showed a net increase for the period of record.

The fact that the chloride content in the water of some wells changed more rapidly and to a greater extent than that in other wells is due to factors such as: (1) distance from the bay; (2) depth below mean sea level; (3) location with respect to nearby drainage wells that may introduce relatively large volumes of fresh water directly into the body of the salt-water wedge at depth, thus diluting the ground water locally and temporarily upsetting equilibrium; and (4) the presence of solution channels that may allow salt water easy access to the area or, conversely, may allow fresh water to discharge freely to the sea. 


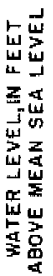
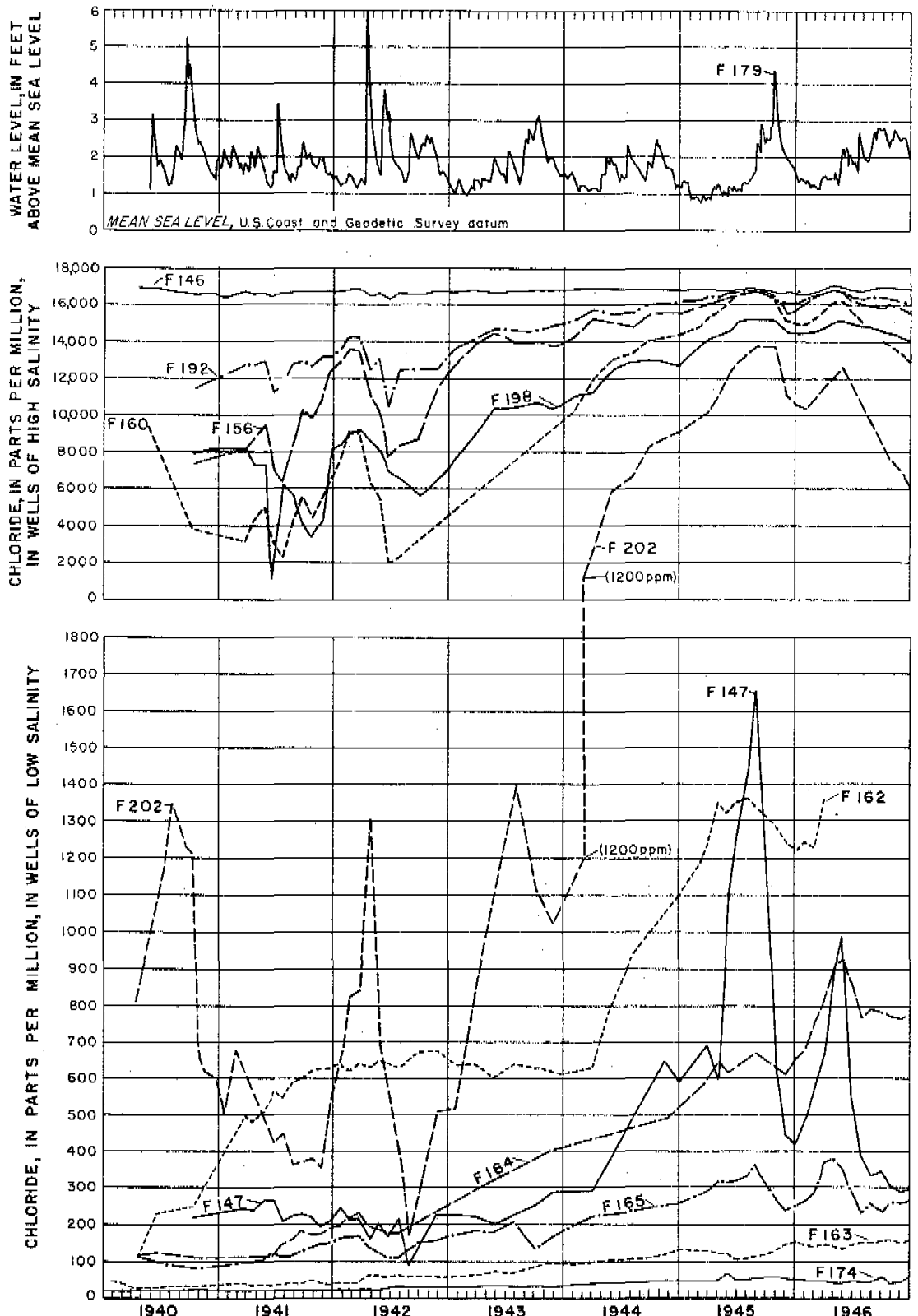

Figure 175.-Graph showing correlation between fluctuation of water level in well F 179 and chloride content in 12 wells of the Silver Bluff area; Miami, 1940-46. 


\section{EFFECT OF MANFALL ON THE ISOCHLOR PATTERN}

As indicated previously, it was difficult to select the optimum times to secure data for the salt water-fresh water studies in the Silver Bluff area. Heavy rains just before, or during, an investigation would cause local distortions in the water table and isochlor pattern sufficient to upset the most carefully collected data. Nevertheless, it was important to obtain information for conditions following heavy rains. Accordingly, the study of July 26, 1941, was conducted just after the rainy-season ground-water peaks that occurred about July 13. Figure 175 suggests that, even though a rainy-season peak had just passed, the time of the survey covered a period during which the water table had already declined to near-average level, or slightly below. Furthermore examination of the chloride graphs for wells in this area shows that at the time of the study not all ground water was declining in chloride content, although in most parts of the aquifer this was true.

The composite profile in figure 172 indicates that at many points the isochlor pattern does not represent the chloride concentrations shown for the various wells. Apparently, therefore, even though the study was made several days following the last heavy showers, the large part of the year's total rain that had fallen during the preceding few weeks had a considerable and lasting disruptive effect on the regularity of the isochlor pattern. Especially tending to upset the regular plotting of the observed data was the direct discharge into the salt-water wedge of relatively large quantities of rain water from drainage wells. At the time of the study therefore, there was still a tendency towards a smoothing-out or stabilizing of conditions, but at the same time, water levels were declining. Postponing the study until the varying factors became stabilized, however, would have meant losing the opportunity for observing the nature of the factors bearing on salt-water encroachment during periods of high water-table conditions. In any study contemplated for a period of high water levels, therefore, unusual precautions should be taken to insure an ample collection of precise and complete data because of the difficulties that may later be experienced in attempting to fit the results together into one comprehensive picture.

In contrast to the study of July 26, 1941, conducted during a comparatively unstable high water-table period, the study of February 4, 1942 was made under conditions of a fairly low and gradually declining water table. The composite profile given in figure 173 reveals well-stablized conditions with good agreement between the chloride concentrations shown for the different wells and a smoothly-drawn isochlor pattern. Inspection of the chloride graphs in figure 175 shows that, without exception, chloride was increasing in all wells sampled at this time, and that the increases were apparently the direct result of the lowered water level. 


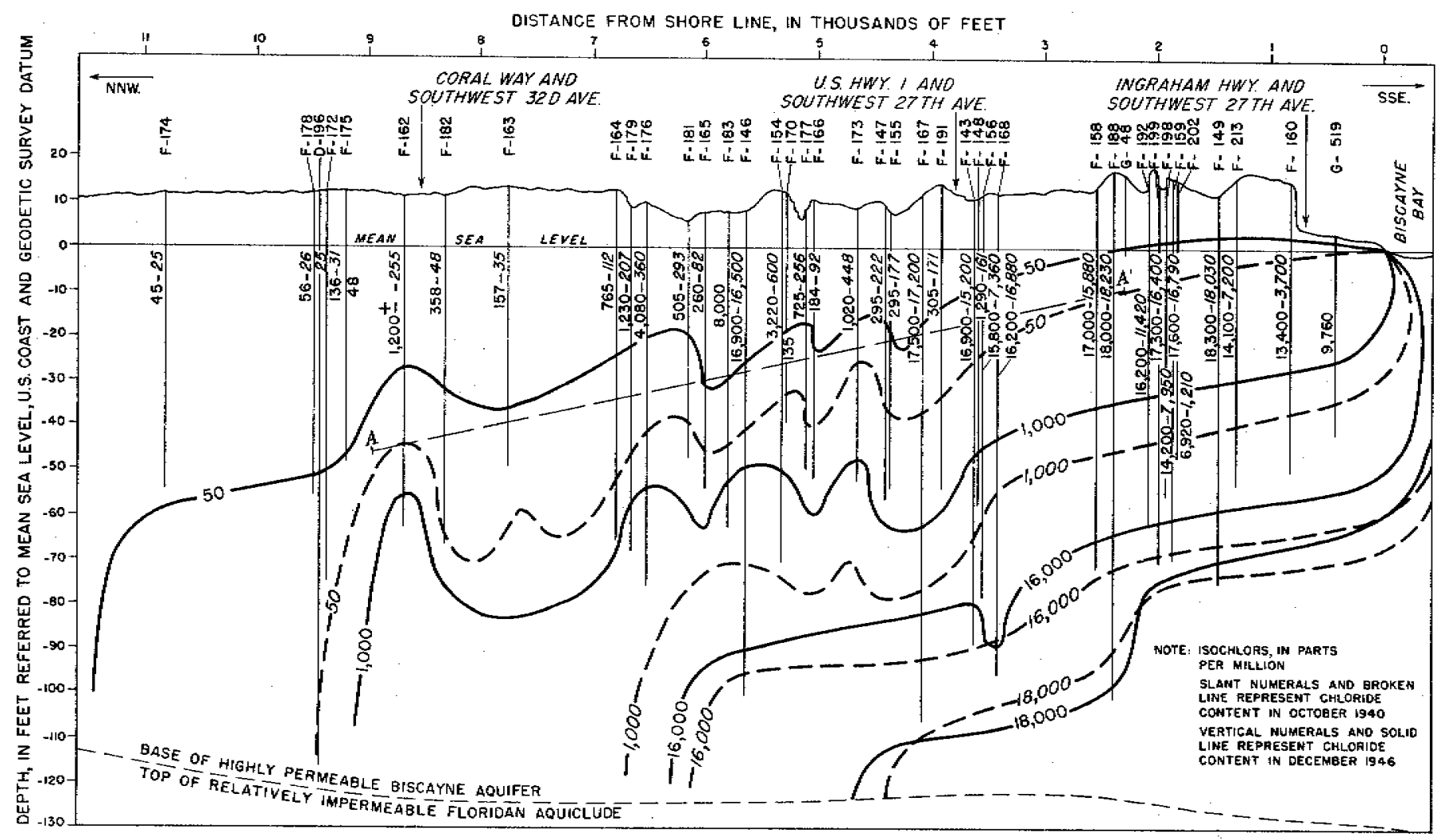


Figure 176 is a generalized composite cross section through the Silver Bluff area showing the change in isochlor patterns in the encroaching salt-water body as of the end of October 1940 and December 1946, the beginning and end of the month-end sampling program.

The cross section shown is more than 11,000 feet long in a general north-northwest direction, oriented normal to the bay shore, and all wells are shown as though they were situated along one line intersecting the bay. Actually, some are as much as several city blocks apart (in a general east-west direction) but they have been placed on the drawing at the ir correct normal distance from the bay. Locations of these wells are shown infigure 170. Most of the wells have been sampled monthly since 1940 , and it was from these pumped samples that data for this plate and figure 175 were obtained.

One of the obvious characteristics of the isochlors drawn for October 1940 and December 1946 is their irregular or wavy shape. This is a characteristic frequently found, but it is especially pronounced following heavy rains in accordance with the information already offered. Some of the irregularity in the isochlor pattern is due to plotting the chloride data for each well at a point corresponding to the bottom of the well whereas actually, water is free to enter a well from any part of the open-hole section below the bottom of the casing.

The isochlors in the cross section actually may be shown less distorted than they would be if the conditions they represent in the aquifer were more precisely known. This is the result of incomplete sampling of the cross section. Enough points of access to the ground-water body are sampled so that a generalized cross section of the salt-water wedge can be drawn. The limitations of the data, however, must be realized.

\section{CHARACTERISTICS AND CHANges IN POSITHON OF THE SALT-water Wedge}

It will be noted in figure 176 that the principal changes of the isochlor pattern between October 1940 and December 1946 took place at and near the inland margin of the salt-water wedge. There, the 1,000 ppm isochlor moved inland approximately 2,000 feet in the 1940-46 interval. There was also a considerable rise of the upper surface of the salt-water wedge, averaging perhaps 15 feet over the distance of more than 9,000 feet that the wedge extends inland from the bay.

The wedge is very blunt-nosed, as shown by the $1,000 \mathrm{ppm}$ isochlor of 1946 and the $50-\mathrm{ppm}$ isochlor of 1940 . It will be noted that a knob-like shape in these two isochlors appears below well F 162. It is believed that this shape is due largely to differential 
dilution of the wedge seaward from $F 162$, and that a truer picture of the shape the wedge would assume if no such dilution effect occurred is shown by the light dashed-line $A-A^{\prime}$. Similar straightening out probably could be done on each isochlor to gain an idea of how such an encroaching wedge would appear in a place not affected by fresh-water recharge directly into the salt-water body.

Comparatively small changes took place in the salt water of higher chloride concentration, the greatest changes taking place in the water containing less than $1,000 \mathrm{ppm}$ chloride. For both 1940 and 1946, the $1,000-\mathrm{ppm}$ isochlor lay near the center of the salt-water wedge, and the change from water of $50 \mathrm{ppm}$, or less, to water of $16,000 \mathrm{ppm}$, or more, took place within a thickness of 70 to 80 feet. These conditions are comparable to those found by Pennink (1904, p. 183-238) along the Netherlands coast where the diffusion zone averaged 20 meters (65.6 feet) in thickness.

The studies of salt-water encroachment made in the Silver Bluff area give evidence of the magnitude of seasonal and long-term changes in the elevation of the water table and in the shift of isochlor patterns. The fact that these patterns can show movement first in one direction and then in the other is of considerable significance. Equilibrium conditions (approximate) have not been reached over the whole area, and the isochlor pattern is probably destined to occupy, at some future date, a new position some distance inland from its present position. However, this movement, persistent as it may be, will be materially slowed down by the seasonal high-water periods of years of heavier-than-normal rainfall.

It has been pointed out that changes in the elevation of the water table do not immediately provoke changes 40 times as great in the position of the isochlor pattern. Indeed, there seems to be so much lag before adjustment can be made to one change in watertable elevation a new and possibly reverse change has occurred; therefore, a complete adjustment may not ever occur. Seasonal changes in the position of the isochlor pattern are therefore smaller than might be expected. The changes in salt-water contamination reflect long-term trends of the water table rather than overnight variations, and the observed relation between salt and fresh water in the Silver Bluff area is a reflection of conditions existing during preceding years.

Referring to the profile for the study of July 26, 1941 (fig. 172), representing near-average conditions, note that the line showing the theoretical contact between salt water and fresh water parallels the isochlor pattern and lies slightly above the $6,000-\mathrm{ppm}$ isochlor at a point about $2,500 \mathrm{ft}$ inland. This indicates that equilibrium, based on average yearly values, is probably established in accordance with the Ghyben-Herzberg principle over that dis tance. Beyond 2,500 ft, the theoretical line gradually flattens out, 
and at about 4,800 ft, it crosses the 1,000-ppm isochlor. Thus, equilibrium is almost reached at a point $4,800 \mathrm{ft}$ inland. Inland beyond this point, however, the divergence between the theoretical line and the isochlors is great.

Figure 174 shows the relatively small amount of actual shift involved in the isochlor pattern between very low and near-average water-table stages and supports the conclusion that equilibrium, based on average yearly water-table elevations, has been reached at least 2,500 $\mathrm{ft}$ inland. However, the relation of low-water levels, such as those of February 4, 1942, to the position of the isochlor pattern is significant primarily to show existence of unbalanced conditions favorable for inducing inland movement of salt water. Certainly the isochlor pattern and the theoretical balance line as of February 4, 1942, show no direct correlation, whereas there is good correlation as of July 26, 1941.

The position of the salt-water wedge at any given time is a result of conditions prevalling over a relatively long period of time. The wedge may be moving very slowly inland, but it is constantly subject to advances and retreats. The leading edge probably can never advance inland beyond the average yearly position occupied by the particular water-table contour that is $2 \frac{1}{2} \mathrm{ft}$ above true average sea level. This follows, inasmuch as a fresh-water head of $2 \frac{1}{2} \mathrm{ft}$ above the true average level of salt water in the bay would depress the top of the encroaching wedge to the relatively impermeable sandy marls of the Floridan aquiclude that underlie the highly permeable Biscayne aquifer, and the salt-water advance would halt there.

It might be assumed that ground water flows approximately parallel to the dip of the highly permeable formations in the Silver Bluff area and that there would be a slight downward, as well as a horizontal, component of motion as the water approached the shore area. However, study of water-table maps for the entire area shows that this is not true, because the greatest flow is not down the dip-minstead, it is toward the canals. A minor part of the total quantity of water moves seaward in the aquifer throughout the year and is effective in limiting the inland progression of the salt-water wedge-particularly at the leading, or inland, edge during the rainy season when the water table becomes fairly high and seaward ground-water movement is pronounced.

The seaward flow of fresh water over the wedge of salty water has a depressive effect on the shape of the wedge, and it probably accounts for most of the rapid vertical descent of the isochlors at a point more than 7,000 ft inland. The factors that are involved in this phenomenon are not known at present, but there is a possible association with the dissipation of the anterior part of the saltwater wedge through mixing with, and being swept away by, seaward-moving fresh water. The present shape of the inland 
front of the salt-water wedge at Silver Bluff may be compared with the steeply dipping isochlors of the inland front of the saltwater wedge in the Cutler area (see fig. 201). It is believed that in the Cutler area the present conditions are comparable to those in the Silver Bluff area before encroachment began, and that they show the normal salt water-fresh water relationship for this coastal zone (at localities where drainage and the consequent lowering of the fresh-water head do not distort conditions).

The pattern at Silver Bluff probably will retain its general shape; however, it is only the sweeping away of the inland front of the wedge that prevents advance farther inland, until, as previously noted, the encroachment would stop at the place where the average annual position of the water table is $2 \frac{1}{2} \mathrm{ft}$ above true average sea level (about $3 \mathrm{ft}$ above U. S. Coast and Geodetic Survey mean sea leve1), 1

It has been pointed out (above) that the water level in a well tapping a section of the water-bearing strata containing highchloride concentrations would be lower than the true water table, as indicated by the water level in an adjacent shallow observation well. By referring to table 69, a comparison of the water levels for paired wells can be made. Parentheses have been used to single out each combination of fire well and adjacent shallow test well. For any such pair of wells, in an area where only water of normal or near-normal chloride content is present, the water levels should be practically equal. Where the chloride concentration of the ground water tapped by the fire well is several hundred parts per million, or more, there will be an appreciable divergence between the water levels in the two wells. This divergence increases in proportion to the increase in chloride concentration. The maximum divergence on both July 26 and February 4 was for wells F 146 and $G 298$ and amounted to $1.89 \mathrm{ft}$. This divergance is associated with a chloride concentration of 16,600 to $16,700 \mathrm{ppm}$ in well $\mathrm{F} 146$.

To show how large a proportion of the divergence in levels can be accounted for through adjustments for density differences only, computations are presented for two selected distances from the shoreline utilizing data taken in part from the composite saltwater-encroachment profile (fig. 173) for February 4, 1942, and in part from two pairs of observation wells (F 158-G $158 \mathrm{~A}$, and F 198-G 293). The maximum chloride concentrations determined in the two fire wells are about $16,000 \mathrm{ppm}$ and $8,000 \mathrm{ppm}$, respectively.

In each of the two sets of sample computations the adjustment method, as devised, involved the necessity of converting to an

\footnotetext{
1 Since this report was written, several additional years of observation and collection of data have occurred. N. D. Hoy and Francis A. Kohout, geologists of the Miami office, have assembled data that indicate that the observed position of the salt-water wedge is in nearequilibrium with presently kpown hydrologic conditions.
} 
equivalent water level for normal ground water the mean water level for the day of the study as observed in the fire well and the average corresponding level of the water table as taken from the composite profile (fig. 173). Thus, computations were madefor each fire well to indicate the level at which the water would stand if the well casing contained water of normal chloride concentration instead of the salt-contaminated water. This involved the determination of the pressure on a unit area at the bottom of the well by means of the known specific gravity of the water in the well multiplied by the observed length of the water column. The length of the new column was computed by equating this pressure to that at the base of a column of normal ground water having a specific gravity of unity. Thus, for well F 158 the mean observed water level on February 4, 1942, was $0.04 \mathrm{ft}$ above mean sea level. The bottom of the well was $71.3 \mathrm{ft}$ below mean sea level (see table 69), and the length of the water column in the casing was $71.34 \mathrm{ft}$. The chloride concentration was $16,100 \mathrm{ppm}$, indicating (see fig. 171) a specific gravity of 1.0215 . The figure 71.34 multiplied by the ratio of this specific gravity to that for normal ground water, $\frac{1.0215}{1.0000}$, gives $72.87 \mathrm{ft}$ as the length of an equivalent column of normal ground water. The difference in lengths of the two columns, $1.53 \mathrm{ft}$, added to the mean observed water level, gives the level at which normal ground water would stand. Thus, $1.53 \mathrm{ft}$ plus $0.04 \mathrm{ft}$ equals $1.57 \mathrm{ft}$ above mean sea level. On the composite profile shown in figure 173, however, the average water-table elevation for a site at this distance from the shoreline appears as $1.30 \mathrm{ft}$ above mean sea level. To convert this to an equivalent elevation for normal ground water obviously requires the consideration of chloride concentrations ranging from $16 \mathrm{ppm}$ at the water table (1. $30 \mathrm{ft}$ above mean sea level) to $16,100 \mathrm{ppm}$ at a depth of $71,3 \mathrm{ft}$ below mean sea level. In figure 177, two curves, obtained from the isochlor pattern drawn in figure 173, show the variations in chloride concentration with depth at the sites of the two fire wells used in these sample computations. The curves are terminated at the depths penetrated by the fire wells. Each curve applies only to one particular site, therefore its upper limit is determined by the average water-table elevation at that particular site as taken from the composite profile in figure 173. A normal chloride concentration of $16 \mathrm{ppm}$ was arbitrarily assigned to the upper limit of each curve.

The computations for adjusting the average wate $r$-table elevation of $1.30 \mathrm{ft}$ (at well F 158) to an elevation for an equivalent column of normal ground water are then resolved essentially into a determination of the area, shown in figure 177 , bounded by the curve of chloride versus depth (the abscissas being drawn through the limiting chloride concentrations of 16 and $16,100 \mathrm{ppm}$ ) and the vertical coordinate axis. Therefore, to obtain the length of the equivalent column of normal ground water the curve was divided into short segments, an average chloride concentration was determined representative of each segment, and the specific gravity 
(fig. 171), indicated by each chloride concentration, was then multiplied by the height of vertical projection of the segment, and these products then were totaled. These computations are assembled in table 70 for each of the two selected sites.

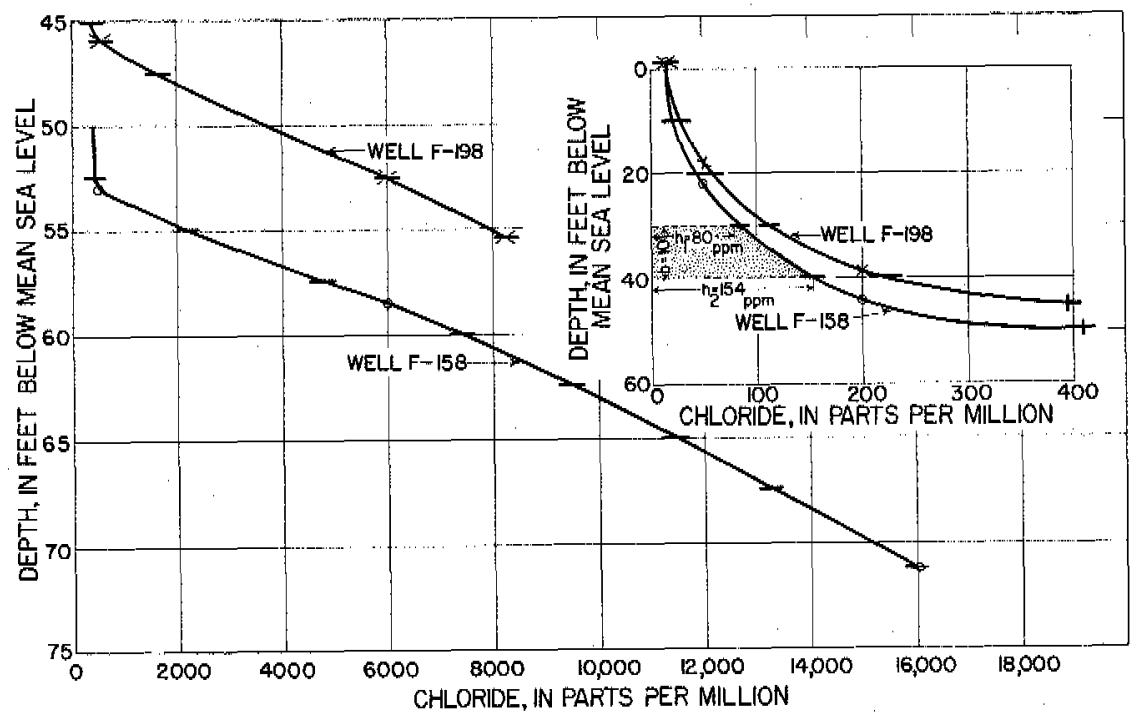

Figure 177. - Variation of chloride with depth in selected wells in Silver Bluff area, Miami, February 4, 1942.

In figure 177 the short, heavy bars cutting across the curves indicate the manner in which they were arbitrarily divided into segments. Also shown in this figure is a stippled zone representing the area between the vertical axis of the graph and a typical segment of the curve. The lettered dimensions for this area will explain the notation appearing in some of the column headings in table 70 . In this table the total of column $1(72.60 \mathrm{ft})$ is the length of the water column in the ground, and the total of column 6 $(72.82 \mathrm{ft})$ is the length of an equivalent column of normal ground water that would have a weight about the same as that in column 1 . An elevation of $1.52 \mathrm{ft}$ is obtained by adding the difference in length of the two water columns, $0.22 \mathrm{ft}$, to the average watertable elevation of $1.30 \mathrm{ft}$, selected from figure 173 . This compares very closely with the elevation of $1.57 \mathrm{ft}$ previously obtained by adjusting the observed water level in fire well F 158. Before adjustments were applied, the water level in well F 158 differed from the average water-table elevations by $1.26 \mathrm{ft}$. After adjustment only for specific gravity, however, the difference has been reduced to $0.05 \mathrm{ft}$.

In similar fashion, computations were made (table 70) to adjust the water levels at the other selected site using data from well F 198. Before making the adjustment, the levels differed by 
Table 70, - Data and computations for adjusting water-table elevations at two selected sites in Silver Bluff $\varepsilon+3 a$, February 4,1942

[See figure 177 for explanation of symbols]

\begin{tabular}{|c|c|c|c|c|c|c|c|}
\hline \multicolumn{4}{|c|}{$\begin{array}{l}\text { Site 2, } 560 \text { feet from shoreline } \\
\text { (Well F 158) }\end{array}$} & \multicolumn{4}{|c|}{$\begin{array}{c}\text { Site 1,960 feet from shoreline } \\
\text { (Well F 198) }\end{array}$} \\
\hline \multirow[b]{2}{*}{$\begin{array}{c}\text { Depth } \\
\text { interval } \\
\text { (b) }\end{array}$} & \multicolumn{2}{|c|}{ Average- } & \multirow{2}{*}{$\begin{array}{c}\text { Equivalent } \\
\text { intervals } \\
\text { of } \\
\text { normal } \\
\text { ground } \\
\text { water } \\
\text { [b (sp. gr. })]\end{array}$} & \multirow[b]{2}{*}{$\begin{array}{c}\text { Depth } \\
\text { intervai } \\
\text { (b) }\end{array}$} & \multicolumn{2}{|c|}{ Average- } & \multirow{2}{*}{$\begin{array}{c}\text { Equivalent } \\
\text { intervals } \\
\text { of } \\
\text { normal } \\
\text { ground } \\
\text { water } \\
\text { [b(sp. gr. )] }\end{array}$} \\
\hline & $\begin{array}{l}\text { Chloride } \\
\text { concentration } \\
\left(\frac{h_{1}+h_{2}}{2}\right)\end{array}$ & $\begin{array}{r}\text { Specific } \\
\text { gravity } \\
\left(\frac{h_{1}+h_{2}}{2}\right. \\
2\end{array}$ & & & $\begin{array}{c}\text { Chloride } \\
\text { concentration } \\
\left(\frac{h_{1}+h_{2}}{2}\right)\end{array}$ & $\begin{array}{c}\text { Specific } \\
\text { gravity } \\
\left(\frac{h_{2}+h_{2}}{2}\right)\end{array}$ & \\
\hline Feet & Ppm & (1) & Feet ${ }^{2}$ & Feet & Ppm & (1) & Feet ${ }^{2}$ \\
\hline (1) & (2) & (3) & (4) & (1) & (2) & (3) & (4) \\
\hline $\begin{array}{l}311.30 \\
10 \\
10 \\
10 \\
10 \\
2.5 \\
2.5 \\
2.5 \\
2.5\end{array}$ & $\begin{array}{r}18 \\
32 \\
62 \\
117 \\
249 \\
400 \\
1,240 \\
3,540 \\
6,100\end{array}$ & $\begin{array}{l}1.0000 \\
1.0000 \\
1.0001 \\
1.0001 \\
1.0003 \\
1.0005 \\
1.0016 \\
1.0046 \\
1.0080\end{array}$ & $\begin{array}{r}11.300 \\
10.000 \\
10.001 \\
10.001 \\
10.003 \\
2.501 \\
2.504 \\
2.512 \\
2.520\end{array}$ & $\begin{array}{l}811.26 \\
10 \\
10 \\
10 \\
5 \\
2.5 \\
2.5 \\
2.5 \\
2.9\end{array}$ & \multirow[t]{3}{*}{$\begin{array}{r}20 \\
42 \\
82 \\
160 . \\
289 \\
835 \\
2,595 \\
4,810 \\
7,120\end{array}$} & \multirow[t]{3}{*}{$\begin{array}{l}1.0000 \\
1.0000 \\
1.0001 \\
1.0002 \\
1.0003 \\
1.0010 \\
1.0034 \\
1.0064 \\
1.0095\end{array}$} & $\begin{array}{r}11.260 \\
10.000 \\
10.001 \\
10.002 \\
5.002 \\
2.502 \\
2.508 \\
2.516 \\
2.928\end{array}$ \\
\hline $\begin{array}{l}2.5 \\
2.5 \\
2.5 \\
2.5 \\
1.3\end{array}$ & \multirow[t]{2}{*}{$\begin{array}{r}8,470 \\
10,520 \\
12,415 \\
14,260 \\
15,645\end{array}$} & $\begin{array}{l}1.0112 \\
1.0141 \\
1.0166 \\
1.0191 \\
1,0211\end{array}$ & $\begin{array}{l}2.5 \\
2.5 \\
2.5 \\
2.5 \\
1.3\end{array}$ & 56.66 & & & 56.719 \\
\hline 72.60 & & & 72.8 & & & & \\
\hline \multicolumn{4}{|c|}{$\begin{array}{l}\text { Adjustment of a verage water-table elevation } \\
\text { of }+1.30 \text { : } \\
\text { Length of water column in the ground }=72.60 \\
\text { feet, total of (1). } \\
\text { Length of an equivalent column of normal } \\
\text { ground wrter }=72.82 \text { feet, total of (4) } \\
\text { Adjusted water-table elevation is } 1.30+ \\
\text { (72.82 }-72.60)=+1.52 \text { feet. } \\
\text { Adjustment of observed fire well water-level } \\
\text { elevation of }+0.04 ; \\
\text { Actual length of water column in well } \\
\text { casing = 71. } 34 \text { feet. } \\
\text { Length adjusted to an equivalent column of } \\
\text { normal ground water, (71.34)(1.0215) } \\
=72.87 \text { feet. } \\
\text { Adjusted water-table elevation is } 0.04+\end{array}$} & \multicolumn{4}{|c|}{$\begin{array}{l}\text { Adjustment of a verage water-table elevation } \\
\text { of }+1,26 \text {; } \\
\text { Length of water column in the ground }=56.66 \\
\text { feet, total of (1). } \\
\text { Length of an equivalent column of normal } \\
\text { ground water }=56.72 \text { feet, total of }(4) \text {. } \\
\text { Adjusted water mbble elevation is } 1.26+ \\
\text { (56.72 }-56.66)=1.32 \text { feet. } \\
\text { Adjustment of observed fire well water-level } \\
\text { elevation of }+0.86 \text { : } \\
\text { Actual length of water column in well } \\
\text { casing }=56.26 \text { feet. } \\
\text { Length adjusted to an equivalent column of } \\
\text { normal ground water, (56.26)(1.0109) } \\
\text { = } 56.87 \text { feet. } \\
\text { Adjusted water-table elevation is } 0.86+ \\
(56.87-56.26)=1.47 \text { feet. }\end{array}$} \\
\hline
\end{tabular}

${ }^{1}$ Computed from value in (2) and use of figure 171

2Product of corresponding values in (1) and (3), divided by specific gravity of wnity.

3Based on average water-table elevations for the two sites, +1.30 and $+1,26$ respectively, taken from figure 173 .

$0.40 \mathrm{ft}$; after adjustment, the difference was reduced to $0.15 \mathrm{ft}$. In view of the number of factors (already discussed that tend to complicate work with data in the Silver Bluff area, the close agreement (within $0.05 \mathrm{ft}$ ) between the adjusted water levels in the first sample computation. may be partly fortuitous. However, the adjustments effected in both sets of computations show the degree of importance that may be attached to the specific-gravity factor alone. Undoubtedly, other adjustments should be applied to accomplish complete reconciliation of the divergence in wate $r$ levels indicated 
by the pairs of wells scattered throughout the Silver Bluff area. However, differences in specific gravity easily account for a major part of the divergence, and these are the only adjustments that have been considered in this report.

\section{TIDAL-STORAGE CHANGES}

Computations were made of the approximate order of magnitude of the maximum amount of salt-water movement inland that could occur during the short space of time elapsing between low tide and the following high tide. The accompanying sketch (fig. 178) represents a schematic profile in which the shaded area " $A$ " indicates the wedge-shaped zone in which ground water is alternately stored and drained as a result of tidal fluctuations in Biscayne Bay. The length of this wedge was considered as $6,410 \mathrm{ft}$, the average distance from the shoreline to the three nearest wells in which tidal fluctuations became so small that they approached the limits of accuracy (nearest $0.01 \mathrm{ft}$ ) of the field water-level measurements, as determined during the study of June 26, 1941 . The height of the wedge is $0.7 \mathrm{ft}$, which represents the amplitude

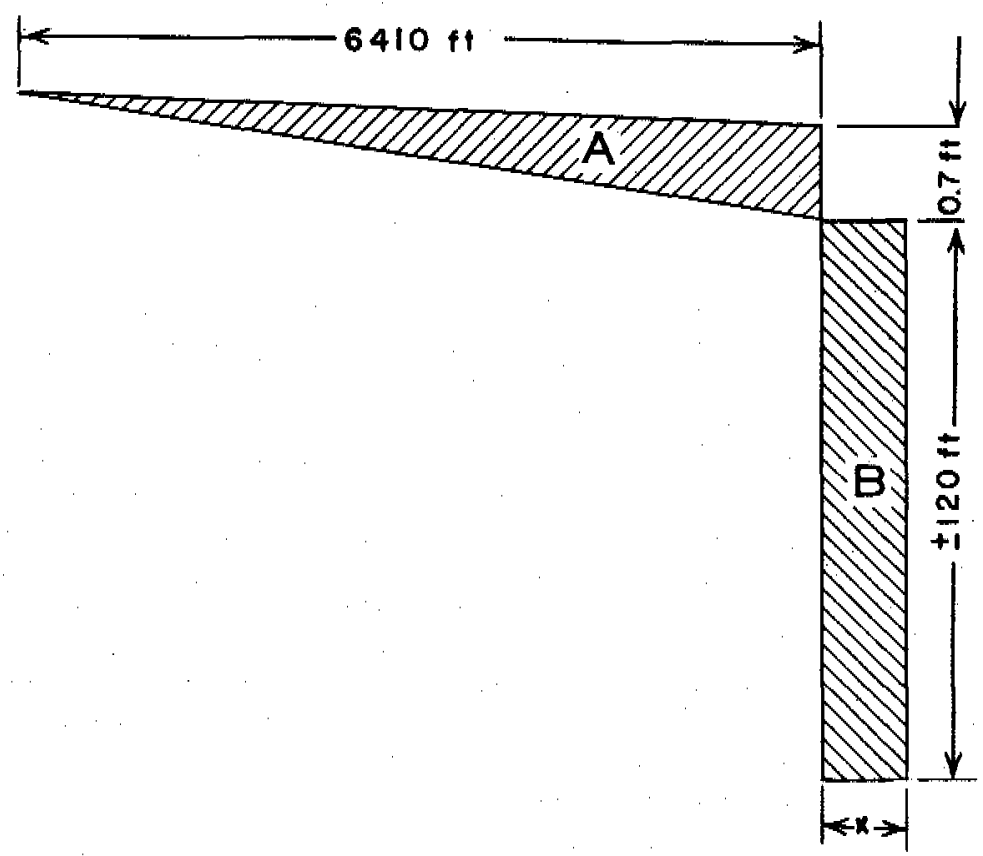


of the tidal fluctuation in well G 334, located $180 \mathrm{ft}$ from the shoreline. The shaded area " $\mathrm{B}$ " indicates a zone whose shape has been assumed for purposes of convenience in making the computation. Its height of about $120 \mathrm{ft}$ is based on the known average thickness of the highly permeable Biscayne aquifer in this locality, and its width, " $\mathrm{X}$ " $\mathrm{ft}$, equals the amount of inland movement of salt.water to be computed, assuming for convenience that the movement is entirely horizontal-as a solid wall of water. Therefore, for a unit length of shoreline, measured normal to the plane of the sketch, the volume of water stored in the wedge "A" may be" equated to the volume of sea water moving in horizontally through the zone " $B$ " Thus,

$$
\begin{gathered}
\frac{1}{2}(0.7)(6,410)(1)=120 \mathrm{X}(1) \\
\mathrm{X}=18.7 \mathrm{ft}
\end{gathered}
$$

This computation ignores the part of wedge " $\mathrm{A}$ " supplied by ground water flowing toward the sea. Therefore, the distance computed exceeds the actual average distance that salt water moves under the influence of tides. The same value, with opposite sign, would apply to the other half of the tide cycle so that the net movement of salt water for one complete cycle would be zero, provided that recharge to the ground-water body remained constant. If the recharge were decreasing, the zone " $B$ " would not be pushed seaward as much as it moves inland each cycle, and there would be a steady advance inland of the salt water. Increasing ground-water recharge would have the opposite effect.

\section{ENCROACHMENT IN THE TIDAL CANALS}

By D. B. Bogart

The study of encroachment of salty water in the canals and canalized natural streams connected with tidal estuaries and bays has been an important phase of the investigations in southeastern Florida. In Broward and Dade Counties, most of the canals empty into the marine sloughs close to, and parallel with, the ocean beach, or into Biscayne Bay and its extensions to the southwest. The marine sloughs, prior to canalization for navigation, probably were brackish for most of the time, except near the ocean inlets or where they broadened into bays. Waterway developments, however, facilitated fresh-water runoff and inland movement of salty water, and the sloughs essentially became arms of the sea. The bottoms of the canals near the coast were excavated to below sea level, and salty water thus had access to them except where attempts were made to control flow.

Uncontrolled canals drain off water that would naturally oppose inland movement of salty water and also provide an easy path for salt-water encroachment because sea water is free to enter during the drier periods of the year. The canals thus perform an adverse 
dual function, but at the same time they are the key to the solution of the problem. It is only by controlling the canals that salt-water encroachment can be stopped in the canals and in the land.

As discussed previously, contamination of part of the municipal water supply of Miami focused attention on the problem of saltwater intrusion. That was sufficient reason for the investigation, but contamination of the canals and waterways is in itself undesirable for various reasons. Commercial vessels and yachts are moored in the fresh-water canals to discourage or destroy marine growths and organisms attached to their hulls. Water is pumped from the canals to the fields for farm and urban irrigation, and because many plants have a low salt tolerance, even mildly salty water usually cannot be used. Fresh water is preferred for cooling purposes in power stations and industrial establishments, and of ten the canals are used directly as sources of fresh water.

\section{SALINITY INVESTIGATIONS}

\section{AREAE STUDIED}

In view of the nature of the problem, the area of most intensive study was in the lower reaches of the Miami Canal. The secondary tidal canals of the Miami area, from Snake Creek Canal on the north to Snapper Creek Canal on the south, were also studied, starting in the spring of 1940. Data were collected to show the changing position of the salt front as affected by various water conditions.

Continuous drought conditions in 1943 and 1944 aroused interest in salt-water contamination in the Fort Lauderdale area. A reconnaissance sampling program was started in the tidal reaches of the lower New River basin in 1944 and was continued through 1946 .

The destruction of crops by salty water in the marl flats east of Homestead activated interest in the contamination problem, and salinity investigations were started there in 1945 . These studies also included the area to the south and southwest of Homestead. In addition, a number of special studies were made of smaller sections within the areas mentioned above.

\section{SAMPLING PROCEDURE}

Observation stations were established along the canals at fairly uniform intervals, particularly at bridges, to facilitate field work. Where bridges were not available, samples were taken from the canal banks. Locations other than the regular stations were used when additional detail was wanted. Observations were also made in lakes (usually in rock pits) connected with the canals and open to contamination. 
Sampling procedure was simple. A sampling device holding a small corked bottle was lowered or thrown in the water. At the desired depth, the cork was withdrawn by jerking the line attached to the sampler, and the bottle was filled with water. Most of the samples were taken near the bottom of the canals, where salty water appears first and where the highest chloride concentrations occur. For special studies, samples were taken at other depths and at the surface. The samples ordinarily were collected at or near the time of high tide at the particular sampling station. The most difficult phase of the sampling procedure was the problem of coordinating the time of the collection with the time of high tide at numerous locations in a relatively large area.

\section{DENSITY CURRENTS AND HYDRAULIC RELATIONSHIPS}

Two or more miscible solutions of different specific gravities tend to remain unmixed when brought together under non-turbulent conditions, even when the difference in specific gravity is very small. The difference may be the result of suspended material (sediment) in one of otherwise similar solutions; it may be the result of temperature differences between identical solutions; or the solutions may be different in composition. When two such solutions are brought together, one will stay above or sink below the other, but motion will continue until hydrostatic balance has been established. When a liquid enters another liquid of slightly different density, the two liquids tend to maintain their separate entities, and the resulting relative motion of one of these liquids to the other is known as a density current. The phenomena of density currents have been described by a number of observers; one of the better general references is a paper by Bell (1942).

\section{DIVDED FLOW AND SHAPE OF DENSTTY CURRENTS}

The density currents discussed here are those occurring in natural waters, particularly where fresh and salt waters meet. The fresh water considered here is assumed to have a specific gravity of 1.000 , and ordinarily this will be nearly correct. Normal sea water at Miami has a specific gravity of 1.027 (see p. 573 ), but it may be as high as 1.032 in shallow water where evaporation has increased the concentration; it will be lower where mixing with fresh water has occurred. Normal sea water in this area contains about $19,800 \mathrm{ppm}$ of chloride. The surface waters of the Miami area range in chloride concentration from $15 \mathrm{ppm}$ for fresh water in the Everglades to as high as $26,000 \mathrm{ppm}$ where pools of highly contaminated water have partly evaporated.

Where a stream enters a body of salt water, the fresh-water discharge does not immediately $\mathrm{mix}$ with the salt water; instead, it may keep its identity as fresh water for a considerable distance. 
The fresh water moves over the top of the larger body of water in a layer of decreasing thickness until it fans out and is dispersed by wind and wave action.

When fresh-water discharge in a tidal canal decreases below some critical quantity, salt water enters the mouth of the canal and moves upstream in a halting fashion underneath the outflowing fresh water. The salt water moves as a long tongue and is quite sharply separated from the fresh water, except for a narrow zone of intermixing. The tongue of salty water has a fairly steep front and the activity at the front is caused by friction and the impact with the fresh-water current. The interface between fresh and salt water extends toward the bay with an increasingly thick zone of mixed water. Depending upon the amount of fresh-water runoff, the interface disappears either at some point downstream or in the bay. Some mixing occurs as a result of wind and wave action, irregularities in the channel, and the effect of tributaries. Under the conditions just described the flow in the canal may be divided into two currents moving in opposite directions. Under other conditions, as discussed in the next section, both currents may be inland, or both toward the bay, but not necessarily with the same velocity.

A most interesting effect has been observed near Miami in Snapper Creek Canal, which is tidal in its lower reaches. This curious effect occurred when the canal was rising as a result of tidal rise in Biscayne Bay. A surface layer of fresh water about $0.8 \mathrm{ft}$ deep was flowing downstream at a velocity of about $2 \mathrm{fps}$, and underneath this layer, $2 \mathrm{ft}$ of strongly salty water was flowing upstream at $1.5 \mathrm{fps}$. The two currents seemed to be quite uniform, as indicated by small pieces of suspended material. In the surface between the two layers of water (the interface) were a number of small yellow elliptical leaves, roughly 9 in. apart horizontally. These leaves defined a plane and were motionless despite being only a fraction of an inch from waters moving swifty in opposite directions.

\section{THE MECHANICS OF SALT CONTAMINATION}

The inland movement of salty water in tidal canals is based upon the relative densities of the waters, the quantity of fresh-water runoff, and tidal action. Salt water, as compared withfresh water, has a "density head" of $0.027 \mathrm{ft}$ for each foot of depth; that is. it takes $1.027 \mathrm{ft}$ of fresh water in a $U$-tube to balance $1.000 \mathrm{ft}$ of sea water. This means that where a fresh-water stream $10 \mathrm{ft}$ deep meets a bay, the fresh water must have a head of 10.27 $10.00=0.27 \mathrm{ft}$ if the salt water is to be kept out of the stream.

The flowing stream, in turn, has a head that is a function of the velocity; that is, the energy of the stream's motion is equivalent 
to a certain amount of static (or vertical) head. This is expressed in the relationship: velocity head, $h=\frac{v^{2}}{2 \xi}$, in which $v$ is the velocity and $g$ is the acceleration due to gravity.

In the case cited above, the mean velocity of the stream would have to be $4.2 \mathrm{fps}$ to keep the sea water out of the canal. If the velocity were less, the sea water would move upstream to where the velocity head plus the elevation head (the difference in elevation between the stream and bay at that point) equalled the density head of the bay. Thus, the salt water moves inland as fresh-water runoff decreases below the critical amount necessary to keep the stream fresh. Each location along the stream, in turn, has a critical rate of discharge which decreases inland.

The actual situation is not nearly so simple as this discussion implies because the stage of a tidal bay changes continually and movements of fresh and salt water are complicated by friction, obstructions, and tidal variations.

Tidal variations affect the stage and discharge of a tidal canal, and therefore the movement of the salt tongue also varies. Thus, with decreasing runoff, the tongue moves farther and farther inland with an intermittent motion. Upstream from the tongue, and over it, the fresh water alternately slows and accelerates toward the sea.

When the flow of fresh water decreases below another critical rate, reverse flow begins in the entire cross section near the mouth of the canal. The action of reverse flows and negative slopes is described in detail starting on page 444 . When negative slopes occur in part of each tide cycle, the inland movement of the tongue is accelerated, but the mass of salty water does not move so fast as the reversal points, which travel as a function of storage rates. The same principles of velocity, elevation, and density head still hold as the salty water continues inland. The ultimate condition is reached when discharge from the upper reaches is less than the losses along the lower reaches, which result from evaporation and use. No fresh water reaches the sea; instead, the fresh water retreats and a net flow inland occurs. When this happens, a tidal canal will soon become contaminated throughout unless salinity controls are installed and operated.

When rains cause increased runoff after the end of a dry period, the salt tongue moves downstream in the same manner that it moved upstream and in response to the same natural laws. At a specific rate of increased discharge, reverse flows cease and all flow is positive. At a greater specific rate of discharge, the canal is cleared of all salty water.

Salt-water intrusion in tidal canals is retarded by constrictions, which increase the velocity of the fresh water and thus check the 
inland movement of salt water. Shoals affect flow the same way, but, in addition, they also act as submerged dams and delay the progress of the salt tongue along the bottom of the canal. If a shoal decreases the channel depth say, by about 25 percent, the salty water may be held back for a period of several weeks depending also upon other factors.

Aquatic vegetation retards the flow of both fresh and salty water and may be a beneficial factor in drought periods. The dense masses of bottom ${ }^{-}$rooted aquatic weeds that infest the canals of the Miami area act as dams, literally thousands of them, which individually are unimportant but which in the aggregate constitute an effective barrier. This damming effect reduces runoff and wastage of fresh water and blocks the inland movement of salty water. In the drought year of 1945 the aquatic weeds undoubtedly delayed the inland movement of salty water and shortened the period of high-chloride concentrations that existed at inland locations.

Dams in the Miami area can be used effectively to stop the intrusion of salty water. The problem is complicated, however, by the highly permeable nature of the rock formations through which the canals were mainly excavated. If a dam lacking a cut-off wall in the aquifer is closed so late in a drought period that negative heads develop at the dam during each tide cycle, salty water tends to seep through the porous rock beneath and around the ends of the dam and thus re-enter the canal above the dam. This mayalso occur if the drought is unduly prolonged, even though the dam may have been closed at a time when positive heads could be held.

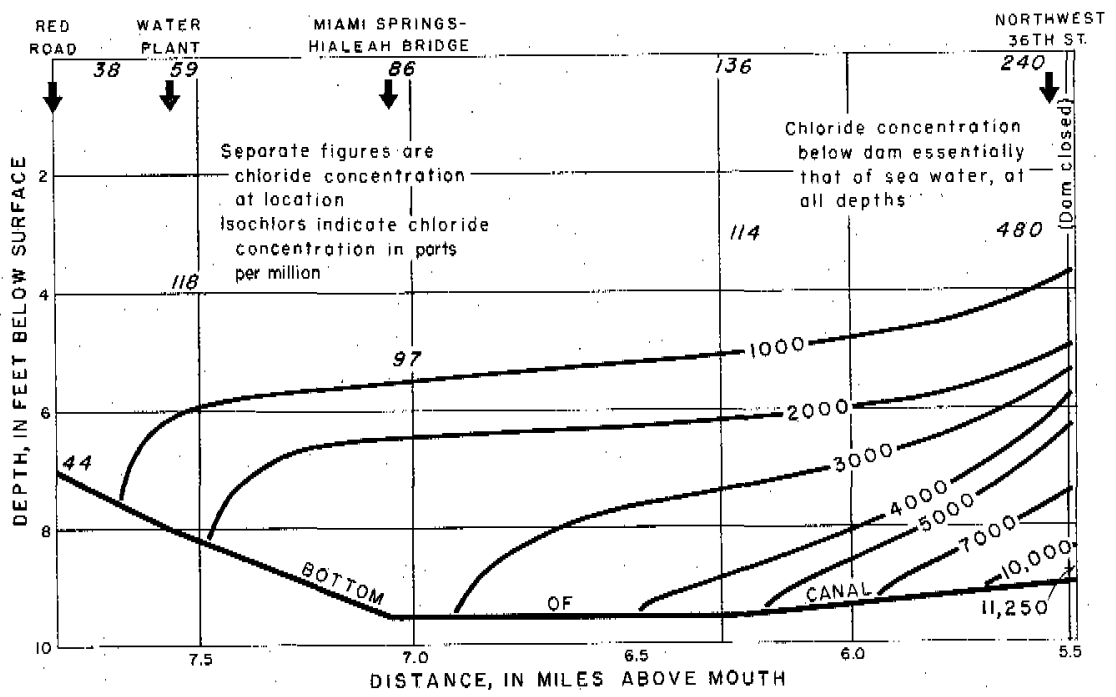

Figure 179. -Ptofile of Miami Canal above NW. 36th Street Dam showing chloride concentrations on May 15, 1945. 
A condition that existed above the NW. 36 th Street Dam in Miami Canal, on May 15, 1945, is shown in figure 179. At that time, the dam was temporary, consisting of interlocking steel piling. Negative heads occurred every high tide, and the water had almost the same concentration as sea water at the downstream face of the dam; therefore a sizable amount of leakage and seepage occurred that contaminated the canal for about 2 miles above the dam. It is fortunate that the rate of contamination was relatively slow because the situation with respect to the well fields was highly critical, Above the dam, the elevation of the water was $0.55 \mathrm{ft}$, while the tidal stage below the dam averaged $0.42 \mathrm{ft}$. The downstream stage at high tide on May 15 was $1.62 \mathrm{ft}$, and a few days earlier it had reached a high of $1.93 \mathrm{ft}$. The profile shows that salty water was still passing the dam, because the isochlors sloped inland. The typical rounded front also shows that a condition of hydrostatic balance had not been established. In this case, the trend of the intrusion was in one direction (inland), but the pattern observed resembles the patterns found where the salt front moves a considerable distance back and forth during each tide cycle. Note the more or less uniform gradation from relatively uncontaminated water to contaminated; this was also found along other profile planes parallel to the centerline of the canal.

Chloride concentrations in a canal are lowest at the surface and grade to the highest at the bottom. The gradation occurs whether the salty water in a canal is moving or still. Figure 180 illustrates the manner in which chloride concentrations vary from the bottom to the surface of a canal at a given location. The data for the sections were obtained at the same time as the data for figure 179 .

The nearly horizontal layering of the salty water is evident. The variations in the figure from truly horizontal layering may have several explanations. The effect of wind on the relatively still pool that existed at the time may have caused enough turbulence to mix the water in some degree. This is supported by the fact that moderate chloride concentrations are found in the upper half of the canal prism, indicating that the fresh water from upstream, which was normally low in chloride, was mildly contaminated. Another possibility is that the cone of depression that extended from the center of the nearby well field to the canal bank at that time induced seepage from the canal toward the wells. This view is supported by the fact that the isochlors dip downward on the side toward the principal well field.

It should be remembered that any mixture of salt and fresh water is a true solution. Salt water will not "settle out" in a still pool of contaminated water, and whatever degree of mixing has occurred is irrevocable. This does not contradict the fact that a gradation of increasing chloride concentrations occurs with depth. The gradation results from the fact that waters of varying degrees 


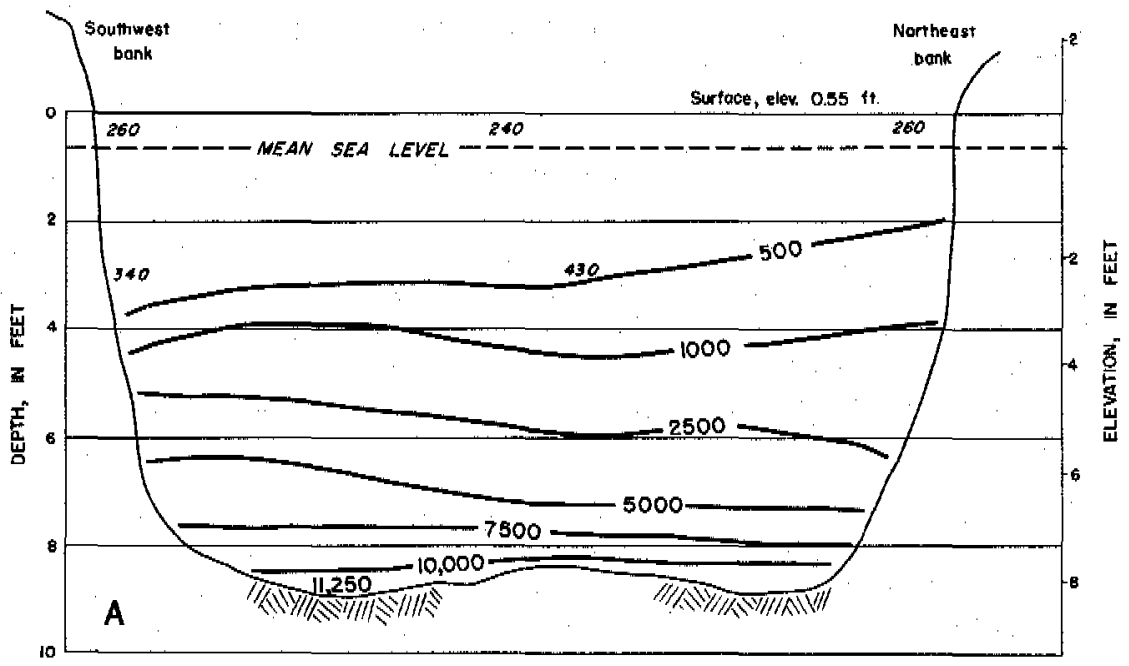

NORTHWEST 36TH STREET, MIAMI

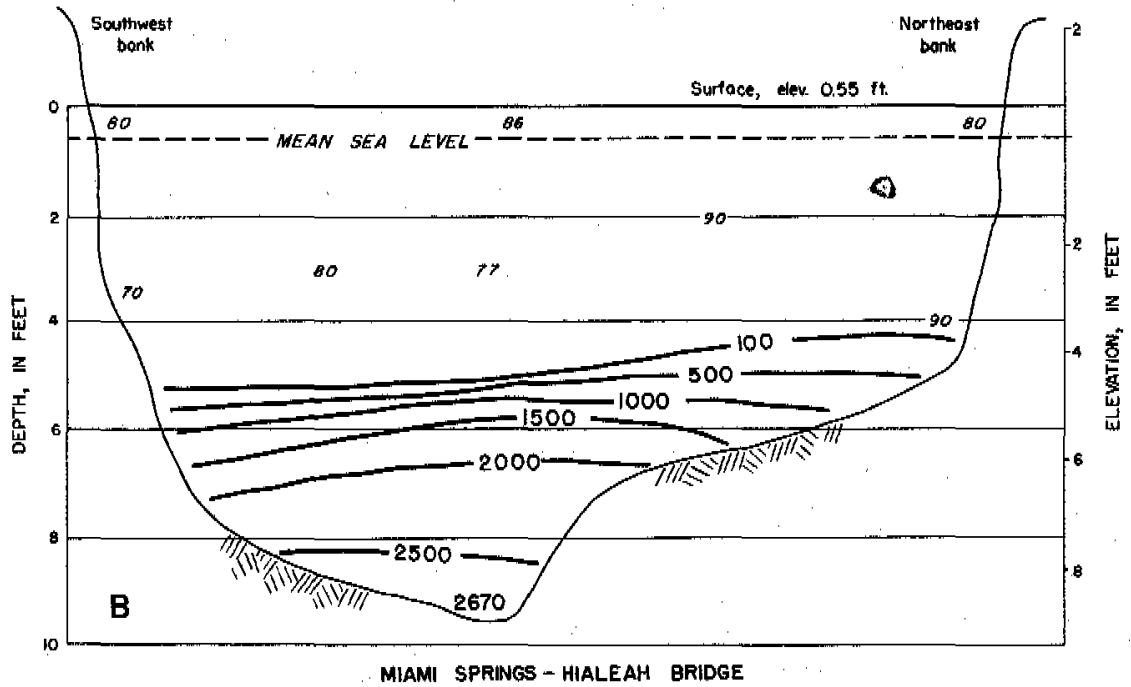

Separate figures are chlorida concentration in parts per million at locotion thown isochlors represent chortate in parts per million

10 0

Figure 180. -Cross sections of Miami Canal, at NW. 36th Street and at the Miami SpringsHialeah bridge showing approximate horizontal layering of salty water on May 15, 1945. 
of contamination ordinarily do not have the opportunity to thoroughly intermix-turbulence is usually too small.

\section{VARATION OF CHLORADE CONCENTRATION WITH TIDES}

The variation of stage and discharge of tidal canals is discussed in detail in the section on Surface water, where it is shown that ordinarily the stage and discharge hydrographs are nearly opposed. At a location where the salt front is in a state of flux, chloride concentrations vary with tides in much the same manner as the stage hydrograph.

The vertical variations of chloride concentration in a tidal canal are shown in figure 181 . Concentrations ranged between 2 and 70 percent of that of sea water, indicating the wide variation in contamination that can exist in a reach where the salt front is alternately advancing and retreating. At low tide, a small and nearly uniform degree of contamination was present. The curve for the high-tide condition shows that fresh-water discharge was completely stopped by the salty water; in fact, the flow was reversed. At the time of the observation, the net fresh-water runoff was quite small and the salt tongue was progressing inland.

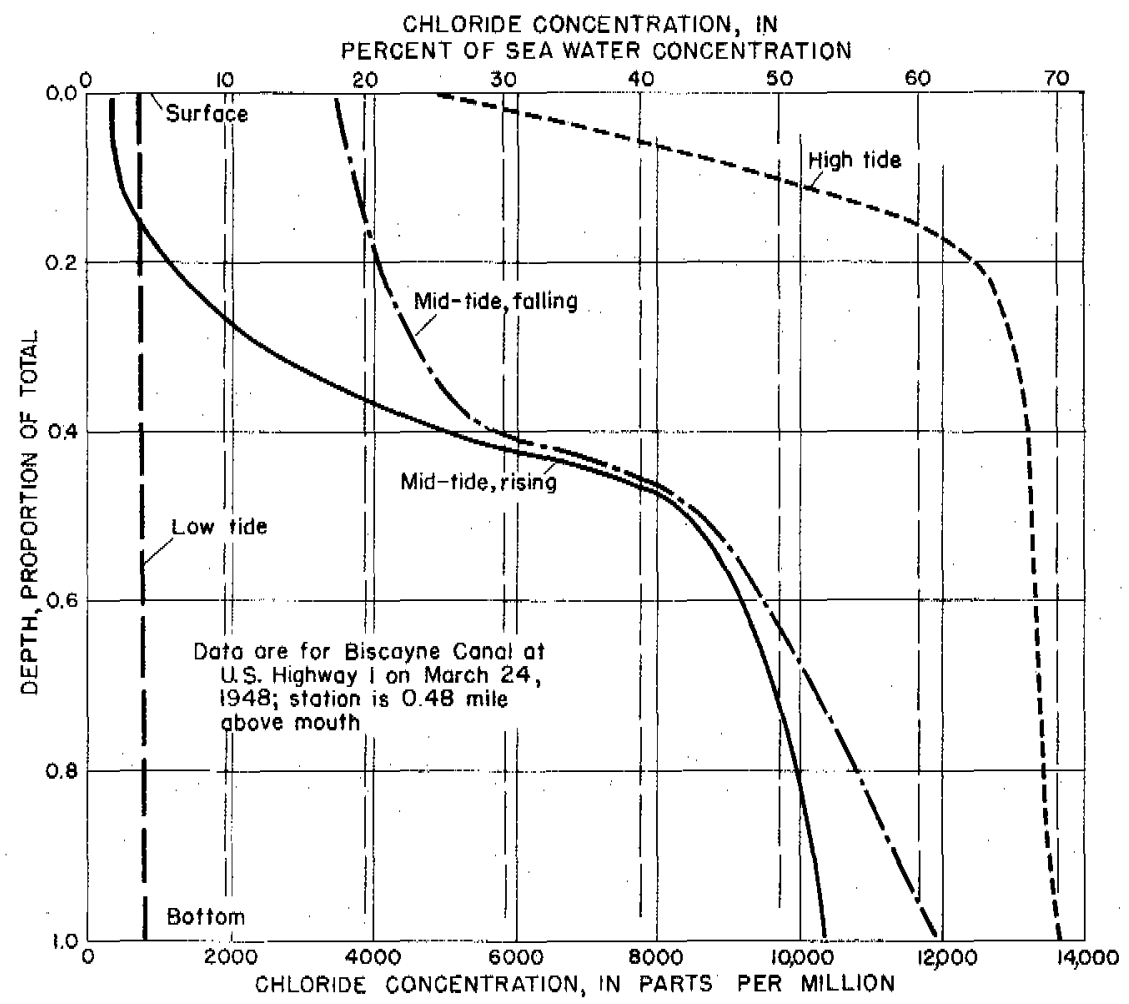

Figure 181. -Graph of vertical variations of chloride concentration in Biscayne Canal at four phases of a tide cycle. 
The relationship among stage, velocity, and chloride concentration for Snapper Creek Canal at Coral Gables, Dec. 11, 1946, is illustrated in figure 182. As discharge is principally a function of velocity, the velocity curve can be considered essentially the same as discharge. The chloride and velocity observations were made at the bottom of the canal in the center of the breachedsalinitycontrol dam. The graph shows that the chloride varied in the same general form as the stage, but, more strikingly, the chloride varied inversely with the velocity, even to the minor variations.

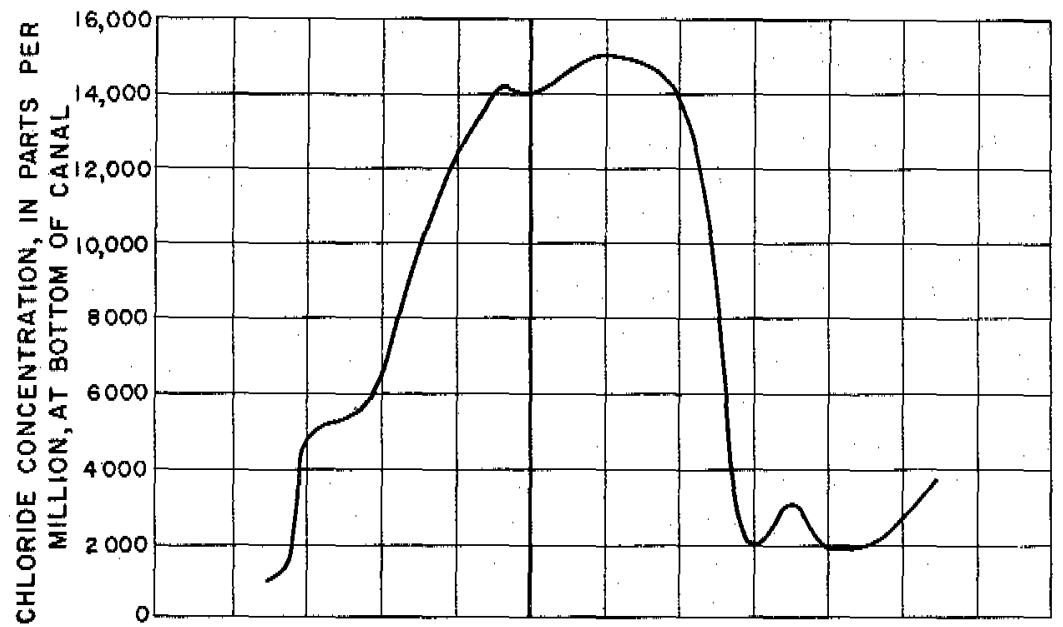

Dota are for Snopper Creek Conal at Corol Gobles, Florida, Dec II, 1946. Observations were made in center of breached salinity control

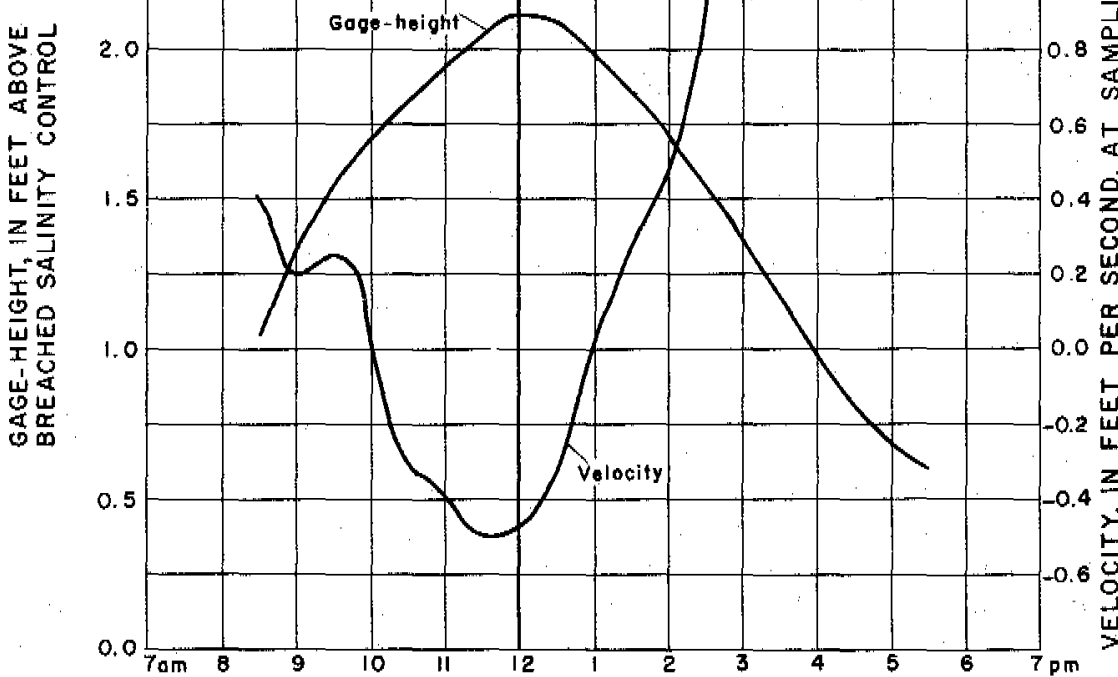

Figure 182. - Variations of stage, velocity, and chloride concentration in Snapper Creek Canal during one tidal cycle. 


\section{LOCATHON OF SALT FRONT}

The "salt front" of a tongue of salty water in a canal has been arbitrarily fixed as the location of the $1,000 \mathrm{ppm}$ chloride concentration (about 5 percent of average sea water). Although, lower concentrations of ten are significant, this degree of contamination is held to be critical. The salt tongue alternately advances and retreats as affected by tidal action and therefore the salt front likewise fluctuates. The $1,000 \mathrm{ppm}$ concentration ordinarily is situated close to the inland end of the salt tongue, and thus it is an indicator of the extent of the contamination.

The salt front moves inland as discharge decreases, and it moves toward the sea as discharge increases. Just as tidal dis charge may be expressed as a mean value for a day, the location of the salt front has a mean position that is related to mean dis charge. For instance, it was found that a discharge of about 400 cfs in Miami Canal was required to hold the salt front below the site of the NW. 36 th Street Dam (without the dam in place).

The change in the location of the salt front during a tide cycle may be considerable, as is demonstrated in figure 183. The distance travelled by the salt front was about 2 miles, and, at the lowest downstream location, the chloride concentration ranged between 600 and $14,000 \mathrm{ppm}$.

The high-tide profile shows an area of uneven chloride distribution at the surface near station 2 . This may have resulted from turbulence connected with the point of reversal of flow, which was moving upstream at the time; or it may have been, in part, connected with the effect of wind. A strong area of contamination appears in the low-tide profile near station 5 . This may have resulted from salty water being trapped upstream behind some high point or obstruction in the canal.

The movement of the salt front with tidal action illustrates the care needed to determine its position, especially the extreme inland position. Where canal water is used directly in an industrial process, the first salty water at the point of intake may disrupt the processing, even though the salty water may be present only a short time.

In the vicinity of well fields that are inducing infiltration from canals, contamination of the ground water may not be identified in the wells until an appreciable period has elapsed and a considerable volume of ground water has been affected. It is therefore especially important to know where the salt front is located and to take steps to stop its inland movement at a safe distance from the point of water use. In some cases, for example where pumpage from wells near the salt front is small, it may be satisfactory to permit salty water to penetrate to the vicinity of the well 


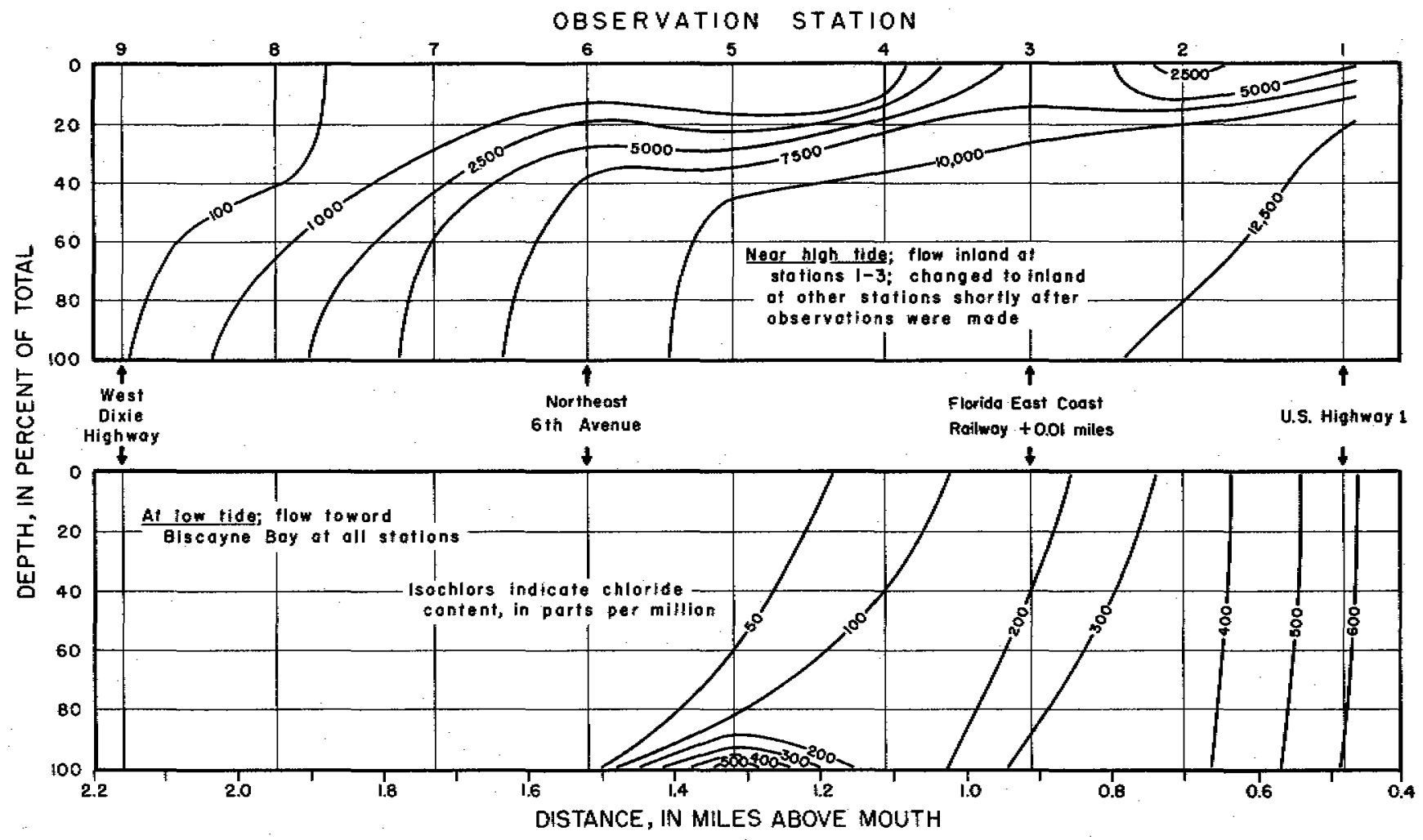

Figure 183, - Profile of Biscayne Canal showing isochlors at high and low tide on March 24, 1948. 
field, as long as the average location of the front is safely downstream from the field. Where the cone of depression in the water table extends to the banks of the canal, the existence of salty water in the canal for any length of time will cause some degree of contamination, and the amount will increase with the length of time salty water is in the canal. This may occur even if salty water is present in the canal for only part of a tide cycle.

\section{RESIDUAL CONTAMINATION}

When drought conditions continue, runoff in uncontrolled tidal canals decreases to the point where salty water moves inland es sentially unopposed, and net flow may be inland. This occurred in the Miami area in 1944 and 1945, when several of the shorter canals became contaminated throughout. Fresh-water runoff ceased, and seepage of salty water to the water table occurred along the canals. During the extreme condition in the spring of 1945, highly saline water was observed entering the ground with visible velocity at points where the bottoms of the canals were above the existing water table. That condition was not merely contamination of a small zone of ground water by contact, but was a direct pouring of salt water into the highly porous formation. It occurred continuously in the period when ground-water levels were below the bottom of the stub canals.

Drought conditions in southern Florida usually are relieved by the heavy rains of the summer and fall. Fresh-water runoff is resumed in considerable volume and salty water in the canals is usually flushed out. Sometimes, when water levels rise slowly, aquatic growth in the upper reaches of a canal may restrict runoff and cause salty water to remain in the upper channel for some time after the lower reaches have been cleared. This may continue until discharge is such that the weeds are beaten down and a flushing action occurs.

Either with or without the presence of weeds, salty ground water from the permeable formations along the upper reaches of a canal may contaminate the canal water. The ground-water levels rise in the formations that previously received salty water from the canals, and seepage toward the canals again occurs. Salty water then contaminates the fresh-water runoff in the canal and chloride concentrations may be found that are greater than those farther downstream. Notall of the salty ground water returns to the canal; some of it may gradually percolate through the formations to form a body of contaminated water beneath and adjacent to the canals. Such a contaminated body of water would be dissipated very slowly.

The extent to which salty water may remain in a canal channel, trapped either by weeds or a constriction, is shown by conditions 
that existed in 1945 in Opa Locka Canal, a tributary of Biscayne Canal:

Location

$\begin{array}{lrrr} & \text { June } 29 & \text { July } 18 & \text { Juty } \mathbf{3 1} \\ & & & \\ \begin{array}{l}\text { Opa Locka Boulevard... } \\ \text { NW. 27th Avenue ............. }\end{array} & 21,900 & 2,700 & 1,100 \\ \begin{array}{l}\text { Seaboard Air Line } \\ \text { Railroad................... }\end{array} & 42 & 1,700 & 10,000 \\ & & & \\ \end{array}$

The contaminated area in the vicinity of NW, 27th Avenue ultimately was flushed of highly saline water, but contamination existed there long after the salt front had been forced far downstream in all canals in the area; a sizable body of ground water probably remained in a contaminated state for a longer period.

\section{MIAMI AREA}

MIAMI CANAL

As all of the canals in the Miami area are connected with Biscayne Bay, salty water can move inland easily, the distance depending upon the amount of fresh-water runoff and the condition of the canals. During periods of moderate to heavy runoff the salty water usually is within 1 or 2 miles of the bay. During an extended dry period, however, salty water has moved inland more than 11 miles in Miami Canal, and two of the shorter canals have become contaminated throughout.

Miami Canal was uncontrolled between 1931 and 1943, and the secondary canals were not controlled until 1945-46. Samples from Miami Canal were collected periodically by the Miami Department of Water and Sewers during the period 1939 to 1946 , the frequency of collections depending upon water conditions. In April 1940, the Geological Survey began a sampling program in which semimonthly series of samples were collected from Biscayne, Little River, Tamiami, and Coral Gables Canals. In April 1941, the work was extended to include Snake Creek and Snapper Creek Canals.

Surface and bottom samples were collected from about six regular sampling stations along each canal. Beginning in October 1942 , only bottom samples were collected, because, with very few exceptions, bottom samples contained the maximum amount of chloride at each location. No effort was made to obtain complete records of concentrations at every station; instead, the series of samples were collected to locate the position of the salt front. 
In the first several years, samples were collected from the six secondary canals without regard to tidal stages. The records, therefore, do not necessarily represent the maximum chloride concentrations. It is believed, however, that the data obtained define the trend of salt-water encroachment in the canals. Starting in 1944, the records were improved by collecting all samples. from the tidal canals at times as close to that of high tide as was practicable.

The maximum chloride concentrations observed in the Miami area during the extreme drought of 1945 are shown in figure 184 . The condition was serious and the only reason it was not worse in some of the canals is that their bottoms were exposed in places and salty water could not flow inland. Heavy weed growth also retarded movement of the salty water, and the dam in Miami Canal was partially effective.

The heavy contamination of Opa Locka Canal endangered the municipal wells at Opa Locka, and many smaller supplies throughout the Miami area were threatened or actually became salty for lengthy periods.

The most significant observation of the drought period in 1945 was at the western ends of Biscayne and Little River Canals. Water in Red Road Canal extended only about $\frac{1}{4}$ mile north and south of the ends of the two canals, and Red Road Canal was otherwise dry. Strongly salty water was observed running inland and sinking into the ground at the end of the wetted channel; thus, water with a chloride concentration three-quarters that of sea water poured directly into the aquifer. (Also see p. 630.)

The contamination of Miami Canal at Miami Springs was a real threat to the municipal well field. Fortunately, rainfall eventually forced the salty water in the canal downstream from the vicinity of the wells, but not before several of them were showing increased chloride content. The detection of the contamination of some of the wells in Miami Springs (ultimately, six of these 15 wells were significantly affected) naturally caused a large degree of concern, and arrangements were made to evaluate the problem and to explore for possible other sources of supply. The obvious source of salty water in the wells was Miami Canal, and a sampling program was established to observe the extent and degree of intrusion. Reconnaissances were made of all possible sources of water, reaching as far afield as Lake Okeechobee. In the meantime, the contaminated wells were pumped to waste, and a careful watch was kept on the chloride content of the other wells.

The first series of samples from Miami Canal, obtained April 25,1939 , showed a chloride concentration of $6,700 \mathrm{ppm}$ at Water Plant, which is 7.7 miles upstream from Biscayne Bay, and decreasingly salty water was found, as far as 2 miles farther inland. 


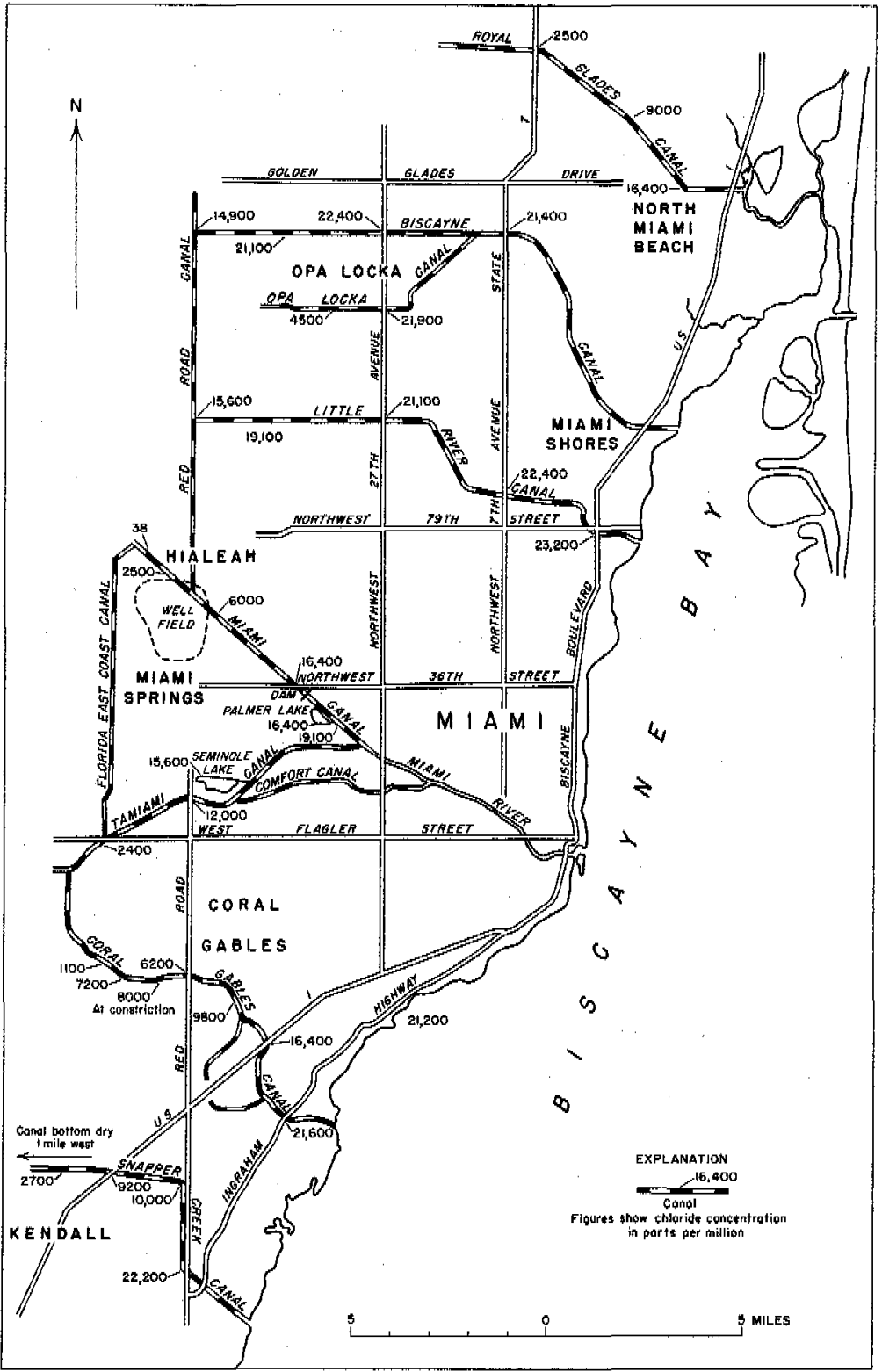

Figure 184. - Map of Miami area showing maximum observed chloride concentrations th the tidal canals, May-July 1945. 
The advance of salty water in the canal continued until early in May when the chloride concentration in the canal at Water Plant reached $13,450 \mathrm{ppm}$ and at NW. 36 th Street reached $17,000 \mathrm{ppm}$. The farthest inland point at which salinity in excess of normal was found was about 4 miles upstream from Water Plant, or about 11.5 miles from Biscayne Bay.

The chloride concentrations determined from samples collected at three locations on Miami Canal in 1939 are listed in table 71 . The variations in location of the salt front inland correspond to variations in the fresh-water runoff of the canal, Rains during May and June of 1939 caused increased runoff and forced the salt front downstream. Salty water moved inland again to a moderate degree during August but the usual heavy runoff in the fall forced the salt front downstream to a more satisfactory location with respect to the public water supply.

Table 71.-. Chloride in Miami Canal during spring and summer of 1939

[Bottom samples. Analyses, in parts per million, made by Miles R. Mountien, city chemist, Miami]

\begin{tabular}{|c|c|c|c|c|}
\hline \multicolumn{2}{|c|}{$\begin{array}{l}\text { Date of } \\
\text { collection }\end{array}$} & $\begin{array}{l}\text { NW. } 36 \text { th Street } \\
\text { (5. } 7 \text { miles from } \\
\text { Biscayne Bay) }\end{array}$ & $\begin{array}{l}\text { Water Plant, Hialeah } \\
\text { (7. } 7 \text { miles from } \\
\text { Biscayne Bay) }\end{array}$ & $\begin{array}{c}3 \text { miles NW, of } \\
\text { Water Plant, Hialeah } \\
\text { (10.7 miles from } \\
\text { Biscayne Bay) }\end{array}$ \\
\hline Apr. & $\begin{array}{l}20 \\
25 \\
27\end{array}$ & $\begin{array}{l}14,900 \\
14,700 \\
12,450\end{array}$ & $\begin{array}{r}6.700 \\
6,700 \\
800\end{array}$ & $\begin{array}{l}26 \\
25 \\
25\end{array}$ \\
\hline May & $\begin{array}{r}2 \\
8 \\
11 \\
19 \\
23 \\
26\end{array}$ & $\begin{array}{r}15,350 \\
17,050 \\
7,500 \\
10,750 \\
2,050 \\
\ldots . . . . . . . . . . . . . . . .\end{array}$ & $\begin{array}{r}10,850 \\
13,450 \\
600 \\
750 \\
300 \\
300\end{array}$ & $\begin{array}{r}180 \\
1,800 \\
37 \\
27 \\
25 \\
. .2 . . . . .\end{array}$ \\
\hline June & $\begin{array}{r}8 \\
19 \\
27\end{array}$ & 8,150 & $\begin{array}{l}88 \\
44 \\
34\end{array}$ & 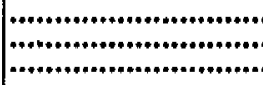 \\
\hline July & $\begin{array}{l}19 \\
26\end{array}$ & $\begin{array}{r}144 \\
92\end{array}$ & $\begin{array}{r}111 \\
32\end{array}$ & 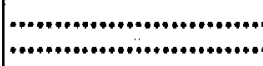 \\
\hline Aug. & $\begin{array}{r}1 \\
7 \\
14 \\
21 \\
28\end{array}$ & $\begin{array}{r}340 \\
60 \\
1,900 \\
1,100 \\
35\end{array}$ & $\begin{array}{l}34 \\
43 \\
33 \\
34 \\
27\end{array}$ & 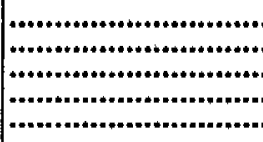 \\
\hline Sept. & $\begin{array}{r}5 \\
12\end{array}$ & $\begin{array}{r}80 \\
111\end{array}$ & $\begin{array}{r}1335 \\
77\end{array}$ & $\mid$ \\
\hline Oet. & $\begin{array}{r}2 \\
9 \\
23 \\
30\end{array}$ & 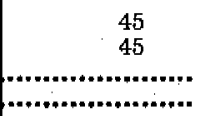 & $\begin{array}{l}23 \\
22 \\
22 \\
32\end{array}$ & 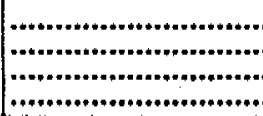 \\
\hline
\end{tabular}

${ }^{1}$ Caused by salty water in city supply wells 13,14 , and 15 being pumped into canal. 
Some of the data collected by the Miami Division of Water Supply are plotted in figure 185 , which shows the most extreme condition of salt contamination in the Miami area that has been observed by the city or the U. S. Geological Survey. Irregularity of the curves may be due in part to the sampling procedure employed but may also be ascribed to variations in the cross section of the canal. The curve for May 11 shows that, although the main body of contaminated water had moved about 4 miles downstream (as compared with the condition of 3 days before), an appreciable degree of contamination remained in the canal above the main body of salty water.

Several hundred feet below the dam site at NW. 36th Street, at the head of the channel improvement completed in 1932, the channel of the canal becomes wider and deeper. There is a 4 -foot step at the bottom of the canal where the change in depth occurs, which has a considerable effect on the movement of salty water in the channel. Salty water, moving along the bottom of the canal, is held by the step until the quantity and velocity of the overlying fresh water decreases to the point where the depth of the salty water becomes great enough to pass the step. Once past a barrier of this type, the salty water will move inland relatively swiftly unless checked by increased runoff or some other barrier. The proportions of the cross-section of a submerged barrier have little bearing on its effectiveness because it is the height of the barrier that is the important factor.

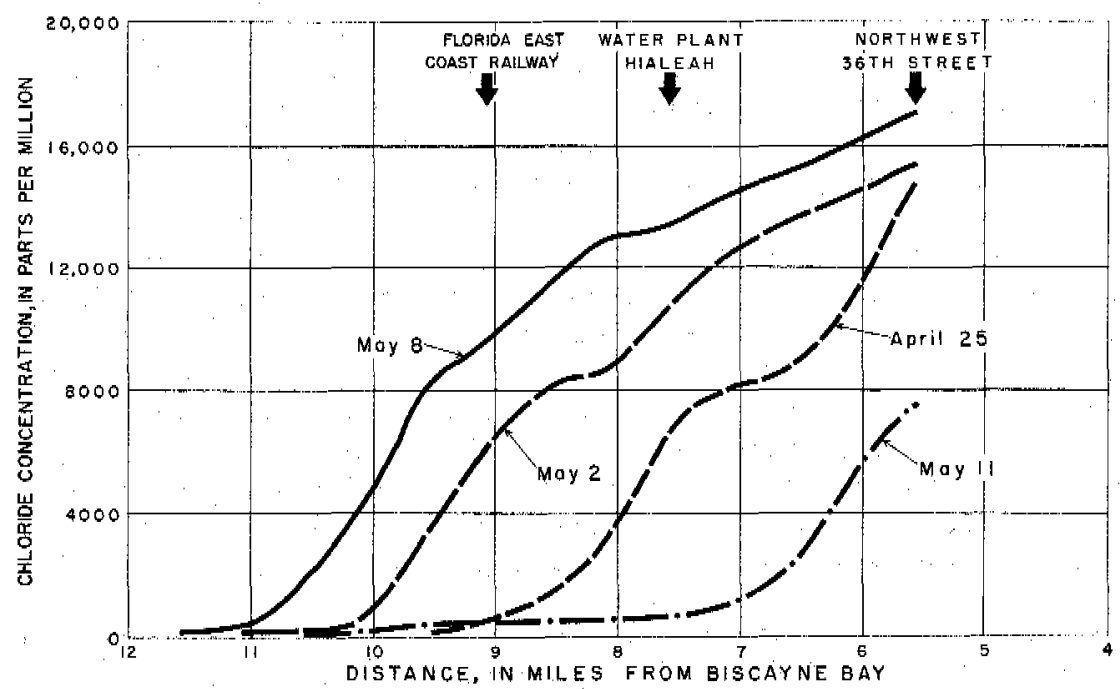

Figure 185. -Graph of chloride concentrations in lower Miami Canal during drought period of 1939 . 


\section{LOCATION OF SALT FRONT}

The relation of the position of the salt front in Miami Canal to the fresh-water runoff is shown in figure 186 . The record to June 1943 includes the combined discharge of Miami Canal at Water Plant and Tamiami Canal at Red Road. Also included on the graph is a continuous log of the installation and operation of dams at NW. 36 th Street. In regard to the periods in which the dam is indicated as being partly open, no attempt was made to record the amount of the opening, which varied from nearly closed to widely breached.

The principal characteristic of the salt-front discharge graph is the opposing effect of the two quantities-the salt-front curve drops when the discharge curve rises, and vice versa. This demonstrates the effect of increased discharge in forcing the salt front downstream, the effect of the dam operation at NW. 36 th Street, and the steady inland advance of the salt front during drought periods. It will be noted that in the period of record the farthest downstream location of the front was just below NW. 12 th Avenue.

From information obtained during the study it appears that when the combined discharge of Miami Canal at Water Plant and Tamiami Canal at Red Road is in excess of about 1,000 cfs, salty water is flushed out of the canal as far downstream as NW. 27th Avenue, When the sum of the discharges at the two gaging stations is $1,000 \mathrm{cfs}$, it is probable that the discharge at NW, 27 th Avenue is greater than $1,000 \mathrm{cfs}$, owing to the intermediate ground-water inflow. Further study shows that a discharge of approximately 400 efs is required to hold the salty water at NW. 36 th Street. The differences in the quantities of flow at the two locations is a reflection of the relative areas of the channels.

In discussing figure 186, the yearly graphs are taken in chronological order. It should be remembered that the locations shown for the salt front represent the point of the salt tongue as it lay in the bottom of the canal but do not necessarily indicate that the entire cross section of the canal was contaminated. The discharge curves were plotted from daily mean discharges, which do not indicate the tidal variations of discharge but which give a truer picture of runoff conditions. The discharge curve for Miami Canal at Water Plant is the same as that appearing in figures 117-123.

1940. -With the usual dry winter conditions developing, the Miami Division of Water Supply started a sheet-steel piling dam at NW. 36 th Street in mid-January. Construction of a boat lift to move small craft around the dam was carried on at the same time and the dam was not closed until April 26 according to A. B. DeWolf, of the Miami Board of Waters and Sewers. Early in May, the crest of the dam was lowered from $2.0 \mathrm{ft}$ to $0.5 \mathrm{ft}$ at the request of farmers adjacent to the canal upstream. Hinged wooden 

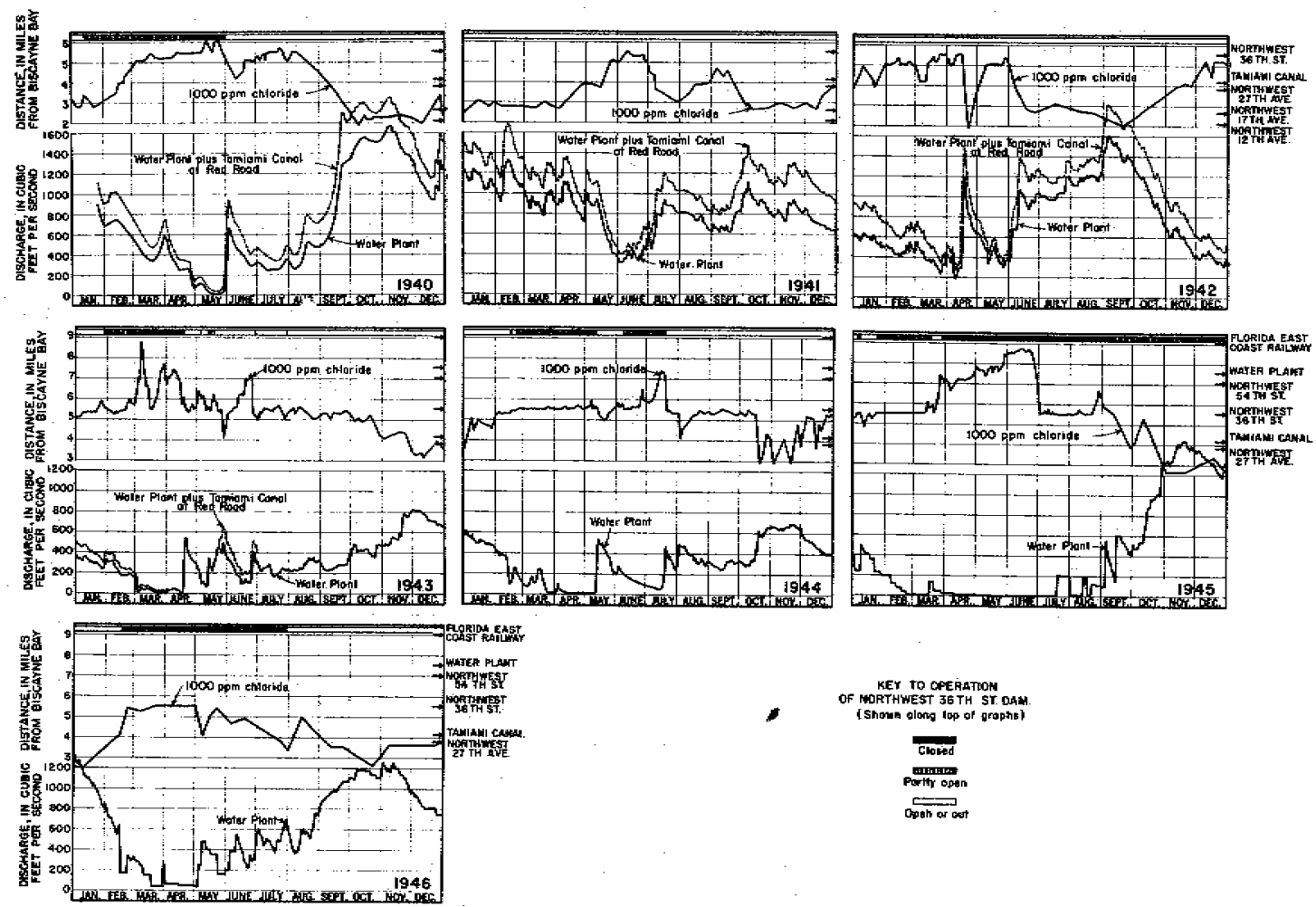

Flgure 186. - Graph of location of 1,000-ppm chloride concentration and discharge of Miami Canal, 1940-46. 
gates were installed on the dam to permitoverflow toward the sea and to prevent reverse flow at high tide. The effect of this activity may be observed in the chloride graph. Some salty water passed the dam and reached the Miami Springs-Hialeah bridge, where a concentration of $800 \mathrm{ppm}$ was observed, but no salty water reached Water Plant:

On May 24, County Line Dam, 16 miles upstream, was breached to release water from the reservoir area above the dam-the effect shows on the graph. Heavy rains at the end of May alleviated the situation and early in June the 36 th Street dam was removed. Rainfall in the early part of the summer was very light and in July the salt front again reached the vicinity of NW. 36 th Street. However, increasing amounts of rain, starting in August, forced the salt front downstream to the vicinity of NW. 12 th Avenue, and no further threat occurred. The fall and early winter period was relatively wet and was noteworthy because the peak discharge of Miami Canal did not occur until early in November.

1941. - With sizable carryover of water in the hinterland from the preceding year and with rains in the normally dry winter period, the inland movement of salty water did not become significant until June. The salt front reached the vicinity of NW. 36 th Street only briefly in June and was no problem during the remainder of the year. It will be noted on the discharge graph that runoff was consistently above the 400 cfs required to hold the salt front below NW. 36 th Street.

1942. - Following a rather dry winter period, the salt front reached the vicinity of NW. 36 th Street several times butwas never a threat to the municipal well field. The great storm of midApril, one center of which was in the Hialeah area, forced the salt front far downstream, but the lack of sustained runoff soon allowed the salty water to move far inland. The increasingly heavy rains in the summer produced large runoff which reached a maximum early in September. However, rainfall in the remainder of the year was very scanty, runoff decreased, and by December the salt front was far inland, although the situation was not critical. It is suggested that the great drought of $1943-45$ actually started in the last quarter of 1942 .

1943. - With the salt front relatively near the well fields for the early part of the year, and with no large rainfall anticipated for several months, the Miami Department of Water and Sewers late in January started the construction of a pneumatic dam for NW. 36 th Street. A temporary emergency dam was constructed to provide protection while the new steel dam was being installed and a large gate was provided to permit boat passages. Because of boat traffic and a sizable amount of leakage around the dam, salty water moved inland to a point more than a mile upstream from Water Plant. Moderate rainfall, augmentation of the available 
water by release of supplies from the upstream reservoir, and the completion of the new dam improved the situation, but a critical condition existed until mid-April. The usual rains in the spring and summer gradually forced the salt front downstream from the critical zone, but at the end of the year it was still far inland. The maximum chloride concentration observed in samples collected from Miami Canal opposite Water Plant was 7, $800 \mathrm{ppm}$ on March 6.

1944. - The salt front progressed steadily inland early in the year and the pneumatic dam was operated starting in midFebruary - the chloride graph shows the effectiveness of this operation. However, a certain amount of leakage occurred through and around the dam structure and probably a much smaller amount seeped through the rock and beneath and around the ends of the dam. This permitted quantities of salty water to move inland nearly to Water Plant. This action was caused by the occurrence of negative heads on the dam as great as $2 \mathrm{ft}$ at low tide. The pneumatic dam was lowered to the bottom of the canal in July and was not operated thereafter. Rainfall and runoff we re only moderate, however, and at the end of the year a near-critical condition existed.

1945. - With salty water in the vicinity of NW. 36 th Street, the dam was operated in a partly opened position starting early in January. On March 17, the dam failed, and, until a temporary sheet piling dam was installed 10 days later, a condition of unobstructed flow occurred. In this critical period, salty water moved upstream to the vicinity of Water Plant and despite the emplacement of the temporary dam, remained there for a period of 3 months and even moved farther inland, nearly to the Florida East Coast Railway bridge. Rains at the end of June flushed the salty water downstream as far as NW. 36 th Street, where it remained at the downstream face of the dam until the last part of August when a short incursion occurred. The second period of contamination above the dam was short, and soon afterwards the salty water started moving downstream. By the end of the year it was in a favorable location insofar as the protection of the public water supply was concerned.

1946. - A nearly water-tight temporary sheet-piling dam was in operation from mid-February to the end of July. Despite the fast decline in runoff early in the year, the salty water was held effectively at the downstream face of the NW. 36 th Street dam for more than 2 months. Increasing runoff in the remainder of the year obviated any further need for the dam.

From the preceding discussion it is apparent that properly constructed barriers can effectively hold the inland movement of salty water. Despite the inevitable leakages that occur and the tendency of the salty water to by-pass the dams through the permeable formations, the dams were highly effective. 
The chief problem in the operation of any dam at NW. 36th Street was that of protecting the municipal water supply and at the same time meeting the water-level demands of land owners adjacent to the canal above the dam. Because of the legal aspects of the problem, emplacement and operation of the dams was sometimes delayed longer than the technical aspects of the problem indicated, with the result that too much water was lost to the sea and not enough remained to hold the desired water levels above the dam. In 1945 the problem was resolved, in part, when Dade County was constituted by legislative action as a water control district and took over the operation of the 36 th Street dam.

The dams at NW. 36 th Street can be considered to be experimental to a large extent and to have shown that, despite the wellknown permeable nature of the adjacent limestone formations, a useful and important degree of water control can be achieved; in fact, properly built and properly operated structures are the only way that satisfactory water control and reduction of contamination can be accomplished. The problem and its solution concerns not only the canals and waterways but also the contamination of underground water.

\section{PALMER LAKE}

Just east of the Seaboard Air Line Railroad and south of Miami Canal is Palmer Lake, a rock pit area of about 20 acres that is connected to Miami Canal (see fig. 184). As it is uncontrolled, the lake is subject to unimpeded tidal action. Palmer Lake has a maximum depth of about $30 \mathrm{ft}$, and much of it is more than $15 \mathrm{ft}$ deep. Its connection with Miami Canal is about $9 \mathrm{ft}$ deep. When salty water moves up Miami Canal to the Seaboard Air Line Railroad and NW. 36 th Street some of it enters Palmer Lake. The iake is much deeper than the canal; therefore this salty water tends to remain there after the canal and upper part of the lake are free of contamination.

The chloride concentrations in the lake of ten show a gradation from lowest at the surface to highest at the bottom. However, in periods of extreme drought, as in June 1945, the entire body of water becomes uniformly contaminated and may have chloride concentrations as high as 80 percent of that of sea water. Palmer Lake is significant, therefore, not only in the problem of contamination of ground water in the immediate vicinity, but it is also associated with the problem of protecting the municipal well field. In dry periods, only a low ground-water divide exists between Palmer Lake and the cone of depression around the wells. If, under continued drought conditions, this low divide should be dissipated, the lake would be another potential source of contamination for the wells. 
TWIN LAKES

Twin Lakes is a small abandoned rock pit, now used only as a scenic attraction, in the center of Miami Springs (see fig. 189). Although smaller than Palmer Lake, it is even more of a threat to the municipal water supply because it is very close to the well fields. Fortunately, its connection to Miami Canal lies above the NW. 36th Street Dam. In periods when contaminated water moved above the dam, some of it entered Twin Lakes and moved toward the well fields. The entrance to the lakes is shallow, however, and no serious situation has occurred there. For the most part, Twin Lakes; has remained fresh or only mildly contaminated.

\section{SNAKE CREEK CANAX.}

Because of its weed-choked channel and numerous constrictions, Snake Creek Canal has never offered an easy route for salty water to move inland. Thus, the salt front fluctuated over a relatively short reach of canal during most of the 6 years of observation. The chloride concentrations observed are presented In table 72. The lower reaches of Snake Creek Canal, south and east of the center of North Miami Beach, are normally contaminated during much of the year. In the wet season, however, the salty water usually is flushed completely out of the canal as far as its mouth at Oleta River. The most notable event shown by the record occurred in 1945 when salty water was detectedat State Highway 7, which is 4.4 miles by canal from Oleta River. This occurred despite the heavy weed growth that existed in much of the canal, and the salty water must be credited with killing much of the growth. The salt front was stopped in 1945 by construction of a temporary dam in Snake Creek Canal at U. S. Highway 1. 


\section{Table 72. Chloride concentrations in Snake Creek Cana1, Miami}

[Parts per million. Before October 1, 1941, the values are the highest obtained from either surface or bottom samples (ustrally the latter); after October 1, 1941, the values are from bottom samples. Mileages in parentheses indicate distance from mouth of canal at Oleta River 1

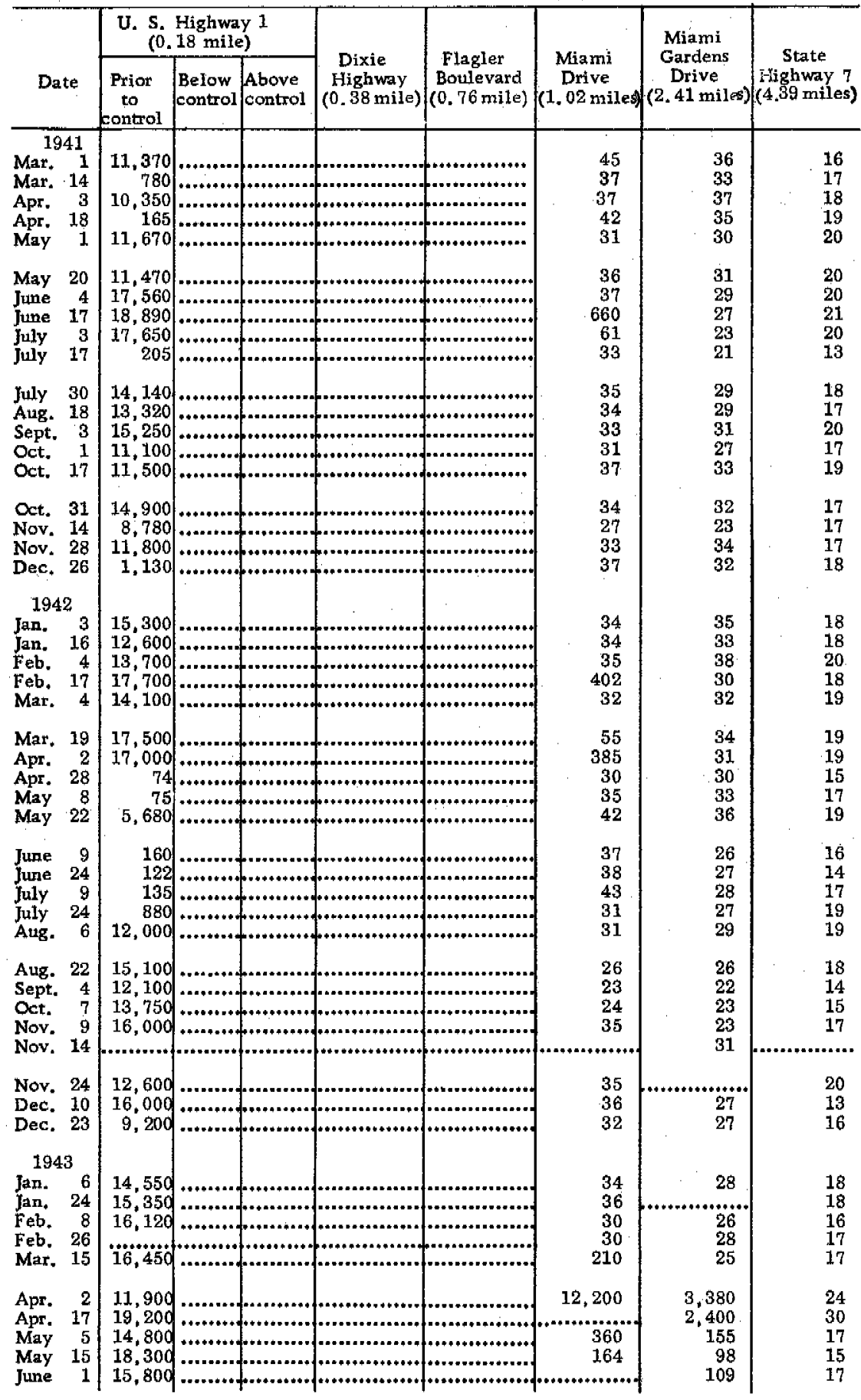


Table 72. - Chloride concentrations in Snake Creek Canal, Miami-Continued

\begin{tabular}{|c|c|c|c|c|c|c|c|c|}
\hline \multirow[b]{2}{*}{ Date } & \multicolumn{3}{|c|}{$\begin{array}{l}\text { U. \$. Highway } 1 \\
(0.18 \text { mile })\end{array}$} & \multirow{2}{*}{$\begin{array}{c}\text { Dixie } \\
\text { Highway } \\
(0.38 \text { mile })\end{array}$} & \multirow{2}{*}{$\begin{array}{c}\text { Flagler } \\
\text { Boulevard } \\
(0.76 \text { mile) }\end{array}$} & \multirow{2}{*}{$\begin{array}{c}\text { Miami } \\
\text { Drive } \\
(1.02 \text { miles })\end{array}$} & \multirow{2}{*}{$\begin{array}{c}\text { Miami } \\
\text { Gardens } \\
\text { Drive } \\
\text { (2.41 miles) }\end{array}$} & \multirow{2}{*}{$\begin{array}{c}\text { State } \\
\text { Highway } 7 \\
\text { (4.39 miles) }\end{array}$} \\
\hline & $\begin{array}{c}\text { Prior } \\
\text { to } \\
\text { control }\end{array}$ & $\begin{array}{l}\text { Below } \\
\text { control }\end{array}$ & $\begin{array}{l}\text { Above } \\
\text { control }\end{array}$ & & & & & \\
\hline ine 49 & & & & & & 680 & 102 & 20 \\
\hline dly 4 & & & & & & & 49 & 17 \\
\hline $\begin{array}{l}1945 \\
\text { me } 29\end{array}$ & & & & & & 16,400 & 8,000 & 000 \\
\hline ly 20 & & & & 12,200 & & & & 1,500 \\
\hline 31 & & & & & ... & & 900 & 230 \\
\hline ept. 3 & & & & & $\ldots \ldots+$ & 0 & 378 & 34 \\
\hline Sept, 24 & & $\ldots \ldots$ & ............... & 358 & *..+* & & 199 & 19 \\
\hline ct. 4 & & & & & & & & \\
\hline ct. $\quad 10$ & & & $\cdots$ & & +*.**t & 440 & 130 & 17 \\
\hline ct. 15 & & $\cdots$ & $\cdots$ & $\because$ & $\cdots+*$ & m.... & (........ & $\cdots$ \\
\hline $\begin{array}{lr}\text { Pet. } & 23 \\
\text { Nov. } & 1\end{array}$ & $\begin{array}{r}12,000 \\
298\end{array}$ & $\mid+\cdots+\ldots+\cdots$ & …................. & 255 & ......... & 105 & 61 & 20 \\
\hline v. & & & & & .. & & & 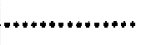 \\
\hline 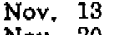 & & & I & & (n..... & & & $\ldots$ \\
\hline ov. 20 & 100 & & …….... & 225 & $\cdots+\cdots$ & 117 & 69 & 19 \\
\hline $\begin{array}{r}\text { ev. } \quad 4 \\
\text { ec. }\end{array}$ & & &. & & a...... & $* *$ & $\ldots . .$. & (..... \\
\hline & & & & & & 1 & 00 & 72 \\
\hline 19 & & 16,600 & $\mid 16,200$ & 年 & ... & thes & 0 & 12 \\
\hline ec. 26 & & 15,200 & 86 & . & ........ & & . & 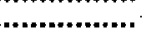 \\
\hline 1946 & & & & & & & & \\
\hline an. $\quad 2$ & $\cdots \cdot . \cdot$ & 13,800 & 40 & 78 & $\cdots \cdot$ & 35 & 34 & 19 \\
\hline lan. 16 & $\ldots$. & $\begin{array}{l}13,800 \\
17,300\end{array}$ & $\begin{array}{l}5 b \\
45\end{array}$ & & 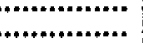 & ..... & ****** & :.+**** \\
\hline Jan. 23 & $\ldots$ & 17,500 & 108 & & $\ldots .$. & 54 & 28 & 19 \\
\hline Jan. $\quad 30$ &. & 16,600 & 129 & $\cdots \cdots$ & ...... & ...... & & ;...* \\
\hline b. 6 & & & 220 & & & & & \\
\hline b. 13 & & & 235 & & & 40 & 32 & 24 \\
\hline $\begin{array}{l}\text { Feb. } 20 \\
\text { Feb. } 27\end{array}$ & 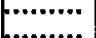 & 18. & $\begin{array}{l}245 \\
275\end{array}$ & & ...... & ....." & ...... & $\cdots \cdot . \cdot$ \\
\hline Mar. 6 & & 18,700 & 250 & & ?....... & 68 & 38 & 17 \\
\hline Ir. & & & 25 & & & & & 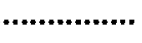 \\
\hline 96 & "'m & & 265 & T & & & & no... \\
\hline & Den & 19, & 8,000 & & & 328 & 54 & 20 \\
\hline 12 & & & 860 & $\cdots$ & & m.... & & $+4+4$ \\
\hline 17 & & & 680 & & & 315 & 50 & 24 \\
\hline & & & 0 & & & & & \\
\hline & & & 9,670 & &.. & 380 & 75 & 32 \\
\hline May 8 & & &, 550 & $\cdots$ & & ...... & ....+*t & ...... \\
\hline May 15 & & & 260 & $\cdots$ & ...... & & ...... & *****+ \\
\hline ay 22 & & & 25 & & & 65 & 63 & 23 \\
\hline ay & & & & & ...... & ..... & ...... & .............. \\
\hline June 5 & $\ldots$ & & $\begin{array}{r}255 \\
55\end{array}$ & & $\cdots \cdot$ & 38 & 52 & $\dddot{30}$ \\
\hline $\begin{array}{l}\text { june } \\
\text { June }\end{array}$ & & & $\begin{array}{l}55 \\
81\end{array}$ & & & So & & 00 \\
\hline & & & & & & & & \\
\hline ne & & & & & & & & \\
\hline & & & 92 & & & 80 & 46 & $\cdots$ \\
\hline July & & & 2 & & & & & , n......., \\
\hline July 24 & & 18,000 & 110 & & & & 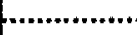 & ט \\
\hline July 31 & & & 40 & & & 40 & 40 & 30 \\
\hline Aug: 14 & & & 140 & & & & & \\
\hline ug. 28 & $*+*+* *$ & $\mid \begin{array}{l}16,500 \\
13,600\end{array}$ & $\begin{array}{r}20 \\
00\end{array}$ & & +*at... & & 30 & 20 \\
\hline ept. 25 & & & & & & 0 & 52 & 22 \\
\hline
\end{tabular}


Table 72. - Chloride concentrations in Snake Creek Canal, Miami-Continued

\begin{tabular}{|c|c|c|c|c|c|c|c|c|}
\hline \multirow[b]{2}{*}{ Date } & \multicolumn{3}{|c|}{$\begin{array}{c}\text { U. S. Highway } 1 \\
(0.18 \text { mile })\end{array}$} & \multirow{2}{*}{$\begin{array}{c}\text { Dixie } \\
\text { fighway } \\
(0,38 \mathrm{mile})\end{array}$} & \multirow{2}{*}{$\begin{array}{c}\text { Flagler } \\
\text { Boulevard } \\
(0.76 \text { mile })\end{array}$} & \multirow{2}{*}{$\begin{array}{c}\text { Miami } \\
\text { Drive } \\
\text { (1.02 miles }\end{array}$} & \multirow{2}{*}{$\begin{array}{c}\text { Miami } \\
\text { Gardens } \\
\text { Drive } \\
(2,41 \text { miles }\end{array}$} & \multirow{2}{*}{$\begin{array}{c}\text { State } \\
\text { chighway } 7 \\
(4.39 \text { miles) }\end{array}$} \\
\hline & $\begin{array}{c}\text { Prior } \\
\text { to } \\
\text { control }\end{array}$ & $\left|\begin{array}{l}\text { Below } \\
\text { control }\end{array}\right|$ & $\begin{array}{l}\text { Above } \\
\text { control }\end{array}$ & & & & & \\
\hline $\begin{array}{lr}1946 . \mathrm{Cg} \\
\text { Oct. } \\
\text { Oct. } 23 \\
\text { Nov. } 6 \\
\text { Nov. } 13 \\
\text { Nov. } 20\end{array}$ & 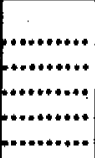 & $\begin{array}{l}10,800 \\
14,500 \\
12,200 \\
13,000 \\
14,500\end{array}$ & $\begin{array}{r}249 \\
14,500 \\
12,000 \\
14,500 \\
14,500\end{array}$ & 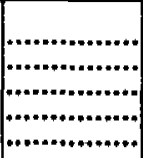 & $\begin{array}{r}50 \\
50 \\
50 \\
50\end{array}$ & $\begin{array}{l}40 \\
\ldots 0 \\
50 .\end{array}$ & $\ldots 0$ & $\begin{array}{r}50 \\
10\end{array}$ \\
\hline $\begin{array}{lr}\text { Nov. } & 27 \\
\text { Dec. } & 4 \\
\text { Dec. } & 11 \\
\text { Dec. } & 18\end{array}$ & (.......... & $\left|\begin{array}{l}14,000 \\
15,600 \\
16,300 \\
15,000\end{array}\right|$ & $\begin{array}{r}14,000 \\
14,000 \\
15,900 \\
5,100\end{array}$ & ............ & $\begin{array}{r}50 \\
6,600 \\
5,780 \\
40\end{array}$ & $\begin{array}{l}50 \\
50 \\
57 \\
50\end{array}$ & 34 & 17.*. \\
\hline $\begin{array}{l}\text { Dec. } 24 \\
\text { Dec. } 31\end{array}$ & (....................... & $\begin{array}{l}14,500 \\
17,000\end{array}$ & $\begin{array}{l}14,000 \\
14,000\end{array}$ & 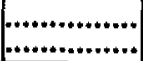 & $\begin{array}{l}50 \\
50\end{array}$ & $\begin{array}{l}40 \\
50\end{array}$ & 50 & 30 \\
\hline
\end{tabular}




\section{BUSCAYNE CANAL}

The longest of the stub canals in the Miami area is Biscayne Canal, which heads at Red Road and extends 10 miles to Biscayne Bay at Miami Shores. The channel is generally about $70 \mathrm{ft}$ wide and $8 \mathrm{ft}$ deep, but its conveyance capacity is reduced by a number of constrictions and by sections containing shoals.

Table 73 presents the observed chloride concentrations. As compared with Snake Creek Canal, the salt front in Biscayne Canal moved over a longer reach. This is a measure of the relative size and conveyance capacity of the channels.

Heavy weed growth in the middle and upper reaches was usually effective in holding the water in the canal and retarding upstream movement of salt water, but in 1945 , during the extreme drought, the channel became completely contaminated. No large supplies are obtained from the canal or from wells nearby.

Opa Locka Canal is a tributary of Biscayne Canal that serves an area in the vicinity of Opa Locka. It becomes contaminated along with the main canal despite the presence of weeds and constrictions. In 1945 contamination extended to the Seaboard Air Line Railroad, which is about at the head of the large channel of the canal. This strong concentration was a real threat to the supply wells of Opa Locka. 
Table 73. Chloride concentrations in Biscayne Cartal, Miami

[Parts per million. Before October 1, 1941, the values are the highest obtained from either surface or bottom samples (usually the latter); after October 1, 1941, the values are from bottom samples. Mileages in parentheses indicate distance from mouth of canal at Biscayne Bay]

\begin{tabular}{|c|c|c|c|c|c|c|c|c|c|c|c|}
\hline \multirow[b]{2}{*}{ Date } & \multirow[b]{2}{*}{$\begin{array}{c}\text { U. S. } \\
\text { Highway } 1 \\
\text { (0.48 mile) }\end{array}$} & \multirow[b]{2}{*}{$\begin{array}{l}\text { Northeast } \\
\text { 6th Avenue } \\
\text { (1. } 52 \text { miles) }\end{array}$} & \multirow[b]{2}{*}{$\begin{array}{c}\text { Dixie } \\
\text { Highway } \\
\text { (2.16 miles) }\end{array}$} & \multicolumn{3}{|c|}{$\begin{array}{l}\text { Northwest i31st Street } \\
\quad(2.84 \text { miles })\end{array}$} & \multirow[b]{2}{*}{$\begin{array}{c}154 \mathrm{th} \\
\text { Street } \\
\text { (4. } 29 \text { miles) }\end{array}$} & \multirow[b]{2}{*}{$\begin{array}{l}\text { Northwest } \\
\text { Tth Avenue } \\
\text { (4.88 miles) }\end{array}$} & \multirow[b]{2}{*}{$\begin{array}{l}\text { Northwest } \\
27 \text { th Avenue } \\
\text { (6.91 miles) }\end{array}$} & \multirow[b]{2}{*}{$\begin{array}{c}\text { Le Jeune } \\
\text { Road } \\
\text { (8.41 miles) }\end{array}$} & \multirow[b]{2}{*}{$\begin{array}{c}\text { Red } \\
\text { Road } \\
\text { (9.97 miles) }\end{array}$} \\
\hline & & & & $\begin{array}{c}\text { Prior } \\
\text { to } \\
\text { control }\end{array}$ & $\begin{array}{l}\text { Below } \\
\text { control }\end{array}$ & $\begin{array}{l}\text { Above } \\
\text { control }\end{array}$ & & & & & \\
\hline \begin{tabular}{lr}
\multicolumn{2}{c}{1940} \\
Mar. & 16 \\
Apr. & 3 \\
Apr. & 14 \\
May & 3 \\
May & 16
\end{tabular} & $\begin{array}{r}15,780 \\
11,760 \\
2,750 \\
17,410 \\
16,360\end{array}$ & $\begin{array}{l}10,010 \\
51 \\
11,860 \\
16,450 \\
17,750\end{array}$ & $\begin{array}{r}56 \\
47 \\
46 \\
10,740 \\
12,930\end{array}$ & (…...... & 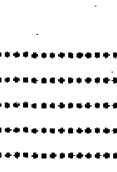 & 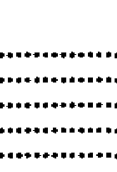 & 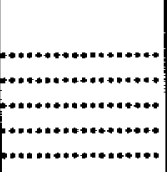 & $\begin{array}{r}27 \\
25 \\
25 \\
25 \\
3,280\end{array}$ & $\begin{array}{l}24 \\
23 \\
23 \\
22 \\
17\end{array}$ & $\begin{array}{l}26 \\
25 \\
25 \\
24 \\
21\end{array}$ & $\begin{array}{l}16 \\
15 \\
16 \\
15 \\
15\end{array}$ \\
\hline $\begin{array}{lr}\text { June } & 5 \\
\text { June } & 17 \\
\text { July } & 1 \\
\text { July } & 18 \\
\text { Aug. } & 1\end{array}$ & $\begin{array}{r}6,080 \\
9,320 \\
14,960 \\
1,390 \\
8,640\end{array}$ & $\begin{array}{r}290 \\
97 \\
7,260 \\
6.520 \\
13,990\end{array}$ & $\begin{array}{r}378 \\
65 \\
60 \\
62 \\
520\end{array}$ & 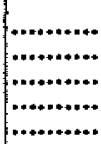 & (n........ & & - & $\begin{array}{l}24 \\
23 \\
24 \\
23 \\
22\end{array}$ & $\begin{array}{l}22 \\
24 \\
23 \\
21 \\
20\end{array}$ & $\begin{array}{l}23 \\
24 \\
24 \\
22 \\
22\end{array}$ & $\begin{array}{l}18 \\
17 \\
16 \\
15 \\
15\end{array}$ \\
\hline $\begin{array}{lr}\text { Aug. } & 16 \\
\text { Sept. } & 4 \\
\text { Sept. } & 18 \\
\text { Oct. } & 3 \\
\text { Oct. } & 18\end{array}$ & $\begin{array}{l}14,480 \\
15,680 \\
12,680 \\
13,560 \\
14,040\end{array}$ & $\begin{array}{r}165 \\
13,120 \\
70 \\
63 \\
64\end{array}$ & $\begin{array}{r}71 \\
5,140 \\
57 \\
62 \\
49\end{array}$ & ( & 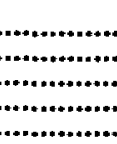 & $\ldots . .$. & 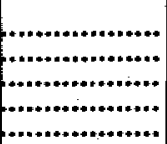 & $\begin{array}{l}19 \\
26 \\
24 \\
27 \\
20\end{array}$ & $\begin{array}{l}21 \\
20 \\
18 \\
13 \\
18\end{array}$ & $\begin{array}{l}21 \\
22 \\
18 \\
15 \\
19\end{array}$ & $\begin{array}{l}13 \\
14 \\
12 \\
10 \\
19\end{array}$ \\
\hline $\begin{array}{lr}\text { Nov. } & 1 \\
\text { Now. } & 15 \\
\text { Dec. } & 3 \\
\text { Dec. } & 17\end{array}$ & $\begin{array}{l}13,900 \\
15,640 \\
16,600 \\
12,150 .\end{array}$ & $\begin{array}{r}63 \\
59 \\
10,980 \\
215\end{array}$ & $\begin{array}{l}52 \\
52 \\
92 \\
69\end{array}$ & 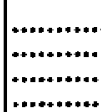 & ........... & ................. & 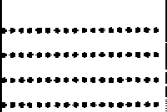 & $\begin{array}{l}23 \\
22 \\
25 \\
24\end{array}$ & $\begin{array}{l}17 \\
20 \\
21 \\
19\end{array}$ & $\begin{array}{l}19 \\
20 \\
21 \\
21\end{array}$ & $\begin{array}{l}17 \\
18 \\
37 \\
17\end{array}$ \\
\hline \begin{tabular}{lr}
\multicolumn{2}{c}{1941} \\
Jan. & 18 \\
Jan. & 31 \\
Feb. & 19 \\
Mar. & 1 \\
Mar. & 14
\end{tabular} & $\begin{array}{r}11,320 \\
17,600 \\
15,010 \\
16,690 \\
2,025\end{array}$ & $\begin{array}{r}71 \\
8,540 \\
54 \\
11,320 \\
12,250\end{array}$ & $\begin{array}{r}48 \\
780 \\
43 \\
37 \\
40\end{array}$ & (…....... & ......... & (n) & 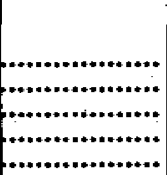 & $\begin{array}{l}21 \\
23 \\
20 \\
19 \\
18\end{array}$ & $\begin{array}{l}18 \\
19 \\
18 \\
18 \\
17\end{array}$ & $\begin{array}{l}19 \\
21 \\
18 \\
18 \\
18\end{array}$ & $\begin{array}{l}15 \\
16 \\
17 \\
17 \\
16\end{array}$ \\
\hline $\begin{array}{r}\text { Apr. } \\
\text { Apr. } \\
18\end{array}$ & $\begin{array}{r}233 \\
9,520\end{array}$ & $\begin{array}{r}11,080 \\
92\end{array}$ & $\begin{array}{r}13,750 \\
50\end{array}$ & & & & & $\begin{array}{l}22 \\
22\end{array}$ & $\begin{array}{l}19 \\
19\end{array}$ & $\begin{array}{l}19 \\
19\end{array}$ & $\begin{array}{l}16 \\
15\end{array}$ \\
\hline
\end{tabular}




\begin{tabular}{|c|c|c|}
\hline $\begin{array}{l}\text { May } 1 \\
\text { May } 20 \\
\text { June }\end{array}$ & $\begin{array}{l}16,740 \\
15,540 \\
11,910\end{array}$ & $\begin{array}{l}14,040 \\
10,010 \\
12,400\end{array}$ \\
\hline $\begin{array}{l}\text { June } \\
\text { July } \\
\text { July } \\
\text { July } \\
\text { Aug. } \\
\text { Ao } \\
18\end{array}$ & $\begin{array}{r}18,700 \\
2,550 \\
95 \\
14,140 \\
13,370\end{array}$ & $\begin{array}{r}17,080 \\
315 \\
67 \\
10,790 \\
8,730\end{array}$ \\
\hline $\begin{array}{ll}\text { Sept. } \\
\text { Oct. } \\
\text { Oct. } & 17 \\
\text { Oct. } & 31 \\
\text { Nov. } & 14\end{array}$ & $\begin{array}{l}10,740 \\
15,400 \\
15,100 \\
11,300 \\
13,600\end{array}$ & $\begin{array}{r}7,260 \\
54 \\
11,200 \\
10,500 \\
45\end{array}$ \\
\hline $\begin{array}{l}\text { Nov. } 28 \\
\text { Dec. } 26\end{array}$ & $\begin{array}{l}17,800 \\
15 ; 100\end{array}$ & $\begin{array}{r}13,000 \\
9,860\end{array}$ \\
\hline \begin{tabular}{l}
\multicolumn{2}{c}{1942} \\
Jan. \\
Jan. 16 \\
Feb. \\
Feb. 17 \\
Mar. 4
\end{tabular} & $\begin{array}{l}13,300 \\
18,000 \\
18,200 \\
17,300 \\
17,400\end{array}$ & $\begin{array}{l}14,800 \\
16,900 \\
17,200 \\
16,200 \\
14,100\end{array}$ \\
\hline $\begin{array}{l}\text { Mar. } 19 \\
\text { Apr. } \\
\text { Apr. } 28 \\
\text { May } \\
\text { May } 22\end{array}$ & $\begin{array}{r}17,500 \\
18,500 \\
68 \\
93 \\
8,640\end{array}$ & $\begin{array}{r}15,500 \\
17,600 \\
48 \\
45 \\
4,350\end{array}$ \\
\hline $\begin{array}{l}\text { June } \\
\text { June } 24 \\
\text { July } \\
\text { July } 24 \\
\text { Aug. }\end{array}$ & $\begin{array}{r}86 \\
66 \\
61 \\
1,975 \\
10,900\end{array}$ & $\begin{array}{r}29 \\
41 \\
43 \\
670 \\
6,960\end{array}$ \\
\hline $\begin{array}{l}\text { Aug. } \\
\text { Sept, } \\
\text { Oct. } \\
\text { Nov. } \\
\text { Nov. } 2\end{array}$ & $\begin{array}{r}2,300 \\
278 \\
5,620 \\
15,800 \\
10,800\end{array}$ & $\begin{array}{r}51 \\
32 \\
11,600 \\
17,200 \\
12,900\end{array}$ \\
\hline
\end{tabular}

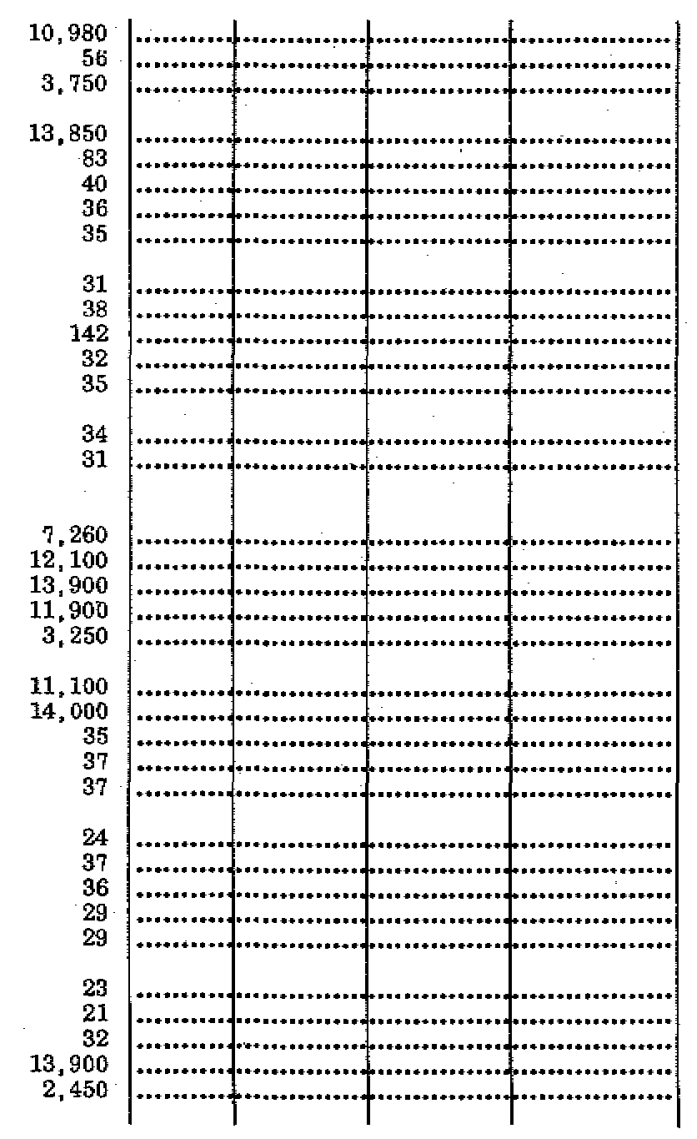


Table 73. - Chitoride concentrations in Biscayne Canal, Miami-Continued

\begin{tabular}{|c|c|c|c|c|c|c|c|c|c|c|c|}
\hline \multirow{2}{*}{ Date } & \multirow{2}{*}{$\begin{array}{c}\text { U. S. } \\
\text { Highway } 1 \\
(0.48 \text { mile })\end{array}$} & \multirow{2}{*}{$\begin{array}{l}\text { Northeast } \\
\text { 6th Avenue } \\
\text { (1.52 miles) }\end{array}$} & \multirow{2}{*}{$\begin{array}{c}\text { Dixie } \\
\text { Highway } \\
\text { (2.16 miles) }\end{array}$} & \multicolumn{3}{|c|}{$\begin{array}{l}\text { Northwest 131st Street } \\
\text { (2.84 miles) }\end{array}$} & \multirow{2}{*}{$\begin{array}{l}\text { 154th } \\
\text { Street } \\
\text { (4. } 29 \text { miles) }\end{array}$} & \multirow{2}{*}{$\begin{array}{l}\text { Northwest } \\
\text { 7th Avenue } \\
\text { (4. } 88 \text { miles) }\end{array}$} & \multirow{2}{*}{$\begin{array}{l}\text { Northwest } \\
27 \text { th Avenue } \\
\text { (6.91 miles) }\end{array}$} & \multirow{2}{*}{$\begin{array}{c}\text { Le Jeune } \\
\text { Road } \\
\text { (8.41 miles) }\end{array}$} & \multirow{2}{*}{$\begin{array}{l}\text { Red } \\
\text { Road } \\
\text { (9.97 miles) }\end{array}$} \\
\hline & & & & $\begin{array}{c}\text { Prior } \\
\text { to } \\
\text { control }\end{array}$ & $\begin{array}{l}\text { Below } \\
\text { control }\end{array}$ & $\begin{array}{l}\text { Above } \\
\text { control }\end{array}$ & & & & & \\
\hline $\begin{array}{ll} & 1942 \\
\text { Dec. } & 10 \\
\text { Dec. } & 23\end{array}$ & $\begin{array}{l}17,300 \\
13,100\end{array}$ & $\begin{array}{l}15,200 \\
13,350\end{array}$ & $\begin{array}{l}9,900 \\
4,020\end{array}$ & & & & & $\begin{array}{l}25 \\
17\end{array}$ & $\begin{array}{l}20 \\
16\end{array}$ & $\begin{array}{l}15 \\
16\end{array}$ & $\begin{array}{l}15 \\
14\end{array}$ \\
\hline \begin{tabular}{lr}
\multicolumn{2}{c}{1943} \\
Jan. & 6 \\
Jan. & 24 \\
Feb. & 8 \\
Feb. & 26 \\
Mar. & 15
\end{tabular} & $\begin{array}{l}18,600 \\
17,940 \\
14,380 \\
18,030 \\
17,170\end{array}$ & $\begin{array}{l}15,050 \\
15,490 \\
14,770 \\
15,250 \\
16,160\end{array}$ & $\begin{array}{r}6,350 \\
9,910 \\
605 \\
11,080 \\
11,710\end{array}$ & $\ldots$ & & & (n) & $\begin{array}{r}25 \\
18 \\
15 \\
17 \\
5,140\end{array}$ & $\begin{array}{l}19 \\
17 \\
15 \\
15 \\
19\end{array}$ & $\begin{array}{l}15 \\
16 \\
14 \\
14 \\
15\end{array}$ & $\begin{array}{l}15 \\
14 \\
14 \\
16 \\
13\end{array}$ \\
\hline $\begin{array}{lr}\text { Apr. } & 2 \\
\text { Apr. } & 16 \\
\text { May } & 5 \\
\text { May } & 15 \\
\text { June } & 1\end{array}$ & $\begin{array}{r}14,000 \\
17,500 \\
7,510 \\
15,400 \\
16,400\end{array}$ & $\begin{array}{r}14,700 \\
17,800 \\
4,900 \\
12,800 \\
13,900\end{array}$ & $\begin{array}{r}10,900 \\
13,500 \\
4,050 \\
1,340 \\
4,100\end{array}$ & & & & "..... & $\begin{array}{r}5,180 \\
1,325 \\
55 \\
35 \\
15\end{array}$ & $\begin{array}{l}23 \\
19 \\
16 \\
16 \\
15\end{array}$ & $\begin{array}{l}16 \\
15 \\
15 \\
15 \\
15\end{array}$ & $\begin{array}{r}15 \\
14 \\
14 \\
14\end{array}$ \\
\hline $\begin{array}{lr}\text { June } & 19 \\
\text { fuly } & 4 \\
\text { July } & 18 \\
\text { Aug. } & 4 \\
\text { Aug. } & 21\end{array}$ & $\begin{array}{r}15,400 \\
17,800 \\
17,600 \\
14,600 \\
.635\end{array}$ & $\begin{array}{r}12,400 \\
5,040 \\
16,100 \\
7,210 \\
55\end{array}$ & $\begin{array}{r}8,930 \\
7,260 \\
3,640 \\
63 \\
41\end{array}$ & & & & 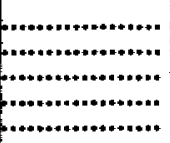 & $\begin{array}{l}32 \\
21 \\
23 \\
28 \\
21\end{array}$ & $\begin{array}{l}17 \\
15 \\
14 \\
15 \\
16\end{array}$ & $\begin{array}{l}16 \\
15 \\
15 \\
15 \\
15\end{array}$ & $\begin{array}{r}16 \\
15 \\
14 \\
17\end{array}$ \\
\hline $\begin{array}{l}\text { Sept. } 6 \\
\text { Sept. } 21 \\
\text { Oct. } 6 \\
\text { Nov. } 2 \\
\text { Nov. } 24\end{array}$ & $\begin{array}{r}99 \\
1,090 \\
15,400 \\
16,100\end{array}$ & $\begin{array}{r}71 \\
4,420 \\
49 \\
83 \\
13,900\end{array}$ & $\begin{array}{l}55 \\
35 \\
38 \\
55 \\
43\end{array}$ & (...... & & & "ש. & $\begin{array}{l}21 \\
17 \\
16 \\
18 \\
14\end{array}$ & $\begin{array}{l}16 \\
15 \\
13 \\
15 \\
13\end{array}$ & $\begin{array}{l}17 \\
15 \\
14 \\
15 \\
17\end{array}$ & $\begin{array}{l}17 \\
15 \\
13 \\
16 \\
12\end{array}$ \\
\hline Dec. 27 & 17,400 & 5,140 & 275 & & & & & 19 & 19 & 17 & 16 \\
\hline \begin{tabular}{lr}
\multicolumn{2}{c}{1944} \\
Jan. & 18 \\
Feb. & 5 \\
Feb. & 23
\end{tabular} & $\begin{array}{l}14,100 \\
18,100 \\
11,900\end{array}$ & $\begin{array}{r}7,460 \\
14,100 \\
13,900\end{array}$ & $\begin{array}{r}40 \\
7,400 \\
10,400\end{array}$ & & & & & $\begin{array}{l}16 \\
19 \\
30\end{array}$ & $\begin{array}{l}17 \\
16 \\
9.0\end{array}$ & $\begin{array}{l}15 \\
16 \\
16\end{array}$ & $\begin{array}{l}15 \\
14 \\
15\end{array}$ \\
\hline
\end{tabular}



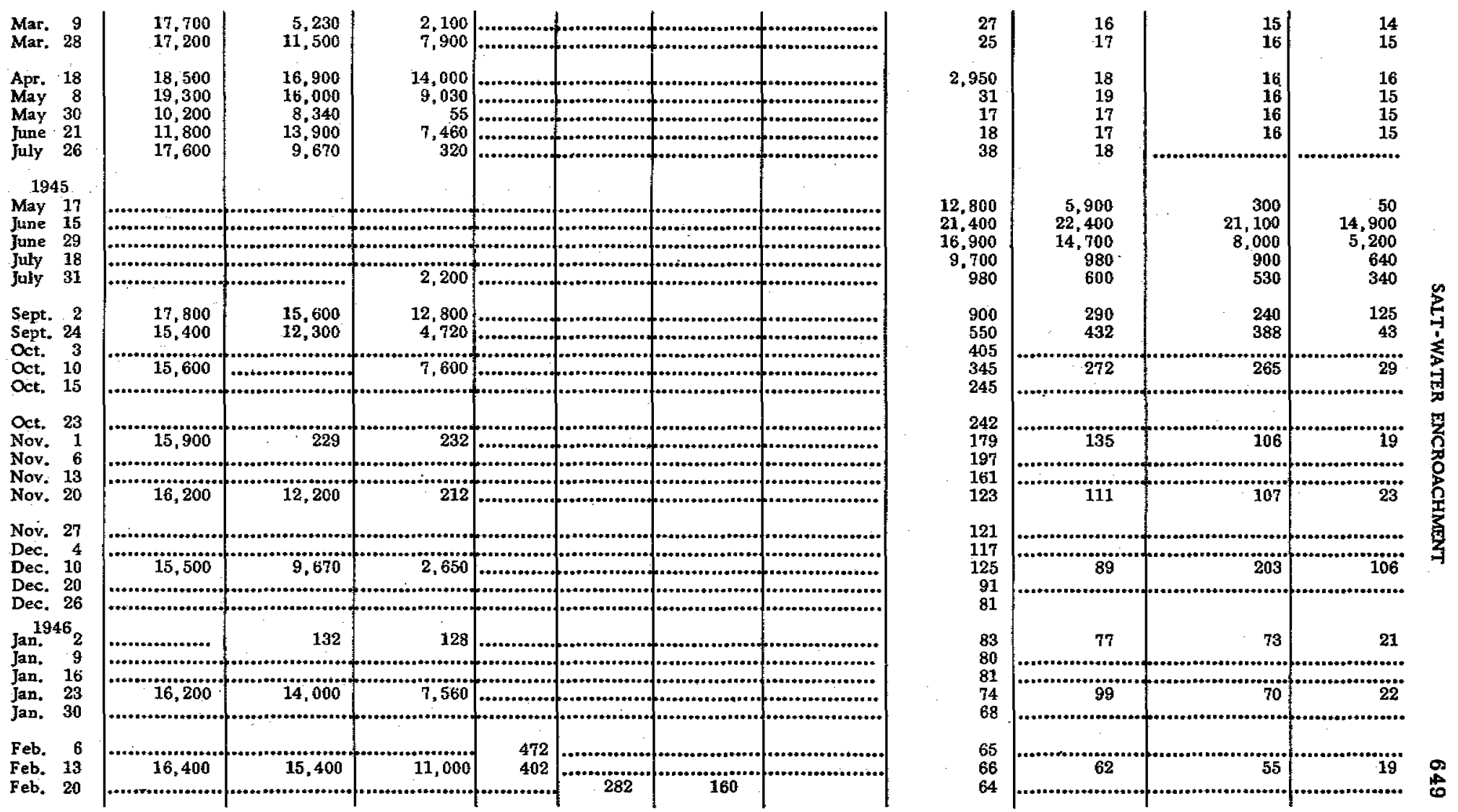
Table 73. - Chloride concentrations in Eiscayne Canal, Miami-Continued

\begin{tabular}{|c|c|c|c|c|c|c|c|c|c|c|c|}
\hline \multirow{2}{*}{ Date } & \multirow[b]{2}{*}{$\begin{array}{c}\text { U. S. } \\
\text { Highway } 1 \\
(0.48 \text { mile })\end{array}$} & \multirow[b]{2}{*}{$\begin{array}{c}\text { Northeast } \\
\text { 6th Avenue } \\
\text { (1.52 miles) }\end{array}$} & \multirow[b]{2}{*}{$\begin{array}{c}\text { Dixie } \\
\text { Highway } \\
\text { (2.16 miles) }\end{array}$} & \multicolumn{3}{|c|}{$\begin{array}{l}\text { Northwest 131st Street } \\
\quad(2.84 \text { miles })\end{array}$} & \multirow[b]{2}{*}{$\begin{array}{c}\text { 154th } \\
\text { Street } \\
\text { (4. } 29 \text { miles) }\end{array}$} & \multirow[b]{2}{*}{$\begin{array}{c}\text { Northwest } \\
7 \text { th Avenue } \\
\text { (4.88 miles) }\end{array}$} & \multirow[b]{2}{*}{$\begin{array}{l}\text { Northwest } \\
27 \text { th Avenue } \\
\text { (6.91 miles) }\end{array}$} & \multirow[b]{2}{*}{$\begin{array}{c}\text { Le Jeune } \\
\text { Road } \\
\text { (8.41 miles) }\end{array}$} & \multirow[b]{2}{*}{$\begin{array}{c}\text { Red } \\
\text { Road } \\
\text { (9.97 miles) }\end{array}$} \\
\hline & & & & $\begin{array}{c}\text { Prior } \\
\text { to } \\
\text { control }\end{array}$ & $\begin{array}{l}\text { Below } \\
\text { control }\end{array}$ & $\begin{array}{l}\text { Above } \\
\text { control }\end{array}$ & & & & & \\
\hline $\begin{array}{l}1946 \\
\text { Feb. } 27\end{array}$ & & & & & 13,600 & 990 & & 62 & & & \\
\hline Mar. 6 & 18,500 & 15,700 & 14,400 & ............... & 11,400 & 1,500 & & 35 & 37 & 31 & 16 \\
\hline $\begin{array}{l}\text { Mar. } 13 \\
\text { Mar. } 20\end{array}$ & 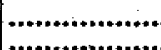 & $\ldots$ & 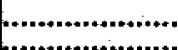 & .................. & 10,400 & $\begin{array}{l}198 \\
174\end{array}$ & ......... & 48 & $\cdots \cdots$ & 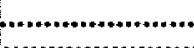 & .......... \\
\hline Mar. 26 & 18,900 & 17,900 & 17,600 & |...................... & 15,700 & 2,150 & 2,350 & 935 & 34 & 34 & 138 \\
\hline $\begin{array}{l}\text { Apr. } \\
\text { Apr. } 12\end{array}$ & ; & 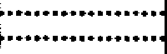 & (1) & ant......... & $\begin{array}{l}13,500 \\
14,500\end{array}$ & $\begin{array}{l}925 \\
645\end{array}$ & (a) & $\begin{array}{r}278 \\
36\end{array}$ & (1) & (1) & 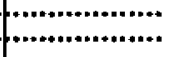 \\
\hline $\begin{array}{l}\text { Apr. } 17 \\
\text { Apr. } 24\end{array}$ & 19.700 & 18,600 & 17,800 & |................. & $\begin{array}{l}16,400 \\
16,600\end{array}$ & $\begin{array}{r}1,580 \\
860\end{array}$ & 67 & $\begin{array}{l}35 \\
39\end{array}$ & 47 & 36 & 15 \\
\hline May 1 & 20.400 & 18,700 & 18,100 & ................... & 16,400 & 2,300 & 77 & 39 & 42 & 34 & 17 \\
\hline $\begin{array}{l}\text { May } \\
\text { May } \\
15\end{array}$ & .................... & (................ & (..4............ & a............... & 12,000 & $\begin{array}{r}157 \\
35\end{array}$ & ............ & 43 & ............ & $*$ & 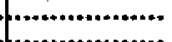 \\
\hline May 22 & 18,300 & 15,700 & 14,200 & $\cdots$ & 9,080 & 36 & 32 & 34 & 41 & 39 & 16 \\
\hline $\begin{array}{l}\text { May } 29 \\
\text { hune } 5\end{array}$ & , .................. & 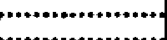 & ............... & ................. & 13,900 & 395 & 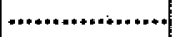 & 35 & . & $\ldots \ldots \ldots \ldots$ & (.......................... \\
\hline $\begin{array}{r}\text { June } \\
\text { June } 12\end{array}$ & 16,200 & 6,570 & 1,000 & 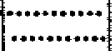 & $\begin{array}{r}10,100 \\
134\end{array}$ & $\begin{array}{l}675 \\
670\end{array}$ & 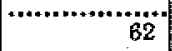 & $\begin{array}{l}47 \\
31\end{array}$ & $(\cdots+\ldots+\ldots \ldots$ & 31 & 19 \\
\hline June 19 & (.............. & & & ................. & 85 & 91 & .............. & 47 & ........ & & ...... \\
\hline June 26 & & & & & 115 & 101 & & 46 & & & \\
\hline July 3 & 16,100 & 178 & 115 & a............ & 99 & 85 & & 42 & 37 & 39 & 18 \\
\hline $\begin{array}{ll}\text { July } & 10 \\
\text { July } & 17\end{array}$ & …......... & ........... & ....... & (n................... & 70 & 72 & ,........... & 40 & $\cdots$ & $1 . .+$ & ....* \\
\hline July 24 & 16,200 & 9,500 & $110^{\circ}$ & a............... & 60 & 60 & (............... & 40 & $\cdots \cdots$ & ....* & ..........* \\
\hline & & & & & & 年 & & 10 & 30 & , & 0 \\
\hline Aug. 14 & 16,000 & 13,900 & 4,200 & & 60 & 60 & & 40 & siv & 20 & 20 \\
\hline $\begin{array}{l}\text { Aug. } 28 \\
\text { Sept. } 11\end{array}$ & 13,000 & 15,600 & 9,600 & .............. & 50 & 40 & ........................ & 20 & 20 & 20 & 20 \\
\hline Sept. 25 & 16,000 & 12,900 & 4,320 & $\mid$ & 55 & 57 & ….................. & 31 & 31 & 29 & 13 \\
\hline Oct. 9 & 16,500 & 12,700 & 99 & & 701 & 57 & & & & & .• \\
\hline
\end{tabular}




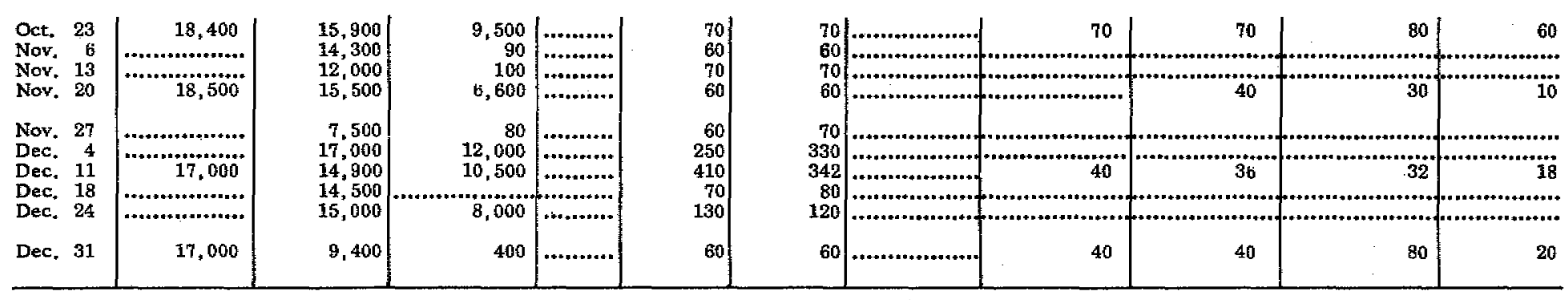




\section{HTTLE RUVER CANAL}

Little River Canal is fairly large and the lower reaches are moderately free of weeds-the pattern of movement of the salt front resembles that of Miami Canal. Table 74 presents the observed chloride concentrations. Little River Canal was uncontrolled until 1946, and the salt front generally was located between the Florida East Coast Railway and NW. 95th Street. No large supply was dependent upon its freshness although a number of adjacent small wells were contảminated and rendered unusable for periods of varying length.

As with Biscayne Canal, Little River Canal was contaminated in 1945 from Biscayne Bay to Red Road, a distance of 8.4 miles. Although the canal channel could have been quickly flushed out in the succeeding wet period, the continuing moderate contamination in the westerly reaches indicated that some contaminated ground water was entering the canal.

A dam was installed at NW. 7th Avenue in 1946 to reduce loss of fresh water to the bay and to act as a barrier to salty water. 
Table 74. - Chloride concentrations in Little River Conal, Miami

[Parts per million. Betore October 1, 1941, the values are the highest obtained from either surface or bottom samples (ustally the latter); after October 1, 1941, the values are from bottom samples. Mileages in parentheses indicate from mouth of canal at Biscayne Bay]

\begin{tabular}{|c|c|c|c|c|c|c|c|c|c|c|c|c|c|}
\hline \multirow{2}{*}{ Daté } & \multirow{2}{*}{$\begin{array}{c}\text { U. S. } \\
\text { Higfway } 1 \\
(0.74 \text { mile })\end{array}$} & \multicolumn{2}{|c|}{ Northeast } & \multirow{2}{*}{$\begin{array}{c}\text { North } \\
\text { Miami } \\
\text { Avemue } \\
\text { (1.85 miles) }\end{array}$} & \multicolumn{3}{|c|}{$\begin{array}{l}\text { Northwest } 7 \text { th Avenue } \\
\text { (2.65 miles) }\end{array}$} & \multirow{2}{*}{$\begin{array}{l}\text { Northwest } \\
95 \text { th Street } \\
(3.75 \text { miles) }\end{array}$} & \multirow{2}{*}{$\begin{array}{l}\text { Northwest } \\
\text { 27th Avenue } \\
\text { (5.34 miles) }\end{array}$} & \multirow{2}{*}{$\begin{array}{c}\text { Le Jeume } \\
\text { Roac } \\
\text { (6. } 88 \text { miles) }\end{array}$} & \multirow{2}{*}{$\begin{array}{c}\text { East } \\
\text { 4th Avenue, } \\
: \text { Hialeah } \\
(7.38 \text { miles })\end{array}$} & \multirow{2}{*}{$\begin{array}{c}\text { Palm } \\
\text { Avemue } \\
\text { (7. } 98 \text { miles })\end{array}$} & \multirow{2}{*}{$\begin{array}{c}\text { Red } \\
\text { Road } \\
\text { (8.38 miles) }\end{array}$} \\
\hline & & $\begin{array}{l}79 \text { th Street } \\
\text { (0.99 mile) }\end{array}$ & $\begin{array}{l}\text { 2nd Avenue } \\
\text { (1.60 miles) }\end{array}$ & & $\begin{array}{c}\text { Prior } \\
\text { to } \\
\text { control }\end{array}$ & $\begin{array}{l}\text { Below } \\
\text { control }\end{array}$ & $\begin{array}{l}\text { Above } \\
\text { control }\end{array}$ & & & & & & \\
\hline \begin{tabular}{rr}
\multicolumn{2}{c}{1940} \\
Apr. & 3 \\
Apr. & 14 \\
May & 3 \\
May & 16 \\
June & 5
\end{tabular} & $\begin{array}{l}14,910 \\
13,990 \\
18.230 \\
18,890 \\
14.620\end{array}$ & 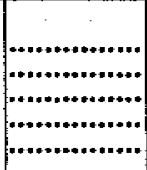 & $\begin{array}{r}11,320 \\
15,010 \\
17,170 \\
125\end{array}$ & $\mid$ & $\begin{array}{r}37 \\
750 \\
10,980 \\
11,910 \\
96\end{array}$ & & & $\begin{array}{r}34 \\
34 \\
8,880 \\
9,080 \\
109\end{array}$ & 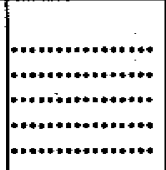 & $\begin{array}{l}19 \\
19 \\
18 \\
18 \\
18\end{array}$ & . & $\because$. & $\begin{array}{l}20 \\
21 \\
19 \\
19 \\
16\end{array}$ \\
\hline $\begin{array}{lr}\text { June } & 17 \\
\text { July } & 1 \\
\text { July } & 18 \\
\text { Aug. } & 1 \\
\text { Aug. } & 16\end{array}$ & $\begin{array}{l}14,720 \\
14,720 \\
15,640 \\
17,170 \\
14,670\end{array}$ & |an & $\begin{array}{r}59 \\
5,360 \\
8,930 \\
13,370 \\
125\end{array}$ & 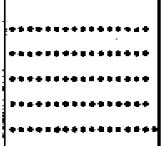 & $\begin{array}{r}46 \\
50 \\
1,680 \\
6,420 \\
101\end{array}$ & & & $\begin{array}{r}39 \\
46 \\
442 \\
3,500 \\
48\end{array}$ & $\begin{array}{r}21 \\
17\end{array}$ & $\begin{array}{l}18 \\
19 \\
18 \\
18 \\
18\end{array}$ & $\mid \begin{array}{l}\ldots \ldots \ldots \ldots \\
\ldots \ldots \ldots \ldots \ldots \\
\ldots \ldots \ldots \ldots \ldots\end{array}$ & $\ddot{\because .}$ & $\begin{array}{l}18 \\
21 \\
20 \\
20 \\
19\end{array}$ \\
\hline $\begin{array}{lr}\text { Sept. } & 4 \\
\text { Sept. } & 18 \\
\text { Oct. } & 3 \\
\text { Oct. } & 18 \\
\text { Nov. } & 1\end{array}$ & $\begin{array}{r}15,100 \\
12,540 \\
11,280 \\
15,970 \\
7,560\end{array}$ & 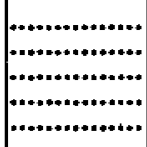 & $\begin{array}{r}7,700 \\
52 \\
52 \\
7,410 \\
42\end{array}$ & 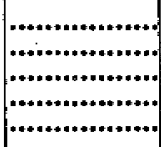 & $\begin{array}{r}1,130 \\
43 \\
68 \\
55 \\
38\end{array}$ & & & $\begin{array}{l}32 \\
42 \\
41 \\
37 \\
30\end{array}$ & $\begin{array}{l}21 \\
21 \\
19 \\
18 \\
19\end{array}$ & $\begin{array}{l}18 \\
16 \\
13 \\
18 \\
17\end{array}$ & $\left.\mid \begin{array}{ll}{[\ldots \ldots} \\
\cdots\end{array}\right]$ & 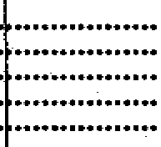 & $\begin{array}{l}18 \\
15 \\
15 \\
18 \\
17\end{array}$ \\
\hline $\begin{array}{c}\text { Nov. } 15 \\
\text { Dec. } 3 \\
\text { Dec. } 17 \\
1941\end{array}$ & $\begin{array}{l}15,830 \\
13,320 \\
15,250\end{array}$ & 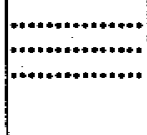 & $\begin{array}{r}46 \\
2,310 \\
10,200\end{array}$ & & $\begin{array}{r}37 \\
32 \\
261\end{array}$ & & & $\begin{array}{l}31 \\
29 \\
24\end{array}$ & $\begin{array}{l}18 \\
19 \\
18\end{array}$ & $\begin{array}{l}18 \\
17 \\
17\end{array}$ & $\cdots$ & & $\begin{array}{l}17 \\
18 \\
19\end{array}$ \\
\hline $\begin{array}{lr}\text { Jan. } & 18 \\
\text { Jat. } & 31 \\
\text { Feb. } & 19 \\
\text { Mar. } & 1 \\
\text { Mar. } & 14\end{array}$ & $\begin{array}{l}15,640 \\
16,500 \\
13,510 \\
14,960 \\
14,380\end{array}$ & 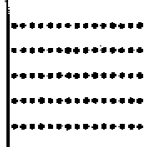 & $\begin{array}{r}9,910 \\
13,270 \\
1,730 \\
7,560 \\
9,320\end{array}$ & 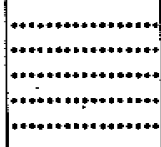 & $\begin{array}{r}37 \\
9,030 \\
27 \\
29 \\
31\end{array}$ & & & $\begin{array}{r}24 \\
770 \\
23 \\
26 \\
25\end{array}$ & $\begin{array}{l}17 \\
21 \\
16 \\
17 \\
17\end{array}$ & $\begin{array}{l}17 \\
17 \\
18 \\
18 \\
17\end{array}$ & 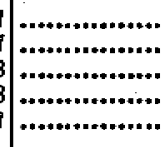 & 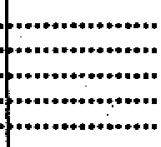 & $\begin{array}{l}19 \\
18 \\
18 \\
19 \\
18\end{array}$ \\
\hline $\begin{array}{lr}\text { Apr. } & 3 \\
\text { Apr. } & 18\end{array}$ & $\begin{array}{l}14,620 \\
13,940\end{array}$ & $\mid$ & $\begin{array}{l}6,170 \\
7,750\end{array}$ & 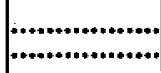 & $\begin{array}{r}267 \\
28\end{array}$ & & & $\begin{array}{l}24 \\
25\end{array}$ & 17 & $\begin{array}{l}17 \\
17\end{array}$ & & & $\begin{array}{l}17 \\
19\end{array}$ \\
\hline
\end{tabular}


Table 74.-Chloride concentrations in Little River Canal, Miami-Continued

\begin{tabular}{|c|c|c|c|c|c|c|c|c|c|c|c|c|c|}
\hline \multirow{2}{*}{ Date } & \multirow[b]{2}{*}{$\begin{array}{c}\text { U. S. } \\
\text { Highway } 1 \\
\text { (0.74 mile) }\end{array}$} & \multirow[b]{2}{*}{$\begin{array}{l}\text { Northeast } \\
79 \text { th Street } \\
\text { (0.99 mile) }\end{array}$} & \multirow[b]{2}{*}{$\begin{array}{l}\text { Northeast } \\
\text { 2nd Avenue } \\
\text { (1. 60 miles) }\end{array}$} & \multirow{2}{*}{$\begin{array}{c}\text { North } \\
\text { Miami } \\
\text { Avenue } \\
\text { (1.85 miles) }\end{array}$} & \multicolumn{3}{|c|}{$\begin{array}{l}\text { Northwest } 7 \text { th Avenue } \\
\text { (2.65 miles) }\end{array}$} & \multirow[b]{2}{*}{$\begin{array}{l}\text { Northwest } \\
95 \text { th Street } \\
\text { (9.75 miles) }\end{array}$} & \multirow[b]{2}{*}{$\begin{array}{l}\text { Northwest } \\
\text { 27th Avesue } \\
\text { (5.34 miles) }\end{array}$} & \multirow[b]{2}{*}{$\begin{array}{l}\text { Le Jeune } \\
\text { Road } \\
\text { (6. } 88 \text { miles }\end{array}$} & \multirow{2}{*}{$\begin{array}{c}\text { East } \\
\text { 4th Avenue, } \\
\text { i fialea: } \\
\text { (7. } 38 \text { miles) }\end{array}$} & \multirow[b]{2}{*}{$\begin{array}{c}\text { Palm } \\
\text { Avenue } \\
\text { (7.88 miles) }\end{array}$} & \multirow[b]{2}{*}{$\begin{array}{c}\text { Red } \\
\text { Road } \\
\text { (8. } 38 \text { miles) }\end{array}$} \\
\hline & & & & & $\begin{array}{c}\text { Prior } \\
\text { to } \\
\text { control }\end{array}$ & $\begin{array}{l}\text { Below } \\
\text { control }\end{array}$ & $\begin{array}{l}\text { Above } \\
\text { control }\end{array}$ & & & & & & \\
\hline \begin{tabular}{lr}
\multicolumn{2}{c}{1941} \\
May & 1 \\
May & 20 \\
June & 4
\end{tabular} & $\begin{array}{l}17,270 \\
15,780 \\
16,400\end{array}$ & 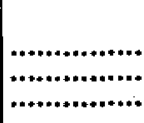 & $\begin{array}{l}13,120 \\
10,590 \\
12,930\end{array}$ & $\mid$ & $\begin{array}{r}11,180 \\
6,030 \\
10,150\end{array}$ & $\cdots$ & 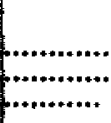 & $\begin{array}{l}2,080 \\
1,260 \\
3,620\end{array}$ & $\begin{array}{l}19 \\
17 \\
17\end{array}$ & $\begin{array}{l}18 \\
17 \\
18\end{array}$ & & & $\begin{array}{l}18 \\
17 \\
18\end{array}$ \\
\hline $\begin{array}{lr}\text { June } & 17 \\
\text { July } & 3 \\
\text { July } & 16 \\
\text { July } & 30 \\
\text { Aug. } & 18\end{array}$ & $\begin{array}{r}18,660 \\
16,400 \\
3,820 \\
15,490 \\
16,210\end{array}$ & 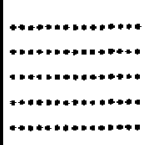 & $\begin{array}{r}15,640 \\
9,030 \\
33 \\
9,270 \\
5,930\end{array}$ & 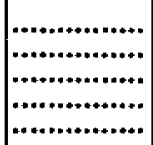 & $\begin{array}{r}13.170 \\
130 \\
25 \\
208 \\
28\end{array}$ & $\begin{array}{l}\ldots . . . \\
\cdots \cdots . \\
\cdots \cdots . \\
\cdots \cdots . \\
\cdots \cdots\end{array}$ & f & $\begin{array}{r}9,030 \\
1,120 \\
22 \\
29 \\
23\end{array}$ & $\begin{array}{l}20 \\
16 \\
15 \\
17 \\
17\end{array}$ & $\begin{array}{l}19 \\
17 \\
16 \\
16 \\
17\end{array}$ & .......... & $+\cdots \cdot$. & $\begin{array}{l}17 \\
17 \\
15 \\
19 \\
15\end{array}$ \\
\hline $\begin{array}{lr}\text { Sept. } & 3 \\
\text { Oct. } & 1 \\
\text { Oct. } & 17 \\
\text { Oct. } & 31 \\
\text { Nov, } & 14\end{array}$ & $\begin{array}{l}14,670 \\
13,300 \\
15,700 \\
11,800 \\
15,400\end{array}$ & 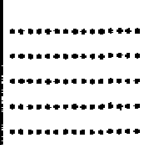 & $\begin{array}{r}9,910 \\
250 \\
11,500 \\
9,860 \\
4,780\end{array}$ & 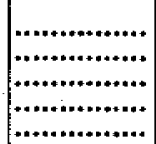 & $\begin{array}{r}558 \\
25 \\
870 \\
1,110 \\
39\end{array}$ & $\mid \begin{array}{l}\cdots \cdots \\
\cdots \cdots \\
\cdots \cdots \cdots \\
\cdots \cdots \\
\cdots \cdots\end{array}$ & {$\left[\begin{array}{c}{[\ldots \ldots} \\
\ldots \ldots \ldots \ldots\end{array}\right.$} & $\begin{array}{l}21 \\
22 \\
19 \\
21 \\
20\end{array}$ & $\begin{array}{l}16 \\
16 \\
16 \\
16 \\
17\end{array}$ & $\begin{array}{l}16 \\
16 \\
15 \\
17 \\
17\end{array}$ & (............ & 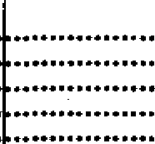 & $\begin{array}{l}16 \\
16 \\
16 \\
16 \\
17\end{array}$ \\
\hline $\begin{array}{l}\text { Nov. } 28 \\
\text { Dec. } 24\end{array}$ & $\begin{array}{l}15,100 \\
16,900\end{array}$ & …........................... & $\begin{array}{r}8,930 \\
12,400\end{array}$ & 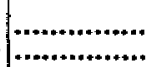 & $\begin{array}{r}245 \\
8,640\end{array}$ & $\ldots .$. & (............................... & $\begin{array}{l}21 \\
21\end{array}$ & $\begin{array}{l}16 \\
16\end{array}$ & $\begin{array}{l}18 \\
16\end{array}$ & & & $\begin{array}{l}16 \\
16\end{array}$ \\
\hline \begin{tabular}{lr}
\multicolumn{2}{c}{1942} \\
Jan. & 3 \\
Jan. & 16 \\
Feb. & 4 \\
Feb. & 17 \\
Mar. & 4
\end{tabular} & $\begin{array}{l}16,300 \\
15,900 \\
16,800 \\
17,300 \\
17,000\end{array}$ & 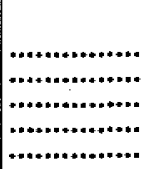 & $\begin{array}{r}12,900 \\
13,300 \\
14,500 \\
13,200 \\
8,880\end{array}$ & 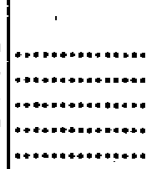 & $\begin{array}{r}5,730 \\
5,980 \\
10,300 \\
6,370 \\
1,480\end{array}$ & …..... & (…............ & $\begin{array}{r}37 \\
590 \\
4,520 \\
3,850 \\
\ldots \ldots \ldots \ldots \ldots\end{array}$ & $\begin{array}{l}17 \\
17 \\
20 \\
16 \\
16\end{array}$ & $\begin{array}{l}16 \\
16 \\
19 \\
18 \\
16\end{array}$ & 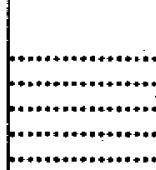 & , & $\begin{array}{l}16 \\
16 \\
19 \\
17 \\
17\end{array}$ \\
\hline $\begin{array}{lr}\text { Mar. } & 19 \\
\text { Apr. } & 2 \\
\text { Apr. } & 28 \\
\text { May } & 8 \\
\text { May } & 22\end{array}$ & $\begin{array}{r}17,600 \\
18.100 \\
308 \\
5.930 \\
13.300\end{array}$ & 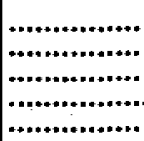 & $\begin{array}{r}13,500 \\
15,600 \\
29 \\
177 \\
7,460\end{array}$ & 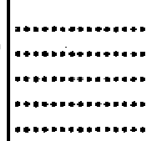 & $\begin{array}{r}7,060 \\
10,400 \\
22 \\
24 \\
26\end{array}$ & 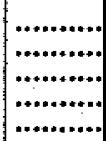 & 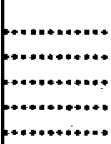 & $\begin{array}{r}5,180 \\
6,860 \\
18 \\
23 \\
24\end{array}$ & $\begin{array}{c}16 \\
133 \\
13 \\
16 \\
18\end{array}$ & $\begin{array}{l}18 \\
18 \\
12 \\
15 \\
17\end{array}$ & (.). & t............ & $\begin{array}{l}19 \\
17 \\
13 \\
14 \\
18\end{array}$ \\
\hline $\begin{array}{l}\text { June } \\
\text { June }\end{array}$ & $\begin{array}{r}12,400 \\
5,830\end{array}$ & (1.................. & $\begin{array}{r}630 \\
28\end{array}$ & $\mid$ & $\begin{array}{l}20 \\
24\end{array}$ & & & $\begin{array}{l}17 \\
19\end{array}$ & $\begin{array}{l}14 \\
15\end{array}$ & $\begin{array}{l}16 \\
15\end{array}$ & & 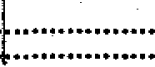 & $\begin{array}{l}13 \\
14\end{array}$ \\
\hline
\end{tabular}




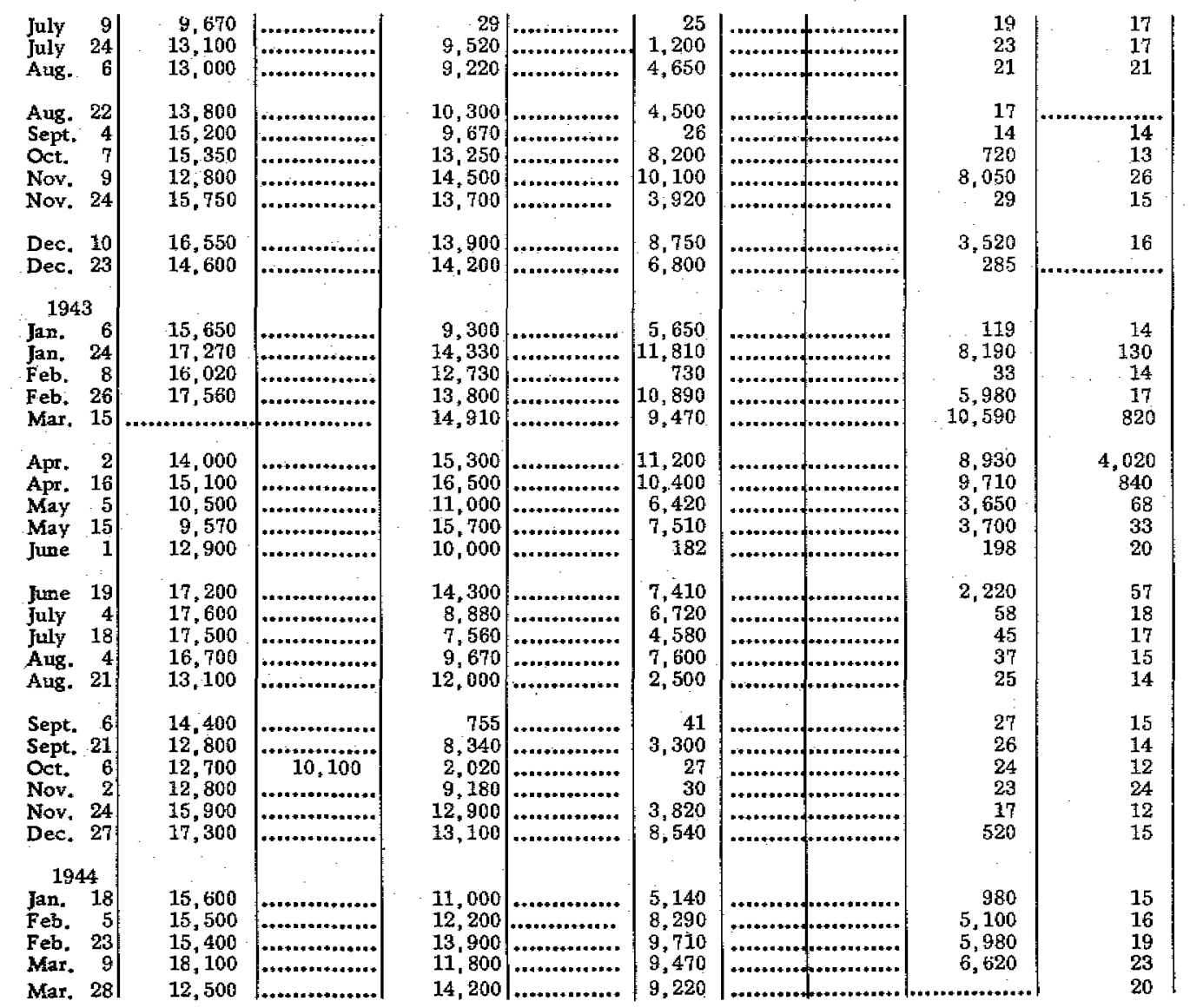

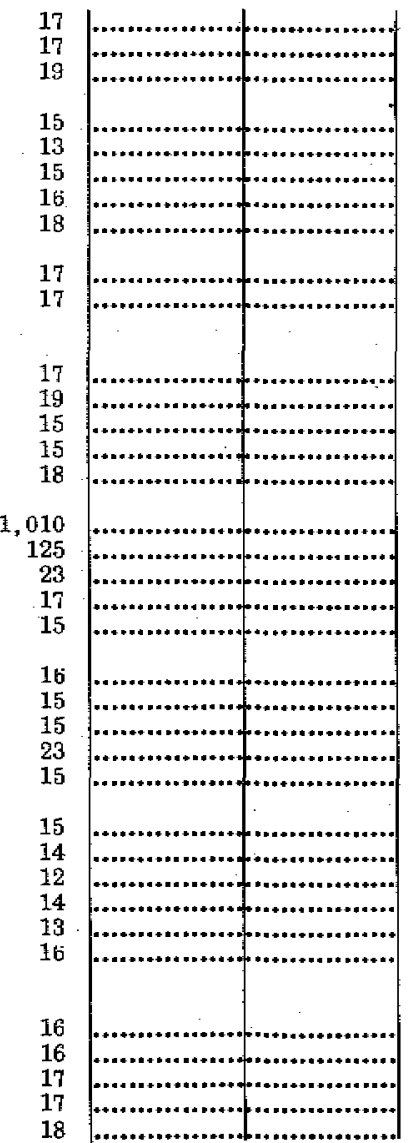


Table 74. - Chlorido concentrations in Little River Caral, Miami-Continued

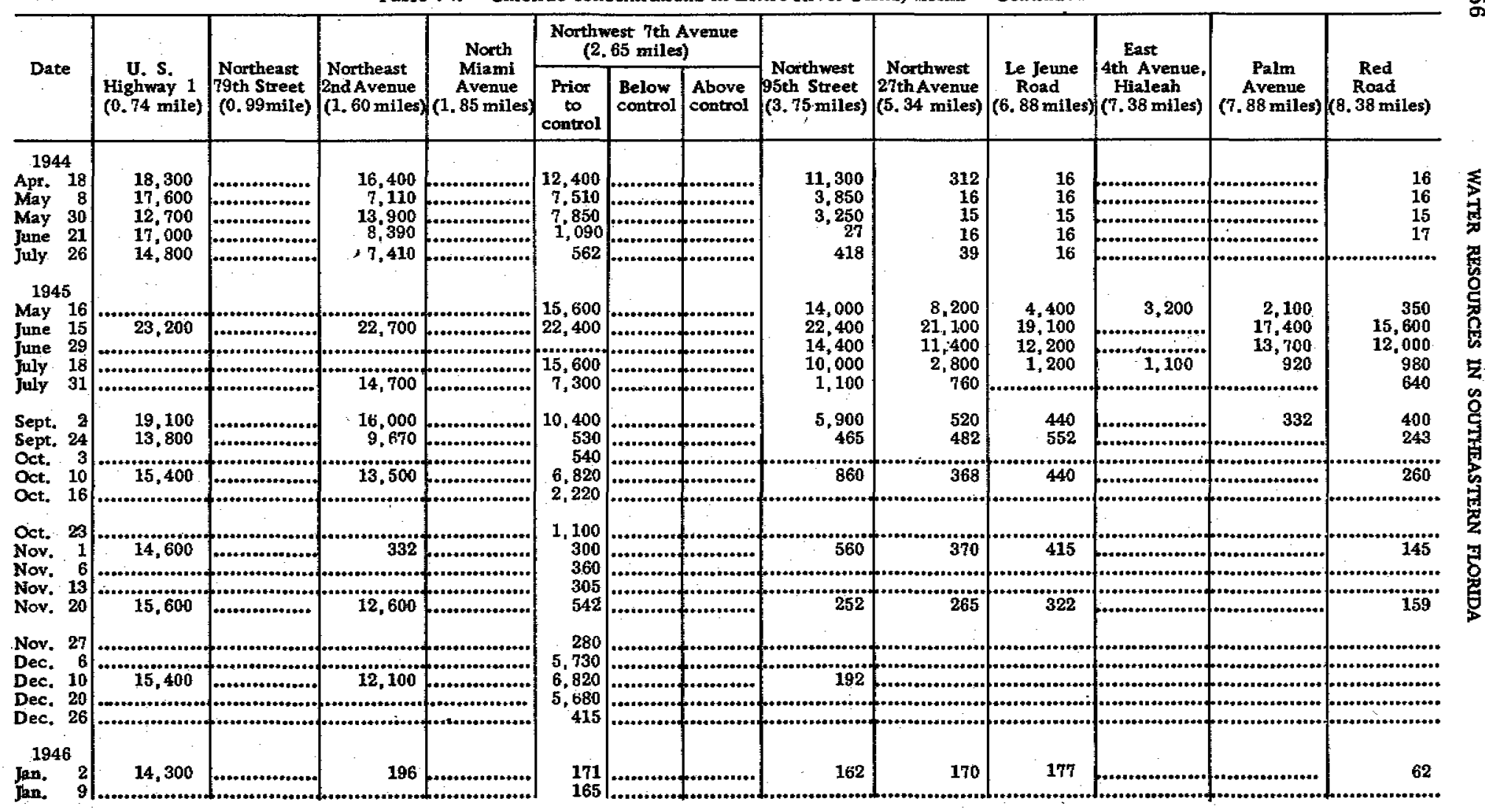



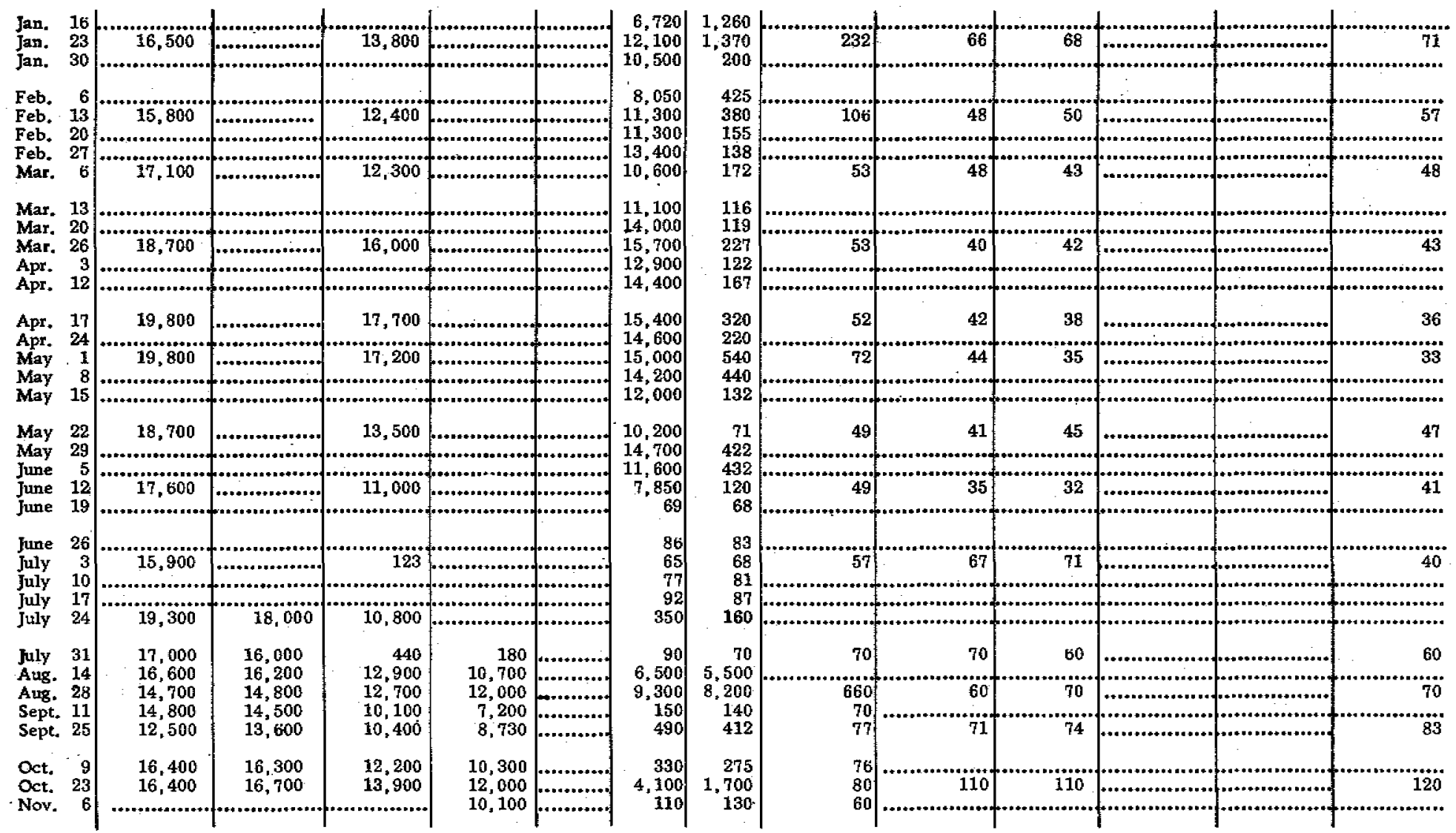
Table 74.-Chloricie concentrations it Little River Canal, Miami-Continued

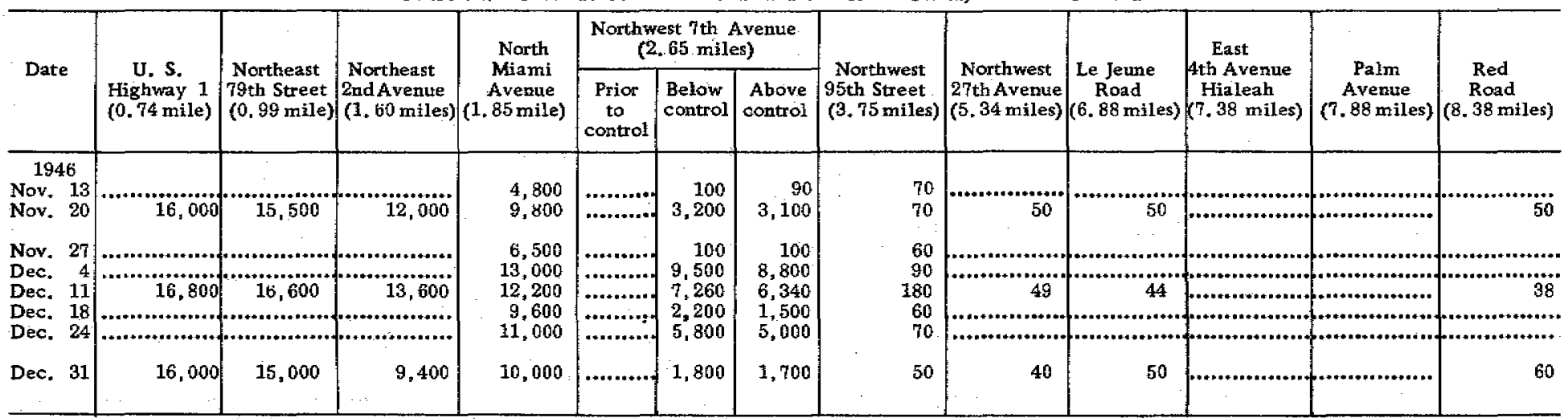


TAMIAMI CANAL

The contamination of Tamiami Canal is directly associated with that of Miami Canal, which it joins just above NW. 27 th Avenue. Table 75 presents the observed chloride concentrations. The fluctuation of the salt front is less than that of most of the other large secondary canals, owing to the sustained flow in Tamiami Canal and to the relatively steep gradient. Tamiami Canal is a threat to the municipal well field in Miami Springs because it passes the well field on the south (fig. 184) and thereby provides a source of contamination from that direction.

Ordinarily, salty water did not progress inland farther than Red Road, but in 1945 contamination was found 4.9 miles above the mouth of the canal. The Florida East Coast Railway (F.E.C.) Canal, a tributary of Tamiami Canal, extends north toward the well fields. A real threat to the water supply existed several times during the 1943-45 drought period and Tamiami Canal was dammed in 1946 below its confluence with F. E. C. Canal to prevent contamination of the well field via $F$. $E$. C. Canal. 
[Parts per million. Before October 1, 1941, the values are the highest obtained from either surface or bottom samples (usually the latter); after October 1, 1941, the values are from bottom samples. Mileages in parentheses indicate distance from mouth of canal at Miami Canal]

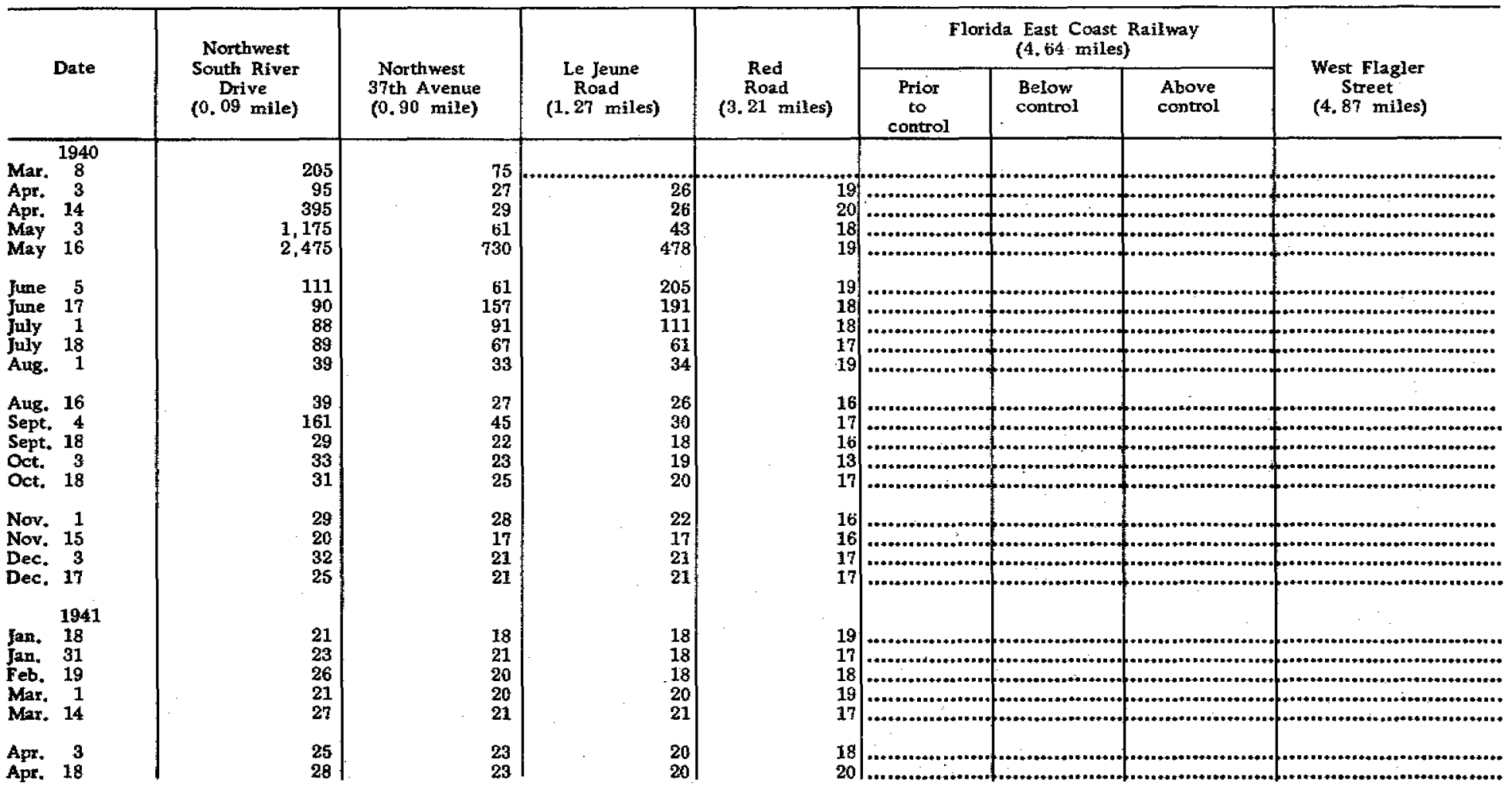




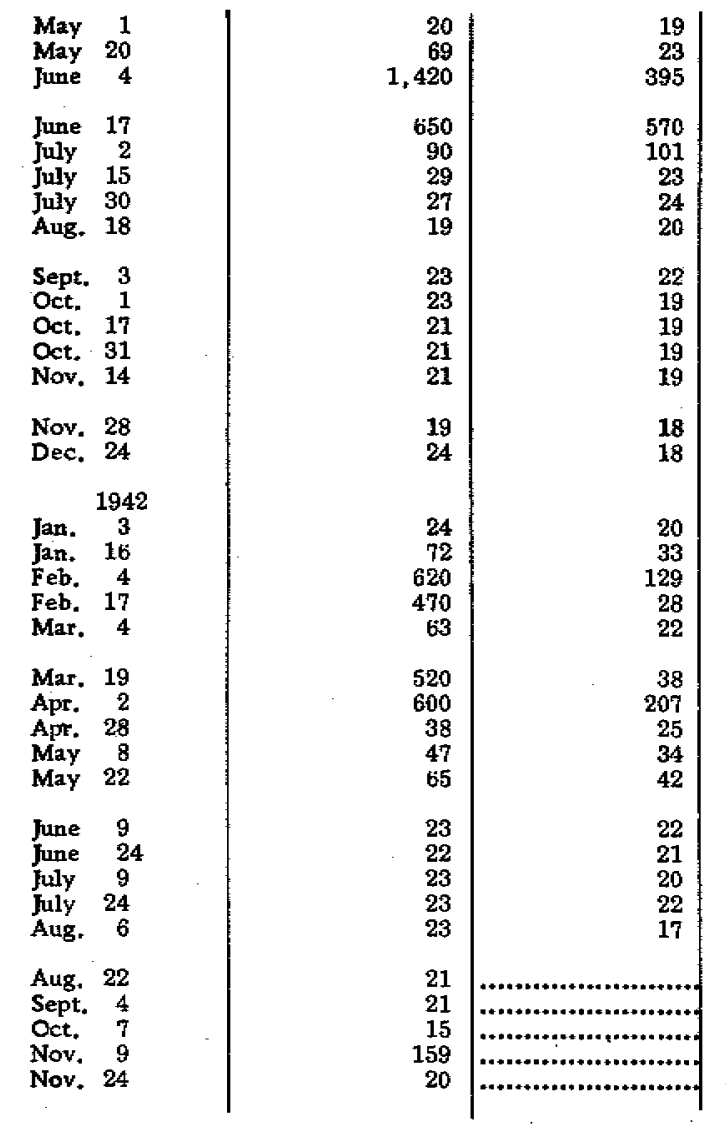

19
21
285
300
42
21
22
20
18
19
19
19
19
19
19

19
21
23
24
19
32
163
23
29
31
27
25
22
21
23
18
19
17
23
18

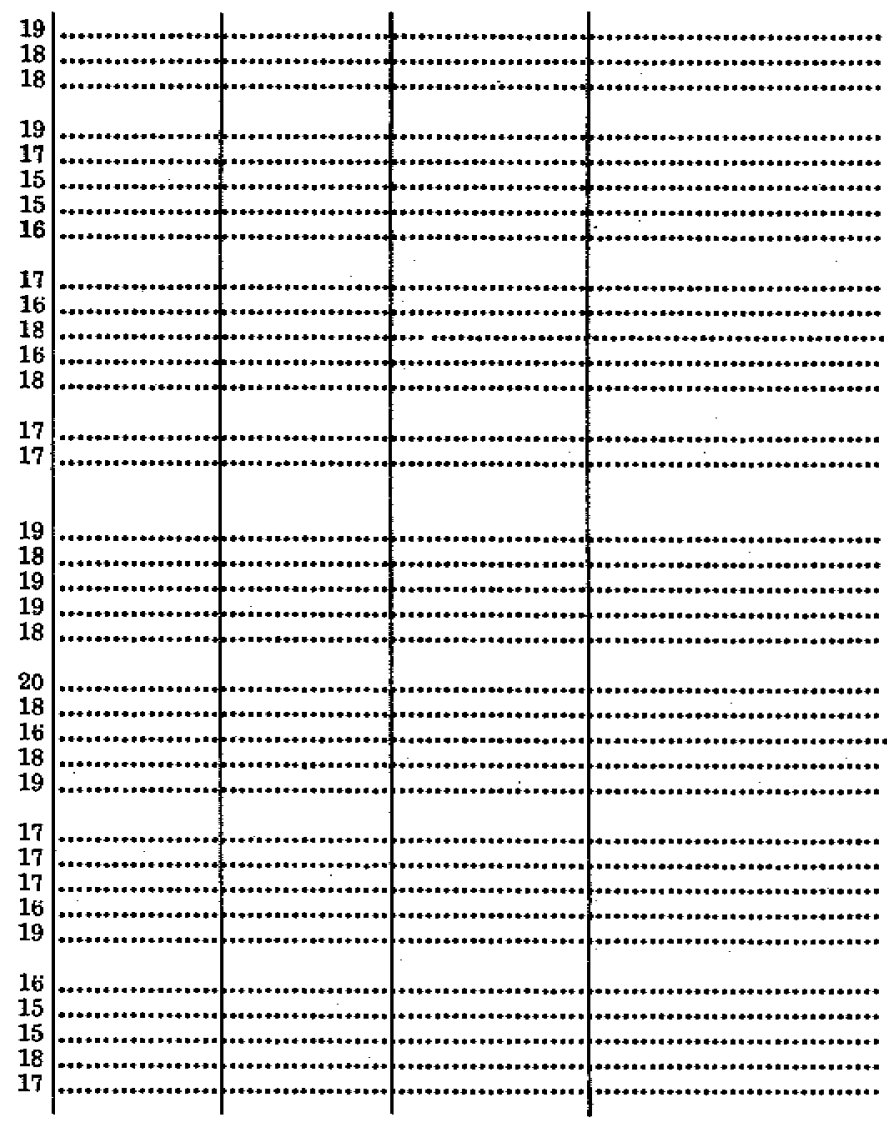


Table 75.-Chloride concentrations in Tamiani Canal, Miami-Continued

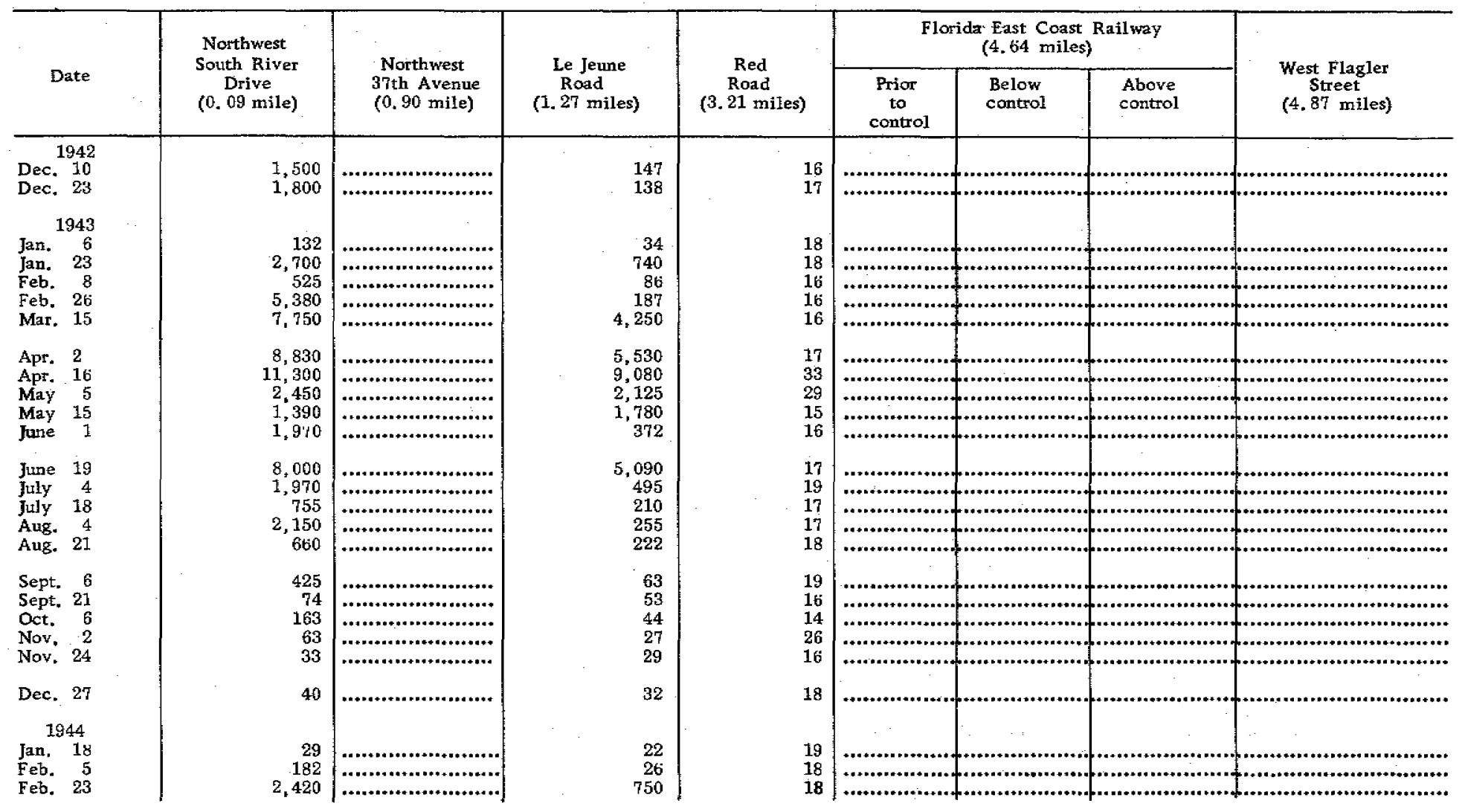




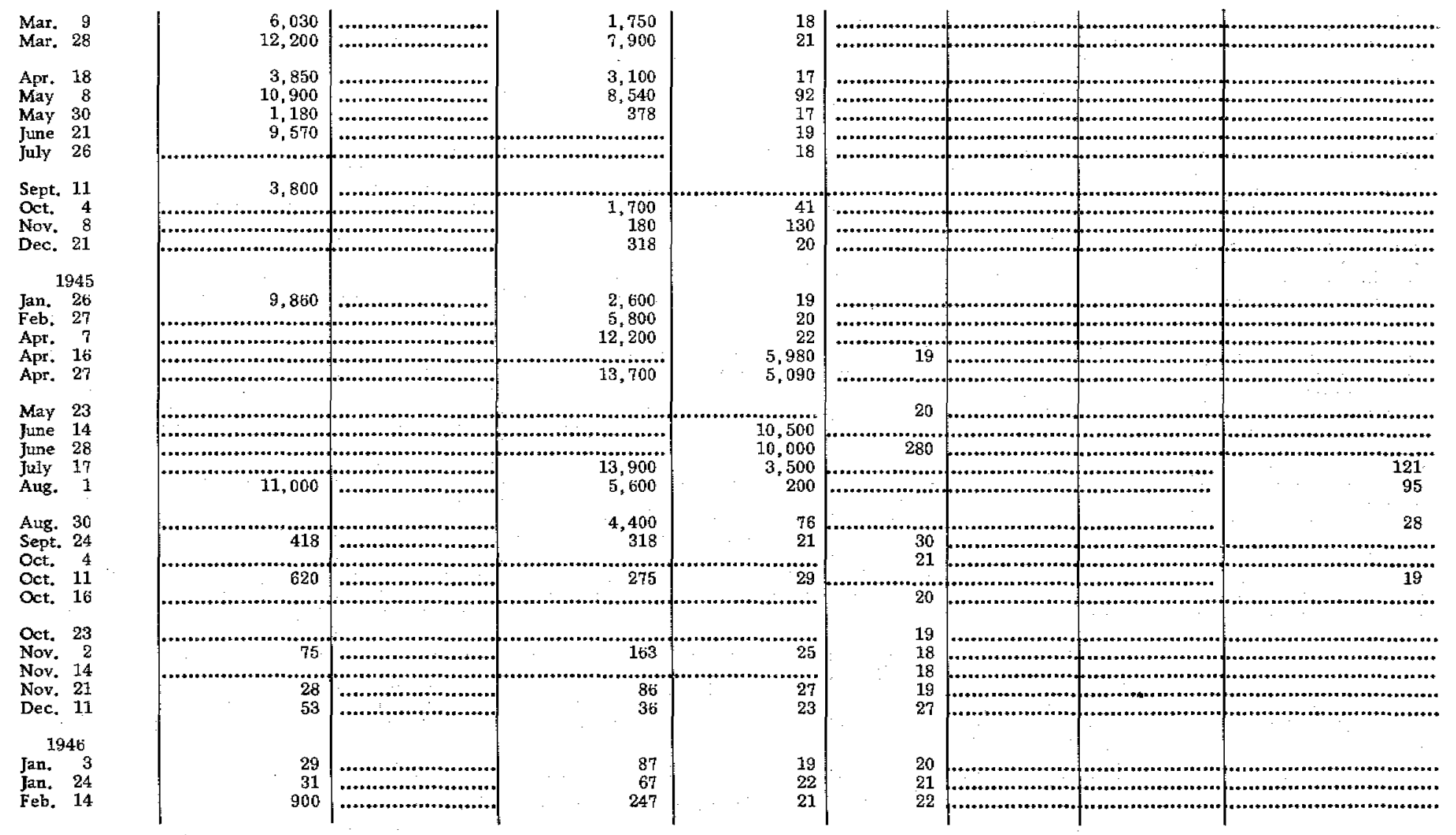


Table 75, -Chloride concentrations in Tamiami Canal, Miani-Continued

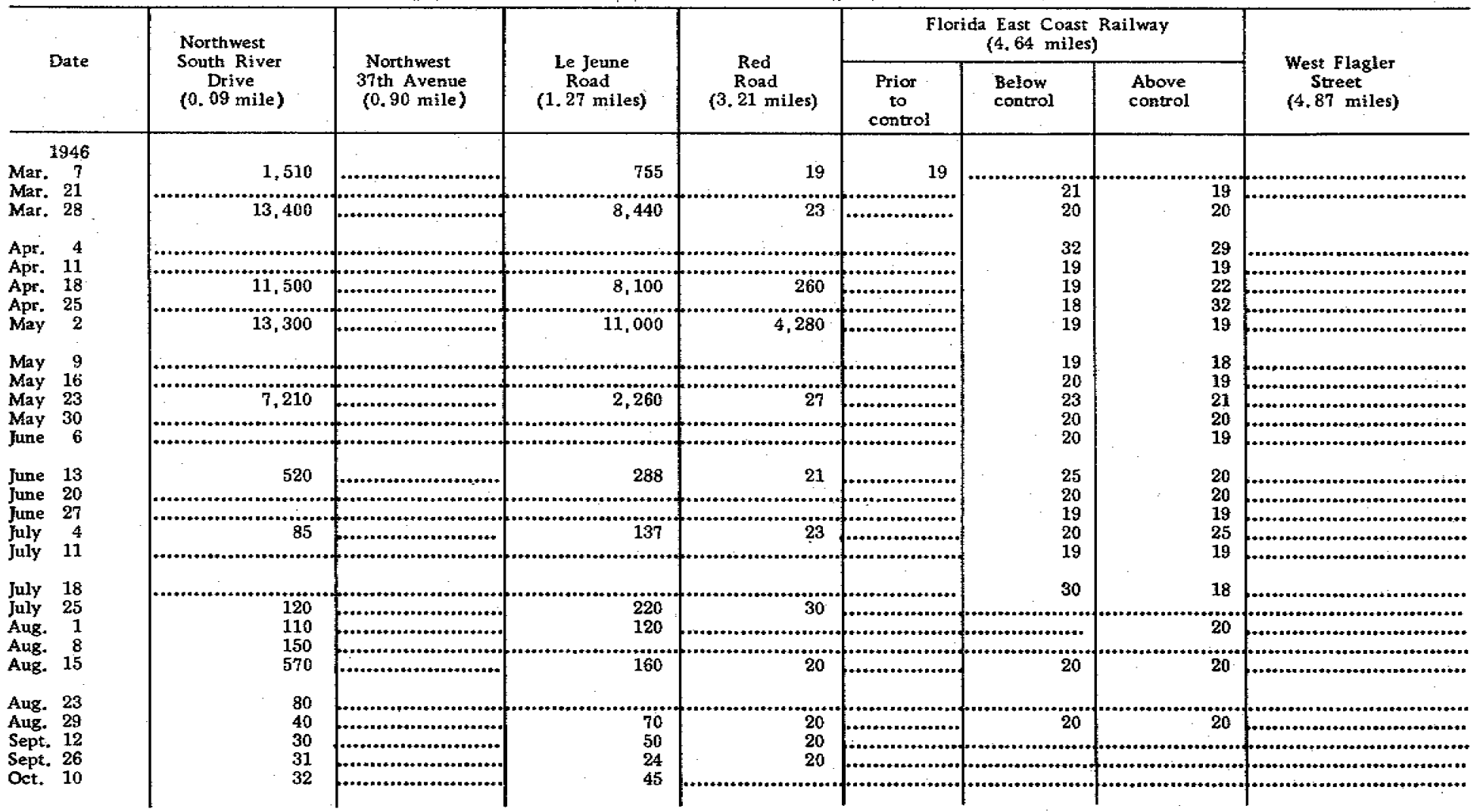




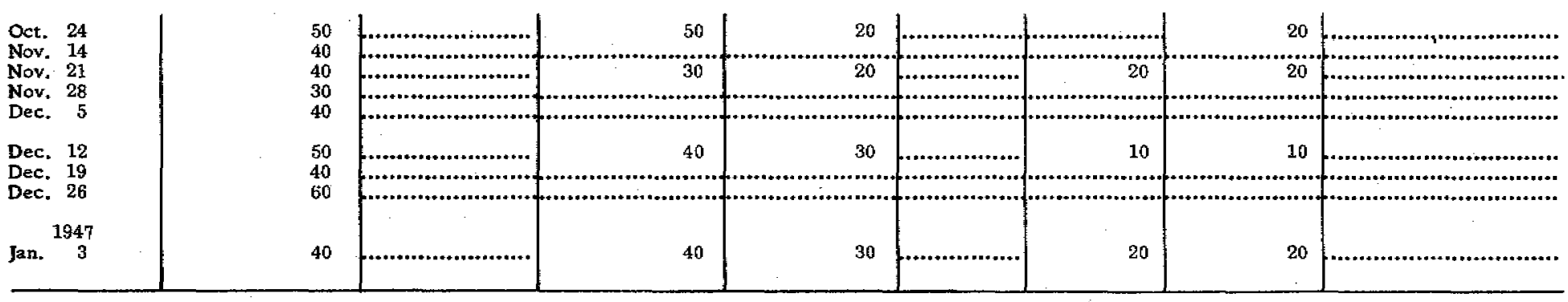




\section{SEMINOLE LAKE}

Just east of Red Road and connected with Tamiami Canal, is Seminole Lake (fig. 184), a rock pit covering an area of about 100 acres, Like Palmer Lake, it becomes contaminated throughout in extremely dry periods and offers another means for salty water to approach the well field. In dry periods, only a low ground-water divide exists between Seminole Lake and the municipal supply wells. If this divide were dissipated in a prolonged dry spell and if the cone of depression in the water table extended to the Lake, it would supply salty water to the well field. 
Coral, gables canaL

Table 76 presents the observed chloride concentrations in Coral Gables Canal. Ordinarily, the canal is strongly salty upstream to U.S. Highway 1 (2.2 miles from Biscayne Bay), which is at the head of the large channel. The channel narrows at this point, and farther upstream it has a fairly low capacity because of shoals and constrictions. The typical upstream limit of contamination is in the vicinity of Bird Road ( 3.18 miles from the bay). In 1945, however, salty water was found at the Florida East Coast Railway bridge west of Red Road (5. 4 miles by canal from Biscayne Bay).

On either side of U. S. Highway 1, stub canals branch off from Coral Gables Canal to form scenic waterways, which have contributed to the salt-water contamination of the adjoining areas. 
Table 76. - Chloride concentrations in Coral Gables Canal, Miami

[Parts per million. Before October 1, 1941, the values are the highest obtained from either surface or bottom samples (usually the latter); after October 1, 1941, the values are from bottom samples. Mileages in parentheses indicate distance from mouth of canal at Biscayne Bay]

\begin{tabular}{|c|c|c|c|c|c|c|c|c|c|c|c|c|c|c|}
\hline \multirow{2}{*}{ Date } & \multirow{2}{*}{$\begin{array}{l}\text { Ingraham } \\
\text { Highway } \\
(0.84 \text { mile) }\end{array}$} & \multirow{2}{*}{$\begin{array}{c}\text { Hardee } \\
\text { Drive } \\
\text { (1.44 miles) }\end{array}$} & \multirow{2}{*}{$\begin{array}{c}\text { Miller } \\
\text { Road } \\
(1,96 \text { miles })\end{array}$} & \multirow{2}{*}{$\begin{array}{c}\text { U. S. } \\
\text { Highway. } \\
(2,21 \text { miles })\end{array}$} & \multirow{2}{*}{$\begin{array}{l}\text { East Spur } \\
\text { west end } \\
(2,34 \text { miles })\end{array}$} & \multirow{2}{*}{$\begin{array}{c}\text { Granada } \\
\text { Boulevard } \\
(2.78 \text { miles })\end{array}$} & \multirow[b]{2}{*}{$\begin{array}{c}\text { Bird } \\
\text { Road } \\
(3,18 \text { miles }\end{array}$} & \multicolumn{3}{|c|}{$\begin{array}{l}\text { Red Road } \\
\text { (4.06 miles) }\end{array}$} & \multirow{2}{*}{$\begin{array}{l}\text { West Spur } \\
\text { south end } \\
(4.50 \text { miles }\end{array}$} & \multirow[b]{2}{*}{$\begin{array}{c}\text { Ludlum } \\
\text { Road } \\
(4,96 \text { miles })\end{array}$} & \multirow{2}{*}{$\begin{array}{c}\text { F.E.C. } \\
\text { Railway } \\
\text { Bridge } \\
\text { (5.41 miles) }\end{array}$} & \multirow{2}{*}{$\begin{array}{c}\text { Coral } \\
\text { Way } \\
(5.63 \text { miles })\end{array}$} \\
\hline & & & & & & & & \begin{tabular}{|c|} 
Prior \\
to \\
control
\end{tabular} & $\begin{array}{l}\text { Below } \\
\text { control }\end{array}$ & $\begin{array}{l}\text { Above } \\
\text { control }\end{array}$ & & & & \\
\hline $\begin{array}{lr}1940 \\
\text { Apr. } & 3 \\
\text { Apr. } & 14 \\
\text { May } & 3 \\
\text { May } & 16 \\
\text { June } & 5\end{array}$ & $\begin{array}{l}15,010 \\
16,360 \\
17,890 \\
18,230 \\
12,730\end{array}$ & $\begin{array}{r}2,900 \\
16,260 \\
16,550 \\
17,120 \\
8,880\end{array}$ & $\begin{array}{r}410 \\
2,850 \\
2,920 \\
4,820 \\
292\end{array}$ & $\begin{array}{r}322 \\
1,150 \\
2,580 \\
4,350 \\
255\end{array}$ & $\mid$\begin{tabular}{|c|}
$\ldots \ldots \ldots \ldots \ldots$ \\
$\ldots \ldots \ldots \ldots \ldots \ldots$
\end{tabular} & $\begin{array}{r}55 \\
129 \\
358 \\
3,000 \\
47\end{array}$ & $\begin{array}{r}16 \\
19 \\
20 \\
790 \\
17\end{array}$ & $\begin{array}{l}15 \\
16 \\
15 \\
15 \\
15\end{array}$ & & & & & & f \\
\hline $\begin{array}{lr}\text { June } & 17 \\
\text { July } & 1 \\
\text { July } & 18 \\
\text { Aug. } & 1 \\
\text { Aug. } & 16\end{array}$ & $\begin{array}{l}14,770 \\
16,020 \\
17,120 \\
19,470 \\
17,750\end{array}$ & $\begin{array}{l}11,370 \\
13,750 \\
14,140 \\
16,740 \\
15,300\end{array}$ & $\begin{array}{r}350 \\
465 \\
780 \\
13,560 \\
167\end{array}$ & $\begin{array}{r}288 \\
368 \\
530 \\
10,590 \\
101\end{array}$ & 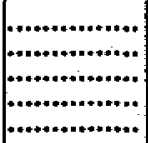 & $\begin{array}{r}57 \\
57 \\
109 \\
4,420 \\
39\end{array}$ & $\begin{array}{l}17 \\
16 \\
17 \\
28 \\
15\end{array}$ & $\begin{array}{l}16 \\
15 \\
15 \\
16 \\
15\end{array}$ & & & & & & a.... \\
\hline $\begin{array}{lr}\text { Sept. } & 4 \\
\text { Sept. } & 18 \\
\text { Oct. } & 3 \\
\text { Oct. } & 18 \\
\text { Nov. } & 1\end{array}$ & $\begin{array}{l}14,480 \\
14,240 \\
12,830 \\
15,400 \\
13,420\end{array}$ & $\begin{array}{l}15,150 \\
12,930 \\
10,400 \\
13,700 \\
11,470\end{array}$ & $\begin{array}{r}4,180 \\
9,180 \\
5,730 \\
10,790 \\
7,410\end{array}$ & $\begin{array}{r}1,040 \\
1,780 \\
820 \\
6,270 \\
1,550\end{array}$ & 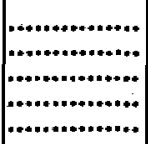 & $\begin{array}{r}85 \\
69 \\
69 \\
94 \\
102\end{array}$ & $\begin{array}{l}17 \\
17 \\
18 \\
18 \\
17\end{array}$ & $\begin{array}{l}15 \\
17 \\
15 \\
15 \\
15\end{array}$ & & & & & & |cken \\
\hline $\begin{array}{l}\text { Nov. } 15 \\
\text { Dec. } 3 \\
\text { Dec. } 17\end{array}$ & $\begin{array}{l}13,320 \\
14,280 \\
12,830\end{array}$ & $\begin{array}{l}10,890 \\
13,700 \\
10,590\end{array}$ & $\begin{array}{r}2,500 \\
542 \\
1,770\end{array}$ & $\begin{array}{r}452 \\
425 \\
1,580\end{array}$ & 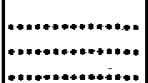 & $\begin{array}{l}67 \\
76 \\
61\end{array}$ & $\begin{array}{l}17 \\
19 \\
19\end{array}$ & $\begin{array}{l}16 \\
17 \\
16\end{array}$ & & & & & & \\
\hline $\begin{array}{lr}\text { Jan. } & 18 \\
\text { Jan. } & 31 \\
\text { Feb. } & 19 \\
\text { Mar. } & 1 \\
\text { Mar. } 14\end{array}$ & $\begin{array}{l}15,730 \\
16,020 \\
15,680 \\
14,140 \\
15,250\end{array}$ & $\begin{array}{l}13,120 \\
13,610 \\
11,470 \\
11,910 \\
13,510\end{array}$ & $\begin{array}{r}302 \\
6,470 \\
9,520 \\
368 \\
6,520\end{array}$ & $\begin{array}{r}190 \\
5,330 \\
1,750 \\
318 \\
522\end{array}$ & 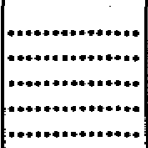 & $\begin{array}{l}47 \\
62 \\
47 \\
47 \\
57\end{array}$ & $\begin{array}{l}18 \\
18 \\
19 \\
19 \\
17\end{array}$ & $\begin{array}{l}15 \\
15 \\
15 \\
15 \\
15\end{array}$ & & & & & & | \\
\hline $\begin{array}{lr}\text { Apr. } & 3 \\
\text { Apr. } & 18\end{array}$ & $\begin{array}{l}15,350 \\
12,830\end{array}$ & $\begin{array}{l}14,140 \\
11,710\end{array}$ & $\begin{array}{r}1,260 \\
950\end{array}$ & $\begin{array}{l}680 \\
320\end{array}$ & $\mid$ & $\begin{array}{l}51 \\
41\end{array}$ & $\begin{array}{l}18 \\
19\end{array}$ & $\begin{array}{l}15 \\
15\end{array}$ & & & & & & \\
\hline
\end{tabular}




\begin{tabular}{|c|c|c|c|}
\hline $\begin{array}{lr}\text { May } 1 \\
\text { May } 20 \\
\text { June } 4\end{array}$ & $\begin{array}{l}14,670 \\
15,100 \\
18,940\end{array}$ & $\begin{array}{l}12,060 \\
13,070 \\
16,980\end{array}$ & $\begin{array}{r}228 \\
3,300 \\
7,650\end{array}$ \\
\hline $\begin{array}{lr}\text { June } & 17 \\
\text { July } & 2 \\
\text { July } & 14 \\
\text { July } & 30 \\
\text { Aus. } & 18\end{array}$ & $\begin{array}{l}18,850 \\
15,830 \\
17,170 \\
16,120 \\
18,850\end{array}$ & $\begin{array}{r}17,120 \\
13,510 \\
15,200 \\
13,420 \\
17,750\end{array}$ & $\begin{array}{r}11,710 \\
612 \\
348 \\
680 \\
1,210\end{array}$ \\
\hline $\begin{array}{l}\text { Sept. } 3 \\
\text { Oct. } 1 \\
\text { Oct. } 17 \\
\text { Oct. } 31 \\
\text { Nov. } 14\end{array}$ & $\begin{array}{l}18,700 \\
12,600 \\
14,800 \\
14,700 \\
15,300\end{array}$ & $\begin{array}{l}17,460 \\
13,000 \\
12,100 \\
14,000 \\
15,300\end{array}$ & $\begin{array}{r}14,820 \\
2,780 \\
3,300 \\
2,800 \\
2,250\end{array}$ \\
\hline $\begin{array}{l}\text { Nov. } 28 \\
\text { Dec. } 24\end{array}$ & $\begin{array}{l}15,600 \\
15,200\end{array}$ & $\begin{array}{l}16,000 \\
14,400\end{array}$ & $\begin{array}{r}10,100 \\
3,350\end{array}$ \\
\hline \begin{tabular}{lr}
\multicolumn{2}{c}{1942} \\
Jan. 3 \\
Jan. 16 \\
Feb. 4 \\
Feb. 17 \\
Mar. 4
\end{tabular} & $\begin{array}{l}16,900 \\
17,000 \\
17,600 \\
16,700 \\
17,600\end{array}$ & $\begin{array}{l}15,800 \\
15,500 \\
16,800 \\
16,600 \\
16,300\end{array}$ & $\begin{array}{r}9,370 \\
12,800 \\
15,400 \\
7,160 \\
7,410\end{array}$ \\
\hline $\begin{array}{l}\text { Mar. } 19 \\
\text { Apr. } 2 \\
\text { Apr. } 28 \\
\text { May } 8 \\
\text { May } 22\end{array}$ & $\begin{array}{l}18,000 \\
17,000 \\
14,100 \\
12,500 \\
13,900\end{array}$ & $\begin{array}{l}11,100 \\
15,900 \\
13,300 \\
10,000 \\
12,700\end{array}$ & $\begin{array}{r}11,900 \\
11,400 \\
1,020 \\
2,125 \\
2,300\end{array}$ \\
\hline $\begin{array}{lr}\text { June } & 9 \\
\text { June } & 24 \\
\text { July } & 9 \\
\text { July } & 24 \\
\text { Aug. } & 6\end{array}$ & $\begin{array}{l}12,600 \\
13,500 \\
12,800 \\
16,400 \\
14,600\end{array}$ & $\begin{array}{l}10,600 \\
11,600 \\
11,700 \\
14,800 \\
14,200\end{array}$ & $\begin{array}{r}161 \\
442 \\
3,150 \\
\ldots \ldots \ldots . .\end{array}$ \\
\hline $\begin{array}{l}\text { Aug. } 22 \\
\text { Sept. } 4 \\
\text { Oct. } 7 \\
\text { Nov. } 9 \\
\text { Nov. } 24\end{array}$ & $\begin{array}{l}15,900 \\
16,400 \\
15,300 \\
16,800 \\
15,350\end{array}$ & $\begin{array}{l}14,300 \\
16,400 \\
14,350 \\
15,750 \\
13,550\end{array}$ & ...... \\
\hline
\end{tabular}

\begin{tabular}{|c|c|c|}
\hline $\begin{array}{r}143 \\
428 \\
8,440\end{array}$ & 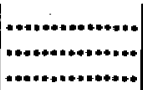 & $\begin{array}{r}28 \\
64 \\
770\end{array}$ \\
\hline $\begin{array}{r}5,040 \\
405 \\
315 \\
320 \\
203\end{array}$ & 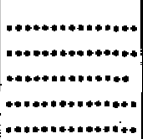 & $\begin{array}{r}990 \\
47 \\
37 \\
39 \\
33\end{array}$ \\
\hline $\begin{array}{r}2,225 \\
610 \\
820 \\
310 \\
500\end{array}$ & 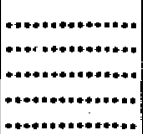 & $\begin{array}{l}30 \\
18 \\
17 \\
21 \\
19\end{array}$ \\
\hline $\begin{array}{r}9,910 \\
352\end{array}$ & 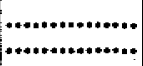 & $\begin{array}{l}18 \\
20\end{array}$ \\
\hline $\begin{array}{l}3,380 \\
8,640 \\
9,620 \\
3,320 \\
2,000\end{array}$ & 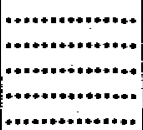 & $\begin{array}{r}45 \\
136 \\
54 \\
790 \\
38\end{array}$ \\
\hline $\begin{array}{r}4,820 \\
7,900 \\
119 \\
365 \\
392\end{array}$ & $\mid$\begin{tabular}{|l|}
$\ldots \ldots \ldots \ldots$ \\
$\ldots \ldots \ldots \ldots$
\end{tabular} & $\begin{array}{r}136 \\
710 \\
36 \\
33 \\
71\end{array}$ \\
\hline $\begin{array}{r}89 \\
348 \\
206 \\
1,050 \\
570\end{array}$ & 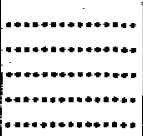 & $\begin{array}{l}18 \\
22 \\
49 \\
33 \\
57\end{array}$ \\
\hline $\begin{array}{r}2,400 \\
163 \\
6,100 \\
9,400 \\
255\end{array}$ & 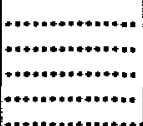 & $\begin{array}{r}29 \\
14 \\
17 \\
2,100\end{array}$ \\
\hline
\end{tabular}

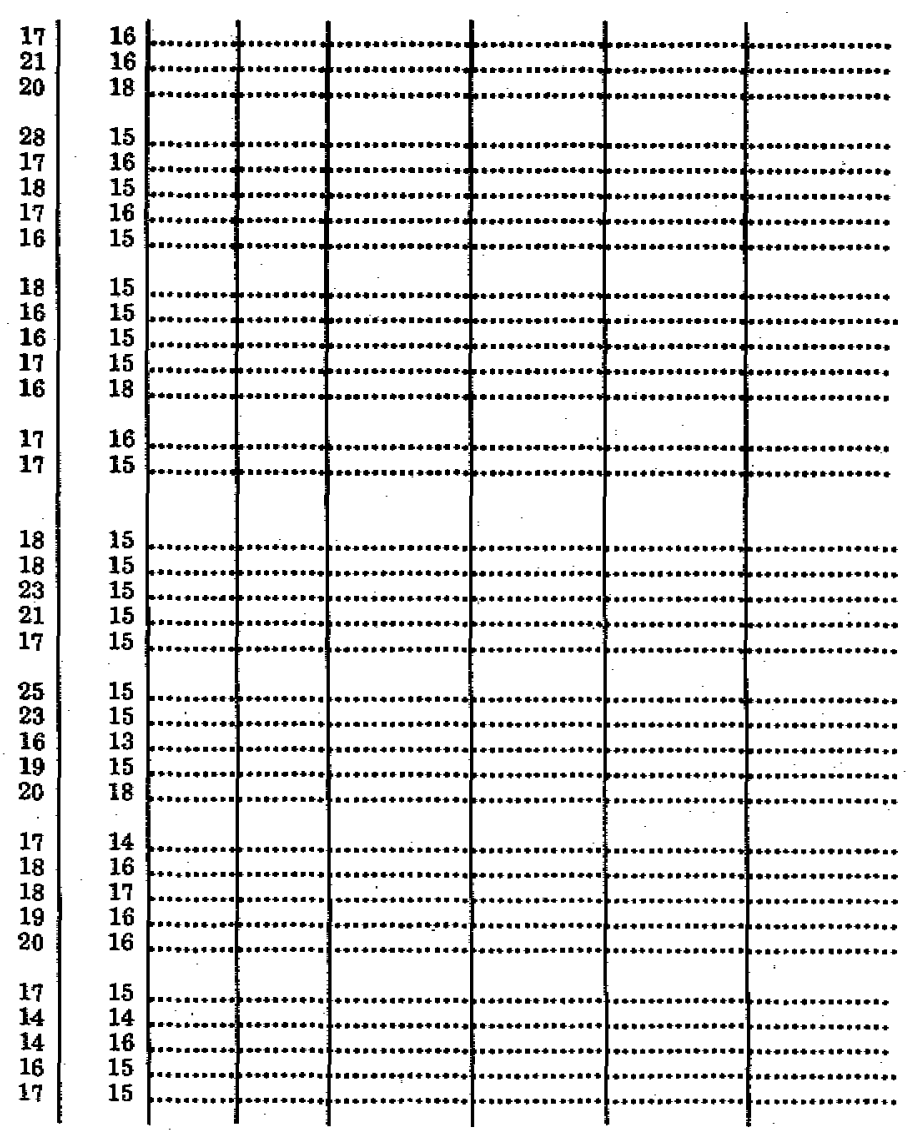


Table 76 - Chloride concentrations in Coral Gables Canal, Miami-Continued

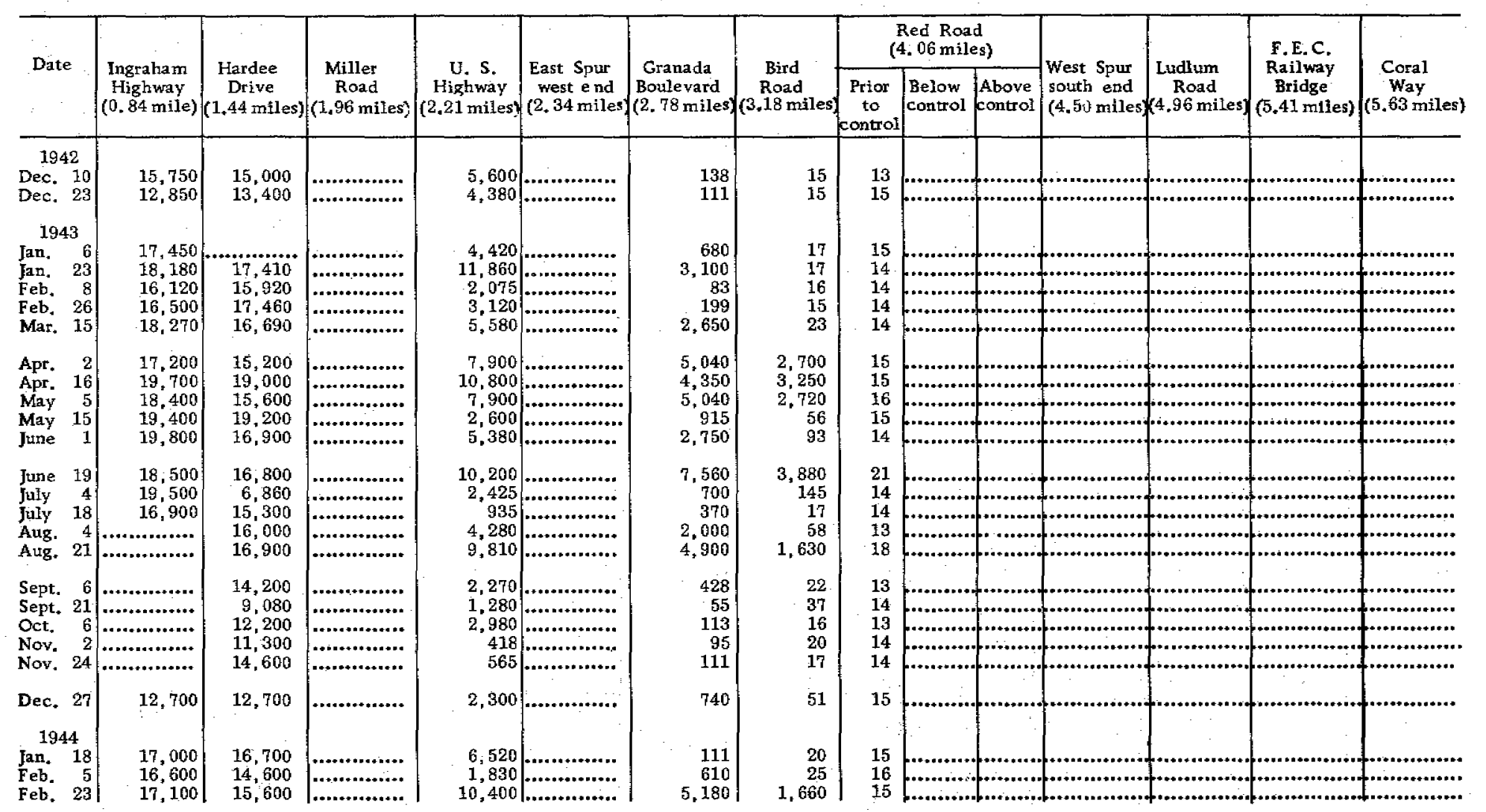




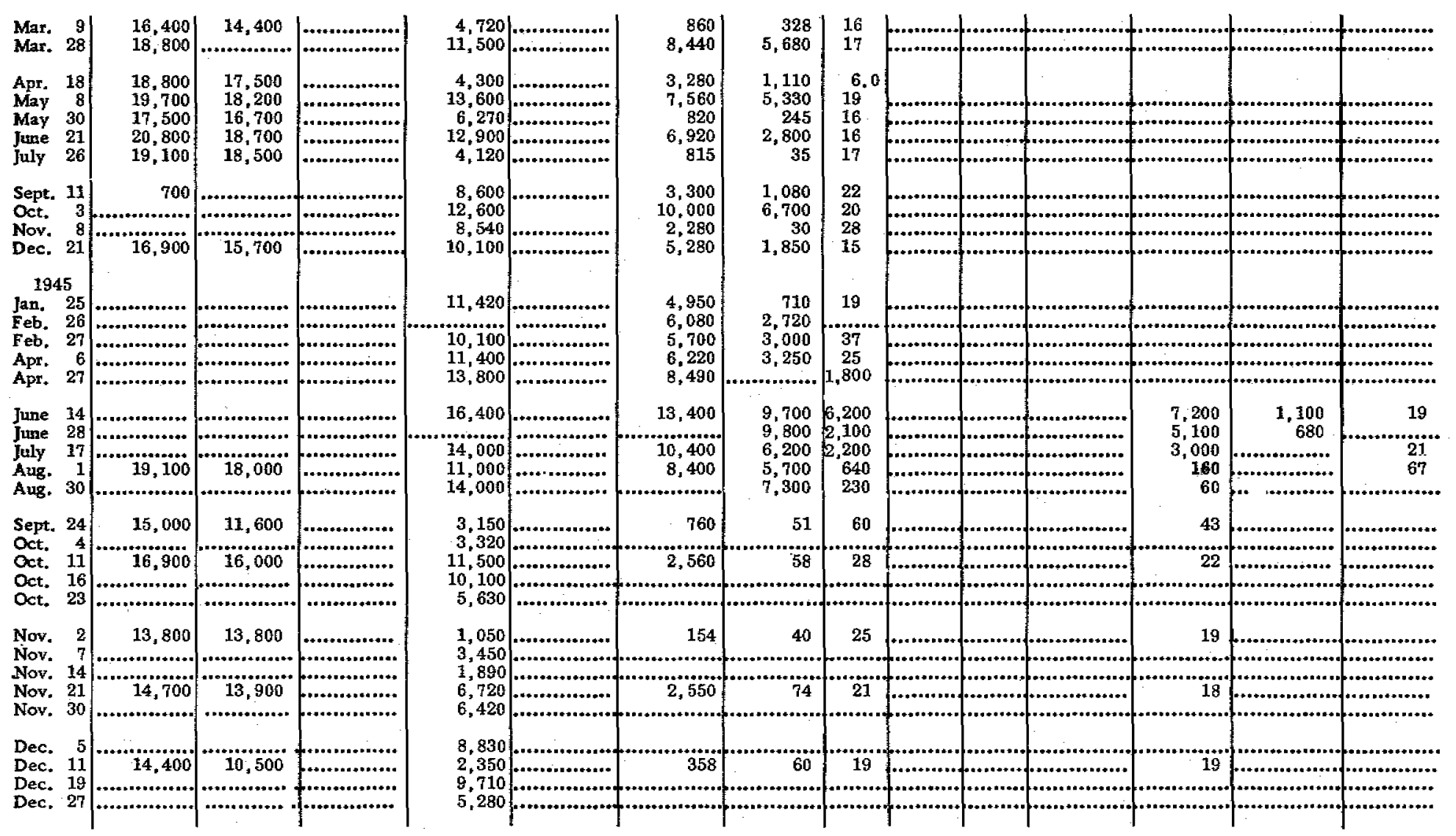


Table 76. - Chioride concentrations in Coral Gables Canat, Miami-Continued

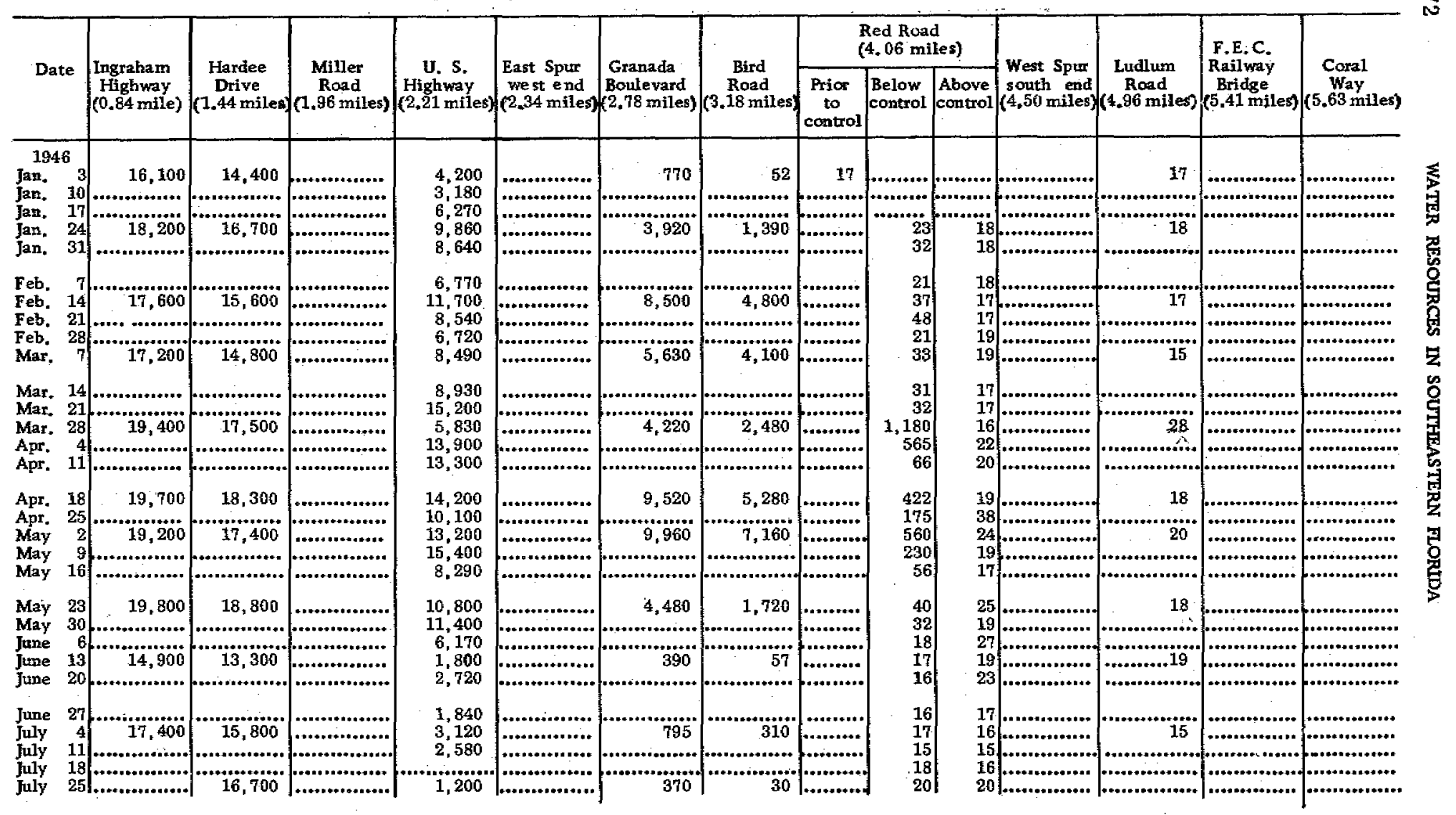




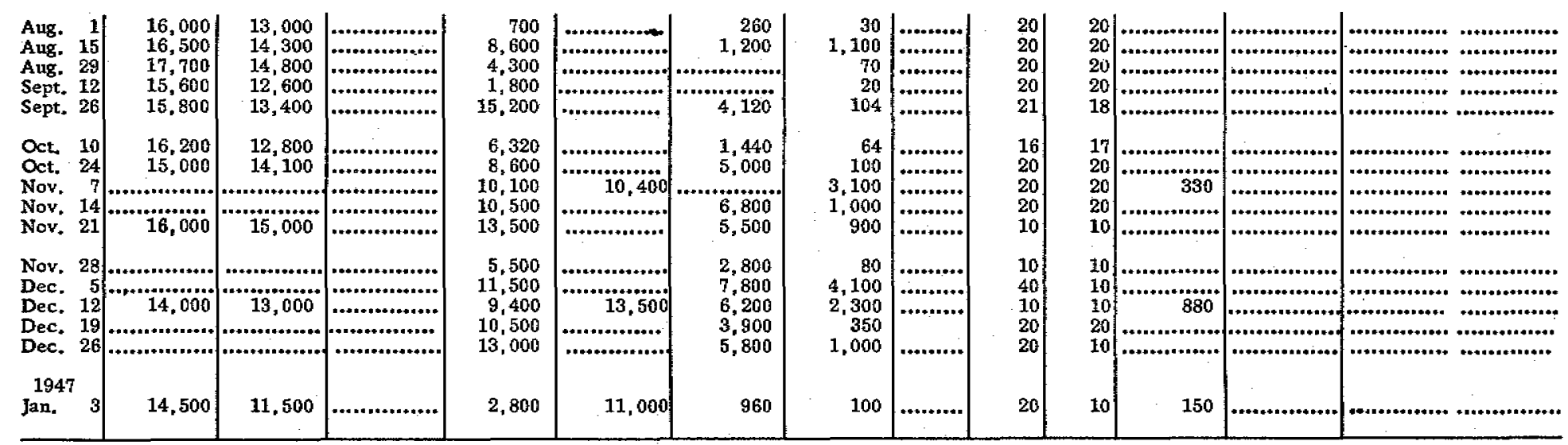




\section{SNAPPER CREDK CANAL}

Snapper Creek Canal is the southernmost of the secondary canals and it traverses one of the least populated sections in the area. Its channel is relatively small, and it is constricted at a number of locations. Table 77 presents the observed chloride concentrations. The intersection of Red Road and North Kendall Drive was usually the farthest inland point of contamination. In 1945, however, salty water moved upstream, despite the shoals and weeds, and was found at Palmetto Road, 4.8 miles inland and west of U. S. Highway 1. A control was placed in the canal at Ingraham Highway in 1946, which effectively stopped inland movement of salty water despite the cavernous nature of the limestone in the area.

In most years, the channel is flushed completely of salty water during the wet period.

Table 77. Chlotide concentrations in Snapper Creek Canal, Miani

[Parts per million. Before October 1, 1941, the values are the highest obtained for either surface or bottom samples (usually the latter); after October 1, 1941, the values are from bottom samples, Mileages in parentheses indicate distance from mouth of canal at Biscayne Bay]

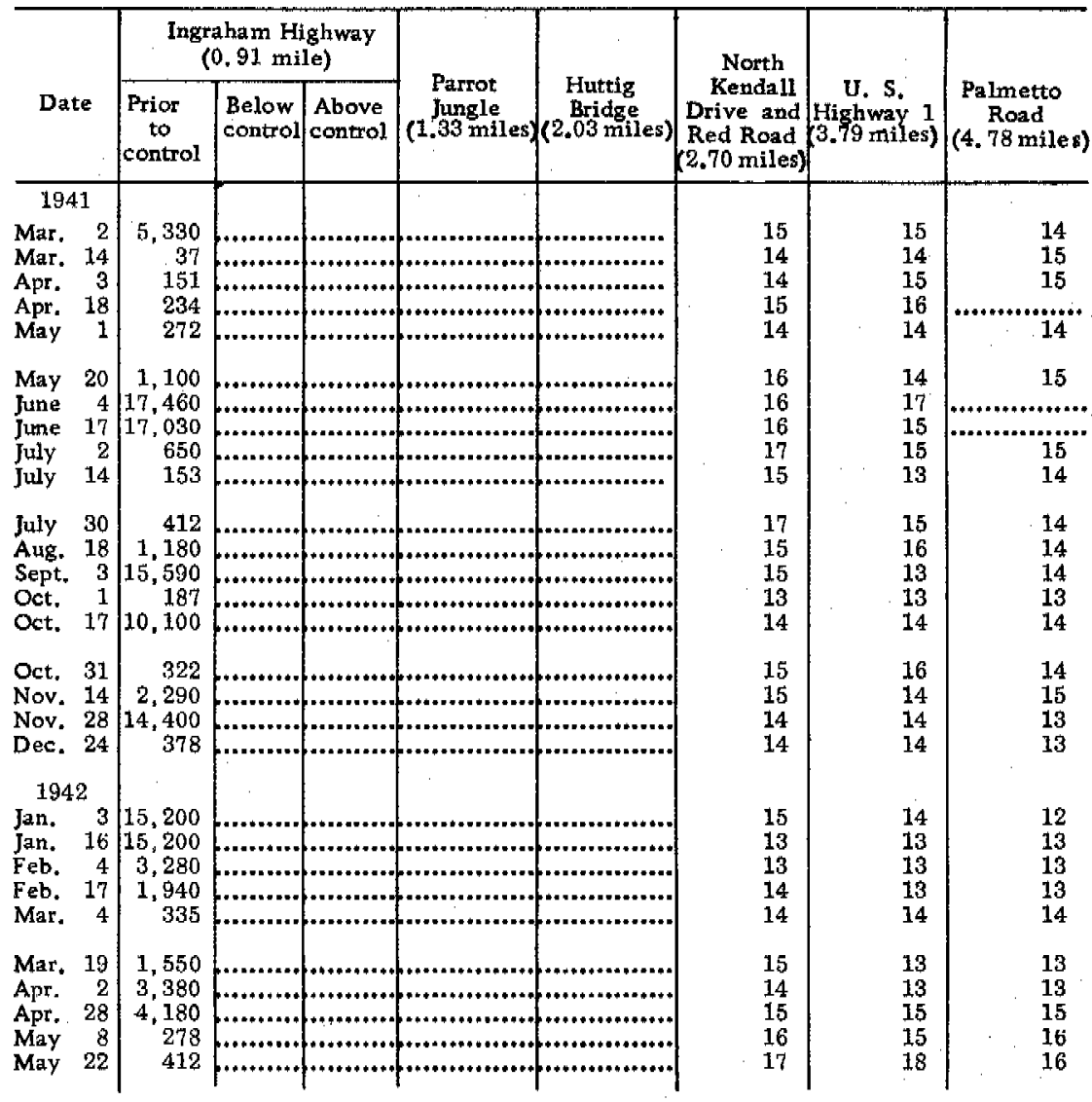


Table 77.-Chloride concentrations in Snapper Creek Canal, Miami-Continued

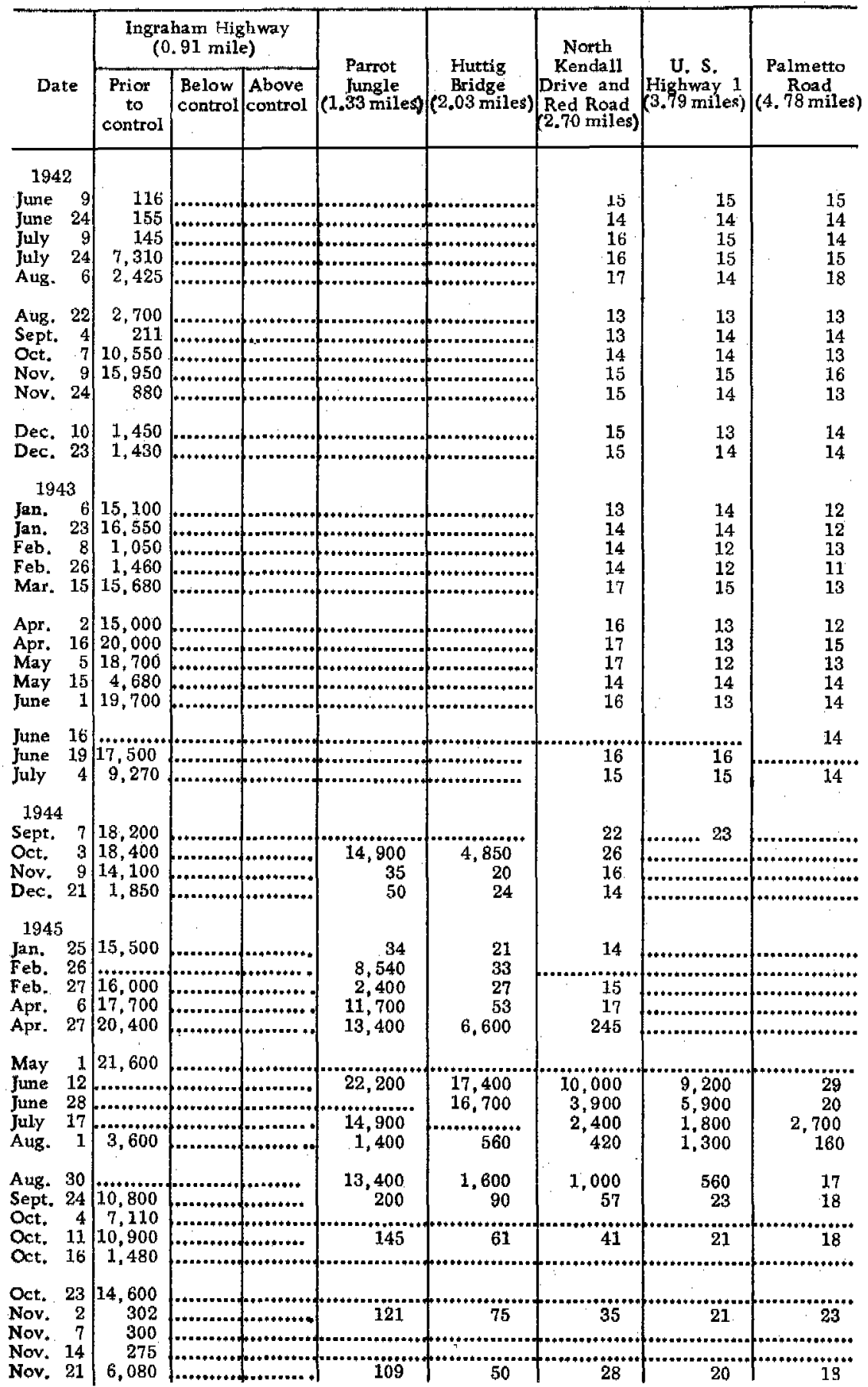


Table 77.-Chloride concentrations in Snapper Creek Canal, Miami-Continued

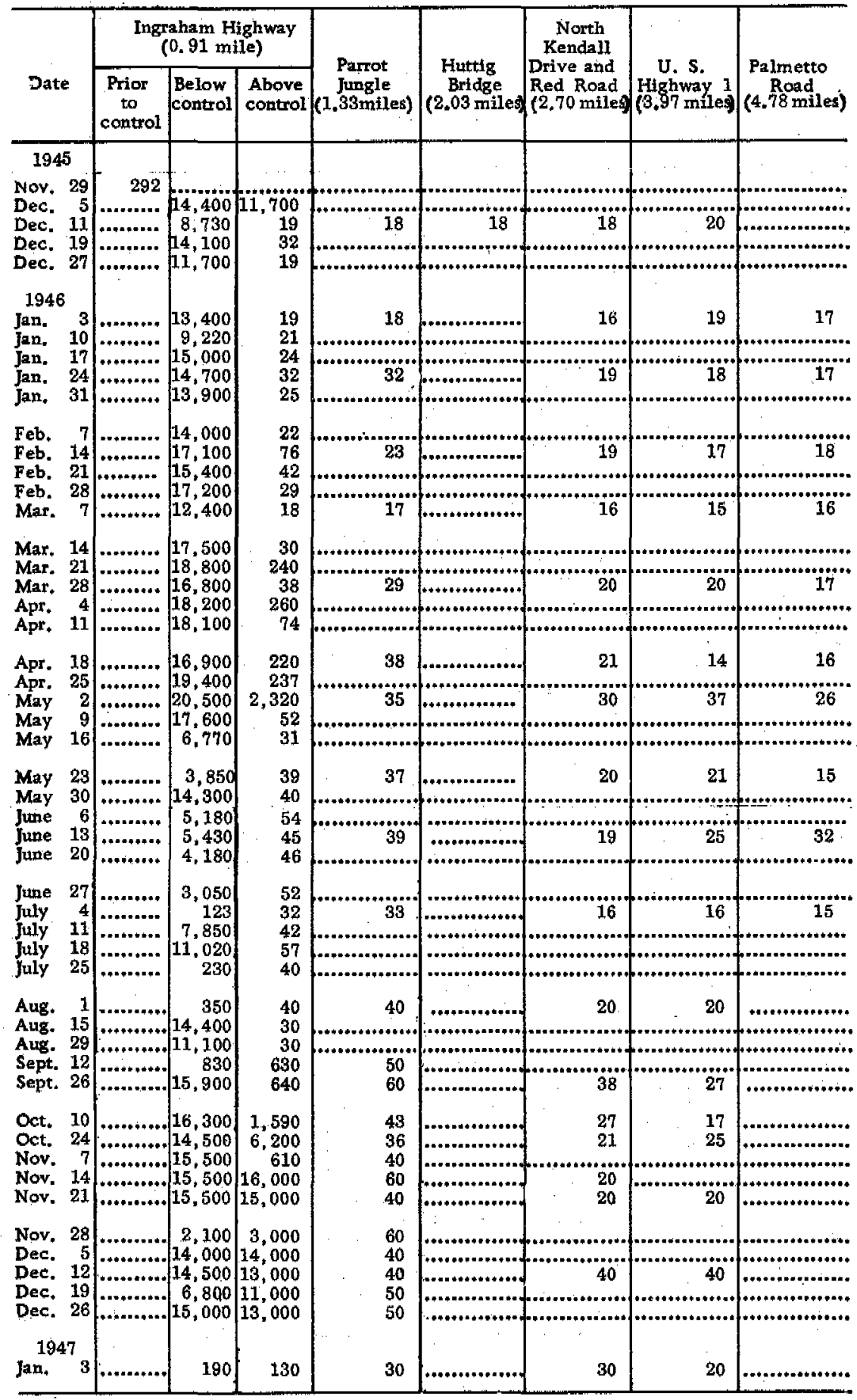




\section{FORT LAUDERDALE AREA}

\section{LOWER NEW RIVER BASW}

When drought conditions became extreme in the spring of 1945 , salty water moved steadily inland in the tidal portion of New River basin. Extensive areas of swamp and slough were contaminated and some of the native jungle growth was killed. The water in the tidal channels could not be used for irrigation, with the result that groves and farms suffered from excessive dryness. It was feared that the municipal well field of Fort Lauderdale might become contaminated because some of the wells are located only about $1 \frac{1}{2}$ miles north of the tidal section of North New River Canal. The Florida Power and Light Company developed a new well farther away from Dania Cutoff Canal to obtain feed-water for the power plant near Dania when the chloride content of the original well became excessive.

The power company had made regular salinity observations in the vicinity of the power plant since the plant was built but these observations were too limited to indicate the entire intrusion pattern. In 1945, the Geological Survey started periodic observations, their frequency depending upon local conditions. Samples were taken at the bottoms of the channels at various strategic locations and as near as possible to time of high tide.

The worst period of salt contamination occurred in 1945 when strongly salty water was found for several months in the whole tidal portion of the basin. Closed controls and locks in North New River and South New River Canals prevented the salt front from penetrating farther inland. Concentrations at the downstream side of these controls were 40 to 60 percent of that of sea water, and essentially normal sea water occupied the lower reaches. Water that was about 25 percent as salty as sea water was found above the easternmost control in South New River Canal and was believed to extend a short distance upstream. This was a result of the occurrence of negative heads and condition of the control, which was not constructed to hold negative heads. Runoff in both canals was limited to a small amount of leakage through the controls.

The 1945 condition was considered to be the extreme of the period of observation, but the highest chloride concentrations were found in April 1946 (see fig. 187). Slightly higher concentrations were observed at a few of the stations at other times but the series of samples collected for this date contained the maximum concentrations at the most locations. The control and lock in South New River Canal at Davie had been repaired since the 1945 intrusion, and the concentration upstream was relatively low. The concentration of $75 \mathrm{ppm}$ upstream from the control and lock in North New River Canal was higher than that of water from the 


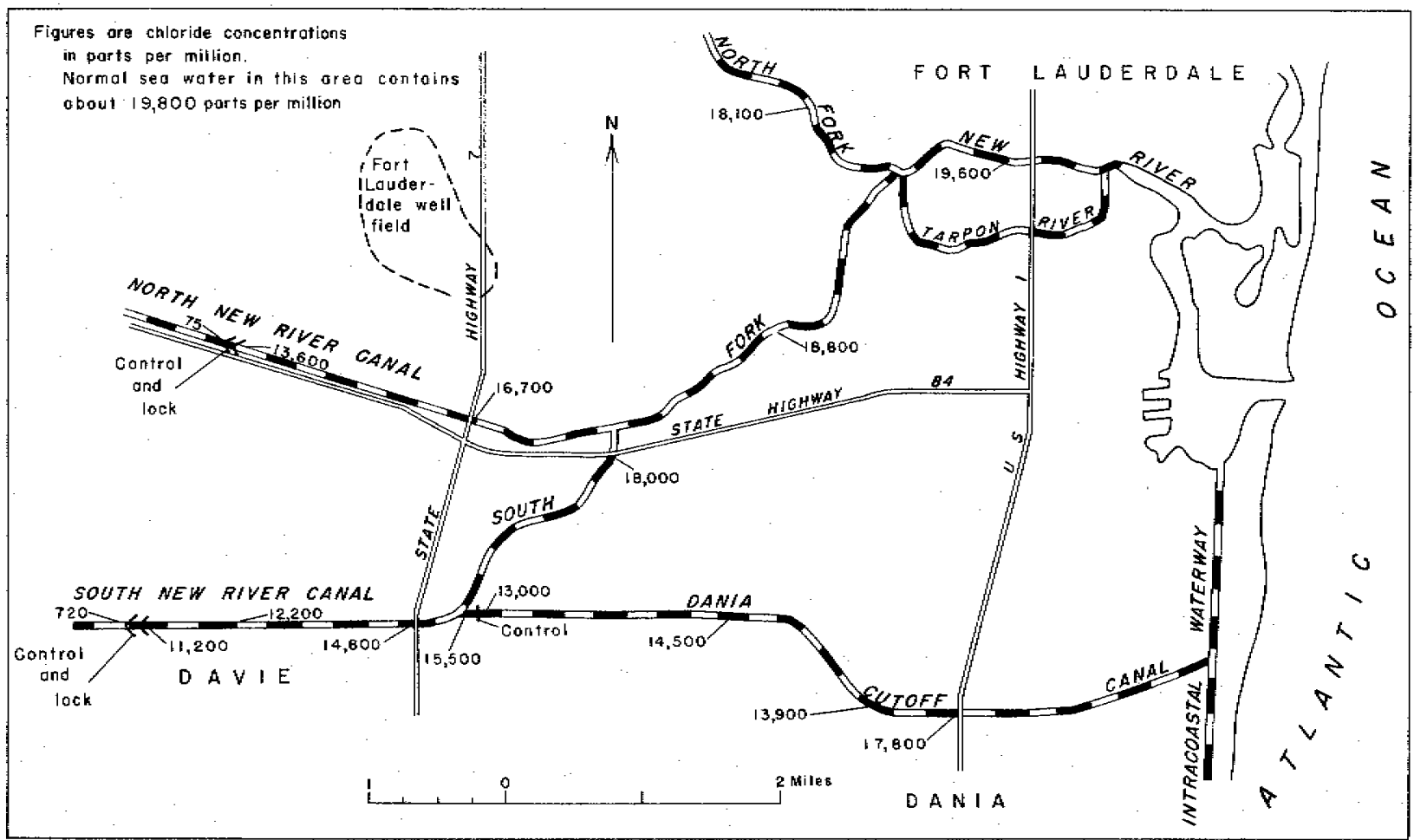

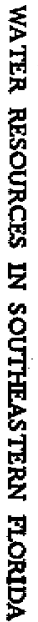

Figure 187, - Map showing chloride concentrations at sampling stations in lower New River basin, April 30, 1946. 
Everglades to the west but was not an indication of local contamination. When ice-age seas withdrew from southern Florida, large quantities of salty water were trapped in the rock and remained the re throughout the ensuing centuries. This residual salty ground water seeps into the middle reaches of the canal and causes a small amount of contamination under most conditions of flow. The degree of contamination varies inversely with the discharge of the canal.

Heavy rains and subsequent large fresh-water runoff force the salty water downstream and in flood periods the salty water may be completely flushed out of the basin. Salty water, however, is usually present in the channels in the vicinity of Fort Lauderdale. No samples were collected from New River Sound and the Intracoastal Waterway but it may be assumed that they are nearly always salty, although they could become brackish under extreme flood conditions.

\section{MODLLE RAVER BASTN}

No regular sampling was done in Middle River basin but miscellaneous observations of North Branch and South Branch at the West Dixie Highway showed chloride concentrations as high as 15 percent of that of sea water; this was undoubtedly not the maximum. These channels are not controlled and are connected with networks of canals and ditches, thus making a sizable area vulnerable to salt contamination-an area that is used for farming and where municipal supplies ultimately may be developed.

\section{HOMESTEAD AREA}

The marl lands, stretching in an increasingly wide zone along the coast from Cutler to Cape Sable, are generally below an elevation of $4 \mathrm{ft}$ and slope gradually into Biscayne Bay and its extensions to the southwest. The marl overlies very permeable oolitic limestone; water control in this area is difficult where the canals and ditches are excavated into the limestone. Despite the high productivity of the soil, a small to moderate amount of rainfall is required for farming during the winter growing season, which is normally quite dry. Owing to the need generally for a low water table, the area is subject to contamination by salty water, particularly along the large east-west canals.

The Homestead area is much like the main Everglades farming area near Lake Okeechobee in that there is excess water in wet periods and a scarcity of water during droughts.

In the drought years of 1943-45 extensive areas of crop land were rendered useless by salt contamination. Salt concentrations 


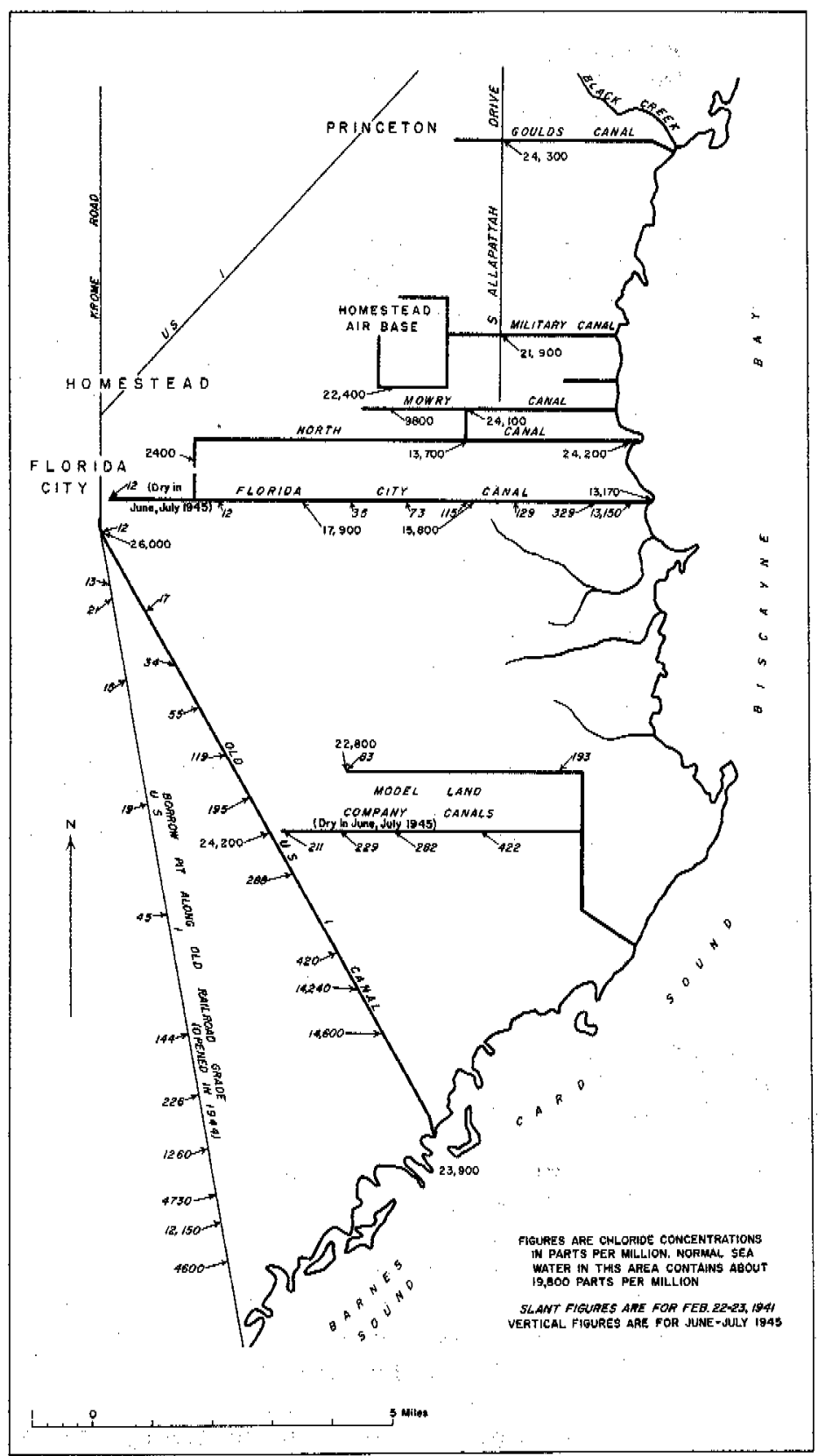

Figure 188. - Map of Homestead area, showing chloride concentrations in canals, February 22, 23,1941 , and June and July 1945 . 
in the soil exceeded the salt tolerance of many plants, and crop failure was the inevitable result. Salt crystals were found on the leaves of several varieties of plants and even on the fruit of cucumber vines. Where ground water and soil moisture were contaminated, evaporation resulted in the formation of thin surface crusts of highly salty soil. Fortunately, the salty soil condition was dissipated annually in the wet season, but ground-water and canal contamination continued in varying degrees.

Although reconnaissance observations of chloride concentrations in the Homestead area were made in 1945, a regular series of observations was not started until 1946. Therefore, it is not possible to show the variations of chloride contamination with the change of water conditions.

Figure 188 shows the chloride concentrations found in some of the canals in the Homestead area. The general reconnaissance in 1941 was made when there were fairly high water levels for the time of the year. The winter of early 1941 was marked by continued high runoff, following a wet fall. The concentrations less than $20 \mathrm{ppm}$ of chloride represent uncontaminated water of the area, which was found only at the head ends of the canals. Of all the canals identified on the map, only North and Florida City Canals were controlled. The heavy concentrations undoubtedly show contamination directly from the sea. The lesser concentrations may have been a result of direct intrusion, but it is more likely that they indicate contamination from salty ground water that was residual from the intrusion of the previous dry season.

The borrow ditch along the east side of the old railroad embankment in this area (now the alignment of U. S. Highway 1) is deeper to the south and connects with Barnes Sound (see fig. 188) in a shorter distance than the borrow ditch on the west side. Contamination was found to extend 2 miles farther north in the east borrow ditch than it did in the west borrow ditch. The embankment is partially effective in preventing salty surface water in the east borrow ditch from penetrating to the west side. The vegetation suggests that the difference in chloride concentrations is more than a temporary condition. Mangroves, which thrive only in salty and brackish waters, were observed about 2 miles nearer to Florida City on the east side than on the west side of the embankment.

The extent of salt-water encroachment in the Homestead area in the extreme drought of 1945 is also shown in figure 188. All of the canals, whether controlled or not, became contaminated with salt water, which in places exceeded the normal concentration of sea water by about 30 percent. At the time, ground-water levels were very low-below sea level in some areas. As a result, net flow in the canals probably was inland and the canals supplied salt water to the porous formations. Water that was more salty than sea wa- 
ter extended to Florida City and the outskirts of Homestead, more than 9 miles from Biscayne Bay.

Most of the salty water in the canals was flushed out by the late summer rains but contaminated water from the ground continued to seep into the canals. No samples were taken along the new route of U. S. Highway 1 in 1945, but later observations indicated that the shallow borrow ditches along the highway fill probably were strongly contaminated to a point less than 6 miles from Florida City. This location is at the northern end of the continuous ditches and borrow pits and it is possible that ground-water contamination continued even farther inland. It was observed also that chloride concentrations were higher along the east side of the highway fill than on the west side, the same situation that was found when only the railroad embankment was there.

Starting in 1946, series of samples were taken from the borrow canal along Ingraham Highway southwest from Royal Palm Park (formerly Royal Palm State Park and now part of Everglades National Park), which is 11 miles southwest of Homestead. Thirteen miles by road; west-southwest from the ranger station in Royal Palm Park, a concrete bridge crosses the borrow canal and the road changes from an east-west to a northeast-southwest course for a distance of 1 mile, and then to a north-south course for a distance of 5 miles. About 2 miles south on the $5-m$ ile northsouth reach, mangroves occur, showing that the soil and water in the area are salty to a considerable degree and for a major part of the time. This essentially continuous contamination is also shown by the sampling program in the canal. The salt front was never found below the lower end of the north-south reach $14 \frac{1}{2}$ miles southwest of the ranger station in Royal Palm Park.

In dry periods, strongly salty water moves inland to the end of the canal near the ranger station at Royal Palm Park. The canal is not controlled, and its value for drainage is limited; however, it is an avenue for salt-water encroachment in the area between Whitewater Bay and Homestead.

\title{
SALT-WATER CONTAMINATION OF THE AQUIFER FROM TIDAL CANALS
}

\author{
By Garald G. Parker
}

The amount of salt water that escapes from a tidal canal into the adjacent rocks is dependent upon several factors: The salinity of the canal water itself; the coefficient of transmissibility of the rocks through which the canal is cut; the presence or absence of a layer of sediment, which, if present, may be relatively impermeable and thus prevent free movement of water from the canal to the adjacent rocks; and the stage of the water table adjacent to the canal compared to the stage of the water surface in the canal. 
Rocks of the Biscayne aquifer in the Atlantic coastal ridge, through which the canals are cut, are of very high permeability and transmit water readily. (See p, 269-270.) The amount of sedimentation in the canals is variable in time and in place. In some parts of the canals the bottom appears to be well sealed by deposits of calcareous mud, organic material, and very fine sand. In other parts, sealing material is absent and canal and ground water are freely exchanged. These conditions lead to the salting of some areas along the canals, whereas other areas remain unsalted or receive only a small amount of salty water. A further complication may result from the pumping of wells. Where the effects of the draft on ground water extend to the canal, pumping may induce or increase the movement of canal water into the aquifer.

For an understanding of the process of salt-water contamination of a fresh-water inland aquifer, a study was made in the area of the Miami well field (see figs. 13 and 189), through which the Miami Canal runs. In all respects, except for the pumping, this area is typical of the coastal area in southeastern Florida. The method of salt-water contamination of the aquifer is the same as would be found in any other tidal canal in which salt water has penetrated into an area of fresh ground water. Pumping from the nearby city-supply wells influences the flow of the ground water in the aquifer and the reby distorts the chloride-contamination pattern.

The following generalizations on salt-water contamination are based on ground-water studies made along Miami Canal between NW. 36 th and NW. 54th Streets. A part of this area of study is usually intersected by the cone of depression formed in the water table by draft from the Miami well field. Figure 189, a map of the area, shows a pair of typical cones of depression in the water table.

Figure $190 \mathrm{~A}$ is a cross section of this same area, showing ground-water conditions as they were before salt water made $i$ ts appearance in this segment of the canal in 1939 .

When salty water first reached this area in large quantities, it moved through the canal bottom, where it was not too heavily silted, and downward toward the bottom of the Biscayne aquifer. In doing so, it constantly encountered fresh water and was steadily diluted until it finally reached the top of the relatively impermeable Floridan aquiclude. When salt water had remained long enough in the canal, all fresh water directly under the canal disappeared (fig. $190 \mathrm{~B}$ ) and saline water, lessening in chloride concentration as the bottom of the aquifer was approached, completely occupied the former fresh-water zone. An average pumpage of $30 \mathrm{mgd}$ in the nearby Miami well field caused a general southwestward movement of the salted body of water. 


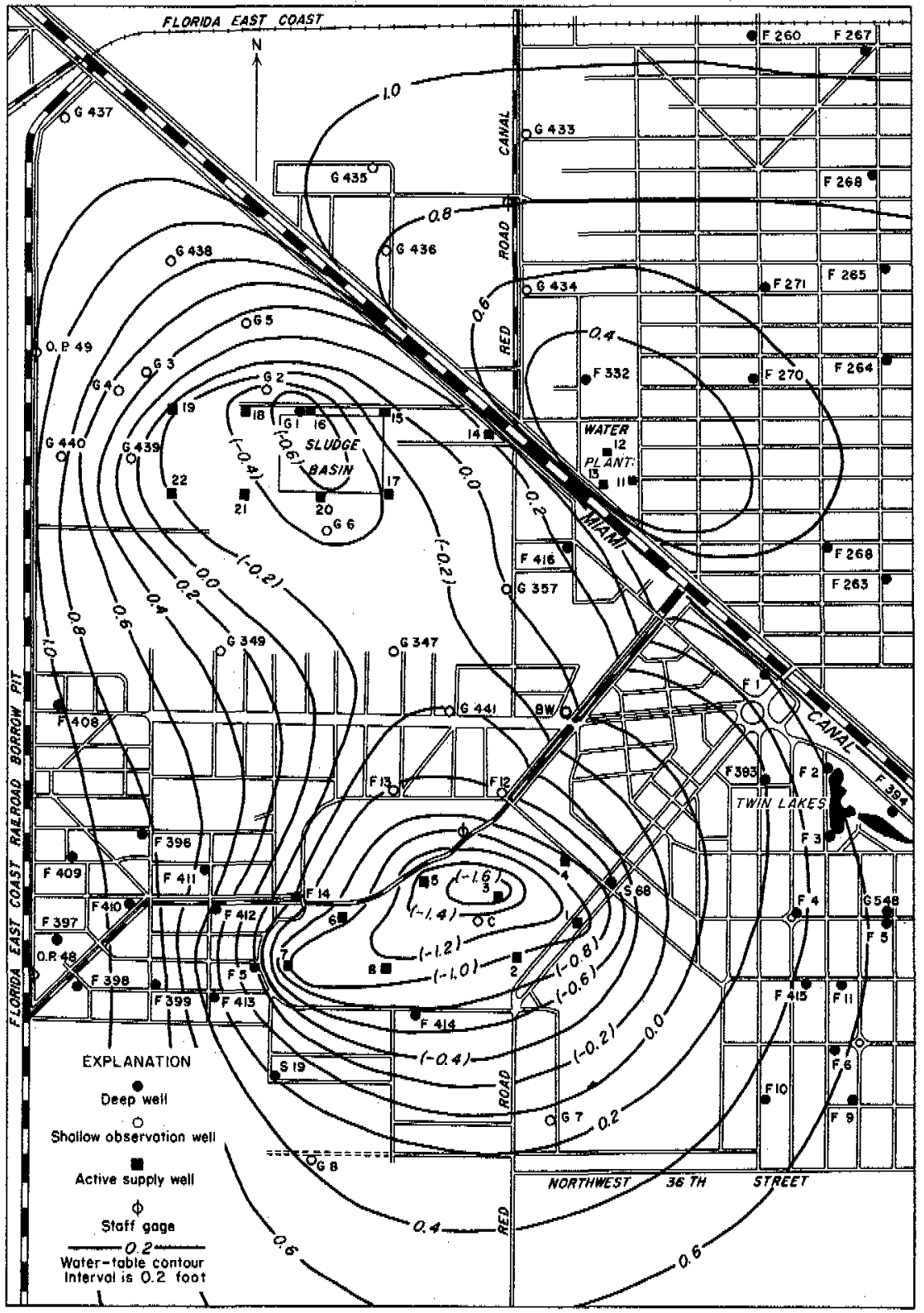

Figure 189. - Map of Miami well-field area showing shape of typical cones of depression in the water table. 


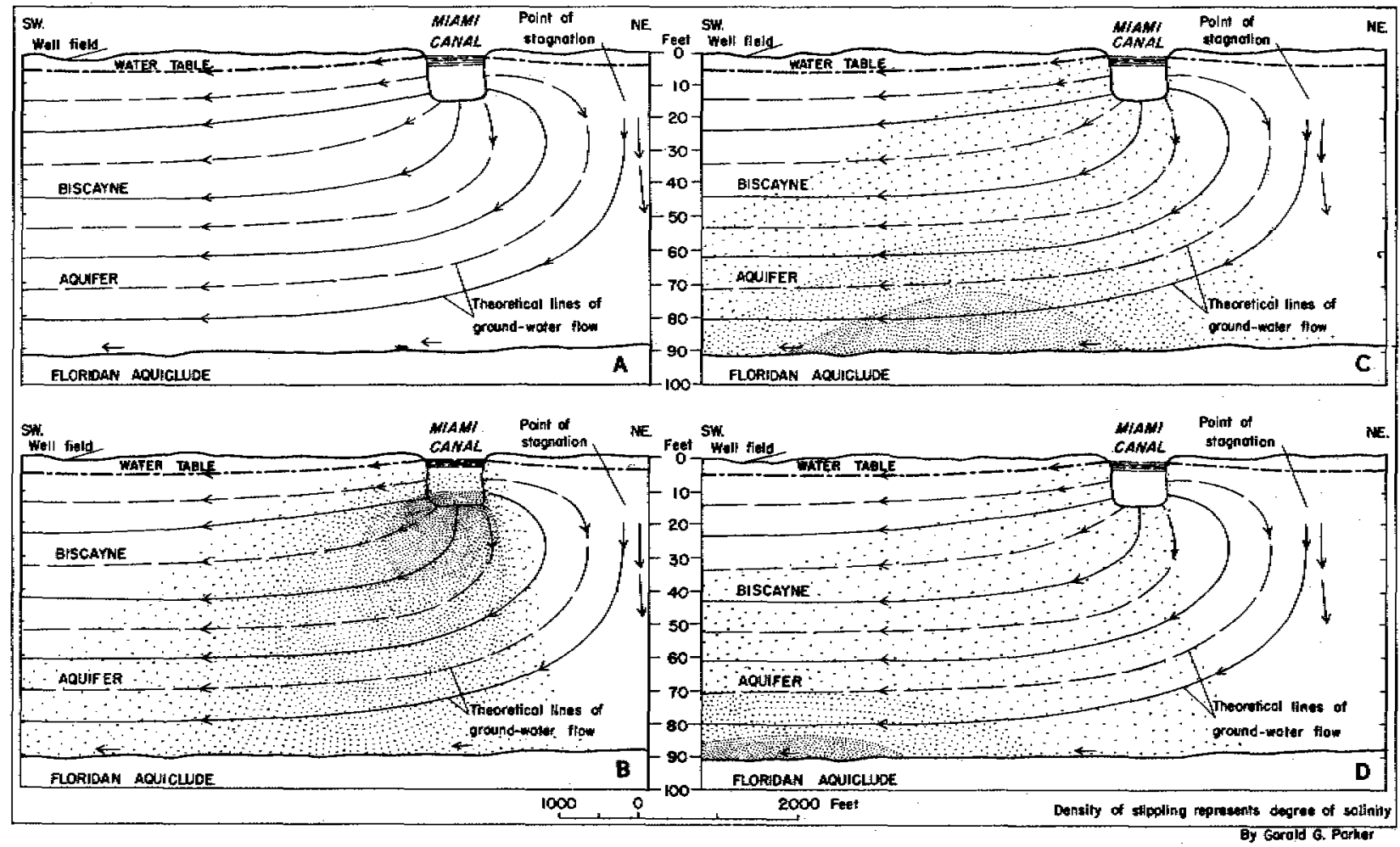

Figure 190. - Geologic cross section near the Miami well field: $A$, prico to salt-water intrusion; $B$, the beginning of the intrusion; $C$, several months later: D. a late stage. 
At the close of the drought period in 1939, the fresh-water discharge in the canal increased, and salty wate $r$ in the canal was swept downstream beyond the new zone of contamination. However, the salty water in the ground under the canal was not removed so quickly. It continued to sink toward the bottom of the Biscayne aquifer, to move toward the well field, and to create a salt-water mound on top of the Floridan aquiclude (fig. $190 \mathrm{~B}, \mathrm{C}$, $D)$. As it was drawn toward the well field, the mound of salty water was diluted by the overlying fresh water from the canal and the surrounding fresh water. Finally, it was entirely isolated from its original source. Owing to its greater density, the water of greatest chloride content moved to the bottom of the aquifer. This mound is shown as an "island" of salty water on the map, figure 193.

Figure $190 \mathrm{D}$ shows a still later stage in the history of the saltwater encroachment. The salty water is continually, but slowly, being diluted by fresh ground water and being removed by pumping from the well field. If no further contamination had occurred through the canal, the final stage would have been reached with a return to original conditions, as shown in figure $190 \mathrm{~A}$.

However, salty water again gained access to this reach of the canal in 1940,1943,1944, and 1945 (see fig. 192). As a result, new patterns of salt-water encroachment were imposed on the altered patterns of preceding encroachments. A more extensive discussion of encroachment in the Miami Springs-Hialeah well field is given in a later section of this report (see p. 691-705).

Encroachment of salt water also takes place in areas along canals that contain salt water continuously. In such areas, however, the manner of encroachment is the same as that which occurs directly from the ocean at depth in the aquifer.

\section{CONTAMINATION OF CANALS BY RESIDUAL SALTY GROUND WATER}

Figure 191 shows how residual bodies of salty water may contaminate fresh water in an overlying canal or other stream. The illustration represents a section of North New River Canal in its upper reach, south of Bolles Canal. When the level of North New River Canal is lower than the adjacent water table, ground water flows into the canal, and salty water from the Fort Thompson formation and the Caloosahatchee marl percolates upward into the canal. Water from the land surface and from Lake Okeechobee is relatively low in dissolved minerals, and the amount of chloride in the water, which may be used as a measure of contamination, is generally less than $20 \mathrm{ppm}$. However, under effluent conditions, as outlined above, it is not unusual for the canal water to contain as much as several hundred parts per million of chloride. 


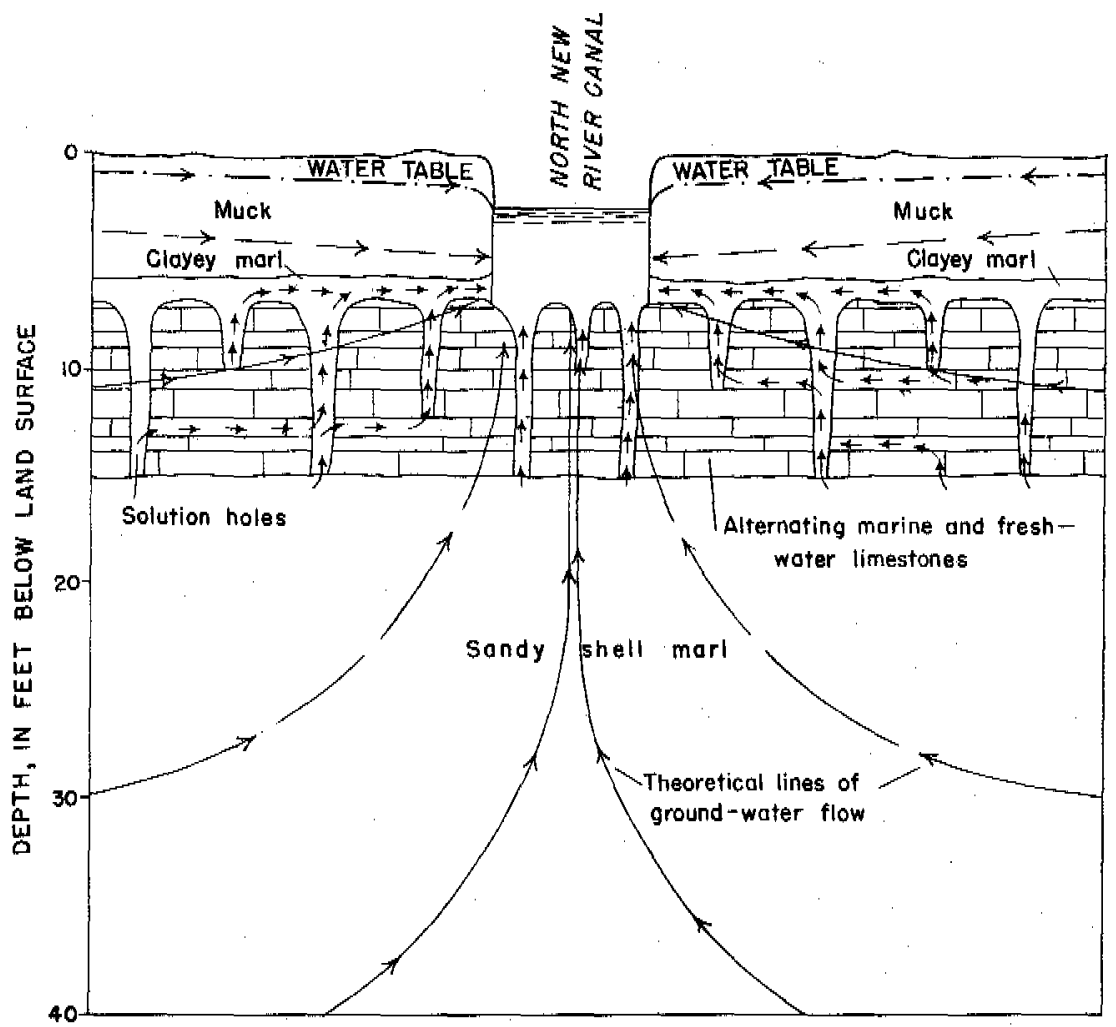

Figure 191. - Geologic cross section under North New River Canal showing residual salty ground water contaminating fresh canal water.

During times when the canal is influent (when the canal level is higher than the adjacent water table, and water is lost to the ground) it of ten carries water with less than $10 \mathrm{ppm}$ of chloride.

\section{SALT-WATER ENCROACHMENT IN THE MIAMI WELL FIELDS}

The development of the water sources used by the city of Miami is described in the section on Ground water (Occurrence), $p$. 163-165. The abandonment of some of these sources was not because of failure of the wells to yield sufficient quantities of water; it was always because of salt-water encroachment.

\section{SPRING GARDENS WELL FIELD}

The Spring Gardens well field occupied the site at NW. 11 th Street and 10 th Avenue, where the present storage tanks are located (see map, fig. 168). H, H, Hyman and H. D. Wright, of the Florida Power and Light Company, reported that when this field 
was first put into use, about 1907, it yielded typical hard limestone water with no salty taste. The depths of the wells are from 80 to $90 \mathrm{ft}$, which is near the base of the Biscayne aquifer. At that time, the refore, salty water was absent from the aquifer of this part of the coastal ridge.

As the city grew and more water was required, additional wells of the same depth were drilled. Then, gradually, the effects of the drainage program began to be felt. The water table declined so much that the wells, which had been flowing into a sunken reservoir, ceased flowing or were so reduced in flow that by about 1918 it was necessary to install pumps. At this time there were about 11 wells.

Shortly after the pumps were installed the water became brackish in the easternmost wells; then, one by one, the other wells became brackish also. It was decided to plug the bottoms of the wells and develop them at shallower depths, where fresh water might be obtained. This was done, and the wells began producing fresh water from about 40 to $45 \mathrm{ft}$ below the land surface. More wells were added, one or two at a time, all located to the north and west. In the latter part of 1918 a total of 24 wells, with average depths of about 40 to $45 \mathrm{ft}$, constituted the well system (Hyman, 1943). Gradually, however, even these shallow wells were contaminated by salt water, and by January 1919 only 13 were still in service. They were the wells located farthest to the north and west.

At the request of the Florida State Board of Health, Clyde P. Ross (1919) of the U. S. Geological Survey prepared a report on the water supply at Miami (table 78).

The composite sample of ground water reported above is a combination of water from 13 pumping wells and is therefore representative of neither the saltiest nor freshest water from this field. Although the water is hard and contains $269 \mathrm{ppm}$ sodium chloride, it is potable, and most people would not detect the chloride by taste.

After 1919, the salinity continued to increase. Lawsuits were brought against both the Miami Water Company and its manager, H. H. Hyman, for selling salty water (Bellamy, 1946). Nevertheless, by reducing the pumpage from the Spring Gardens field and drilling additional wells elsewhere in the city, the water company continued its service until the new municipally owned well field in the Miami Springs - Hialeah area was developed and put into operation in the spring of 1925 . At present, even very shallow wells in the Spring Gardens well field yield only salty water. 
Table 78. - Analyses of Eround and surface water at ifiami, Jousary 21, 1919

[Simples collected by C. P. Ross. Analyses, in parts per million, by M. D. Foster and C. M Forman]

\begin{tabular}{|c|c|c|c|c|c|c|c|c|c|c|c|}
\hline Source & $\begin{array}{l}\text { Dissolved } \\
\text { solids }\end{array}$ & $\begin{array}{l}\text { Silica } \\
\left(\mathrm{SiO}_{2}\right)\end{array}$ & $\begin{array}{l}\text { Iron } \\
\text { (Fe) }\end{array}$ & $\begin{array}{l}\text { Calcium } \\
\text { (Ca) }\end{array}$ & $\begin{array}{c}\text { Magnesium } \\
\text { (Mg) }\end{array}$ & $\begin{array}{l}\text { Sodjum } \\
\text { and } \\
\text { potassium } \\
(\mathrm{Na}+\mathrm{K})\end{array}$ & $\begin{array}{c}\text { Bicarbonate } \\
\left(\mathrm{HCO}_{3}\right)\end{array}$ & $\begin{array}{c}\text { Sulfate } \\
\left(\mathrm{SO}_{4}\right)\end{array}$ & $\begin{array}{c}\text { Chloride } \\
\text { (C1) }\end{array}$ & $\begin{array}{l}\text { Nitrate } \\
\left(\mathrm{NO}_{3}\right)\end{array}$ & $\begin{array}{l}\text { Organic } \\
\text { matter }\end{array}$ \\
\hline
\end{tabular}

${ }^{1}$ Composite sample from 13 pumping wells, average depth about 45 feet.

From middle of stream, tmder Miami Canal bridge (probably the bridge formerly at NW. 27th Ave.). 

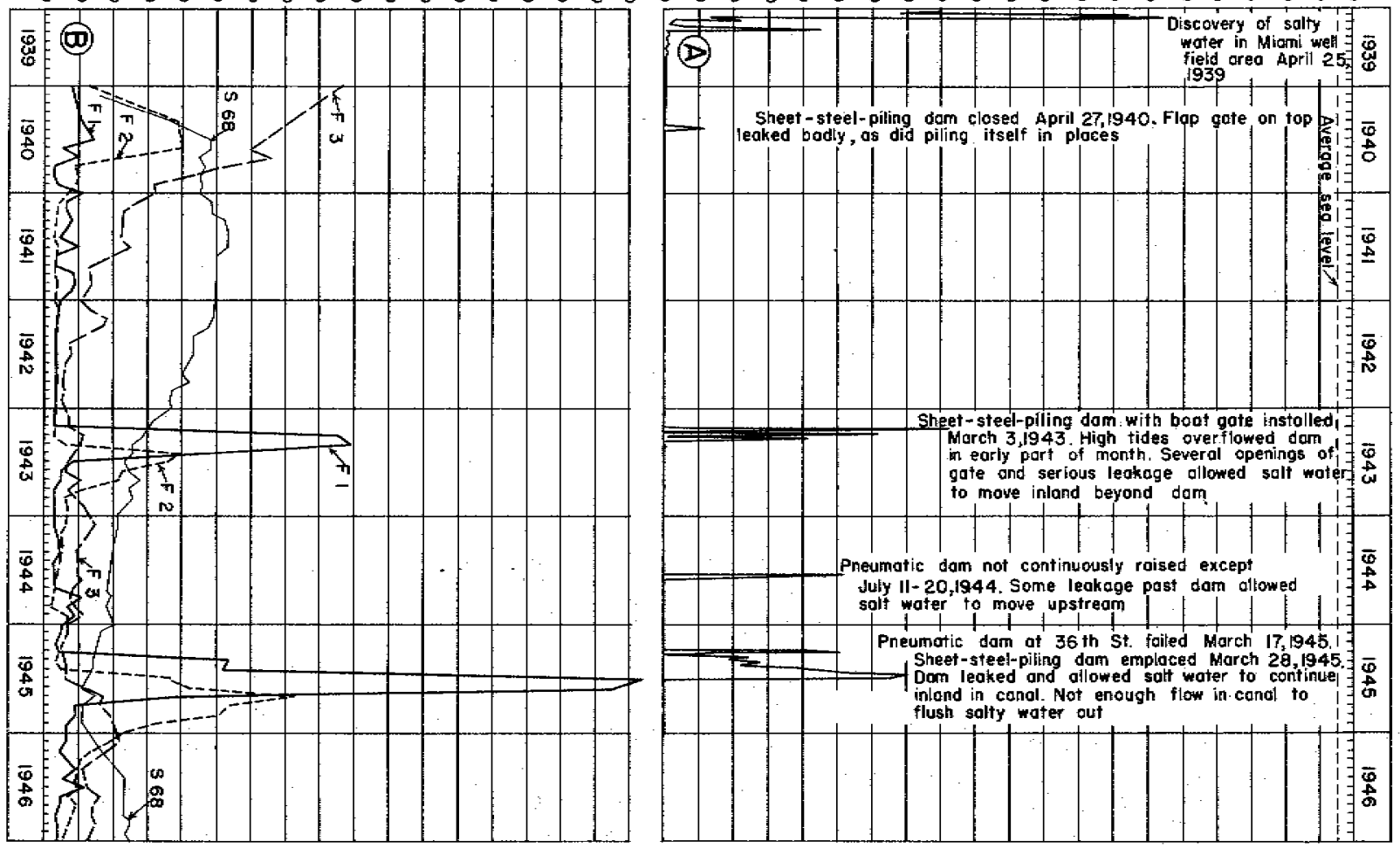

Figure 192. - Graph showing variation of chloride in: A, Miami Canal at NW. 54th Street; $B$, wells F1, F2, F3, and S68, Miami well-field area. 
The salting of the water at Spring Gardens made it necessary to find a new water source. This was found in the Miami Springs-Hialeah area. According to W. L. Black, superintendent of the Miami Water Works, it was developed largely in 1924 and put into service in March 1925. The raw water from the new well field apparently was quite similar to that first obtained in downtown Miami (see p. 163-165) and from the Spring Gardens well fielda hard limestone water containing considerable organic color. It continued to yield water of this quality until April 1939, when certain wells nearest Miami Canal began producing salty water. By mid-May, the chloride concentration of water from some of the wells had increased to $1,900 \mathrm{ppm}$. Figure $192 \mathrm{~A}$ is a graph based on data furnished by the Miami Department of Water and Sewers. It shows the variation of chloride concentration in water of the Miami Canal at the NW. 54th Street Bridge between Hialeah and Miami Springs. The record begins on April 29, 1939, by which time the chloride content of the canal water had already reached $8,100 \mathrm{ppm}$; by mid-May it had increased to $14,400 \mathrm{ppm}$, equivalent to 73.8 percent of sea water.

The U. S. Geological Survey began sampling ground water from the well-field area in December 1939, but it did not achieve adequate areal coverage until April 1940; all critical wells since that time have been sampled at least once a month. In addition to the fire and supply wells already existing in the area, the Survey drilled 12 observation and test wells that penetrated to the base of the Biscayne aquifer at an average depth of about $100 \mathrm{ft}$. Water from about 45 wells (see map, fig. 189), including the 20 city supply wells, was sampled.

\section{SALT-WATEA INTRUSIONS IN THE MLAMI CANAL}

Figure 186 shows the approximate position of water in Miami Canal containing $1,000 \mathrm{ppm}$ of chloride. Figure $192 \mathrm{~A}$ shows that the highest recorded. chloride concentration in the canal water at the 54 th Street bridge sampling station occurred in 1939. The record for 1939 is incomplete, however, for it does not start until April 25, and it is probable that salt water had occupied the canal at that point for a considerable time before discovery and sampling. By October, the salt had retreated downstream and the canal water at the 54 th Street Bridge was again normal. (See pages 636-640 for a discussion of salt-water encroachment in $\mathrm{Mi}$ ami Canal from 1940 to 1946 .) 


\section{CONTAMTNATON OF WHLCS}

As a' result of the several incursions of salt water in Miami Canal in the Miami well-field area, salt water contaminated the adjacent ground water. The method of contamination is shown in figures 190 and $192 \mathrm{D}$, and in map form in figures $193-198$.

Figure $192 B$ is a graph showing variation in the chloride content of ground water at four wells situated at increasing distances from Miami Canal (see fig. 189). Well $F 1$ is about $80 \mathrm{ft}$ from the canal and is about $50 \mathrm{ft}$ deep; $F 2$ is about $400 \mathrm{ft}$ from the canal and is about $71 \mathrm{ft}$ deep; $F$ is about $900 \mathrm{ft}$ from the canal and is about $46 \mathrm{ft}$ deep; and $\mathrm{S} 68$ is about $2,900 \mathrm{ft}$ from the canal and is about $61 \mathrm{ft}$ deep. Wells $F 1$ and $F 2$ are adjacent to Twin Lakes.

It was not until December 1939 that samples were collected from these wells and the water in Twin Lakes was analyzed for chlorides. Therefore, a direct comparison cannot be made with the Miami Canal record, which begins in April 1939.

Figure $192 B$ shows that in 1940 the salinity was greatest in well $F 3$, less in F 2, and still less in F 1. The plate also shows that while F 3 was declining in salinity, the other two were increasing, and the amount of increase was less in F 1 (farthest from F 3 ) than in F 2. This suggests that a pocket of saline water, probably trapped in the deepest part of West Twin Lake, was slowly seeping downward and outward. Months after the adjacent Miami Canal water had returned to normal, this salty water was further contaminating the ground water immediately adjacent to it. The occurrence of such an isolated pocket of salty water in Twin Lakes is possible because the canal connecting them with Miami Canal is much shallower than either the lakes or Miami Canal. When this salty water entered the lakes it could leave only by relatively slow underground seepage.

Later incursions of saline water in the Miami Canal (1940 and 1943-45) were all of a lower concentration than that in 1939 (fig. $192 \mathrm{~A}$ ). This saline water occupied only the canal bottom and did not spill over the shallow entrance into Twin Lakes (as in 1939). Therefore, it did not create a local source of contamination in the lakes. The truth of this statement is illustrated by the fact that the increase in chloride concentration was not significant in wells $F 1$ and $F 2$ after the removal of the contamination in Miami Canal, whereas the increase was significant in 1940 following the incursion of 1939. The incursion of 1943 was moderate, but typical: $F 1$ responded first and in greatest amount; $F 2$, next and in lesser amount; and $F 3$, still later and in least amount. These responses indicate that the salt water seeps downward and outward from $\mathrm{Mi}$ ami Canal, and that it becomes progressively diluted as it moves farther from the canal. 

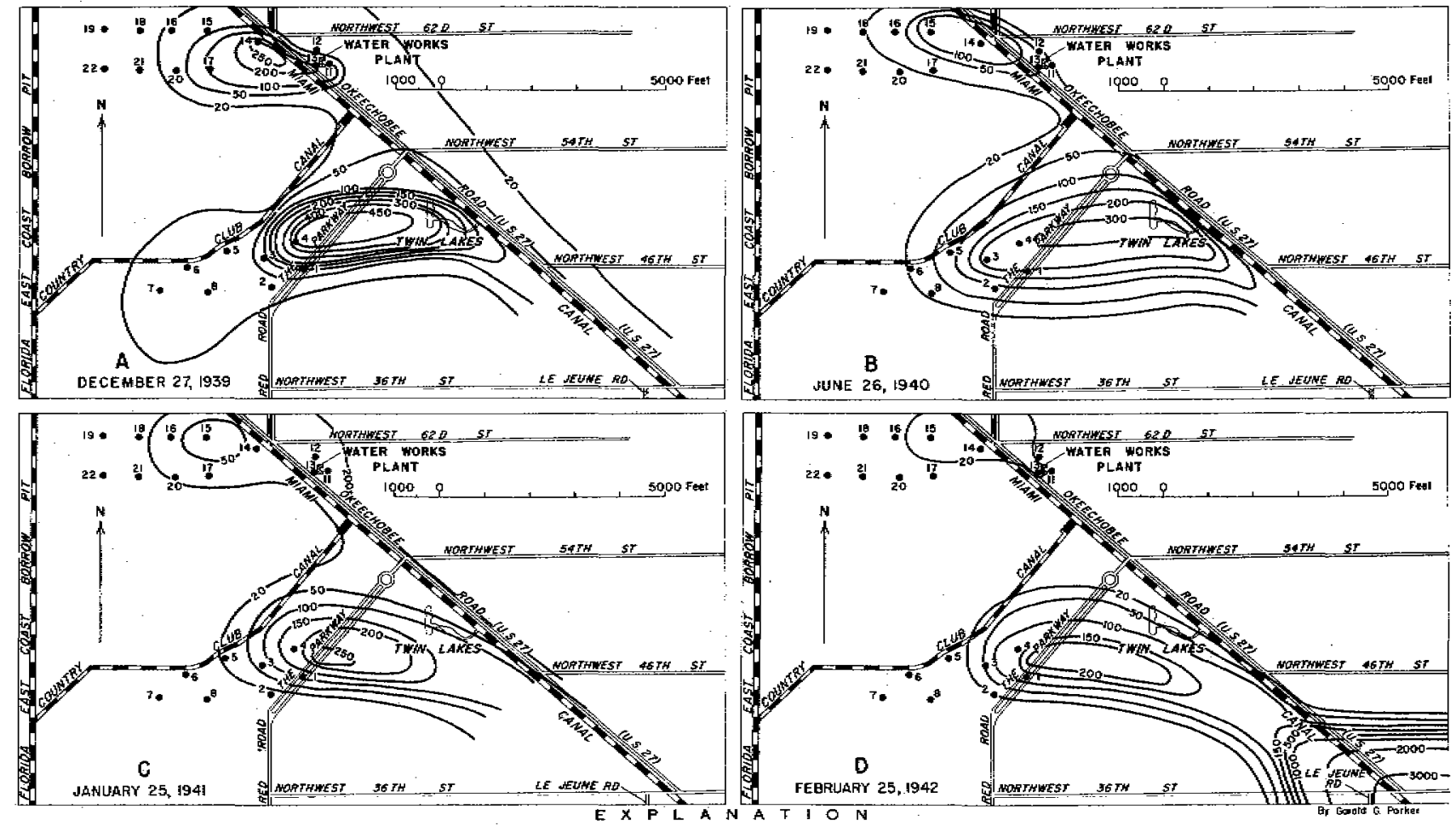

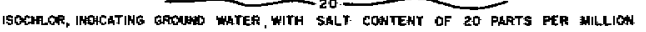

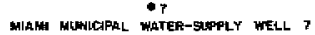

Figure 193. - Iscichlor map of the Miami well-field area: $A$, December 1939; $B$, June $1940 ; C$, January $1941 ;$ and $D$, February 1942. 
The response of well $\mathrm{S} 68$, which is $2,900 \mathrm{ft}$ from the canal, was entirely different from that of $F 1, F 2$, and $F 3$, which are nearer the canal. For example, the increase in chloride caused by the 1939 incursion did not reach a maximum in S 68 until May 1940 -a lag of about 6 months. Similarly, the incursions of March 1943 and June 1944 caused small increases in chloride in $S 68$ that did not reach their peaks until August and December, respectively. The extensive incursions that occurred from March to June 1945 resulted in an increase in salinity at $S 68$ that did not reach its peak until early in 1947. However, most of this increase had taken place by May 1946. A period of about 6 months to a year was thus required for the salt water to move approximately $2,900 \mathrm{ft}$, which is at the rate of 8 to $16 \mathrm{ft}$ per day. This variation was chiefly due to changes in the rate of pumping in the well field.

Chloride maps (figs. 193-198) were prepared as a result of regular month-end studies that were made in the well-field area from the time the U. S. Geological Survey began its investigation. These 24 maps (selected from 96 maps) are considered necessary for a full understanding of the history of salt-water encroachment in the well-field area.

As the investigation proceeded, it became apparent that certain critical spots in the salt-front area were not adequately covered. Therefore, additional observation and test wells, penetrating to the bottom of the aquifer, were drilled from time to time. Each month, water levels in these wells were observed and water samples were collected for chloride analysis. These data were then plotted on topographic base inaps, which gave month-end information on the shape of the water table, including the extent of the cone of depression and the concentration of salt in the ground water. Only isochlors are plotted in figures 193-198.

Figure 193A. shows chloride conditions in December 1939, six months after the salt-water incursion in Miami Canal reached the 54 th Street bridge. The oval-shaped body, or "island", of salty ground water (maximum chloride content slightly more than 450 ppm), extending from the Twin Lakes area to the lower well field, is notable in the figure. The map indicates the role that $T w$ in Lakes played in the original salting of this area (see p. 692). It shows that the salty water did not come directly from the tongue of salty ground water in the vicinity of NW. 36 th Street, as has much of the salty water of later invasions. From its source at Twin Lakes, the salty water, in response to pumping in the lower well field, was drawn in almost a straight line into the well field.

Another island of contamination that is notable in figure $193 \mathrm{~A}$ is in the upper well field. It now has a maximum chloride content of slightly more than $250 \mathrm{ppm}$; at one time, however, its chloride 
content was more than $1,000 \mathrm{ppm}$. This contamination is directly related to pumping in the upper well field.

Figure $193 B$ shows chloride conditions in the well-field area in June 1940. A slight incursion of salty water occurred in Miami Canal in May, but it did not greatly change the chloride pattern of December 1939. In the lower field, the pattern widened somewhat and moved much farther into the well field. In the upper field, the pattern became smaller and the salinity decreased considerably.

Figure $193 \mathrm{C}$ shows conditions in the well-field area in January 1941,19 months after the extensive salt-water incursion of 1939 had withdrawn and 8 months after the minor incursion of 1940 . By this time the upper well field had returned almost to normal, and the lower well field contained only one small area where chloride was in excess of $250 \mathrm{ppm}$. The entire pattern in this area was greatly reduced, and the axis of the pattern shifted from approximately S. $80^{\circ}$ W. (Dec. 27,1939 ) to approximately S. $80^{\circ} \mathrm{E}$.

Figure $193 \mathrm{D}$ shows conditions in the well-field area in February 1942. Since May 1940 no new incursions of salt water had occurred in Miami Canal above NW. 36th Street. In the upper well field there remained only one small area of ground water that had a chloride content slightly above $20 \mathrm{ppm}$. (Chloride of less than $20 \mathrm{ppm}$ is regarded as normal for this area.) In the lower well field the ground water that had contained 250 ppm or more of chloride had disappeared. Now, for the first time, the tongue of salty ground water near NW, 36 th Street and Le Jeune Road could be related to the salty water in the well field. This tongue was merely the westernmost extension of the salt-water wedge that extended inland from the western shore of Biscayne Bay along the canal. Similar tongues extended from Biscayne Bay along, and beneath, each of the tidal canals of Dade County (see fig. 200); these tongues were not induced by pumpage in the Miami well field.

Figure $194 \mathrm{~A}$ represents salinity conditions in ground water of the well-field area at the end of January 1943. New incursions of salty water had not taken place in Maimi Canal, and conditions had improved in both the upper and lower well fields, where the highest isochlor was $150 \mathrm{ppm}$. The NW, 36 th Street tongue had advanced only slightly on the south side of NW. 36 th Street and west of Le Jeune Road.

Figure $194 B$ shows conditions in March 1943 immediately following the second of two salt-water incursions up Miami Canal in March. As a result of these incursions a new center of contamination developed in the upper well field. The lower field was not affected, however, and there the salinity lessened. This continued improvement is credited to dilution, a factor that is quite apparent when the increased extent of the zone of 20-to 50-ppm concentration 

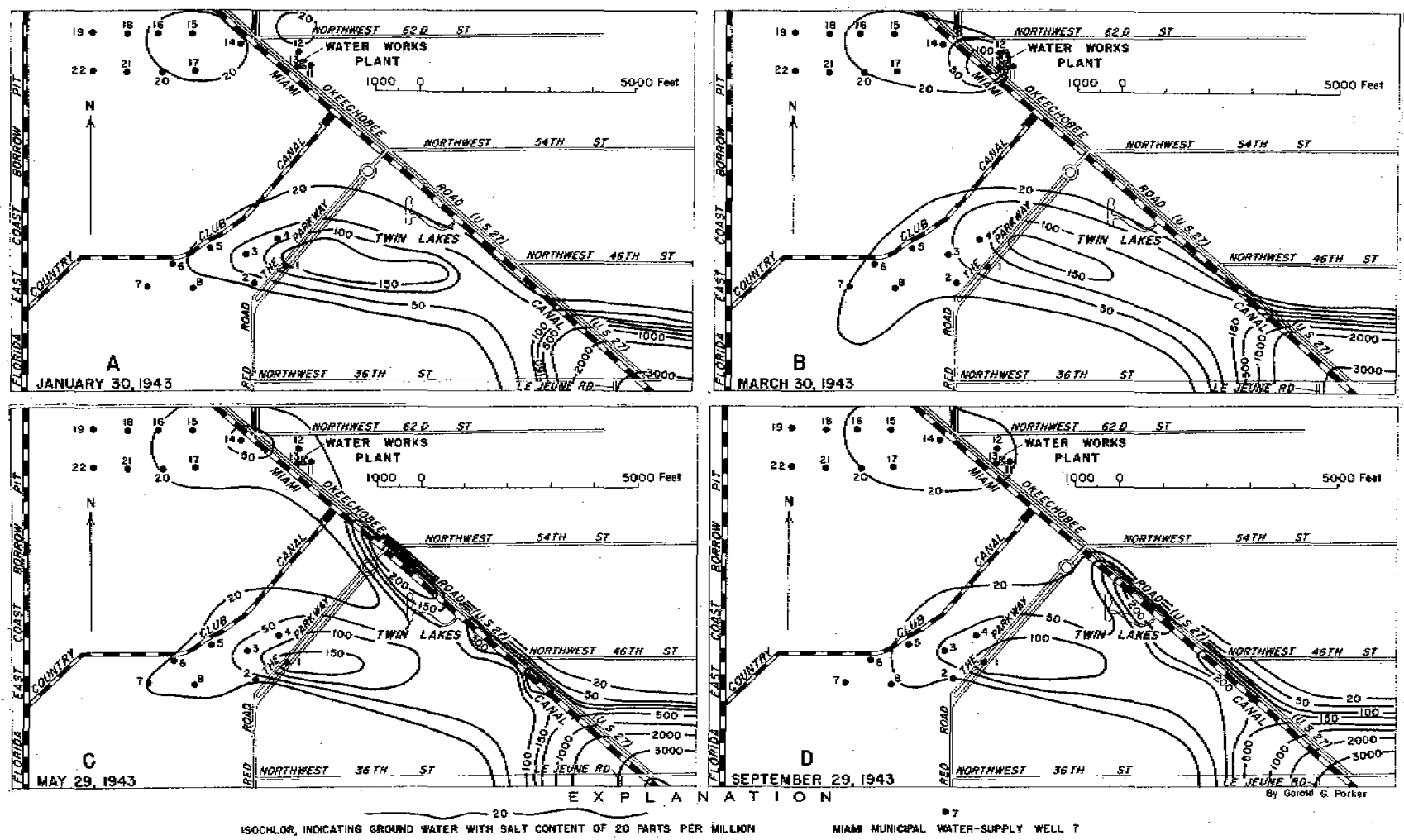

Figure 194. -Isochlor map of the Miami well field area: 4, January 1943; B, March 1943; C, May 1943; and D, September 1943. 

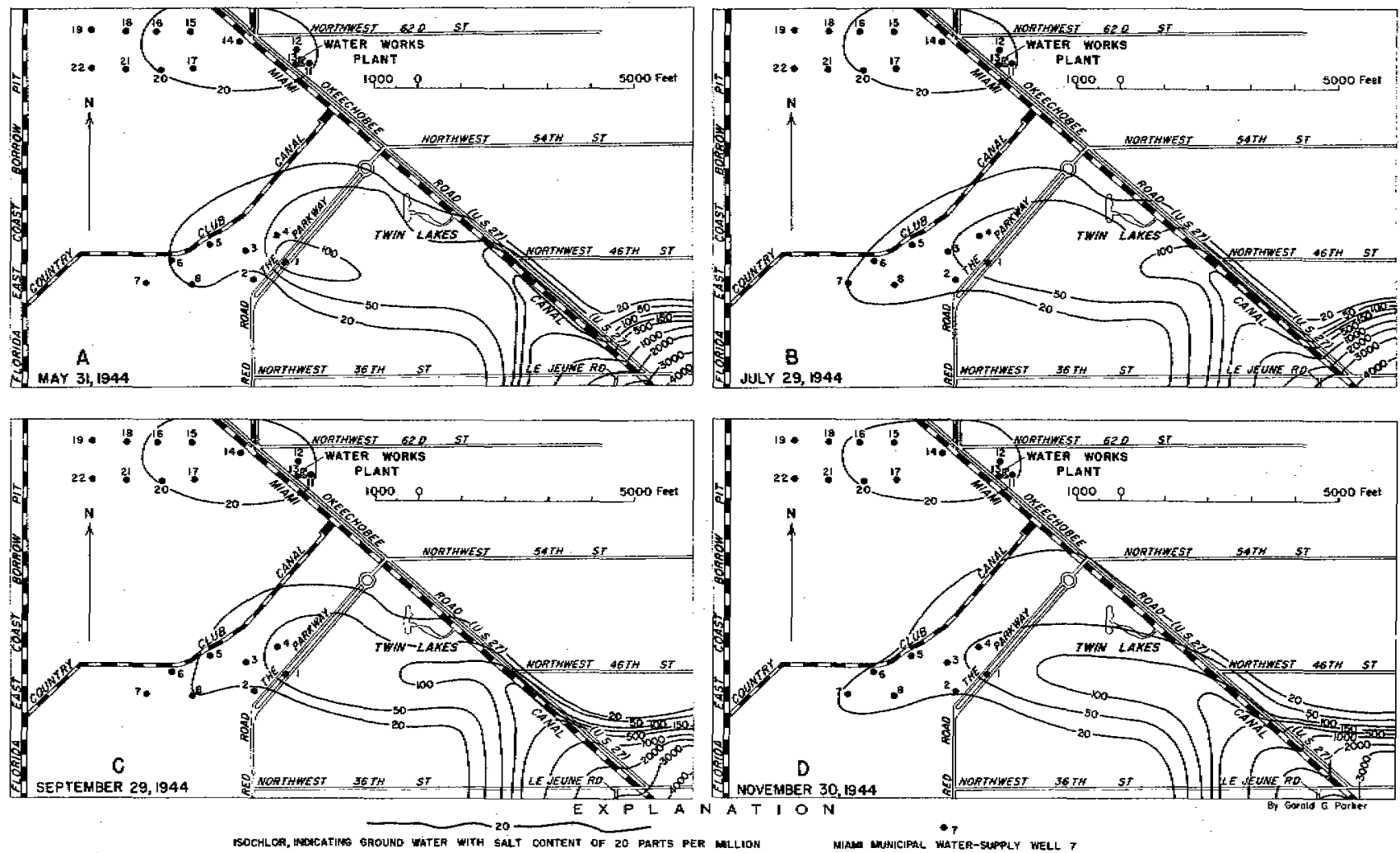

Figure 195. - Isochlor map of the Miami well-field area: $A$, May 1944; $B$, July 1944; $C$, September 1944; and $D$, November 1944. 
is considered. Note also the westward advance of the NW, 36th Street tongue south of NW. 36 th Street and west of Le Jeune Road.

Figure $194 \mathrm{C}$ represents conditions in May $1943,1 \frac{1}{2}$ months after the withdrawal of the salt water in Miami Canal. The upper well field now shows considerable improvement, and the lower well field continues to improve. However, several local pockets of salty ground water have developed, principally along the southwest bank of Miami Canal: Twin Lakes did not act as a focal point of contamination this time, as they apparently did in 1939-40. Note the initial appearance of a 4,000-ppm isochlor in the NW. 36th Street tongue downstream from the NW. 36 th Street dam.

Figure 194D shows conditions at the end of September 1943, 4 months later. Miami Canal had been free of salt water in the well-field area since March; therefore, conditions in both the upper and lower field's continued to improve. The areas of contamination along the southwest bank of Miami Canal have tended to coalesce and move slightly toward the lower well field.

Figure 195A represents conditions in the well-field area 8 months later, at the end of May 1944. New incursions had not occurred in Miami Canal in this area, and conditions had generally improved. For water-supply purposes the upper well field was back to normal. In the lower well field the water of highest chloride content was now enclosed in a relatively small area bounded by the $100-\mathrm{ppm}$ isochlor. The contamination that occurred on the southwest side of the canal 1 year before (May 1943) had since been greatly reduced; however, part of this reduction was at the expense of an enlargement of the areas bounded by the $20-$ and $50-\mathrm{ppm}$ isochlors. Slightly west of Le Jeune Road, the NW. 36 th Street tongue had widened, and it was now being diluted by fresh canal water.

Figure $195 B$ shows conditions only 2 months later (July 1944). At this time an offshoot of salty ground water was beginning to move directly toward the lower well field from the NW. 36th Street tongue. This offshoot was a remnant of the contamination that was initiated in March 1943 on the southwest side of the canal. It was drawn toward the well field in consequence of the extension of the cone of depression from the field. In the lower well field no trace remained of chlorides in excess of $100 \mathrm{ppm}$; the isochlor of highest value was now only $50 \mathrm{ppm}$. Note that the NW. 36 th Street tongue was still being diluted, and that it was moving west from Le Jeune Road.

Figure $195 \mathrm{C}$ represents chloride conditions in the well-field area in September 1944. The continued westward movement of the offshoot from the NW. 36 th Street tongue is of interest. In 2 months it had advanced approximately $950 \mathrm{ft}$ (475 ft per month or $5,700 \mathrm{ft}$ per year), an extremely rapid rate. However, this tongue had not moved in the area west of Le Jeune Road. 

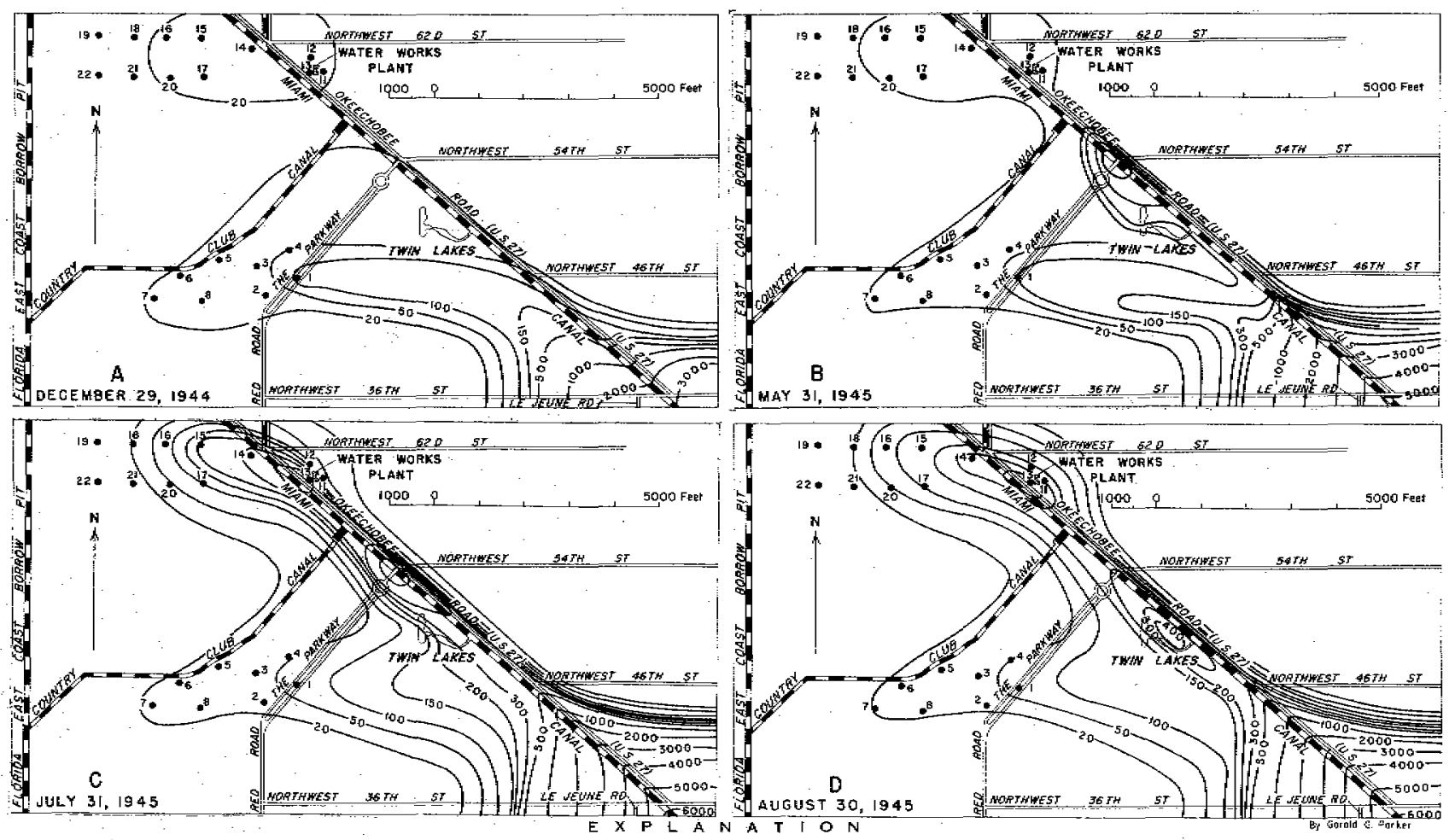

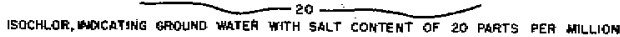

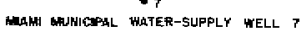

Figure 196. - Isochlor map of the Miami well-field area: A, December 1944; $B$, May 1945; $C$, July 1945; and D, August 1945. 
Figure $195 \mathrm{D}$ shows conditions in November 1944 . The NW. 36 th Street offshoot was moving more rapidly than before. During the 2 months between September 29 and November 30, the offshoot had moved westwand $1,030 \mathrm{ft}$, which is at the rate of $515 \mathrm{ft}$ per month or $6,180 \mathrm{ft}$ per year.

Figure $196 \mathrm{~A}$ represents conditions in December 1944. The offshoot of the NW. 36 th Street tongue had now moved another 1,400 ft into the well field at the very high rate of $16,800 \mathrm{ft}$ per year. This was more than twice the velocity of the previous month. The increased velocity is explained by the fact that the velocity of ground-water flow increases as flow lines converge toward the center of a well field cone of depression. The gradient along which the movement took place is approximately 0.6 foot per thousand feet (measured on the mapped water table for December $29,1944)$. The average daily pumpage from the well field at that time was about $35 \mathrm{mgd}$.

Figure 196B shows chloride conditions in the well-field area May 1945, 5 months later. On March 17, salty water had gained access to Miami Canal in this area because of the failure of the pneumatically controlled tidal dam. It was not until March 28 that a sheet-steel piling dam replaced this loss. In the meantime, the water levels had continued to decline until the highest altitude of the water table between the well field and the dam was $0.2 \mathrm{ft}$ above the U, S. Coast and Geodetic Survey's mean sea level. Average sea level in Biscayne Bay was about $0.4 \mathrm{ft}$ higher than this datum plane; therefore, the highest level of the water table referred to above was at least $0.2 \mathrm{ft}$ below the actual observed average sea level. These conditions prevented the flushing out of the salt water from the canal above the dam, and, by the creation of a strong negative hydraulic head at times of flood tide, they caused additional salty water to leak through the dam and into the underlying permeable limestone. The result was a major incursion of salty water in Miami Canal that lasted until July (see fig. $192 \mathrm{~A}$ ).

Figure $196 B$ shows conditions $2 \frac{1}{2}$ months after the pneumatic dam had failed. The NW, 36th Street tongue now showed a 5,000ppm isochlor. All isochlors were elongated upstream, showing a strong contamination effect on the ground water. In addition, a new offshoot $(150 \mathrm{ppm})$ had made a rapid thrust westward, following the path of the previously traced 100-ppm offshoot. Since December 29, 1944, the 150-ppm offshoot had traveled 2, $750 \mathrm{ft}$, which is at the rate of $550 \mathrm{ft}$ per month or $6,600 \mathrm{ft}$ per year. The $100-\mathrm{ppm}$ offshoot traveled at the rate of 5,700 to $6,180 \mathrm{ft}$ per year when it was in the same position. It is noted also that the NW. 36 th Street tongue showed a strong westward movement beyond Le Jeune Road. A new contamination pattern, similar to that of 1943 (see fig. $194 \mathrm{~B}$ ), had developed in the Twin Lakes area. As before, the lakes appear to have had no effect on the encroachment pattern. $A$ new "island" of salty water was just beginning to develop in the upper well field. 

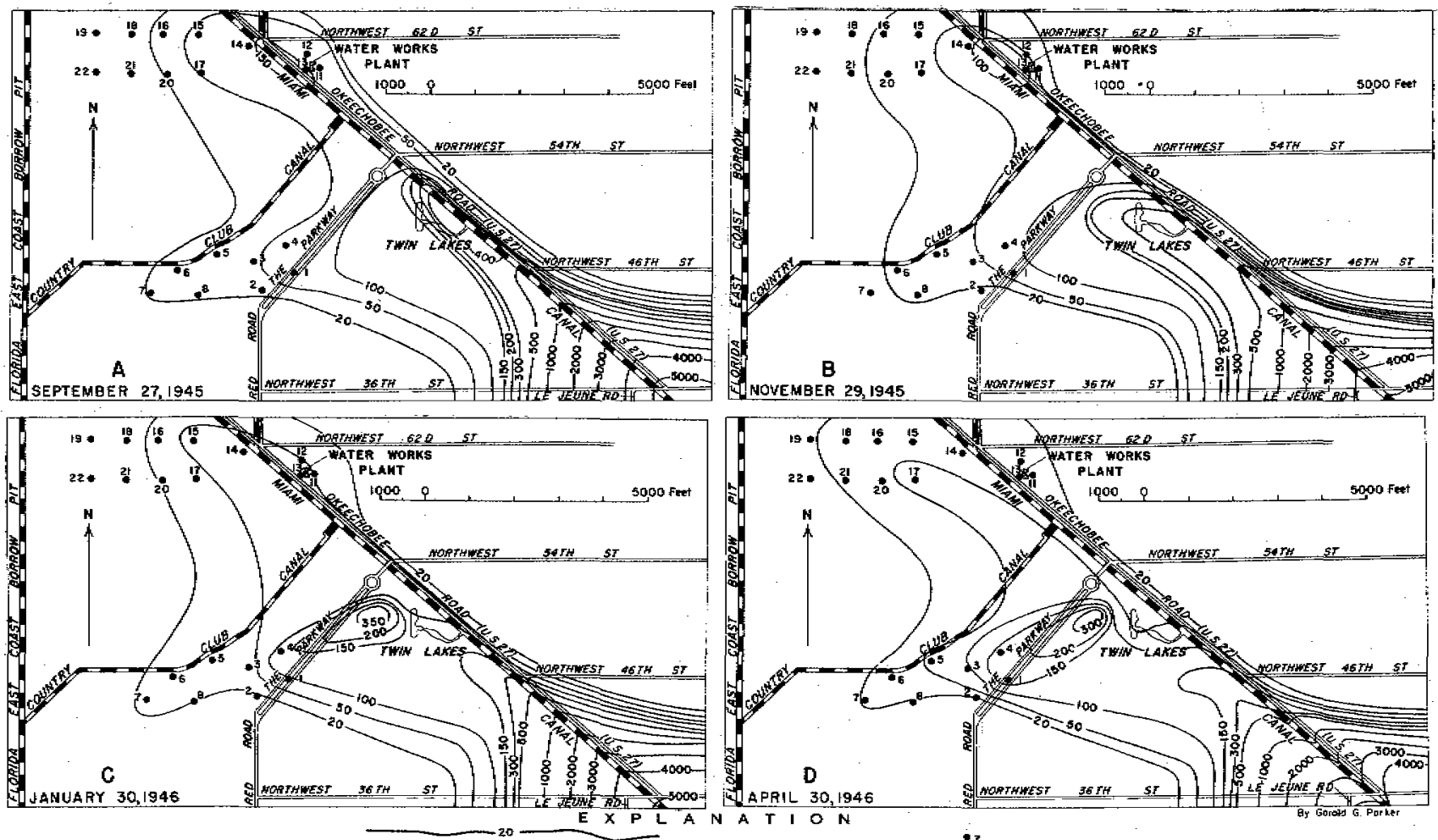

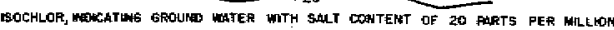

MIRAM HAMICPAL WRTER-SUPPLY WELL

Figure 197. -Isochlor map of the Miami well-field area: $A$, September $1945 ; \quad B$, November $1945 ; C$, January 1946; and $D$, April 1946. 
Figure $196 \mathrm{C}$ represents conditions in July 1945, 1 month after Miami Canal in this area had been flushed of its salty water. A 6,000 ppm isochlor had pushed into the NW. 36 th Street tongue, and the entire pattern in that area had moved upstream and laterally. Pockets of salty water, in excess of $800 \mathrm{ppm}$ and $450 \mathrm{ppm}$, had developed near Twin Lakes and in the upper well-field, respectively, and the $150-\mathrm{ppm}$ offshoot had merged with the pattern of contamination on the southwest side of the canal.

Figure $196 D$ shows conditions in August 1945, just 1 month later. Nofurther incursions of salty water had occurred in Miami Canal. The diluting effect of ground-water movement is apparent from the figure, especially in the Twin Lakes and upper well-field areas. The $6,000 \mathrm{ppm}$ isochlor had moved downstream, but no other notable change had taken place in the NW. 36 th Street tongue.

Figure 197A illustrates conditions in September 1945. Still further improvement is shown, especially in the upper well-field area where the $20-\mathrm{ppm}$ isochlor had widened in response to dilution, and where the 400-ppm area of the previous month had been reduced to a smaller area of only $150 \mathrm{ppm}$. The local $300 \mathrm{mppm}$ isochlor near Twin Lakes and the 300-ppm isochlor of the NW. 36 th Street tongue, which had been separated during the previous month, had now joined. The resulting offshoot of $300 \mathrm{ppm}$ or more enclosed an "island" of 400 ppm or more.

Figure $197 B$ indicates changes in the chloride pattern that took place during October and November 1945. Continued dilution of the higher concentrations is evident by the wider spread of the 20-and 50-ppm isochlors, especially in the Miami Springs area. Near Twin Lakes the 400-ppm isochlor had disappeared as a result of the enlargement and southwestward movement (toward the lower well field) of the 300-ppm area.

Figure $197 \mathrm{C}$ represents conditions in January 1946,2 months later. Most notable in the figure is the pinching off of the western end of the 300-ppm offshoot from the NW. 36th Street tongue. An elongated "island" of salty ground water west of Twin Lakes, oriented approximately $\mathrm{S} .70^{\circ} \mathrm{W}$. (toward the lower well field), was thus formed. The upper well field had become cleared of the 100-ppm zone of 2 months before, largely through dilution. Consequently, the 50-ppm area expanded widely.

Figure $197 D$ illustrates chloride conditions in the well-field area at the end of April 1946. Concentration of contaminated water in the upper well field had lessened considerably, especially the smaller area enclosed by the 50-ppm isochlor. The elongated "island of salty water in the Twin Lakes area had moved considerably to the southwest and had expanded as the higher chloride concentrations were diluted. The NW. 36 th Street tongue also 

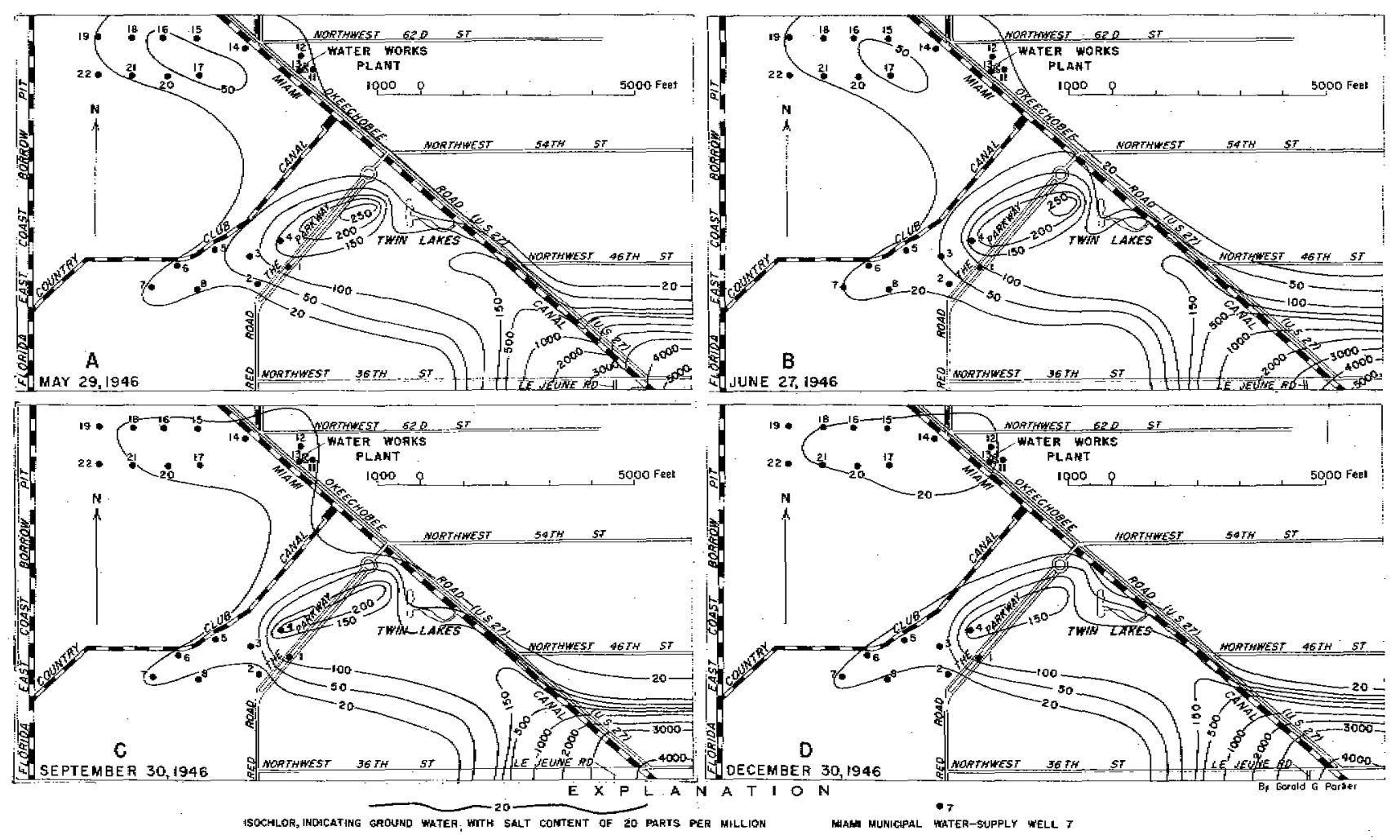

Figure 198. - Isochlor map of Miami well-field area: A, May 1946; $B$, June 1946; C, September 1946; and $D$, December 1946. 
shows dilution effect, particularly where the isochlors approach the canal.

Figure $198 \mathrm{~A}$ shows conditions on May 29, 1946. In the upper well field the area enclosed by the 50-ppm isochlor hadbeen greatly reduced and was now isolated. The Twin Lakes "island" of salty ground water was reduced both in size and concentration. No notable change occurred in the NW. 36 th Street tongue.

Figure 198B illustrates conditions at the end of June 1946, In both the upper and lower well-field areas the contamination zones continued to diminish in size and concentration. Partial opening of the NW. 36th Street dam during this month allowed minor amounts of salty water to creep a short distance upstream in Miami Canal, resulting in the filling-out of the NW. 36 th Street tongue once more. Note the change in shape of isochlors near the canal, as compared with the previous month.

Figure $198 \mathrm{C}$ shows conditions at the end of September 1946,3 months later. The continued decrease of chloride is apparent in both upper and lower well-field areas. The "island" of salty ground water west of Twin Lakes had now become extremely elongated, and the $150-\mathrm{ppm}$ offshoot from the NW. 36th Street tongue had retreated seaward about 850 feet.

Figure $198 D$ shows conditions in the well-field area at the end of Necember 1946. Note the improvement in the upper and lower well-field areas. The $20-\mathrm{ppm}$ isochlor has separated the two fields, leaving the upper field entirely isolated from the contamination pattern of the lower field and the NW. 36 th Street tongue. The area of salty ground water near Twin Lakes had been reduced in size and was now surrounded by the $150-\mathrm{ppm}$ isochlor. The NW. 36th Street tongue shows little change.

A comparison of the last map (December 1946) with the one for February 1942, when the contamination pattern of the whole area was first drawn, reveals that the patterns are remarkably similar. The principal difference is in the NW. 36 th Street tongue south of NW. 36 th Street and west of Le Jeune Road. In this area the pattern has made a steady westward advance. Using the 500-ppm isochlor as a measure of movement, it is found that north from the canal,measured along the eastern side of the map, this isochlor occupied approximately the same position in 1946 as in 1942; also, if measured northwestward to its apex, the position of the isochlor is the same for both years. However, if measured due west from the 36 th Street Bridge the isochlor is found to have advanced approximately $1,380 \mathrm{ft}$. Thus, a westward advance has been made on a broad front south of $\mathrm{NW}$. 36 th Street rather than along the canal. 
The advance of $1,380 \mathrm{ft}$ was made in 4 years and 10 months, which is an average of nearly $24 \mathrm{ft}$ per month or about $290 \mathrm{ft}$ per year. If this rate continues, the NW. 36 th Street tongue will reach the lower well field in about 20 years. However, as pointed out earlier (p. 700), as a salt-water tongue approaches a well field, it travels faster; therefore, the time required may be less than 20 years.

Another factor to be considered is that this advance of $1,380 \mathrm{ft}$ has been made during a relatively dry period, when salt water was always free to advance at least as far inland as the NW. 36 th Street dam in Miami Canal; up the Tamiami Canal to, and beyond, Red Road; and into the several rock pits between Miami and Tamiami Canals east of Red Road. Thus, salt water has always been available for encroachment into the well-field area.

When the proposed lock and dam in Miami Canal below the confluence of Miami and Tamiami Canals is installed, salt water will no longer gain access to this area by way of the canals; instead, it will be held at some point downstream from NW. 20th street (proposed site of the control). As a result, the ground-water conditions in this area will change favorably, and the life of the Miami well field will be prolonged indefinitely. The NW. 36 th Street saltwater tongue will then be cut off from its source and will probably disappear, as have other high-chloride tongues that have been present in the well field.

\section{COCONUT GROVE WELL FIELD}

The Coconut Grove well field was developed in 1925 near Loquat Avenue east of Le Jeune Road (see fig. 199). The site is about 2, $200 \mathrm{ft}$ east of Coral Gables Canal and $1 \mathrm{mile}$ from Biscayne Bay. Two wells (S 171 and $S 172$ ), $10 \mathrm{in}$. in diameter and $46 \mathrm{ft}$ deep, with 1,000-gpm pumps, served until 1933. In that year, Charles Morgan, Miami City chemist, noted that the chloride content of the water, which had normally been 13 ppm (Collins and Howard 1928, p. 210-211), suddenly began to increase. It was decided that a shallower source west of the two original wells would alleviate the situation. Accordingly, three wells (grouped as S 378), 3 in. in diameter and about $35 \mathrm{ft}$ deep, were drilled and coupled by a manifold so that they were operated with a single pump. At first, this new source, pumped at $1,000 \mathrm{gpm}$, produced water with a chloride content of about $16 \mathrm{ppm}$. However, the salinity soon began to rise and by 1937 the chloride content was 500 ppm.

In an attempt to get better water, a pit $20 \mathrm{ft}$ square and $16 \mathrm{ft}$ deep was dug. Inasmuch as the land surface at the site is approximately $12 \mathrm{ft}$ above mean sea level, the bottom of the pit was about $4 \mathrm{ft}$ below mean sea level (U. S. Coast and Geodetic Survey datum). 

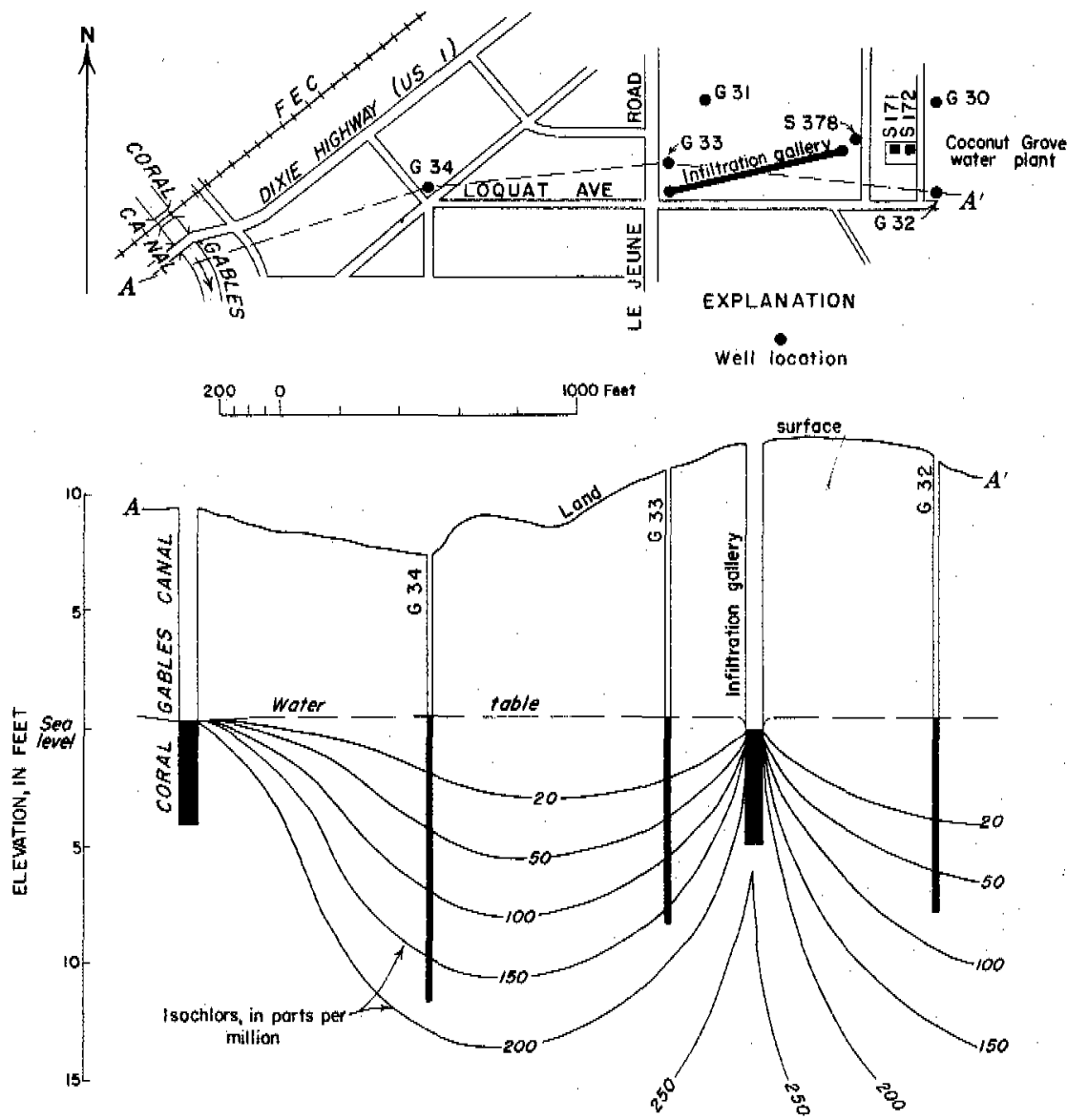

Figure 199. - Map and cross section of the Coconut Grove well-field area showing location and depth of wells and infiltration gallery, isochlor pattern, and water-table profile for June 20,1940 .

According to A. B. DeWolf (1941), water from this shallow source was excellent at first, but it, too, soon began to produce salty water. With increasing demand the pit would notyield the required amount of water, so additional water had to be pumped from the old wells. By January 1939 the salinity of this mixed water was 700 ppm.

It was known that the water of lowest salinity occurs at, or near, the water table. Therefore, an infiltration gallery, or horizontal well, was dug so as to skim the water just below the water table. It was $650 \mathrm{ft}$ long, $4 \mathrm{ft}$ wide, and $17 \mathrm{ft}$ deep-a size sufficient to yield about $600,000 \mathrm{gpd}$. This well was put into service April 4, 1939.

Analysis of the waterfirst obtained from this gallery shows that it fluctuated in salinity from 112 to $170 \mathrm{ppm}$, probably in accordance with intermittent recharge from rainfall and with change in 
pumping rates. On December 10, 1939, shortly after the U. S. Geological Survey opened the Miami district office, a sample of the water was analyzed for most of the common minerals. Later, samples were taken from several shallow wells in the vicinity. Some of these data are given in table 79.

Table 79.-Analyses of water from infittration gallery and shallow wells in the Coconut Grove well field

[Analyses in parts per million, except as indicated]

\begin{tabular}{|c|c|c|c|c|c|c|c|c|c|c|}
\hline $\begin{array}{c}\text { Well } \\
\text { no. }\end{array}$ & $\begin{array}{l}\text { Depth } \\
\text { (feet) }\end{array}$ & Date & $\mid \begin{array}{l}\text { Iron } \\
(\mathrm{Fe})\end{array}$ & $\begin{array}{c}\text { Cal- } \\
\text { citum } \\
\text { (Ca) }\end{array}$ & $\begin{array}{l}\text { Magne- } \\
\text { sium } \\
\text { (Mg) }\end{array}$ & $\begin{array}{l}\text { Sodium and } \\
\text { potassium } \\
(\mathrm{Na}+\mathrm{K})\end{array}$ & $\begin{array}{l}\text { Bicar- } \\
\text { bonate } \\
\left(\mathrm{HCO}_{\mathrm{g}}\right)\end{array}$ & $\begin{array}{l}\text { Sul- } \\
\text { fate } \\
\left(\mathrm{SO}_{4}\right)\end{array}$ & $\begin{array}{l}\text { Chlo- } \\
\text { ride } \\
\text { (Cl) }\end{array}$ & $\begin{array}{c}\text { Total hardness } \\
\text { as } \\
\mathrm{CaCO}_{3}\end{array}$ \\
\hline $\begin{array}{c}\text { Infiltra- } \\
\text { ton } \\
\text { gallery } \\
\text { G } 30 \\
\text { G } 31 \\
\text { G } 32 \\
\text { G } 33 \\
\text { G } 34\end{array}$ & $\begin{array}{l}17 \\
19 \\
18 \\
19 \\
18.2 \\
19.5\end{array}$ & $\begin{array}{r}12 / 10 / 39 \\
6 / 20 / 40 \\
6 / 20 / 40 \\
6 / 20 / 40 \\
6 / 20 / 40 \\
6 / 20 / 40\end{array}$ & $\mid \begin{array}{c}0.09 \\
\ldots \ldots . . . \\
\ldots \ldots . . . \\
\cdots \ldots . . \\
\cdots \ldots . . \\
\cdots \ldots .\end{array}$ & 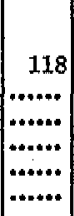 & 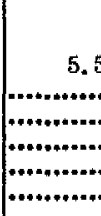 & $\begin{array}{c}106 \\
\ldots \ldots+\ldots+\ldots \ldots * \\
\ldots \ldots \ldots \ldots+\ldots \ldots * \\
\ldots \ldots \ldots \ldots \ldots \ldots * \\
\ldots \ldots \ldots \ldots+\ldots \ldots * \\
\ldots \ldots \ldots \ldots \ldots+\ldots\end{array}$ & 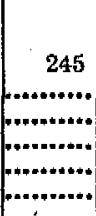 & $\mid \begin{array}{c}31 \\
\ldots \ldots \ldots \\
\ldots \ldots \ldots \ldots \\
\ldots \ldots \ldots \ldots \\
\ldots \ldots \ldots \ldots \\
\ldots \ldots \ldots\end{array}$ & $\begin{array}{r}223 \\
17 \\
167 \\
91 \\
155 \\
164\end{array}$ & 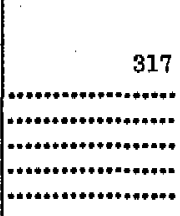 \\
\hline
\end{tabular}

Figure 199 shows a cross section $\left(A-A^{\prime}\right)$ extending in a general east-west direction from Coral Gables Canal through the Coconut Grove well field. Depths of the canal; the infiltration gallery, and wells intersected by the plane of the section are plotted with reference to mean sea level (U. S. Coast and Geodetic Survey, datum of 1929). The water-table profile and isochlors for June 20, 1940 are also shown. The water-table profile is based on measurements made in the wells and gallery, and the isochlors are based on values of chloride in samples of ground water pumped from the wells and gallery.

It is important to note the effect of pumping from the gallery (which obtains water just below the water table) on the chloride pattern. Obviously, Coral Gables Canal is the principal contributing source of salt water, and if it were not for the pumping from the gallery the isochlors would slope gently outward and downward away from the canal. Pumping, however, induces an upward movement of ground water into the gallery, with a resultant upward deflection of the isochlor pattern. The highest isochlor shown in this section for June 20,1940, is $250 \mathrm{ppm}$; it does not quite reach the bottom of the gallery. On later dates, chloride values of 260 to $270 \mathrm{ppm}$ were observed in the gallery water. These values, in excess of U. S. Public Health Service standards for public supplies $(250 \mathrm{ppm})$, caused the final abandonment of the Coconut Grove well field in August 1941. 


\section{SALT-WATER ENCROACHMENT ALONG THE DADE COUNTY SHORELINE. OTHER THAN AT SILVER BLUFF}

The Silver Bluff area (see p. 593-607) was believed to be typical of the coastal area of Dade County, and extensive studies of salt- and fresh-water relationships have been made there. These studies, in brief, show the following: (1) A blunt-nosed wedge of salt water is encroaching inland because of an upset equilibrium between salt and fresh water, which is caused by the lowering of the average height of the water table in that part of the coastal area; (2) Inland for a distance of about 2, 500 ft the salt-water wedge appears to be approaching equilibrium with the overlying fresh water; (3) In the nose of the salt-water wedge the isochlor pattern dips down rather abruptly; (4) The thickness of the zone of diffusion between the 50-ppm and 16,000-ppm isochlors, measured at a distance of about $3,000 \mathrm{ft}$ from the shore, is about $60 \mathrm{ft}$ whereas in the nose of the wedge, the width, measured parallel to the base of the aquifer, was about $3,500 \mathrm{ft}$ in 1940 and about 5,200 ft in 1946; (5) Only a small amount of movement has been shown by the isochlors representing high salinity (the 16,000- and 18,000-ppm isochlors), whereas there has been a comparatively large inland movement of the isochlors representing lesser salinity (the 50-to 1,000-ppm isochlors).

In December 1946 it was decided to investigate the salt- and fresh-water relationship in one of the coastal areas that had a comparatively narrow encroachment zone (see fig. 200). The Cutler area was selected because it is relatively undeveloped and lies seaward from an area that the city of Miami was considering as a potential new well field (pumping tests in this area are described on p. 249-270). Several test and observation wells were drilled, the most important of which are shown in figure 201. In the Cutler area the isochlor pattern is much different from that at silver Bluff; a blunt-nosed wedge of encroaching salt water exists, but it extends inland from the shore only about 1, $200 \mathrm{ft}$ (measured to the $1,000-\mathrm{ppm}$ isochlor). The vertical thickness of the zone of diffusion, measured between the 100- and 15,000-ppm isochlors, is only about $35 \mathrm{ft}$ at a point about $250 \mathrm{ft}$ inland from the shore. The horizontal width between these isochlors, as measured along the line of 120-ft depth, is about $525 \mathrm{ft}$.

The pattern in the Cutler area appears to be little affected by a drainage-upset equilibrium, and it is probably quite similar to that which existed in the Silver Bluff area prior to drainage. The fact that it has not expanded inland, as it has at Silver Bluff, is probably due to a locally higher water table. The nearest drainage canal, Snapper Creek, which empties into Biscayme Bay about 4 miles to the northeast, has relatively little effect on the ground water of the Cutler area. 


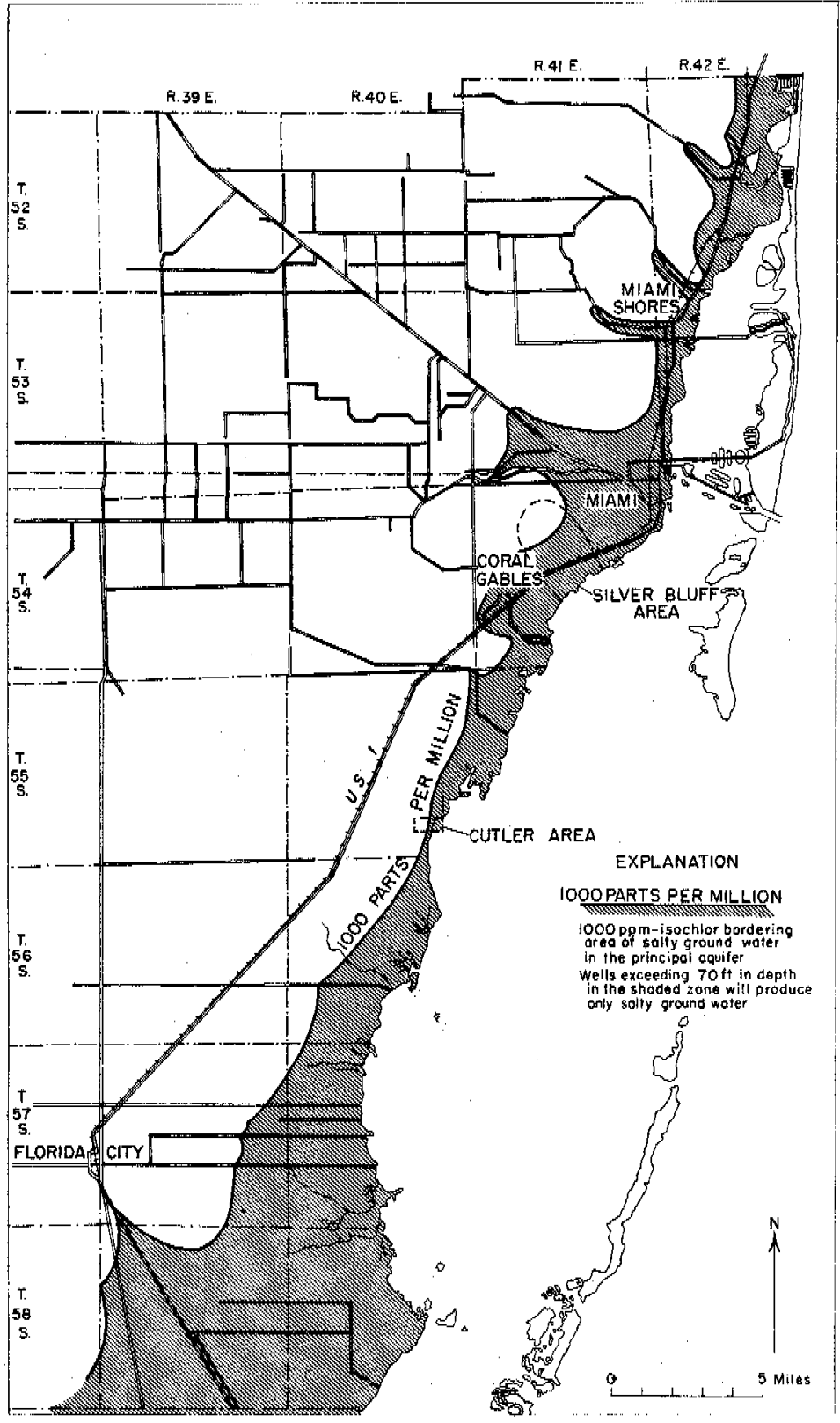

Figure 200, - Map of eastern Dade County showing the area bounded by the 1,000-ppm isochlor of ground water in the Biscayne aquifer. Wells exceeding 70 feet in depth in the shaded zone will produce only salty water. 


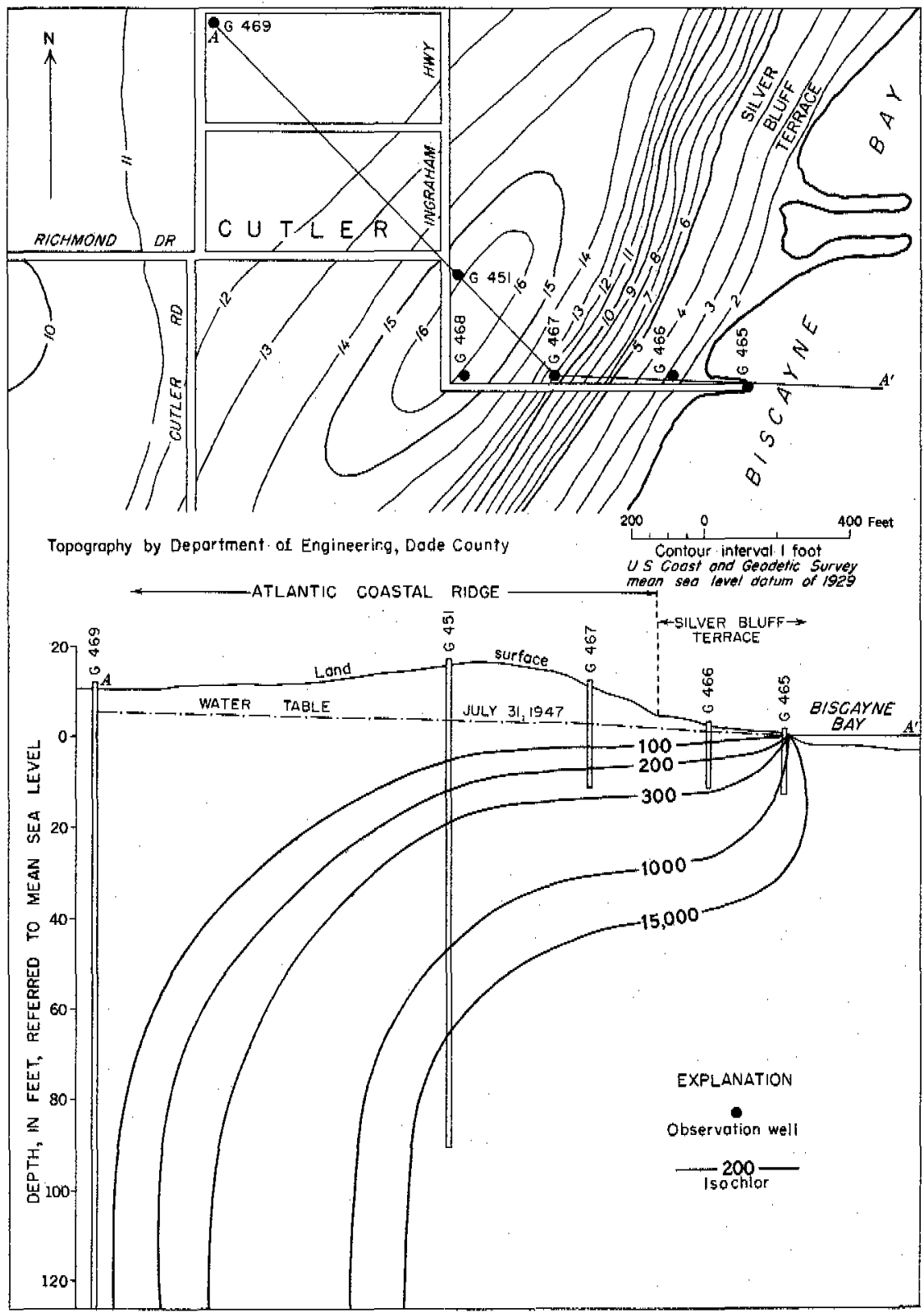

Figure 201, - Topographic map and cross section of the Cutler area., Dade County, showing locations and depths of wells. , isochlor pattern, and water-table profile. 
The widest zone of salt-water encroachment occurs in the marl flats along the southeastern Dade County coast line where a maze of drainage canals has lowered the water table. During times of drought, each canal has acted as an artery for inland movement of salt water. Samples of canal water, taken during the drought of 1945 at the inland limits of tidal canals near Florida City and Homestead, contained chloride in excess of $26,000 \mathrm{ppm}$ (as compared to about 19,800 ppm for normal sea water). This unusual chloride content is due to a high rate of evaporation of the water in the canals, which is replenished by ocean water at each high tide and again evaporated and concentrated. The concentrated salt water, which seeps outward and downward from the sides and bottoms of each canal (see p. 682-686), was the cause of the disastrous crop failure in this area during the $1945 \mathrm{drought}$. M. $\mathrm{H}$. Gallatin; of the U. S. Department of Agriculture, estimated that salt-water encroachment had ruined more than 18,000 acres of winter-growing vegetable land in southern Dade County by the end of 1945 .

Encroachment in many shallow soils need not be permanent, however, because seasonal rains will flush the salted water to depths where it will not affect the growth of most vegetable crops. Dams, placed at the coastal limits of the canals to prevent salt water from again gaining access to the upper reaches, would aid in preserving the soils for farming. However, in the areas most damaged by salt-water encroachment it may never again be possible to utilize wells as a source of water for irrigation during droughts.

Elsewhere along the shoreline in Dade County, the inland encroachment zone is narrower than at Silver Bluff or in the marl flats discussed above. Inland along each of the principal tidal canals, tongues of salty ground water extend for several miles (see fig. 200). These tongues are a result of the dredging of the canals, which have become saline arms of Biscayne Bay. The tongues are in no way related to pumping. In 1939 and 1945 , when, owing to the drought, the inland limits of such canals as Biscayne and Little River became dry, salty ocean water from Biscayne Bay flowed inland at each high tide and soaked downward into the rocks of the canal bottoms in the vicinity of Red Road. This process of contamination was taking place along the entire length of these canals, but it was visible only at the inland limits where, at high tide, salt water moved in over the dry canal bottoms.

2Oral communication. 


\section{ELECTRICAL-RESISTIVITY STUDIES}

By H. Cecil Spicer

\section{INTRODUCTION}

During the study of salt-water encroachment in southeastern Florida, an effort was made to utilize as many techniques as possible. Consequently, a series of electrical-resistivity studies were made to evaluate the usefulness of a geophysical method in mapping the position of the underground fresh-and salt-water contact.

\section{ELECTRIC CONDUCTION}

Nearly all dry rocks and rock-forming minerals are poor conductors, and thus, they are good insulators. The conductivity of a rock is dependent upon the following factors: (1) porosity or pore space; (2) arrangement of pores or grain packing; (3) amount of pore space filled with electrolytes; and (4) conductivity of the electrolyte, both native and acquired.

An equation was given by Maxwell (1904) for spherical grains in a regular packing arrangement. Hummel (1935) has shown that if the material is completely filled with an electrolyte and if the porosity is 50 percent, then the conductivity of the material increases almost in direct proportion to the conductivity of the electrolyte. For the work in Florida it was decided that if the porosity of the rocks was assumed to be 50 percent, it would be justifiable to disregard the conductivity of the rock grains and to consider only the conductivity of the electrolyte filling the pores.

Chloride determinations and measurements of specific conductance of some Florida waters are given by Collins and others (1941-44) and by Howard and Love (1945) for some canals, creeks, and rivers. Values for the preparation of figure 202 were selected at random from the above papers and include the low range of values with chloride content less than $160 \mathrm{ppm}$. Figure 203 was prepared in a manner similar to that for figure 202 , except that the maximum chloride content shown was $20,000 \mathrm{ppm}$. It is apparent from these graphs that the relation between conductivity and chloride content is linear except for the very high and very low concentrations of chloride. No attempt has been made to separate the interference produced on the chart by sulfate or bicarbonate, these being the other cations of highest conductivity in solutions, and thus it is possible that they may be the cause for the nonlinearity.

A more detailed study, perhaps by localities, of the relation of conductivity and chloride concentration would also assist in the final interpretation of the electrical resistivity data. 


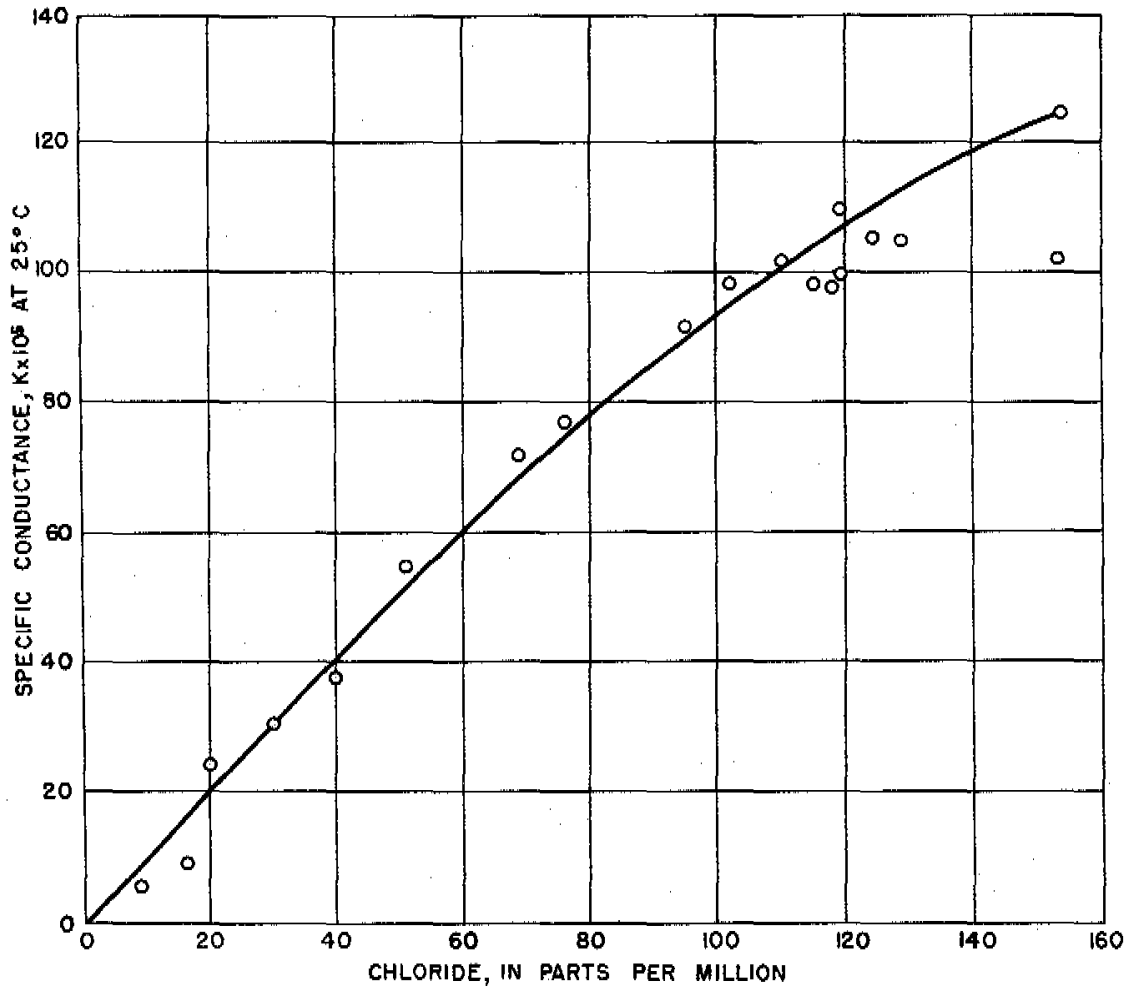

Figure 202, -Specific conductance of salty water for low ranges of chloride content.

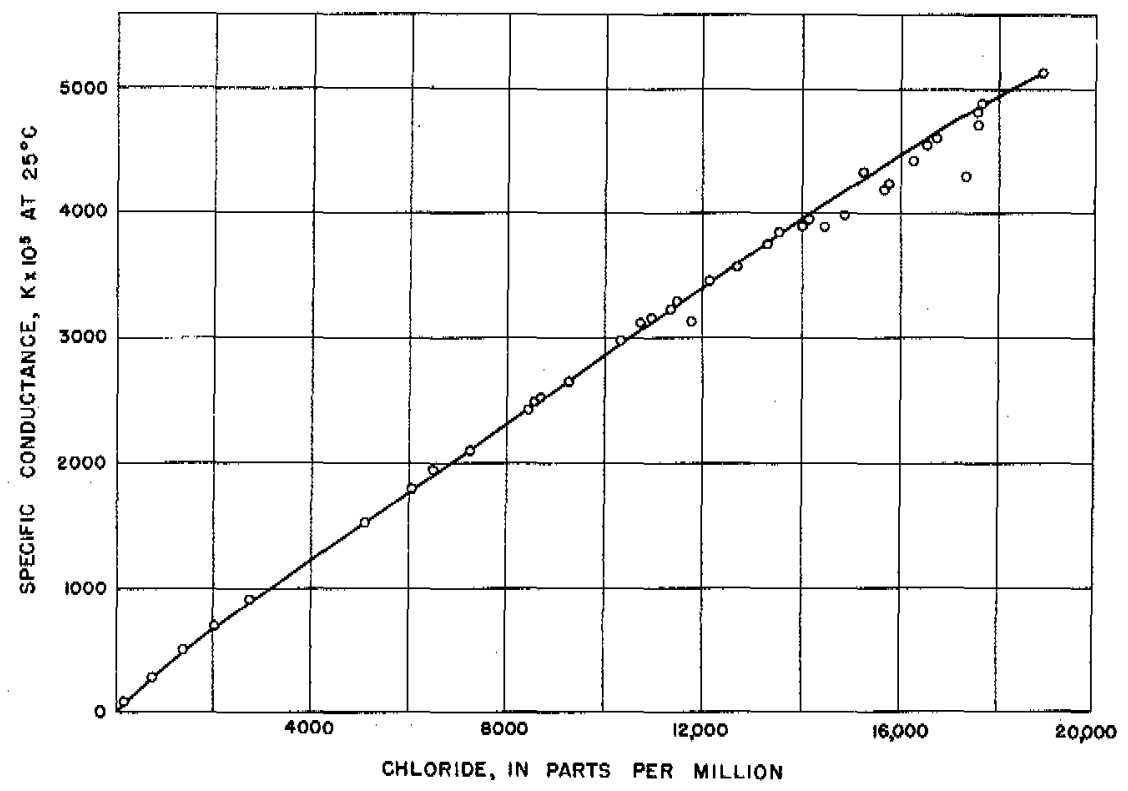

Figure 203. - Specific conductance of salty water for high and low ranges of chloride content. 


\section{FIELD MEASUREMENTS}

The Gish-Rooney Earth Resistivity Apparatus, as modified by the writer, was used to make the measurements. The electrodes were copper-clad steel rods with steel driving heads that were pushed or driven into the earth to make contact for the potential and current connections to the instrument. The earth around the electrodes was wetted and tamped when better contact was needed.

The character of the formations and the presence of salt water were most important considerations in this problem; therefore depth profiling was used throughout. A modification of the Lee variation of the Wenner electrode configuration was used, and the electrode intervals were expanded outward from the central station. With this method, three apparent resistivity curves were obtained at each station, one in each direction from the center and one over the full interval. These are termed the "P-1", "P-2", and "full" curves. Bearings for the line directions (see Appendix) are referred to P-1. Power for driving the instrument was supplied by the battery on the truck used to transport the equipment, and current to pass through the earth was provided by a bank of

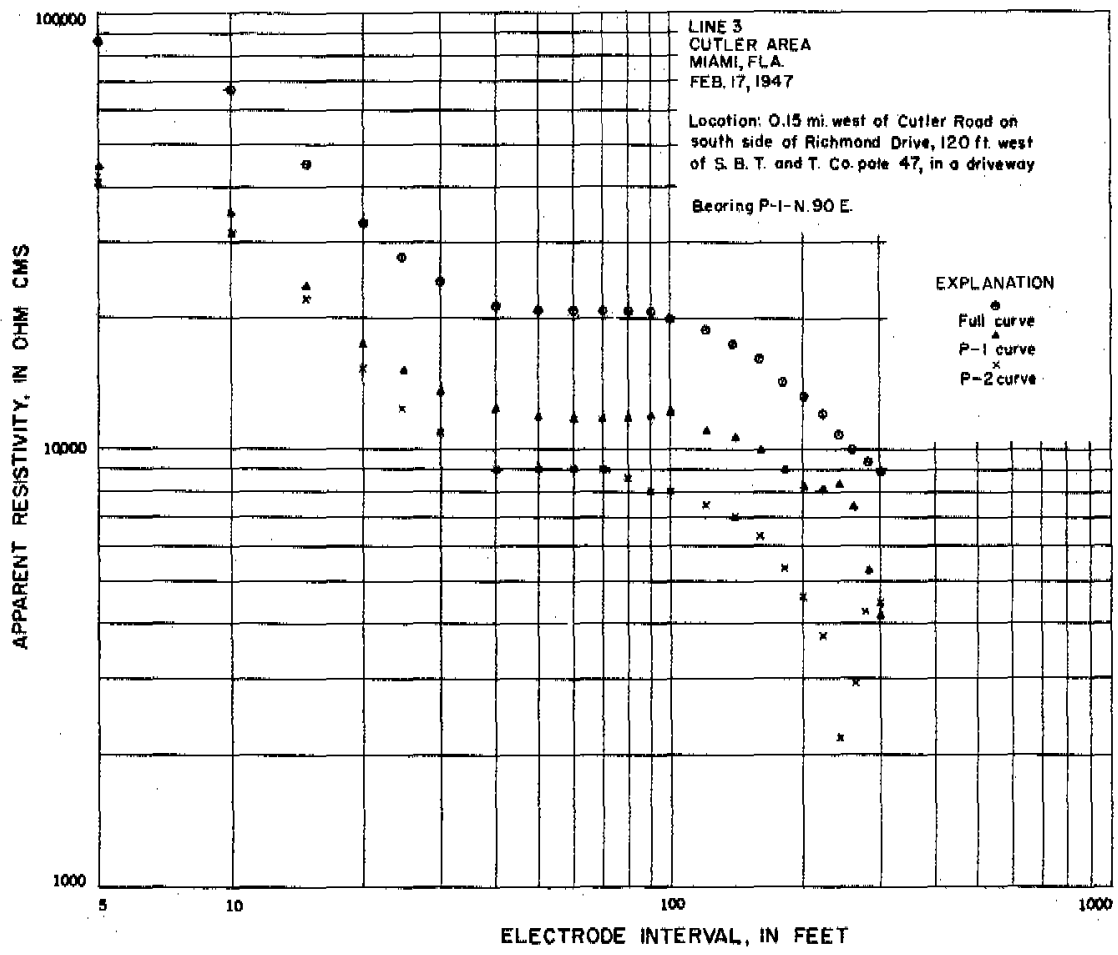

Figure 204. - Resistivity curves obtained in the Cutler area. 
super " $\mathrm{B}$ " batteries. The fundamental technique of operation is described by the maker of the apparatus and by other authors (such as Heiland, 1940, p. 619-824). A set of curves obtained at one station in the Cutler area is illustrated in figure 204.

\section{INTERPRETATION OF THE RESISTIVITY CURVES}

The resistivity curves were interpreted in part by procedures explained by Hummel (1931), Roman (1931, 1934, 1941), Tagg (1937), and Watson (1934, 1938). The methods described in these references are based upon theoretical and mathematical considerations; in most respects they have been found to be more reliable than any other methods proposed. Furthermore, all the above methods are based upon the theory of images (Jeans, 1925) and apply to two or more layers.

\section{MEASUREMENTS AT MIAMI}

The electrical resistivity work at Miami was carried out at Silver Bluff and Cutler (fig. 200). At Silver Bluff, the area extending from Biscayne Bay northward through Coconut Grove, Coral Gables, and Miami proper. At Cutler, these were two areas-one nor th of Cutler, extending nor thwestward from Biscayne Bay toward the intersection of Ludlum Road and Coral Reef Drive, and the other at Cutler, extending from Biscayne Bay northwestward toward the intersection of Ingraham Highway and Richmond Drive. These areas were chosen for the initial measurements because of the large amount of subsurface control that was available. This control consisted of well logs and chloride data concerning strategically located points throughout the area.

Because of the proximity of city improvements in the first area, such as water pipes and mains, sewers; gas pipes and mains, sprinkling systems, and buried telephone cables, considerable difficulty was experienced in the location of places to make meas urements. A few lines that were started had to be abandoned because of interference on the apparent resistivity curves. Some other curves may contain interference from unknown conductors, which is attributed in the interpretations to subsurface geologic conditions. Experience has shown that electrical resistivity meas urements obtained in and near cities are usually of questionable value because of the interference from power distribution networks and buriedtconductors.

\section{SIVER BLUFF AREA}

Of the six depth profiles begun in the Silver Bluff area, only one was abandoned because of interference from buried conductors. 


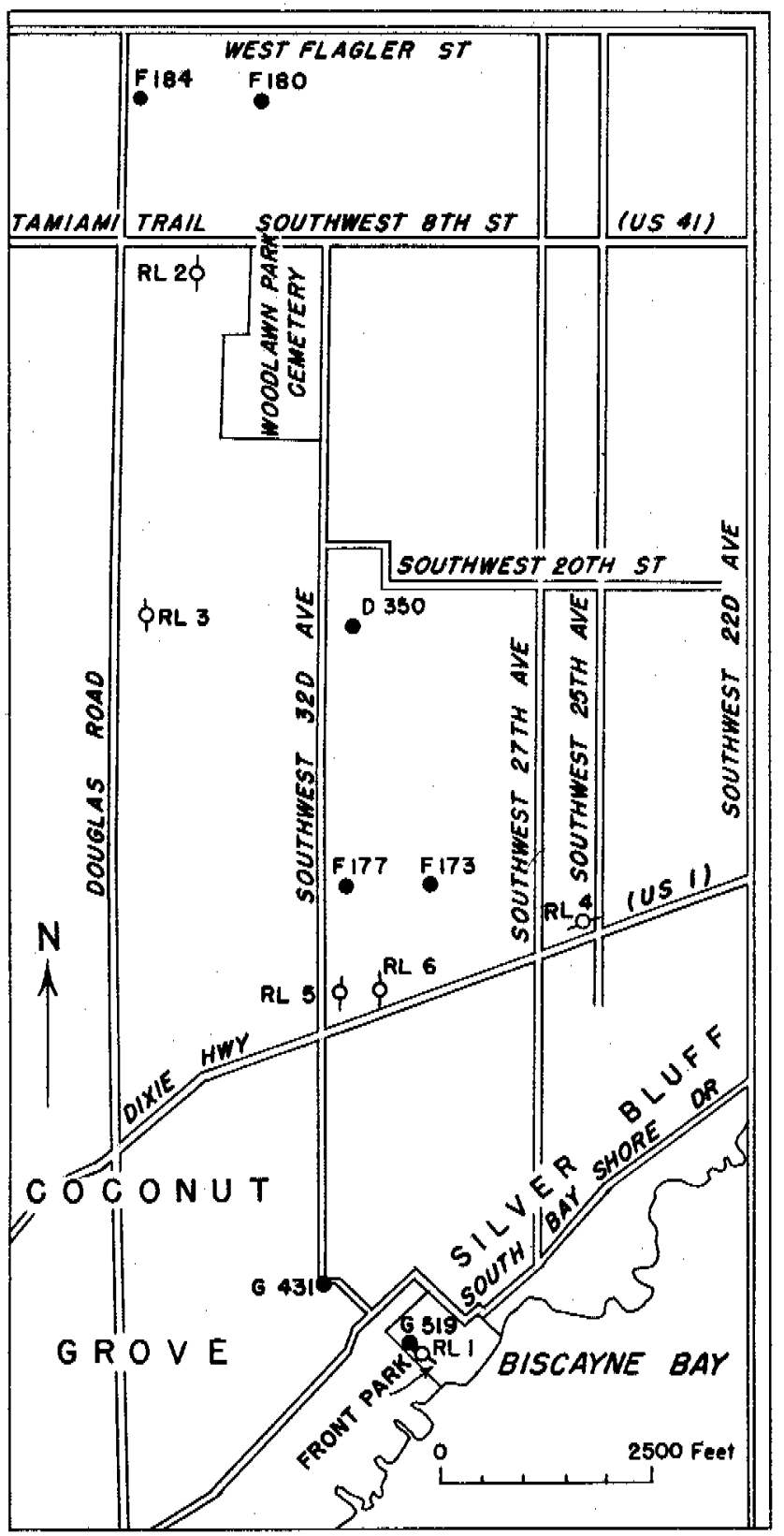

EXPLANATION $-O$

Resistivity line 
All of the apparent resistivity curves of this area were interpreted as three-layer curves.

The position of the resistivity line centers (RL1, RL2, etc.) in the Silver Bluff area are shown in figure 205. The locations of the wells used in correlating the resistivity results are also included in this figure. Well logs and chloride logs are given in the Appendix.

A comparison of the well logs and chloride logs for wells $\mathrm{G} 519$ and D 350 with the interpretation of resistivity lines 1 and 3 is given in figure 206. It appears that the electrical properties of the

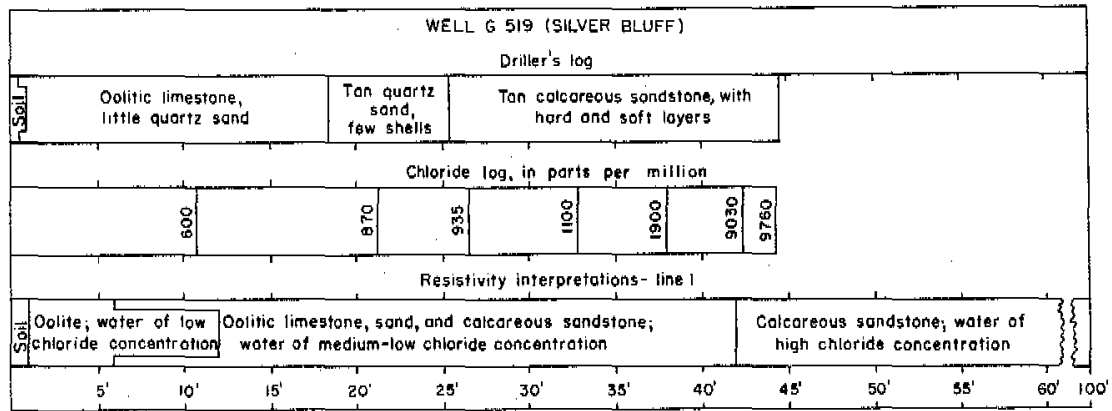

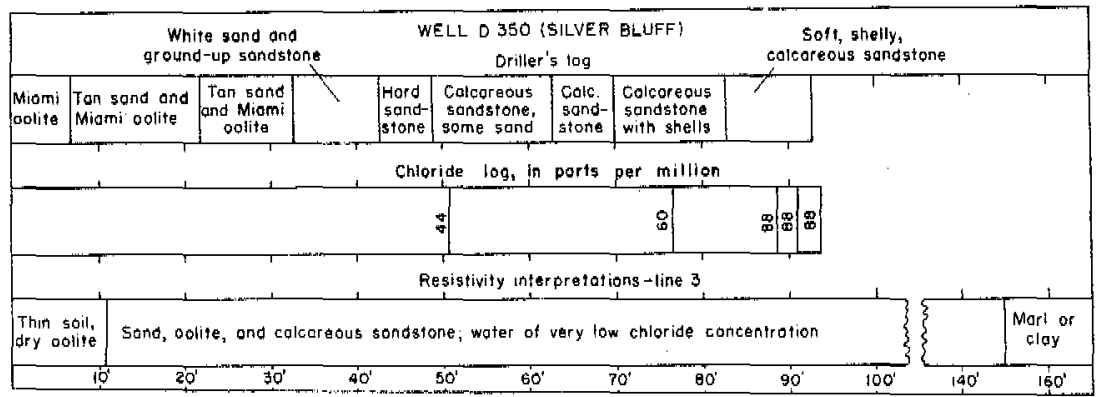

Figure 206. - Comparison of driller's logs and chloride logs with resistivity interpretations, Silver Bluff area, Miami.

Miami oolite, the sands, and the calcareous sandstones are essentially the same if wet. The values of resistivity computed for the different layers, as given in table 80 , reveals that the controlling factor in the variation of the resistivity is the chloride content of the contained water. In this table, the resistivity lines are arranged in the order of their distance (farthest to nearest) from Biscayne Bay.

It is apparent that the salty water has diffused to the surface and has caused a variation in the resistivities of the upper layers. The seemingly low resistivity value for the salt-water layer of 
Table 80.-Resistivities of layers in the Silver Blutf anas, Miami

[Resistivities in ohm cms; depths are from interpretations of resistivity curves]

\begin{tabular}{|c|c|c|c|c|}
\hline $\begin{array}{c}\text { Resistivity } \\
\text { line no, }\end{array}$ & $\begin{array}{l}\text { Surface } \\
\text { layer, } \\
0 \text {-10 feet }\end{array}$ & $\begin{array}{c}\text { Intermediate } \\
\text { layer } \\
10-42 \text { feet }\end{array}$ & $\begin{array}{c}\text { Bottom } \\
\text { layer, } \\
42 \text { feet }\end{array}$ & $\begin{array}{c}\text { Salt-water } \\
\text { layete }\end{array}$ \\
\hline $\begin{array}{l}2 \\
3 \\
4 \\
6\end{array}$ & $\begin{array}{c}241,000 \\
122,000 \\
89,000 \\
47,200 \\
24,500\end{array}$ & $\begin{array}{r}8,740 \\
15,850 \\
113,300 \\
2,020 \\
141,600 \\
980 \\
1,420\end{array}$ & $\begin{array}{r}486 \\
616 \\
\ldots .020 \\
2,020 \\
9.2 . \ldots \\
98\end{array}$ & $\begin{array}{c}8,740 \\
15,850 \\
2,020 \\
980 \\
42\end{array}$ \\
\hline
\end{tabular}

${ }^{1}$ Resistivity showing that salt water is at bottom of layer.

${ }^{2}$ Top of salt-water laver is shom 49 feet below ground surface.

line no. 2, as compared to the value for line no. 3 , probably indicates a more permeable layer or perhaps a localized infiltration of salt water. The values of resistivity given for the bottom layer have no particular relation to the salt-water encroachment problem because of the wide range of depth from which they were taken.

\section{CUTLER AREA}

Thirteen resistivity lines were completed in the Cutler area; seven were completed in the immediate vicinity of Cutler; five about 1 mile north of Cutler; and one near Goulds. Only one line, no. 8, was abandoned because of interference. On most of the resistivity curves in the Cutler area another layer is present; therefore, they are interpreted as four-layer curves.

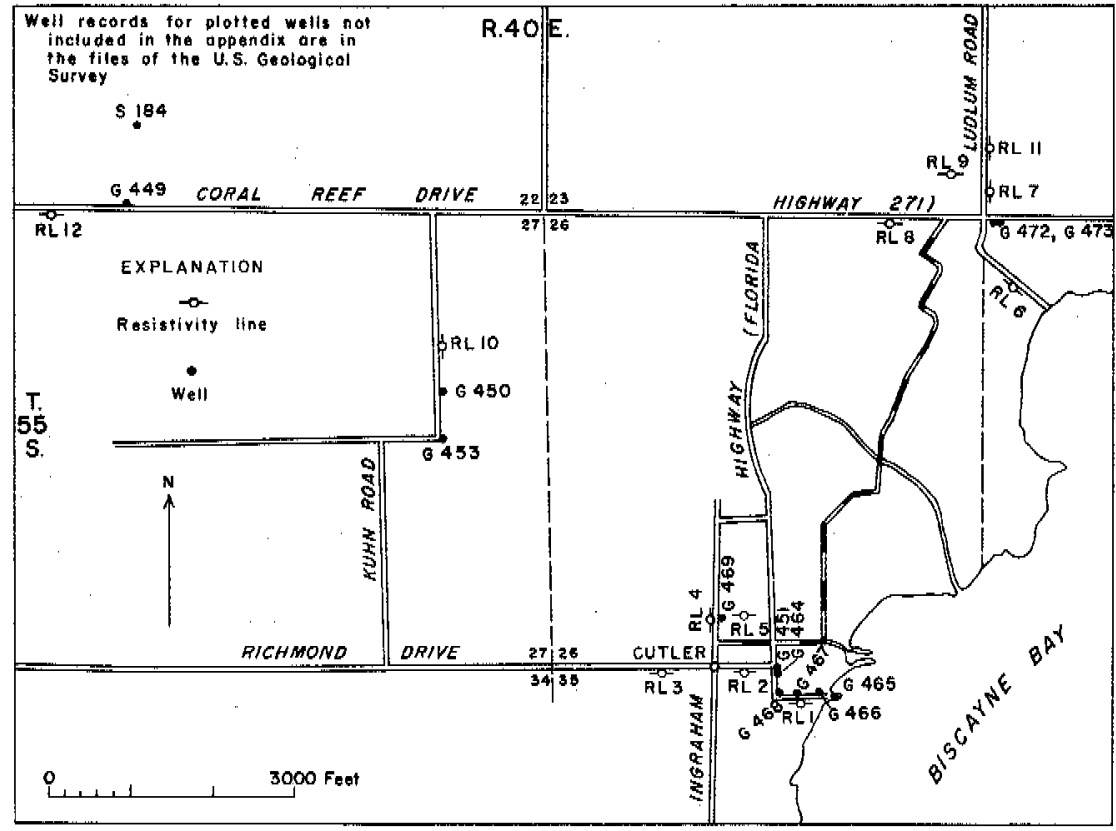


Figure 207 shows the locations of the resistivity lines (RL1, RL2, etc. ) in the Cutler area. The resistivity line near Goulds is not included because it is more than 6 miles southwest of the Cutler area. Locations of the wells that were used for correlation purposes are also shown in the figure. Copies of the well logs and chloride logs are in the Appendix or in the files of the U. S. Geological Survey.

Some of the interpretations from the resistivity curves made near wells in the Cutler area are compared with well logs and chloride logs in figures $208-210$.

In the Cutler area, as in the Silver Bluff area, the oolite and calcareous sandstone are very similar in electrical properties near the surface. A layer or bed that probably is rather impermeable and hard, and that is considered to contain some fresh water, appears on nearly all the curves. Salt water, where present in the formations, controls the resistivity and may even eliminate the inherent electrical properties of the beds. This control is shown more clearly in table 81 , which gives the values of resistivity computed for the different layers. These values are separated into related areas-Cutler, north of Cutler, and Gouldsand are arranged in order of their distance from Biscayne Bay, those farthest from the bay being listed first.

A study of table 81 reveals the extent of salt-water infiltration in the different layers of each area. At Cutler there is little or no

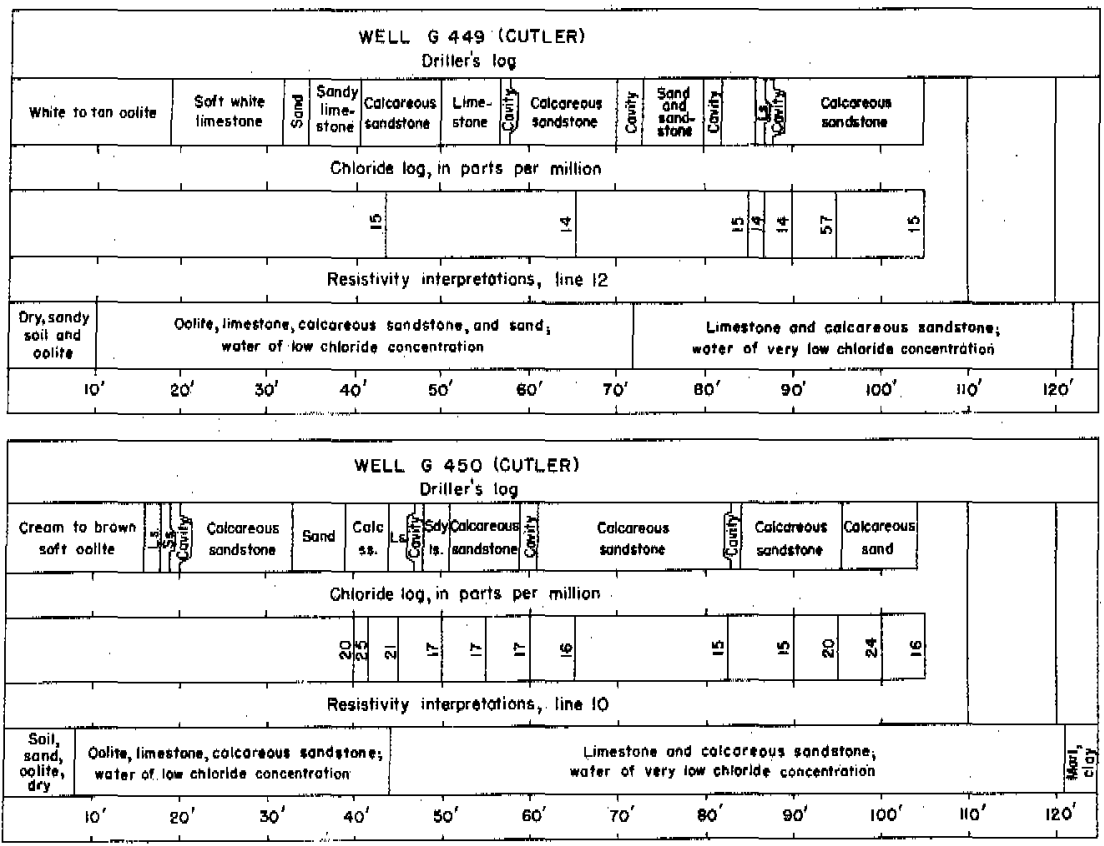

Figure 208. -Comparison of driller's logs and chloride logs with resistivity interpretations, Cutler area. 


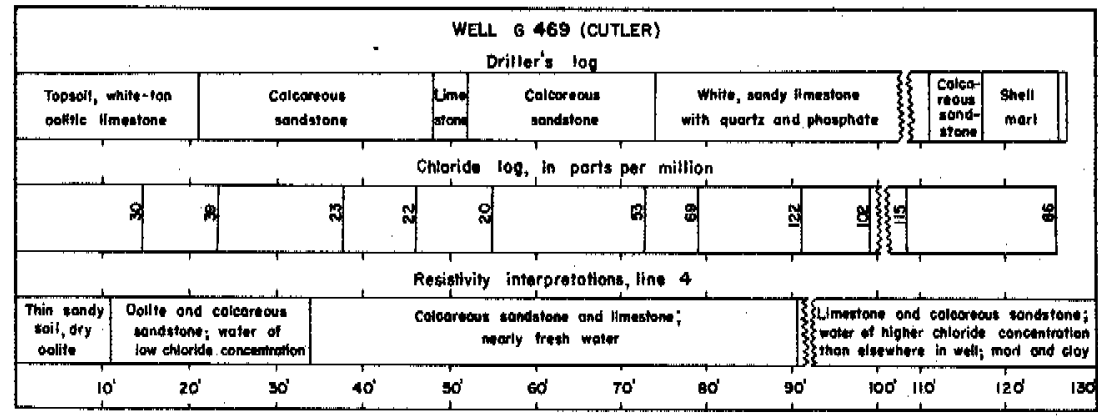

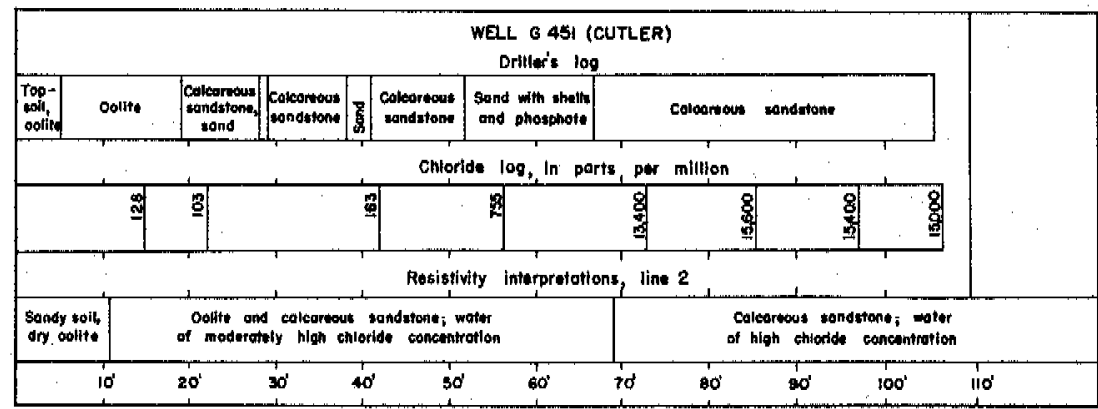

Figure 209. - Comparison of driller's logs and chloride logs with resistivity interpyetations, Cutler area.

indication of saltwater in the surface materials. The upper intermediate layer may be slightly contaminated westward from Biscayne Bay up to, and including, line no. 4. This is indicated by the lower resistivity, approximately 8,000 ohm cms. The

\section{Table 81.-Resistivities of layers in the Cut ler area}

[Resistivities, in ohms cms; depths, in feet, are from interpretations of resistivity curves]

\begin{tabular}{|c|c|c|c|c|}
\hline $\begin{array}{l}\text { Resistivity } \\
\text { line no. }\end{array}$ & $\begin{array}{c}\text { Surface layer. } \\
0=10 \text { feet }\end{array}$ & $\begin{array}{l}\text { Upper inter- } \\
\text { mediate layer, } \\
\text { depth variable }\end{array}$ & $\begin{array}{l}\text { Lower inter- } \\
\text { mediate layer, } \\
\text { depth variable }\end{array}$ & $\begin{array}{l}\text { Bottom layer } \\
39-122 \text { feet }\end{array}$ \\
\hline \multicolumn{5}{|c|}{ Cutler } \\
\hline $\begin{array}{r}12 \\
10 \\
3 \\
4 \\
5 \\
2 \\
1 \\
\end{array}$ & $\begin{array}{r}126,000 \\
131,000 \\
91,000 \\
67,500 \\
103,000 \\
112,000 \\
79,000 \\
\end{array}$ & $\begin{array}{r}14,000 \\
10,620 \\
13,000 \\
7,500 \\
8,320 \\
7,780 \\
7,600 \\
\end{array}$ & $\begin{array}{c}41,620 \\
51,180 \\
51,180 \\
49,630 \\
50,340 \\
\text { (1) } \\
\text { (1) } \\
\end{array}$ & $\begin{array}{r}6,360 \\
2,720 \\
4,760 \\
3,670 \\
4,990 \\
285 \\
86 \\
\end{array}$ \\
\hline \multicolumn{5}{|c|}{ North of Cutler } \\
\hline $\begin{array}{r}9 \\
11 \\
7 \\
6\end{array}$ & $\begin{array}{r}179,000 \\
120,000 \\
120,000 \\
2,260\end{array}$ & $\begin{array}{r}16,630 \\
360,000 \\
360,000 \\
6,780\end{array}$ & $\begin{array}{r}\text { (b) } \\
12,080 \\
12,080 \\
3,110\end{array}$ & $\begin{array}{r}50 \\
750 \\
16 \\
53\end{array}$ \\
\hline \multicolumn{5}{|c|}{ Goulds } \\
\hline 13 & 7,350 & 41,650 & (1) & 6,540 \\
\hline
\end{tabular}

${ }^{1}$ This layer is not apparent on the resistivity curve. 


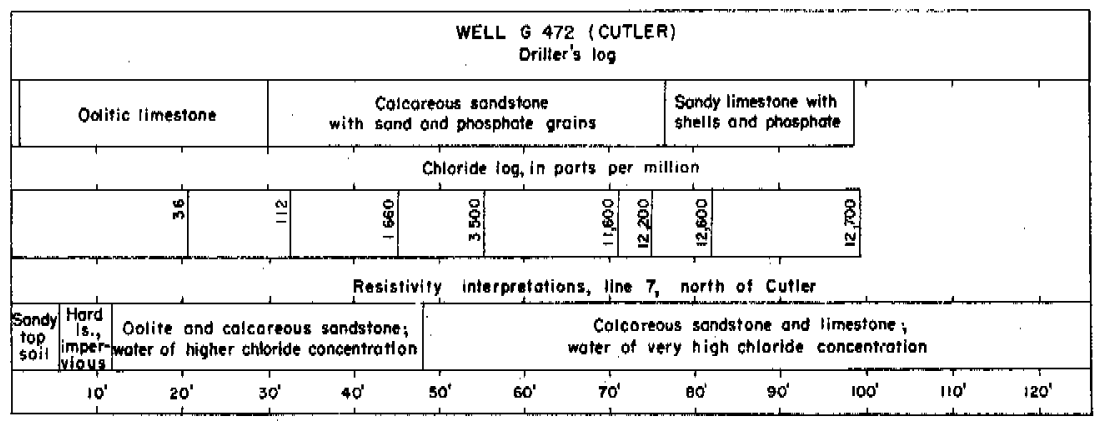

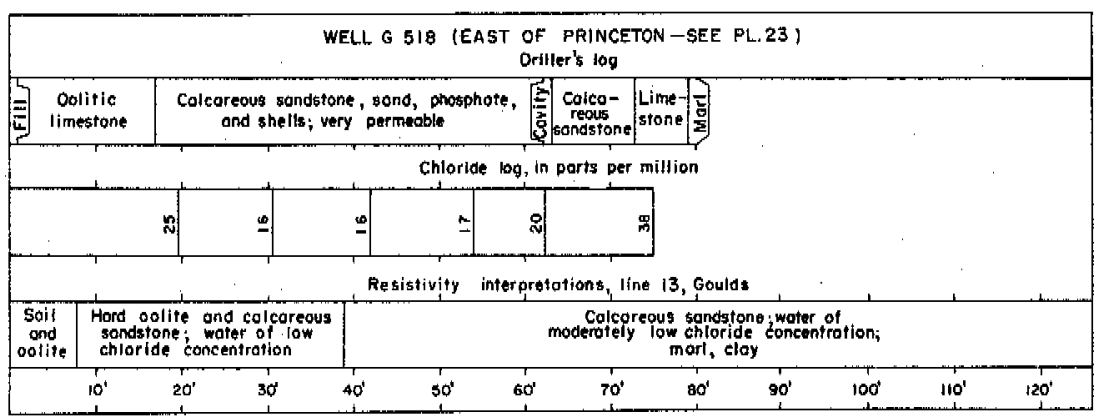

Figure 210. - Comparison of driller's logs and chloride logs with resistivity interpretations, Cutler area and near Goulds.

lower intermediate bed appears to be rather hard and impervious; near Biscayne Bay, its electrical identity is missing. The bottom layer shows that the sea water has infiltrated to a point somewhere between lines no, 2 and no, 5, and that the limestone and sandstone beds saturated with salt water are lower in resistivity than are the marl and clay lying beneath them.

The situation north of Cutler is the same, except that here the sea-water invasion has extended to the surface materials as far inland as line no. 6 . This is apparent from the low resistivity values for all of the layers in this line.

The resistivity line at Goulds was taken just across the road from Goulds Canal near well G 518 east of Princeton (see pl. 23). The low resistivity of the surface materials indicates the presence of chlorides, although no samples were taken in this section for the chloride log. It appears that some contamination from the canal may have caused the low resistivity in the upper layer. The resistivity of the intermediate layer indicates that the chloride content of the water there is relatively low. The resistivity of the deeper materials is about the same as is found in the adjacent areas.

\section{MEASUREMENTS AT FORT LAUDERDALE}

The electrical resistivity measurements at Fort Lauderdale were made near the Fort Lauderdale water plant, well field, and 
golf course, located a short distance west of the city. Some control, in the form of well logs and chloride logs, was available, but it was not always possible to obtain resistivity measurements close to the drill holes because of nearby buried conductors or grounded power lines.

Thirteen resistivity profile measurements were begun in this area. One profile was abandoned because it was impossible to get sufficient current into the earth through the very dry sand cover. Another measurement was temporarily abandoned because of instrument failure, but it was made later with a different instrument. A third measurement was of no value beyond the $15-\mathrm{ft}$ interval because negative potentials appeared with a corresponding inequality of the $\mathrm{P}-1$ and $\mathrm{P}-2$ readings. The apparent resistivity curves obtained in this small area are widely variable, both as to the number of layers and the resisitivities of the layers.

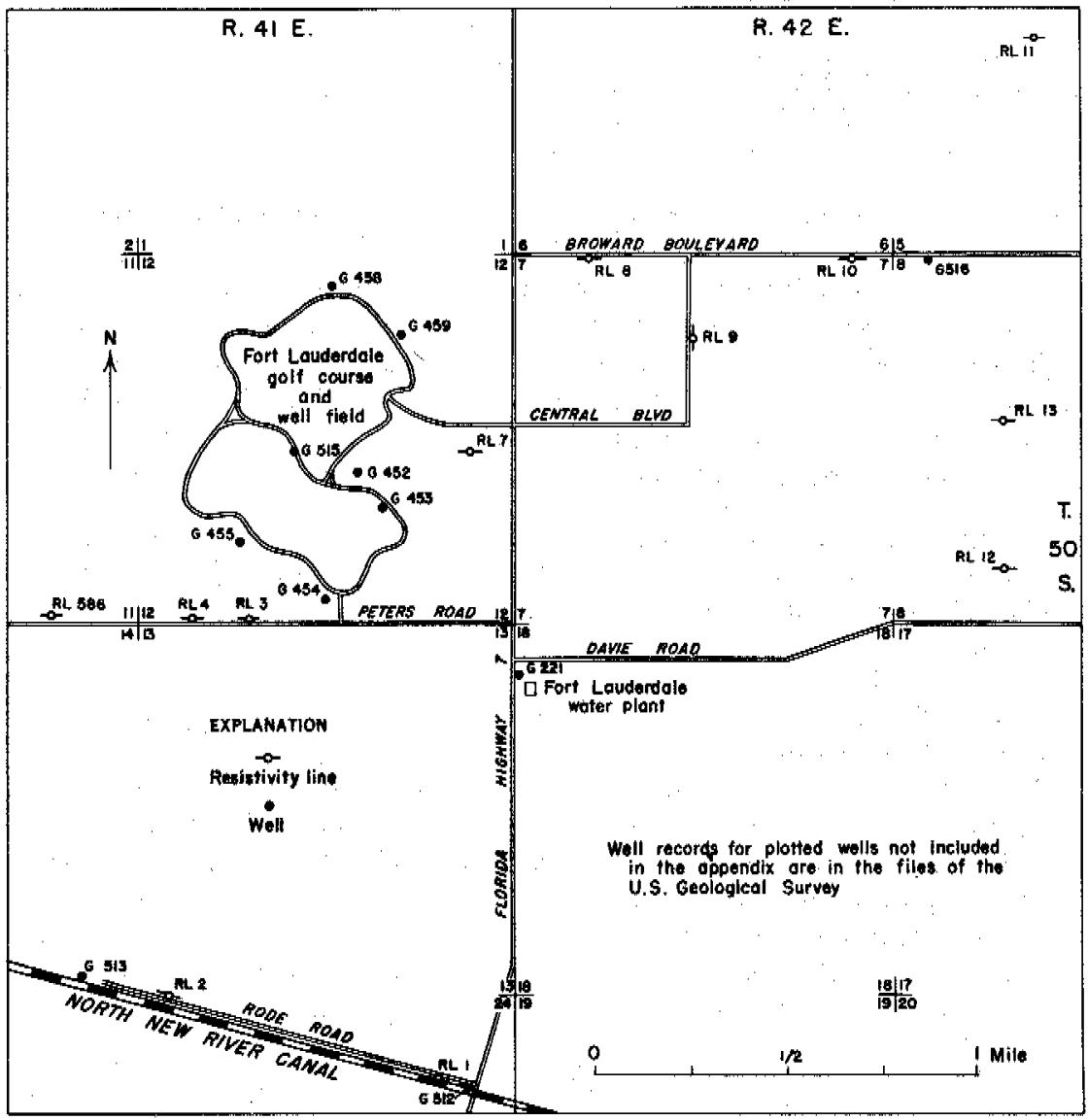

Figure 211. - Location of resistivity lines and related wells, Fort Lauderdale area. 


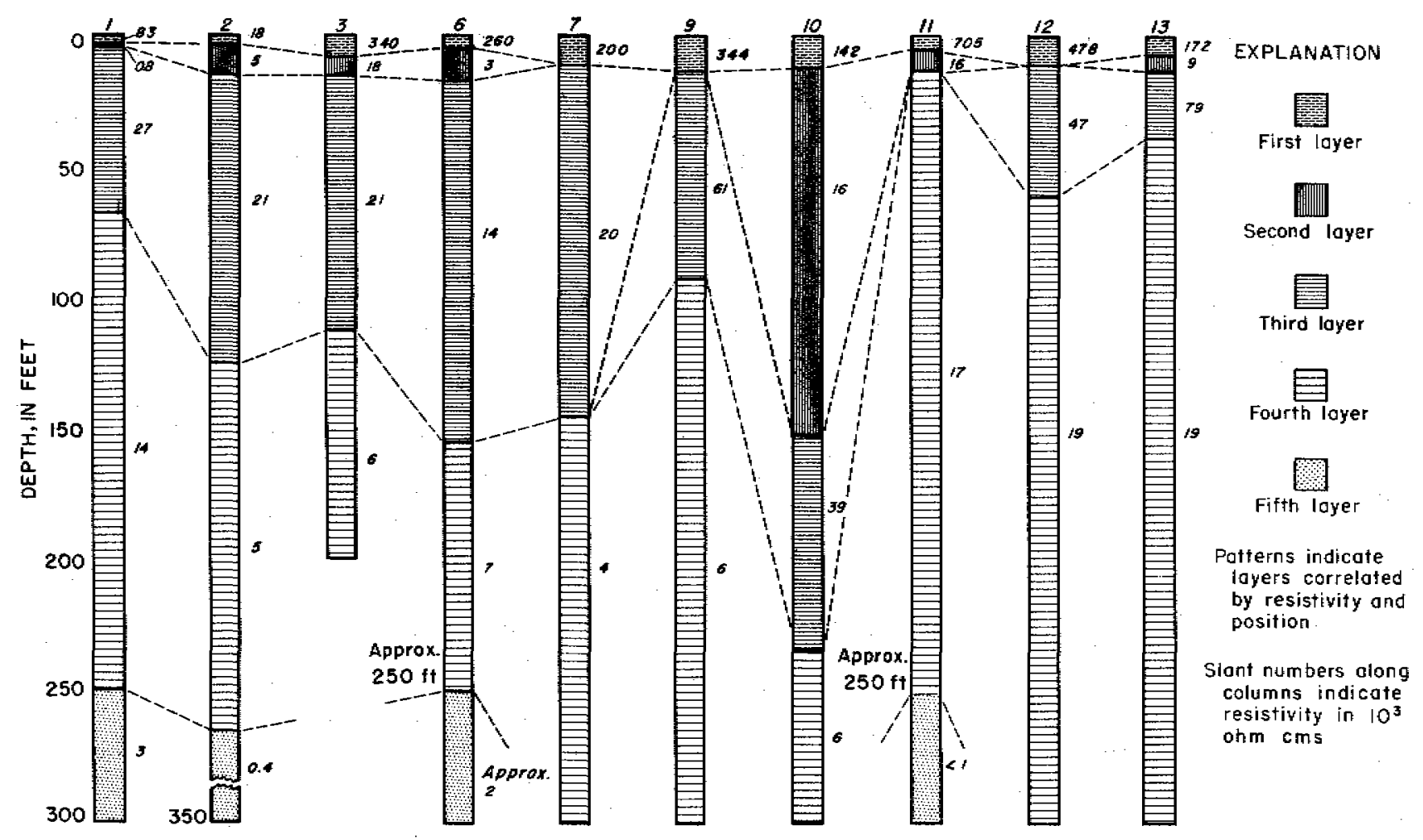

Figure 212. - Correlation of resistivity layers near Fort Lauderdale. 
The locations of the resistivity lines in the Fort Lauderdale area are given in figure 211 . The wells used in the correlation of the resistivity measurements are also shown in this figure. Copies of the well logs and chloride logs are in the Appendix and in the files of the U. S. Geological Survey.

On plate 18 the interpretations of the apparent resistivity curves are compared graphically with the well logs and chloride logs of the nearest wells. It is apparent from the interpretations that the numerous beds described in the well logs do not have uniquely dis tinguishing electrical characteristics. Furthermore, the well logs and the analysis of the apparent resistivity curves indicate that the beds may not be continuous throughout the small area in which the resistivity measurements were made.

The resistivity of the surface material varies between 18,200 and $478,000 \mathrm{ohm} \mathrm{cms}$; of the intermediate materials, 14,100 to $60,700 \mathrm{ohm} \mathrm{cms}$; of the deepest materials within the range of observations, 400 to $7,100 \mathrm{ohm} \mathrm{cms}$.

A layer-correlation chart, based upon the computed apparent resistivities of the layers, is presented in numerical sequence from left to right in figure 212. The layer just below the surface layer varies greatly in thickness; however, it is missing at locations 7,9 , and 12 , and appears greatly thickened at location 10 . The next deeper layer, the third from the surface, changes electrical charactertistics at locations 9 and 10 , becoming respectively about three times and two times as resistant; however, this layer is missing at location 11 .

The three uppermost layers probably contain water of very low chloride concentration, but the next deeper layer, the fourth, is considered to contain water of moderately low chloride concentration. The latter zone is variable both in the amount of chlorides present and the depth to which it extends. According to the interpretations of the resistivity curves, the bottom of this zone was not reached at locations $3,7,9,10,12$, and 13. A very low resistivity was determined for the bottom layer at locations 1,2 , 6 , and 11. Any water that is present in this layer would be expected to contain a high concentration of chlorides, perhaps nearly as much as sea water.

Locations 1, 2, 3, and 6 probably contain more chlorides in the water near the surface than any of the others.

Vorhis (1948) states that well G 512 contained salt water at 42 ft and that well G 513 contained salt water at 10 and $52 \mathrm{ft}$. The concentrations of chlorides are rather low, $180 \mathrm{ppm}$ in the first well and 59 and $52 \mathrm{ppm}$, respectively, in the other. Resistivity line no. 1 was completed a short distance west of well G 512. The 
only possible salt-water contamination zone indicated by the resistivity interpretations is the one between 2.7 and $3.1 \mathrm{ft}$. Resistivity line no. 2 was centered about $700 \mathrm{ft}$ east of well G 513. Resistivity interpretations indicate that a possible zone of salt-water infiltration is between 2.5 and $14 \mathrm{ft}$. There is, however, no indication of salt-water contamination corresponding to the measured depth of $52 \mathrm{ft}$. The bed of black muck near the surface probably masks the interpretation of the salt-water zone to a certain extent.

The resistivity interpretations indicate that the zone of nearsurface infiltration of salt water has not extended as far west as resistivity line nos. 11, 13, and 12 .

\section{EVALUATION OF THE METHOD}

It has been demonstrated that salty ground water can be located in the coastal area near Miami by a very careful selection of sites for resistivity lines. The brief study near Fort Lauderdale clearly shows the possibility of carrying out resistivity surveys to trace salt-water encroachment in that area also. To keep a record of the advance and retreat of the salt water, a series of resistivity line centers would have to be laid out and observations would have to be taken at regular intervals. The apparent resis tivity curves could be interpreted, a chart of the resistivity prepared, and the entire problem then followed graphically. Furthermore, with more field measurements it should be possible to correlate the formations and determine the geology in the areas between the drill holes. Some difficulties would be encountered, such as interference from power lines, buried mains, pipes, and cables. The very dry mantle of sand would also give trouble. However, with more time and careful planning, these difficulties could be overcome. 


\title{
QUALITY OF GROUND AND SURFACE WATERS
}

\author{
By S. K, Love
}

INTRODUCTION

The wide range in composition of waters available, or in use, in southeastern Florida is indicated by analyses of several hundred samples of surface and ground waters made during the course of this investigation. Except for its color, some of the water in the area would be classed as excellent for all ordinary uses. Some of the water can be made entirely satisfactory for all uses by fairly simple treatment, but water from other sources cannot be made sujtable for general use by any practical treatment.

Because the most urgent need for information about the quality and quantity of water in southeastern Florida is in connection with municipal supplies for the cities of Miami, Miami Beach, and other nearby communities, most of the intensive analytical work has been done on samples from sources in, or near, the metropolitan area of Miami. The work has included determinations of the general character of surface water and its contamination by salt water. Information has been obtained about the general character of shallow ground water and of artesian water in the Miami area. A large number of determinations were made on samples of water from test wells, and analyses were made to show the extent of contamination of the public supply wells. Looking to the possibility of obtaining supplies at a greater distance from the Miami area, attention was given to the character of surface water and ground water in the Lake Okeechobee area and in the coastal areas of Broward and Palm Beach Counties.

\section{EARLIER REPORTS ON QUALITY OF WATER}

A few analyses of ground waters in southeastern Florida are reported by Sellards and Gunter (1913, p. 103-290), and by Matson and Sanford (1913). These analyses indicate that shallow ground water in the permeable aquifers near the coast (where uncontaminated with salt water) was hard, but otherwise suitable for domestic and industrial use. The authors of both reports point out that artesian water obtained from deep wells in West Palm Beach and farther south were highly mineralized and unsatisfactory for most uses.

A report by Collins and Howard (1928, p. 177-233) includes analyses of practically all of the public supplies in southeastern 
Florida, together with analyses of several privately owned wells and of a few surface waters.

Prior to this investigation, a considerable number of chloride determinations were made by the cities of Miami and Miami Beach in an attempt to determine the extent of salt-water contamination in the Miami area. All of these records were made available to the Geological Survey and have proved invaluable in providing a background for the comprehensive investigation of water resources.

During the course of the investigation, information about the quality of surface waters was released in a progress report (Cross, Love, Parker, and Wallace, 1940), and in a paper by Cross and Love (1942, p. 490-504). A paper by Love and Swenson (1942, p. 1624-1628) gives analyses of the 25 public supplies in southeastern Florida.

The chemical character of ground water in the Everglades has been discussed by Stringfield (1933a), by Parker (1942, p. 47-76), and by Parker and Hoy (1943, p. 33-55).

\section{METHODS OF INVESTIGATION}

\section{COLLECTION AND EXAMINATION OF SAMPLES}

The general survey of southeastern Florida included a systematic study of the chemical character of all of the major streams, lakes, and canals. On the larger streams and canals, complete analyses were made of 10-day composites of samples collected daily for a period of a year. Less frequent analyses were made of samples collected from smaller and less important streams. Two surveys were made of the quality of water in Lake Okeechobee by making analyses of samples collected from about 40 points in the lake; one survey was made in 1940 when the lake was at a low stage, and another was made in 1941 when it was at a comparatively high stage.

Semimonthly samples were collected from several tidal canals in, and near, Miami throughout most of the period of the investigation in order to follow the trend of salt-water intrusion from Biscayne Bay.

Chloride was determined in a large number of samples collected in 1939 and 1940 from wells in the Miami area in order to determine the extent of contamination by sea water, and every month thereafter chloride was determined on samples collected from a group of key wells that would adequately reflect significant movements of salt water in the aquifers. 
More complete analyses were made of several hundred samples from wells both in Miami and in other parts of southeastern Florida to obtain reliable information about the character of the ground waters.

A series of analyses were made of water samples collected from a large number of test wells that were drilled to obtain information on the geologic and hydrologic properties of the waterbearing formations and about the chemical character of the waters at different depths.

In addition to the regular program of sampling and analyses, several hundred chemical examinations and analyses were made of water samples that might furnish relevant information.

\section{EXPRESSION OF RESULTS}

The analyses are reported in parts per million for all mineral constituents. Specific conductance is reported in reciprocal ohms (mhos); $\mathrm{pH}$ is reported in standard $\mathrm{pH}$ units; and color is reported in dimensionless units defined by standard platinumcobalt scale.

The analytical results obtained in chemical analyses are, strictly speaking, in milligrams per liter. For all practical purposes, however, for waters having a total concentration of dissolved mineral matter of less than $10,000 \mathrm{mg}$ per liter, the units "milligrams per liter" and "parts per million" are essentially equal. For waters in which the content of dissolved solids is greater than $10,000 \mathrm{mg}$ per liter, the two units can no longer be assumed to be equivalent. The increase in density of the waters having a concentration of over $10,000 \mathrm{mg}$ per liter makes it necessary to use a correction factor to report the analysis in parts per million. Because chloride is the predominant constituent of most concentrated waters in southeastern Florida, and also because sea water is the chief source of mineralmatter in the concentrated waters, it was found satisfactory to apply a correction factor to all waters in which chloride was found in excess of 5, 000 $\mathrm{mg}$ per liter in order that the results of analysis could be expressed uniformly in parts per million.

\section{CONSTITUENTS AND PROPERTIES OF NATURAL WATERS}

The mineral constituents of natural waters generally reflect the composition and solubility of the rock materials with which the waters have been in contact. In southeastern Florida the mineral matter found in surface and ground waters is derived not only from rocks and rock material, but also through the medium 
of ion exchange from organic mucks and soils to which mineral matter has been adsorbed. It is also derived in some parts of the Everglades from saline residues remaining from former invasions of the sea which have not been completely flushed out by meteoric water. Still another source of mineralization is sea water that has contaminated some surface and ground waters near the coast and along the tidal canals.

\section{COLOR}

In water analysis the term "color" refers to the appearance of water that is free of suspended matter. Water for domestic use and for some industrial uses should be free from perceptible color. All of the surface waters and most of the ground waters in southeastern Florida are colored.

Natural color in surface and ground waters is caused almost entirely by organic matter extracted from leaves, roots, and other substances in the ground. The platinum-cobalt standard proposed by Hazen $(1892, p .300-310)$ is the commonly adopted standard for measuring color in water (Am. Public Health Assoc,, 1936, p. 12-14) in the United States, the unit of color being that produced by $1 \mathrm{mg}$ of platinum per liter, dissolved as platinic chloride, with the addition of enough cobalt chloride to give a color matching the shade of the natural water. The figures for color given in the table of analyses represent units on this platinumcobalt scale.

Color was determined of almost all samples of surface and ground waters for which analyses are given in this report.

\section{SPECIFIC CONDUCTANCE}

The specific conductance of a water is a measure of its ability to conduct an electric current. Specific conductance, which is the reciprocal of specific resistance in ohms, is expressed in reciprocal ohms at $25^{\circ} \mathrm{C}\left(77^{\circ} \mathrm{F}\right)$. In order that the use of awkwardly small figures may be avoided, the measured values of specific conductance are multiplied by $10^{5}$, as indicated in the heading at the top of the column in the tables of analyses.

The specific conductance of a water is a function of the amount and kind of the dissolved mineral matter. It varies with the concentration and also with the degree of ionization of the minerals in solution. It is of value in determining the volume to be used for anaiysis and, particularly in southeastern Florida, in determining the extent to which surface and ground water are contaminated with sea water. 
SILICA

Silica $\left(\mathrm{SiO}_{2}\right)$ is dissolved from practically all rocks and rock materials. Its state in natural waters is not definitely known, but in reports of analyses it is assumed to be in the colloidal state, taking no part in the equilibrium between acids and bases. In southeastern Florida, the concentration of silica, in those waters in which it was determined, ranged from about 2 to $20 \mathrm{ppm}$, with an average of somewhat less than $10 \mathrm{ppm}$. The silica in a water may be precipitated with other scale-forming materials in steam boilers. This may be a serious matter in the operation of highpressure boilers. Otherwise, silica is of comparatively little importance in determination of water use.

\section{IBON}

Iron ( $F e)$ is dissolved from practically all soils and rocks and frequently from iron pipes. Soft waters low in mineral content and other waters of low $\mathrm{pH}$ will dissolve iron from iron pipes and particularly from hot-water lines and boilers. The quantity of iron in ground water is not so uniform over large areas as the quantity of calcium and other constituents. Wells, close together, have been found to differ considerably in the quantity of iron in their waters. Surface waters in southeastern Florida generally contain less than $0.1 \mathrm{ppm}$ of iron but ground waters may contain from a few hundredths of a part to 3 or $4 \mathrm{ppm}$ and even larger amounts have been found in some wells.

Water furnished to consumers by public supplies should not contain more than about $0.2 \mathrm{ppm}$ of iron. Water that contains much more than this amount of iron is not suitable because of the appearance of "red-water," or reddish-brown sediment caused by the oxidation of the iron. The iron will make stains on white porcelain, enameled ware and fixtures, and on clothing or other fabrics. Many industrial plants, including those manufacturing and preparing foods, carbonated beverages, beer, textiles, dyed fabrics, high-grade paper, and ice, must have water practically free from iron. The excess iron may be removed by simple aeration and filtration from most waters but some waters require the addition of lime or some other substance.

\section{CALCIUM}

Calcium ( $\mathrm{Ca}$ ) is dissolved in large quantities from limestone, which is largely calcium carbonate. Corals and shells are also nearly all calcium carbonate. Calcium is, therefore, found in considerable quantities in all ground waters in southeastern Florida. 
Calcium carbonate is not very soluble in pure water, but when enough carbon dioxide is available, large quantities of calcium carbonate go into solution as the bicarbonate. Calcium is the main cause of the hardness of waters in southeastern Florida.

\section{MAGNESIUM}

Magnesium $(\mathrm{Mg})$ is dissolved from practically all rocks but mainly from dolomite and dolomitic limestones. The limestones of southeastern Florida contain little magnesium, the refore the ground waters carry only small quantities. Magnesium is one of the abundant constituents of sea water and therefore will be found in large quantities in ground water contaminated with sea water, or with salts embedded in the deposits of ancient seas. Magnesium and calcium are the only elements that cause appreciable hardness in most natural waters.

\section{SODIUM AND POTASSIUM}

Sodium (Na) and potassium (K) are dissolved from almost all rocks, but they make up only a small part of the dissolved mineral matter in most of the surface and ground waters in southeastern Florida. As sea water is mainly a solution of common salt (sodium chloride), considerable quantities of sodium are found in waters contaminated with sea water or in waters with salts enclosed in the older marine deposits. The quantity of sodium may be from 5 to $30 \mathrm{ppm}$ in an ordinary surface or ground water or several hundred parts per million in a highly mineralized water. The quantity of potassium is generally comparatively small. Natural waters that contain only 3 or $4 \mathrm{ppm}$ of sodium and potassium are likely to contain about equal quantities of the two. As the total quantity of these constituents increases, the proportion of potassium becomes less. In waters carrying from 30 to $50 \mathrm{ppm}$ of both of these constituents, the ratio of sodium to potassium may vary from about $4: 1$ to $10: 1$. For waters that carry increasing amounts of sodium, the ratio of sodium to potassium may be even larger.

A calculated quantity of sodium and potassium is given in many analyses - the quantity that is needed, in addition to the calcium and magnesium, to balance the acid radicles: bicarbonate, sulfate, chloride, and nitrate. The quantity thus calculated is affected by any errors in the determination of the individual constituents. The calculation sometimes leads to a negative quantity for sodium, especially if no nitrate is reported in the analysis. In a few such analyses, the sodium and potassium are not reported. 
BICARBONATE

Bicarbonate $\left(\mathrm{HCO}_{3}\right)$ in natural waters results from the action by carbon dioxide (dissolved in the water) on carbonate rocks. A few natural waters contain carbonate $\left(\mathrm{CO}_{3}\right)$, but generally its presence in samples is the result of the action of the water on the sample bottle or of previous treatment of the water.

Surface and ground waters that have not been in contact with limestone may have less than $20 \mathrm{ppm}$ of bicarbonate. The ordinary surface and ground waters in southeastern Florida, however, have about 150 to $400 \mathrm{ppm}$ of bicarbonate. In some parts of the Everglades, concentrations of 500 to $1,000 \mathrm{ppm}$ of bicarbonate are not uncommon.

Bicarbonate is the principal acid radicle in nearly all waters used for public supplies. Its relationship to hardness is discussed below.

\section{SULFATE}

Sulfate $\left(\mathrm{SO}_{4}\right)$ is dissolved in large quantities from gypsum (calcium sulfate) in the rocks and soil. It is also formed by the oxidation of sulfides of iron, and sulfates from this source cause serious pollution of streams in parts of the country where the opening of mines has exposed large quantities of iron sulfide to the action of air and water. The waters in southeastern Florida that have large quantities of sulfate appear to have obtained it from solution of concentrated deposits of sodium sulfate or calcium sulfate.

Sulfate itself has little effect on the general use of a water. Magnesium sulfate and sodium sulfate may be present in sufficient quantity to give a bitter taste. Sulfate in a hard water may increase the cost of softening and will form a much more troublesome scale in a steam boiler.

\section{CHLORTE}

Chloride $(\mathrm{Cl})$ is an abundant constituent of sea water and is dissolved in small quantities from rock materials. Many of the surface waters of southeastern Florida have less than $15 \mathrm{ppm}$ of chloride, but ground waters with $100 \mathrm{ppm}$, or more, are not uncommon. Along the coast, ground waters contain from 10 to 30 ppm of chloride, and in some parts of the Everglades shallow wells may contain several hundred parts per million. Deeper wells in the Everglades have been known to contain as much as $3,150 \mathrm{ppm}$ of chloride. 
Chloride, like sodium, with which it forms sodium chloride (commonsalt), has little effect on water for ordinary uses unless there is enough present to give a salty taste. Waters high in chloride may be corrosive to plumbing and steam boilers and harmful to irrigated crops.

\section{FLUORDE}

Fluoride $(F)$ has been reported to be as prevalent as chloride in rocks (Shepherd, 1940, p. 117-128). However, the quantity in natural waters is very much less than that of chloride. Surface waters in southeastern Florida do not contain more than $0.6 \mathrm{ppm}$ of fluoride and usually less than $0.3 \mathrm{ppm}$ was found. Fluoride concentrations in public supplies ranged from 0 to $0.3 \mathrm{ppm}$, except for one small supply obtained from a deep artesian well that contained over $2 \mathrm{ppm}$. (See analysis of public supply at LaBelle, Hendry County.)

Fluoride in water is associated with the dental defect known as mottled enamel (Dean, 1936, p. 1269-1272) if children drink the water during the calcification or formation of their teeth. Normally formed teeth have not been known to become mottled later, regardless of the fluoride content of the drinking water. Teeth having mottled enamel become a dull chalky white color, which, in many cases, later takes on a characteristic dark-brown stain. It is generally recognized that water containing $1 \mathrm{ppm}$, or less, of fluoride will have no deleterious effect on tooth enamel and waters with slightly higher concentrations are used for public supplies without noticeable effect. Except for the single public supply mentioned above, there is no evidence to show that fluoride concentrations in potable surface and ground waters in southeastern Florida are sufficient to produce mottled enamel on children's teeth. It has been reported (Dean, Jay, Arnold, and Elvove, 1941 , p. 761-792) that quantities of fluoride not sufficient to produce mottled enamel may have a beneficial effect on teeth by reduction of the incidence of dental caries (decay).

\section{NTRATE}

Nitrate $\left(\mathrm{NO}_{3}\right)$ is a relatively unimportant constituent of most of the analyses given in this report. Nitrate may indicate previous contamination by sewage or other organic matter because it represents the final stage of oxidation in the nitrogen cycle. Most waters in southeastern Florida carry less than $2 \mathrm{ppm}$ of nitrate. This small quantity has little effect on the value of water for ordinary uses. 


\section{DUSSOLVED BOLJDS}

The residue, on evaporation, of a water consists mainly of the rock materials reported in the analyses. A small quantity of organic material and a little water of crystallization are sometimes included. The amount of dissolved solids in the surface and ground waters of southeastern Florida range from less than 50 to several thousand parts permillion. Waters with less than 500 ppm of dissolved solids are generally entirely satisfactory for domestic use, except for the difficulties resulting from their hardness. The waters with more than 1,000 ppm are likely to contain enough of certain constituents to produce a noticeable taste or to make the water unsuitable for many domestic and industrial uses.

\section{HARDNESS}

Hardness of a water is most commonly recognized by a lack of suds in washing. Most of the figures for hardness given in the tables of analyses were calculated from the determinations of quantities of calcium and magnesium. In some of the less complete analyses, the hardness was determined by the soap method. In addition to causing trouble in the use of soap, these constituents are active agents in the formation of scale in steam boilers and other vessels in which water is heated or evaporated.

Hardness may be of two kinds-carbonate and noncarbonate. Carbonate hardness, sometimes referred to as temporary hardness, is caused by calcium and magnesium bicarbonate. Much of the carbonate hardness can be removed by boiling or by treatment with lime. Noncarbonate hardness, often called permanent hardness, is caused by calcium and magnesium sulfate (chloride and nitrate) and is more difficult and costly to remove. Both forms of hardness may be entirely removed by passing the water through a zeolite-type of water softener, but water softened by this method still contains approximately the original quantity of dissolved mineral matter.

Water with a hardness of less than $60 \mathrm{ppm}$ is generally rated as soft, and its treatment for the removal of hardness is rarely justified. Hardness between 60 and 120 ppm does not seriously interfere with the use of water for most purposes, but it does slightly increase the consumption of soap, and its removal by a softening process is profitable for laundries and allied industries. Hardness between 120 and 200 ppm is troublesome for many industrial processes and requires treatment for the prevention of scale in boilers. Hardness above $200 \mathrm{ppm}$ is objectionable for most industrial and domestic uses. Water having a hardness of from 200 to $400 \mathrm{ppm}$ is used by many people who obtain their water supplies from privately owned wells and is also furaished by 
some of the larger public supplies. There is an increasing tendency, however, for cities to soften their water supplies if the raw water has a hardness in excess of $150 \mathrm{ppm}$. Where municipal water supplies are softened, an attempt is generally made to reduce the hardness to about $85 \mathrm{ppm}$.

Waters of widely differing degrees of hardness are found in southeastern Florida. The surface waters flowing into Lake Okeechobee are very soft, but surface waters in canals and streams south and east of Lake Okeechobee have a hardness ranging from about 100 to $400 \mathrm{ppm}$. Practically all ground waters are decidedly hard, ranging from about 150 to $500 \mathrm{ppm}$.

\section{HYDEOGEN SUL,FIDE}

Hydrogen sulfide $\left(\mathrm{H}_{2} \mathrm{~S}\right)$ was not detected in any samples of surface water and was found in only a few samples of ground water. Therefore this constituent is not shown in the tables of analyses. Hydrogen sulfide is a gas that gives the characteristic odor to sulfur waters. It is formed during the decomposition of eggs and other organic materials that contain considerable sulfur. Hydrogen sulfide in ground waters is commonly believed to be formed by the reduction of sulfates.

Many ground waters in Florida carry small quantities of hydrogen sulfide, but it usually disappears quickly when the water is allowed to stand in an open vessel. Treatment for the removal of iron will insure the removal of hydrogen sulfide from most of these waters.

\section{HYDROGEN-TON CONCENTRATION (pH)}

The degree of acidity or alkalinity of a water, as indicated by the hydrogen-ion concentration (Clark, 1928), is of importance with reference to the corrosiveness and the proper treatment for coagulation at the water-treatment plant. The hydrogen-ion concentration is commonly reported as $\mathrm{pH}$.

Technically, $\mathrm{pH}$ is the number of moles of ionized hydrogen per liter, or to put it more simply, it is a number denoting the degree of acidity or alkalinity. A pH value of 7.0 represents neutrality, which means that the water is neither acid nor alkaline. Values higher than 7.0 denote increasing alkalinity; values lower than 7.0 denote increasing acidity. Waters that have a pH of less than 7.0 are likely to be corrosive, while waters that have a $\mathrm{pH}$ of more than 7,0 are less likely to be corrosive. Other factors entering into chemical equilibrium, however, make it impossible to correlate corrosive characteristics of waters on the basis of $\mathrm{pH}$ alone. 
Inasmuch as most of the surface and ground waters in southeastern Florida are decidedly hard and are, therefore, generally noncorrosive, pH was not determined on most of the samples. However, $\mathrm{pH}$ is reported for practically all of the public water supplies.

\section{CoRROSIVENESS}

The corrosiveness of water is that property which makes the water aggressive to metal surfaces and frequently causes trouble by the appearance of "red-water." The disadvantages of iron in a water supply have been previously discussed. However, in addition to the trouble caused by iron in water, corrosion causes the deterioration of water pipes, steam boilers, and water-heating equipment. Many waters that do not appreciably corrode coldwater lines will aggressively attack hot-water lines, because raising the temperature of the water greatly increases its corrosivity. Corrosion of pipe lines, resulting in tuberculation (Alexander, 1940, p. 371-385), causes economic losses due to increased friction and loss of flow. Speller (1935), in his book on corrosion, presents a comprehensive inventory of available information on the general principles, causes, and prevention of corrosion. Oxygen, carbon dioxide, free acid, and acid-generating salts are the principal constituents in water that cause corrosion. A method has been developed by Langelier (1936, p. 1500-1521) for computing the corrosive tendency of a water, providing that the content of calcium and dissolved mineralmatter, the total alkalinity, and the $\mathrm{pH}$ of the water are known.

In a general way, very soft waters tend to be corrosive and hard waters tend to be noncorrosive. Most of the soft waters in southeastern Florida are found in the Kissimmee River and in smaller streams to the north and west of Lake Okeechobee. Although no factual data are available, it is probable that these waters are corrosive to plumbing and boilers. Generally, the hard surface and ground waters to the south and east of Lake Okeechobee are not noticeably corrosive. Waters containing appreciable amounts of sea water, however, and waters in which sodium chloride is present in moderately large amounts, are likely to be corrosive.

Corrosion may be checked by protective coatings, by the addition of lime, soda ash, or other chemicals that adjust the $\mathrm{pH}$, and by the addition of sodium hexametaphosphate, sodium silicate, or certain other chemicals.

\section{CHEMICAL CHARACTER OF SURFACE WATERS}

Surface waters that discharge into Lake Okeechobee from the north and west are soft, low in dissolved mineral matter, and 
highly colored. South and east of Lake Okeechobee, surface waters, which usually flow away from the lake, are variable in character but are usually hard, contain moderate to large amounts of dissolved mineral matter, and are also highly colored. The amount of dissolved matter in Lake Okeechobee is intermediate between the soft inflowing water to the north and west and the hard water flowing seaward to the south and east.

\section{KISSIMMEE RIVER}

Complete chemical analyses were made on 10-day composites of daily samples collected from the Kissimmee River at Harding Bridge on State Highway 70 , about 10 miles west of the town of Okeechobee, for a period of a year ending February 28, 1941 (see table 82). The analyses show that there was little variation in concentration of any of the chemical constituents throughout the year. Dissolved solids ranged from 61 to $80 \mathrm{ppm}$. The Kis simmee River is the largest source of soft water in southern Florida. The hardness ranged from only 17 to $26 \mathrm{ppm}$ during the period of record, and it is probable that the hardness seldom exceeds 30 or $35 \mathrm{ppm}$. The river water is, however, highly colored with organic matter, the color remaining practically constant at 110 through the year. Although the Kissimmee River is the largest tributary to Lake Okeechobee, the composition of the river water is very different from the composition of the lake water. An explanation will be presented in the section on Lake Okeechobee:

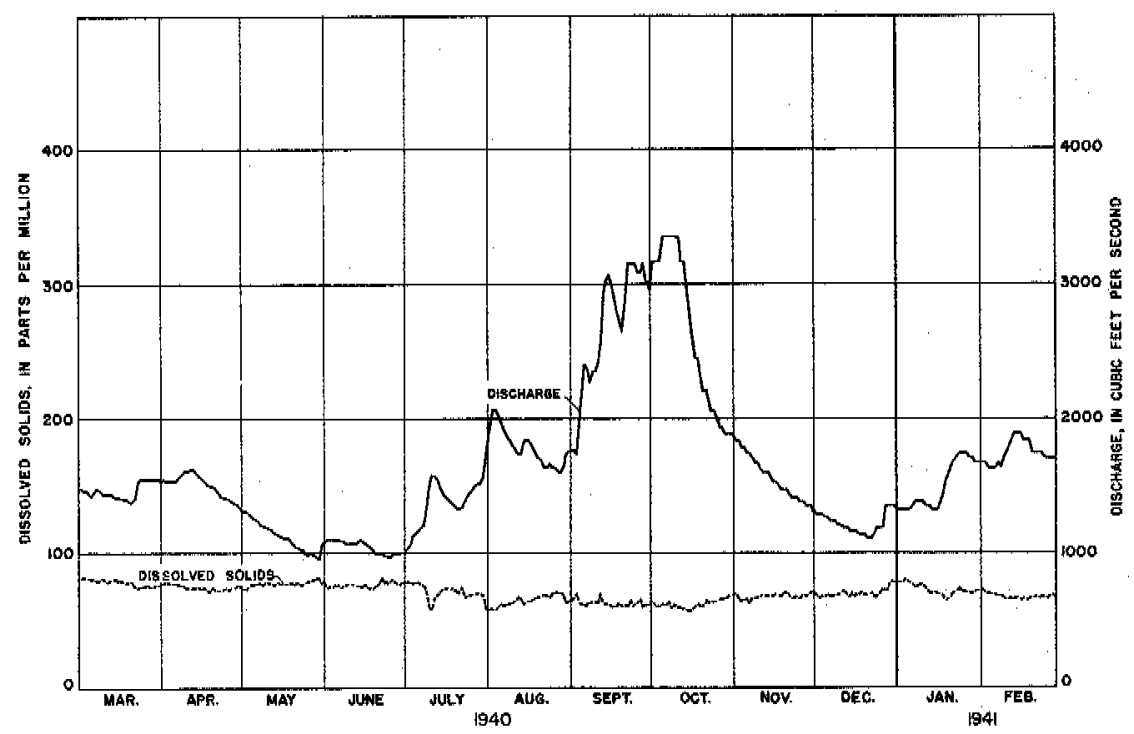

Figure 213. -Graph showing discharge and dissolved solids in the Kissimmee River near Okeechobee, $1940-41$. 
Table 82. -Analyses, in parts per million, of water from the Kissinnte River near Okeechobee

\begin{tabular}{|c|c|c|c|c|c|c|c|c|c|c|c|c|c|c|c|c|}
\hline $\begin{array}{c}\text { Date } \\
\text { of } \\
\text { collection }\end{array}$ & $\begin{array}{c}\text { Mean } \\
\text { discharge } \\
\text { (cfs) }\end{array}$ & Color & $\begin{array}{c}\text { Specific } \\
\text { conductance } \\
\left(\mathrm{K} \times 10^{\circ}\right. \\
\left.\text { at } 25^{\circ} \mathrm{C}\right) \\
\end{array}$ & $\mid \begin{array}{c}\text { Silica } \\
\left(\mathrm{SiO}_{2}\right)\end{array}$ & $\begin{array}{l}\text { lzon } \\
(\mathrm{Fe})\end{array}$ & $\begin{array}{c}\text { Calcium } \\
\text { (Ca) }\end{array}$ & $\begin{array}{c}\text { Magnesium } \\
(\mathrm{Mg})\end{array}$ & $\begin{array}{c}\text { Sodium } \\
\text { (Na) }\end{array}$ & $\begin{array}{c}\text { Potassium } \\
\text { (K) }\end{array}$ & $\begin{array}{c}\text { Bicarbonate } \\
\left(\mathrm{HCO}_{\mathrm{y}}\right)\end{array}$ & $\mid \begin{array}{r}\text { Sulfate } \\
\left(\mathrm{SO}_{4}\right)\end{array}$ & $\begin{array}{c}\text { Chloride } \\
\text { (Cl) }\end{array}$ & $=\begin{array}{c}\text { Fluoride } \\
\text { (F) }\end{array}$ & $\begin{array}{l}\text { Nitrate } \\
\left(\mathrm{NO}_{3}\right)\end{array}$ & $\begin{array}{c}\text { Dissolved } \\
\text { solids }\end{array}$ & $\begin{array}{c}\text { Total } \\
\text { hardness } \\
\text { as } \\
\mathrm{CaCO}_{3}\end{array}$ \\
\hline \begin{tabular}{lr}
\multicolumn{2}{c|}{1940} \\
Mar. & $1-10$ \\
Mar. & $11-20$ \\
Mar. & $21-31$ \\
Apr. & $1-10$ \\
Apr. & $11-20$ \\
Apr. & $21-30$
\end{tabular} & $\begin{array}{l}1,454 \\
1,410 \\
1,534 \\
1,560 \\
1,545 \\
1,384\end{array}$ & $\begin{array}{l}110 \\
110 \\
110 \\
110 \\
110 \\
110\end{array}$ & $\begin{array}{l}9.1 \\
8.9 \\
8.4 \\
8.1 \\
8.4 \\
8.3\end{array}$ & $\begin{array}{l}1.2 \\
1.3 \\
1.3 \\
1.5 \\
1.5 \\
1.4\end{array}$ & $\begin{array}{l}0.02 \\
.02 \\
.02 \\
.02 \\
.04 \\
.03\end{array}$ & $\begin{array}{l}6.4 \\
6.2 \\
6.0 \\
6.0 \\
5.9 \\
5.9\end{array}$ & $\begin{array}{l}2.4 \\
2.3 \\
2.2 \\
2.1 \\
1.7 \\
1.9\end{array}$ & $\begin{array}{l}8.6 \\
8.6 \\
8.4 \\
8.2 \\
8.6 \\
8.1\end{array}$ & $\begin{array}{l}1.1 \\
.6 \\
.8 \\
.6 \\
.6 \\
.6\end{array}$ & $\begin{array}{l}14 \\
15 \\
15 \\
15 \\
16 \\
15\end{array}$ & $\begin{array}{l}6.6 \\
6.5 \\
5.8 \\
5.3 \\
6.3 \\
6.5\end{array}$ & $\begin{array}{l}15 \\
14 \\
13 \\
13 \\
12 \\
12\end{array}$ & $\begin{array}{r}0.2 \\
.2 \\
.2 \\
.2 \\
.2 \\
.2\end{array}$ & $\begin{array}{l}0.1 \\
.1 \\
.1 \\
.1 \\
.2 \\
.2\end{array}$ & $\begin{array}{l}80 \\
79 \\
77 \\
76 \\
72 \\
73\end{array}$ & $\begin{array}{l}26 \\
25 \\
24 \\
24 \\
22 \\
23\end{array}$ \\
\hline $\begin{array}{lr}\text { May } & 1-10 \\
\text { May } & 11-20 \\
\text { May } & 21-31 \\
\text { June } & 1-10 \\
\text { June } & 11-20 \\
\text { June } & 21-30\end{array}$ & $\begin{array}{r}1,242 \\
1,113 \\
1,011 \\
1,088 \\
1,050 \\
989\end{array}$ & $\begin{array}{l}110 \\
110 \\
110 \\
110 \\
110 \\
110\end{array}$ & $\begin{array}{l}8.6 \\
8.7 \\
9.2 \\
8.9 \\
8.8 \\
9.1\end{array}$ & $\begin{array}{l}2.0 \\
1.6 \\
1.3 \\
1.7 \\
1.6 \\
2.2\end{array}$ & $\begin{array}{l}.02 \\
.02 \\
.02 \\
.02 \\
.02 \\
.02\end{array}$ & $\begin{array}{l}5.8 \\
6.4 \\
6.1 \\
6.3 \\
6.3 \\
6.4\end{array}$ & $\begin{array}{l}1.4 \\
1.4 \\
.1 .7 \\
1.3 \\
1.4 \\
2.0\end{array}$ & $\begin{array}{l}8.9 \\
8.5 \\
9.2 \\
8.8 \\
8.6 \\
8.5\end{array}$ & $\begin{array}{l}.5 \\
.6 \\
.6 \\
.5 \\
.7 \\
.6\end{array}$ & $\begin{array}{l}16 \\
14 \\
15 \\
15 \\
15 \\
15\end{array}$ & $\begin{array}{l}6.7 \\
7.2 \\
7.6 \\
7.2 \\
7.4 \\
8.1\end{array}$ & $\begin{array}{l}12 \\
12 \\
13 \\
14 \\
12 \\
13\end{array}$ & $\begin{array}{l}.2 \\
.2 \\
.2 \\
.2 \\
.2 \\
.2\end{array}$ & $\begin{array}{l}.2 \\
.2 \\
.2 \\
.2 \\
\therefore 2 \\
.2\end{array}$ & $\begin{array}{l}76 \\
76 \\
79 \\
76 \\
76 \\
79\end{array}$ & $\begin{array}{l}20 \\
22 \\
22 \\
21 \\
22 \\
24\end{array}$ \\
\hline $\begin{array}{lr}\text { July } & 1-10 \\
\text { July } & 11-20 \\
\text { July } & 21-31 \\
\text { Aug. } & 1-10 \\
\text { Aug. } & 11-20 \\
\text { Aug. } & 21-31\end{array}$ & $\begin{array}{l}1,232 \\
1,429 \\
1,505 \\
1,935 \\
1,765 \\
1,660\end{array}$ & $\begin{array}{l}110 \\
110 \\
110 \\
110 \\
110 \\
110\end{array}$ & $\begin{array}{l}8.1 \\
7.6 \\
7.2 \\
6.2 \\
6.5 \\
6.8\end{array}$ & $\begin{array}{l}1.6 \\
1.6 \\
3.3 \\
2.4 \\
2.7 \\
2.6\end{array}$ & $\begin{array}{l}.04 \\
.02 \\
.15 \\
.13 \\
.13 \\
.12\end{array}$ & $\begin{array}{l}5.7 \\
5.8 \\
5.7 \\
5.2 \\
5.4 \\
5.6\end{array}$ & $\begin{array}{l}1.5 \\
1.8 \\
1.8 \\
1.6 \\
1.8 \\
1.9\end{array}$ & $\begin{array}{l}8.0 \\
7.6 \\
7.3 \\
6.6 \\
6.5 \\
6.6\end{array}$ & $\begin{array}{l}.7 \\
.6 \\
.8 \\
.7 \\
.7 \\
.6\end{array}$ & $\begin{array}{l}15 \\
14 \\
14 \\
11 \\
12 \\
12\end{array}$ & $\begin{array}{l}6.3 \\
8.6 \\
4.8 \\
5.2 \\
4.6 \\
5.4\end{array}$ & $\begin{array}{c}12 \\
12 \\
9.5 \\
9.0 \\
10 \\
10\end{array}$ & $\begin{array}{l}.2 \\
.2 \\
.2 \\
.2 \\
.4 \\
.2\end{array}$ & $\begin{array}{l}.2 \\
.2 \\
.2 \\
.2 \\
.2 \\
.2\end{array}$ & $\begin{array}{l}73 \\
72 \\
66 \\
60 \\
64 \\
66\end{array}$ & $\begin{array}{l}20 \\
22 \\
22 \\
20 \\
21 \\
22\end{array}$ \\
\hline $\begin{array}{lr}\text { Sept. } & 1-10 \\
\text { Sept. } & 11-20 \\
\text { Sept. } & 21-30 \\
\text { Oct. } & 1-10 \\
\text { Oct. } & 11-20 \\
\text { Oct. } & 21-31\end{array}$ & $\begin{array}{l}2,178 \\
2,865 \\
3,087 \\
3,284 \\
2,753 \\
1,991\end{array}$ & $\begin{array}{l}110 \\
110 \\
110 \\
110 \\
110 \\
110\end{array}$ & $\begin{array}{l}6.2 \\
6.6 \\
6.6 \\
6.6 \\
6.6 \\
7.2\end{array}$ & $\begin{array}{l}2.7 \\
3.2 \\
3.4 \\
3.4 \\
2.5 \\
4.7\end{array}$ & $\begin{array}{l}.14 \\
.02 \\
.02 \\
.02 \\
.02 \\
.02\end{array}$ & $\begin{array}{l}5.0 \\
5.1 \\
5.1 \\
4.8 \\
4.7 \\
5.0\end{array}$ & $\begin{array}{l}1.9 \\
1.6 \\
1.2 \\
1.4 \\
1.2 \\
1.6\end{array}$ & $\begin{array}{l}6.9 \\
4.6 \\
5.5 \\
5.8 \\
5.9 \\
6.6\end{array}$ & $\begin{array}{l}.6 \\
.6 \\
.6 \\
.6 \\
.6 \\
.6\end{array}$ & $\begin{array}{l}11 \\
13 \\
13 \\
12 \\
12 \\
12\end{array}$ & $\begin{array}{l}4.9 \\
4.7 \\
4.3 \\
3.8 \\
3.8 \\
4.6\end{array}$ & $\begin{array}{c}9.0 \\
9.0 \\
9.5 \\
10 \\
9.5 \\
12\end{array}$ & $\begin{array}{l}.3 \\
.1 \\
.1 \\
.1 \\
.1 \\
.1\end{array}$ & $\begin{array}{l}.1 \\
.1 \\
.0 \\
.0 \\
.2 \\
.1\end{array}$ & $\begin{array}{l}62 \\
62 \\
63 \\
63 \\
61 \\
66\end{array}$ & $\begin{array}{l}20 \\
19 \\
18 \\
18 \\
17 \\
19\end{array}$ \\
\hline $\begin{array}{lr}\text { Nov. } & 1-10 \\
\text { Nov. } & 11-20 \\
\text { Nov. } & 21-30 \\
\text { Dec. } & 1-10 \\
\text { Dec. } & 11-20 \\
\text { Dec. } & 21-31\end{array}$ & $\begin{array}{l}1,741 \\
1,533 \\
1,380 \\
1,255 \\
1,158 \\
1,241\end{array}$ & $\begin{array}{l}110 \\
110 \\
110 \\
110 \\
100 \\
100\end{array}$ & $\begin{array}{l}7.8 \\
7.8 \\
8.2 \\
8.3 \\
8.6 \\
9.4\end{array}$ & $\begin{array}{l}2.2 \\
2.2 \\
1.9 \\
2.0 \\
1.8 \\
3.4\end{array}$ & $\begin{array}{l}.02 \\
.02 \\
.02 \\
.02 \\
.03 \\
.07\end{array}$ & $\begin{array}{l}5.2 \\
5.2 \\
5.4 \\
5.4 \\
5.4 \\
5.8\end{array}$ & $\begin{array}{l}1.4 \\
1.7 \\
1.8 \\
1.6 \\
1.5 \\
2.1\end{array}$ & $\begin{array}{l}7.1 \\
7.1 \\
6.9 \\
7.0 \\
7.6 \\
9.0\end{array}$ & $\begin{array}{r}.7 \\
.6 \\
.8 \\
.8 \\
1.0 \\
1.1\end{array}$ & $\begin{array}{l}13 \\
13 \\
12 \\
13 \\
13 \\
16\end{array}$ & $\begin{array}{l}4.9 \\
5.6 \\
6.0 \\
5.8 \\
5.9 \\
6.9\end{array}$ & $\begin{array}{l}12 \\
12 \\
13 \\
13 \\
13 \\
16\end{array}$ & $\begin{array}{l}.1 \\
.1 \\
.1 \\
.1 \\
.1 \\
.1\end{array}$ & $\begin{array}{l}.0 \\
.0 \\
.1 \\
.2 \\
.3 \\
.1\end{array}$ & $\begin{array}{l}69 \\
70 \\
70 \\
70 \\
72 \\
75\end{array}$ & $\begin{array}{l}19 \\
20 \\
21 \\
20 \\
20 \\
23\end{array}$ \\
\hline
\end{tabular}


Table 82. - Analyses, in parts per million, of water from the Kissinmee River near Okeochobee- Continued

\begin{tabular}{|c|c|c|c|c|c|c|c|c|c|c|c|c|c|c|c|c|}
\hline $\begin{array}{l}\text { Date } \\
\text { of } \\
\text { millection }\end{array}$ & $\begin{array}{c}\text { Mean } \\
\text { discharge } \\
\text { (cfs) }\end{array}$ & Color & $\begin{array}{c}\text { Specific } \\
\text { conductance } \\
(\mathrm{K} \times 105 \\
\left.\text { at } 25^{\circ} \mathrm{C}\right)\end{array}$ & $\begin{array}{l}\text { Silica } \\
\left(\mathrm{SiO}_{2}\right.\end{array}$ & $\begin{array}{l}\text { Iron } \\
\text { (Fe) }\end{array}$ & $\begin{array}{c}\text { Calcium } \\
\text { (Ca) }\end{array}$ & $\begin{array}{c}\text { Magnesium } \\
(\mathrm{Mg})\end{array}$ & Sodium & $\begin{array}{l}\text { Potassium } \\
\text { (K) }\end{array}$ & $\begin{array}{c}\text { Bicarbonate } \\
\left(\mathrm{HCO}_{3}\right)\end{array}$ & $\begin{array}{l}\text { Sulfate } \\
\left(\mathrm{SO}_{4}\right)\end{array}$ & $\begin{array}{c}\text { Chloride } \\
\text { (Cl) }\end{array}$ & $\begin{array}{c}\text { Fluoride } \\
\text { (F) }\end{array}$ & $\begin{array}{c}\text { Nitrate } \\
\text { (NO) }\end{array}$ & $\begin{array}{l}\text { Dissolved } \\
\text { solids }\end{array}$ & $\begin{array}{c}\text { Total } \\
\text { hardness } \\
\text { as } \\
\mathrm{CaCO}_{3}\end{array}$ \\
\hline \begin{tabular}{lr}
\multicolumn{2}{c}{1941} \\
Jan. & $1-10$ \\
Jan. & $11-20$ \\
Jan. & $21-31$ \\
Feb. & $1-10$ \\
Feb. & $11-19$ \\
Feb. & $20-28$
\end{tabular} & $\begin{array}{l}1,347 \\
1,418 \\
1,704 \\
1,660 \\
1,846 \\
1,718\end{array}$ & $\begin{array}{l}110 \\
100 \\
110 \\
110 \\
110 \\
110\end{array}$ & $\begin{array}{r}10.1 \\
9.2 \\
9.1 \\
8.7 \\
8.3 \\
8.4\end{array}$ & $\begin{array}{l}3.3 \\
2.5 \\
2.8 \\
1.9 \\
1.6 \\
1.3\end{array}$ & $\begin{array}{l}0.07 \\
.05 \\
.07 \\
.04 \\
.03 \\
.05\end{array}$ & $\begin{array}{l}5.6 \\
5.5 \\
5.3 \\
5.4 \\
5.0 \\
5.2\end{array}$ & $\begin{array}{l}2.1 \\
2.0 \\
1.8 \\
1.8 \\
1.7 \\
1.8\end{array}$ & $\begin{array}{l}10 \\
9.0 \\
9.4 \\
8.6 \\
8.2 \\
8.0\end{array}$ & $\begin{array}{l}1.0 \\
1.2 \\
1.0 \\
1.1 \\
1.1 \\
1.2\end{array}$ & $\begin{array}{l}16 \\
15 \\
15 \\
15 \\
19 \\
14\end{array}$ & $\begin{array}{l}7.1 \\
6.3 \\
6.3 \\
5.1 \\
5.5 \\
5.4\end{array}$ & $\begin{array}{l}17 \\
16 \\
16 \\
15 \\
14 \\
14\end{array}$ & $\begin{array}{r}0.1 \\
.1 \\
.1 \\
.1 \\
.1 \\
.1\end{array}$ & $\begin{array}{r}0.1 \\
.4 \\
.1 \\
.2 \\
.2 \\
.2\end{array}$ & $\begin{array}{l}80 \\
71 \\
73 \\
70 \\
67 \\
69\end{array}$ & $\begin{array}{l}23 \\
22 \\
21 \\
21 \\
19 \\
20\end{array}$ \\
\hline Average & ............ & 109 & 8.1 & 2.2 & 0.04 & 5.6 & 1.7 & 7.7 & 0.8 & 14 & 5.9 & 12 & 0.2 & 0.2 & 71 & 21 \\
\hline
\end{tabular}

$\stackrel{\overrightarrow{0}}{0}$ 
The range of dissolved solids in the samples analyzed during the year ending February 28, 1941, together with the daily discharge is shown in figure 213 .

OTHER STREAMS CONTRIBUTING TO LAKE OKEECHOBEE

In adiition to the Kissimmee River, the principal streams that flow into Lake Okeechobee are Fisheating Creek, Indian Prairie Canal, and Taylor Creek. Analyses of samples collected at irregular intervals from these streams indicate that Fisheating and Taylor Creeks are similar in composition to the Kissimmee River. (See table 101.) A single sample collected from Indian Prairie Canal contained considerably more dissolved matter than samples collected from the other two streams. Color in samples collected from three streams ranged from 180 to 380 , whereas color in the Kissimmee River averaged 110 .

\section{LAKE OKEECHOBEE AND PRINCIPAL OUTFLOW CANALS}

\section{LAKE OKEECHOBEE}

It would be reasonable to suppose that the composition of the wate $r$ in Lake Okeechobee would be similar to the composition of the inflowing water. Actually, however, the concentration of dissolved matter in the lake is about three times as great as the concentration in the major tributary streams, and the hardness is about five to seven times as great as that of the inflowing water.

In order to study the composition of the water in different parts of Lake Okeechobee two series of samples were collected (fig. 214). The first series of samples was collected in July 1940, and the second series of samples was collected in March 1941, corresponding to a low stage and a relatively high stage, respectively (see table 83). Analyses of both series of samples show that the composition of the lake water during each of the two sampling periods was fairly uniform. An exception was observed in the 1941 series at sampling stations 59 and 60 near the mouth of the Kissimmee River. At these stations the concentration of dissolved solids in the lake water was lowered by the very dilute water from the river. In the 1940 samples, dissolved solids ranged from 189 to $207 \mathrm{ppm}$ and hardness ranged from 134 to $148 \mathrm{ppm}$. In the 1941 samples, dissolved solids and hardness ranged from 167 to 197 and from 124 to $144 \mathrm{ppm}$, respectively, not including the results for samples collected near the Kissimmee River.

Several explanations have been advanced for the large difference in concentration of dissolved matter ordinarily found in the lake and the concentration found in the main tributary streams. It has 


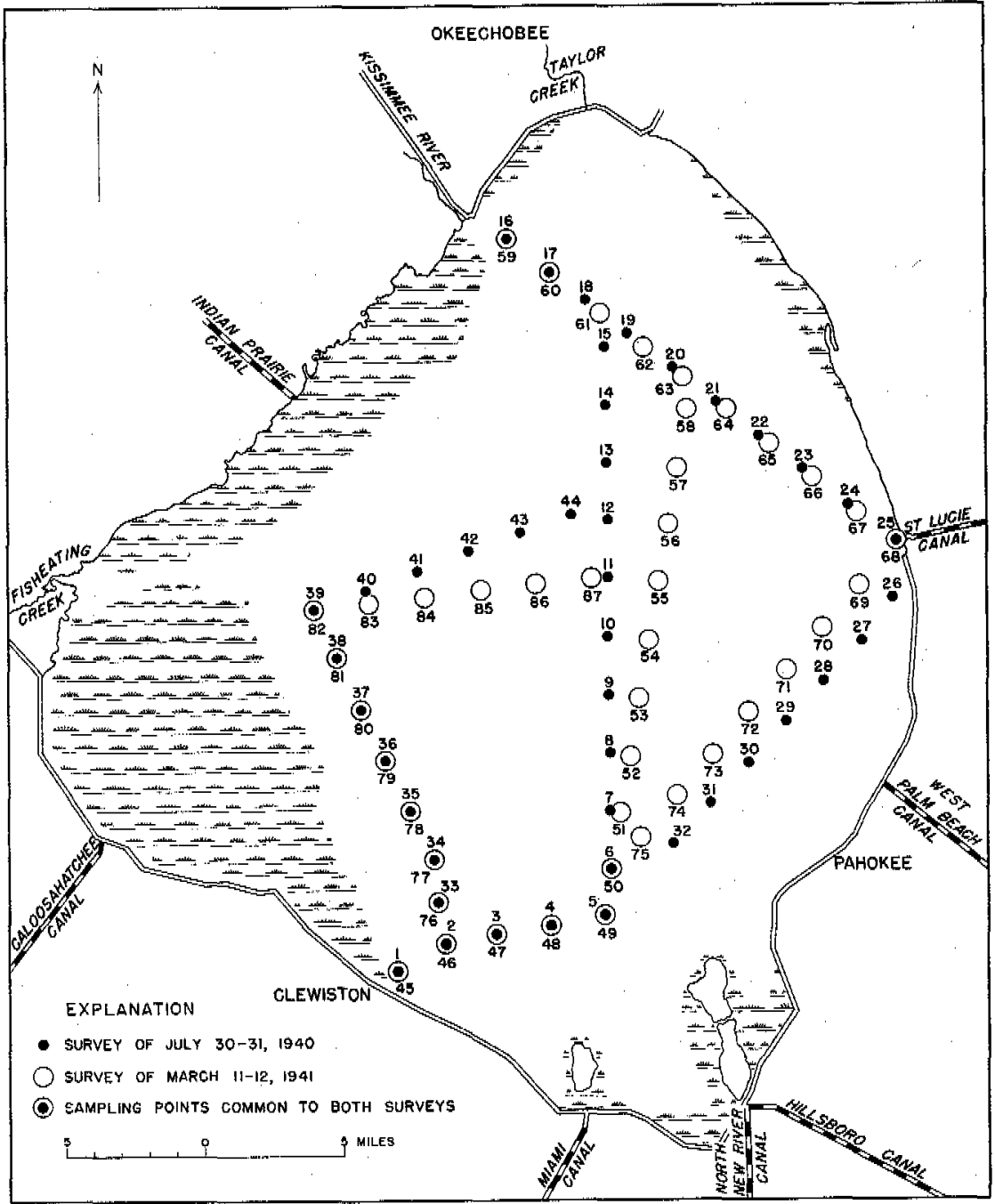

Figure 214. -Location of sampling stations in Lake Okeechobee.

been suggested that it is a result of springs in the bottom of the lake that contain much larger quantities of dissolved matter than is found in the inflowing water. If this were true, it is probable that the water near the springs would be more concentrated than at some distance from them. Analyses of surface and bottom samples from over 40 points in the lake did not support such an explanation.

Another view is that the high concentration of dissolved mineral matter in water discharged into the lake during short rainy periods from the Hillsboro and Nor th New River Canals (and at times from the West Palm Beach Canal), may account for the increase in the 
concentration of dissolved matter in Lake Okeechobee. It is true that these canal waters are rather highly mineralized at certain times during the year. High and variable concentrations in the Hillsboro Canal have caused the town of Belle. Glade much trouble in treating its public water supply during periods that the canal discharges into the lake. However, the amount of water discharged into the lake from these canals is relatively small and is considered to be insufficient to account for the concentrations of dissolved matter found in the lake.

Still another factor to be considered is the concentration resulting from evaporation. Tremendous quantities of water are evaporated from the lake during the course of a year. Measure ments show that evaporation ranges from about 40 to 45 in. per year. Precipitation averages about 50 to 55 in. Hence, evaporation is more than counterbalanced by precipitation. Evaporation cannot, therefore, account for any large increase in concentration of dissolved solids in the lake.

The most probable explanation for the concentration of dissolved matter in Lake Okeechobee seems to be as follows:

The inflowing water is normally low in concentration because the rivers and creeks drain sandy soil which is relatively insoluble. When the water enters the lake it soon comes in contact with shell marls or other limestone formations, which are known to lie at or very near the surface of the ground over much of the area covered by the lake. The lake is very shallow even at the highest stages. The deeper parts of the lake are little more than $15 \mathrm{ft}$ deep and the average is much less. As a result of its shallow depth, the surface of the lake is quickly affected by winds, and agitation of the water throughout probably takes place during rela tively short periods of moderate wind velocities. The water becomes very turbid during storm periods and has noticeable turbidity even during extended periods of relative calm. The almost constant motion of the water brings it in ever-changing contact with the shell marls on the bottom of the lake; this facilitates soIution of the calcium carbonate, thereby increasing the concentration of dissolved matter in the lake. Organic matter, growing, dying, and finally decaying on the lake bottom, also promotes solution of the limestone. It may be that this organic matter and the carbon dioxide dissolved from the air effectively controls the maximum concentration of dissolved matter, which is principally calcium carbonate.

Analyses of samples collected from Kissimmee River, Fisheating Creek, and Lake Okeechobee are shown graphically in figure 215 . 
Table 83.-Analyses, in parts per million, of water from Lake Okeechobee

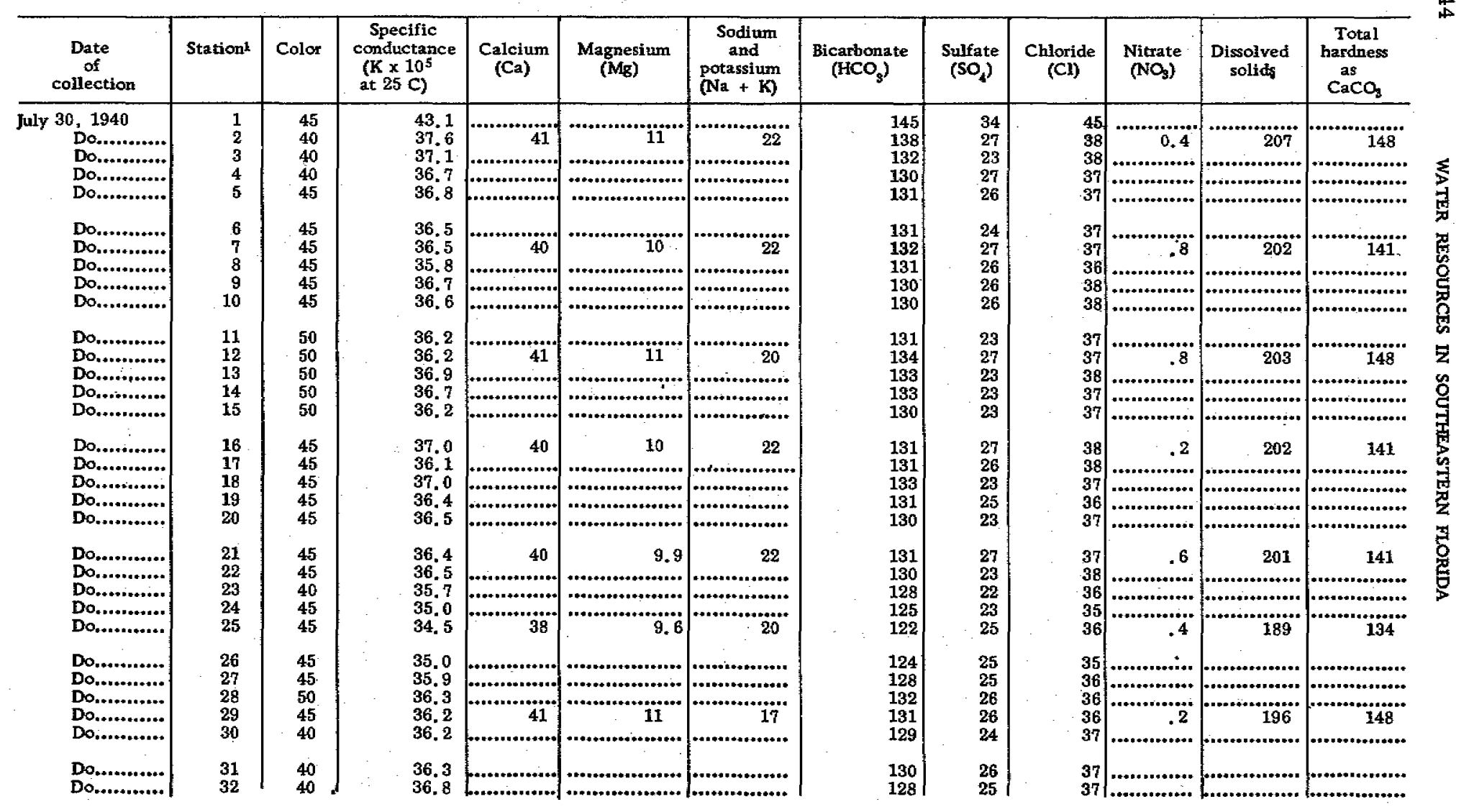




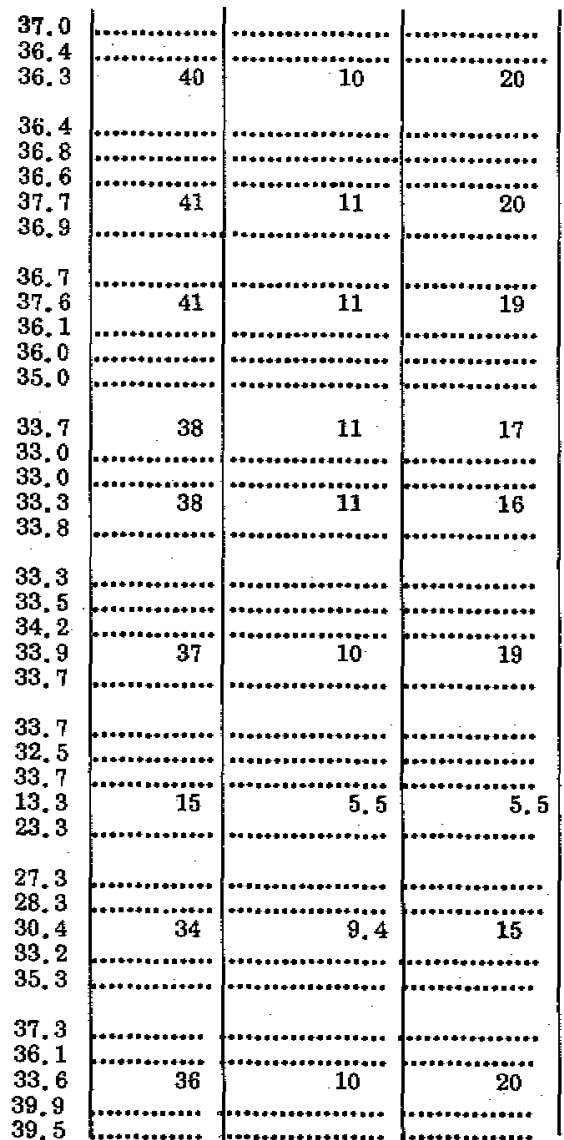

\begin{tabular}{|c|c|}
\hline $\begin{array}{l}132 \\
134 \\
131\end{array}$ & $\begin{array}{l}23 \\
28 \\
24\end{array}$ \\
\hline 131 & 25 \\
\hline 131 & 23 \\
\hline 131 & 25 \\
\hline 132 & 27 \\
\hline 132 & 23 \\
\hline 132 & 23 \\
\hline 130 & 27 \\
\hline 129 & 26 \\
\hline 130 & 25 \\
\hline 124 & 25 \\
\hline 121 & 29 \\
\hline 119 & 27 \\
\hline 120 & 20 \\
\hline 120 & 28 \\
\hline 119 & 20 \\
\hline 122 & 28 \\
\hline 121 & 18 \\
\hline 123 & 29 \\
\hline 120 & 26 \\
\hline 121 & 24 \\
\hline 120 & 22 \\
\hline 115 & 20 \\
\hline 122 & 20 \\
\hline $\begin{array}{l}38 \\
76\end{array}$ & $\begin{array}{l}16 \\
13\end{array}$ \\
\hline 104 & 15 \\
\hline 107 & 17 \\
\hline 108 & 25 \\
\hline 118 & 22 \\
\hline 122 & 23 \\
\hline 127 & 2 \\
\hline 124 & 25 \\
\hline 120 & 25 \\
\hline $\begin{array}{l}134 \\
134\end{array}$ & $\begin{array}{l}25 \\
23\end{array}$ \\
\hline
\end{tabular}

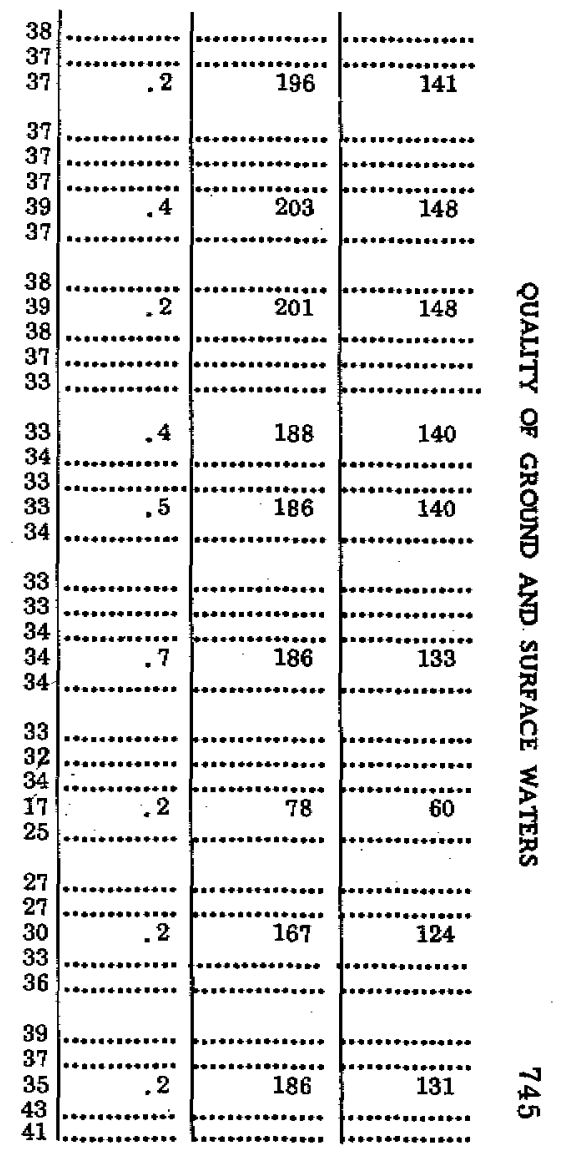


Table 83.-Analyses, in parts per million, of water from Lake Okeechobee-Continued

\begin{tabular}{|c|c|c|c|c|c|c|c|c|c|c|c|c|}
\hline $\begin{array}{l}\text { Date } \\
\text { of } \\
\text { collection }\end{array}$ & Station 1 & Color & $\begin{array}{c}\text { Specific } \\
\text { conductance } \\
\left(\mathrm{K} \times 10^{5}\right. \\
\text { at } 25 \mathrm{C})\end{array}$ & $\begin{array}{c}\text { Calcium } \\
\text { (Ca) }\end{array}$ & $\begin{array}{l}\text { Magnesium } \\
(\mathrm{Mg})\end{array}$ & $\begin{array}{l}\text { Sodium } \\
\text { and } \\
\text { potassium } \\
(\mathrm{Na}+\mathrm{K})\end{array}$ & $\begin{array}{c}\text { Bicarbonate } \\
\left(\mathrm{HCO}_{3}\right)\end{array}$ & $\begin{array}{c}\text { Sutfate } \\
\left(\mathrm{SO}_{4}\right)\end{array}$ & $\begin{array}{l}\text { Chloride } \\
\text { (Cl) }\end{array}$ & $\begin{array}{l}\text { Nitrate } \\
\left(\mathrm{NO}_{3}\right)\end{array}$ & $\begin{array}{l}\text { Dissolved } \\
\text { solids }\end{array}$ & $\begin{array}{c}\text { Total } \\
\text { hardness } \\
\text { as } \\
\mathrm{CaCO}_{3}\end{array}$ \\
\hline $\begin{array}{r}\text { Mar. } 11,1941 \\
\text { Do............ } \\
\text { Do........... } \\
\text { Do........... } \\
\text { Do........... } \\
\text { Do........... }\end{array}$ & $\begin{array}{l}71 \\
72 \\
73 \\
74 \\
75\end{array}$ & $\begin{array}{l}70 \\
75 \\
75 \\
70 \\
70\end{array}$ & $\begin{array}{l}36.8 \\
36.0 \\
34.2 \\
33.3 \\
33.2\end{array}$ & $\mid \begin{array}{c}\ldots \ldots \\
\ldots \ldots \\
\ldots \ldots \ldots \ldots \ldots\end{array}$ & 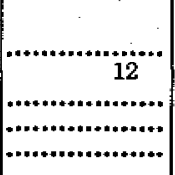 & $\left|\begin{array}{r}\ldots \ldots \ldots \ldots \ldots \\
19 \\
\ldots \ldots \ldots \ldots \ldots \ldots \\
\ldots \ldots \ldots \ldots \ldots \ldots \ldots\end{array}\right|$ & $\begin{array}{l}126 \\
126 \\
122 \\
122 \\
122\end{array}$ & $\begin{array}{l}24 \\
28 \\
22 \\
22 \\
22\end{array}$ & $\begin{array}{l}37 \\
37 \\
33 \\
33 \\
33\end{array}$ & 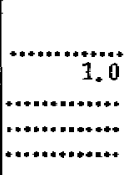 & $\begin{array}{r}197 \\
\ldots \ldots \ldots \ldots \ldots \\
\ldots \ldots \ldots \ldots \ldots \ldots \ldots\end{array}$ & $\begin{array}{l}144 \\
\ldots \ldots \ldots \ldots\end{array}$ \\
\hline $\begin{array}{c}\text { Mar. } 12,1941 \\
\text { Do........... } \\
\text { Do........... } \\
\text { Do............ } \\
\text { Do........... }\end{array}$ & $\begin{array}{l}76 \\
77 \\
78 \\
79 \\
80\end{array}$ & $\begin{array}{r}90 \\
100 \\
90 \\
75 \\
80\end{array}$ & $\begin{array}{l}32.1 \\
31.2 \\
31.8 \\
32.1 \\
32.1\end{array}$ & $\left|\begin{array}{c}\ldots \ldots \ldots \ldots \ldots \ldots \\
32 \\
\ldots \ldots \ldots \ldots \ldots \ldots\end{array}\right|$ & $\mid \begin{array}{c}\ldots \ldots \ldots \ldots \ldots \ldots \ldots \ldots \\
12 \\
\ldots \ldots \ldots \ldots \ldots \ldots \ldots \ldots \\
\ldots \ldots \ldots \ldots \ldots \ldots \ldots\end{array}$ & $\mid \begin{array}{r}\mid \ldots \ldots \\
\ldots \ldots \ldots \ldots \\
\ldots \ldots \ldots \ldots \\
\ldots \ldots \ldots \ldots\end{array}$ & $\begin{array}{l}116 \\
117 \\
112 \\
119 \\
117\end{array}$ & $\begin{array}{l}23 \\
23 \\
25 \\
24 \\
22\end{array}$ & $\begin{array}{l}31 \\
31 \\
33 \\
33 \\
32\end{array}$ & 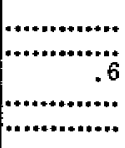 & $\begin{array}{r}174 \\
\ldots \ldots \ldots \\
\ldots \ldots \ldots \ldots\end{array}$ & $\begin{array}{c}129 \\
\ldots \ldots \ldots \ldots\end{array}$ \\
\hline $\begin{array}{l}\text { Do........... } \\
\text { Do........... } \\
\text { Do............ } \\
\text { Do........... } \\
\text { Do............ }\end{array}$ & $\begin{array}{l}81 \\
82 \\
83 \\
84 \\
85\end{array}$ & $\begin{array}{r}95 \\
100 \\
90 \\
80 \\
90\end{array}$ & $\begin{array}{l}31.8 \\
29.3 \\
30.9 \\
31.9 \\
33.0\end{array}$ & $\begin{array}{c}30 \\
36\end{array}$ & $\mid \begin{array}{c}12 \\
\ldots \ldots \ldots \ldots \\
11\end{array}$ & 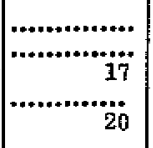 & $\begin{array}{l}117 \\
106 \\
116 \\
115 \\
124\end{array}$ & $\begin{array}{l}20 \\
22 \\
24 \\
18 \\
28\end{array}$ & $\begin{array}{l}32 \\
29 \\
29 \\
31 \\
33\end{array}$ & 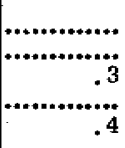 & $\begin{array}{r}170 \\
190\end{array}$ & $\begin{array}{c}124 \\
135\end{array}$ \\
\hline $\begin{array}{l}\text { Do........... } \\
\text { Do............ }\end{array}$ & $\begin{array}{l}86 \\
87\end{array}$ & $\begin{array}{l}70 \\
75\end{array}$ & $\begin{array}{l}33.0 \\
32.1\end{array}$ & 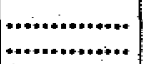 & | & 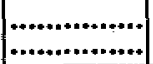 & $\begin{array}{l}119 \\
117\end{array}$ & $\begin{array}{l}20 \\
23\end{array}$ & $\begin{array}{l}32 \\
33\end{array}$ & ....................................... & 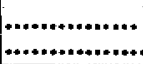 & 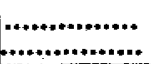 \\
\hline
\end{tabular}

${ }^{1}$ Numbers refer to locations of sampling stations in figure 214 . 


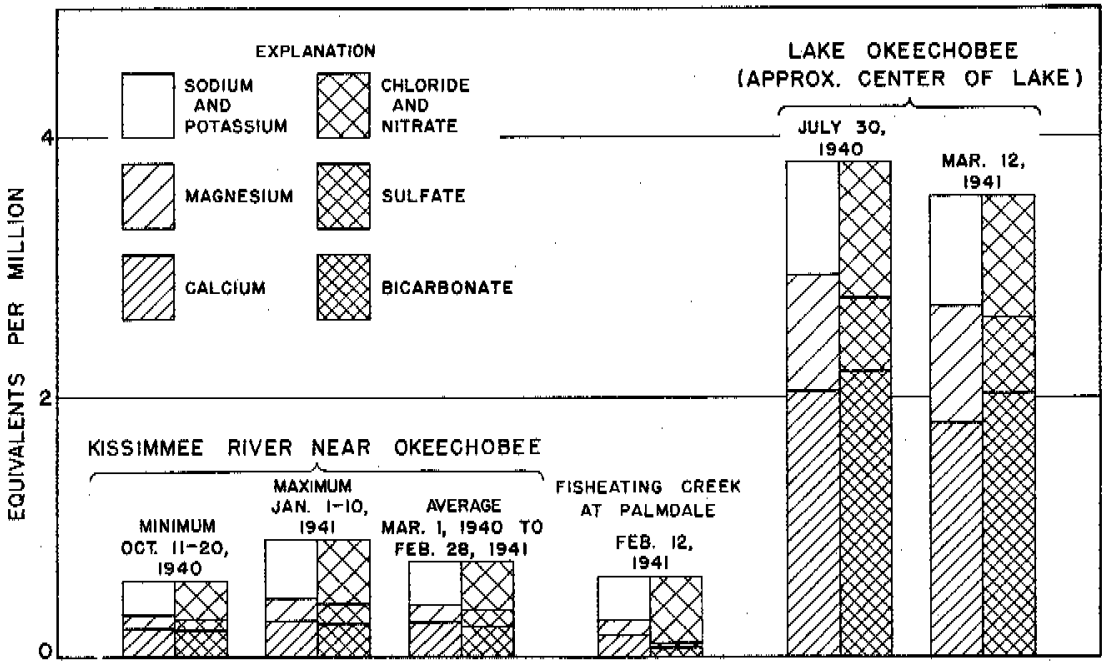

Figure 215. -Graph showing analyses of waters of the Kissimmee River, Fishezting Creek, and Lake Okeechobee.

\section{ST, LUCTE CANAL}

Daily samples were collected from the St. Lucie Canal about $200 \mathrm{ft}$ from Lake Okeechobee during the 2 -year period ending February 28, 1942 (table 84). Inasmuch as there is no tributary to Lake Okeechobee near the St. Lucie Canal, it is believed that the composition of the water flowing from the lake into the canal is fairly representative of the composition of the main body of the lake during a large part of the time. Analyses of 10-day composites of the daily samples show that dissolved solids ranged from 142 to $297 \mathrm{ppm}$, and that hardness ranged from 102 to $163 \mathrm{ppm}$ during the period of record. The dissolved mineral matter consists chiefly of calcium and bicarbonate as well as relatively large amounts of sodium, sulfate, and chloride. Color ranged from 35 to 130 and averaged about 50 , which is about one-half that of the color found in the Kissimmee River. 
Table 84,-Analyses, in parts per million, of water from St. Lucie Canal at lock 1, Lake Okeechobee

\begin{tabular}{|c|c|c|c|c|c|c|c|c|c|c|c|c|c|c|c|c|}
\hline $\begin{array}{c}\text { Date } \\
\text { of } \\
\text { collection }\end{array}$ & $\begin{array}{l}\text { Mean } \\
\text { discharge } \\
\text { (cfs) }\end{array}$ & Color & \begin{tabular}{|c|} 
Specific \\
conductance \\
( $\mathrm{K} \times 10^{5}$ \\
at $25 \mathrm{C})$
\end{tabular} & $\left|\begin{array}{l}\text { Silica } \\
\left(\mathrm{SiO}_{2}\right)\end{array}\right|$ & $\begin{array}{l}\text { Iron } \\
\text { (Fe) }\end{array}$ & $\begin{array}{c}\text { Calcium } \\
\text { (Ca) }\end{array}$ & $\begin{array}{c}\text { Magnesium } \\
(\mathrm{Mg})\end{array}$ & $\begin{array}{l}\text { Sodium } \\
\text { (Na) }\end{array}$ & $\begin{array}{c}\text { Potassium } \\
\text { (K) }\end{array}$ & $\begin{array}{l}\text { Bicarbonate } \\
\left(\mathrm{HCO}_{3}\right)\end{array}$ & $\begin{array}{c}\text { Sulfate } \\
\left(\mathrm{SO}_{4}\right)\end{array}$ & $\begin{array}{c}\text { Chloride } \\
\text { (Cl) }\end{array}$ & Fluoride & $\begin{array}{r}\text { Nitrate } \\
\left(\mathrm{NO}_{3}\right)\end{array}$ & $\begin{array}{l}\text { Dissolved } \\
\text { solids }\end{array}$ & $\begin{array}{c}\text { Total } \\
\text { hardness } \\
\text { as } \\
\mathrm{CaCO}\end{array}$ \\
\hline $\begin{array}{ll} & 1940 \\
\text { Mar. } & 1-10 \\
\text { Mar. } & 11-20\end{array}$ & $\begin{array}{l}488 \\
764\end{array}$ & $\begin{array}{l}45 \\
45\end{array}$ & $\begin{array}{l}35.2 \\
32.8\end{array}$ & $\begin{array}{l}8.7 \\
6.7\end{array}$ & $\begin{array}{r}0.03 \\
.04\end{array} \mid$ & $\begin{array}{l}36 \\
35\end{array}$ & $\begin{array}{l}9.2 \\
8.4\end{array}$ & $\begin{array}{l}25 \\
22\end{array}$ & $\begin{array}{l}1.8 \\
1.8\end{array}$ & $\begin{array}{l}128 \\
121\end{array}$ & $\begin{array}{l}27 \\
23\end{array}$ & $\begin{array}{l}36 \\
34\end{array}$ & $\begin{array}{r}0.2 \\
.4\end{array}$ & 0.1 & $\begin{array}{l}227 \\
211\end{array}$ & $\begin{array}{l}128 \\
122\end{array}$ \\
\hline $\begin{array}{lr}\text { Mar. } & 21-31 \\
& 24-31 \\
\text { Apr. } & 1-10 \\
\text { Apr. } & 11-20 \\
\text { Apr. } & 21-30\end{array}$ & $\begin{array}{l}1,406 \\
3,554 \\
4,007 \\
3,618\end{array}$ & $\begin{array}{l}45 \\
50 \\
50 \\
45\end{array}$ & $\begin{array}{l}34.1 \\
36.0 \\
35.0 \\
36.0\end{array}$ & \begin{tabular}{c|}
8.2 \\
11 \\
9.0 \\
8.6
\end{tabular} & $\begin{array}{l}.08 \\
.05 \\
.05 \\
.05\end{array}$ & $\begin{array}{l}35 \\
39 \\
39 \\
40\end{array}$ & $\begin{array}{l}8.9 \\
9.3 \\
9.0 \\
9.1\end{array}$ & $\begin{array}{l}24 \\
24 \\
23 \\
24\end{array}$ & $\begin{array}{l}1.6 \\
1.9 \\
2.3 \\
1.9\end{array}$ & $\begin{array}{l}123 \\
132 \\
132 \\
134\end{array}$ & \begin{tabular}{l|}
25 \\
23 \\
22 \\
23
\end{tabular} & $\begin{array}{l}35 \\
35 \\
32 \\
33\end{array}$ & $\begin{array}{l}.2 \\
.2 \\
.2 \\
.2\end{array}$ & $\begin{array}{l}.1 \\
.6 \\
.6 \\
.6\end{array}$ & $\begin{array}{l}220 \\
226 \\
220 \\
225\end{array}$ & $\begin{array}{l}124 \\
136 \\
134 \\
137\end{array}$ \\
\hline $\begin{array}{lr}\text { May } & 1-3, \\
& 5-10 \\
\text { May } & 11-20 \\
\text { May } & 21-31 \\
\text { June } & 1-10 \\
\text { June } & 11-20 \\
\text { June } & 21-28\end{array}$ & $\begin{array}{r}3,263 \\
595 \\
62 \\
422 \\
2,206\end{array}$ & $\begin{array}{l}45 \\
45 \\
45 \\
45 \\
50\end{array}$ & $\begin{array}{l}36.3 \\
34.9 \\
36.6 \\
35.5 \\
33.7\end{array}$ & $\begin{array}{l}9.0 \\
8.1 \\
7.9 \\
9.9 \\
9.8\end{array}$ & $\begin{array}{l}.04 \\
.08 \\
.06 \\
.05 \\
.07\end{array}$ & $\begin{array}{l}40 \\
39 \\
40 \\
38 \\
36\end{array}$ & $\begin{array}{l}9.3 \\
9.1 \\
9.5 \\
9.1 \\
8.6\end{array}$ & $\begin{array}{l}25 \\
23 \\
25 \\
24 \\
23\end{array}$ & $\begin{array}{l}2.1 \\
1.7 \\
1.8 \\
1.7 \\
1.8\end{array}$ & $\begin{array}{l}132 \\
132 \\
132 \\
128 \\
119\end{array}$ & $\begin{array}{l}24 \\
23 \\
24 \\
24 \\
22\end{array}$ & $\begin{array}{l}35 \\
35 \\
35 \\
35 \\
33\end{array}$ & $\begin{array}{l}.2 \\
.2 \\
.4 \\
.2 \\
.2\end{array}$ & $\begin{array}{l}.6 \\
.6 \\
.6 \\
.6 \\
.5\end{array}$ & $\begin{array}{l}230 \\
225 \\
230 \\
227 \\
215\end{array}$ & $\begin{array}{l}138 \\
135 \\
139 \\
132 \\
125\end{array}$ \\
\hline 30 & 2,534 & 45 & 35.9 & 8.6 & .05 & 38 & 9.2 & 24 & 1.9 & 125 & 25 & 36 & .4 & .3 & 229 & 133 \\
\hline $\begin{array}{rr}\text { July } & 1-10 \\
\text { July } & 11-13\end{array}$ & 1,411 & 45 & 35.2 & 8.0 & .05 & 38 & 9.0 & 24 & 1.6 & 125 & 24 & 35 & .4 & .4 & 224 & 192 \\
\hline $\begin{array}{lr}\text { July } & 15-20 \\
\text { Autg. } & 1-10 \\
\text { Aug. } & 11-20 \\
\text { Aug. } & 21-31\end{array}$ & $\begin{array}{r}131 \\
293 \\
402 \\
441 \\
50\end{array}$ & $\begin{array}{l}45 \\
50 \\
45 \\
45 \\
50\end{array}$ & $\begin{array}{l}35.9 \\
35.4 \\
35.1 \\
34.4 \\
31.7\end{array}$ & $\begin{array}{c}8.2 \\
8.5 \\
14 \\
7.6 \\
4.9\end{array}$ & $\begin{array}{l}.10 \\
.08 \\
.06 \\
.08 \\
.08\end{array}$ & $\begin{array}{l}39 \\
38 \\
38 \\
37 \\
34\end{array}$ & $\begin{array}{l}9.2 \\
9.0 \\
8.9 \\
8.6 \\
7.9\end{array}$ & $\begin{array}{l}24 \\
24 \\
25 \\
24 \\
22\end{array}$ & $\begin{array}{l}2.1 \\
1.9 \\
2.1 \\
1.9 \\
2.0\end{array}$ & $\begin{array}{l}128 \\
125 \\
126 \\
122 \\
111\end{array}$ & $\begin{array}{l}26 \\
24 \\
24 \\
24 \\
23\end{array}$ & $\begin{array}{l}36 \\
36 \\
35 \\
34 \\
31\end{array}$ & $\begin{array}{l}.2 \\
.2 \\
.2 \\
.4 \\
.1\end{array}$ & $\begin{array}{l}.5 \\
.6 \\
.6 \\
.4 \\
.3\end{array}$ & $\begin{array}{l}227 \\
226 \\
229 \\
217 \\
201\end{array}$ & $\begin{array}{l}135 \\
132 \\
131 \\
128 \\
117\end{array}$ \\
\hline $\begin{array}{lr}\text { Sept. } & 1-10 \\
\text { Sept. } & 11-18 \\
\text { Sept. } & 21-30 \\
\text { Oct. } & 1-10 \\
\text { Oct. } & 11-20 \\
\text { Oct. } & 21-31\end{array}$ & $\begin{array}{l}1,523 \\
3,438 \\
3,502 \\
3,858 \\
3,731 \\
1,865\end{array}$ & $\begin{array}{l}55 \\
70 \\
70 \\
45 \\
40 \\
35\end{array}$ & $\begin{array}{l}36.4 \\
42.5 \\
46.7 \\
41.3 \\
38.2 \\
37.3\end{array}$ & \begin{tabular}{|c|}
7.2 \\
10 \\
12 \\
9.6 \\
9.1 \\
8.1
\end{tabular} & $\begin{array}{l}.05 \\
.08 \\
.05 \\
.05 \\
.06 \\
.02\end{array}$ & $\begin{array}{l}36 \\
41 \\
44 \\
42 \\
41 \\
40\end{array}$ & $\begin{array}{l}9.1 \\
11 \\
13 \\
11 \\
9.6 \\
9.7\end{array}$ & $\begin{array}{l}24 \\
30 \\
34 \\
26 \\
24 \\
25\end{array}$ & $\begin{array}{l}1.6 \\
2.0 \\
1.9 \\
2.1 \\
2.1 \\
1.2\end{array}$ & $\begin{array}{l}126 \\
146 \\
160 \\
146 \\
142 \\
137\end{array}$ & $\begin{array}{l}24 \\
30 \\
34 \\
29 \\
26 \\
24\end{array}$ & $\begin{array}{l}36 \\
45 \\
49 \\
42 \\
37 \\
35\end{array}$ & $\begin{array}{l}.3 \\
.4 \\
.4 \\
.2 \\
.3 \\
.1\end{array}$ & $\begin{array}{l}.4 \\
.6 \\
.6 \\
.2 \\
.3 \\
.6\end{array}$ & $\begin{array}{l}219 \\
270 \\
297 \\
257 \\
236 \\
231\end{array}$ & $\begin{array}{l}127 \\
148 \\
163 \\
150 \\
142 \\
140\end{array}$ \\
\hline $\begin{array}{lr}\text { Nov. } & 1-10 \\
\text { Nov. } & 11-16 \\
\text { Nov. } & 26-30 \\
\text { Dec. } & 1-10\end{array}$ & $\begin{array}{r}1,258 \\
275 \\
498 \\
1,178\end{array}$ & $\begin{array}{l}35 \\
35 \\
35 \\
40\end{array}$ & $\begin{array}{l}38.8 \\
38.6 \\
38.2 \\
38.6\end{array}$ & $\begin{array}{l}8.0 \\
.9 .4 \\
6.2 \\
6.2\end{array}$ & $\begin{array}{l}.01 \\
.01 \\
.05 \\
.03\end{array}$ & $\begin{array}{l}41 \\
41 \\
40 \\
40\end{array}$ & $\begin{array}{c}10 \\
10 \\
9.7 \\
10\end{array}$ & $\begin{array}{l}25 \\
25 \\
25 \\
25\end{array}$ & $\begin{array}{l}1.0 \\
1.1 \\
1.4 \\
1.0\end{array}$ & $\begin{array}{l}142 \\
142 \\
137 \\
139\end{array}$ & $\begin{array}{l}24 \\
24 \\
24 \\
26\end{array}$ & $\begin{array}{l}36 \\
35 \\
36 \\
35\end{array}$ & $\begin{array}{l}.1 \\
.1 \\
.2\end{array}$ & $\begin{array}{r}.7 \\
.6 \\
1.0 \\
.9\end{array}$ & $\begin{array}{l}239 \\
241 \\
238 \\
243\end{array}$ & $\begin{array}{l}143 \\
143 \\
140 \\
141\end{array}$ \\
\hline
\end{tabular}




\begin{tabular}{|c|c|c|}
\hline $\begin{array}{l}\text { Dec. } 11-17 \\
\text { Dec. } 23-31\end{array}$ & $\begin{array}{r}528 \\
59\end{array}$ & $\begin{array}{l}40 \\
45\end{array}$ \\
\hline \begin{tabular}{lr}
\multicolumn{2}{c}{1941} \\
Jan. & $1-10$ \\
Jan. & $11-20$ \\
Jan. & $21-31$ \\
Feb. & $1-10$ \\
Feb. & $11-19$ \\
Feb. & $20-28$
\end{tabular} & $\begin{array}{r}303 \\
233 \\
1,909 \\
3,157 \\
2,788 \\
2,718\end{array}$ & $\begin{array}{l}45 \\
45 \\
70 \\
55 \\
55 \\
50\end{array}$ \\
\hline Average & 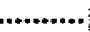 & 47 \\
\hline \begin{tabular}{l}
\multicolumn{2}{c}{1941} \\
Mar. $1-10$ \\
Mar. $11-20$ \\
Mar. $21-31$ \\
Apr. $1-10$ \\
Apr. $11-20$ \\
Apr: $21-30$
\end{tabular} & $\begin{array}{r}2,620 \\
2,476 \\
665 \\
652 \\
3,311 \\
3,404\end{array}$ & $\begin{array}{r}65 \\
100 \\
90 \\
75 \\
90 \\
130\end{array}$ \\
\hline $\begin{array}{lr}\text { May } & 1-10 \\
\text { May } & 11-20 \\
\text { May } & 21-31 \\
\text { June } & 1-10 \\
\text { June } & 11-20 \\
\text { Jume } & 21-30\end{array}$ & $\begin{array}{r}3,427 \\
3,357 \\
3,025 \\
186 \\
36 \\
77\end{array}$ & $\begin{array}{l}50 \\
50 \\
80 \\
90 \\
60 \\
60\end{array}$ \\
\hline $\begin{array}{lr}\text { July } & 1-10 \\
\text { Jaly } & 11-20 \\
\text { July } & 21-31 \\
\text { Autg. } & 1-10 \\
\text { Aug. } & 11-20 \\
\text { Aug. } & 21-31\end{array}$ & $\begin{array}{r}410 \\
1,435 \\
3,309 \\
3,631 \\
3,569 \\
3,495\end{array}$ & $\begin{array}{l}45 \\
45 \\
60 \\
80 \\
60 \\
70\end{array}$ \\
\hline $\begin{array}{lr}\text { Sept. } & 1-10 \\
\text { Sept. } & 11-20 \\
\text { Sept. } & 21-30 \\
\text { Oct. } & 1-10 \\
\text { Oct. } & 11-20 \\
\text { Oct. } & 22-31\end{array}$ & $\begin{array}{l}3,345 \\
1,470 \\
3,483 \\
2,695 \\
1,449 \\
3,383\end{array}$ & $\begin{array}{r}65 \\
60 \\
70 \\
100 \\
70 \\
65\end{array}$ \\
\hline $\begin{array}{l}\text { Nov. } \quad 1-7 \\
\text { Nov. } 8-20\end{array}$ & $\begin{array}{l}3,884 \\
3,482\end{array}$ & $\begin{array}{r}100 \\
90\end{array}$ \\
\hline
\end{tabular}

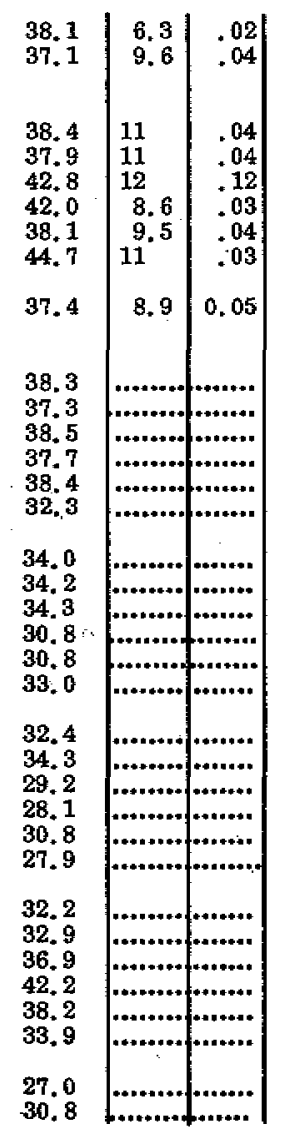

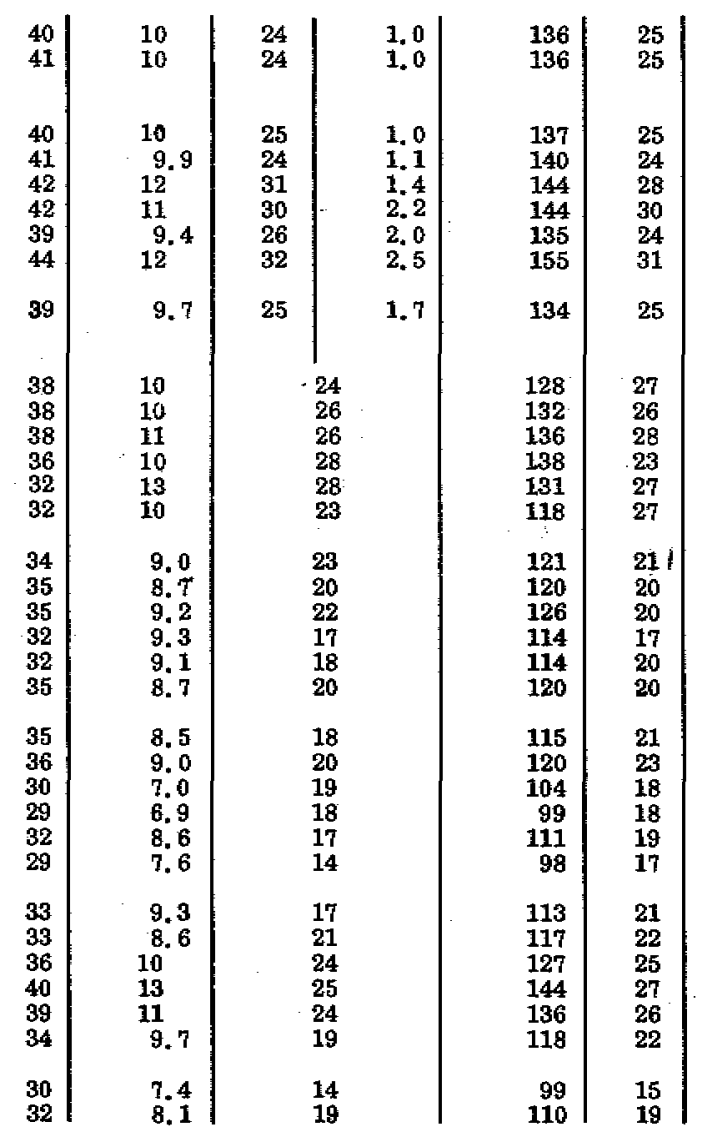

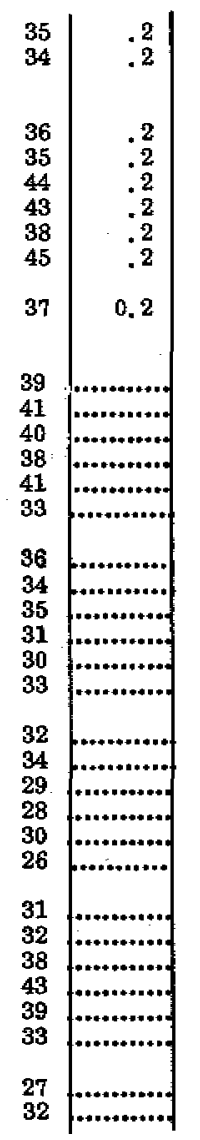

\begin{tabular}{|c|c|}
\hline $\begin{array}{r}.6 \\
.8\end{array}$ & $\begin{array}{l}232 \\
237\end{array}$ \\
\hline $\begin{array}{l}1.0 \\
1.2 \\
2.2 \\
1.0 \\
1.1 \\
2.1\end{array}$ & $\begin{array}{l}243 \\
244 \\
278 \\
263 \\
239 \\
282\end{array}$ \\
\hline 0.7 & 236 \\
\hline $\begin{array}{r}.6 \\
.6 \\
.6 \\
2.0 \\
.6 \\
.7\end{array}$ & $\begin{array}{l}202 \\
207 \\
211 \\
205 \\
206 \\
184\end{array}$ \\
\hline $\begin{array}{r}.3 \\
.3 \\
.3 \\
.3\end{array}$ & $\begin{array}{l}184 \\
177 \\
184 \\
163 \\
166 \\
176\end{array}$ \\
\hline & $\begin{array}{l}172 \\
182 \\
154 \\
149 \\
162 \\
142\end{array}$ \\
\hline $\begin{array}{r}.0 \\
1.0 \\
.2\end{array}$ & $\begin{array}{l}167 \\
174 \\
196 \\
220 \\
206 \\
176\end{array}$ \\
\hline 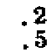 & $\begin{array}{l}142 \\
165\end{array}$ \\
\hline
\end{tabular}

141
143

141

143

154

150

137

136

136

140

131

121

122

123

125

117

123

122

104

102

115

104

121

118

131

153
143

125

105 
Table 84.-Anal yses, in parts per million, of water front St. Lucie Canal at lock 1, Lake Okeechobee-Continued

\begin{tabular}{|c|c|c|c|c|c|c|c|c|c|c|c|c|c|c|c|c|}
\hline $\begin{array}{c}\begin{array}{c}\text { Date } \\
\text { of } \\
\text { collection }\end{array} \\
\end{array}$ & $\begin{array}{c}\text { Mean } \\
\text { discharge } \\
\text { (cfs) }\end{array}$ & Color & $\begin{array}{c}\text { Specific } \\
\text { conductance } \\
\left(\mathrm{K} \times 10^{5}\right. \\
\text { at } 25 \mathrm{C}) \\
\end{array}$ & $\begin{array}{l}\text { Silica } \\
\left(\mathrm{SiO}_{2}\right)\end{array}$ & $\begin{array}{l}\text { Iron } \\
(\mathrm{Fe})\end{array}$ & $\begin{array}{c}\text { Calciumi } \\
\text { (Ca) }\end{array}$ & $\begin{array}{l}\text { Magnesium } \\
\text { (Mg) }\end{array}$ & $\begin{array}{l}\text { Sodium } \\
\text { (Na) }\end{array}$ & $\begin{array}{c}\text { Potassi um } \\
\text { (K) }\end{array}$ & $\begin{array}{c}\text { Bicarbonate } \\
\left(\mathrm{HCO}_{3}\right)\end{array}$ & $\begin{array}{l}\text { Sulfate } \\
\left(\mathrm{SO}_{4}\right)\end{array}$ & $\begin{array}{l}\text { Chloride } \\
\text { (CI) }\end{array}$ & $\begin{array}{l}\text { Fluoride } \\
\text { (F) }\end{array}$ & $\begin{array}{l}\text { Nitrate } \\
\left(\mathrm{NO}_{3}\right)\end{array}$ & $\begin{array}{l}\text { Dissolved } \\
\text { solids }\end{array}$ & $\begin{array}{c}\begin{array}{c}\text { Total } \\
\text { hardness } \\
\text { as } \\
\mathrm{CaCO}_{3}\end{array} \\
\end{array}$ \\
\hline 1941 & 559 & 100 & 353 & & & 36 & 8.8 & & 25. & 12. & & & & & & \\
\hline Dec. $1-10$ & 824 & 70 & 36.5 & a......... & .............. & 38 & $11^{8.0}$ & & 21 & $\begin{array}{l}120 \\
130\end{array}$ & $\begin{array}{l}24 \\
26\end{array}$ & $\begin{array}{l}36 \\
37\end{array}$ & 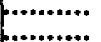 & $\begin{array}{r}0.5 \\
.4\end{array}$ & $\begin{array}{l}192 \\
197\end{array}$ & $\begin{array}{l}126 \\
140\end{array}$ \\
\hline Dec. $11-20$ & 464 & 70 & 37.4 & ..... & ......... & 38 & 11 & & 23 & 133 & 28 & $3 T$ & & .4 & 203 & 140 \\
\hline Dec. $21-31$ & 732 & 70 & 36.6 & ........... & $\ldots \ldots$ & 38 & 11 & & 22 & 130 & 27 & 37 & $\ldots \ldots+\ldots$ & .4 & 199 & 140 \\
\hline 1942 & & & & & & & & & & & & & & & & \\
\hline Jan. $\quad 1-10$ & 386 & 70 & 33.2 & |..+, & |....... & 35 & 9.2 & & 24 & 123 & 25 & 35 & ........ & .4 & 189 & 125 \\
\hline fan. $11-20$ & 573 & 90 & 36.5 & ......... & ....... & 38 & 12 & & 20 & 133 & 26 & 37 & ................. & .4 & 199 & 144 \\
\hline Jan. 21-31 & 311 & 60 & 34.5 & ......... & ........ & 35 & 9.4 & & 23 & 124 & 26 & 33 & ................. & .3 & 188 & 126 \\
\hline Feb, $\quad 1-9$ & 1,723 & 70 & 34.2 & ......... & ........ & 36 & 8.7 & & 23 & 124 & 26 & 33 & ................ & .3 & 188 & 126 \\
\hline Feb. $\quad 10-20$ & 600 & 70 & 33.8 & ............. & $\ldots . . . .$. & 34 & 9.2 & & 22 & 122 & 23 & 33 & .................... & .2 & 182 & 123 \\
\hline Feb. $21-28$ & 997 & 70 & 32.8 & ......... & ......... & 33 & 9.1 & & 24 & 124 & 22 & 33 & F................ & 1 & 182 & 120 \\
\hline Average & c............... & 74 & 34.1 & ......... & ........... & 35 & 9.5 & & 21 & 122 & 23 & 34 & $\ldots$ & 0.4 & 183 & 126 \\
\hline
\end{tabular}

깅 


\section{Caloosahatchee canat}

Analyses of daily samples collected from the Caloosahatchee Canal at Moore Haven show that the water discharging from Lake Okeechobee at this point is variable in composition (see table 85). At times, the concentration of dissolved matter is similar to that in the main body of the lake, while at other times the concentration drops until it is little more than that found in the main tributary streams. Investigation showed that water discharging through the locks at Moore Haven does not come directly from Lake Okeechobee, instead, it comes from the deep floodway channel just inside the levee to the northwest and southeast of Moore Haven. Directly in front of the canal entrance is a dense growth of saw grass, covering several square miles, which effectively prevents discharge direct from the lake. A series of samples was collected from the floodway channel on October 27, 1941. Analyses of these samples (see table 86) show that the concentration of dissolved matter was progressively smaller north of Moore Haven and that it approached the low concentration found in the water in Fisheating Bay. They show also that samples collected from the channel southeast of Moore Haven contained about as much dissolved matter as is normally found in the main body of the lake.

It appears, therefore, that the water discharged from Lake Okeechobee into the Caloosahatchee Canal is composed of water from the lake, flowing through the floodway channel from the southeast, and of water from Fisheating Creek, flowing through the channel from the north, without mixing to an appreciable extent with water in the main body of the lake. Variations in the composition of the canal water are caused by changes in lake stage, direction of the wind, the amount of water discharging from Fisheating Creek, and, to some extent, the operation of the locks.

The ranges in concentration of dissolved mineral matter in samples collected from the Caloosahatchee and St. Lucie Canals are shown graphically in figure 216 . 
Table 85. - Analyses, in parts per million, of water from Caloosahatchee Canal at Moore Haven

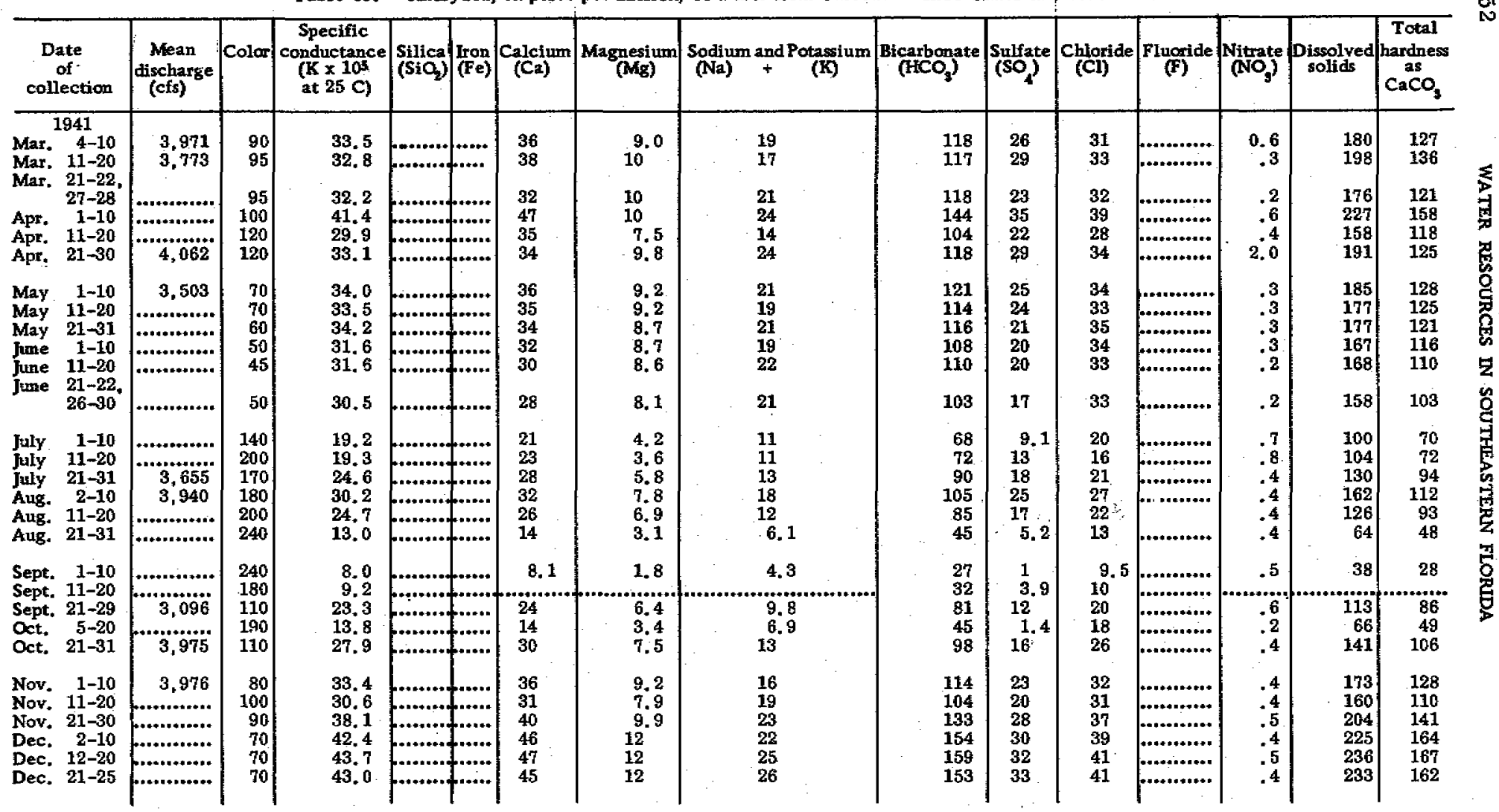




\begin{tabular}{|c|c|c|c|c|c|c|c|c|c|c|c|c|c|c|}
\hline 1942 & & & & & & & & & & & & & & \\
\hline $\begin{array}{r}7-10 \\
\text { Jan. }\end{array}$ & (n............. & $\begin{array}{l}70 \\
60\end{array}$ & $\begin{array}{l}39.7 \\
38.9\end{array}$ & $f \cdot \ldots$ & $\begin{array}{l}41 \\
38\end{array}$ & 13 & 20 & 143 & $\begin{array}{l}30 \\
25\end{array}$ & 36 & ............... & .4 & 211 & 156 \\
\hline Jan. $22-31$ & [n............. & 90 & 32.4 & 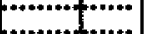 & 30 & 7,6 & 25 & 114 & 19 & 34 & 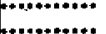 & .49 & 172 & 106 \\
\hline $1-10$ & .............. & 110 & 26.6 & [......... T.t... & 26 & 6.1 & 18 & 88 & 16 & 29 & [.............. & .1 & 138 & 90 \\
\hline Feb. $11-20$ & (..................... & 90 & 27.4 & 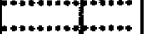 & 28 & 7.1 & 18 & 97 & 15 & 30 & ............. & 1 & 146 & 99 \\
\hline Feb. $21-27$ & ................. & 60 & 32.6 & ............... & 33 & 8.2 & 23 & 128 & 15 & 33 & .................... & .1 & 175 & 116 \\
\hline Average & ................... & 111 & 29.7 & $\ldots$ & 32 & 8.0 & 18 & 107 & 20 & 30 & . & 0.4 & 161 & 113 \\
\hline
\end{tabular}


Table 86. - Analyses of watet from Lake Okeechooee floodway channel near Moore Haven, October 27, 1941

[Constituents in parts per millions]

\begin{tabular}{|c|c|c|c|c|c|c|c|c|}
\hline Station & $\begin{array}{l}\text { Dista } \\
\text { of sourc } \\
\text { Moore F } \\
\text { (mile }\end{array}$ & $\begin{array}{l}\text { ace } \\
\text { e from } \\
\text { aven1 } \\
\text { s) }\end{array}$ & Sample & Color & $\begin{array}{c}\text { Specific } \\
\text { conductance } \\
\left(K \times 10^{5}\right. \\
\text { at } 25 \mathrm{C})\end{array}$ & $\begin{array}{c}\text { Bicarbonate } \\
\left(\mathrm{HCO}_{\mathrm{s}}\right)\end{array}$ & $\begin{array}{l}\text { Sulfate } \\
\left(\mathrm{SO}_{4}\right)\end{array}$ & $\begin{array}{l}\text { Chloride } \\
\text { (CI) }\end{array}$ \\
\hline 1 & 0 & & Composite & 100 & 28.6 & 98 & 15 & 29 \\
\hline 2 & 2 & NW. & $\begin{array}{l}\text { Surface } \\
\text { Bottom }\end{array}$ & $\begin{array}{l}140 \\
140\end{array}$ & $\begin{array}{l}17.0 \\
17.8\end{array}$ & $\begin{array}{l}50 \\
56\end{array}$ & $\begin{array}{l}10 \\
10\end{array}$ & $\begin{array}{l}20 \\
20\end{array}$ \\
\hline 3 & 4 & Nw. & $\begin{array}{l}\text { Surface } \\
\text { Bottom }\end{array}$ & $\begin{array}{l}140 \\
140\end{array}$ & $\begin{array}{l}16.6 \\
16.8\end{array}$ & $\begin{array}{l}49 \\
49\end{array}$ & $\begin{array}{r}10 . \\
9\end{array}$ & $\begin{array}{l}21 \\
20\end{array}$ \\
\hline 4 & 5.5 & NW. & $\begin{array}{l}\text { Surface } \\
\text { Bottom }\end{array}$ & $\begin{array}{l}150 \\
160\end{array}$ & $\begin{array}{l}16.7 \\
16.8\end{array}$ & $\begin{array}{l}49 \\
49\end{array}$ & $\begin{array}{l}10 \\
12\end{array}$ & $\begin{array}{l}20 \\
20\end{array}$ \\
\hline 5 & 7.5 & NW. & $\begin{array}{l}\text { Surface } \\
\text { Bottom }\end{array}$ & $\begin{array}{l}160 \\
160\end{array}$ & $\begin{array}{l}15.3 \\
17.6\end{array}$ & $\begin{array}{l}42 \\
50\end{array}$ & $\begin{array}{l}10 \\
11\end{array}$ & $\begin{array}{l}20 \\
21\end{array}$ \\
\hline 6 & 9 & NW. & $\begin{array}{l}\text { Surface } \\
\text { Bottom }\end{array}$ & $\begin{array}{l}120 \\
130\end{array}$ & $\begin{array}{l}22.7 \\
20.4\end{array}$ & $\begin{array}{l}71 \\
61\end{array}$ & $\begin{array}{l}14 \\
12\end{array}$ & $\begin{array}{l}25 \\
23\end{array}$ \\
\hline 7 & & NW. & $\begin{array}{l}\text { Surface } \\
\text { Bottom }\end{array}$ & $\begin{array}{r}95 \\
100\end{array}$ & $\begin{array}{l}25.5 \\
25.1\end{array}$ & $\begin{array}{l}84 \\
82\end{array}$ & $\begin{array}{l}14 \\
14\end{array}$ & $\begin{array}{l}27 \\
27\end{array}$ \\
\hline $2_{8}$ & & NW. & Composite & 240 & 6.2 & 10 & 1 & 13 \\
\hline 9 & 2 & SE. & $\begin{array}{l}\text { Surface } \\
\text { Bottom }\end{array}$ & $\begin{array}{l}70 \\
70\end{array}$ & $\begin{array}{l}38,5 \\
38,6\end{array}$ & $\begin{array}{l}140 \\
140\end{array}$ & $\begin{array}{l}27 \\
26\end{array}$ & $\begin{array}{l}35 \\
35\end{array}$ \\
\hline 10 & 4.5 & SE. & $\begin{array}{l}\text { Surface } \\
\text { Bottom }\end{array}$ & $\begin{array}{l}75 \\
80\end{array}$ & $\begin{array}{l}43.4 \\
45.3\end{array}$ & $\begin{array}{l}153 \\
163\end{array}$ & $\begin{array}{l}34 \\
38\end{array}$ & $\begin{array}{l}39 \\
39\end{array}$ \\
\hline
\end{tabular}

1 Distance measured along floodway channel.

${ }^{2}$ Near mouth of Fisheating Creek. 


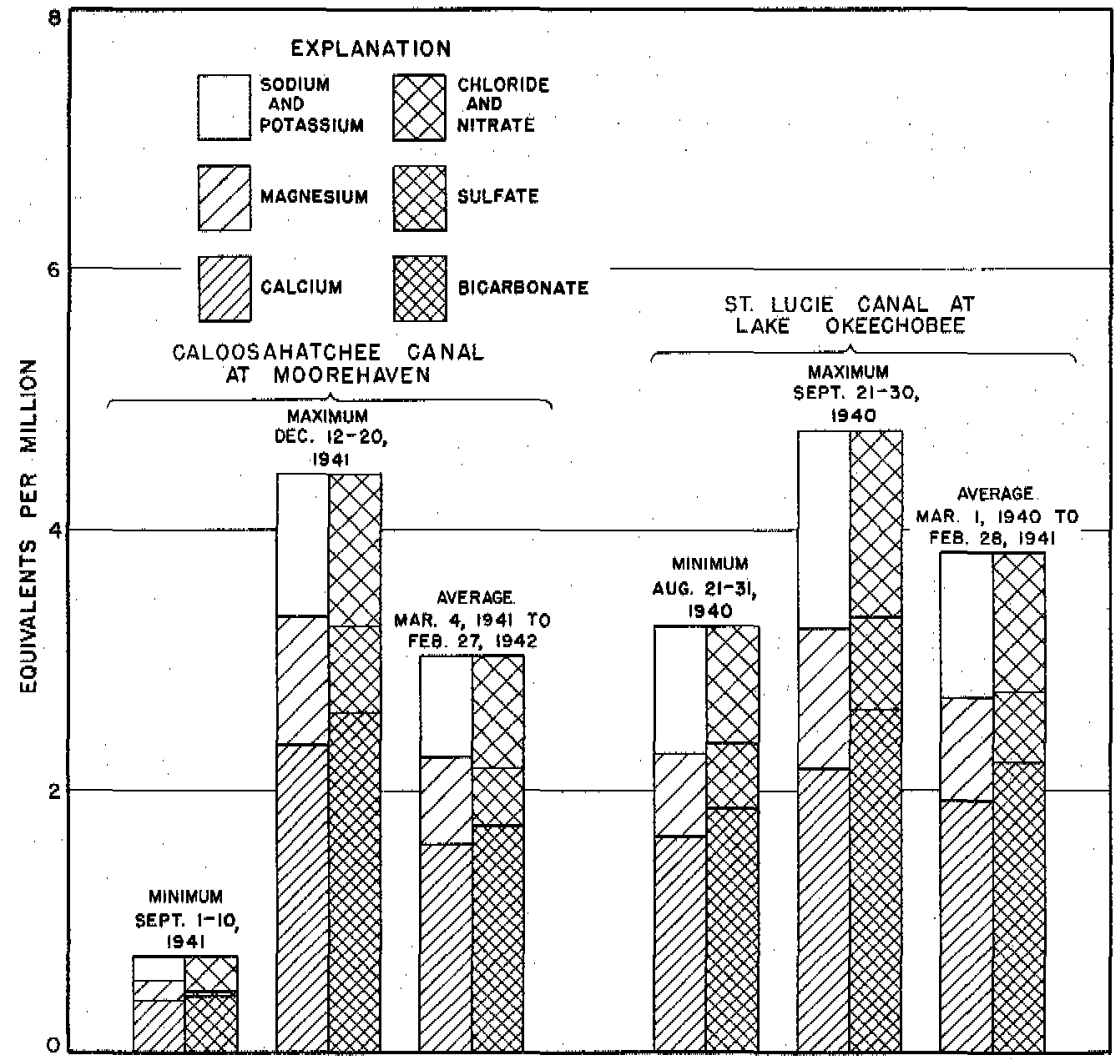

Figure 216. Graph showing analyses of waters from Caloosahatchee and St. Lucie Canals.

\section{MAJOR EVERGLADES DRAINAGE CANALS}

\section{WEST PALM BEACII CANAL}

Samples were collected from West Palm Beach Canal at irregular intervals except for those collected monthly at the gaging station at West Palm Beach beginning in March 1941 (table 87).

The composition of water in the West Palm Beach Canal varies over a rather wide range, depending on the amount of rainfall in the area, the operation of large drainage pumps, and the pointat which the samples are taken. Two series of samples were collected from the canal at points about 5 miles apart between Canal Point and West Palm Beach (see table 88). In the series collected on July 31,1940 , the hardness ranged from 124 , to $471 \mathrm{ppm}$, and in the series collected on March 14, 1941, the hardness ranged from 158 to $281 \mathrm{ppm}$. The composition of the water at Canal Point was essentially the same as that of Lake Okeechobee, but at points 5 to 20 miles southeast of Canal Point the concentration of dissolved 
Table 87.-Analyses; in parts per million, of water from West Palm Beach Canal at West Palm Deach

\begin{tabular}{|c|c|c|c|c|c|c|c|c|c|c|c|}
\hline $\begin{array}{c}\text { Date } \\
\text { of } \\
\text { collec- } \\
\text { tion }\end{array}$ & Color & \begin{tabular}{|c|} 
Specific \\
conduct- \\
ance \\
$\left(\mathrm{K} \times 10^{5}\right.$ \\
at $25 \mathrm{C})$
\end{tabular} & $\begin{array}{l}\text { Cal- } \\
\text { cium } \\
\text { (Ca) }\end{array}$ & $\begin{array}{l}\text { Magne- } \\
\text { sium } \\
(\mathrm{Mg})\end{array}$ & $\begin{array}{c}\text { Sodium } \\
\text { and po- } \\
\text { tassium } \\
(\mathrm{Na}+\mathrm{K})\end{array} \mid$ & $\begin{array}{l}\text { Bicar- } \\
\text { bonate } \\
\left(\mathrm{HCO}_{3}\right)\end{array}$ & $\begin{array}{l}\text { Sul- } \\
\text { fate } \\
\left(\mathrm{SO}_{4}\right)\end{array}$ & $\begin{array}{l}\text { Chlo- } \\
\text { ride } \\
\text { (Cl) }\end{array}$ & $\begin{array}{l}\mathrm{Ni}- \\
\text { trate } \\
\left(\mathrm{NO}_{3}\right)\end{array}$ & $\begin{array}{l}\text { Dis- } \\
\text { solved } \\
\text { solids }\end{array}$ & $\begin{array}{l}\text { Total } \\
\text { hard* } \\
\text { ness } \\
\text { as } \\
\mathrm{CaCO}_{3}\end{array}$ \\
\hline \begin{tabular}{lr}
\multicolumn{2}{c}{1941} \\
Aar. & 14 \\
pr. & 2 \\
apr. & 23 \\
hay. & 21 \\
uly & 17 \\
ugg. & 21 \\
ept. & 19 \\
Det. & 23 \\
Jov. & 26 \\
bec. & 26
\end{tabular} & $\begin{array}{l}220 \\
140 \\
170 \\
190 \\
220 \\
280 \\
280 \\
160 \\
130 \\
130\end{array}$ & $\begin{array}{l}75.0 \\
89.1 \\
75.8 \\
87.2 \\
17.4 \\
41.3 \\
42.6 \\
24.1 \\
67.9 \\
86.4\end{array}$ & $\begin{array}{l}54 \\
67 \\
60 \\
65 \\
20 \\
40 \\
36 \\
27 \\
51 \\
57\end{array}$ & $\begin{array}{c}19 \\
25 \\
20 \\
25 \\
2,5 \\
11 \\
9.4 \\
5.8 \\
13 \\
18\end{array}$ & $\begin{array}{l}75 \\
90 \\
76 \\
84 \\
13 \\
30 \\
36 \\
14 \\
72 \\
98\end{array}$ & $\begin{array}{r}224 \\
259 \\
230 \\
258 \\
73 \\
144 \\
137 \\
102 \\
196 \\
233\end{array}$ & $\begin{array}{l}42 \\
69 \\
53 \\
56 \\
6.2 \\
20 \\
16 \\
7.0 \\
32 \\
42\end{array}$ & $\begin{array}{r}105 \\
127 \\
107 \\
125 \\
16 \\
50 \\
54 \\
22 \\
101 \\
138\end{array}$ & $\begin{array}{r}4.0 \\
2.0 \\
2.0 \\
.0 \\
.4 \\
3.1 \\
2.0 \\
1.2\end{array}$ & $\begin{array}{r}405 \\
510 \\
431 \\
484 \\
94 \\
222 \\
222 \\
76 \\
400 \\
469\end{array}$ & $\begin{array}{r}213 \\
270 \\
232 \\
265 \\
60 \\
145 \\
128 \\
91 \\
181 \\
216\end{array}$ \\
\hline 1942 & & & & & & & & & & & \\
\hline $\begin{array}{lr}\text { Jan. } & 22 \\
\text { Feb. } & 19 \\
\text { Apr. } & 8 \\
\text { May } & 7 \\
\text { June } & 4 \\
\text { July } & 9 \\
\text { Aug. } & 7 \\
\text { Sept. } & 3 \\
\text { Oct. } & 8 \\
\text { Nov. } & 11 \\
\text { Dec. } & 10\end{array}$ & $\begin{array}{r}110 \\
130 \\
180 \\
180 \\
140 \\
240 \\
280 \\
200 \\
80 \\
150 \\
65\end{array}$ & $\begin{array}{r}71.4 \\
70.6 \\
77.1 \\
67.3 \\
18.0 \\
23.7 \\
79.1 \\
71.0 \\
79.9 \\
101 \\
91.3\end{array}$ & $\begin{array}{l}57 \\
54 \\
58 \\
51 \\
19 \\
22 \\
58 \\
57 \\
55 \\
67 \\
56\end{array}$ & $\begin{array}{l}17 \\
17 \\
18 \\
15 \\
3.6 \\
4.6 \\
20 \\
18 \\
18 \\
25 \\
19\end{array}$ & $\begin{array}{r}72 \\
73 \\
80 \\
69 \\
15 \\
19 \\
76 \\
60 \\
84 \\
103 \\
105\end{array}$ & $\begin{array}{r}230 \\
221 \\
230 \\
200 \\
61 \\
94 \\
245 \\
207 \\
212 \\
252 \\
214\end{array}$ & $\begin{array}{l}34 \\
36 \\
49 \\
30 \\
14 \\
5.8 \\
34 \\
31 \\
47 \\
67 \\
50\end{array}$ & $\begin{array}{r}103 \\
103 \\
108 \\
101 \\
22 \\
22 \\
110 \\
101 \\
121 \\
153 \\
154\end{array}$ & $\begin{array}{r}.4 \\
.5 \\
1.0 \\
.4 \\
.2 \\
.1 \\
.4 \\
1.2 \\
1.2 \\
1.6 \\
2.2\end{array}$ & $\begin{array}{l}392 \\
392 \\
427 \\
366 \\
104\end{array}$ & $\begin{array}{r}212 \\
205 \\
218 \\
189 \\
62 \\
74 \\
226 \\
216 \\
212 \\
270 \\
218\end{array}$ \\
\hline 194 & & & & & & & & & & & \\
\hline $\begin{array}{lr}\text { Jan. } & 7 \\
\text { Feb. } & 4 \\
\text { Mar. } & 4 \\
\text { Apr. } & 1 \\
\text { May } & 5 \\
\text { June } & 2 \\
\text { July } & 7 \\
\text { Aug. } & 5 \\
\text { Sept. } & 2 \\
\text { Oct. } & 7 \\
\text { Nov. } & 2 \\
\text { Nov. } & 30 \\
\text { Dec. } & 31\end{array}$ & $\begin{array}{r}75 \\
60 \\
65 \\
42 \\
50 \\
55 \\
160 \\
180 \\
190 \\
160 \\
58 \\
120 \\
95\end{array}$ & $\begin{array}{r}85.2 \\
75.5 \\
78.4 \\
60.6 \\
68.4 \\
74.5 \\
110 \\
70.7 \\
51.8 \\
29.4 \\
67.7 \\
85.6 \\
107\end{array}$ & $\begin{array}{l}56 \\
54 \\
59 \\
56 \\
59 \\
58 \\
88 \\
63 \\
46 \\
34 \\
52 \\
54 \\
62\end{array}$ & $\begin{array}{l}17 \\
16 \\
16 \\
14 \\
16 \\
16 \\
28 \\
17 \\
12 \\
6.6 \\
16 \\
17 \\
22\end{array}$ & $\begin{array}{r}99 \\
77 \\
79 \\
47 \\
58 \\
72 \\
108 \\
56 \\
41 \\
12 \\
63 \\
101 \\
132\end{array}$ & $\begin{array}{r}211 \\
194 \\
210 \\
188 \\
200 \\
206 \\
320 \\
218 \\
160 \\
98 \\
184 \\
222 \\
252\end{array}$ & $\begin{array}{l}50 \\
45 \\
46 \\
36 \\
40 \\
41 \\
70 \\
39 \\
25 \\
10 \\
37 \\
36 \\
58\end{array}$ & $\begin{array}{r}141 \\
115 \\
116 \\
77 \\
94 \\
110 \\
158 \\
92 \\
68 \\
33 \\
102 \\
145 \\
188\end{array}$ & $\begin{array}{r}1.5 \\
.6 \\
.7 \\
.6 \\
.8 \\
12 \\
13 \\
1.4 \\
.4 \\
.3 \\
.8 \\
1.0 \\
.8\end{array}$ & $\begin{array}{l}468 \\
403 \\
420 \\
323 \\
366 \\
399 \\
623 \\
376 \\
271 \\
144 \\
361 \\
463 \\
587\end{array}$ & $\begin{array}{l}210 \\
201 \\
213 \\
198 \\
213 \\
210 \\
334 \\
227 \\
164 \\
112 \\
196 \\
205 \\
245\end{array}$ \\
\hline 1944 & & & & & & & & & & & \\
\hline $\begin{array}{lr}\text { Jan. } & 31 \\
\text { Mar. } & 1 \\
\text { Mar. } & 31 \\
\text { May } & 3 \\
\text { May } & 31 \\
\text { July } & 1\end{array}$ & $\begin{array}{l}70 \\
70 \\
65 \\
55 \\
30 \\
70\end{array}$ & $\begin{array}{r}85.7 \\
84.6 \\
88.8 \\
64.3 \\
51.0 \\
105\end{array}$ & $\begin{array}{l}59 \\
60 \\
62 \\
57 \\
53 \\
60\end{array}$ & $\begin{array}{l}17 \\
18 \\
17 \\
13 \\
12 \\
20\end{array}$ & $\begin{array}{r}97 \\
89 \\
100 \\
60 \\
35 \\
133\end{array}$ & $\begin{array}{l}220 \\
204 \\
222 \\
196 \\
178 \\
272\end{array}$ & $\begin{array}{l}49 \\
53 \\
54 \\
37 \\
28 \\
49\end{array}$ & $\begin{array}{r}138 \\
138 \\
144 \\
89 \\
58 \\
175\end{array}$ & $\begin{array}{l}1.0 \\
1.5 \\
1.5 \\
.4 \\
.4 \\
.2\end{array}$ & $\begin{array}{l}469 \\
460 \\
488 \\
353 \\
274 \\
571\end{array}$ & $\begin{array}{l}217 \\
224 \\
224 \\
196 \\
182 \\
232\end{array}$ \\
\hline 1945 & & & & & & & & & & & \\
\hline $\begin{array}{ll}\text { May } & 26 \\
\text { Sept. } & 22\end{array}$ & $\begin{array}{r}70 \\
320\end{array}$ & $\begin{array}{l}77.8 \\
21.5\end{array}$ & $\begin{array}{l}52 \\
24\end{array}$ & $\begin{array}{c}16 \\
5.9\end{array}$ & $\begin{array}{c}83 \\
6.0\end{array}$ & $\begin{array}{r}202 \\
82\end{array}$ & $\begin{array}{r}38 \\
8\end{array}$ & $\begin{array}{r}121 \\
15\end{array}$ & $\begin{array}{r}.0 \\
1.3\end{array}$ & $\begin{array}{l}410 \\
101\end{array}$ & $\begin{array}{r}196 \\
84\end{array}$ \\
\hline
\end{tabular}

solids increased rapidly. The increase appears to have resulted from mixing with concentrated drainage waters that are discharged into the canal by large pumps. These pumps are located on ditches. that are used to drain large areas planted with sugar cane. Analyses of samples of water collected from three of these drainage ditches show that the waters contain large quantities of dissolved 
Table 88. - Analyses, in parts per million, of water from West Palm Eeach Canal from Canal Point to West Palm Beach

\begin{tabular}{|c|c|c|c|c|c|c|c|c|c|c|c|}
\hline $\begin{array}{c}\text { Distance } \\
\text { of source } \\
\text { from } \\
\text { Canal Point } \\
\text { (miles) }\end{array}$ & Color & $\begin{array}{l}\text { Specific } \\
\text { eonduct- } \\
\text { ance } \\
\left(\mathrm{K} \times 10^{3}\right. \\
\text { at } 25 \mathrm{C})\end{array}$ & $\begin{array}{l}\text { Cal- } \\
\text { cium } \\
\text { (Ca) }\end{array}$ & $\begin{array}{c}\text { Magne- } \\
\text { sium } \\
(\mathrm{Mig})\end{array}$ & $\begin{array}{l}\text { Sodium } \\
\text { and po- } \\
\text { tassium } \\
(\mathrm{Na}+\mathrm{K})\end{array}$ & $\begin{array}{l}\text { Bicar- } \\
\text { bonate } \\
\text { (HCO, }\end{array}$ & $\begin{array}{l}\text { Sul - } \\
\text { fate } \\
\left(S Q_{4}\right)\end{array}$ & $\begin{array}{l}\text { Chlo- } \\
\text { ride } \\
\text { (Cl) }\end{array}$ & $\begin{array}{l}\mathrm{Ni}- \\
\text { trate } \\
\left(\mathrm{NO}_{9}\right)\end{array}$ & $\begin{array}{l}\text { Dis- } \\
\text { solved } \\
\text { solids }\end{array}$ & $\begin{array}{c}\text { Total } \\
\text { hard- } \\
\text { ness } \\
\text { as } \\
\mathrm{CaCO}_{8}\end{array}$ \\
\hline \multicolumn{12}{|l|}{ July 31,1940} \\
\hline $\begin{array}{r}0 \\
5 \\
10 \\
15 \\
20\end{array}$ & $\begin{array}{r}55 \\
360 \\
380 \\
280 \\
190\end{array}$ & $\begin{array}{r}37.8 \\
177^{\circ} \\
93.7 \\
48.1 \\
69.9\end{array}$ & & & & $\begin{array}{l}146 \\
450 \\
240 \\
133 \\
154\end{array}$ & $\begin{array}{r}22 \\
128 \\
56 \\
36 \\
46\end{array}$ & $\begin{array}{r}37 \\
252 \\
149 \\
68 \\
116\end{array}$ & & |........... & $\begin{array}{l}150 \\
471 \\
237 \\
124 \\
150\end{array}$ \\
\hline $\begin{array}{l}25 \\
30 \\
35 \\
40\end{array}$ & $\begin{array}{r}210 \\
140 \\
140 \\
95\end{array}$ & $\begin{array}{l}88.0 \\
66.9 \\
65.6 \\
55.0 .\end{array}$ & & & & $\begin{array}{l}260 \\
175 \\
177 \\
169\end{array}$ & $\begin{array}{l}53 \\
40 \\
38 \\
30\end{array}$ & $\begin{array}{r}126 \\
98 \\
97 \\
72\end{array}$ & & & $\begin{array}{l}231 \\
147 \\
138\end{array}$ \\
\hline \multicolumn{12}{|l|}{ March 14, 1940} \\
\hline $\begin{array}{r}0 \\
5 \\
10 \\
15 \\
20\end{array}$ & $\begin{array}{r}80 \\
180 \\
190 \\
220 \\
260\end{array}$ & $\begin{array}{r}42.1 \\
102 \\
89.0 \\
87.8 \\
74.7\end{array}$ & $\begin{array}{l}42 \\
62 \\
66 \\
62 \\
54\end{array}$ & $\begin{array}{l}13 \\
28 \\
27 \\
26 \\
21\end{array}$ & $\begin{array}{r}27 \\
115 \\
80 \\
83 \\
70\end{array}$ & $\begin{array}{l}141 \\
292 \\
236 \\
248 \\
224\end{array}$ & $\begin{array}{l}37 \\
62 \\
84 \\
62 \\
43\end{array}$ & $\begin{array}{r}45 \\
153 \\
119 \\
123 \\
103\end{array}$ & ....... & $\begin{array}{l}234 \\
564 \\
492 \\
478 \\
401\end{array}$ & $\begin{array}{l}158 \\
270 \\
276 \\
262 \\
221\end{array}$ \\
\hline $\begin{array}{l}25 \\
30 \\
35 \\
40\end{array}$ & $\begin{array}{l}200 \\
280 \\
260 \\
230\end{array}$ & $\begin{array}{l}66.6 \\
92.4 \\
81.4 \\
72.5\end{array}$ & $\begin{array}{l}52 \\
68 \\
52 \\
54\end{array}$ & $\begin{array}{l}17 \\
27 \\
21 \\
20\end{array}$ & $\begin{array}{l}60 \\
90 \\
88 \\
64\end{array}$ & $\begin{array}{l}196 \\
274 \\
234 \\
216\end{array}$ & $\begin{array}{l}43 \\
78 \\
45 \\
39\end{array}$ & $\begin{array}{r}89 \\
121 \\
119 \\
98\end{array}$ & $\ldots$ & $\begin{array}{l}358 \\
519 \\
440 \\
381\end{array}$ & $\begin{array}{l}200 \\
281 \\
216 \\
217\end{array}$ \\
\hline
\end{tabular}

mineral matter, and are particularly high in bicarbonate (table 101). Bicarbonate ranged from 632 to $728 \mathrm{ppm}$ and hardness from 605 to $843 \mathrm{ppm}$. The waters were also highly colored, the color ranging from 280 to 440 .

It has been observed that high concentrations of dissolved matter in the West Palm Beach Canal in the vicinity of Canal Point may be expected during rainy periods. This is probably accounted for 'argely by the increased discharge of the drainage pumps during periods of high water. When the normal direction of flow toward the ocean is reversed toward Lake Okeechobee the high color of the water flowing into the lake frequently interferes with the operation of the plant that furnishes waterfrom Lake Okeechobee to the town of Canal Point.

Analyses of samples collected about once a month from the West Palm Beach Canal at West Palm Beach from March 1941 to July 1944 (table 87) indicate that the concentration of dissolved matter at the sampling station ranged between rather wide limits. The minimum observed concentration of dissolved solids was $76 \mathrm{ppm}$ in October 1941 and the maximum was $587 \mathrm{ppm}$ in December 1943 . It is probable that the concentration fluctuated considerablybetween sampling periods. In a general way, increases in concentration occurred at times of low discharge and decreases occurred at times of relatively high discharge. Hydrographs of the discharge of West Palm Beach Canal at West Palm Beach and at Canal Point are in the section on "Surface water." 
HILLSBORO CANAL

Analyses of monthly samples collected from the Hillsboro Canal near Deerfield Beach from March 1941 to July 1944 (table 89) indicate that the range in composition was similar to that in the West Palm Beach Canal. Dissolved solids determined in samples collected during the period ranged from 98 to $841 \mathrm{ppm}$. The

Table 89.-Analyses, th parts per million, of tratet from Hillsboro Canal near Deerfield Beach

\begin{tabular}{|c|c|c|c|c|c|c|c|c|c|c|c|}
\hline $\begin{array}{c}\text { Date } \\
\text { of } \\
\text { collection }\end{array}$ & Color & $\begin{array}{c}\text { Specific } \\
\text { conduct- } \\
\text { ance } \\
\left(\mathrm{K} \times 10^{5}\right. \\
\text { at } 25 \mathrm{C})\end{array}$ & $\begin{array}{l}\text { Cal- } \\
\text { cium } \\
\text { (Ca) }\end{array}$ & $\begin{array}{c}\text { Magne- } \\
\text { siumn } \\
\text { (Mg) }\end{array}$ & $\begin{array}{l}\text { Sodium } \\
\text { and po- } \\
\text { tassitum } \\
(\mathrm{Na}+\mathrm{K})\end{array}$ & $\begin{array}{l}\text { Bicar- } \\
\text { bonate } \\
\text { (HCO) }\end{array}$ & $\begin{array}{l}\text { Sul- } \\
\text { fate } \\
\left(\mathrm{SO}_{4}\right)\end{array}$ & $\begin{array}{l}\text { Chlo- } \\
\text { ride } \\
\text { (Cl) }\end{array}$ & $\begin{array}{l}\mathrm{Ni}^{-} \\
\text {trate } \\
\left(\mathrm{NO}_{8}\right)\end{array}$ & $\begin{array}{l}\text { Dis - } \\
\text { solved } \\
\text { solids }\end{array}$ & $\begin{array}{c}\text { Total } \\
\text { hard- } \\
\text { ness } \\
\text { as } \\
\mathrm{CaCO}_{3}\end{array}$ \\
\hline \multicolumn{12}{|l|}{1941} \\
\hline $\begin{array}{lr}\text { Mar. } & 19 \\
\text { Apr. } & 23 \\
\text { May } & 21 \\
\text { July } & 3 \\
\text { Aug. } & 22 \\
\text { Sept. } & 19 \\
\text { Oct. } & 23 \\
\text { Nov. } & 26 \\
\text { Dec. } & 26\end{array}$ & $\begin{array}{l}140 \\
100 \\
200 \\
220 \\
240 \\
\ldots \ldots \\
180 \\
130 \\
110\end{array}$ & $\begin{array}{l}67.5 \\
61.7 \\
84.0 \\
60.0 \\
34.4 \\
36.3 \\
37.8 \\
49.9 \\
65.4\end{array}$ & $\begin{array}{l}53 \\
52 \\
58 \\
52 \\
32 \\
29 \\
32 \\
42 \\
52\end{array}$ & $\begin{array}{c}17 \\
13 \\
18 \\
12 \\
9.2 \\
8.1 \\
10 \\
12 \\
15\end{array}$ & $\begin{array}{l}65 \\
85 \\
96 \\
58 \\
26 \\
35 \\
34 \\
45 \\
69\end{array}$ & $\begin{array}{l}213 \\
196 \\
256 \\
210 \\
131 \\
130 \\
143 \\
164 \\
217\end{array}$ & $\begin{array}{l}28 \\
21 \\
21 \\
14 \\
6.6 \\
6.6 \\
11 \\
15 \\
22\end{array}$ & $\begin{array}{r}98 \\
97 \\
139 \\
83 \\
42 \\
48 \\
47 \\
72 \\
100\end{array}$ & $\begin{array}{r}2.0 \\
.5 \\
.5 \\
1.0 \\
.8 \\
1.1 \\
.4 \\
1.6 \\
.6\end{array}$ & $\begin{array}{l}368 \\
366 \\
459 \\
323 \\
180 \\
192 \\
205 \\
268 \\
366\end{array}$ & $\begin{array}{l}202 \\
135 \\
219 \\
179 \\
118 \\
106 \\
121 \\
154 \\
191\end{array}$ \\
\hline \multicolumn{12}{|l|}{1942} \\
\hline $\begin{array}{lr}\text { Jan. } & 22 \\
\text { Feb. } & 19 \\
\text { May } & 7 \\
\text { June } & 4 \\
\text { July" } & 9 \\
\text { Aug. } & 7 \\
\text { Sept. } & 3 \\
\text { Oct. } & 7 \\
\text { Nov. } & 11 \\
\text { Dec. } & 10 .\end{array}$ & $\begin{array}{r}100 \\
110 \\
180 \\
120 \\
180 \\
240 \\
180 \\
160 \\
100 \\
90\end{array}$ & $\begin{array}{r}17.8 \\
78.4 \\
35.7 \\
21.9 \\
22.0 \\
99.4 \\
59.0 \\
114 \\
94.7 \\
94.4\end{array}$ & $\begin{array}{l}22 \\
62 \\
32 \\
22 \\
22 \\
72 \\
56 \\
89 \\
80 \\
85\end{array}$ & $\begin{array}{c}1.6 \\
14 \\
9.2 \\
4.4 \\
5.5 \\
23 \\
17 \\
27 \\
21 \\
21\end{array}$ & $\begin{array}{r}14 \\
83 \\
26 \\
17 \\
14 \\
98 \\
33 \\
114 \\
88 \\
86\end{array}$ & $\begin{array}{r}69 \\
239 \\
122 \\
81 \\
84 \\
314 \\
205 \\
365 \\
307 \\
329\end{array}$ & $\begin{array}{c}6.4 \\
25 \\
5.3 \\
9.9 \\
3.3 \\
21 \\
14 \\
42 \\
30 \\
31\end{array}$ & $\begin{array}{r}20 \\
12 \\
48 \\
24 \\
25 \\
148 \\
71 \\
167 \\
138 \\
129\end{array}$ & $\begin{array}{r}.1 \\
1.0 \\
.4 \\
.1 \\
.1 \\
.2 \\
.3 \\
2.4 \\
1.2 \\
1.6\end{array}$ & $\begin{array}{r}98 \\
482 \\
181 \\
117 \\
111 \\
517 \\
292 \\
620 \\
509 \\
516\end{array}$ & $\begin{array}{r}62 \\
212 \\
118 \\
73 \\
78 \\
274 \\
211 \\
333 \\
286 \\
298\end{array}$ \\
\hline \multicolumn{12}{|l|}{1943} \\
\hline $\begin{array}{lr}\text { Jan. } & 7 \\
\text { Feb. } & 4 \\
\text { Mar. } & 4 \\
\text { Apr. } & 1 \\
\text { May } & 6 \\
\text { June } & 2 \\
\text { July } & 7 \\
\text { Aug. } & 5 \\
\text { Sept. } & 2 \\
\text { Oct. } & 7 \\
\text { Nov. } & 2 \\
\text { Nov. } & 30 \\
\text { Dec. } & 31\end{array}$ & $\begin{array}{r}100 \\
90 \\
65 \\
65 \\
80 \\
120 \\
90 \\
180 \\
170 \\
300 \\
240 \\
190 \\
150\end{array}$ & $\begin{array}{c}94.7 \\
116 \\
103 \\
123 \\
120 \\
147 \\
144 \\
115 \\
105 \\
51.2 \\
59.3 \\
113 . \\
52,2\end{array}$ & $\begin{array}{r}80 \\
98 \\
98 \\
103 \\
104 \\
106 \\
106 \\
102 \\
99 \\
55 \\
54 \\
25 \\
46\end{array}$ & \begin{tabular}{c|}
21 \\
23 \\
17 \\
22 \\
22 \\
27 \\
26 \\
29 \\
26 \\
13 \\
15 \\
7.4 \\
12
\end{tabular} & $\begin{array}{r}90 \\
113 \\
95 \\
125 \\
121 \\
182 \\
166 \\
104 \\
86 \\
30 \\
43 \\
12 \\
40\end{array}$ & $\begin{array}{r}325 \\
374 \\
336 \\
360 \\
377 \\
384 \\
395 \\
442 \\
394 \\
190 \\
194 \\
72 \\
156\end{array}$ & $\begin{array}{l}22 \\
34 \\
37 \\
43 \\
30 \\
52 \\
47 \\
21 \\
34 \\
16 \\
16 \\
5.6 \\
12\end{array}$ & $\begin{array}{r}136 \\
172 \\
147 \\
198 \\
188 \\
285 \\
255 \\
152 \\
134 \\
60 \\
80 \\
38 \\
79\end{array}$ & $\begin{array}{l}.2 \\
.5 \\
.2 \\
.3 \\
.4 \\
.0 \\
.9 \\
.0 \\
.2 \\
.4 \\
.4 \\
.2 \\
.2\end{array}$ & $\begin{array}{l}509 \\
625 \\
560 \\
669 \\
657 \\
841 \\
796 \\
626 \\
573 \\
268 \\
304 \\
124 \\
266\end{array}$ & $\begin{array}{r}286 \\
339 \\
314 \\
348 \\
350 \\
376 \\
372 \\
374 \\
354 \\
191 \\
196 \\
93 \\
164\end{array}$ \\
\hline \multicolumn{12}{|l|}{1944} \\
\hline $\begin{array}{lr}\text { Jan. } & 31 \\
\text { Feb. } & 29 \\
\text { Mar. } & 31 \\
\text { May } & 2 \\
\text { May } & 31 \\
\text { July } & 1\end{array}$ & $\begin{array}{r}120 \\
82 \\
66 \\
80 \\
90 \\
180\end{array}$ & $\begin{array}{c}79.4 \\
103 \\
94.6 \\
83.8 \\
131 \\
106\end{array}$ & $\begin{array}{l}70 \\
99 \\
82 \\
91 \\
92 \\
97\end{array}$ & $\begin{array}{l}15 \\
17 \\
18 \\
15 \\
26 \\
29\end{array}$ & $\begin{array}{r}74 \\
97 \\
92 \\
69 \\
147 \\
89\end{array}$ & $\begin{array}{l}242 \\
334 \\
288 \\
319 \\
388 \\
430\end{array}$ & $\begin{array}{l}23 \\
33 \\
39 \\
26 \\
34 \\
19\end{array}$ & $\begin{array}{l}123 \\
156 \\
144 \\
106 \\
216 \\
129\end{array}$ & $\begin{array}{l}.8 \\
.5 \\
.1 \\
.1 \\
.2 \\
.2\end{array}$ & $\begin{array}{l}425 \\
567 \\
517 \\
464 \\
706 \\
575\end{array}$ & $\begin{array}{l}236 \\
317 \\
278 \\
288 \\
336 \\
361\end{array}$ \\
\hline \multicolumn{12}{|l|}{1945} \\
\hline May 26 & 160 & 156 & 121 & 21 & 186 & 412 & 57 & 280 & .0 & 868. & 388 \\
\hline
\end{tabular}


principal constituents of these samples were calcium, bicarbonate, sodium, and chloride. Hardness ranged from 62 to $376 \mathrm{ppm}$, and color, which was relatively high, ranged from 65 to 300 . A single sample collected in 1945 showed dissolved solids of 868 ppm and a total hardness of $388 \mathrm{ppm}$.

\section{NORTH NET PVER CANAL}

Daily samples were collected for analysis from the Nor th New River Canal at 26-Mile Bend from March 1 to October 5, 1941, and at the lock and dam near Fort Lauderdale from October 22, 1941 , to February 28, 1942. It was intended that daily samples should be collected at 26-Mile Bend throughout the year ending February 28, 1942, but because of inability to keep an observer at this isolated place the station was abandoned early in October. The station near Fort Lauderdale is about 19 miles downstream from 26-Mile Bend. Analyses of several series of samples collected allalong the canal indicate that the composition of the water at the lock and dam is probably similar to the composition of the water at 26-Mile Bend.

Generally, analyses of 10-day composites of the daily samples show that the composition may fluctuate rapidly and between wide limits. (See tables 90 and 91.) Ranges in concentrations of dissolved matter and their relations to changes in discharge are

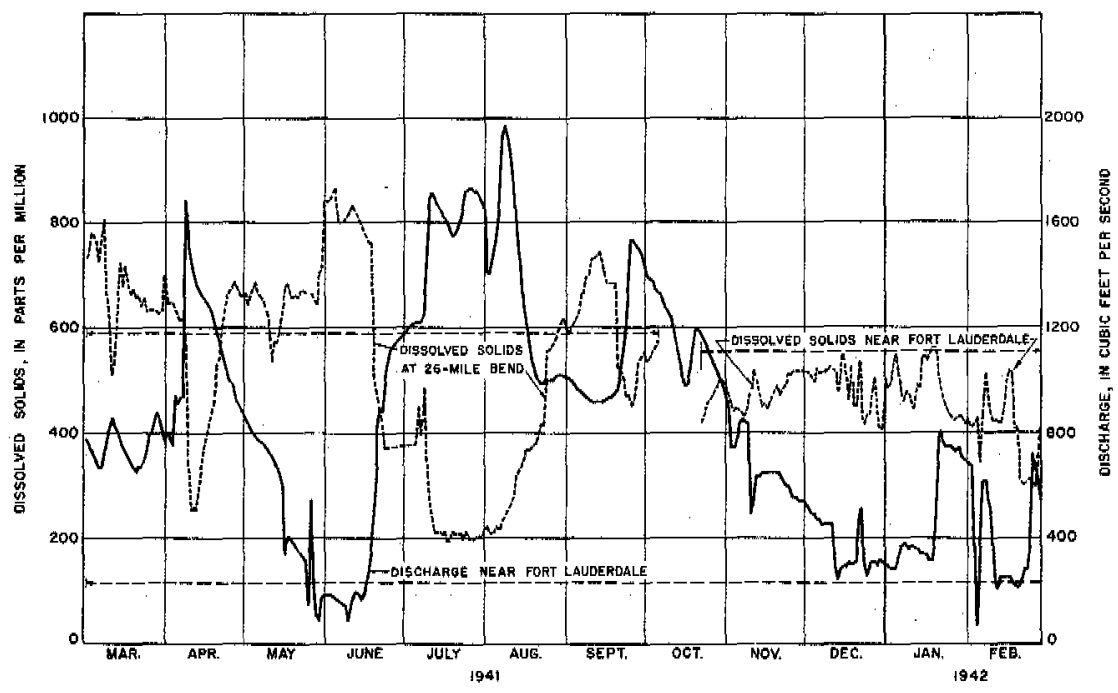

Figure 217. -Graph showing discharge and dissolved solids in North New River Canal at 26-Mile Bend and near Fort Lauderdale, 1941-42, 
Table 90. - Analyses, in parts per million, of 10-day conposite samples of water fron North New River Canal near Fort Lauderdale

\begin{tabular}{|c|c|c|c|c|c|c|c|c|c|c|c|c|c|c|c|c|}
\hline $\begin{array}{c}\begin{array}{c}\text { Date } \\
\text { of } \\
\text { collection }\end{array} \\
\end{array}$ & $\begin{array}{c}\text { Mean } \\
\text { discharge }\end{array}$ & Color & $\begin{array}{c}\text { Specific } \\
\text { conductance } \\
\text { (K } \times 10^{5} \\
\text { at } 25 \mathrm{C})\end{array}$ & $\mid \begin{array}{l}\text { Silica } \\
\left(\mathrm{SiO}_{2}\right)\end{array}$ & $\begin{array}{l}\text { Iron } \\
\text { (Fe) }\end{array}$ & $\mid \begin{array}{c}\text { Calcium } \\
\text { (Ca) }\end{array}$ & $\underset{\text { (Mg) }}{\text { Magnesium }}$ & $\begin{array}{c}\text { Sodium } \\
\text { (Na) }\end{array}$ & $\begin{array}{c}\text { Potassium } \\
\text { (K) }\end{array}$ & $\begin{array}{c}\text { Bicarbonate } \\
(\mathrm{HCO})\end{array}$ & $\begin{array}{l}\text { Sulfate } \\
\left(\mathrm{SO}_{4}\right)\end{array}$ & $\mid \begin{array}{c}\text { Chloride } \\
\text { (CI) }\end{array}$ & $\begin{array}{c}\text { Fluoride } \\
\text { (F) }\end{array}$ & $\begin{array}{l}\text { Nitrate } \\
\left(\mathrm{NO}_{3}\right)\end{array}$ & $\begin{array}{c}\text { Dissolved } \\
\text { solids }\end{array}$ & $\begin{array}{c}\text { Total } \\
\text { hardness } \\
\text { as } \\
\mathrm{CaCO}_{3}\end{array}$ \\
\hline & \multicolumn{16}{|c|}{ At $26-$ Mile Bend } \\
\hline \multicolumn{17}{|l|}{1941} \\
\hline $\begin{array}{l}\text { Mar. } 1-10 \\
\text { Mar. } 11-20 \\
\text { Mar. } 21-24,\end{array}$ & …….................... & $\begin{array}{l}170 \\
180\end{array}$ & $\begin{array}{l}110 \\
98.5\end{array}$ & $\begin{array}{l}20 \\
16\end{array}$ & $\begin{array}{r}0.06 \\
.06\end{array}$ & $\begin{array}{r}106 \\
89\end{array}$ & $\begin{array}{l}38 \\
31\end{array}$ & $\begin{array}{l}77 \\
74\end{array}$ & 5.1 & $\begin{array}{l}382 \\
356\end{array}$ & $\begin{array}{l}99 \\
62\end{array}$ & $\begin{array}{l}119 \\
115\end{array}$ & $\begin{array}{r}0.5 \\
.5\end{array}$ & $\begin{array}{l}2.2 \\
1.3\end{array}$ & $\begin{array}{l}738 \\
647\end{array}$ & $\begin{array}{l}421 \\
350\end{array}$ \\
\hline $\begin{array}{cc} & 28-31 \\
\text { Apr. } & 1-8 \\
\text { Apr. } & 14-16\end{array}$ & (............................. & $\begin{array}{l}180 \\
160\end{array}$ & $\begin{array}{l}100 \\
97.7\end{array}$ & $\begin{array}{l}16 \\
15\end{array}$ & $\begin{array}{l}.08 \\
.08\end{array}$ & $\begin{array}{l}91 \\
86\end{array}$ & $\begin{array}{l}33 \\
32\end{array}$ & $\begin{array}{l}81 \\
79\end{array}$ & $\begin{array}{l}4.5 \\
4.5\end{array}$ & $\begin{array}{l}366 \\
360\end{array}$ & $\begin{array}{l}57 \\
48\end{array}$ & $\begin{array}{l}119 \\
118\end{array}$ & $\begin{array}{l}.3 \\
.4\end{array}$ & $\begin{array}{l}1.1 \\
1.2\end{array}$ & $\begin{array}{l}648 \\
626\end{array}$ & $\begin{array}{l}362 \\
346\end{array}$ \\
\hline Apr. $\begin{array}{c}19-20 \\
21-27\end{array}$ & $\cdots$ & 240 & 58.7 & 7.8 & .12 & 72 & 20 & 31 & 3.2 & 245 & 48 & 43 & .2 & 1.7 & 420 & 262 \\
\hline $29-30$ & $\cdots$ & 180 & 93.8 & 16 & .12 & 94 & 31 & 70 & 4.5 & 358 & 68 & 98 & .4 & 1.1 & 637 & 362 \\
\hline $\begin{array}{lr}\text { May } & 1-3 \\
& 5-9 \\
\text { May } & 11-13 \\
16-17\end{array}$ & ................ & 170 & 98,6 & 16 & .08 & 94 & 33 & 74 & 5.1 & 363 & 64 & 112 & .4 & 1.5 & 651 & 370 \\
\hline $\begin{array}{cc} & 19-20 \\
\text { May } & 21-31 \\
\text { Jume } & 2,4-7\end{array}$ & ............................ & $\begin{array}{l}190 \\
180\end{array}$ & $\begin{array}{l}92.0 \\
105\end{array}$ & $\begin{array}{l}17 \\
18\end{array}$ & $\begin{array}{r}.10 \\
.14\end{array}$ & $\begin{array}{l}91 \\
97\end{array}$ & $\begin{array}{l}31 \\
35\end{array}$ & $\begin{array}{l}65 \\
82\end{array}$ & $\begin{array}{l}4.6 \\
4.5\end{array}$ & $\begin{array}{l}358 \\
396\end{array}$ & $\begin{array}{l}69 \\
52\end{array}$ & $\begin{array}{r}95 \\
124\end{array}$ & $\begin{array}{l}.3 \\
.4\end{array}$ & $\begin{array}{l}1.9 \\
1.4\end{array}$ & $\begin{array}{l}619 \\
682\end{array}$ & $\begin{array}{l}354 \\
386\end{array}$ \\
\hline $\begin{array}{ll} & 11 \\
\text { Jume } & 17-19\end{array}$ & ............... & 180 & 125 & 22 & .12 & 112 & 43 & 101 & 5.6 & 462 & 66 & 154 & .5 & 2.0 & 813 & 456 \\
\hline 21,23 & ................. & 180 & 86.1 & 12 & .18 & 85 & 27 & 62 & 5.3 & 330 & 38 & 93 & .4 & 1.6 & 562 & 323 \\
\hline $\begin{array}{lc}\text { July } & 3-9 \\
\text { July } & 11-20 \\
\text { July } & 21-27\end{array}$ & …............ & $\begin{array}{l}340 \\
320\end{array}$ & $\begin{array}{l}55.2 \\
26.4\end{array}$ & $\begin{array}{l}9.4 \\
5.6\end{array}$ & $\begin{array}{l}.14 \\
.12\end{array}$ & $\begin{array}{l}60 \\
39\end{array}$ & $\begin{array}{l}19 \\
7.6\end{array}$ & $\begin{array}{c}37 \\
8.9\end{array}$ & $\begin{array}{l}3.5 \\
2.5\end{array}$ & $\begin{array}{l}218 \\
138\end{array}$ & $\begin{array}{l}30 \\
6.0\end{array}$ & $\begin{array}{l}51 \\
13\end{array}$ & .1 & $\begin{array}{l}1.3 \\
1.2\end{array}$ & $\begin{array}{l}395 \\
210\end{array}$ & $\begin{array}{l}228 \\
128\end{array}$ \\
\hline $\begin{array}{lc} & 20-31 \\
\text { Aug. } & 2-7 \\
\text { Aug. } & 11-12\end{array}$ & ……......... & $\begin{array}{l}320 \\
310\end{array}$ & $\begin{array}{l}25.8 \\
27.7\end{array}$ & $\begin{array}{l}8.3 \\
8.1\end{array}$ & $\begin{array}{r}.14 \\
.14\end{array}$ & $\begin{array}{l}38 \\
39\end{array}$ & $\begin{array}{l}7.5 \\
8.4\end{array}$ & ${ }_{10}^{8,8}$ & $\begin{array}{l}2.2 \\
2.6\end{array}$ & $\begin{array}{l}140 \\
145\end{array}$ & $\begin{array}{l}5.2 \\
4.9\end{array}$ & $\begin{array}{l}12 \\
16\end{array}$ & $\begin{array}{l}.3 \\
.2\end{array}$ & .8 & $\begin{array}{l}205 \\
217\end{array}$ & $\begin{array}{l}126 \\
132\end{array}$ \\
\hline Aug. $\begin{array}{c}14-20 \\
22-25\end{array}$ & ................ & 300 & 47.8 & 13 & .16 & 58 & 15 & 24 & 4.1 & 228 & 14 & 38 & .4 & .6 & 344 & 206 \\
\hline $29-31$ & .............. & 260 & 77.4 & 18 & .28 & 83 & 26 & 52 & 5.9 & 326 & 37 & 76 & .6 & 1.0 & 537 & 314 \\
\hline
\end{tabular}




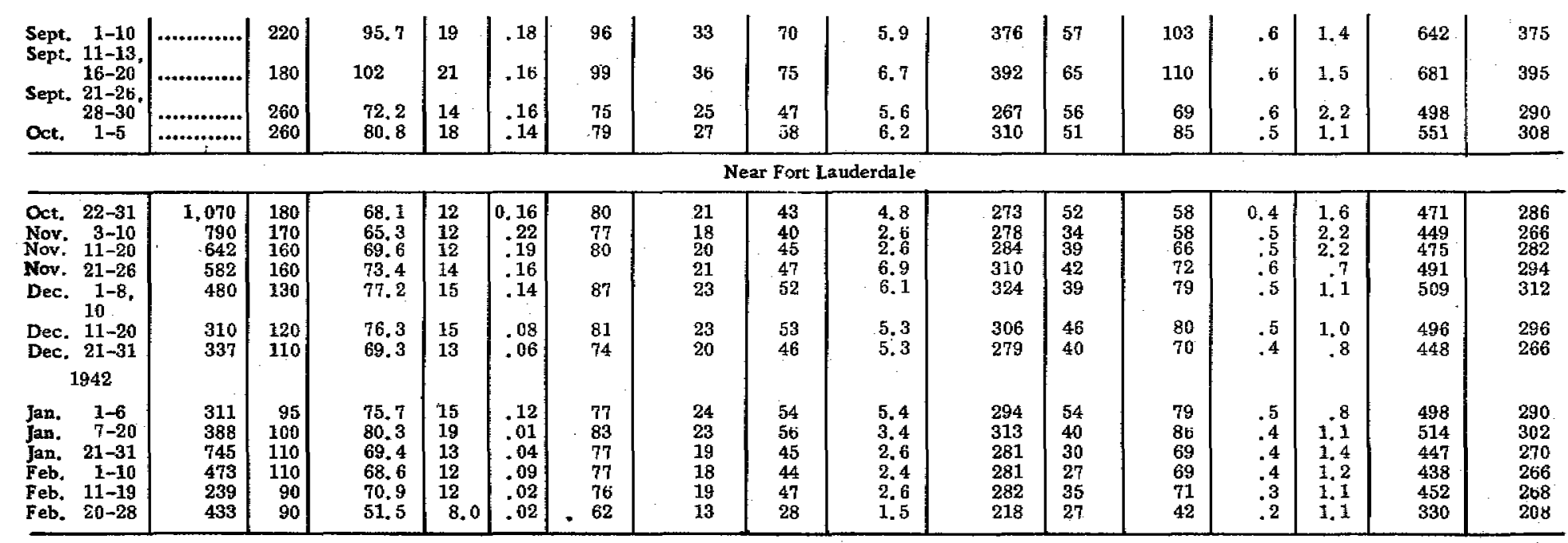


Table 91,-Analyses, in parts per million, of weter from North New River Canal near Fort Lauderdele

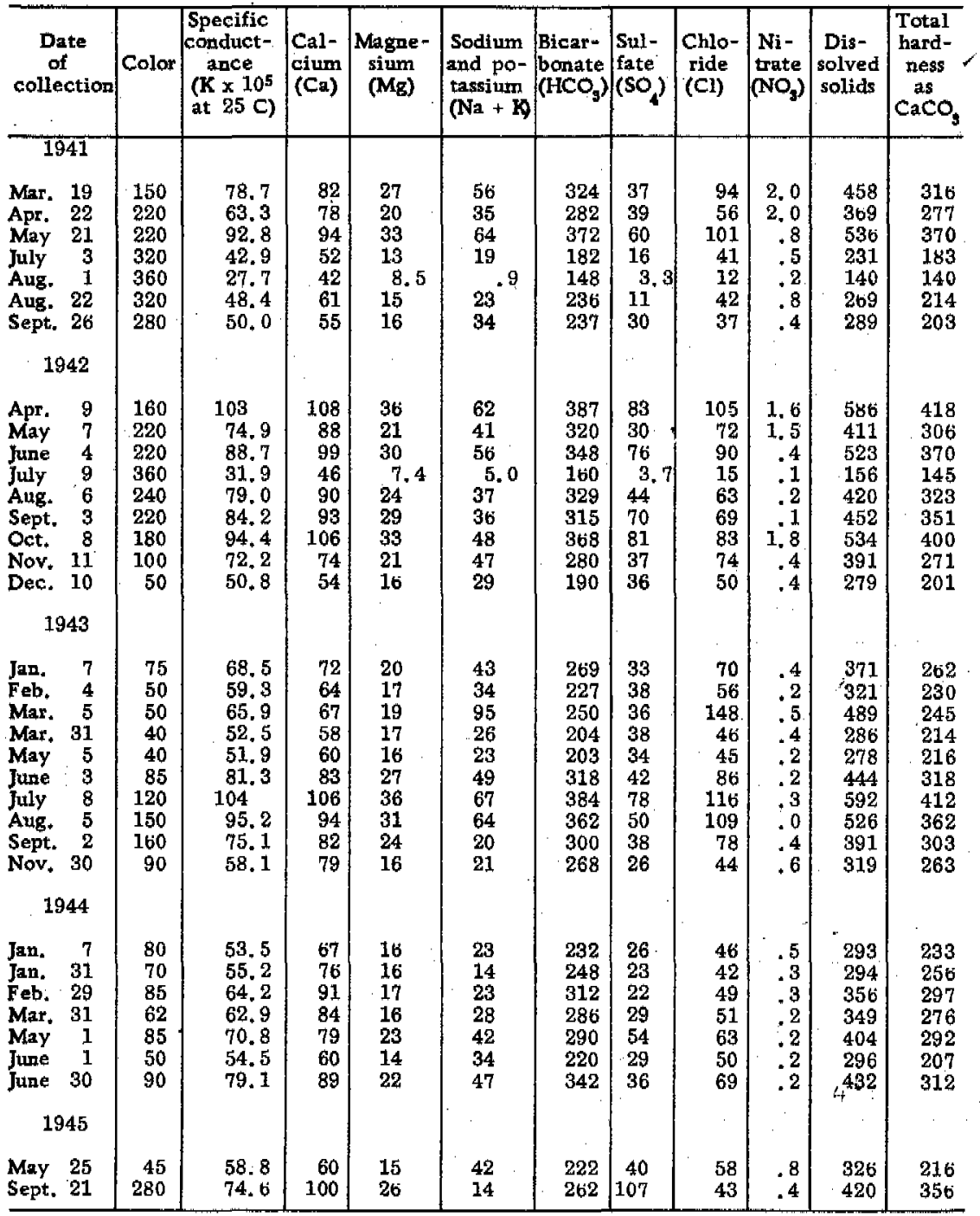

Note, -For analyses of 10-day (generally) composite samples Oct. 22, 1941, to F eb. 28, 1942, see table 90 .

shown graphically in figure 217 . When the discharge is high, the concentration of dissolved matter is generally low, and when the discharge is low, the concentration of dissolved solids increases to high values.

At irregular intervals, series of samples were collected at several points along the North New River Canal between South Bay and State Highway 7 (table 92). Chloride was the only constituent 
Table 92. Analyses, in parts per million, of water from North New River Canal from South Bay to State Highway 7 near Fort Lauderdale

\begin{tabular}{|c|c|c|c|c|c|c|c|c|c|c|c|}
\hline $\begin{array}{c}\text { Distance } \\
\text { of source } \\
\text { from } \\
\text { South Bay } \\
\text { (miles) }\end{array}$ & Color & $\begin{array}{c}\text { Specific } \\
\text { conduct- } \\
\text { ance } \\
\left(\begin{array}{l}\text { K } \times 10^{5} \\
\text { at } 25 \mathrm{C}\end{array}\right)\end{array}$ & $\begin{array}{l}\text { Cal- } \\
\text { cium } \\
\text { (Ca) }\end{array}$ & $\begin{array}{c}\text { Magne- } \\
\text { sium } \\
(\mathrm{Mg})\end{array}$ & $\begin{array}{l}\text { Sodi um } \\
\text { and po- } \\
\text { tassium } \\
(\mathrm{Na}+\mathrm{K})\end{array}$ & $\mid \begin{array}{l}\text { Bicar- } \\
\text { bonate } \\
\left(\mathrm{HCO}_{3}\right)\end{array}$ & $\begin{array}{l}\text { Sul- } \\
\text { fate } \\
\left(\mathrm{SO}_{4}\right)\end{array}$ & $\begin{array}{l}\text { Chlo- } \\
\text { ride } \\
\text { (CI) }\end{array}$ & $\begin{array}{l}\mathrm{Ni}- \\
\text { trate } \\
\left(\mathrm{NO}_{3}\right)\end{array}$ & $\begin{array}{l}\text { Dis } \\
\text { solved } \\
\text { solids }\end{array}$ & $\begin{array}{l}\text { Total } \\
\text { hard- } \\
\text { ness } \\
\text { as } \\
\mathrm{CaCO}\end{array}$ \\
\hline \multicolumn{12}{|l|}{ July 28,1940} \\
\hline $\begin{array}{r}0 \\
14 \\
8 \\
13 \\
18\end{array}$ & $\begin{array}{r}65 \\
65 \\
150 \\
150 \\
150\end{array}$ & $\begin{array}{l}52.4 \\
48.6 \\
55.7 \\
62.2 \\
78.8\end{array}$ & $\begin{array}{l}57 \\
52 \\
62 \\
69 \\
78\end{array}$ & $\begin{array}{l}15 \\
15 \\
15 \\
19 \\
21\end{array}$ & $\begin{array}{l}20 \\
15 \\
28 \\
35 \\
59\end{array}$ & $\begin{array}{l}172 \\
162 \\
204 \\
236 \\
278\end{array}$ & $\begin{array}{l}28 \\
24 \\
34 \\
40 \\
50\end{array}$ & $\begin{array}{l}54 \\
47 \\
53 \\
65 \\
92\end{array}$ & 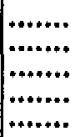 & $\begin{array}{l}259 \\
233 \\
292 \\
344 \\
437\end{array}$ & $\begin{array}{l}204 \\
192 \\
216 \\
250 \\
281\end{array}$ \\
\hline $\begin{array}{l}20 \\
21 \\
23 \\
27 \\
32\end{array}$ & $\begin{array}{l}150 \\
150 \\
150 \\
150 \\
160\end{array}$ & $\begin{array}{l}81.5 \\
82.2 \\
85.5 \\
91.8 \\
87.0\end{array}$ & $\begin{array}{l}78 \\
80 \\
82 \\
86 \\
83\end{array}$ & $\begin{array}{l}24 \\
23 \\
27 \\
28 \\
27\end{array}$ & $\begin{array}{l}58 \\
59 \\
53 \\
63 \\
61\end{array}$ & $\begin{array}{l}290 \\
294 \\
304 \\
318 \\
316\end{array}$ & $\begin{array}{l}44 \\
46 \\
46 \\
44 \\
40\end{array}$ & $\begin{array}{r}96 \\
95 \\
103 \\
114 \\
106\end{array}$ & 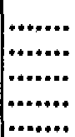 & $\begin{array}{l}443 \\
448 \\
461 \\
492 \\
473\end{array}$ & $\begin{array}{l}293 \\
294 \\
316 \\
330 \\
318\end{array}$ \\
\hline $\begin{array}{l}35 \\
38 \\
41 \\
49 \\
54 \\
56\end{array}$ & $\begin{array}{l}160 \\
160 \\
160 \\
160 \\
150 \\
140\end{array}$ & $\begin{array}{l}86.6 \\
87.0 \\
85.1 \\
78.6 \\
73.8 \\
76.8\end{array}$ & $\begin{array}{l}84 \\
86 \\
83 \\
82 \\
84 \\
83\end{array}$ & $\begin{array}{l}27 \\
26 \\
24 \\
24 \\
24 \\
22\end{array}$ & $\begin{array}{l}64 \\
59 \\
55 \\
48 \\
55 \\
51\end{array}$ & $\begin{array}{l}316 \\
318 \\
318 \\
302 \\
306 \\
304\end{array}$ & $\begin{array}{l}50 \\
36 \\
34 \\
36 \\
46 \\
36\end{array}$ & $\begin{array}{r}105 \\
103 \\
91 \\
87 \\
91 \\
87\end{array}$ & 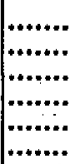 & $\begin{array}{l}486 \\
467 \\
444 \\
426 \\
451 \\
429\end{array}$ & $\begin{array}{l}321 \\
322 \\
306 \\
303 \\
308 \\
298\end{array}$ \\
\hline \multicolumn{12}{|l|}{ Feb. 13, 1941} \\
\hline $\begin{array}{r}0 \\
14 \\
18 \\
23 \\
27\end{array}$ & $\begin{array}{l}110 \\
190 \\
260 \\
260 \\
250\end{array}$ & …......... & $\begin{array}{l}119 \\
184 \\
105 \\
104 \\
100\end{array}$ & $\begin{array}{l}52 \\
65 \\
34 \\
34 \\
34\end{array}$ & $\begin{array}{r}108 \\
52 \\
22 \\
16 \\
18\end{array}$ & $\begin{array}{l}446 \\
466 \\
268 \\
264 \\
268\end{array}$ & $\begin{array}{l}168 \\
310 \\
139 \\
131 \\
116\end{array}$ & $\begin{array}{r}146 \\
95 \\
61 \\
58 \\
63\end{array}$ & 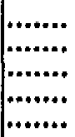 & $\begin{array}{l}813 \\
936 \\
493 \\
473 \\
463\end{array}$ & $\begin{array}{l}511 \\
726 \\
402 \\
399 \\
389\end{array}$ \\
\hline $\begin{array}{l}32 \\
35 \\
41 \\
49 \\
54 \\
56\end{array}$ & $\begin{array}{l}250 \\
250 \\
220 \\
220 \\
210 \\
200\end{array}$ & 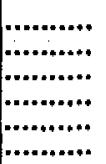 & $\begin{array}{l}84 \\
75 \\
77 \\
82 \\
88 \\
74\end{array}$ & $\begin{array}{l}14 \\
25 \\
25 \\
24 \\
24 \\
21\end{array}$ & $\begin{array}{l}67 \\
4.8 \\
12 \\
20 \\
20 \\
19\end{array}$ & $\begin{array}{l}276 \\
224 \\
232 \\
224 \\
240 \\
208\end{array}$ & $\begin{array}{l}92 \\
35 \\
51 \\
81 \\
80 \\
67\end{array}$ & $\begin{array}{l}64 \\
57 \\
55 \\
56 \\
58 \\
51\end{array}$ & 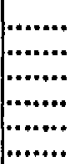 & $\begin{array}{l}457 \\
307 \\
334 \\
373 \\
388 \\
384\end{array}$ & $\begin{array}{l}267 \\
290 \\
295 \\
303 \\
318 \\
271\end{array}$ \\
\hline \multicolumn{12}{|l|}{ March 10, 1941 } \\
\hline $\begin{array}{l}0 \\
14 \\
10 \\
15 \\
20\end{array}$ & $\begin{array}{r}75 \\
220 \\
240 \\
220 \\
260\end{array}$ & $\begin{array}{c}79.4 \\
140 \\
92.0 \\
92.7 \\
84.8\end{array}$ & $\begin{array}{r}64 \\
174 \\
104 \\
95 \\
82\end{array}$ & $\begin{array}{l}25 \\
63 \\
36 \\
34 \\
31\end{array}$ & $\begin{array}{l}66 \\
48 \\
43 \\
55 \\
\mathbf{5 1}\end{array}$ & $\begin{array}{l}244 \\
468 \\
312 \\
304 \\
287\end{array}$ & $\begin{array}{r}70 \\
274 \\
130 \\
110 \\
70\end{array}$ & $\begin{array}{l}93 \\
88 \\
77 \\
93 \\
94\end{array}$ & $\begin{array}{l}1.6 \\
5.0 \\
1.6 \\
1.0 \\
4.0\end{array}$ & $\begin{array}{l}440 \\
882 \\
545 \\
538 \\
473\end{array}$ & $\begin{array}{l}263 \\
693 \\
408 \\
377 \\
332\end{array}$ \\
\hline $\begin{array}{l}25 \\
30 \\
35 \\
41 \\
49\end{array}$ & $\begin{array}{l}260 \\
240 \\
220 \\
160 \\
150\end{array}$ & $\begin{array}{l}79.9 \\
79.4 \\
85.8 \\
90.4 \\
84.3\end{array}$ & $\begin{array}{l}78 \\
75 \\
79 \\
88 \\
86\end{array}$ & $\begin{array}{l}28 \\
28 \\
30 \\
20 \\
27\end{array}$ & $\begin{array}{l}47 \\
58 \\
68 \\
59 \\
57\end{array}$ & $\begin{array}{l}288 \\
292 \\
310 \\
332 \\
324\end{array}$ & $\begin{array}{l}51 \\
55 \\
70 \\
49 \\
46\end{array}$ & $\begin{array}{r}86 \\
92 \\
100 \\
105 \\
96\end{array}$ & $\begin{array}{r}3.0 \\
2.0 \\
1.4 \\
.6 \\
1.2\end{array}$ & $\begin{array}{l}435 \\
454 \\
501 \\
495 \\
473\end{array}$ & $\begin{array}{l}310 \\
302 \\
321 \\
343 \\
326\end{array}$ \\
\hline $\begin{array}{l}54 \\
56\end{array}$ & $\begin{array}{l}180 \\
170\end{array}$ & $\begin{array}{l}88.0 \\
75.8\end{array}$ & $\begin{array}{l}91 \\
81\end{array}$ & $\begin{array}{l}29 \\
25\end{array}$ & $\begin{array}{l}55 \\
48\end{array}$ & $\begin{array}{l}334 \\
296\end{array}$ & $\begin{array}{l}56 \\
49\end{array}$ & $\begin{array}{l}94 \\
82\end{array}$ & $\begin{array}{l}1.2 \\
1.2\end{array}$ & $\begin{array}{l}491 \\
432\end{array}$ & $\begin{array}{l}346 \\
305\end{array}$ \\
\hline \multicolumn{12}{|l|}{ Aug. 1, 1941} \\
\hline $\begin{array}{r}7 \\
16 \\
26 \\
35 \\
46 \\
54\end{array}$ & $\begin{array}{l}280 \\
440 \\
440 \\
360 \\
280 \\
360\end{array}$ & $\begin{array}{l}29.3 \\
32.6 \\
30.4 \\
27.0 \\
33.8 \\
27.7\end{array}$ & $\begin{array}{l}46 \\
48 \\
42 \\
38 \\
54 \\
42\end{array}$ & $\begin{array}{l}8.3 \\
12 \\
11 \\
8.7 \\
8.7 \\
8.5\end{array}$ & $\begin{array}{r}2.9 \\
2.6 \\
3.6 \\
4.3 \\
4.6 \\
79\end{array}$ & $\begin{array}{l}170 \\
188 \\
166 \\
150 \\
190 \\
148\end{array}$ & $\begin{array}{l}2.9 \\
6.2 \\
4.5 \\
1.2 \\
8.2 \\
3.3\end{array}$ & $\begin{array}{r}9 \\
10 \\
12 \\
11 \\
11 \\
12\end{array}$ & $\begin{array}{r}.2 \\
.2 \\
.2 \\
.2 \\
1.0 \\
.2\end{array}$ & $\begin{array}{l}153 \\
172 \\
155 \\
137 \\
181 \\
142\end{array}$ & $\begin{array}{l}149 \\
169 \\
150 \\
131 \\
171 \\
140\end{array}$ \\
\hline
\end{tabular}

${ }^{1}$ About $500 \mathrm{ft}$ north of Bolles Canal. 
determined in most of the samples, but the wide range in chloride concentration at different times and between different sampling points in a single day indicate that all of the chemical constituents varied similarly. The range in chloride is shown graphically in figure 218.

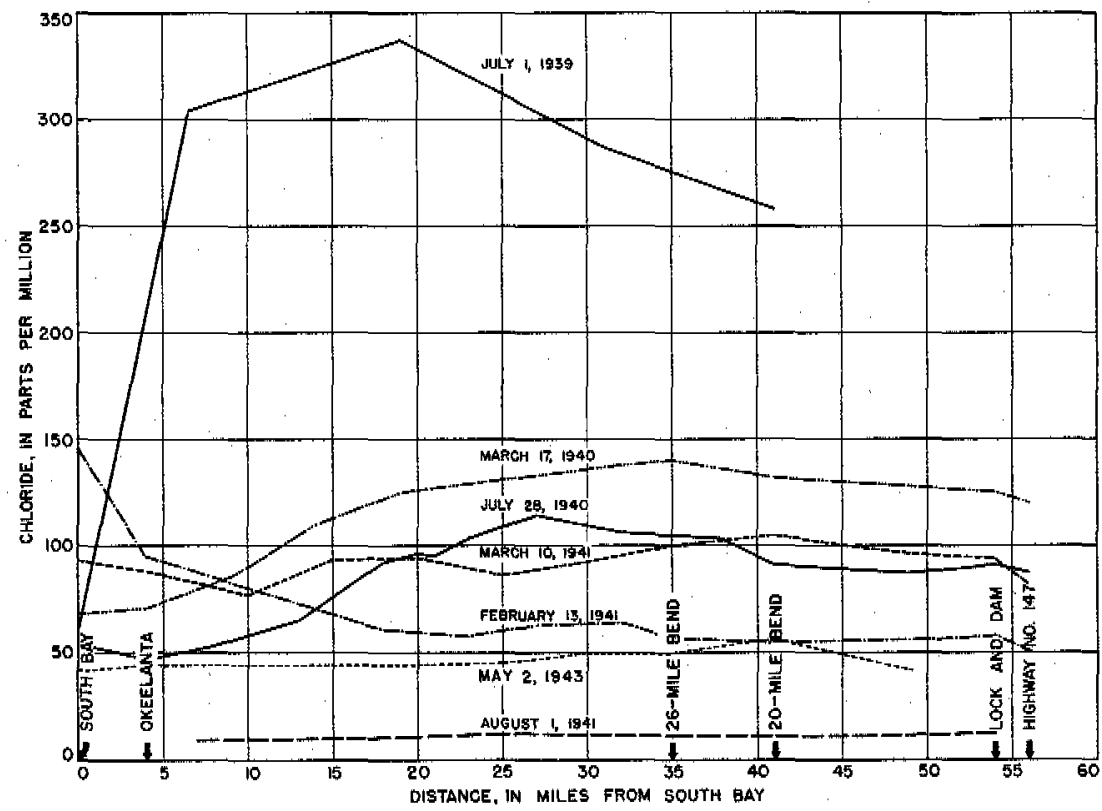

Figure 218. -Graph showing chloride concentrations in North New River Canal between South Bay and State Highway 7.

Several suggestions have been offered to explain the high concentration of dissolved mineral matter in the North New River Canal. Probably, several factors should be considered in arriving at the correct explanation.

One factor is indicated by analyses of water samples (collected during the drilling of test wells), which show that highly mineralized water lies underneath large areas of the Everglades. At many places it is only a few feet beneath the surface of the ground. During periods of high discharge in the canal, very little of the underlying mineralized water discharges from the ground, and, as a result, the concentration of dissolved matter in the canal is relatively low. When the canal discharge is low, however, a fairly large proportion of the water comes from the ground, including some of the more highly mineralized water. As a consequence, the concentration of dissolved matter in the canal is relatively high. The available data indicate that there is an area reaching 10 to 15 miles along the canal north from 20-Mile Bend where the concentration is slightly higher than it is in either direction from this 
area, particularly during periods of low flow. A decrease in concentration is especially noticeable in the vicinity of Okeelanta, which is about 4 miles from South Bay. This decrease near Okeelanta presumably is caused by the lower concentration of dissolved matter that is usually found in inflowing water from Bolles Canal and in water released from Lake Okeechobee. (See table 101.) A more complete discussion of the composition of ground water in the Everglades is given on pages $818-822$.

A second factor that affects the composition of water in North New River Canal is water discharged from Lake Okeechobee. Records of discharge at South Bay show that the flow at this point is only a small proportion of the flow at the lock and dam near Fort Lauderdale and that during periods of high water the direction of flowat South Bay is reversed so that some of the waterflows toward Lake Okeechobee. During periods of moderate to low flow, however, some lake water is discharged through North New River Canal. When this occurs, the concentration of dissolved matter at 26-Mile Bend is rather high. It seems probable, however, that the water from Lake Okeechobee has a beneficial effect on the quality of the canal water at 26-Mile Bend because it has a diluting effect on the more concentrated inflowing ground water. Inflowing water from Bolles Canal, as mentioned above, apparently has a similar diluting effect.

A third factor that affects the quality of water in the North New River Canal is the quantity and composition of water discharged from drainage pumps in the agricultural area near Lake Okeechobee. During the growing seasons large pumps are operated to lower the water table in the cultivated fields. The water discharged by these pumps is usually much more concentrated than water from the surface of the Everglades, as shown by analyses of a few samples. (See table 101). There are several of these drainage pumps in the vicinity of South Bay and Okeelanta and on the Hillsboro Canal in the vicinity of Belle Glade. At times, concentrated water from Hillsboro Canal flows into the North New River Canal through a connection on the landward side of the levee on the southeast side of Lake Oreechobee.

A fourth factor that has an effect on the quality of the water in the North New River Canal is the surface inflow from the Everglades during rainy periods. Most of this water flows from the surface of the muck and saw grass areas and although it is usually highly colored, it generally contains only a small amount of dissolved mineral matter. During these periods, the volume of surface flow is large in comparison with ground-water discharge and, as a result, the concentration of dissolved matter in the canal is relatively low.

It is readily seen that changes in the composition of water in the North New River Canal are the results of several variable factors. In a general way, however, when the discharge is high the 
concentration of dissolved matter is relatively low, and when the discharge is low the concentration is relatively high. Any development in southeastern Florida that involves the use of large quantities of water from North New River Canal must make allowance for rapid and large changes in the composition of the water.

\section{gOUTH NEW RIVER CANAL}

No regular series of samples was collected from South New River Canal. Analyses of occasional samples indicate that the water in this canal is usually similar in composition to water in Miami Canal north of the dam at the Dade-Broward County line. The two canals are connected at a point about 8 miles west of State Highway 25 and about 10 miles northwest of the Dade-Broward County line. Partial analyses (table 93) suggest that both the concentration of dissolved solids and the hardness of water in the canal west of Sta te Highway 25. ranges from about 150 to $200 \mathrm{ppm}$. A dam about $\frac{1}{2}$ mile east of Highway 25 prevents free flow throughout the canal. Analyses of a few samples collected from South New River Canal near Davie, which is about 7 miles east of Highway 25, indicate that water in this park of the canal may contain slightly more dissolved mineral matter and may be a little harder than water west of Highway 25 (see table 101).

Table 93._-Analyses, in parts per million, of water from South New River Canal west of bridge on State Highway 25

\begin{tabular}{|c|c|c|c|c|c|c|c|c|c|c|c|c|}
\hline Date & $\begin{array}{c}\text { Distance } \\
\text { of source } \\
\text { from bridge } \\
\text { on } \\
\text { Highway } 25 \\
\text { (miles) }\end{array}$ & Color & $\begin{array}{l}\text { Specific } \\
\text { conduct } \\
\text { ance } \\
\left(\mathbf{K} \times 10^{5}\right. \\
\text { at } 25 \mathrm{C})\end{array}$ & $\begin{array}{l}\text { Cal- } \\
\text { cium } \\
\text { (Ca) }\end{array}$ & $\begin{array}{l}\text { Magne } \\
\text { sium } \\
(\mathrm{Mg})\end{array}$ & $\begin{array}{l}\text { Sodium } \\
\text { and po- } \\
\text { tassium } \\
(\mathrm{Na}+\mathrm{K})\end{array}$ & $\left(\begin{array}{l}\text { Bicar- } \\
\text { bonate } \\
\text { (HCQ) }\end{array}\right.$ & $\left\{\begin{array}{l}\text { Sul- } \\
\text { fate } \\
\text { (SO) }\end{array}\right.$ & $\begin{array}{l}\text { Chlo- } \\
\text { ride } \\
\text { (Cl) }\end{array}$ & $\begin{array}{l}\mathrm{Ni}- \\
\text { trate } \\
\text { (NO) }\end{array}$ & $\begin{array}{l}\text { Dis- } \\
\text { solved } \\
\text { solids }\end{array}$ & $\begin{array}{l}\text { Total } \\
\text { hard- } \\
\text { ness } \\
\text { as } \\
\mathrm{CaCO}_{3}\end{array}$ \\
\hline 1941 & & & & & & & & & & & & \\
\hline eb. 19 & 0 & 110 & 34.2 & 60 & 6.1 & 2.9 & 197 & 1.2 & 13 & & 180 & 175 \\
\hline Apr. 25 & 0 & 110 & & 61 & 6.8 & 5.4 & 207 & & 15 & 0.2 & 191 & 180 \\
\hline June 5 & 0 & ... & 40.3 & ....... & .......... & ......+*... & 239 & ..... & 19 & ..... & |......... & $\cdots \cdots \cdots$ \\
\hline July 29 & 0 & ...... & 29.1 & $\mid \ldots . .$. & ......... & $+\ldots+\ldots \ldots$ & 158 & ..... & 9 & $\cdots$ & $\cdots \cdots \cdots$ & $+\ldots+\ldots$ \\
\hline Aug. 28 & 0 & & 32.2 & $+\cdots \cdots$ & ......... & $1+\cdots+\cdots$ & 178 & $\ldots .$. & & f..... & …....... & $+\cdots++\ldots$ \\
\hline Oct. 8 & 0 & & 25.1 & *n..... & ......... & ........... & 136 & ....* & 13 & ...... & 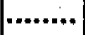 & $+*+\cdots * *$ \\
\hline Dec. 31 & 0 & & 39.3 & $\ldots \ldots$ & .......... & $\cdots \ldots$ & 220 & $\because \ldots$ & 19 & $\cdots$ & ד.... & 177 \\
\hline 25 & 2 & 110 & 36.6 & 60 & 6.6 & 10 & 21 & 1 & 16 & .1 & 199. & 177 \\
\hline Aug. 28 & 2 & ..... & 29.5 & ...... & ".........." & $\mid . . . . . . .$. & 165 & ...... & 12 & ...... & $\mid \cdots \ldots . .$. & 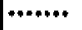 \\
\hline Oct. 8 & 2 & & & . & ........... & $\ldots \ldots .$. & 127 & ...... & 19 & ..... & a..., , . & $\mid * * \cdots+* * *$ \\
\hline Nov. 25 & 2 & ....... & 36.7 & *n...e. & .......... & $\mid+\cdots \cdots \cdots$ & 191 & ..... & 26 & $\ldots$ & $\ldots . . . .$. & $\cdots \cdots$ \\
\hline & 2 & ..... & 40 & $\ldots \ldots$ & ........*4 & +............ & 226 & $\ldots$ & 18 & $\cdots \cdot$ & 188 & $\ldots$ \\
\hline & 5 & 110 & 34.2 & 59 & 10 & ............... & 196 & 1.0 & 16 & ...... & 188 & 188 \\
\hline
\end{tabular}


mani canal,

Miami Canal is not excavated in rock north of a point about $\frac{1}{4}$ mile north of its junction with the South New River Canal. Consequently, the discharge of the canal consists largely of runoff derived from areas south of the junction with South New River Canal. During rainy periods, considerable surface water flows from the Everglades through breaks in the rock spoil banks into the excavated part of Miami Canal and also into South New River Canal. There is a dam in Miami Canal at the Dade-Broward County line that prevents direct flow from the upper to the lower part of the canal. The excess water spills into the Everglades at this point and some of it probably finds its way back into the lower part of the canal through the ground. Gates have been placed in the dam so that water can be discharged directly from the upper to the lower part of the canal. Normally, however, all of the flow in Miami Canal, as measured at Water Plant, Hialeah, is derived from surface and ground water inflow below the County Line Dam.

Analyses of 10-day composites of daily samples collected from Miami Canal at Water Plant during the year ending February 28, 1942 , show that the composition of the water was fairly uniform. (See table 94.) Dissolved solids rangedfrom 282 to $328 \mathrm{ppm}$ and hardness from 207 to $254 \mathrm{ppm}$. Color ranged from 80 to 120 in the same period. Table 95 contains additional analyses for the period August 1943 to June 1948. Variation in dissolved solids and discharge are compared graphically in figure 219.

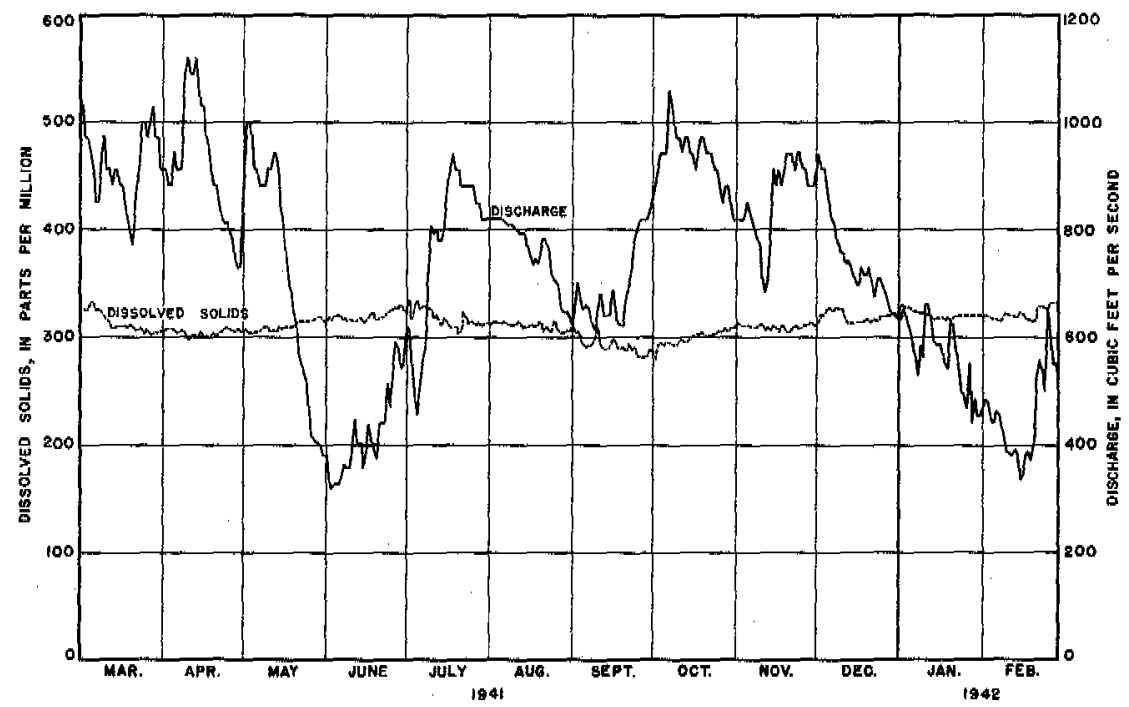

Figure 219. -Graph of discharge and dijsolved solids in Mlami Canal at Water Plant, Hialeah, $1941-42$. 
Table 94.-Analyses, in parts per million, of 10-day compasite samples of water from Miami Canal at Water Plant, Hialeah

\begin{tabular}{|c|c|c|c|c|c|c|c|c|c|c|c|c|c|c|c|c|}
\hline $\begin{array}{c}\text { Date } \\
\text { of } \\
\text { collection }\end{array}$ & $\begin{array}{c}\text { Mean } \\
\text { dischargee } \\
\text {. (cfs) }\end{array}$ & Color & $\begin{array}{c}\text { Specific } \\
\text { conductance } \\
\left(\mathrm{K} \times 10^{5}\right. \\
\text { at } 25 \mathrm{C})\end{array}$ & $\left|\begin{array}{l}\text { Silica } \\
\left(\mathrm{SiO}_{2}\right)\end{array}\right|$ & $\begin{array}{l}\text { Iron } \\
\text { (Fe) }\end{array}$ & $\begin{array}{c}\text { Calcium } \\
\text { (Ca) }\end{array}$ & $\begin{array}{c}\text { Magnesium } \\
\text { (Mg) }\end{array}$ & $\begin{array}{c}\text { Sodium } \\
\text { (Na) }\end{array}$ & $\begin{array}{c}\text { Potassium } \\
\text { (K) }\end{array}$ & $\begin{array}{c}\text { Bicarbonate } \\
\left(\mathrm{HCO}_{5}\right)\end{array}$ & $\left\{\begin{array}{l}\text { Sulfate } \\
\left(\mathrm{SO}_{4}\right)\end{array}\right.$ & $\begin{array}{c}\text { Chloride } \\
\text { (Cl) }\end{array}$ & $\begin{array}{c}\text { Fluoride } \\
\text { (F) }\end{array} \mid$ & $\begin{array}{c}\text { Nimate } \\
\left(\mathrm{NO}_{y}\right)\end{array}$ & $\begin{array}{c}\text { Dissolved } \\
\text { solids }\end{array}$ & $\begin{array}{c}\text { Total } \\
\text { hardness } \\
\text { as } \\
\mathrm{CaCO}_{\mathrm{g}}\end{array}$ \\
\hline 1941 & & & & & & & & & & & & & & & & \\
\hline $\begin{array}{lr}\text { Mar. } & 2-10 \\
\text { Mar. } & 11-20 \\
\text { Mar. } & 21-31 \\
\text { Apr. } & 1-10 \\
\text { Apr. } & 11-20 \\
\text { Apr. } & 21-30\end{array}$ & $\begin{array}{l}925 \\
862 \\
960 \\
965 \\
992 \\
796\end{array}$ & $\begin{array}{l}90 \\
80 \\
85 \\
85 \\
90 \\
90\end{array}$ & $\begin{array}{l}47.4 \\
46.8 \\
46.1 \\
45.7 \\
45.4 \\
45.8\end{array}$ & $\begin{array}{r}7.5 \\
6.0 \\
4.6 \\
5.6 \\
5.6\end{array}$ & $\begin{array}{r}0.08 \\
.05 \\
.12 \\
.12 \\
.14 \\
.18\end{array}$ & $\begin{array}{l}84 \\
84 \\
83 \\
81 \\
80 \\
82\end{array}$ & $\begin{array}{l}7.1 \\
6.5 \\
6.8 \\
6.4 \\
6.3 \\
6.6\end{array}$ & $\begin{array}{l}14 \\
13 \\
12 \\
13 \\
13 \\
13\end{array}$ & $\begin{array}{r}1.0 \\
1.0 \\
.9 \\
1.0 \\
.9 \\
1.0\end{array}$ & $\begin{array}{l}266 \\
264 \\
258 \\
257 \\
256 \\
259\end{array}$ & $\begin{array}{l}5.4 \\
5.4 \\
5.0 \\
5.1 \\
4.7 \\
4.8\end{array}$ & $\begin{array}{l}21 \\
21 \\
21 \\
22 \\
21 \\
21\end{array}$ & $\begin{array}{r}0.1 \\
.1 \\
.1 \\
.1 \\
.1 \\
.1\end{array}$ & $\begin{array}{l}1.4 \\
1.4 \\
1.4 \\
1.3 \\
1.1 \\
1.1\end{array}$ & $\begin{array}{l}32 b \\
308 \\
303 \\
300 \\
299 \\
303\end{array}$ & $\begin{array}{l}239 \\
236 \\
235 \\
228 \\
226 \\
232\end{array}$ \\
\hline $\begin{array}{lr}\text { May } & 1-10 \\
\text { May } & 11-20 \\
\text { May } & 21-31 \\
\text { June } & 1-10 \\
\text { June } & 11-20 \\
\text { June } & 21-30\end{array}$ & $\begin{array}{l}926 \\
787 \\
459 \\
347 \\
409 \\
532\end{array}$ & $\begin{array}{l}90 \\
90 \\
90 \\
90 \\
90 \\
85\end{array}$ & $\begin{array}{l}45.9 \\
46.6 \\
47.4 \\
47.8 \\
48.3 \\
49.5\end{array}$ & $\begin{array}{l}5.2 \\
6.8 \\
4.5 \\
6.3 \\
8.3 \\
7.8\end{array}$ & $\begin{array}{l}.20 \\
.27 \\
.22 \\
.26 \\
.04 \\
.10\end{array}$ & $\begin{array}{l}82 \\
83 \\
85 \\
86 \\
85 \\
87\end{array}$ & $\begin{array}{l}6.6 \\
6.4 \\
6.8 \\
7.0 \\
7.0 \\
7.1\end{array}$ & $\begin{array}{l}12 \\
12 \\
12 \\
13 \\
13 \\
13\end{array}$ & $\begin{array}{l}1.0 \\
1.0 \\
.8 \\
1.1 \\
1.2 \\
1.1\end{array}$ & $\begin{array}{l}259 \\
262 \\
267 \\
271 \\
270 \\
278\end{array}$ & $\begin{array}{l}4.7 \\
4.8 \\
4.9 \\
4.2 \\
4.8 \\
3.0\end{array}$ & $\begin{array}{l}21 \\
21 \\
22 \\
25 \\
24 \\
22\end{array}$ & $\begin{array}{l}.1 \\
.1 \\
.1 \\
.1 \\
.2 \\
.2\end{array}$ & $\begin{array}{l}1.5 \\
1.4 \\
1.7 \\
2.1 \\
1.2 \\
1.0\end{array}$ & $\begin{array}{l}304 \\
309 \\
314 \\
317 \\
316 \\
324\end{array}$ & $\begin{array}{l}232 \\
233 \\
240 \\
243 \\
241 \\
246\end{array}$ \\
\hline $\begin{array}{lr}\text { July } & 1-10 \\
\text { July } & 11-20 \\
\text { July } & 21-23\end{array}$ & $\begin{array}{l}606 \\
861\end{array}$ & $\begin{array}{l}90 \\
90\end{array}$ & $\begin{array}{l}49.6 \\
46.6\end{array}$ & $\begin{array}{l}8.2 \\
9.0\end{array}$ & .10 & $\begin{array}{l}86 \\
82\end{array}$ & $\begin{array}{l}7.0 \\
5.9\end{array}$ & $\begin{array}{l}13 \\
11\end{array}$ & $\begin{array}{l}1.2 \\
1.2\end{array}$ & $\begin{array}{l}276 \\
254\end{array}$ & $\begin{array}{l}10 \\
13\end{array}$ & $\begin{array}{l}20 \\
18\end{array}$ & .2 & $\begin{array}{l}1.0 \\
1.1\end{array}$ & $\begin{array}{l}326 \\
314\end{array}$ & $\begin{array}{l}244 \\
229\end{array}$ \\
\hline $\begin{array}{lr} & 25-31 \\
\text { Aug. } & 1-4 \\
6-10 \\
\\
\text { Aug. } 11-20 \\
\text { Aug. } 21-31\end{array}$ & $\begin{array}{l}853 \\
814 \\
767 \\
688\end{array}$ & $\begin{array}{l}110 \\
110 \\
110 \\
110\end{array}$ & $\begin{array}{l}45.9 \\
45.8 \\
45.7 \\
45.2\end{array}$ & $\begin{array}{r}7.9 \\
8.1 \\
8.3 \\
11\end{array}$ & $\begin{array}{r}.03 \\
.05 \\
.06 \\
.02\end{array}$ & $\begin{array}{l}83 \\
82 \\
81 \\
80\end{array}$ & $\begin{array}{l}6.7 \\
6.6 \\
6.8 \\
6.7\end{array}$ & $\begin{array}{l}11 \\
11 \\
12 \\
13\end{array}$ & $\begin{array}{l}1.2 \\
1.1 \\
1.2 \\
1.3\end{array}$ & $\begin{array}{l}262 \\
263 \\
261 \\
259\end{array}$ & $\begin{array}{l}10 \\
7.0 \\
5.7 \\
4.7\end{array}$ & $\begin{array}{l}18 \\
20 \\
20 \\
20\end{array}$ & $\begin{array}{l}.2 \\
.1 \\
.2 \\
.2 \\
.\end{array}$ & $\begin{array}{r}1.0 \\
.7 \\
.8 \\
.9\end{array}$ & $\begin{array}{l}315 \\
311 \\
311 \\
311\end{array}$ & $\begin{array}{l}234 \\
232 \\
230 \\
227\end{array}$ \\
\hline $\begin{array}{lr}\text { Sept. } & 1-10 \\
\text { Sept. } & 11-20 \\
\text { Sept. } & 21-30 \\
\text { Oct. } & 1-10 \\
\text { Oct. } & 11-18\end{array}$ & $\begin{array}{r}655 \\
648 \\
796 \\
1.010\end{array}$ & $\begin{array}{l}110 \\
110 \\
120 \\
120\end{array}$ & $\begin{array}{l}44.3 \\
44.0 \\
40.7 \\
41.8\end{array}$ & $\begin{array}{l}7.1 \\
5.5 \\
6.2 \\
5.8\end{array}$ & $\begin{array}{r}.05 \\
.04 \\
.13 \\
.02\end{array}$ & $\begin{array}{l}78 \\
78 \\
73 \\
76\end{array}$ & $\begin{array}{l}6.4 \\
6.5 \\
6.1 \\
6.3\end{array}$ & $\begin{array}{l}12 \\
12 \\
10 \\
11\end{array}$ & $\begin{array}{l}1.1 \\
1.0 \\
1.6 \\
1.3\end{array}$ & $\begin{array}{l}253 \\
258 \\
23 \mathrm{~b} \\
239\end{array}$ & $\begin{array}{l}4.1 \\
3.9 \\
4.0 \\
4.9\end{array}$ & $\begin{array}{l}19 \\
20 \\
16 \\
18\end{array}$ & $\begin{array}{l}.2 \\
.2 \\
.3 \\
3\end{array}$ & $\begin{array}{r}1.0 \\
.9 \\
.9 \\
1.0\end{array}$ & $\begin{array}{l}302 \\
298 \\
282 \\
287\end{array}$ & $\begin{array}{l}221 \\
221 \\
207 \\
216\end{array}$ \\
\hline $\begin{array}{ll} & 20 \\
\text { Oct. } & 21-31\end{array}$ & $\begin{array}{l}922 \\
837\end{array}$ & $\begin{array}{l}120 \\
110\end{array}$ & $\begin{array}{l}43.1 \\
44.0\end{array}$ & $\begin{array}{l}5.3 \\
5.6\end{array}$ & .13 & $\begin{array}{l}78 \\
79\end{array}$ & $\begin{array}{l}7.0 \\
6.6\end{array}$ & $\begin{array}{l}11 \\
12\end{array}$ & $\begin{array}{l}1.3 \\
1.2\end{array}$ & $\begin{array}{l}249 \\
253\end{array}$ & $\begin{array}{l}4.3 \\
4.0\end{array}$ & $\begin{array}{l}20 \\
19\end{array}$ & $\begin{array}{r}.3 \\
.3\end{array}$ & $\begin{array}{l}.9 \\
.9\end{array}$ & $\begin{array}{l}296 \\
304\end{array}$ & $\begin{array}{l}224 \\
224\end{array}$ \\
\hline $\begin{array}{lr}\text { Nov. } & 1-10 \\
\text { Nov. } & 11-20 \\
\text { Nov. } & 21-30 \\
\text { Dec. } & 2-10\end{array}$ & $\begin{array}{l}797 \\
869 \\
848 \\
781\end{array}$ & $\begin{array}{r}110 \\
110 \\
95 \\
95\end{array}$ & $\begin{array}{l}44.8 \\
44.8 \\
44.6 \\
45.0\end{array}$ & $\begin{array}{l}6.6 \\
7.2 \\
8.3 \\
6.0\end{array}$ & $\begin{array}{l}.07 \\
.13 \\
.07 \\
.08\end{array}$ & $\begin{array}{l}80 \\
81 \\
81 \\
82\end{array}$ & $\begin{array}{l}6.3 \\
6.4 \\
7.2 \\
6.9\end{array}$ & $\begin{array}{l}12 \\
12 \\
12 \\
12\end{array}$ & $\begin{array}{l}1.2 \\
1.2 \\
2.0 \\
1.9\end{array}$ & $\begin{array}{l}255 \\
257 \\
257 \\
261\end{array}$ & $\begin{array}{l}5.1 \\
5.4 \\
5.0 \\
5.0\end{array}$ & $\begin{array}{l}20 \\
19 \\
20 \\
20\end{array}$ & $\begin{array}{l}.3 \\
.3 \\
.2 \\
.2\end{array}$ & $\begin{array}{l}1.5 \\
1.3 \\
1.0 \\
1.4\end{array}$ & $\begin{array}{l}308 \\
306 \\
305 \\
313\end{array}$ & $\begin{array}{l}226 \\
228 \\
232 \\
233\end{array}$ \\
\hline
\end{tabular}




\begin{tabular}{|c|c|c|c|c|c|c|c|c|c|c|c|c|c|c|c|c|}
\hline $\begin{array}{c}\text { Dec. } 11-20 \\
\text { Dec. } 21-31 \\
1942\end{array}$ & $\begin{array}{l}698 \\
643\end{array}$ & $\begin{array}{l}95 \\
90\end{array}$ & $\begin{array}{r}46.1 \\
46.6\end{array}$ & $\begin{array}{l}6.1 \\
6.0\end{array}$ & $\begin{array}{l}.12 \\
.13\end{array}$ & $\begin{array}{l}84 \\
85\end{array}$ & $\begin{array}{l}7.3 \\
7.0\end{array}$ & $\begin{array}{l}12 \\
11\end{array}$ & $\begin{array}{l}1.4 \\
1.5\end{array}$ & $\begin{array}{l}268 \\
269\end{array}$ & $\begin{array}{r}5.2 \\
5.2\end{array}$ & $\begin{array}{l}20 \\
19\end{array}$ & $\begin{array}{l}.2 \\
.2\end{array}$ & $\begin{array}{l}1.4 \\
1.7\end{array}$ & $\begin{array}{l}310 \\
314\end{array}$ & $\begin{array}{l}240 \\
241\end{array}$ \\
\hline $\begin{array}{lr}\text { Jan. } & 1-10 \\
\text { Jan. } & 11-20 \\
\text { Jan. } & 21-31 \\
\text { Feb. } & 1-10 \\
\text { Feb. } & 11-19 \\
\text { Feb. } & 20-28\end{array}$ & $\begin{array}{l}602 \\
602 \\
526 \\
477 \\
440 \\
494\end{array}$ & $\begin{array}{l}90 \\
90 \\
90 \\
90 \\
90 \\
90\end{array}$ & $\begin{array}{l}46.5 \\
48.9 \\
49.3 \\
49.1 \\
48.9 \\
49.8\end{array}$ & $\begin{array}{l}5.6 \\
5.9 \\
5.7 \\
5.5 \\
5.7 \\
5.2\end{array}$ & $\begin{array}{l}.17 \\
.08 \\
.07 \\
.09 \\
.10 \\
.16\end{array}$ & $\begin{array}{l}85 \\
87 \\
88 \\
88 \\
88 \\
90\end{array}$ & $\begin{array}{l}7.3 \\
6.7 \\
6.9 \\
6.9 \\
7.0 \\
7.2\end{array}$ & $\begin{array}{l}12 \\
13 \\
12 \\
13 \\
12 \\
12\end{array}$ & $\begin{array}{l}1.8 \\
1.3 \\
1.4 \\
1.4 \\
1.4 \\
1.2\end{array}$ & $\begin{array}{l}275 \\
277 \\
279 \\
281 \\
280 \\
289\end{array}$ & $\begin{array}{l}5.2 \\
5.2 \\
5.1 \\
4.7 \\
4.3 \\
5.5\end{array}$ & $\begin{array}{l}20 \\
20 \\
20 \\
20 \\
21 \\
20\end{array}$ & $\begin{array}{l}.2 \\
.1 \\
.1 \\
.1 \\
.0 \\
.1\end{array}$ & $\begin{array}{l}1.6 \\
1.8 \\
2.0 \\
1.8 \\
2.0 \\
2.0\end{array}$ & $\begin{array}{l}316 \\
318 \\
322 \\
321 \\
320 \\
328\end{array}$ & $\begin{array}{l}242 \\
244 \\
248 \\
248 \\
248 \\
254\end{array}$ \\
\hline Average & ................... & 97 & 46.2 & 6.6 & 0.11 & 83 & 6.7 & 12 & 1.2 & 263 & 5.4 & 20 & 0,2 & 1.3 & 310 & 235 \\
\hline
\end{tabular}


Table 95. - Analyses, in parts per million, of water from Miami Canal at Water Plant, Hialeah

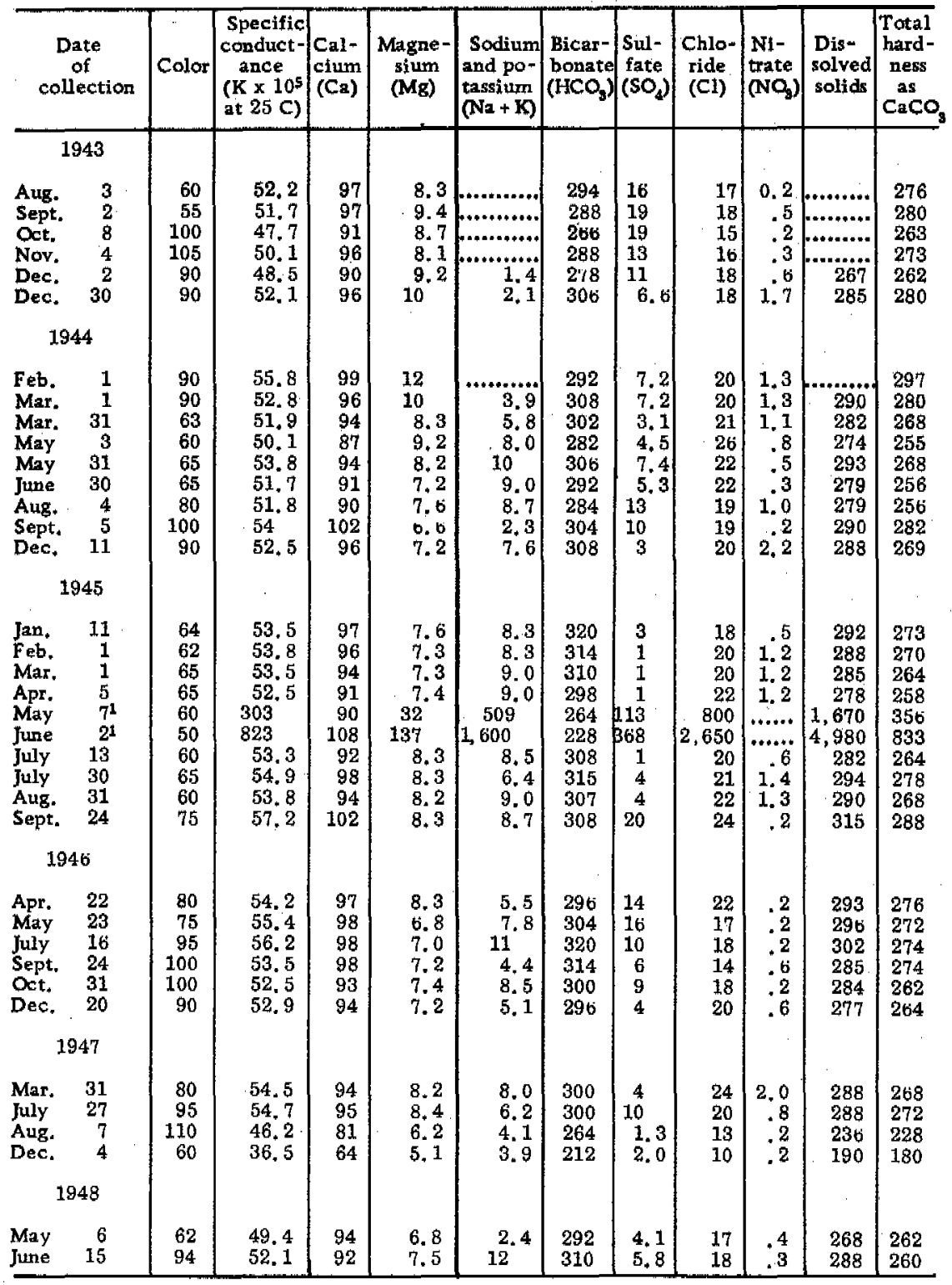

${ }^{1}$ Graph of discharge of Miami Canal during this period shows that net discharge was zero. See figures $117-123$. 
The nearly uniform composition of the water in Miami Canal may be explained as follows:

The saline ground waters known to be present in the vicinity of North New River Canal and also along the middle reaches of Miami Canal apparently have been flushed out of the shallow strata south of South New River Canal. Consequently, the only source of mineral matter is the limestone rock through which most of the water percolates before reaching the canal. Since there is little direct runoff into the canal, except during rains of high intensity, most of the surface water travels at least a short distance through the permeable limestone and becomes charged with a fairly uniform amount of calcium bicarbonate and other soluble constituents.

See table 96 for analyses of samples north of the dam at the Dade-Broward County line and table 97 for samples between Biscayne Bay and Pennsuco. Analyses of samples at Lake Harbor are given in table 101. The ranges in concentration of dissolved mineral matter in Miami and North New River Canals are shown graphically in figure 220 , 
Table 96. - Analyses, in parts per miltion, of water from Miami Canal northof dan at Dade-Broward County line

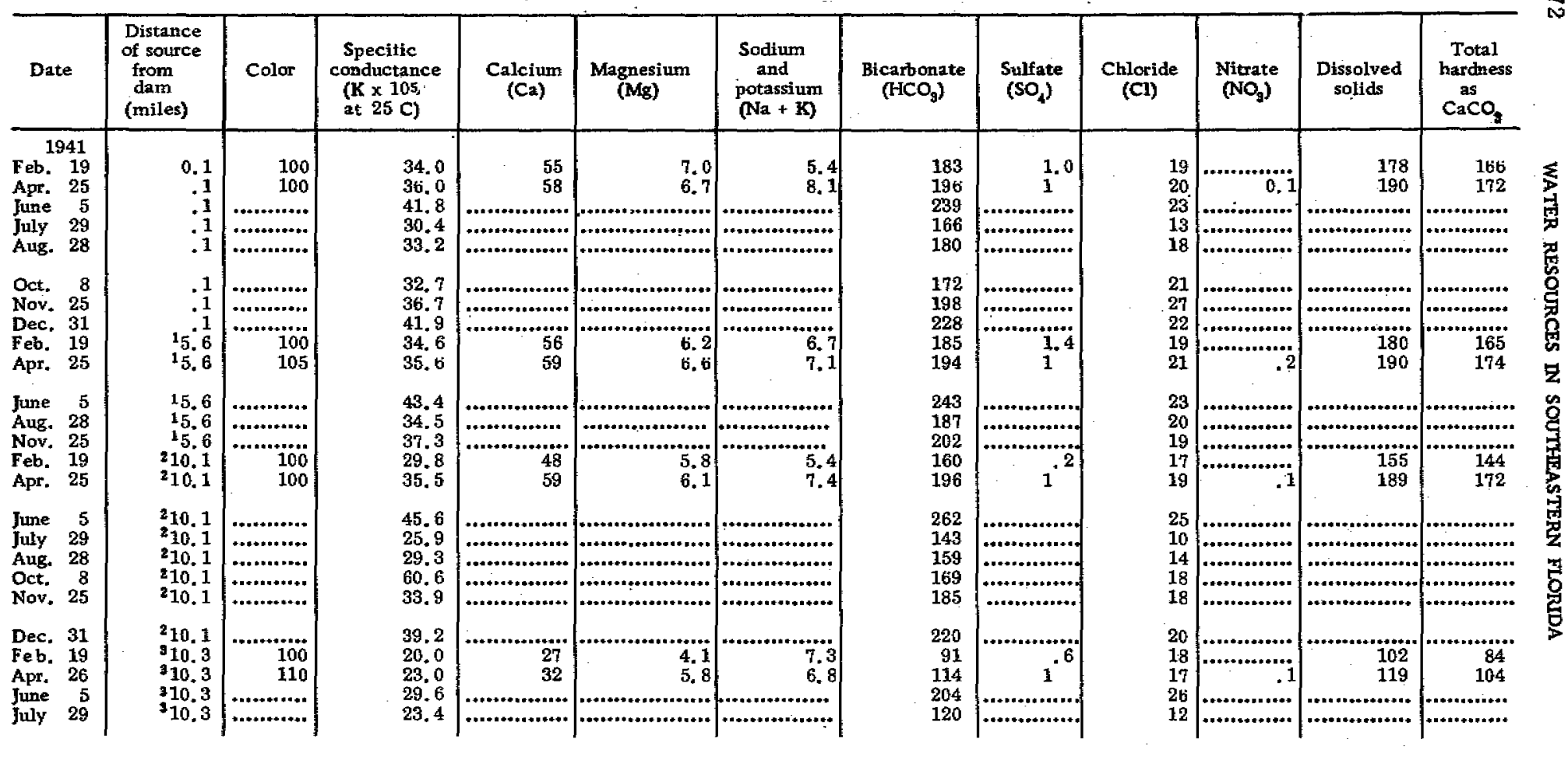




\begin{tabular}{|c|c|c|c|c|c|c|c|c|c|c|c|c|}
\hline $\begin{array}{l}\text { Aug. } 28 \\
\text { Oct. } 8 \\
\text { Nov. } 25 \\
\text { Dec. } 31\end{array}$ & $\begin{array}{l}s_{10.3} \\
s_{10.3} \\
3_{10.3} \\
9_{10.3}\end{array}$ & 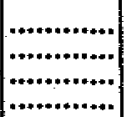 & $\begin{array}{l}26.6 \\
27.2 \\
28.1 \\
44.6\end{array}$ & 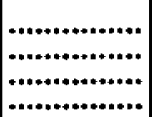 & 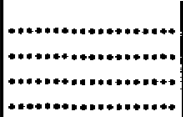 & 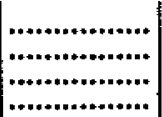 & $\begin{array}{l}131 \\
142 \\
143 \\
252\end{array}$ & & $\begin{array}{l}19 \\
17 \\
19 \\
23\end{array}$ & 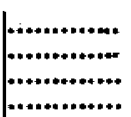 & 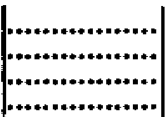 & 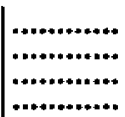 \\
\hline
\end{tabular}


Table 97. - Analyses, in parts per million, of water from Mirmi Cmal between Royal Palm Dock in Biscayne Bay and Pentrsuco, near Hialeah

\begin{tabular}{|c|c|c|c|c|c|c|c|c|c|c|c|c|}
\hline Date & $\begin{array}{c}\text { Distance } \\
\text { of source } \\
\text { from } \\
\text { Royal Palm } \\
\text { Dock } \\
\text { (miles) }\end{array}$ & Color & $\begin{array}{l}\text { Specific } \\
\text { conductance } \\
\left(\mathrm{K} \times 10^{5}\right. \\
\text { at } 25 \mathrm{C})\end{array}$ & $\begin{array}{l}\text { Calcium } \\
\text { (Ca) }\end{array}$ & $\begin{array}{l}\text { Magnesium } \\
\text { (Mg) }\end{array}$ & $\begin{array}{l}\text { Sodium } \\
\text { and } \\
\text { potassium } \\
(\mathrm{Na}+\mathrm{K})\end{array}$ & $\begin{array}{c}\text { Bicarbonate } \\
\left(\mathrm{HCO}_{9}\right)\end{array}$ & $\begin{array}{l}\text { Sulfate } \\
\left(\mathrm{SO}_{4}\right)\end{array}$ & $\begin{array}{l}\text { Chloride } \\
\text { (Cl) }\end{array}$ & $\begin{array}{l}\text { Nitrate } \\
\left(\mathrm{NO}_{3}\right)\end{array}$ & $\begin{array}{c}\text { Dissolved } \\
\text { solids }\end{array}$ & $\begin{array}{c}\text { Total } \\
\text { hardness } \\
\text { as } \\
\mathrm{CaCO}\end{array}$ \\
\hline \begin{tabular}{ll}
\multicolumn{2}{c}{1939} \\
Dec. 10 \\
Dec. 10 \\
Dec. 10 \\
Dec. 10 \\
Dec. 10
\end{tabular} & $\begin{array}{r}10 \\
1.2 \\
1.7 \\
11.6 \\
3.8\end{array}$ & 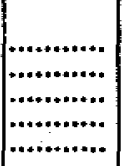 & $\begin{array}{c}1,740 \\
683 \\
469 \\
196 \\
55.3\end{array}$ & $\begin{array}{r}188 \\
128 \\
115 \\
102 \\
91\end{array}$ & $\begin{array}{r}400 \\
143 \\
97 \\
35 \\
9.5\end{array}$ & $\begin{array}{r}3,240 \\
1,130 \\
737 \\
246 \\
14\end{array}$ & $\begin{array}{l}239 \\
261 \\
264 \\
268 \\
269\end{array}$ & $\begin{array}{r}828 \\
294 \\
210 \\
81 \\
24\end{array}$ & $\begin{array}{r}5,750 \\
2,020 \\
1,320 \\
446 \\
36\end{array}$ & |............... & $\begin{array}{r}10,500 \\
2,830 \\
2,600 \\
1,040 \\
308\end{array}$ & $\begin{array}{r}2,110 \\
907 \\
686 \\
398 \\
266\end{array}$ \\
\hline $\begin{array}{l}\text { Dec. } 9 \\
\text { Dec. } 13\end{array}$ & $\begin{array}{r}7.6 \\
15.0\end{array}$ & $\mid \ldots \ldots . . . . . .$. & $\begin{array}{l}50.5 \\
49.2\end{array}$ & $\begin{array}{l}90 \\
87\end{array}$ & $\begin{array}{l}8.0 \\
7.9\end{array}$ & $\begin{array}{l}8.5 \\
6.8\end{array}$ & $\begin{array}{l}277 \\
273\end{array}$ & $\begin{array}{l}20 \\
12\end{array}$ & $\begin{array}{l}20 \\
20\end{array}$ & 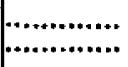 & $\begin{array}{l}283 \\
268\end{array}$ & $\begin{array}{l}258 \\
250\end{array}$ \\
\hline
\end{tabular}

1 Contaminated with sea water. 


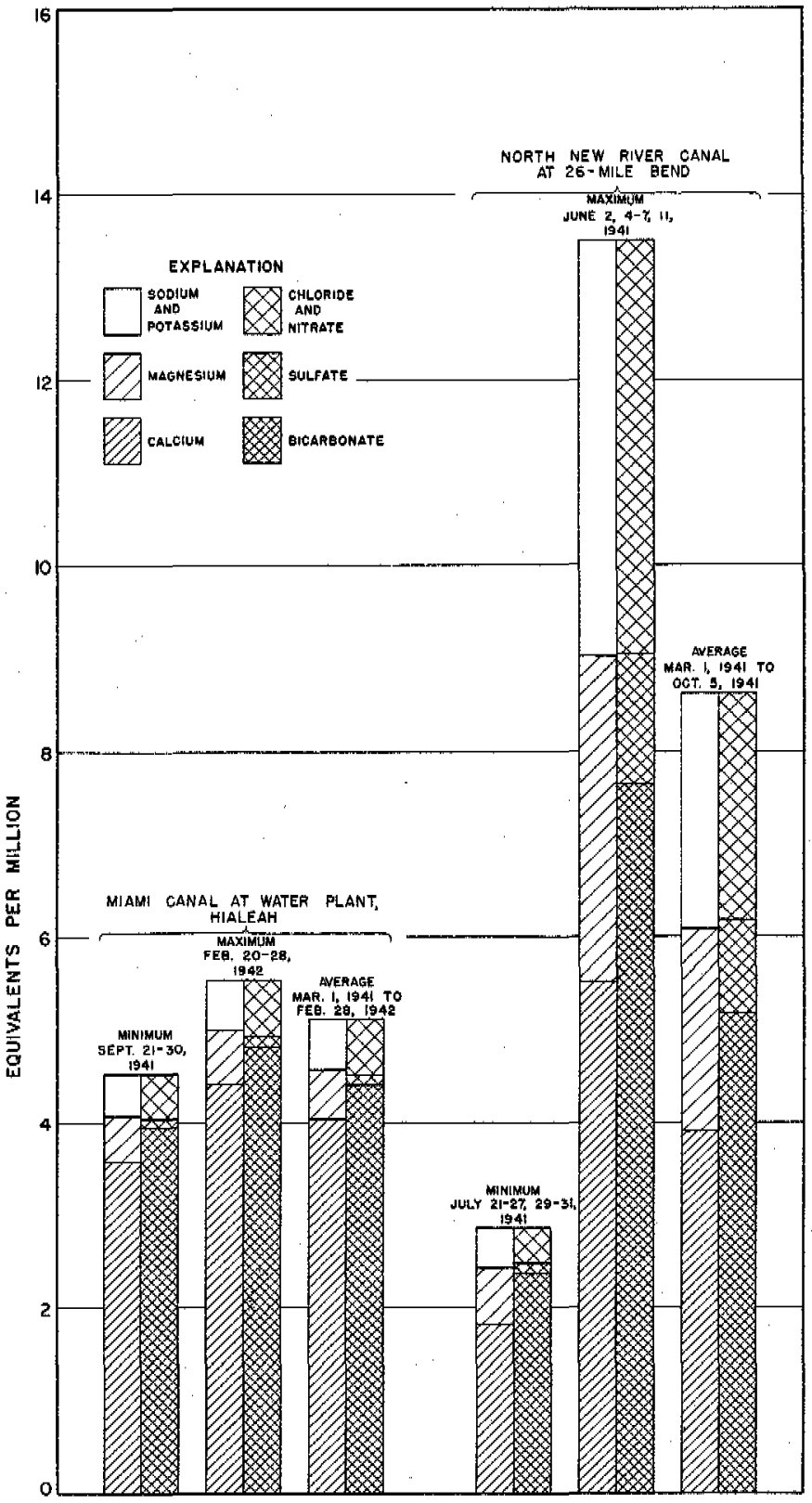

Figure 220. -Graph showing analyses of waters of Miami and North New River Canals. 
Table 98, - Analyses, in parts per million, of water ttom Cypress Creek Canal, at

\begin{tabular}{|c|c|c|c|c|c|c|c|c|c|c|c|}
\hline $\begin{array}{l}\text { Date } \\
\text { of } \\
\text { collection }\end{array}$ & Color & $\begin{array}{l}\text { Specific } \\
\text { conduct- } \\
\text { ance } \\
(\mathrm{K} \times 105 \\
\text { at } 25 \mathrm{C})\end{array}$ & $\begin{array}{c}\text { Cal- } \\
\text { cium } \\
(\mathrm{Ca})\end{array}$ & $\begin{array}{c}\text { Magne- } \\
\text { sium } \\
(\mathrm{Mg})\end{array}$ & $\begin{array}{l}\text { Sodium } \\
\text { and po- } \\
\text { tassium } \\
(\mathrm{Na}+\mathrm{K})\end{array}$ & $\left\{\begin{array}{l}\text { Bicar- } \\
\text { bonate } \\
\left(\mathrm{HCO}_{3}\right)\end{array}\right.$ & $\begin{array}{l}\mathrm{Sul}- \\
\text { fate } \\
\left(\mathrm{SO}_{4}\right)\end{array}$ & $\begin{array}{l}\text { Chlo- } \\
\text { ride } \\
\text { (Cl) }\end{array}$ & $\begin{array}{l}\mathrm{Ni}- \\
\text { trate } \\
\left(\mathrm{NO}_{3}\right)\end{array}$ & $\begin{array}{l}\text { Dis- } \\
\text { solved } \\
\text { solids }\end{array}$ & $\begin{array}{c}\text { Total } \\
\text { hard- } \\
\text { ness } \\
\text { as } \\
\text { CaCO }\end{array}$ \\
\hline 1941 & & & & & & & & & & & \\
\hline $\begin{array}{lr}\text { Mar. } & 26 \\
\text { Apr. } & 22 \\
\text { May } & 21 \\
\text { July } & 3 \\
\text { Aug. } & 22 \\
\text { Sept. } & 26 \\
\text { Oct. } & 23 \\
\text { Nov. } & 26 \\
\text { Dec. } & 26\end{array}$ & $\begin{array}{r}70 \\
70 \\
50 \\
100 \\
120 \\
240 \\
90 \\
90 \\
70\end{array}$ & $\begin{array}{l}50.4 \\
44.2 \\
44.1 \\
52.6 \\
50.1 \\
28.2 \\
46.9 \\
48.3 \\
47.7\end{array}$ & $\begin{array}{r}92 \\
84 \\
83 \\
102 \\
93 \\
40 \\
96 \\
88 \\
89\end{array}$ & $\begin{array}{l}6.1 \\
3.5 \\
3.5 \\
3.9 \\
4.6 \\
3.1 \\
3.3 \\
2.8 \\
3.3\end{array}$ & $\begin{array}{l}14 \\
8.8 \\
10 \\
7.4 \\
11 \\
20 \\
9.2 \\
14 \\
11\end{array}$ & $\begin{array}{l}254 \\
238 \\
242 \\
257 \\
264 \\
147 \\
268 \\
245 \\
258\end{array}$ & $\begin{array}{l}35 \\
16 \\
13 \\
33 \\
23 \\
13 \\
20 \\
21 \\
14\end{array}$ & $\begin{array}{l}29 \\
22 \\
21 \\
29 \\
25 \\
15 \\
23 \\
27 \\
23\end{array}$ & $\begin{array}{r}0.4 \\
.5 \\
2.5 \\
.5 \\
.4 \\
.0 \\
.4 \\
.5 \\
.3\end{array}$ & $\begin{array}{l}302 \\
307 \\
252 \\
302 \\
287 \\
164 \\
284 \\
274 \\
268\end{array}$ & $\begin{array}{l}255 \\
224 \\
222 \\
271 \\
251 \\
113 \\
253 \\
231 \\
236\end{array}$ \\
\hline 1942 & & & & & & & & & & & \\
\hline $\begin{array}{lr}\text { Jan, } & 22 \\
\text { Feb. } & 19 \\
\text { Apr. } & 8 \\
\text { May } & 7 \\
\text { June } & 4 \\
\text { July } & 9 \\
\text { Aug. } & 6 \\
\text { Sept. } & 3 \\
\text { Oct. } & 8 \\
\text { Nov. } & 11 \\
\text { Dec. } & 10\end{array}$ & $\begin{array}{r}100 \\
90 \\
60 \\
90 \\
130 \\
110 \\
95 \\
120 \\
45 \\
45 \\
150\end{array}$ & $\begin{array}{l}26.1 \\
44.5 \\
49.2 \\
45.4 \\
44.2 \\
43.9 \\
47.1 \\
40.0 \\
48.8 \\
45.2 \\
47.4\end{array}$ & $\begin{array}{l}38 \\
80 \\
93 \\
80 \\
74 \\
79 \\
86 \\
67 \\
90 \\
86 \\
70\end{array}$ & $\begin{array}{l}1.6 \\
3.1 \\
3.5 \\
4.1 \\
3.7 \\
3.1 \\
4.1 \\
6.8 \\
2.6 \\
2.2 \\
7.0\end{array}$ & $\begin{array}{c}14 \\
12 \\
8.3 \\
11 \\
17 \\
11 \\
4.5 \\
2.8 \\
10 \\
7.8 \\
21\end{array}$ & $\begin{array}{l}102 \\
235 \\
258 \\
234 \\
204 \\
232 \\
247 \\
160 \\
260 \\
244 \\
187\end{array}$ & $\begin{array}{l}24 \\
15 \\
16 \\
16 \\
33 \\
12 \\
10 \\
39 \\
14 \\
12 \\
38\end{array}$ & $\begin{array}{l}16 \\
21 \\
26 \\
22 \\
25 \\
22 \\
20 \\
21 \\
21 \\
20 \\
38\end{array}$ & $\begin{array}{r}.6 \\
.2 \\
.2 \\
.4 \\
.0 \\
.1 \\
.1 \\
.2 \\
.3 \\
.3 \\
2.6\end{array}$ & $\begin{array}{l}144 \\
247 \\
274 \\
249 \\
253 \\
242 \\
246 \\
216 \\
266 \\
248 \\
269\end{array}$ & $\begin{array}{l}101 \\
212 \\
246 \\
216 \\
200 \\
210 \\
231 \\
194 \\
235 \\
224 \\
204\end{array}$ \\
\hline 18 & & & & & & & & & & & \\
\hline $\begin{array}{ll}\text { lan. } & 7 \\
\text { eb. } & 4 \\
\text { Mar. } & 4 \\
\text { Apr. } & 2 \\
\text { May } & 6 \\
\text { lune } & 2 \\
\text { luly } & 7\end{array}$ & $\begin{array}{l}60 \\
60 \\
45 \\
40 \\
40 \\
60 \\
55\end{array}$ & $\begin{array}{l}48.3 \\
64.5 \\
45.3 \\
44.4 \\
44.6 \\
57.5 \\
50.9\end{array}$ & $\begin{array}{l}87 \\
90 \\
86 \\
86 \\
86 \\
98 \\
93\end{array}$ & $\begin{array}{l}4.4 \\
8.7 \\
3.3 \\
3.9 \\
4.1 \\
5.9 \\
4.4\end{array}$ & $\begin{array}{c}9.2 \\
33 \\
5.3 \\
3.6 \\
3.8 \\
16 \\
9.4\end{array}$ & $\begin{array}{l}258 \\
282 \\
252 \\
246 \\
252 \\
286 \\
265\end{array}$ & $\begin{array}{c}12 \\
18 \\
10 \\
12 \\
8,6 \\
16 \\
15\end{array}$ & $\begin{array}{l}22 \\
59 \\
16 \\
17 \\
17 \\
38 \\
27\end{array}$ & $\begin{array}{l}.1 \\
.4 \\
.2 \\
.4 \\
.2 \\
.0 \\
.2\end{array}$ & $\begin{array}{l}262 \\
348 \\
245 \\
244 \\
244 \\
315 \\
280\end{array}$ & $\begin{array}{l}235 \\
260 \\
228 \\
231 \\
232 \\
269 \\
250\end{array}$ \\
\hline 1945 & & & & & & & & & & & \\
\hline $\begin{array}{ll}\text { lay } & 26 \\
\text { ept. } & 21\end{array}$ & $\begin{array}{l}40 \\
80\end{array}$ & $\begin{array}{l}46.9 \\
66.2\end{array}$ & $\begin{array}{l}89 \\
99\end{array}$ & $\begin{array}{l}2.5 \\
5.5\end{array}$ & $35^{6.4}$ & $\begin{array}{l}264 \\
256\end{array}$ & $\begin{array}{r}7 \\
59\end{array}$ & $\begin{array}{l}16 \\
53\end{array}$ & $\begin{array}{l}0 \\
1\end{array}$ & $\begin{array}{l}251 \\
378\end{array}$ & $\begin{array}{l}232 \\
270\end{array}$ \\
\hline
\end{tabular}

\section{CYPRES CREEK CANAL}

Analyses of monthly samples collected from Cypress Creek Canal at Pompano, covering the period March 1941 to June 1943, indicate that the composition of the water varies considerably but not so-extensively as that of West Palm Beach, Hillsboro, or North New River Canals (see table 98). Dissolved solids during that period ranged from 144 to $315 \mathrm{ppm}$, and hardness ranged from 101 to $271 \mathrm{ppm}$. Color varied inversely with dissolved solids and ranged from 40 to 240 . Samples taken during the drought of 1945 showed higher dissolved solids. 
TALAMI CANAL

- Samples were collected from Tamiami Canal at Krome Road, 10 miles west of Coral Gables, from March 1941 to September 1944 , and at a point $\frac{1}{2}$ mile west of Coral Gables from March 1941 to June 1948. (See tables 99 and 100.) Analyses of these samples indicate that the concentration of dissolved solids usually was somewhat lower at Krome Road than at Coral Gables. At Krome

Table 99. - Analyses, in parts per million, of water from Taniami Canal at Krome Road, near Miani

\begin{tabular}{|c|c|c|c|c|c|c|c|c|c|c|c|}
\hline $\begin{array}{c}\text { Date } \\
\text { of } \\
\text { collection }\end{array}$ & Color & 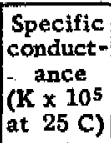 & $\begin{array}{l}\text { Cal- } \\
\text { cium } \\
\text { (Ca) }\end{array}$ & $\begin{array}{c}\text { Magne- } \\
\text { sium } \\
(\mathrm{Mg})\end{array}$ & $\begin{array}{l}\text { Sodium } \\
\text { and po- } \\
\text { tassium } \\
\text { (Na + Ko }\end{array}$ & $\begin{array}{l}\text { Bicar- } \\
\text { bonate } \\
\text { (HCOS }\end{array}$ & $\begin{array}{l}\text { Sul- } \\
\text { fate } \\
\left(\mathrm{SO}_{4}\right)\end{array}$ & $\begin{array}{l}\text { Chlo- } \\
\text { ride } \\
\text { (Cl) }\end{array}$ & $\begin{array}{l}\mathrm{Ni}- \\
\text { trate } \\
\left(\mathrm{No}_{3}\right)\end{array}$ & $\begin{array}{c}\text { Dis- } \\
\text { solved } \\
\text { solids }\end{array}$ & $\begin{array}{c}\text { Total } \\
\text { hard- } \\
\text { ness } \\
2 \mathrm{as} \\
\mathrm{CaCO}_{3}\end{array}$ \\
\hline 19 & & & & & & & & & & & \\
\hline $\begin{array}{cc}\text { Mar. } & 25 \\
\text { Apr. } & 29 \\
\text { May } & 27 \\
\text { July } & 15 \\
\text { Aug. } 25 \\
\text { Sept, } 24 \\
\text { Oct. } 23 \\
\text { Nov, } 18 \\
\text { Dec. } 27 \\
1942\end{array}$ & $\begin{array}{r}90 \\
80 \\
70 \\
70 \\
160 \\
70 \\
60 \\
60 \\
60\end{array}$ & $\begin{array}{l}27.3 \\
28.2 \\
34.0 \\
24.4 \\
30.0 \\
26.2 \\
24.6 \\
27.8\end{array}$ & $\begin{array}{l}48 \\
48 \\
57 \\
38 \\
48 \\
42 \\
40 \\
44\end{array}$ & $\begin{array}{l}5.0 \\
4.8 \\
7.2 \\
3.1 \\
4.8 \\
3.5 \\
3.7 \\
4.1 \\
5.5\end{array}$ & $\begin{array}{c}6.0 \\
15 \\
8.6 \\
11 \\
7.7 \\
7.8 \\
9.3 \\
9.3 \\
6.5\end{array}$ & $\begin{array}{l}149 \\
150 \\
181 \\
126 \\
156 \\
134 \\
132 \\
139 \\
162\end{array}$ & $\mid \begin{array}{c}4.9 \\
23 \\
9.1 \\
4.7 \\
1 \\
33 \\
4.1 \\
5.8 \\
3.7\end{array}$ & $\begin{array}{l}18 \\
18 \\
23 \\
14 \\
19\end{array}$ & $\begin{array}{r}1.0 \\
.5 \\
.5 \\
3.1 \\
.8 \\
.4 \\
.2 \\
2.0 \\
.3\end{array}$ & $\begin{array}{l}156 \\
183 \\
195 \\
136 \\
158 \\
169 \\
138 \\
152 \\
169\end{array}$ & $\begin{array}{l}140 \\
140 \\
172 \\
108 \\
140 \\
119 \\
115 \\
127 \\
152\end{array}$ \\
\hline \begin{tabular}{lr} 
Jan. & 20 \\
Feb. & 16 \\
Apr. & 9 \\
May & 20 \\
June & 4 \\
July & 15 \\
Aug. & 5 \\
Sept. & 1 \\
Oct. & 16 \\
Nov, & 3 \\
Dec. & 9 \\
\multicolumn{2}{c}{1943}
\end{tabular} & $\begin{array}{r}100 \\
70 \\
60 \\
40 \\
70 \\
120 \\
90 \\
100 \\
40 \\
50 \\
50\end{array}$ & $\begin{array}{l}33.5 \\
42.7 \\
53.5 \\
51.0 \\
37.4 \\
27.0 \\
28.0 \\
27.5 \\
28.4 \\
33.3\end{array}$ & $\begin{array}{l}54 \\
70 \\
95 \\
88 \\
64 \\
42 \\
45 \\
46 \\
48 \\
57\end{array}$ & $\begin{array}{l}4.1 \\
5.7 \\
4.8 \\
7.0 \\
4.8 \\
3.3 \\
4.8 \\
6.6 \\
3.7 \\
4.4 \\
7.0\end{array}$ & $\begin{array}{r}13 \\
14 \\
13 \\
14 \\
11 \\
9.8 \\
.8 \\
\ldots . . .1 \\
5.3 \\
11\end{array}$ & $\begin{array}{l}150 \\
175 \\
312\end{array}$ & $\begin{array}{l}1.9 \\
4.9 \\
1.6 \\
7.0 \\
4.9 \\
1.9 \\
1 \\
2.5 \\
2.7 \\
2.7 \\
4.9\end{array}$ & $\begin{array}{l}14 \\
17 \\
23\end{array}$ & $\begin{array}{r}.3 \\
.4 \\
.5 \\
.2 \\
.2 \\
.1 \\
.1 \\
.1 \\
.4 \\
1.1 \\
2.8\end{array}$ & $\begin{array}{l}184 \\
233 \\
289 \\
283 \\
216 \\
142 \\
134 \\
\ldots 148 \\
174 \\
299\end{array}$ & $\begin{array}{l}152 \\
198 \\
256 \\
248 \\
179 \\
118 \\
132 \\
142 \\
135 \\
160 \\
271\end{array}$ \\
\hline $\begin{array}{cr}\text { Jan. } & 5 \\
\text { Feb. } & 5 \\
\text { Mar. } & 8 \\
\text { Apr. } & 2 \\
\text { May } & 7 \\
\text { June } & 5 \\
\text { July } & 6 \\
\text { Oct. } & 11 \\
\text { Nov. } & 7 \\
\text { Dec. } & 8 \\
\text { Dec. } & 30 \\
& \\
1944\end{array}$ & $\begin{array}{l}50 \\
35 \\
35 \\
36 \\
38 \\
40 \\
37 \\
35 \\
45 \\
60 \\
58\end{array}$ & $\begin{array}{l}56.0 \\
57.3 \\
58.5 \\
58.5 \\
55.7 \\
61.6 \\
52.0 \\
44.6 \\
44.5 \\
44.7 \\
44.0\end{array}$ & $\begin{array}{r}101 \\
104 \\
108 \\
110 \\
108 \\
107 \\
90 \\
86 \\
84 \\
83 \\
81\end{array}$ & $\begin{array}{l}7.4 \\
8.3 \\
7.4 \\
8.3 \\
8.3 \\
9.2 \\
7.6 \\
6.8 \\
7.2 \\
8.3 \\
8.7\end{array}$ & $\begin{array}{c}12 \\
6.9 \\
6.2 \\
4.1 \\
3.9 \\
12 \\
9.4 \\
1.2 \\
\ldots \ldots \ldots \ldots . . \\
\ldots \ldots \ldots . . . .\end{array}$ & $\begin{array}{l}327 \\
332 \\
340 \\
342 \\
324 \\
338 \\
264 \\
256 \\
254 \\
252 \\
248\end{array}$ & \begin{tabular}{|c|}
4.7 \\
5.8 \\
4.3 \\
3.9 \\
3.5 \\
7.2 \\
14 \\
13 \\
8.0 \\
8.4 \\
8.4
\end{tabular} & $\begin{array}{l}23 \\
20\end{array}$ & $\begin{array}{l}4.2 \\
2.9 \\
3.2 \\
4.6 \\
2.9 \\
2.2 \\
2.1 \\
.6 \\
.5 \\
.8 \\
.6\end{array}$ & $\begin{array}{r}313 \\
312 \\
317 \\
320 \\
301 \\
336 \\
284 \\
249 \\
\ldots \ldots \ldots \ldots \\
\ldots \ldots \ldots \ldots\end{array}$ & $\begin{array}{l}282 \\
294 \\
300 \\
308 \\
291 \\
305 \\
256 \\
242 \\
239 \\
241 \\
238\end{array}$ \\
\hline $\begin{array}{lr}\text { Jan. } & 27 \\
\text { Mar. } & 1 \\
\text { Mar. } & 28 \\
\text { May } & 3 \\
\text { May } & 30 \\
\text { July } & 3 \\
\text { Aug. } & 10 \\
\text { Sept. } & 6\end{array}$ & $\begin{array}{l}53 \\
57 \\
40 \\
34 \\
30 \\
35 \\
65\end{array}$ & $\begin{array}{l}42.4 \\
46.7 \\
44.6 \\
41.4 \\
48.0 \\
44.4 \\
49.2 \\
48.0\end{array}$ & $\begin{array}{l}79 \\
88 \\
82 \\
78 \\
88 \\
79 \\
86 \\
88\end{array}$ & $\begin{array}{l}7.4 \\
7.4 \\
6.3 \\
5.9 \\
5.9 \\
5.6 \\
6.3 \\
8.5\end{array}$ & $\begin{array}{c}2.3 \\
2.3 \\
4.6 \\
6.0 \\
5.5 \\
6.9 \\
13 \\
1.2\end{array}$ & $\begin{array}{l}242 \\
272 \\
252 \\
238 \\
268 \\
246 \\
274 \\
274\end{array}$ & $\begin{array}{c}6.4 \\
6.0 \\
6.4 \\
8.8 \\
10 \\
9.3 \\
9.3 \\
5.6\end{array}$ & $\begin{array}{l}18 \\
19\end{array}$ & $\begin{array}{r}.6 \\
.8 \\
.8 \\
1.3 \\
.4 \\
.3 \\
.5 \\
1.0\end{array}$ & $\begin{array}{l}234 \\
256 \\
243 \\
236 \\
260 \\
239 \\
274 \\
257\end{array}$ & $\begin{array}{l}228 \\
250 \\
230 \\
219 \\
244 \\
220 \\
240 \\
254\end{array}$ \\
\hline
\end{tabular}


Table 100.-Analyses, in parts per million, of water from Tamiami Camal, near Coral .. Gables

\begin{tabular}{|c|c|c|c|c|c|c|c|c|c|c|c|}
\hline $\begin{array}{l}\text { Date } \\
\text { of } \\
\text { sollection }\end{array}$ & Color & 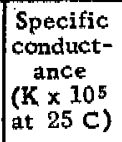 & $\begin{array}{l}\text { Cal- } \\
\text { ciumn } \\
\text { (Ca) }\end{array}$ & $\begin{array}{l}\text { Magne- } \\
\text { sium } \\
(\mathrm{Mg})\end{array}$ & $\begin{array}{l}\text { Sodium } \\
\text { and po- } \\
\text { tassium } \\
(\mathrm{Na}+\mathrm{K})\end{array}$ & $\mid \begin{array}{c}\text { Bicar- } \\
\text { bonate } \\
\left(\mathrm{HCO}_{3}\right)\end{array}$ & $\left|\begin{array}{l}\text { Sul- } \\
\text { fate } \\
\mathrm{SO}_{4}\end{array}\right|$ & $\begin{array}{l}\text { Chlo- } \\
\text { ride } \\
\text { (Cl) }\end{array}$ & $\begin{array}{l}\text { Ni- } \\
\text { trate } \\
\left(\mathrm{NO}_{3}\right)\end{array}$ & $\begin{array}{l}\text { Dis- } \\
\text { solved } \\
\text { solids }\end{array}$ & $\begin{array}{c}\text { Total } \\
\text { hard- } \\
\text { ness } \\
\text { as } \\
\text { Caco }\end{array}$ \\
\hline 1941 & & & & & & & & & & & \\
\hline \begin{tabular}{cc} 
Mar. & 25 \\
Apr. & 21 \\
May & 26 \\
July & 15 \\
Aug. & 25 \\
Sept. 24 \\
Oct. 23 \\
Nov. 18 \\
Dec. 27 \\
\multicolumn{1}{c}{1942}
\end{tabular} & $\begin{array}{r}70 \\
60 \\
7.4 \\
70 \\
60 \\
90 \\
65 \\
70 \\
90\end{array}$ & $\begin{array}{l}42.5 \\
40.8 \\
41.8 \\
41.4 \\
42.3 \\
40.8 \\
37.8 \\
40.5 \\
42.7\end{array}$ & $\begin{array}{r}78 \\
77 \\
-\cdots \\
-76 \\
86 \\
73 \\
70 \\
73 \\
77\end{array}$ & $\begin{array}{r}4.6 \\
6.3 \\
\ldots .7 \\
5.7 \\
5.0 \\
4.1 \\
5.0 \\
5.2 \\
5.7\end{array}$ & $\begin{array}{r}11 \\
5.8 \\
4.3 \\
7.0 \\
8.2 \\
8.0 \\
11 . \\
7.3\end{array}$ & $\begin{array}{l}246 \\
238 \\
240 \\
238 \\
256 \\
232 \\
223 \\
236 \\
245\end{array}$ & $\begin{array}{r}9.9 \\
7.0 \\
7.4 \\
1.8 \\
2.9 \\
5.1 \\
8.6 \\
4.9\end{array}$ & $\begin{array}{l}18 \\
19 \\
19 \\
14 \\
15 \\
16 \\
17 \\
17 \\
18\end{array}$ & $\begin{array}{r}1.0 \\
2.0 \\
\ldots .0 \\
.0 \\
.8 \\
1.5 \\
.8 \\
2.0 \\
.3\end{array}$ & $\begin{array}{l}228 \\
234 \\
\cdots \ldots . \\
225 \\
258 \\
220 \\
226 \\
233 \\
234\end{array}$ & $\begin{array}{l}214 \\
218 \\
\ldots 213 \\
213 \\
235 \\
199 \\
195 \\
204 \\
216\end{array}$ \\
\hline $\begin{array}{lr}\text { Jan. } & 20 \\
\text { Feb. } & 17 \\
\text { Apr. } & 9 \\
\text { May } & 20 \\
\text { June } & 5 \\
\text { July } & 15 \\
\text { Aug. } & 5 \\
\text { Sept. } & 1 \\
\text { Oct. } & 16 \\
\text { Nov. } & 3 \\
\text { Dec. } & 11\end{array}$ & $\begin{array}{r}120 \\
110 \\
80 \\
70 \\
70 \\
120 \\
90 \\
100 \\
70 \\
65 \\
70\end{array}$ & $\begin{array}{l}43.3 \\
45.5 \\
47.0 \\
45.2 \\
46.3 \\
41.4 \\
41.5 \\
41.5 \\
41.6 \\
43.0 \\
44.7\end{array}$ & $\begin{array}{l}79 \\
82 \\
86 \\
80 \\
86 \\
74 \\
72 \\
72 \\
74 \\
79 \\
82\end{array}$ & $\begin{array}{l}5.0 \\
5.7 \\
5.0 \\
5.9 \\
5.2 \\
3.5 \\
6.1 \\
7.4 \\
4.6 \\
3.1 \\
5.7\end{array}$ & $\begin{array}{r}8.0 \\
7.8 \\
7.4 \\
7.3 \\
9.7 \\
10 \\
2.5 \\
2.3 \\
4.8 \\
7.4 \\
7.1\end{array}$ & $\begin{array}{l}251 \\
266 \\
269 \\
250 \\
268 \\
232 \\
226 \\
228 \\
232 \\
243 \\
258\end{array}$ & $\begin{array}{c}2.5 \\
1.6 \\
4.9 \\
13 \\
16 \\
9.1 \\
3.5 \\
2.3 \\
3.5 \\
5.6 \\
4.9\end{array}$ & $\begin{array}{l}19 \\
18 \\
18 \\
15 \\
15 \\
15 \\
15 \\
18 \\
14 \\
14 \\
18\end{array}$ & $\begin{array}{r}.1 \\
.1 \\
.3 \\
.2 \\
.2 \\
.2 \\
.2 \\
.1 \\
1.2 \\
1.4 \\
3.2\end{array}$ & $\begin{array}{l}237 \\
246 \\
254 \\
245 \\
264 \\
226 \\
211 \\
214 \\
216 \\
230 \\
248\end{array}$ & $\begin{array}{l}218 \\
228 \\
235 \\
224 \\
236 \\
199 \\
205 \\
211 \\
204 \\
210 \\
229\end{array}$ \\
\hline 1943 & & & & & & & & & & & \\
\hline $\begin{array}{cc}\text { Jan. } & 5 \\
\text { Feb. } & 5 \\
\text { Mar. } & 8 \\
\text { Apr. } & 2 \\
\text { May } & 7 \\
\text { June } & 8 \\
\text { July } & 6 \\
\text { Aug. } & 2 \\
\text { Sept. } & 4 \\
1944\end{array}$ & $\begin{array}{l}80 \\
60 \\
55 \\
60 \\
70 \\
38 \\
45 \\
33 \\
32\end{array}$ & $\begin{array}{l}45.0 \\
46.4 \\
44.9 \\
42.1 \\
45.0 \\
46.6 \\
45.8 \\
46.7 \\
46.5\end{array}$ & $\begin{array}{l}84 \\
87 \\
84 \\
80 \\
84 \\
88 \\
88 \\
87 \\
90\end{array}$ & $\begin{array}{l}6.1 \\
6.6 \\
6.6 \\
5.4 \\
5.7 \\
7.0 \\
7.0 \\
7.0 \\
7.2\end{array}$ & $\begin{array}{l}6.2 \\
1.2 \\
2.1 \\
1.1 \\
3.8 \\
.9 \\
1.4 \\
3.2\end{array}$ & $\begin{array}{l}263 \\
268 \\
258 \\
238 \\
257 \\
267 \\
260 \\
264 \\
260\end{array}$ & $\begin{array}{r}7.6 \\
4.5 \\
7.4 \\
5.3 \\
7.2 \\
9.5 \\
12 \\
13 \\
16\end{array}$ & $\begin{array}{l}16 \\
15\end{array}$ & $\begin{array}{r}2.7 \\
1.8 \\
1.2 \\
1.3 \\
.8 \\
.4 \\
.7 \\
.6 \\
.4\end{array}$ & $\begin{array}{l}252 \\
248 \\
243 \\
226 \\
244 \\
252 \\
255 \\
257 \\
\cdots \cdots . .\end{array}$ & $\begin{array}{l}234 \\
244 \\
236 \\
222 \\
233 \\
248 \\
248 \\
246 \\
254\end{array}$ \\
\hline $\begin{array}{l}\text { ct. } 4 \\
1945\end{array}$ & 60 & 8 & & & & 272 & 5 & 17 & 1.0 & ...... & 268 \\
\hline $\begin{array}{lr}\text { Jan. } & 11 \\
\text { Feb. } & 1 \\
\text { Mar. } & 1 \\
\text { Apr. } & 5 \\
\text { May } & 2 \\
\text { June } & 4 \\
\text { July } & 3 \\
\text { Aug. } & 1 \\
\text { Aug. } & 30 \\
\text { Sept. } & 24\end{array}$ & $\begin{array}{l}43 \\
40 \\
42 \\
42\end{array}$ & $\begin{array}{l}0 \\
9 \\
1 \\
1 \\
3 \\
7 \\
2 \\
2\end{array}$ & $\begin{array}{r}92 \\
91 \\
92 \\
83 \\
68 \\
70 \\
66 \\
80 \\
86 \\
118\end{array}$ & $\begin{array}{l}5.0 \\
5.5 \\
6.0 \\
6.1 \\
6.3\end{array}$ & $\begin{array}{r}8.0 \\
5.3 \\
6.4 \\
6.9 \\
6.2 \\
12 \\
9.0 \\
2.3 \\
7.4 \\
1.4\end{array}$ & $\begin{array}{l}228 \\
251 \\
292\end{array}$ & $\begin{array}{r}9 \\
2 \\
2 \\
2 \\
4 \\
6 \\
8 \\
17\end{array}$ & 16 & $\begin{array}{r}1.0 \\
.8 \\
.4 \\
.7 \\
1.0 \\
1.6\end{array}$ & $\begin{array}{l}273 \\
261 \\
267 \\
246 \\
207 \\
226 . \\
210 \\
235 \\
265 \\
344\end{array}$ & $\begin{array}{l}251 \\
248 \\
251 \\
228 \\
191 \\
195 \\
187 \\
224 \\
240 \\
320\end{array}$ \\
\hline 1946 & & & & & & & & & & & \\
\hline $\begin{array}{cc}\text { Apr. } & 18 \\
\text { May } & 23 \\
\text { July } & 16 \\
\text { Sept. } & 27 \\
\text { Oct. } & 31 \\
\text { Dec. } & 20 \\
\text { Feb. } & 27 \\
\text { Mar. } & 31 \\
1947\end{array}$ & $\begin{array}{r}75 \\
100 \\
55 \\
65 \\
80 \\
55 \\
50 \\
50\end{array}$ & $\begin{array}{l}50.7 \\
46.7 \\
47.5 \\
48.2 \\
49.6 \\
49.7\end{array}$ & $\begin{array}{l}90 \\
92 \\
94 \\
84 \\
84 \\
88 \\
92 \\
90\end{array}$ & $\begin{array}{l}5.5 \\
5.8 \\
6.2 \\
6.7 \\
6.7 \\
6.1\end{array}$ & $\begin{array}{r}2.3 \\
6.7 \\
4.4 \\
\cdots \ldots \ldots \ldots \\
2.3 \\
9.4\end{array}$ & $\begin{array}{l}264 \\
292 \\
272 \\
260 \\
264 \\
266 \\
280 \\
276\end{array}$ & $\begin{array}{r}18 \\
7 \\
16 \\
12 \\
4 \\
4 \\
5 \\
15\end{array}$ & $\begin{array}{l}16 \\
17 \\
17 \\
19 \\
20\end{array}$ & $\begin{array}{l}.2 \\
.8 \\
.8 \\
.8\end{array}$ & $\begin{array}{l}268 \\
273 \\
268 \\
253 \\
246 \\
24 \ldots \\
264 \\
277\end{array}$ & $\begin{array}{l}246 \\
252 \\
257 \\
234 \\
235 \\
247 \\
257 \\
250\end{array}$ \\
\hline $\begin{array}{lr}\text { June } & 5 \\
\text { Aug. } & 7 \\
\text { Nov, } & 26\end{array}$ & $\begin{array}{c}38 \\
54 \\
40\end{array}$ & $\begin{array}{l}51.1 \\
45.4 \\
38.2\end{array}$ & $\begin{array}{l}90 \\
80 \\
68\end{array}$ & $\begin{array}{l}5.6 \\
4.9 \\
4.0\end{array}$ & $\begin{array}{l}8.5 \\
7.6 \\
4.8\end{array}$ & $\begin{array}{l}286 \\
252 \\
216\end{array}$ & $\begin{array}{l}5.8 \\
8.2 \\
2.6\end{array}$ & $\begin{array}{l}18 \\
15 \\
12\end{array}$ & .2 & $\begin{array}{l}269 \\
240 \\
198\end{array}$ & $\begin{array}{l}248 \\
220 \\
186\end{array}$ \\
\hline
\end{tabular}


Table 100.-Analyses, in parts per million, of water from Taniami Canel, near Coral Gables-Continued

\begin{tabular}{|c|c|c|c|c|c|c|c|c|c|c|c|}
\hline $\begin{array}{l}\text { Date } \\
\text { of } \\
\text { collection }\end{array}$ & Color & $\begin{array}{c}\text { Specific } \\
\text { conduct- } \\
\text { ance } \\
\left(\mathrm{K} \times 10^{5}\right. \\
\text { at } 25 \mathrm{C}) \\
\end{array}$ & $\begin{array}{l}\text { Cal- } \\
\text { cium } \\
(\mathrm{Ca})\end{array}$ & $\begin{array}{c}\text { Magne- } \\
\text { sium } \\
\text { (Mg) }\end{array}$ & $\begin{array}{c}\text { Sodium } \\
\text { and po- } \\
\text { tassium } \\
\mathrm{N}_{\mathrm{n}}+\mathrm{K}\end{array}$ & $\begin{array}{l}\text { Bicar- } \\
\text { bonate } \\
\left(\mathrm{HCO}_{3}\right)\end{array}$ & $\mid \begin{array}{c}\text { Sul- } \\
\text { fate } \\
\left(\mathrm{SO}_{4}\right)\end{array}$ & $\begin{array}{l}\text { Chlo- } \\
\text { ride } \\
\text { (Cl) }\end{array}$ & $\begin{array}{l}\mathrm{Ni}- \\
\text { tate } \\
\left(\mathrm{NO}_{3}\right)\end{array}$ & $\begin{array}{c}\text { Dis- } \\
\text { solved } \\
\text { solids }\end{array}$ & $\begin{array}{l}\text { Total } \\
\text { hard- } \\
\text { ness } \\
\text { as } \\
\mathrm{CaCO}\end{array}$ \\
\hline 1948 & & & & & & & & & & & \\
\hline $\begin{array}{lr}\text { Feb. } & 5 \\
\text { May } & 6 \\
\text { June } & 24\end{array}$ & $\begin{array}{r}52 \\
132 \\
42\end{array}$ & $\begin{array}{l}43.2 \\
46.7 \\
47.6\end{array}$ & $\begin{array}{l}82 \\
91 \\
91\end{array}$ & $\begin{array}{l}5.7 \\
5.8 \\
5.9\end{array}$ & $\begin{array}{r}2.9 \\
5.8 \\
5.5\end{array}$ & $\begin{array}{l}254 \\
274 \\
280\end{array}$ & $\begin{array}{r}6.0 \\
4.9 \\
12\end{array}$ & $\begin{array}{l}14 \\
16 \\
15\end{array}$ & $\mid \begin{array}{r}.3 \\
+5 \\
.3\end{array}$ & $\begin{array}{l}236 \\
254 \\
268\end{array}$ & $\begin{array}{l}228 \\
251 \\
251\end{array}$ \\
\hline
\end{tabular}

Road, dissolved solids ranged from 134 to $336 \mathrm{ppm}$ and total hardness ranged from 108 to $308 \mathrm{ppm}$. At Coral Gables dissolved solids ranged from 198 to $344 \mathrm{ppm}$, and total hardness ranged from 186 to $320 \mathrm{ppm}$. Presumably, the slightly greater concentration at Coral Gables during most of the period of record was caused by the higher mineral content of ground water that seeped into the canal between these two collection points.

\section{MISCELLANEOUS SAMPLING}

The results of analyses of miscellaneous samples collected from the major canals at points other than regular sampling points and from the smaller streams and canals are given in table 101. Additional analyses of samples from the major canals, made for special studies in regard to effects of drought, are given in table 102 . 


\begin{tabular}{|c|c|c|c|c|c|c|c|c|c|c|c|c|}
\hline Source & Date & Color & $\begin{array}{c}\text { Specific } \\
\text { conductance } \\
\left(\mathrm{K} \times 10^{5}\right. \\
\text { at } 25 \mathrm{C}) \\
\end{array}$ & $\begin{array}{c}\text { Calcium } \\
\text { (Ca) }\end{array}$ & $\begin{array}{c}\text { Magnesium } \\
\text { (Mg) }\end{array}$ & 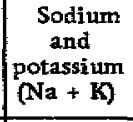 & $\begin{array}{c}\text { Bicarbonate } \\
(\mathrm{HCO},)^{\prime}\end{array}$ & $\begin{array}{l}\text { Sujffate } \\
(\text { So, })\end{array}$ & $\begin{array}{c}\text { Chloride } \\
\text { (Cl) }\end{array}$ & $\begin{array}{l}\text { Nitrate } \\
\left(\mathrm{NO}_{3}\right)\end{array}$ & $\begin{array}{c}\text { Dissolved } \\
\text { solids }\end{array}$ & $\begin{array}{c}\text { Total } \\
\text { hardness } \\
\text { as } \\
\mathrm{CaCO}_{3}\end{array}$ \\
\hline 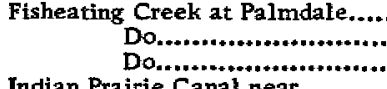 & $\begin{array}{l}\text { Dec. } 20,1939 \\
\text { Feb. } 12,1941 \\
\text { Oct. } 27,1941\end{array}$ & $\begin{array}{l}180 \\
240\end{array}$ & $\begin{array}{c}9.1 \\
6.0\end{array}$ & $\begin{array}{r}3.5 \\
2.5\end{array}$ & $\begin{array}{r}1.3 \\
1.7\end{array}$ & $\begin{array}{r}7.6 \\
6.3\end{array}$ & $\begin{array}{r}10 \\
5 \\
9\end{array}$ & $\begin{array}{l}1 \\
1 \\
2.3\end{array}$ & $\begin{array}{l}\mathbf{1 9} \\
\mathbf{1 8} \\
\mathbf{1 2}\end{array}$ & a......... & 30 & $\begin{array}{l}16 \\
14 \\
13\end{array}$ \\
\hline $\begin{array}{l}\text { Indian Prairie Canal near } \\
\text { Oke echobee........................ } \\
\text { Taylor Creek near Okeechobee.. }\end{array}$ & $\begin{array}{ll}\text { Feb. } & 12,1941 \\
\text { Oct. } & 27,1941\end{array}$ & $\begin{array}{l}380 \\
240\end{array}$ & 7.2 & $\begin{array}{l}42 \\
7.0\end{array}$ & 12 & 6.0 & $\begin{array}{l}12 \\
22\end{array}$ & 87 & $\begin{array}{l}21 \\
10\end{array}$ & 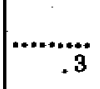 & 38 & $\begin{array}{r}154 \\
22\end{array}$ \\
\hline 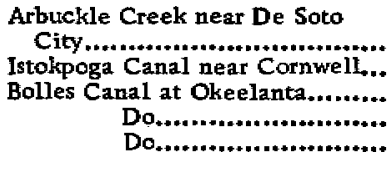 & 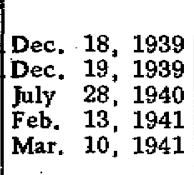 & $\begin{array}{r}320 \\
240 \\
280\end{array}$ & $\begin{array}{r}7.5 \\
9.1 \\
61.4 \\
79.3\end{array}$ & $\mid \begin{array}{c}0 . \ldots \ldots \ldots \\
82 \\
54 \\
94\end{array}$ & $\mid \begin{array}{c}21 \\
15 \\
30\end{array}$ & $\mid \begin{array}{c}5.8 \\
\cdots \ldots \ldots \ldots \ldots \\
26\end{array}$ & $\begin{array}{r}10 \\
9 \\
250 \\
122 \\
248\end{array}$ & $\begin{array}{r}12 \\
10 \\
42 \\
37 \\
115\end{array}$ & $\begin{array}{r}8 \\
10 \\
39 \\
30 \\
64\end{array}$ & 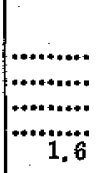 & $\mid \begin{array}{r}313 \\
\cdots \cdots+\ldots \ldots+\ldots \\
\cdots \\
\cdots\end{array}$ & $\begin{array}{r}22 \\
34 \\
291 \\
196 \\
358\end{array}$ \\
\hline 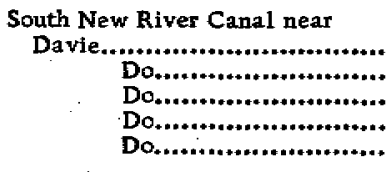 & $\begin{array}{lr}\text { Dec. } & 8,1939 \\
\text { Maz. } & 26,1941 \\
\text { Apr. } & 22,1941 \\
\text { May } & 21,1941 \\
\text { July } & 3,1941\end{array}$ & $\begin{array}{r}70 \\
70 \\
65 \\
110\end{array}$ & $\begin{array}{l}51.5 \\
50.1 \\
33.0 \\
47.4 \\
35.3\end{array}$ & $\begin{array}{l}91 \\
90 \\
44 \\
82 \\
54\end{array}$ & $\begin{array}{c}8.0 \\
8.5 \\
12 \\
9.2 \\
5.7\end{array}$ & $\begin{array}{c}9.0 \\
8.3 \\
13 \\
8.5 \\
15\end{array}$ & $\begin{array}{l}292 \\
278 \\
188 \\
262 \\
194\end{array}$ & $\begin{array}{l}-13 \\
13 \\
8.2 \\
14 \\
12\end{array}$ & $\begin{array}{l}19 \\
24 \\
17 \\
22 \\
13\end{array}$ & $\begin{array}{r}3.0 \\
2.0 \\
.8 \\
1.4\end{array}$ & $\begin{array}{l}284 \\
284 \\
189 \\
266 \\
197\end{array}$ & $\begin{array}{l}260 \\
260 \\
159 \\
242 \\
158\end{array}$ \\
\hline 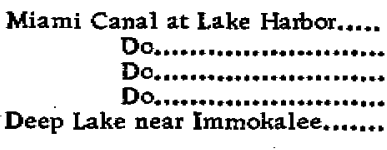 & $\begin{array}{l}\text { Dec. } 18,1939 \\
\text { July, } 28,1940 \\
\text { Mar. } 10,1941 \\
\text { Oct. } 26,1941 \\
\text { Dec. } 16,1939\end{array}$ & $\begin{array}{r}190 \\
200 \\
280 \\
\cdots \cdots\end{array}$ & $\begin{array}{l}42.5 \\
66.6 \\
35.1 \\
19.4 \\
47.4\end{array}$ & $\begin{array}{l}45 \\
49 \\
28 \\
85\end{array}$ & \begin{tabular}{r|}
13 \\
11 \\
5.2 \\
5.8
\end{tabular} & \begin{tabular}{r|}
22 \\
8.3 \\
2.9 \\
9.2
\end{tabular} & $\begin{array}{r}152 \\
231 \\
152 \\
94 \\
277\end{array}$ & $\begin{array}{c}32 \\
108 \\
23 \\
5.8 \\
2\end{array}$ & $\begin{array}{l}39 \\
50 \\
26 \\
10 \\
19\end{array}$ & 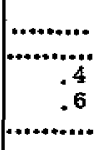 & $\begin{array}{r}226 \\
270 \\
99 \\
254\end{array}$ & $\begin{array}{r}166 \\
273 \\
168 \\
91 \\
236\end{array}$ \\
\hline $\begin{array}{l}\text { Lake Trafford near Immokalee.... } \\
\text { Still Lake near Fort Myers......... } \\
\text { Twelvemile Creek near For }\end{array}$ & $\ldots \ldots$............... & $\cdots 22$ & 11.5 & $\begin{array}{l}13 \\
52\end{array}$ & $\begin{array}{l}1.7 \\
9.9\end{array}$ & $3 i^{7.0}$ & $\begin{array}{r}47 \\
192\end{array}$ & $\begin{array}{l}2 \\
6.3\end{array}$ & $\begin{array}{l}10 \\
52\end{array}$ &..... .0 & $\begin{array}{r}57 \\
253\end{array}$ & $\begin{array}{r}39 \\
170\end{array}$ \\
\hline 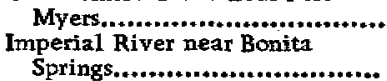 & $\begin{array}{l}\text { Dec. 16, } 1939 \\
\text {.....do.............. }\end{array}$ & $\ldots . . .$. & $\begin{array}{l}68.4 \\
44.4\end{array}$ & $\begin{array}{l}93 \\
76\end{array}$ & $\begin{array}{l}20 \\
4.8\end{array}$ & $\begin{array}{l}27 \\
11\end{array}$ & $\begin{array}{l}351 \\
241\end{array}$ & $\begin{array}{r}18 \\
1\end{array}$ & $\begin{array}{l}47 \\
25\end{array}$ & $\ldots \ldots$ & $\begin{array}{l}378 \\
236\end{array}$ & $\begin{array}{l}314 \\
209\end{array}$ \\
\hline $\begin{array}{l}\text { Shark River Canal at Tamiami } \\
\text { Trail Bridge } 169 . . . . . . . . . . . . . . . . .\end{array}$ & Dec. 9,1939 & $\cdots$ & 30.0 & 48 & 3.7 & 8.2 & 153 & 2 & 18 & & 155 & 135 \\
\hline
\end{tabular}




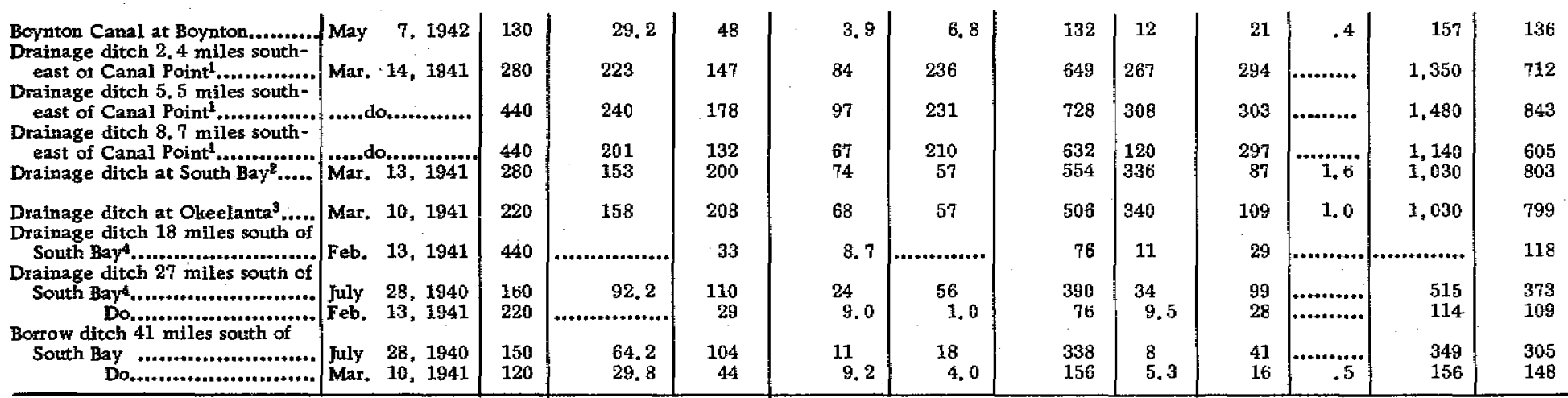

At pumphouse on State Highway $71 \mathrm{~b}$.

${ }^{2}$ At pumphouse 0.1 mile north of railroad bridge over North New River Canal.

3 West of State Highway 25 and south of Bolles Canal.

4 Along SCS dike west of State Highway 25.

5 Along west side of State Highway 25 at 20 -Mile Bend. 
Table 102.-Analyses, in parts per million, of miscelleneous surface waters in southeastern Florida, May and September 1945

\begin{tabular}{|c|c|c|c|c|c|c|c|c|c|c|c|c|}
\hline Source & Date & Color & \begin{tabular}{|c|} 
Specific \\
conductance \\
$\left(\mathrm{K} \times 10^{5}\right.$ \\
at $25 \mathrm{C})$
\end{tabular} & $\begin{array}{c}\text { Calcium } \\
\text { (Ca) }\end{array}$ & $\begin{array}{c}\text { Magnesium } \\
(\mathrm{Mg})\end{array}$ & $\begin{array}{c}\text { Sodium } \\
\text { and } \\
\text { potassium } \\
(\mathrm{Na}+\mathbf{K})\end{array}$ & $\begin{array}{c}\text { Bicarbonate } \\
\left(\mathrm{HCO}_{\mathrm{g}}\right)\end{array}$ & $\begin{array}{l}\text { Sulfate } \\
\left(\mathrm{SO}_{4}\right)\end{array}$ & $\begin{array}{c}\text { Chloride } \\
\text { (Cl) }\end{array}$ & $\begin{array}{c}\text { Nitrate } \\
\left(\mathrm{NO}_{3}\right)\end{array}$ & $\begin{array}{c}\text { Dissolved } \\
\text { solids }\end{array}$ & $\begin{array}{c}\text { Total } \\
\text { hardness } \\
\text { as } \\
\mathrm{CaCO}_{3}\end{array}$ \\
\hline 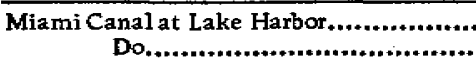 & $\begin{array}{l}\text { May } 29 \\
\text { Sept. 23 }\end{array}$ & $\begin{array}{l}180 \\
190\end{array}$ & $\begin{array}{r}147 \\
41.8\end{array}$ & $\begin{array}{r}168 \\
65\end{array}$ & $\begin{array}{l}39 \\
11\end{array}$ & $\begin{array}{l}99 \\
12\end{array}$ & $\begin{array}{l}568 \\
186\end{array}$ & $\begin{array}{l}69 \\
57\end{array}$ & $\begin{array}{r}178 \\
14\end{array}$ & $\begin{array}{r}8.3 \\
.4\end{array}$ & $\begin{array}{l}841 \\
251\end{array}$ & $\begin{array}{l}580 \\
207\end{array}$ \\
\hline 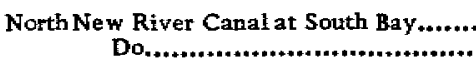 & $\begin{array}{ll}\text { May } & 25 \\
\text { Sept. } 21\end{array}$ & $\begin{array}{r}50 \\
300\end{array}$ & $\begin{array}{c}52.8 \\
111\end{array}$ & $\begin{array}{r}52 \\
147\end{array}$ & $\begin{array}{l}15 \\
48\end{array}$ & 32 & $\begin{array}{l}160 \\
380\end{array}$ & $\begin{array}{r}48 \\
212\end{array}$ & $\begin{array}{l}53 \\
22\end{array}$ & $20^{7.0}$ & $\begin{array}{l}286 \\
643\end{array}$ & $\begin{array}{l}192 \\
564\end{array}$ \\
\hline 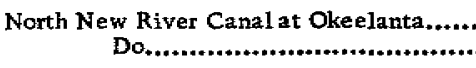 & $\begin{array}{ll}\text { May } & 25 \\
\text { Sept. } & 21\end{array}$ & (............ & 134 & $\mid \cdots+\ldots \ldots \ldots$ & (n) & (n)............. & $\begin{array}{r}204 \\
\ldots \ldots \ldots \ldots \ldots\end{array}$ & $\begin{array}{r}55 \\
\cdots \cdots\end{array}$ & $\begin{array}{l}58 \\
85\end{array}$ & (........... & (n) & $\begin{aligned} 210 \\
\ldots \ldots \ldots \ldots+\ldots+\end{aligned}$ \\
\hline 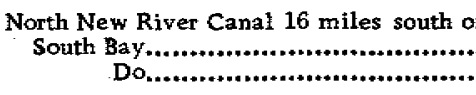 & $\begin{array}{ll}\text { May } 25 \\
\text { Sept. } 21\end{array}$ & $\begin{array}{r}50 \\
340\end{array}$ & $\begin{array}{l}52.1 \\
93.8\end{array}$ & $\begin{array}{r}49 \\
125\end{array}$ & $\begin{array}{l}15 \\
36\end{array}$ & $\begin{array}{l}37 \\
28\end{array}$ & $\begin{array}{l}180 \\
308\end{array}$ & $\begin{array}{r}36 \\
173\end{array}$ & $\begin{array}{l}56 \\
52\end{array}$ & $18^{.2}$ & $\begin{array}{l}282 \\
584\end{array}$ & $\begin{array}{l}184 \\
460\end{array}$ \\
\hline 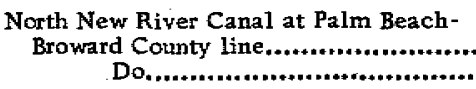 & $\begin{array}{ll}\text { May } & 25 \\
\text { Sept. } & 21\end{array}$ & 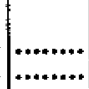 & $\begin{array}{c}55.6 \\
111\end{array}$ & 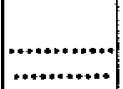 & 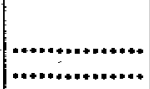 & 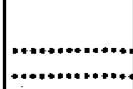 & $\begin{array}{r}204 \\
\ldots\end{array}$ & $\begin{array}{r}50 \\
\ldots . . .\end{array}$ & $\begin{array}{r}56 \\
110\end{array}$ & 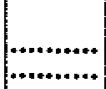 & 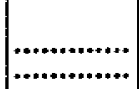 & $\begin{array}{r}180 \\
\ldots . . . . . .\end{array}$ \\
\hline 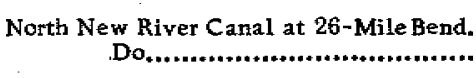 & $\begin{array}{ll}\text { May } 25 \\
\text { Sept. 21 }\end{array}$ & $\begin{array}{r}50 \\
320\end{array}$ & $\begin{array}{l}54.7 \\
82.7\end{array}$ & $\begin{array}{r}54 \\
109\end{array}$ & $\begin{array}{l}15 \\
31\end{array}$ & $\begin{array}{l}35 \\
22\end{array}$ & $\begin{array}{l}202 \\
280\end{array}$ & $\begin{array}{r}26 \\
133\end{array}$ & $\begin{array}{l}57 \\
47\end{array}$ & $16^{.0}$ & $\begin{array}{l}286 \\
496\end{array}$ & $\begin{array}{l}196 \\
400\end{array}$ \\
\hline 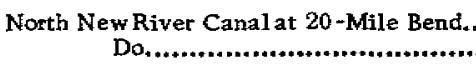 & $\begin{array}{ll}\text { May } & 25 \\
\text { Sept. } & 21\end{array}$ & $\ldots \ldots$ & $\begin{array}{l}61.1 \\
82.2\end{array}$ & 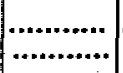 & (n) & 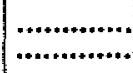 & \begin{tabular}{|r}
240 \\
$\quad \ldots \ldots \ldots \ldots \ldots \ldots$ \\
\end{tabular} & 50 & $\begin{array}{l}57 \\
52\end{array}$ & ............ & 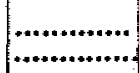 & 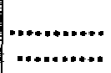 \\
\hline 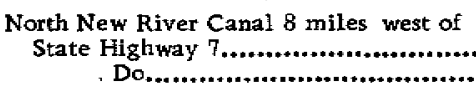 & $\begin{array}{ll}\text { May } 25 \\
\text { Sept. 21 }\end{array}$ & ....................... & $\begin{array}{l}62.7 \\
92.3\end{array}$ & 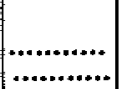 & ….............. & 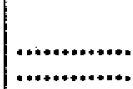 & $\begin{array}{r}282 \\
\ldots \ldots \ldots \ldots \ldots \ldots\end{array}$ & $\begin{array}{r}34 \\
\ldots \ldots \ldots . . .\end{array}$ & $\begin{array}{l}58 \\
88\end{array}$ & 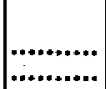 & $\mid$\begin{tabular}{c}
$\ldots \ldots \ldots \ldots \ldots$ \\
\hdashline$\ldots \ldots \ldots \ldots \ldots \ldots$
\end{tabular} & $\begin{array}{r}216 \\
\ldots \ldots \ldots\end{array}$ \\
\hline 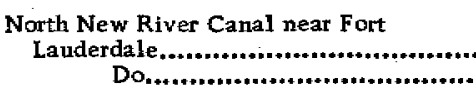 & $\begin{array}{ll}\text { May } & 25 \\
\text { Sept. } & 21\end{array}$ & $\begin{array}{r}45 \\
280\end{array}$ & $\begin{array}{l}58.8 \\
74.6\end{array}$ & $\begin{array}{r}60 \\
100\end{array}$ & $\begin{array}{l}16 \\
26\end{array}$ & $\begin{array}{l}42 \\
14\end{array}$ & $\begin{array}{l}.222 \\
262\end{array}$ & $\begin{array}{r}40 \\
107\end{array}$ & $\begin{array}{l}58 \\
43\end{array}$ & $\begin{array}{l}.8 \\
.4\end{array}$ & $\begin{array}{l}326 \\
420\end{array}$ & $\begin{array}{l}216 \\
356\end{array}$ \\
\hline 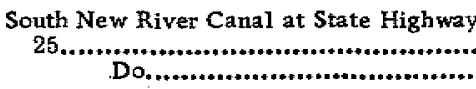 & $\mid \begin{array}{ll}\text { May } & 26 \\
\text { Sept. } & 27\end{array}$ & $\begin{array}{r}60 \\
110\end{array}$ & $\begin{array}{l}34.5 \\
52.9\end{array}$ & $\begin{array}{l}51 \\
90\end{array}$ & $\begin{array}{l}7.6 \\
7.9\end{array}$ & 12.4 & $\begin{array}{l}172 \\
224\end{array}$ & $\begin{array}{r}5 \\
63\end{array}$ & $\begin{array}{l}18 \\
22\end{array}$ & 2.8 & $\begin{array}{l}173 \\
308\end{array}$ & $\begin{array}{l}158 \\
257\end{array}$ \\
\hline 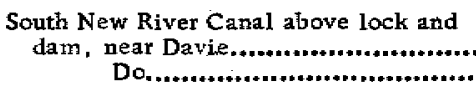 & $\begin{array}{ll}\text { May } & 25 \\
\text { Sept. } & 21\end{array}$ & $\begin{array}{r}140 \\
82\end{array}$ & $\begin{array}{l}55.2 \\
60.2\end{array}$ & $\begin{array}{r}84 \\
102\end{array}$ & $\begin{array}{l}10 \\
8.8\end{array}$ & $\begin{array}{l}19 \\
20\end{array}$ & $\begin{array}{l}288 \\
310\end{array}$ & $\begin{array}{l}10 \\
32\end{array}$ & $\begin{array}{l}32 \\
29\end{array}$ & $\begin{array}{r}.0 \\
5.6\end{array}$ & $\begin{array}{l}297 \\
350\end{array}$ & $\begin{array}{l}250 \\
290\end{array}$ \\
\hline
\end{tabular}




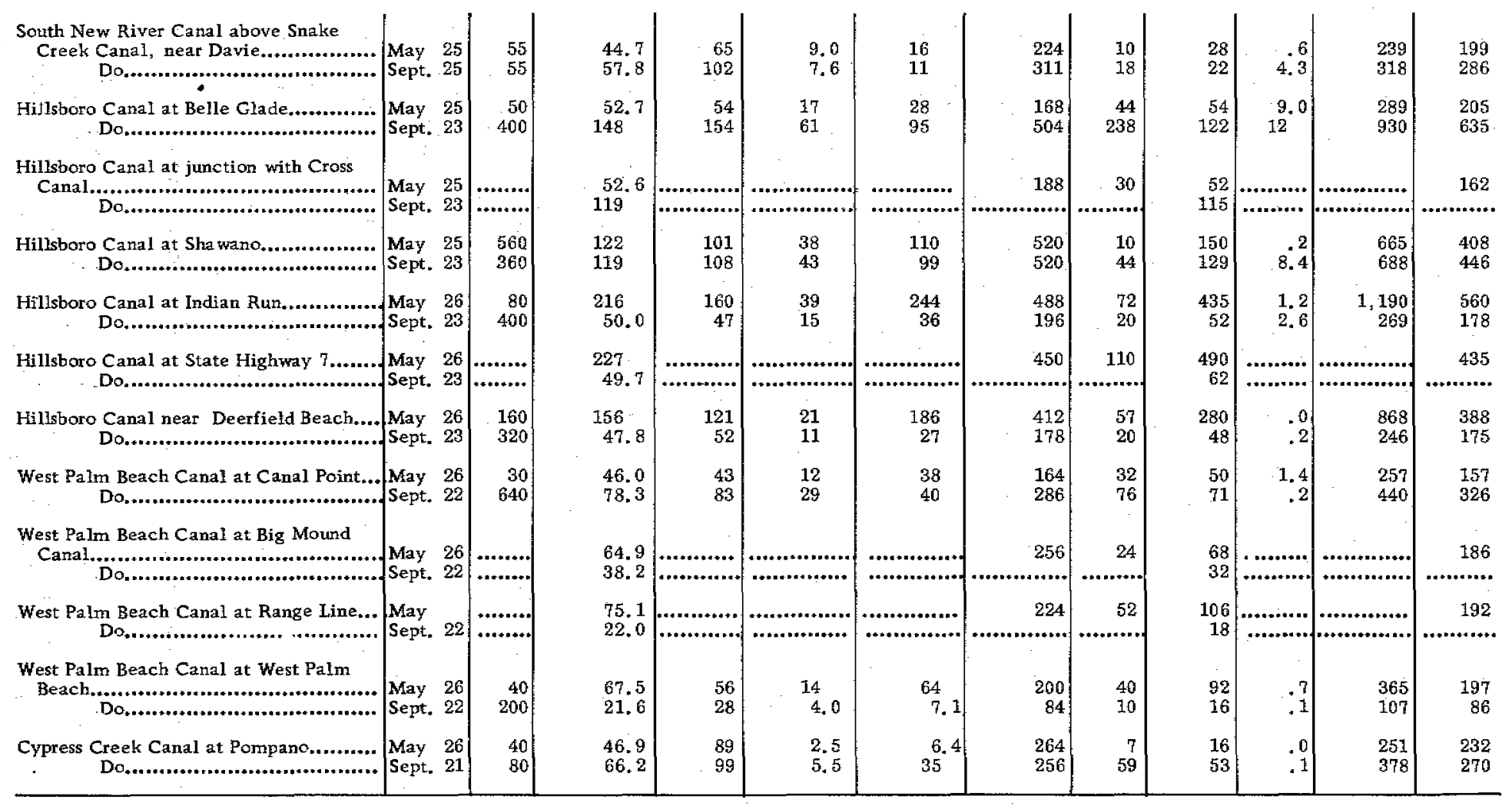




\section{EFFECT OF DROUGHT CONDITIONS ON CHEMICAL QUALITY OF EVERGLADES CÄNALS}

Drought conditions in southeastern Florida during 1945 resulted not only in unusual inland penetration of salt water from the ocean, but also in increased concentration of dissolved salts in the Everglades canals. Owing to greatly deficient rainfall during this period the runoff in the major drainage canals was derived largely from ground-water storage, which generally contains higher concentrations of dissolved salts than does direct surface inflow.

By May 1945, the accumulated deficiencies in precipitation for the year amounted to more than 11 inches in the Miami area. Because the summer rain ordinarily begins in late May or early June, it was decided to collect a series of samples of surface waters in the major Everglades canals prior to the rainy season. Another series was scheduled for collection in the early fall, which normally coincides with the end of the rainy season. It was anticipated that the samples collected in May would contain much larger amounts of dissolved salts then would the samples collected in September.

The results of the analyses of the two series of samples are shown in table 102. Contrary to expectation, the concentrations found in the September samples, for a majority of the sampling locations, were considerably higher than the concentrations found in the May samples. Because the two series of single samples could not possibly reflect all the changes that took place in the Everglades canals during the period, it is impossible to explain satisfactorily why most of the September samples were more concentrated than the May samples and, at the same time, to explain why the reverse was true for other sampling locations.

During the extremely dry months it is possible that the heavy draf $t$ on the water table by vegetation resulted in an accumulation of salts at, or near, the surface of the ground as a result of transpiration. With the coming of the rains and the rising of the water table to the surface of the ground, the accumulated salts would have been dissolved and gradually discharged into the canals. It is probable that many other factors were to some degree responsible for the increase in concentration in the canal samples in September over that in May, but the above explanation may account for a part of the increase.

\section{CHEMICAL CHARACTER OF NONARTESIAN GROUND WATERS}

Nonartesian ground waters along the low coastal ridge in Dade and Broward Counties are, in general, moderately hard waters in which the dissolved mineral matter consists largely of calcium and bicarbonate. Hardness ranges from about 150 to $300 \mathrm{ppm}$. 
Shallow ground waters in the Everglades are generally harder and more concentrated than the shallow coastal ground waters because of remnants of saline residues resulting from former invasions of the area by the sea. Maps showing the locations of the wells that were sampled are in the Appendix.

\section{METROPOLITAN AREA OF MIAMI}

Most of the public and private supply wells in the Miami area are less than $100 \mathrm{ft}$ deep and, of those over $100 \mathrm{ft}$ deep, not many exceed $120 \mathrm{ft}$. The dissolved mineral matter in the water, unless contaminated with salt water, consists essentially of calcium and bicarbonate with smaller amounts of magnesium, sodium, sulfate, chloride and other constituents. From 70 to 80 percent of the dry residue remaining after evaporation of the water consists of calcium carbonate. (See table 103.)

The calcium ordinarily ranges from about 90 to $110 \mathrm{ppm}$ and the magnesium ranged from about 4 to $8 \mathrm{ppm}$. Hardness ranges from about 200 to $300 \mathrm{ppm}$ (expressed as calcium carbonate). Sulfate in the uncontaminated ground water ranges from about 30 to $50 \mathrm{ppm}$, and the chloride ranged from about 15 to $25 \mathrm{ppm}$. Sodium and potassium are usually present in concentrations that are nearly equivalent to the chloride. Iron is present in amounts that range from $0.1 \mathrm{ppm}$ (or less) to about $3 \mathrm{ppm}$. 
Table 103. - Analyses, in parts per million, of nonartesian waters in the lliami metropolitan area

[See plates 21 and 22]

\begin{tabular}{|c|c|c|c|c|c|c|c|c|c|c|c|c|c|c|c|c|}
\hline $\begin{array}{c}\text { Well } \\
\text { no. }\end{array}$ & Location & $\begin{array}{c}\text { Date } \\
\text { of } \\
\text { collection }\end{array}$ & $\begin{array}{l}\text { Depth } \\
\text { (feet) }\end{array}$ & $\begin{array}{l}\text { Tem- } \\
\text { pera- } \\
\text { ture } \\
\text { ("F) }\end{array}$ & Color & $\begin{array}{l}\text { Specific } \\
\text { conduct- } \\
\text { ance } \\
(\mathbf{K} \times 105 \\
\text { at } 25 \mathrm{C})\end{array}$ & Iron & $\begin{array}{l}\text { Cal- } \\
\text { cium } \\
\text { (Ca) }\end{array}$ & $\begin{array}{l}\text { Magne - } \\
\text { síum } \\
(\mathrm{Mg})\end{array}$ & $\begin{array}{c}\text { Sodium } \\
\text { and po- } \\
\text { tassium } \\
(\mathbf{N a}+\mathbf{K})\end{array}$ & $\begin{array}{l}\text { Bicar- } \\
\text { bonate } \\
\left(\mathrm{HCO}_{3}\right)\end{array}$ & $\begin{array}{c}\text { Sul- } \\
\text { fate } \\
\left(\mathrm{SO}_{4}\right)\end{array}$ & $\begin{array}{l}\text { Chlo- } \\
\text { ride } \\
\text { (Cl) }\end{array}$ & $\left|\begin{array}{l}\mathrm{Ni}- \\
\text { trate } \\
\left(\mathrm{NO}_{3}\right)\end{array}\right|$ & $\begin{array}{l}\text { Dis- } \\
\text { solved } \\
\text { solids }\end{array}$ & $\begin{array}{c}\text { Total } \\
\text { hard- } \\
\text { ness } \\
\text { as } \\
\mathrm{CaCO}_{3} \\
\end{array}$ \\
\hline 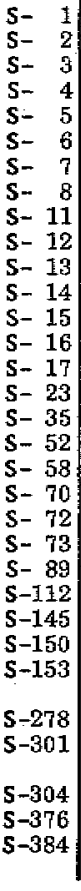 & $\begin{array}{l}\text { Miami Springs, Hialeah well field.. } \\
\ldots \ldots \ldots \ldots \ldots \\
\ldots \ldots \ldots \ldots\end{array}$ & 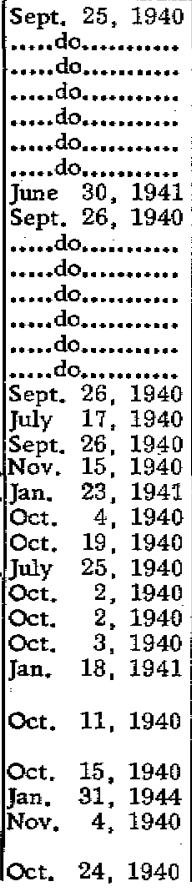 & $\begin{array}{c}67 \\
96 \\
62 \\
94 \\
100 \\
62 \\
62 \\
64 \\
91 \\
90 \\
55 \\
73 \\
85 \\
90.5 \\
87 \\
64 \\
51 \\
60 \\
36 \\
100.5 \\
32 \\
37 \\
50 \\
96 \\
63 \\
66 \\
45- \\
50 \\
80 \\
100 \\
60 \\
75 \\
63.5\end{array}$ & $\begin{array}{r}77 \\
78 \\
77 \\
78 \\
76 \\
77 \\
78 \\
\ldots \ldots \ldots \\
78 \\
77 \\
76 \\
76 \\
76 \\
76 \\
77 \\
79 \\
77 \\
80 \\
77 \\
\ldots \ldots . . \\
82 \\
80 \\
80 \\
80 \\
79 \\
79 \\
\ldots \ldots \ldots \\
77\end{array}$ & $\begin{array}{r}60 \\
65 \\
60 \\
65 \\
65 \\
65 \\
60 \\
45 \\
65 \\
80 \\
65 \\
75 \\
65 \\
65 \\
90 \\
50 \\
3 \\
5 \\
30 \\
5 \\
5 \\
25 \\
5 \\
5 \\
5 \\
5 \\
5 \\
15 \\
\\
20 \\
35 \\
35 \\
75\end{array}$ & $\begin{array}{c}64.2 \\
54.7 \\
74.5 \\
138 \\
59.8 \\
53.0 \\
53.3 \\
51.0 \\
54.1 \\
56.1 \\
77.3 \\
76.1 \\
85.9 \\
56.2 \\
59.0 \\
47.3 \\
70.0 \\
69.4 \\
151 \\
59.0 \\
1.050 \\
818 \\
48.3 \\
104 \\
202 \\
132 \\
63.7 \\
94.4 \\
89.2 \\
167 \\
51.5 \\
57.8\end{array}$ & 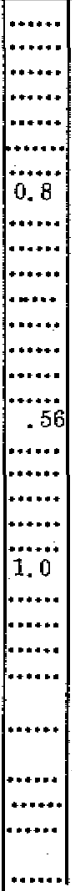 & \begin{tabular}{|r}
$\ldots \ldots$. \\
117 \\
142 \\
105 \\
$\ldots \ldots .$. \\
$\ldots \ldots$. \\
94 \\
96 \\
99 \\
97 \\
97 \\
118 \\
$\ldots \ldots \ldots$ \\
104 \\
92 \\
115 \\
104 \\
$\ldots \ldots$. \\
$\ldots \ldots \ldots$ \\
183 \\
155 \\
92 \\
106 \\
102 \\
124 \\
90 \\
135 \\
116 \\
150 \\
101 \\
101
\end{tabular} & \begin{tabular}{|c}
8.0 \\
13 \\
6.4 \\
$\ldots \ldots \ldots \ldots$ \\
6.8 \\
6.9 \\
7.8 \\
12 \\
12 \\
10 \\
$\ldots .8$ \\
4.0 \\
5.0 \\
5.0 \\
$\ldots \ldots \ldots$ \\
$\ldots \ldots \ldots$ \\
220 \\
168 \\
3.6 \\
9.0 \\
35 \\
8.5 \\
4.2 \\
5.4 \\
10 \\
14 \\
3.5 \\
6.8
\end{tabular} & 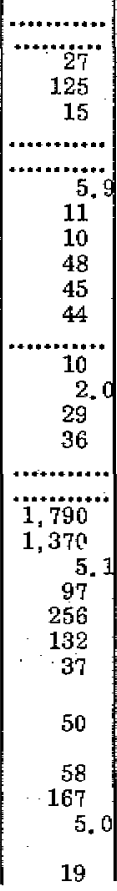 & $\begin{array}{r}268 \\
266 \\
258 \\
264 \\
274 \\
273 \\
276 \\
266 \\
276 \\
274 \\
278 \\
282 \\
281 \\
271 \\
291 \\
238 \\
291 \\
297 \\
318 \\
66 \\
206 \\
290 \\
235 \\
248 \\
264 \\
252 \\
251 \\
2 \\
284 \\
2 \\
269 \\
296 \\
274\end{array}$ & \begin{tabular}{|c|c}
$\ldots \ldots \ldots$ \\
61 \\
67 \\
47 \\
$\cdots \ldots \ldots$ \\
$\cdots \ldots \ldots$ \\
31 \\
38 \\
41 \\
44 \\
47 \\
47 \\
$\ldots \ldots \ldots$ \\
43 \\
42 \\
52 \\
31 \\
$\cdots \ldots \ldots$ \\
$\cdots \ldots \ldots$ \\
655 \\
348 \\
37 \\
40 \\
70 \\
21 \\
22 \\
25 \\
83 \\
44 \\
29 \\
\end{tabular} & $\begin{array}{r}46 \\
20 \\
77 \\
273 \\
33 \\
19 \\
18 \\
17 \\
19 \\
24 \\
86 \\
78 \\
108 \\
21 \\
19 \\
9.0 \\
55 \\
59 \\
308 \\
1,640 \\
3,120 \\
250 \\
17 \\
189 \\
472 \\
285 \\
67 \\
148 \\
\\
106 \\
358 \\
16\end{array}$ & 1.3 & 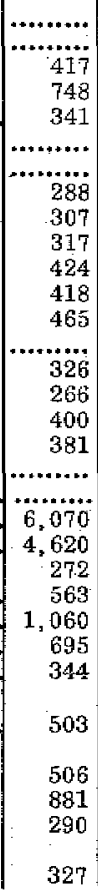 & $\begin{array}{r}325 \\
400 \\
288 \\
\ldots \ldots . . . \\
263 \\
268 \\
279 \\
291 \\
291 \\
336 \\
\ldots . \ldots \\
288 \\
246 \\
308 \\
280 \\
\ldots . . . . \\
\ldots \ldots . . . \\
1,360 \\
1,080 \\
244 \\
302 \\
398 \\
344 \\
242 \\
\\
359\end{array}$ \\
\hline
\end{tabular}




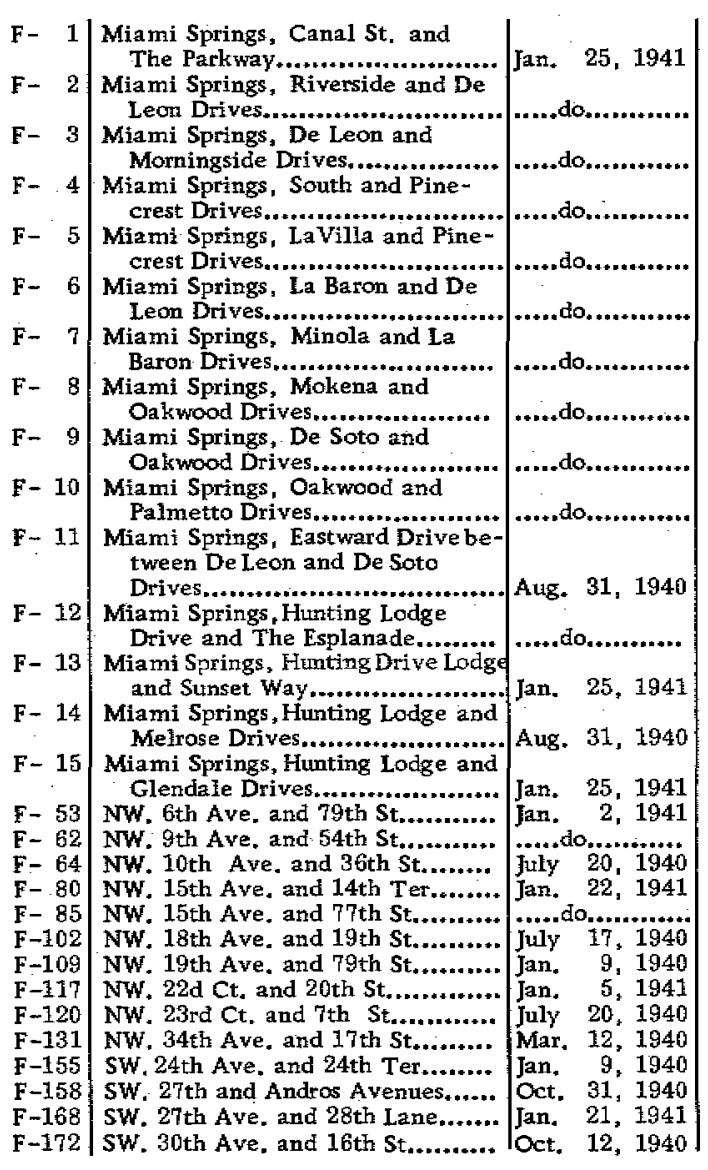

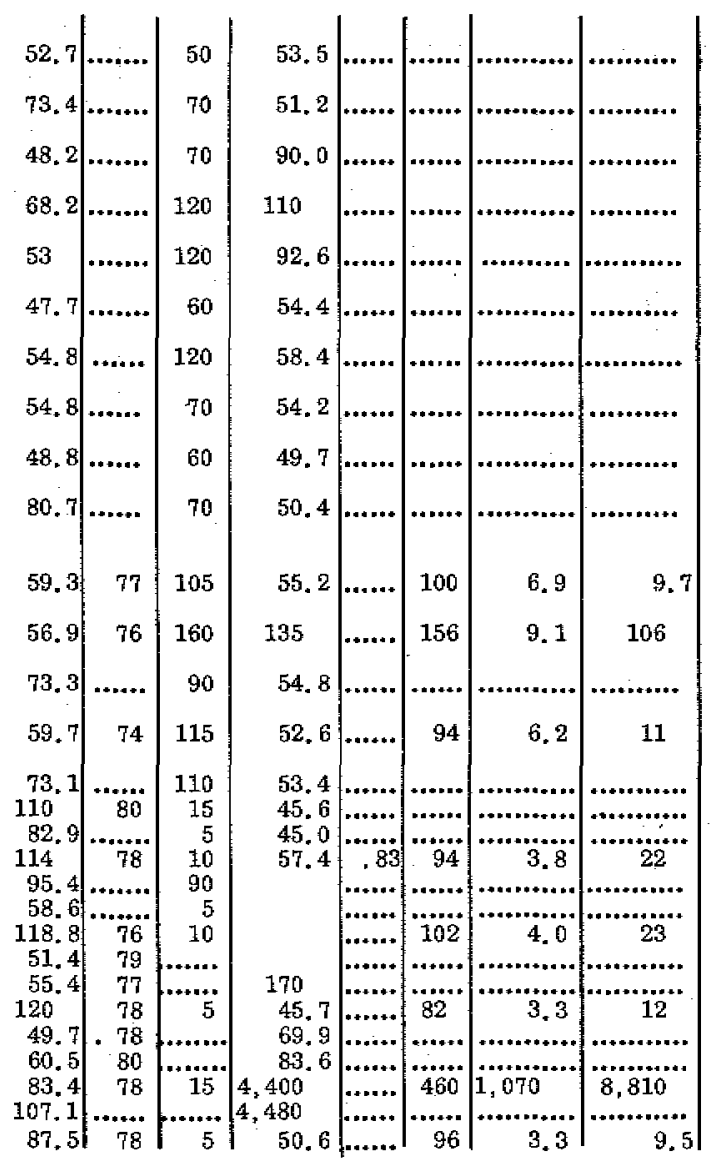
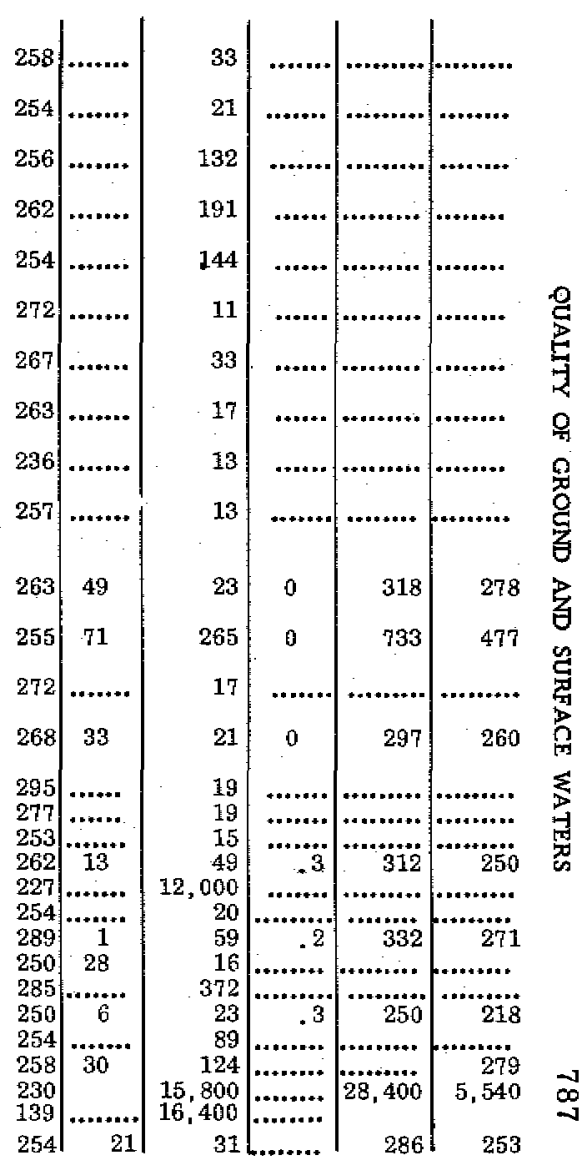
Table 103.-Analyses, in parts per million, of nonartesian waters in the Miani metropolitan area-Continued

\begin{tabular}{|c|c|c|c|c|c|c|c|c|c|c|c|c|c|c|c|c|}
\hline $\begin{array}{l}\text { Well } \\
\text { no. }\end{array}$ & Location & $\begin{array}{l}\text { Date } \\
\text { of } \\
\text { collection }\end{array}$ & $\mid \begin{array}{r}\text { Depth } \\
\text { (feet) }\end{array}$ & $\begin{array}{l}\text { Tem - } \\
\text { pera - } \\
\text { ture } \\
\text { ("F) }\end{array}$ & Color & \begin{tabular}{|c|} 
Specific \\
conduct- \\
ance \\
$\left(\mathrm{K} \times 10^{\circ}\right.$ \\
at $25 \mathrm{C})$
\end{tabular} & $=$ & $\begin{array}{l}\text { Cal- } \\
\text { cium } \\
\text { (Ca) }\end{array}$ & $\begin{array}{c}\text { Magne- } \\
\text { sium } \\
(\mathrm{Mg})\end{array}$ & $\begin{array}{l}\text { Sodium } \\
\text { and po- } \\
\text { tassium } \\
(\mathrm{Na}+\mathrm{K})\end{array}$ & $\begin{array}{l}\text { Bicar- } \\
\text { bonate } \\
\left(\mathrm{HCO}_{3}\right)\end{array}$ & $\begin{array}{l}\text { Sul- } \\
\text { fute } \\
\left(\mathrm{SO}_{4}\right)\end{array}$ & $\begin{array}{l}\text { Chlo- } \\
\text { ride } \\
\text { (Cl) }\end{array}$ & $\begin{array}{l}\mathrm{Ni}- \\
\text { trate } \\
\mathrm{NO}_{3}\end{array}$ & $\begin{array}{c}\text { Dis- } \\
\text { solved } \\
\text { solids }\end{array}$ & $\begin{array}{l}\text { Total } \\
\text { hard- } \\
\text { ness } \\
\text { as } \\
\text { Caco }\end{array}$ \\
\hline 173 & h St....... & Oct. & 60.2 & 78 & 5 & 1 & & 157 & 9.4 & 204 & 258 & 29 & 448 & & 974 & 430 \\
\hline & & Jan. & 67 & 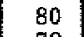 & .......... & & ........ & ........... & .............. & .............. & & 28 & & & $|+\ldots \ldots+\infty|$ & \\
\hline & $\cdots$ & ......do,.. & 63.1 & 78 & $\ldots . . .$. & & $\cdots \cdots$ & .......... & (.............. & .............. & 268 & 30 & 14 & ....... & ........... & 249 \\
\hline $\begin{array}{ll}188 \\
202\end{array}$ & $\begin{array}{l}\text { d and Mary St........................ } \\
\text { Ave, and Mary St. }\end{array}$ & $\begin{array}{l}\text { Jan. } 21,1941 \\
\text { Jan. } 18,1941\end{array}$ & $\begin{array}{c}115.3 \\
62\end{array}$ & 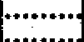 & $\begin{array}{r}140 \\
5\end{array}$ & 4,880 & $\cdots . . .$. & ........ & $\ldots$ & (............. & $\begin{array}{r}79 \\
264\end{array}$ & $\ldots$. & $\mid 18,000$ & ....... & $\cdots \cdots$ & $\ldots$ \\
\hline & ............... & JuIy 17, 1940 & 50 & 80 & 5 & 50.6 & .52 & ${ }^{2013}$ & 2.9 & 14 & 254 & $\because 37$ & 21 & .*. & 295 & 247 \\
\hline & t..... & Aug. 24, & 53 & 78 & 95 & & & 89 & 3.3 & 8.4 & 254 & 25 & 1A & .0 & 265 & 236 \\
\hline & ..... & July & 90 & 79 & & & .97 & 97 & 2 . & & 2 & 42 & & .1 & 322 & 254 \\
\hline & & July ? & 48 & 78 & 5 & & .58 & 96 & 3. & & 261 & 37 & 2 & 4 & 299 & 253 \\
\hline & $\ldots$ & July? & 70 & 78 & 15 & & .76 & 102 & 2 . & & 260 & 45 & 4 & .3 & 342 & 266 \\
\hline & & Ang. 2 & & 79 & 5 & & 1.7 & 127 & 3. & 1 & 391 & 7 & 3 & .0 & 381 & 332 \\
\hline & ....... & & 114 & 78 & 65 & & .70 & 10. & 3 & & & 53 & & .0 & 325 & 266 \\
\hline & $\ldots . . .$. & July 5 , & & 78 & .......... & & .12 & 84 & 2. & & 2 & 18 & 1 & .1 & 255 & 221 \\
\hline-248 & St...... & $\begin{array}{l}\text { Aug. } 24,1940 \\
\text { July } 5,1940\end{array}$ & $\begin{array}{l}93.1 \\
56.2\end{array}$ & $\begin{array}{l}76 \\
77\end{array}$ & $\begin{array}{l}95 \\
50\end{array}$ & $\begin{array}{l}55.3 \\
53.0\end{array}$ & $\begin{array}{l}1.0 \\
1.1\end{array} \mid$ & $\begin{array}{l}95 \\
94\end{array}$ & ${ }_{11}^{8.0}$ & ${ }^{10} 6.8$ & $\begin{array}{l}304 \\
287\end{array}$ & $\begin{array}{l}13 \\
27\end{array}$ & 2 & & $\begin{array}{l}298 \\
305\end{array}$ & $\begin{array}{l}270 \\
280\end{array}$ \\
\hline 000 & 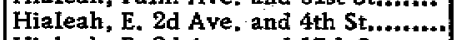 & Aug. 24, 194 & 101.7 & 77 & 100 & 0.0 & 1.60 & 94 & 6.7 & 11 & 272 & 37 & & & 300 & 262 \\
\hline & (........... & Nov. 22, & 45 & 77 & .......... & 5 & $\ldots$ & $\ldots . .$. & ............... & .................. & 269 & $\ldots$ & 1 & & ......... & .......... \\
\hline-275 & id & |Des. & & & & & & ......... & |........... & $\mid+\ldots \ldots+\ldots \ldots$ & 257 & t.... & & & …...... & ........." \\
\hline-284 & 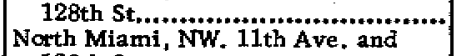 & Aug. & 51. & 78 & 55 & 5 & .43 & 204 & 3.5 & 8.3 & 231 & 77 & 16 & .0 & 323 & 274 \\
\hline$=-296$ & NE....... & |July & 59. & 78 & 40 & 44 & & 84 & 4.4 & 5.8 & 255 & 8 & 16 & .5 & 244 & 228 \\
\hline & $\ldots$ & .......do... & 46 & 79 & 20 & 6.4 & 3 & 108 & 4.4 & 25 & 284 & 2 & 75 & 1,0 & 358 & 288 \\
\hline & $\begin{array}{l}\text { ni. NE. 10th Ave. } \\
\text { ark NE 8th Ave, }\end{array}$ & 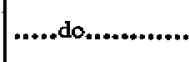 & 8 & 78 & 120 & 57.2 & 8 & 115 & 4.0 & 11 & 301 & 52 & 19 & .8 & 359 & 303 \\
\hline & rk, NE. 8th Ave. & Aug. 24,1940 & 204.5 & 76 & 30 & 106 & 1 & 108 & 111 & 95 & 320 & 10 & 177 & .0 & 560 & 315 \\
\hline-301 & $\begin{array}{l}\text { North Miami Beach } \\
\text { and Arriola Way. } \\
\text { Coral Gables, Men }\end{array}$ & July & 91. & 77 & 20 & 49.2 & 2. & 95 & 2.9 & 16 & 279 & 21 & 2 & 5.6 & 301 & 249 \\
\hline 94 & $\begin{array}{l}\text { and Douglass Road...... } \\
\text { Le Jeune Rrosd and }\end{array}$ & Oct. 4,1940 & 57.5 & 80 & 3 & 49.8 & & 96 & 3.7 & 7.4 & 267 & 27 & 17 & & 283 & 255 \\
\hline-307 & ntonio Aye, and & ......do. & & 8 & 3 & 48.9 & & 94 & 3.7 & 5.6 & 263 & 23 & 16 & & 272 & 250 \\
\hline & sovet & do & 18. & 80 & 3 & 48 & & 94 & 3.5 & 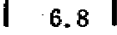 & 267 & 18 & & & 272 & 248 \\
\hline
\end{tabular}




\begin{tabular}{|c|c|c|c|c|c|c|c|c|c|c|c|c|}
\hline $\begin{array}{l}F-309 \\
G-42 \\
G-48 \\
G-158 A \\
G-182\end{array}$ & 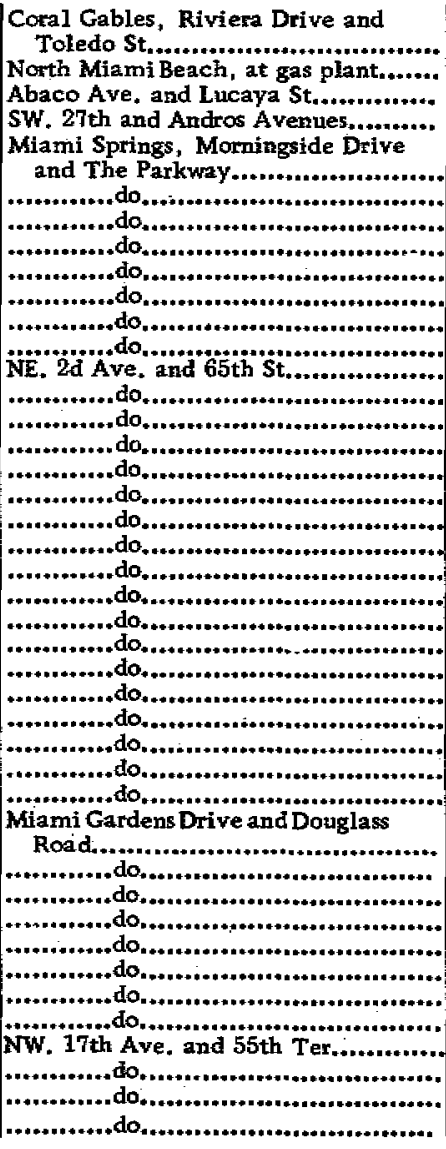 & 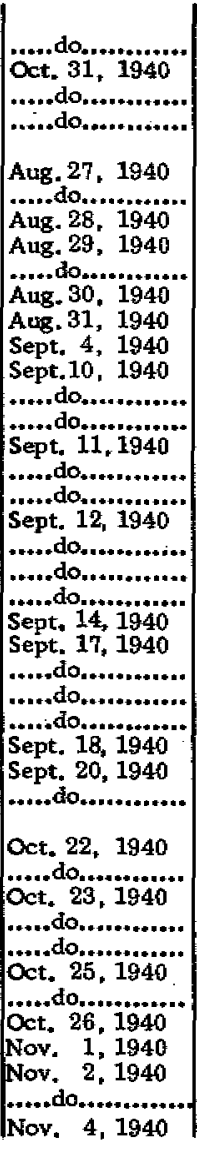 & $\begin{array}{r}13.9 \\
14.3 \\
13.1 \\
16.7 \\
19.0 \\
24.4 \\
50.4 \\
88.8 \\
104.1 \\
162.4 \\
218.8 \\
291.6 \\
5.9 \\
28.6 \\
45.4 \\
50.6 \\
90.7 \\
98.8 \\
101.2 \\
105.0 \\
108.3 \\
111.9 \\
128.8 \\
174.6 \\
178.4 \\
182.5 \\
186.4 \\
275.4 \\
306.9 \\
331.2 \\
52.6 \\
57.1 \\
68.3 \\
86.4 \\
99.0 \\
113.0 \\
120.7 \\
198.4 \\
41.6 \\
68.2 \\
88.9 \\
109.2\end{array}$ & $\begin{array}{r}82 \\
100 \\
79 \\
82 \\
82 \\
78 \\
80 \\
78 \\
77 \\
78 \\
78 \\
80 \\
80 \\
81 \\
81 \\
80 \\
80 \\
81 \\
82 \\
80 \\
81 \\
80 \\
80 \\
80 \\
80 \\
80 \\
78 \\
79 \\
79 \\
76 \\
77 \\
74 \\
78 \\
77 \\
77 \\
78 \\
78 \\
78 \\
77 \\
77 \\
77\end{array}$ & 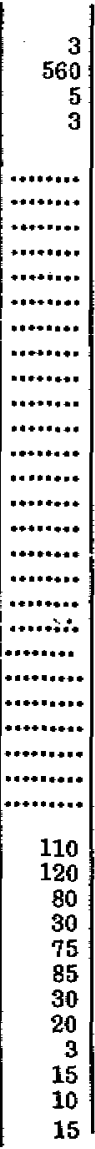 & $\begin{array}{c}53.0 \\
184 \\
54.1 \\
61.3 \\
78.2 \\
132 \\
133 \\
121 \\
91.8 \\
73.1 \\
81.8 \\
78.8 \\
46.4 \\
50.0 \\
49.4 \\
53.1 \\
47.9 \\
49.6 \\
47.2 \\
82.3 \\
118 \\
88.3 \\
863 \\
2,130 \\
2,230 \\
2,280 \\
2,130 \\
150 \\
578 \\
318 \\
\\
39.0 \\
39.0 \\
42.3 \\
46.4 \\
58.8 \\
59.0 \\
72.7 \\
188 \\
47.5 \\
47.2 \\
48.5 \\
51.6\end{array}$ & • & $\begin{array}{r}108 \\
152 \\
130 \\
123 \\
132 \\
56 \\
81 \\
30 \\
78 \\
84 \\
67 \\
85 \\
82 \\
86 \\
78 \\
100 \\
124 \\
107 \\
351 \\
342 \\
352 \\
354 \\
341 \\
46 \\
94 \\
38 \\
74 \\
74 \\
74 \\
81 \\
102 \\
104 \\
110 \\
52 \\
89 \\
87 \\
90 \\
95\end{array}$ & $\begin{array}{c}4.3 \\
5.4 \\
12 \\
13 \\
17 \\
32 \\
31 \\
25 \\
3.3 \\
3.1 \\
3.9 \\
3.5 \\
4.4 \\
3.7 \\
5.2 \\
7.1 \\
6.1 \\
6.0 \\
113 \\
436 \\
463 \\
479 \\
433 \\
3 \\
114 \\
44 \\
\\
5.2 \\
5.2 \\
6.1 \\
7.3 \\
8.6 \\
9.0 \\
14 \\
39 \\
2.8 \\
4.3 \\
4.3 \\
5.1\end{array}$ & $\begin{array}{c}9.3 \\
357 \\
14 \\
24 \\
\\
63 \\
120 \\
127 \\
101 \\
48 \\
55 \\
53 \\
108 \\
18 \\
23 \\
24 \\
27 \\
14 \\
16 \\
14 \\
57 \\
105 \\
64 \\
1,380 \\
3,950 \\
4,170 \\
4,480 \\
3,920 \\
224 \\
965 \\
578 \\
2 \\
3.6 \\
1.4 \\
7.0 \\
9.2 \\
12 \\
11 \\
55 \\
303 \\
9.8 \\
8.0 \\
9.0 \\
11 \\
\end{array}$ & $\begin{array}{l}279 \\
286 \\
236 \\
229 \\
487 \\
338 \\
409 \\
340 \\
256 \\
278 \\
220 \\
253 \\
234 \\
242 \\
226 \\
241 \\
253 \\
230 \\
269 \\
274 \\
289 \\
301 \\
276 \\
359 \\
270 \\
318 \\
225 \\
221 \\
236 \\
256 \\
322 \\
327 \\
394 \\
416 \\
256 \\
257 \\
267 \\
298\end{array}$ & $\begin{array}{c}12 \\
12 \\
14 \\
19 \\
19 \\
20 \\
6.2 \\
85 \\
19 \\
17 \\
17 \\
4.7\end{array}$ \\
\hline
\end{tabular}

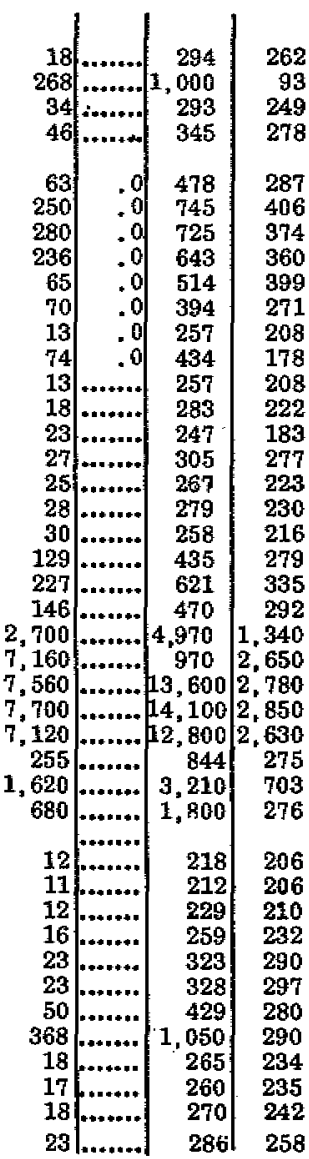


Table 103.-Analyses, in parts per million, of nonartesian waters in the Mimi metropolitan area-Conti nued

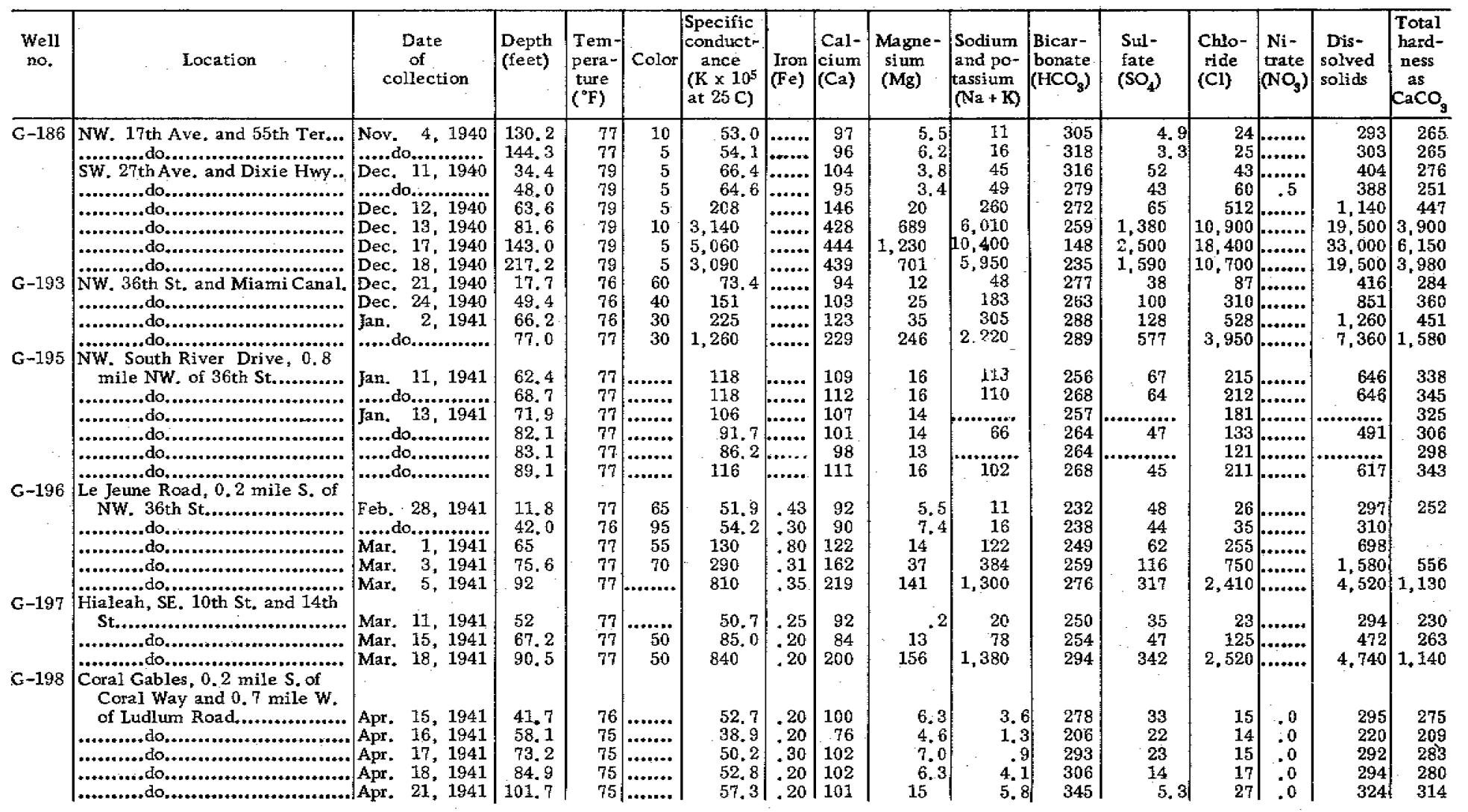




\begin{tabular}{|c|c|c|c|c|c|c|c|c|c|c|c|c|c|c|c|c|c|}
\hline G-199 & 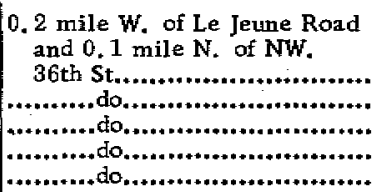 & $\begin{array}{l}\text { June } \\
\text { June } \\
\text { June } \\
\text { June } \\
\text { June }\end{array}$ & $\begin{array}{r}6,1941 \\
7,1941 \\
9,1941 \\
13,1941 \\
14,1941\end{array}$ & $\begin{array}{r}56.3 \\
71.2 \\
85.8 \\
888.5 \\
92\end{array}$ & $\begin{array}{l}77 \\
77 \\
77 \\
77 \\
78\end{array}$ & 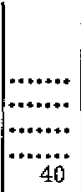 & $\begin{array}{c}60.6 \\
99.4 \\
364 \\
406 \\
486\end{array}$ & $\mid \begin{array}{c}\cdots \ldots \\
\cdots \ldots \\
\cdots \ldots \\
.15 \\
.15\end{array}$ & $\begin{array}{l}109 \\
125 \\
178 \\
191 \\
189\end{array}$ & $\begin{array}{c}9.6 \\
10 \\
46 \\
56 \\
75\end{array}$ & $\begin{array}{c}6.0 \\
67 \\
503 \\
576 \\
728\end{array}$ & $\begin{array}{l}244 \\
280 \\
274 \\
305 \\
287\end{array}$ & $\begin{array}{r}83 \\
59 \\
136 \\
165 \\
189\end{array}$ & $\begin{array}{r}27 \\
148 \\
965 \\
1,090 \\
1,370\end{array}$ & 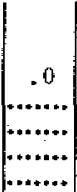 & $\begin{array}{r}355 \\
547 \\
1,960 \\
2,230 \\
2,690\end{array}$ & $\begin{array}{l}312 \\
353 \\
633 \\
707 \\
780\end{array}$ \\
\hline
\end{tabular}




\section{COASTAL AREAS SOUTH OF MIAMI}

All of the coastal area south of Miami is within Dade County, reaching from the southern edge of the area of Miami near South Miami to Florida Bay south of Homestead and Florida City. The samples from this area were collected from 4 supply wells, 2 fire wells, and 14 test wells in the vicinity of Homestead and Florida City. Most of the test wells were drilled in connection with the development of a public supply for Key West.

Analyses of the uncontaminated ground waters south of Miami show that they contained somewhat less dissolved mineral matter and less color than ground waters in the Miami area. (See table 104.) Dissolved solids in the analyzed samples ranged from 187 to $252 \mathrm{ppm}$, and hardness ranged from $134 \mathrm{ppm}$ in well G216 to 208 $\mathrm{ppm}$ in wells not contaminated with sea water. The dissolved matter consisted primarily of calcium and bicarbonate. Sulfate ranged from 2 to $12 \mathrm{ppm}$ and chloride ranged from 10 to $22 \mathrm{ppm}$ in uncontaminated water.

Some test welis encountered salty water at depths of only $20 \mathrm{ft}$ at localities several miles south of Florida City; salty water was found at somewhat greater depths in the vicinity of Florida City. Essentially, these test wells were exploratory wells to determine the characteristics of the water-bearing formations and to determine the extent to which the Biscayne aquifer had been invaded by salt water. (See section on Salt-water encroachment.) 
Table 104.-Analyses, in parts per million, of nonartesian waters in Dade County, outside Miami metropolitan area

[See plate 6]

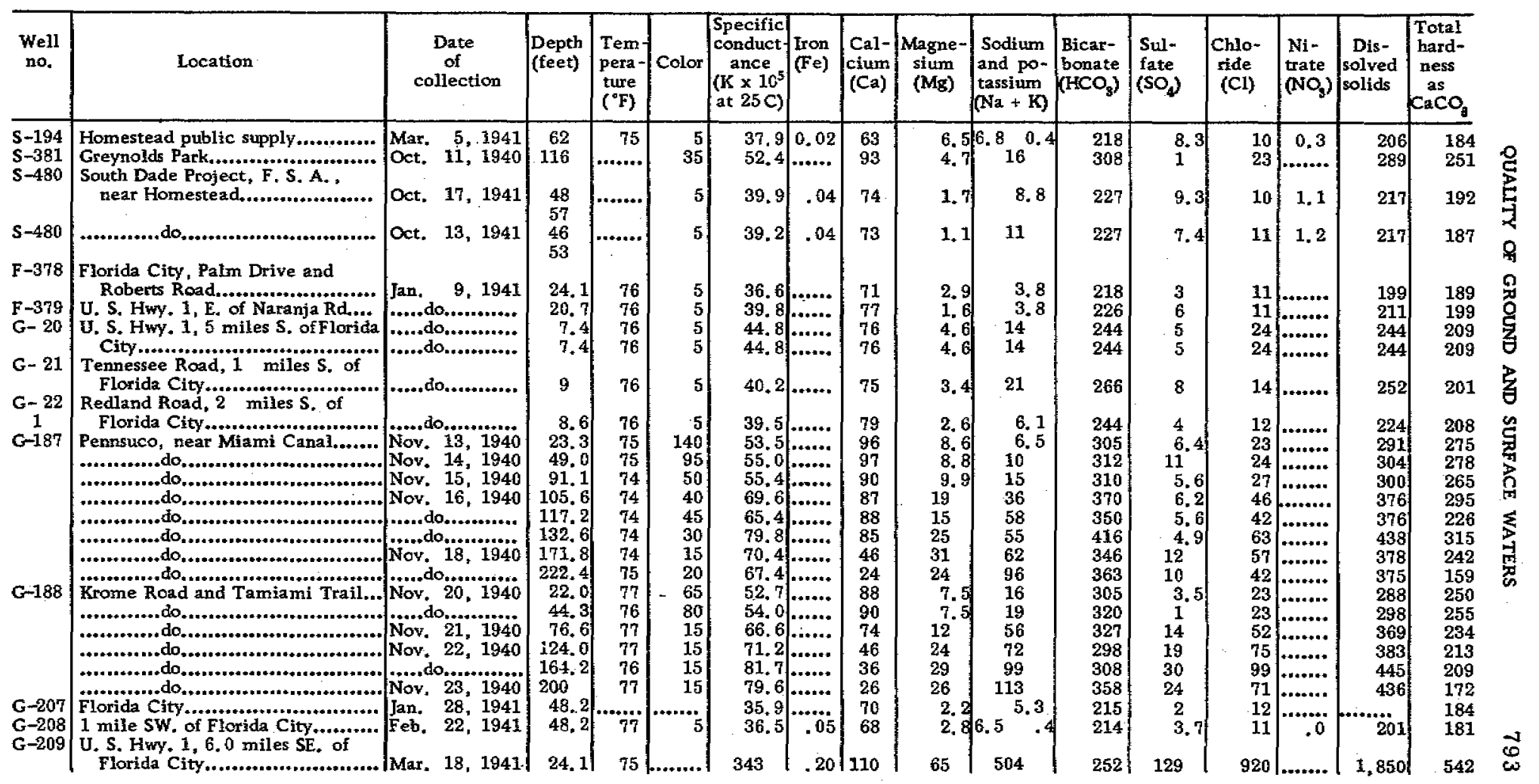


Table 104.-Analyses, in patts per million, of nonartesian waters in Dade County, outside Miani métropolitan area-Continued

\begin{tabular}{|c|c|c|c|c|c|c|c|c|c|c|c|c|c|c|c|c|}
\hline $\begin{array}{c}\text { Well } \\
\text { no. }\end{array}$ & Location & $\begin{array}{c}\text { Date } \\
\text { of } \\
. \quad \text { collection }\end{array}$ & $\begin{array}{l}\text { Depth } \\
\text { (feet) }\end{array}$ & $\begin{array}{l}\text { Tem- } \\
\text { pera- } \\
\text { ture } \\
\left({ }^{\circ} \mathrm{F}\right)\end{array}$ & Color & $\begin{array}{l}\text { Specific } \\
\text { conduct- } \\
\text { ance } \\
\left(\mathrm{K} \times 10^{5}\right. \\
\text { at } 25 \mathrm{C})\end{array}$ & $\mid \begin{array}{l}\text { Iron } \\
(\mathrm{Fe})\end{array}$ & $\begin{array}{l}\text { Cal- } \\
\text { cium } \\
\text { (Ca) }\end{array}$ & $\begin{array}{l}\text { Magne- } \\
\text { sium } \\
(\mathrm{Mg})\end{array}$ & $\mid \begin{array}{c}\text { Sodium } \\
\text { and po- } \\
\text { tassium } \\
(\mathrm{Na}+\mathrm{K})\end{array}$ & $\mid \begin{array}{l}\text { Bicar- } \\
\text { bonate } \\
\left(\mathrm{HCO}_{3}\right)\end{array}$ & $\begin{array}{l}\text { Sul- } \\
\text { fate } \\
\left(\mathrm{SO}_{4}\right)\end{array}$ & $\begin{array}{l}\text { Chlo- } \\
\text { ride } \\
\text { (C1) }\end{array}$ & $\begin{array}{l}\mathrm{Ni}- \\
\text { trate } \\
\left(\mathrm{NO}_{3}\right)\end{array}$ & $\begin{array}{c}\text { Dis- } \\
\text { solved } \\
\text { solids }\end{array}$ & $\begin{array}{l}\text { Total } \\
\text { hard- } \\
\text { ness } \\
\text { as } \\
\mathrm{CaCO}_{3}\end{array}$ \\
\hline-209 & 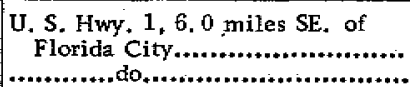 & $\mid \begin{array}{l}\text { Mar. } 18,1941 \\
\text { Mar. } 20,1941\end{array}$ & $\begin{array}{l}37.1 \\
59 .\end{array}$ & $\begin{array}{l}76 \\
77\end{array}$ & ..... & $\mid \begin{array}{l}2,370 \\
4,120\end{array}$ & 0.39 & $\begin{array}{l}840 \\
410\end{array}$ & $\begin{array}{l}158 \\
986\end{array}$ & $\begin{array}{l}4,520 \\
8,310\end{array}$ & $\begin{array}{l}230 \\
198\end{array}$ & 1,060 & $\begin{array}{r}7.990 \\
14,800\end{array}$ & ....... & $\begin{array}{r}1,470 \\
26,600\end{array}$ & 2,750 \\
\hline$G-210$ & 5 miles $S$, of Florida City and 1 . & Mar. 27, 1941 & 45.6 & 75 & & $\begin{array}{l}41.8 \\
37.7\end{array}$ & & $\begin{array}{l}67 \\
60\end{array}$ & 6.3 & $\begin{array}{l}12 \\
10\end{array}$ & $\begin{array}{l}216 \\
209\end{array}$ & 12 & 21 & 0.1 & $\begin{array}{l}225 \\
221\end{array}$ & 193 \\
\hline G-211 & 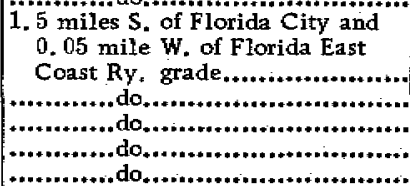 & 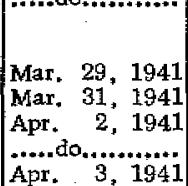 & $\begin{array}{l}33.9 \\
45.1 \\
59.4 \\
72 \\
81.9\end{array}$ & $\begin{array}{l}76 \\
76 \\
76 \\
77 \\
77\end{array}$ & $\mid \begin{array}{c}\cdots \\
\cdots \cdots \cdot . \\
\cdots \cdots \\
\end{array}$ & $\begin{array}{l}34.9 \\
36.2 \\
34.5 \\
35.4 \\
36.5\end{array}$ & $\mid \begin{array}{cc}.24 \\
\cdots \cdots . . . \\
\cdots .30\end{array}$ & $\begin{array}{l}67 \\
73 \\
73 \\
73 \\
71\end{array}$ & $\begin{array}{l}5.0 \\
3.7 \\
3.7 \\
4.4 \\
4.6\end{array}$ & $\begin{array}{r}.2 \\
.3 \\
2.3 \\
.8 \\
2.2\end{array}$ & $\begin{array}{l}204 \\
218 \\
220 \\
220 \\
218\end{array}$ & $\begin{array}{l}5.3 \\
3.7 \\
6.2 \\
4.5 \\
3.7\end{array}$ & $\begin{array}{l}11 \\
11 \\
11 \\
12 \\
13\end{array}$ & $\begin{array}{l}1 \\
01 \\
.1 \\
.1 \\
1\end{array}$ & $\begin{array}{l}189 \\
199 \\
205 \\
203 \\
202\end{array}$ & $\begin{array}{l}188 \\
197 \\
197 \\
200 \\
196\end{array}$ \\
\hline-212 & 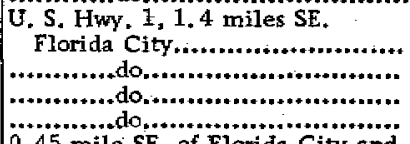 & $\begin{array}{lll}\text { Apr. } & 10,1941 \\
\text { Apr. } & 11,1941 \\
\text { Apr. } & 12, & 1941 \\
\text { Apr. } & 15,1941\end{array}$ & $\begin{array}{l}35.0 \\
53.3 \\
72.2 \\
78.6\end{array}$ & $\begin{array}{l}77 \\
77 \\
77 \\
76\end{array}$ & $\mid \cdots \cdots$ & $\begin{array}{r}37.9 \\
36.1 \\
42.7 \\
108\end{array}$ & $|\cdots \cdots \cdot|$ & $\begin{array}{l}72 \\
72 \\
67 \\
76\end{array}$ & $\begin{array}{r}4.8 \\
4.8 \\
7.6 \\
18\end{array}$ & $\begin{array}{r}9.6 \\
2.6 \\
18 \\
116\end{array}$ & $\begin{array}{l}227 \\
214 \\
223 \\
221\end{array}$ & $\begin{array}{c}14 \\
9.9 \\
13 \\
31\end{array}$ & $\begin{array}{r}14 \\
14 \\
29 \\
215\end{array}$ & $\begin{array}{l}.0 \\
.0 \\
.0\end{array}$ & $\begin{array}{l}226 \\
209 \\
244 \\
565\end{array}$ & $\begin{array}{l}199 \\
199 \\
198 \\
264\end{array}$ \\
\hline G-213 & $\begin{array}{l}0.45 \text { mile SE. of Florida City and } \\
3 \text { miles E. of } U \text {. S. Hwy. } 1 \text {. }\end{array}$ & $\begin{array}{ll}\text { Apr. } & 16,1941 \\
\text { Apr. } & 18,1941 \\
\text { Apr. } & 19,1941\end{array}$ & $\begin{array}{l}22 \\
55.9 \\
77.6\end{array}$ & $\begin{array}{l}76 \\
76 \\
76\end{array}$ & $\cdots \cdots$ & $\begin{array}{r}56.6 \\
71.4 \\
104\end{array}$ & $|\cdots \cdots \cdot|$ & $\begin{array}{l}68 \\
67 \\
86\end{array}$ & $\begin{array}{l}4.8 \\
7.6\end{array}$ & $\begin{array}{r}31 \\
57 \\
109\end{array}$ & $\begin{array}{l}212 \\
186 \\
228\end{array}$ & $\begin{array}{l}17 \\
23 \\
33\end{array}$ & $\begin{array}{r}53 \\
104 \\
201\end{array}$ & $\mid \begin{array}{l}.8 \\
\ldots \ldots . . . \\
\ldots . . .\end{array}$ & $\begin{array}{l}281 \\
350 \\
554\end{array}$ & $\begin{array}{l}198 \\
198 \\
268\end{array}$ \\
\hline$G-214$ & 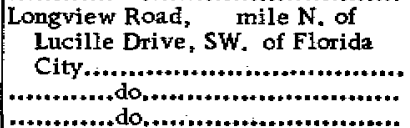 & 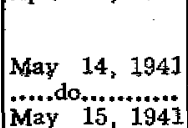 & $\begin{array}{l}37.2 \\
50.8 \\
61.4\end{array}$ & $\begin{array}{l}76 \\
76 \\
76\end{array}$ & $\mid \cdots \cdots$ & $\begin{array}{l}37.6 \\
38.5 \\
39.2\end{array}$ & $\cdots \cdots$ & $\begin{array}{l}70 \\
68 \\
66\end{array}$ & $\begin{array}{l}4.4 \\
3.1 \\
4.8\end{array}$ & $\begin{array}{r}12^{-4} \\
6.7\end{array}$ & $\begin{array}{l}202 \\
224 \\
210\end{array}$ & $\begin{array}{l}6.6 \\
5.3 \\
8.2\end{array}$ & $\begin{array}{l}15 \\
13 \\
13\end{array}$ & $\begin{array}{l}.0 \\
.0\end{array}$ & $\begin{array}{l}196 \\
212 \\
202\end{array}$ & $\begin{array}{l}193 \\
182 \\
184\end{array}$ \\
\hline$G-216$ & 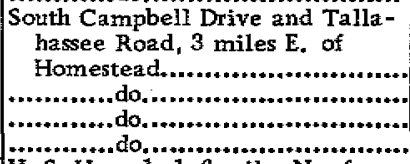 & 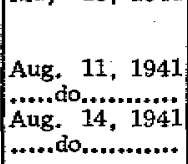 & $\begin{array}{l}25.5 \\
43.5 \\
71.1 \\
82.0\end{array}$ & $\begin{array}{l}76 \\
76 \\
76 \\
76\end{array}$ & $\mid \cdots \cdots$ & $\begin{array}{l}38.5 \\
37.2 \\
38.9 \\
38.7\end{array}$ & $\ldots$ & $\begin{array}{l}74 \\
70 \\
70 \\
60\end{array}$ & $\begin{array}{l}3.9 \\
3.3 \\
3.5 \\
4.4\end{array}$ & $\begin{array}{c}5.5 \\
4.8 \\
8.6 \\
17\end{array}$ & $\begin{array}{l}219 \\
208 \\
219 \\
205\end{array}$ & $\begin{array}{l}16 \\
11 \\
8.6 \\
16\end{array}$ & $\begin{array}{l}11 \\
11 \\
13 \\
14\end{array}$ & $\begin{array}{r}1.3 \\
1.5 \\
1.2 \\
.3\end{array}$ & $\begin{array}{l}220 \\
204 \\
213 \\
213\end{array}$ & $\begin{array}{l}201 \\
188 \\
189 \\
168\end{array}$ \\
\hline$G-217$ & 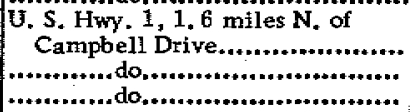 & $\begin{array}{l}\text { Aug. } 20,1941 \\
\text { Aug. } 22,1941 \\
\text { Aug. } 26,1941\end{array}$ & $\begin{array}{l}45.7 \\
67.8 \\
87.8\end{array}$ & $\begin{array}{l}76 \\
76 \\
76\end{array}$ & (....... & \begin{tabular}{l|}
37.3 \\
36.2 \\
37.6
\end{tabular} & (...... & $\begin{array}{l}68 \\
62 \\
67\end{array}$ & $\begin{array}{l}1.7 \\
2.6 \\
3.5\end{array}$ & \begin{tabular}{c|c|}
12 \\
8.6 \\
7.2
\end{tabular} & $\begin{array}{l}214 \\
193 \\
212\end{array}$ & $\begin{array}{l}9.5 \\
7.4 \\
8.2\end{array}$ & $\begin{array}{l}11 \\
12 \\
10\end{array}$ & $\begin{array}{l}.0 \\
1.2 \\
1.5 \\
1.0\end{array}$ & $\begin{array}{l}209 \\
189 \\
201\end{array}$ & $\begin{array}{l}177 \\
165 \\
182\end{array}$ \\
\hline
\end{tabular}




\begin{tabular}{|c|c|c|c|c|c|c|c|c|c|c|c|c|c|c|c|c|}
\hline $\mathrm{G}-218$ & Near Russian Colony Canal ${ }_{T}$ & Aug. 27,1941 & 108.5 & 76 & ...... & 38.8 & ...... & 64 & 5.5 & 14 & 219 & 17 & 11 & .8 & 220 & 182 \\
\hline$\checkmark=210$ & miles W, of Hialeah................. & Aug. $28 ; 1941$ & 19.6 & 76 & 70 & 53.5 & .03 & 97 & 6.3 & 15 & 328 & 5.81 & 19 & .0 & 305 & 268 \\
\hline & [............ do & Aug. 28, 1941 & 64.4 & 74 & 70 & 52.7 & .03 & 93 & 6.8 & 11 & 312 & 2.5 & 18 & .0 & 285 & 260 \\
\hline & {$[\ldots \ldots \ldots \ldots \ldots$ do } & Aug. 29, 1941 & 96.3 & 77 & $\mathbf{5}$ & 63.1 & .03 & 48 & 16 & 36 & 255 & 3.3 & 48 & .0 & 277 & 186 \\
\hline & {$[\ldots \ldots \ldots+\ldots, \ldots$} & Aug. 30, 1941 & 105.2 & 75 & 5 & 77.2 & .03 & 61 & 25 & 69 & 351 & 7.0 & 78 & .0 & 413 & 255 \\
\hline & 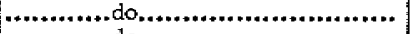 & Sept. 2, 1941 & 141.4 & 77 & 5 & 98.8 & .03 & 73 & 32 & 98 & 50 & 5.3 & 108 & +0 & 538 & 314 \\
\hline $\mathrm{G}-222$ & U. S, Hwy. 94,30 miles $w$ of & (....................... & $|158.8|$ & 77 & 5 & 99.4 & .03 & 58 & 36 & 108 & 136 & 10 & 114 & .0 & 541 & 293 \\
\hline $\mathrm{G}-224 \mathrm{~A}$ & 1. 5 miles W. of Milam Diary Road & Dec. 31, 1941 & 41.5 & 77 & 20 & 130 & .... & 160 & 30 & 92 & 688 & 3.1 & 110 & .1 & 1,470 & 523 \\
\hline & 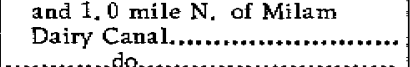 & Mar. 9,1942 & $\begin{array}{l}36.6 \\
91 \\
3\end{array}$ & 74 & 70 & 56.6 & $\cdots \cdot$ & $\begin{array}{r}102 \\
99\end{array}$ & 9.6 & $\begin{array}{l}3.7 \\
9.7\end{array}$ & $\begin{array}{l}300 \\
318\end{array}$ & 28 & 19 & .0 & 310 & 294 \\
\hline & ; & $\begin{array}{lll}\text { Mar. } & 10, & 1942 \\
\text { Mar, } & 11, & 1942\end{array}$ & $\begin{array}{l}91.3 \\
99\end{array}$ & 74 & $\cdots . .$. & $\begin{array}{l}60.6 \\
54.5\end{array}$ & $\cdots$. & $\begin{array}{l}99 \\
76\end{array}$ & $\begin{array}{l}11 \\
11\end{array}$ & 18 & $\begin{array}{l}318 \\
253\end{array}$ & $\begin{array}{l}18 \\
19\end{array}$ & $\begin{array}{l}24 \\
33\end{array}$ & .0 & & 234 \\
\hline & 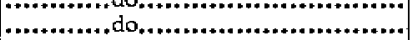 & .....do............... & 102 & 76 & & 69.6 & & 69 & 9.6 & 58 & 275 & 12 & TI & .0 & 355 & 212 \\
\hline$G-225$ & Dade-Broward Levee............................ & Apr. 7,1942 & 23.7 & 72 & 100 & 48.4 & .15 & 88 & 8.7 & 5.8 & 284 & 5.8 & 19 & 2.5 & 270 & 256 \\
\hline & .......... do & Apr. 8, 1942 & 43.8 & 72 & 130 & 51.4 & .20 & 92 & 7.9 & 6.0 & Th & 1.2 & 21 & 2.5 & 277 & 262 \\
\hline$G-270$ & NW. 103 rd St., 2.6 miles W. of & Apr. 28, 1942 & 100 & 75 & 10 & 121 & .10 & 77 & 34 & 142 & & 11 & 141 & .2 & 33 & 332 \\
\hline & Mian & Mar. $\quad 6,1941$ & 4.6 & & & 4 & & 82 & 4.4 & 13 & 268 & 3.3 & 18 & 2,0 & 255 & 223 \\
\hline G-271 & $\begin{array}{l}\text { Near Snapper Creek Canal, } 5.3 \\
\text { miles N. of U. S. Hwy. } 94, \ldots \ldots \ldots\end{array}$ & Ans & 7.31 & & & 52.0 & & 93 & 6.2 & 11 & 304 & 2.7 & & 3.0 & 286 & 258 \\
\hline$G-272$ & W. of Milam Dairy Road & & & & & & & & & & & & & & & \\
\hline G-273] & $\begin{array}{l}\text { and } 3 \text { miles } \mathrm{N} \text {. of Fla } \\
2.5 \text { miles } W \text {. of Milam } 1\end{array}$ & ......do................ & 5.5 & & & 5 & $\cdots$ & 96 & $6.3^{\circ}$ & 8.5 & 89 & 22 & 16 & 2.0 & 293 & 265 \\
\hline 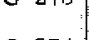 & er St........ & ...do... & 5.5 & & & 42,0 & & 100 & 5.2 & 5.6 & 304 & 17 & 11 & 1.0 & 290 & $2 \eta 1$ \\
\hline$G-274$ & Eiry Road & & & & & & & & & & & & & & & \\
\hline $\mathbf{G}-275$ & $\begin{array}{l}\text { ler St....... } \\
1,2 \text { miles }\end{array}$ & .....do... & 5.1 & & & 48.9 & .... & 95 & 4.9 & 5.7 & 74 & 25 & 13 & 1.0 & 280 & 257 \\
\hline 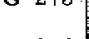 & 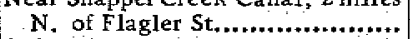 & ....do.... & 5.4 & & & 39.8 & & 76 & 4.7 & 6.5 & 25 & 6.2 & 15 & 1.5 & 227 & 209 \\
\hline$G-276$ & U. S. Hwy. 94 and & & & & & & & & & & & & & & & \\
\hline & E. of Krome Ave.... & a....do..... & 7.0 & & & 33.5 & & 60 & 4. & 7. & 189 & 3.7 & 17 & 2.0 & 188 & 169 \\
\hline $\mathrm{G}-447$ & 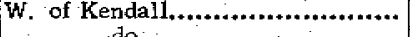 & Aug. 28, 194 & 30 & $\cdots \cdots$ & 15 & ............... & .3 & 81 & 3. & 4. & (........... & 16 & 0 & $\ldots . . .$. & 4 & 215 \\
\hline & 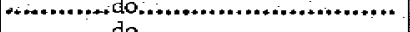 & Aug. 29,1946 & 40 & $\cdots \cdots$ & 15 & n............. & .8 & 80 & 3 . & 3. & & 9.9 & 11 & .. & & 211 \\
\hline & (n).................... & Aug. 30,1946 & 60 & [...... & 18 & n............. & .6 & 81 & 2. & 5.0 & & 13 & 9 & & & 211 \\
\hline & & Sept. 4, 1946 & 80 & & 5. & [............. & .2 & & & 7 . & & 5. & & & & \\
\hline$G-448$ & (n) & Aug. 21,1946 & 37.8 & .......... & 13 & [............. & .8 & 100 & & 8. & $\ldots$ & 46 & & {$[\cdots .$.} & 7 & \\
\hline & ...enten. & Aug. 26, 1946 & 88.1 & $\cdots \cdots \cdot \cdot$ & $\begin{array}{l}11 \\
10\end{array}$ & a............. & .5 & $\begin{array}{l}94 \\
92\end{array}$ & 4. & $\begin{array}{l}8.0 \\
3.0\end{array}$ & & 23 & 7 & $\cdots+\cdots$ & $2_{5}^{2}$ & 2 \\
\hline$G-449$ & , & $\begin{array}{l}\text { sept. } 23,1440 \\
\text { Sept, 11, } 1946\end{array}$ & $40^{\circ}$ & [a...... & 3 & 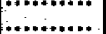 & 1 & 80 & 2. & $\begin{array}{l}3.0 \\
4.6\end{array}$ & & 1.6 & & & & 21 \\
\hline & ....... & Sept. 13, 1946 & 80 & ....... & 3 & & .05 & 78 & 2. & 4.0 & & 0.5 & & & & \\
\hline$G-450$ & 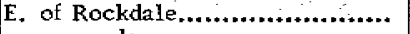 & Sept: 1 & 40 & 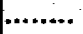 & 5 & ..... & .45 & 91 & 2. & 13 & & 22 & & $\because$ & & 2 \\
\hline & $\mid, \ldots \ldots \ldots \ldots$...................... & Sept. 16, & 60 & & 3 & & .15 & & 2. & 29 & & 4.5 & & & 257 & 218 \\
\hline
\end{tabular}


Table 104.-Analyses, in parts per million of nonartesian waters in Dade County, outside Miami metropolitan area-Continued

\begin{tabular}{|c|c|c|c|c|c|c|c|c|c|c|c|c|c|c|c|c|}
\hline $\begin{array}{c}\text { Well } \\
\text { no. }\end{array}$ & Location & $\begin{array}{l}\text { Date } \\
\text { of } \\
\text { collection }\end{array}$ & $\begin{array}{l}\text { Depth } \\
\text { (feet) }\end{array}$ & $\begin{array}{l}\text { Tem- } \\
\text { pera- } \\
\text { ture } \\
\left({ }^{\circ} \mathrm{F}\right)\end{array}$ & Color & $\begin{array}{l}\text { Specific } \\
\text { conduct- } \\
\text { ance } \\
(\mathrm{K} \times 105 \\
\text { at } 25 \mathrm{C})\end{array}$ & $\begin{array}{l}\text { Iron } \\
\text { (fe) }\end{array}$ & $\begin{array}{l}\text { Cal- } \\
\text { sium } \\
\text { (Ca) }\end{array}$ & $\begin{array}{l}\text { Magne- } \\
\text { sium } \\
\text { (Mg) }\end{array}$ & $\begin{array}{l}\text { Sodium } \\
\text { and po- } \\
\text { tassium } \\
(\mathrm{Na}+\mathrm{K})\end{array}$ & $\begin{array}{l}\text { Bicar- } \\
\text { bonate } \\
\left(\mathrm{HCO}_{3}\right)\end{array}$ & $\begin{array}{l}\mathrm{Sul-} \\
\text { fate } \\
\left(\mathrm{SO}_{4}\right)\end{array}$ & $\begin{array}{l}\text { Chlo- } \\
\text { ride } \\
\text { (C1) }\end{array}$ & $\begin{array}{c}\mathrm{Ni}- \\
\text { trate } \\
\left(\mathrm{NO}_{3}\right)\end{array}$ & $\begin{array}{l}\text { Dis- } \\
\text { solved } \\
\text { solids }\end{array}$ & $\begin{array}{l}\text { Total } \\
\text { hard- } \\
\text { ness } \\
\text { as } \\
\mathrm{CaCO}_{3}\end{array}$ \\
\hline GS-14 & 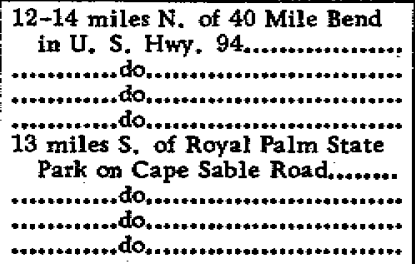 & $\begin{array}{l}\text { Sept. } 24,1942 \\
\text { Sept. } 25,1942 \\
\text { Sept. } 26,1943 \\
\text { Sept. } 7,1943 \\
\text { Sept. } 8,1943 \\
\text { Sept. } 10,1943\end{array}$ & $\begin{array}{l}(1) \\
18.5 \\
40.4 \\
51 \\
16.3 \\
28 \\
34 \\
64\end{array}$ & $\begin{array}{r}94 \\
77 \\
77 \\
78 \\
76 \\
76 \\
\ldots\end{array}$ & $\begin{array}{r}50 \\
20 \\
20 \\
10 \\
10 \\
7 \\
7 \\
75\end{array}$ & $\begin{array}{r}27.0 \\
90.0 \\
111 \\
147 \\
199 \\
951 \\
1,190 \\
256\end{array}$ & $\begin{array}{l}0.10 \\
.10 \\
.10 \\
.10 \\
.04 \\
.05 \\
.02 \\
.10\end{array}$ & $\begin{array}{r}41 \\
140 \\
128 \\
108 \\
94 \\
94 \\
254 \\
272 \\
70\end{array}$ & $\begin{array}{c}3.1 \\
10 \\
14 \\
18 \\
33 \\
149 \\
218 \\
47\end{array}$ & $\begin{array}{r}8.6 \\
78 \\
99 \\
205 \\
\\
262 \\
1,580 \\
2,030 \\
368\end{array}$ & $\begin{array}{l}125 \\
523 \\
480 \\
508 \\
\\
224 \\
234 \\
242 \\
122\end{array}$ & $\begin{array}{c}1.4 \\
5.8 \\
29 \\
49 \\
62 \\
364 \\
475 \\
99\end{array}$ & $\begin{array}{r}20 \\
51 \\
120 \\
228 \\
\\
490 \\
2,920 \\
3,750 \\
685\end{array}$ & $\begin{array}{r}2.2 \\
.2 \\
\ldots \ldots \ldots \\
.5 \\
\ldots \ldots \ldots \\
\cdots \ldots \ldots\end{array}$ & $\begin{array}{r}138 \\
543 \\
627 \\
859 \\
1,050 \\
5,380 \\
6,860 \\
1,230\end{array}$ & $\begin{array}{r}\mathbf{1 1 5} \\
\mathbf{3 9 0} \\
\mathbf{3 7 7} \\
\mathbf{3 4 4} \\
\\
\mathbf{3 7 0} \\
1,250 \\
1,580 \\
368\end{array}$ \\
\hline
\end{tabular}

${ }^{\mathrm{I}}$ Surface sample from Everglades near site of Well GS-14. 


\section{COASTAL AREAS NORTH OF MIAMI}

\section{BROWARD COUNTY}

Most of the wells in the coastal area in Broward County from which samples were collected are located on the low sandy ridge that occupies a narrow strip about 10 miles wide between the Everglades and the ocean. Most of the population and all of the urban communities, including Deerfield Beach, Pompano Beach, Fort Lauderdale, Dania, and Hollywood, are in this area. (See fig. 222.) All of the public supplies for these towns are obtained from wells.

The composition of ground water in the coastal strip in Broward County is similar to that in Dade County. except that the total mineral content is somewhat less. (See table 105.) The dissolved matter was composed primarily of calcium and bicarbonate. Concentrations of magnesium were usually less than $5 \mathrm{ppm}$, and concentrations of sulfate and chloride were usually less than 25 pprn. 
Table 105. - Analyses, in parts per million, of nonartesian waters in Broward County

[See plates 19 and 20]

\begin{tabular}{|c|c|c|c|c|c|c|c|c|c|c|c|c|c|c|c|c|}
\hline $\begin{array}{l}\text { Well } \\
\text { no. }\end{array}$ & Location & $\begin{array}{l}\text { Date } \\
\text { of } \\
\text { collection }\end{array}$ & $\begin{array}{l}\text { Depth } \\
\text { (feet) }\end{array}$ & $\begin{array}{c}\text { Tem- } \\
\text { pera- } \\
\text { ture } \\
\left({ }^{\circ} \mathrm{F}\right)\end{array}$ & Color & $\begin{array}{l}\text { Specific } \\
\text { conduct- } \\
\text { ance } \\
\left(\mathrm{K} \times 10^{5}\right. \\
\text { at } 25 \mathrm{C})\end{array}$ & $\begin{array}{l}\text { Iron } \\
(\mathrm{Fe})\end{array}$ & $\begin{array}{l}\text { Cal- } \\
\text { cium } \\
\text { (Ca) }\end{array}$ & $\begin{array}{l}\text { Magne- } \\
\text { sium } \\
(\mathrm{Mg})\end{array}$ & $\begin{array}{l}\text { Sodium } \\
\text { and po- } \\
\text { tassium } \\
(\mathrm{Na}+\mathrm{K})\end{array}$ & $\begin{array}{l}\text { Bicar - } \\
\text { bonate } \\
\left(\mathrm{HCO}_{3}\right)\end{array}$ & $\begin{array}{l}\text { Sul- } \\
\text { fate } \\
\left(\mathrm{SO}_{4}\right)\end{array}$ & $\begin{array}{l}\text { Chlo- } \\
\text { ride } \\
\text { (Cl) }\end{array}$ & $\mid \begin{array}{l}\mathrm{Ni}- \\
\text { trate } \\
\left(\mathrm{NO}_{3}\right)\end{array}$ & $\begin{array}{l}\text { Dis- } \\
\text { solved } \\
\text { solids }\end{array}$ & $\begin{array}{l}\text { Total } \\
\text { hard- } \\
\text { ness } \\
\text { as } \\
\mathrm{CaCO}_{3}\end{array}$ \\
\hline $\begin{array}{l}\mathrm{S}-332 \\
\mathbf{S}-333\end{array}$ & Holly wood, public supply (raw wat & Dec. 10, 1941] & $\begin{array}{l}70 \\
70\end{array}$ & & 40 & 53.1 & 0.24 & 103. & 2.6 & 11 & 301 & 19 & 17 & 0.1 & 333 & 268 \\
\hline$s-337$ & $\begin{array}{l}\text { Oakland Park, Old Dixie Hwy. opposite } \\
\text { Florida East Coast Ry. station........... } \\
\text { Fort Lauderdale, Old Dixie Hwy, and }\end{array}$ & Nov. 19,1940 & 60.9 & .7 & 130 & 46.8 & & 89 & 3.1 & 7.6 & 265 & 5.8 & 20 & & 256 & 235 \\
\hline $5-340$ & $\begin{array}{l}\text { Middle Rivex................................. } \\
\text { Pompano Beach, public supply............ }\end{array}$ & $\begin{array}{l}\text { Oct. } 18,1940 \\
\text { Nov. } 29,1941\end{array}$ & $\begin{array}{r}72 \\
170 \\
190\end{array}$ & $\cdots \cdots$ & $\begin{array}{l}50 \\
20\end{array}$ & $\begin{array}{l}64.3 \\
26.8\end{array}$ & & $\begin{array}{r}113 \\
47\end{array}$ & $\begin{array}{l}3.1 \\
2.3\end{array}$ & $\begin{array}{c}18 \\
8.5\end{array}$ & $\begin{array}{l}297 \\
136\end{array}$ & $\mathbf{1 1}$ & $\begin{array}{l}64 \\
15\end{array}$ & & $\begin{array}{l}345 \\
165\end{array}$ & $\begin{array}{l}295 \\
127\end{array}$ \\
\hline $\begin{array}{l}S-341 \\
S-342\end{array}$ & $\begin{array}{l}\text { Pompano Beach, NE. Ave. and 4th St... } \\
\text { Deerfield Beach, public supply.......... }\end{array}$ & $\begin{array}{l}\text { Oct. } 18,1940 \\
\text { Nov. } 29,1941\end{array}$ & $\begin{array}{r}189 \\
72\end{array}$ & 79 & $\begin{array}{l}20 \\
25\end{array}$ & $\begin{array}{l}30.7 \\
28.0\end{array}$ & 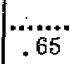 & $\begin{array}{l}56 \\
51\end{array}$ & $\begin{array}{l}2.5 \\
3.1\end{array}$ & $\begin{array}{l}5.8 \\
5.6\end{array}$ & $\begin{array}{l}173 \\
153\end{array}$ & $\begin{array}{l}1 \\
7.6\end{array}$ & $\begin{array}{l}14 \\
13\end{array}$ & 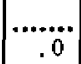 & $\begin{array}{l}164 \\
164\end{array}$ & $\begin{array}{l}150 \\
140\end{array}$ \\
\hline $\begin{array}{l}S-366 \\
S-369\end{array}$ & Fort Lauderdale, public supply.. & Dec. 4,1941 & $\begin{array}{r}81 \\
106\end{array}$ & $x_{0}+2$ & 110 & 45.8 & 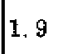 & 88 & 3.3 & 12 & 266 & 2.4 & 18 & 2.1 & 294 & 233 \\
\hline $5-372$ & Pompano Beach, old race track.. & Oct. 18,1940 & 120 & …... & 40 & 38.9 & & 74 & 2.7 & 5.4 & 226 & 1 & 15 & & 209 & 196 \\
\hline $5-393$ & Dania, public supply................ & Dec. 10,1941 & 103 & $\ldots . . . .$. & 100 & 56.6 & 2 & 107 & 4.0 & 14 & 307 & 27 & 24 & 1 & 355 & 283 \\
\hline $\begin{array}{l}S-427 \\
S-427\end{array}$ & Davie Air Field................................ & Jan. 27,1941 & 99.2 & 77 & $\ldots . . .$. & 34.5 & $\ldots \ldots$ & 52 & 6.6 & 6.5 & $17 \mathrm{~T}$ & 7.4 & 13 & ... & 173 & 157 \\
\hline $\begin{array}{l}S-427 \\
S-428\end{array}$ & .............do....................................... & Jan. 29,1941 & 103.2 & 76 & 140 & 49.5 & $\ldots+\cdots$ & 92 & 7.8 & 6.9 & 292 & 21 & 11 & 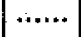 & 282 & 262 \\
\hline $\begin{array}{l}3-428 \\
S-440\end{array}$ & 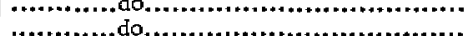 & Jan. 30,1941 & 53.2 & $\pi$ & & $\begin{array}{l}43.8 \\
36.2\end{array}$ & 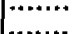 & 60 & $\begin{array}{l}6.9 \\
5.2\end{array}$ & 4.0 & $\begin{array}{l}245 \\
216\end{array}$ & 17 & $\begin{array}{r}13 \\
9\end{array}$ & $\cdots \cdots *$ & $\begin{array}{l}242 \\
194\end{array}$ & 228 \\
\hline$s-441$ & ..............do....... & Feb. 1, 1941 & 53 & 77 & & 31.9 & & 62 & 2.9 & 14 & 212 & 12 & 8 & $\cdots$ & 203 & $16 ?$ \\
\hline$S-452$ & Perry Air Field.............. & Feb. 21,1941 & 52.2 & 77 & & 40.0 & 1.8 & 82 & 2.8 & .9 & 210 & 32 & 9 & & 230 & 216 \\
\hline$S-454$ & North Perry Air Field................ & Feb. 24,1941 & 100.4 & 77 & & 52.0 & 2: 4 & 98 & 8.1 & 3.5 & 295 & 19 & 17 & $\ldots$ & 291 & 278 \\
\hline$S-455$ & 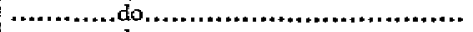 & Mar. 3, 1941 & 78.5 & 77 & 90 & 34.6 & 80 & 65 & 5.6 & 3.0 & 210 & 8 & 8 & ....... & 193 & 185 \\
\hline $5-463$ & do............ & Mar. 12,1941 & 67.0 & 77 & 110 & 42.0 & .90 & 81 & 5.5 & .2 & 247 & .7 & 11 & .0 & 226 & 225 \\
\hline$F-292$ & Holly wood, 24th Ave, and Adams St.... & 5,1940 & 72.4 & 78 & 40 & 55.6 & 1.9 & 110 & 3.7 & 14 & 296 & 42 & 23 & .5 & 339 & 290 \\
\hline $\begin{array}{l}F-294 \\
G-184\end{array}$ & $\begin{array}{l}\text { Hollywood, } 24 \text { th A Are, and Hayes St...... } \\
\text { Holly wood Blvd, } 7 \text { miles } W \text {. of State }\end{array}$ & ,.....do........... & 133.4 & $\ldots$ & 30 & 50.4 & 2.5 & 100 & 5.7 & 13 & 294 & 24 & 23 & 3.0 & 314 & 273 \\
\hline & Hwy. $7 \ldots \ldots \ldots \ldots \ldots \ldots \ldots \ldots \ldots \ldots \ldots \ldots \ldots$ & Oct. 15, 1940 & 46.1 & 77 & 45 & 71.8 & & 128 & 11 & 15 & 386 & 43 & 25 & & 412 & 365 \\
\hline & ...............dondo. & .....do........... & 62.2 & 78 & 20 & 56.1 & $\cdots$ & 90 & 11 & 16 & 282 & 33 & 27 & $\cdots \cdots$ & 316 & 270 \\
\hline . & do.. & 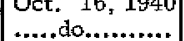 & 92.4 & 78 & $\begin{array}{l}20 \\
25\end{array}$ & $\begin{array}{l}53.1 \\
48.8\end{array}$ & $\cdots \cdots$ & $\begin{array}{l}68 \\
68\end{array}$ & 10 & $\begin{array}{l}18 \\
22\end{array}$ & $\begin{array}{l}285 \\
243\end{array}$ & $\begin{array}{l}16 \\
15\end{array}$ & $\begin{array}{l}30 \\
31\end{array}$ & & $\begin{array}{l}300 \\
266\end{array}$ & $\begin{array}{l}253 \\
211\end{array}$ \\
\hline & 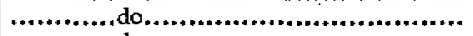 & .....do........... & 108.0 & 75 & 30 & 60.6 & & 103 & 8.6 & 15 & 343 & 1 & 31 & ......... & 328 & 292 \\
\hline$G-190$ & State $\mathrm{Hw}, 25,12$ miles $\mathrm{N}$. of $20-\mathrm{Mile}$ & Oct. 17,1940 & 144.7 & $7 T$ & 20 & 104 & & 97 & 22 & 102 & 487 & $\hat{2}$ & 108 & .......... & 571 & 333 \\
\hline & Bend. & Nov. $27,1940 \mid$ & 17.1 & 78 & 35 & 71.2 & & 79 & 26 & 40 & 365 & 20 & 44 & & $39 ?$ & 304 \\
\hline
\end{tabular}




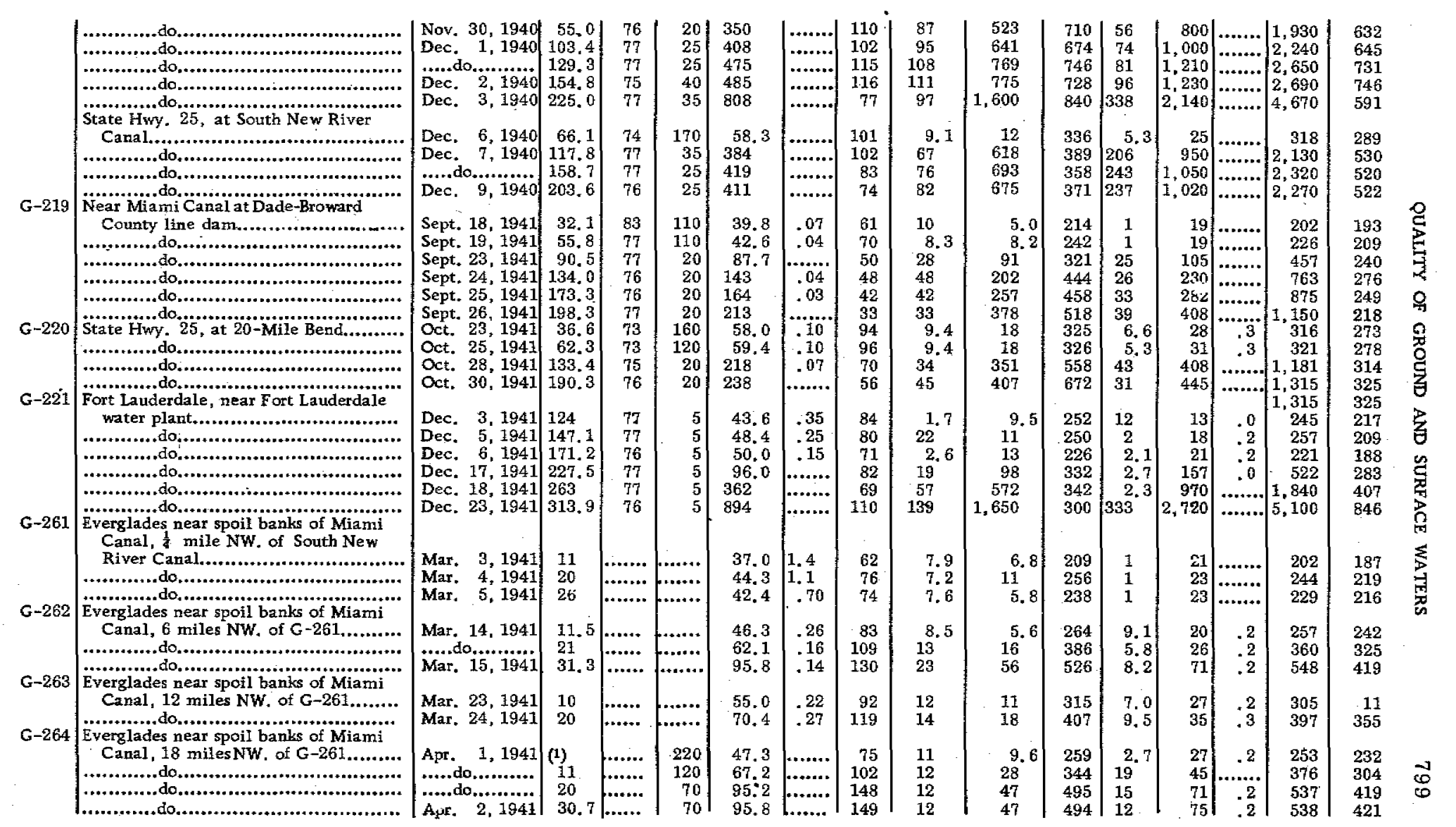


Table 105.-Analyses, in parts per million, of nonartesian waters in Broward County-Continued

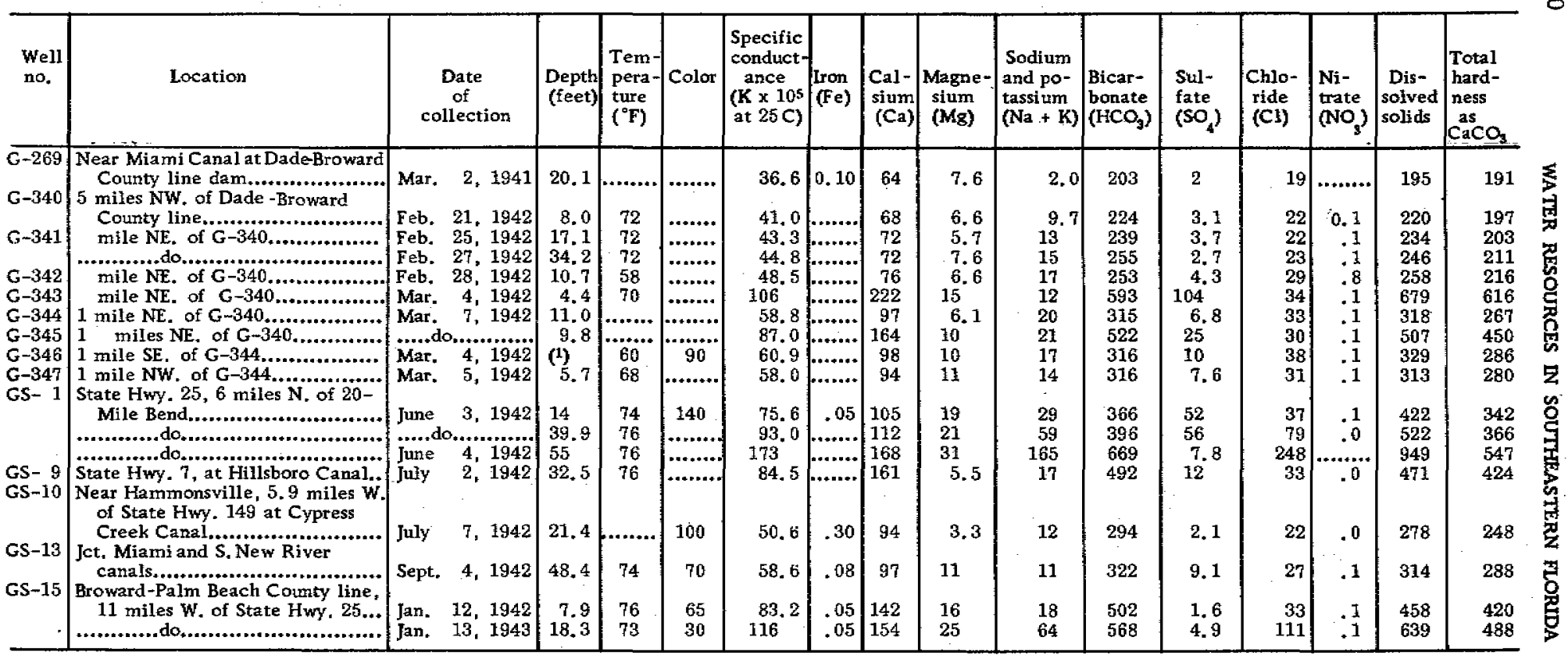

\footnotetext{
1 Surface water.
} 


\section{PALM BEACH COUNTY}

The chemical character of ground water in coastal areas in Palm Beach County differs considerably from the character of ground water in coastal areas of Dade and Broward Counties. (See table 106.) In an area about 10 miles inland from the coast and about 35 miles north and south, extending from the Broward County line to near the Martin County line, water samples were collected for analys is from about 80 wells. The wells range from a few feet to over $100 \mathrm{ft}$ in depth.

There are a large number of wells in the coastal area of Palm Beach County, most of which are used by owners of small farms for domestic purposes or for watering stock and for irrigation.

The public supplies of Lantana, Lake Worth, Boynton Beach, Delray Beach, Boca Raton, Riviera, and Lake Park are taken from wells. The public supply of West Palm Beach is obtained from surface sources. In West Palm Beach, ground water is used by several light industries. Some of the wells near the coast, both in West Palm Beach and in other places in the county, have been contaminated with sea water.

Wells, less than 50 feet deep, within 1 to 3 miles from the coast usually yield relatively soft water-less than 100 ppm hardness; farther inland, they are likely to yield somewhat harder water. Water from wells over $50 \mathrm{ft}$ deep, both near the coast and farther inland, is usually harder than water from shallow wells. 
Table 106. - Analyses, in parts per million, of nonartesian waters in eastem Palm Beach County

[See plates 19 and $\overrightarrow{24}$ ]

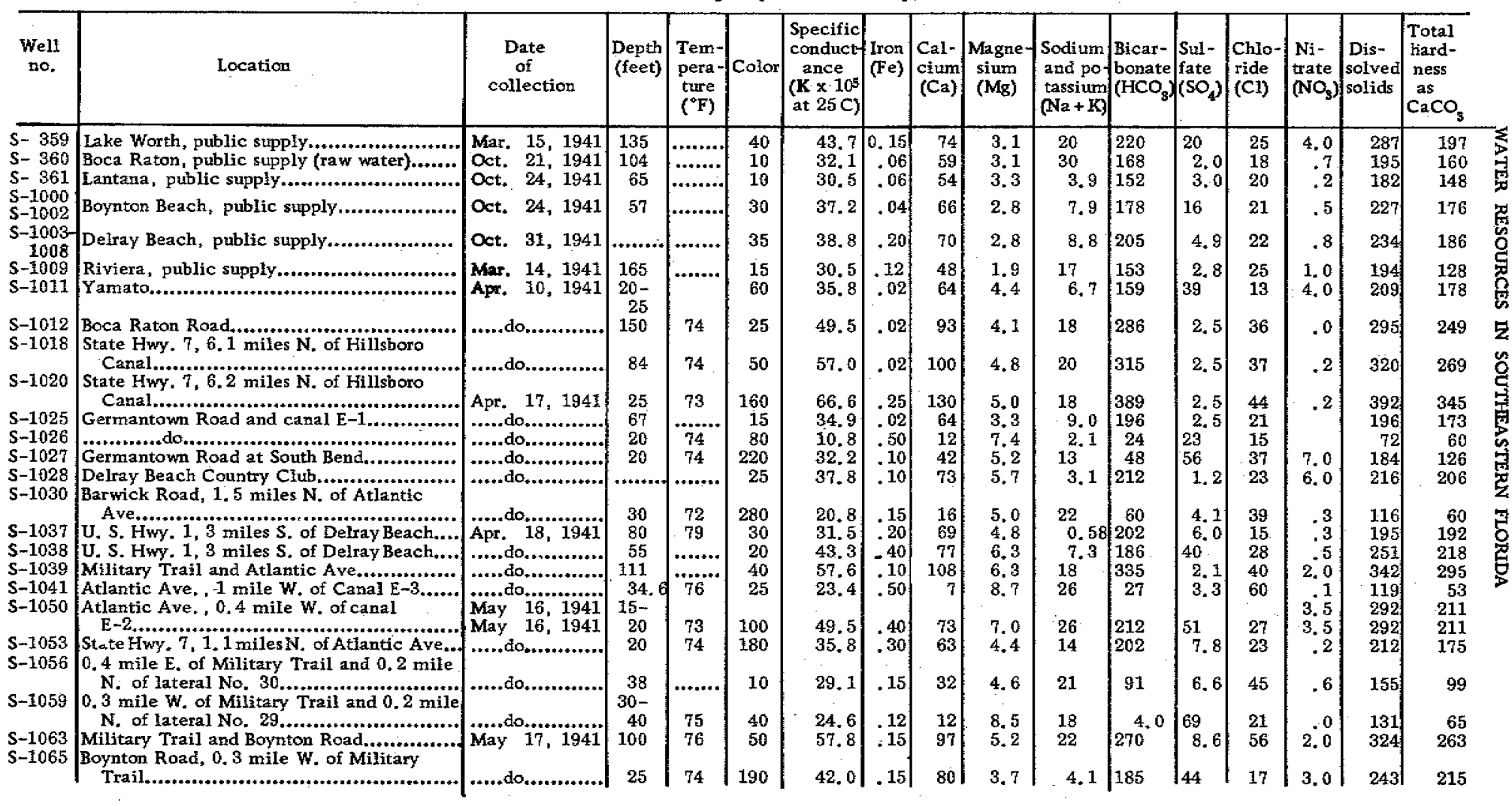




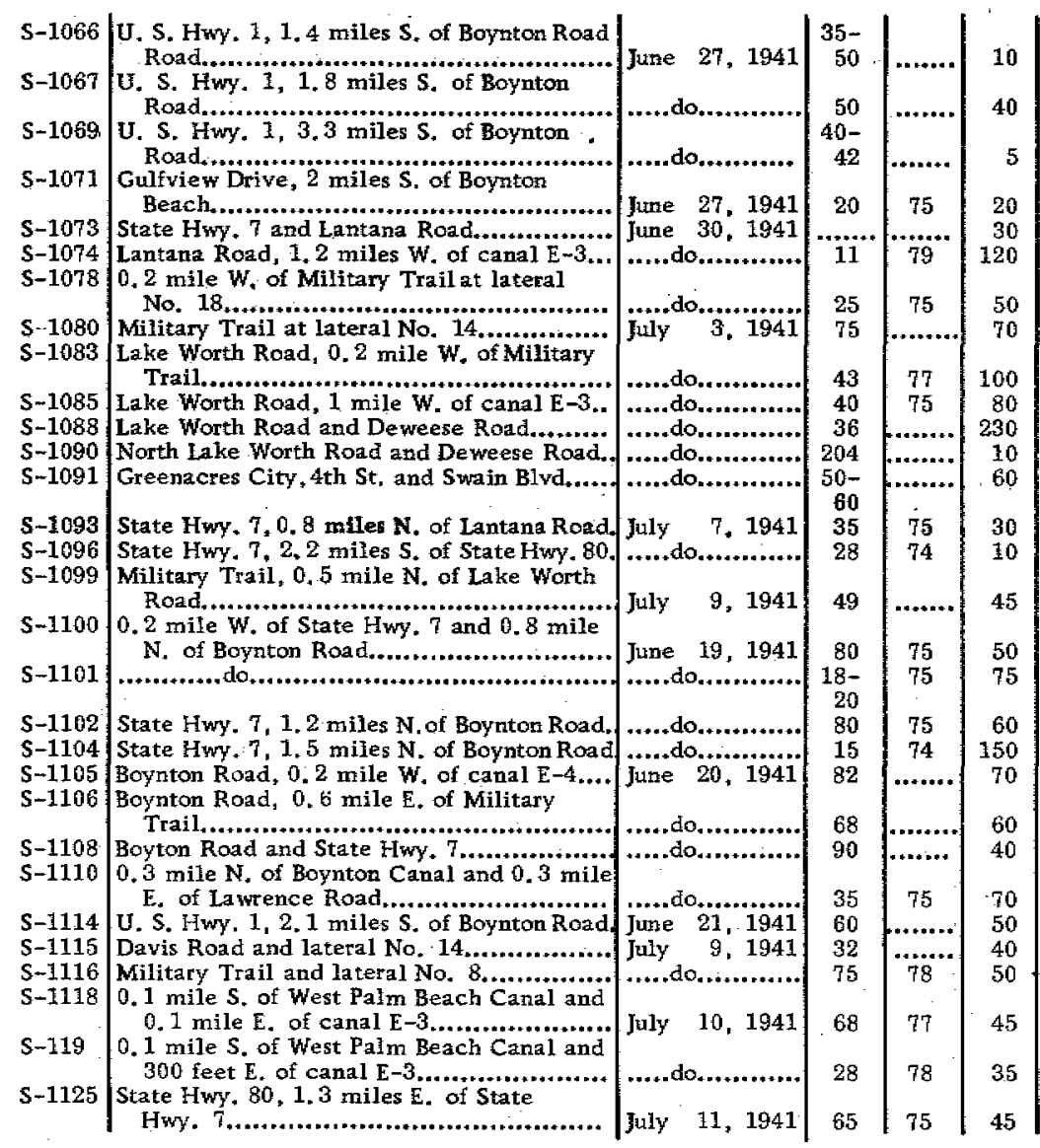

\begin{tabular}{|c|c|c|c|c|c|c|c|c|c|c|}
\hline 30.6 & .40 & 49 & 2.0 & 12 & 146 & 7.0 & 21 & .2 & 164 & 131 \\
\hline 42,2 & .50 & 74 & 5.0 & 7.1 & 220 & 7.4 & 23 & .2 & 226 & 205 \\
\hline 18.1 & .20 & 30 & 2.8 & 5.3 & 81 & 14 & 12 & .1 & 104 & 86 \\
\hline $\begin{array}{c}158 \\
52.9\end{array}$ & .20 & $\begin{array}{l}134 \\
101\end{array}$ & $\begin{array}{l}1.1 \\
4.4\end{array}$ & $\begin{array}{l}189 \\
6.0\end{array}$ & $\begin{array}{l}250 \\
271\end{array}$ & $\begin{array}{l}69 \\
25\end{array}$ & $\begin{array}{r}335 \\
24\end{array}$ & 1,5 & $\begin{array}{l}852 \\
296\end{array}$ & $\begin{array}{l}339 \\
270\end{array}$ \\
\hline 91.2 & .20 & 120 & 5.2 & 71 & 312 & 77 & 98 & 1.2 & 526 & 321 \\
\hline $\begin{array}{l}61.6 \\
62.4\end{array}$ & .20 & 95 & 2.4 & 34 & 298 & 1 & 54 & .0 & 333 & 247 \\
\hline & .10 & 81 & & & 1300 & 1.2 & 57 & .0 & 10 & 236 \\
\hline 30.5 & 1.1 & 46 & 3.3 & 15 & 160 & 2.9 & 19 & .8 & 167 & 128 \\
\hline 46.2 & .15 & 72 & 3. & 20 & 225 & 2.7 & 35 & & & 194 \\
\hline & .23 & 22 & 2. & 18 & 60 & 18 & 25 & 1.8 & 117 & 65 \\
\hline 86.6 & .03 & 120 & 8. & 61 & 432 & 1.4 & 80 & .0 & 484 & 335 \\
\hline 41.9 & .55 & 66 & 3.9 & 21 & 224 & 15 & 16 & 5.3 & 2.31 & 181 \\
\hline 61.6 & .06 & 114 & 2.4 & 12 & 318 & 4.3 & 38 & 3.0 & 330 & 294 \\
\hline 67.6 & .10 & 124 & 5.5 & 15 & 382 & 8.6 & 30 & 1.7 & 373 & 332 \\
\hline 60.0 & .60 & 92 & 5.9 & 29 & 299 & 1.4 & 50 & .0 & 326 & 254 \\
\hline 70.0 & .20 & 80 & 4.8 & 74 & 360 & 5. 3 & 56 & .0 & 398 & 219 \\
\hline 86.2 & .60 & 70 & 2.0 & 136 & 443 & 30 & 60 & .0 & 517 & 183 \\
\hline 75.9 & .30 & 116 & 3.7 & 52 & 377 & 12 & 68 & 0 & 438 & 305 \\
\hline 65.4 & .20 & & 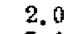 & 32 & 38 & 6.2 & 23 & 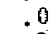 & 375 & 295 \\
\hline 83.0 & 15 & 131 & 7.4 & 42 & 336 & 133 & 25 & .2 & 504 & 357 \\
\hline 39.6 & .35 & 58 & 2.2 & 26 & 10 & 9.1 & 30 & .0 & 221 & 154 \\
\hline 2.7 & .20 & 78 & 7 & 68 & 329 & 6.2 & 49 & .0 & 364 & 197 \\
\hline 22.9 & .20 & 36 & 5.9 & 4.4 & 120 & 9. & 11 & .0 & 126 & 114 \\
\hline & .35 & 71 & 5. & 8.1 & 21 & 12 & 22 & .2 & & 200 \\
\hline & 1.3 & 72 & 6.1 & 15 & 23 & 4.1 & 30 & .0 & 24 & 205 \\
\hline 6 & .22 & 100 & 11 & 27 & 317 & 2.3 & 65 & 0 & 362 & 295 \\
\hline 50.8 & .60 & 82 & 4.6 & 21 & 256 & 31 & 19 & .0 & 284 & 224 \\
\hline 56.4 & .40 & 90 & 5.5 & 20 & 275 & 14 & 35 & 2.5 & 303 & 247 \\
\hline 10 & 20 & 134 & 10 & 67 & 382 & 11 & 139 & 1.6 & 551 & 376 \\
\hline
\end{tabular}


Table 106.-Analyses in parts per million, of nonartesian waters in eastem Palm Beach County-Continued

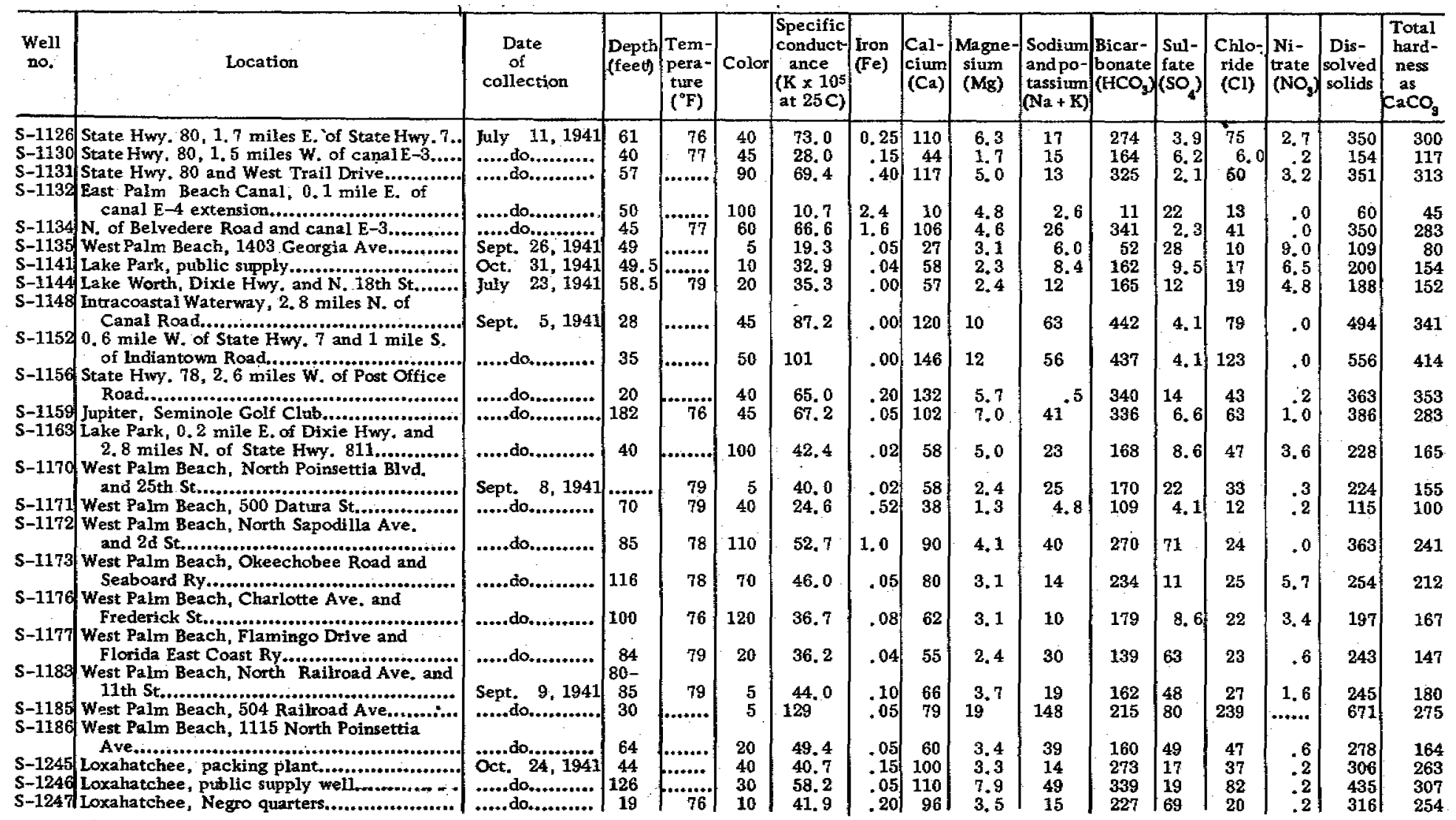




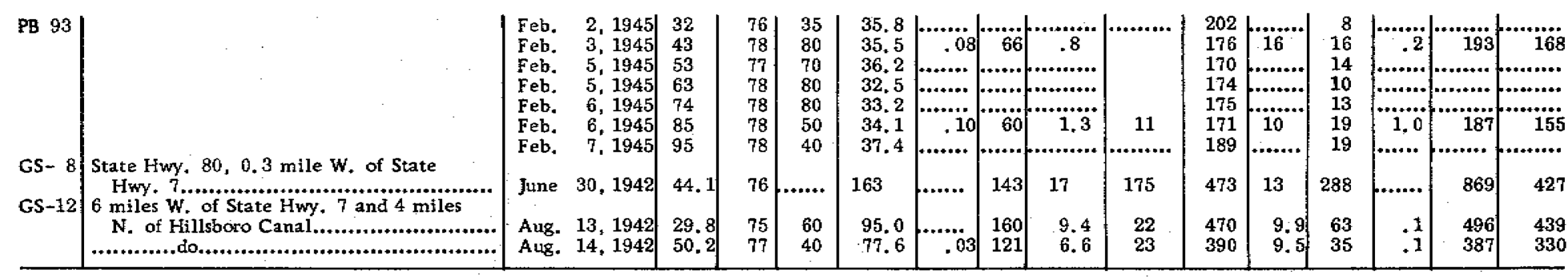




\section{AREAS SURROUNDING LAKE OKEECHOBEE}

In the areas adjacent to Lake Okeechobee private water supplies for domestic use and for watering stock are generally obtained from wells less than $100 \mathrm{ft}$ deep. The town of Moore Haven obtains part of its public supply from three wells, $28 \mathrm{ft}$ deep, near the Caloosahatchee Canal. Most of the wells start in muck soils, although nearly all of them terminate in shell marl or lime rock beneath the muck. In Okeechobee County, on the north side of the lake, the muck layer is very thin, or entirely absent, and the surface soils are sandy.

As indicated in the following discussion of counties, the ground water in wells within a few miles of Lake Okeechobee usually contains considerably more dissolved matter than is found in the ground water in the coastal areas of southeastern Florida or in the lake. The lake water is not readily avallable to individual farms, which must, therefore, use the less desirable well water.

\section{GLADES COUNTY}

Samples were collected from 20 wells in Glades County near the northwestern, western, and southwestern border of Lake Okeechobee. (See table 107.) Most of the wells are less than $100 \mathrm{ft}$ deep. Dissolved solids ranged from 366 to $2,276 \mathrm{ppm}$ and hardness ranged from 255 to $833 \mathrm{ppm}$. The most characteristic constituent of the dissolved mineral matter in these samples was bicarbonate, which ranged in concentration from 250 to $632 \mathrm{ppm}$. Samples collected from wells north of Moore Haven were usually less concentrated than samples collected south and southeast of Moore Haven.

Water from wells south and southeast of Moore Haven contained relatively large amounts of sodium, sulfate, and chloride, in addition to bicarbonate. Sodium concentrations in these well waters ranged from 47 to $559 \mathrm{ppm}$, sulfate ranged from 27 to $212 \mathrm{ppm}$, and chloride ranged from 133 to $1,008 \mathrm{ppm}$. Chloride was sometimes present in amounts more than equivalent to the sodium. Although specific information as to the corrosiveness of these waters was not available, waters that contain more chloride than sodium are frequently corrosive to plumbing. The concentration of dissolved solids was so high in many of the wells that the water probably would not be used for domestic purposes if more suitable water were readily procurable. 
Table 107. - Analyses, in perts per million, of nonartesian waters in Glades County

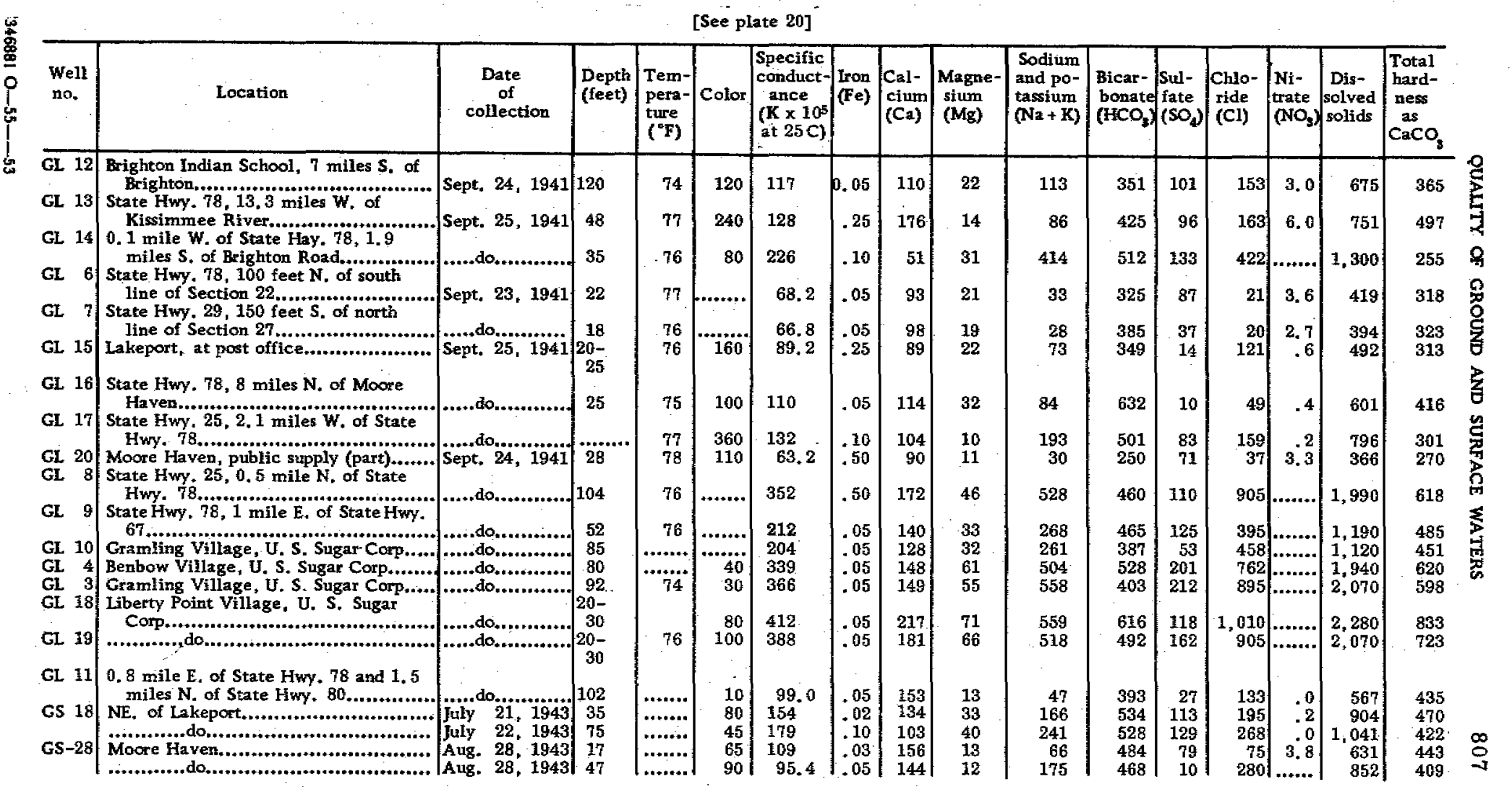


Table 107.-Analyses, in parts per million, of nonartesian waters in Glades County-Continued

\begin{tabular}{|c|c|c|c|c|c|c|c|c|c|c|c|c|c|c|c|c|}
\hline $\begin{array}{c}\text { Well } \\
\text { no. }\end{array}$ & Location & $\begin{array}{l}\text { Date } \\
\text { of } \\
\text { collection }\end{array}$ & $\begin{array}{l}\text { Depth } \\
\text { (feet) }\end{array}$ & $\begin{array}{l}\text { Tem- } \\
\text { pera- } \\
\text { ture } \\
\left({ }^{*} \mathrm{~F}\right)\end{array}$ & Color & \begin{tabular}{|c|} 
Specific \\
conduct- \\
ance \\
$\left(\mathrm{K} \times 10^{5}\right.$ \\
2t $25 \mathrm{C})$
\end{tabular} & $\begin{array}{l}\text { Iron } \\
(\mathrm{Fe})\end{array}$ & $\left|\begin{array}{l}\text { Cal- } \\
\text { cium } \\
(\mathrm{Ca})\end{array}\right|$ & $\begin{array}{c}\text { Magne- } \\
\text { sium } \\
(\mathrm{Mg})\end{array}$ & $\begin{array}{l}\text { Sodium } \\
\text { and po- } \\
\text { tassium } \\
(\mathrm{Na}+\mathrm{K})\end{array}$ & $\begin{array}{l}\text { Bicar- } \\
\text { bonate } \\
\left(\mathrm{HCO}_{3}\right)\end{array}$ & $\begin{array}{l}\text { Sul- } \\
\text { fate } \\
\left(\mathrm{SO}_{4}\right)\end{array}$ & $\begin{array}{l}\text { Chlo- } \\
\text { ride } \\
\text { (Cl) }\end{array}$ & $\left.\begin{array}{l}\mathrm{Ni}- \\
\text { trate } \\
\mathrm{NO}_{3}\end{array}\right)$ & $\begin{array}{l}\text { Dis- } \\
\text { solved } \\
\text { solids }\end{array}$ & $\begin{array}{l}\text { Total } \\
\text { hard- } \\
\text { ness } \\
\text { as } \\
\mathrm{CaCO}_{3}\end{array}$ \\
\hline $\begin{array}{ll}\text { GS } 28 \\
\text { GS } 29\end{array}$ & 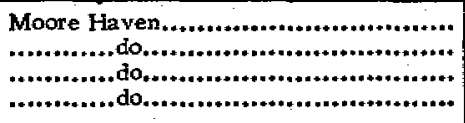 & $\begin{array}{l}\text { Aug. } 28,1943 \\
\text { Aug. } 31,1943 \\
\text { Sept. } 1,1943 \\
\text { Sept. } 1,1945\end{array}$ & $\begin{array}{l}63 \\
33.7 \\
51 \\
75\end{array}$ & (n...... & $\begin{array}{r}42 \\
90 \\
20 \\
\ldots+\cdots\end{array}$ & $\begin{array}{l}115 \\
161 \\
153 \\
160\end{array}$ & $\begin{array}{c}0.02 \\
.06 \\
.07 \\
\cdots \cdots\end{array}$ & $\begin{array}{r}156 \\
174 \\
78 \\
\cdots \cdots\end{array}$ & $\begin{array}{c}17 \\
31 \\
36 \\
\cdots \cdots \cdots\end{array}$ & $\begin{array}{r}83 \\
135 \\
201 \\
2\end{array}$ & $\begin{array}{l}476 \\
464 \\
384 \\
374\end{array}$ & $\begin{array}{r}88 \\
154 \\
96 \\
\cdots\end{array}$ & $\begin{array}{l}112 \\
218 \\
258 \\
270\end{array}$ & $\begin{array}{r}0.2 \\
9.6 \\
.1 \\
\cdots \cdots \\
\cdots . . .\end{array}$ & $\begin{array}{r}691 \\
950 \\
858 \\
\ldots \ldots \ldots\end{array}$ & $\begin{array}{r}460 \\
562 \\
342 \\
\ldots \ldots\end{array}$ \\
\hline
\end{tabular}




\section{HENDEY COUNTY}

Water samples from wells near Lake Okeechobee contained moderately large amounts of dissolved matter and generally contained much less sulfate than was shown in samples from wells in Glades County. (See table 108.) Dissolved solids ranged from 238 to $1,230 \mathrm{ppm}$ and hardness ranged from 233 to $469 \mathrm{ppm}$. Calcium and bicarbonate were the characteristic constituents. Calcium ranged from 67 to $165 \mathrm{ppm}$ and bicarbonate ranged from 253 to $683 \mathrm{ppm}$. Chloride exceeded sodium in two samples by small amounts.

Well GS 4 is about 12 miles southwest of Lake Okeechobee, and well GS 5 is about 20 miles southwest of the Lake. Water collected when well GS 4 was $18.9 \mathrm{ft}$ deep contained $292 \mathrm{ppm}$ of calcium, $31 \mathrm{ppm}$ of bicarbonate, $628 \mathrm{ppm}$ of sulfate, and $45 \mathrm{ppm}$ of chloride. Calcium and sulfate concentrations decreased with depth, while sodium bicarbonate and chloride increased with depth.

The concentration of dissolved matter in samples collected from well.GS 5 did not change appreciably with depth, as indicated by results of preliminary examination of the samples. Only one analysis is given in the table. The concentration of dissolved solids in this sample was $455 \mathrm{ppm}$. 
[See plate 19]

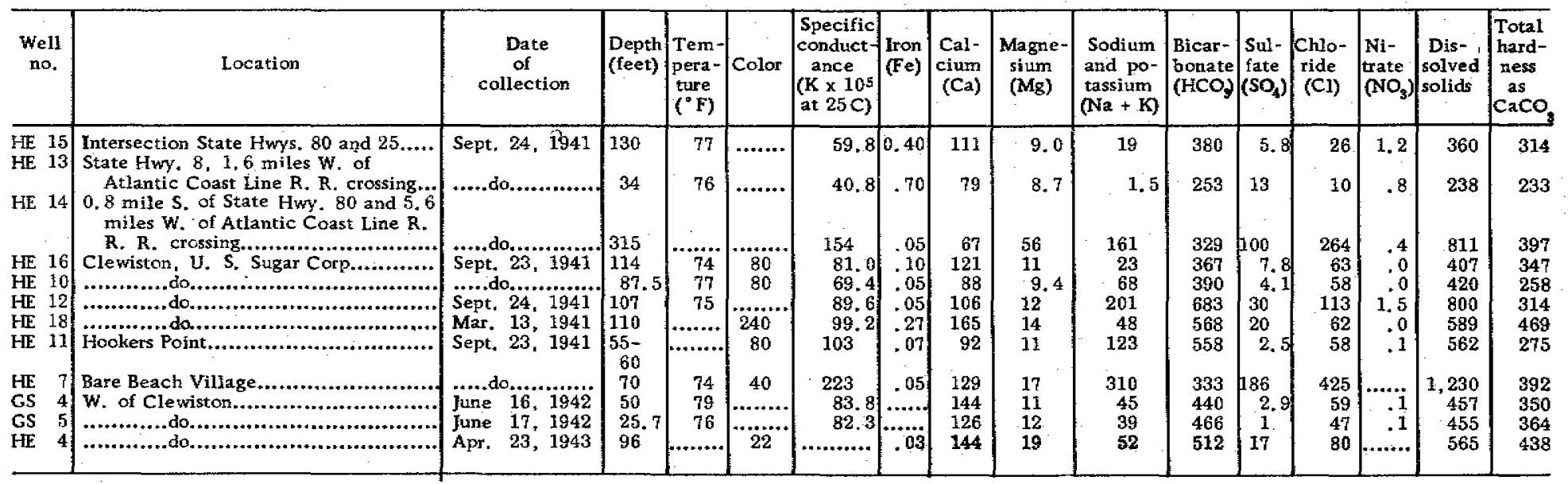




\section{PALM DEACH COUNTY}

Samples were collected from 20 supply wells in Palm Beach County in the vicinity of Lake Okeechobee (see table 109). Conm centrations of dissolved mineral matter in these samples were among the highest found in shallow ground water in southeastern Florida. Dissolved solids ranged from 557 to $5,670 \mathrm{ppm}$ and in 9 of the 20 samples the amount of dissolved solids was in excess of $1,000 \mathrm{ppm}$. Only two of the wells are over $50 \mathrm{ft}$ deep.

Bicarbonate is the most characteristic constituent of the dis solved matter in all of the samples. Some of the samples contained large amounts of sodium, while in others the sodium concentration was relatively low. Several hundred parts per million of sulfate and chloride were found in some samples, but in other samples these constituents were present in amounts less than 100 ppm.

Almost all of the wells from which the 20 samples were collected are located in areas where the top soil consists of several feet of muck, and it is possible that some of the most shallow wells terminate in the muck. Most of the wells terminate in marl or lime rock beneath the muck.

The maximum concentration of dissolved mineral matter in shallow wells in Palm Beach County near Lake Okeechobee was found in a sample collected from well $\mathrm{S} 350$, which is $66 \mathrm{ft}$ deep and located at Miami Locks just south of the south border of Lake Okeechobee. The sample contained $5,670 \mathrm{ppm}$ of dissolved solids, 2,300 parts of which consisted of chloride.

Test wellGS 3 was drilled to a depth of $50 \mathrm{ft}$ near well S 1212 about 1 mile south of Florida Highway 80 and 3 miles west of Florida Highway 25. Analyses were made of three samples collected during the drilling operations at depths of $18.9,34.6$, and $50 \mathrm{ft}$. The maximum concentrations of dissolved solids and sulfate, and the maximum hardness were found at $18.9 \mathrm{ft}$. Concentrations were less at $34.6 \mathrm{ft}$ and were least at $50 \mathrm{ft}$. Sodium and chloride increased with depth. The water in all three samples was reported to have a strong odor of hydrogen sulfide. It seems probable that reduction of sulfate by decomposing organic matter or by bacterial action was responsible for the decrease in sulfate concentration and also for the presence of hydrogen sulfide. 
[See plate 19]

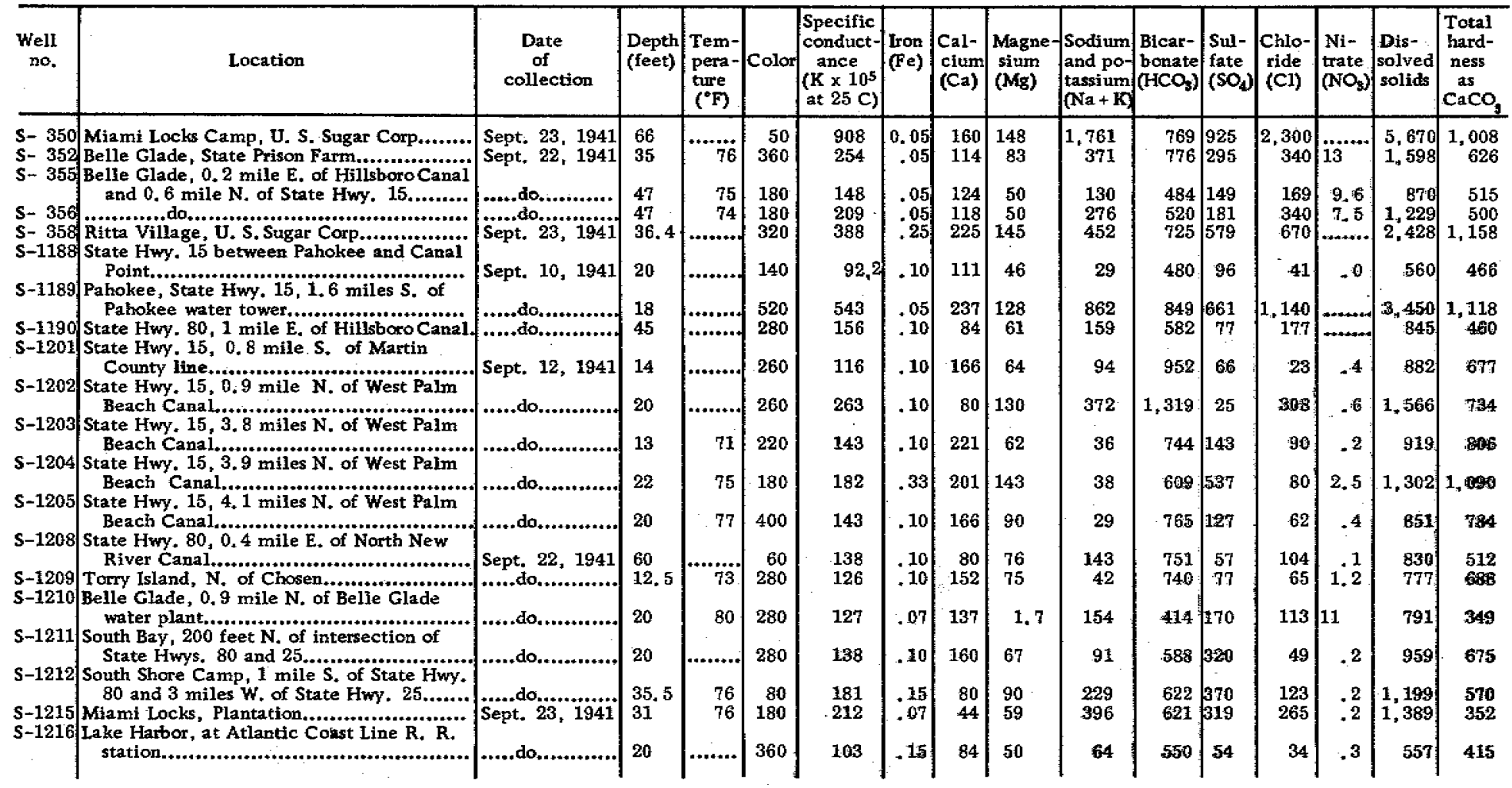




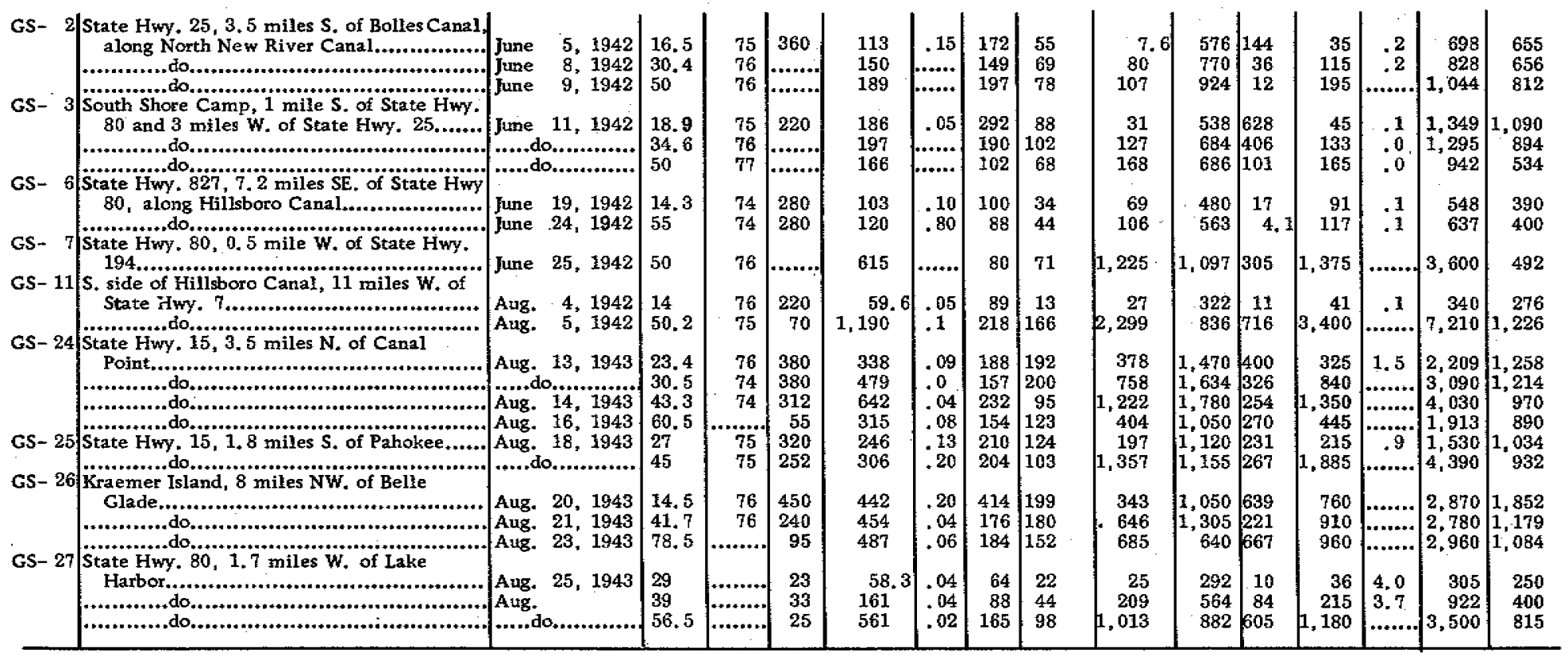




\section{MAETWN COUNTY}

Samples were collected from six wells near the eastern edge of Lake Okeechobee in Martin County. (See table 110.) The muck soil in Martin County is relatively thin and occupies only a narrow strip of land near the lake. Some of the wells from which samples were.collected are located in sand lands, and all of the wells are less than $50 \mathrm{ft}$ deep.

Samples from wells located in the muck soil were high in calcium and bicarbonate, while samples from wells in the sandy soil contained much smaller amounts of these constituents. Water from the sandy soil was very low in sulfate and chloride. 
Table 110. - Analyses, in parts per million, of nonartesian waters in Hartin County

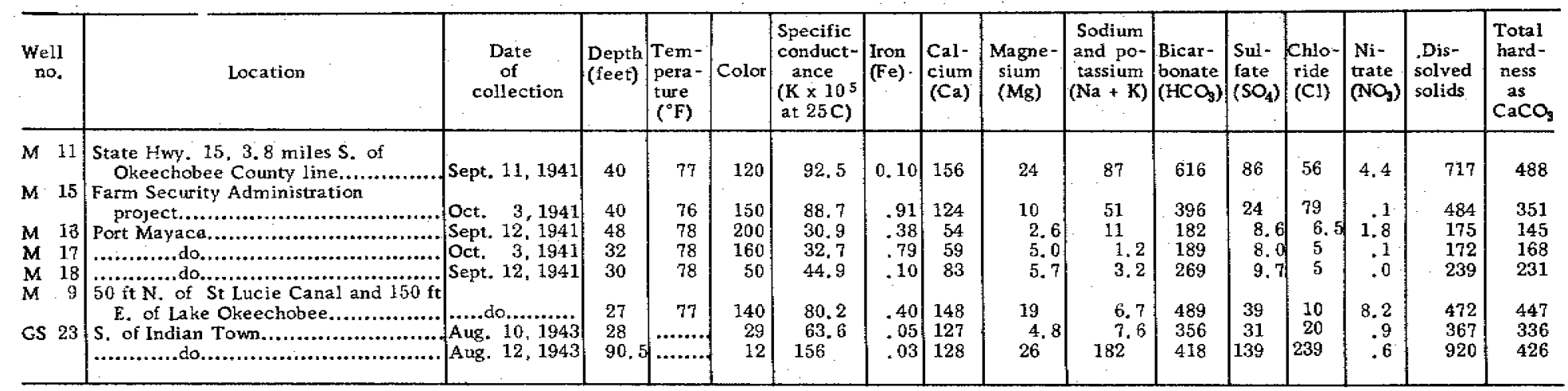

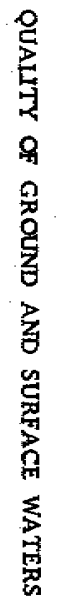




\section{OKEECHOAEE COUNTX}

Okeechobee County is north of Lake Okeechobee and only a narrow strip immediately adjacent to the lake is covered with muck soil. This strip of muck is usually very thin and it disappears at some places.

Twelve wells, for which analyses are available (see table 111), are located in areas'where the muck layer is thin or nonexistent. Dissolved solids ranged from 37 to $1,800 \mathrm{ppm}$ and hardness ranged from 23 to $587 \mathrm{ppm}$. Most of the samples contained over $300 \mathrm{ppm}$ of bicarbonate. One sample contained $860 \mathrm{ppm}$ of chloride. The dissolved minerals in shallow ground waters in wells in the sandy areas to the north of Lake Okeechobee consist primarily of calcium and bicarbonate. The composition of these waters is similar to that of shallow ground water in the metropolitan area of Miami. 
Table 111.-Analyses, in parts per million, of nonartesian waters in Okeochobee County

\begin{tabular}{|c|c|c|c|c|c|c|c|c|c|c|c|c|c|c|c|c|}
\hline $\begin{array}{c}\text { Well } \\
\text { no. }\end{array}$ & Location & $\begin{array}{l}\text { Date } \\
\text { of } \\
\text { collection }\end{array}$ & $\begin{array}{l}\text { epth } \\
\text { eet) }\end{array}$ & $\mid \begin{array}{l}\text { Tem- } \\
\text { pera- } \\
\text { ture } \\
\left({ }^{\circ} \mathrm{F}\right)\end{array}$ & Color & \begin{tabular}{|l|} 
Specific \\
conduct \\
ance \\
$\left(K \times 10^{8}\right.$ \\
at $25 \mathrm{C})$
\end{tabular} & $\begin{array}{l}\text { Iron } \\
(\mathrm{Fe})\end{array}$ & $\begin{array}{l}\text { Cal- } \\
\text { cium } \\
\text { (Ca) }\end{array}$ & $\begin{array}{c}\text { Magne- } \\
\text { sium } \\
(\mathrm{Mg})\end{array}$ & $\begin{array}{l}\text { Sodium } \\
\text { and po- } \\
\text { tassium } \\
(\mathrm{Na}+\mathrm{K})\end{array}$ & $\left|\begin{array}{l}\text { Bicar- } \\
\text { bonate } \\
\left(\mathrm{HCO}_{3}\right)\end{array}\right|$ & $\begin{array}{l}\text { Sul- } \\
\text { fate } \\
\left(\mathrm{SO}_{4}\right)\end{array}$ & $\begin{array}{l}\text { Chlo- } \\
\text { ride } \\
\text { (Cl) }\end{array}$ & $\begin{array}{l}\mathrm{Ni}- \\
\text { trate } \\
\left(\mathrm{NO}_{\mathrm{g}}\right)\end{array}$ & $\begin{array}{l}\text { Dis- } \\
\text { solved } \\
\text { solids }\end{array}$ & $\begin{array}{l}\text { Total } \\
\text { hard- } \\
\text { ness } \\
\text { as } \\
\text { CaCO }\end{array}$ \\
\hline $\begin{array}{ll}\text { OK } & 14 \\
\text { OK } & 15 \\
\text { OK } & 8 \\
\text { OK } & 9 \\
\text { OK } & 13 \\
\text { OK } & 10 \\
\text { OK } & 11 \\
\text { OK } & 12 \\
\text { GS } & 16\end{array}$ & 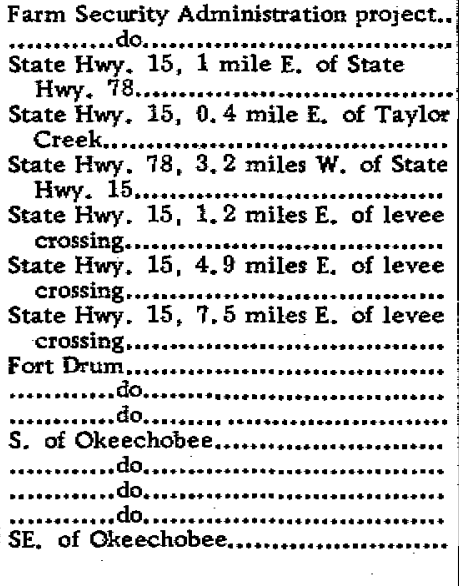 & 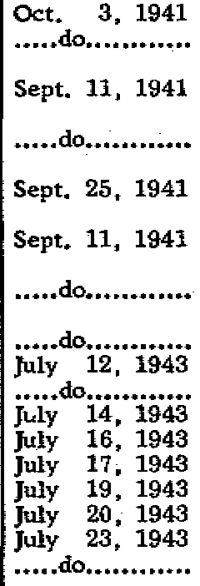 & \begin{tabular}{|c|}
80 \\
95 \\
75 \\
48 \\
65 \\
100 \\
57 \\
105 \\
6 \\
19.9 \\
90 \\
44 \\
49 \\
90.3 \\
131 \\
19 \\
49
\end{tabular} & \begin{tabular}{r}
74 \\
74 \\
74 \\
75 \\
$75 \ldots$ \\
\hdashline$\ldots .$. \\
\hdashline 79 \\
78 \\
$\cdots 78$ \\
78 \\
$\ldots \ldots$
\end{tabular} & $\begin{array}{r}15 \\
30 \\
25 \\
60 \\
20 \\
60 \\
520 \\
40 \\
850 \\
175 \\
20 \\
300 \\
38 \\
35 \\
60 \\
55 \\
32\end{array}$ & \begin{tabular}{|c|}
59.2 \\
55.7 \\
313 \\
122 \\
135 \\
82.8 \\
142 \\
\\
326 \\
7.7 \\
4.4 \\
46.3 \\
31.7 \\
206 \\
307 \\
166 \\
155 \\
304 \\
\end{tabular} & $\begin{array}{c}9.10 \\
.10 \\
.05 \\
.05 \\
.10 \\
.05 \\
.38 \\
.10 \\
.02 \\
.04 \\
.07 \\
2.5 \\
.08 \\
.04 \\
.15 \\
.05 \\
.03\end{array}$ & $\begin{array}{c}103 \\
108 \\
99 \\
\\
105 \\
109 \\
90 \\
200 \\
110 \\
3.6 \\
5.2 \\
90 \\
41 \\
184 \\
120 \\
92 \\
168 \\
139\end{array}$ & $\begin{array}{c}6.6 \\
4.1 \\
40 \\
14 \\
15 \\
12 \\
28 \\
68 \\
4.3 \\
2.5 \\
7.0 \\
7.2 \\
31 \\
38 \\
24 \\
35 \\
55\end{array}$ & $\begin{array}{c}12 . \\
6.1 \\
499 \\
147 \\
152 \\
87 \\
72 \\
492 \\
6.0 \\
4.5 \\
\ldots \ldots . . \\
225 \\
501 \\
233 \\
129 \\
424\end{array}$ & $\begin{array}{c}344 \\
343 \\
286 \\
380 \\
390 \\
371 \\
543 \\
411 \\
4.0 \\
18 \\
278 \\
122 \\
730 \\
470 \\
376 \\
514 \\
392\end{array}$ & $\begin{array}{c}2.1 \\
2.9 \\
170 \\
34 \\
32 \\
44 \\
86 \\
71 \\
24 \\
9.3 \\
11 \\
5 \\
5 \\
288 \\
116 \\
109 \\
63\end{array}$ & $\begin{array}{r}19 \\
11 \\
770 \\
207 \\
221 \\
80 \\
168 \\
860 \\
8 \\
6 \\
10 \\
4 \\
335 \\
610 \\
288 \\
218 \\
785\end{array}$ & $\mid \begin{array}{c}\cdots . . . \\
.3 \\
.2 \\
.1 \\
.0 \\
.0 \\
.0 \\
.0 \\
2.8 \\
. . . . .\end{array}$ & $\begin{array}{r}312 \\
301 \\
1,720 \\
694 \\
721 \\
496 \\
822 \\
1,800 \\
48 \\
37 \\
255 \\
\ldots \ldots \ldots \\
1,140 \\
1,789 \\
938 \\
915 \\
1,659\end{array}$ & $\begin{array}{r}320 \\
334 \\
274 \\
614 \\
554 \\
27 \\
23 \\
254 \\
132 \\
586 \\
456 \\
328 \\
564 \\
573\end{array}$ \\
\hline
\end{tabular}




\section{SUMMARY OF QUALITY OF GROUND WATEK IN LAKE OREECHOBEE AREA}

Analyses of samples collected from about 80 wells, located in five counties near the shores of Lake Okeechobee, show that most of the ground water in this region is highly mineralized. Most of the wells are less than $100 \mathrm{ft}$ deep and terminate in lime rock or shell marl. With few exceptions, the surface soil consists of muck ranging from a few inches to several feet in depth. It appears that high mineral concentrations in the ground waters are related to the occurrence of the muck soils and to the low permeability. of both the muck and the underlying marls.

Saline waters and residues left by. Pleistocene invasions of the area by the sea have never been completely flushed out of the for mations in much of the Everglades, particularly in areas near the borders of Lake Okeechobee. Saline waters are present in the formations, and it is probable that the muck and rock contain much soluble material cther than carbonates. Some wells less than $50 \mathrm{ft}$ deep yield water high in sulfate and chloride.

The high concentrations of bicarbonate cannot be explained by entrapment of ancient sea water, because brines ordinarily contain only small amounts of bicarbonate. The high concentrations of bicarbonate found in most of the ground waters near Lake Okeechobee are associated with the presence of muck soils that have high percentages of organic matter. The decaying organic matter facilitates the solution of calcium carbonate by furnishing carbon dioxide, which, when it reacts with water to form carbonic acid, reacts with calcium carbonate to give soluble calcium bicarbonate.

It has long been known that certain organic soils play an active role in cation exchange. It is probable that the organic muck soils have played a large part in transforming calcium-bicarbonate waters into sodium-bicarbonate waters. Because large concentrations of calcium bicarbonate are notordinarily found in natural waters, it is possible that several stages of solution of lime rock, and subsequent transformation into sodium bicarbonate by cation exchange, have been necessary to produce the high concentration of bicarbonate found in some of the waters.

The phenomenon of cation exchange is discussed more fully below under the heading "Source of Mineralization of Ground Waters in the Everglades" and in the section on "Salt-water encroachment."

The chemical character of ground water in the Everglades has been discussed briefly by Stringfield (1933a), Parker (1942, p. 477.6), and Parker and Hoy $(1943$, p. $33-55)$, and is touched upon 
in this report in the discussion of ground waters in the vicinity of Lake Okeechobee. Outside the Lake Okeechobee area, most of the information about the character of the ground water was obtained from test wells, drilled for the purpose of collecting samples of water and rock and for determining the geologic and hydrologic characteristics of the water-bearing formations.

Water samples were collected at intervals of only a few feet while the wells were being drilled. Chloride and specific conductance were determined on all samples, and more complete analyses were made on samples that seemed (from the chloride and conductance values) to represent different types of water.

Analyses of a large number of samples collected from wells scattered over the Everglades indicate that the most concentrated waters are found in the Lake Okeechobee area and that the least concentrated waters are found in the southern and southeastern parts of the Everglades. In general, water from wells less than $20 \mathrm{ft}$ deep contains less dissolved mineral matter than water from greater depths. Some very shallow wells, however, yield rather highly concentrated water.

In the vicinity of Lake Okeechobee, some well waters contain large, but variable, amounts of sodium and bicarbonate and others contain relatively large amounts of sulfate and chloride. Farther south, calcium and bicarbonate are the major constituents of the dissolved matter in many well waters, although chloride may be present in relatively large amounts.

To show in a general way the range in concentration of dissolved matter in ground water in the Everglades, the range in chloride concentration for different depths was chosen to represent approximate ranges in the degree of mineralization. It is recognized that other constituents, particularly in water from wells near Lake Okeechobee, may make up a greater part of the dissolved mineral matter than chloride. Considering the Everglades as a whole, however, it is believed that ranges in chloride concentration give a more reliable index to the various degrees of mineralization.

Figure 221 shows, in a general way, the ranges in chloride concentration that may be expected in three depth intervals in all except the western part of the Everglades. The metropolitan area of Miami and the eastern part of Palm Beach County are not included because the character of ground water in these areas is treated more fully in other sections and also because very little of these coastal strips lies within the Everglades proper.

Lines between any two chloride ranges in figure 221 indicate the approximate boundaries between chloride concentrations in the 

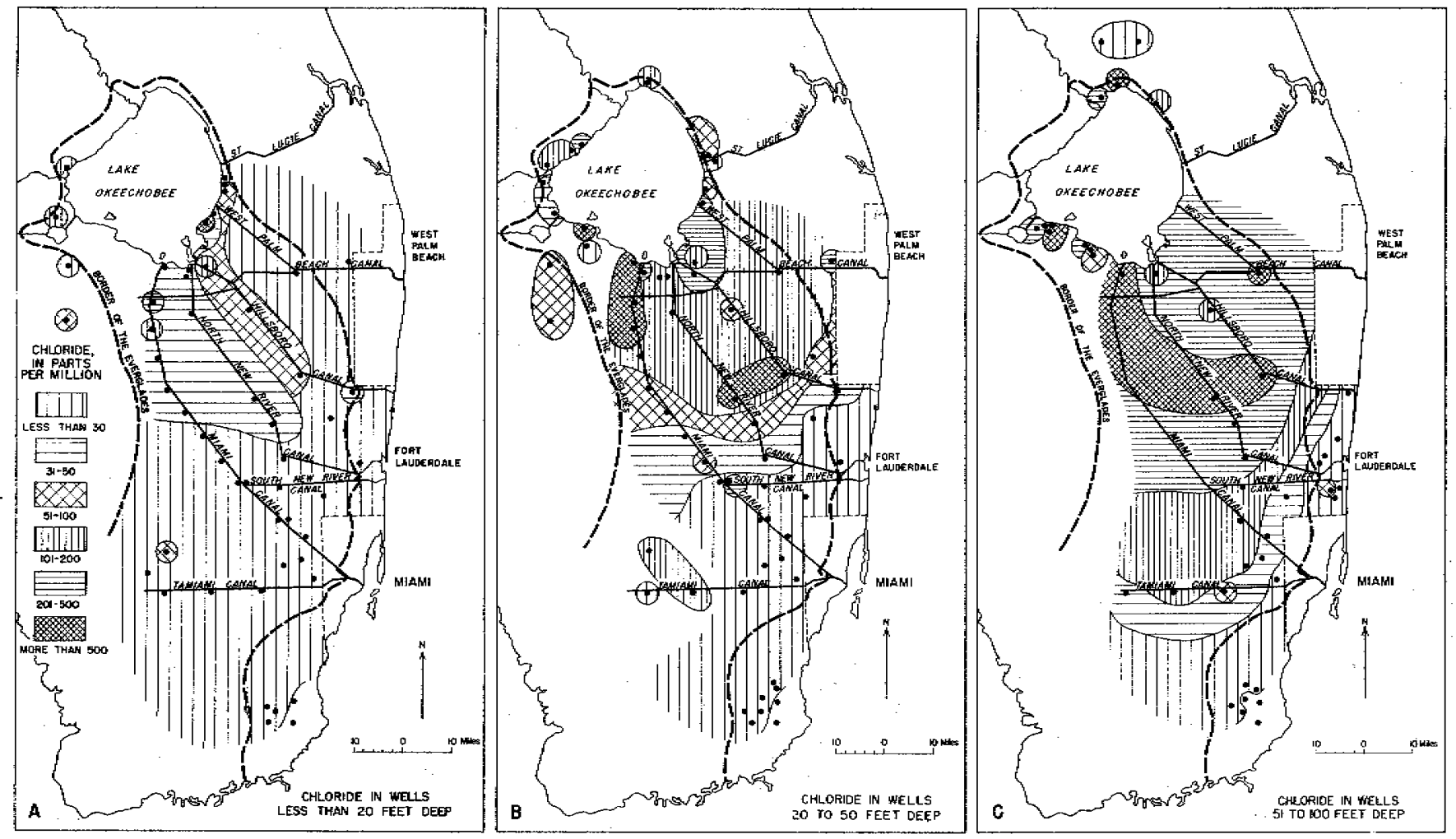
two areas. Exceptions to the concentrations generally found within an area are shown as islands of a different concentration. Undoubtedly, many other exceptions would be found with the drilling of additional wells. It is entirely possible that the shading of a whole area might be changed as a result of additional information. It is believed, however, that the three illustrations give an approximate representation of the distribution of chloride in the three depth ranges.

The hachures on the fringes of the main body of the shaded area have been left without boundary lines to indicate that chloride concentrations in the several ranges may be found for some distance beyond the areas already shaded. Boundary lines have been placed around small islands outside the main shaded area, not to convey the idea that the se islands may notbe of larger extent, but instead, to make the different concentration ranges more discernible.

It should be emphasized that the chloride concentrations in ground water in the Everglades are not the result of recent seawater contamination but rather that saline residues of ice-age invasions of the sea have not been entirely flushed out.

Figure 221 does not show the effect of present sea-water contamination of ground water near the coast except to show the approximate boundary at different depths in the vicinity of Homestead in the southeastern part of Dade County. This area is outside the border of the Everglades.

\section{SOURCE OF MINERALIZATION OF GROUND WATERS IN THE EVERGLADES}

The mineral content of ground waters in the Everglades has resulted partly from remnants of saline residues that have not been completely flushed out of the ground and partly from cationexchange processes. In the Miami area, it is postulated that organic colloids, saturated with sodium and magnesium from ancient brines, were brought in contact with calcium-bicarbonate solutions derived from rainwater, lime rock, and carbon dioxide, with the result that the adsorbed sodium and magnesium were exchanged for calcium. All of the saline residues were completely flushed from the formations and were replaced with fresh ground water in which calcium and bicarbonate were the chief constituents.

In the Everglades area, the organic matter and rocks were undoubtedly exposed to the same processes, but the action is not complete. Because the muck and rock of the Everglades are much less permeable than the sandstones and limestones of the Biscayne aquifer, the saline residues have not been entirely flushed out, and the organic colloids are still partly saturated with sodium and magnesium, presumably adsorbed from ancient sea water. Calcium bicarbonate is readily brought into solution in the presence 
of carbon dioxide furnished, in large part, by decomposing organic matter. When brought in contact with sodium and magnesiumbearing clays, the calcium in the solution is exchanged for sodium and magnesium in the clays. The water then comes in contact with more lime rock, which dissolves to form more calcium bicarbonate. Repetition of the process increases the bicarbonate concentration to high values, In many waters, bicarbonate is present in concentrations in excess of $500 \mathrm{ppm}$ and concentrations of $1,000 \mathrm{ppm}$ are not unusual. The cations in solution may consist largely of sodium, or sodium and magnesium, but in some waters they consist largely of calcium. The proportion of each cation in solution is apparently determined, in part, by the composition of the exchangeable clays and organic colloids and, in part, by the number of times that the solution and exchange cycle is repeated. The high concentrations of sulfate and chloride in many of the ground waters in the Everglades are apparently derived from saline residues from earlier invasions by the sea.

\section{COLLIER COUNTY}

Only seven samples of ground water were collected from shallow aquifers in Collier County. The analyses show that dissolved solids ranged from 70 to $115 \mathrm{ppm}$ and hardness ranged from 25 to $62 \mathrm{ppm}$ (see table 112). Except for the high color-60 to 160these waters are suitable for almost all purposes. Unfortunately, large yields are not obtainable from shallow aquifers in Collier County. See table 113 for analyses of artesian waters. 
Table 112.-Analyses, in pants per million, of nonartesian waters its Collier County

\begin{tabular}{|c|c|c|c|c|c|c|c|c|c|c|c|c|c|c|c|c|}
\hline $\begin{array}{c}\text { Well } \\
\text { no. }\end{array}$ & Location & $\begin{array}{l}\text { Dat } \\
\text { of } \\
\text { collection }\end{array}$ & $\mid \begin{array}{l}\text { Depth } \\
\text { (feet) }\end{array}$ & $\begin{array}{c}\text { Tem- } \\
\text { pera- } \\
\text { ture } \\
\left({ }^{\circ} \mathrm{F}\right)\end{array}$ & Color & $\begin{array}{l}\text { Specific } \\
\text { conduct- } \\
\text { ance } \\
\left(\mathrm{K} \times 10^{5}\right. \\
\text { at } 25 \mathrm{C})\end{array}$ & $\begin{array}{l}\text { Iron } \\
(\mathrm{Fe})\end{array}$ & $\begin{array}{l}\text { Cal- } \\
\text { cium } \\
\text { (Ca) }\end{array}$ & $\begin{array}{l}\text { Magne- } \\
\text { sìum } \\
\text { (Mg) }\end{array}$ & $\begin{array}{l}\text { Sodium } \\
\text { and po- } \\
\text { tassium } \\
(\mathrm{Na}+\mathrm{K})\end{array}$ & $\begin{array}{l}\text { Bicar- } \\
\text { bonate } \\
\left(\mathrm{HCO}_{3}\right)\end{array}$ & $\begin{array}{l}\text { Sul- } \\
\text { fate } \\
\left(\mathrm{SO}_{4}\right)\end{array}$ & $\begin{array}{l}\text { Chlo- } \\
\text { ride } \\
\text { (cl) }\end{array}$ & $\left(\begin{array}{l}\mathrm{Ni}- \\
\text { trate } \\
\left.\mathrm{NO}_{3}\right)\end{array}\right.$ & $\begin{array}{l}\text { Dis- } \\
\text { solved } \\
\text { solids }\end{array}$ & $\begin{array}{l}\text { Total } \\
\text { hard- } \\
\text { ness } \\
\text { as } \\
\mathrm{CaCO}\end{array}$ \\
\hline $\begin{array}{l}\text { C } 20 \\
\text { C } 18 \\
\text { C } 17 \\
\text { C } 15 \\
\text { C } 16 \\
\text { C } 12 \\
\text { C } 43\end{array}$ & 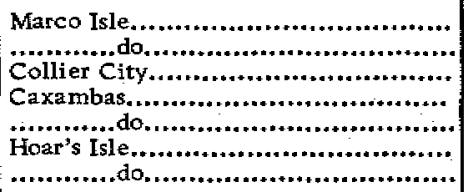 & 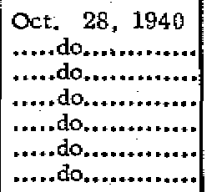 & $\begin{array}{c} \pm 2 \\
22 \\
13 \\
6.9 \\
16 \\
12\end{array}$ & $\begin{array}{r}76 \\
78 \\
+\cdots \\
78 \\
77 \\
81 \\
81\end{array}$ & $\begin{array}{r}60 \\
160 \\
160 \\
85 \\
65 \\
140 \\
\ldots \ldots\end{array}$ & $\begin{array}{l}19.5 \\
13.9 \\
24.2 \\
15.0 \\
28.5 \\
19.3 \\
19.0\end{array}$ & & $\begin{array}{c}12 \\
6.0 \\
6.6 \\
22 \\
7 \ldots .6 \\
7.6 \\
\ldots \ldots \ldots\end{array}$ & $\begin{array}{r}3.2 \\
2.5 \\
7.3 \\
1.7 \\
\ldots \ldots \ldots \ldots \\
3.1\end{array}$ & $\begin{array}{c}18 \\
18 \\
27 \\
4.7 \\
\ldots \ldots \ldots \ldots \\
22 \\
\ldots \ldots \ldots \ldots \ldots\end{array}$ & $\begin{array}{c}24 \\
28 \\
18 \\
63 \\
8.0 \\
22 \\
16\end{array}$ & $\begin{array}{r}6 \\
4 \\
6 \\
2 \\
12 \\
10 \\
14\end{array}$ & $\begin{array}{l}49 \\
26 \\
59 \\
13 \\
70 \\
37 \\
39\end{array}$ & $\mid \begin{array}{c}\ldots \ldots . . \\
\ldots \ldots \ldots . . \\
\ldots \ldots \ldots \\
\ldots \ldots \ldots . . \\
\ldots \ldots \ldots . \\
\ldots \ldots \ldots . \\
\ldots \ldots \ldots . .\end{array}$ & $\begin{array}{r}91 \\
70 \\
115 \\
74 \\
\ldots \ldots \ldots \\
90 \\
\ldots \ldots \ldots . .\end{array}$ & $\begin{array}{l}43 \\
25 \\
46 \\
62 \\
34 \\
32 \\
56\end{array}$ \\
\hline
\end{tabular}


Table 113, - Analyses, in parts per million, of artesian waters in southeastern Florida

\begin{tabular}{|c|c|c|c|c|c|c|c|c|c|c|c|c|c|c|c|c|}
\hline $\begin{array}{r}\text { Well } \\
\text { no. }\end{array}$ & Location & $\begin{array}{l}\text { Date } \\
\text { of } \\
\text { collection }\end{array}$ & $\begin{array}{l}\text { Depth } \\
\text { (feet) }\end{array}$ & $\begin{array}{l}\text { Tem- } \\
\text { pera- } \\
\text { ture } \\
\left({ }^{\circ} \mathrm{F}\right)\end{array}$ & Color & $\begin{array}{c}\text { Specific } \\
\text { conduct- } \\
\text { ance } \\
(\mathrm{K} \times 105 \\
\text { at } 25 \mathrm{C})\end{array}$ & $\begin{array}{c}\text { Iron } \\
(\mathrm{Fe})\end{array}$ & $\begin{array}{c}\text { Cal- } \\
\text { cium } \\
(\mathrm{Ca})\end{array}$ & $\begin{array}{c}\text { Magne- } \\
\text { sium } \\
(\mathrm{Mg})\end{array}$ & $\begin{array}{l}\text { Sodium } \\
\text { and po- } \\
\text { tassium } \\
(\mathrm{Na}+\mathrm{K})\end{array}$ & $\begin{array}{l}\text { Bicar- } \\
\text { bonate } \\
\left(\mathrm{HCO}_{3}\right)\end{array}$ & $\begin{array}{l}\text { Sul- } \\
\text { fate } \\
\left(\mathrm{SO}_{4}\right)\end{array}$ & $\begin{array}{l}\text { Chlo- } \\
\text { ride } \\
\text { (Cl) }\end{array}$ & $\begin{array}{c}\mathrm{Ni}- \\
\text { trate } \\
\left(\mathrm{NO}_{3}\right)\end{array}$ & $\begin{array}{l}\text { Dis- } \\
\text { solved } \\
\text { solids }\end{array}$ & $\begin{array}{l}\text { Total } \\
\text { hard- } \\
\text { ness } \\
\text { as } \\
\text { CaCO }_{3}\end{array}$ \\
\hline \multicolumn{17}{|c|}{ Dade County } \\
\hline $\begin{array}{l}\text { S- } 125 \\
\text { S- } 142 \\
\text { S- } 144 \\
\text { S- } 155 \\
\text { S- } 158 \\
\text { s- } 160 \\
\text { S- } 161 \\
\text { S- } 450 \\
\text { F- } 152 \\
\text { G- } 101\end{array}$ & 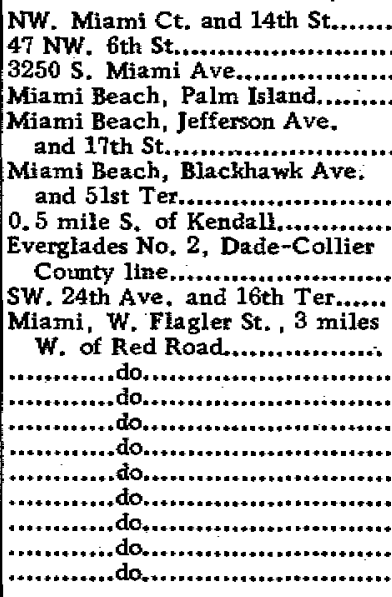 & 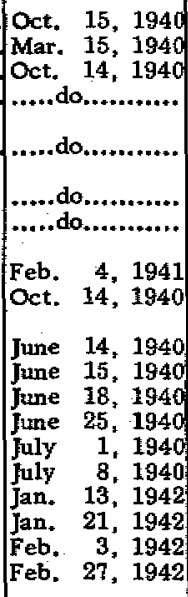 & $\begin{array}{l}1,950 \\
1,165 \\
1,000 \\
1,000 \\
1,060 \\
1,000 \\
5,432 \\
585 \\
990 \\
534 \\
552.6 \\
607 \\
716.8 \\
785.1 \\
812 \\
113.8 \\
234.1 \\
411 \\
600\end{array}$ & $\begin{array}{c}76 \\
71 \\
71 \\
70 \\
70 \\
\\
79 \\
76 \\
78 \\
72 \\
\ldots \ldots \\
\ldots \ldots \ldots \\
\ldots \ldots \ldots \\
\ldots \ldots \ldots \\
72 \\
77 \\
77 \\
78 \\
80\end{array}$ & \begin{tabular}{|c}
15 \\
$\ldots \ldots \ldots$ \\
15 \\
10 \\
5 \\
20 \\
10 \\
140 \\
5 \\
$\ldots$ \\
$\ldots \ldots \ldots$ \\
$\ldots \ldots \ldots \ldots$ \\
$\ldots \ldots \ldots \ldots$ \\
$\ldots \ldots \ldots \ldots$ \\
$\ldots \ldots \ldots \ldots$ \\
$\ldots \ldots \ldots \ldots$ \\
$\ldots \ldots \ldots \ldots$
\end{tabular} & $\begin{array}{c}1,950 \\
585 \\
576 \\
554 \\
913 \\
\\
615 \\
692 \\
\\
80.5 \\
593 \\
\\
216 \\
324 \\
425 \\
473 \\
524 \\
579 \\
77.3 \\
56.2 \\
47.4 \\
58.1\end{array}$ & \begin{tabular}{|}
$\ldots \ldots \ldots$ \\
$\ldots \ldots \ldots$ \\
$\ldots \ldots \ldots$ \\
$\ldots \ldots \ldots \ldots$ \\
$\ldots \ldots \ldots \ldots$ \\
$\ldots \ldots \ldots \ldots$ \\
$\ldots \ldots \ldots$. \\
$\ldots \ldots \ldots$ \\
$\ldots \ldots \ldots$ \\
$\ldots \ldots \ldots$ \\
$\ldots \ldots \ldots$ \\
$\ldots$
\end{tabular} & \begin{tabular}{|c|}
214 \\
$\ldots \ldots \ldots$ \\
$\ldots \ldots \ldots$ \\
$\ldots \ldots \ldots$ \\
161 \\
82 \\
78 \\
\\
15 \\
$\ldots \ldots \ldots$ \\
21 \\
22 \\
20 \\
22 \\
48 \\
77 \\
84 \\
35 \\
12 \\
20
\end{tabular} & $\begin{array}{c}464 \\
\ldots \ldots \ldots \ldots \\
\ldots 199 \\
133 \\
138 \\
16 \\
\ldots \ldots \ldots \ldots \\
16 \\
33 \\
49 \\
67 \\
107 \\
121 \\
24 \\
21 \\
7.9 \\
14\end{array}$ & \begin{tabular}{|r|}
3,650 \\
$\ldots \ldots \ldots \ldots \ldots$ \\
1,520 \\
1,010 \\
1,190 \\
\\
155 \\
$\ldots \ldots \ldots \ldots$ \\
451 \\
666 \\
887 \\
928 \\
952 \\
1,020 \\
39 \\
60 \\
89 \\
84
\end{tabular} & $\begin{array}{r}129 \\
154 \\
183 \\
150 \\
148 \\
\\
29 \\
65 \\
\\
447 \\
182 \\
\\
419 \\
444 \\
409 \\
366 \\
303 \\
313 \\
397 \\
319 \\
267 \\
233\end{array}$ & \begin{tabular}{|c|c|}
1,030 \\
$\ldots \ldots \ldots \ldots$ \\
$\ldots \ldots \ldots \ldots$ \\
575 \\
\\
370 \\
379 \\
\\
21 \\
$\ldots \ldots \ldots$ \\
292 \\
507 \\
791 \\
748 \\
594 \\
619 \\
12 \\
5.8 \\
4.5 \\
4.9
\end{tabular} & $\begin{array}{r}6,520 \\
1,580 \\
1,480 \\
1,470 \\
2,700 \\
1,800 \\
2,040 \\
\\
37 \\
1,540 \\
\\
320 \\
725 \\
725 \\
900 \\
1,250 \\
1,420 \\
39 \\
27 \\
23 \\
67\end{array}$ & \begin{tabular}{|l}
$\ldots \ldots \ldots$ \\
$\ldots \ldots \ldots$ \\
$\ldots \ldots \ldots$ \\
$\ldots \ldots \ldots$ \\
$\ldots \ldots \ldots$ \\
$\ldots \ldots \ldots$ \\
$\ldots \ldots \ldots$ \\
$\ldots \ldots \ldots$ \\
$\ldots \ldots \ldots$ \\
$\ldots \ldots \ldots$ \\
$\ldots \ldots \ldots$ \\
$\ldots \ldots$ \\
$\ldots 0$ \\
.0 \\
.0 \\
.0 \\
.0 \\
0 \\
$\ldots$
\end{tabular} & $\begin{array}{r}11,900 \\
\ldots \ldots \ldots \\
\ldots \ldots \ldots \\
5,230 \\
3,410 \\
3,850 \\
\\
464 \\
\ldots \ldots . . . \\
1,310 \\
1,980 \\
2,670 \\
2,850 \\
3,100 \\
3,410 \\
394 \\
306 \\
268 \\
305\end{array}$ & \begin{tabular}{|r}
2,440 \\
$\ldots \ldots \ldots \ldots$ \\
$\ldots \ldots \ldots$ \\
1,220 \\
\\
752 \\
742 \\
\\
103 \\
$\ldots \ldots \ldots$ \\
118 \\
191 \\
251 \\
330 \\
560 \\
690 \\
308 \\
174 \\
62 \\
108
\end{tabular} \\
\hline \multicolumn{17}{|c|}{ Palm Beach County } \\
\hline $\begin{array}{l}s-353 \\
s-382 \\
s-383 \\
s-1184\end{array}$ & 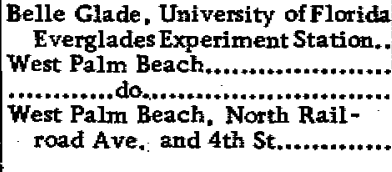 & $\begin{array}{l}\text { Sept, } 12,1941 \\
\text { Oet. 28, } 1940 \\
\text { Sept.... 9o.......... } \\
\text { Sep. } 1941\end{array}$ & $\left\{\begin{array}{l}1,332 \\
1,080 \\
1,050 \\
1,035\end{array}\right.$ & $\begin{array}{l}78 \\
73 \\
73 \\
73\end{array}$ & $\begin{array}{r}10 \\
5 \\
5 \\
5\end{array}$ & $\begin{array}{l}616 \\
810 \\
802 \\
726\end{array}$ & $\begin{array}{r}0.03 \\
.10 \\
.10\end{array}$ & $\begin{array}{l}166 \\
140 \\
141 \\
127\end{array}$ & $\begin{array}{l}191 \\
181 \\
180 \\
161\end{array}$ & $\begin{array}{r}864 \\
1,354 \\
1,320 \\
1,207\end{array}$ & $\begin{array}{r}22 \\
186 \\
182 \\
194\end{array}$ & $\begin{array}{r}5.8 \\
481 \\
479 \\
449\end{array}$ & $\mid \begin{array}{l}1,990 \\
2,400 \\
2,350 \\
2,110\end{array}$ & & $\begin{array}{l}3,170 \\
4,650 \\
4,560 \\
4,150\end{array}$ & $\begin{array}{r}953 \\
1,094 \\
1,092 \\
979\end{array}$ \\
\hline
\end{tabular}


Okeechobee County

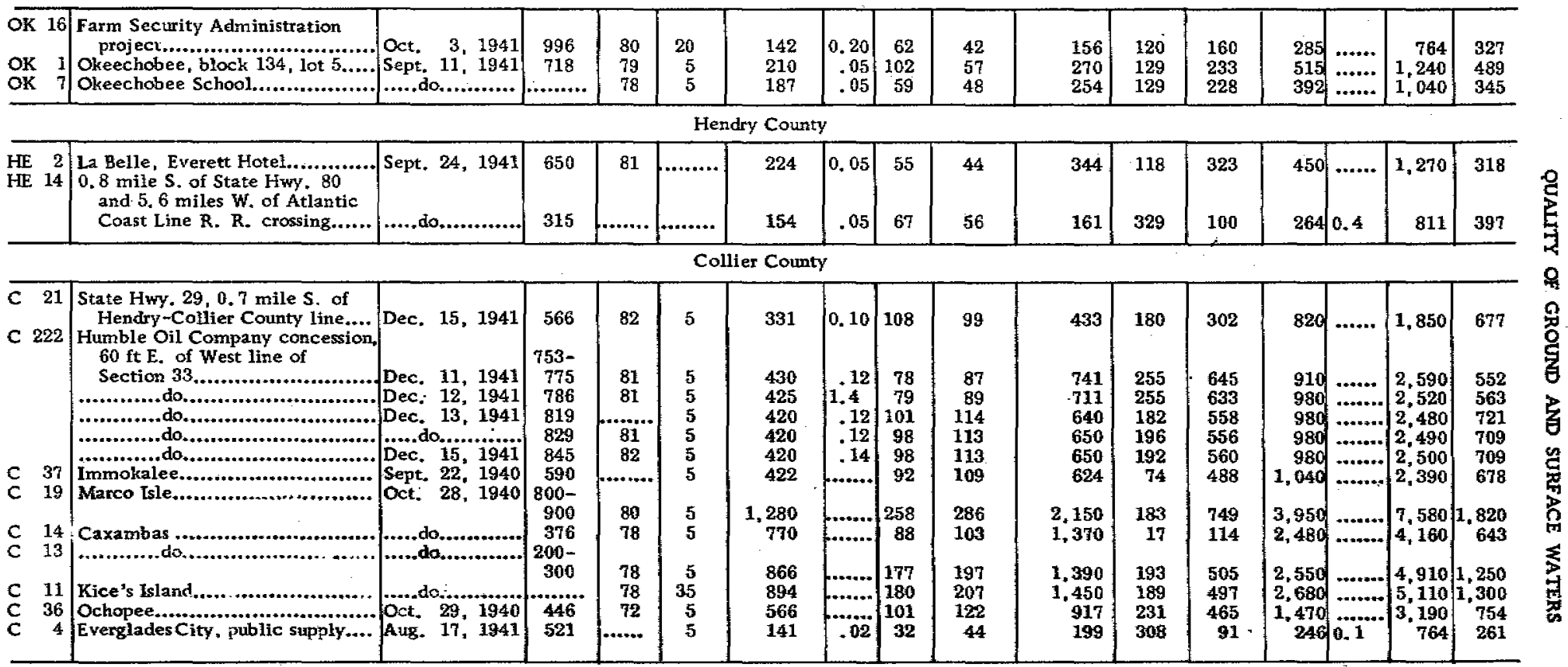




\section{CHEMICAL CHARACTER OF ARTESIAN WATERS}

Artesian water of the Floridan aquifer is encountered in wells at depths of 800 to $1,000 \mathrm{ft}$ in, and near, Miami, and at somewhat shallower depths north of Miami. Much of this water is brackish and unfit for domestic use and most other purposes. In general, the chloride concentration ranged between 500 and $4,000 \mathrm{ppm}$. The higher concentrations in some wells may have resulted from a mixture of sea water through leaky casings.

The public supply at La Belle, Hendry County, is artesian and it contains $2.4 \mathrm{ppm}$ of fluoride, the highest found in samples taken in southeastern Florida. See pages 188-196 for a discussion of artesian water. Table 113 contains analyses of artesian waters from various wells in southeastern Florida. 


\section{PUBLIC WATER SUPPLIES}

In 1941-42, chemical analyses were made on water samples collected from 25 public water supply systems in Broward, Dade. Glades, Hendry, Okeechobee and Palm Beach Counties, In 1948, these public supplies were resampled and additional samples were collected from six towns in Collier, Indian River, Martin, Monroe, and St. Lucie Counties. Results of analyses for the two periods are shown in tables 114 and 115 .

Miami, the largest city in southeastern Florida, obtains its water supply from wells and furnishes water to Miami Beach, Coral Gables, Miami Shores, El Portal, Surfside, Indian Creek Village, Hialeah, and Miami Springs. Other places using ground water are: Boca Raton, Boynton Beach, Dania, Deerfield Beach, Delray Beach, Everglades, Fort Lauderdale, Hobe Sound, Hollywood, Homestead, Indian Town, Key West, La Belle, Lake Park, Lake Worth, Lantana, North Miami, North Miami Beach, Opa Locka, Pompana Beach, Riviera, and Stuart.

Key West had no public supply system prior to 1942 and was dependent on rainwater and on water that was transported from the mainland for domestic use. A few privately owned shallow wells yielded small quantities of relatively fresh water during periods of heavy rainfall, but nearly all these wells became salty soon after the end of the rainy periods. A supply of fresh water is now piped to Key Westfrom near Homestead (where it is obtained from wells). The ground water is softened before transmission to Key West. Several fishing camps, and other private users, along the pipe-line route over the Florida Keys obtain water from the Key West supply.

West Palm Beach is the largest city in southeastern Florida that uses surface water. Palm Beach is also supplied by this system. Other towns supplied with surface water are: Belle Glade, Canal Point, Clewiston, Moore Haven, Okeechobee, and Pahokee. These six towns are located on, or near, Lake Okeechobee and are normally supplied with lake water. Fort Pierce obtains about 80 percent of its supply from surface water and obtains the remainder from wells. The hardness of the finished water from 25 supplies sampled in $1941-42$ is indicated in figure 222 .

The largest use of water from the public supplies is for domestic purposes; agricultural use of water from public supplies is very small. Irrigation is practiced during dry periods, but water for this purpose is usually obtained from shallow wells or drainage canals.

There is practically no heavy industry in the southeastern part of the State. Most of the industrial plants in the coastal cities are connected directly, or indirectly, with the building trades or public 
Table 114. - Analyses, in parts per million, of public water supplies in southern Florida, 1941-42

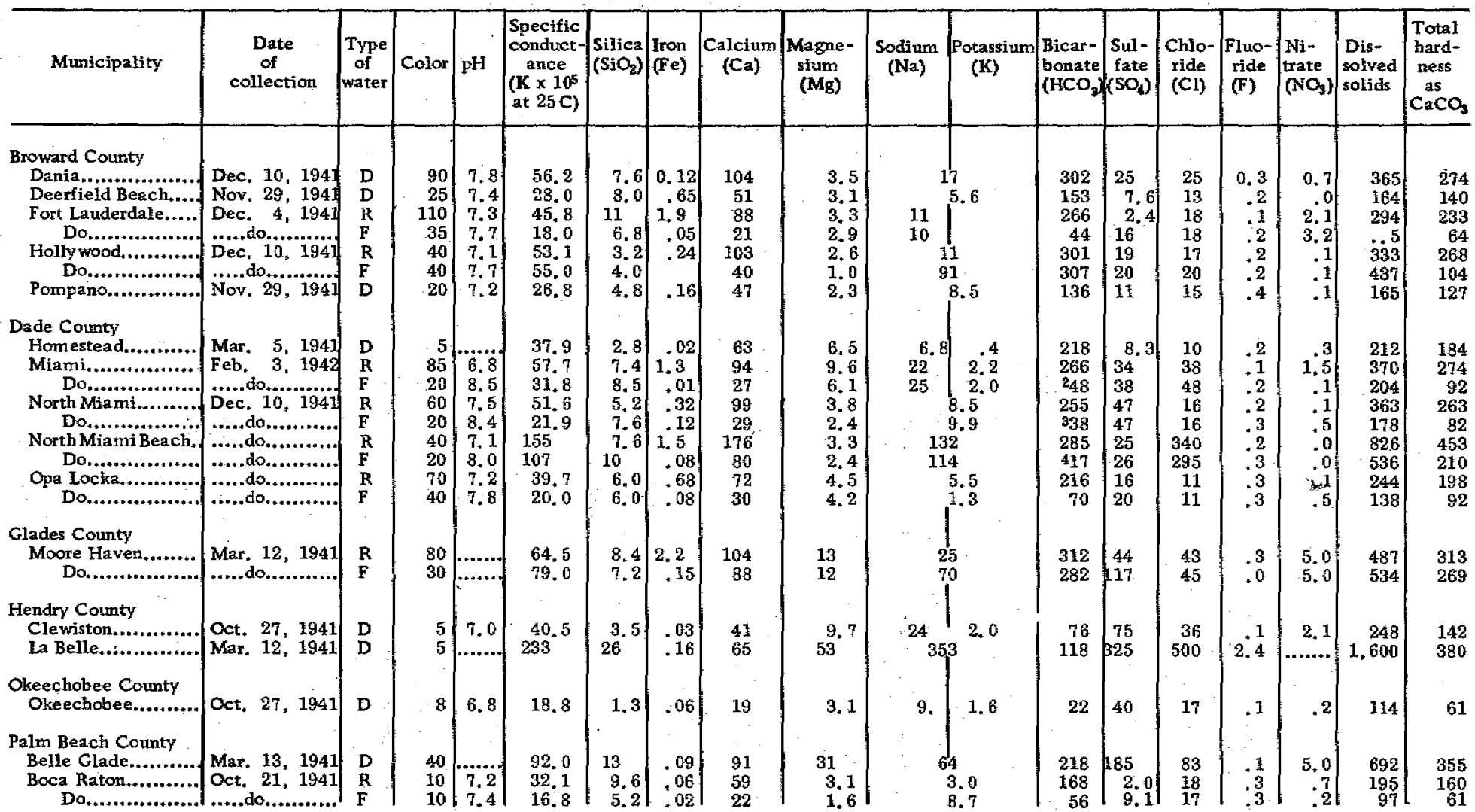




\begin{tabular}{|c|c|c|c|c|c|c|c|c|c|c|c|c|c|c|c|c|c|}
\hline $\begin{array}{l}\text { Boynton Beach........ } \\
\text { Canal Point............ } \\
\text { Delray Beach......... } \\
\text { Lake Park ............ } \\
\text { Lake Worth............ } \\
\text { Lantana,................ } \\
\text { Pahokee................ } \\
\text { Riviera.................. } \\
\text { West Palm Beach..... } \\
\text { Do.................... }\end{array}$ & 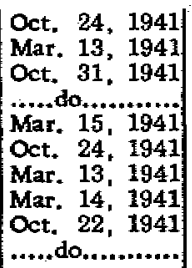 & $\begin{array}{l}\mathbf{D} \\
\mathbf{D} \\
\mathbf{D} \\
\mathbf{D} \\
\mathbf{D} \\
\mathbf{D} \\
\mathbf{D} \\
\mathbf{D} \\
\mathbf{R} \\
\mathbf{F}\end{array}$ & $\begin{array}{r}30 \\
25 \\
35 \\
10 \\
40 \\
10 \\
35 \\
15 \\
55 \\
5\end{array}$ & $\mid \begin{array}{c}7.3 \\
7 . \ldots \\
7.5 \\
\ldots \ldots \ldots \\
7.2 \\
7 . . . \\
6.4 \\
9.0\end{array}$ & $\begin{array}{c}37.2 \\
45.1 \\
38.8 \\
32.9 \\
43.7 \\
30.5 \\
51.6 \\
30.5 \\
6.51 \\
13.5\end{array}$ & $\begin{array}{l}5.2 \\
3.8 \\
3.2 \\
6.4 \\
4.8 \\
6.8 \\
7.6 \\
6.8 \\
1.0 \\
3.6\end{array}$ & $\begin{array}{l}.04 \\
.13 \\
.20 \\
.04 \\
.72 \\
.06 \\
.06 \\
.17 \\
.04 \\
.02\end{array}$ & $\begin{array}{l}66 \\
46 \\
70 \\
58 \\
74 \\
54 \\
56 \\
48 \\
7.0 \\
17\end{array}$ & $\begin{array}{r}2.8 \\
12 \\
2.8 \\
2.3 \\
3.1 \\
3.3 \\
16 \\
1.9 \\
1 . .^{9}\end{array}$ & 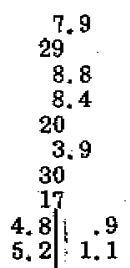 & $\begin{array}{l}178 \\
127 \\
205 \\
162 \\
220 \\
152 \\
160 \\
153 \\
16 \\
66\end{array}$ & $\begin{array}{c}16 \\
54 \\
4.9 \\
9.5 \\
20 \\
3.0 \\
67 \\
2.8 \\
1.6 \\
23\end{array}$ & $\begin{array}{c}21 \\
47 \\
22 \\
17 \\
25 \\
20 \\
47 \\
25 \\
9.5 \\
11\end{array}$ & $\begin{array}{l}.3 \\
.1 \\
.2 \\
.2 \\
.1 \\
.3 \\
.3 \\
.3 \\
.1 \\
.1\end{array}$ & $\begin{array}{r}.5 \\
1.0 \\
6.8 \\
4.0 \\
.2\end{array}$ & $\begin{array}{r}227 \\
311 \\
234 \\
200 \\
287 \\
182 \\
371 \\
194 \\
49 \\
87\end{array}$ & $\begin{array}{r}176 \\
164 \\
186 \\
154 \\
197 \\
148 \\
206 \\
128 \\
21 \\
47\end{array}$ \\
\hline
\end{tabular}

${ }^{1} D$, delivered; $R$, raw; $F$, finished

Includes equivalent of $3.9 \mathrm{ppm}$ of $\mathrm{CO}_{3}$.

Includes equivalent of $9.8 \mathrm{ppm}$ of $\mathrm{CO}^{3}$.

Includes equivalent of $4.9 \mathrm{ppm}$ of $\mathrm{CO}_{3}$.

Formerly Kelsy City.

Includes equivalent of $6.9 \mathrm{ppm}$ of $\mathrm{CO}_{3}$. 
Table 115.-Analyses, in parts per million, of public water supplies in southern Florida, 1948

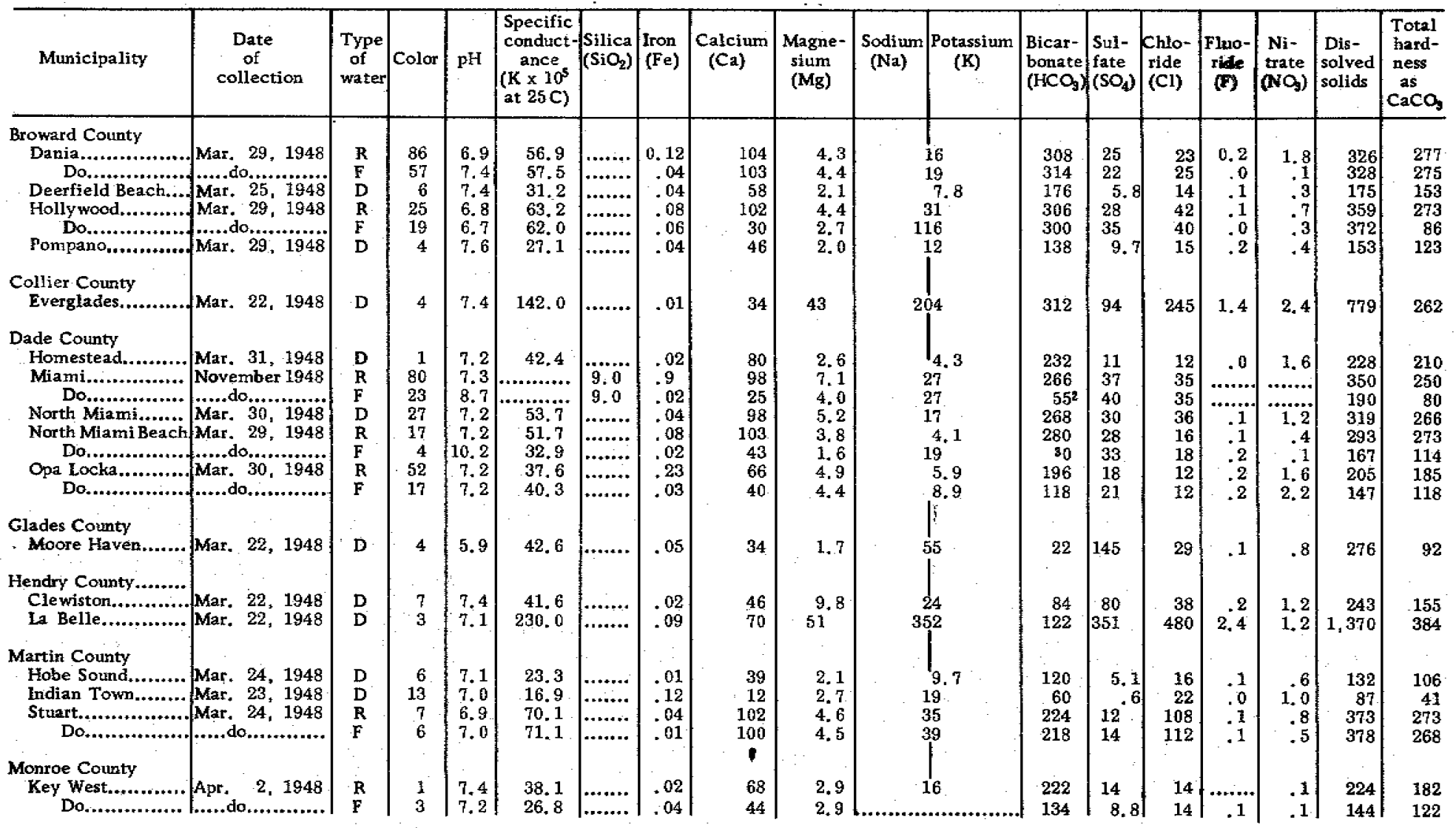




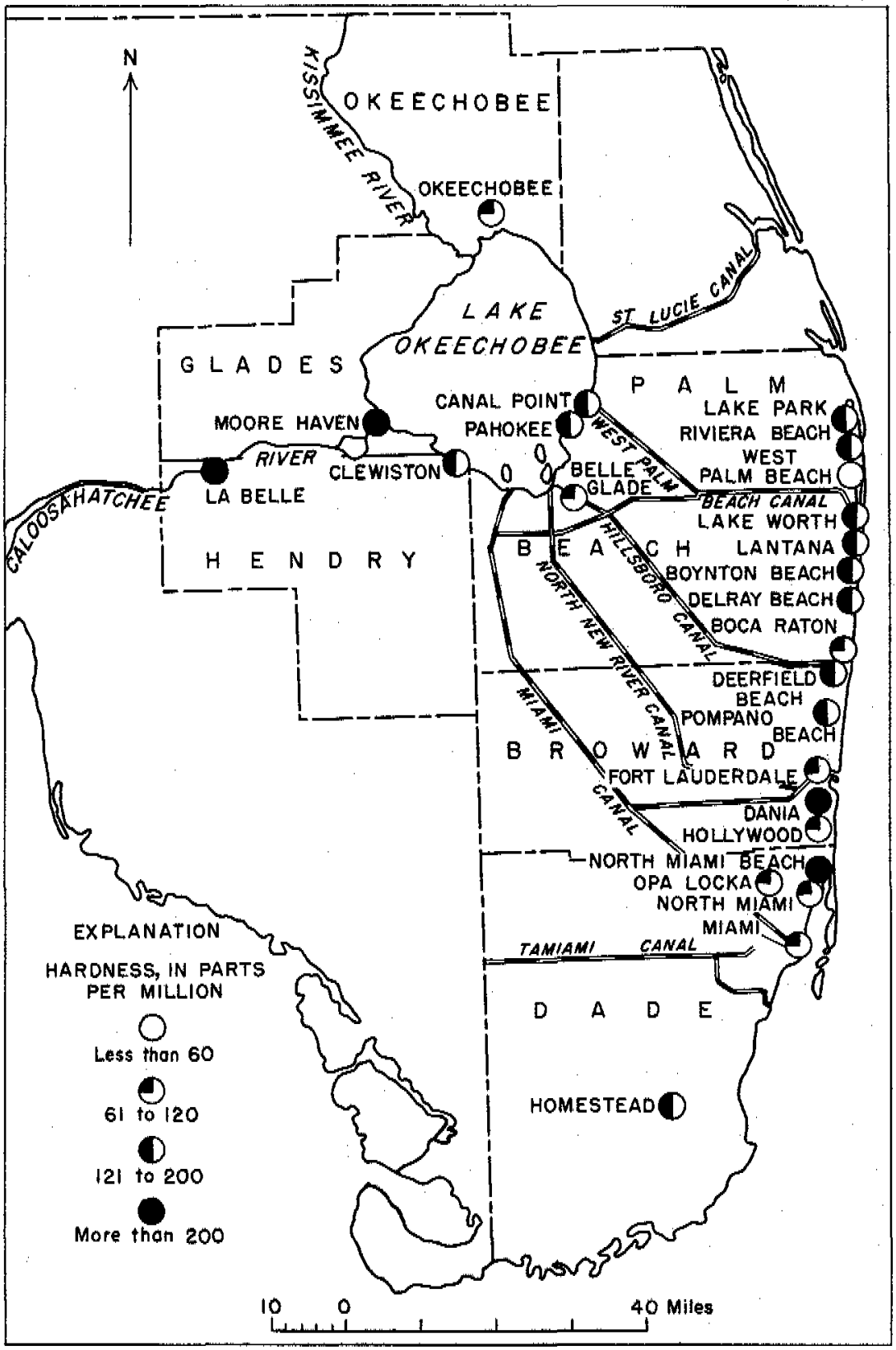

Figure 222, - Map showing hardness of public water supplies in southeastem Florida, 1941. 
services and a large part of the water used by them is obtained from privatefy owned wells.

Several Army and Navy air fields and training bases were established during the war along the lower eastcoast of Florida and in the north-central part of the area covered by this report. Existing public supplies furnish water to some of them and others have installed their own supplies. Water from public supply systems is also furnished to shipping at Miami, Port Everglades, and the Port of Palm Beach. 


\section{APPENDIX}

WELL RECORDS 
Table 116. Records of wells it Lroward County

[See plates 19 and 20]

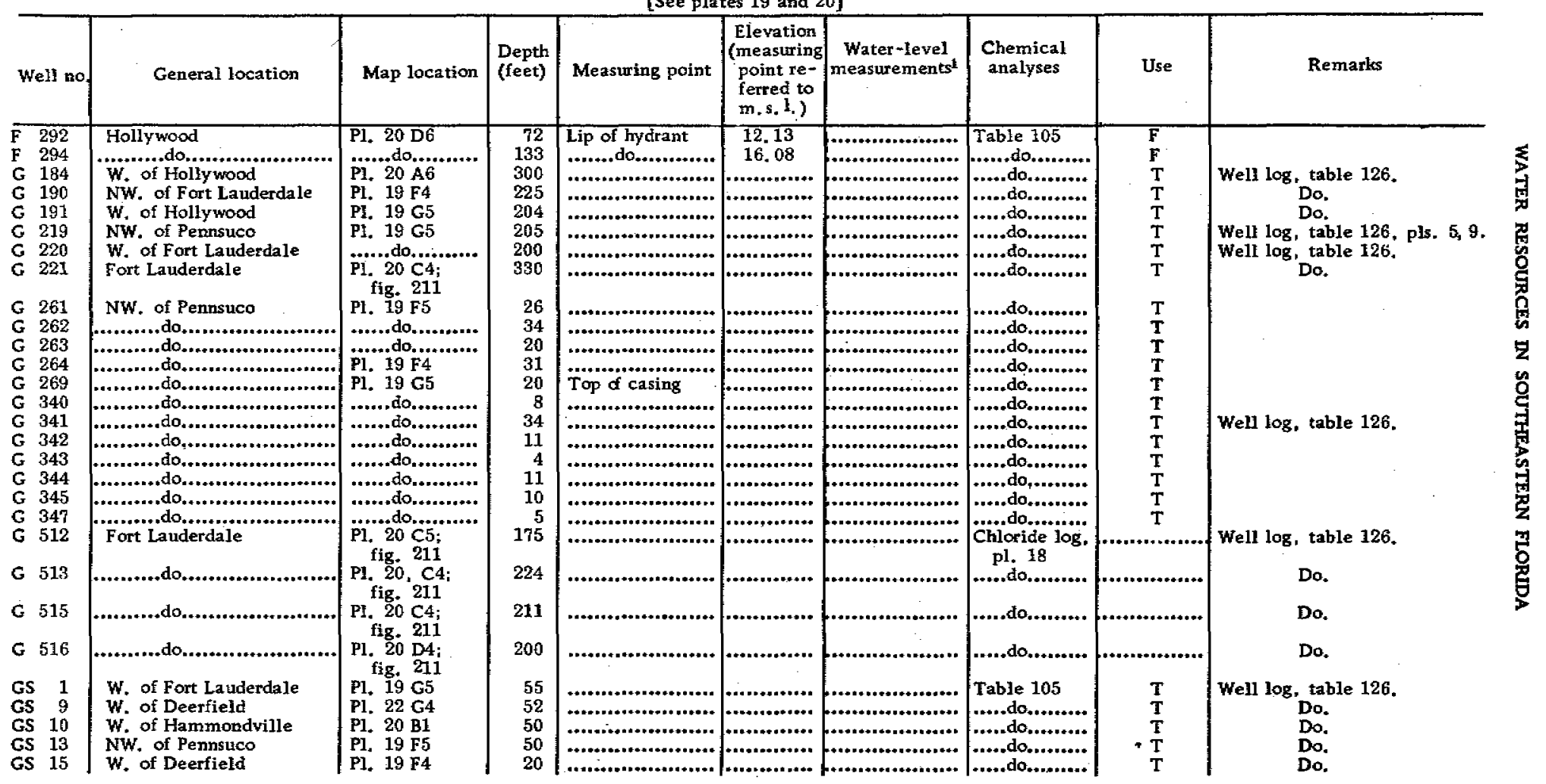




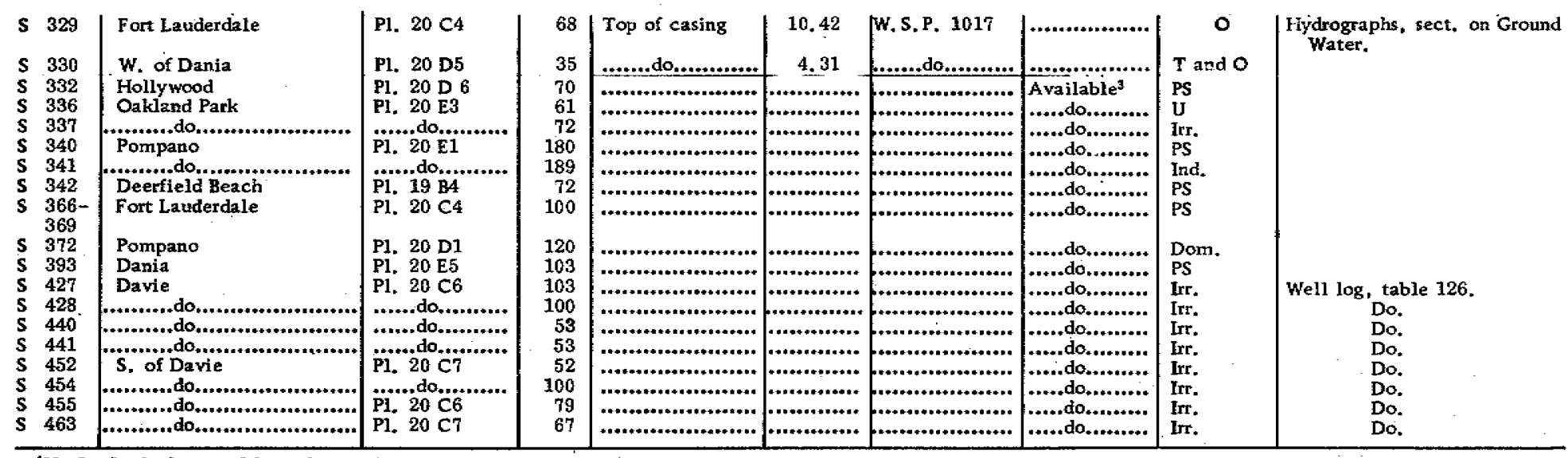

1U. S. Geol. Survey Water-Supply Paper.

2F, fire; T, test; $O$, observation; PS, public supply; $U$, umused; Irr. , irrigation; Ind., industrial; Dom. , domestic.

Section on "Quality of ground and surface water. " 
[See plate 19]

\begin{tabular}{|c|c|c|c|c|c|c|c|c|c|}
\hline Well no. & General location & Map location & $\begin{array}{l}\text { Depth } \\
\text { (feet) }\end{array}$ & $\begin{array}{l}\text { Meastring } \\
\text { point. }\end{array}$ & $\begin{array}{l}\text { Elevation } \\
\text { (meastuing } \\
\text { point re- } \\
\text { ferred to } \\
\text { m.s.1.) }\end{array}$ & $\begin{array}{c}\text { Water-level } \\
\text { measurements } 1\end{array}$ & $\begin{array}{l}\text { Che } \\
\text { an }\end{array}$ & Use? & Remarks \\
\hline $\begin{array}{lr}C & 4 \\
C & 11 \\
C & 12 \\
C & 13 \\
C & 14 \\
C & 15 \\
C & 16 \\
C & 17 \\
C & 18 \\
C & 19 \\
C & 20 \\
C & 21 \\
C & 22 \\
C & 36 \\
C & 37 \\
C & 43\end{array}$ & 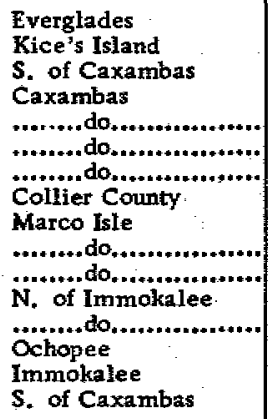 & 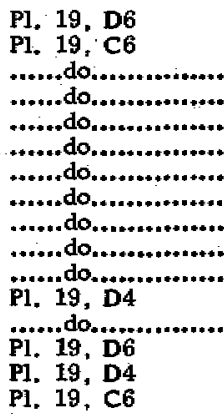 & \begin{tabular}{|c|c|}
521 \\
15 \\
300 \\
376 \\
13 \\
7 \\
22 \\
$\ldots \ldots \ldots \ldots$ \\
900 \\
12 \\
566 \\
845 \\
446 \\
590 \\
12
\end{tabular} & 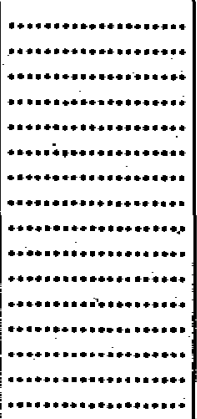 & 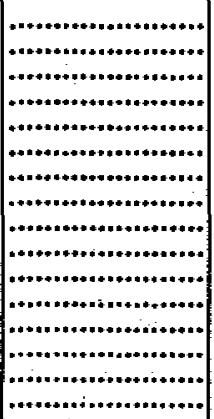 & 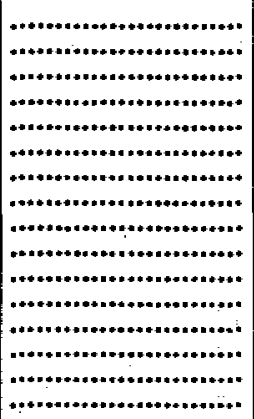 & 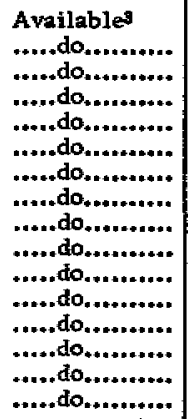 & $\begin{array}{l}\text { PS } \\
\text { U } \\
\text { Dom. } \\
\text { U } \\
\text { Dom. } \\
\text { Dom. } \\
\text { PS } \\
\text { Dom. } \\
\text { Dom. } \\
\text { Dom. } \\
\text { T } \\
\text { T } \\
\text { Dom. } \\
\text { Dom. } \\
\text { Dom. }\end{array}$ & \\
\hline
\end{tabular}

1U. S. Geol. Survey Water-Supply Paper.

2PS, public supply; $U$, unused; Dom. , domestic; $T$, test.

sSection on "Quality of ground and surface water." 
Table 118.-Records of wells in Dade County

[See plates 19, 21, 22, and 23]

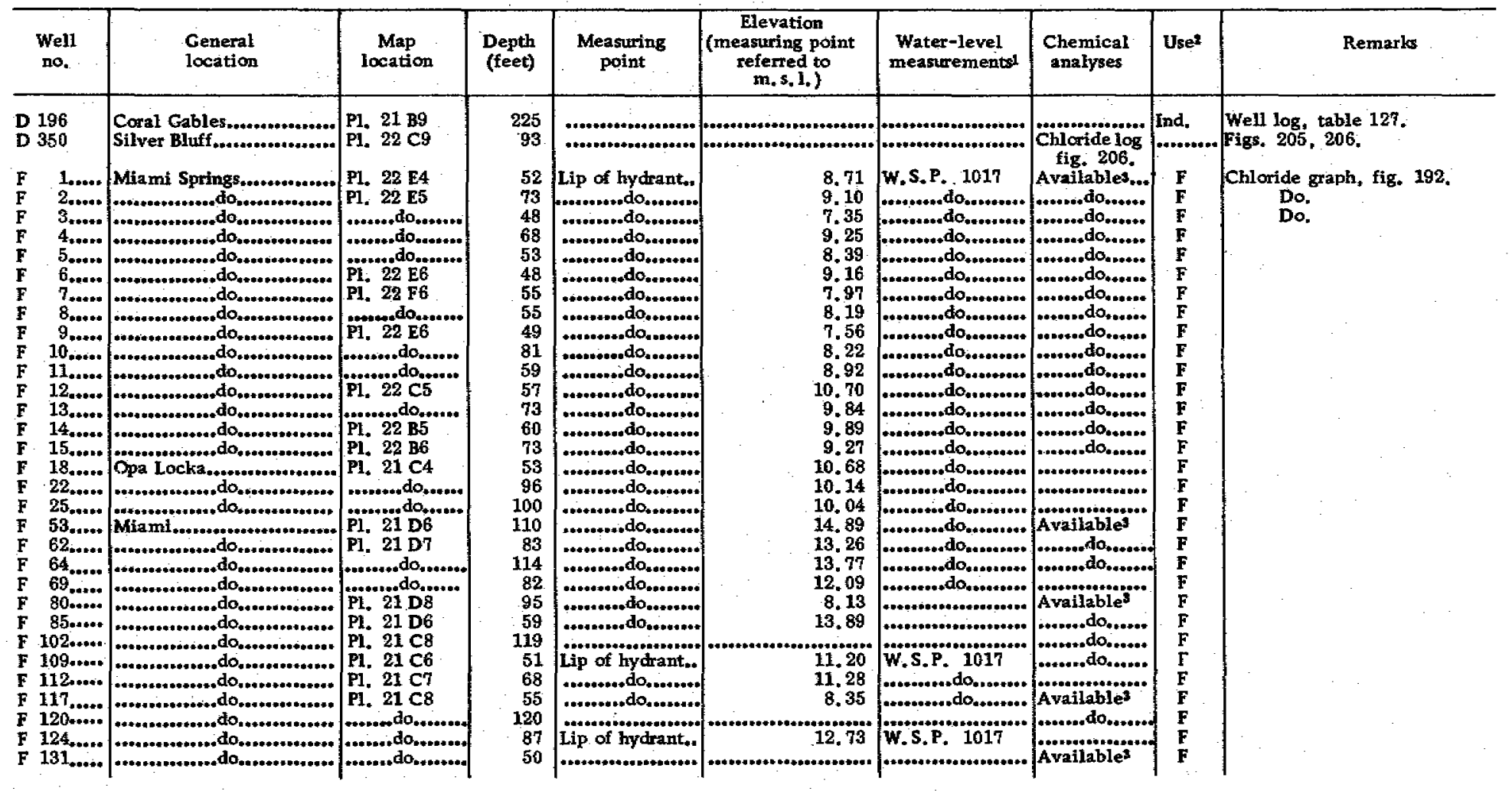


Table 118. - Records of wells in Dade County-Continued

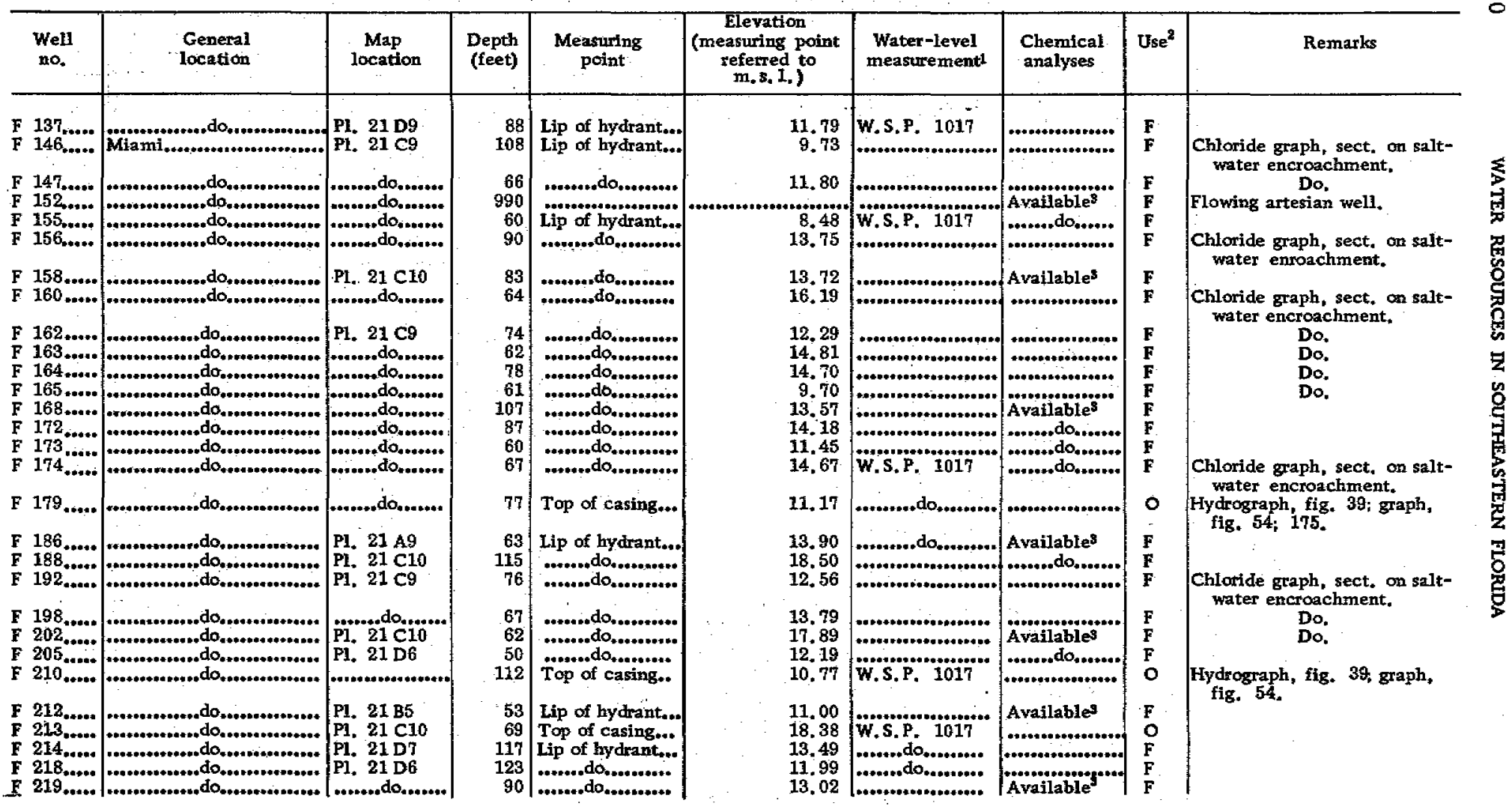




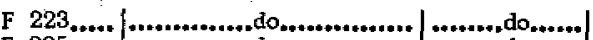

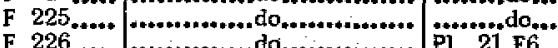

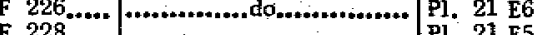

F 233 .

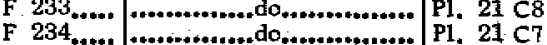

F $235 \ldots . . .1$ Tialeah................... P1. $22 \mathrm{H} 6$

F 236................................... 22 G5

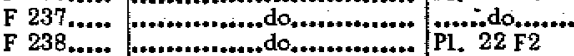

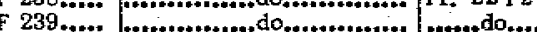

F 240.....

F 243.....

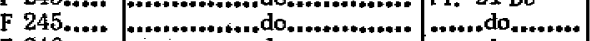

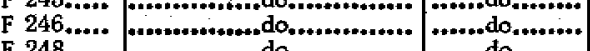

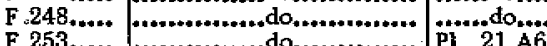

F 257 .*..*

F 257..... ..............do............. Pl. 21 B6

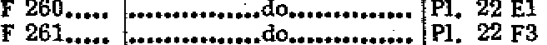

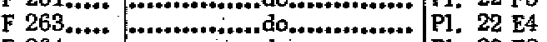

F 264.....

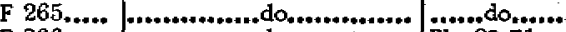

F $266, \ldots . .$.

F $268 \ldots \ldots$ PI. 22 E3

F $270 \ldots \ldots * *$...............do............... PI. 22 E2

F 271 .....

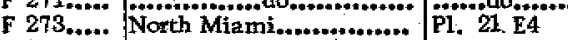

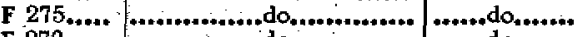

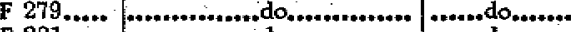

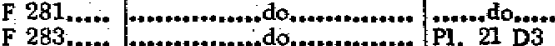

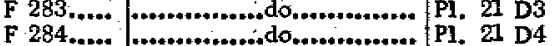

F 288...

F 296.....

F $297 \ldots$ Pro 21 E4

F 299... Biscayne Park

\begin{tabular}{l|l|l|} 
F . 300..... & N. Miami Beach,........... & P1. 21 E3
\end{tabular}

F 301..... Coral Gables............... 1 P1; 21 B9

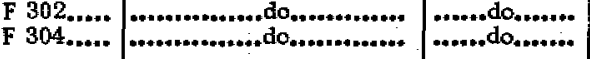

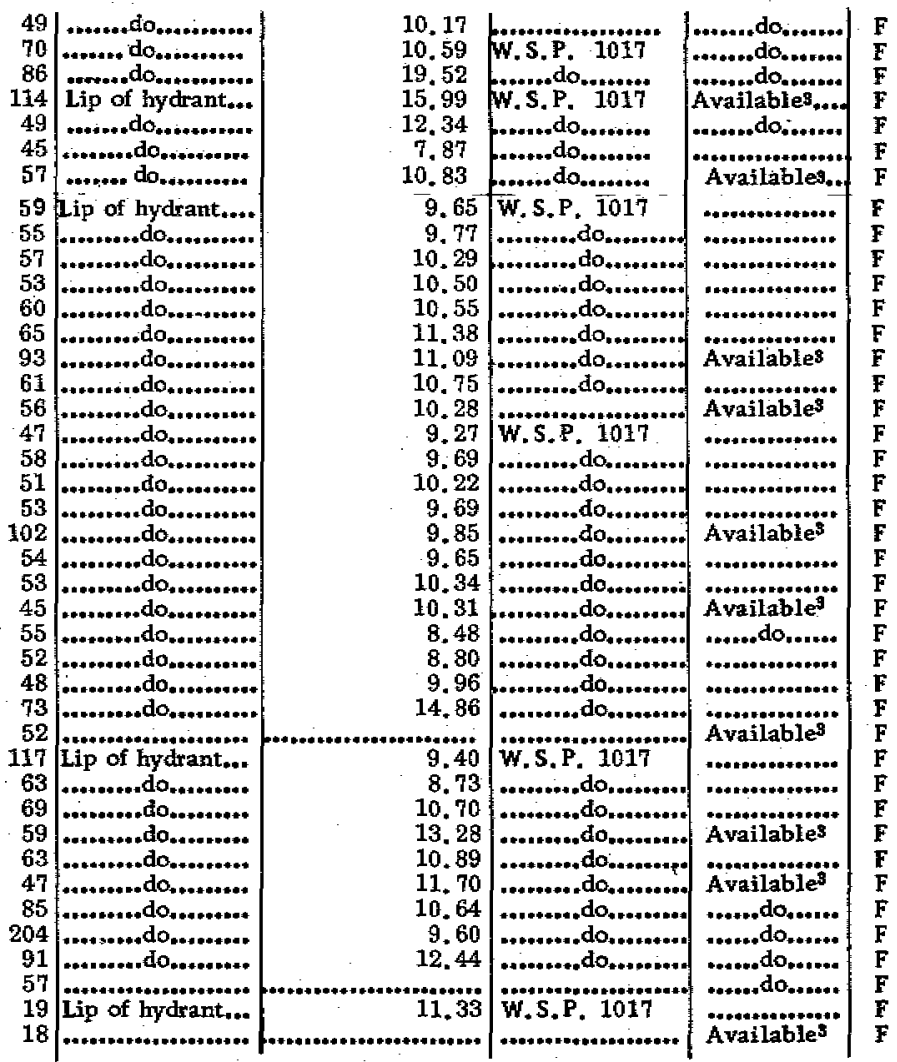


Table 118.-Records of wells in Dade Connty - Continued

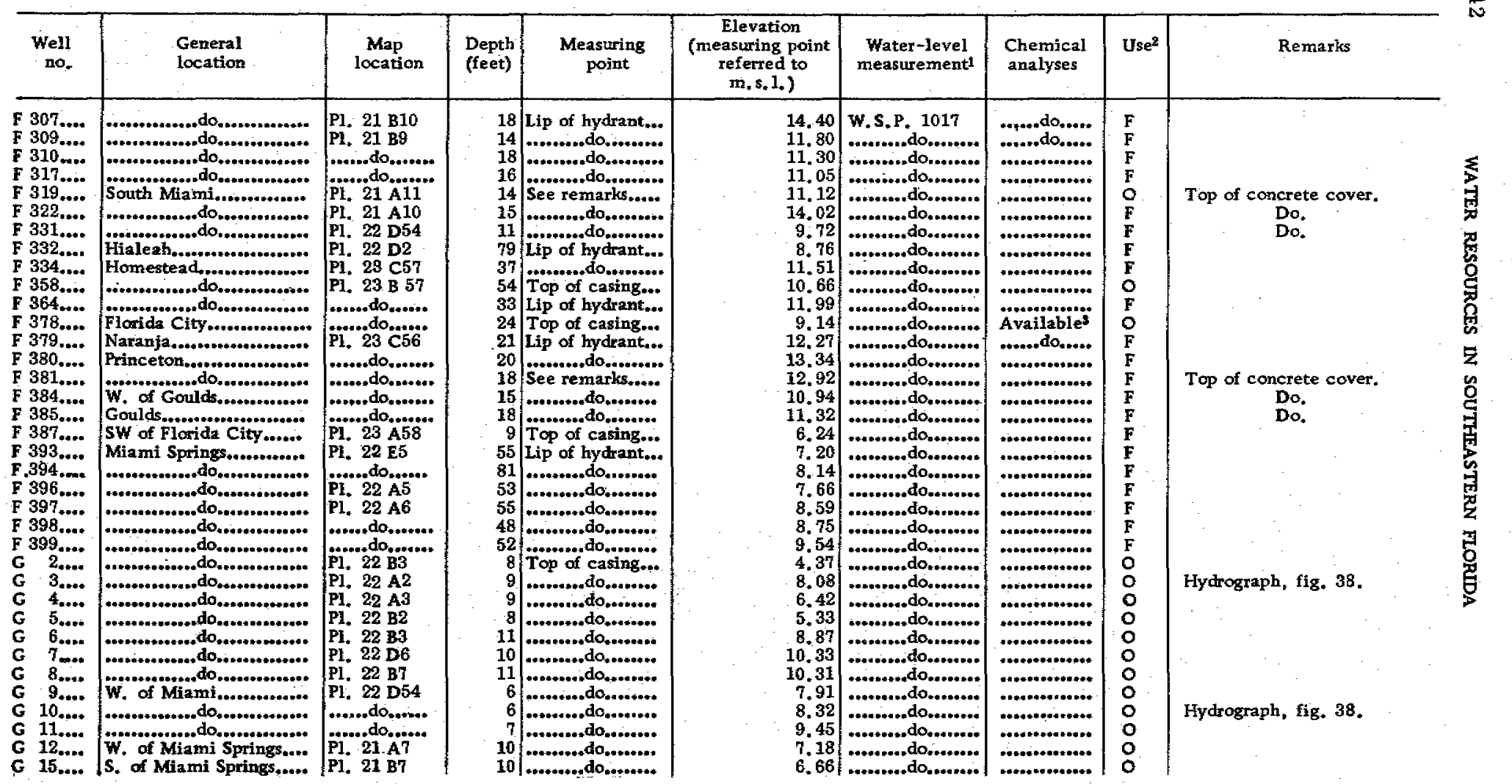




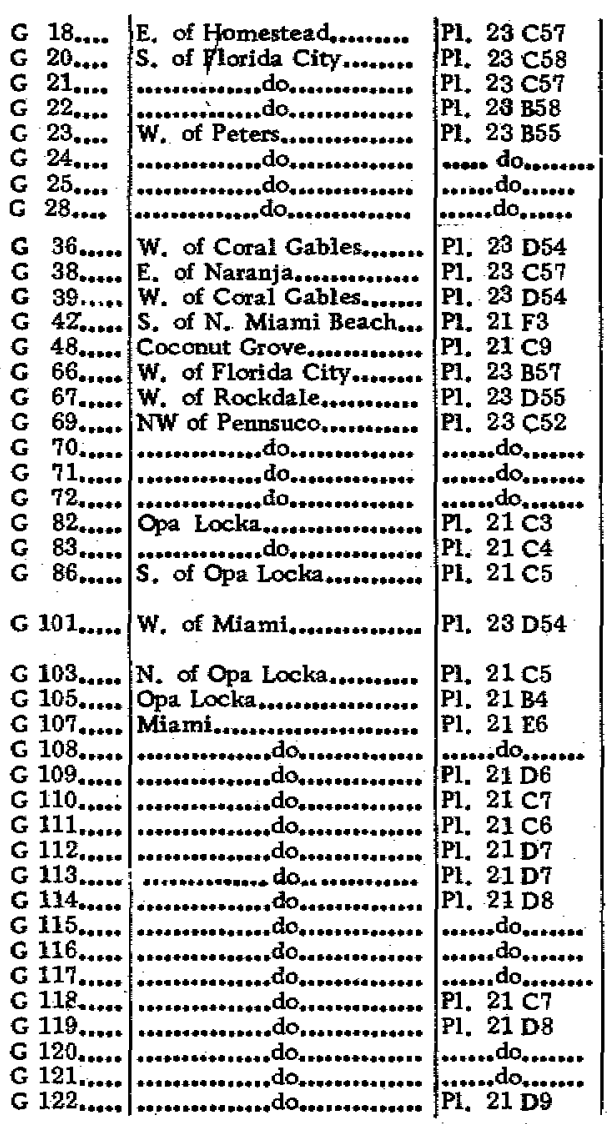

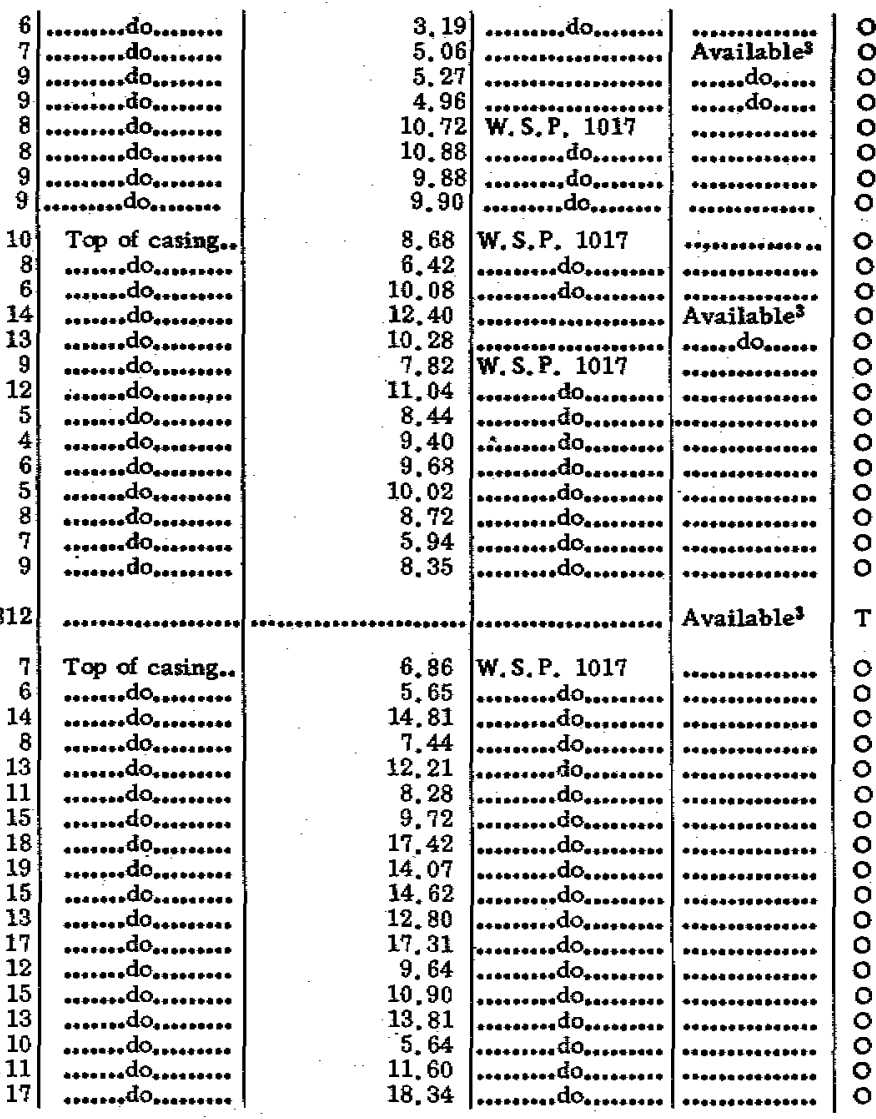

Hydrograph, figf. 38, 48, 52.

Hydrograph fig. 49 ; graph. fig. Well $\log$, table 127; pls. 5, 6 ,

9; p. 99 . 
Table 118.—Records of wells in Dade County-Continued

\begin{tabular}{|c|c|c|c|c|c|c|c|c|c|}
\hline $\begin{array}{l}\text { Well } \\
\text { no. }\end{array}$ & $\begin{array}{l}\text { General } \\
\text { location }\end{array}$ & $\begin{array}{l}\text { Map } \\
\text { location }\end{array}$ & $\begin{array}{l}\text { epth } \\
\text { feet) }\end{array}$ & $\begin{array}{c}\text { Measuring } \\
\text { point }\end{array}$ & $\begin{array}{c}\text { Elevation } \\
\text { (measuring point } \\
\text { zeferred to } \\
\text { m.s.1.) }\end{array}$ & $\begin{array}{l}\text { Water } \\
\text { measur }\end{array}$ & & Use $^{2}$ & Remarks \\
\hline 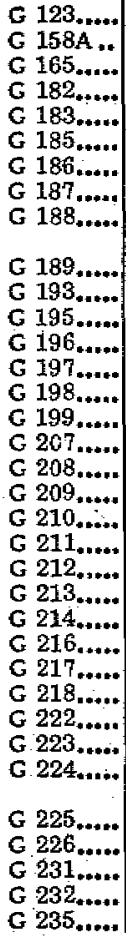 & 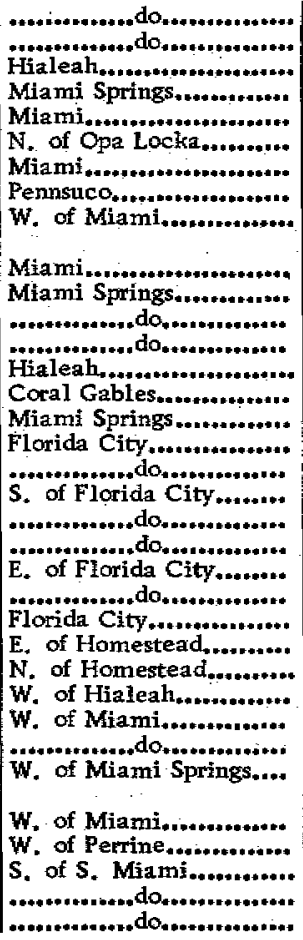 & 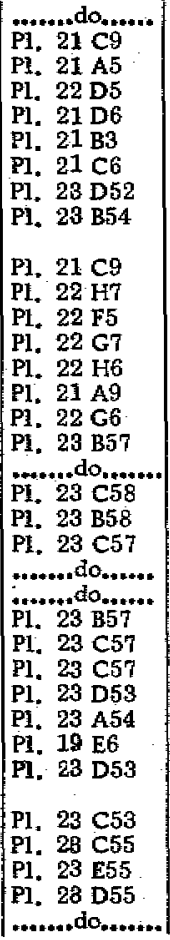 & $\begin{array}{r}10 \\
16 \\
7 \\
301 \\
350 \\
301 \\
300 \\
222 \\
200 \\
\\
241 \\
84 \\
95 \\
92 \\
91 \\
102 \\
92 \\
108 \\
46 \\
66 \\
45 \\
88 \\
79 \\
78 \\
37 \\
110 \\
120 \\
202 \\
77 \\
604 \\
104\end{array}$ & 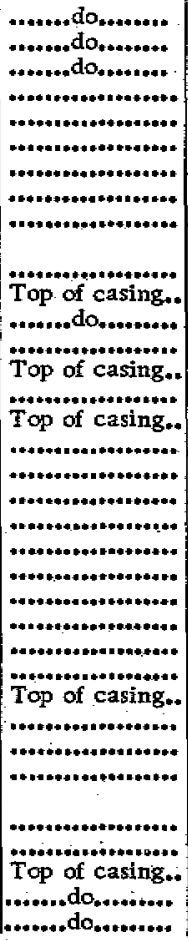 & 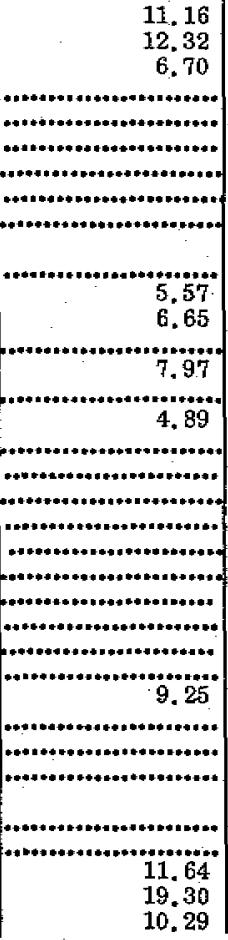 & 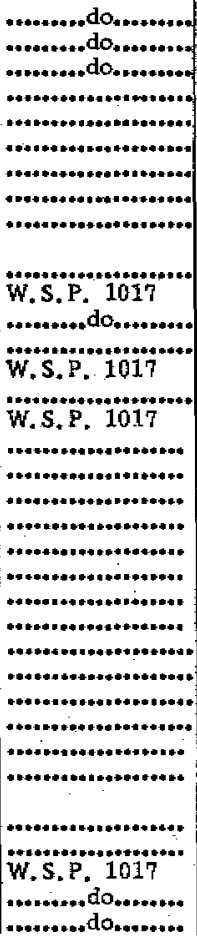 & "... & \begin{tabular}{|c|}
$O$ \\
$O$ \\
$T$ \\
$T$ \\
$T$ \\
$T$ \\
$T$ \\
$T$ \\
$T$ \\
$T$ and $O$ \\
$T$ and $O$ \\
$T$ \\
$T$ and $O$ \\
$T$ \\
$T$ and $O$ \\
$T$ \\
$T$ \\
$T$ and $O$ \\
$T$ and $O$ \\
$T$ and $O$ \\
$T$ and $O$ \\
$T$ and $O$ \\
$T$ \\
$T$ and $O$ \\
$T$ \\
$T$ and $O$ \\
$T$ \\
$T$ \\
$T$ \\
$T$ \\
$T$ \\
$O$ \\
$O$ \\
$T$
\end{tabular} & 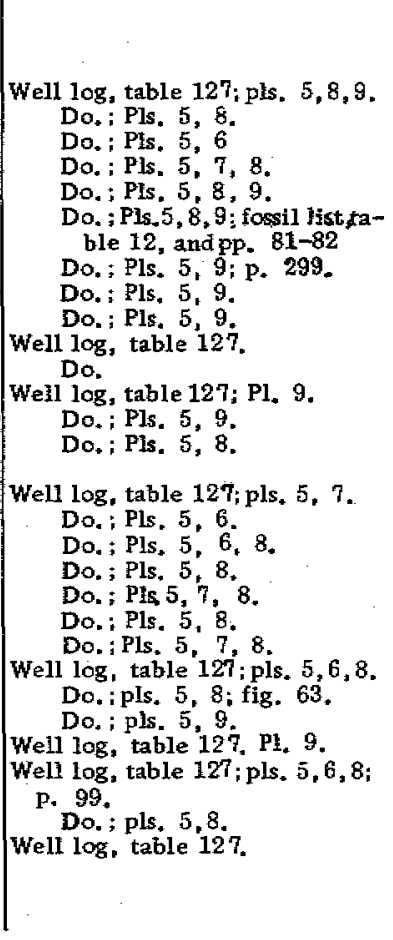 \\
\hline
\end{tabular}




\begin{tabular}{|c|c|c|}
\hline 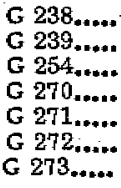 & 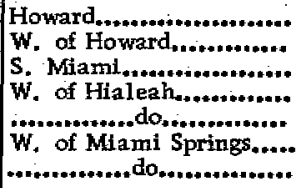 & 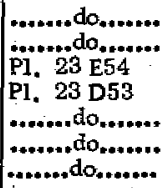 \\
\hline 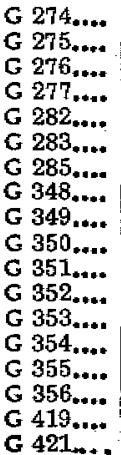 & 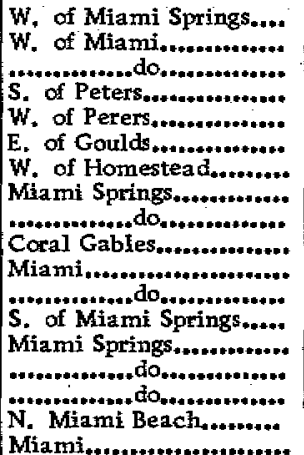 & 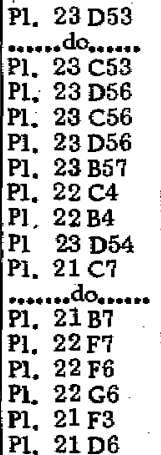 \\
\hline 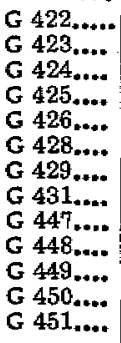 & 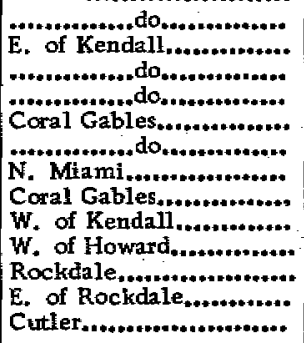 & 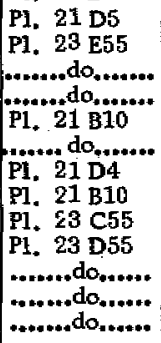 \\
\hline $\begin{array}{l}\text { G 469. } \\
\text { G 471. }\end{array}$ & E. of Peters....................* & ........do......4 \\
\hline
\end{tabular}

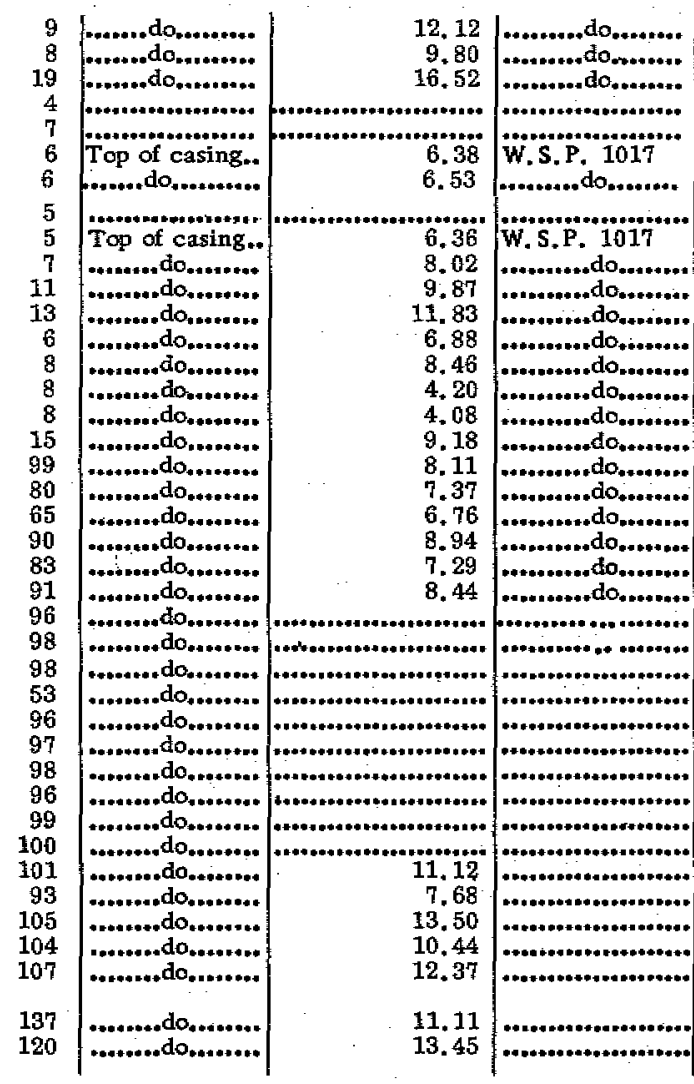

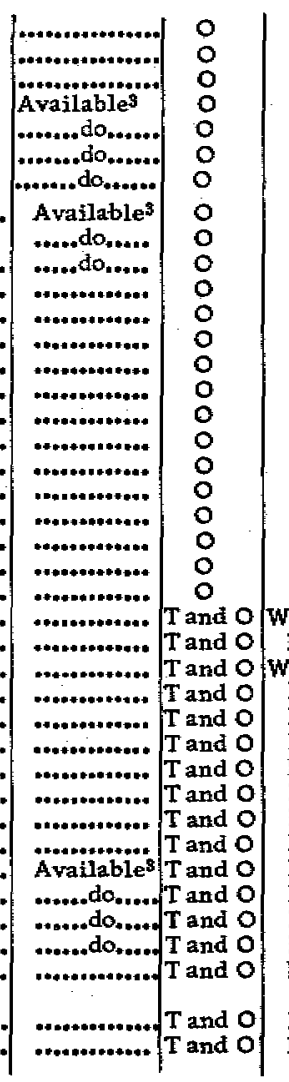

Well log, table 127 ; pls. 5,7 .
Do.; table $127 ;$ pls. $5,7,8$. 
Table 118.-Recond's of wells in Dade County-Continued

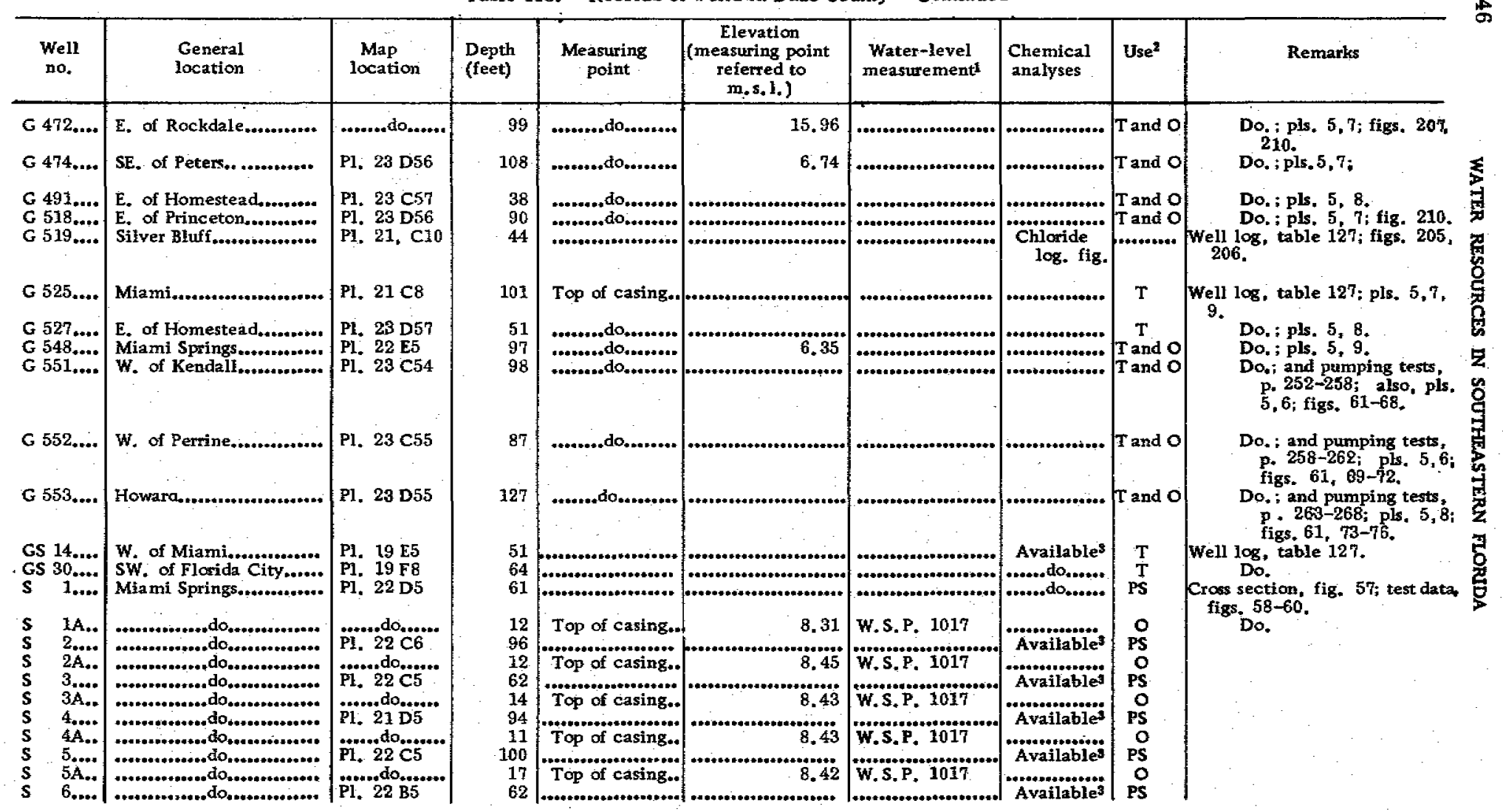




\begin{tabular}{|c|c|c|}
\hline $\begin{array}{ll}\text { S } & 6 A . . \\
\text { S } & 7 \ldots \ldots * \\
\text { S } & 7 A_{\ldots *} \\
\text { S } & 8 \ldots \ldots \\
\text { S } & 8 A \ldots \\
\text { S. } & 11 \ldots \ldots\end{array}$ & 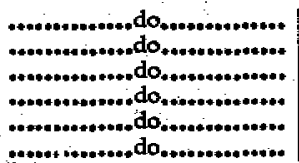 & 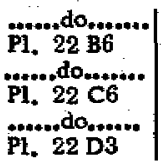 \\
\hline 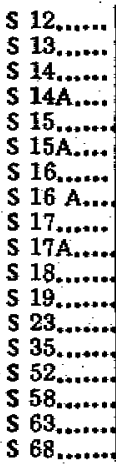 & 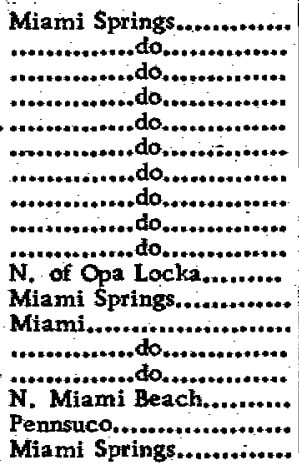 & 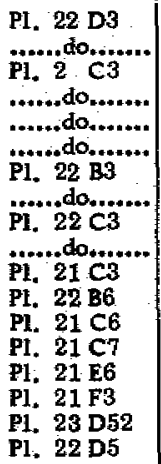 \\
\hline $\begin{array}{l}\text { S } 70 . . \\
\text { s } 72 . . \\
\text { S } 73 \ldots \\
\text { S } 84 . . \\
\text { s } 89 . \\
\text { s } 112 . \\
\text { s } 125 . \\
\text { s } 142 . \\
\text { s } 144 . \\
\text { S } 145 . \\
\text { S } 150 . \\
\text { S } 153 . \\
\text { S } 155 .\end{array}$ & 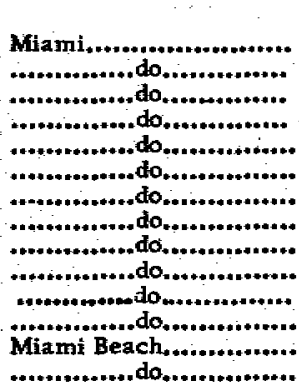 & 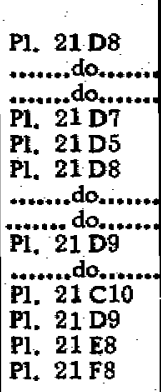 \\
\hline
\end{tabular}

\begin{tabular}{|c|c|c|c|c|}
\hline $\begin{array}{l}12 \\
62\end{array}$ & Top of casing.. & 8.48 & W.S.P. 1017 & Avai \\
\hline 12 & Top of casing. & 8.46 & W.S.P. 1017 & \\
\hline $\begin{array}{l}64 \\
10\end{array}$ & Tom of cresing & $849 \quad \longrightarrow 2$ & W S P 1017 & Ava \\
\hline 91 & .......................... & 0.94 & 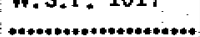 & Available" \\
\hline 90 & 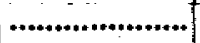 & & ............. & Available \\
\hline $\begin{array}{l}55 \\
73\end{array}$ & 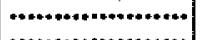 & (................... & 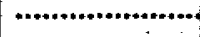 & ...... \\
\hline 11 & Top of casing. & 8.41 & W.s.P. 1017 & \\
\hline 11 . & Top of casing. & 8.42 & W.s.p. 1017 & \\
\hline 90 & Ton of casing & 8,411 & ws.p. 1017 & \\
\hline 87 & & & & $2 b l e^{9}$ \\
\hline 10 & Top of casing+. & 8.45 & W.S.P. 1017 & $\cdots . .$. \\
\hline 52 & ........... do do........ & $\begin{array}{r}10.12 \\
8.44\end{array}$ & ............dond.......... & ?..... \\
\hline $\begin{array}{l}90 \\
64\end{array}$ & 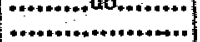 & {$\left[\begin{array}{r}8.44 \\
\ldots \ldots \ldots+\ldots\end{array}\right.$} & 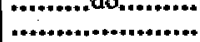 & Available**: \\
\hline 51 & *an. & ( …….............................. & (............................ & .......ds \\
\hline 36 & Top of casing. & 13.16 & 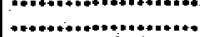 & ..................... \\
\hline $\begin{array}{l}37 \\
61\end{array}$ & 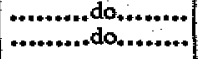 & $\begin{array}{l}8.78 \\
9.75\end{array}$ & 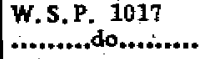 & 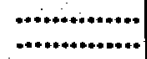 \\
\hline 100 & .........to... & 14. 69 & & Available $^{3}$ \\
\hline 32 & {$[\ldots \ldots+\ldots+\cdots+\ldots \ldots \ldots, \ldots]$} & 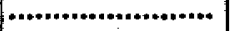 & 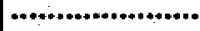 & ......do..... \\
\hline 40 & Top of casing. & 17.501 & W.S.P. 1017 & ........ \\
\hline 50 & ............ & 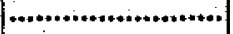 & ............................ & Avail \\
\hline 90 & $\ldots$ & 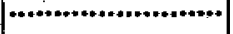 & ........ & ........do \\
\hline 65 & (............ & ...................... & ........... & ................... \\
\hline 100 & ......... & 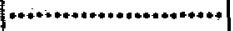 & 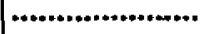 & Availables \\
\hline 66 & $\mid$ & 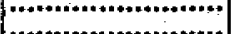 & ; n & ….." \\
\hline & 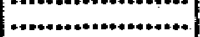 & $\mid$ & ....................... & .......do.... \\
\hline 000 & ......... & 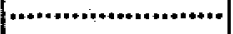 & .... & \\
\hline & & & & \\
\hline
\end{tabular}

\begin{tabular}{|l} 
O \\
PS \\
O \\
PS \\
O \\
PS \\
PS \\
PS \\
PS \\
O \\
PS \\
O \\
PS \\
O \\
PS \\
o \\
O \\
O \\
SP \\
Irr. \\
Ind. \\
U \\
U \\
O \\
\\
U \\
Ind. \\
Ind. \\
U \\
Dom \\
Ind. \\
Ind. \\
U \\
Irr. \\
Irr. \\
Ind. \\
Ind. \\
PS \\
U \\
\end{tabular}

Graph, fig 54 , hydrograph, fig 40

Graph, fig. 54; cross section,

fig. 57 ; chloride graph,

fig. 192 .

Flowing artesian well. Do.

Flowing artesian well. Do. 
Table 118, - Records of wells in Dade County - Continued

\begin{tabular}{|c|c|c|c|c|c|c|c|c|c|}
\hline $\begin{array}{c}\text { Well } \\
\text { no. }\end{array}$ & $\begin{array}{l}\text { General } \\
\text { location } \\
\therefore\end{array}$ & $\begin{array}{l}\text { Map } \\
\text { location }\end{array}$ & $\begin{array}{l}\text { Depth } \\
\text { (feet) }\end{array}$ & $\begin{array}{l}\text { Measuring } \\
\text { point }\end{array}$ & $\begin{array}{c}\text { Elevation } \\
\text { (measuring point } \\
\text { referred to } \\
\text { m.s.1.) }\end{array}$ & $\begin{array}{l}\text { Water-level } \\
\text { measurementsi }\end{array}$ & $\begin{array}{l}\text { Chemical } \\
\text { analyses }\end{array}$ & Use ${ }^{2}$ & Remarks \\
\hline 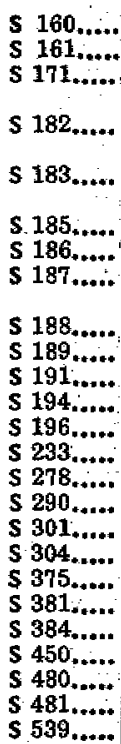 & 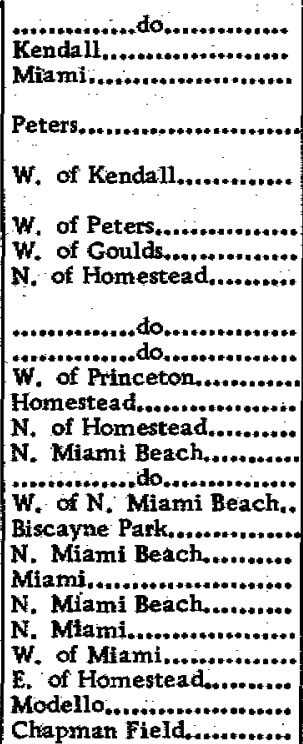 & 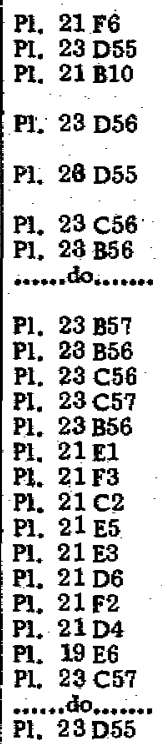 & $\begin{array}{r}1,000 \\
5,432 \\
40 \\
51 \\
15 \\
14 \\
15 \\
17 \\
14 \\
18 \\
20 \\
62 \\
20 \\
9 \\
80 \\
84 \\
100 \\
60 \\
54 \\
116 \\
63 \\
1,280 \\
57 \\
53 \\
29\end{array}$ & 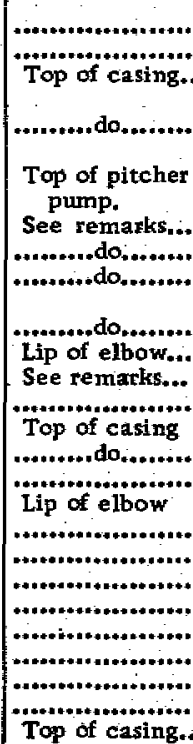 & 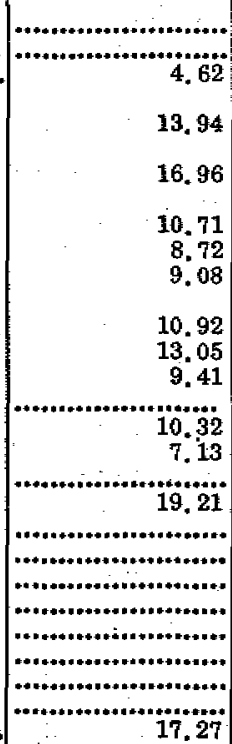 & 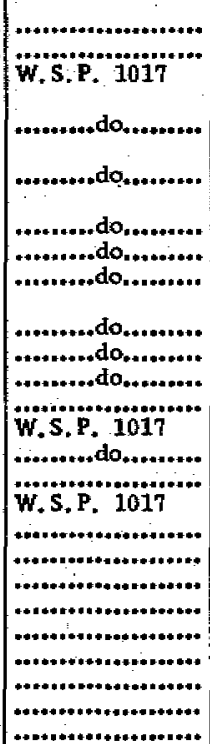 & 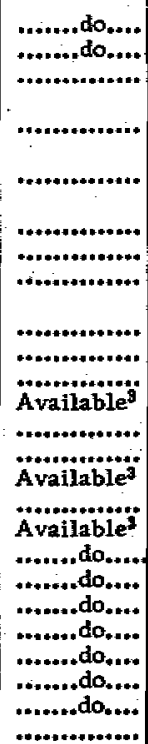 & \begin{tabular}{|l}
$\mathbf{U}$ \\
$\mathbf{T}$ \\
$\mathbf{0}$ \\
$\mathbf{0}$ \\
$\mathbf{U}$ Dom. \\
Irr. \\
Irr. \\
Dom. \\
Irr. \\
Irr. \\
Irr. \\
PS \\
$\mathbf{O}$ \\
$\mathbf{O}$ \\
PS \\
U \\
Dom. \\
APS \\
PS \\
PS \\
Irr. \\
T \\
Dom. \\
PS \\
O
\end{tabular} & 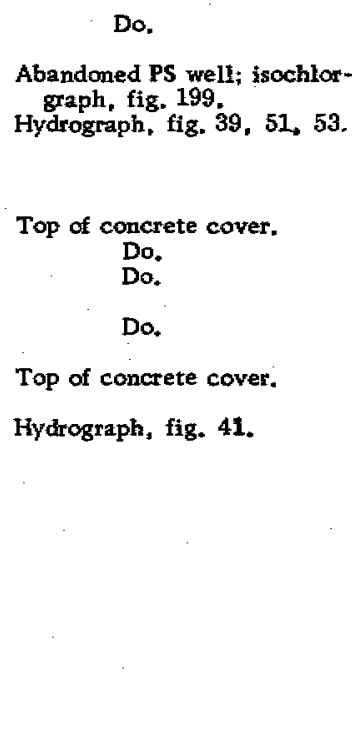 \\
\hline
\end{tabular}

1U. S. Geol. Survey Water-Supply Paper.

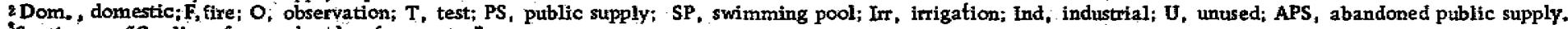

"Section on "Quality of ground and surface water". 
Table 119. - Records of wells in Glades County

[See plate 19]

\begin{tabular}{|c|c|c|c|c|c|c|c|c|c|}
\hline Well no. & General location & Map location & $\begin{array}{l}\text { Depth } \\
\text { (feet) }\end{array}$ & $\begin{array}{l}\text { Measuring } \\
\text { point }\end{array}$ & $\begin{array}{l}\text { Elevation } \\
\text { (measuring } \\
\text { point re- } \\
\text { ferred to } \\
\text { m. s. l:) }\end{array}$ & $\begin{array}{c}\text { Water-level } \\
\text { measurementsi }\end{array}$ & $\begin{array}{l}\text { Chemical } \\
\text { analyses }\end{array}$ & Us $\mathrm{e}^{2}$ & Remarks \\
\hline $\begin{array}{l:c}\text { GL } & 3 \\
\text { GL } & 4 \\
\text { GL } & 6 \\
\text { GL } & 7 \\
\text { GL } & 8 \\
\text { GL } & 9 \\
\text { GL } & 10 \\
\text { GL } & 11 \\
\text { GL } & 12 \\
\text { GL } & 13 \\
\text { GL } 14 \\
\text { GL } 15 \\
\text { GL } 16 \\
\text { GL } 17 \\
\text { GL } 18 \\
\text { GL } 19 \\
\text { GL } 20 \\
\text { GS } 18 \\
\text { Gs } 28 \\
\text { GS } 29\end{array}$ & 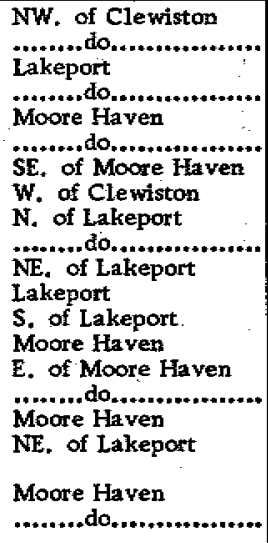 & 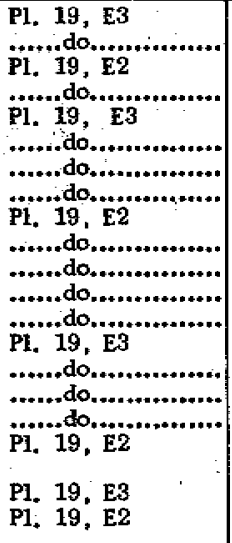 & $\begin{array}{r}92 \\
80 \\
22 \\
18 \\
104 \\
52 \\
85 \\
102 \\
120 \\
48 \\
35 \\
25 \\
25 \\
18 \\
30 \\
30 \\
28 \\
75\end{array}$ & 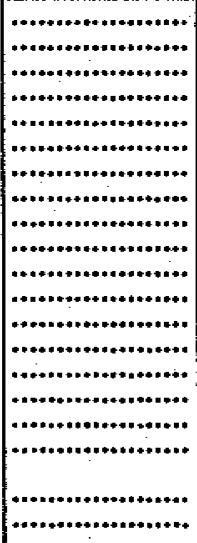 & 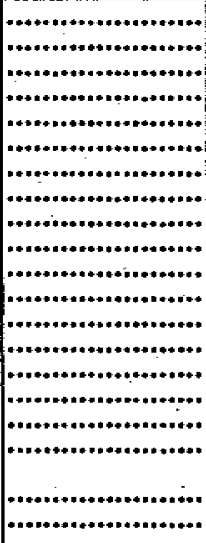 & 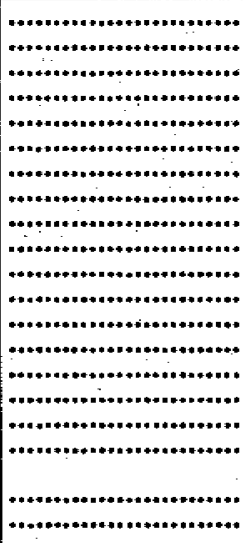 & 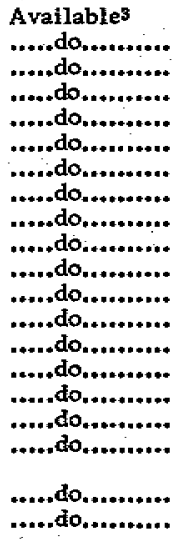 & $\begin{array}{l}\text { Dom. } \\
\text { Dom. } \\
\text { S } \\
\text { Dom. } \\
\text { U } \\
\text { Dom. } \\
\text { Dom. } \\
\text { Dom. } \\
\text { Dom. } \\
\text { S } \\
\text { Dom. } \\
\text { Dom. } \\
\text { Dom. } \\
\text { Dom. } \\
\text { Dom. } \\
\text { Dom. } \\
\text { PS } \\
\text { T } \\
T \\
T\end{array}$ & $\begin{array}{l}\text { Well log, } \\
\text { table } 128 \\
\text { Do. } \\
\text { Do. }\end{array}$ \\
\hline
\end{tabular}

1U. S. Geol. Survey Water-Supply Paper.

2Dom. , domestic; S, stock; U, unused; PS, public supply; $T$, test.

section on "Quality of ground and surface water." 
Table 120.-Records of wells in Hendry County

[See plate 19]

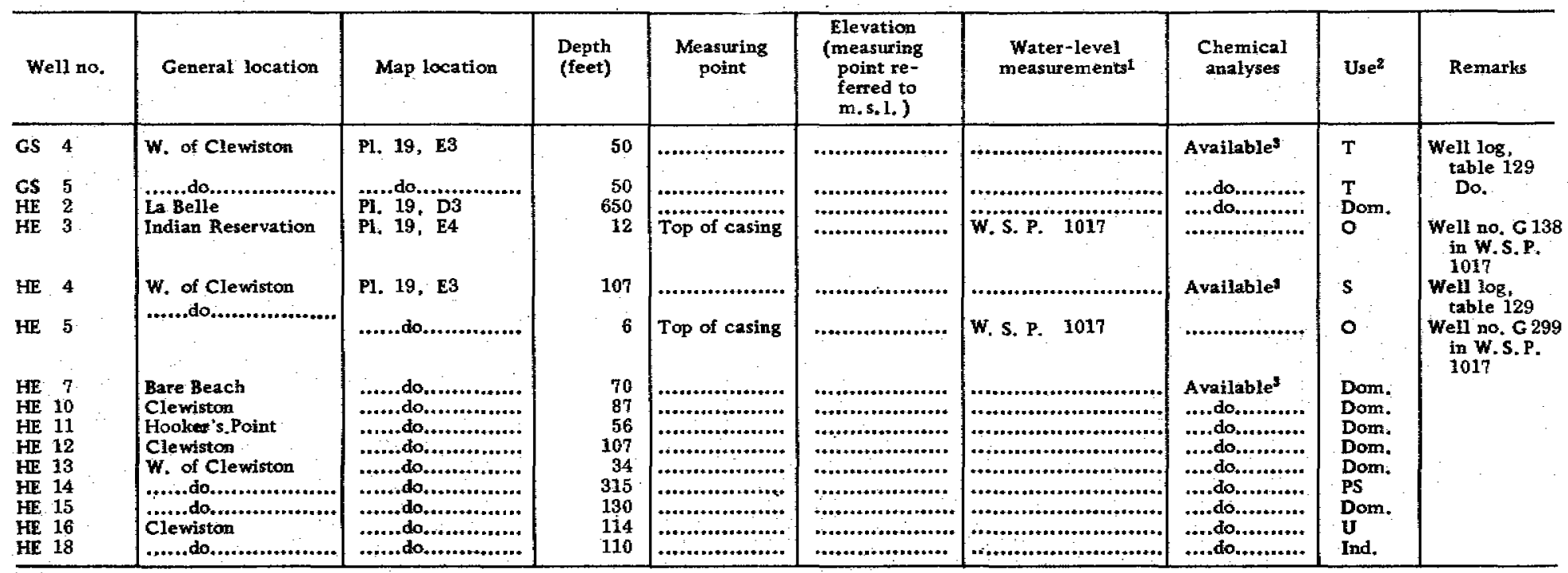

${ }^{1}$ U. S. Geol. Survey Water-Supply Paper.

${ }^{2} \mathrm{~T}$, test; Dom, domestic; O, observation; $S$, stock; PS, public supply; $\mathrm{U}$, unused; Ind, industrial.

secticn on "Quality of ground and surface water." 
Table 121. - Reconds of wells in Higatands County

[See plate 19]

\begin{tabular}{|c|c|c|c|c|c|c|c|c|c|}
\hline Well no. & General location & $\begin{array}{l}\text { Map location } \\
\text { (pl. and no.) }\end{array}$ & $\begin{array}{l}\text { Depth } \\
\text { (feet) }\end{array}$ & $\begin{array}{c}\text { Measuring } \\
\text { point }\end{array}$ & $\begin{array}{l}\text { Elevation } \\
\text { (measuring } \\
\text { point re- } \\
\text { ferred to } \\
\text { m.5.1.) }\end{array}$ & $\begin{array}{l}\text { Water-level } \\
\text { measurements1 }\end{array}$ & $\begin{array}{l}\text { Chemical } \\
\text { analyses }\end{array}$ & Use $^{2}$ & Remarks \\
\hline $\begin{array}{l}\text { GS } 20 \\
\text { GS } 21 \\
\text { GS } 22\end{array}$ & $\begin{array}{l}\text { SE. of Childs } \\
\text { Lake Istokpoga } \\
\text { Ft. Bassinger }\end{array}$ & $\begin{array}{l}\text { P1. 19, D1 } \\
\text { P1...do,............. }\end{array}$ & $\begin{array}{r}125 \\
65 \\
101\end{array}$ & 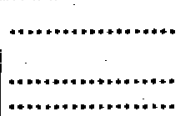 & 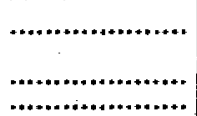 & 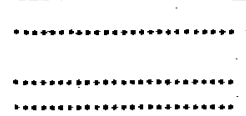 & $\begin{array}{l}\text { Available } \\
\text {.....do............ } \\
\text {.....do.......... }\end{array}$ & $\begin{array}{l}\mathrm{T} \\
\mathrm{T} \\
\mathrm{T}\end{array}$ & $\begin{array}{l}\text { Well } \log \\
\text { table } 130 \\
\text { Do. } \\
\text { Do. }\end{array}$ \\
\hline
\end{tabular}

${ }^{1} U$. S. Geol. Survey Water-Supply Paper.
${ }^{2} T$, test.

"Section on "Quality of ground and surface water." 
[See plate 19]

\begin{tabular}{|c|c|c|c|c|c|c|c|c|c|}
\hline Well no. & General location & Map location & $\begin{array}{l}\text { Depth } \\
\text { (feet) }\end{array}$ & $\begin{array}{l}\text { Measuring } \\
\text { point }\end{array}$ & $\begin{array}{l}\text { Elevation } \\
\text { (measuring } \\
\text { point re- } \\
\text { ferred to } \\
\text { m. s.1.) }\end{array}$ & $\begin{array}{l}\text { Water-level } \\
\text { measurements } 1\end{array}$ & $\begin{array}{l}\text { Chemical } \\
\text { analyses }\end{array}$ & Use $\mathrm{e}^{2}$ & Remarks \\
\hline GS 23 & S. of Indian Town & P1. 19, G2 & 91 & ...................... & , .................. & .......................... & Available & $\mathrm{T}$ & Well log, \\
\hline $\begin{array}{lr}M & 8 \\
M & 9 \\
M & 11 \\
M & 12\end{array}$ & $\begin{array}{l}\text { Port Mayaca } \\
\text { NW...do.................. } \\
\text { Hobe Soundian Town }\end{array}$ & $\begin{array}{l}\text { P1. 19, } \mathbf{F 2} \\
\text { P1. } 19, \mathrm{H} 2\end{array}$ & $\begin{array}{r}30 \\
27 \\
40 \\
117\end{array}$ & $+\ldots \ldots+\ldots+\ldots \ldots+\ldots$ & 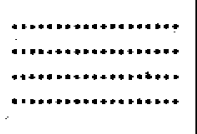 & 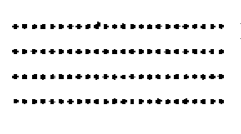 & 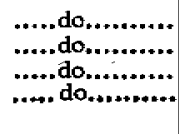 & $\begin{array}{l}\text { Irr. } \\
\text { U } \\
\text { Dom. } \\
\text { PS }\end{array}$ & $\begin{array}{l}\text { Well } \log _{\text {table }} 131 \\
\text { tablo }\end{array}$ \\
\hline $\begin{array}{ll}M & 15 \\
M & 16 \\
M & 17\end{array}$ & $\begin{array}{l}\text { NW. of Indian Town } \\
\text { Port Mayaca } \\
\text {......do................. }\end{array}$ & $\begin{array}{l}\text { P1. 19, } F 2 \\
\ldots \ldots \ldots \text { do............... } \\
\ldots \ldots \ldots \text { do............... }\end{array}$ & $\begin{array}{l}40 \\
48 \\
32\end{array}$ & & [.................. & …................... & 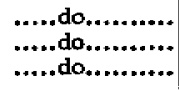 & $\begin{array}{l}\text { S } \\
\text { Dom. } \\
\text { Dom. }\end{array}$ & \\
\hline
\end{tabular}

IU. S. Geol. Survey Water-Supply Paper.

${ }^{2} T$, test; Irr, irrigation; $U$, unused; Dom, domestic; PS, public supply; $S$, stock.

"Section on "Quality of ground and surface water."

$$
\text { * }
$$


Table 123.-Records of wells in Okeechobee Cotmty

[See plate 19]

\begin{tabular}{|c|c|c|c|c|c|c|c|c|c|}
\hline Well no. & General location & Map location & $\begin{array}{l}\text { Depth } \\
\text { (feet) }\end{array}$ & $\begin{array}{l}\text { Measuring } \\
\text { point }\end{array}$ & $\begin{array}{l}\text { Elevation } \\
\text { (measuring } \\
\text { point re- } \\
\text { ferred to } \\
\text { m.s.1.) }\end{array}$ & $\begin{array}{l}\text { Water-level } \\
\text { measurements }\end{array}$ & $\begin{array}{l}\text { Chemical } \\
\text { analyses }\end{array}$ & Use $^{2}$ & Remarks. \\
\hline $\begin{array}{lr}\text { GS } & 16 \\
\text { GS } & 17 \\
\text { GS } & 19 \\
\text { OK } & 1 \\
\text { OK } & 7 \\
\text { OK } & 8 \\
\text { OK } & 9 \\
\text { OK } & 10 \\
\text { OK } & 11 \\
\text { OK } & 12 \\
\text { OK } & 13 \\
\text { OK } & 14 \\
\text { OK } & 15 \\
\text { OK } & 16\end{array}$ & 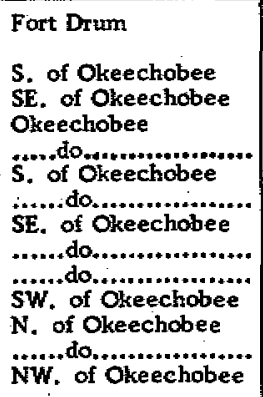 & 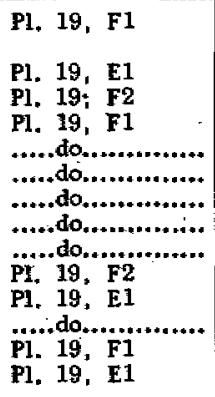 & $\begin{array}{r}90 \\
131 \\
49 \\
1718 \\
75 \\
48 \\
100 \\
57 \\
105 \\
65 \\
80 \\
95 \\
996\end{array}$ & 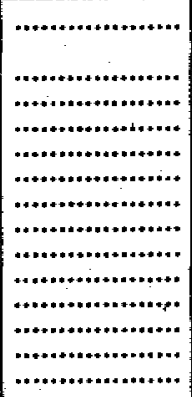 & 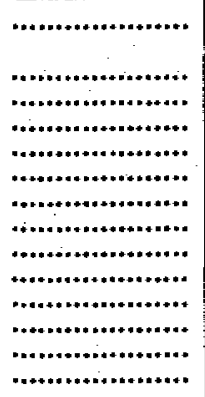 & 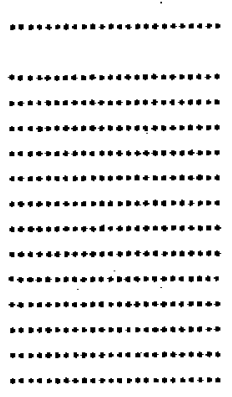 & 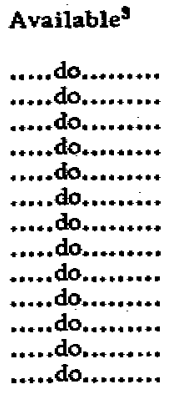 & $\begin{array}{l}T \\
T \\
T \\
\text { U } \\
\text { Dom. } \\
\text { Dom. } \\
\text { Dom. } \\
\text { Dom. } \\
\text { S } \\
\text { Dom. } \\
\text { Dom. } \\
\text { Dom. } \\
\text { Dom. } \\
\text { S }\end{array}$ & $\begin{array}{l}\text { Well log, } \\
\text { table } 132 \\
\text { Do. } \\
\text { Do. }\end{array}$ \\
\hline
\end{tabular}

1U. S. Geol, Survey Water-Supply Paper.

2T, test; U, unused; Dom, domestic; S, stock.

ssection on "Quality of ground and surface water." 
[See plates 19 and 24]

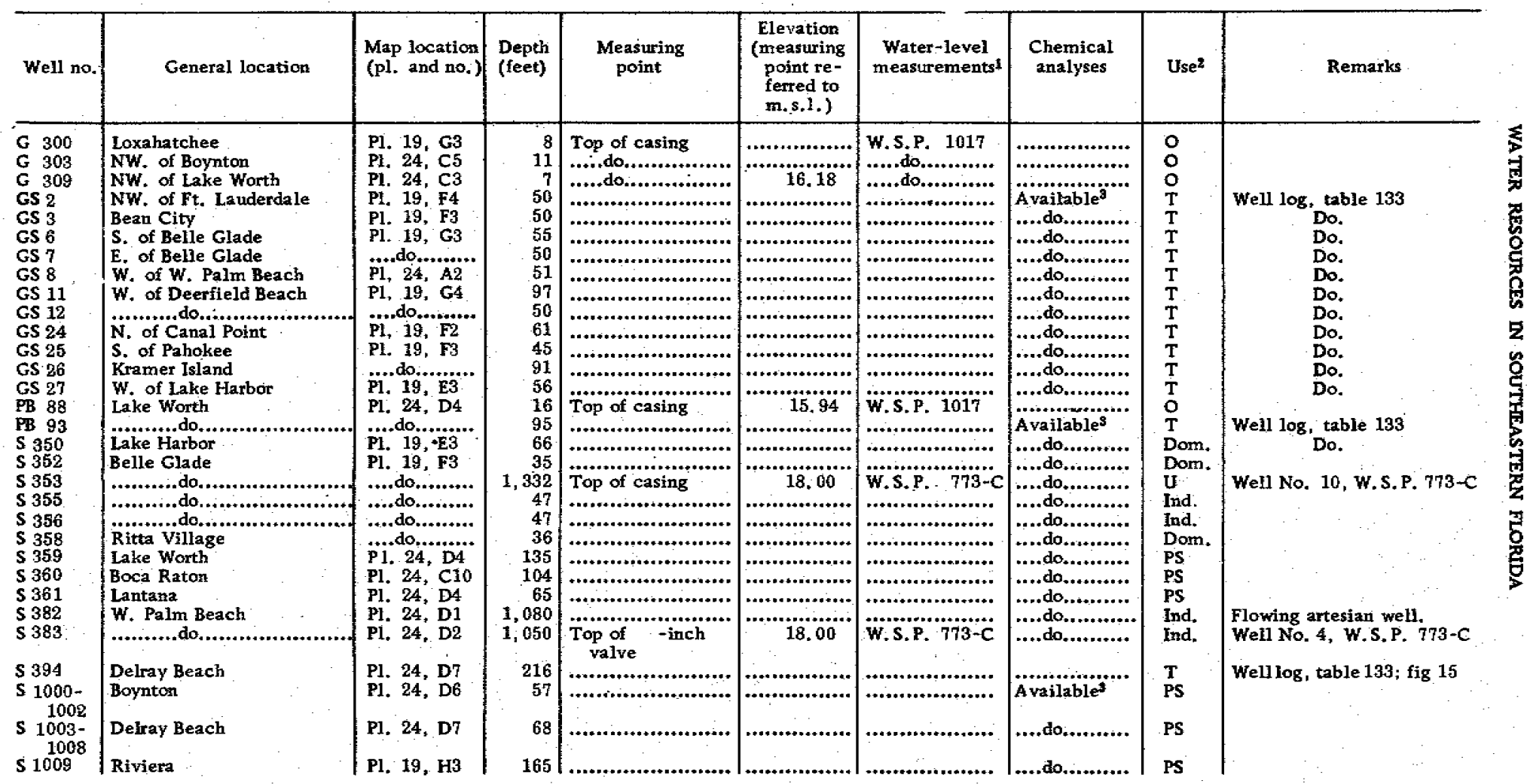




\begin{tabular}{|c|c|c|c|c|c|c|c|c|}
\hline $\begin{array}{l}1011 \\
1012 \\
1018 \\
1020 \\
1025 \\
1026 \\
1027 \\
1028 \\
1030 \\
1037 \\
1038 \\
1039 \\
1041 \\
1042 \\
1050 \\
1053 \\
1056 \\
1059 \\
1063 \\
1065 \\
1066 \\
1067 \\
1069 \\
1071 \\
1073 \\
1074 \\
1078 \\
1080 \\
1083 \\
085 \\
1088 \\
1090 \\
1091 \\
1093 \\
1096 \\
099 \\
100 \\
101 \\
102 \\
104 \\
105 \\
106\end{array}$ & 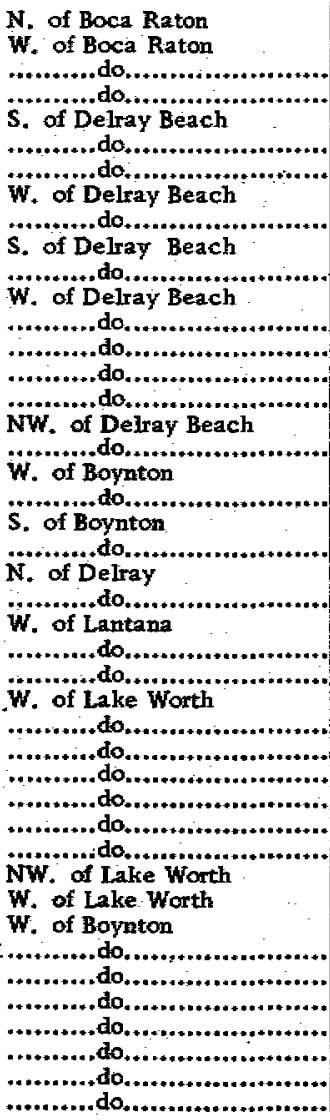 & 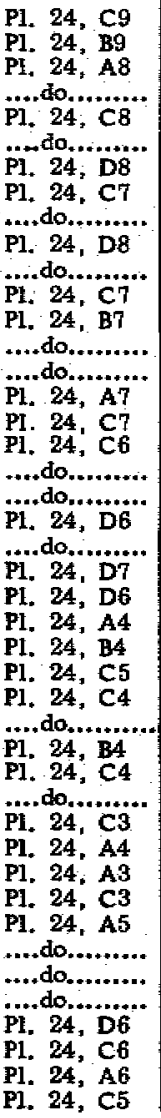 & $\begin{array}{r}25 \\
150 \\
84 \\
25 \\
67 \\
20 \\
20 \\
30 \\
80 \\
55 \\
111 \\
35 \\
120 \\
20 \\
20 \\
38 \\
40 \\
100 \\
25 \\
50 \\
50 \\
42 \\
20 \\
7 \\
11 \\
25 \\
75 \\
43 \\
40 \\
36 \\
204 \\
28 \\
35 \\
28 \\
49 \\
80 \\
20 \\
80 \\
15 \\
82 \\
68 \\
90 \\
35\end{array}$ & (1) & " & (A) & 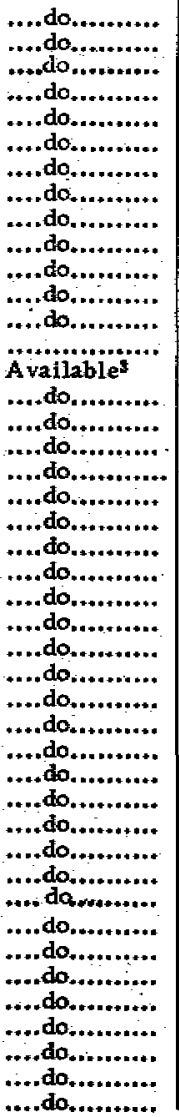 & $\begin{array}{l}\text { Dom. } \\
\text { Dom. } \\
\text { Irr. } \\
\text { Irr. } \\
\text { Dom. } \\
\text { S } \\
\text { Irr. } \\
\text { Dorn. } \\
\text { Dom. } \\
\text { Dom. } \\
\text { Dom. } \\
\text { Dom, } \\
\text { Dom. } \\
\text { O } \\
\text { Dom. } \\
\text { Dom. } \\
\text { Dom. } \\
\text { Dom. } \\
\text { Dom. }\end{array}$ \\
\hline
\end{tabular}


Table 124. - Records of wells in Palm Beach County-Continued

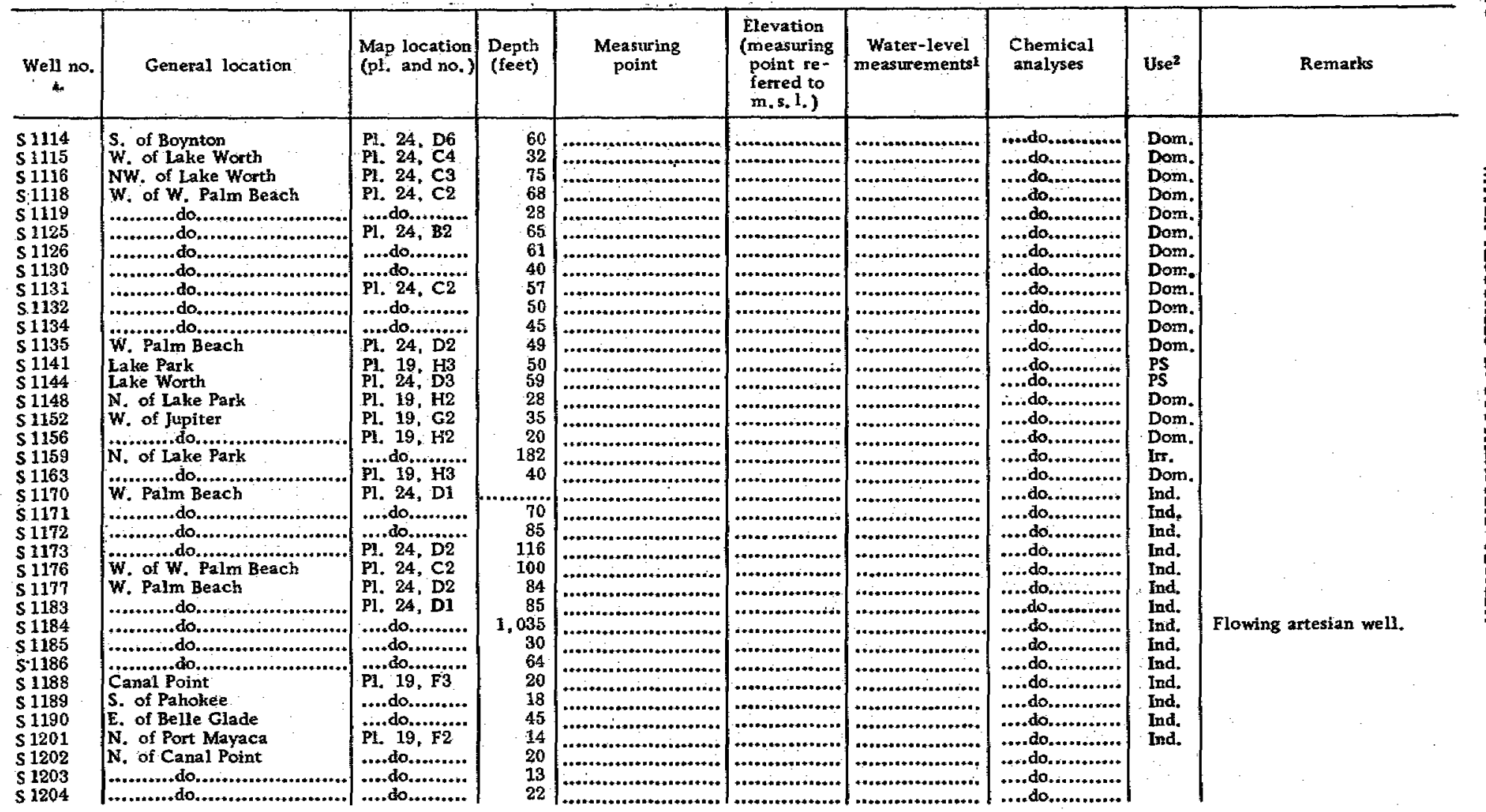




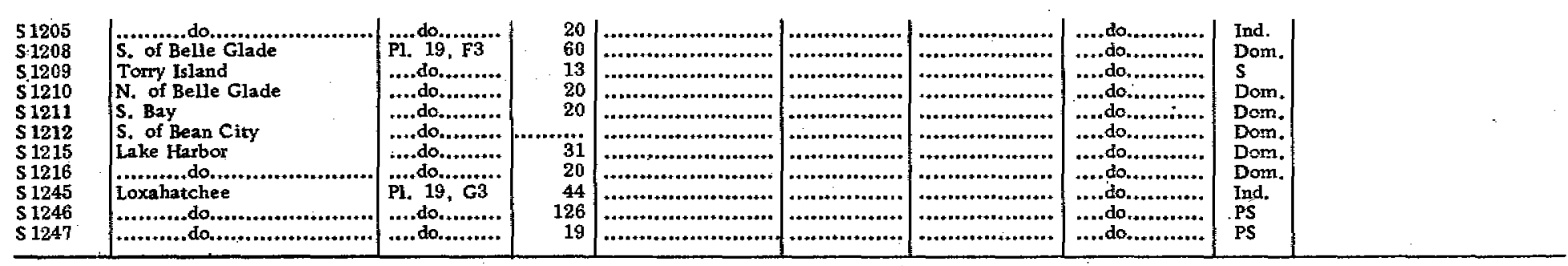

1U. S. Geol. Survey Water-Supply Paper.

${ }^{2} O$, observation; T, test; Dom, domestic; $U$, unused; Ind, industrial; PS, public supply; Irr, irrigation; $S$, stock.

'Section on "Quality of ground and surface water." 
Table 125. - Record of well in St, Lucie County

[See plate 19]

\begin{tabular}{|c|c|c|c|c|c|c|c|c|c|}
\hline Well no. & General location & $\begin{array}{l}\text { Map location } \\
\text { (pl. and no.) }\end{array}$ & $\begin{array}{l}\text { Depth } \\
\text { (feet) }\end{array}$ & $\begin{array}{l}\text { Measuring } \\
\text { point }\end{array}$ & $\begin{array}{c}\text { Elevation } \\
\text { (measuring } \\
\text { point re- } \\
\text { ferred to } \\
\text { m. } s_{y} l_{*} \text { ) }\end{array}$ & $\begin{array}{l}\text { Water-level } \\
\text { measuremients } 1\end{array}$ & $\begin{array}{l}\text { Chemical } \\
\text { analyses }\end{array}$ & Uset & Remarks \\
\hline St. L. 4 & Ft Pience & P1. 19, G1 & 130 & Top of casing & 27.09 & ............................... & (....................... & $T$ and $O$ & $\begin{array}{l}\text { Well log } \\
\text { table } 134\end{array}$ \\
\hline
\end{tabular}

IU. S. Geol. Survey Water-Supply Paper.

${ }^{2} \mathrm{~T}$, test; $O$, observation. 


\section{WELL LOG\$}

Table 126. 一 Logs of wells in Droward County

Well G 184

Location: Sec. 14, T. 51 S., R. 40 E., 7 miles west of Florida, on Koute 7, Hollywood Boulevard.

Elevation of land surface: $9 \mathrm{ft}$ above mean sea level.

Depth: $300 \mathrm{ft}$.

Diameter: 6 in.

Depth, in feet

below land surface

Road fill

Muck and peat.

Sand, quartx, gray-white..............................................................

Limentone, cream-colored, oolitic (Miaml oolite), fossiliferous, Contains

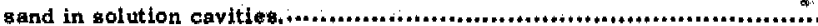

Sandstone, calcareous, and sandy limestone with occasional layers or

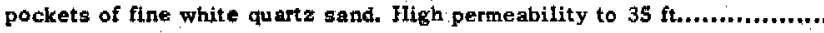

Sand, quartz, white, fine. Low permeability.......................................

Sandstone, Erayish-brown, calcareous, with considerable quantities of fine white quartz gand in places. Hoh permeability from 106 to 115 ft.............

Sandetone, calcareous, shelly, gritty., probably a consolldated sandy shell

mati. Color become greenish at $135 \mathrm{ft}$ and permeability becomes low.......

Sandstone, gray to ereen, calcareous, with occasional layers of goft clayey, silty, and sendy mart Very low permeabllity.....................................

Sandstone, dark-gray, calcareous, fossiliferous, Low permeability.............

Marl, dark-green, sandy, shelly in places. Practically impermeable..............

Sand, quartz, green, fine, marly and shelly in places. The green material is a colloidal carbonate.

$$
\begin{array}{r}
0-5 \\
5-9 \\
9-10 \\
10-30 \\
30-69 \\
69-79 \\
79-130 \\
130-161 \\
161-190 \\
190-195 \\
195-243 \\
243-300
\end{array}
$$

Well G 190

Location: SE $1 / 4$ SW1/4 sec. 35, T. 47 S., R. 38 E.; 12.2 miles north of 20 -Mile Bend in North New River Canal, on Florida Highway 25 .

Elevation of land surface: $10.6 \mathrm{ft}$ above mean sea level.

Depth: $225 \mathrm{ft}$

Diameter: 6 in.

Road ftll.

Muck and peat above; a thin layer of sand and fresh-water gray matl at base..

Limestone, gray, dense, hard, of fresh-water origin, Relatively impermeable..

Limestone and marl, gray, contalns fresh- and brackish-water shells. Relat lvely impermeablo;

Depth, in teet below I snd surtace

Shell marl, gray, sandy. Low pormeability.

$0-3$

$\begin{array}{lll}3 & - & 7\end{array}$

$7-8$

$8-10$

$10 \rightarrow 11$ 
Table 126, Logs of wells in Broward County-Continued

Well G 190 - Continued

$D$ epth, in teot below tand auface

Limestone, gray, with marl and shells; matne. Low permeability................. Limestone, gray, hard, with nonmarine shells. Low permeability..................... Limestone, gray, with marine ohellm; probably an indurated shell marl Pumping teat shows permeability to be fairiy low,

Shell marl, gray, indurated in places to make a hard rock; includes a few thin layers of sand, Low permeability.

Sandstone, Eray, shelly, calcareous, or an indurated sandy shell marl. Low permeability generally; thin permeable section at $38 \mathrm{ft} . . . . . . . . . . . . . . . . . . . . . . . . .$. Sand, gray, medium to coarge, includes many shéth fragments,+................... Sandstone, gray, shelly, calcareous, with some quartz sand.

Shell bed. Shells are perfectly preserved, uncemented, and the sample contains little sand. This shotld have been very permeable, but contained little water, May have been shell lens sealed off by adjacent relatively impermeable material a,

$$
\begin{aligned}
& 11-17 \\
& 17-20 \\
& 20-24 \\
& 24-29 \\
& 29-50 \\
& 50-52 \\
& 52-62
\end{aligned}
$$

Shell marl, indurated. Low permeability..................................................

Marl, greenish-grey, Eandy, shelly. Very low penieability..........................

Sandstone, dark-gray, coxtre-textured, shelly in places, with beds of șand intercalated throughout the Interval. Generally of low permeability; thin

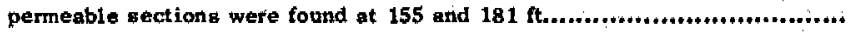

Shell mar1, greenish-gray, and greenish; sandy. Shell content ranges from about 95 percent at top to about 50 percent at base. Low permeability........ Marl, greenich-gray, sandy, becoming silty and helly toward bose. Low permeability.

Marl, greenish-gray, silty. Very low permeability

\section{Well G 191}

Location: $\mathrm{SE} 1 / 4 \mathrm{SW} 1 / 4$ sec. 27, T. 50 S., R. 39 E. On Florida Highway 25 at South New River Canal.

Elevation of land surface: $6.8 \mathrm{ft}$ above mean sea level.

Depth : $204 \mathrm{ft}$

Diameter; 6 in.

Depth in fort bolow land surfaco

$$
\begin{array}{r}
0=5 \\
5-8 \\
8-20 \\
20-27 \\
27-80 \\
80-184 \\
184=204
\end{array}
$$


Table 126, - Logs of wolls in Droward County-Continued

Well G 219

Location: NEt/SW1/4 sec. 33, T. 51 S., R. 39 E. On Dade*Broward Levee at Miami Canal.

Elevation of land surface $7.2 \mathrm{ft}$ above mean sea level.

Depth: 205 ft.

Diameter: $6 \mathrm{in.}$

Depth, in teet

below land surface

Roed fill.

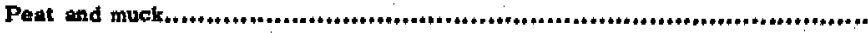

Limestone, datk to light, sandy, dense, vary hard. Probably altered by agcondary proceseses of solution and todeposition..............................................

Limestone, white to cream, hard, dense, breaks gemiconchoidally, Solution

holes give this rock a high permeablity. Sand pockets neat base................

Sandstone, white, calcereous, and white sandy limestone with lenees or poekete of very tine to fine white quartz sand; few shells, Madium permeability,

Sand, white, quaxtz, very line to medium. Low permeability ..........men.............

Sandetone, white, calcareous, porous.....................................................

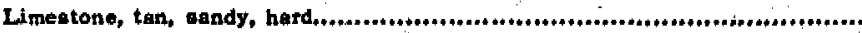

Sandstone, white, calcareons, with very fine to medium, white quartz sand in pockets or thin lenses. Medium permeabllity.

Shell marl, darkegray, very sandy. Low permeability...................................

Sand, greeniah, shelly, with thin layers of green sandy, clayey marl. Low permeobility.

Sand, green, silty and clayey; tew ghells, Low permeability........................

Shell marl, green, sandy, silty. Very low permeability................................

Sandstone, gray, calcareous, helly, probably a consolldated eandy shell marl. Low pemeability.

Limestone, gray-white, sandy, with numerous phosphate grains, Low permeability.

Candstone, oray, calcareous, with strogen few thin layers of green sandstone. Low permetbility.

Sandetone, greenish, calcareous, and quartz sand, containing sholls and phosphate graing, Low permeability.

sond, groenish, vory tine, with phosphate graing. The green color is due to a collotdal carbonate. Very low pormeability.

Mat1, gray*green, ilty, shelly, Practically impermeable,............................

Mart, dark-green, clayey, silty. Practically impermeable.............................

\begin{tabular}{|c|c|c|}
\hline 0 & - & \\
\hline 5 & 4 & \\
\hline 9 & - & 1 \\
\hline 16 & - & 3 \\
\hline & & \\
\hline 30 & - & 4 \\
\hline 43 & 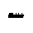 & 48 \\
\hline 48 & - & 5 \\
\hline 50 & $m$ & 5 \\
\hline 52 & - & 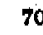 \\
\hline 70 & - & 86 \\
\hline 86 & - & 101 \\
\hline 101 & - & 117 \\
\hline 117 & - & 121 \\
\hline & & \\
\hline 121 & - & \\
\hline 139 & - & 143 \\
\hline 143 & - & 130 \\
\hline 158 & $=$ & 17 \\
\hline 173 & - & 18 \\
\hline 187 & - & 191 \\
\hline 191 & - & 205 \\
\hline
\end{tabular}

Well G 220

Location: SW1/4W1/4 sec. 27, T. 49 S., R. 49 E. At 20-Mile Bend in North New River Canal.

Elevation of land surface: $10.6 \mathrm{ft}$ above mean sea level.

Depth: $200 \mathrm{ft}$.

Diameter: 6 in.

Depth, in feot :

below tand eurface

Rond fill

Peat and muck

Marl, calcareous, gray, of fresh-water origin..........................................

Limestone, gray, hard, dense, of fresh-water origin.

Sand, quartz, ẹray-white, containlng stiall immature pelecypod shells...........

$0-4$
$4-9$
$9-10$
$10-12$
$12-16$




\section{Table 126. Logs of wells in Broward County-Continued}

Well G 220-Continued

$D$ epth, in feet bolow lathd surface

Sandstone, gray-white, calcareous, riddled with solution holes generally filled with white, very fine to medium quartz sand. Medium permeability..... Sandatone, tan-gray, calcareous, with thin lenses of quartz sand, and with few pieces of white chalky marl. Numerous Pectens. ILgh permeability......

Sand, dark+gray, thelly, with thin layers of shelly calcarsous sandstone; also, phosphate pebblos as large as $1 /$ in, dimeter.

Sand, dark-gray shelly. Law permeability .....t+..........................................

Sand, quartz, dark-greenigh-gray, with thin layers of greenish clay, and a

1 arge amount of phosphate grains. Low permeability.

Sand; quartz, green-gray, and calcareous sandstone nodules; also a few thin layers of calcareous sandatone, Low permeability.

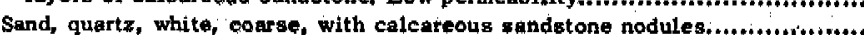

Sandstone, calcareous or sandy limestone, with lenses of fine shelly quartz sand. Low permeability,

Sandstone, gray-green, calcareous, shelly, poorly consolldated, Low permeability.

Sand, greenish to dark-gray, Low permeability.

Marl, green, silty and elayoy, with occasional shelly quartz sand layers. Very

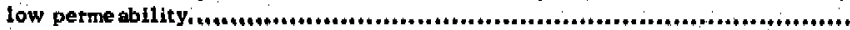
Marl, green, sandy, with thin lenges of clay, very low permeability ............... Shell mart, green, eandy. Low permeability................................................ Marl, green, clayey and sandy. Ftactically impermeable...

$16-38$
$38-67$
$67-77$
$77-84$
$84-94$
$94-100$
$100-109$
$109-151$
$151-162$
$162-172$
$172-184$
$184-190$
$190-194$
$194-200$

Location: NWL/4NWL/4 sec, 18, T. 50 S., R. 42 E. On Florida Highway 7, 1.0 mile N. of North New River Canal,

Elevation of land surface: $15.6 \mathrm{ft}$ above mean sea level.

Depth: $330 \mathrm{ft}$.

Diameter $6 \mathrm{in}$.

Sand, whlte, quartx, partly filling solution holes in the underlying oolitic limegtone.

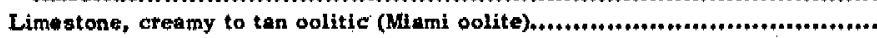

Sand, quartz, tan-brown; color due to iron oxide stain.

Sand, quartz, black, carbonaceous, very fine to medium.................................

Sand, quattz, white, very flne to medium, containing sholl fregments and wanstone nodules, Low permeability.

Sand, quartz, gray, vety fine to medium, Low permeabllity.

Sand, quertz, and some ochre-colored clayey material. Containg nodular calcareous sandstone, corals, and a fow holls Low permeability..................

Sand, quartz, tan-gray, and sandstone noduleg, Low permeability...................

Sand, quartz, gray*white, with fine shell perticles. Low permeability...........

Sand, quartz, gray, medium to coarse, and nodular calcareous sendstone. Low potmeability.

Sandstone, light-gray, calcureout, and large quantitids of very fine to medium, white quartz sand The and epparontly fills tolution holes. Low perme ability.

Saridstone, light-gray to tan, calcareous, and inndy limentone with lensiss

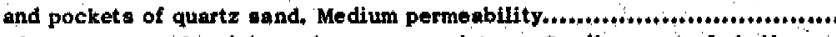

Sand, tanmray, arid nodular calcareous sandatone. Small amount of shell tragments. Low permeability. 
Table 126. - Logs of wells in Broward County - Continued

Well G 221-Continued

Dapth, in foot

below land murface

Sand, grayish-green, masty, partly consolidated in pleces to a shelly cal-

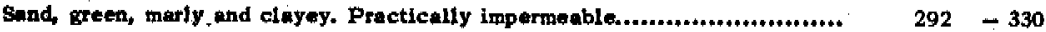

$238-292$

\section{Well G 341}

Location: NE $/ 4 \mathrm{NE}^{1 / 4} \mathrm{sec}, 14$, T. 51 S., R. $38 \mathrm{E}$., 5 miles northwest of Dade-Broward County Line Dam, and 0,3 mile northeast of Miami Canal.

Elevation of land surface: $8.0 \mathrm{ft}$ above mean sea level.

Depth: $34 \mathrm{ft}$.

Diameter: $1 \frac{1}{4}$ in.

Depth, in teet

belo tand eutface

Muck and marl.

Limestone, brown-white, very hard to $7 \mathrm{ft}$, soft and sandy from 7 to $26 \mathrm{ft}$.

Cavity from 26.5 to $28 \mathrm{ft}$.

Sand, quartz, eray, with small amount of 1008 se sandy limestone....................

Limetone, gray sandy.

$0-3.5$
$3.5-28$
$28-33$
$33-34$

\section{Well G 512}

Location: NE1/4NE1/4 sec. 24,T. 50 S., R. 41 E., W. side of Florida Highway 7 on N, bank of North New River Canal.

Elevation of land surface: about $10 \mathrm{ft}$ above mean sea level.

Depth, in feet

below land aurfaca

Road fill

Muck, ,organic, black.

Limentone, oolitic, crenmy to whit, with layers of quartz $\mathrm{s}$ and...................

Limestone, oolitic, very eandy and soft.................................................

Dolite, quart $z$ and, fine, Low permeabllity.,.+.....4..................................

Sand, quarti, white to grayish-white, fine-grained.......................................

Sandatone, calcareous, very hard.

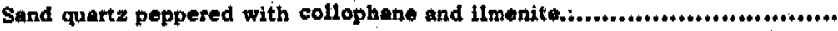

Sandstone, calcareous, altemating with thin beds of quart $x$ sund................

Limestone.

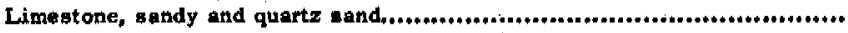

Cevity. Large yield.

Gravel lying on a thit tayer of lineatone

Cavity.

Limostons, sandy with thin layere of quartz sand. Modium permeability......

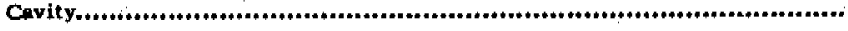

Limtotone, very denee.

Cavity.

Limostone, very dense,

\begin{tabular}{|c|c|c|}
\hline 0 & - & 11 \\
\hline 11 & - & 14 \\
\hline 14 & - & 20 \\
\hline 20 & - & 28 \\
\hline 28 & - & 40 \\
\hline 40 & - & 61 \\
\hline 61 & $\ldots$ & 70 \\
\hline 70 & - & 126 \\
\hline 126 & $-\pi$ & 140 \\
\hline 140 & - & 141 \\
\hline 141 & $=$ & 142 \\
\hline 142 & - & 144 \\
\hline 144 & $\ldots$ & 146 \\
\hline 146 & - & 151 \\
\hline 151 & - & 170 \\
\hline 170 & - & 171 \\
\hline 171 & - & 172 \\
\hline 172 & - & 174 \\
\hline 174 & - & 175 \\
\hline
\end{tabular}




\title{
Table 126. - Logs of wells in Droward County-Continued
}

\author{
Well G 513
}

Location: SE $1 / 4 \mathrm{SE}^{1 / 4}$ sec. 14, T. 50 S., R. 41 E., left bank of North New River Canal, 1.1 miles W. of Florida Highway 7.

Elevation of land surface, about $6.4 \mathrm{ft}$ above mean sea level.

Deptih, in feet

below land surface

Spoil.

Muck, black,

Limiest one,oolitic with altemating hard and soft layers.

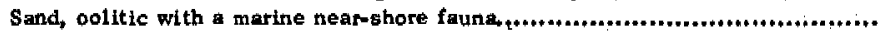

Sand, quartz, fine-grained, angulaz; some dark colloidal matertal at the upper

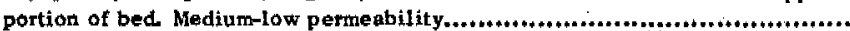

Sandstone, calcareous to sandy limestone, light-colored, Hith permeability.....:

Sand, quartz, fine.

Limest one and calcareous sandstone................................................

Sendstone.

Sandatone, calcareous.

Sand quartz.

Limestone, shelly with some quartz sath Very permeableacas.

Marl, white.

Sandstone, calcareous, shelly. Very permeable........................................

Limestone, sandy, dense, grading dowbward to a fossiliferous gandy marl.

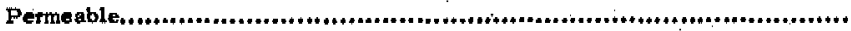

Sand, quart $z$ and sandstone with some yellow-green ilmestone.......................

Clay.

$\begin{array}{rlr}0 & - & 3 \\ 6 & - & 10 \\ 10 & - & 19 \\ 19 & - & 24 \\ & & \\ 24 & - & 58 \\ 58 & -66 \\ 66 & - & 72 \\ 72 & -93 \\ 93 & -112 \\ 112 & -118 \\ 118 & -122 \\ 122 & -129 \\ 129 & -137 \\ 137 & -152 \\ 152 & -180 \\ 180 & -220 \\ 220 & -224\end{array}$

\section{Location: NE1/4WW1/4 sec. 12, T. 50 S., R. 41 E., In center of Fort Lauderdale Golf and} Country Club, near City well 6.

Elevation of land surface: about $9.0 \mathrm{ft}$ above mean sea level.

Sand, 'quartz', grayish-white.

Sand, quartz, dark-brown, medium-grained, containing a large amount of organic material. Moderately' permeable..

Sand, quartz. finaorained.

Sand, quartz, very fine-grained with some admixed clay. Low permeability ...+....

Limestone, sandy, caverous, with some quartz sand. Limestone has weathered : appearance, Moderately permeable.

Limestone, sandy, and quartz sand. Each have peppered appearance due to presence of collophane. Medium to low permeability.

Sand, quartz, very fine-grained, peppered with collophane and ilmenite. Low permeability.

Limestone, sandy, and calcareous 8 andstone, fossiliferous. Very permeable between 107 and $123 \mathrm{ft}$; low, between 123 and $167 \mathrm{ft. \ldots ..........................}$

Sandstone, calcareous, Permeable.

Sand, quartz, interbedded with thin layers of elay. Low permedility..............

Mar1, clayey, gray-green with thin Ienses of quartz and conteining some ilmenite. Very low permeability.

$0-3$
$3-31$
$31-42$
$42-61$
$61-68$
$68-94$
$94-104$
$104-167$
$167-175$
$175-204$
$204-211$


Table 126. - Logs of wells in Broward County-Continued

Well G 516

Location: NW1/4NW1/4 sec. 8, T. 50 S., R. 42 E., On Broward Blvd., 1.1 miles E. of Florida Highway 7.

Elevation of land surface: $7.4 \mathrm{ft}$ above mean sea level.

Depth, in feet bolow land durface

Soili,

Sand, quartz, finemgrained.

\begin{tabular}{|c|c|}
\hline 0 & - \\
\hline 1 & -40 \\
\hline 40 & -42 \\
\hline 42 & -50 \\
\hline 50 & -58 \\
\hline 58 & -65 \\
\hline 65 & -114 \\
\hline 114 & -117 \\
\hline 117 & -122 \\
\hline 122 & -127 \\
\hline 127 & \\
\hline 168 & -173 \\
\hline 173 & -199 \\
\hline 199 & -200 \\
\hline
\end{tabular}

Sand, quartz, with small proportion of blue clay.........................................

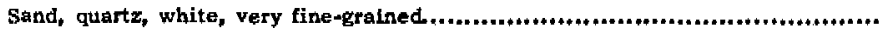

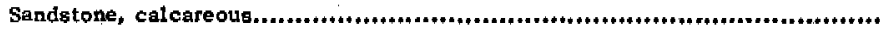

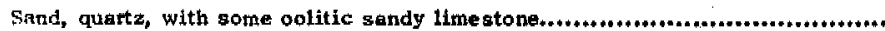

jisicstone, gendy, and calcareous sandstone beds alternating with thin layers of sand. Very permeable except between 102 and 114 lt...........................

Sand, quartz, coarse, with some blue clay; telatively impermeable..................

Limestone and quartz gand, some blue clay, low permeability..........t.+.+........

Sand, quartz alternating with thin beds of soft, blue-gray fissile shale; very

low permeabillty.

Limestone, sandy with few thin layers of quartz send; some calcareous sand-

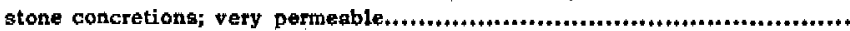

Limestone, cavemous; very permeable.

Sandstone, calcareous with thin layers of quartz sand, very permeable............

Cavity.

$199-200$

\section{Well GS 1}

Location: SE $1 / 4 \mathrm{SE}^{1 / 4}$ sec. 29 , T. 48 S., R. 39 E. On Florida Highway 25,6 miles north of Florida Highway 84 .

Elevation of land surface: $8.6 \mathrm{ft}$ above mean sea level.

Depth: $\cdot 55 \mathrm{ft}$.

Diameter: 4 in.

Peat...

Sandstone, calcareous, of fregh-water origin f.ow permeability*....................

Marl, sandy, shelly, consolidated in places to a ghelly calcareous sandstone.

Very low permeability.

Sand, quart $z$, shelly.

Sand, quart $z$, fossiliferous. Low pertneability

Marl, dark-gray, shelly and sandy. Very low permeability.

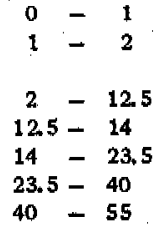


Table 126._- Logs of wells in Broward County-Continued Well GS 9

Location: NE1/4SE3/4 sec. 36, T. 47 S.,R 41 E. At Florida Highway 7 and Hillsboro Canal. Elevation of land surface: Approximately $15 \mathrm{ft}$ above mean sea level.

Depth: $52 \mathrm{ft}$.

Diameter: 4 in.

Depth, in foet below land artace

Sand, quartz, occurring in solution holes of underlying aolitic limestone........ Limestone, oolitic, riddled with solution holes filled with sand..................... Sand, quartz, very fine, Low permeability..........................................+..... Sand, quartz, with thin layers of dark-brown sandy clay marl containing a large amount of carbonaceous material; evidently an ancient mangrove swamp. Low perme abilit y.....................................................................................

Sand, quart $x$, white, very fine to coarse. Low permeability.

$$
\begin{array}{r}
0-3 \\
3-8 \\
8-24
\end{array}
$$

$24-45$

45. -52

\section{Well GS 10}

Location: Sec. 5, T. 49 S., R. 41 E. Approximately 6 miles west of Florida Highway 7, on south side of Cypress Creek Canal.

Elevation of land surface: Approximately $12 \mathrm{ft}$ above mean sea level.

Depth: $50 \mathrm{ft}$.

Diameter; 4 int.

Depth, in toet b dow land autece

Rock till

Muck and fresh-water marl..

$0 \quad 2$

Limestone, sandy, hard; probably of treah-water otiola

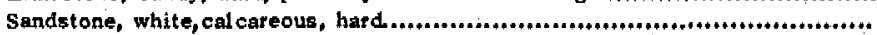

Sand, quartz, and nodulai sands tone.

Sandstone, tan, calcareous, and chalky limettone, Low permeability...............

Sandstone, calcareous, hard, containing pockets of quartz sand. Figh

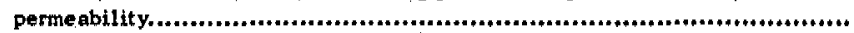

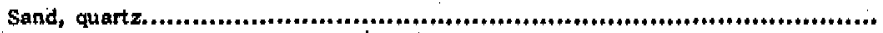

Sand, quartz, shelly; very fine to fine. Low perme ability.

$10.5-12$

$12-16.5$

$16.5 \div 21$

$21-22$

$22-50$

\section{Well GS 13}

Location: Sec. 30, T. 50 S., R. 38 E. Northeast side of Miami Canal, 0.25 mile northwest of South New River Canal.

Elevation of land surface: Approximately $11.5 \mathrm{ft}$ above mean sea level.

Depth: $50 \mathrm{ft}$.

Diameter: 4 in. 
Table 126. - Logs of wells in Broward County-Continued

Well GS 13 -Continued

Depth, in feet

below lend surface

Marl, grayish-white

$\begin{aligned} 4 & -5 \\ 5 & -7 \\ 7 & -22 \\ 22 & -25.5 \\ 25.5 & -35.5 \\ 33.5 & -50\end{aligned}$

Sand stone, tan-gray, calcareous; riddled with solution holes..............................

Limestone, gray, hard.

Sand, quattz, and pieces of calcateous sandstone. May be a solution-tiddled

limestone filled with sand..............................................................

Limestone, sandy, shelly.

$33.5-50$

\section{Well GS 15}

Location: T. 46 S., R. 38 E. Approximately 11 miles west of Florida Highway 7 at the Broward-Palm Beach County Line.

Elevation of land surface: Approximately $15 \mathrm{ft}$ above mean sea level,

Depth: $19.5 \mathrm{ft}$.

Diameter: 4 in.

Depth, in feet

below land surface

Peat

$0-3$
$3-3.5$
$3.5-11$
$11-13$
$13-19.5$

Well S 427

Location: NE1/4NW1/4 sec. 2, T. 51 S., R. 41 E. Davie Air Field, Dania-Davie Road, 1 mile west of Florida Highway 7.

Elevation of land surface: $5.0 \mathrm{tt}$ above mean sea level.

Depth: $103 \mathrm{ft}$.

Diameter; 4 in,

Depth, in toot bolow land arfiace

Sand, quartz, tan to white, medium

$0 \div 51$

Sandstone, gray-white, calcareous, containing come and and shells..............

$51-56$

Sand, quartx, fray-white, and some loose shelly calcareous andstone.............

$56-77$

Sandstone, grayith-white, calcareous, shelly, containing large amount loose:

send.

$77-103$ 
Table 126. - Logs of wells in Eroward County-Continued

Well \$ 428

Location: NEt/4NW/4 sec, 2, T. 51 S., R. 41 E. Davie Air Field Dania-Davie Road, 1 mile west of Florida Highway 7 .

Elevation of land surface: $5.0 \mathrm{ft}$ above mean sea level.

Depth: $100 \mathrm{ft}$.

Diameter: 4 in.

Depth, in teet below land aurface

Sand, quartz, white, medium

Sand atone, gray, calcareons,

$0-48$
$48-76$
$76-82$
$82-100$

Sandstope, gray, calcareous, shelly, and some medium to firte quartz sand........

$82-100$

Well S 440

Location: NW1/4NE1/4 sec, 2, T. 51 S., R. 41 E. Davie Air.Field, Dania-Davie Road, 1 mile west of Florida Highway 7.

Elevation of land surface: $5 \mathrm{ft}$ above mean sea level.

Depth: $53 \mathrm{ft}$.

Diameter 4 in.

Depth, In föt bolow $l$ and ourface

Sand, quartz, white,

$0-51$

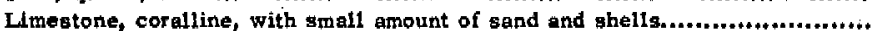

$51-53$

Well s 441

Location: NW1/4NE1/4 sec. 2, T. 51 S., R. 41 E. Davie Air Field, Dania-Davie Road, 1 mile west of Florida Highway 7 .

Elevation of land surface: $5.0 \mathrm{ft}$ abóve mean sea level.

Depth: $107 \mathrm{ft}$.

Diameter. 4 in.

Depth, in teet below land purtace

Sand, quartz, white, medium to conese.

0. $\quad-52$

Limestone, gray, with sand containing pieces of chalk and some gray marly

sand.

Sand

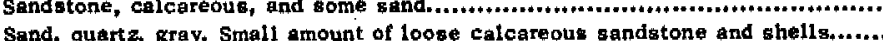

Sandstone, gray, calcareous, shelly, and sand.

Send, quartz, gray, coarge, containing ghells and nodular calcareous sandstone..

$52-53$

$53-58$

$58-76$

$76-90$

$90-107$ 
Table 126. Logs of wells in Sroward County-Continued

Well s 452

Location: NE $1 / 4$ NW1/4 sec. 26, T. 51 S., R. 41 E. South Perry Air Field, 0.5 mile south of Pembroke Road and 1.0 mile west of Flonda Highway 7 .

Elevation of land surface: $5 \mathrm{ft}$ above mean see level.

Depth: $52 \mathrm{ft}$.

Diameter: 4 in.

Depth, in feet

below land surface

Sand, quartz, gray.

$0 \rightarrow 21$

Sandstone, light-brown, calcareous, ....................................................

$21-31$

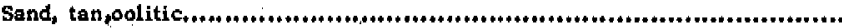

$31-46$

Sandstone, brown, calcareous, and some coralline timestone.

$46-52$

\section{Well S 454}

Location: NE1/4NEt/4 sec, 22, T. 51 S., R. 41 E. North Perry Air Field, 0.5 mile north of Pembroke Road and 2.0 miles west of Florida Highway 7 .

Elevation of land surface: $5 \mathrm{ft}$ above mean sea level.

Depth: $100 \mathrm{ft}$.

Diameter: 4 in,

Depth, in feet

below land surface

Sand, quartz, white, medium to fine.

0
$49-49$
$61-61$
$95-100$

Sandstone, gray, calcareous, soft and quartz sand with few shells,+4+4+.....

Sand, quartz, gray and poorly cemented calcareous sandstone. Few shell

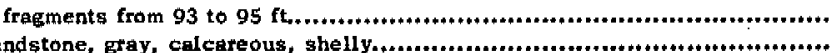

$95-100$

\section{Well S 455}

Location: NE $1 / 4 N^{1 / 3}$ sec. 22, T. 51 S., R. 41 E. North Perry Air Field, 0.5 mile north of Pembroke Road and 2.0 miles west of Florida Highway 7.

Elevation of land surface: $5 \mathrm{ft}$ above mean sea level.

Depth: $78 \mathrm{ft}$.

Diameter: $4 \mathrm{in.}$

Sand, quartz, gray, wedium, with zome poorly cemented calcareous $\$$ andstone

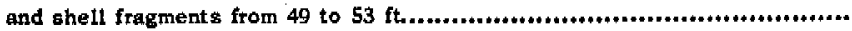

Sandatone, gray, calcareous, soft, and quartz sand...............................

Sand, quartz, gray, medium, with shell fragments, $\ldots \ldots \ldots \ldots \ldots \ldots \ldots \ldots+\ldots+\ldots+\ldots+\ldots \ldots \ldots \ldots \ldots . .$.

Sandstone, calcareous, shelly.

$0-53$
$53-66$
$66=74$
$74-78$.


Table 126, - Logs of wells in Broward County - Continued

\section{Well S 463}

Location: SE $1 / 4 N^{1 / 1} / 4$ sec. 22, T. 51 S., R. 41 E. North Perry Air Field, 0.5 mile noth of Pembroke Road and 2.0 miles west of Florida Highway 7.

Elevation of land surface: $5 \mathrm{ft}$ above mean sea level.

Depth: $67 \mathrm{ft}$,

Diameter, 4 in,

Sand, quartz, gray........................................................................

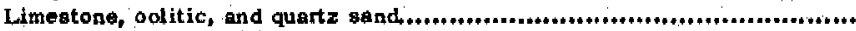

Sand, quartr, gray, medium to fine, with loose colcareous sandstone and pieces of blue sandy marl between 37 and $48 \mathrm{ft}$

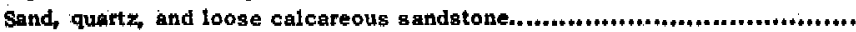

Limestone, brown, calcareous, hatd,
$0 \quad-5$

$5-20$

$20-53$

$53-65$

$65-67$ 
Table 127.- Logs of wells in Dade County

\author{
Well D 196
}

Location: NE $1 / 4 \mathrm{NE}^{1 / 4}$ sec, 17, T. 54 S., R. 41 E. Southwest corner of Douglas Road and Coral Way, Coral Gables.

Elevation of land surface: $10 \mathrm{ft}$ above mean sea level.

Depth: $225 \mathrm{ft}$.

Diameter: $6 \mathrm{in}$.

Depth, in feet

below land surface

Limestone, brownish-white, oolitic, hard to soft

Limestone, coralline, very soft

Sandstone, brown, calcareous, very hard from 39 to $49 \mathrm{ft} \ldots \ldots \ldots+\ldots+\ldots+\ldots+\ldots \ldots+\ldots+4$.

Sand, quartz, medium to fine, and pieces of calcareous sandstone................

Sandstone, calcareous, hard, and coarse quartz sand. Cavity, 615 to $63,5 \mathrm{ft}$

Sand, quartz, gray.

Limestone, sandy, and fine to very fine white sand .............................

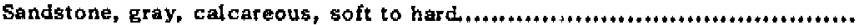

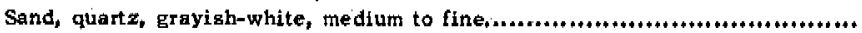

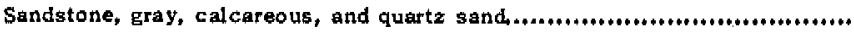

Sand, quartz, grayish-white, fine to very fine, $\ldots+\ldots+\ldots+\ldots+\ldots+\ldots+\ldots+\ldots+\ldots+\ldots+\ldots \ldots \ldots+\ldots \ldots+$

Sandstone, gray, calcareous, and quartz sand..................................

Sand, quartz, gray, ghelly, coarse....................................................

Marl, green, sandy, shelly. Very low permeability.

\begin{tabular}{|c|c|}
\hline 0 & -21 \\
\hline 21 & -28 \\
\hline 28 & -49 \\
\hline 49 & -61 \\
\hline 61 & -74 \\
\hline 74 & -93 \\
\hline 93 & -101 \\
\hline 101 & -125 \\
\hline 125 & -129 \\
\hline 129 & -135 \\
\hline 135 & -142 \\
\hline 142 & -149 \\
\hline 149 & -168 \\
\hline 168 & -225 \\
\hline
\end{tabular}

\title{
Well D 350
}

Location: NW1/4NE1/4 sec. 16, T. 54 S., R. 41 E., SW 22 St. and 31st Court, Miami.

Elevation of land surface: about $10 . \mathrm{Ct}$ above mean sea level.

Depth, in teet

below I and surface

Limestone oolitic (Miami oolite)

$0-7$

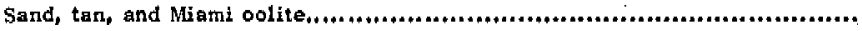

$7-22$

Sand, tan, and Mlami oolite..........4....................................................

$22-33$

Sand, white, and some ground-up sandstone.......................................

Sand, white to approximately $48.50 \mathrm{ft}$, then reddish-brown sandstone...........

Sandstone, calcareous, light-gray, and some sand..................................

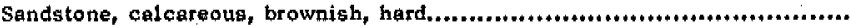

Sandstone, light-gray, shelly, soft, tannish-grey, and shell.

$33-43$

$43-49$

$49 \div 63$

$63-70$

$70-83$

Sands tone, calcareous, light-grey, shelly, soft.

$83-93$

\section{Well G 101}

Location: NW's SW1/4 sec, 3, T. 54 S., R. 40 E. On Flagler Street, 3 miles west of Red Road.

Elevation of land surface; $4.9 \mathrm{ft}$ above mean sea level.

Depth: $812 \mathrm{ft}$.

Diameter. 6 in, to $435 \mathrm{ft}$ and $4 \mathrm{in.}$ to $812 \mathrm{ft}$, 


\title{
Table 127. - Logs of wells in Dado County - Continued
}

\author{
Well os $101 \rightarrow$ Continued
}

Depth, in feet

$b$ elow $l$ and aurface

Sand, quartz, black to brown organic stain in upper portion, white at base, Fills solution holes in oolite.

Limestone, cream-colored, oolitic (Miami oolite), honeycombed and perforated by vertical solution holes filled with white quartz sand.

Sand, quartz, white, and oolitic limestone. Sand composes 70 percent of the sample. Representa transition from limestone to sand..............................

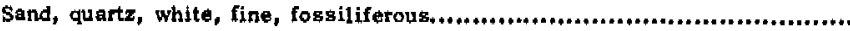

Sandstone, grayish-white, calcareous. High perneability.

Sandstone, graylsh to tan, calcareous fossiliferous, with lenses or pockets of quartz sand; very high permeability.

Limestone, gray-white, dense, hard, and quartz sand; fossiliferous. High permeability.

Sand, quartz, white, fine, and pieces of limestone.

Limestone, white, sandy, with occasional small pockets of and. Itigh permeability...

Sand, quartz, fithe to medium, and pieces of lime atone

Limestone, gray-white, hard, with pockets of quart $z$ and.........................

Shell marl, dark-gray, gandy. Low permeability........................................

Marl, greenish, sandy, shelly in places, especislly at 174 to 182 and 187 to

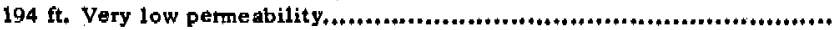

Sand, quartz, white, medium, with thin layers of sandy green marl.................

Sand, green, fine to medium, marly. The green color appears to be due to finely disteminated colloidal carbonate material that coats the quartz grains

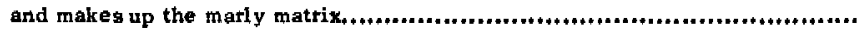

Sand, quartz, gray-white, medium....................................................... Marl, green, gandy, shelly. Very low perme abllity...........+....................+..... Sand, Ereen, very fine to medium, with occasional thin layers of green clay or

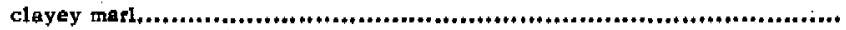

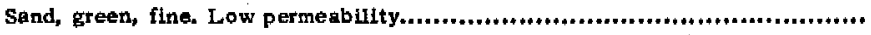

Marl, green, sandy, fine, with thin layers of green clayey mat1.....................

Sand, green, very fine to fine; becomes silty tow ard base.....,....................

Marl, green, silty. Very low pemeabillty.............+.+.............................

Marl, green, clayey, with occasional thin layers of gilty merl....................

Marl, green, eloyey, grades into gray-white calcareous shelly marl................

Marl, gray, gilty; contains thin layers of chalky white marl and some shells...

Matl, grayish-gteen, silty, with thin layers of green clay marl, Shells are common, Very low permeability.

Limestone, white, fossiliferous, impure in part, owing to admixed sand and

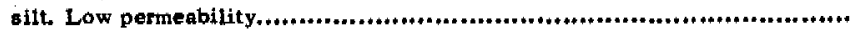

Marl, greenieh-gray to light-gray, gity, very calcareous toward base...............

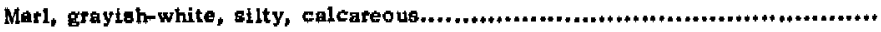
Shell marl, grey, sandy. Low permeability.

Marl, gray-white, silty, calcareous, shelly. Last few feet toward base quite clayey. Low permeability.

Shell marl, gray, sandy, Low permeability..............................................

Limestone, gray-whlte to datk-gray, hard. Low permeability.........................

Marl, dakk-gray; clayey. Very low permeability.........+4..............................

Shell mari, gray, sandy. Low permeability....

Limestone, gray-white, hard. Medium perme abillty....................................

Mar1, light-gray, silty, shelly, calcareoun. Low permeabllity.........................

Marl, light-gray, vory shelly....

Limestone, grayish-white, hard, fosstlferous, Modium permeability....+*.+........

Sand, white, calcareous, very fine...........t+........t.................................

Limeetone, white, hard, sandy in places. Medium permerbility. Arteslan flow at 809.5 ft below land surface. 
Table 127. - Logs of wells in Dade County- Continued

Well G 182

Location: NW1/4NW1/4 sec, 19, T. 53 S., R. 41 E. Momingside Drive and Curtiss Patkway, Miami Springs.

Elevation of land surface: $6 \mathrm{ft}$ above mean sea level.

Depth: $301 \mathrm{ft}$.

Diameter. $6 \mathrm{in}$.

Depth, in foet

below land gurface

Sand, quartz, white, fine to medium, and organic material..........................

Limegtone, cream-colored, oolitic (Miami oolite), and sand as above...............

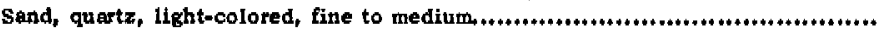

Limestone, sandy, and tan-brown calcareous sandstone with thin beds of sand,

High perme ability.

Sandgtone, calcareous, and gray-white, fosalliferous, sandy limestone. Very

high permeability.

$0-2$

$2-20$

$20-33$

33.56

$56-83$

Shell tharl, light-gray to greenieh-gray, sandy, with sandy nodules in some places. Low permeability from 95 to $107 \mathrm{ft}$, and only slightiy permeable

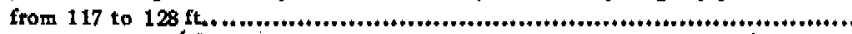

Sand, greenish, finéto coarse, marly in upper portion. Very low permeability...

Sand, green, very fine to medium, marly in places, fossitiferous, with a fow

thin layers of calcateous sandstone and phosphate pebbles between 196 and

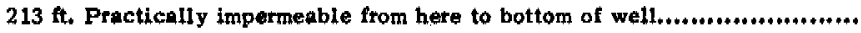

Marl, dark-gray, sandy, and fine quartz sand..........................................

Sand, green, very fine to fine, and green sandy mark....................................

Clay, green, mariy.

Sand, green, very fine to fine, and sandy marl............................................

Clay, gréen, marly.

Location: SW $1 / 4$ NW1/4 sec, 18, T. 53 S., R. 42 E. At NE. Second Avenue and 65 th Street Extension, Miami.

Elevation of land surface: $11.8 \mathrm{ft}$ above mean sea level.

Depth: $351 \mathrm{ft}$.

Diameter: 6 in.

Limestone, cream-colored, oolitic (Miami oolite), with orange quartz sand included in deep solution holes in the limestone.

Limestone, white, sandy, porous, in places cavernous. Quart $z$ eand, very fine to fine, white, occurs in solution holes, or in lenses in the rock. Very high permesbility.

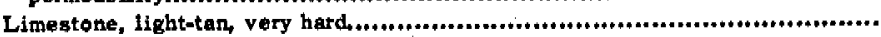

Sand, quartz, white, fine, fossiliferous..

Sandstone, light-grayish-brown, calcareous, and a little quartz sand. Iligh permeability.

Limestone, light-brown, slightly sandy, and some quartz sand......................

Sondstone, light-gray, calcareous, with pockets or layers of quartz sand. Fosiliferous in places. Highly permeable.

Llmestone, white to cteam-colored, sandy, with occasional beds or pockets of quartz and containing shells.

$18-63$

$63+67$

$67-69$

$69-79$

$79-84$

$84-183$

$183-216$ 


\section{Table 127. - Logs of wells in Dade County-Continued}

Well G 183-Continued

Depth, in feet

below tand surface

Sandstone, light-green, calcareous, with some loose sand and shells; probably an indurated green 8 and. Low permeability.

Mart, light-green, clayey, fossiliferous, with occasional layers of silty and sandy marl. Practically impermeable,

\section{Well G 185}

Location: NW/4/4WW/4 sec. 9, T. 52 S., R. 41 E. Miami Gardens Drive and Douglas Road. Elevation of land surface: $7.2 \mathrm{ft}$ above mean sea level.

Depth: $301 \mathrm{ft}$.

Diameter: 6 in.

Depth, in teet

below Iand surtace

Muck.

Sand, quartz, white, very fine to medium..................................................

Sand, quartz, black. Color to due to organic stain which rubs off easily.........

Sand, quartz, brown to white, very fine to coarse, averages medium changes from brown to white at $19 \mathrm{ft}$.

Sand and nodular pieces of white limestone, Low permeability because of sand.

Limestone, brown, sandy, very hard, and sand as above. Medium permeabllity..

Sandstone, gray, calcareous, very hard in places. Some sand and shell in pockets of layers, High permeability

$$
\begin{aligned}
& 0-0.4 \\
& 0.4-25 \\
& 2.5-3 \\
& 3-33 \\
& 33-42 \\
& 42-51 \\
& 51-113 \\
& 113-131 \\
& 131-166 \\
& 166-173 \\
& 173-186
\end{aligned}
$$

Shell marl, greenish, sandy. Similar to interval from 131 to $166 \mathrm{ft.............}$
Sandstone, light-green, calcareous, with a few shells. Quattz grains are medium to coarse, sharp to subrounded. From 212 to 228 ft it becomes

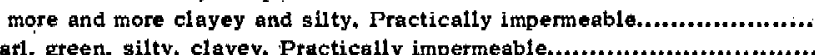

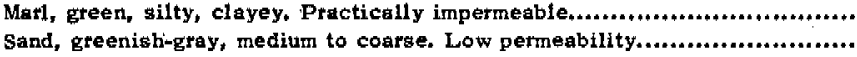

Marl, green, sandy. Practically impermeable.

Location: SE $1 / 4 \mathrm{SE}^{1 / 4}$ sec, 15, T. 53 S., R. 41 E. NW. 17 th Avenue and 55th Terrace, Miami. Elevation of land surface: $11.9 \mathrm{ft}$ above mean sea level.

Depth: $300 \mathrm{ft}$.

Diameter: $6 \mathrm{in}$.

Depth, in feet

below land ourface

Limestone, oolitic, and some white quartz sand, (Miami oolite)...................

Sand, quartz, brown to tan, fine to medium, and some calcareous material. Low permeability.

Limestone, brownishugray, sandy, with pockets or thin lenses of very fine to medium-white quartz sand. Medium permeability.

$$
\begin{gathered}
0-20 \\
20-37 \\
37-51
\end{gathered}
$$


Table 127, - Logs of wells in Dade County - Continued

\author{
Well G $186 \cdots$ Continued
}

Depth, in feet

below land aurface

Limestone, corralline.

$51-55$

Sandstone, gray, calcareous, with small amount of sand and shells. Iligh permeability

Sand, quartz, gray-white, fine to coarse, contains some shells

$71-74$

Limestone, sandy, and creamy calcareous sandstone. Some pockets or thin

lenses of sand with shells. Low permeability from 118 to 128 ft.................

$74-128$

Sandstone, shelly, soft, and greenish shell marl. Very low permeability..........

Marl, greenish, sandy, shelly in places, with very thin lenses of calcareous sandstone. Practically impermeable.

$128-197$

$197-300$

\title{
Well G 187
}

Location: SW/4NE1/4 sec. 30, T. 52 S., R. 40 E. On Florida Highway 25 at Pennsuco.

Elevation of land suiface: $7.6 \mathrm{ft}$ above mean sea level.

Depth: $222 \mathrm{ft}$.

Diameter: 6 in.

Spoil.

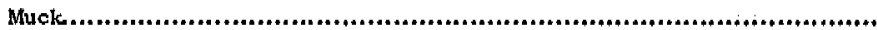

Marl, gray, of fresh-water origin, and quartz sand............n............................

Limestone, ootitic. Very hard and dense, but contains small solution holes.

(Miami oolite)

Limestone, brown to gray, sandy, very hat, shelly in part. Low permeability..

Sandstone, brown to gray, calcareous, very hard in places, becomes sandy and shelly toward the base. Medium permeability

Sandstone, gray to white, calcareous, shelly in places; contains thin lenges: or pockets of white quartz sand. High permeability down to $69 \mathrm{ft}$, where increased amount of sand reduces permeability greatly...............................

Shell marl, gray, very sandy; becomes a sandy marl near base. Low permeability.

Shell marl, greenish, becoming silty toward base. Very low permeability........

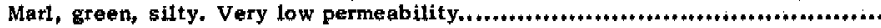

Sandstone, gray, calcareous, shelly. Low permeability $\ldots \ldots \ldots \ldots+\ldots \ldots \ldots+\ldots \ldots \ldots \ldots \ldots \ldots . . .4$

Marl, light-gray, aandy. Very low permeability.

Sand, gteen, gilty and elayey toward base. Practically impermeable..............

Marl, gxeen, clayey, sandy. Practically impermeable.

$$
\begin{aligned}
& 0 \quad-3 \\
& 3-6 \\
& 6-8 \\
& 8-18 \\
& 18-26 \\
& 26-51 \\
& 51-80 \\
& 80 \quad-117 \\
& 117-133 \\
& 133-140 \\
& 140-155 \\
& 155-172 \\
& 172-184 \\
& 184-222
\end{aligned}
$$

\section{Well G 188}

Location: NE1/4NE1/4 sec, 12, T. 54 S., R. 38 E. Krome Road and Tamiami Trail.

Elevation of land surface: $8.9 \mathrm{ft}$ above mean sea level.

Depth: $200 \mathrm{ft}$.

Diameter: $6 \mathrm{in.}$ 


\title{
Table 12\%_L Logs of wells in Dade County - Continued
}

\author{
Well G 188-Continued
}

Depth, in feet

balow land autlace

Marl, sandy.

Limestone, gray, dense, recrystallized; quartz sand probably occurring in golution holes. Low permeability......................................................

Limestone, gray-white, sandy, dense, and some calcareous sandstone. Quartz sand occurs in solution holes or in thin lenses. High permeability.............

Shell marl, dark-gray, sandy, and thin beds of sandy marl. In places about 90 percent of the sample consists of excellently proserved mollusk shells. Very low permeability down to $145 \mathrm{ft}$, at which depth the well could be pumped at low rate with large drawdown

Sand, quartz, gray, fine to medium, with intercalated thin layers of clayey marl. Low permeability.

Marl, green, sandy, with intercalated thin layers of clayey marl Very low permeability.

Well G 189

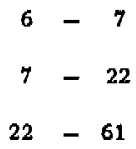

$61-164$

$164-187$

$187^{\prime} 200$

Location: NW1/4SW1/4 sec. 15, T. 54 S., R. 41 E. SW. 27th Avenue and Dixie Highway, Miami.

Elevation of land surface: $11.6 \mathrm{ft}$ above mean sea level.

Depth: $241 \mathrm{ft}$.

Diameter: 6 in.

Depth, in feet

below tend aurface

Sand.

$0-0.5$
$0.5-11$
$11-22$
$22-25$
$25-51$
$31-42$
$42-44$
$44-53$
$53-66$
$66-68$
$68-73$
$73-79$
$79-81$
$81-83$
$83-84$
$84-110$
$110-132$

Limestone, creamy, soft, oolitic (Miami oolite) $+\ldots+\ldots+\ldots+\ldots+\ldots+\ldots+\ldots+\ldots+\ldots+\ldots+\ldots+\ldots+\ldots+\ldots+$.

Cavity.

Limestone, creamy, soft, oolitic (Miami ool ite).......................................

Sand, cream-colored, quartz, very fine to fine, and calcareous material;

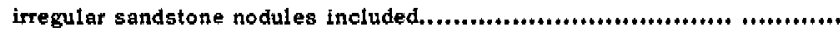

Limestone, creamy to tan, coralline, and coral and quartz sand. Iligh

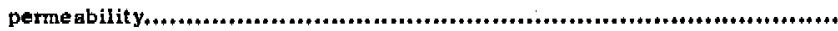

Conglomerate of calcareous rocks; probably waste from coral reef. Pebbles

are subangular.

Sandstone, creamy to white, calcareous, and considerable very fine to fine white quartz s and.

Limestore, tan-brown, very porous hard. High permeability...........*.............

Sand, quartz, gray, very fine to fine; includes calcareous sandstone nodules..

Sandstone, gray-whte, calcareous, and very fine to fine white quartz andi.+*

Limestone, dense, hatd.

Cavity

Limestone,

Limestone, light-colored, hard, fosgilliferous.

Sandstone, gray, calcareous, fossiliferous; contains scattered grains of

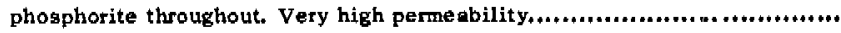

Limestone, grayish, sandy. Iligh permeability.

$110-132$

Sand, green, in places consolidated to form thin layers of calcareoug andstone. Sand is very fine to fine and contains a few shells. Very low permeability. 
Location: NW/4NE $1 / 4$ sec, 29, T. 53 S., R. 41 E. NW. 36th Street and Miami Canal, Miami. Elevation of land surface: $6.0 \mathrm{ft}$ above mean sea level.

Depth: $84 \mathrm{ft}$.

Diameter: 2 in.

Depth, in feet below land surface

Sand, quartz, gray.

Limestone, creamy, soft, oolitic (Miami oolite), with quartz gand partly.

filling solution holes. Medium permeabllity.

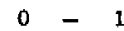

Sandstone, white, calcareous, hard and a little sand. Very high pertneability.,

Limestorie, white, sandy, hard, and small amount of coralline limestone and quartz sand. Iligh' permeability.

Sandstone, white, calcareous, and slliceous white limestone that is exceedingly hard. Iligh permeability.

Sandstone, white, calcareous, with thin beds of fine white quartz sand. Fligh permeability except for the sand beds.

$0-1$
$1-22$
$22-41$
$41-49$
$49-61$
$61-82$
$82-84$

Sandstone, calcare ous, shelly, and quartz sand........................................

Well G 195

Location: SW $1 / 4 \mathrm{NW} 1 / 4$ sec. 20 , T. 53 S., R. 41 E., $25 \mathrm{ft}$ northeast of South River Drive and 0.8 mile north west of NW. 36th Street.

Elevation of land surface: $5.0 \mathrm{ft}$ above mean sea level.

Depth: $95 \mathrm{ft}$.

Diameter: 2 in.

Depth; In teet below land aurfoce

Sand, quartz, white,

$0-1$

Limestone, creamy, oolitic (Miami oolite)............................................

Sand, white to gray, very fine to coarse, averaging medium.

$1-16.5$

Sand and calcareous sandstone, white, and shells, Minor amount of sandstone.

$16.5-52$

Sandstone, calcareous, shelly, soft. Riddled with solution holes which are

filled with quartz sand.

$52-62$

$62-95$

Well G 196

Location: NE $1 / 4 \mathrm{NW}^{1 / 4}$ sec. 29, T. 53 S., R. 41 E., 25 ft west of LeJeune Road and $0.3 \mathrm{mile}$ south of NW, 36th Street.

Slevation of land surface: $5.0 \mathrm{ft}$ above mean sea level.

Depth: $92 \mathrm{ft}$.

Diameter, 2 in. : 
Table 127.-Logs of wells in Dade County-Continued

Well G 196-Continued

Depth, in feet

below land surface

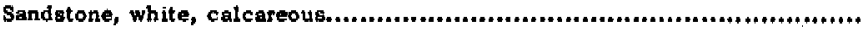

$21-24$

Cavity.

$24-31$

Sand, quartz, white, very fine to coarse, and nodular pieces of calcareous

sandetone...

Sand, quartz, white, very fine to coarse, and white sandy lithestone.

Limestone, tanmbrown, coralline, with a few pockets of quartz sand................

Sandstone, white, calcareous, and very fine to medium white quart $z$ tand. The sand occurs in thin beds or pockets in the rock. Two cavities noted, one is $0.4 \mathrm{ft}$ deep, the other is $0.5 \mathrm{ft}$ deep, between 89 and $91 \mathrm{ft}$. Very high permeability in consolidated portions of this interval....

\section{Well G 197}

Location: SE1/4SE1/4 sec, 20, T, 53 S., R. 41 E. SE. 10th Court and 14th Street, Hialeah.

Elevation of land surface: $8.0 \mathrm{ft}$ above mean sea level.

Depth: $91 \mathrm{ft}$.

Diameter: 2 in.

Depth, In feet

below land surface

Sand, quartz, white, very fine to medlum, fills solution holes in limestone..... Limestone; oolitic.

Sand, quartz, white, very fine to fine, and calcareous sandstone................... Sand, quattz, white, very fine to fine..................................................... Sandstone, white, calcareous, faitly soft, and coarse to very fine white quartz sand. Iligh perme ability,

Lime gtone, white, sandy, hard, and minor amounts of quartz sand, probably in

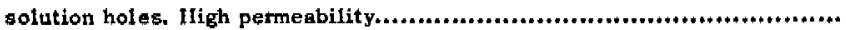

Sandstone, white, calcareous, and sandy limestone.

Cavity.

Sandṣtone, gray, calcareous, dense, hard. Very little sand..

$$
\begin{array}{r}
0-1 \\
1-21 \\
21-31 \\
31-42 \\
42-49 \\
49-67 \\
67-76 \\
76-80 \\
80-91
\end{array}
$$

\section{Well G 198}

Location: NE $1 / 4 \mathrm{NW}^{1 / 4}$ sec. 14 , T. 54 S., R. 40 E., 0.2 mile south of Coral Way and 0.7 mile west of Ludlum Road.

Elevation of land surface; $6.2 \mathrm{ft}$ above mean sea level.

Depth: $102 \mathrm{ft}$.

Diameter: 2 in.

Sand, quartz, white, fine to medium

Limestone, oolitic (Miami oolite), solution-riddled and filled with sand.......

Limestone, brown, dense, hard, silice ous, Low permeability...................... Sandstone, gray to white, calcareous, porous to dense, contains beds and pockets of fine to coarse white quartz sand. Iligh permeability..................

Limestone, white, dense, siliceous......................................................

Sandstone, white, calcareous, and medium to coatse white quartz sand. Very 
Table 127. - Logs of wells in Dade County-Continued

Well G 198-Continued

Depth, in feet below land surface

Cavity, paytly filled with sand.

Limestone, grayish-white, sandy, and small amount of fine to medium-white quartz sand.

Cavity, partly flled with sand.

Limestone, oratsh-white, sandy,

Limestone, white, dense, hard.

Sand, dark-gray, shelly. Sand is very fine to coarse, averages medium. Low permeability.

$$
\begin{aligned}
& 65-70 \\
& 70-75 \\
& 75-81 \\
& 81-95 \\
& 95-98 \\
& 98-102
\end{aligned}
$$

\section{Well G 199}

Location: $\mathrm{SE}^{1 / 4 \mathrm{SW}^{1 / 4}} \mathrm{sec}, 20, T, 53 \mathrm{~S}$, R, $41 \mathrm{E},, 0.1$ mile north of 36 th Street and 0.25 mile west of LeJeune Road, Miami Springs.

Elevation of land surface: $4.5 \mathrm{ft}$ above mean sea level.

Depth: $98 \mathrm{ft}$.

Diameter: 2 in,

Sand, quartz, white, fine to medium..

Limestone, creamy to white, oolitic, with sand in solution holos

Sand, quartz, white, very fine to medium, averaging fine. Thin hard layer of brown limestone at $37,5 \mathrm{ft}$.

Limestone, white, sandy, and white calcareous sandstone. Pockets of white quartz sand and shells.

Sand, quartz, grayikh-white, very fine to medium, and nodulat sandstone. Few shells and phosphate granules.

Sandstone, white, calcareous, and a large amount of very fine to fine white sand and shells

Sandstone, white, calcareous, hard, Very high permeability........................

Sand, dark-gray, shelly, or sandy shell marl. The sand is very fine to medium.

Low permeability.

$$
\begin{array}{r}
0-2 \\
2-19 \\
19-43 \\
43-56 \\
56-68 \\
68-86 \\
86-97 \\
97-98
\end{array}
$$

Well G 207

Location: SW1/4SW/4 sec. $25, T, 57$ S., R. 38 E., 0.1 mile noth of Lucille Drive and 0.15 mile east of Redlands Road.

Elevation of land surface: $7.8 \mathrm{ft}$ above mean sea level.

Depth: $108 \mathrm{ft}$.

Diameter: $2 \frac{1}{2}$ in.

Limestone, oolitic (Miami oolite), soft, except between 15 and $15.5 \mathrm{ft}$, where it is extremely hard. This hard layer is widespread throughout the Homestead-Florida City area, and usually occurs in the interval between 7 and $9 \mathrm{ft}$ below mean sea lovel. The "hard rock" is dense,

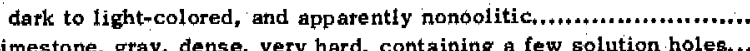




\section{Table 127.- Logs of wells in Dade County — Continued}

Well G 207-Continued

Depth, in feet

below land surface

Limestone, white to gray to tan, sandy, ganerally quite hard, with very fine to medium, white quartz sand included in poskets or lenses. Hligh permeability* Cavity from 48 to $49.5 \mathrm{ft}$.

Sand, quartz; white, very fine to fine, Low permeability..............................

Shell mart, and large amount of very fine dark gray gand, Practically impermeable.

$39-57$
$57-63$
$63:-108$

\section{Well G 209}

Location: NW/4NE1/4 sec. 21, T. 58 S., R. 39 E. On U. S. Highway 1, 6.0 miles south of Palm Drive, Flopida City.

Elevation of land surface: $2.3 \mathrm{ft}$ above mean sea level.

Depth: $66 \mathrm{ft}$.

Diameter: $2 \frac{1 / 2}{2}$ in

Depth, in feot

bolow land sutface

Marl, gray, calcareous, sticky. Comparatively impermeable.

$0-6$

Limestone, oolitic (Miami oolite), altered by secondary processes so that few oollthe are preserved. Small amount of very fine to fine white quartz 8 and in solution holes. Two very hard gray limestone layers between 13 and $14.5 \mathrm{ft}$ and 16 and $17 \mathrm{ft}$....

Limestone, tan-brown, sandy, shelly in places. Solution holes and cavities common in this interval; one cavity from 27 to $28 \mathrm{ft}$. High permeability.......... Sandstore, white to gray, calcareous, with beds or pocketg-of quartz sand. Many amall cavities, Very high permeability.

Sand, gray, shelly, or sandy shell marl. Sand is very fine to fine. Low pemenbillty.

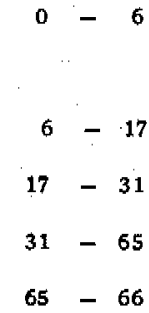

Well G 210

Location: NE $1 / 4$ NW1/4 sec. 24, T. 58 S., R. 38 E., 5 miles south of Palm Drive on Roberts Road.

Elevation of land surface: $2.7 \mathrm{ft}$ above mean sea level.

Depth: $62 \mathrm{ft}$.

Diameter. $2 \frac{1}{2}$ in.

Depth, In feet

below land ourface

Road fitl.

$0-0.5$

Marl, gray, calcareous; sticky, partly fills solution holes in underlying oolltic

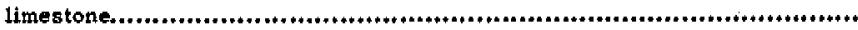

Limestone, oolitic (Miami oolite), soft, porous; with little or no sand. Hard layer from 10.5 to $11 \mathrm{ft}$

Limestone, fight-brown, sandy, and fome coralline limestone. Containg many small cavities, Iligh permeability

$0.5-2$

$2-16$

Sandstone, white to tan, calcateous, and sandy white limestone, An exceed-

$16-22$

ingly hard, dark-gray, impure limestone from 33.8 to $36.5 \mathrm{ft}$. Numerous

cavities were noted, the langest three being from 39.7 to $40.6 \mathrm{ft}, 41.7$ to

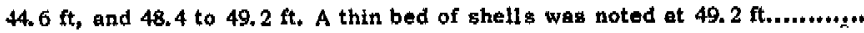


Table 127. - Logs of wells in Dade County - Continued

Well G 210 - Continued

Depth, in teet

below land surface

Sand, quartz, very fine to medium, averages fine. Colot is white to $54,1 \mathrm{ft}$; below this depth it is dark-gray. Small amount of shells, Very low permeability

Location: NW1/4WW1/4 sec, 31 , T. 57 S., R. 39 E. Near old F. E. C. Railroad embankment, $11 / 2$ miles south of Palm Drive, Florida City.

Elevation of land surface: $2.4 \mathrm{ft}$ above mean sea level.

Depth: $88 \mathrm{ft}$.

Diameter: $2^{\prime \prime}$ in.

Depth, in feet below land surface

Road fill.

Marl, gray, calcareous, sticky, partly fils solution holes in underlying oolitic limestone.

Limestone, creany to white, oolitic (Miami oolite). Contains very hard rock layers from 10.9 to $11.6 \mathrm{ft}$, and from 15,1 to $16 \mathrm{ft}$.

Limestone, creamy, hard. At $21 \mathrm{ft}$ it is softer and is ground to a chalky paste in drilling. Medium petmeability........................................................

Limestone, creamy, fairly hatd, with dark gray impure limestone layers from 33.5 to $33.9 \mathrm{ft}$ and 35.8 to $39.6 \mathrm{ft}$. Medium permeability.

$0-0.5$
$0.5-6$
$6-16$
$16-22$
$22-40$
$40-61$
$61-63.5$
$63.5-81$
$81-82$
$82-87$
$87-88$

Limestone, white, sandy, with many small cavities and varying amounts of very fine to fine white quertz sand. Iligh permeability $\ldots \ldots \ldots \ldots+\ldots \ldots+\ldots \ldots \ldots+\ldots \ldots+\ldots \ldots \ldots \ldots$

Limestone, dark-Eray, sandy, impure, exceedingly hard, contains some shell

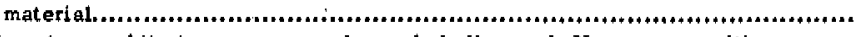

Iimestone, white to creamy, sandy, and shelly sand. Numerous cavities occur, the most important being from 63,5 to $64 \mathrm{ft} ; 64,8$ to $65,9 \mathrm{ft} ; 77,5$ to $78,4 \mathrm{ft}$; and 78.9 to $80.9 \mathrm{ft}$.

.....

Gravel, limestone, worn, subrounded, and very fine to fine white quartz sand.... Sandstone, white, calcareous, porous; contains considerable very fine to fine white quart $z$ sand in solution holes. Two cavities noted, from 83.7 to $84,4 \mathrm{ft}$; and from 86.6 to $87.8 \mathrm{ft}$. Uligh perme abitity...

Sand, quartz, blue-gray, very fine to fine, fossiliferous. Low permeability........

Well G 212

Location: SW1/4NW1/4 sec. 31 , T. 57 S., R. 39 E., 1.4 miles south of Florida City on east side of U. S. Highway 1.

Elevation of land surface: $4.0 \mathrm{ft}$ above mean sea level.

Depth: $79 \mathrm{ft}$.

Diameter: $2 / 2$ in. 
Table 127. - Logs of wells in Dade County-Continued

Well G $212-$ Continued

Depth, in feet below 1 and gurface

Limestone, cream-colored to white, oolitic, becomes soft and sandy at $20 \mathrm{ft}$. Two hard rock layers from 11.6 to $12,4 \mathrm{ft}$ and 15 to $16 \mathrm{ft} \ldots \ldots \ldots \ldots \ldots \ldots \ldots \ldots \ldots \ldots$

Limestone, gray-tan, sandy, hard, very little sand. Cavity from 30 to $33,6 \mathrm{ft}$, and thin layer of extremely hatd, dark-gray, almost black, dense limestone at $36 \mathrm{ft}$. Very high permeability.

Sand, quartz, tan, shelly, very fine to coarse, averaging fine, and some nodular sandstone.

Limestone, tan-gray, sandy, and sand. Medium permeability........................

Limestone, white, sandy, and very fine to medium quartz sand filling solution holes. Cavities from 50.5 to $51 \mathrm{ft}, 53.3$ to $54.8 \mathrm{ft}$, and 58.0 to $59.5 \mathrm{ft}$

Limestone, dark-gray to almost black, exceedingly hard, and a thin bed of small subrounded, limestone gravel...

Limestone, white to cream, sandy, containing pockets of sand with shells. Small cavities at 71,73 , and $76 \mathrm{ft}$. High permeability

Sand, quartz, white, shelly, very fine to fine, Low permeability.

$5-22$
$22-36$
$36-42$
$42-47$
$47-61$
$61-64$
$64-76 /$
$76-79$

Well G 213

Location: SW $/ 4 \mathrm{NW} / \frac{1}{4}$ sec, 27, T. 57 S., R. 39 E. Three Mile Road, 0.45 mile south of Palm Drive.

Elevation of land surface: $3.0 \mathrm{ft}$ above mean sea level.

Depth: $78 \mathrm{ft}$.

Diameter, $21 / 2 \mathrm{in}$.

Depth, in feat bolow land arface

Marl, gray, calcareous, sticky. .

Limestone, oolitic (Miami oolite), soft, includes two very hard rock layers from 10.5 to $11.5 \mathrm{ft}$, and from 14.5 to $15.5 \mathrm{ft}$

$0 \quad-\quad 2$

Limestone, cavemous, white to tan, hard. Very high permeability....................

Chalk, soft, white, Low permeability...............................................

$2-16$

$16-41$

$41-43$

Limestone, white to brown, sandy, very porous, and some calcareous sandstone; cavity ftom 52.5 to $54.5 \mathrm{ft}$. Smail amount of very fine to fine, white quartz sand.

\section{Well G 214}

Location: SE $1 / 4 S^{1} 1 / 4$ sec. 26, T. 57 S., R. 38 E., 30 ft west of Longview Road and 0.3 mile north of Lucille Drive.

Elevation of land surface: $8.0 \mathrm{ft}$ above mean sea level.

Depth: $61 \mathrm{ft}$.

Diameter: $21 / 2$ in. 
Table 127. - Logs of wells in Dade County - Continued

Well G 214-Continued

Depth, in feet

below land surface

Limestone, dark-gray, dense, very hard, and a few ohell fragments.

$34.5-37$

Chalk, grayish-white, and some quartz sand. Low perme ability...................

37.38

Limestone, sandy, and calcareous sandstone, gray to white. Many small cavities and considerable amount of very fine to fine white quartz sand.

$38-61$

\section{Well G 216}

Location: NW/4NW1/4 sec. 14, T. 57 S., R. 39 E. Campbell Drive and Tallahassee Road, Elevation of land surface: $3.6 \mathrm{ft}$ above mean sea level.

Depth: $110 \mathrm{ft}$.

Diameter: $2 \frac{1 / 2}{2}$ in.

Depth, in feet

bolow land surface

Marl, gray, calcareous, sticky, fills solution holes in underlying oolitic timestone. There is $1 \mathrm{ft}$ or more of muck overlying the marl in some places nearby.

Limetone, oolitic (Miami oolite), creamy, soft. In the interval between 11.5 and $17 \mathrm{ft}$ there are alternate hard and soft layers...

$0-5$

Limestone, tan, very hard

$5-17$

Limestone, tan to orange, coralline, and considerable very fine to fine white quartz sand which occurs in voids in the rock. Medium permeability.............

Limestone, tan-gray, sandy, and quartz sand. Medium permeability....................

Limestone, tan to gray, sandy, hard, and some coralline limestone. Iligh permeabillty

Limestone, gray to white, sandy, and a large amount of very fine to fine white quartz sand from 41 to $48 \mathrm{ft}$.

Sandstone, gray to white, calcareous, phosphatic, and a small amount of coralline limestone. Becomes quite fossiliferous at $53.5 \mathrm{ft}$. Cavity between 61.1 and $61.6 \mathrm{ft}$. Very high permeability.

Sandstone, gray-tan, calcareous, and a large amount of very fine to fine white

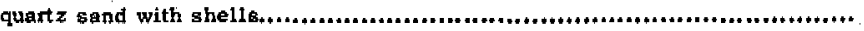

Sand, quartz, gray-tan, very fine to fine; contains large quantities of shell material. Low permeability...........................................................

Shell marl, datk-gray, very sandy. Sand is quartz, very fine to fine. Very low permeability.

Marl, green, clayey, sticky. Practically impermeable.

$48-64$
$64-71$
$71-76$
$76-94$
$94-110$

Well G 217

Location: SW1/4SE1/4 sec. 5, T. 57 S., R. 39 E. On U. S. Highway $1,1.6$ miles north of Campbell Drive.

Elevation of land surface: $9.1 \mathrm{ft}$ above mean sea level.

Depth: $120 \mathrm{ft}$.

Diameter: $2 \frac{1 / 2}{2}$ in. 
Table 127,-Logs of wells in Dade County- Continued

Well G 217-Continued

Depth, in feet

below land aurface

Limestone, composed of two very hard, dense rock layers separated by a soft layer between 16.5 and $17 \mathrm{ft}$.

Limestone, white, sandy...........................................................

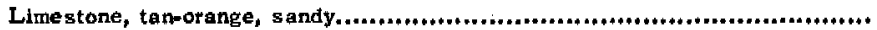

Sand, quartz, grayish-white, fine to medium...........................................

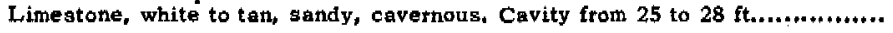

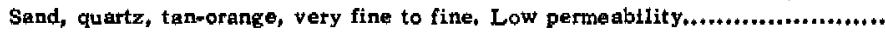

Limestone, white, sandy, varying from soft to hard with pockets or thin lenses of sand. High permetability.....

Sandstone, calcareous, soft and friable, with some coralline and chalky limestone. Cavities from 56.5 to $57.5 \mathrm{ft}$ and 58.5 to $61 \mathrm{ft}$. Very high perme ability..

Sandatone, white, calcareous, hard, fossiliferous. Iligh permęability.................

Shell marl, gray, sandy, locally consolidated into a shelly calcareous sandstone.

Sand content ranges from 50 to 80 percent of total sample. Low permeability...

Shell marl, dark-gray, sandy, unconsolidated. Sand is composed of quart $z$ and shells, very fine to coarse, averaging medium. Low permeability..................

Shell marl, greenish, containing very fine sand and silt. Very low permeability.. Mart, green, clayey. Practically impormeable.

$16-18$
$18-20$
$20-21.5$
$21.5-25$
$25-30$
$30-34$
$34-53$
$53-61$
$61-71$
$71-90$
$90-108$
$108-115$
$115-120$

\section{Well G 218}

Location: NW1/4NW1/4 sec. 18, T. 53 S., R. 40 E. East bank of Snapper Creek Canal, 2 miles south of Russian Colony Canal.

Elevation of land surface: $5.1 \mathrm{ft}$ above mean sea level.

Depth: $202 \mathrm{ft}$.

Diameter: 6 in.

Depth, in toet below land surface

Road fill.

Peat and muck.

Limestone, tan-white, dense, very hard, apparently nonoolitic......................

Limestone, oolitic (Miami oolite), white, generally quite soft $+\ldots \ldots \ldots \ldots . . . . . . . . . . \ldots . .$.

Limestone, light-gray, sandy, with small amount of sand in lenses or pockets. Medium permeability.

Sandstone, light-gray, calcareous, shelly, and a small amount of sand. Rock is porous, with cavity from 42 to $43 \mathrm{ft}$. Very high permeability.......................

Limestone, gray, sandy, hard, shelly, and porous. Very high permeability........

Sandstone, light-gray, calcareous, soft, and a large amount of very fine to

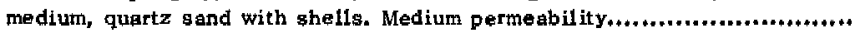

Shell marl, dark-gray, very sandy. Low permeability...................................

Marl, greenish, sandy, shelly in plaçes, and a few nodules of calcareous sandstone. Low permeability.

Sandst one, greenish, calcareous, shelly

Sand, greenish, thelly, and shelly calcareous sandstone nodules, Low permeability,

Sand, quartz, geenish, very fine to medium, and green silf with shells, Low permeability.

Sand, quartz, gray, medium to coarge, and a few shells. Medium perneability....

Sand, quartz, gray, medium to coarse, and few shells, with intercalated layers of green silt about $1 / 2$-inch thick, showing paper-thin bedding. Medium permea-

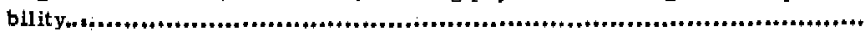

Clay, green, and green clayey marl. Practically impermeable.

$0-25$
$25-7$
$7-12$
$12-20$
$20-32$
$32-64$
$64-74$
$74-105$
$105-111$
$111-132$
$132-138$
$138-149$
$149-164$
$164-169$
$169-180$
$180-202$


Table 127.-Logs of wells in Dade County-Continued

Well G 222

Location: NW1/4NE1/4 sec. 7, T. 54 S., R. 37 E. South side of Tamiami Trail, 30.5 miles west of Miami.

Elevation of land surface: $9,1 \mathrm{ft}$ above mean sea level.

Depth: $77 \cdot \mathrm{ft}$.

Diameter: 6 in.

Depth, in feet

below land aurface

Road fill.

Muck and brown fibrous peat overlying a thin layer of fresh-water gray marl....

Limestone, aolitic (Miami oolite), with marl partly fliline solution holes in the oolitic limestone.

Sandstone, tan-gray, calcareous, with fine to coarse quartz sand and sbell fragments. Medium permeability..............................................................

Sand, quartz, dark+gray, very fine to medium. Low permeability.......................

Shell marl, Grayish-white sandy. Low permeability.

Sand, quarts, graytsh, fine to medium; contains sandstone nodules and thin beds of shells. Low pertineability.

Shell matl, grayish, sandy. Sand is fine except near base where very coarse sand and fine subrounded gravel was noted. Low permeabitity....................

Sand, quartz, dark-green, clayey, silty with thin lenses of friable sandstone.

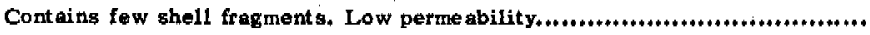

Silt, dark-greon, with small amount of very fine sand and thin layers of green clay. Shell bed in the silt at $77 \mathrm{ft}$. Practically imperneable.

$$
\begin{array}{r}
0-2 \\
2-6 \\
6-8 \\
8-22 \\
22-26 \\
26-31 \\
31-49 \\
49-61 \\
61-68 \\
68-77
\end{array}
$$

\section{Well G 223}

Location: Sec. 27, T. 54 S., R. 35 E. South side of Tamiami Trail, 40 miles west of Miami.

Elevation of land surface: $11.5 \mathrm{ft}$ above mean sea level.

Depth: $604 \mathrm{ft}$.

Diameter: $6 \mathrm{in.}$

Marl, dark-brown to black, due to admixture of muck; contains fresh-water gastropods

Limestone, oolitic (Miami oolite), hard, white to tan, most of the ooliths dissolved, leaving a pock-marked limestone

Sandstone, calcareotus, tan to brown, very hard, or sandy limestone, with numerous solution holes. Medium permeability.

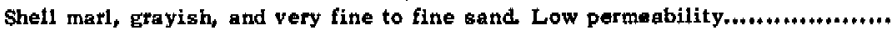

Shell marl, light-greeth, sandy. Some beds of modium gand bear limited amounts of water. Low permeability.

Sendstone, light-green, calcareous, shelly. Silt is common in some places, sand

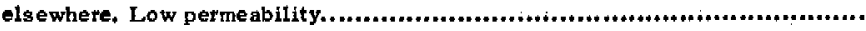

Sandstone, light-green, calcareous, with shell fragments. Low permeability.......

Sandstone, gray, calcareous, shelly, soft and friable. Low permeability...........

Sand, quartz, gray-white, very fine to coarse, contains sandstone nodules, shell fragments, and a minor amount of heavy minerals and phosphate grains. The heavy minerals appear to be mainly ilmenite, rutile, zircon, monazite, and staurolite. 
Table 127.-Logs of wells in Dade County-Continued

Well G $223-$ Continued

Depth, in teet

below letid surtace

Silt and very fine, greenish, sand. Contains coarse quart $x$ sand and phosphate Eraits, generally subrounded, Very low permeability.

Sand, light-gray, with faint greenish tint, fine to coarse, speckled with phosphate graing and minor amounts of other heavy minerals ...........................

Clay, green, gandy and silty, with a few phosphate graing and large quartz grains. Practically impormodble.

\begin{tabular}{|c|c|}
\hline 187 & -200 \\
\hline 200 & -204 \\
\hline 204 & -214 \\
\hline 214 & -226 \\
\hline & \\
\hline 226 & -278 \\
\hline 278 & -332 \\
\hline 332 & -342 \\
\hline 342 & -364 \\
\hline 364 & -377 \\
\hline 377 & -417 \\
\hline 417 & -468 \\
\hline 468 & -474 \\
\hline
\end{tabular}

Sand, quartz, gray, with thin streaks of green clay. The sand contains 15 to 25 percent of phosphate grains with other heavy minerals, especially ilmenite, zircon, rutile, athd monazite. Low permeability...

Marl, green, elayey, locally gilty ot very finely sandy; contains clay nodules and many phosphate pebbles or fine phosphate gravel; pebbles are usually discoid, with a maximum diameter of one-half inch Contains numerous shark teeth, crab claws, and tishbone fragments. Practically impermeable..............

Clay, green, with layers of silt and clay containing minor amounts of quartz and phosphate granwles; some are subrounded but most of the phosphate grains are oval and flattened, Shark teeth common. Practically impermeable.................

Silt, green, clayey to sandy, fossiliferous. Practically impermeable..................

Silt, green, sandy; generally practically impermeable but occasional shelly beds

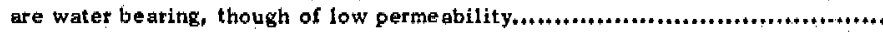

Sand, quartz, green, silty. The color is due to the clayey, silty materials. Contains some shell fragments and shark teeth. Practically impermeable,............

Sand, quartz, green, sitty. There are some shell fragments and a few shark teeth. Small amount of water recoverable. Low permeability.................................

Silt, green, dayey. Practically impermeable.

Sand stone, greenish-gray, calcareous, friable. Low permeability

Marl, green, clayey, helly, with occasional thin layers of practically dry clay and silt. Shells in some places compose as much as 40 percent of total sample, but shells are broken and fragmental as a rule. At base of this interval is a bed of very fine phosphate pebbles, a few inches thick. Very low

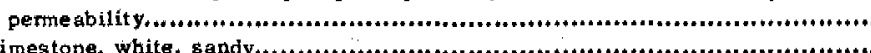

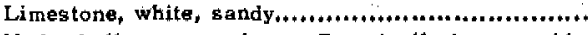

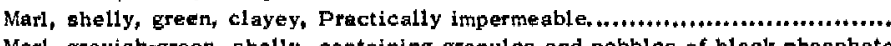

Marl, grayish-green, shelly, containing granules and pebbles of black phosphate and occasional streaks of gray silty marl. Practically impermeable................

Limestone, gray, hard, fossiliferous, and soft gray marl in minor quantities.......

Sand, greenleh, very fine to fine, and silt with shell fragments, Low permeability

Limestone, gray, sandy, friable, with occasional thin gray-white limestone layers containing a few green clay nodules. Low permeability.

\begin{tabular}{|c|c|}
\hline 474 & -504 \\
\hline 504 & -505 \\
\hline 505 & -509 \\
\hline 509 & -51 \\
\hline 518 & -53 \\
\hline 532 & 5 \\
\hline 534 & -5 \\
\hline 551 & -5 \\
\hline 561 & \\
\hline & 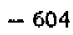 \\
\hline
\end{tabular}

Limestone, gray to white, sandy in places, contains streaks of green clayey sandy silt at intervals. Many casts of fossils noted. Low permeability...........

Limestone, gray, sandy, shelly, intercalated with soft thin sandy marl layers toward base. Low permeability.

Marl, gray, sandy and shelly. Very low permeability.....................................

$594-604$

Well G 224

Location: SW1/4W1/4 sec, 15, T. 53 S., R. 40 E,, 1.5 miles west of Milam Dairy Road and 1,0 mile notth of Milam Dairy Canal.

Elevation of land surface: $6.2 \mathrm{ft}$ above mean sea level.

Depth: $104 \mathrm{ft}$.

Diameter: 4 in. 
Table 127, - Logs of wells in Dade County_-Continued

Well G 224-Continued

Depth, In feet

below land surface

Marl, gray, of fresh-watet otigin ......................................................
Limestone, creamy-white, oolitic (Miami oolite), soft, with quartz sand party

fulling solution holes.

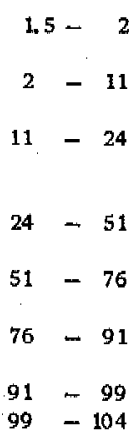

Send, quartx, white, contains sandstone nodules and shells cemented to sand. Low permeability.

Sandstote, gray-white, calcareous, and sandy limestone with very fine to medium, white quartz sand in cavities, Open cavity noted between 28.9 and

$29,6 \mathrm{ft}$. High permeability............................................................

Sand, quartz, gray to white, fine to very fine, and calcareous sandstone no-

dules. Few fossils. Low permeability.

Sandstone, grayish-white, calcareous, and sandy limestone with a few thin

layers of sand. High permeability.

Sand, quartz, gray, very fine to fine, and numerous small shells, Low per-

meability.

Sand, quartz, shells, and gray calcareous sandstone, Low permeability...........

$99-104$

Well G 225

Location: NE $1 / 4 \mathrm{NE}^{1 / 4}$ sec. 20, T. 53 S., R. 39 E. Dade-Broward Levee, 4.4 miles north of Tamiami Trail.

Elevation of land surface: Approximately $9 \mathrm{ft}$ above mean sea level.

Depth: $100 \mathrm{ft}$.

Diameter 4 in.

Depth, in teet

below land surface

Fill.

Muck, black, and brown fibrous peat.

$0 \quad-2$

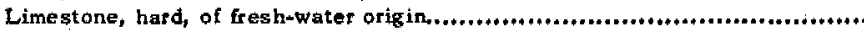

Limestone, creamy-white, oolitic (Miami oolite).......................................

Sandstone, tan-gray, calcareous, hard. High permeability..........................

Limestone, white, sandy, or calcareous sandstone containing a few fossils.

Very high permeability

Limestone, creamy-white, sendy, with chalky limestone layer about a foot thick.

$2-7$

$7-9$

$9-12$

$12-17$

Limestone, creamy to white, and hard sandy limestone, cavity between 47 and

$48.9 \mathrm{tt}$. Very high perme ability.

Sand, quartz, white, very fine to fine; contains broken bits of shells,.............

Marl, tan to gray, shelly, sandy. Low permeability

$17-33$

Mar1, shelly and sandy, partly consolidated, Low permeablity.

$33-35$

$35-50$

$50-52$

$52-85$

$85-100$ 
Table 127.-Logs of wells in Dade Cotnty- Continued

Well G 226

Location: SE $1 / 4$ sec. 26, T. 55 S., R. 39 E., $3 \frac{1}{2}$ miles west of Perrine and 0.2 mile north of Richmond Drive.

Elevation of land surface: $12 \mathrm{ft}$ above mean sea level.

Depth: $100 \mathrm{ft.}$

Diameter: 3 in.

Sand, quartz, gray, partly fills solution holes in underlying oolitic limestone....

Limestone, oolitic (Minmi oolite).......................................................

Sand, quartz, white, containing a fe,w calcareous gandstone nodules. Medium permeabilit $y$.

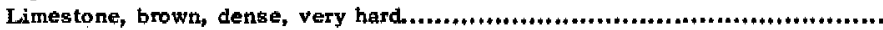

Limestone, reddish-brown, hard.........................................................

Limestone, white to tan, sandy, riddled with solution holes. Cavity between 38,5 and $39,5 \mathrm{ft}$. High permeability.

Sand, quartz, white, very fine to medium..............................................

Limestone, white, sandy, shelly in places, High permeability.......................

Limestone, brown, porous, shelly. Highly permeable.

$40-42$

$42 \quad-54$

Limestone, sandy, alternating with thin gand layers, ligh permeability..........

Sand, quartz, white, medium-grained.

Sandstone, gray, calcareous, with alternating thin layers of sand. High permeability

Sandstone, white, shelly, or sandy coquina; very soft between 85 and $90 \mathrm{ft} . \ldots$. Marl, dark-gray, sandy, shelly. Low permeat it ity.

Location: NW1/4NE $1 / 4$ sec. 16, T. 53 S., R. 42 E. East of U. S. Highway 1 and south of Snake Creek Canal.

Elevation of land surface: $5.0 \mathrm{ft}$ above mean sea level.

Depth: $95 \mathrm{ft}$.

Diameter: 2 in.

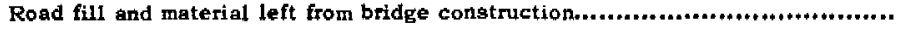
Sandstone, calcareous, soft, with some sand and shells

$0-16$

Sandstone, gray, calcareous, very hard to $38 \mathrm{ft}$, alternately soft and hard, with 
Table 127.-Logs of wells in Dade County- Continued

Well G 421

Location: NW1/4NW1/4 sec, 12, T. 53 S., R. 41 E. South of Little River Canal and NW. 7th Avenue.

Elevation of land surface: $5.0 \mathrm{ft}$ above mean sea level.

Depth: $97 \mathrm{ft}$.

Diameter: 2 in.

Depth, ith feet

below tand surface

Road fill.

Muck and marl,

quartz, fine to medium.

Sandstone, brownish, calcareous, hard,

Sandstone, calcareous, soft and friable, with a sand layer from 49 to 52 ft

Limestone, white, sandy, soft. Hard layer from 91 to $93 \mathrm{ft}_{*}$ ligh permeability..*

$0-3.5$
$3.5-6.5$
$6.5-17$
$17-39$
$39-40$
$40-62$
$62-97$

Well G 422

Location: SE $1 / 4 \mathrm{SE}^{1 / 4}$ sec. 2, T. 53 S., R. 41 E., 0.3 mile west of NW. 7 th Avenue on north side of Little River Canal.

Elevation of land surface: $5.0 \mathrm{ft}$ above mean sea level.

Depth: $98 \mathrm{ft}$.

Diameter: 2 in.

Depth, in feet below land surface

Muck, $0-2$

Limestone, oolitic, with very little sand. Some calcite and shells at bottom of

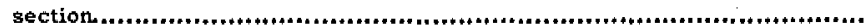

Sand, oolitic, shelly.......................................................................

Sand, quartz, and soft, toose sandy limestone......................................

Sand, quartz and small amount of soft calcareous sandstone.........................

Limestone, white, sandy, porous, with some sand and phosphate pebbles in

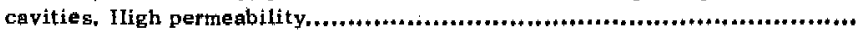

Limestone, sandy, soft, with several hard layers, High permeability...............

$2-19$
$19-23$
$23-33$
$33-50$
$50-63$
$63-98$

\section{Well G 423}

Location: NE $1 / 4 \mathrm{SW}^{1 / 4}$ sec, 6, T. 55 S., R. 41 E., 0.5 mile south of Kendal Drive and 0.4 mile east of Red Road.

Elevation of land surface: $4.0 \mathrm{ft}$ above mean sea level.

Depth: $52 \mathrm{ft}$.

Diameter: 2 in. 
Table 127. - Logs of wells in Dade County -Continued

Well G 423-- Continued

Depth, in foot

below land surfece

Sand, quart 3 , fine to medium.

Limestone, light-brown; sandy, very hard, soft from 28 to $32 \mathrm{ft} . . . . . . . . . . . . . . . .$.

$23-25$

$25-32$

Sand, quart $z$, fine.

Limestone, white sandy, very hard.

$32-38$

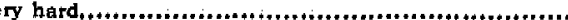

$38-46$

Lmestone, sandy, porous, and small amount of sand. High permeability.

$46-52$

\section{Well G 424}

Location: NE1/4SW1/4 sec. 7, T. 55 S., R. 41 E. West of Snapper Creek Canal, east of Ingraham Highway.

Elevation of land surface: $12.0 \mathrm{ft}$ above mean sea level.

Depth: $95 \mathrm{ft}$.

Diameter: 2 in.

Depth, in feot

below tand aurface

Limestone, oolitic, sandy.

$0 \quad-22$

Cavity.................................................................................. $22 \quad-25$

Sand, quattz, with congiderable amount of organic material....................... $\quad 25 \quad-28$

Limestone, gray-brown, very hard. Soft layers with small amount of chalky marl from 33 to $43 \mathrm{ft}$, and soft sandy limestone from 43 to $60 \mathrm{ft}$. High permea-

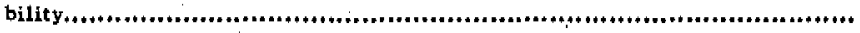

Sandstone, calcareous, soft, and some fine quartz sand. High perme ability.......

Limestone, white, gandy, shelly. Alternately soft and hard with pocketa of sand. Hard layer from 92 to $95 \mathrm{ft}$. Hilgh permeability.

$28-60$
$60-72$
$72-95$

\section{Well G 425}

Location: SW $1 / 4$ NW1/4 sec. 7, T. 55 S., R. 41 E. West of Red Road, 0.4 mile north of intersection with Ingraham Highway,

Elevation of land surface: $6.0 \mathrm{ft}$ above mean sea level.

Depth: $97 \mathrm{ft}$.

Diameter: 2 in.

Limestone, oolitic, sandy, porous,...t.t.t............................................

Sand, quartz, white.....................................................................

Limestone, brown-gray, very hard.....................................................

Sand, quartz, with small amount of sandy limestone.

Limestone, brown, hard....................................................................

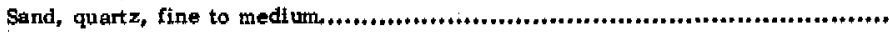

Limestone, tan, shelly. Alternate soft and hard layers. High permeability........

Sand, quartz, fine to medium.

Limestone, white, sandy. High permeability............................................

Sandstone, calcareous, soft, and fine quartz sand. High permeability.............

Limestone, white, sandy, shelly. Alternate soft and hard layers from 68 to $81 \mathrm{ft}$, hard from 81 to $97 \mathrm{ft}$. Iligh permeability. 


\section{Table 127. - Logs of wells in Dade County-Continued}

Well G 426

Location: SW/ $/ 4$ SW/ sec. 20, T. 54 S., R. 41 E. Southwest of intersection of U. S. Highway No, 1 and Coral Gables Canal.

Elevation of land surface: $11 \mathrm{ft}$ above mean sea level.

Depth: $98 \mathrm{ft}$.

Diameter $2 \frac{1}{2}$ in.

Depth, in teet

below land surface

Limestone, oolitic, with large amount of loose sand from 15 to $21 \mathrm{ft} . . . . . . . . . . .$. .

$0-21$

Sand, quartz, medium................................................................., $21 \quad-28$

Limestone, sandy, soft, and a small amount of coralline limestone.............. $28 \quad-32$

Sand, quartz, medium to fine..................................................... . $32 \quad-36$

Limestone, shelly, sandy, very hard. Few soft layers and small amount of

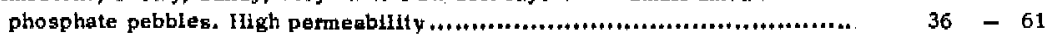

Limestone, sandy, soft, and quartz sand. Medium permeability,.................. $61 \quad-269$

Linestone, sandy, porous, very soft. Cavernous between 77 and $98 \mathrm{ft}$. Small

amount of loose sand. Few casts of shells, High permeability.................. $69 \quad 98$

Well G 428

Location: SW1/4SE1/4 sec. 18, T. 54 S., R. 41 E. West of Coral Gables Canal and north of ijird Drive, Coral Gables.

Elevation of land surface; $12 \mathrm{ft}$ above mean sea level.

Depth: $96 \mathrm{ft}$.

Diameter: $2^{1 / 2}$ in.

Depth, in teat

below land surface

Limestone, oolitic, sandy

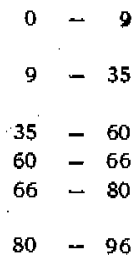

Sand, quart $z$, tan-white, medium, with shells and pieces of calcareous sand.

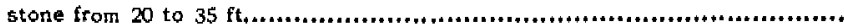

Limestone, light-tan, shelly, sandy. Very porous and permeable from 35 to 40

ft, Texture changesfrom medium to coarge quartz and from 52 to $60 \mathrm{ft}, \ldots+\ldots \ldots$.

Limestone, white, hard.

Sandstone, calcareous, shelly, and $\$$ mall amount quartz sand.......................

Lithestone, sandy. Alternate soft and hard layers with large amount of sand in soft sections. Few shells. Very hard white limestone from 94 to $96 \mathrm{ft}$.

$80-96$

\section{Well G 429}

Location: $N^{1 / 4} N^{11 / 4}$ sec. 30, T. 52 S., R. 42 E. East of Biscayne Canal and NE. 131st Street, North Miami.

Elevation of land surface: $3.0 \mathrm{ft}$ above mean sea level.

Depth: $99 \mathrm{ft}$.

Diameter: $2 \frac{1}{2}$ in:

Depth, in teet

below land surface 
Table 127. - Logs of wells in Dade County-Continued

Well G 429 - Continued

Depth, in feet

below land surface

Limestone, oolitic, soft, with quartz sand and loose coralline limestone from

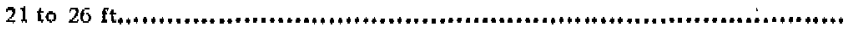

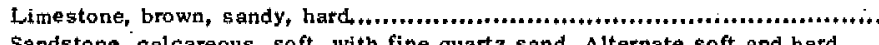

Sandstone, calcareous, soft, with tine quartz sand Alternate soft and hard

layers from 40 to $51 \mathrm{ft}$. Hligh permeability

Sand, quartz, mediun to coarse, with some loose calcareous sandstone..........

Sandstone, calcarecus, soft, and quartz sand,

$9-26$
$26-32$
$32-75$
$75-85$
$85-99$

Well G 431

Location: NE $/ 4 N^{1 / 4}$ sec. 20, T. 54 S., R. 41 E. LeJeune Road and Bird Drive, Cotal Gables.

Elevation of land surface: $12 \mathrm{ft}$ above mean sea level.

Depth: $100 \mathrm{ft}$.

Diameter: $21 / 2$ in.

Dopth, in feet

below land aurface

Road fill,

Limestone, oolitic, very hard from 5 to $6 \mathrm{ft}$

$0-3$
$3-17$
$17-46$
$46-67$
$67-78$
$78-82$
$82-90$
$90-100$

Sand, quartz, tan-white, with small amount of soft sandy limestone at $41 \mathrm{ft}, \ldots \ldots$....

Limestone, brownish-white, hard. Soft and sandy from 50 to $59 \mathrm{ft}$, and very hard

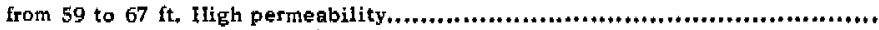

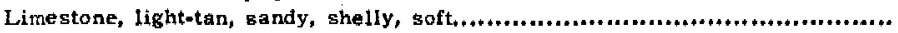

Cavity.

Sand, quartz, medium, and shell fragments with some loose sandy limestone......

Limestone, white, shelly, soft.

$90-100$

Well G 447

Location: NW1/4NW1/4 sec. 11, T. 55 S., R. 39 E. Lindgren Road, 1 mile south of N. Kendall Drive.

Elevation of land surface: $10.4 \mathrm{ft}$ above mean sea level.

Depth: $104 \mathrm{ft}$.

Diameter: $21 / 2$ in.

Depth, in feet

below land surtace

Rock filt.

$0 \quad-2$

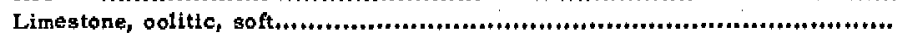

Limestone, sandy, very hard, dense..................................................

Limestone, oolitic, soft...............................................+4+4+t+.................

Limestone, sandy, with alternating hard and soft layers. IIIgh permeability........

Cavity.

Sandstone, white, calcareous, with hard and soft layers. Cavitieg at 52 to 54,58

to 59,62 to 63 , and 70 to $72 \mathrm{ft}$. Very high permeability..............................

Sandstone, calcareous, shelly, soft, with a cavity at 77 to 79 ft. Very high permeability. 
Table 127, _ Logs of wells in Dade County-Continued

Well G 448

Location: NW1/4W1/4 sec. 18, T. 55 S., R. 40 E., 3 miles west of Howard.

Elevation of land surface: $7.5 \mathrm{ft}$ above mean sea level.

Depth: $96 \mathrm{ft}$.

Diameter: $2 \frac{1}{2}$ in.

Depth, in feet

below land surface

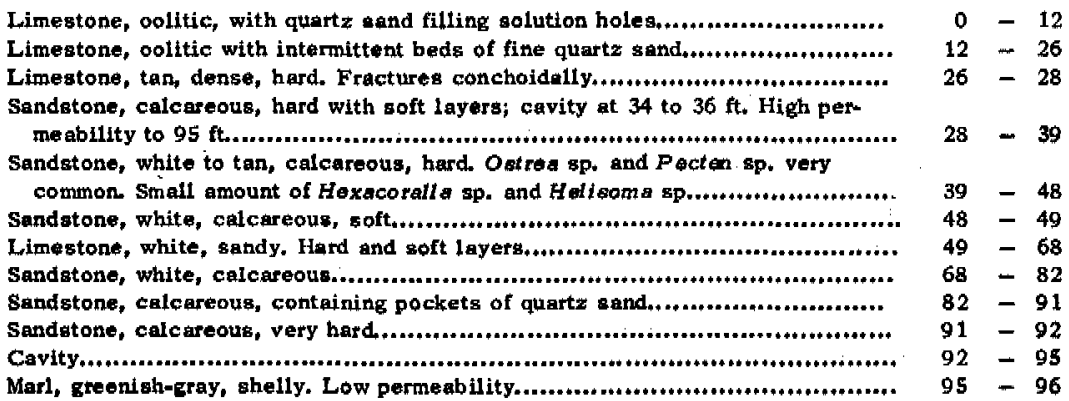

Well G 449

Location: SW1/4SW1/4 sec, 22, T. 55 S., R. 40 E. North of Coral Reef Drive, 0.5 mile east of U. S. Highway 1 .

Elevation of land surface: $13.0 \mathrm{ft}$ above mean sea level.

Depth: $105 \mathrm{ft}$.

Diameter, $21 / 2$ in.

Depth, in teet

betow land surface

Limestone, ootitic.

$0-19$
$19-32$
$32-35$
$35-41$
$41-50$
$50-53$
$53-73$
$73-74$
$74-95$
$95-105$

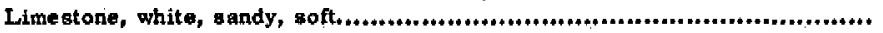

Sand, quartz.............................................................................+....

Limestone, white, sandy, hard.

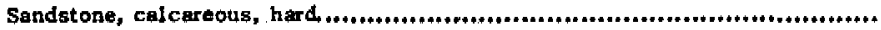

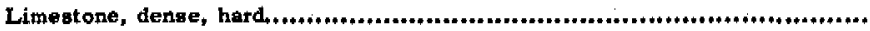

Sandxtone, calcareous, with hard and soft layers, Cavities at 57 to 58 and 70

to $73 \mathrm{ft}$.

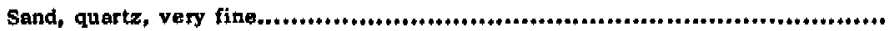

Sandstone, calcareous, hard and denee, Cavities from 80 to 82 and 87 to $88 \mathrm{ft...}$

$95-105$ 
Table 127. Logs of wells in Dade County-Continued

Well G 450

Location: NE⿺𠃊1/4SW1/4 sec. 27 , T. 55 S., R. 40 E. Kuhn Road 0.5 mile south of Coral Reef Drive.

Elevation of land surface: $9.2 \mathrm{ft}$ above mean sea level.

Depth: $104 \mathrm{ft}$.

Diameter, $2 \frac{1}{2}$ in.

Depth, in feet below land surface

Limestone, oolitic.

$0-16$

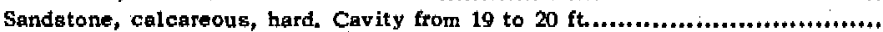

$16-21$

Sandstone, calcareous, soft, with pockets or layers of fine quartz sand...........,

Sandstone, calcareous, hard................................t............................

Sand, quartz, fine.

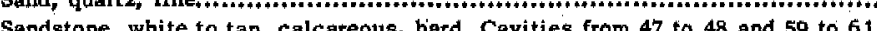

Sandetone, calcareous, containing pockets or layers of quartz sand................

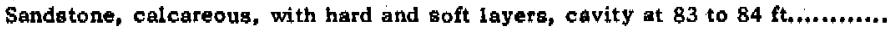

\section{Well G 451}

Location: NW1/4NE1/4 sec. $35, T, 55$ S., R. 40 E. Southeast corner of Cutler Road and Richmond Drive.

Elevation of land surface: $\mathbf{1 2 , 3} \mathrm{ft}$ above mean sea level.

Depth: $107 \mathrm{ft}$.

Diameter, $2 \frac{1}{2}$ in,

Depth, in feet below land surface

Limestone, o olitic, with quatz sand filling solution holes.

$0 \quad-19$

Sandstone, calcareous, with pockets of quartz sand..................................

$19-28$

Cavity.

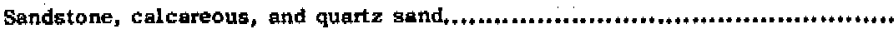

$29.5-38.5$

Sand, quartz, fine to medium

$38.5-41$

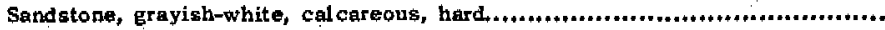

$41-59$

Sand, quartz, tan, fine to medium. Contains shell fragments and phosphate

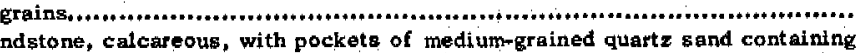

sandstone, cals framents and phosphate grains, 
Table 127._Logs of wells in Dade County —Continued

\section{Well G 469}

Location: $\mathrm{SE}^{1 / 4 W^{1} / 4}$ sec. 26 , T. 55 S., R. 40 E., $20 \mathrm{ft}$ east of Ingraham Highway and $640 \mathrm{ft}$ notth of Richmond Drive, Cutler.

Elevation of land surface: $10.5 \mathrm{ft}$ above mean sea level.

Depth: $137 \mathrm{ft}$.

Diameter: $2 \frac{1}{2}$ in.

Depth, in feot

below 1 and surface

Limestone, white-tan, oolitic, soft to medium hard..............................+..... 0.21

Sandstone, brownish, calcareous, hard, containing smali amount of fine to medium quartz $z$ rains

Limestone, white, sandy, soft. Contains shells and phosphate grains...............

Sandstone, gray-white, calcareous, hard, with fine to medium quartz sand fillitg solution holes.

Limestone, white, sandy, shelly, and some quartz gand, Alternating hard and soft layers.

Sandstone, gray-white, calcareous, shelly, and some quartz sand in pockete....

Shell marl, grayish-green, sandy. Low permeability.

$74-111$

$111-117$

$117-126$

Marl, greenish, clayey, sandy, and shell fragmenis, Very low permeability........

$126-137$

\section{Well G 471}

Location: $\mathrm{SE}^{1 / 4 \mathrm{SE}^{1 / 4}}$ sec. 34, T. 55 S., R. 40 E., $30 \mathrm{ft}$ west of Ingraham Highway and $60 \mathrm{ft}$. north of Eureka Drive.

Elevation of land surface: $12.5 \mathrm{ft}$ above mean sea level.

Depth: $119 \mathrm{ft}$,

Diameter: $2 \frac{1}{2}$ in.

Depth, in foet

betow land sutace

Black topgoil.

$$
\begin{array}{r}
0-0.5 \\
0.5-31 \\
31-66 \\
66-68 \\
68-107 \\
107-111 \\
111-119
\end{array}
$$

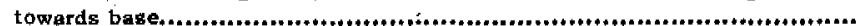

Limestone, grayish-white, sandy, hard, containing quartz sand in solution

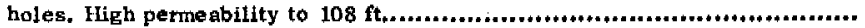

Limestone, white, sandy, shelly, cont aining pockets of white quartz sand.......

Sandstone, gray and white, calcateous, very hard,.....................................

Sandstone, grayish-white, calcareous, hard, and some fine to medium quartz

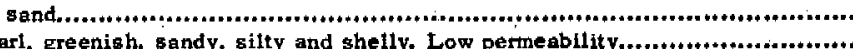




\section{Table 127.-Logs of wells in Dade County-Continued}

Well G 472

Location: NW $1,4 N^{\prime} / 4$ sec. $25, T, 55$ S., R. 40 E., $25 \mathrm{ft}$ south of intersection of Coral Reef Drive and Ludlum Road.

Elevation of land surface: $15.7 \mathrm{ft}$ above mean sea level.

Depth: $98 \mathrm{ft}$.

Diameter, $2 \frac{1}{2}$ in.

Depth, in foat

below land surface

Black topsoil,

Limestone, light-tan, oolitic, becoming sandy toward base.............................

$0 \quad-1$

Sandstone, Erayish-white, calcareous, and gome quartz Eand in solution holes.

High permeability.

$1-30$

Limestone, white, sandy, containing pockets white fithe to medium, quartz sand, and ohosphate grains, High permegbility.

Limestone, white, $s$ andy, shelly, contalning pockets white fine to medium, quartz sand. Iligh permeability.

$30-76$

$76-88$

$88-98$

Well G 474

Location: SW $1 / 4 N^{\prime} W^{\prime}$ sec. 10, T. 56 S., R. 40 E., 0.2 mile south of Ingraham Highway and $20 \mathrm{ft}$ south of Tenella Boulevard.

Elevation of land surface: $4.5 \mathrm{ft}$ above mean sea level.

Depth: $107 \mathrm{ft}$.

Diameter: $2 \frac{1 / 2}{\text { in }}$.

Depth, in foet below Iand surface

Topsoil and muck.

$$
\begin{aligned}
& 0=1.5 \\
& 1.5=18 \\
& 18-26 \\
& 26=31 \\
& 31-44 \\
& 44-106 \\
& 106-107
\end{aligned}
$$

Limestone, light-tan, oolitic, soft to medium hard.......................................

Sandstone, tan to brownish, calcareous, containing some fine to medium, quartz

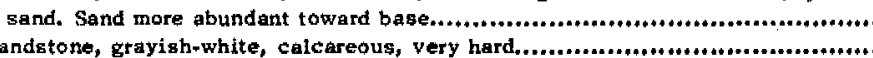

Sandstone, light-tan to graylsh-white, calcareous, soft, with some fine to medium, quartz gand. Iligh permeability................................................. pockets, with grains of phosphate throughout. High permeability.................... Marl, gray-green, shelly, sandy, sprinkled with phosphate grains. Low permeability.

\section{Well G 491}

Location: NE1/4NE1/4 sec. 24, T, 57 S., R. 39 E. Intersection of Mowry Drive and Six Mile Road.

Elevation of land surface: $3.0 \mathrm{ft}$ above mean sea level.

Depth: $38 \mathrm{ft}$.

Diameter: $2 / 2 \mathrm{in}$.

Depth, in teet

below $f$ and surface 
Table 127.-Logs of wells in Dade County_Continued

Well G 491-Continued

Depth, in feet

below land surface

Limestone, oolitic, with sand filling solution holes.................................

Limestone, white, hard.

$6.5-23$

Limestone, tan, very hard,

$23-26$

$26-38$

Well G 518

Location: NE $\frac{1 / 4 N W 1 / 4}{3}$ sec. 30, T. 56 S., R. 40 E. South Allapattah Road and Coconut Palm Drive.

Elevation of land surface: $5.0 \mathrm{ft}$ above mean sea level.

Depth: $90 \mathrm{ft}$.

Diameter: $4 \mathrm{in.}$

Depth, in teet

below land surface

Road fill.

$0-1$
$1-17$
$17-30$
$30-46$
$46-62$
$62-63$
$63-75$
$75-79$
$79-90$

Limestone, cream coloted, oolitic. Soft to hard.......................................

Sandstone, light-tan, calcareous, Ilard, with pockets of fine white quartz sand.

Sandstone, light-tan to white, calcareous, shelly, soft, containing quartz sand in

solution holes. lligh perme ability.

Sandstone, white, calcareous, hard, with pockets of quartz sand. High permea-

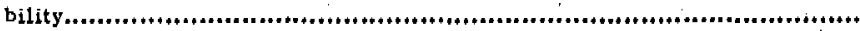

Cavity.

Sandstone, porous, shelly, calcareous, with some quartz sand in solution holes.

Iligh permeability.

Limestone, hard, shelly, with some goft sandy limestone. Little sand in solu-

tion holes. Iligh permeability.

Marl, gray, shelly, sandy. Low permeability.

Well G 519

Location: SW1/4 sec. 21, T. 54 S., R. 41 E., Coconut Grove Patk, $450 \mathrm{ft}$ NW. of Biscayne Bay, Miami.

Elevation of land surface: about $9.0 \mathrm{ft}$ above mean sea level,

Depth: $44.5 \mathrm{ft}$.

Diameter:

Depth, in foet

below tand arface

Topsoil, black.

$0 \quad-0.5$

Limestone, oolitic with small amount of quartz sand,..................................

$0.5-18,5$

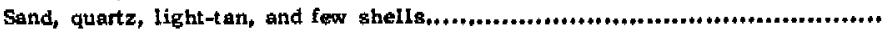

Sandstone, light-tan, calcareous. liard and soft layers.................................

$18.5-25.5$

$25.5-44.5$ 
Table 127.-Logs of wells in Dade County-Continued

Well G 525

Location: NE1/4NE $1 / 4$ sec. 33, T. 53 S., R. 41 E., 0.2 mile west of NW. 27 th Avenue and $50 \mathrm{ft}$ south of NW. South River Drive, Miami.

Elevation of land surface: $7.0 \mathrm{ft}$ above mean sea level.

Depth: $113 \mathrm{ft}$

Diameter: 2 in.

Depth, in toot

below $l$ and surface

Road fill and topgoil.

$0-3.5$

Limestone, white to light-tan, oolitic, soft, increasing in fine quartz sand

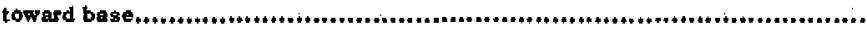

$3,5-25$

Sandstone, white to grayish-white, and lightan, calcareous. Contains small solution holes filled with fine to mediun quattz gand; increasing number to-

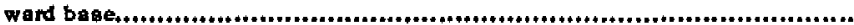

Sandstone, white to gray-white, calcareous, hard. Several small solution holes, filled with sand, between 64 and $66 \mathrm{ft}$.

Sandstone, grayish-white, calcareous, shelly, soft. Riddled with solution holes. Increasing amount of shells and sand toward base, Several small cavities between 72 and $78 \mathrm{ft}$.

$70-98,5$

Sandatone, 1ight-tan, calcareous. Very hard.

$98.5-101$

Sandstone, white to gray-white, calcareous, containing few shells at top, increasing amount of sand and shells toward bottom

$101-113$

Well G 527

Location: NW1/4NW1/4 sec, 20, T. 57 S., R. 40 E., 2.1 miles east of Six Mile Road on south side of North Canal.

Elevation of land surface: $3 \mathrm{ft}$ above mean sea level.

Depth: $51 \mathrm{ft}$.

Diameter. 4 in.

Depth, in feet

below land surfaco

Road fill and marl.

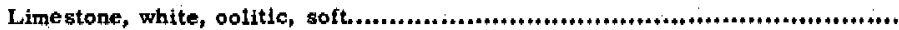

Sandstone, gray to tan, calcareous, with quartz sand filling solution holes. Very hard dense layers from 22 to $27 \mathrm{ft}$ and 33 to $37 \mathrm{ft}$.

$0 \quad-7$

$7-14$

$14-51$

\section{Well G 548}

Location: SE $1 / 4 \mathrm{NE}^{1 / 4}$ sec, 19, T. 53 S., R. 41 E. Pinecrest Drive and La Villa Drive, Miami Springs.

Elevation of land surface: $6.5 \mathrm{ft}$ above mean sea level.

Depth: $97 \mathrm{ft}$.

Diameter 2 in. 
Table 127.-Logs of wells in Dade County-Continued

Well G 548-Continued

Depth, in feet

below land surface

Sand, quartz, tan, and few shell fregments.

Sandstone, grayish-white, calcareous, Riddled with solution holes partly filled

$19-36$

with quartz sand. Very high permeability.

Sand, quartz

Sandstone, grayish-white, calcareous, shelly. Cavity from 75 to $77 \mathrm{ft}$. 11 igh permeability.

Limestone, white, shelly, soft. High permeability.

Sandstone, calcaseous, shelly, with hard and solt layers, and pockets of quartz sand. Several amall cavities between 86 and $92 \mathrm{ft}$. Iligh permeability.

$36-60$

$60-65$

$65-83$

$83-85$

$85-97$

\section{Well G 551}

Location: NW1/4W1/4 sec. 36, T. 54 S., R. 39 E., $51 / 2$ miles west of U. S. Highway 1 and 0.3 mile north of North Kendall Drive,

Elevation of land surface: $8 \mathrm{ft}$ above mean sea level.

Depth: $98 \mathrm{ft}$.

Diameter: $24 \mathrm{in.}$ to $30 \mathrm{ft}$ and $18 \mathrm{in.}$ to $98 \mathrm{ft}$.

Depth, in feet

below land surtace

Limestone, white, oolitic, hard, solution-riddled, with gray marl filing holes.....

$0-15$

Limestone, tan-brown to gray-white, eandy, cavemous, dense, hard, with a soft calcareous layer from 18 to $19 \mathrm{ft}$. Alternate soft and hard layers from 19 to 84 $\mathrm{ft}$, and numerous molds of fossils from 36 to 40 and 46 to $49 \mathrm{ft}$, Very high perm meabllity

Sandgt one, gray-white, calcareous, soft, and guartz gand............................

Marl, eray, sandy, shelly, very soft, Low permeability

$15 \quad-84$

$84-88$

$88-98$

\section{Well G 552}

Location: SW1/4NW1/4 sec. 27, T. 55 S., R. 39 E., 1.5 miles north of Eureka Drive and 300 ft east of Naranja Road.

Elevation of land surface: $9.0 \mathrm{ft}$ above mean sea level.

Depth: $87 \mathrm{ft}$.

Diameter: $24 \mathrm{in}$, to $30 \mathrm{ft}$ and $18 \mathrm{in.}$ to $87 \mathrm{ft}$.

$D$ epth, in feat

below land surface

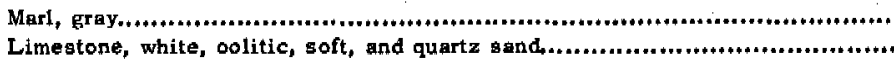

Sand, quartz, with pieces of riddled oolitic limestone...............4...............

Limestone, white, sandy, with oolitic sand filling solution holes, ...................

Limestone, white, sandy, shelly, soft to medium hard with solution holes partly filled with quartz sand. Cavity from 40 to $\mathbf{4 1} \mathrm{ft}$. Very high permeability.........

Sand, quariz, grayish-white. Very high permeabllity.

Limestone, white sandy, shelly, hard to soft, with numerous amall cavities between 58 and $70 \mathrm{ft}$. Very high permeability

Sandstone, calcareous, very soft, extremely riddled with solution holes. Very high permeability.

$$
\begin{array}{r}
0-2 \\
2-11 \\
11-17 \\
17-28 \\
28-43 \\
43-47 \\
47-71 \\
71-82 \\
82-87
\end{array}
$$$$
\text { Sand, 'quartz, very fine to medium, average is the, containing nodules of gandy }
$$$$
\text { limestone and numerous shells, Low permeability. }
$$ 


\section{Table 127.-Loss of wells in Dade County-Continued}

\section{Well G 553}

Location: NE $1 / 4 \mathrm{SE}^{1 / 4}$ sec. 16, T. 55 S., R. 40, E., 0.5 mile west of U. S. Highway No. 1 , on south side of Motu Drive.

Elevation of land surface: $12.0 \mathrm{ft}$ above mean sea level.

Depth: $127 \mathrm{ft}$.

Diameter. 24 in. to $30 \mathrm{ft}$ and $18 \mathrm{in}$. to $127 \mathrm{ft}$.

Depth, in foet

balow land surfece

Limestone, white, oolitic, sandy

$$
0-16
$$

Sand, oolitic....

Limestone, sandy shelly, porous, soft to hard, with graylsh-white, very fine quartz sand in solution holess. Cavity from 41 to $45 \mathrm{ft}$. Iligh permeabillty to $93 \mathrm{ft}$.

Sandstone, calcareous, shelly, soft to hard, and large amount of grayigh-white very fine quartz sand. Numerous casts and molds from 78 to $82 \mathrm{ft................}$

Sand, quartz, very fine to medium, average is fine, and pieces of nodular grayishwhite calcareous sandstone. Low permeability.

$$
\begin{aligned}
& 36-74 \\
& 74-93 \\
& 93-127
\end{aligned}
$$

\section{Well GS 14}

Location: T. 51 S., R. 35 E. Johnny Pool's Island approximately 15 miles north of the Tamiami Trail and 39 miles west of Miami.

Elevation of land surface: Approximately $14 \mathrm{ft}$ above mean sea level.

Depth: $51 \mathrm{ft}$.

Diameter: 4 in.

Muck

Limestone, aandy, soft, of fresh-water origin

Sandstone, calcareous, and soft gray
in the sandstone. Low perme ability.

Sand, quartz, tan, very fine to medium. Low permeability.................................

Sand, quattz, white, and friable calcareous sandstone.............................

Shell marl, gray, gandy. Low permeability.

Shell marl, green, clayey. Practically impermeable.

Shell marl, gray. Consolidated in places to a shelly sandstone. Low petmea-

bility to $50 \mathrm{ft} .00 \mathrm{cos}$

$$
\begin{gathered}
0-1 \\
1-2.5 \\
2.5-7.5 \\
7.5-10.5 \\
10.5-29.5 \\
29.5-32 \\
32-39.5 \\
39.5-51
\end{gathered}
$$


Table 127. - Logs of wells in Dade County-Continued

\section{Well GS 30}

Location: T. 59 S., R. 35 E., 13 miles southwest of Royal Palm State Park on south side of Florida Highway 27.

Elevation of land surface: Approx. $3.5 \mathrm{ft}$ above mean sea level.

Depth: $64 \mathrm{ft}$.

Diameter: 4 in.

Fill.

$0-1.5$

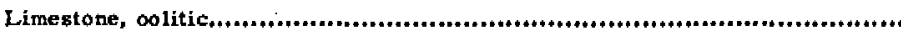

$1,5-13$

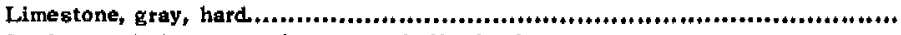

Sandgtone, light-gray, calcareous, shelly, hard......................................

$13-21$

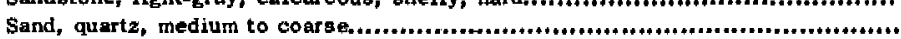

$21-34$

Sand, quartz, fine to medium, and small. amount of brown silt..........................

$34-39$

$39-64$ 
Table 128._- Logs of wells in Glades County

Well GS 18

Location: NW/4SW1/4 sec. 18, T. 39 S., R. 34 E., 0.15 mile southwest of Indian Prairie Canal on Florida Highway 78.

Elevation of land surface: Approximately $17 \mathrm{ft}$ above mean sea level.

Depth: $75 \mathrm{ft}$.

Diameter: 4 in.

Depth, in feet below land surfa

Sand, quartz, carbonaçęus.

$0 \quad-0.5$

Sand, quartz.

$0.5-3$

Shell bed of marine origin..................................................................

$3-7$

Marl, very sandy, few shells and thin layers of calcareoug sandstone between 18 and $23 \mathrm{ft}$.

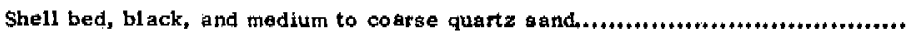

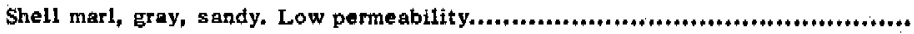

$7-30$

Marl, light-green, clayey, sandy. Very low pemeability.

$30 . \quad 44$

$44-54$

$54-75$

Well GS 28

Location: NW1/4SW1/4 sec. 11, T. 42 S., R. 32 E., $200 \mathrm{ft}$ west of Moore Haven High School, Moore llaven.

Elevation of land surface: Approximately $17.5 \mathrm{ft}$ above mean sea level.

Depth: $63 \mathrm{ft}$.

Diameter, 4 in.

Depth, in feet below land surface

Peat. $0-3$

Sand, quartz.

$3-10$

Shell bed with latge amounts of quartz $\$$ and $\ldots+\ldots+4,+\ldots+\ldots+\ldots+\ldots, \ldots+\ldots \ldots \ldots \ldots \ldots \ldots \ldots \ldots, \ldots$

$10-14$

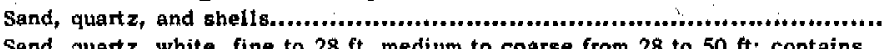

$14-17$

Sand, quartz, white, fine to $28 \mathrm{ft}$, medium to coarse from 28 to $50 \mathrm{ft}$; contains some calcareous sandstone.

$17-50$

Sand, quartz, shelly, coarse.

$50-63$

Well GS 29

Location: Sec, 22, T, 40 S, , R, 32 E, 1 mile east of Lakeport on Florida Highway 78.

Elevation of land surface: Approximately $15.5 \mathrm{ft}$ above mean sea level.

Depth: $75 \mathrm{ft}$.

Diameter: 4 in.

Depth, In teet below land ourface 
Table 128. - Loss of wells in Glades County-Continued

\section{Well GS 29-Continued}

Depth, in leet below land surface

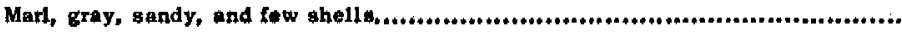

$11-28.5$

Marl, light-gray, eholly, very tandy..........................................................

$28.5-41.5$

Sand, quartz, fine to medium, and shelle..............................................tet.

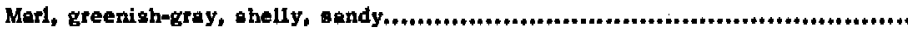

$41.5-47.5$

Mat1, greenioh-gray, allty, plastic, and fow shell fragmonts............................ $47,5-55,5$

Mari, cray, sandy, very thotly.

$55.5-61.5$

$61.5-75$ 


\section{Table 129. - Logs of wells in Hendry County}

\section{Well HE 4}

Location: SW1/4SE1/4 sec. 17, T. 43 S., R. 33 E., 7 miles west of Clewi ston and 1 mile south of Florida Highway 80 .

Elevation of land surface: Approximately $19 \mathrm{ft}$ above mean sea level.

Depth: $127 \mathrm{ft}$.

Diameter. 6 in.

Lime ștone, dark-brown, hard.................................................................

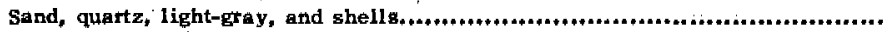

Sand, quattz, light-gray, shelly, marly..............................................

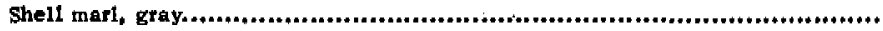

Shell marl, dark-gray, 8 andy. Approximately 90 percent of shells are Ostrea sp.

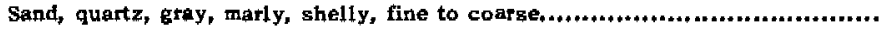

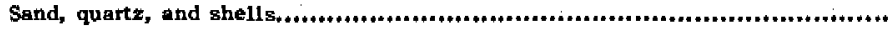

Sand, quartz, coarse, with few pebbles and shell fragments...........................

Clay, green, sandy. Practically impermeable.

\section{Well GS 4}

Location: NW1/4SW1/4 sec. 34, T. 43 S., R. 32 E. Devil's Garden Road, 3.6 miles south of Florida Highway 80.

Elevation of land surface: Approximately $23 \mathrm{ft}$ above mean sea level.

Depth: $50 \mathrm{ft}$.

Diameter, 4 in,

Sand and few shells.

$$
\begin{array}{r}
0-6 \\
6-14 \\
14-23 \\
23-50
\end{array}
$$

Sandstone, calcareous, soft, friable, containing solution holes filled with sanc.

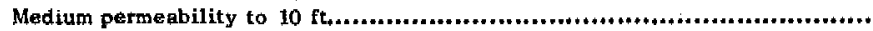

Sand, quartz, tan to btowh. Low permeability.

\section{Well GS 5}

Location: SW1/4 sec. 22, T. 45 S., R. 32 E. Devil's Garden Road, 13.8 miles south of Florida Highway 80 .

Elevation of land surface: Approximately $27 \mathrm{ft}$ above mean sea level,

Depth: $50 \mathrm{ft}$.

Diameter, 4 in, 
Table 129._L Logs of wells in Hendty County-Continued

Well GS 5 - Continued

Depth, in feet below land surface

Shell marl, sandy, of marine origin, Low permeability............................. $22.5-25.5$

Marl, sandy, shelly. Low permeability.

$25.5-40$

Marl, sandy, clayey, Practically impermeable.............+4+.......................

$40-50$ 
Table 130.-Logs of wells in Highlands County

Well GS 20

Location: SW1/4 sec, $31, T$ T. 37 S., R. 31 E., 27 miles west of Okeechobee on Florida Highway 70.

Elevation of land surface: $36 \mathrm{ft}$ above mean sea level.

Depth: $125 \mathrm{ft}$.

Diameter: 4 in.

Depth, in foet

below land surface

Sand, black, carbonaceous.

$0-0.5$

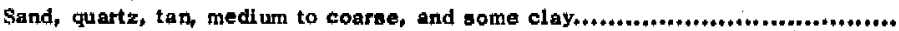

$0.5-11$

Clay, whitish-gray, sandy, and thin layers of gray calcareous sandstone from $\mathbf{2 4}$

to $32 \mathrm{ft}$. Low permeability........................................................................

Limestone, gray, sandy, containing amall smount of sandy clay and few phos-

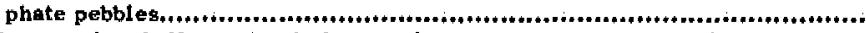

Clay, sandy, shelly, with thin layers of calcareous sandstone and gravel........

Sand, quartz,gray, very fine.................................................................

Sandatone, calcareous, soft, and thin beds of clay with pieces of chalk............

Sand, quartz, gray, indurated, coarse, and thin layers of clay+t.......................

Sandstone, gray, calcateous, soft, containing alternate layers of quartz sand and thin beds of clay. Thin layere of sandy, shelly matl from 99 to $108 \mathrm{ft}$

Mati, green, sandy, and thin leyers of soft, calcareous sandstone from 108 to 118

ft.

$11-32$

$32-46$

$46-67$

$67-70$

$70-81$

$81-89$

$89-108$

$108-125$

\section{Well GS 21}

Location: Sec. 35, T. 36 S., R. 31 E. South side of Istokpoga Canal, approximately 1 mile east of Lake Istokpoga.

Elevation of land surface: $39 \mathrm{ft}$ above mean sea level.

Depth; $65 \mathrm{ft}$.

Diameter: 4 in,

Depth, in toet

below lind outface

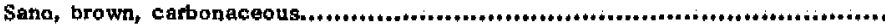

$0-3$
$3-9$
$9-19$
$19-32$
$32-46$
$46-53$
$53-65$

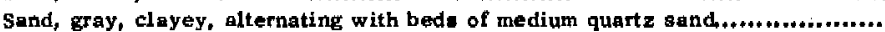

Sand, brown, clayey.........................................................................

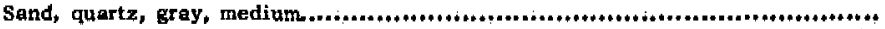

Clay, gray-green, sandy, light and plastic...........................................

Sand, quartz, gray, fine to medium.

53

Marl, blue-green to.gray-white, sandy, shelly.

65 
Table 130.-Logs of wells in Highlands County-Continued

Well GS 22

Location: Sec. 8, T. 36 S., R. 33 E. Intersection of Florida Highway 66 and Kissimmee River, near Fort Bassinger.

Elevation of land surface: Approximately $30 \mathrm{ft}$ above mean sea level.

Depth: $101 \mathrm{ft}$.

Diameter: 4 in.

Depth, in feet

below land aurface

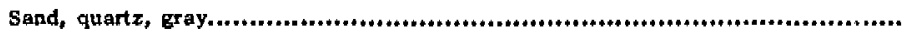

$0-2$

Sand, quartz, reddish-brown, indurated....................................................

$2 \div 20$

Sand, quartz, gray, and small amount of clay............................................

$20-30$

Clay, dark-gray, sandy, medium to coarse..................................................

$30-36$

Sand, dark-gray, clayey, medium to caarse...t+.................................................

$36-48$

Shell marl, grayish-green, sandy, and a small amount of calcareous sandstone....

$48-65$

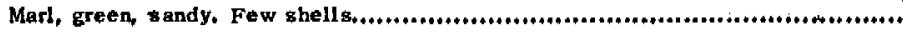

$65-70$

Marl, gray, helly, sandy...................................................................

$70-85$

Marl, bright-green, clayey, containing very little sand or shells.

$85-101$ 
Location: Sec, 23, T. 40 S., R. 40 E., 8.5 miles southeast of St, Lucie Canal on Florida Highway 710 .

Elevation of land surface: Approximately $24 \mathrm{ft}$ above mean sea level.

Depth: $90.5 \mathrm{ft}$.

Diameter: 4 in.

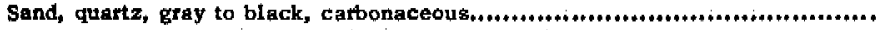

Shell bed, of marine origin, and quartz sand.

Sandstone, calcareous, riddled with solution holes largely filled with quartz

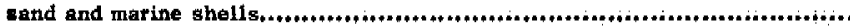

Sand, quartz, gray, shelly, fine to medium Low permeability..........................

Send, quartz, dark-gray, shelly, marly. Small amount of phosphate pebbles.

Low permeability.

Location: Sec. 27, T. 39 S., R. 42 E., $200 \mathrm{ft}$ east of U. S. Highway 1, and 0.3 mile northeast of pump house, Hobe Sound.

Elevation of land surface: $22 \mathrm{ft}$ above mean sea level.

Depth: $117 \mathrm{ft}$.

Diameter: 12 in.

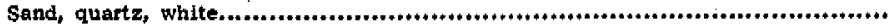

Sand, quartz, tan, shelly....

$0-5$

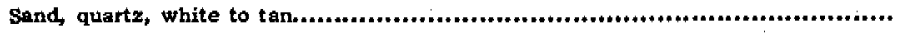

Sandstone, calcareous, thelly.............t...............t.te+..............................

Sand, quartz, white, fine to medium, and nodular sandsto ne.

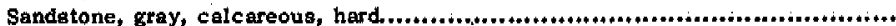

Sandstone, shelly, calcareous, almost a coquina,.......................................

Sand, quartz, white, very fine to medium..........................................4+4t+4

Sandstone, shelly, grading into coquina............................................... $106 \quad-117$ 
Table 132.-Logs of wells in Okeechobee County

Well GS 16

Location: Sec. 18, T. 34 S., R. 36 C., 19 miles north of Okeechobee, and 2 miles east of Fort Drum.

Elevation of land surface: $50 \mathrm{ft}$ above mean sea level,

Depth: $90 \mathrm{ft}$. :

Diameter 4 in,

Depth, in teet

below land surface

Sand, quartz, gray.

$0-2.5$
$25-6$

Sand, dark-brown, carbonaceous, indurated "hardpan "...

Sand, quartz, dark-brown, medium............................................................

$6-12$

Sand, quartz, dark-brown, medium to coarse, and a smatl amount of friable cal-

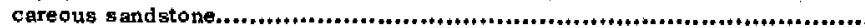

Sand, quartz, light-tan to gray, fine to medium........................................

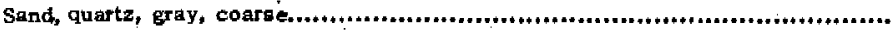

Sand, quartz, gray, and thin layers of elayey mark......................................

Sand, quartz, shelly, coarse

$12-20$

$20-44$

$44-57$

$57-62$

$62-73$

Shell marl, gray, sandy.

$73-90$

\section{Weil GS 17}

Location: SEl/4NW1/4 sec. 19, T. 38 S., R. 35 E., 0.15 mile northeast of Kissimmee River on Florida Highway 78.

Elevation of land surface: Approximately $21 \mathrm{ft}$ above mean sea level.

Depth: $131 \mathrm{ft}$.

Diameter: $4 \mathrm{in}$.

Depth, in feet below ind surface

Sand, quartz. Lake Okeechobee beach ridge.........................................

Sand, quartz, dark-brown, carbonaceous...............................................

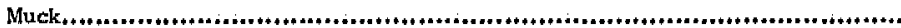

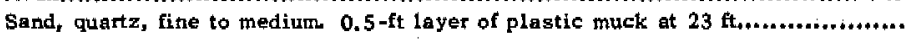

Shell marl, gray, sandy. Low permeability.

$0-6$
$6-9$
$9-12$
$12-29$
$29-53$
$53-54,5$
$54,5-75$
$75-81$
$81-90$
$90-110,5$
$110,5-123$
$123-131$

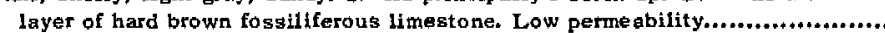

Marl, shelly, sandy, phosphatic. Low permeability,......................+...........*

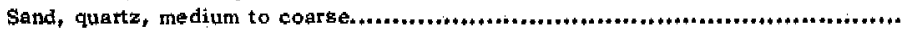

Sand, quartz, marly, tew shell fragments...............................................

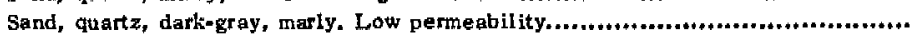

Marl, greenish-gray, shelly, sandy. Low perme ability....................................

Sand, quartz, greenish-gray, marly, fine to medium. Low permeability. 


\section{Table 132.-Logs of wells in Okeechobee County-Continued}

\section{Well GS 19}

Location: NE1/4NE1/4 sec. 36, T. 38 S., R. 36 E. West side Florida Highway 15, 0.1 mile north of Martin County Line.

Elevation of land surface: Approximately $16 \mathrm{ft}$ above mean sea level.

Depth: $80 \mathrm{ft}$.

Diameter 4 in.

Depth, in tout balow tand eurface

Sand, quartz, Lake Okeechobee beach tidge............................................

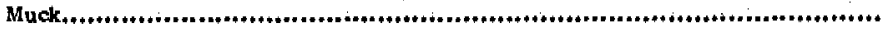

$0 \quad 3.5$

Quartz, sand, marl, matitie shell bed, and thin tayer fresh-water limestone, in

order from top to bottom. .t+*.............t.t....................................................

Shell bed, sandy, and lenses of fine quattz sand......................................

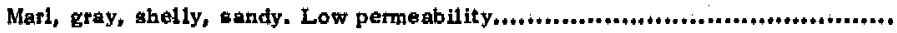

Sand, quart $z$, fine to medium, and shells, Low permeability.............................

Shell bed, Fandy, and small amount of marl. Low permeability.........................

shell marl, very sandy. Low parmeability.

$3.5-5$

Marl, very sandy, and few shell fragments. Low permeability..........................

Marl, sandy, sticky, and very few shells. Low permeability.

$5-9$

$9-15$

$15-26$

$26-35.5$

$35.5-46$

$46-49$

$49-66$

$66-80$ 
Table 133. - Logs of wells in Palm Beach County

\section{Well GS 2}

Location: T. 45 S., R. 36 E. Florida Highway 25, 3.5 miles south of Bolles Canal.

Elevation of land surface: $13,1 \mathrm{ft}$ above mean sea level.

Depth: $50 \mathrm{ft}$.

Diameter: 4 in.

Depth, in feet

below land surfece

Muck and peat

$0 \quad 6.8$

Sandstone, calcareous, hard, shelly, containing both marine and fresh-water

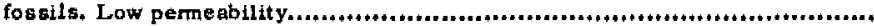

Marl, shelly, poorly consolidated in places to a friable shelly sandst one. Low permeability.

Sand and shells, probably a sandy shell marl, Low permeability......................

Sandstone, calcareous, shelly

$6.8-16.5$

Marl, shelly, sandy in places, containing thin hard layers where the marl is con* solidated into limestone. Low permeabillty.............................................

Sand, quartz, very fine. Low permeability...

$16.5-30.4$

$30.4-36.5$

$36.5-38.2$

$38.2-49$

$49-50$

\section{Well GS 3}

Location; Sec. 8, T. 44 S., R. 36 E., 3 miles west of South Bay, and 1 mile south of Florida Highway 80.

Elevation of land surface: $15 \mathrm{ft}$ above mean sea level.

Depth: $50 \mathrm{ft}$.

Diameter: 4 in.

Depth, in foet

below land surface

Muck and peat.

$0-7,5$

Shell marl, sandy, with layers of hard, flinty limestone and soft white limestone.

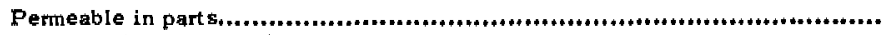

Shell marl, gray to dark-gray, sandy. Few thin layerz of rock between 32 and 33

$7,5-23,5$

ft, Low permeabllity......................................................................

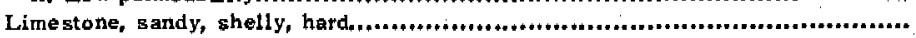

Shell marl, gandy. Low permeability.

$23.5-34.5$

$34.5-36$

$36-50$

\section{Well GS 6}

Location: T. 45 S., R. 38 E. Florida Highway $827,7.2$ miles south of its intersection with Florida Route 80.

Elevation of land surface: Approximately $15 \mathrm{ft}$ above mean sea level.

Depth: $55 \mathrm{ft}$.

Diameter: $4 \mathrm{in.}$ 
Table 133, - Logs of wells in Palm Beach County-Continued

Well GS 6 - Continued

Depth, in feet

below land aurface

Shell marl, sandy, alternating with limestone and calcareous sandstone..

$11-14.5$

Sand, tan, shelly, Low permeability......................................................

$14.5-18.5$

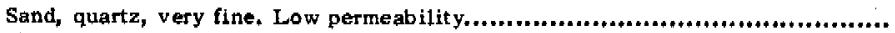

$18.5-26.5$

Shell marl, sandy. Low permeability.

$26.5-38.5$

Shell marl, partly consolidated, Low permeability...................................

$38.5-43.5$

Shell marl, soft and sandy. Low permeability.

$43.5-55$

\section{Well GS 7}

Location: T. 44 S., R. 39 E. Flotida Highway $80,0.5$ mile southwest of intersection with Florida Highway 716.

Elevation of land surface: Approximateiy $15 \mathrm{ft}$ above mean sea level.

Depth: $50 \mathrm{ft}$.

Diameter: 4 in.

Depth, in feat below land surface

Road fill. $0-2$

Muck

$2-13$

Limestone, of fresh and brackish-water origin Low permeability.

$13-16$

Shell marl, sandy, in places poorly consolidated. Low permeability..................

$16-21.5$

Sand, quartz, with few shells, Low permeability.

$21.5-30$

Shell marl, light to dark-gray, wandy. Low permeability.

$30-50$

\section{Well GS 8}

Location: T. 43 S., R. 41 E. Florida Highway $80,0.35$ mile west of intersection with Florida Highway 7 .

Elevation of land surface: Approximatel y $17 \mathrm{ft}$ above mean sea level.

Depth: $51 \mathrm{ft}$.

Diameter: $4 \mathrm{in.}$

Depth, in feet balow land surface

Sand, quartz, fine to medium. Low permeability.

$0-3$

Sandstone, calcareous, riddied with golution holes, Low permeability..............

Sand, quartz, tan, and shells, Low petmeability.....................................

$3-5.5$

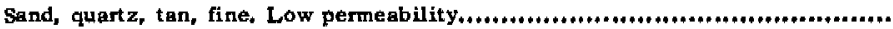

Sand, quartz, light-green, very fine, Low permgability............................

Sand, quartz, containing organic material. Low permeability........................

Sand, quartz, light-gray, with shell fragments. Hard calcareous sandstone layer

from 48 to $49 \mathrm{ft}$

$5.5-10$

$10-35.5$

$35.5-44$

$44-47$

$47-51$ 
Table 133.-Logs of wells in Palm Beach County-Continued

\section{Well GS 11}

Location: T. 47 S., R. 40 E. South side of Hillsboro Canal, 11 miles west of Florida Highway 7 .

Elevation of land surface: Approximately $12 \mathrm{ft}$ above mean sea level.

Depth: $96.5 \mathrm{ft}$.

Diameter: 4 in.

Road fill.

Muck and peat

Sand and marl.

Shell marl, darik-gray, sandy.

Sand, quartz, gray-white, fine.

Sandstone, calcareous, hard, containing both n.drine and fresh-water fossils.

Probably alternating marine and fresh-twater beds....................................

Sand, quartz, very fine, shelly in places, Low permeability...........................

Sand, quartz, shelly, fine, and some nodular sandstone.

Sand, quartz, gray, very fine, contalning a few shell tragments. Low permeability.

Sandatone, calcareous, shelly, soft.

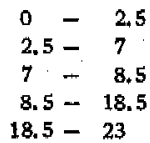

\section{Well GS 12}

Location: Sec. 6, T. 47 S., R. 41 E. Approximately 6 miles west of Florida Highway 7, and 4 miles north of Hillsboro Canal.

Elevation of land surface: Approximately $15.5 \mathrm{ft}$ above mean sea level.

Depth: $50 \mathrm{ft}$.

Diameter: 4 in.

Peat

Marl, white, sandy, of fresh-water origin Practically impermeable...............

Sandstone, dark-gray, calcareous, a few marine shella

Shell mat1, eandy, containing both marine and fresh-water fossils. Low per-

meability.

Sand, quartz greenish-gray, shelly and some nodular sandgtone, Low permeability

Sand and shells, gray, and dark-gray calcareous sandstone.......+.+............

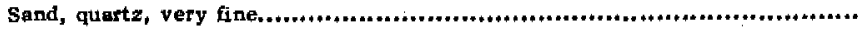

Shell marl, consolidated to shelly limest one in places.

$0-13.5$
$13.5-14.5$
$14.5-16.5$
$16.5-30$
$30-36$
$36-40$
$40-47$
$47-50$


Table 133, - Logs of wells in Palm Beach County-Continued

\section{Well GS 24}

Location: SE $1 / 4$ SW $1 / 4$ sec. 14, T. 41 S., R. 41 E., 3.6 miles north of Canal Point on Florida Highway 15.

Elevation of land surface: Approximately $16 \mathrm{ft}$ above mean sea level.

Depth: $70 \mathrm{ft}$.

Diameter, 4 in.

Depth, in feet

below land surface

Muck and peat

$0-12.5$

Marl, dark-gray, and few shells.

$12,5-15$

Limestone, light-gray, hard....................................................................

$15-23.5$

Sandatone, calcareous, shelly, with lenses and pockets of quartz sand..............

$23.5-43.5$

Sand, quartz, fine, and few ghell fragmenis..............................................

$43.5-45$

Shell bod and medium to coarse quart $z$ sand, Shell make up approximately 60 to

70 percent of sample. Small amount of shelly calcareous sandstone..t.t. $\ldots .+\ldots . . . .$.

Marl, greenish-gray, shelly, sandy. Low permeability.

$45-65$

$65-70$

\section{Well GS 25}

Location: Sec. 20, T, 42 S., R. 37 E., 0,3 mile east of Florida Highway 15, and 2 miles south of Pahokee.

Elevation of land surface: Approximately $15.5 \mathrm{ft}$ above mean sea level.

Depth: $59 \mathrm{ft}$.

Diameter: 4 in.

Depth, in teet batow land surface

Peat......................................................................................

Mar1, gray, of fresh-water origith....................................................

Shell bed and quartz sand............................................................

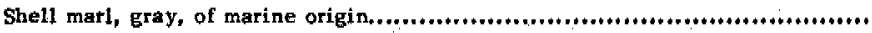

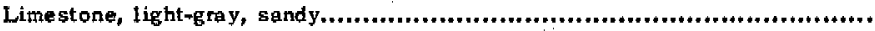

Shell bed, dark-gray, and $\mathrm{s}$ ome matl and quartz sand................................

Sandstone, Iight to datk-gray, calcareous, shelly, and some quart $z$ sand..........

Marl, gray, shelly, sandy, and some nodular, shelly, calcareous sandstore.

Low permeabillty.

$0-11.5$

$11.5-15$

$15-18$

$18-27$

$27-30$

$30-34.5$

$34.5-45$

$45-59$

\section{Well GS 26}

Location: T. 42 S., R. 36 E. On northem tip of Kreamer Island, 8 miles northwest of Belle Glade.

Elevation of land surface: Approximately $14 \mathrm{ft}$ above mean sea level.

Depth: $91.5 \mathrm{ft}$.

Diameter: 4 in.

Depth, in feet below land surface 
Table 133. - Logs of wells in Palm Beach County-Continued

Well GS 26-Continued

Depth, in feet

below land surface

Marl, white, chalky.

$9-12.5$

Limestone, dark-gray, nodular, and marl $+\ldots+\ldots+\ldots+\ldots+\ldots+\ldots \ldots+\ldots+\ldots+\ldots+t+\ldots+\ldots+\ldots+\ldots+\ldots+\ldots+\ldots$,

$12,5-14,5$

Shell marl, gray, and some nodular calcareous sandstone..............................

$14,5-25$

Sandatope, gray, calcareous, shelly, hard..............................................

$25-40$

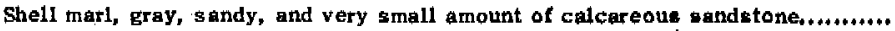

$40-82$

Sand, quartz, gray, medium to coarse, and a few shell fragments......................

$82 \ldots 91.5$

\section{Well GS 27}

Location: Sec. 34, T. 43 S., R. 35 E., 1.7 miles northwest of Lake Harbor on Florida Highway 80 .

Elevation of land surface: Approximately $16.5 \mathrm{ft}$ above mean sea level.

Depth: $56.5 \mathrm{ft}$.

Diameter: $4 \mathrm{in}$.

Depth, in feet

below land surface

Muck and peat.

$0-8.5$

Marl, gray, Indurated, of fresh-water origin.................................................

$8.5=9$

Shell marl and shell beds, contalning both fresh-water and marine fossils ...........

Sandstone, calcareous, shelly, nodular, and shelly sand....

$9-18.5$

Sand, quartz, and shells. Low permeability.............................................

Sand; quattz, marly, and thin layers of calcareous sandatone between 34 and $39 \mathrm{ft}$.

Low pertneabthity..

$18.5-23.5$

$23,5-27,5$

Shell bed, containing varying amounte of quartz sand and marl, Low permeabillty.

$27.5-46$

$46-56.5$

\section{Well PB 93}

Location: $\mathrm{SE}^{1 / 4 \mathrm{NW}^{1 / 4}}$ sec. 21 , T. 44 S., R. 43 E. 8th Avenue North, 0.1 mile west of A St., Lake Worth.

Elevation of land surface: $14 \mathrm{ft}$ above mean sea level.

Depth: $95 \mathrm{ft}$.

Diameter. 6 in.

Depth, in feet

bolow land surface

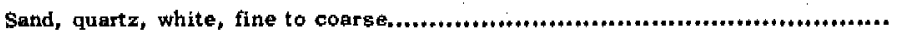

Sand, quartz, white, with shell fragments, and a large amount of nodular, shelly,

calcareous sandstone. Medium permeability..........................................

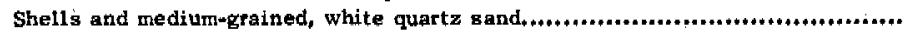

Sand, quartz, gray, fine to medium, with very few shell fragments...................

Shells and fine-grained, white to tan quart $z$ sand.

$$
\begin{aligned}
& 0-20 \\
& 20-57 \\
& 57-69 \\
& 69-80 \\
& 80-95
\end{aligned}
$$


Table 133. - Logs of wells in Palm Beach County-Continued

\section{Well S 394}

Location: NE $1 / 4 \mathrm{SW} 1 / 4$ sec, 21, T. 46 S., R. $43 \mathrm{E}, 300 \mathrm{ft}$ west of Swinton Avenue, and $200 \mathrm{ft}$ southwest of ground storage tank, Delray Beach well field.

Elevation of land surface: $20 \mathrm{ft}$ above mean sea level.

Depth: $216 \mathrm{ft}$.

Diameter, 10 to 16 in.

Depth, in feet

below land surface

Sand, quartz.

$0-42$

Sandstone, calcareous......................................................................

Coquina, coarse...

$42-42.5$

Sandstone, calcareous, and coquina

$42.5-43$

Sandstone, ealcareous, and shells

$43-67$

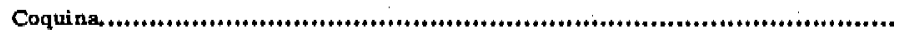

Limestone, chalky.......................................................................

$67-93$

$93-108$

Sandstone, calcareous..............................................................

$108-108.5$

Sand, quart $z$, and shells....................................................4....... $109-135$

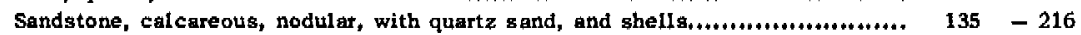


Table 134. - Log of well in St. Lucie County

\section{Well St. L 4}

Location; City of Fort Pierce well field, $30 \mathrm{ft}$ east of City supply well 3.

Elevation of land surface: $25 \mathrm{ft}$ above mean sea level.

Depth: $135 \mathrm{ft}$.

Diameter: $2 \frac{1}{2}$ in.

Depth, in feet

below land surface

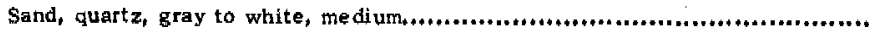

Sand, quartz, light-tan, medium to coarse...........................................

Sand, quartz, dark-brown, weakly cemented, forming "hardpan.".

$0-10.5$

$10.5-16.0$

Sand, quartz, dark-brown to black, carbonaceous, Water from this interval is highly colored.

$16.0-21.0$

Sand, quartz, dark-reddish-brown, medium to coarse. Water is very highly colored. ......

$21.0-38.0$

Alternating layers of dark-gray, sandy, marl, gray, cquartz sand, and clayey mar1. Practically impermeable. Acts as an aquiclude.............................

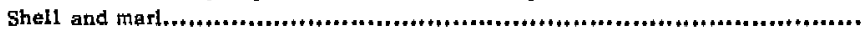

Sand, quartz, gray, fine, and some shells. Also, considerable amount of organic matetial of deep reddish-brown color; probably old mangrove awamp. Low permeability.

Sand, quartz, dark-gray, fine, approximately 20 percent of sample composed of

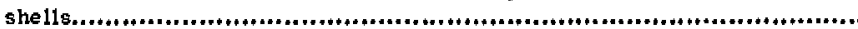

Shell bed, dark-gray, with small amount of quartz sand, and marl..................

Shell marl, dark-gray, sandy.........................................................

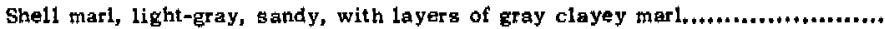

Shell mart, dark-gray sandy, and small amount of soft calçareous sandstone,

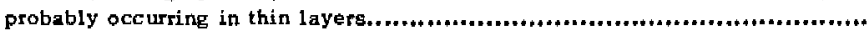

Marl, green, sandy, shelly, with small amount of soft calcareous sandstone.......

$38.0-60.0$

$60.0-74.0$

$74.0-75,0$

$75.0-79.0$

$79.0-90.5$

$90.5-104$

$104-112$

$112-122$

$122-133$

$133-135$ 
Table 135.-Municipal water supplies in Broward County

Dania

\section{Population in 1945: \\ Source and date of information:}

Ownerghip:

Source of supply:

\section{Pumpage (esti- mated):}

\section{Storage:}

Treatment;

Analysts:

Population in 1945:

\section{Source and date of} information:

Ownership:

Soturce of supply:

\footnotetext{
Pumpage (estimated);
}

Storage:

\section{2,979}

Paul Heckert, water plant superintendent, March 1948 ,

Municipal.

Three wells.

Well 1. 1st Avenue $s W$, and 1st Street. Depth, 60 to $65 \mathrm{ft}_{\text {; diameter, }}$ $8 \mathrm{in}$; type, open; equipped with 400-gpm turbine pump and $7 / \mathrm{rhp}$. electric motor; static water level, 8.0 ft below land surface, September 19, 1947.

Well 2. Beach Boulevard and 1st Aventue SW. Depth 60 to $65 \mathrm{ft}$; diameter, 6 in, type, open; equipped with 750- $\mathrm{gpm}$ centrifugal pump and Buick motor; static water level approximately the same as well 1 .

Well 3. Parker Street sw, and 3rd Avenue; well drilled in 1948 and not yet in service.

Average $400,000 \mathrm{gpd}$ in 1946 .

Ground reservoir: 163,000 gals. Elevated tank; 200,000 gals.

Aeration and chlorination.

See section on Quality of ground and surface watere.

\section{Deerfield Beach}

2,008

Mr. Hutchkinson, plant operator, March 1948.

Municipal.

Two wells.

Well t. $50 \mathrm{ft}$ north of ground reservoir, NW. 1st Street and 1st Avenue. Depth, $72 \mathrm{ft}$; diameter, 6 in,; Type, open.

Well 2. $50 \mathrm{ft}$ west of well 1. Drilled in 1947; depth, $72 \mathrm{ft}$; diameter, 8 in, type, open; equipged with $300-\mathrm{gpm}$ centrifugal pump and 5-hp. electric motor.

Average 300,000 gpd in 1946.

Elevated tank: 100,000 gals. 
Table 135.+-Muticipal water supplies in Broward County-Continued Deerfield Beach - Continued

Treatment:

Analysis:
Aeration

See section on "Quality of ground and gurface waters,"

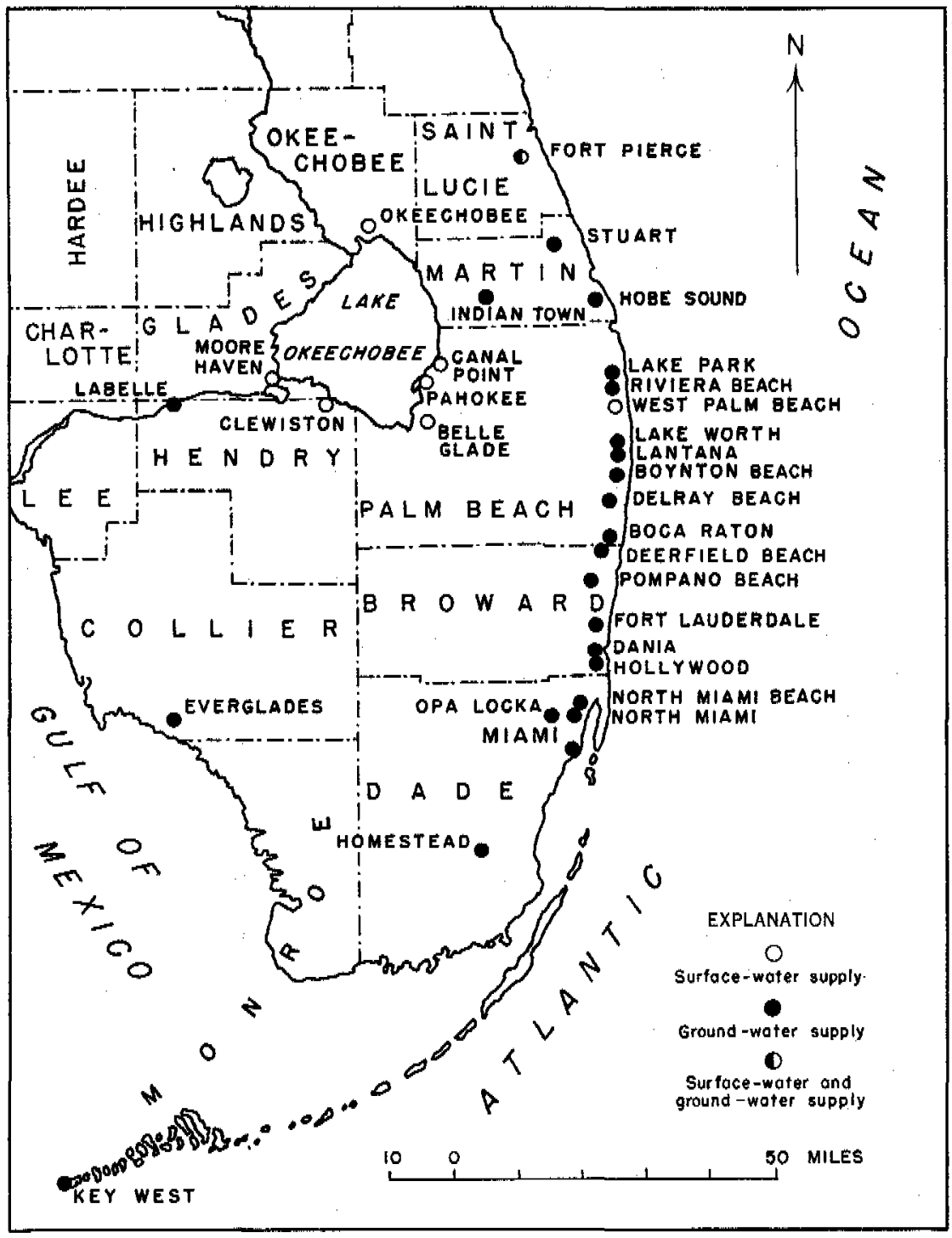

Figure 223. - Index map showing municipal water supplies in southern Florida. 
Table 135. - Municipal water supplies in Broward County-Continued

rort Lauderdale

Population in 1945:

Source and date of information:

Ownership:

Source of supply:
26.185

Charles Fiveash, water plant superintendent, March 1948.

Municipal.

Twelve wells.

Well 1. Fort Lauderdale Golf Course. This well does not contribute to the City supply but is used exclusively fot watering the golf course. It was drilled and developed in the same manter as well 2

Wells $2,3,4,5$, and 6 . Fort Lauderdale Golf Course, approximately 7 miles from the Atlantic Ocean and $1 \frac{1}{4}$ miles north of the North New River Canal. Drilled in 1927; depth, $90 \mathrm{ft}$; easing set approximately $80 \mathrm{ft}$ below land surface, with $10 \mathrm{ft}$ of open hole below bottom of casing; deepened in 1940 to $135 \mathrm{ft}$; $35 \mathrm{ft}$ of screen instatled with 10 $\mathrm{ft}$ of blank pipe below the screen; gravel-packed; diameter, 12 in; 400 -epm centrifugal pumps and $7 \frac{1}{2}$ hp-electric motors.

We11 7. Fort Lauderdale Golf Course; drilled in 1940; depth, $115 \mathrm{ft}$; 12-in. casing seated $80 \mathrm{ft}$ below land surface with $35 \mathrm{ft}$ of 6 -in, screen below the casing; gravel-packed; 500-gpm deep-well turbine pump and 10-hp electric motor.

Well 8. Fort Lauderdale Golf Course. Drilled in 1940; depth, $97 \mathrm{ft}$; 12-in. casing seated $62 \mathrm{ft}$ below land burface with $35 \mathrm{ft}$ of 6-in. soreen below bottom of casing; gravel-packed; $500-\mathrm{gpm}$ deep-well turbine pump and $10 \mathrm{mp}$ electric motor.

Wells 9 and 10. Fort Lauderdale Golf Course. Drilled in 1945; depth, $115 \mathrm{ft}$; diameter, $12 \mathrm{in.}$; casing set approximately 80 feet below land surface with $35 \mathrm{ft}$ of screen below casing; gravel-packed; deep-well turbine pumps and 10 -hp electric motors.

Well 11. $100 \mathrm{ft}$ east of water plant. Drilled in 1947; depth, $136 \mathrm{ft}$; diameter, $10 \mathrm{in}$; easing seated $125 \mathrm{ft}$ below land surface with $12 \mathrm{ft}$ of open hole below bottom of cesing; 600-gpm deep-well turbine pump and 15 -hp electric motor, reported yield, $675 \mathrm{gpm}$ with a drawdown of $11 \mathrm{ft}$.

Well 12. $100 \mathrm{ft}$ east of water plant. Drilled in 1927; depth, $102 \mathrm{ft}$; diameter, 12 ith; casing seated $92 \mathrm{ft}$ below land surface with $10 \mathrm{ft}$ of open hole below bottom of casing. In 1940 , 35 ft of screen was installed below casing; gravel-packed; $400-\mathrm{gpm}$ centrifugal pump and $71 / 2$ hp-electric motor.

Averape pumpage (spd)

\begin{tabular}{|c|c|}
\hline $1930 . \ldots \ldots \ldots$ & $1939 \ldots \ldots \ldots \ldots \ldots \ldots \ldots, 670,000$ \\
\hline $1931 \ldots \ldots \ldots \ldots \ldots \ldots \ldots \ldots . . \ldots 55,000$ & $1940 \ldots \ldots \ldots \ldots \ldots \ldots \ldots 1,877,000$ \\
\hline $1932 \ldots \ldots \ldots \ldots \ldots \ldots+\ldots, \ldots, \ldots 00$ & $\ldots 2,230,000$ \\
\hline $1933, \ldots \ldots \ldots \ldots \ldots \ldots \ldots+\ldots, 69,000$ & $1942 \ldots \ldots \ldots \ldots \ldots \ldots \ldots 2,390,000$ \\
\hline $1934, \ldots \ldots \ldots \ldots \ldots$ & $\ldots . .3,010,000$ \\
\hline $1935, \ldots \ldots \ldots \ldots \ldots+\ldots \ldots+\ldots, 960,000$ & $1944, \ldots \ldots+\ldots \ldots \ldots \ldots 3,765,000$ \\
\hline $1936, \ldots \ldots \ldots \ldots \ldots \ldots$ & $1945 \ldots \ldots \ldots \ldots \ldots \ldots \ldots 3,810,000$ \\
\hline $1937 \ldots \ldots \ldots \ldots \ldots \ldots 1,295,000$ & $1946 \ldots \ldots \ldots \ldots \ldots \ldots, 190,000$ \\
\hline
\end{tabular}

Storage:

Ground reservoir: $3,750,000$ gals. Elevated tanks: $1,050,000$ gals.

Aeration, lime-silica, filtration, chlorination. 
Table 135. - Municipal water supplies in Broward Coupty-Continued

\section{Hollywood}

\author{
Population in 1945: \\ Source and date of \\ information:
}

Ownerghip:

Source of supply:

Storage:

Treatment:

Analysis:

Population in 1945:

Source and date of infórmation:

Ownership:

Source of supply:
Purpage (esti-
mated);

Storage:

Treatment:

Analysis:

\section{7,740}

R. F. Armstrong, water plant superintendent, March 1948.

Municipal.

Five wells.

Wells located from 5 to 500 ft north of water plant, which is on Hollywood Boulevard, epproximately 2 miles west of U. S. Highway 1. Depth, $70 \mathrm{ft}$; diameter, 10 to $12 \mathrm{in.}$; type, open; two wells equipped with 650 - and 700-gpm turbine pumps and 20-hp electric motors; two with $900-\mathrm{gpm}$ centrifugel pumpe and 20-hp electric motors; one with 1,000, tpm centrifugal pump and 75-hp electric motor static water level, $10.5 \mathrm{ft}$ below land surface, March 29, 1948.

Two salt-water wells on Hollywood Beach; depth, $80 \mathrm{ft}$; diameter, 12 in, : equipped with 300 gpm centrifugal pump and $71 / 2^{-m}$ and $15-h p$ electric motors; salt water is used for zeolite regeneration.

\begin{tabular}{|c|c|}
\hline \multicolumn{2}{|c|}{ Average pump age ( $g p d)$} \\
\hline$+4+4+4++\ldots \ldots \ldots 740,000$ & $1944 \ldots .$. \\
\hline $1942 \ldots \ldots \ldots \ldots \ldots \ldots \ldots \ldots 22,000$ & 1945. \\
\hline 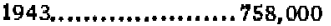 & 1,145 \\
\hline
\end{tabular}

Ground reservoir: 1,000,000 gals. Elevated tank; 960,000 gals.

Aeration, chlotination, and zeolite softening,

See section on Quality of ground and surface waters.

\section{Pompano Beach}

2,445.

W. E. Smith, water plant superintendent, March 1948.

Municipal.

One well adjacent to pumping station. Depth, $170 \mathrm{ft}$; diameter, 12 in ; type, open; equipped with 750 -gpm centrifugal pump and 60 -hp electric motor; emergency stand-by10-hp gasoline motor with 200 gpm centrifugal pump; static water level, $12 \mathrm{ft}$ below land surface, March 29, 1948.

Average $328,000 \mathrm{gpd}$ in 1946.

Elevated tank: 300,000 gals.

None

See section on Quality of ground and surface waters. 
Table 136.-Municipal water supplies in Collier County

\section{Everglades}

Population in 1945:

\section{Source and date of} information:

Ownership:

Source of supply:

Pumpage (estimated);

Storage:

Treatment:

Analysis:
629

E. L. Lezotte, chief engineer, Everglades Railway, Light and Power Company, March 1948 .

\section{Collier Comoration.}

Three wells,

Well. 1. 0.5 mile south of water plant and $500 \mathrm{ft}$ west of Collier County Court Ilouse. Depth, $640 \mathrm{ft}$; diameter, 4 in, typc, open; natural flow, $80 \mathrm{gpm}$ (reported), and 22 pounds pressure at land surface; $300-\mathrm{gpm}$ centrifugal pump with $20 \mathrm{hp}$ electric motor pumps water from all three wells to ground reservoir at water plant.

Well 2, $150 \mathrm{ft}$ NW. of well 1. Depth, $640 \mathrm{ft}$; diameter, $4 \mathrm{in}$; thatural flow, 60 gpm (reported), and 21 pounds pressure at land surface.

Weil 3. $150 \mathrm{ft}$ north of well 1 ; depth, $640 \mathrm{ft}$; diameter, $6 \mathrm{in}$; type, open; natural flow, 120 gpm (reported).

Average 130,000 gpd in 1946.

Ground reservoir: 300,000 gals. Elevated tank: 75,000 gals.

Chlorination.

See section on Quality of ground and surface waters. 


\section{Table 137.-Municipal water supplies in Dade County}

Homestead

\author{
Population in 1945: \\ Source and date of \\ information:
}

Ownership:

Source of supply:

\section{Pumpage (esti- mated):}

Storage:

Treatment:

Analysis:

Population in 1945:

Source and date of information:

Ownership:

Source of supply:
G. W. Ivy, water plant superintendent, March 1946.

Municipal,

Two wells.

Well 1. East side of Ilomestead Power and Light Plant; depth, $65 \mathrm{ft}$; diameter, $10 \mathrm{in}$; type, open; equipped with 650mpm centrifugal pump and 30 -hp electric motor; static water level, 7.0 ft below land surface, March 31, 1948; emergency stand-by, 1,500-gpm centrifugal pump and 150- hp electric motor.

Well 2, 11/2 miles north of well ti depth, $65 \mathrm{ft}$; diameter, $12 \mathrm{in}$; 6 -in. drop line to $20 \mathrm{ft} ; 650$-epm centrifugal pump and 30 -hp electric motor.

Average $800,000 \mathrm{gpd}$ in 1946.

Elevated tank; 100,000 gals.

None.

See section on Quality of ground and surface waters.

Miami

245,577 (Miami, Miami Beach, Coral Gables; Iiialeah, Miami Springs, E1 Portal, Miami \$hores, Surfside, and Biscayne Park).

W. L. Black, water plant superintendent, March. $19 \dot{9} 48$.

Municipal.

Twenty-two wells.

Well 1. Lower well field, Miemi Springs Golf Course, approximately 1 mile south of water plant; drilled in 1923; depth, $67 \mathrm{ft}$; diameter, 14 in.; casing seated $60 \mathrm{ft}$ below land surface with $7 \mathrm{ft}$ of open hole below bottom of casing; 5,000-gpm centrifugal pump and 75-hp electric motor. Yield, 6 million gpd with drawdown of $7.6 \mathrm{ft}$, as determined by a pumping test run November 19 to 26,1926 ; water level, $7,6 \mathrm{ft}$ below land surface, May 27, 1948.

Well 2. $800 \mathrm{ft}$ sW. of well 1; drilled in 1924; depth, $96 \mathrm{ft}$; diameter, 12 in.; casing seated $79 \mathrm{ft}$ below land surface with 17 it of open hole below bottom of casing; 2,500 -gpm centrifugal pump and $40-\mathrm{hp}$ electric motor, water level, $8.6 \mathrm{ft}$ below land surface, May 27, 1948.

Well 3. 1,000 ft NW. of well 1; drilled in 1924; depth, $62 \mathrm{ft}$; diameter, 12 in.; casing seated $52 \mathrm{ft}$ below land surface with $10 \mathrm{ft}$ of open hole below bottom of casing; 2,500-gpm centrifugal pump and 40-hp electric motor; water level, $9.5 \mathrm{ft}$ below Iand surface, May 27, 1948.

Well 4, $600 \mathrm{ft}$ noth of well 1 ; drilled in 1924; depth, $94 \mathrm{ft}$; diameter, 12 in, casing seated 83 ft below land surface with 11 ft of open hole below bottom of casing; $2,500 \cdot \mathrm{gpm}$ centrifugal pump and $40-\mathrm{hp}$ electric motor; water level, $8.2 \mathrm{ft}$ below land surface, May 27, 1948. 
Table 137.-Municipal water supplies in Dade County-Continued

\section{Miami-Continued}

Well 5, 1,700 ft NW. of well 1; drilled in 1924; depth, $100 \mathrm{ft}$; diatneter, 14 in.; casing seated $82 \mathrm{ft}$ below land surface with $18 \mathrm{ft}$ of open hole below bottom of casing; 2,500-gpm centrifugal pump and 40 mp electric motor; water level, 8.8 ft below land surface, May 27, 1948.

Well 6. About 2,500 ft west of well 1 ; drilled in 1924; depth, $62 \mathrm{ft}$; diameter, $14 \mathrm{in}$; casing seated $49 \mathrm{ft}$ below land surface with $13 \mathrm{ft}$ of open hole below bottom of casing; 2,500-gpm centrifugal pump and 40-hp electric motor; water level, 8.9 ft below lend surface, May 27, 1948 .

Well 7. About $3,800 \mathrm{ft} \mathrm{SE}$. of well 1; drilled in 1924; depth, $62 \mathrm{ft}$; diameter, $14 \mathrm{in}$; casing seated $48 \mathrm{ft}$ betow land gurface with $14 \mathrm{ft}$ of open hole below bottom of casing; 2,500-gpm centrifugal pump and 40 hp electric motor; water level, 8,8 ft below land surface, May 27 , 1948 .

Well 8. About 2,100 ft SE. of well I; drilled in 1924; depth, $64 \mathrm{ft}$; diameter, $12 \mathrm{in}$; casing seated $50 \mathrm{ft}$ below land surface with $14 \mathrm{ft}$ of open hole below bottom of casing; 2,500-gpm centrifugal pump and 40 hp electric motor; water level, $7.5 \mathrm{ft}$ below land surface, May 27, 1948.

Wells 9 and 10. Moore Fark, NW. 36th street and 8th Avenue; drilled in 1925; depth, 98 and $145 \mathrm{ft}$; diameter, 14 ith; casing seated 88 and $116 \mathrm{ft}$ below land surface with 10 and $29 \mathrm{ft}$ of open hole below bottom of casing; 2,500 gpm centrifugal pumps and 40mp electric motors; stand-by wells.

Wells 11, 12, and 13. At Water Plant, liialeah; drilled in 1928; depth, 55 to $91 \mathrm{ft}$; diameter, $14 \mathrm{in}$; casing seated 43 to $85 \mathrm{ft}$ below land surface with 6 to 12 ft of open hole below bottom of casing $2,500 \mathrm{gmm}$ centrifugal pumps and 40 -hp electric motors.

Wells 14,$15 ; 16$, and 17 . Upper well field, approximately 0.2 to 0.6 mile west of Water Plant, lialeah; drilled in 1936; depth, 73 to $91 \mathrm{ft}$; diameter, $14 \mathrm{in}$; casing seated from 67 to $79 \mathrm{ft}$ below land surface with 6 to $13 \mathrm{ft}$ of open hole below botton of casing; 2,500 -gpm centrifugal pumps and 40 -hp electric motors; water level, $6.4 \mathrm{ft}$ below land surface, May 27, 1948.

Wells $18,19,20,21$, and 22 Upper well field, approximately 0.6 to 0.9 mile west of Water Plant, IIIaleah; drilied in 1945; depth, 90 to 94 $\mathrm{ft}$; diarteter, 14 in.; casing seated 80 to 86 ft below land surface with 7 to. $10 \mathrm{ft}$ of open hole below bottom of casing; $2,500 \mathrm{mpm}$ centrifugal pumps and 40 -hp electric motor.

Storage:

1936

$14,220,000$

$15,147,000$

\begin{tabular}{|c|c|}
\hline \multicolumn{2}{|c|}{ A verage pumpage (spd) } \\
\hline $1926_{4} \ldots \ldots \ldots \ldots \ldots \ldots \ldots \ldots 12,684,000$ & $1937 \ldots \ldots \ldots \ldots \ldots \ldots \ldots+4,16,946,000$ \\
\hline $1927 \ldots \ldots \ldots \ldots \ldots \ldots \ldots \ldots 12,631,000$ & $\ldots \ldots \ldots \ldots \ldots 17,845,000$ \\
\hline $1928 . \ldots \ldots \ldots \ldots \ldots \ldots 10,056,000$ & $1939, \ldots \ldots \ldots \ldots \ldots \ldots 19,574,00$ \\
\hline$\ldots 9,707,000$ & $\ldots 22,486,0$ \\
\hline $1930 \ldots \ldots \ldots \ldots \ldots \ldots \ldots 10,253,000$ & $1941, \ldots \ldots \ldots \ldots \ldots \ldots 23,536,00$ \\
\hline $1931 \ldots \ldots \ldots \ldots \ldots \ldots \ldots 11,352,000$ & $1942, \ldots \ldots \ldots \ldots \ldots \ldots \ldots 24,508,0$ \\
\hline \#11,876,000 & $\ldots 27,911,0$ \\
\hline $1933 \ldots \ldots \ldots \ldots \ldots \ldots 11,520,000$ & $1944, \ldots \ldots \ldots \ldots \ldots \ldots \ldots 30,611,00$ \\
\hline $1934 \ldots \ldots \ldots \ldots \ldots \ldots \ldots 12,208,000$ & $1945, \ldots \ldots \ldots \ldots \ldots \ldots \ldots \ldots 33,903,0$ \\
\hline $1935 \ldots \ldots \ldots \ldots \ldots \ldots 14,220,000$ & $1946 . \ldots \ldots \ldots \ldots \ldots \ldots . \ldots, 36,596,00$ \\
\hline
\end{tabular}

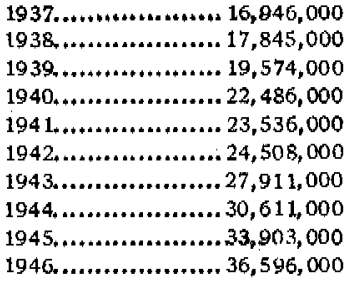

Elevated tank; 1,000,000 gals,; four conctete ground reservoirs, $2,500,000 \mathrm{gals}$, each; and four steel groutd reservoirs, 2,500,000 gals. each. Not included are the storage facilities maintained by other municipalities using the Miami supply.

Chlorination, filtration, lime, and soda-gsh 
Table 137.-Municipal water supplies in Dade County -Continued

North Miami

Population in 1945:
Source and date of
information:

Ownership:

Source of supply:

Pumpage (estimated):

Storage:

Treatment:

Analysis:

Population in 1945:

Soturce and date of information:

Ownership:

Source of supply:

Storage:

Treatment:

Analysis:
2,776

D. W. Jones, superintendent of Public Works, March 1948.

Municipal.

Two wells.

Well 1. NE, 125th Street and $200 \mathrm{ft}$ east of 8th Aventue; depth, $60 \mathrm{ft}$; diameter, 8 in, ; 750-gpm centrifugal pump and 15-hp electric motor; type, open; emergency stand-by, 500-gpm pump and Chrysler motor.

Well 2. 55 ft east of well 1; depth, $60 \mathrm{ft}$; diameter, 8 in; type, open; 400-gpm centrifugal pump and $7 / 2-h p$ electric motor.

Average 400,000 gpd in 1946.

Ground teservoir: 150,000 gals. Elevated tank: 60,000 gals.

Aeration and chlorination, and lime.

See section on Quality of ground and surfece waters.

\section{North Miami Beach}

1,082

W. Oeffler, water plant superintendent, March 1948.

Sunny Isles Water Company.

Two wells.

Located 1 mile west of Sunny Isles water plant; depth, $80 \mathrm{ft}$; diameter, $8 \mathrm{in}$, and $6 \mathrm{in}$. (stand-by); 8 -in. well semi-gravel-packed for $7 \mathrm{ft}$; 6-in. well open; deep-well 500-gpm turbine pump and 20-hp electric motor; emergency stand-by, $500 \mathrm{mgm}$ centrifugal pump and gasoline motor; static water level, $10 \mathrm{ft}$ below land surface, March 29, 1948.

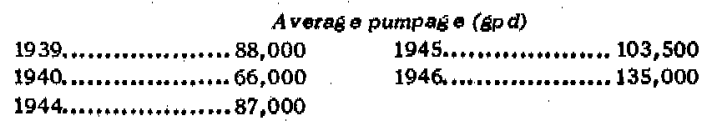

Ground teservoir; $150,000 \mathrm{gals.}$

Chlorination, lime, soda, silica, and sulfuric acid.

See section on Quality of ground and surface waters.

\section{Opalocka}

Population in 1945:

1,855

Source and date of information:
11. C. Weber, water plant superintendent, March 1948. 
Table 137.-Municipal water supplies in Dade County-Continued

Opalocka-Continued

Ownership:

Source of supply:

Pumpage (estim mated):

Storage:

Treatment:

Analysis;
Municipal.

Two wells.

Well 1. Northe ast corner of aerator, between Burington St. and Seaboard Air Line Railfoad; depth, $59 \mathrm{ft}$; diameter, 6 in,; 4-in. drop line to $20 \mathrm{ft}$; $500-\mathrm{EPm}$, centrifugal pump and $7 / / \mathrm{hp}$ electric motor; static water level, 7.5 ft below land surface, March 30,1948 .

Well 2. East side of earator, $30 \mathrm{ft}$ south of well 1; depth, $58 \mathrm{ft}$; diameter, $6 \mathrm{in}$; 4 -in drop line to $20 \mathrm{ft} ; 300$-gpm centrifugal pump and 10hp electric motor; static water level same as well 1.

Emergency stand-by, 500-gpin centrifugal pump and gasoline motor.

Average 200,000 gpd, in 1946.

Elevated tank, 75,000 gals.

Aeration, chlorination, ammoniation, and lime alum,

See section on Quality of ground and surface waters. 
Table 138. - Municipal water supply in Glades County

\section{Moore Haven}

\section{Population in 1945: \\ Source and date of information:}

Ownership:

Source of supply:

Pumpage (esti-
mated):

Storage:

Treatment:

Analysis:
599

E. Lundy, water plant superintendent, March 1948.

Municipal.

Lake Okeechobee; approximately 1,000 ft north of water plant; intake line in dredged channel extending into Lake Okeechobee; intake, centrifugal pump and 15-hp electric motor; discharge, 180-gpm centrifugal pump and electric motor.

Average 100,000 gpd in 1946.

Elevated tank, 50,000 gals,

Aeration, chlorination, hydrated fime, aluminum sulfate, and filtration. See section on Quality of ground and $s$ urface waters. 
Table 139.-Municipal water supplies in Ilendry County.

\section{Clewiston}

Population in 1945:

Source and date of information:

Ownership:

Source of supply:

Pumpage (estimated):

Storage:

Treatment:

Analysis:

Population in 1945:

Source and date of information:

Owner:

Source of supply:

\section{Pumpage (esti- mated):}

Storage:

Tteatment:

Analysis:
1,917

W. L. Brantiey, Jr., city engineer; and S. J. Finley, water plant operator, March 1948.

Municipal.

Lake Okeechobee; $500 \mathrm{ft}$ north of water plant; 12-in, intake line extends approximately $1 / 2$ mile into Lake Okeechobee; two 180-gpm centrifugal pumps with 5 -hp motors connected to intake line; discharge, two 180-gpm centrifugal pumps and 15-hp motors.

Average 170,000 gpd in 1946.

Elevated tank, 75,000 ral $\mathrm{s}$.

Chlorination, aeration, aluminum sulfate, hydrated lime, and activated carbon.

See section on Quality of ground and sufface waters.

\section{LaBelle}

848

Mrs. Ilall, and R. W. Davenport, Mayor, March 1948 .

Mrs, Hall,

Well 0.4 mile north of Florida Highway 80 , one block east of Florida Ilighway 78 , and 250 ft south of Caloosahatchee River; drilled between 1915 and 1920 ; depth, $602 \mathrm{ft}$; diameter, 6 in.; flowing well; flows directly. into distribution main under its own pressure.

5,000 gpd in 1946. This is supplemented by geveral private wells.

None.

None.

See section on Quality of ground and surface waters. 


\section{Table 140.-Municipal water supplies in Martin County}

\section{Hobe Sound}

\begin{abstract}
Population in 1945:
Source and date of information:
\end{abstract}

Owner:

Source of supply:

\section{Pumpage (eati- mated):}

Storage:

Treatment:

Analysis:

Population in 1945;

\section{Source and date of} information:

Owner:

Soutce of supply:

\section{Pumpage (esti- mated);}

Storage:

Treatment:

Analyais:
749

Albert King, water plant superintendent, March 1948.

Hobe Sound Company.

Three wells.

Wells located $200 \mathrm{ft}$ east of U. S. Ilighway 1 and 0.25 mile northwest of pumping station; depth 78 to $117 \mathrm{ft}$; diameter, $12 \mathrm{in}$; type, open; 250-gpm deep-well turbine pumps and electric motots; two booster pumps (275-gpm centrifugal pumps) and 5-hp electric motors; static water level, approximately $10 \mathrm{ft}$ below land surface, March 24, 1948 .

Average $200,000 \mathrm{gpd}$ in 1946.

Ground teservoir: 440,000 gals. Elevated tank: 75,000 gals. None.

See section on Quatity of ground and surface waters.

\section{Indian Town}

475

W. F. Fortune, water plant operator, March 1948 .

Indian Town Development Corporation.

10 wells.

Five wells on west side of water plant connected in manifold and five on southwest aide connected in manifold; depth, 25 to $30 \mathrm{ft}$; diameter, 2 in, type, open; one 140-gpm centrifugal pump with 3 -hp electric motor is used to pump all wells; similar pump and motor used as standby.

75,000 gpd during winter season; 60,000 gpd during gummer, in 1946 .

Ground reservoir: 56,000 gals. Elevated tank: 80,000 gels.

Aeration, chlorination, and lime-goda abh

Ses section on Quality of ground and surface waters.

Stuart

Population in 1945: 2,516

Source and date of information:

F. J. Walton, water plant superintendent, March 1948. 
Table 140.-Municipal water supplies in Martin County-Continued

Stuart $=$ Continued

Source of supply:

Three wells.

One well is in water plant, another is $75 \mathrm{ft}$ north of plant, and the third is $75 \mathrm{ft}$ south of plant; depth, 75 to $85 \mathrm{ft}$; diameter, $6 \mathrm{in}$; $6 \mathrm{ft}$ of screen in bottom section of each well; two 200-gpm centrifugal pumps with 5 hp electric motors; static water level, approximately 14 ft below land surfece, March 24, 1948.

Pumpage (estimated):

Average 135,000 gpd in 1946.

Storage:

Ground reservoir: 40,000 gals. Elevated tank: 60,000 gal a.

Treatment:

Aeration, chlorination, and filtration.

Analysis:

See section on Quality of ground and surface waters. 
Table 141.-Muricipal water supply in Monroe County

Key West

Population in 1945 :

Source and date of information:

Owners hip:

Source of supply:

Pumpage (estimated):

Storage:

Treatment:

Analysis:
$14,246$.

T. HI. Griggs, water plant superintendent, and A. C. Ilusband, Public Works officer, U. S. Naval Station, Key West, Florida, June 1948.

Key West Aqueduct Commission.

Three wells.

Located on the mainland adjacent to the pumping station, which is about 2 miles southwest of llomestead, Dade County; two 10-in gravity-feed wells and one 20 -in. well, ranging in depth from 40 to $62 \mathrm{ft}$; type, open; static water level, $7.5 \mathrm{ft}$ below land surface, April 2, 1948.

Average 2,600,000 god in 1946. This supply serves several other Keys.

20,000-galion concrete $\$$ ump with $1,7,50-\mathrm{gpm}$ turbine pump and 50-hp electric motor.

Chlotination, phosphate, and lime.

Sese section on Quality of ground and surface waters. 
Table 142. - Municipal water supply in Okeechobee County

\section{Okeechobee}

Population in 1945;

Source and date of Information:

Ownership:

Source of supply;

\section{Pumpage (estim} mated):

\section{Storage:}

Treatrent:

Analysis:

\section{1,435}

J. R. Minehan, Jr., water plant operator, March 1948.

Municipal.

Lake Okeechobee.

Water plant approximately $500 \mathrm{ft}$ north of Lake Okeechobee; 12-in intake line extends 400 ft into Lake; intake, two 500-gpm centrifugal pumps with $7 / 2$-hp electric motors; discharge, two 250 -gpm centrifugal pumps with 20-hp motors.

Average 225,000 gpd during winter season; $150,000 \mathrm{gpd}$ during summer, 1946.

Elevated tank, 150,000 gals.

Aeration, chlorination, activated carbon, and lime.

See section on Quality of ground and surface waters. 


\section{Table 143.-Municipal water supplies in Palm Beach County}

Belle Glade

\author{
Poptation in 1945: \\ Source and date of \\ information:
}

Ownership:

Source of supply:

\section{Pumpage (esti- mated):}

\section{Storage:}

Treatment:

Analysis:

\section{Population in 1945: \\ Source and date of information:}

Ownership:

Source of supply:

Storage:

Treatment:

Analysis:
4,800

C. It Throop, water plant superintendent, March 1948.

Municipal.

Lake Okeechobee.

Water plant approximately $31 / 2$ miles east of Lake Okechobee and $200 \mathrm{ft}$ south of Ilillsboro Canal; 16-in. intake line extends from plant to Lake; intake, 1,500-gpm centrifugal pump (not in use), 2,100-gpm centrifugal pump (not in use), and 1,050-gpm centrifugal pump in service at present time; discharge, $1,000-\mathrm{gpm}$ centrifugal pump and 50-hp electric motor, and 500-Epm centrifugal pump whth 25-hp electric motot.

Average $650,000 \mathrm{gpd}$ in 1946.

Elevated tank: 50,000 gals.

Chlorination, aeration, alum, activated carbon, and filtration.

See section on Quality of ground and surface waters.

\section{Boca Raton}

\section{1,387}

W. R Eddinget, water plant operator, March 1948.

Muthicipal.

Three wells,

Located 75 to 300 ft from water plent; depth, 106 to $115 \mathrm{ft}$; diameter, $10 \mathrm{in}$; type, open; two wells equipped with $300 \mathrm{kpm}$ centrifugal pumps and $7 \%$ hp electric motors and one well with $1,000-\mathrm{gpm}$ de epwell turbine pump.

\begin{tabular}{|c|c|}
\hline \multicolumn{2}{|c|}{ A verage pumpase (Gpd) } \\
\hline $1930 \ldots+\ldots+\ldots+\ldots+\ldots, 000$ & $1939, \ldots \ldots \ldots \ldots \ldots \ldots$ \\
\hline $1931, \ldots \ldots \ldots \ldots \ldots \ldots+\ldots 101,000$ & $1940, \ldots \ldots \ldots \ldots \ldots \ldots \ldots$ \\
\hline $1932 \ldots \ldots . . .$. & $\ldots \ldots 149,000$ \\
\hline $1933 .+\ldots \ldots \ldots \ldots \ldots \ldots . \ldots 75,000$ & $1942 \ldots \ldots \ldots+\ldots+\ldots+\ldots, 000$ \\
\hline $1934, \ldots \ldots \ldots \ldots \ldots \ldots+121,000$ & $1943 \ldots \ldots \ldots \ldots \ldots \ldots 483,000$ \\
\hline $1935 . \ldots$ & 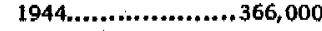 \\
\hline $1936 \ldots \ldots \ldots \ldots \ldots \ldots 117,500$ & 1945................ 438,000 \\
\hline $\begin{array}{l}1937 \ldots \ldots \ldots \ldots \ldots 134,000 \\
1938 \ldots \ldots \ldots \ldots\end{array}$ & $1946, \ldots \ldots \ldots \ldots \ldots \ldots, 56,000$ \\
\hline
\end{tabular}

Ground reservoit; 65,000 galg. Elevated tank: 125,000 gals.

Chlorination, sodium silicate, and filtration.

See section on Quality of ground and surface waters. 
Table 143.-Municipal water supplies in Paln Beach County-Continued

\section{Boynton Beach}

\section{Population in 1945: \\ Source and date of Information;}

Ownership:

Source of supply:

\section{Pumpage (esti- . mated):}

Storage:

Treatment:

Analysis:

Population in 1945:

Source and date of information:

Ownership:

Source of supply:

\section{Pumpage (esti- mated):}

Storage:

Treatment:

Analysis:

Population in 1945;

Source and date of information:

Ownership:

$$
2,001
$$

J. E. Raulerson, water pI ant operator, March 1948.

Municipal.

Three wells,

On north side of water plant; depth 55 to $65 \mathrm{ft}$; diameters, $4 \mathrm{in}$. (one weil) and 6 in (two wells); type, open; equipped with 150-, 200-, and 300-gpm centrifugal pumps and 10-, 20, and 25-hp motors.

Average 245,000 gpd in 1946.

Elevated tank: 500,000 gals.

None.

See section on Quality of ground and surface watera.

\section{Canal Point}

464

X. W. Griffith, water plant operator, March 1948.

United Statea Sugar Corporation.

Lake Okeechobee.

Water plent approximately $300 \mathrm{ft}$ east of Lake Okeechobee and 0,2 mile north of West Palm Beach Canal; 6win intalce line from water plant with a 4in. line extending about $400 \mathrm{ft}$ into Lake Okeechobee; intake, two 130 and $180-g p m$, centrifugal pumps, with $21 / 2=$ and $5-h p$ electric motors; discharge, 130 mpm centrifugal pump and $21 / 2-h p$ electric motor.

Average 155,000 gpd in 1946; $86,000 \mathrm{gpd}$ in 1941, and 45,000 gpd in 1933.

Ground reservolr; 20,000 gals. Elevated tank: 70,000 gals.

Chlorination and lime-alum.

See section on Quality of ground and surface waters.

\section{Del ray Beach}

\section{4,943}

C. E. Black, City Manager, March 1948.
Municipal, 


\section{Table 143. - Municipal water supplies in Palm Beach County-Continued}

\section{Delray Beach-Continued}

Source of supply:

Pumpage (esti-
mated):

Storage:

Treatment:

Analyeis;

Population in 1945:

Source and date of information:

Ownership:

Source of supply:

Pumpage (estimated):

Storage:

Treatment:

Analysis:

Population in 1945

Source and date of information:

Ow nership:
Seven wells.

Wells located 200 to $600 \mathrm{ft}$ west of swinton Avenue, in vicinity of gerator and elevated tank; wells 1 to 6 drilled in 1929; well.7 drilled in 1940; depths, 65 to $72 \mathrm{ft}$; diameters, 4 in. (one well), 6 in. (five wells), and 10 in (othe well); well 7 originally drilled to 216 ft and dynamited at $72 \mathrm{ft} ; 550$ to $750 \mathrm{gpm}$ centrifugat pumps and 25 . to 30 -hp electric motors; well 7 equipped with deep-well turbine pump and electric motor.

Average $1,000,000 \mathrm{gpd}$ in 1946.

Ground reservoir: 500,000 gals, Elevated tank: 300,000 gals.

Aertation and chlorination.

See section on Quality of ground and surface waters.

\section{Lake Park}

537

J. A. Wright, water plant operator, March 1948.

Municipal.

Two wells,

Wells located on east side of pumping plent, $8 \mathrm{ft}$ apart; depth, $40 \mathrm{ft}$; diameters, 4 and 6 in.; type, open; equipped with centrifugal pump and 10 hp electric motor and a stand-by centrifugal pump with piesel motor; static water level, about $8 \mathrm{ft}$ below land surface, March 24, 1948.

Average, 100,000 gpd during winter seasọt, and 60,000 gpd during. summer season in 1946.

Elevated tank: 100,000 gals.

None.

See section on Quality of ground and surface waters,

\section{Lake Worth}

10,615

J. W. Brock, water plant superintendent, March 1948.

Municipal. 
Table 143. - Municipal water supplies in Palm Beach County-Continued

Lake Worth—Continued

Source of supply:

\section{Pumpage (esti- mated):}

\section{Ștotage:}

Treatment:

Analysis:

Population in 1945:

Source and date of information:

Ownership:

Source of supply:

\section{Pumpege (esti- mated):}

Storage:

Treatment:

Analysis:

Population in 1945:

Source and date of information:

Owher ship:

Source of supply:
Four wells.

Adjacent to water plant; drilled 1925-1938; depth, $135 \mathrm{ft}$; gravelpacked, with $50 \mathrm{ft}$ of screen in bottom section; diameter, 12 in,; 750to 1,300 -gpm deep-welt turbine pumps with electric motors; static water level, $19 \mathrm{ft}$ below land surface, March 15, 1941.

Five new wells located about $700 \mathrm{ft}$ south of water plant were put in operation in 1948 .

Average 2,000,000 gpd in 1946.

Elevated tank: 600,000 gals.

Chlorination

See section on Quality of ground and surface waters.

\section{Lantana}

504

R. C. Hibrant, water plant superintendent, March 1948.

Municipal.

Three wells.

Wells located south of pump house, $50 \mathrm{ft}$ apart; depth, $54 \mathrm{ft}$; diameter, 4 in, (two wells) and 8 in. (one well); type, open; the 8 . in well, with a reported yield of $800 \mathrm{gpm}$ with a $6 \mathrm{ft}$ drawdown, is not in use at the present time; 4in. wells equipped with 350- and 125-gpm centrifugal pumps and 25 and $7 / 2$ hp electric motors.

Average 135,000 gpd in 1946.

Elevated tank: 125,000 gals.

None.

See section on Quallty of ground and surface waters,

\section{Pahokee}

4,413

R. J. Schroder, water plant superintendent, March 1948.

Municipal.

Lake Okeechobee,

Water plant is located about $100 \mathrm{ft}$ east of Lake Okeechobee and 200 ft west of Florta Highway 15; 14-int intake line extends 300 to 400 ft into Lake Ofeechobee; intake, centrifugal pump and 5-bp electric motor; discharge, centrifugal puimp and 15 -hp electric motor. 
Table 143.-Municipal water supplies in Palm Beach County-Cortinued

\section{Pahokee-Continued} Pumpage (esti-
mated):

Storage:

Treatment:

Analyois;

Population in 1945:

Source and date of information:

Ownership:

Source of supply:

Pumpage (ostimated):

Storage:

Treatment:

Analysis:

Population in 1945:

Source and date of information:

Ownership:

Source of supply:
Average 250,000 gpd in 1946

Ground teservoir: 125,000 gale. Elevated tank: 75,000 gals.

Aeration, chlorination, alum, lime, and sodium silicate.

See section on Quality of ground and surface waters.

Riviera Beach

2,512 .

Charles Dick, water plant operator, March 1948.

Municipal.

Five wells,

Three wells spaced $30 \mathrm{ft}$ apart located at the town hall; one well is 0.5 mile north and one 0.2 mile south of the town hall; depths, $85 \mathrm{ft}$; dimeters, 6 in, water is pumped directly into mains from the wells north and south of the town hall; wells at town hall are connected in manifold and equipped with one 175 -cem centrifugal pump with a 10hp electic motor; emergency stand-by, centrifugal pump and gasoline motor.

Average $200,000 \mathrm{gpd}$ in 1946.

Elevated tank: 50,000 gals.

None.

See section on Quality of ground and surface waters.

West Palm Beach

44,195

J. G. Simmons, water plant superinténdent, March 1948.

West Palm Beach Water Company.

Clear Lake and one well.

Water plant on south edge of Clear Lake, 300 tt north of Tamarind Avenue; intake in Clear Lake; three centrifugal pumps, 2,100-, 5, 250-, and 10,500 - gpm, with 40 , 100-, and 125 hp electric motors; well water used only in chemical makéup of water treatment. 
Table 143. - Municipal water supplies in Palm Beach County-Continued

$$
\text { West Palm Beach — Continued }
$$

\begin{tabular}{|c|c|}
\hline \multicolumn{2}{|c|}{ A verage pumpase $(g p d)$} \\
\hline $19 ; 2, \ldots \ldots \ldots \ldots \ldots \ldots \ldots, 4,45,000$ & $1935 . \ldots \ldots \ldots . . .$. \\
\hline $1923 \ldots \ldots \ldots \ldots \ldots+1,850,000$ & $1936 \ldots \ldots \ldots \ldots \ldots+\ldots, 3,535,000$ \\
\hline $1924 \ldots \ldots \ldots \ldots \ldots \ldots \ldots 2,460,000$ & $1937 \ldots \ldots \ldots \ldots \ldots \ldots \ldots, 4,000,000$ \\
\hline$\ldots \ldots \ldots, 3,780,000$ & $\ldots .4,455,000$ \\
\hline $1926 \ldots \ldots \ldots \ldots \ldots \ldots \ldots \ldots 5,470,000$ & $1939 \ldots \ldots \ldots \ldots \ldots \ldots \ldots 4,275,000$ \\
\hline $1927 \ldots \ldots \ldots \ldots \ldots \ldots 4,600,000$ & $1940, \ldots \ldots \ldots \ldots \ldots \ldots, 050,000$ \\
\hline $1928, \ldots \ldots+\ldots+\ldots+1,120,000$ & $\ldots+4,140,000$ \\
\hline $1929, \ldots+\ldots \ldots \ldots \ldots \ldots \ldots, 805,000$ & $1942 \ldots$ \\
\hline $1930 \ldots \ldots \ldots \ldots \ldots \ldots \ldots 3,840,000$ & $1943 \ldots \ldots \ldots \ldots \ldots \ldots \ldots . .4,520,000$ \\
\hline $1931 \ldots \ldots \ldots \ldots \ldots \ldots . \ldots 3,845,000$ & $1944 \ldots \ldots \ldots \ldots \ldots \ldots \ldots .5,370,000$ \\
\hline $1932 \ldots \ldots+\ldots \ldots+\ldots, 515,000$ & $1945 \ldots \ldots \ldots \ldots \ldots$ \\
\hline 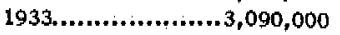 & $1946 \ldots \ldots \ldots \ldots \ldots \ldots \ldots, 220,000$ \\
\hline$\ldots \ldots \ldots \ldots \ldots+3,340,000$ & \\
\hline
\end{tabular}

Storage;

Treatment:

Analyses:
Ground reservoir: 3,000,000 gals, Elevated tank: 2,000,000 gals.

Chlorination, filtration, alum, and lime.

See section on Quality of ground and surface waters. 
Table 144. -Municipal water supply in St. Lacie County

\section{Fort Pierce}

Population in 1945:

Source and date of information:

Ownership:

Source of supply:

Storage:

Treatment:

Analysis:
9,482

Hatry Gahn, water plant superintendent, March 1948.

Municipal.

Six wells and Savanna.

Welis located adjacent to the water plant, spaced 300 to $500 \mathrm{ft}$ apart; approximately 2.5 miles south of the downtown are a of Fort Pierce and 0.4 mile west of Indian River; drilled in 1939; depths, 118 to 168 ft; diameters, 8 in; type, gravel-packed, each well having 20 to $60 \mathrm{ft}$ of screen set at varying depths; 300-gpm deepwell turbine pumps and 10-hp electric motors; well water utilized since March 1939.

Savanna. The Savanna, extending south from the water piant, is 12 to 15 miles long and 0.26 to 0.5 mile wide and lies to the west of and adjacent to the Pleistocene beach ridge that borders the western margin of Indian River, a salt-water lagoon; two 1200-宛m and one $750-\mathrm{gpm}$ centrifugal pumps and electric motors.

\begin{tabular}{|c|c|}
\hline \multicolumn{2}{|c|}{ A verag e pumpage (gpd) } \\
\hline $1928 \ldots \ldots \ldots \ldots \ldots \ldots . \ldots 47,000$ & $1938 \ldots \ldots$ \\
\hline 1929. & $1939 \ldots \ldots \ldots \ldots \ldots 70,000$ \\
\hline $1930 \ldots \ldots \ldots \ldots \ldots \ldots \ldots . \ldots 406,000$ & 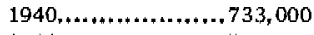 \\
\hline $1931 \ldots \ldots \ldots \ldots \ldots 38,000$ & $1941 \ldots \ldots \ldots \ldots \ldots \ldots \ldots 708,000$ \\
\hline $1932 \ldots \ldots \ldots \ldots \ldots \ldots \ldots . \ldots 346,000$ & $1942, \ldots \ldots \ldots \ldots \ldots \ldots, 514,000$ \\
\hline $1933 \ldots \ldots \ldots \ldots \ldots \ldots . . . \ldots 95,000$ & $1943, \ldots \ldots \ldots \ldots \ldots \ldots 1,180,000$ \\
\hline $1934, \ldots \ldots \ldots \ldots \ldots \ldots, \ldots, \ldots, 000$ & $1944 \ldots \ldots \ldots \ldots \ldots \ldots \quad 1,865,000$ \\
\hline $1935 \ldots \ldots \ldots+\ldots, 500$ & $1945 \ldots \ldots \ldots \ldots \ldots \ldots 2,035,000$ \\
\hline $1936 \ldots \ldots \ldots \ldots \ldots \ldots \ldots, \ldots 5,000$ & $1946 \ldots \ldots \ldots \ldots, 1,250,000$ \\
\hline$\ldots 538,000$ & \\
\hline
\end{tabular}

Ground reservoir: 1,500,000 gals. Elevated tank: 75,000 gals.

Chlorination, peration, lime, activated carbon, and filtration.

See section on Quality of ground and surface waters. 


\section{INTERPRETATION OF APPARENT RESISTIVITY CURVES}

Table 145.--Interpretations of apparent resistivity curves at Silver Bluff

\section{LINE 1.}

Location: in Coconut Grove Park, $45 \mathrm{ft}$ east of stone wall at westem boundary and about $375 \mathrm{ft}$ north of water's edge, Biscayne Bay. Direction of line $-\mathrm{N}, 60^{\circ} \mathrm{W}$.

Electrical dopth profile:

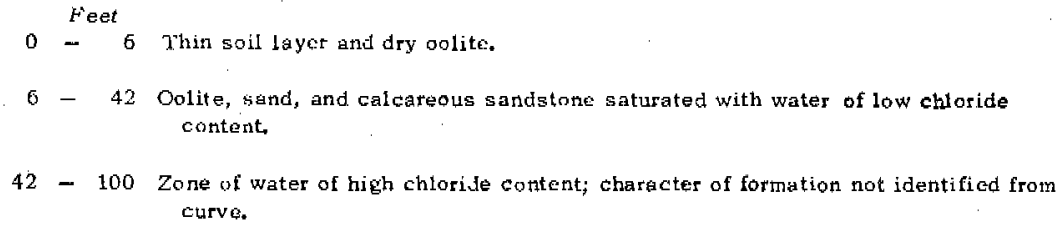

\section{LINE 2.}

Iocation: Along SW. 35th Avenue in center of SW. 9th Terrace. Direction of line-N. $2^{\circ}$ W.

Electical depth profilo:

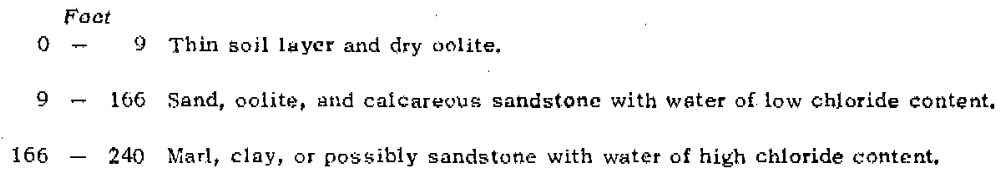

LINE 3.

Location: $275 \mathrm{ft}$ east of Douglas Road and $390 \mathrm{ft}$ north of Coral Way. Direction of line-N. ${ }^{\circ} 7^{\circ} \mathrm{W}$. Eloctricat depth pofile:

Feet

0 - 11 Thin sandy soil cover and dry bolite

11 - 145 Sand, oflite, and celcareous sandstone with water of low-chloride content,

145 - 200 Marl, clay, or possibly wandstore with water of high chloride content.

\section{LINE 4.}

Location: $77 \mathrm{ft}$ from center of Dixie Highway at SW. 28th Terrace, along F. F. C. Ratlroad right-ofway. Direction of lines. $67^{\circ} \mathrm{W}$.

Electrical depth profile:

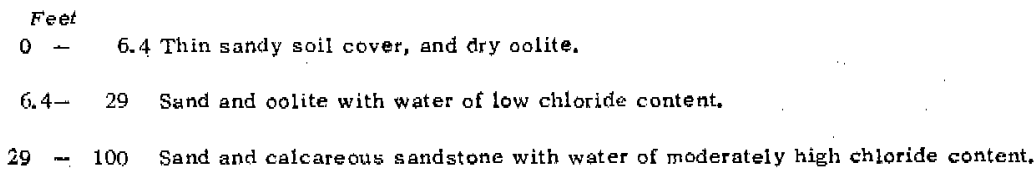


Table 145.-Interpretations of apparent resistivity curves at Silver Bluff-Continued

\section{LINE 5.}

Location: On Boys' Club grounds at SW. 32nd Avenue and S. Dixie Highway. Abandoned because of interference from butied pipes in sprinkling system on the grounds.

\section{LINE 6}

Location: Along SW, 31 st Avenue, 0,2 mile notth of S. Dixie Ilighway. Direction of line-N, $5^{\circ} \mathrm{W}$.

Electricat depth profil e:

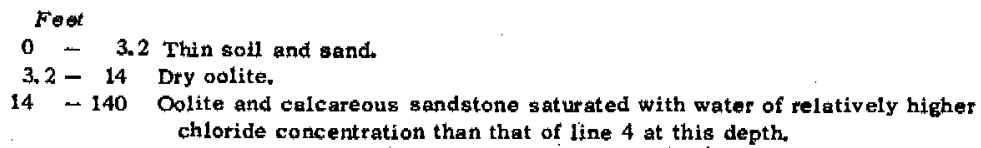

Table 146. - Interpretations of epparent resistivity curves at Cutler

\section{LINE 1.}

Location: $324 \mathrm{ft}$ west of sea wall, $390 \mathrm{ft}$ west of water's edge and $35 \mathrm{ft}$ southwest of well G-467 on south side of Richmond Drive offset. Direction of line-N. $84^{\circ} \mathrm{E}$.

Electrical depth profile:

$$
\text { Fe'et }
$$

$0-9$ Thin soil layer and dry oolite.

9 - 73 Oolite and calcareous sandstone containing water of moderately high chloride content.

73 - 200 Calcareous sandstone containing water of high chlotide content.

\section{LINE 2}

Location: $280 \mathrm{ft}$ from center of Cutler Road on south side of Richmond Drive oppogite store and gasoline station. Direction of line-N. $86^{\circ} \mathrm{E}$.

Electricat depth profile:
Fogt
0 - 11 Thin sandy soil and dry oolite.
11 - 69 Oolite and calcareous sandstone containing water of moderately high chloride content.
$69-200$ Calcareous sandstone containing water of high chloride content.

LINE 3.

Location; 0.15 mile west of Cutler Road on Richmond Drive, on south side of road 120 ft west of S, B, T. T. Co, pole No 47, Direction of line-E-W.

Electrical depth profile:
Feet
0 - to Thin sandy soil and dry oolite.
10 - 36 Dolite and calcareous sandstone containing water of low-chloride content.
36 - 80 Calcareous sandstone and some limestone containing nearly fresh water.
$80-300$ Limestone and calcateous sandstone with water of higher chloride content than 
Table 146.-Interpretations of apparent resistivity curves at Cutler-Continued

LINE 4.

Location: Opposite well G 469 on West Cutler Road north of Richmond Drive.

Electrical depth proflle:
$0-\quad$ Feet
Thin sandy topaoil and dry oolite.
11 - 34 Oolite and calcareous sandstone containing water of moderately low chloride content.
34 - 91 Calcareous sandstone and limestone containing nearly fresh water.
$91-300$ Limestone and calcareous sandstone with water of higher chloride content than at any other place in the depth profile; marl and clay.

\section{LINE 5 ,}

Location: $400 \mathrm{ft}$ est of line 4 and midway between East and West Cutler Roads. Direction of line-N. $85^{\circ} \mathrm{E}$.

Electrical depth profil e;
Feet
$0 \quad-\quad 7.7$ Thin soil and dry oolite.
$7.7-32$ Oolite and calcareous sandstone containing water of moderately low chloride content.
$32-78$ Calcareous sandstone and some limestone containing rearly fresh water.
$78-200$ Limestone and some calcareous sandstone containing water of higher chloride content than at any other level in the depth profile; marl and clay.

LINE 6.

Location: Cotal Reef Drive offset, $1 / 4$ mile west of Biscayne Bay. Direction of line-S. $52^{\circ} \mathrm{E}$.

EI ectrical depth profile:

$$
\text { Feet }
$$

$0 \quad-\quad 7.4$ Soil and oolite: considerable concentration of chloride.

$7.4-26$ Oolite and calcareous sandstone; lower chloride content in this horizon,

$26-200$ Calcareous sandstone and limestone; very high chloride content.

LINE 7.

Location: Along Ludlum Road, $287 \mathrm{ft}$ north of well G-472. Direction of line-N.-S.

Electrical depth protile:
Fieet
5.8 Sandy topsoil and oolite.
$5.8-11.8$ Hard limestone, rather impervious,
$11.8-48 \quad$ Oolite and calcareous sandstone with water of appreciably higher chloride content.
$48-160$
Calcareous sandstone and limestone saturated with water of very high chloride content.

\section{LINE 8.}

Location: 0.22 mile west of Ludlum Road on Coral Reef Drive. Direction of line-E. $-W$. 
Table 146. -Interpretations of apporent resistivity curves at Cutler-Continuer LINE 9.

Location: $375 \mathrm{ft}$ west of Ludium Road and 0.1 mile north of Cotal Reef Drive. Direction of lineN. $88^{\circ} \mathrm{E}$.

Electrical dopth ptofilo:

Foet

$0-15$ Dry sandy soil and oolite.

$15-103$ Oolite, calcareous sandstone, and limestone containing water of moderately low chloride content.

$103-200$ Limestone containing water of very high chloride content; marl and clay.

LINE 10.

Location: 0.3 mile south of Coral Reef Drive along west side of Kuhn Drive near well G 450 . Direction of line- N. - s.

Electrical depth profile:

Foet

$0 \quad-\quad 8.25$ soil and oolite, dry.

8.25 - 44 Oolite, limestone, and calcareous sandstone containing water of low chloride content.

$44-121$ Limestone and calcareous sandstone containing water of very low chloride content.

$121-200 \quad$ Marl and clay.

\section{LINE 11.}

Location: 0.15 mile north of well $\mathrm{G}-472$, along east gide of Iudlum Road Direction of line-N, $-\mathrm{S}$. Flectrical depth profile:

Feet

$0 \quad-\quad 5.8$ Dry soil and oolite.

5.8 - 11.8 Ilard limestone, impervious.

11.8 - 72 Oolite, limestone, calcareous sandstone, and sand containing water of low chloride content.

$72-200$ Calcareous sandstone containing water of moderately high chloride content; mat 1 and clay.

\section{LINE 12.}

Location: 0.35 mile east of U. S. ILighway 1 along Coral Reef Drive, Direction of line E, $-W$.

Electrical depth profile:

$F$ eet

$0 \quad-10,5$ Dry sandy soil and oolite.

10.5 - 72 Oolite, limestone, calcareous sandstone, and sand with water of low chloride content.

$72-122$ Timestone, sand, and calcareous sandstone containing water of very low chloride content.

$122-300$ Marl and clay. 
Table 146.-Interpretations of apparent resistivity curves at Cutler-Continued

\section{LINE 13.}

Location: 0.15 mile east of Allapattah Drive along north side of Goulds Canal, 0.15 mile east of well G-518. Direction of line-E-W.

El ectrical depth profite:

$$
\text { Fet }
$$

0 - 8 Soil, sand, and oolite.

8 - 39 Hard oolite and calcareous sandatone with water of low chloride content.

39 - 300 Calcareous gandstone with water of moderately low chloride content; marl, clay.

Table 147.-Interpretations of apparent resistivity curves at Fort Lauderdale

\section{LINE 1.}

Location: $520 \mathrm{ft}$ west of Florida Highway 7 on Rode Road, along north gide of North New Rivet Canat. Direction of line-N. $75^{\circ} \mathrm{W}$.

Electrical depth profil e:
Feet
0 - 2.7 Road fill and sand.
2.7 - 3.1 Black muck or oolite saturated with water of rather high chloride content.
31 - 68 Oolite and compact sand of relatively high resistivity, indicating water of low chloride content.
$68-250$ Sand, calcareous sandstone, and limestone of moderately high resistivity, in- dicating an increase of chloride content over the previous layer.
$250-300 \quad$ Sand and marl of low resigtivity; water probably of high chloride content

\section{LINE 2}

Location; 0.9 mile wegt of Florida Highway 7 on Rode Road along north side of North New River Canal. Direction of line-N. $75^{\circ} \mathrm{W}$.

El ectrical depth profile:
Feet
$0 \quad-2.5$ Sandy soil.
2.5 - 14 Black muck or oolite saturated with water of rather high chloride content.
14 - 125 Colite, compact sand, calcareous sandstone, and limestone; relatively high resistivity, Indicating water of low chloride content. Zones of probable salt- water contamination hear 40 . and $68 \mathrm{ft}$ tivity, indicating an inctease it chloride content with respect to the layer immediately above.
125 - 265 Marl, calcareous sandstone, limestone, sand, and clay; moderately low resig-
$265-350$ Marl, clay, and eand; very low resistivity with comegpondingly high chloride content. 
Table 147.-Interpretations of apparent resistivity curves at Fort Lauderdale-Continued LINE 3.

Location: 0.7 mile west of Florida Flighway 7 along north gide of Peters Road. Direction of lineE. - W.

El ectrical depth profil e:
$0 \quad$ Feet 8 Loose, very dry send.
$8-15$ Sand containing organic material moistened with water of low chloride content.
$15-112$ Sand and sandy timestone of relatively higher resistivity than the above layer, indicating low chloride content.
112 - 200 Calcareous sandstone and limestone in the upper part of this layer is of moder- ately low resistivity, indicating the presence of higher chlotide concentrations than in the layer above; lower part, below $175 \mathrm{ft}$ is probably clay and marl of low resistivity and high chloride content.

\section{LINE 4.}

Location: 0.85 mile west of Florida Highway 7 on Peters Road, Abandoned because of loose, dry sand at the surface; unable to obtain electrode contact.

\section{LINES 5 AND 6.}

Location; 1.2 miles west of Florida Highway 7 along north side of Peters Rond. Direction of lineN.-E. (Line 5 was abandoned because of instrument trouble and Line 6 was taken in its place from the same center).

Electrical depth profite:

$$
\text { Feet }
$$

$0 \quad-\quad 4.4$ Loose, very dry sand.

4.4 - 17 Muck and some sand, probably of relatively high chloride content as its resistivity is low.

17 - 155 Sand, sandy limestone, and calcareous sandstone; water probably of low chloride content.

$155 \sim 250$ Sand with some clay and marl; chlorides increasing with depth and becoming high below $250 \mathrm{ft}$.

$250-300$ Marl, elay, and sand with water of rather high chloride content.

\section{LINE 7.}

Location: First street south of Country Club Road at intersection of firat atreet west of Florida Highway 7, along north side of street, Direction of line- E.-W.

El ectrical depth profile:
Feat
0 - 11 Loose, very dry sand,
$11-145$ Sand, sandstone, and sandy limestone; resistivity relatively high, indicating low chloride content.
$145-300$ Clay, marl, and aand; water probsbly of moderately high chloride content.

\section{LINE 8.}

Location: 0.2 mile east of Flotida Highway 7 along south side of Broward Blvd. Direction of line-E.-W. Observations taken to the 200-ft interval distance, but results beyond the 15-ft interval distance are of no value; unable to send current through the dry sand cover. 
Table 147.-Interpretations of apparent resistivity curves at Fort Laudendale-Continued

LINE 9.

Location: 0.22 mile south of new W. Broward Blvd, along east side of former Broward Blvd. Direction of line- $\mathbf{N}_{+}-\mathbf{S}$.

Electrical depth profile:

Feat

$0 \quad-12.5$ Loose, dry sand,

125 - 92 Sand with mall amount of organic material, calcateous sandstone, and sandy limestone; moderately high resistivity, indicating little or no chloride in the water.

92 - 300 Sandy limestone, sand, calcareous sandstone, and some clay and marl; water in this zone does not have high chloride content.

LINE 10.

Location: 0.9 mile east of Florida Highway 7 along south side of Broward Bivd. Direction of line- $E_{4}-W_{\text {. }}$

Electrical depth profile:

Feet

0 - 11.5 Looge, dry sand.

11.5 - 152 Sand with Empll amount of orgenic material, calcareous sandstone, and sandy limestone; moderately bigh resistivity, indicating little or no chloride in the water.

$152-232$ Sandy limestone and calcareous sandstone that is either compact of saturated with relatively fresh water.

$232-300$. Probably clay, marl and sand; the chloride content of this zone is comparatively low, but the apparentresistivity curves indicate an increased salinity west of the center station.

LINE 11.

Location; Along south slde of NW. 6th St. at 28th Ave. Direction of Iine-E.-W.

Electrical depth profile:

o Feat 4.5 Dry, loose sand.

4.5 - 12.5 Sand with small amount of organic material; chloride content of water is tow, as indicated by the moderately high regigtivity.

12.5 - 250 Sand, calcareous sandstone, and sandy limegtone of glightly higher resistivity than the previous layer; contains water of low chloride content.

$250-400 \quad$ Probably clay and marl with water of rathet high chloride content. Because of the variability of $P_{1}$ and $P_{2}$, only a qualitative interpretation is given for this bottom layer.

LINE 12.

Location: 0.22 mile west of Westwood Road and 0.15 mile north of Davie Bivd Direction of HineE. -W. 
Table 147.-Interpretations of apparent resistivity curves at Fort Lauderdale-Continued

\section{LINE 12, - Continued}

Electrical depth profile:

Feet

$0-10,2$ Sand, loose and very dry.

10.2 - 61 Sand and calcareous sandstone; high resigtivity, indicating water of very low chloride content.

$61-300$ Sandy timestone, calcareous sandstone, and sand; mediummigh resistivity, indicating water of low chloride content.

\section{LINE 13.}

Location: 0,4 mile directly north of resistivity line 12 . Direction of line-E $-W_{4}$

Electical depth profile:

Feet

0 - 6.1 Loose, dry sand.

6. 1 - 12.5 Moist sand with some organic material.

12.5 - 38 Compact sandy limestone or calcareous sandstone of high-resistivity.

$38-300$ Sandy limestone, calcareous sandstone, and sand; medium=high resistivity, indicating water of low chloride content. 


\section{SELECTED BIBLIOGRAPHY}

[Reports marked by an asterisk (*) are by U. S. Geological Survey staff members and are based on data gathered as a result of the Southeaştern Floricla Water-Resources Investigation]

Agassiz, Louis, 1852, Florida reefs, keys, and coast: U. S. Coast Survey Rept. for 1851 , App. 10.

Alexander, L. J., 1940, Economic evaluation of tuberculation in pipe lines: Am. Water Works Assoc. Jour., v. 32.

Allison, R. V., 1928, Movement of underground waters: Florida Agr. Expt. Sta., Ann. Rept.

1939, The soil and water conservation problem in the Everglades: Soil Sci. Soc. Florida Proc., v. 1.

Soc. Florida The need of the Everglades for a specific plan of development based on the physical and chemical characteristics of its soils and a rational handling of its natural water supply: Soil Sci. Soc. Florida Proc., v, 5-A.

American Public lealth Association and American Water Works Association, 1936, Standard methods for the examination of water and sewage, 8th ed.

Applin, P. L., and Applin, F. R., 1944, Regional subsurface stratigraphy and structure of Florida and southern Georgia: Am. Assoc. Petroleum Geologists Bull., v. 28, no. 12.

Barksdale, H. C., Sundstrom, R. W., and Brunstein, M. S., 1936, Supplementary report on the ground-water supplies of the Atlantic City region: New Jersey State Water Policy Com. Special Rept. 6.

Bell, H. S., 1942, Stratified flow in reservoirs and its use in prevention of silting: U. S. Dept. Agriculture Misc. Pub, 491.

Bellamy, Jeanne, 1946, Salt in water was big problem twenty-seven years ago: The Miami Herald, Miami, Fla.

Miami, Fla.

1947, Taming the Everglades, A teport on water control: The Miami Herald,

Bestot, H. A., 1942, The principal elements of a longtime soil and water conservation plan for the Everglades: Soil Sci. Soc. Florida Proc. v. 4-A.

Bogart, D. B., and Clayton, B. S., 1948, The effect of aquatic weeds on the flow of canals: [paper presented at 9th annual meeting of the Soil Sci. Soc. of Florida, Clew* iston, Fla].

Btay, R. H., 1942, Ionic competition in base exchange telations: Am. Chem, Jour., V. 64.

Brooks, C. E. P., 1949, Climate through the ages, McGraw-Hill Co.

Brown, J. S., 1925, A study of coastal ground water, with special reference to Connecticut: U. S. Geol. Survey Water-Supply Paper 537.

*Brown, R. H., 1944, Water levels and artesian pressure in southeastern Florida (1942): U. S. Geol, Survey Water-Supply. Paper 945.

*Brown, R. H., and Parker, G. G., 1945, Salt-water encroachment in limestone at Silvet Bluff, Miami, Florida: Econ。 Geology, v. 40, no, 4.

Califomia Department of Public Works, Division of Water Resources, 1942, Use of water by native vegetation: Bull, 50 .

Campbell, R. B., 1939a, Report of laboratory analysis in letter to Dr. Herman Gunter, Florida state geologist,

-1939b, Deep test well in the Everglades: Am. Assoc. Petroleum Geologists Bull., v. 23, no. 11 .

$1939 \mathrm{c}$, Outline of the geologic history of"peninsular Florida: Florida Acad. Sci. Proc., v. 4 [1940].

Carson, Emest, 1940, Annual meteorological summary with comparative data, Miami, Fla.: U. \$. Weather Bureau.

Challenger Report, 1844, Physics and chemistry, v. 1.

Chapman, H. D., and Kelley, W. P., 1930, The determination of the replaceable bases and the base exchange capacity of soils: Soil Sci., v, 30 .

Clark, W. M., 1928, The determination of hydrogen ions, 3d ed., Williams \& Wilkins Co.

Clayton, B. S., 1938, Water control in the peat soils of Florida: U. S. Dept. Agriculture, Bur. Agriculture Eng. Release 1077. 
Clayton, B. S., and Neller, J. R., 1943, Nature and extent of surface subsidence of the organic soils of the Everglades: Soil Sci. Soc. Florida Proc, v, 5-A,

Clayton, B. S., Neller, J. R., and Allison, R. V., 1942, Water control in the peat and muck soils of the Florida Everglades: Florida Agr. Exper. Sta., Bull. 378.

Cole, W. S., 1941, stratigraphic and paleontologic studies of wells in Florida: Florida Geol. Survey Bull. 19.

1944, Stratigraphic end paleontologic studies of wells in Florida, No, 3: Florida Geol. Survey Bull. 26.

Collins, W. D., and Howard, C. S., 1928, Chenical character of waters of Florida: U. S. Geol. Survey Water-Supply Paper 596-G.

Collins, W. D., and Love, S. K., 1944, Quality of surface waters of the United States (1942): U. S. Geol. Survey Water-Supply Paper 950.

Collins, W. D., Howard, C. S., and Love, S. K., 1943, Quality of surface waters of the United States (1941): U. S. Geol, Survey Water-Supply Paper 942.

Congressional documents: 76th Cong., 1st sess., H. Doc. 469.

Cooke, C. W., 1930, Pleistocene seashores: Washington Acad. Sci. Jour,, v. 20.

Sci. Jour., v. 21.

1931, Seven coastal terraces in the southeastern States: Washington Acad.

1935, Tentative ages of Pleistocene shore lines; Washington Acad, Sci. Jour., v. 25.

1937, The Pleistocene Horry clay and Pamlico formation near Myrtle Beach, S. C.: Washington Acad, Sci. Jour., v. 27, no, 1. 1939, Scenery of Florida: Florida Geol. Survey Bull. 17.

1945, Geology of Florida: Flotida Geol. Survey Bull. $29,339 p$.

Cooke, C. W., and Mossom, Stuart, 1928, Geology of Florida: Florida Geol. Survey 20th Ann. Rept.

Cooper, H. H., Jr., 1944, Ground-water investigations in Flotida: Am. Water Works Assoc. Jour., v. 36, no, 2.

Cooper, H. H., Jr,, and Jacob, C. E., 1946, A generalized graphical method for evaluating formation constants and summarizing well-field history: Am. Geophys, Union Trans., v. 27, no. $4, p .526-534$.

*Cooper, H. H., Jr., and Parker, G. G., 1945, Water levels and artesian pressure in Flotida (1943): U. S. Geol. Survey Water-Supply Paper 987.

Cooper, H. H., Jr., and Warren, M. A., 1945, The perennial yield of artesian water in the coastal area of Georgia and northeastern Florida: Econ. Geology, v. 40, no. 4,

*Cross, W. P., 1942, Water levels and artesian pressure in southeastern Florida (1940): U. S. Geol. Survey Water-Supply Paper 907.

* 1943, Water levels and artesian pressure in southeastem Florida (1941); U. S. Geol. Survey Water-Supply Paper 937.

*Coss, W. P., and Cooper, H. H., J t., 1940, Water levels and artesian pressure in southeastern Florida (1939): U. S. Geol. Survey Water-Supply Paper 886.

*Cross, W. P., and Love, S. K., 1942, Ground water in southeastern Florida: Am. Water Works Assoc. Jour,, v. 34, no. 4.

*Cross, W. P., Love, S. K., Parker, G. G., and Wallace, D. S., 1940, Progress report on the investigation of water resources in southeastem Florida: [Mimeographed in small quantity; now exhausted. Copies on file in Geological Survey offices in Miami, Ocala, and Tallahessee, Fla, and in Washington, D. C.].

Cushman, J. A., 1942, Report, on well samples from Florida: [Memo, to John B. Reeside, Jr.].

Dall, W. H., 1887, Notes on the geology of Florida: Am, Jour. Sci, 3rd se r, v, 34. 1893, Geological results from the study of the Tertiary fauna of Florida: Wagner Free Inst. Sci. Trans, v, 3,pt. 6 .

Daly, R. A., 1934, The changing world of the ice age, Yale Univ. Press.

Davis, C. K., 1942, The plan and progress of soil and water conservation studies in the Everglades: Soil Sci. Soc. Florida Proc., v, 4-A.

1943, Summary of three years of conservation work in the Everglades and plans for the future: Soil Sci. Soc. Florida Proc., v, 5-A.

Davis, J. H., 1940, The ecology and geologic role of mangroves in Florida: Carnegie Inst. Washington Pub. 517. 25. 1943, The natural features of southern Florida: Florida Geol. Survey Bull.

Dean, H. T., 1936, Chronic endemic dental fluorosis: Am. Med. Assoc, Jour., v. 107. Dean, H. T., Jay, Phillip, Atnold, F. H., Jt., and Elvove, Elias, 1941, Domestic water and dental caries: U. S. Public Health Repts., v. 56. 
DeWolf, A. B., 1941, Report on water shed conditions, Miami, Fla. Dept. Public Service, typewritten manuscript, sec. 2 , p. 1.

Dickerson, R. E., 1942, Trend of Pleistocene ocean currents across the Florida Everglades: Geog. Rev., v. 32, no. 1.

Dole, R. B., 1914, Some chemical characteristics of sea water at Tortugas and around Biscayne Bay, Fla: Camegie Inst. Washington, v. 5, rept. 182.

Dole, R. B., and Chambers, A. C., 1918, Salinity of ocean water at Fowey Rocks, Florida: Camegie Inst. Washington Pub., v. 9, rept. 213.

Dovell, J. E., 1942, A brief history of the Florida Everglades: Soil Sci. Soc. Florida Proc., v. 4-A.

Elliott, F. C., Everglades Drainage District: Biennial report, 1925-26; 1927; 1927-28; 1929.

Erickson, D. B., 1945, The Gulf Hammock formation in Florida: Science, new ser., v. 102, no, 2644 .

Evans, C. B., and Allison, R. V., 1942, The soils of the Everglades in relation to reclamation and conservation operations: Soil Sci. Soc. Florida Proc., v. 4-A.

Everglades Drainage District, 1944, Report by advisoty committee on the present drainage system in relation to water control requirements.

1946, General const tuction regulations (West Palm Beach, Fla.). [mimeo.].

Fenneman, N. M., 1938, Physiography of eastern United States,' McGraw-Hill Book Co., Inc.

*Ferguson, G. E., 1942, The plan and progress of recent surface-water studies in the Everglades: Soil Sci, Soc. Florida Proc., v. 4-A.

*___ 1943, Summary of three years of surface water studies in the Everglades: Soil Sci. Soc. Florida Proc,, v, 5-A.

*Ferguson, G. E., Lingham, C. W., Love, S. K., and Vernon, R. O., 1947, Springs of Florida: Florida Geol. Survey Bull. 31.

Flint, R. F., 1941, Glacial geology, in Geology, 1888-1938: Geol. Soc. America, 50th Anniversary Volume.

1947, Glacial geology and the Pleistocene epoch, John Wiley and Sons.

Florida Agticultural Experimental Station, in cooperation with U. S. Soil Conservation Service, 1948, Soils, geology, and water control in the Everglades region; Univ. of Fla. Bull. 442, Mar. 1948.

Florida Internal Improvement Fund, 1909, Minutes of Trustees: v. 7.

Fuller, M. L., 1904, Contributions to the hydrology of eastern United States: U. S. Geol. Survey Water-Supply Paper 102.

Griswold, L. S., 1896, Notes on the geology of southern Florida: Harvard Coll. Mus. Comp. Zoology Bull., v. 28, no. 2.

Harding, S. T., 1942, Evaporation from free water surfaces, ch. 3 in Hydrology, by O. E. Meinzer, McGraw-Hill Book Co., Inc.

Hatper, R. M., 1927, Natural resources of southem Florida: Florida Geol. Survey 18th Ann. Rept.

Hazen, Allen, 1892, A new color standard for natural waters: Am. Chem. Jour., v. 14.

Heiland, C. A., 1940, Geophysical exploration, Prentice-Hall.

Heilprin, Angelo, 1887, Explotations on the west coast of Florida and in the Okeechobee wilderness: Wagner Free Inst. Sci. Trans., v. 1.

Henbest, L. G*, 1942, [Memo. to G. G. Parker, regarding the age indicated by Foraminifera from U. S. Geol. Survey test well G 188].

Herr, Ben, 1937 [Memo, on Lake Okeechobee, Okeechobee Flood Control District]. District.

Houk, I. E., 1921, Rainfall and munoff in the Miami Valley: Miami Conserv. Dist. Tech. Repts., pt. 8.

Howard, C. S., and Love, S. K., 1945, Quality of surface waters of the U nited States (1943): U. S. Geol. Survey Water-Supply Paper 970.

Hoy, N. D., and Schroeder, M, C., 1952, Age of subsurface "Tamiami" formation near Miami, Flas: Jour. Geol.

*Hoy, N. D., Cooper, H. H., Jr., and Parker, G. G., 1947, Water levels and artesian pressure in Florida (1944): U. S. Geol. Survey Water-Supply Paper 1017.

Hubbert, M. K., 1940, The theory of ground water motion: Jour. Geology, pt. 1.

Hummel, J. N., 1932, A theoretical study of apparent resistivity in surface potential methods: Am. Inst. Mech. Eng. Trans,, Geophysical Prospecting.

Geophysik, v. 5, no. 1 .

Hyman, H. H., 1943, Progress-Miami Water Co.; [typewritten manuscript in files of U. S. Geol. Survey, Miami, Fla.].

Jeans; J. F., 1925, Mathematical theory of electricity and magnetism, 5th ed. Cambridge Univ, Press. 
Jennings, W. S., 1909, letter in Annual Report of Trustees of the Intemal Improvement Fund, State of Florida, p. 122.

Jenny, Hans, 1932, Studies on the mechanism of ionic exchange in colloidal aluminum silicates: Phys. Chemistry Jour., v. 39.

Johnson, Lamar, 1944, Proposed plan of regulation of North New River Canal: Ever* glades Drainage Dist., West Palm Beach, Fla. [in typewritten form],

1948, The hyacinth eradication program of Everglades Drainage District, Florida, 1946-48: Everglades Drainage Dist., West Palt Beach, Fla, [mimeo. form].

Jones, L. A., 1948, Soils, geology, and water control in the Everglades region: Univ. Florida Agr. Exper. Sta, in cooperation with U. S. Soil Cons, Service, Bull, 442.

Kadel, B. C., 1919, Instructions for the installation and operation of Class " $A$ " evapotation stations: Circ. L, Instrument Div., U, S. Weather Bureau.

Kelley, W. P., and Brown, S. M., 1924, Replaceable bases in soils: California Univ. Tech. Paper 15.

Knudsen, Martin, 1901, Hydrographische Talballen, G. E. C. Gad, Copenhagen.

Langelier, W. F., 1936, The analytical control of anti-corrosion water treatment: Am. Water Works Assoc. Jour, v, 28.

LeConte, Joseph, 1879, Elements of geology, D. Appleton \& Co.

Leverett, Frank, 1931, The Pensacola terrace and associated beaches and bars in Flotida: Flotida Geol. Survey Bull. 7.

Lobeck, A. K., 1939, Geomorphology, McGraw-Hill Book Co., Inc,

Longwell, C. R., Knopf, Adolph, and Flint, R. F., 1932, Textbook of geology, pt. 1, Physical geology, John Wiley \& Sons.

*Love, S. K., 1945, Cation exchange in ground water contaminated with sea water near Miani, Flas: Am. Geophys. Union Trans,, pt, 6 (1944).

* Love, S. K., and Swenson, H. A., 1942; Chemical character of public water supplies in southeastern Florida: Am. Water Works Assoc. Jour,, v. 34, no, 11.

MacNeil, F. S., 1950, Pleistocene shore lines in Florida and Georgia: U. S. Geol. Survey Ptof. Paper 221-F.

McGeorge, W. T., 1930, Base exchange property of organic soils; Arizona Agr. Exper. Sta. Tech. Bull. 33.

Mansfiel d, W. C., 1931a, Pliocene fossils from limestone in southern Florida: U. \$. Geol. Survey Ptof. Paper 170-D.

v. 79 , art 21 .

1931b, Some Tertiary mollusks from southern Florida, U. S. Nat, Mus. Proc,,

1937, Mollusks of the Tampa and Suwannee limestones of Flotida: Florida Geol. Survey Bull. 15.

1939, Notes on the upper Tertiary and Pleistocene mollusks of peninsular

Florida: Florida Geol. Survey Bull. $18,7 \$$

Marmer, H. A., 1941, Tide observations at Baltimore and the problem of coastal stability: Geol. Rev., v. 33.

Marston, Anson, McCrory, S. H., and Hills, G. B., 1927, Report of Everglades Engineering Board of Review: Everglades Drainage Dist,, West Palm Beach, Fla.

Martin, R. J., 1930, Climatic summary of the United States, sec. 105, Southem Florida: U. S. Dept. of Agr., Weather Bureau.

Matson, G. C., and Clapp, F. G., 1909, A preliminary report on the geology of Florida: Florida Geol. Survey, 2d Ann. Rept.

Matson, G. C., and Sanford, Samuel, 1913, Geology and ground waters of Florida: U, S. Geol. Survey Water-Supply Paper 319.

Maxwell, J. C., 1904, Electricity and magnetism, Oxford Univ, Press, 3d ed.

Meinzer, O. E., 1923a, The occurrence of ground Water in the United States: U. S. Geol. Survey Water-Supply Paper 489.

Paper 494.

1923b, Outline of ground-water hydrology: U. S. Geol. Survey Water-Supply v. 23, no. 4 .

1931, Outline of methods for estimating ground-water supplies; U. S. Geol. Survey Water-Supply Paper 638-C [1932]. 1933, Geologic teconnaissance of a region adjacent to Guantanamo Bay:
Washirigton Acad, Sci. Jour. 23 .

กo. 19. 1937, Land subsidence caused by pumping: Eng. News-Record, v. 118,

1942, Occurrence, origin and discharge of ground water, in Physics of the earth-IX, Hydrology; McGtaw-Hill Book Co., Inc,

Meinzer, O. E., and Stearns, N. D., 1929, A study of ground water in the Pomperaug basin, Connecticut: U. \$. Geol. Survey Water-Supply Paper 587B.

Meinzer, O. E., and Wenzel, L. K., 1942, Permeability of water-bearing materials, in Physics of the earth-IX, Hydrology, McGraw-Hill Book Co., Inc. 
Mossum, Stuart, 1926, Review of the structure and stratigraphy of Florida: Florida Geol Survey, 17th Ann. Rept.

Munroe, R. M., 1930, The commodore's story, Ives Washburn Press.

Muskat, Morris, 1937, The flow of homogeneous fluid through potous media, McGraw-Hill Book Co., Inc.

National Research Council, 1949-1950, Report of Committee on the measurement of geologic time.

O'Reilly, John, 1940, South Florida's amazing Everglades: Nat, Geog. Mag., v. 77, no. 1.

*Parker, G. G., 1942, Notes on the geology and ground water of the Everglades in southenn Florida: Soil Sci. Soc. Florida Ptoc., v. 4-A.

*___ 1945a, Salt-water encroachment in southern Florida: Am. Water Works Assoc. Jout., v. 37 , no. 6 , p. $526-542$.

* _ 1945b, Effects of the Pleistocene epoch on the geology and ground water of southern Florida: Florida Acad, Sci. Jour., v. 8, no. 2.

*_1947, Municipal water-supply problems of southern Florida: Soil Sci. Soc. Florida Proc., v. 8-A.

1951, Geologic and hydrologic factors in the perennial yield of the Biscayne aquifer, Miami area, Florida: Am. Water Works Assoc. Jour.

*Patker, G. G., and Cooke, C. W., 1944, Late Cenozoic geology of southern Florida, with a discussion of the ground water: Flotida Geol. Survey Bull. 27, 19 p.

*Parker, G. G., and Hoy, N. D., 1943, Additional notes on the geology and ground water of the Everglades: Soil Sci. Soc. Florida Proc., v. 5-A.

* 1955, Geology and ground water of the Kissimmee River-Lake Okeechobee area, Florida: Soil Sci. Soc. Flotida Proc., v. 6 (in press).

*Patker, G. G., and Stringfield, V. T., 1950, Effects of earthquakes, trains, tides, winds, and atmospheric pressure changes on water in geologic formations of southern Florida: Econ. Geol. Bull., v. 45, no. 5, p. 441-460.

*Parker, G. G., Cooper, H. H., Jr., and Hoy, N. D., 1948, Water levels and artesian pressure in Florida (1945): U. S. Geol. Survey Water-Supply Paper 1024.

*Parker, G. G., Ferguson, G. E., and Love, S. K., 1944, Interim report on the investigations of water resources in southeastem Florida with special reference to the Miami area in Dade County: Florida Geol. Survey Rept. of Inv, 4.

Pennink, J. M. K., 1904, De "prise d'eau" der Amsterdamsche duin water-leiding: K. Inst. Ing. Tijdschr., 1903-4, The Hague.

Pillsbury, G. B., 1940, Tidal hydraulics: U. S. War Dept., Corps of Engineers Prof. Paper 34.

Pressler, E. B., 1947, Geology and occurrence of oil in Florida: Am. Assoc. Petroleum Geologists Bull, v, 31, no. 10 .

Richards, H. G., 1938, Marine Pleistocene of Florida: Geol. Soc, America Bull., v. 49.

Roman, Irwin, 1931, How to compute tables for determining electrical resistivity of underlying beds and their application to geophysical problems: U. S. Bur. Mines Tech. Paper 502.

1934, Some interpretations of earth resistivity data: Am. Inst. Mech. Eng. Trans., v. 110, p. 183.

1941, Superposition in the interpretation of two-layer earth-resistivity curves:

U. S. Geol. Survey Bull, 927-A, 18 p.

Ross, C. P., 1919, Report on investigation of the water supply of Miami, Fla.: U. S. Geol. Survey.

Sanford, Samuel, 1909, Topography and geology of southern Florida: Florida Geol. Survey 2d Ann, Rept.

Paper 319.

1913, Geology and ground waters of Florida: U. S. Geol. Survey Water-Supply

Schrontz, C. C., about 1936, A systematic plan for the regulation of Lake Okeechobee, Florida: U. S. Corps of Engineers, Jacksonville, Fla, [unpublished].

Schrontz, C. C., and Stephens, J. C., 1942, Principal characteristics of the KissimmeeEverglades watershed: Soil Sci. Soc. Florida Proc., v. 4-A.

Schuchert, Charles, and Dunbar, C. O., 1933, A textbook of geology, pt. 2, Historical geology, 3d ed., John Wiley \& Sons [reprinted 1936 with changes].

Sellards, E. H., 1912, Soils and other surface residual material of Florida: Florida Geol. Survey 4th Ann. Rept.

vey 12 th Ani, Rept.

Sellards, E. H., and Gunter, Herman, 1910, The artesian water supply of eastern Florida: Florida Geol, Survey 3d Ann. Rept.

1913, The artesian water supply of eastern and southern Florida: Flotida Geol. Survey 5th Ann. Rept. 
Sewell, John 1933, John Sewell's memoirs and history of Miami, v. 1, chap. 6, Miami's water supply and its source, Franklin Press, Miami, Fla,

Shaler, N. S., 1890, The topography of Florida: Harvard Coll. Mus, Comp. Zoology Bull., v. 16 , no, 7 .

Shepherd, E. S., 1940, Note on the fluoride content of rocks and ocean-bottom samples: Am. Jour. Scí, v. 238.

Simpson, G. G., 1929, Extinct land manmals of Florida: Florida Geol. Survey 20th Ann. Rept.

Speller, F. N., 1935, Corrosion, causes and prevention, 2d ed., McGraw-Hill Book Co.

Stearns, H. T., and Macdonald, G. A., 1942, Geology and ground-water resources of the island of Maui, T. H.: Hawaii Div. Hydrography, Bull. 7.

Stephens, J. C., 1943, The relationship of subsurface hydrology to water control and land use in the Everglades: Soil Sci. Soc. Florida Proc, v. 5-A.

Stringfield, V. T., 1933a, Ground water in the Lake Okeechobee area, Florida: Florida Geol. Survey Rept. of Inv. 2.

1933b, Ground-water resources of Sarasota County, Fla.: Flotida Geol. Survey 23d-24th Ann. Rept.

1936, Artesian water in the Florida Peninsula: U. S. Geol, Survey WaterSupply Paper $773-\mathrm{C}$.

1938, Ground-water supplies in Floride: Civil Eng., v. 8, no. 7.

Stringfield, V. T., Warren, M, A., and Cooper, H, H., Jr, 1941, Artesian water in the coastal area of Georgia and northeastem Florida: Econ. Geology, v. 36, no. 7.

Stubbs, S. A., 1937, A study of the artesian water supply of Serninole County, Fla.: Florida Acad. Sci. Proc., v. 2.

Sverdrup, H. U., Johnson, M. W., and Fleming, R. H., 1942, The oceans, their physics, chemistry, and general biology, Prentice-Hall.

Tagg, G. F., 1937, Interpretation of earth resistivity curves: Am, Inst. Mech. Eng. Tech. Pub. 755.

Theaman, J. R., 1943, The heaviest rainfall of Flotida [20-page booklet printed by John $R$. Theaman, 733 Park Ave., Indianapolis, Ind.].

Theis, C. V., 1935, The relation between the lowering of the piezometric surface and the rate and duration of discharge of a well using ground-water storage: Am. Geophys. Union Trans.

Thompson, T. G., and Robinson, R. J., 1932, Chemistry of the sea: Nat, Research Council Bull. 85, Washington, $\mathrm{D}$. C.

Thompson, T. G., and Wirth, H. E., 1931, The specific gravity of sea water at zero degrees in relation to chlorinity: Conseil Intern, Exploration Mer Jour, v, 6.

Thornthwaite, C. W., 1931, Climates of North America according to a new classification: Geog. Rev.

Pub. 421.

Thornthwaite, C. W., and Holzman, B. J., 1942, Measurement of evaporation from land and water surfaces: U. S. Dept, Agr. Tech. Bull, 817.

Tolman, C. F., 1937, Ground water, McGraw-Hill Book Co.

United States Coast and Geodetic Survey, 1947, Tide tables, Atlantic Ocean, serial no. 678.

United States Corps of Engineers, 1945, Storm rainfall in the United States, depth-areaduration data, [Loose-leaf processed,]

United States Geological Survey: Surface water supply of the United States, 1940, 1941, $1942,1943,1944,1945,1946$, part 2, South Atlantic slope and eastern Gulf of Mexico basins: Water-Supply Papers 892, 922, 952, 972, 1002, 1032, and 1052, respectively.

Unklesbay, A. G., 1944, Ground-water conditions in Orlando and vicinity: Florida Geol. Survey Rept. of Inv. 5 .

Upson, J. E., 1951, Former marine shore lines of the gaviota quadrangle, Santa Barbara County, Calif.: Jour. Geol., v. 59, no. 5, p. 415-446.

Vaughan, T. W., 1910, Contributions to the geologic history of the Floridian Plateau: Carnegie Inst. Washington Pub. 133.

Veatch, A. C., and Smith, P. A., 1939, Atlantic submatine valleys of the United States: Geol. Soc. America Spec. Paper 7.

*Vorhis, R. C., 1948, Geology and ground water of the Fort Lauderdale area, Florida: Florida Geol. Survey Rept, of Inv. 6.

Wallis, W. T., 1942, The history of Everglades drainage and its present status: Soil Sci. Soc. Florida Proc., v. 4-A.

Walton, H. F., 1942, Ion exchange between solids and solutions: Franklin Inst. Jour., v. 232.

Warren, M. A., 1944, Artesian water in southeastern Georgia: Georgia Geol. Survey Bull. 49. 
Watson, R. J., 1934, A contribution to the theory of the interpretation of resistivity measurements obtained from surface potential observations: Am. Inst. Mech, Eng. Tech. Pub. 518.

Watson, R. J., and Johnson, J. F., 1938, On the extension of two-layer methods of interpretation of earth resistivity data to three and more layers: Geophysics, v. 3, no. 1, p. $7-21$.

Wegener, Kurt, 1933, Deutsche Grö̈nland-expedition Alfred Wegener, 1929 und 1930-31, F. A. Brockhaus, Leipzig.

Wentworth, C. K., 1939, The specific gravity of see water and the Ghyben-Herzberg ratio at Honolulu: Univ. Hawaii Bull., v. 18, no. 8. 1942, Storage consequences of the Ghyben-Herzberg theory: Am, Geophys. Union Trans., pt. 2.

Wenzel, L, K., 1942, Methods for determining permeability of water-bearing materials: U. S. Geol, Survey Water-Supply Paper 887.

Williams, G. R., and others, 1940, Natural water loss in selected drainage basins: U. S. Geol, Survey Water-Supply Paper 846.

Willoughby, H. L., 1898, Across the Everglades, J. B. Lippincott Co. 


\section{INDEX}

A

Page

Abstract

$1-4$

Allapattah Marsh, description.........+........ 143

Anastasia formation, age.................66, 100

lithologic features. $66,100,101,120,122$

occurrence and distribution.......... 100, 101

water-bearing characteristics.. 66, 101, 102

Annual runoff, data of selected drainage

basins....................513, 514, 515, 516

Appendix ,...................................835-948

Aquifer, definition...............................157

Aquifer at Everglades, description..... 196-197

Aquifers at Fort Pierce and in the

Kissimmee valley, description....194-196

Arbuckle Creek, description..............311-312

Arca zone, description..............................70

Arch Creek, origin.............t.t.........125, 127

Areal studies, characteristics...t...............509

Everglades..................................509-510

west of Hialeah................................. 510

Artesian aquifer, functioning..................159

Artesiat aquifer at Indian Town, description............................. 193-194

Artesian head, general statement............. 159

Artesian water, chemical character......... 826 definition................................158-159

general statement........................... 188

shallow aquifers............................193-197

Atlantic Coastal Ridge, deep sand-filled Pleistocene channels through...... 150-151

description................................... 145

Atlantic Coastal Ridge in Broward County, aquifer and ground water........... 169-171 development of wells,..........................172 effect of .................................... 171-172

Atlantic Coastal Ridge in Palm Beach County, aquifer and ground water..................................... 172-173

development of wells........................175

effects of drainage............................ 174

Atlantic Coastal Ridge in \$t. Lucie County. aquifer and ground water.................. 176

development of wells..........................176

Atlantic Coastal Ridge north of Greater Miami, aquifer and ground water................................... 168-169

Atlantic Coastal Ridge south of Greater Miami, aquifer and ground water....... 167

development of wells..................167-168

Atlantic Coastal Ridge north of Miami, development of wells........................169

Atlantic Ocean, chemical composition.

$572-573$

contamination by...............+.........572-573

specific gravity..........................573-574

Avon Park limestone formation, age........ 67 lithologic features....................... 67,68 water-bearing characteristics................67 67
B

Page

Bar and swale topography,

description.123 $124,139,142,143,152$

Base exchange, description..578-579, 821-822

Base flow, explanation................. 524-528

Base storage, explanation..............528, 530

Basins tibutary to Lake Okeechobee,

characteristics................................+. 300

general drainage system.........+*....300-301

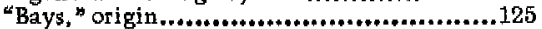

Beach sand, age,.............+.................. 111

fossil identification.......................... 111

Iithologic features...........................111

occurrence and distribution..., t.... 110, 111

Bicarbonate, in ground water..................733

Big Cypress-Devil's Garden area, aquifer

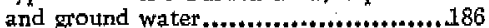

development of wells........................186

Big Cypress Swamp, description........ 144-145

Big Pine Key, description...61, 146, 155, 177 ground-water tidal fluctuation............. 177

Biscayne aquifer, compared to Floridan aquifer at Jacksonville, Fla., and

Savannah, Ga........................... 270 description.................. 160 -162, 166, 198

factors affecting............................... 199

occurrence and water........................... 96

peremial yield........................t+t.........200

Pleistocene building...........................94

recharge rates......................... 220-221

response to pressure changes,......... 198-199

salt-water encroachment..................... 200

transmissibility and storage

coefficients......+........+............ 269-270

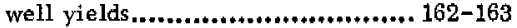

Biscayne Bay, chloride concentration $+474-577$ ground-water discharge into.......... 592-593 salt-water contamination..............574-577

Biscayne Canal, salt-water encroachment......................... 645-652

Boynton Canal, description................ 502-505

Brevard County, precipitation..............22-40

rain gages..........................................18

Broward County, chemical character of nonartesian ground waters...........797-800

chemical character of public water supplies.................................828,8 830

development of wells........................172

effect of drainage....................... 171-172

municipal water supplies.............. 919-922

precipitation.................................22-40

rain gages..........................................18

salt-water encroachment...............171-172

well logs.............................859-870

well records........................836-837

Buckingham formation, fossil

identification................................... 87

lithologic features.............................. 87 
Calcareous rocks, solution..........90,96-99, $104,128-129,132-134$

Calcium, in ground water................731-732

Caloosahatchè Canal, chemical character of water...................751-755

Caloosahatchee marl formation, age

of..................67, 89

forsil identification........................... 87

lithologic features.................. 67, 88, 89 occurrence and distribution............ 87, 88 water-bearing characteristics......... 67, 89 , 118,119

Caloosahatchee River, Cancell aria zone......70 capillary fringe.................................221 cation exchange............578-579, 821-822 dates of canal construction ................. 587 description......................................... 141

Camp Murphy, wells............................ 175

Campbell, Robert B.............................65

Cenozoic era, time correlation................. 111

Charlotte County, precipitation...........22-40 rain gages.........................................18

Chemical character of artesian water. general statement................... 826-833

Chemical character of nonartesian ground waters, general statement..........784-785

Chemical character of surface waters general statement....................737-784

Chemical quality of nonartesian ground waters, areas surounding Lake Okeechobee.

Chemical quality of surface waters, effect of drought on Everglades canals..........784 major Everglades drainage canals....755-779 miscellaneous sampling................ 779-783

Chloride, description in ground water..733-734

Chlorides, taste levels of human perception

W. S. Public Health Service standards.....96

Circular ponds, origin and description.. 141-142

Climate, general statement......... 15-57, 132

Climatic effects on topography, general statement........................................132

Climatic Optimum, definition............... 125

Climatologic data, analysis....+...t...516-524

Coastal areas north of Miami, chemical character of nonartesian ground wa ters.................................... 798-796

Coastal marshes and mangrove swemps, description.......................................154

Coconut Grove, early springs..................581 ground water in early days................... 580 well field established..........................705

Coconut Grove well-field, salt-water encroachment.

Coefficient of permeability, definition.

$236-237$

Coefficient of storage, definition............ 237

Coefficient of transmissibility, definition.. 237

Collier County, chemical character of nonartesi an ground waters.......... 822-825

chemical character of public water

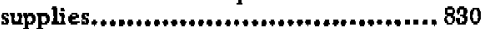

contamination of shallow ground water by salty artesian water.................... 192

Cory No, 1 well, water analyses............ 65

Everglades City aquifer and ground water....................................... 196-197 municipal water supplies..................... 923 precipitation.............................. 22 -40 rain gages.........................................18 well records......................................836

Color of ground and surface waters,

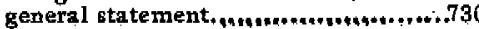

Cooke, C. Wythe 70

Coral Gables Canal, salt-water encroachinent...................667-674

Corrosiveness of ground water. general statement ..........................737

"Coskinolina zone" of Stubbs, general statement ,...........................67

Cushman, J. A. ..............................81, 82

Cutler, interpretations of apparent resistivity curves at,.............. 942-945

Cutler area, measurements of salt-water encroachment by electricalresistivity studies ......................718-721

Cypress Creek Canal, chemical chardeter of waters .........................776 description............................... 505-507

Dade County, chemical character of

Biscayne aquifer water ...............792-796 chemical character of public water

supplies ,.............................. 828,830 estimated purnpage of ground water..., 236 municipal water supplies.............. 924-927 precipitation..................................23-40

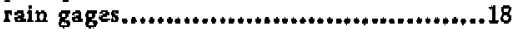
well logs...............................871-901 well records, ,.............t.t............839-848

Dade County shoreline, salt-water encroachment.........................708-711

Darns, salt-water controls. $.590,640,652,705$ Dania, aquifer and ground water near................................ encroachment from,........................ 171 Darcy's law, general statement........206, 274 Density of ground water, effect on water-table elevation .............. 613-617

De Soto County, precipitation.............. 22-40 rain gages...................t.....................19 Development of area, problems,.............9-11 Devil's Garden, description....................186 Dictyoconus americanus zope of Cole.......... 68 . Dictyoconus cookel wone of Cole .............. 68 Direct flow, explanation................. 524-528 Dissolved solids, general statement...........735 Drainage, results................................9-11 Drainage canals, salt-water encroachment from ................................682-686

time of construction......................... 587 Droughts, description.........................93-40 Droughts and salt-water encroachment, general statement.................. $587-588$ $679-681,784$

Duplin marl formation, age...............70, 71 fossil identification........................70-82 lithologic features................................70 occurence and distribution...................70

Ecphora zone...t+.............t.............t.........7 70 Effective recharge, definition .................28I Electrical resistivity, studies ............712-725 Eocene series, general statement............, 64 Equivalents per million, defined............. 577 Erosion, description...........134-135, 147, 155 of channels through the Atlantic

Coastal Ridge......................... 150-151

Evaporation, general statement.............42-57

methods of computation...m........516, 524 computation.................... 516, 524 
Evapotranspiration, general statement...42-57 salvage.................................285-287

Everglades, central, aquifer and ground water. 183-184 development of wells 184

quality of water. seepage. $183-184$

Everglades ground water. development of wells $179=180$ seepage. 180

verglades, lower, west of Hialeah, water-table conditions.............. 180-183

Everglades; The, chemical character of nonartesian ground water........... 818-821 description 147-148 drainage pattern.........................152-153

flobx......................................149-151 geologic history....................... 118-125 "grain" ............................................. 152 rock floor................................... 149-151 soils

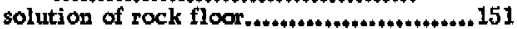
source of mineralization of ground waters

"subsidence valleys." $821-822$ vegetation $152-153$ water storage......................... 566 , 567

Everglades, The, and the Atlantic Coastal Ridge, aquatic weeds,............... 342-344 bars and shoals........................... $341-342$ characteristics................................... 332 chemical quality of ground water... 818-821 combined natural and artificial control regimen. $347-348$

Everglades hydrologic unit.............332-335 factors affecting canal capacity......338-344 general drainage features.....................332 ground-water flow from Atlantic

Coastal Ridge to. 591

soil subsidence....................................... $338-34$ source of mineralization of ground water.

topographic and geologic factors of water control

water-control facllities................ 335-338

Everglades, The, area, hydrologic studies.

.

tion.......561, 566,568,569,570 runoff.............. 561, 566, 567, 569, 570 seepage... 561

Everglades, upper, aquifer and ground water...........................184-185

development of wells se epage....................................4.4......185 Everglades $\mathrm{City}$, aquifer and ground water at................................ 186-197 "Everglades Keys"," general state ment.......................................145-146

Everglades National Park area, aquifer and ground water...........................178 development of wells..................178-179 quality of water...........................4....178

\section{F}

Fahkahatchee Slough, description........... 142 fire wells...........................................166

Fisheating Bay, description....................137

Fisheating Creek, chemical character of water.

description........................139, 140,141

Fisheating Creek basin, characteristics..... 315
Fisheating Creek valley, description.........139

"Floating islands," definition...................154

Florida City area, aquifer and ground water....................................167, 711

Florida Keys, aquifer and ground water............................. 100, 176-177

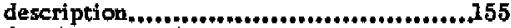
development of wells..................167-177 ground-water tidal fluctuation....... 176-177 Floridan aquifer and aquiclude,

contamination...............................192

description.................................188-189 distribution and pressure..................189-191

in Miami area..............................*4..+...,192

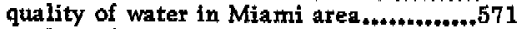
quality of water in southeastern

Florida $824-826$

temperature...................................... 191 utility.................................. 191-192

yield to wells............................4.4...... 191

Floridan Plateau, effect of fluctuating sea

level upon...................................... 129

features.....................................60-62

geology .....................................61-62

stability....................................... 114

Fluoride, in ground water.................734-735

Foraminifera, lists.................................81

Fort Lauderdale, colored water................170

interpretations of apparent resistivity curves at............................. 945-948

measurements of salt-water encroachment

by electrical-resistivity studies 721-725

precipitation................................. 22-40

public-supply wells...............................172

transmissibility of Biscayne aquifer.......170

Fort Lauderdale area, depth to

bedrock.................................150-151

Pleistocene residual sea water near........170

salt-water encroachmant.............677 -679

Fort Pierce, aquifer and ground water....... 176

Fort Thompson formation, age.............66 66

$94,95,118$

fossil identification....94,95,98,99, 120

lithologic features......66, 90, 91, 92, 93, $94,95,96,118,121,122$ occurrence and distribution........... 90, 92 , $93,94,118,149$ relation to Anastasia formation........... 90 . $170,172-173$ section at type locality................117-118 water-bearing characteristics.............66, $90,94,95,96,98,99,119$

G

Gallatin, M. H..................................711 Gardner, Julia, macrofauna identification.............................71-80

Geologic formations, table..............66, 67

Geologic investigations, from outcrop data methods...................................... 57-58 test-well drilling.................59-60, 64-65

Geology and gound-water resources, relationship..............................57, 64 Ghyben-Herzberg principle...........100, 278 , $279,591-592,604,611$

Glades County, chemical character of public water supplies...............828, 830 chemical quality of nonartesian

ground waters......................... 806-809 Glades Peninsula.............................. 139

municipal water supplies....................928 


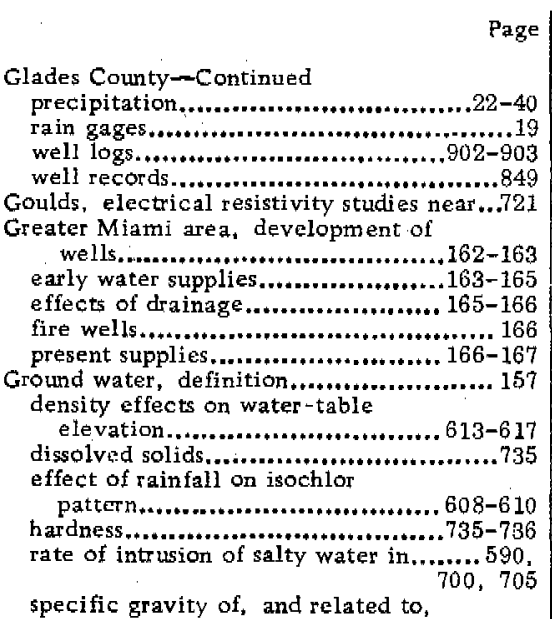
sea water................................. 598-600 temporature.....................................191 tidal-storage changes..................617-618 Ground-water discharge, Collier

County..................806-818, 822-823 decline of water table in the Atlantic

Coastat Ridgc......................... 232-233 description...................................... 221 early supplies in Miami...................163-165 evaporation and transpiration,..............222 flow towards the Everglades....591, 818-821 Lake Okeechobee area................... 806-818 pumpage in Dade County....................236 relation to Ghyben-Herzberg lens...........593 studies in Dade County..................222-228 studies north of Kendall................233-235 studies south of Kendall..................228-232

Ground-water inventory, necessity

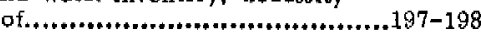

Ground-water occurrence, methods of investigating

Ground-water pumping test, conclusions reached................................. 269-270

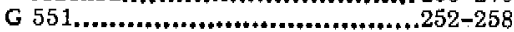

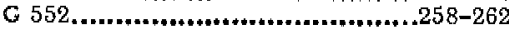

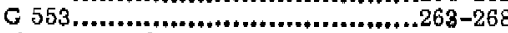

objectives of ..............................249-252

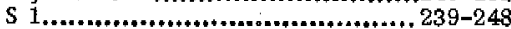

Ground-water quantitative studies, canal inflow..........................274-276

cone of depression in Miami well

field +...........4.......................... 274

F 85 pumping test...t................. 270-272

G 218 punping test...................... 272-274

introduction to................................. 197

Ground-water recharge, description.... 212-214

in relation to muck of the

Everglades............................215-216

in relation to oolite of the Atlantic

Coastal Ridge...........................218-221

in relation to sand of the Atlantic

Copstal Ridge ........................216-217

"Gulf Hammoek formation" of

Ericleson

Gulf Stream, salinity.............................68

\section{$\mathrm{H}$}

Hardee County, precipitation............... 22-40 rain gages...........................................19
Hamey Pond Canal, drainage characteristics................................. 319

Hawthorn formation, age........67, $71,83-84$ fossil identification........................70-82 lithologic features..............67, $70,83-84$ occurrence and distribution........70, 83-84 water-bearing characteristics.........67, 84 Henbest, Lloyd $G$. , and Cushman, Joseph A., microfossil identification,......................... 81-82 Hendry County, chemical character of

public water supplies................828, 830 chemical quality of nonartesian

ground water.......................... $809-810$ municipal water supplies....................929 precipitation...............................22-40 rain gages.......................................... 19 well logs................................ 904-905 well records....................................... 850

Hernando County, precipitation...........22-40 Hialeah, water-table maps...............180-182 Highlands County, Highlands Peninsula.... 136 precipitation ................................ 22-40 rain gages...................................... 19 well logs................................. 906-907 well records...................................... 851

Hillsboro Canal, characteristics.............. 362 chemical charactes of waters.........758-759 descr iption.............+....................362-365

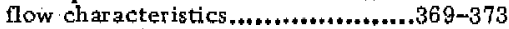
records..................t...................365-369 special studies,.......................... 373-374

Hillsboro Lakes Marsh, description........... 154 Hillsborough County, precipitation.......22-40 rain gages . ............t..............................19

Hobe Sound, wells......+**+.....................175 Homestead area, aquifer and ground water

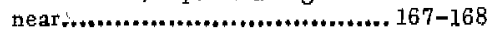
lateritic soils near.t.t....................... 110 salt-water encroachment..............679-682 Hungryland Slough, description.............. 143

Hurricanes, tidal action ......................4. 131 wind velocities............................... 153

Hydrogen-ion $(\mathrm{pH})$, of ground water..736-737 Hydrogen-sulfide, in ground water..........736 Hydrologic cycle, definition............511-512

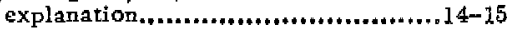

Hydrologic data, annual summary..t+..+...512 Hydrologic properties, coefficient of permeability........................ 236-237 coefficient of storage.......................237 coefficient of transmissibility............ 237 Theis nonequilibrium formula....... 238-239 Hydrologic studies, general features of

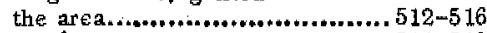
general statement.......................511-512

\section{I}

Illinoian glacial age, general statement...120 Immokalee Island, description................ 139 Indian Prairie Canal, chemical character of water..................................... 741 drainage characteristics $\ldots \ldots \ldots . . . . . .317-318$

Indian River County, precipitation.......22-40

rain gages....................................... 19

Indian Run, general statement............... 154 Indian Town, aquifer and ground water............................, 175, 193

well supplies...................................106

Infiltration from canals, general statement ............................. 287-290

Interpretation of apparent resistivity curves.................................941-948 
Introduction......... 5-14 Iron, in ground water..........................731 Isochlors, effect of rainfall .............608-610 in canals. 629 Istokpoga Canal, description............313-314 Istokpoga Strait, description.

\section{$\mathbf{K}$}

Kansan glacial age, general

statement............ 120

Karst topography, description.......... 128, 135 Kendall area, aquifer and ground water............................... 167-168 Key Largo limestone formation, age........66, 99. 100

fossil identification............................ 100 lithologic features of.......................... 66 , $99,100,119,120$ occurrence and distribution............99, 100 water-bearing characteristics....66, 99, 100 Key West, general statement................146, $155,176-177$

Kiser, H. E ............. 163, 164 Kissimmee, droughts.................. 34-40 Kissimmee Island, general statement,...... 136 Kissimmee River, average depletion hydrograph 527 chemical character of water.........738-741 depletion rating curve........................526 description........................ 139, 140, 141 hydrograph..................................... 525 recession rating curve of direct runoff.... 529 relation between rate of base flow and base storage.

Kissimmee River basin, annual runoff analyses of............................... $531-540$ annual summary of hydrologic data.......550 base storage..............................528-530 characteristics...............4................301

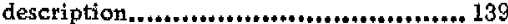
direct-runoff storage..................530-531 monthly rainfall-runoff relations,... + 540-544 precipitation..............................517-524 separation of direct and base flow...524-528 similar geologic structure................... 159 water losses and storage................544-551

Kissimmee River lower basin, Arbuckle

$$
\text { Creek. }
$$
.311-312 characteristics. $307-310$

flood frequency.....................t+....310-311

Istokpoga Canal.............t.t.............. $313-314$

Kissimmee River upper basin, characteristics........................302-305

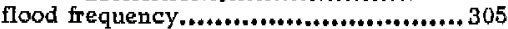

Reedy Creek.............................305-307

Kissimmee Sound, general statement....... 137 Kissimmee valley, aquifer and ground water in development of wells in.................... 187

\section{$\mathbf{L}$}

La Belle fluoride in public water supply.... 826

Lag, definition.....................................511

Lake City limestone formation, age..........67 lithologic features............................67 water-bearing characteristics..............67

Lake County, precipitation...................22-40 rain gages.........................................19

Lake Flirt marl formation, age................66, fossil identification
Lake Flirt marl formation-Continued

lithologic features................66, 107, 108 occurrence and distribution.........107, 108 water-bearing characteristics..66, I08, 109

Lake Hatchineha, origin....................... 138

Lake Istokpoga, description................... 139 origin.........t.................................... 139

Lake Kissimmee, origin.......................138

Lake Okeechobee, beach ridge..............153 chemical character of ground water nearby. $806-818$ description,...............................140, 153 chemical character of water...... 741-747 during Clim atic Optimum.................. 125 evaporation....................558, 559, 560 hydrologic summary..................55l-560 inflow.............................551, 558 rtunoff................................. 560

seepage........................................558 summary of quality of ground water in

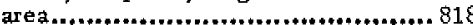

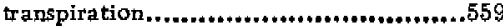

Lake Okeechobee and principal canals,

Caloosahatchee Canal..............327-330

characteristics.................................321

lake-regulation program.............. 321-327

physical features............................. 321

St. Lucie Canal.......................... 330-332

Lake Okeechobee area, summary of quality of ground water..............................818

Lake Tahopekaligu, origin.................... 138

Land forms, composition.................127-129 effect of climate and vegetation on......132 effect of erosion on.......................134-135 effect of fluctuating sea level on ..........129 effect of shoreline processes on.......129-131 effect of solution on.....................132-134 factors affecting.............................127

Laterite, Redlands district, age „............110 occurrence and distribution.................110 water-bearing characteristics.............. 110

Lee County, precipitation................. 22-40 rain gages........................................ 19

Limestone, breccia......................100, 102 iron oxide in............................99, 102 origin of oolite........................ 103-104 solution processes in ................. 103-104, $128-129,133-134$

Little River Canal, salt ${ }^{-}$water

encroachment

Lower Cretaceous rocks, description......61-62

Lower Miami Canal, characteristics........412 description................................412-421 discharge computation..................471-486 dredging.......................................584 flow characteristics....................458-470 hydraulic characteristics of

headwaters, . ............................ 435-439

records .....................................4 421-435

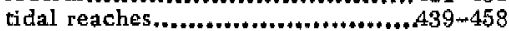

Lower New River basin, characteristics..... 399 description................................399-400

flow characteristics....................400-402 salt=water encroachment..............677-679 special studies........................... 402-406

Loxahatchee Marsh, description............... 143

\section{M}

MacNeil, F, Stearns, macrofossil identification ..............86-88, 95, 100

Macrofatmas, listing.......................72-81 magnesium, in ground water...............732 
Magruder, R. H..............................163 Manatee County, precipitation............ 22-40 rain gages...........................................19

Mangrove swamps, description.................154

Marine terraces, general statement....135-136 Pamlico..........140-146 Penholoway.................................... 137 shorelines......................... 62, 114, 117 Silver Bluff..............................146-154 Talbot.................................139-140 Wicom ico................................ 136-137

Marine terraces east of Kissimmee valley, aquifer and ground water............ 187-188 development of wells..........................188

Marl, description and location,.........64, 129

Martin County, aquifer and ground water... 174 chemical character of public water supplies.

chemical quality of nonartesian ground water.............................. 814-815 developinent of wells....................175-176 municipal water supplies.............. 930-931 precipitation...................................22-40

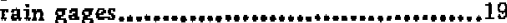
well logs..........................................908 well records.................................852

Miami, chemical characteristics of

Biscayne aqui fer water............. 785-791

drainzge operations............................. 584

droughts ........................................34-40 early ground - water conditions........580 -584 fire wells........................................ 166 ground-water conditions 1907 to $1939 \ldots . .584$ measurements of salt-water

encroachment by electrical-

resistivity studies.

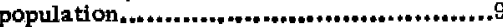
precipitation..................................22 40

Miami area well field (proposed), cone of depressión. $281-285$

conclusions. 290 evapotranspiration \$alvage............ 285-287 general statement......................277-281 infiltration from canals.............. 287-290 salt-water encroachment theoretical drawdowns .............. 584.281

Miami Beach, tide levels................ 441-442

"Miami Bench"............................... 146

Miami Canal, chemical character of waters.

salt-water encroachment.......631-641, 691

Miami Canal-upper and middle reaches, characteristics................................406 description.......... 406-407

flow characteristics.................... 411-412 records

Miami metropolitan area, chemical character of nonartesian ground waters. $408-410$

early water stuplies.................... 163-165

Miami oolite formation, age................ 66,

$102,103,104$

fossil identification.................. 102, 103

lithologic features......................66, 102, $103,104,120,121$

occurence and distribution................102, $103,104,105,149$

water-bearing characteristics................66, $102,103,104,105$

Miaml River, origin

Miami Springs ${ }^{-H i a l e a h ~ w e l l ~ f i e l d . ~}$ coefficients of transmissibility and storage. .125

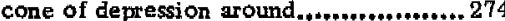

Miami Springs-Hialeah well field-Continued establishment and first use of well

field..................................166, 691

pum page..........................................235

salt-water encroachment..............691-705

Middle River basin, salt-water

encroachment................................6 679

Miocene series, general statement ............,70

Monometer, merctry...........................251

Monroe County, chemical character of

public water supplies...................... 830

muniçipal water supplies................... 932

precipitation..................+.+*+*.........22-40

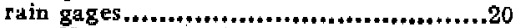

Moore Haven, ground-water supply.......... 806

Muck, age........................................... 109

evapotranspiration.....................222, 224

lithologic features............................... 109

occurrence and distribution.................. 109

water-bearing characteristics................ 109

Municipal water supplies, general

statement..............................919-940

Muskat, Morris........t...................592-593

$\mathbf{N}$

Natural wells, description ............+*.t...... 155

Nebraskan glacial age, general

statement..........................118-119

New River, origin...t...................... 125

New River basin, drainage operations........ 584

New River valley, depth to bedrock.........169

Nitrate, in ground water.................734, 735

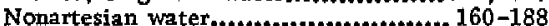

definition.................................. 157-158

North Miami, general statement...t.t.+....*t, 166

North Miami Beach, general statement..... 166

North New River Canal, characteristics..... 375 chemical character of waters........759-766 description................................. $375-378$

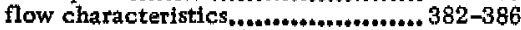
records......+............................... 378-382 salt-water encroachment from......*...... 171 seepage rates.............................+. $386-389$

Ocala anticline, geology..........t.......62-63

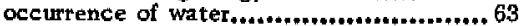

Ocala limestone formation, age.......... 67,68 lithologic features.................67, 68,69 occurrence and distribution................. 68 water-bearing characteristics,....67, 68, 69 Okaloacoochee Slough and Devil's Garden. description,................................ 142-143

Okeechobee County, chemical character

of public water supplies.............828, 831

chemical quality of nonartesian

ground water........................816-817

municipal water supplies in..................933

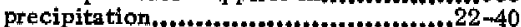

rain gages

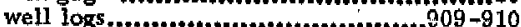

well records........................................ 853

Okeechobee Peninsula, general statement..137

Oligocene series, general statement........... 69

Opa Locka, description......................... 166

Opa Locka area, water-table map.t......... 275

Orange County, precipitation.............. 22-40

rain gages...................................... 22

Osceola County, precipitation............. 22-40

rain gages.................................... 220

Osceola Island, general statement...... 136-137 
Palm Beach County, aquifer and ground water ..................................... 172-173 chemical character of nonartesian ground water...............801-805, 811-813 chemical character of public water supplies..................................828, 831 effect of drainage operations on ground water.................................4..........., 173

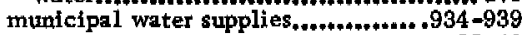

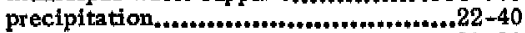

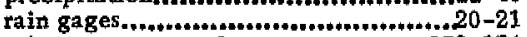
salt-water encroachment............... 173-174 well development........................+........174 well logs,.....................................911-916 well records...............................854-857 Palmer Lake, salt-water encroachment.

Palmsdale, Glades County....................., 137

Pamlico sand formation, age.................... 66

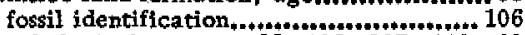
lithologic features,...66, 106, 107, 118,123 occurrence and distribution.. 106, 107, 118, water-bearing characteristics.,.66, 107, 118

Parker Sand Islands, general statement...... 139

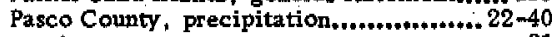
rain gages............................................21

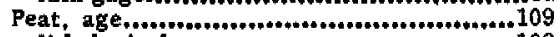
lithologic features................................109 occurrence and distribution.................... 109 origin..............................105, 125, 132 water-bearing characteristics............... 109

Penholoway formation, age............... 66, 105 fossil identification.....................1105, 106 lithologic features............... 66, 105, 106

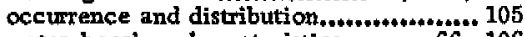
water-bearing characteristics......... 66, 106

Pennick, J. M. K. _.......................591-592

Perennial yield, Miami area.................... 200

Permeater tests, Terrace sands.................. 106

Perrine, ground-water supplies...................166

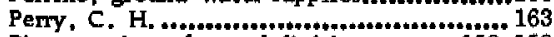

Piezometric surface, definition..........158-159 relation to water table......................... 158

Pinellas County, precipitation............. 22-40

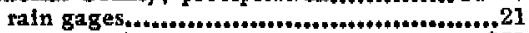

Pitometer, description............................ 251

Pleistocene and Pliocene formations,

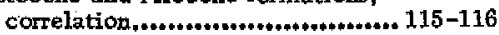

Pleistcoene or "Great Ice Age,"

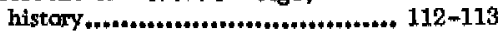

Pleistocene sedimentation, general statement.

Pleistocene series, general statement......... 89

Pleistocene shorelines. Seb. Marine terraces,

Pliocene reefs and "shoestring sands," general statement............................... 89

Pliocene series, 'general statement:............. 88

Polk County, precipitation................... $22-40$

rain gages............................................ 21

Population, southern Florida counties............ 8

Porosity, definition...................................... 214

Potassium, in ground water..................... 732

Pre-Tertiary rocks, occurrence and water.,.................................65-66

Precipitation, a mount...........21-40, 132, 512 methods of computation............... 516, 524 records....+....t.t...........................t... 16-21

Previous investigations......................... 13-15

Public water supplies, chemical char-

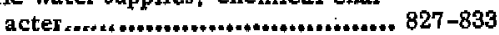

Pumping tests. Sed Ground-water pumping tests.

Purpose and scope of investigation...........5-13

Quality of waters, bicarbonate.................733

calcium.....................................731-732

chloride...................................733-734

collection and examination of

samples

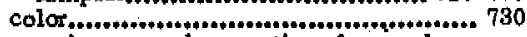

constituents and properties of natural

waters.................................... 729-730

corrosiveness...................................... 737

dissolved solids..................................... 735

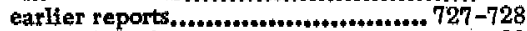

expression of results...*.+4*4.................. 729

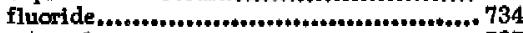

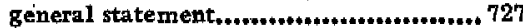

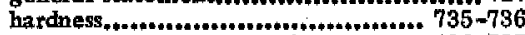

hydrogen-ion concentration............ 736-737

hydrogen sulfide.........................4......... 736

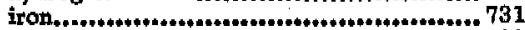

magnesium,

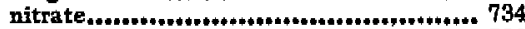

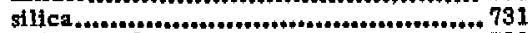

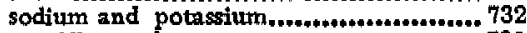

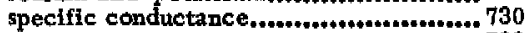

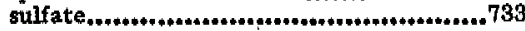

\section{$\mathbf{R}$}

Rainfall. See Precipitation.

Recent epoch, general statement....... 124-126

Reedy Creek, description................ 305-307

Residual Ice Age sea water, general

statement...................................... 123

Royal Palm Hotel, early ground-water

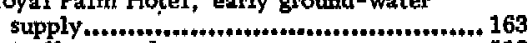

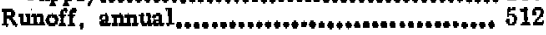

\section{$\mathbf{S}$}

Saint Lucie Canal, chemical character of water...*n.......................... 747-750,

Saint Lucie County, chemical character of public water stipplies.................... 831 municipal water supplies...................... 940 precipitation.4...4........................ 22-40

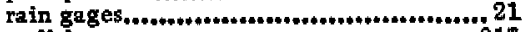
well jogs.................................... 917

well records...................................... 858

Salt contamination of ground waters. chemical composition............... 577-579

Salt contamination of surface waters, chemical composition.................... 577

Salt front, in tidal canals, $628-629,636-640$, $641,645,652,659,682$

Salt-water contamination, source...... 571-577 Salt-water contamination of aquifer from tidal canals, from Palmer Lake........ 640 general statement........................682-686 studies along Minmi Canal............. 683-686 Salt-water contamination of canals by residual ground water, description $686-687$

Salt-water contamination of wells in

Minimi area, chloride concen" tration................................. 694-705

Salt-water contamination of wells in Miami area, description............. 687-708

Salt-water encroachment along Dade County shoreline, description.....708-711

Salt-water encroachment determinations by electrical resistivity studies, electric conduction................ 712-713 evaluation of method............................ 725 field measurements.................... $714-715$ 
Salt-water encroachment determinations by electrical resistivity studies-Con. interpretation of resistivity curves.......... 715 measurements at Cutler area.......... $718-721$ measurements at Fort Lauderdale.... 721-725. measurements at Miami....................715 measurements at Silver Bluff area... $715-718$ Salt-water encroachment in Biscayne

Cana1, chloride concentration.....646-651 description.......................................... 645

Salt-water encroachment in coastal ground water, review of literature on........................................591-593

shape of encroaching salt-water wedge,.................................610-611

Salt-water encroachment in Coconut Grove well field, chloride concentration............................................ 707 description................................ . 705-707

Salt-water encroachment in Coral Gables Canal, chloride concen tration.4n............................. 668-673 description.....................................667

Salt-water encroachment in Fort Lauderdale area, description

Salt-water encroachment in Homestead area, chloride concentration...... $680-682$

description........................................679

Salt-water encroachment in Little River Canal, chlcride concentration... 653-658

description...4...............t.................652

Salt-water encragchment in lower $\mathrm{New}$ River basin, chloride concentration...........................**.. 677-679

description................................ 677-679

Salt-water encroachment in Miami area, between 1907 and 1939... 584-587

early conditions, ......................... 580-584

Miami Water Co. sued,...................... 165

rate of encroachment........... 590,700,705

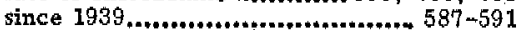

Salt-water encroachment in Miami Canal, description.

location of salt front

Palmer Lake...................................... 640

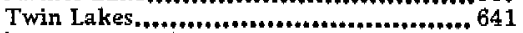

Salt-water encroachment in Miami Springs-Hialeah well field, description..

Salt-water encroachment in Miami well fields, description............. 687-708

Salt-water encroachment in Middle River basin, chloride concentration. ..679

description........................................ 679

Salt-water encroachment in Silver Bluff area, characteristics and changes In position of the salt-water wedge 610-617 data from studies,............................ 600-607 effect of rainfall on the isochlor pattern...................................,608-610

erosion of salt-water wedge by seaward-flowing ground water.

objectives.

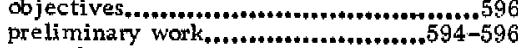
procedures.................................. 596-598 selection of site for study .............. $593-594$ specific gravity of sea and ground

water.................................... 598-600

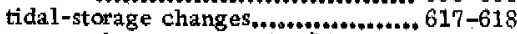
water-table related to isochlor

Salt-water encroachment in Snake Creek

Canal, chloride concentration.... 642-644

description. 641
Salt-water encroachment in Snapper Creek Canal, chloride concen m

tration.................................. 674-676

description....................................... 674

Salt-water encroachment in Spring

Gardens well field, description. .687-691

Miami Water Co. prosecuted for sale of salt water.

Salt-water encroachment in Tamiami

Canal, chloride concentration.....660 6665

description.........................................659

Seminole Lake................................666

Salt-water encroachment in tidal canals, areas studied................................. 619

density currents and hydraulic relationships................................ .620 630

divided flow and shape of density currents.

location of salt front $+\ldots \ldots+\ldots \ldots \ldots \ldots \ldots \ldots \ldots . . .628-630$

mechanics of salt contamination......621-626

Miarni area.........................4..4...631-676

residual contamination................. $630-631$

salinity investigations................. $619-620$

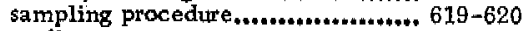

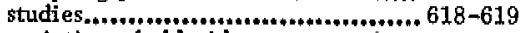

variation of chloride concentration

with tides............................... $626+627$

Sand, beach............................ 626 . 128

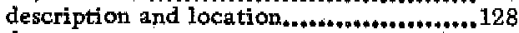

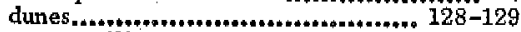

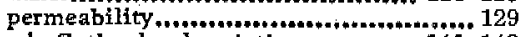

Sandy flatlands, description...............141-142

Sandy flatlands south of Loxahatchee

Marsh, description ....................143-144

Sangamon interglacial age............ 121-122

Sarasota County, precipitation....***..... 22-40

rain gages.......................................... 21

Sea level, effect of Aftonian inter-

glacjal age............................ 119-120

effect of climatic conditions during

Recent epoch......................... 124-125

effect of Illinoian glacial age.........*.... 121

effect of Kansan glacial age................ 120

effect of Nebraskan glacial age....... 118-119

effect of Sagamon interglacial age..121-122

effect of Wisconsin glacial age .....122-124

effect of Yarmouth interglacial age.120-121

fluctuations and effect on land

forms......................................... 129

glacial control........................... 113-114

progressive increase,...................4 441-443

Sea water, chemical analyses................. 572

specific gravity ........................ $573-574$

specific gravity related to ground

water,............................, $598-600$

Secondary canals, characteristics............502

description............................+.....502 -509

Selected bibliography .................... 949-956

Seminole Bay, general statement,............139

Seminole Lake, salt=water encroach-

ment.....................................666 66667

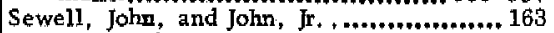

Shoal River formation, general

statement..........................................70

Shoreline processes and effect on land forms, general statement 129-131, 146, 147

Silica, in ground water.........................731

Silver Bluff, interpretations of apparent

resistivity ctrves...........................941-942

Silver Bluff area, general state-

metrt..................93, 130, 145, 710

measurements of salt-water encroach-

ment by electrical-resistivity.

studies.

$715 \cdot 718$

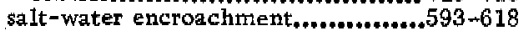


Silver Bluff terrace, \$ee Marine terraces.

Snake Creek Canal, salt-water en-

croachment..............................

Snapper Creek Canal, salt-water etr ${ }^{*}$

croachment................................. 677

641.645

Sodium and potassium, in ground water.....731

Soil moisture, role in hydrologic cycle.

Solution holes, formation $546-548$

South Miami, round -water supplies.

South New River Cana1, characteristics......389 chemical character of waters................ 766 description................................. 389-391 flow characteristics...................... 397-399 records . .................................391-396

Specific conductance, of ground water......730 Specific retention, definition.................. 214 Specific yield, definition....................... 214 Spring Gardens well field, general statement................................ 164-165 salt-water encroachment........687-691

Springs, locations,

Silver Springs..........................t.t......, 69

Wakulla Spring.................................. 69

Stormes.

Stratigraphy and water-bearing characteristics of formations

Stuart, wells........................................ 175

Sulfate, in ground water...................... 733

Surface water, characteristics,.............. 291

chemical quality........................ 737-784

collection and interpretation of

data........................................ 291-295

index of gaging stations................ 296-300

methods of investigation and ex-

planation of dat

291

Suwamee limestone formation, age...........67

lithologic features......................... 67,69

occurrence and distribution................69-70

water-bearing characteristics................ 67

"Swales, " origin............................. 125, 152

Talbot formation, age

66,105

fossil identification...........105

lithologic features................66, 105,106 occurrence and distribution.......... 105, 106 water-bearing characteristics...66, 105, 106

Tamiami Canal, characteristics...............486 chemical character of waters........ 777-779

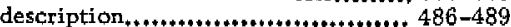
flow characteristics...................4 495-501 records..................................... 489.494 salt-water encroachment. ............. $659-667$ seepage rates and profile..............501-502

Tamiami formation, age.............. 67, 85 fossil identification...................... lithologic features........................67, 85 occurrence and distribution............84,85 water-bearing characteristics........... 67,85

Tampa limestone formation, age....... 67, 82 fossil identification....................... 70 - 82

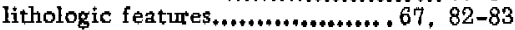
occurrence and distribution.........70, 82-83 water-bearing characteristics............ 67,83

Taylor Creek, chemical character of water.

drainage characteristics .............319-320

Temperature................................... 40-41

Test wells, Dade County...................96-99 drilling.

Theis nonequilibrium method explation.

Thiessen precipitation computation method, explanation
Tidal canals in the Miami area, description.

Tidal effects, on ground water in

limestone.......................... 176-177, 201

Tidal inlets, southward irrigation,4.,4..... I31

Tidal neap, definition......................... 439

Tidal range, definition......t..................439

in Biscayne Bay, ... . 199, 440, 442-445, 596

Tiual scour, general statement..............t155

Tidal spring, definition........................ 439

Tíde levels, Miami Beach......................441

Tides, amplitude..................t...t...........4 439

funda mental..................t.......t..t.....4 439

hurricane..................125, 153, 443-444

in Miamí Canal......................... 448-458

in sea -level canals..................... 444-448

Transpiration, general statement..........42-57

Transverse glades, general statement. 144, 146

"Tree islands," origin and des-

cription........................125, 148, 152

Tributaries, drainage characteristics........317

Tuttle, Harry ..................................... 163

Twin Lakes, salt-water encroachment...... 641

\section{V}

Vadose water, general statement....... 157-158

Vernon, Robert O......................... 63, 68

\section{W}

Wagner's Creek, Miami.........................164

Water level fluctua tions, graphs........ 202-205 meaning........................................201

Water losses in drainage basin, method of computation....t........+4+1+4+.... 544-545

Water storage, types............................513 Water storage in drainage basin, method of computation........................ 544-546

Water table, adjustment for density variance in ground water....t...... $613-617$ correlations with rainfall..............215-221 Dade County studies.....................210-212 declines below sea level........ 210-211, 226 description.................157-158, 201 +202 effect of canals ..........................203 -204 effect of evapotranspiration.........., 222-228 effect on plant distribution............144, 148 maps.......+...................................t.+........ 158 Miami area studies.................... 204-210 relation to land surface..................157-158 relation to piezometric surface............. 158 Well logs.....t...............................859-918 Well records,................................. 835-858

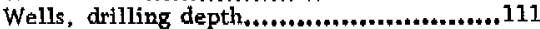

Wentworth, C. K. ..............................593

West Palm Beach Canal, characteristics.... 348 chemical character of waters........ 755-757 description................................ 348-451 flow characteristics.................... 355-358 records....................................351-355 special studies........................... 358-362

Wind, effects on tides........ 129; 153,443-444 general statement.......................... . 41-42 Wisconsin glacial age, general statement.

Yarmouth interglacial age, general statement............................... 120 121

Yoldia zone, general statement...............70 


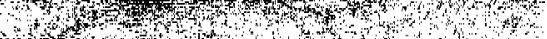

